


\section{REVISTA DE DIREITO INTERNACIONAL}

\section{BRAZILIAN JOUNAL OF INTERNATIONAL LAW}

\section{Responsáveis por essa edição:}

Nitish Monebhurrun

Michelle Ratton Sanchez Badin

Gustavo Ferreira Ribeiro

Alice Rocha da Sllva 
REVISTA DE DIREITO INTERNACIONAL

BRASILIAN JOURNAL OF INTERNATIONAL LAW

Programa de Mestrado e Doutorado em Direito

Centro Universitário de Brasília

Reitor

Getúlio Américo Moreira Lopes

Presidente do Conselho Editorial do UniCEUB

Elizabeth Regina Lopes Manzur

Diretor do ICPD

João Herculino de Souza Lopes Filho

Coordenador do Programa de Mestrado e Doutorado e Editor

Marcelo Dias Varella

Linha editorial

A Revista de Direito Internacional (RDI) foi criada como instrumento de vinculação de trabalhos acadêmicos relacionados a temáticas tratadas pelo Direito Internacional Público e Privado. A revista é sucessora da Revista Prismas, que foi dividida em dois periódicos (junto com Revista Brasileira de Políticas Públicas), em virtude da quantidade de submissão de artigos e procura. Na busca pelo desenvolvimento e construção de visões críticas a respeito do Direito Internacional, a RDI possui sua linha editorial dividida em dois eixos:

1. Proteção internacional da pessoa humana: abrange questões referentes ao direito internacional ambiental, direito humanitário, internacionalização do direito, além de pesquisas sobre a evolução do direito dos tratados como forma de expansão do direito internacional contemporâneo.

2. Direito Internacional Econômico: abrange questões referentes aos sistemas regionais de integração, direito internacional econômico e financeiro e solução de controvérsias comerciais e financeiras. A RDI busca incentivar a pesquisa e divulgação de trabalhos relacionados as disciplinas voltadas para o estudo do Direito Internacional publicando artigos, resenhas e ensaios inéditos. A revista está aberta às mais diversas abordagens teóricas e metodológicas impulsionando a divulgação, o estudo e a prática do Direito Internacional.

Comitê editorial

Alice Rocha da Silva, Centro Universitário de Brasília

Cláudia Lima Marques, Universidade Federal do Rio Grande do Sul

José Augusto Fontoura Costa, Universidade de São Paulo

Julia Motte Baumvol, Université de Nice

Nádia de Araújo, Pontíficia Universidade Católica do Rio de Janeiro

Nitish Monebhurrun, Centro Universitário de Brasília

Layout capa

Departamento de Comunicação / ACC UniCEUB

Disponível em:

www.rdi.uniceub.br

Circulação

Acesso aberto e gratuito

Matérias assinadas são de exclusiva responsabilidade dos autores.

Citação parcial permitida com referência à fonte. Ficha catalográfica elaborada pela Biblioteca Reitor João Herculino 
Revista de Direito Internacional / Centro Universitário de Brasília, Programa de Mestrado e Doutorado em Direito, volume 12, número 2 - . Brasília : UniCEUB, 2011- .

Semestral.

ISSN 2237-1036

Disponível também on-line: http://www.rdi.uniceub.br/Continuação de: Revista Prismas: Direito, Políticas Públicas e Mundialização. Programa de Mestrado em Direito do UniCEUB.

1. Direito Internacional. 2. Políticas Públicas. 3. Mundialização. I. Programa de Mestrado em Direito do UniCEUB. II. Centro Universitário de Brasília.

CDU 34(05)

Ficha catalográfica elaborada pela Biblioteca Reitor João Herculino

Endereço para Permuta

Biblioteca Reitor João Herculino

SEPN 707/907 Campus do UniCEUB

Cep 70790-075 Brasília-DF

Fone: 61 3966-1349

e-mail: biblioteca@uniceub.br 


\title{
- Editorial -
}

\section{Edição Especial: Avaliando vinte anos de OMC}

\author{
Editora Especial: Michelle Ratton Sanchez Badin ${ }^{1 *}$
}

O aniversário da Organização Mundial do Comércio (OMC), em 31 de dezembro de 2014, foi pouco alardeado nas mídias nacional e internacional, diante dos impasses em se avançar para a conclusão da Rodada Doha. Mesmo entre os contratempos, há uma tentativa de imprimir a ideia de avanço pelo seu Diretor Geral, Roberto Azevêdo. No último encontro do Conselho Geral da OMC, órgão centralizador das atividades cotidianas da organização, em 10 de dezembro passado, Azevedo anunciou 2015 como um ano especial para a OMC, com a celebração de seus vinte anos e a realização da sua $10^{\mathrm{a}}$. Conferencia Ministerial.

Aos vinte anos a OMC enfrenta os desafios de fechar a Rodada Doha, a pulverização de outros espaços regulatórios, com a expansão dos acordos regionais e preferenciais de comércio, e o impacto no comércio internacional da carência regulatória internacional em outros temas econômicos e sociais. Isso coloca a OMC em xeque nos seus trabalhos internos, no seu âmbito de atuação que é o comércio internacional especificamente, mas também num espaço mais amplo da governança global.

Por outro lado, a OMC conseguiu se valer de um relevante grau de institucionalização no cenário internacional, com a prerrogativa das regras acordadas entre os seus membros. Nesse sentido, a continuidade dos seus trabalhos, sobretudo de acompanhamento e supervisão das políticas comerciais de seus membros, ainda no cenário de retomada da economia internacional após a crise de 2008 , e a credibilidade no funcionamento do seu sistema de solução de controvérsias são pontos de destaque entre os organismos internacionais.

A relevância da organização para a projeção internacional do Brasil e as prerrogativas da sua política externa, em prol do multilateralismo nas relações econômicas internacionais, também traz elementos adicionais para essa analise retrospectiva e prospectiva nos vintes anos de OMC, neste numero da RDI.

Este número especial da RDI convocou, com sucesso, a comunidade acadêmica para refletir, de forma interdisciplinar, sobre o comércio internacional hoje, o papel da OMC na governança do sistema multilateral e seus desafios no século XXI. É com satisfação que publicamos aqui os resultados selecionados a partir desta chamada.

Os artigos que aqui se encontram abordam as temáticas sobre a OMC, seus arranjos e regras, sobre propostas de reforma do sistema multilateral e de sistemas alternativos no debate do comércio internacional, sobre as regras do comércio internacional e os impactos para políticas nacionais de desenvolvimento, bem como sobre evoluções recentes do sistema de solução de controvérsias. Artigos com reflexões teóricas sobre o funcionamento da OMC e o impacto político dos trabalhos desta organização para a inserção internacional de países em desenvolvimento como o Brasil também enriquecem este numero, projetando novas questões sobre a OMC enquanto organismo internacional e seu papel na política internacional.

Esperamos que o numero contribua, assim, para enriquecer o debate nacional sobre o papel do direito no sistema de comercio internacional e a inserção do Brasil neste cenário.

\section{Desejamos uma boa leitura a todos!}

\footnotetext{
* Professora da Escola de Direito da FGV-São Paulo.
} 


\section{CRônicas}

1. Crônicas da ATualidade do Direito Internacional

Nitish Monebhurrun (org.)

Crônica 1: Um panorama sobre as negociações do Pacote de Bali e os seus desdobramentos no âmbito da OMC.......16 Erika Braga

Crônica 2: Incorporação do F.A.T.C.A. - Foreign Account Tax Compliance Act no ordenamento jurídico brasileiro e impactos jurisprudenciais no conceito de sigilo bancário.

Carolina Reis Jatobá Coêlho

Crônica 3: As sanções aplicadas pela União Europeia à Rússia em razão da anexação da península da Crimeia ...24 Tiago Felipe de Oliveira

Crônica 4: International Law and the Curious Case of Scottish Independence .27

Eshan Dauhoo

Crônica 5: Evolution or Procrastination? The Ongoing Debate(s) on the Recognition of the Palestinian State.......30 Nitish Monebhurrun (org)

\section{Crônicas da JURISPRUdênCIA INTERnACIONAL}

Decisões da Corte Internacional de Justiça e do Tribunal Internacional Sobre o Direito do Mar. 34

Nitish Monebhurrun

José Eduardo Siqueira

Questões relacionadas com a apreensão e detenção de certos documentos e dados (Timor Leste c/

Austrália), Medidas Provisórias, 03 de março de 2014

Gleisse Ribeiro Alves

Alice Rocha da Silva

O caso Austrália c. Japão perante a Corte Internacional de Justiça, Decisão, 31 de março de 2014

Liziane Paixão Silva Oliveira

Maria Edelvacy Marinho

Caso do Parecer consultivo do Tribunal Internacional de Direito do Mar de $\mathbf{1}^{\circ}$ de fevereiro de 2011

Gabriela Garcia B. Lima

Comentários ao caso m/v "Virginia " (Panamá c. Guiné-Bissau), 14 de abril de 2014.

Carina Costa de Oliveira

Natália da Silva Gonçalves 
Nitish Monebhurrun

Tema 1: Reflexão sobre os (futuros) acordos brasileiros relativos à proteção dos investimentos: os acordos de

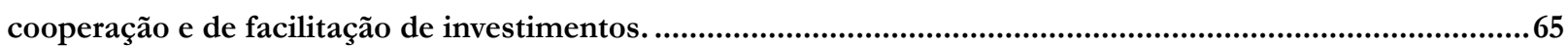

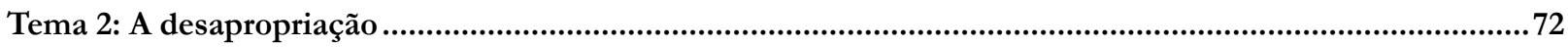

\section{Os Vinte Anos dA OMC}

EXPORT CONTROLS AS INDUSTRIAL POLICY ON NATURAL RESOURCES: REGULATORY LIMITATIONS ON CHINA - RAW MATERIALS AND CHINA - RARE EARTHS CASES .............................................. 78

Gustavo Ferreira Ribeiro

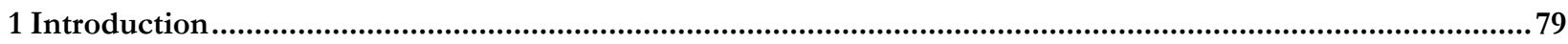

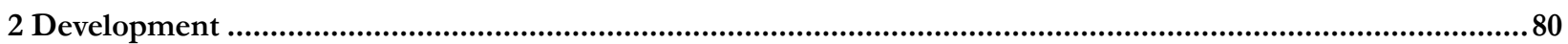

2.1 The rebirth of export controls: from mercantilism to the multilateral system ............................. 80

2.2 The recent cases: China - raw materials and China - rare earths ...................................................81

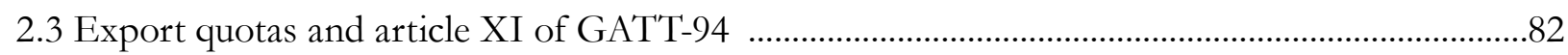

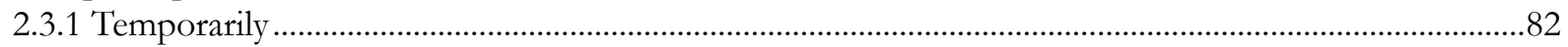

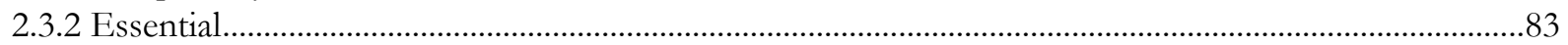

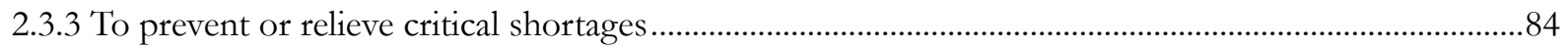

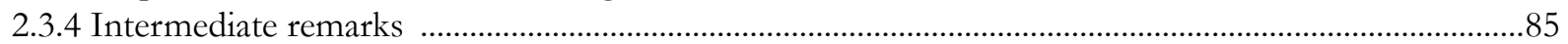

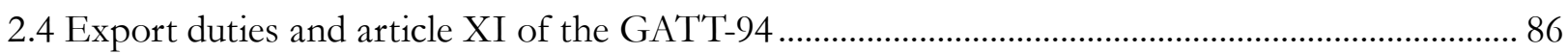

2.5 Export restraints (in various types) and the downstream industry exception: article XX(i)

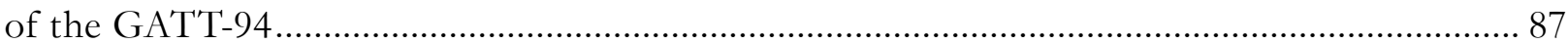

2.6 Export restraints and the general and local shortage exception conditioned by the equity

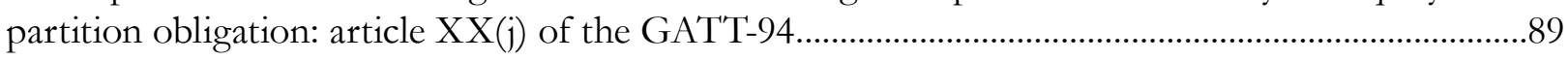

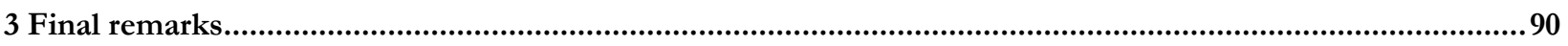

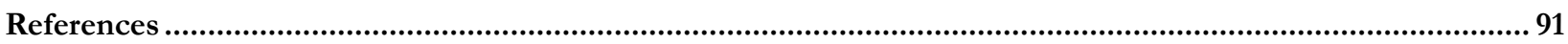

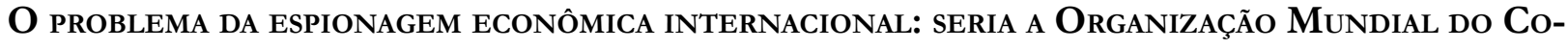
MÉRCIO O FORO ADEQUADO PARA SUA APRECIAÇÃo? ........................................................ 93

Humberto A.Vasconcelos Lima

Naiana Magrini Rodrigues Cunha

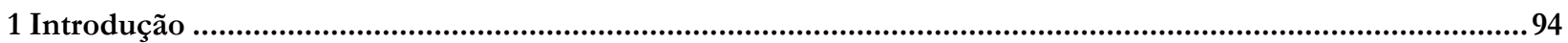

2 Espionagem econômica, propriedade intelectual e comércio internacional ......................................................95

2.1 Espionagem econômica como tema afeto à propriedade intelectual................................................95

$2.2 \mathrm{O}$ vínculo entre propriedade intelectual e comércio internacional................................................96

3 Espionagem econômica diante das normas do acordo TRIPS e do sistema de solução de controvérsias da OMC.....97

3.1 Atos de espionagem econômica violam obrigações assumidas no acordo TRIPS? .......................98

3.2 O órgão de solução de controvérsias da OMC poderia apreciar atividades de espionagem econômica como uma violação a costume internacional? ....................................................................... 100

3.3 Mecanismo de apreciação de reclamações em situações de não violação (Non-violation

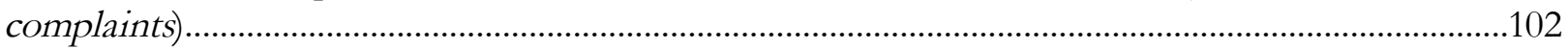

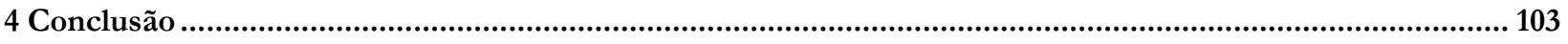

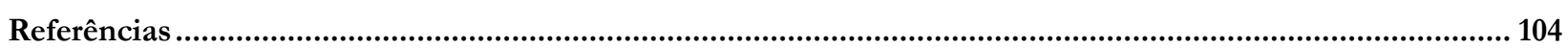


Guihong Zhang

Jiani Jiang

Can Wang

1 Introduction.

2 Transfer of climate-friendly technologies and minimum protection standards for IP ................................... 109

3 Reflection on "Minimum Protection Standards" in the international IP system .............................................112

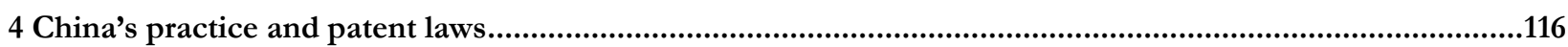

5 Suggestions to Improve the Standards for IP Protection ...................................................................................118

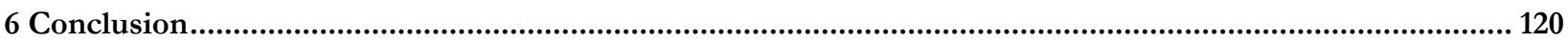

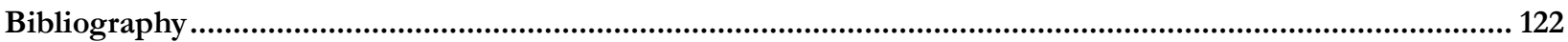

Os vinte anos da OMC, suas conquistas E desafios: uma ANÁlise do Brasil E o Sistema de

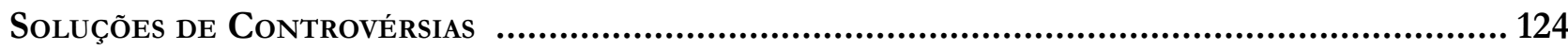

Etiene M. Bosco Breviglieri

Luciano Meneguetti Pereira

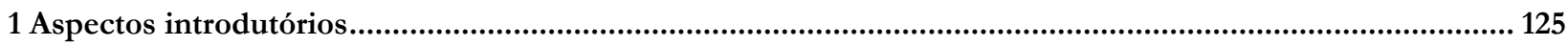

2 A Organização Mundial do Comércio: conquistas e desafios.......................................................................... 125

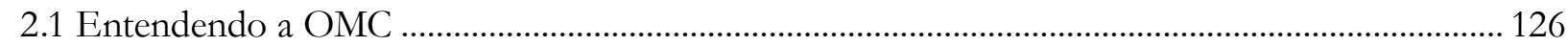

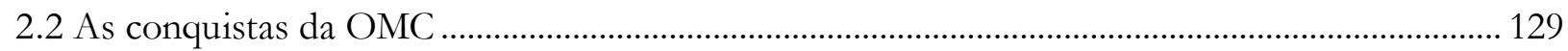

2.3 Os desarranjos e os desafios da OMC na atualidade ..................................................................131

3 O órgão solucionador de controvérsias: conceituação e alcance ........................................................................ 139

4 As soluções de controvérsias na OMC e o Brasil: efetivação do comércio e desenvolvimento de uma política econômico-diplomática ..........................................................................................................................................141

4.1 O Brasil nos Contenciosos da OMC: Aspectos Relevantes.............................................................143

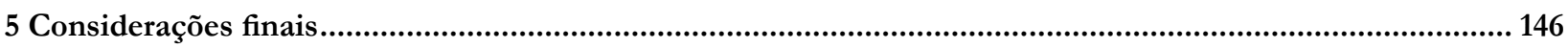

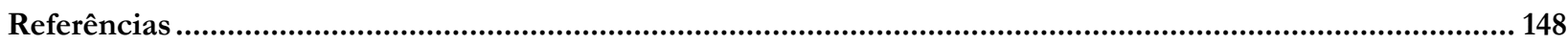

A relaÇão entre os tratados multilaterais ambientais e os acordos da OMC: é Possível

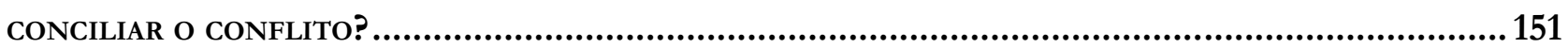

Fabio Costa Morosini, Luisa Zuardi Niencheski

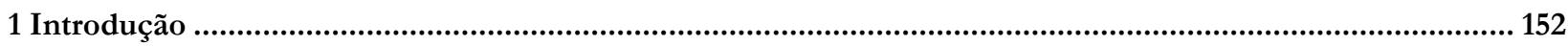

2 Obstáculo para superação: análise do surgimento de conflitos ................................................................... 152

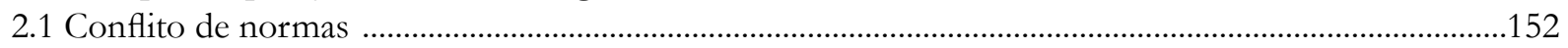

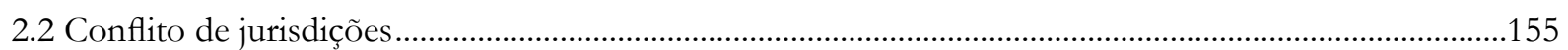

3 Interpretação e integração aplicáveis aos subsistemas do direito internacional .............................................. 156

3.1 Convenção de Viena sobre o Direito dos Tratados: instrumentos à interpretação..................................156

3.2 Aplicação do desenvolvimento sustentável como diretriz interpretativa .................................................159

4 Conciliando medidas restritivas do comércio e objetivos ambientais ..................................................................161

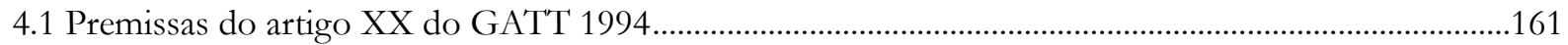

4.2 Incidência prática das exceções ao sistema multilateral comercial ..........................................................162

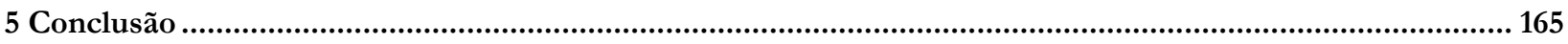

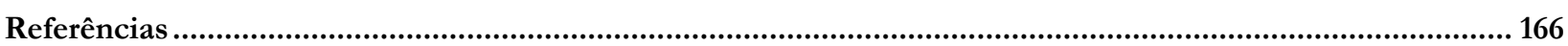


Matheus Linck Bassani

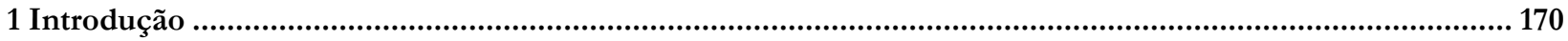

2 Desafios no comércio de energia na Organização Mundial do Comércio .................................................... 170

2.1 Tarifas e outras medidas aduaneiras afetando importação de bens .................................................170

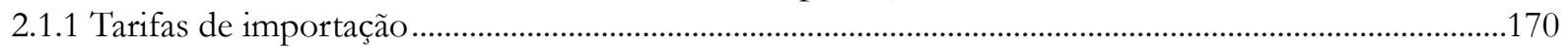

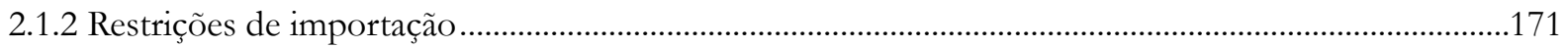

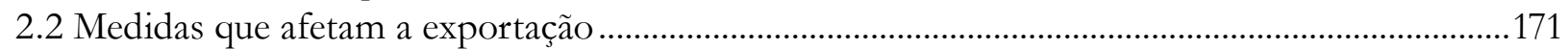

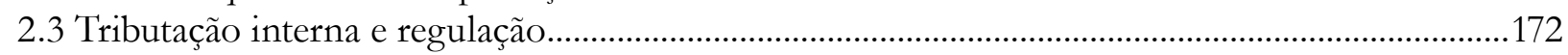

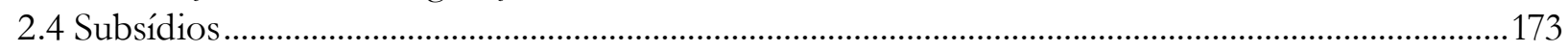

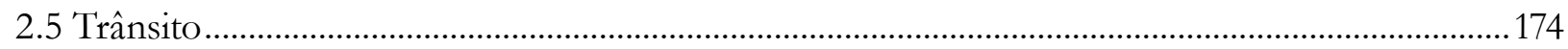

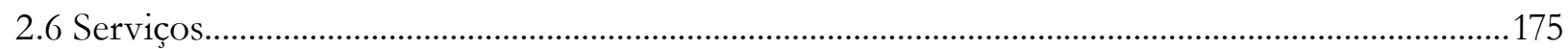

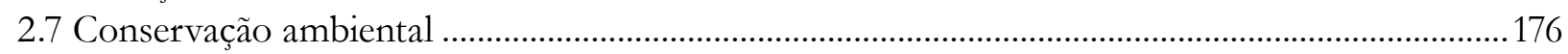

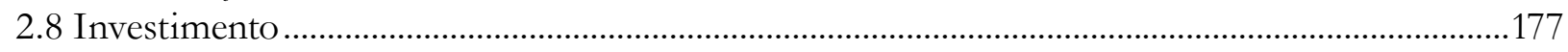

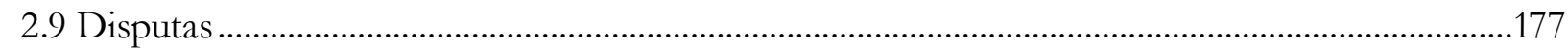

3 Viabilidade de um acordo plurilateral sobre energia .......................................................................................... 180

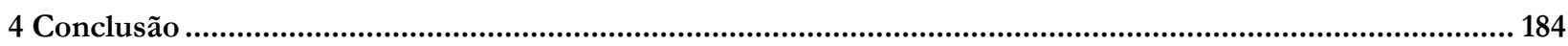

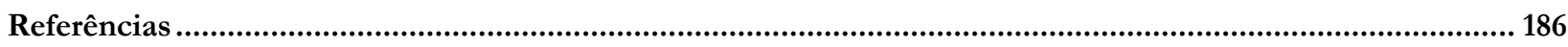

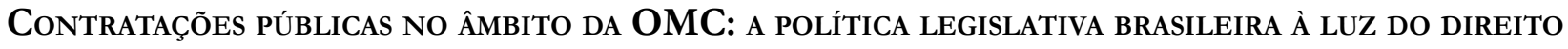

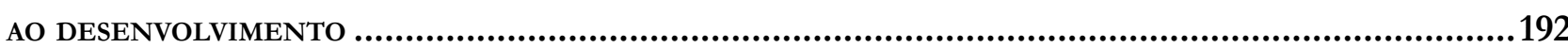

André Jansen do Nascimento

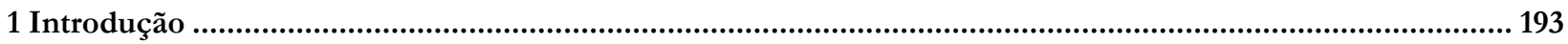

2 Plano normativo da ONU e o direito fundamental ao desenvolvimento ......................................................... 195

3 O direito fundamental ao desenvolvimento na Constituição Federal de 1988................................................... 197

4 Os vinte anos do Agreement on Government Procurement (GPA).................................................................. 199

5 A política legislativa das compras governamentais brasileira: a licitação como instrumento regulatório e

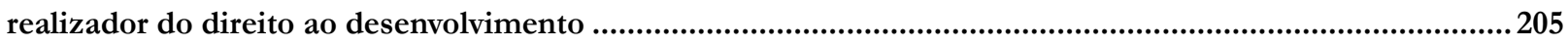

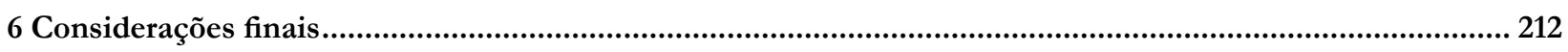

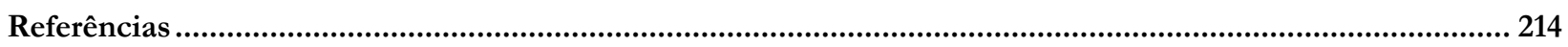

Governança global e a Organização Mundial do Comércio: desafios impostos pelo novo

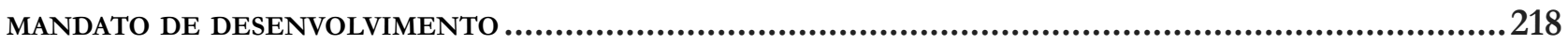

Letícia de Souza Daibert

Ana Luísa Soares Peres

1 Introdução

2 Relevância da governança global para o funcionamento das organizações internacionais .

3 Desenvolvimento das organizações internacionais de finalidade específica no século xx: governança e mudanças paradigmáticas motivadas pelo adensamento das relações internacionais...

4 A OMC como agente fomentador de uma governança global em matéria de comércio internacional e desenvolvimento econômico

4.1 Interpretação dos acordos da OMC: reconhecimento da existência de valores compartilhados pelos membros da organização 


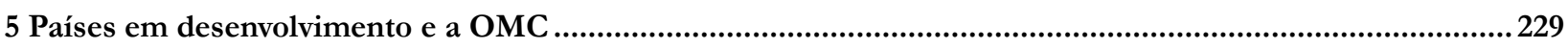

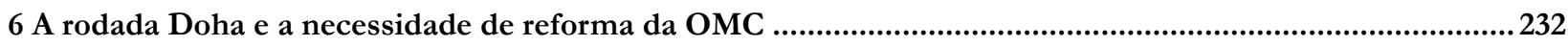

6.1 Reforma do processo de tomada de decisão ....................................................................................... 232

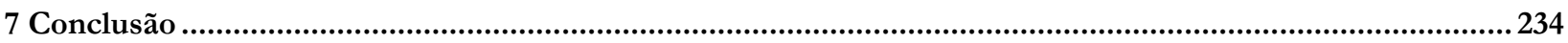

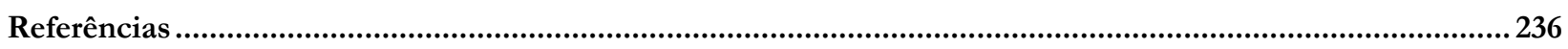

Vinte Anos de Crise para a África? Poder, Assimetrias e a Abordagem Liberal da OMC.....239 Igor Abdalla Medina de Souza

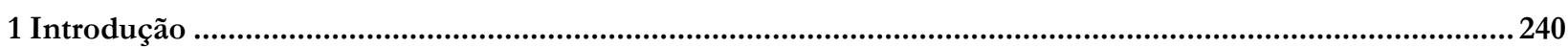

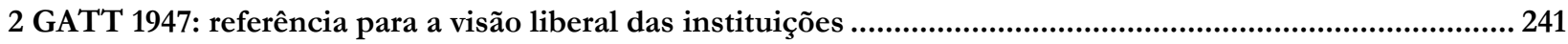

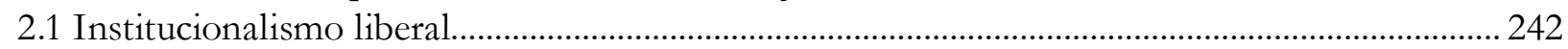

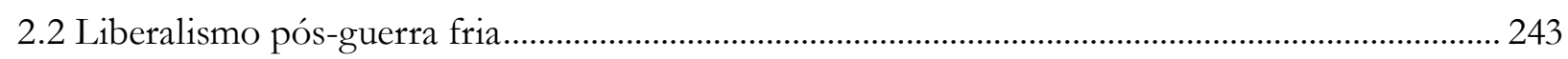

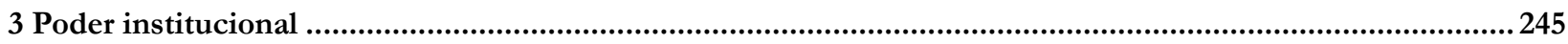

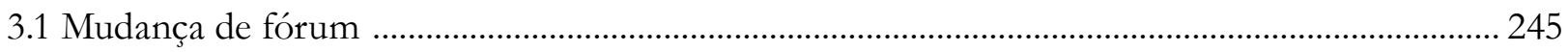

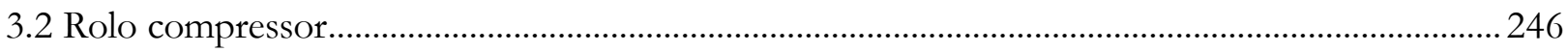

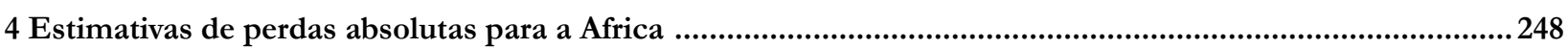

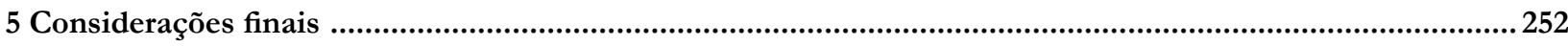

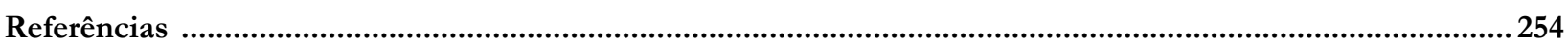

OS MECANISMOS DE INDUÇão AO CUMPRIMENTO NO ÂMBITO DA OMC .....................................258

Fernando Lopes Ferraz Elias

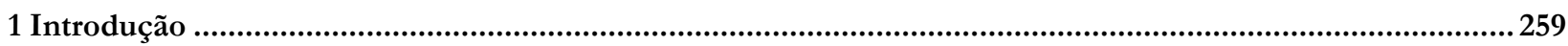

2 Entre a política e o direito, a implementação das regras e das decisões da OMC ...........................................260

3 Fatores que influenciam o descumprimento das regras e das decisões da OMC pelos países desenvolvidos 263

4 Fatores que influenciam o descumprimento das regras e das decisões da omc pelos países em

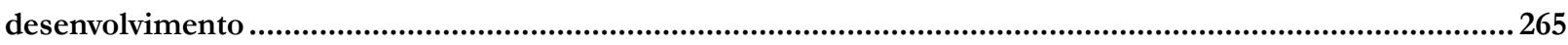

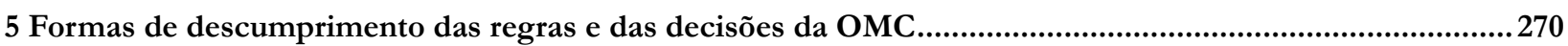

6 Análise de dados e estatísticas pertinentes ao cumprimento das regras e das decisões da OMC .................... 271

7 Propostas e perspectivas de aprimoramento do cumprimento das decisões da OMC .......................................273

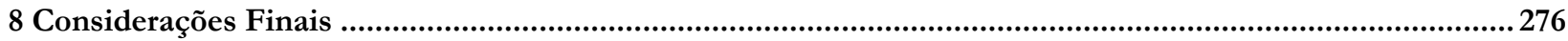

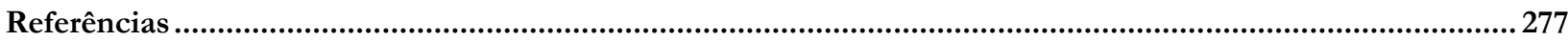

\section{A promoção de accountability na Organização Mundial do Comércio: uma análise hori-} ZONTAL E VERTICAL

Celso Henrique Cadete de Figueiredo

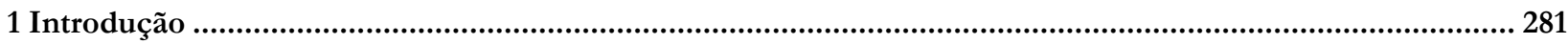

2 As dificuldades da aplicação da accountability na governança global.............................................................. 283

3 Para quem a OMC deve promover accountability? ..............................................................................................286

4 Elementos de accountability no plano horizontal ............................................................................................28

4.1 O componente legislativo como elemento de estabelecimento de padrões ..................................28

4.2 O Mecanismo de Revisão de Políticas Comerciais como cerne no monitoramento e na difusão de informações através da transparência ..........................................................................................2290

4.3 Órgão de Solução de Controvérsias como elemento de aplicação de sanções ............................. 291 
5 Elementos de accountability na OMC sob uma perspectiva vertical

5.1 A participação da sociedade civil na OMC .......................................................................294

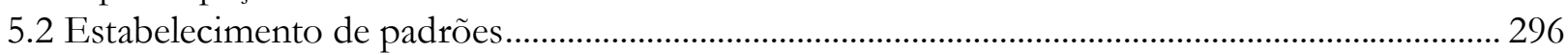

5.3 Transparência na prática de difusão de informações ..............................................................297

5.4 A participação da sociedade civil no processo de enforcement das regras pelo Órgão de

Solução de Controvérsias ...............................................................................299

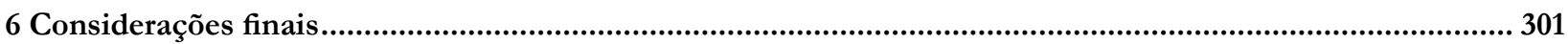

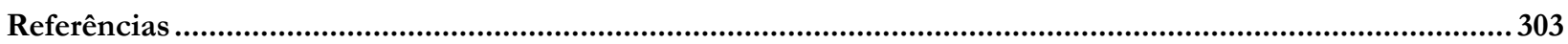

LA OMC Y EL PROCESO DE GLOBALIZACION DE LA REGULACIÓN ALIMENTARIA ..................................307

Maria Eugenia Marichal

$1 \mathrm{La}$ emergencia de un régimen alimentario global ...........................................................................308

2 El Codex Alimentarius y su articulación con la OMC ..................................................................309

3 El sustento científico subyacente a la regulación alimentaria del complejo OMC e Codex Alimentarius...... 312

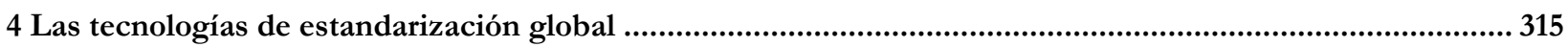

4.1 La metodología de análisis de riesgos alimentarios .................................................................315

4.2 La implementación de Sistemas Nacionales de Control Alimentario ........................................317

5 Algunas problemas y límites del régimen global alimentario .............................................................. 319

O ACORDO GATS E SUA APLICAÇÃo AOS SERVIÇOS DO COMÉRCIO ELETRÔNICO ................................322

Gleisse Ribeiro Alves

1 Introdução 323

2 A classificação dos serviços do comércio eletrônico ...........................................................................324

3 A implementação efetiva das recomendações e decisões do OSC no domínio dos serviços do comércio

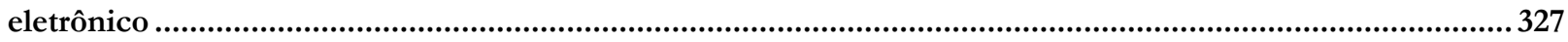

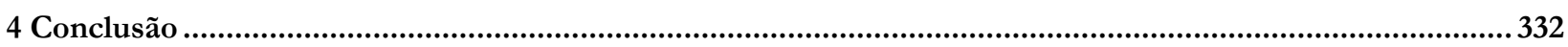

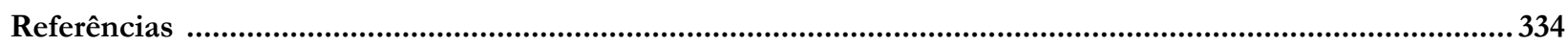

A OMC E O REgIONALISMO do SÉculo XXI: ESTRATÉGIA DE IMPOSIÇÃo de MODELOS NORMATIVOS? .. 337

Camilla Capucio

1 Introdução: a OMC e o regionalismo..............................................................................................338

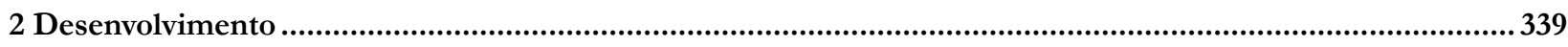

2.1 A dicotomia superada: stumbling blocs e building blocs ...........................................................339

$2.2 \mathrm{O}$ regionalismo do século XXI como vetor para imposição de modelos normativos ............... 341

2.3 Os modelos normativos europeus e norte-americanos ............................................................ 342

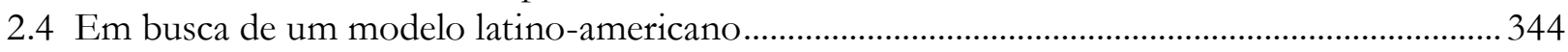

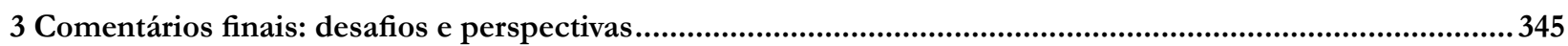

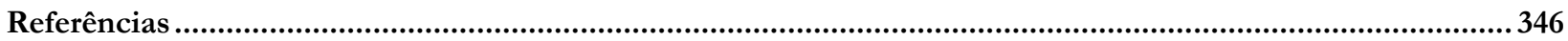

A ORGANIZAÇÃo MUNDIAL do COMÉRCIO E A CHINA: DIREITO DE PROPRIEDADE E PROPRIEDADE INTELECTUAL NO PAÍS

Lucas Costa dos Anjos

1 Considerações iniciais 350

2 Direito de propriedade na China 


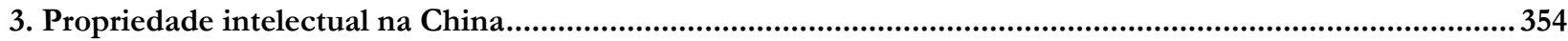

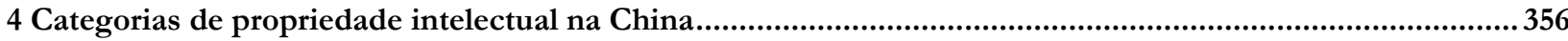

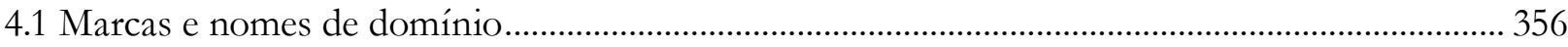

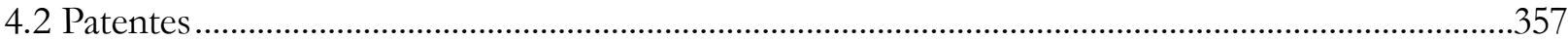

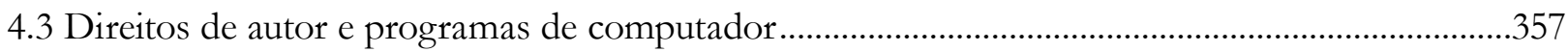

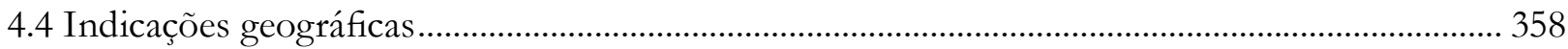

5 Considerações finais: implementação de padrões mínimos de proteção, adequação internacional e inovação na

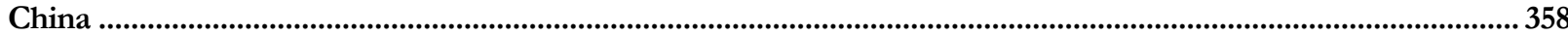

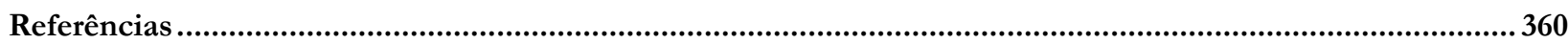

Dos contenciosos na OMC com ENFoque EM RESTrições Às EXPORTAÇões dA China .................363

\section{Marco Antônio Alcântara Nascimento}

1 Introdução .364

2 Restrições às exportações no Sistema Multilateral de Comércio: um novo (velho) tema a ser enfrentado......366

3 Antecedentes recentes dos contenciosos da China: a construção da "diplomacia das matérias-primas”, com atuação destacada Organização para Cooperação e Desenvolvimento Econômico...........................................369

4 Dos contenciosos na OMC: casos China-Matérias-Primas (CMP) e China-Terras-Raras (CTR) ................... 372

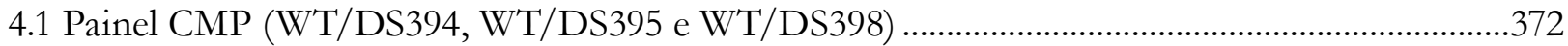

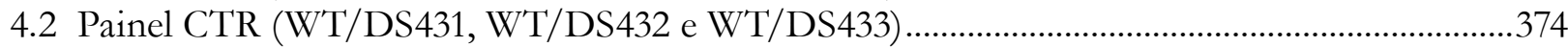

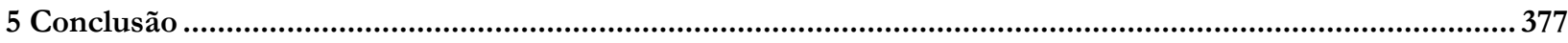

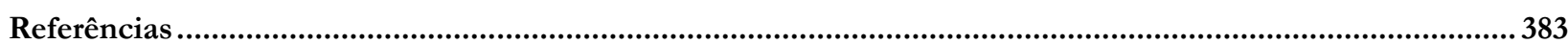

O redimensionamento da OMC no trato dos Acordos Comerciais Regionais........................387

Alice Rocha da Silva

1 Introdução .388

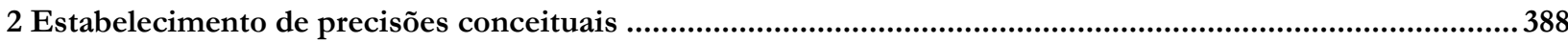

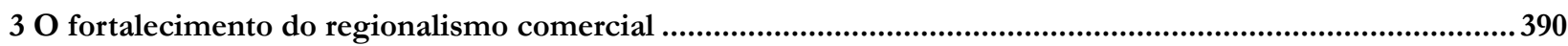

4 A proliferação de mecanismos de solução de controvérsias previstos em ACR …………………………….......392

5 Os efeitos da proliferação de ACR para o sistema multilateral de comércio da OMC ......................................393

6 O papel da OMC e do multilateralismo para a governança mundial aliada a novos arranjos regionais ...........396

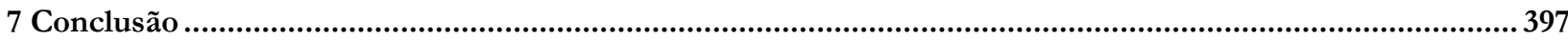

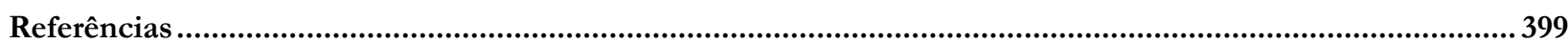

\section{Outros Temas}

Derechos Humanos en la REALIDAd aCtual: LA GLOBALIZACión y El MUlticulturalismo

David Falcão

1 Introducción.

2 Globalización: Sus implicaciones en el debate acerca de Derechos Humanos .........................................404

3 Multiculturalismo: El cáncer de los Derechos Humanos versus un pluralismo integrador razonable ........... 406

4 La amenaza multiculturalista a la integración respetuosa ............................................................407

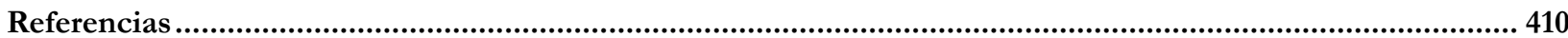


IMUNIDADE DE JURISDIÇÃo do EsTADO E REPARAÇÃo CIVIL PELA PRÁtICA DE TORTURA: O CASO ZAHRA

Patrícia Maria Lara Abreu

Rodrigo Otávio Bastos Silva Raposo

1 Introdução 412

2 O caso Kazemi e a disputa entre jus cogens e imunidade de jurisdição. 414

2.1 O assassinato de Zahra Khazemi e a busca por reparação civil na justiça canadense 415

2.2 A disputa entre as categorias jus cogens e imunidade de jurisdição no caso Kazemi 416

3 O assassinato da Sra. Kazemi não é justiciável, mas o dano causado a seu filho o é: o caso na Quebec

Superior Court

3.1 A proibição da tortura como jus cogens e o Canada State Immunity Act.

3.2 Os danos sofridos pelo herdeiro e a hipótese de competência do art. 6(a) do Canada State Immunity Act.

$4 \mathrm{O}$ dano causado ao herdeiro não permite fixar a jurisdição canadense: o caso na Quebec Court of Appeal...... 425

4.1 A Constituição canadense interpretada à luz do jus cogens: razões para indenizar o espólio.........425

4.2 Dano moral não configura a hipótese de competência do art. 6(a) do Canada State Immunity Act. a reversão da decisão da Quebec Superior Court.

5 A limitação à responsabilização patrimonial do estado estrangeiro pela prática de atos de tortura não afronta a sociedade democrática de direito: o caso na Supreme Court of Canada .428 5.1 Hipóteses de exceção à imunidade de jurisdição e a qualificação da prática de tortura como ato oficial do Estado: impedimentos infraconstitucionais à desconsideração da imunidade de jurisdição.429 5.2 A limitação ao direito de reparação em casos de tortura é compatível com a sociedade democrática de direito: a constitucionalidade do SIA.

6 CONCLUSÃO

Referências.

Da NACIONALIDAdE COMO DIREITO HUMANO: DA NECESSÁRIA AMPLIAÇÃo DAS HIPÓTESES DE APLICAÇÃo DO CRITÉRIO DO JUS SANGUINIS NOS CASOS DE ADOÇÃo INTERNACIONAL.

Hitala Mayara Pereira de Vasconcelos

1 Introdução

2 Da evolução do conceito de nacionalidade: do mero reflexo da soberania estatal para a noção de direito humano ...438

30 princípio da proteção ao interesse superior da criança e seus efeitos em matéria de nacionalidade nas hipóteses de adoção internacional

4 Da postura do Brasil quanto ao reconhecimento da nacionalidade brasileira nos casos de adoção internacional.

5 Conclusão 449

Referências.

INTERREgIONAL ORgANIZATIONS (IROS) IN EUROPE: NEW SUBJECTS OF CONTEMPORARY INTERNATIONAL LAW?.

Davorin Lapas

1 Introduction

2 Interregional organizations (IROs) - new forms of institutionalized sub-state co-operation in Europe.

2.1 European Groupings of Territorial Cooperation (EGTCs) and Euroregional Co-operation

Groupings (ECGs) 


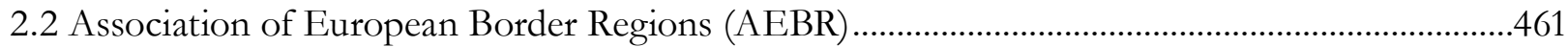

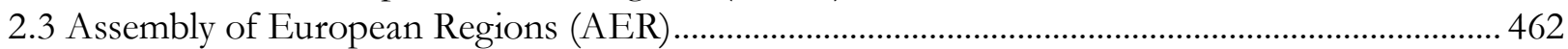

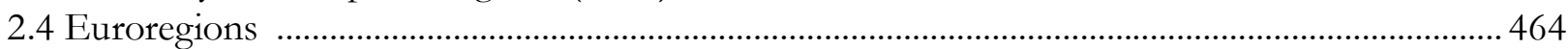

3 Hybrid or quasi-IROs (QUAIROs) - shared membership for states and sub-state entities ............................. 467

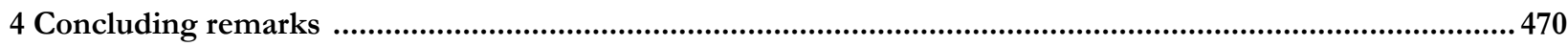

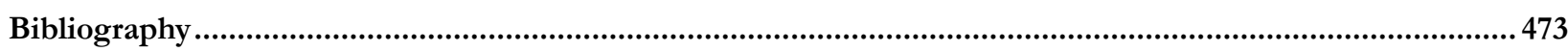

A CONEXÃo ENTRE OS DIREITOS HUMANOS E A CORRUPÇÃo ........................................................477

Gabriela Alves Mendes Vieira

Marcelo Dias Varella

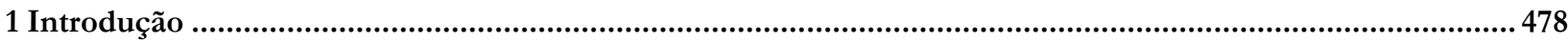

2 A difícil conceituação da corrupção e as suas implicações ...............................................................................478

2.1 Os conceitos trazidos pelos principais instrumentos legais de combate à corrupção .................478

2.2 Instrumentos legais de combate à corrupção ................................................................................ 480

2.3 Quadros internacionais e outros instrumentos que relatam a corrupção e os direitos humanos ...... 483

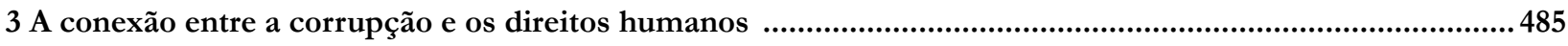

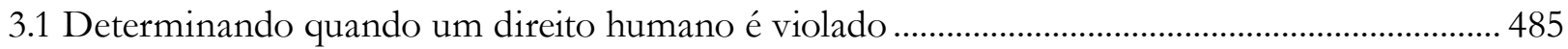

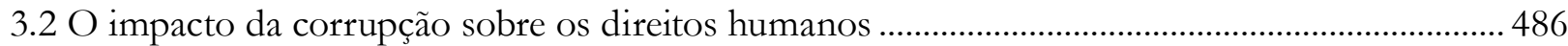

3.3 Conectando a corrupção a um direito humano específico.......................................................... 489

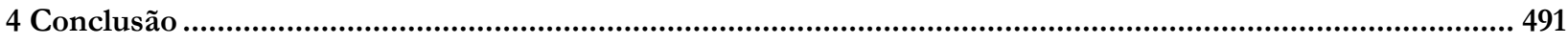

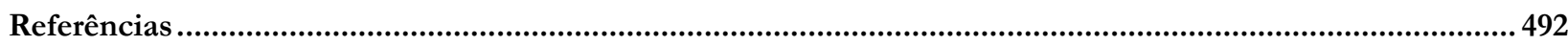

GRUPO DE SOCIEDADES: INSTRUMENTO JURÍDICO DE ORGANIZAÇÃO DA EMPRESA PLURISSOCIETÁRIA.....495

Daniel Amin Ferraz

1 Introdução

2 Breve tipologia do grupo de sociedades e suas distinções jurídico-doutrinárias: instrumento societário ou

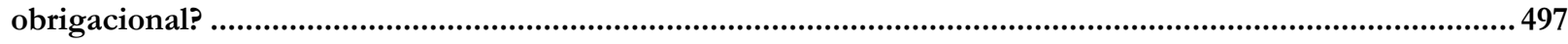

3 O grupo de sociedades de base societária e outros instrumentos de concentração empresarial ......................497

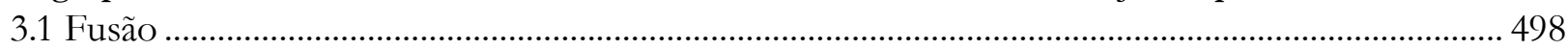

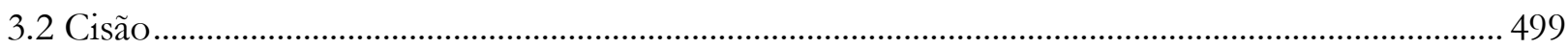

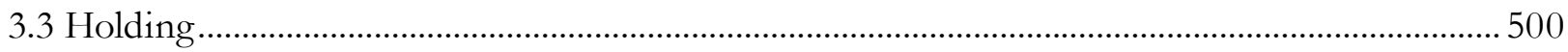

$4 \mathbf{O}$ grupo de sociedades e a Joint Venture........................................................................................................................... 501

4.1 A joint venture e as relações internacionais ...................................................................................... 501

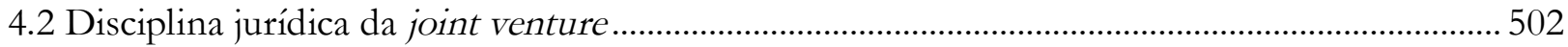

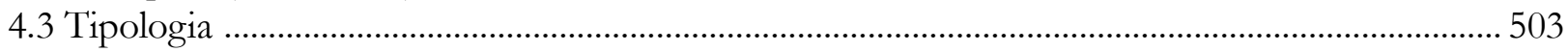

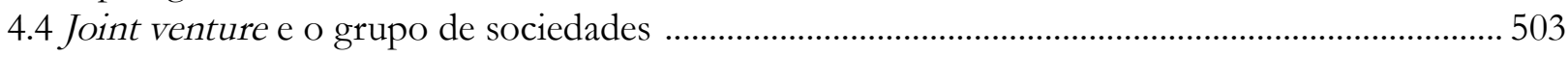

5 Conclusão: o grupo de sociedades e as relações de domínio múltiplo ...........................................................504

Referências ........................................................................................................................................................................... 507 


\section{CRÔNICAS DA ATUALIDADE DO DIREITO INTERNACIONAL}

Nitish Monebhurrun (org.)*

Crônica 1: um panorama sobre as negociações do Pacote de Bali e os seus desdobramentos no âmbito da OMC (Erika Braga Justo).

Crônica 2: incorporação do F.A.T.C.A. - Foreign Account Tax Compliance Act no ordenamento jurídico brasileiro e impactos jurisprudenciais no conceito de sigilo bancário. (Carolina Reis Jatobá Coêlho).

Crônica 3: as sanções aplicadas pela União Europeia à Rússia em razão da anexação da península da Crimeia. (Tiago Felipe de Oliveira).

Crônica 4: international Law and the Curious Case of Scottish Independence. (Eshan Dauhoo).

Crônica 5: evolution or Procrastination? The Ongoing Debate(s) on the Recognition of the Palestinian State. (Nitish Monebhurrun).

\section{Crônica 1: Um panorama sobre as negociações do Pacote de Bali e os seus desdobramentos no âmbito da OMC}

Erika Braga**

$\mathrm{Na}$ dinâmica mundial de (re)acomodação de poderes, a OMC exerce um importante papel. É um foro multipolar que abandona a então bipolaridade existente nas décadas anteriores à sua constituição. $\mathrm{O}$ jogo entre duas potências cede espaço para novos integrantes, que, dentro do contexto das negociações de comércio internacional, são contemplados com a igualdade jurídica no modelo decisório da Organização Mundial do Comércio.

É certo que a igualdade jurídica não representa uma isonomia de poderes - o que limita a efetividade do equilíbrio entre as partes —, mas isso não minimiza a relevância desse avanço. O sistema multilateral combate o regionalismo fechado, indicador de tendências conflitivas no cenário internacional por seu caráter de exclusão. A escalada de tensões e os desentendimentos entre Estados são algumas das marcas da bipolaridade e do regionalismo fechado, ambos remodelados na atualidade pela multipolaridade emergente. Essa recente tendência de equilíbrio permite o protagonismo de diversos atores, muitas vezes fortalecidos por grupos de concertação, como demonstra a atuação destacada dos países em desenvolvimento.

É sob esse prisma que o marco normativo único da OMC se mostra estratégico. O processo de negociação alicerçado pelo "single undertaking" abole a possibilidade de escolha de normas à la carte. Anteriormente, sob a égide do GATT 47, a cada Estado era facultado o direto de optar e se comprometer apenas com os acordos que fossem convenientes aos seus exclusivos interesses. Nos moldes atuais, os Estados Membros vinculam-se imperativamente a todas as regras ${ }^{1}$, em igualdade de direitos e deveres.

** Advogada, Mestre em Direito Internacional Econômico (Escola de Direito da Sorbonne, Paris). erikabjusto@yahoo.com.br
* $\mathrm{PhD}$ in International law (School of Law of Sorbonne, Paris), Associate Professor (University Centre of Brasília), Visiting Professor (Universidad de la Sabana, Bogotá). Nitish.monebhurrun@gmail.com

\footnotetext{
1 Apenas quatro acordos se limitam a um grupo restrito de signatários. São relativos às seguintes matérias: comércio de aeronaves civis, compras governamentais, laticínios e carne bovina.
} 
O preço a ser pago corresponde à maior dificuldade em se finalizar um acordo. ${ }^{2} \mathrm{O}$ peso do poder político de cada Estado membro - ou a falta dele - se contrasta com a igualdade jurídica garantida pelo arcabouço legal. É um embate geopolítico, em última instância. Por isso a importância dos sistemas multilaterais, capazes, não de superar o desnível do poder político e econômico, mas de garantir um mecanismo jurídico apto a promover uma melhor pulverização de forças no cenário global.

A Rodada de Doha é um reflexo dessa balança. A sua paralisia chegou a colocar em xeque o futuro da própria instituição. Sinais de evolução foram dados na IX Conferência Ministerial ${ }^{3}$ ocorrida em dezembro de 2013 em Bali, conduzida pelo brasileiro Roberto Azevêdo, diretor-geral da OMC.

A IX Conferência Ministerial era aguardada como a mais importante em muitos anos. Os seus resultados moldariam o futuro da organização e do sistema global de comércio. As questões enfrentadas envolviam temas complicados, razão pela qual o Pacote de Bali, em caso de fracasso, comprometeria a capacidade da OMC para negociar acordos futuros. Um elemento importante inserido no debate foi o risco de exclusão dos países menos desenvolvidos em face de uma paralisia das negociações multilaterais. Além de caracterizar um retrocesso, cederia mais espaço para a realização de acordos bilaterais - excludentes por natureza. Um passo importante, portanto, deveria ser dado na direção da retomada da Rodada de Doha.

Numa atmosfera de tensão, anunciou-se o avanço. O Pacote de Bali foi divulgado como um sucesso diplomático e a superação de alguns pontos nevrálgicos que bloqueavam a evolução das negociações (I). Após a conclusão dos trabalhos formalizados pela Decisão Ministerial de 7 de dezembro de 2013, a Índia, com uma nova composição de governo, recua, valendo-se do veto ao Acordo sobre a Facilitação do Comércio para barganhar outros pontos ainda pendentes de consenso, especificamente, a flexibilização dos Estoques Públicos de Alimentos para fins de Segurança Alimentar (II).

\footnotetext{
2 As dificuldades impostas por esse modelo decisório desafiam os Estados a encontrar um caminho jurídico alternativo, sem depender da anuência de um número tão elevado de partes. $\mathrm{O}$ aumento significativo de Acordos de Livre Comércio (Free Trade Agreements) celebrados por membros da OMC é indicador de que há uma tendência de bifurcação das normas internacionais de comércio, até certa medida, por meio do bilateralismo.

3 A Conferência Ministerial é o órgão de decisão supremo na OMC, que se reúne a cada dois anos.
}

\section{a. Os resultados da IX Conferência Ministerial de Bali}

O chamado "Pacote de Bali" representou uma vitória diante do congelamento das negociações na Rodada de Doha e, pontualmente, das controvérsias acerca das reformas propostas durante a IX Conferência Ministerial de Bali.

A tensão maior foi gerada por posições divergentes entre os Estados Unidos e a Índia. O debate mais crítico circunscreveu-se ao tema sobre Subsídios e Estoque de Alimentos para fins de Segurança Alimentar (A), ameaçando, inclusive, o êxito do Acordo sobre Facilitação do Comércio (B).

\section{- A "cláusula de paz" como mecanismo de flexibilização favorável aos países em desenvolvimento em casos de Estoque de Alimentos para fins de Segurança Alimentar}

As negociações sobre questões agrícolas são as mais complexas no comércio internacional. A polarização entre os países desenvolvidos e o grupo de países em desenvolvimento ganha realce quando o objeto de novas regulamentações é a proteção à agricultura de cada Estado membro. Se, por um lado, os países em desenvolvimento produtores e exportadores de commodities agrícolas defendem uma legislação mais rígida contra a proteção dos produtores nacionais, do lado oposto estão os países desenvolvidos. A razão é simples e a solução mostrase distante: uma legislação mais rígida impediria que grandes potências continuassem a subsidiar significativamente a produção agrícola nacional, e a falta de competitividade de seus produtores internos seria uma das consequências diretas, abarcando todos os respectivos efeitos danosos.

No caso em questão, entretanto, foi o posicionamento da Índia que, por muito pouco, não levou as negociações ministeriais de Bali ao colapso. A ausência de acordo sobre a vigência da cláusula de paz no âmbito dos subsídios e de estoque de alimentos para a segurança alimentar foi o motivo do impasse (i). O temido fracasso foi evitado nas últimas horas, quando as partes chegaram a um consenso após muita articulação e consultas feitas pelo diretor-geral Roberto Azevêdo (ii).

(i) O impasse provocado pela Índia durante as negociações da cláusula de paz

4 Declaração ministerial de Bali: WT/MIN(13)/DEC. 
A segurança alimentar é um dos temas sensíveis para Estados com grandes dimensões e densidade populacional. Quando se trata de uma negociação de normas vinculantes que possivelmente atingem essa questão, a postura, naturalmente, é de defesa e menor disponibilidade de transação.

Esse foi o tenso e inesperado cenário enfrentado em Bali, pois as negociações prévias realizadas em Genebra apontavam para um consenso entre as partes (a). O fator surpresa foi o recuo da Índia (b).

\section{(a) Os rascunhos Pré-Bali}

As reformas propostas sobre subsídios agrícolas para estocagem de alimentos para fins de segurança alimentar foram o motivo da controvérsia. Em novembro de 2012, o G-33, composto por países em desenvolvimento e liderado pela Índia, havia proposto a flexibilização da regra: os países em desenvolvimento deveriam ter maior margem de manobra para subsidiar a compra de alimentos e a sua respectiva estocagem quando a finalidade fosse garantir a segurança alimentar, sem que a distorção de mercado resultante se configurasse em um ilícito comercial.

Diante da complexidade, como é peculiar às matérias relacionadas ao Acordo sobre Agricultura, o tempo seria escasso para negociar uma emenda até a data da IX Conferência Ministerial em Bali. De maneira paliativa, os Estados trabalharam sobre um texto legal que garantisse uma solução interina: os membros, temporariamente, se absteriam de apresentar uma queixa legal e de iniciar uma disputa no Órgão de Solução de Controvérsias na hipótese de distorções de mercado provocadas pelas políticas praticadas por países em desenvolvimento comprometidas com segurança alimentar. A esse compromisso foi dado o nome de "cláusula de paz".

Dessa forma, o rascunho do acordo foi aprovado por todos os membros e a IX Conferência Ministerial de Bali seria apenas o palco para a formalização.

\section{(b) O recuo da Índia durante a IX Conferência Ministerial de Bali}

O governo indiano, no decorrer dos trabalhos em Bali, obteve papel de destaque ao se posicionar contrário à versão do texto, alegando que a segurança alimentar seria inegociável ${ }^{5}$. A controvérsia instalou-se precisamente sobre o termo "solução interina", cujo teor indica que a vigência da cláusula de paz seria temporária. É importante mencionar que os Estados Unidos, bem como outros membros, ainda em Genebra, haviam condicionado a aceitação desta cláusula à existência de um prazo limite para a sua validade.

Diante disso, todas as outras negociações, a exemplo desta, também foram prejudicadas, dada a insistência da Índia em impedir qualquer prosseguimento do texto nos termos acordados em Genebra. O resultado do dissenso dependeria de uma questão técnica e, principalmente, da vontade política dos envolvidos. A interpretação jurídica do termo "solução interina" seria, portanto, a chave do sucesso ou do fracasso da Ministerial de Bali.

Para a Índia, significaria um compromisso vigente até que uma solução permanente fosse encontrada pelos membros, consensualmente. Para os Estados Unidos, alinhados aos outros membros que receavam o provável impacto da aplicação da cláusula de paz por tempo indeterminado, "solução interina" não poderia ser entendida como algo diferente de uma medida com prazo-limite definido.

\section{(ii) A articulação diplomática e a solução apresentada}

Em face deste desafio, reuniões de bastidores foram articuladas a fim de superar esse impasse que significaria uma séria crise institucional no seio da OMC —, considerando-se a já grave paralisia da agenda de Doha.

$\mathrm{Na}$ tentativa de resgatar o Pacote de Bali, consultas foram feitas entre Roberto Azevêdo, os Estados Unidos e a Índia. Nesse momento, a Índia já não sustentava uma posição comum ao G-33, o que aumentava a pressão sobre ela. Algumas alternativas, pendentes de validação pelos outros membros, foram apresentadas pelo diretor-geral, mas não foram aceitas pelo governo indiano.

No entanto, apesar da iminência de uma "tragédia institucional", um consenso foi anunciado no último dia da IX Conferência Ministerial. A saída encontrada foi mais diplomática do que jurídica. O texto da solução proposta por Roberto Azevêdo e aceito pelas partes registra o compromisso dos membros em negociar uma

5 http://pt.ictsd.org/bridges-news/pontes/news/ subs $\%$ C $3 \%$ ADdios-e-estoque-de-alimentos-tema-decisivo-nopacote-de-bali 
solução permanente até a XI Conferência Ministerial de 2017, com a vigência da cláusula de paz até esta data. A revisão também restringe o alcance do acordo apenas às políticas de armazenagens já existentes.

A partir dessa vitória diplomática, o caminho ficou livre para a finalização do acordo principal, referente à facilitação do comércio.

\section{B) A conclusão do Acordo sobre Facilitação de Comércio}

Com o Acordo sobre Facilitação do Comércio ${ }^{6}$ sugere um revigoramento da quase fracassada Rodada de Doha. Em quase vinte anos, foi o primeiro acordo multilateral concluído pelos Estados membros da OMC, que cria compromissos vinculantes em operações de importação e exportação.

Trata-se de regras para o estabelecimento de critérios mais transparentes e ágeis no processamento de documentos, bem como a simplificação e redução de requisitos nas transações de comércio exterior. Especialistas demonstram que a harmonização dos procedimentos e a maior eficiência decorrente das novas regras podem significar um ganho superior à redução tarifária?.

Não há dúvidas quanto à dupla importância desse acordo. Em termos econômicos, tem o potencial de promover um aumento real da circulação internacional de mercadorias e do PIB global. Em termos jurídicos e diplomáticos, representa uma vitória - mesmo que parcial - para o multilateralismo da OMC, que vinha sendo fortemente questionado e ameaçado pela sua ineficaz Rodada de Doha.

Considerada a relevância do Acordo de Facilitação Comercial em ambos os aspectos mencionados, podese visualizar a dimensão do problema causado pelo veto da Índia no âmbito do Acordo sobre Agricultura. O impasse paralisou toda a agenda de negociações e colocou em risco o avanço de uma das peças principais do Pacote de Bali.

Apesar de todas as dificuldades, a IX Conferência Ministerial entregou o Pacote de Bali com os progressos comerciais, jurídicos e diplomáticos esperados. Estabeleceu-se 31 de julho de 2014 como

\section{$6 \quad \mathrm{WT} / \mathrm{MIN}(13) / 36$}

7 Os benefícios ainda dependem da ratificação do Acordo e da implementação das medidas, que demandam reformas institucionais e ajustes nos sistemas aduaneiros. data limite para se adotar o Protocolo de Emenda do Acordo sobre Facilitação do Comércio, elaborado pelo Comitê Preparatório durante a reunião do Conselho Geral. Nessa data, o Protocolo seria aberto à aceitação até 31 de julho de 2015. A surpresa indigesta veio em julho de 2014, meses após a conclusão do Pacote de Bali. Novamente a Índia tem o protagonismo ao vetar o acordo, bloqueando não só a sua evolução como a de todos os outros temas, inclusive a Agenda de Desenvolvimento de Doha.

\section{O Pacote de Bali e seus desdobramentos}

\section{A. O novo recuo da Índia e a comunicação de mais um veto}

Concluído o Pacote de Bali, iniciaram-se os trabalhos do Comitê Preparatório sobre Facilitação do Comércio, encarregado de realizar um exame jurídico de caráter formal, com o escopo de garantir o funcionamento eficiente do Acordo. Um Protocolo de Emenda deveria ser apresentado em 31 de julho de 2014, durante a reunião do Conselho Geral, quando começaria o prazo para aceitação do Acordo sobre Facilitação do Comércio como parte do conjunto de normas vinculantes da OMC.

Próximo ao prazo limite, a Índia manifestou-se contrária à continuidade dos trabalhos, e as mesmas questões superadas em Bali foram resgatadas. Especificamente, indicou que não aceitaria o Protocolo enquanto não houvesse uma solução permanente sobre a flexibilização das regras nos casos de estoques públicos de alimentos para fins de segurança alimentar.

Todo o trabalho realizado em Bali perderia sua eficácia. Sob o prisma jurídico, o Acordo sobre Facilitação do Comércio — o maior avanço nos últimos 20 anos da organização - não poderia, sequer, ser ratificado pelos Estados membros. Essa foi a estratégia da Índia, barganhar usando o vínculo político entre os dois instrumentos jurídicos: Acordo sobre Facilitação do Comércio v. solução interina (temporária) sobre Estoque Público de Alimentos para fins de Segurança Alimentar.

O Protocolo não foi aceito pela Índia na data-limite e a crise foi instalada no seio da OMC. Os Estados Unidos posicionaram-se do lado oposto. Não concordam em negociar nos moldes impostos pelo governo indiano e o impasse congela o processo de implementação das normas negociadas em Bali, englobando as respectivas 
negociações multilaterais. O colapso provocado pela Índia ameaçava potencialmente a continuidade da própria Rodada de Doha. Nesse sentido, Roberto Azevêdo declarou que a OMC enfrentava a pior crise desde a sua criação, e a própria existência/finalidade da organização estava em jogo.

Muita articulação política e diplomática, aparentemente sem efeitos, eleva a crise a patamares ainda mais preocupantes. O desgaste político foi inevitável, e a Índia, por maior que fosse o seu poder de barganha, viu-se efetivamente pressionada pelos Estados membros e pelo diretor-geral Roberto Azevêdo. A conjuntura conflituosa demandava uma avaliação atenta do trade-off: o prejuízo político indiano deveria ser melhor calculado.

Assim foi feito. A crise foi revertida, e na reunião do Conselho Geral, em 27 de novembro de 2014, foi anunciado um novo acordo sobre a situação.

\section{B. A recente decisão adotada pelo Conselho Geral sobre o Pacote de Bali}

A reunião do Conselho Geral, em 27 de novembro de 2014, foi o palco para a declaração que colocou fim ao impasse. A solução pauta-se por três decisões:

1. Esclarecimento da decisão de Bali sobre Estoques Públicos de Alimentos para fins de Segurança alimentar. Fica acordado que a cláusula de paz permanecerá vigente até que uma decisão permanente seja adotada. Além disso, antecipa-se a data limite para a conclusão das negociações relativas à matéria. Nas decisões de Bali o prazo determinado estendia-se a 2017. Com a revisão, a nova data passa a ser 31 de dezembro de 2015, assegurada a continuidade da cláusula de paz caso as partes não cheguem a um consenso. ${ }^{8}$

2. O Protocolo de Emenda do Acordo sobre Facilitação do Comércio foi adotado, iniciandose o processo de implementação. Abre-se a fase de ratificações, respeitadas as regras internas de cada Estado. A entrada em vigor do Acordo depende do depósito do instrumento de ratificação feito por dois terços dos Estados membros.?

3. Implementação imediata de todas as Decisões Ministeriais de Bali, o que inclui o Programa de Trabalho das questões remanescentes da Agenda

\footnotetext{
$8 \quad \mathrm{WT} / \mathrm{GC} / \mathrm{W} / 688$;

$9 \quad \mathrm{WT} / \mathrm{PCTF} / \mathrm{W} / 28$
}

de Doha, com um novo prazo acordado para a sua conclusão: julho de 2015.

Superado o conflito, fica o desafio a ser enfrentado: a OMC precisa atuar com maior rapidez e eficiência para garantir a sua relevância como foro multilateral e cumprir o seu papel de facilitador do comércio internacional. Roberto Azevêdo encerrou o seu discurso feito na reunião do Conselho Geral conclamando os Estados membros a encontrar uma nova forma de negociar: "We need do find an easier way of doing things. (...) We can't wait another two decades to deliver further multilateral outcomes. We have to think about how we can operate in a more efficient way." $"$.

Espera-se, assim, que os Estados membros concluam os trabalhos e as ratificações nos prazos definidos, resgatando a relevância da OMC no complexo jogo geopolítico de (re)acomodação de poderes globais.

Crônica 2: Incorporação do F.A.T.C.A. - Foreign Account Tax Compliance Act no ordenamento jurídico brasileiro e impactos jurisprudenciais no conceito de sigilo bancário.

Carolina Reis Jatobá Coêlho*

\section{Apresentação do FATCA e os impactos quanto o sigilo bancário}

The era of banking secrecy is over"13

A declaração dos membros do $\mathrm{G} 20^{14}$ exarada no contexto de pós-crise econômica que foi caracterizada — dentre outros fatores - pela evasão fiscal e quebra de confiança no sistema financeiro, na forma como dita, parece até incontestável em qualquer contexto

$10 \mathrm{WT} / \mathrm{GC} / \mathrm{W} / 690$

11 Ver declaração completa em:http://www.wto.org/english / news_e/news14_e/gc_rpt_27nov14_e.htm

* Mestranda em Direito das Relações Internacionais no Centro Universitário de Brasília. Advogada da Caixa Econômica Federal e Gerente Executiva Substituta da Gerência Nacional de Atendimento Jurídico às Vices-Presidências de Contratações, Governo e Tecnologia. carolinarjcoelho@hotmail.com

13 “A era do sigilo bancário acabou”. LEADER'S STATEMENT. GROUP OF TWENTY. LONDON SUMMIT. G20 ACTION PLAN FOR RECOVERY AND REFORM. Declaration on Strengthening 2 April 2009. Disponível em: <http://www.imf.org/ external/np/sec/pr/2009/pdf/g20_040209.pdf>. Acesso em: 03 dez. 2013.

14 O Grupo dos Vinte reúne, desde 1999, os Ministros das Finanças e Presidentes dos Bancos Centrais das 19 maiores economias do mundo - incluindo o Brasil. 
e para qualquer cidadão-correntista do mundo. O sigilo bancário é um direito ancião e corresponde a uma obrigação imposta por contrato, norma, prática costumeira ou por lei positivada infra ou constitucionalmente às instituições financeiras ou equiparadas de manter em segredo dados que lhes cheguem ao conhecimento como consequência de relações jurídicas vinculadas às suas atividades.

No Brasil, ao direito ao sigilo bancário está conformado, de forma interpretativa por doutrina e jurisprudência, ora no inciso X, ora no inciso XII, ora em ambos os incisos do art. $5^{\mathrm{o}}$ da Constituição ${ }^{15}$. O inciso $\mathrm{X}$ protege a vida privada e intimidade, tendo por foco a pessoa, enquanto o inciso XII tem em vista a manifestação de pensamento da pessoa. Não há, portanto, previsão expressa constitucional sobre o próprio sigilo bancário. Infraconstitucionalmente, ao contrário, o sigilo bancário apresenta não só proteção específica, mas encontra hipóteses de exceção na Lei Complementar $\mathrm{n}^{\mathrm{o}}$ 105/2001. Quanto ao afastamento para fins fiscais, há regulamentação infralegal específica no Decreto $\mathrm{n}^{\mathrm{o}}$ 3.724/2001, que foi recentemente alterado pelo Decreto n⿳⺈ ${ }^{-}$8.303, de 04 de setembro de 2014.

Mas será mesmo que o direito ao sigilo bancário está fadado a desaparecer, ainda que enquadrado — em alguns ordenamentos jurídicos, a exemplo do brasileiro - como um direito de estatura constitucional vinculado aos direitos humanos de privacidade $\mathrm{e}$ intimidade? Cinco anos após a declaração dada na Cúpula de Londres, não se pode dizer de forma peremptória que o direito ao sigilo bancário não existe mais, mas muitas iniciativas aparecem de forma global e simultânea na intenção de flexibilizá-lo em face de valores relacionados ao combate à lavagem de dinheiro, corrupção e evasão fiscal. Pode-se apontar como uma dessas iniciativas legislativas o um conjunto de normas norte-americanas de efeitos extraterritoriais em etapas

15 BRASIL. Constituição da República Federativa do Brasil (1988). Disponível em: < http://www.planalto.gov.br>. Acesso em 30 out 2014. "Art. 50 Todos são iguais perante a lei, sem distinção de qualquer natureza, garantindo-se aos brasileiros e aos estrangeiros residentes no País a inviolabilidade do direito à vida, à liberdade, à igualdade, à segurança e à propriedade, nos termos seguintes: $\mathrm{X}$ - são invioláveis a intimidade, a vida privada, a honra e a imagem das pessoas, assegurado o direito a indenização pelo dano material ou moral decorrente de sua violação; XII - é inviolável o sigilo da correspondência e das comunicações telegráficas, de dados e das comunicações telefônicas, salvo, no último caso, por ordem judicial, nas hipóteses e na forma que a lei estabelecer para fins de investigação criminal ou instrução processual penal”. que apresenta clara intenção de recuperar a economia norte-americana, arrasada com a crise dos subprimes, incrementando a arrecadação de tributos por parte de cidadãos residentes fora daquele território estatal.

A legislação referida inseriu um capítulo inteiro (seções 1471 a 1474, correspondente ao Capítulo IV) ao Código Tributário Norte-Americano de 1986 (Internal Revenue Code), o que foi denominado no Título $\mathrm{V}$ do Hire Act de F.A.T.C.A. - Foreign Account Tax Compliance, normatização que estabeleceu obrigações com efeitos extraterritoriais, estabelecendo às Instituições Financeiras Estrangeiras (Foreign Financial Institution ou FFI) procedimentos para a identificação, documentação e monitoramento de contas de pessoas consideradas norte-americanas ${ }^{16}$

Acerca da abrangência da norma, vale definir dois grupos principais que a devem observância, na posição de intermediários das informações: (i) Foreign Financial Institutions (FFIs) - Instituições Financeiras Estrangeiras e (ii) Non Finacial Foreign Entities (NFFEs) - Entidades não classificadas como Instituições Financeiras Estrangeiras. A norma impõe obrigações a tais entes, incluindo como destinatários finais da norma as denominadas US Person, que poderão ser pessoas físicas (US Individuals) ou jurídicas, cujas contas serão objeto de reporte às autoridades norte-americanas.

Dentre tantos pontos polêmicos ${ }^{17}$, destaca-se que a legislação estrangeira de efeitos extraterritoriais impõe às Instituições Financeiras e assemelhadas o encaminhamento de informações pessoais e financeiras de cidadãos norte-americanos à Receita Norte-Americana (Internal Revenue Service - IRS), o que, em tese, poderia colidir frontalmente em restrições constitucionais, legais e jurisprudenciais de países que consideram o sigilo das operações bancárias em seu ordenamento jurídico doméstico, como é o caso do Brasil.

16 US GOVERNMENT PRINTING OFFICE. Congressional Bills. House Bill. 111TH Congress. Disponível em: <http://www. gpo.gov/fdsys/pkg/PLAW-111publ147/html/PLAW-111publ147. htm >. Acesso em: $10 \mathrm{dez} 2013$. Conforme a alínea b (Apresentação de Relatórios) da Seção 1471 (Retenção de Pagamentos às Instituições Financeiras), os requerimentos da subseção são atendidos com relação a qualquer instituição financeira estrangeira que mantenha um acordo em vigor, ou seja PFFI - Participating Foreign Financial Institutions.

17 Vale descrever que outro ponto polêmico é que a implementação da norma implica custos operacionais que deveriam recair sob a responsabilidade do órgão de arrecadação dos E.U.A. originalmente, cuja competência tributária se afirma. 
As informações requeridas referem-se a dados pessoais e também financeiros de cidadãos norteamericanos como: nome, endereço, número de identificação fiscal, número, saldo e movimentação de contas bancárias detidas por $^{18}$ : i) US Individuals/ Person cujo valor da conta bancária exceda U\$50.000,00 (cinquenta mil dólares) ou ii) US Entities - pessoas jurídicas cujo saldo em conta bancária ultrapasse o valor de U\$250.000,00 (duzentos e cinquenta mil dólares). ${ }^{19}$

Destaca-se que o procedimento de reporte ocorrerá de forma eletrônica e automática, sem quaisquer autorizações judiciais ou administrativas ou até instauração de qualquer procedimento ou pedido. Essa perspectiva é mais do que um passo adiante em comparação com modelos de intercâmbio de informações para fins fiscais, sempre firmados por intermédio de acordos ou tratados de cooperação com vinculação e respeito à legislação de cada país sobre o sigilo bancário. É um real desafio para conformação jurídica da proteção ao sigilo bancário na legislação nacional dos países, principalmente quando a lei ou a jurisprudência condicionem o acesso das informações bancárias pelo Fisco a algumas circunstâncias procedimentais, como a instauração de procedimento fiscal ou autorização judicial específica.

Inspiração para adoção de norma semelhante pela União Europeia e pelos países-membros da O.C.D.E., a proposta apresenta tendência de multiplicação via acordos bilaterais (com tentativas de um acordo multilateral conduzido pela O.C.D.E.) em todo o mundo, o que demonstra que a afirmação epigrafada pode, sim, vir a constituir-se como uma verdade em um futuro próximo, falando-se já em um regime internacional de troca de informações denominado informalmente de GATCA, uma espécie de FATCA global. Ora, ao se considerar que a aderência é numerosa

$18 \mathrm{Na}$ condição de participantes ou aderentes, as instituições financeiras estrangeiras assumirão obrigações de Due Diligence para identificar em sua base de clientes pessoas titulares de contas financeiras que sejam qualificadas como US Person, que, em geral serão indivíduos com nacionalidade norte-americana, nascidos nos E.U.A. ou com pais norte-americanos, pessoas com visto de permanência nos E.U.A. (Green Card). Quando tais pessoas detiverem mais de 10\% de participação direta ou indireta no capital ou lucro de empresas brasileiras (estrangeiras fora dos EUA), também serão consideradas US Person na modalidade pessoa jurídica independentemente de serem constituídas ou residentes fiscais no Brasil.

19 Para conferir os parâmetros gerais da norma: IRS. Summary of Key FATCA Provisions. Disponível em < http://www.irs.gov/ Businesses/Corporations/Summary-of-Key-FATCA-Provisions $>$ Acesso em 17 ago 2014.
- mais do que 80 (oitenta) jurisdições participantes ${ }^{20}$ — e que a maioria delas está tendente a assinar ou já assinou um Acordo Intergovernamental com efeitos de reciprocidade, mais ainda o perímetro da norma alarga-se, fazendo do mundo contemporâneo um lugar de constantes trocas de informações bancárias e, por que não dizer, quase sem resquício ao direito de sigilo bancário.

Ao optar por não aderir ao F.A.T.C.A., a Instituição Financeira ou assemelhada sofre, a partir de 2014, retenções na fonte de $30 \%$ sobre rendimentos de fontes dos E.U.A.; a partir de 2015, retenções de 30\% sobre o valor principal da venda de participações societárias e renda fixa de fonte dos E.U.A. e a partir de 2017, concomitante às demais, retenções de $0,01 \%$ a $30 \%$ do valor dos juros e do principal de aplicações financeiras efetuadas em outras instituições financeiras brasileiras ou não, participantes do F.A.T.C.A., quer as aplicações tenham ou não direta relação com os E.U.A ${ }^{21}$.

Em poucas palavras, a recusa das Instituições Financeiras é possível em teoria, mas não na prática. As instituições que não cooperarem poderão ser excluídas do sistema financeiro internacional. O custo de não adesão é bastante alto — senão impraticável - já que a instituição financeira que não participar do F.A.T.C.A., além de sofrer retenções na fonte de seus investimentos, poderá apresentar condições mais desfavoráveis para competir no mercado internacional, sofrendo restrições ou incremento de custos para operar com instituições financeiras participantes do

20 Na página do Tesouro Norte-Americano, há uma lista das jurisdições já aderentes. Dentre os nomes que já assinaram Acordos Intergovernamentais (IGA - Intergovernamental Agreement) e merecem destaque estão: Ilhas Man, Ilhas Cayman, Malta e outras locais reconhecidos como paraísos fiscais. O Brasil está negociando um Acordo. US DEPARTAMENT OF TREASURY. Jurisdictions that have signed agreements. Jurisdictions that have reached agreements in substance and have consented to being included on this list (beginning on the date indicated in parenthesis). Disponível em <http://www.treasury.gov/resource-center/tax-policy/treaties/ Pages/FATCA-Archive.aspx> . Acesso em 18 ago 2014.

21 Isso ocorre porque, na economia globalizada, os papéis ligados ao mercado financeiro encontram-se inevitavelmente entrelaçados, de modo que, em algum ponto da cadeia de movimentação bancária ou interbancária, o agente financeiro não aderente poderá prejudicarse no relacionamento com os demais, evitando a manutenção de negócios recíprocos, já que os custos de transacionar com um não aderente acabará por impactar no aderente que se relaciona com ele, restando, pois, este último isolado no mercado. Para conferir os parâmetros gerais de retenção de tributos: IRS. Notice 2014-33. Further Guidance on the Implementation of FATCA and Related Withholding Provisions. Disponível em: <http://www.irs.gov/ pub/irs-drop/n-14-33.pdf > Acesso em 03 dez 2014. 
F.A.T.C.A. Impelidas a participação no cenário global, a aderência ao F.A.T.C.A. pelas instituições financeiras soa imperiosa, em paralelo à discussão jurídica acerca do tratamento nacional jurisprudencial ao sigilo bancário.

Ocorre que, para adesão com segurança jurídica, as Instituições Financeiras precisariam de uma moldura jurídica que lhes oferecessem o mínimo de proteção. Ainda que se discuta que a jurisdição norte-americana circunscreva-se ao próprio território, ao contrário do que o apregoado por doutrinadores norte-americanos que ampliam aquela jurisdição fiscal para onde houver contribuintes daquele Estado, aplicando-se de forma irrestrita o princípio da universalidade, a adesão à legislação torna-se facultativa via formalização e internalização de instrumento internacional ${ }^{22}$, o que de fato ocorreu no Brasil.

\section{As implicações da incorporação do FATCA no Brasil, principalmente diante da jurisprudência do Supremo Tribunal Federal Brasileiro}

Em 23 de setembro de 2014, o Brasil, representado pelo Ministro da Fazenda Guido Mantega, e Estados Unidos da América - E.U.A., representado pelo embaixadora Liliana Ayalde, assinaram o Acordo de Cooperação Intergovernamental para a troca automática de informações tributárias. O Brasil já é signatário do Acordo para Intercâmbio de Informações Tributárias assinado em março de 2007 e promulgado pelo Decreto no 8.003, de 15/05/13 $3^{23}$. O documento precisava ser ampliado para atender aos requisitos do F.A.T.C.A. A troca de informações se fará respeitando a confidencialidade da informação por ambas as partes, ou seja, observando-se o sigilo fiscal.

No processo de incorporação da legislação FATCA ao ordenamento jurídico brasileiro, várias questões se apresentam: i)natureza jurídica do instrumento que internaliza as normas e sua validade e eficácia; ii)

22 O acordo pode apresentar como pólos da tratativa: ou órgãos fazendários de ambos os lados ou instituições financeiras estrangeiras e órgão fazendário norte-americano. Estão disponíveis dois modelos para adesão, conforme exista ou não tratado ou acordo internacional prevendo troca de informações para fins fiscais entre os países e considerando ou não as hipóteses de reciprocidade de obrigações para ambos os casos.

23 BRASIL. Decreto $n^{\circ}$ 8.003, de 15 de maio de 2013. Promulga o Acordo entre o Governo da República Federativa do Brasil e o Governo dos Estados Unidos da América para o Intercâmbio de Informações Relativas a Tributos, firmado em Brasília, em 20 de março de 2007. Disponível em: <http://www.planalto.gov.br>. Acesso em: 30 out. 2014. constitucionalidade formal e material das normas diante da interpretação da Corte Constitucional Brasileira (STF) sobre a proteção ao sigilo bancário; iii)alteração no sentido e alcance interpretativo da proteção ao sigilo bancário em todo o mundo e seu reflexo no Brasil.

Diante de algumas dessas questões, observa-se inadequação da lenta e burocrática clássica lógica de incorporação de normas jurídicas - com processos de questionamento acerca do recebimento da legislação em território pátrio - em detrimento do processo de interação da globalização econômica, que cria um constante e intenso movimento de interferências recíprocas entre as racionalidades jurídicas nacionais e internacionais, permitindo-se observar certa padronização nos ordenamentos jurídicos, fruto da internacionalização do Direito e da necessidade de criar respostas semelhantes ou harmônicas em todo o mundo para problemas globais.

Fica claro também que a incorporação da norma implica na alteração da concepção e limites do direito ao sigilo bancário e que o impacto desta discussão internacional alcança interesses nacionais institucionais. A abertura do sigilo bancário independentemente da necessidade de requisição judicial sempre foi desejada pela Receita Federal do Brasil, que já ostenta autorização restrita à existência de procedimento formalizado de fiscalização tributária em alguns $\operatorname{casos}^{24}$.

Portanto, embora exista uma moldura jurídica adjacente para tratar a questão, o tratamento jurisprudencial brasileiro acerca do sigilo bancário, mais especificamente o do Supremo Tribunal Federal, ainda é bastante conservador ou garantista, vinculando a abertura do sigilo à reserva judicial. Para elucidar esta premissa, cita-se o posicionamento pretoriano que vige atualmente pelo julgamento do RE 389.808/PR, no qual o relator, Ministro Marco Aurélio, determina que a decretação da quebra do sigilo bancário - ressalvada tão somente a competência extraordinária das CPIs prevista no art. 58, $\int 3^{\mathrm{o}}$ da Carta Constitucional "pressupõe, sempre, a existência de ordem judicial, sem o que não se imporá à instituição financeira o dever de fornecer, seja à administração tributária, seja ao

24 A Receita Federal do Brasil já ostenta autorização restrita à existência de procedimento formalizado de fiscalização tributária: i) iniciado pelo Ministério Público Federal (existência ou indícios consistentes de crime fiscal); ii) no curso de despacho ou revisão aduaneiros; iii) em vigilância e repressão ao contrabando e descaminho, realizado em operação ostensiva ou iv) relativo ao tratamento automático das declarações de IR (malhas finas). 
Ministério Público, seja, ainda, à Polícia Judiciária, as informações que lhe tenham sido solicitadas".

Fica claro que a assinatura do Acordo Intergovernamental entre EUA e Brasil, visando formalizar a adesão ao FATCA ${ }^{25}$ trará discussões acerca da alteração da concepção do sigilo bancário brasileiro, mais especificamente, nos termos da interpretação dada ao direito constitucional pelo Supremo Tribunal Federal.

\section{Crônica 3: As sanções aplicadas pela União Europeia à Rússia em razão da anexação da península da Crimeia}

Tiago Felipe de Oliveira* *

\section{Introdução}

A anexação da península da Crimeia e da cidade de Sebastopol pela Rússia, no começo de 2014, contou com a desaprovação de parte significativa da comunidade internacional. A Assembleia Geral da ONU aprovou resolução, de caráter não vinculante, exortando os Estados e organizações internacionais a não reconhecerem qualquer modificação no estatuto da República Autônoma da Crimeia e da cidade de Sebastopol. Já o Conselho da União Europeia aplicou sanções diversas a pessoas singulares, entidades e organizações Russas de algum modo relacionadas à anexação de Crimeia. Referidas sanções, em sentido lato, têm natureza punitiva e visam, também, pressionar a Rússia a negociar uma saída pacífica para a crise ucraniana. Há o risco, contudo, de que o efeito e alcance das sanções possam afetar significativamente as relações comerciais entre Rússia e União Europeia, ocasionando um agravamento ainda maior da crise nas relações políticas entre Ucrânia, Rússia e o bloco europeu.

O texto pretende abordar o tema em três etapas distintas. De início, procura apresentar um breve histórico dos fatos que permitem compreender a crise da Crimeia. Posteriormente, busca demonstrar, a partir do posicionamento da Assembleia Geral das Nações Unidas, o entendimento da comunidade internacional em relação à anexação da Crimeia pela Federação Russa. Por fim, são apontadas as decisões do Conselho da União Europeia que impuseram sanções à Rússia,

25 U.S. DEPARTAMENT OF TREASURY. Jurisdictions that have signed agreements. Disponível em: <http://www.treasury. gov/resource-center/tax-policy/treaties/Pages/FATCA-Archive. aspx >.Acesso em: 30 set. 2014.

* * Mestrando em Direito e Políticas Públicas no Centro Universitário de Brasília. Advogado. tiagofelipea@hotmail.com com a indicação do alcance e dos efeitos de tais sanções em relação a parcerias econômicas e políticas mantidas entre Ucrânia, Rússia e União Europeia.

\section{Breve histórico da crise Crimeia.}

A crise da Crimeia se desatou no contexto das negociações de um acordo de associação entre Ucrânia e União Europeia. No final do ano de 2013, o ex-presidente ucraniano Viktor Yanukovych rejeitou acordo comercial com a União Europeia, expondo o receio de que as relações comerciais com a Rússia fossem comprometidas e de que o setor agrícola e a indústria ucraniana restassem fragilizados ante os estímulos econômicos recebidos pelo setor produtivo europeu.

A decisão de não assinar o acordo de associação com a União Europeia e de estreitar relações comerciais com a Rússia foi recebida com significativa desaprovação pela sociedade ucraniana, que iniciou uma onda de protestos pelo país, com epicentro na Praça da Independência de Kiev, capital da Ucrânia, culminando com a deposição do presidente Viktor Yanukovych e a antecipação de novas eleições presidenciais.

Ante a situação política instável da Ucrânia e o vazio de governo ocasionado com a deposição do expresidente, a Rússia interveio militarmente na região da Crimeia. Logo em seguida, o parlamento regional da Crimeia aprovou uma declaração de independência de península em relação à Ucrânia, invocando o direito dos povos à autodeterminação.

No dia 16 de março de 2014, o governo da recémdeclarada República da Crimeia realizou referendo interno no território apresentando duas perguntas aos cidadãos. A primeira pergunta questionava se o consultado era favorável à reunificação da Crimeia à Rússia como integrante da Federação Russa. Uma segunda alternativa questionava se o consultado era favorável à restauração da Constituição da República da Crimeia de 1992 e a condição da Crimeia como parte da Ucrânia.

É preciso salientar que a Constituição da República da Crimeia de 1992 ampliava a autonomia da região em relação à Ucrânia, sendo factível que a segunda opção do referendo possibilitaria à Crimeia manterse integrada ao território ucraniano, ao passo em que poderia seguir alinhamento político e econômico com a Federação Russa. Por tal razão, segundo críticos ucranianos, o referendo da Crimeia traria somente as opções de "sim" e "sim" em direção à Rússia. 
Informações do governo da Crimeia indicaram que mais de $80 \%$ das pessoas aptas a votar compareceram ao ato, dos quais $95,5 \%$ teriam optado pela reunificação à Federação Russa. Valendo-se do referendo, o parlamento da Crimeia declarou oficialmente a independência da península, ao passo que oficializou pedido de anexação à Rússia. Dois dias após o referendo, o presidente russo Vladimir Putin assinou acordo com líderes políticos da Crimeia para tornar a península parte da Rússia.

O tratado para anexação da Crimeia à Federação Russa foi aprovado na Duma, a Câmara baixa do parlamento russo, e ratificado na Câmara alta, nominada Conselho da Federação. Após a ratificação, o presidente Putin promulgou a incorporação da República da Crimeia e do porto de Sebastopol à Rússia. O Tribunal Constitucional Russo validou o tratado, por decidir estar de acordo com a Constituição do país.

\section{3 o posicionamento da comunidade internacional sobre a anexação da Crimeia pela Rússia}

Parte significativa da comunidade internacional se posicionou de modo contrário à anexação da Crimeia pela Rússia. Os Estados Unidos da América tentaram aprovar resolução junto ao Conselho de Segurança da ONU, com vistas a declarar a invalidade do referendo na Crimeia. Contudo, o projeto de resolução foi rejeitado devido ao veto da Rússia, membro permanente do referido Conselho.

Poucos dias após a anexação da Crimeia, a Assembleia Geral das Nações Unidas aprovou a Resolução n. 68/262, de 27 de março de 2014, sobre a integridade territorial da Ucrânia. O texto enfatiza a importância da Carta das Nações Unidas, reafirmando o princípio de que o território de um Estado não será objeto de aquisição, por outro Estado, derivada da ameaça e do uso da força.

A Resolução 68/262 cita que o referendo realizado na República Autônoma da Crimeia e na cidade de Sebastopol em 16 de março de 2014 não contou com a autorização da Ucrânia. Diz, ainda, que o referendo não tem validade, exortando os Estados e organizações internacionais a não reconhecerem qualquer modificação no estatuto da República Autônoma da Crimeia e da cidade de Sebastopol. Referida Resolução, que não possui natureza vinculante, contou com o voto favorável de 100 países, 11 votos contrários e 58 abstenções.

A anexação da Península da Crimeia pela Rússia, em 18 de março de 2014, foi condenada pelos EstadosMembros da União Europeia, que consideraram violadas a integridade territorial, soberania e a independência da Ucrânia. O Conselho da União Europeia entendeu ilegal a realização do referendo e decidiu impor sanções à Federação Russa e a pessoas responsáveis pelas ações que comprometem ou ameacem a integridade territorial, a soberania e a independência da Ucrânia.

Em comum, o Conselho da União Europeia e a Assembleia Geral da ONU, via Resolução 68/262, consideraram que a Rússia fez uso de ameaça ou emprego de força contra a integridade territorial e independência política da Ucrânia, violando a proibição de agressão disposta no art. $2^{\circ}$ da Carta da ONU. A proibição da agressão é norma imperativa de Direito Internacional geral, jus cogens, de hierarquia superior às demais normas. De igual modo, sustentam ambos os documentos a impossibilidade de que a autoridade regional da Crimeia pudesse consentir com intervenção ou anexação de território por parte de Estado estrangeiro, razões pelas quais apontam o cometimento de ilícito internacional pela Rússia.

De fato, a alegação russa de que a anexação da Crimeia estaria amparada no princípio da autodeterminação dos povos pode ser afastada em razão de inexistir o direito à secessão no caso em concreto, já que não havia perseguição a grupos minoritários ou violações de direitos humanos na Crimeia. Prevalece no caso, portanto, o princípio da integridade territorial dos Estados, sendo considerada ilícita a anexação da península à Rússia.

No caso, o caráter não vinculante das resoluções da Assembleia Geral da ONU impede que a organização promova sanções e retaliações à Rússia. Já a União Europeia, via Conselho, tomou medidas para pressionar a Rússia a interromper o ilícito internacional e procurar uma solução negociada para a crise junto ao governo da Ucrânia.

\section{As sanções aplicadas pela União Europeia}

A Decisão 2014/145/PESC do Conselho da União Europeia, de 17 de março de 2014, suspendeu as conversações bilaterais com a Federação Russa em matéria de vistos e sobre um novo acordo global, que substituiria o acordo de cooperação e parceria vigente, firmado no ano de 1997. Foram impostas medidas restritivas de viagens e o congelamento de bens de cidadãos da Crimeia envolvidos na promoção e realização do referendo e de autoridades Russas que apoiaram a anexação da Crimeia.

As sanções da União Europeia se concentraram sobre pessoas diretamente responsáveis pela 
política russa na Ucrânia, notadamente militares e parlamentares russos com atuação determinação na legislação relacionada à anexação da Crimeia. A opção inicial por não focar empresas russas, bancos e seus respectivos administradores pareceu estar embasada na significativa parceria comercial entre a Rússia e União Europeia, responsável pela importação de mais de $80 \%$ do gás e petróleo russo. Sanções capazes de afetar significativamente a economia russa trariam prejuízos não só à parceria estratégica comercial com a União Europeia, mas também à própria Ucrânia e Crimeia, todos dependentes da energia russa.

Contudo, em 8 de setembro de 2014, o Conselho da União Europeia, por meio da Decisão 2014/658/ PESC, decidiu prorrogar os efeitos da Decisão 2014/45, ampliando-os ainda, em razão da preocupação com a intensificação dos combates em curso no leste da Ucrânia e da persistência de ações que comprometem ou ameacem a integridade territorial, a soberania e a independência da Ucrânia. A nova decisão aumentou a lista de pessoas singulares sancionadas com proibição de entrada e trânsito no território europeu e com o congelamento de fundos e recursos econômicos de pessoas, entidades ou organismos relacionados com o apoio político, material ou financeiro à anexação da Crimeia pela Federação Russa.

A ampliação da lista de pessoas sujeitas ao congelamento de bens e restrição de viagens contempla o nome de líderes separatistas do leste ucraniano em regiões como Donetsk e Luhansk, que chegaram a realizar referendos separatistas. As novas sanções da União Europeia também buscam atingir empresas confiscadas pelas autoridades da Crimeia após a anexação russa, situação de uma empresa produtora de gás sediada na Crimeia, a Chernomorneftegaz, e uma fornecedora de petróleo da mesma região, a Feodosia. Embora ainda limitadas a numero determinado de indivíduos e organizações, a expansão das sanções afetou bancos, a indústria de defesa e energia russos. O Sberbank, por exemplo, maior banco da Rússia, está privado de acesso a capitais ocidentais de longo prazo e já apresentou recurso à Corte de Justiça Europeia, contra as sanções da UE.

Parte da indústria de energia russa também ficou impossibilitada de captar recurso em mercados ocidentais e importar bens e tecnologias de dupla utilização — que podem ser utilizados tantos para fins pacíficos quanto para fins militares - o que limita o acesso a tecnologias para exploração de petróleo no Ártico russo e projetos de óleo xisto. A Rosneft, maior produtora de petróleo russa, precisará substituir a importação de equipamentos e tecnologia por conta das sanções aplicadas pela UE.

A Rússia ameaça retaliar as sanções europeias, mediante a proibição de uso do espaço aéreo do país por companhias ocidentais, o que encareceria as rotas de voo e também com o fim das importações de automóveis, grande mercado de carros usados da Europa. Não obstante as ameaças russas, o principal temor europeu é o referente à questão energética. A Comunicação 2014/0654 da Comissão ao Parlamento Europeu traz estudos detalhados sobre eventuais perturbações no abastecimento de gás no outono e inverno 2014/2015 na Europa, inclusive com simulações de crise e testes destinados a avaliar a capacidade da resposta da rede europeia de gás a uma ruptura grave do aprovisionamento à UE no próximo inverno.

Em razão das negociações para o reestabelecimento do fornecimento de gás russo à Ucrânia, o acordo de associação entre Ucrânia e União Europeia teve a implementação adiada até 2016. A empresa russa Gazprom, também sancionada pela EU, aumentou o preço do gás a patamares sem precedentes e suspendeu o fornecimento à Ucrânia no mês de junho de 2014, em razão de uma dívida ucraniana de US $\$ 1,45$ bilhão, além de exigir o pagamento antecipado das próximas remessas. A Ucrânia não possui recursos para saldar a dívida e recorre a auxílios da UE e do FMI para avançar nas negociações com a Rússia.

\section{Considerações finais}

O posicionamento incisivo da União Europeia em relação à ilegitimidade da anexação da Crimeia pela Rússia decorre não só das relações multilaterais entre o bloco europeu, Ucrânia e Rússia, mas também das circunstâncias do ilícito internacional, que envolve a violação de normas jus cogens, o que torna o fato uma questão de ordem pública internacional. A anexação da Crimeia pela Rússia parece ser fato consumado, restando pouco provável a península seja restituída, até mesmo em razão das poucas condições materiais ucranianas para promover retaliações. Há grande preocupação, contudo, que o episódio venha a se repetir em relação a demais regiões da Ucrânia que ainda manifestam pretensões separatistas, fato que justificou, inclusive, o endurecimento das sanções inicialmente impostas pela U.E. à Rússia.

De fato, a questão energética, as parcerias econômicas e industriais e a própria lógica das relações de poder tornam a questão ucraniana altamente complexa. A 
imposição de novas e mais pesadas sanções à Rússia podem afetar significativamente a economia europeia, além de aumentar o risco de que o atual regime russo seja consolidado, em consequente eliminação das correntes progressistas, tecnocratas e pró-ocidentais dentro da elite russa, o que isolaria o país e dificultaria ainda mais qualquer saída pacífica para a situação ucraniana. O único consenso aparente, até o momento, é que a possibilidade mais efetiva e menos danosa de resolução da crise entre Ucrânia e Rússia demanda negociação por meios pacíficos, diretos e moderados. As consequências de um acirramento das posições são imprevisíveis e potencialmente danosas a todos os envolvidos.

\section{Crônica 4: International Law and the Curious Case of Scottish Independence}

Eshan Dauhoo* *

The only way to resist temptation is to yield to it...

Oscar Wilde (1891)

On $18^{\text {th }}$ September 2014, the people of Scotland were gifted a unique opportunity to vote on becoming an independent state. They resisted temptation and, by a strong majority $(55.3 \%-44.7 \%)$, chose to remain within the UK.

At the time of the referendum debates, little was mentioned regarding the potential international legal ramifications of the "go it alone path". However, the man on the street could be excused for asking how, if in any way, was international law relevant to the Scottish referendum. After all, it could potentially be construed as being essentially a national affair governed by UK constitutional law.

However, it would be a fallacy to assume that the scope of international law is limited merely to purely international situations in the classical sense. A case in point is international human rights law which applies directly to the subjects of a state. Besides in today's globalised world there seems to be a fine line between national and international situations; and events that seem purely domestic in nature, have the potential to impact well beyond national borders. Even the European Union (EU) is commonly referred to as "a

* LLB, BSc Political Science, Postgraduates in International Law, European Law and Psychology (Head of Law at South Thames College and Law Module Leader at Blake Hall College, London, UK) email: eshan.dauhoo@south-thames.ac.uk new legal order of international law". As such, it was perhaps the fear of opening Pandora's Box that led the Scottish independence referendum to attract so much international attention. Moreover, the fact that a vote in favour of independence would raise questions of state secession and membership to international organisations meant that international law was always going to play an important part in the independence process.

Although Scotland did reject independence, it is nevertheless an excellent case study in international law. It is worthwhile considering the "if" and looking at the international legal implications of such a choice. As such, this article will firstly consider whether, as an independent state, Scotland would be a successor state or continuator state; and secondly, how Scotland's membership of international organisations such as the EU, United Nations (UN), North Atlantic Treaty Organization (NATO), the International Monetary Fund (IMF) and the World Bank would potentially be affected, as well as whether it would still be bound by the UK's international treaties.

\section{Successor state or continuator state?}

Statehood is most often acquired within the context of decolonisation or involving a complicated struggle. In the case of Scotland, however, there was no such struggle and the Edinburgh Agreement (2012) provided the necessary legitimacy for the independence referendum to take place. Therefore, a more important question from the point of view of international law would be whether Scotland would be regarded as a 'successor state' or 'continuator' state; as these labels carry with them fundamentally different legal implications.

The UK Government called upon Professor Crawford and Professor Boyle, legal experts on international law, to produce an opinion which considered the international legal aspects of independence. Although three possible legal outcomes of the Scottish independence were presented, they highlighted that the most likely outcome would be that Scotland would become a new state under international law whilst the remainder of the UK would continue to exist. This would be a similar outcome to the creation of the Irish Free State in 1922, where the UK also continued to exist. Also, given the international community's tendency to frown upon the dissolution 
of states, this would also be a preferred solution for the international community.

However, Scotland represents approximately a third of the UK territory. Could this nevertheless be significant enough to dissolve the UK? It should be highlighted that when South Sudan broke away from the Republic of Sudan (it took with it a sizable portion of territory and population), the Republic of Sudan continued to exist. The same can be said of Pakistan after Bangladesh broke away. Therefore, it could be said that the fate of the remainder of the UK would have been that it would continue to exist. However, with Scotland being cast in the role of the successor state, what would this have meant to Scotland in terms of its international rights and obligations?

Generally, the "clean slate" principle is applied to successor states. As such, had Scotland voted for independence, it would not have automatically inherited the rights and obligations associated with the UK, but instead would have been expected to initiate its own treaties as well as membership to international organisations. However, it should be noted that the laws on state succession are not unequivocal and much is determined on a case by case basis. A potential devolution period could have been agreed or an interim period could have been established allowing for the transition to take place smoothly. This would have seemed a possibility for an independent Scotland given that the UK had provided its consent to a referendum as well as the promise of a peaceful and collaborative approach under the Edinburgh Agreement.

\section{Membership of the EU}

Interestingly, whilst Scotland sought independence from the UK, it did not want to break away from the EU. One might even argue that the protection afforded by the EU makes secession even more accessible to countries such as Scotland as it provides a sort of "safety net". Furthermore, Scotland's case was very different from those states joining the EU from the outside as Scotland had been an EU member state for over 30 years, met the other EU membership criteria and would have obtained secession from the UK in a perfectly legitimate and democratic manner. As such, would it have been possible for Scotland, following independence, to be able to obtain immediate continued membership of the EU?
It would seem that the answer to the above question would depend upon whether Article 48 or Article 49 of the European Treaties was applied. However, herein rests a further problem in that there is no precedent where, following admission to the EU, a member state then proceeds to be broken into two independent states. What further complicates the issue is that there is no specific treaty provision allowing for succession to EU membership. As such, would there be any reason to believe that without some form of accession process, an independent Scotland would have been able to become an EU member by a treaty amendment under Article 48?

It could be argued that legally it would not have been impossible for Scotland, like the rest of the UK, to remain a member of the EU. After all, there is no treaty provision preventing Scotland from remaining a member. Therefore, effective negotiation and cooperation between Scotland, the rest of the UK and the EU could have made such a possibility a reality. Furthermore, as previously mentioned, Scotland, through the UK, is already strongly integrated into the EU and its laws are commonly applied in Scotland. It would seem then that Scotland already ticked all the right boxes in relation to EU membership and the Scottish Government wanted to remain a member of the EU. As from the perspective of the EU, it would also seem to be a less complicated route, given EU citizens also enjoy EU rights within the Scottish territory. Therefore, excluding Scotland would have led to numerous complications, in particular legal ones.

On the other hand, it has also been strongly argued that EU treaties would not have applied to Scotland once it seceded and therefore the legal basis for Scotland's accession to the EU would rest with Article 49, which would have required Scotland to apply for EU membership. This would involve ratification by the $28 \mathrm{EU}$ member states. However, two problems could have potentially arisen here. Whilst the first one would be of a political nature, with member states such as Spain potentially blocking Scottish membership due to concerns that it could encourage the separatist movements in Catalan to seek secession; the second would have been that Scotland would surely have lost the Treaty opt-outs that it had secured when part of the UK.

It could be argued that a more plausible outcome (taking into account the political implications) would have involved an interim arrangement which would have, instead of cutting Scotland off, secured the 
continuing effect of EU law in relation to Scotland. This would then have delayed formal membership of Scotland until negotiations were complete and the accession agreement had been ratified by all the EU member states. Of course, this route would have been a long process, but it seems that there would have been no alternative fast-track routes available to Scotland in terms of EU membership.

\section{Membership of other international organisations}

The UK holds prominent positions within a number of international organisations. It is a key member of the IMF, a permanent member of the UN Security Council as well as a founding member of the World Bank and NATO. It has also been linked with over 13,000 treaties. What would have been the implications for membership to these organisations for Scotland and the rest of the UK following independence? Would these treaties still apply to both the UK and Scotland?

As Professor Crawford and Professor Boyle's legal opinion pointed out, upon independence the remainder of the UK, as the continuing state, would have maintained its membership (and its terms) of international organisations without being greatly affected. This includes membership of the IMF, UN and NATO, among others. This would seem reasonable given the UK's prominent position within these institutions, and states would no doubt have preferred to avoid the difficulties associated with amending the UN Charter or the Articles of Association for international organisations such as the IMF. Likewise, it would also seem reasonable (given that the UK would have been the continuator state) to assume that all existing UK treaties would also have continued to apply to the remainder of the UK.

On the other hand, Scotland, as a new state, would have faced a less favourable situation. It would seem that it would have had to reapply to become a member of these international organisations. Would it have been possible for Scotland to concurrently succeed to the UK's membership of these international organisations together with the remainder of the UK? It is true that Article 34 of the Vienna Convention on Succession of States in Respect of Treaties 1978 does state that (at the date of succession) a successor state will continue to be bound by treaties that were in force over the territory as a whole. However, it should be noted that the UK is not actually a signatory to this particular Vienna Convention and Article 4 of the said Convention also stresses that rules of each international organisation trump the principles of succession to treaties.

In relation to the $\mathrm{UN}$, the situation would most likely be that the UK, as the continuator state, would retain both its membership and permanent seat on the Security Council (SC). On the other hand, Scotland, as a new state, would have had to reapply for membership. This has been the case for new states such as the Czech Republic as well as other dividing states such as Pakistan and Bangladesh. Scotland would have had little difficulty meeting the conditions for admission that are set out in Article 4. Whilst, if satisfied that the necessary criteria are met, the World Bank and IMF would generally allow for Scotland to succeed to membership of their organisation, the WTO, on the other hand, is somewhat more demanding. Part of the readmission process would require, amongst other conditions, WTO member states to vote in relation to the terms of Scotland's accession package. As for membership of NATO, it would have been interesting to see whether a potential stumbling block to retention of membership would have been the Scottish Government's views on nuclear weapons or their interest in closing down of the nuclear submarine bases based in Scotland.

In relation to many international treaties entered into by the UK, it would seem that Scotland would have had to reapply or re-negotiate; although this may be different when it comes to international human rights treaties, where the approach seems to be that (given that they are more attached to the subjects of a state than the state itself) they will continue to bind successor states.

\section{Concluding remarks}

The above commentary is based upon an analysis of the potential international legal implications if Scotland had succumbed to temptation and chose the path of independence. It would have set a precedent that other separatist movements in the EU could have potentially emulated. However, whilst the referendum may have been a fairly smooth process and indicated a potential repeat of the "velvet divorce" (where a smooth division of Czechoslovakia into Slovakia and the Czech Republic took place), the Scottish independence case, as has been discussed, appears to be far more complicated than it may at first appear. Scotland, the rest of the 
UK, the EU and even other international organisations may have escaped a potential legal minefield. That said, however, there may be a similar opportunity for further analysis with the Catalans also tempted to tread the path of independence from Spain.

\section{Crônica 5: Evolution or Procrastination? The Ongoing Debate(s) on the Recognition of the Palestinian State}

Nitish Monebhurrun*

On the $2^{\text {nd }}$ December 2014, the French National Assembly adopted a resolution urging the government to recognise the existence of a Palestinian State. The resolution does not bind the government; it is not an official French recognition of Palestine as a State but is, without a doubt, symbolically charged. The Parliaments of the United Kingdom, of Ireland and of Spain have also recently followed what appears to be a European trend in upholding a Palestinian State. Recently, the latter has officially been recognised by Sweden. The Parliament of the European Union must also vote on the recognition of the said State until the end of this year.

The Palestine long-lasting conundrum has always torn the concerned observers between hope and cynicism. And every new step hesitates between aspiration and bitterness. In law, it is possible to affirm that Palestine is a State: it fulfils the legal conditions for a State to exist, namely, a population, a territory, a political organisation, and its independence. The Palestinian population and its right to independence and self-determination have always been acknowledged by the United Nations Organisation ${ }^{29}$. The existence of a territory within the 1967 borders $^{30}$ — the so-called Green line - has already been indirectly affirmed by the International Court of Justice ${ }^{31}$ and by the Security Council of the United Nations ${ }^{32}$, both of which stated that the Palestinian lands were being occupied by the

\footnotetext{
* $\mathrm{PhD}$ in International law (School of Law of Sorbonne, Paris), Associate Professor (University Centre of Brasília), Visiting Professor (Universidad de la Sabana, Bogotá). Nitish. monebhurrun@gmail.com

29 For a recent Resolution, see: Status of Palestine in the United Nations, General Assembly Resolution, A/67/L.28, 26/12/2012.

30 See: Figure 1.

31 Legal Consequences of the Construction of a Wall in the Occupied Palestinian Territory, Advisory Opinion, I.C.J. (09/07/2004), I.C.J. Report 2004, paras. 75-78.

32 See for instance: Security Counci, Resolution S/RES/242 (22/11/1967).
}

Israeli State. By definition, this implies that Palestine has a territory which is being partly occupied - and an occupied territory does not hinder its qualification as a criterion for the recognition of a State. The current political organisation is the Palestinian National Authority which is recognised by international organisations like the United Nations, the World Bank Group or the International Monetary Fund ${ }^{33}$. Professor Jean Salomon's work on the issue is brilliantly telling ${ }^{34}$.

Conspicuously, the legal possibility of a Palestinian State is not always in line with the political reality. And the ongoing European debate appears as a déjà-vu: strong will, symbolical steps but with poor effects on a persisting problem. The question of a real evolution or of another procrastination therefore appears on the front line. Recognition is worthy but its real consequences invite some skepticism. Indeed, even if Palestine has undoubtedly been recognised as a State (I) its existence as a "normal" sovereign State seems to be highly compromised (II).

\section{The Effective Recognition of Palestine as a State: a Doubtless Affirmation}

There are two types of State's recognition: unilateral (A) and multilateral ones (B), both of which exist in the Palestinian case.

\section{A) The effective Recognition of a Palestinian State on a Unilateral Basis}

Any State has the capacity to admit and acknowledge the existence of another one. It does so internally, as per its domestic laws and the effects are afterwards international. This has, for instance, recently been done by Sweden ${ }^{35}$ and it seems that something is boiling in this sense regarding other European States.

The effects always seem to be more striking when such acts result from the European continent as they would have been if the United States were to proceed to such recognition. The debate is - or rather seems - actual because the problematic is being examined by prominent European States. Observers (and

33 This is affirmed in the preamble of the following resolution: Status of Palestine before the UNO, General Assembly Resolution, A/67/L.28, 26/12/2012.

34 Jean Salomon. 'La qualité d'État de la Palestine'. Revue Belge de Droit International, vol.1. 2012. pp. 13-40.

35 Sweden recognised Palestine as a State in October 2014. 
newspapers) worldwide have their eyes cast and their attention focused.

This being said, excessive eurocentrism on such questions can sometimes act as a distorting mirror of reality. It must not be forgotten that 135 States that is the great majority of States - , have already recognised Palestine as a State; these include, for example, most Latin American States, encompassing Brazil $^{36}$. However, the non-recognition by leading powers such as the United States has blatantly had a detrimental impact on the effectivity of a "fullgrown" Palestinian State. In another context, it can be recalled that the United States' support of a Kosovar State facilitated the latter's construction and existence. Strategic support is therefore fundamental, but is, in the Palestinian case, lacking.

Unilateral recognition, even if effective, might not be sufficient. A newly recognised State must not only be considered as a State but must also be treated as such through concrete and permanent bilateral relations in the diplomatic, economic or cultural matters. And many States offer recognition only punctually, like a frozenin-time manifestation, without any real follow-up. In such cases, the act of recognition, even if effective, mainly has a symbolical value. This reality is also often reflected on the multilateral level.

B) The effective Recognition of a Palestinian State on a Multilateral level

For the United Nations, Palestine is a State and the General Assembly's Resolution A/67/L.28 bears testimony by deciding to "accord to Palestine nonmember observer State status in the United Nations" 37 . To be a non-member observer State a given entity must beforehand be a... State, and fulfil all the conditions to be considered as such. As the General Assembly's important resolutions are adopted by a majority of twothirds $^{38}$, it is clear that even on a multilateral level, at least two-thirds of the members grant a State's capacity to Palestine. This only echoes the aforementioned 135 unilateral recognitions. It can be expected that States like France which voted in favour of the 2012 Status of Palestine in the United Nations resolution will be likely to embark on a unilateral recognition of the State of

\footnotetext{
36 Brazil recognised Palestine as a State in 2010.

37 See: Status of Palestine in the United Nations, General Assembly Resolution, A/67/L.28, 26/12/2012 (highlighted by the author).
}

38 As per article 18(2) of the United Nations Charter.
Palestine, thereby following its National Assembly's position. And it would only reveal coherence should the French government follow the votes of its own majority deputies.

In a similar vein, Palestine has been accepted as a member State of United Nations Educational, Scientific and Cultural Organisation (UNESCO) ${ }^{39}$. It adhered to the UNESCO in 2011, 107 of the 194 States having voted in favour of its membership. Accordingly, the multilateral acceptance can only be corroborated. In her welcoming speech, the Director-General of UNESCO, Mrs Irina Bokova, boldly stated that she was conscious of the financial risk which the new membership could imply for the Organisation - the United States, having voted against and being its most important contributor, could easily jeopardise the general agenda. Still, the support of the majority hold firm.

Despite this vast recognition and a seemingly new European tendency in the same sense, the practical consequences and their intrinsic legal nature are still unclear - the back to square one image seems indelible.

\section{The Uncertain Consequences of Palestine's Recognition as a State}

Every new step made towards the recognition of a Palestinian State seems to be above all emblematic. Symbolism sometimes bears its own considerable strength but is not always enough to solve serious and concrete problematics: the symbolical support of 135 States has not settled the conflict between Israel and Palestine. The negotiations and dialogue between the two States are in a deadlock. The process of colonisation of the Palestinian territory has not stopped and has even increased. The water distribution problem is still topical; Israel keeps a strong stranglehold of water management and distribution and overtly discriminates between its colonies and Palestinians of Cisjordania ${ }^{40}$. As a State, Palestine has a volatile sovereignty in many strategic fields.

A European support might not necessarily change this reality because the settlement of peace and security

39 Palestine appears as a member State in UNESCO's list of members; see: http://www.unesco.org/new/en/member-states/ countries/

40 Hervé Ascensio. 'Propos introductifs : Les eaux du Jourdain comme parabole' in Société Française pour le Droit International. L'eau en droit international. Colloque d'Orléans. Paris. Pédone, 2011, p. 275-276. 
questions is first of all incumbent upon Israel and Palestine... and their good will. The dynamic will change if Israel officially recognises a Palestinian State with territorial concessions accepted by both Parties - and the 1967 borders are often referred to in this context ${ }^{41}$. Unfortunately, this not likely to happen in a near future; it is even the exact opposite which is occurring with the ever-growing colonisations on one hand, and the preoccupying security questions on the other. This means that should a Palestinian State ever be recognised by Israel, a necessary decolonisation would be needed
- a situation which can hardly be imagined without bloodshed. For Israel security questions prevail and might, as such, gain the upper hand in the debate on the existence of a neighbouring Palestinian State.

The conflict hence continues in the form of a vicious and eternal chess game where the slightest miscalculated move can lead to a crimson checkmate. On whether there has been an evolution or a mere procrastination, it can be stated that the new recognitions are definitely a sign of evolution even if they are insufficient for Palestine to really exist as a State.

41 See: Figure 1.

Figure 1: Evolution of the loss of territories ${ }^{42}$
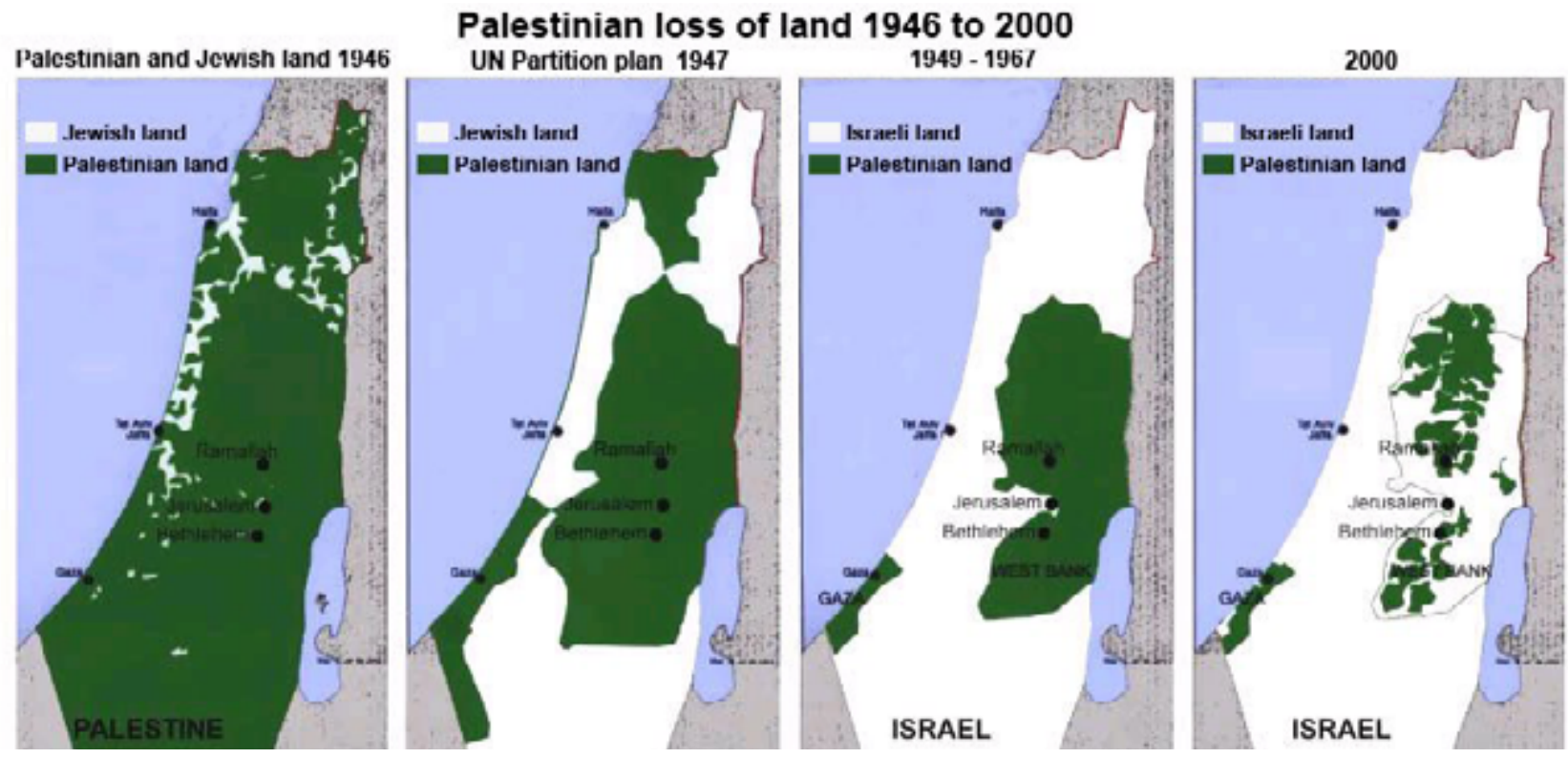


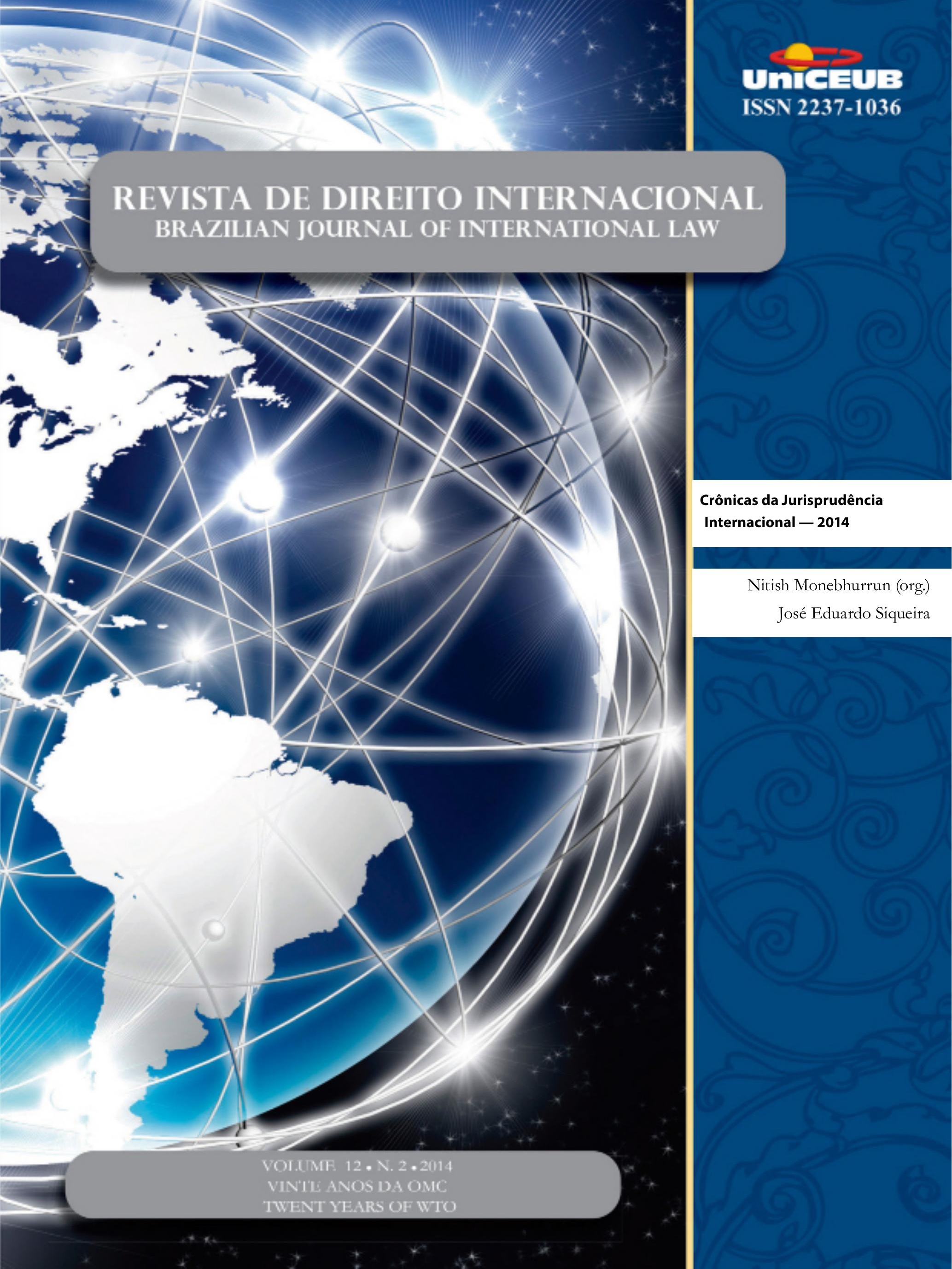




\section{Decisões da Corte Internacional de Justiça e do Tribunal Internacional Sobre o Direito do Mar}

\section{Corte Internacional de Justiça}

1 Caso da Delimitação Marítima entre o Peru e o Chile, Decisão, 24 de janeiro de 2014.

Nitish Monebhurrun* José Eduardo Siqueira**

\section{Introdução}

No dia 24 de janeiro de 2014, a Corte Internacional de Justiça (C.I.J.) julgou o caso atinente à delimitação marítima entre o Peru e o Chile no Oceano Pacífico1. As partes pediram à Corte de determinar e de traçar as fronteiras marítimas que as separam e sob as quais cada uma exerce o seu poder soberano. Como requerente, o Peru afirmava que não existe uma delimitação marítima com o Chile, pedindo, dessarte, à C.I.J. o uso do método da equidistância para definir as fronteiras. O Chile defendia por sua parte a existência de uma delimitação marítima na base da Declaração de Santiago de 1952: a fronteira marítima começava, segundo o réu, a partir do ponto da fronteira terrestre entre ambos os países seguindo o paralelo de latitude até uma distância de 200 milhas náuticas. Pela questão jurídica submetida à C.I.J., esperava-se que ela se baseasse nos acordos de delimitação marítima entre o Peru e o Chile bem como nos princípios gerais do Direito Internacional Público aplicáveis ao caso para determinar e definir as fronteiras marítimas. Utilizando esses instrumentos jurídicos, a Corte construiu a delimitação marítima entre ambos os países. Tratando da questão clássica do uso do princípio da equidistância no seu ratio decidendi (2), a C.I.J. confirmou uma tendência jurisprudencial sobre a questão jurídica da delimitação marítima (3) e nesse processo, um obter dictum merece ser salientado por conferir de maneira notável valor vinculante a uma declaração entre dos Estados — a Declaração de Santiago de 1952 (4).

\section{0 ratio decidendi: a aplicação do princípio da equidistância para delimitar a fronteira entre o Peru e o Chile}

Equidistância significa que a fronteira marítima deve encontrar-se a uma distância igual entre os Estados-partes a uma disputa. Em relação à delimitação do mero mar

* Doutor em Direito Internacional (Escola de Direito de Sorbonne, Paris) e Professor Associado (Centro Universitário de Brasília) nitish. monebhurrun@gmail.com.

** Mestrando (Centro Universitário de Brasília) jose_eduardosiqueira@ hotmail.com. territorial - isto é, uma delimitação de apenas 12 milhas náuticas das linhas de base —, o artigo 15 da Convenção das Nações Unidas sobre o Direito do Mar, a Convenção de Montego Bay já prevê o uso do princípio da equidistância ${ }^{2}$ que tem,

1 Caso da Delimitação Marítima entre o Peru e o Chile. CORTE INTERNACIONAL DE JUSTIÇA. 2014. Sentença de 24 de Janeiro, Peru vs Chile.

2 O artigo 15 dispõe: "Quando as costas de dois Estados são adjacentes ou se encontram situadas frente a frente, nenhum desses Estados tem o direito, salvo acordo de ambos em contrário, de estender o seu mar territorial além da linha mediana cujos pontos são equidistantes dos pontos mais próximos 
nesse caso específico, valor costumeiro ${ }^{3}$. Contudo, para uma delimitação geral da fronteira marítima que inclui a zona econômica exclusiva e a plataforma continental isto é, uma distância de 200 milhas náuticas das linhas de base —, a referência ao dito princípio decorre de interpretação jurisprudencial. Esta influenciou claramente a decisão da C.I.J. no caso Peru/Chile.

Para determinar a fronteira marítima entre os Estados, a Corte examinou antes de tudo todos os acordos marítimos e as proclamações aplicáveis entre eles, notadamente: as proclamações chilenas e peruanas de 1947 pelas quais os países reivindicaram alguns direitos no mar até uma distância de 200 milhas náuticas, as partes concordando todavia que não tratava-se de delimitações marítimas; a Declaração de Santiago de 1952 sobre a proteção dos recursos naturais das partes no interesse do seu desenvolvimento econômico; um acordo complementar à Declaração de Santiago, uma convenção relativa a medidas de controle nos seus espaços marítimos e um acordo sobre uma zona fronteiriça marítima especial, todos de 1954; alguns acordos de 1968-1969 relativos à construção de faróis por eles.

No entanto, esses instrumentos não permitiram estabelecer a existência de uma fronteira no mar. Baseandose no acordo relativo a uma zona fronteiriça marítima especial, a Corte ressaltou que já existia um acordo tácito entre o Peru e o Chile sobre uma fronteira marítima ${ }^{4}$ : não obstante, a natureza da fronteira - a sua largura e os seus limites — não aparece em nenhum texto. É apenas certo que se estende além das 12 milhas náuticas. Ao perscrutar as práticas dos Estados, em especial no âmbito haliêutico, a Corte concluiu que essa fronteira tinha ao menos um limite de 80 milhas náuticas.

das linhas de base, a partir das quais se mede a largura do mar territorial de cada um desses Estados. Contudo, este artigo não se aplica quando, por motivo da existência de títulos históricos ou de outras circunstâncias especiais, for necessário delimitar o mar territorial dos dois Estados de forma diferente". Uma versão da Convenção de Montego Bay está disponível em português no Decreto n. 1530 do 22 de junho de 1995. O decreto internalizou a Convenção na ordem jurídica brasileira. BRASIL. Câmara dos Deputados. Decreto n.1.530, de 22 de junho de 1995. Declara a entrada em vigor da Convenção das Nações Unidas sobre o Direito do Mar, concluída em Montego Bay, Jamaica, em 10 de dezembro de 1982. Disponível em: < http://www2. camara.leg.br/legin/fed/decret/1995/decreto-1530-22-junho-1995435606-publicacaooriginal-1-pe.html>. Acesso em: 08 dez. 2014.

3 Caso da Delimitação marítima e questões territoriais entre o Qatar e o Bahrein. CORTE INTERNACIONAL DE JUSTIÇA. 2001. Sentença de 16 de Março, Qatar vs Bahrein. \$176

4 Caso da Delimitação Marítima entre o Peru e o Chile. CORTE INTERNACIONAL DE JUSTIÇA. 2014. Sentença de 24 de Janeiro, Peru vs Chile. $\$ 151$, nota 1
Um dos primeiros passos fundamentais para poder determinar a delimitação no mar é o ponto de partida da fronteira. Para tanto, a C.I.J. referiu-se ao Tratado de Lima cujo objeto era a determinação da fronteira terrestre entre o Peru e o Chile. $\mathrm{Na}$ base do artigo 3 desse tratado, uma comissão mista tinha traçado a fronteiras terrestre pelo uso de pontos fronteiriços o primeiro ponto, para tanto sendo o Ponto fronteiriço n. 1. A Corte notou que ao erigir os seus faróis o mesmo Ponto n. 1 foi utilizado como ponto de partida da fronteira. Portanto, a C.I.J. afirmou que a fronteira marítima seguia o paralelo que atravessa o Ponto fronteiriço n. $1^{5}$ até 80 milhas náuticas ${ }^{6}$, o ponto $\mathbf{A}$ no mapa na figura 1. Nessa configuração, a Corte utiliza depois um método ao qual ela já se referiu em alguns casos anteriores. Primeiramente, se não tiver qualquer razão imperiosa apontando no sentido contrário, ela traça uma linha de equidistância provisória. Em seguinte, verifica-se que não tenha circunstâncias que justifiquem um ajustamento dessa linha para um resultado mais equitativo. Finalmente e na base de um eventual ajustamento, a Corte examina a determinação da linha não está desproporcionada em relação aos espaços marítimos conferidos a cada parte.

$\mathrm{Na}$ primeira etapa do método, o Ponto A serve de referência para desenhar a linha de equidistância provisória. Para calcular a equidistância, é preciso ter as linhas de base a partir do Chile por um lado, e a partir do Peru, por outro. Considerando o paralelo que cruza o Ponto A até a distância de 80 milhas náuticas, as linhas de base mais perto nas costas chilenas ficam entre Tacna e Arica ${ }^{7}$, na linha da delimitação marítima com o Peru. Para o Peru, as linhas de base encontramse no território peruano onde é possível traçar um arco de círculo (com o uso de um compasso) a partir do Ponto A - isto é, a partir de 80 milhas náuticas - e das linhas de base do Chile ${ }^{8}$. A linha de equidistância provisória começa no ponto onde a distância das linhas de base peruanas são equivalentes às do Chile. Portanto, indo das linhas de base do Peru para achar essa distância percebe-se que a linha começa depois do ponto $\mathbf{A}$, em outras palavras, depois de uma distância

5 CORTE INTERNACIONAL DE JUSTIÇA. 2014. Sentença de 24 de Janeiro, Peru vs Chile. \$169-175, nota 1.

6 CORTE INTERNACIONAL DE JUSTIÇA. 2014. Sentença de 24 de Janeiro, Peru vs Chile. \$177.

7 Ver Figura 1

8 CORTE INTERNACIONAL DE JUSTIÇA. 2014. Sentença de 24 de Janeiro, Peru vs Chile. 
de 80 milhas náuticas, pois antes desse ponto não há uma equidistância entre ambos os Estados?. Nessa lógica, determinam-se os pontos de encontro entre as linhas de base peruanos e chilenos até uma distância de 200 milhas náuticas, o Ponto $\mathbf{B}$ no mapa ${ }^{10}$. A linha provisória segue, portanto e em uma linha reta, uma direção ao sudeste do Ponto $\mathbf{A}$ até o Ponto $\mathbf{B}$ onde a distância com as linhas de ambos os países é de 200 milhas náuticas. No entanto, a partir desse Ponto $\mathbf{B}$ a Corte observou que os limites de 200 milhas náuticas para o Chile continuavam um pouco mais ao sul até o Ponto $\mathbf{C}^{11}$.

Ao chegar a segunda etapa do método, a C.I.J. constatou que não havia quaisquer circunstâncias justificando um ajustamento da linha provisória traçada $a^{12}$. E finalmente, na última etapa do método, a Corte tampouco notou uma desproporção na repartição do espaço marítimo entre as partes; ela referiu-se a sua jurisprudência ${ }^{13}$, afirmando, à vista disso, que o objetivo da delimitação é de encontrar uma solução equitativo e não de garantir uma repartição igual do território marítimo ${ }^{14}$. Sendo assim, ela concluiu que a delimitação marítima começa a partir do supramencionado Ponto fronteiriço n. 1 até o Ponto $\mathbf{A}$, a partir do qual a fronteira segue a linha de equidistância até o Ponto B, e, depois, até os limites de 200 milhas náuticas das linhas de base do Chile, isto é, até o Ponto $\mathbf{C}^{15}$.

O raciocínio da C.I.J. revela, nesse sentido, confirmação da sua jurisprudência concernente à delimitação marítima. Não há mais dúvida sobre o uso do método da equidistância para esse propósito.

9 CORTE INTERNACIONAL DE JUSTIÇA. 2014. Sentença de 24 de Janeiro, Peru vs Chile.

10 CORTE INTERNACIONAL DE JUSTIÇA. 2014. Sentença de 24 de Janeiro, Peru vs Chile.

11 Ver Figura 1. Caso da Delimitação Marítima entre o Peru e o Chile (Peru c. Chile). CORTE INTERNACIONAL DE JUSTIÇA. 2014. Sentença de 24 de Janeiro, Peru vs Chile. \$185-190, nota 1.

12 Caso da Delimitação Marítima entre o Peru e o Chile. CORTE INTERNACIONAL DE JUSTIÇA. 2014. Sentença de 24 de Janeiro, Peru vs Chile. \$191, nota 1.

13 Caso da Delimitação Marítima no Mar Negro. CORTE INTERNACIONAL DE JUSTIÇA. 2009. Sentença de 3 de Fevereiro, Romênia vs Ucrânia. \$111.

14 Caso da Delimitação Marítima entre o Peru e o Chile. CORTE INTERNACIONAL DE JUSTIÇA. 2014. Sentença de 24 de Janeiro, Peru vs Chile. \$193.

15 Ver figura 2.

\section{A confirmação de uma tendência jurisprudencial atinente ao uso do método da equidistância}

A referência à equidistância sempre foi em filigrana das decisões da C.I.J. para as questões de delimitação marítima. A Corte sempre buscou encontrar a solução mais equitativa para as partes. Nessa lógica, o método da equidistância não deve ser utilizado se o resultado não tiver equitativo. No caso da Plataforma Continental do Mar do Norte, ela afirmou que não há um princípio geral do Direito Internacional impondo o uso sistemático da equidistância para delimitar a fronteira marítima; é possível referir-se a vários métodos — até de uma forma concomitante - considerando que a solução seja in fine equitativo $^{16}$. No caso Jan Mayen relativo à delimitação da plataforma continental entre a Dinamarca e a Noruega, a C.I.J. adotou posição ligeiramente diferente, apresentando a equidistância como o método principal $^{17}$. A Corte citou $^{18}$ na sua argumentação o caso da Delimitação da Plataforma Continental entre o Reino Unido e a Irlanda do Norte e a França, uma sentença arbitral, apontando que os métodos de delimitação são normalmente uma modificação ou um variante do princípio da equidistância - em outras palavras, não há outros métodos $^{19}$. No entanto, em 2007, a C.I.J. aportou uma nuança - na realidade, reafirmou a sua posição no caso da Delimitação da Plataforma Continental no Mar do Norte - a essa linha jurispudencial no caso da Disputa territorial e marítima no mar do Caribe: o método da equidistância não tem uma prevalência sobre outros métodos de delimitação, pois podem ter circunstâncias que tornam a sua aplicação inconveniente ${ }^{20}$. Ora, em 2009, no caso da Delimitação Marítima no Mar Negro a C.I.J. voltou a sua jurisprudência Jan Mayen, apresentando

16 Caso da Plataforma Continental do Mar do Norte. CORTE INTERNACIONAL DE JUSTIÇA. 1969. Sentença de 20 de Fevereiro, Alemanha vs Holanda vs Alemanha vs Dinamarca. $\$ 69$

17 Caso da Delimitação Marítima na Região entre Gronelândia e Jan Mayen. CORTE INTERNACIONAL DE JUSTIÇA. 1993. Sentença de 14 de Junho, Dinamarca vs Noruega. \$51.

18 CORTE INTERNACIONAL DE JUSTIÇA. 1993. Sentença de 14 de Junho, Dinamarca vs Noruega.

19 Delimitação da Plataforma Continental entre o Reino Unido e a Irlanda do Norte e a França. Reports of International Arbitral Awards. CORTE INTERNACIONAL DE JUSTIÇA. 1977. Sentença de 30 de Junho, Dinamarca vs Noruega. \$249. Disponível em: $<$ http://legal.un.org/riaa/cases/vol_XVIII/3-413.pdf>. Acesso em: 08 dez. 2014.

20 Caso da Disputa territorial e marítima entre o Nicaragua e o Honduras no mar do Caribe. CORTE INTERNACIONAL DE JUSTIÇA. 2007. Sentença de 2 de Outubro, Nicaragua vs. Honduras. $\$ 272$ 
o método da equidistância como o primeiro passo fundamental de toda delimitação marítima ${ }^{21}$. Se não tiver alguma circunstância indicando o contrário, o princípio da equidistância prevalece ${ }^{22}$. O caso Peru c. Chile de 2012 segue, no princípio, a decisão de 2009.

Até certo ponto, essas decisões da C.I.J. podem parecer conflituosas ou contraditórias. Nada obstante, é possível coadunar os ditames que delas emanam para mostrar que não há um óbice para o entendimento do princípio geral da delimitação marítima; as decisões e a tendência da jurisprudência não são necessariamente conflituosas ou contraditórias. Uma fórmula para resumi-las será: em princípio, aplica-se o método da equidistância a não ser que dita aplicação conduza a uma solução manifestamente não equitativa, desproporcional e obviamente absurda. Por exemplo, na sua opinião parcialmente dissidente no caso Peru c. Chile, o juiz Orrego-Vicuña explicou que a aplicação da equidistância não tinha necessariamente trazido uma solução equitativo, porém não afastou a utilidade intrínseca do método. O princípio da equidistância é certamente enraizado no Direito Internacional e não há dúvidas sobre a sua existência. Dito isso, as modalidades da sua aplicação podem variar segundo as circunstâncias. Os casos Romênia c. Ucrânia e Peru c. Chile afirmaram essa tendência que será seguramente seguida doravante.

O caso em tela é também interessante para outras razões relacionadas ao próprio entendimento do Direito Internacional. Um aspecto fundamental que a decisão salientou em um obter dictum notável, é a consideração de que uma declaração - a Declaração de Santiago de 1952 - pode revestir-se das características de um tratado, tornando-se assim vinculante.

\section{Um obiter dictum notável: o valor vinculante conferido à Declaração de Santiago de 1952}

Conforme adiantado, um dos problemas mais interessantes que se constatou nesse julgado foi dar efeitos vinculantes para a declaração de Santiago de 1952. Isso porque uma análise rápida faria acreditar que a C.I.J está desconstruindo um conceito clássico

21 Caso da Delimitação Marítima no Mar Negro. CORTE INTERNACIONAL DE JUSTIÇA. 2009. Sentença de 3 de Fevereiro, Romênia vs Ucrânia. \$118, nota 13.

22 Caso da Delimitação Marítima no Mar Negro. CORTE INTERNACIONAL DE JUSTIÇA. 2009. Sentença de 3 de Fevereiro, Romênia vs Ucrânia. \$116. da teoria do direito internacional consubstanciada na natureza jurídica das declarações, atos de direito internacional caracterizados, ordinariamente, por instituir intenções e horizontes que pessoas jurídicas de direito internacional visam alcançar. As declarações, nesse sentido, não seriam compromissos capazes de ensejar responsabilizações aos declarantes. Não obstante a C.I.J, ao adentrar na análise específica da declaração sob exame, estabeleceu que, verificadas certas circunstâncias é possível firmar a responsabilização dos Estados, no sentido de tornar disposições como vinculantes, mesmo no âmbito de uma declaração.

Nesse sentido, cumpre investigar o raciocínio que a C.I.J utilizou para este precedente. $O$ raciocínio empregado pode ser considerado trivial se o leitor considerar somente as referências expressas utilizadas pela C.I.J na sua fundamentação, eis que ela se restringe unicamente a verificar que, em algum ponto, ambas as partes assumiram a declaração de Santiago como um compromisso, ou em suas próprias palavras como um tratado $^{23}$.

Não obstante, a C.I.J dignou-se a investigar as disposições da declaração de Santiago de 1952 de forma a determinar, em que medida, essa declaração era vinculante, ou seja, quais elementos - além do mero reconhecimento formal das partes — eram relevantes para ensejar a caracterização de uma declaração, ou parte dela, como uma disposição vinculante. Isso permite deduzir que existem outros critérios utilizados pela C.I.J para a determinação desse efeito vinculante. Não obstante, esses elementos não são explicitamente descritos, motivo pelo qual irá se investigar duas propostas.

A primeira, cuja ideia podemos deduzir de um argumento do governo do Peru, é de que existem elementos procedimentais que, uma vez realizados, permitem intuir a mudança do estatuto jurídico de uma declaração para um tratado. A ideia do governo do Peru é que, quando concebida, a declaração de Santiago realmente pretendia unicamente uma declaração de política externa conjunta dos países declarantes ${ }^{24}$. Contudo, com a ratificação da declaração pelo parlamento dos países signatários, bem como com o depósito da declaração no secretariado das nações

23 CORTE INTERNACIONAL DE JUSTIÇA. 2014. Sentença de 24 de Janeiro, Peru vs Chile. 447.

24 CORTE INTERNACIONAL DE JUSTIÇA. 2014. Sentença de 24 de Janeiro, Peru vs Chile. $\$ 46$ 
unidas, a declaração poderia ser considerada um Tratado, e portanto, vinculante.

Esse argumento parece válido a priori. No entanto, há de se constatar que não existe, na decisão da C.I.J, nenhum argumento que reforce essa compreensão. Isso ocorre porque o Tribunal não se manifestou sobre qualquer critério procedimental como determinante de validade, mas ao contrário, o seu silêncio sobre esse critério apresentado pela delegação peruana leva a crer que isso não é relevante para a caracterização da vinculação - eis que essa estava garantida pelo reconhecimento das partes ${ }^{25}$. Isso não implica que os atos formais não possam ser utilizados para verificar o reconhecimento das partes, mas significa que esse fator não é determinante para a mudança da natureza de uma declaração para a de um tratado.

Sendo assim, a segunda hipótese é que há elementos na própria declaração de Santiago de 1952 que permitem deduzir um efeito vinculante. Essa hipótese parece ser a mais profícua, eis que a fundamentação da decisão, ao que parece, acomoda bem esse critério. Isso se observa pelo fato de que a C.I.J tomou como um dos seus focos principais de argumentação nessa parte do caso o argumento do Chile segundo o qual o parágrafo IV da declaração de Santiago fixava fronteiras marítimas entre os Estados partes da declaração ${ }^{26}$.

$\mathrm{O}$ argumento Chileno era de que o disposto no parágrafo IV especificava, além de uma regra para as fronteiras insulares, uma regra mais geral para a fixação das fronteiras marítimas ${ }^{27}$. Isso porque as regras de fixação de fronteiras insulares só fariam sentido se a regra geral também fosse essa, eis que, de modo a determinar se uma ilha se encontra dentro do perímetro de duzentas milhas náuticas da zona de um dos países era necessário saber, primeiramente, qual era essa área.

25 CORTE INTERNACIONAL DE JUSTIÇA. 2014. Sentença de 24 de Janeiro, Peru vs Chile. $\$ 47$

26 CORTE INTERNACIONAL DE JUSTIÇA. 2014. Sentença de 24 de Janeiro, Peru vs Chile. $\$ 51$.

27 CORTE INTERNACIONAL DE JUSTIÇA. 2014. Sentença de 24 de Janeiro, Peru vs Chile. $\$ 52$.
Assim, ao ter decido que esse era um dos elementos relevantes para a decisão, a C.I.J afirma, de maneira implícita, que sua análise para a resolução da decisão busca verificar se há, na declaração, um conteúdo de natureza vinculante, como por exemplo um acordo sobre a fixação de fronteiras marítimas. A C.I.J então, aplicando os métodos de interpretação estabelecidos pela convenção de Viena ${ }^{28}$ verificou, por meio do uso do método que leva em consideração o significado ordinário das expressões empregadas na declaração, que havia sim, naquele tratado, um conteúdo que, por sua expressão escrita e pela vontade expressa pelas partes naquele acordo, era vinculante: isto é, a demarcação de fronteiras entre Estados quando de territórios insulares ou de territórios a eles contíguos ${ }^{29}$.

Isso permite deduzir que o critério do conteúdo foi utilizado, quando da análise da C.I.J, para a determinação dos efeitos vinculantes à declaração de Santiago de 1952. Em outras palavras, a C.I.J verificou que uma certa disposição, o parágrafo IV, por conta da natureza do conteúdo que estabelecia, fez com que aquilo que deveria ser uma mera expressão de fins políticos fosse uma obrigação a ser respeitada pelos Estados declarantes - podendo ser ela mesmo oposta contra eles como um fundamento jurídico de responsabilização.

Assim, percebemos, no caso em tela, um avanço interessante na jurisprudência da C.I.J, eis que, além de estabelecer a possibilidade de considerar uma declaração como um tratado para efeito de responsabilidade jurídica, forneceu alguns elementos metodológicos para que o intérprete possa antecipar situações nas quais isso possa voltar a ocorrer.

28 CORTE INTERNACIONAL DE JUSTIÇA. 2014. Sentença de 24 de Janeiro, Peru vs Chile.\$57-58.

29 CORTE INTERNACIONAL DE JUSTIÇA. 2014. Sentença de 24 de Janeiro, Peru vs Chile. $\$ 70$. 
Figura 1 - A aplicação do método para delimitar a fronteira marítima ${ }^{3}$

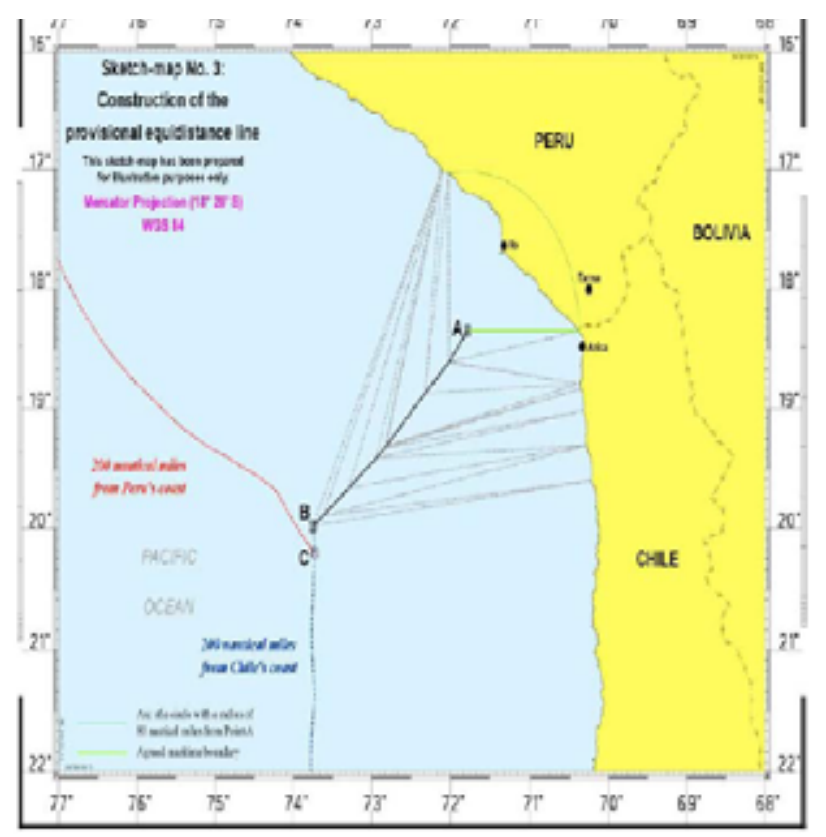

Figura2 - delimitação marítima final

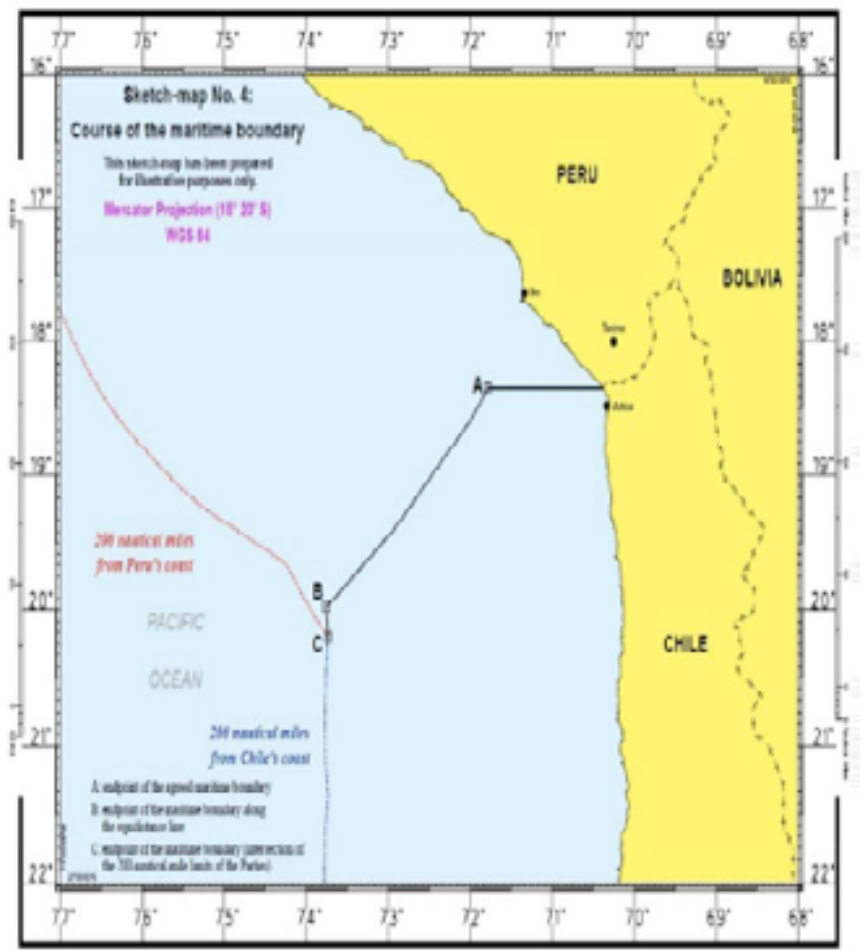

30 Trata-se do mapa utilizado pela própria C.I.J. E que se encontra no texto da decisão.

31 Trata-se do mapa utilizado pela própria C.I.J. E que se encontra no texto da decisão. 


\section{Questões relacionadas com a apreensão e detenção de certos documentos e dados (Timor Leste c/ Austrália), Medidas Provisórias, 03 de março de 2014}

\author{
Gleisse Ribeiro Alves* \\ Alice Rocha da Silva**
}

\section{Introdução}

O Caso Timor-Leste c/ Austrália teve início em 17 de dezembro de 2013 com a denúncia feita pelo TimorLeste à CIJ, acusando a Austrália de ter apreendido e detido, por meio de seus agentes, documentos, dados e outros bens pertencentes ao Timor-Leste ou que este tenha o direito de proteger segundo as leis internacionais. Timor-Leste afirmou perante a CIJ que no dia 03 de dezembro de 2013, agentes australianos, pertencentes à Organização Australiana de Inteligência de Segurança, supostamente no âmbito de um mandado emitido pela Procuradoria-Geral da Austrália, apreenderam do gabinete da assessoria jurídica profissional e privada de Timor-Leste localizado em Narrabundah (subúrbio de Canberra, território da capital Australiana), entre outras coisas, documentos, correspondências e dados contendo as comunicações privadas realizadas entre o Governo de Timor-Leste e seus assessores legais. Em especial, foram apreendidos documentos relativos ao processo de arbitragem que está em andamento entre Timor-Leste ea Austrália, nos termos do Tratado de 20 de maio de 2002 sobre o Mar do Timor.

Diante dos fatos, o Timor-Leste solicitou medidas cautelares $^{34}$ para impedir prejuízos irreparáveis provenientes do conhecimento e da divulgação dos

\footnotetext{
* Doutora em Direito pela Universidade Nancy 2 - França (Tese indicada ao prêmio de melhor tese do ano de 2011); Mestre em Direito das Relações Internacionais pelo UniCEUB; Graduada em Relações Internacionais pela Universidade Católica de Brasília. Professora do UniCEUB e do Mestrado em Ciência Política do UNIEURO. Linhas de pesquisa: Serviços eletrônicos, Direito da União Europeia, Direito da Organização Mundial do Comércio, Direito Internacional Público e Privado, Ciência Política. CV Lattes: http://lattes.cnpq. br/2226009228595251. Email:gleisse@yahoo.com

** Professora do Programa de Mestrado e Doutorado em Direito do Centro Universitário de Brasília (UniCEUB) e da graduação da Faculdade Processus. Doutora em Direito Internacional Econômico pela Aix-Marseille Université, França, Mestre em Direito das Relações Internacionais pelo UniCEUB. Graduada em Direito pelo UniCEUB e Graduada em Relações Internacionais e Ciência Política pela Universidade de Brasília-UnB. Email: rochaalice@yahoo.com.br

34 Pedido fundamentado no artigo 41 do Estatuto da Corte Internacional de Justiça: "A Corte terá a faculdade de indicar, se julgar que as circunstâncias o exigem, quaisquer medidas provisórias que devam ser tomadas para preservar os direitos de cada parte".
}

elementos apreendidos. Assim, ele fez as seguintes solicitações à Corte: i) aplicação de medidas como o recolhimento e guarda de tais documentos; ii) que a Austrália informe quais pessoas tiveram conhecimento de tais dados; iii) que a Austrália destrua todas as cópias de tais documentos e que assegure que não interceptará mais as comunicações entre o Timor-Leste e seus conselheiros jurídicos localizados em território australiano. Por 12 votos contra 4, a CIJ decidiu que tais documentos e dados não deveriam ser utilizados contra o Timor-Leste e que a Australia deveria conservar e guardar tais elementos até o término do processo de arbitragem. Além disso, por 15 votos contra 1, a CIJ determinou que a Austrália não interceptasse as comunições entre o Timor-Leste e seus conselheiros jurídicos localizados na Austrália. Nesse caso, apesar da Corte determinar que a Austrália não obstacularizasse a comunicação do Timor-Leste com seus conselheiros jurídicos, a CIJ concedeu medidas cautelares que não sanaram completamente o perigo de dano irreparável pela difusão de dados e documentos do Timor-Leste ao determinar que os mesmos ficassem sob a guarda da Austrália ao invés de depositados junto à Corte. Tal posicionamento deve ser analisado a partir da análise de duas vertentes de tratamento dos princípios gerais de direito internacional: o reconhecimento do princípio da igualdade soberana entre os Estados (1) e a violação do princípio da boa administração da justiça (2).

\section{Reconhecimento do princípio da igualdade soberana entre os estados}

O princípio da igualdade soberana entre os Estados foi levado em consideração na análise de diversos pontos, entre eles o aspecto plausível do pedido do Timor-Leste. Nesse ponto, a CIJ considerou que deveria haver uma ligação entre o pedido principal do caso e a proteção solicitada em caráter cautelar. $\mathrm{Na}$ opinião da Corte, nenhuma das partes contestou o fato de que documentos relacionados a resolução arbitrária de uma controvérsia envolvendo os dois Estados estariam entre os documentos apreendidos pelo Estado australiano. Sendo assim, a CIJ considerou que haveria ligação entre o pedido principal e a medida cautelar, na medida em que ao estabelecerem este modo pacífico de solução de controvérsias, presume-se que as defesas serão preparadas sem ingerência da outra parte, com base no princípio da igualdade soberana.

35 A dependência entre o pedido principal e a medida cautelar 
Além disso, o reconhecimento do princípio da igualdade entre os Estados foi considerado a partir do ponto em que, sendo um Estado soberano, o Timor teria o direito de se comunicar de modo confidencial com seus conselheiros jurídicos sobre questões relativas a procedimento de arbitragem em andamento ou futuras negociações entre as partes, mesmo se estes estivessem em território de terceiro. Motivação que levou a decisão da corte de que a Austrália não deveria mais manifestar qualquer ingerência nas comunicações entre o Timor Leste e seus conselheiros jurídicos no caso relacionado a Arbitragem em virtude do tratado de 20 de maio de 2002 sobre o mar do Timor ou qualquer outro processo de solução de controvérsias envolvendo os dois Estados. Ou seja, sendo este princípio fundamental no direito internacional público, conforme artigo 2 par.1 da Carta das Nações Unidas, a Austrália não poderia apresentar ingerência a esta comunicação entre o Timor-Leste e seus conselheiros jurídicos e portanto a CIJ considerou a proteção desse direito plausível.

Interessante ainda considerar que, com base no princípio da igualdade soberana entre os Estados, não haveria espaço para a discussão de esgotamento de via jurisdicionais internas, visto que o direito do Timor Leste de se comunicar com seus conselheiros ou manter o sigilo dos documentos mesmo em território australiano é por si só um direito próprio do Timor enquanto Estado. Nas palavras do juiz Cançado Trindade "par in parem non babet imperium, non habet jurisdictionem". ${ }^{36} \mathrm{O}$ reconhecimento do princípio da igualdade soberana entre os Estados está diretamente ligado à observância do princípio da boa administração da justiça que serviu de base para diversos posicionamentos neste caso.

\section{Violação ao princípio da boa administração da justiça}

Ao considerar o pedido formulado pelo TimorLeste de que os documentos fossem selados e guardados pela CIJ, além da destruição de cópias em poder da Austrália, a Corte analisou o risco de prejuízo irreparável e urgência que estariam consubstanciados

foi questionada pelo juiz Cançado Trindade, Segundo o qual cada vez mais existe o reconhecimento de um regime jurídico autônomo, sendo suficiente a necessidade de proteção de direitos e obrigações correspondentes aos Estados envolvidos. OPINION individuelle de m. le juge Cançado Trindade. Disponível em: <http://www.icj-cij. org/docket/files/156/18083.pdf>. Acesso em: 08 dez. 2014.

36 TRINDADE, A. A. C. The application of the rule of exhaustion of local remedies in international law. Cambridge: Cambridge University Press, 1983. p. 173-174. na observância do princípio da boa administração da justiça. Todavia, ao determinar medidas cautelares baseadas em ato unilateral incerto e de caráter nãovinculante, a CIJ prejudicou a aplicação de tal princípio.

A Corte gerou dúvidas e incertezas ao instituir a aplicação de medidas cautelares apoiadas em atos unilaterais tendo em vista estes serem fundamentados em promessas ou compromissos com caráter pouco vinculativo. No caso em espécie, a CIJ amparou sua decisão de manter os documentos e dados em poder da Austrália em compromisso por escrito apresentado por agente australiano em 21 de janeiro de 2014 nos seguintes termos:

A Austrália se compromete que as informações, os documentos, dados ou pertences que foram apreendidos e detidos do Timor-Leste por meio dos agentes australianos não serão utilizados por nenhuma entidade do governo australiano, para qualquer fim, exceto para questões de segurança nacional (em particular no contexto das autoridades de referência da aplicação da lei e repressão). Ela igualmente se compromete que caso haja uma circunstância que venha a exigir o conhecimento desses elementos, a Austrália informará primeiramente à Corte e, no caso específico será fixado posteriormente outros compromissos.). ${ }^{37}$

A crítica que pode ser realizada a essa medida da CIJ se relaciona com a decisão de permitir que os documentos e dados permanecessem em poder do Estado australiano com base na aplicação de promessas ou compromissos unilaterais. Todavia, estes não eliminam os riscos ou incertezas.Em sua decisão, a Corte argumentou que o procurador-geral australiano teria o poder efetivo e manifesto de assumir compromissos obrigando a Austrália, tanto em relação ao direito interno quanto ao direito internacional. $\mathrm{E}$ que não haveria razões que levassem a pensar que tal compromisso não seria cumprido, presumindo-se a boa-fé da Austrália.

Ao adotar tal posicionamento, a corte não estaria excluindo os riscos de que tais informações fossem divulgadas, sobretudo pelo fato do procurador-geral ter deixado uma brecha ao afirmar que por razões de segurança nacional e outras, tais informações poderiam ser utilizadas. Vale ressaltar que a consideração de aspectos de "segurança nacional"estão fora da 37 CORTE INTERNACIONAL DE JUSTIÇA. 2014. Sentença de 21 de Janeiro, Timor-Leste vs Austrália. \$31-48. 
competência do direito aplicável, sendo muito mais um aspecto a obstacularizar o processo e o cumprimento do princípio da "igualdade de armas". ${ }^{38}$

Ora, tal posicionamento mostra-se uma afronta ao princípio da boa administração da justiça, tendo em vista que o risco persiste de que os dados sejam divulgados. A CIJ deveria ter deferido medidas cautelares independentemente de promessas e compromissos unilaterais seja do Estado ou dos agentes que o representam. Afinal, o imperativo da justiça deve prevalecer sobre a boa-vontade dos Estados. Além disso, o princípio da igualdade entre os Estados, analisado acima, prescinde que a proteção aos documentos de propriedade do Timor seja assegurada independentemente de promessas ou atos unilaterais. ${ }^{39}$

Atos unilaterais são manifestações autônomas da vontade de um Estado, endereçada a outros Estados ou Organizações Internacionais, com o objetivo de criar obrigações jurídicas no contexto internacional. ${ }^{40}$ Entre os atos unilaterais mais comuns entre os Estados, está a promessa que é justamente um comprometimento do Estado em adotar determinado comportamento no futuro.

Atos unilaterais não estão previstos na lista de fontes do direito internacional conforme estipula o art. 38 do Estatuto da CIJ e não vinculam os Estados e as Organizaçoes Internacionais como um tratado, mas podem ser alegados em um contencioso como fonte legítima de direito internacional. ${ }^{41}$

O juiz Caçado Trindade precisou, em sua opinião individual, que outros tribunais internacionais contemporâneos também tem sido confrontados com a adoção de atos unilaterais assumidos pelas partes em um litígio. Ele assinalou que "a resolução judicial dos litígios internacionais tem sua própria lógica, que

38 Nesse sentido ver a opinião do juiz Cançado Trindade OPINION individuelle de $\mathrm{m}$. le juge Cançado Trindade. \$41. Disponível em: <http://www.icj-cij.org/docket/files/156/18083. pdf $>$. Acesso em: 08 dez. 2014.

39 Nesse sentido ver a opinião do juiz Cançado Trindade OPINION individuelle de $\mathrm{m}$. le juge Cançado Trindade. $\$ 47$. Disponível em: <http://www.icj-cij.org/docket/files/156/18083. pdf $>$. Acesso em: 08 dez. 2014.

40 NATIONS UNIES. Actes Unilatéraux des États: Deuxième rapport sur les actes unilatéraux des États, par M. Víctor Rodríguez Cedeño, rapporteur spéci. Victor Rodríguez Cedeño. 1999. Disponível em: $<$ http://legal.un.org/ilc/documentation/french/a_ cn4_500.pdf>. Acesso em: 08 dez. 2014.

41 Contencioso entre Burkina Fasso e Malisobre a disputa fronteiriça. CORTE INTERNACIONAL DE JUSTIÇA. 1986. Sentença de 22 de Dezembro, Burkina Fasso vs Malisobre. esta não pode ser equiparada àquela existente nas relações diplomáticas". Segundo ele, "persistir na fundamentação de decisões em atos unilaterais que são próprios das relações diplomáticas não é o caminho acertado para se liquidar o litígio judicial internacional". E, acrescentou ainda:

$\mathrm{Na}$ verdade, permitir que atos unilaterais sejam realizados (como parte de um processo judicial internacional), independentemente de seu caráter discricionário — ou mesmo arbitrário - e autorizar compromissos deles decorrentes, na verdade o tribunal reduz a aplicação da decisão a uma mera probabilidade. Dessa forma, se retorna àincerteza e àimprevisibilidade e assim, acabase por conceder o benefício exclusivo ao autor do ato unilateral em detrimento da outra parte. ${ }^{42}$ (Parag. 25).

Contudo, contrariando o posicionamento do juiz Caçado Trindade, com essa decisão a CIJ manteve seu entendimento, que vem sido seguido pela doutrina ${ }^{43}$, de que as promessas e os compromissos unilaterais são revestidos de caráter obrigatório e devem ser executados e fundamentados no princípio da boa-fét ${ }^{44}$.

A Corte tem assumido, em algumas decisões, o caráter obrigatório da execução de um compromisso unilatetal. Conforme a decisão no caso que opôs Nicarágua c/ Estados Unidos de 1984 sobre as atividades militares e paramilitaresna e contra a Nicaráguaa, a CIJ precisou que:

[...] os Estados são livres para subscreverem as condições e para realizarem compromissos unilaterais. Mas, o caráter unilateral não implica que o Estado em questão seja livre para modificar segundo sua vontade o alcance e o conteúdo do compromisso assumido. ${ }^{45}$

42 CORTE INTERNACIONAL DE JUSTIÇA. 1986. Sentença de 22 de Dezembro, Burkina Fasso vs Malisobre.

43 CHARPENTIER, Jean. Engagements unilatéraux et engagements conventionnels: différences et convergences. In: KRZYSZTOF, Mélanges Skubiszewski. Theory of International Law at the Threshold of the 21st Century. Hague: Kluwer Law International, 1996. p. 367-392.

44 CHARPENTIER, Jean. Engagements unilatéraux et engagements conventionnels: différences et convergences. In: KRZYSZTOF, Mélanges Skubiszewski. Theory of International Law at the Threshold of the 21st Century. Hague: Kluwer Law International, 1996. p. 367-392..

45 EISEMANN, Pierre-Michel. L'arrêt de la C.I.J. du 26 novembre 1984 (compétence et recevabilité) dans l'affaire des activités militaires et para-militaires au Nicaragua et contre celuici (Nicaragua c/ États-Unis d'Amérique). Annuaire français de droit international, 1984 , v. 30, n. 30. Disponível em: < http:// 
Da mesma forma, a CIJ em sua decisão no caso que opôs Nova Zelândia c/ França sobre os Testes nucleares em 1974, analisou os compromissos orais realizados pela Nova Zelândia. A Corte concluiu que esse Estado reconhece a possibilidade de a disputa ser resolvida por meio de um compromisso unilateral da Franca se comprometendo que não haverá mais nenhum teste aéreo nuclear. A CIJ entendeu que:

\begin{abstract}
As afirmações realizadas pelas autoridades francesas por envolverem situações factuais ou legais que limitem a liberdade de ação do Estado, poderão gerar obrigações legais. Complementou ainda que por ser um ato unilateral não é necessário que nenhum Estado se pronuncie a seu respeito ou que seja necessária qualquer manifestação em seu favor para que a afirmação seja enxergada como a constituição de uma obrigação legal. Por fim, a Corte ressaltou que a forma na qual a afirmação é realizada não interfere em validade e que a boafé constitui princípio básico a ser observado pelos Estados já que a confiança é o ponto essencial para a realização da cooperação internacional ${ }^{46}$.
\end{abstract}

Em nome do princípio da boa administração da justiça, a CIJ determinou que não haveria problema na concorrência entre jurisdições relacionadas ao mesmo caso, sendo inclusive uma previsão expressa do Tribunal Arbitral e da CPA. Na opinião de alguns, a possibilidade de recurso a diversas instâncias, acaba por permitir um maior acesso a justiça aos Estados, sendo a missão comum das jurisdições internacionais oferecer soluções justas aos casos apresentados. ${ }^{47}$

O caso em apreço demonstra algumas falhas na efetivação do princípio da boa administração da justiça, ao considerar uma promessa de agente público como ato suficiente para suprimento dos prejuízos irreparáveis provenientes do conhecimento e da divulgação dos elementos apreendidos por autoridades australianas. A partir do reconhecimento da igualdade soberana entre os Estados resta o questionamento: será que a

www.persee.fr/web/revues/home/prescript/article/afdi_00663085_1984_num_30_1_2610>.Acesso em: 08 dez. 2014.

46 Bernardo Souza Leão e Caroline Guimarães. Nova Zelândia vs França. CORTE INTERNACIONAL DE JUSTIÇA. 1974. Nova Zelândia vs França Disponível em: <http://academico.direito-rio.fgv.br/wiki/CIJ_-Caso_2>

47 Nesse sentido ver a opinião do juiz Cançado Trindade OPINION individuelle de $\mathrm{m}$. le juge Cançado Trindade. \$11-12. Disponível em: <http://www.icj-cij.org/docket/ files/156/18083.pdf>. Acesso em: 08 dez. 2014. decisão seria a mesma se os polos estivessem invertidos e fosse o Timor Leste o acusado de apreensão e guarda indevida de documentos australianos?

\section{O caso Austrália c. Japão perante a Corte Internacional de Justiça, Decisão, 31 de março de 2014}

\author{
Liziane Paixão Silva Oliveira* \\ Maria Edelvacy Marinho**
}

\section{Introdução}

Observa-se entre os julgados da Corte Internacional de Justiça (CIJ) um aumento nos últimos 10 anos de casos, envolvendo temas ambientais. Pode-se entender que a ampliação da consciência referente à necessidade de proteção do meio ambiente aliada a aprovação de acordos internacionais voltados ao tema tenha favorecido a esse cenário. Em 2006, a Argentina ingressa perante a Corte com uma reclamação contra o Uruguai referente à construção das usinas de papel e a poluição provocada por essas indústrias ${ }^{50}$. Em 2008, o Equador deposita uma reclamação contra a Colômbia, versando sobre a aplicação de agrotóxicos por aviões. Por fim, em 2010, a Austrália deposita uma "requête" contra o Japão referente à pesca de baleias na Antártica. Essa é a primeira vez que a CIJ se pronuncia acerca da aplicação de um tratado com implicações diretas sobre a preservação do meio ambiente. Com o intuito de contribuir para o estudo das decisões da CIJ, acerca de casos envolvendo temas de proteção ambiental, esse artigo versará sobre a decisão da CIJ no caso Austrália c. Japão proferida em 31 de março de 2014, da apresentação do caso (I) se passará ao estudo da argumentação inovadora proposta pela Corte (II).

* Doutora em Direito pela Université d'Aix-Marseille III, Mestre em Direito pela Universidade de Brasília, Coordenadora do Programa de Pós-Graduação em Direito-Mestrado em Direitos Humanos da Universidade Tiradentes, Líder do Grupo de Pesquisa (CNPq) Novas tecnologias e o impacto nos Direitos Humanos.

** Doutora em Direito pela Université de Paris, Mestre em Direito pelo UniCEUB, Professora do Programa de Mestrado e Doutorado do UniCEUB, Advogada.

50 Sobre o Caso das papeleiras cf. MALJEAN-DUBOIS, Sandrine; KERBRAT, Yann. La Cour Internationale de Justice face aux enjeux de protection de l'environnement : réflexions critiques sur l'arrêt du 20 avril 2010, Usines de pâte à papier sur le fleuve Uruguay (Argentine c. Uruguay). RGDIP, n. 1, 2011, t. 115, p. 39-75, jul. 2011. 


\section{Da apresentação do caso}

\section{A) A apresentação factual do caso}

O Regime de proteção internacional das baleias conta entre seus instrumentos com a Convenção Internacional para a Regulamentação da Pesca da Baleia (1946) ${ }^{51}$, com a Convenção das Nações Unidas sobre o Direito do Mar (CNUDM) e com a Convenção sobre Diversidade Biológica (1992).A Convenção Internacional para a Regulamentação da Pesca da Baleia adotada em 2 de dezembro de 1946, por quinze Estados Partes, em Washington D.C., hoje a Convenção conta com mais de oitenta adesões. ${ }^{52}$ Essa, todavia, não foi a primeira convenção dedicada ao tema, em 24 de setembro de 1931 havia sido firmada, em Genebra, a Convenção para a Regulamentação da pesca a Baleia; posteriormente, em 8 de junho de 1937, se concluiu o Acordo Internacional para a regulamentação da Pesca a Baleia. Logo, a Convenção de 1946 vem a retomar e aprimorar alguns dos dispositivos dos textos anteriores.

A Convenção tem, dentre as suas finalidades, a de conservar algumas espécies de baleias e permitir a pesca de outras tornando possível " $\mathrm{O}$ desenvolvimento ordenado da indústria baleeira" ${ }^{53}$. Nela estão regulamentadas dois tipos de pesca, são elas: a pesca comercial, a científica $\cdot{ }^{54} \mathrm{~A}$ pesca aborígine tradicional foi prevista pela Comissão no artigo 13 a) do Regulamento ${ }^{55}$, ela é praticada por alguns povos na

51 Nesse artigo, seguindo a tendência da CIJ, a Convenção Internacional para a Regulamentação da Pesca da Baleia (1946) será denominada Convenção ou Convenção de 1946.

52 BRASIL. Senado Federal. Decreto Legislativo $n^{\circ}$ 77, 05 de dezembro de 1973. Aprova o texto da Convenção Internacional para a Regulamentação da Pesca da Baleia, concluída em Washington, a 2 de dezembro de 1946. Disponível em: <http://legis.senado.gov.br/ legislacao $/$ ListaPublicacoes.action?id=229065 $>$. Acesso em: $08 \mathrm{dez}$. 2014.

53 BRASIL. Senado Federal. Decreto Legislativo n ${ }^{\circ} 77,05$ de dezembro de 1973. Aprova o texto da Convenção Internacional para a Regulamentação da Pesca da Baleia, concluída em Washington, a 2 de dezembro de 1946. Preâmbulo Disponível em: <http://legis. senado.gov.br/legislacao/ListaPublicacoes.action?id=229065>. Acesso em: 08 dez. 2014.

54 BRASIL. Senado Federal. Decreto Legislativo $\mathrm{n}^{\circ} 77$, 05 de dezembro de 1973. Aprova o texto da Convenção Internacional para a Regulamentação da Pesca da Baleia, concluída em Washington, a 2 de dezembro de 1946. Disponível em: <http://legis.senado.gov.br/legislacao/ListaPublicacoes. action?id=229065>. Acesso em: 08 dez. 2014.

55 COMISSÃO BALEEIRA INTERNACIONAL. Convenção Internacional para a Regulamentação da Caça à Baleia e Protocolo. Disponível em: <http://www.iwcoffice.
Rússia, na Dinamarca, nos Estados Unidos (Alaska), em São Vicente, nas Granadinas. ${ }^{56}$

Desde 1982, a Comissão Baleeira Internacional $(\mathrm{CBI})^{57}$ proibiu a pesca comercial de baleias, tendo em vista a redução acentuada do seu estoque, essa moratória começou a vigorar em 1986. Logo,a partir de 1986 as quotas autorizadas para a pesca de baleia foram fixadas em zero. Todavia, a despeito da interdição, o Japão, o Peru, a Noruega e a União Soviética continuaram realizando a pesca por entenderem que não estavam obrigados pela decisão da Comissão. ${ }^{58}$

Quanto à pesca com finalidade científica, nos termos da Convenção (artigo VIII) seria facultada a permissão aos Estados Partes para conceder aos seus nacionais permissão especial, autorizando-os a matar, capturar e tratar baleias com propósito de pesquisas científicas, sob-reserva de tais restrições, quanto ao número e de outras condições que o governo contratante julgar útil prescrever; nesse caso, a presente convenção será inoperante no que refere às baleias abatidas, capturadas e tratadas ${ }^{59}$.

Ante a proibição de se realizar a pesca comercial, o Japão passou a não mais se referir à pesca comercial, mas a pesca científica. ${ }^{60}$ Segundo ospesquisadores do IFAW" no nation has taken advantage of the Article VIII clause to the extent that Japan has. Between 1952 and 1986, the total number of whales killed by all countries (including Japan) under Article VIII was approximately 2100. Since 1987, Japanalonehaskilled in excessof 14000 whales" ${ }^{261}$.Nos

org/>. Acesso em: 07 abr. 2012.

56 PEW WHALES COMMISSION BULLETIN. A report on the Pew Commission on Whale Conservation in the21st century. New York, International Institute for Sustainable Development, v. 37, n. 5, p. 2, 2009.

57 A Commission Baleinière Internationale (CBI) foi constituida em 1948.

58 PEW WHALES COMMISSION BULLETIN. A report on the Pew Commission on Whale Conservation in the21st century. New York. International Institute for Sustainable Development, v. 37, n. 5, p. 2, 2009.

59 BRASIL. Senado Federal. Decreto Legislativo no 77, 05 de dezembro de 1973. Aprova o texto da Convenção Internacional para a Regulamentação da Pesca da Baleia, concluída em Washington, a 2 de dezembro de 1946. Art. 8 Disponível em: < http://legis.senado. gov.br $/$ legislacao $/$ ListaPublicacoes.action?id $=229065>$. Acesso em: 08 dez. 2014.

60 INTERNATIONAL FUND FOR ANIMAL WELFARE. The Economics of Japanese Whaling: a collapsing industry burdens taxpayers. Massachusetts: IFAW, 2013. p. 16.

61 INTERNATIONAL FUND FOR ANIMAL WELFARE. The Economics of Japanese Whaling: a collapsing industry burdens taxpayers. Massachusetts: IFAW, 2013. p. 16. 
dias atuais, três países praticam ou permitem a pesca de baleia, a Noruega, a Islândia e o Japão. A Noruega e a Islândia, por sua inércia ou incapacidade para impedir a pesca e o Japão permitir a atividade baleeira como científica $^{62}$.

Assim, com fulcro no texto da Convenção e ante a proibição da pesca comercial pela Comissão, o Japão concedeu diversas permissões para programas de pesquisa científica sobre as baleias da Antártica, tais como os Projetos JARPN, JARPA, JARPN II e JARPA II, sendo este ultimo o motivo da contenda interposta pela Austrália.

\section{B) A apresentação do problema jurídico}

Em 31 de maio de 2010, a Austrália deposita junto à CIJ uma "requête" contra o Japão referente à violação da Convenção Internacional para a Regulamentação da Pesca a Baleia (1946) e outras obrigações internacionais relativas à preservação dos mamíferos marinhos e do meio ambiente. ${ }^{63} \mathrm{~A}$ Austrália questiona se as autorizações concedidas, pelo Japão,no âmbito do programa JARPA II, para a pesca de baleias com fins de pesquisa científica cumprem os requisitos do parágrafo 1, do artigo VIII da Convenção. Ao analisar o volume de baleias capturadas e as descobertas científicas alcançadas, a Austrália entende que o programa JARPA II não é um programa voltado para empreender uma pesquisa científica no contexto do artigo VIII. ${ }^{64}$

Ainda segundo os argumentos levantados pela Austrália, a permissão especial concedida pelo Japão violaria as obrigações concretas assumidas no âmbito da referida Convenção internacional, quais sejam: observar o limite fixado em zero, o número para a pesca e morte de baleias para fins comerciais; parar as atividades de captura das rorquais comuns"com finalidade comercial no Oceano Austral; impedir os

62 PEW WHALES COMMISSION BULLETIN. A report on the Pew Commission on Whale Conservation in the21st century. New York, International Institute for Sustainable Development, v. 37, n. 5, p. 2, 2009. p. 12.

63 Chasse à la baleine dans l'Antarctique (Australie c. Japon ; Nouvelle-Zélande (intervenant). CORTE INTERNACIONAL DE JUSTIÇA. 2014. Sentença de 31 de Março, Australia vs. Japão. Disponível em: <http://www.icj-cij.org/docket/files/148/18137. pdf $>$. Acesso em: 10 set. de 2014.

64 CORTE INTERNACIONAL DE JUSTIÇA. 2014. Sentença de 31 de Março, Australia vs. Japão. \45. Disponível em: < http:// www.icj-cij.org/docket/files/148/18137.pdf>. Acesso em: 10 set. de 2014 navios baleeiros ${ }^{65}$, as usinas flutuantes. Além de violar as obrigações de procedimento do parágrafo 30 do Regulamento. Assim, a Austrália solicita a Corte que ordene ao Japão para encerrar a execução do programa JARPA II, revogar todas as permissões, autorizações e licenças concedidas.

O Japão, em sua defesa, alega que as suas atividades são lícitas e que as permissões concedidas atendem aos requisitos do artigo VIII e questiona a competência da Corte para decidir sobre o caso. ${ }^{66}$ Todavia a Corte entende que o caso versa sobre a questão de saber se as atividades autorizadas pelo Japão, no JARPA II, são ou não compatíveis com as obrigações assumidas no âmbito da Convenção Internacional e não se as atividades se desenvolvem em zona marítima australiana e por isso são proibidas. Logo, a Corte excluiu a exceção de incompetência solicitada pelo Japão. ${ }^{67}$

Nesse caso a CIJ se dedicará pela primeira vez a análise da Convenção Internacional para a Regulamentação da Caça a Baleia e da exceção para a permissão de pesca de baleia para fins de pesquisa científica.

\section{Das implicações do caso}

A decisão do caso apresentou dois elementos de análise relevantes que podem servir de base para a interpretação de acordos internacionais que tratem da pesquisa científica e suas exceções. O primeiro ponto consistiu na definição do poder discricionário dos Estados-Partes da Convenção em determinar se as atividades submetidas à concessão de uma licença especial para caça de baleias teriam por objetivo a realização de uma pesquisa científica. $O$ segundo se refere ao exame dos objetivos, implementação e

65 CConsoante o artigo 2 da Convenção entende-se por usina flutuante o navio no qual as baleias são tratadas; por navio baleeiro aquele utilizado para pescar, capturar, rebocar, prender ou localizar baleias. Artigo II. BRASIL. Senado Federal. Decreto Legislativo $\mathrm{n}^{\circ}$ 77, 05 de dezembro de 1973. Aprova o texto da Convenção Internacional para a Regulamentação da Pesca da Baleia, concluída em Washington, a 2 de dezembro de 1946. Art. 8 Disponível em: $\quad<$ http://legis.senado.gov.br/legislacao/ListaPublicacoes. action?id=229065> . Acesso em: 08 dez. 2014.

66 CORTE INTERNACIONAL DE JUSTIÇA. 2014. Sentença de 31 de Março, Australia vs. Japão. \$30. Disponível em: <http:// www.icj-cij.org/docket/files/148/18137.pdf>. Acesso em: 10 set. de 2014.

67 CORTE INTERNACIONAL DE JUSTIÇA. 2014. Sentença de 31 de Março, Australia vs. Japão. \40-41. Disponível em: <http://www.icj-cij.org/docket/files/148/18137.pdf>. Acesso em: 10 set. de 2014 
razoabilidade do projeto com meios utilizados para se alcançar os resultados.

\section{A) Definição do poder dos Estados para concessão de licenças especiais}

A pergunta se a CIJ pode analisar o conteúdo das licenças especiais da Convenção é interessante porque estabelece precedente para questionamentos quanto a futuras licenças concedidas pelos Estados-partes. Sobre o tema, o Japão primeiramente argumentou que caberia à Corte apenas analisar a "integridade do processo decisional", não devendo examinar a "decisão propriamente dita." ${ }^{68}$ Em seguida modificou seu posicionamento, passando a defender que a Corte poderia verificar se o programa de pesquisa seria objetivamente justificável. ${ }^{69}$

Para a Corte, o Artigo VIII confere ao Estado parte da Convenção o poder discricionário de rejeitar um pedido de permissão especial ou de precisar as condições da concessão de tal permissão. Todavia, a resposta para a pergunta se a matança, captura ou processamento de baleias, em razão da permissão especial solicitada, segue os fins de pesquisa científica, não dependeria simplesmente da percepção deste Estado.

Entre os elementos identificados pela Corte, para decidir se o projeto JARPA II atenderia à finalidade de pesquisa como contemplada pela Convenção, destacase o objeto da pesquisa.

Quanto ao objeto, A CIJ entendeu que a finalidade de pesquisa, justificativa para exceção concedida pela Convenção para a caça às baleias, deveria ser interpretada de acordo com a finalidade da Convenção

68 CORTE INTERNACIONAL DE JUSTIÇA. 2014. Sentença de 31 de Março, Australia vs. Japão. \$65. Disponível em: <http:// www.icj-cij.org/docket/files/148/18137.pdf>. Acesso em: 10 set. de 2014

69 CORTE INTERNACIONAL DE JUSTIÇA. 2014. Sentença de 31 de Março, Australia vs. Japão. \$40-41. Disponível em: < http:// www.icj-cij.org/docket/files/148/18137.pdf>. Acesso em: 10 set. de 2014

70 Tradução livre: “ l'article VIII confère à un Etat partie à la convention le pouvoir discrétionnaire de rejeter une demande de permis spécial ou de préciser les conditions de l'octroi d'un tel permis. Toutefois, la réponse à la question de savoir si la mise à mort, la capture et le traitement de baleines en vertu du permis spécial demandé poursuivent des fins de recherche scientifique ne saurait dépendre simplement de la perception qu'en a cet Etat. » CORTE INTERNACIONAL DE JUSTIÇA. 2014. Sentença de 31 de Março, Australia vs. Japão. \61. Disponível em: <http://www.icjcij.org/docket/files/148/18137.pdf>. Acesso em: 10 set. de 2014. disposta em seu preâmbulo. ${ }^{71}$ Por esse entendimento, a CIB não poderia alterar o objeto nem a finalidade da Convenção. Contudo, não se deveria interpretar a obrigação do artigo VIII de maneira extensiva nem restritiva. Nesse ponto, a Corte reforça o entendimento do valor normativo do preâmbulo dos tratados. Com base no Guidelines daIWC, a pesquisa, no caso, poderia ter outra finalidade que a conservação e exploração sustentável das baleias, que no próprio texto aparece como " outras necessidades de importância capital em matéria de pesquisa" 72

Estando estabelecido que a Corte poderia analisar o conteúdo do projeto para verificar se este apresentaria uma finalidade de pesquisa científica, passa-se a identificar possíveis critérios para essa identificação.

\section{B) Critérios para a determinação da finalidade de pesquisa no projeto JARPA II}

Os critérios examinados pela Corte para verificar o cumprimento do artigo VIII no caso foram extraídos principalmente a partir dos argumentos trazidos pela Austrália.

Primeiramente a Corte buscou identificar se o programa submetido à licença especial comportava atividades de pesquisa. $^{73} \mathrm{Em}$ segundo, passou a verificar se a morte, a captura e processamento das baleias, e, mais especificamente, o uso de métodos letais seriam razoáveis para se alcançar os objetivos propostos no programa de pesquisa. Quanto a essa questão, a Corte tece algumas considerações: caberá ao Estado que concedeu a autorização de provar a Corte que "a realização das pesquisas científicas justificaria o recurso aos métodos letais como parte do programa em questão"74. A Corte esclarece, entretanto, que

71 CORTE INTERNACIONAL DE JUSTIÇA. 2014. Sentença de 31 de Março, Australia vs. Japão. \56. Disponível em: < http:// www.icj-cij.org/docket/files/148/18137.pdf>. Acesso em: 10 set. de 2014.

72 CORTE INTERNACIONAL DE JUSTIÇA. 2014. Sentença de 31 de Março, Australia vs. Japão. \$56. Disponível em: <http:// www.icj-cij.org/docket/files/148/18137.pdf>. Acesso em: 10 set. de 2014.

73 CORTE INTERNACIONAL DE JUSTIÇA. 2014. Sentença de 31 de Março, Australia vs. Japão. \67. Disponível em: <http:// www.icj-cij.org/docket/files/148/18137.pdf>. Acesso em: 10 set. de 2014

74 CORTE INTERNACIONAL DE JUSTIÇA. 2014. Sentença de 31 de Março, Australia vs. Japão. \$68. Disponível em: <http:// www.icj-cij.org/docket/files/148/18137.pdf>. Acesso em: 10 set. de 2014. Tradução livre : "A cet égard, la Cour relève que le différend dont elle est saisie découle de la décision prise par un Etat partie à 
o artigo VIII permite o uso de métodos letais. As resoluções aprovadas pela $\mathrm{CBI}$ não teriam natureza constitutiva, pois não obtiveram o apoio de todos os Estados-parte da Convenção. Portanto, as resoluções e linhas diretrizes seriam apenas recomendações, cuja observação não seria de natureza obrigatória, mas fortemente aconselhável.

A Austrália propôs que um dos critérios fosse a submissão da pesquisa ao exame de outros cientistas para validação. Para a Corte, a Convenção "adotou uma abordagem diferente" ${ }^{\text {" }}$ : a avaliação seria realizada por um comitê científico durante e após a realização da pesquisa ${ }^{77}$.

O quarto critério apresentado pelas partes dispõe que "o programa de pesquisa científica deve evitar todo o efeito prejudicial ao estoque de baleias." 78

Apesar dos critérios apresentados, a Corte concluiu que não haveria a necessidade que estes fossem apresentados de maneira cumulativa para que se determinasse a existência de uma pesquisa científica em conformidade com a Convenção ${ }^{79}$. Tais critérios não constituiriam "um meio de interpretar a noção de "pesquisa científica" tal como utilizado na Convenção"

la convention de délivrer des permis spéciaux au titre de l'article VIII de cet instrument. Une telle décision implique que cet Etat soit parvenu à la conclusion que la conduite de recherches scientifiques justifiait le recours aux méthodes létales dans le cadre du programme en question. C'est par conséquent à l'Etat ayant délivré les permis spéciaux qu'incombe la tâche d'exposer à la Cour les éléments objectifs sur lesquels est fondée cette conclusion. » (grifo nosso)

75 CORTE INTERNACIONAL DE JUSTIÇA. 2014. Sentença de 31 de Março, Australia vs. Japão. \83. Disponível em: < http:// www.icj-cij.org/docket/files/148/18137.pdf>. Acesso em: 10 set. de 2014.

76 CORTE INTERNACIONAL DE JUSTIÇA. 2014. Sentença de 31 de Março, Australia vs. Japão. \84. Disponível em: < http:// www.icj-cij.org/docket/files/148/18137.pdf>. Acesso em: 10 set. de 2014

77 CORTE INTERNACIONAL DE JUSTIÇA. 2014. Sentença de 31 de Março, Australia vs. Japão. \84. Disponível em: <http:// www.icj-cij.org/docket/files/148/18137.pdf>. Acesso em: 10 set. de 2014.

78 CORTE INTERNACIONAL DE JUSTIÇA. 2014. Sentença de 31 de Março, Australia vs. Japão. \84. Disponível em: <http:// www.icj-cij.org/docket/files/148/18137.pdf>. Acesso em: 10 set. de 2014.

79 CORTE INTERNACIONAL DE JUSTIÇA. 2014. Sentença de 31 de Março, Australia vs. Japão. \86. Disponível em: < http:// www.icj-cij.org/docket/files/148/18137.pdf>. Acesso em: 10 set. de 2014

80 CORTE INTERNACIONAL DE JUSTIÇA. 2014. Sentença de 31 de Março, Australia vs. Japão. \86. Disponível em: <http:// estabelecer outros critérios ou propor uma definição geral dessa noção." ${ }^{81}$ De fato, não caberia a Corte definir o que seria a pesquisa científica, nem quais seriam seus elementos.

A Corte estabelece que seria relevante para o caso precisar o sentido da exceção "para fins de pesquisa cientifica", principalmente a expressão "para fins de". ${ }^{82}$ Para tanto, o foco primeiramente estaria em determinar se o programa japonês foi construído e executado tendo como objetivo a pesquisa científica e não a pesca comercial. E, para esse objetivo, não interessaria determinar a intenção dos representantes do governo em questão. ${ }^{83}$ Nesse ponto a Corte concluiu que as atividades de JARPA II podem ser qualificadas como pesquisa científica por duas razões: o programa descreve os objetos de estudo de maneira correspondente aos quatro objetivos que o programa se propõe e que há coleta e análise sistemática dos dados por cientistas. ${ }^{84} \mathrm{~A}$ Corte apresenta os critérios que ela considera relevantes para se determinar se um programa atende a propósitos científicos ou não: coerência entre objeto e objetivos, coleta e análise sistemática de dados por um corpo de pesquisadores qualificados.

Para se determinar se o uso de métodos letais no caso JARPA II, apresentaria finalidade científica, a Corte passa a examinar se a concepção e implementação do www.icj-cij.org/docket/files/148/18137.pdf>. Acesso em: 10 set. de 2014.

81 CORTE INTERNACIONAL DE JUSTIÇA. 2014. Sentença de 31 de Março, Australia vs. Japão. \86. Disponível em: <http:// www.icj-cij.org/docket/files/148/18137.pdf>. Acesso em: 10 set. de 2014. Tradução livre "« Compte tenu de ces observations, la Cour n'est pas persuadée que, pour relever de la «recherche scientifique» dans le contexte de l'article VIII, les activités d'un programme doivent satisfaire aux quatre critères avancés par l'Australie. Tels qu'ils sont formulés par celle-ci, ces critères semblent, pour l'essentiel, refléter ce que l'un des experts cités par cet Etat a indiqué attendre d'un programme de recherche scientifique bien conçu, plutôt que constituer un moyen d'interpréter la notion de «recherches scientifiques» telle qu'utilisée dans la convention. La Cour ne juge toutefois pas nécessaire d'établir d'autres critères ou de proposer une définition générale de cette notion.

82 CORTE INTERNACIONAL DE JUSTIÇA. 2014. Sentença de 31 de Março, Australia vs. Japão. \87. Disponível em: <http:// www.icj-cij.org/docket/files/148/18137.pdf>. Acesso em: 10 set. de 2014.

83 CORTE INTERNACIONAL DE JUSTIÇA. 2014. Sentença de 31 de Março, Australia vs. Japão. \$97. Disponível em: <http:// www.icj-cij.org/docket/files/148/18137.pdf>. Acesso em: 10 set. de 2014.

84 CORTE INTERNACIONAL DE JUSTIÇA. 2014. Sentença de 31 de Março, Australia vs. Japão. \$127. Disponível em: <http:// www.icj-cij.org/docket/files/148/18137.pdf>. Acesso em: 10 set. de 2014. 
programa seriam razoáveis tendo em vista os objetivos propostos pelo próprio programa ${ }^{85}$. Os elementos que permitiriam esse exame consistiriam:

[...]Nas decisões sobre o uso de métodos letais, a escala do uso da amostragem letal, a metodologia utilizada para determinar o tamanho da amostra, a comparação entre os tamanhos das amostras a colher e as amostras efetivamente coletadas, o calendário associado ao programa, os resultados científicos dos mesmos e o grau de coordenação entre as atividades do programa com projetos de pesquisa relacionados. ${ }^{86}$

Quanto ao primeiro elemento, as Partes apresentaram dados contraditórios que por estarem sujeitos à apreciação científica, a Corte preferiu não se manifestar. A Contradição, nesse caso, atuou em benefício do Japão. ${ }^{87}$ Entretanto, pesou contra o Japão, o fato de estarem disponíveis técnicas não letais para se atingir alguns dos objetivos do programa que não foram consideradas como opção no momento da concepção do programa. ${ }^{88}$ Outro fato negativo à argumentação japonesa foi o uso acentuado de métodos letais na condução do programa, e que este uso poderia estar associado ao fato de que tal método ofereceria "uma

85 O Plano de pesquisa JARPA II tem por objetivos pesquisar o ecossistema antártico; estabelecer um modelo de concorrência entre as espécies de baleias; compreender a evolução espaço-tempo de estrutura do estoque de baleias; melhorar o procedimento de gestão das populações de pequenas rorquais da Antártica. A Corte irá se questionar se o plano de pesquisa empreendido pelo JARPA II corresponde aos quatro objetivos de pesquisa propostos pelo programa. CORTE INTERNACIONAL DE JUSTIÇA. 2014. Sentença de 31 de Março, Australia vs. Japão. \$127. Disponível em: < http://www.icj-cij.org/docket/files/148/18137.pdf>. Acesso em: 10 set. de 2014.

86 CORTE INTERNACIONAL DE JUSTIÇA. 2014. Sentença de 31 de Março, Australia vs. Japão. \88. Disponível em: <http:// www.icj-cij.org/docket/files/148/18137.pdf>. Acesso em: 10 set. de 2014.

87 CORTE INTERNACIONAL DE JUSTIÇA. 2014. Sentença de 31 de Março, Australia vs. Japão. \$135. Disponível em: < http:// www.icj-cij.org/docket/files/148/18137.pdf>. Acesso em: 10 set. de 2014. Compte tenu des éléments de preuve indiquant qu'il n'est pas possible de recourir à d'autres moyens, non létaux, au moins en ce qui concerne la collecte de certaines données, et dès lors que l'utilité et la fiabilité de ces données sont une question d'appréciation scientifique, la Cour considère que rien ne permet de conclure que l'emploi de méthodes létales n'est pas, en soi, raisonnable dans le cadre de JARPA II.

88 CORTE INTERNACIONAL DE JUSTIÇA. 2014. Sentença de 31 de Março, Australia vs. Japão. \137. Disponível em: < http:// www.icj-cij.org/docket/files/148/18137.pdf>. Acesso em: 10 set. de 2014. fonte de financiamento susceptível de cobrir os custos da pesquisa." 89

O segundo elemento, "escala do uso da amostra letal", visa verificar quantas baleias de cada espécie foram mortas a cada ano da pesquisa..$^{90}$ A Corte utilizou como fundamento para esse exame uma comparação entre o Programa JARPA II e seu antecessor. Ao comparar os objetivos dos programas, a Corte identificou mais semelhanças que diferenças entre objeto de estudo, objetivos e métodos. ${ }^{91}$ Apesar das semelhanças e da continuidade observada entre os dois programas, se constatou um aumento significativo na coleta de amostras de baleias Mink. E quea captura dessas baleias continuou no programa JARPA II sem que os resultados do seu antecessor estivessem disponíveis, o que colocaria em dúvida a razoabilidade e propósito da decisão de aumentar o número das baleias Mink capturadas no programa JAPRPA II. Esse critério comparativo definido pela Corte revela o cuidado com o exame da coerência dos programas japoneses para se determinar se de fato haveria um propósito de pesquisa nestes.

Quanto ao terceiro, quarto e quinto elementos, as provas indicam que o programa JARPA II não apresentou condições razoáveis para se atingir os objetivos pretendidos. O período de captura, para as baleias comuns e jubarte, seria insuficiente para alcançar "resultados estatisticamente relevantes." 22 Para Corte, faltou transparência no projeto JARPA II no que se refere à escolha do tamanho das amostras em diferentes parâmetros do estudo. ${ }^{93}$ A caça quase que exclusiva a baleias mink põe em dúvida os propósitos

89 CORTE INTERNACIONAL DE JUSTIÇA. 2014. Sentença de 31 de Março, Australia vs. Japão. \144. Disponível em: < http:// www.icj-cij.org/docket/files/148/18137.pdf>. Acesso em: 10 set. de 2014.

90 CORTE INTERNACIONAL DE JUSTIÇA. 2014. Sentença de 31 de Março, Australia vs. Japão. \$145. Disponível em: <http:// www.icj-cij.org/docket/files/148/18137.pdf>. Acesso em: 10 set. de 2014.

91 CORTE INTERNACIONAL DE JUSTIÇA. 2014. Sentença de 31 de Março, Australia vs. Japão. \151. Disponível em: <http:// www.icj-cij.org/docket/files/148/18137.pdf>. Acesso em: 10 set. de 2014.

92 CORTE INTERNACIONAL DE JUSTIÇA. 2014. Sentença de 31 de Março, Australia vs. Japão. \181. Disponível em: <http:// www.icj-cij.org/docket/files/148/18137.pdf>. Acesso em: 10 set. de 2014.

93 CORTE INTERNACIONAL DE JUSTIÇA. 2014. Sentença de 31 de Março, Australia vs. Japão. \188. Disponível em: < http:// www.icj-cij.org/docket/files/148/18137.pdf>. Acesso em: 10 set. de 2014. 
científicos do projeto fornecidos pelo próprio Japão. Este, em sua defesa, argumentava que a caça a baleias que não aportariam ganho econômico diferenciaria o projeto JARPA II de outros projetos com finalidade comercial. Fato que não se comprovou no caso. Se a finalidade era examinar o ecossistema e a concorrência entre as espécies de baleias, não se justificaria a coleta quase que exclusiva de apenas uma espécie. ${ }^{94}$ Quanto ao calendário da pesquisa, a Corte estima que o Japão poderia ter oferecido uma previsão de metas intermediárias ao longo da pesquisa mesmo que este não houvesse definido a duração do projeto JARPA II. ${ }^{95}$

Quanto aos resultados científicos do programa, a avaliação da Corte é que estes foram modestos, tendo em vista a quantidade de baleias mortas no período estudado. ${ }^{96}$ Nesse ponto a Corte faz uma avaliação da qualidade dos resultados que permitiriam um questionamento quanto à competência desta para tanto. Sabe-se que a depender do objeto estudado os resultados podem demorar anos e cumular uma série de fracassos. A identificação do critério científico dos projetos submetidos à licença especial pelos resultados não parece se coadunar com a realidade da prática científica. No caso japonês se apreende por outras provas que, de fato, o programa se revestia da natureza científica para ocultar a prática da caça comercial de baleias.

Por fim a Corte constatou a falta de cooperação do projeto JARPA II com outros projetos de pesquisa sobre o tema.

Pelos motivos listados acima, a Corte, por 12 votos contra $4{ }^{97}$, decidiu que o programa JARPA II não tinha

94 CORTE INTERNACIONAL DE JUSTIÇA. 2014. Sentença de 31 de Março, Australia vs. Japão. \$181. Disponível em: < http:// www.icj-cij.org/docket/files/148/18137.pdf>. Acesso em: 10 set. de 2014.

95 CORTE INTERNACIONAL DE JUSTIÇA. 2014. Sentença de 31 de Março, Australia vs. Japão. \$188. Disponível em: <http:// www.icj-cij.org/docket/files/148/18137.pdf>. Acesso em: 10 set. de 2014.

96 CORTE INTERNACIONAL DE JUSTIÇA. 2014. Sentença de 31 de Março, Australia vs. Japão. \$210. Disponível em: < http:// www.icj-cij.org/docket/files/148/18137.pdf>. Acesso em: 10 set. de 2014.

97 A favor: Tomka, presidente ; Sepúlveda-Amor, vice-presidente; Juizes Keith, Skotnikov, Cançado Trindade, Greenwood, Xue, Donoghue e Gaja. Sebutinde,Bhandari, Charlesworth, (juiz ad hoc ); Contra , juizes : Owada, Abraham, Bennouna e Yusuf. por finalidade a pesquisa conforme estipulado no artigo VIII da Convenção.

\section{Conclusão}

Apesar de o tema ser de natureza ambiental, a CIJ, nesta decisão, não examinou a aplicação de princípios de direito ambiental. A decisão foi, em quase sua totalidade, baseada na definição e análise de critérios que pudessem identifica se finalidade de pesquisa científica em um projeto submetido à licença especial poderia estar em conformidade com a Convenção. $\mathrm{O}$ grau de especificidade do exame do programa japonês chama a atenção nessa decisão da CIJ. A Corte não apenas se declarou competente para o exame do projeto, como definiu critérios para a determinação do caráter científico do programa que poderão servir de base para outras decisões que envolvam o uso de pesquisa científica. A decisão limitou o poder discricionário dos Estados na concessão de licenças para a caça, captura e processamento de baleias, ao tornar tal decisão passível de controle pela CIJ. Apesar de festejada por ambientalistas, ainda restar saber o quão efetiva esta decisão será.

\section{Tribunal Internacional do Direito do Mar}

\section{Caso do Parecer consultivo do Tribunal Internacional de Direito do Mar de $1^{\circ}$ de fevereiro de 2011}

Gabriela Garcia B. Lima* *

\section{Introdução}

No dia $1^{\circ}$ de fevereiro de 2011, a Câmara de Controvérsia dos Fundos Marinhos ${ }^{99}$ emitiu um Parecer consultivo sobre responsabilidade internacional estatal. Tratou-se de resposta a um pedido do Conselho da Autoridade Internacional dos Fundos Marinhos ${ }^{100}$.

Doutora em Direito pela Universidade de Aix-Marseille em cotutela com o Centro Universitário de Brasília, professora substituta de direito ambiental da Universidade de Brasília e professora de direito administrativo da Universidade Paulista.

99 Órgão judiciário distinto do Tribunal Internacional do Direito do Mar (TIDM), com competência consultiva e contenciosa.

100 Conforme competência prevista no artigo 191 da Convenção das Nações Unidas sobre o Direito do Mar. UNITED NATIONS. United Nations Convention on the Law of the Sea (with annexes, final act and procès-verbaux of rectification of the final act dated 3 March 1986 and 26 July 1993). Concluded at Montego Bayon 10 December 1982. Disponível em: <http://www.un.org/Depts/los/ convention_agreements/texts/unclos/unclos_f.pdf $>$. Acesso em: 
O Conselho indagou quais eram, no quadro da Convenção das Nações Unidas sobre o Direito do Mar, as responsabilidades e obrigações jurídicas dos Estados quando estes são a autoridade responsável pelo controle de atividades que se realizam na Zona, ou seja, nos fundos marinhos e seus subsolos para além da jurisdição nacional ${ }^{101}$. A Zona é regulamentada na Parte XI da Convenção e pelo Acordo de 1994, relativo à aplicação da parte XI da Convenção.

Pelo pedido do Conselho, foram três principais indagações: primeiramente, quais eram as responsabilidades dos Estados membros financiadores de atividades realizadas na Zona, conforme a parte XI da Convenção e o Acordo de 1994; em segundo lugar, em que medida a responsabilidade de um Estado membro deveria ser caracterizada conforme a parte XI da Convenção e o Acordo de 1994, diante da omissão de entidades que ele financiara com base no artigo n ${ }^{\circ} 153$, $\$ 2^{\circ}$, "b" da Convenção ${ }^{102}$; e, em terceiro lugar, quais as medidas necessárias que um Estado financiador deveria tomar para não caracterizar a sua responsabilidade perante o artigo 139 da Convenção, assim como do anexo III do Acordo de 1994, ou seja, como proceder para evitar a caracterização da responsabilização do Estado tendo em vista a natureza jurídica da Zona como patrimônio comum da humanidade? ${ }^{\text {103 }}$

\section{0 out. 2014.}

101 Conforme o artigo $1^{\circ}$ da Convenção das Nações Unidas sobre o Direito do Mar. UNITED NATIONS. United Nations Convention on the Law of the Sea (with annexes, final act and procès-verbaux of rectification of the final act dated 3 March 1986 and 26 July 1993). Concluded at Montego Bayon 10 December 1982. Disponível em: <http://www.un.org/Depts/los/convention_ agreements/texts/unclos/unclos_f.pdf>. Acesso em: 20 out. 2014. 102 O artigo n $153, \S 2^{\circ}$, "b" da Convenção visa caracterizar as atividades executadas na zona em associação com o Estado, pelo próprio Estado, por pessoas de nacionalidade do Estado, ou que estão sob seu controle, por entidades que o Estado patrocina, dentre outros. UNITED NATIONS. United Nations Convention on the Law of the Sea (with annexes, final act and procès-verbaux of rectification of the final act dated 3 March 1986 and 26 July 1993). Concluded at Montego Bayon 10 December 1982. Disponível em: <http://www.un.org/Depts/los/convention_agreements/texts/ unclos/unclos_f.pdf $>$. Acesso em: 20 out. 2014.

103 Câmara de Controvérsia dos Fundos Marinhos. Parecer consultivo de $1^{\circ}$ de fevereiro de 2011 sobre a "Responsabilités et obligations des États qui patronnent des personnes et entités dans le cadre d'activités menées dans la Zone. INTERNATIONAL TRIBUNAL FOR THE LAW OF THE SEA. Chambre pour le règlement des différends relatifs aux fonds marins du Tribunal International du Droit de la Mer Disponível em: <http://www.itlos.org/fileadmin/itlos/documents/cases/ case_no_17/adv_op_010211_fr.pdf>. Acesso em: 20 out. 2014.
Os questionamentos dizem respeito a uma antiga indagação no direito internacional, qual seja: a caracterização da responsabilidade internacional ambiental dos Estados. Para tal esclarecimento, o Parecer levou em consideração o Projeto de Artigos sobre responsabilidade do Estado por fato internacionalmente ilícito da Comissão de Direito Internacional (CDI) das Nações Unidas (doravante Projeto de artigo da CDI) (2), considerando a diferenciação entre a obrigação primária e obrigação secundária (3); além da incidência complementar de regras gerais e regras especiais de responsabilidade (4). Outro ponto relevante diz respeito aos fundamentos de direito ambiental que o Parecer sustenta para caracterizar a diligência devida (due diligence) perante um patrimônio comum da humanidade (5).

\section{A caracterização da responsabilidade internacional ambiental dos Estados}

No esclarecimento da caracterização da responsabilidade estatal na Convenção do Mar, o Parecer consultivo merece destaque pela sua hermenêutica ao elaborar uma relação entre diferentes institutos de direito internacional. Especificamente, provocou interface da Convenção do Mar com o Projeto de Artigos da $\mathrm{CDI}^{104}$. Com isso, em um âmbito de pouca consistência como é o da responsabilidade internacional ambiental, o Parecer fortaleceu a sua forma de construção e de validade jurídica.

A responsabilidade internacional ambiental dos Estados é um domínio marcado pela complexidade haja vista os seus fundamentos não serem unificados em uma única Convenção. Trata-se de campo jurídico que repousa ainda na interpretação arbitral, resultando em uma diversidade de formas de enquadramento dada a estrutura descentralizada do direito internacional ambiental ${ }^{105}$. Alguns campos, como o nuclear e a poluição por hidrocarbonetos,

104 Projets d'articles sur la responsabilité de l'état pour fait internationalement illicite et commentaires y relatifs. . INTERNATIONAL TRIBUNAL FOR THE LAW OF THE SEA. Projet d'articles sur la responsabilite de l'éta Pour fait internationalement illicite 2001. Disponible sur: <http://www1.umn.edu/humanrts/instree/ Fwrongfulacts.pdf $>$. Acesso em: 20 out. 2014.

105 LE PRESTRE, Philippe; MARTIMORT-ASSO, Benoît. A reforma na governança internacional do meio ambiente: os elementos do debate. In: VARELLA, Marcelo Dias; BARROSPLATIAU, Ana Flávia (Org). Proteção internacional do meio ambiente. Brasília: UniCEUB, 2009. p. 401. 
possuem responsabilidade objetiva ${ }^{106}$ definida em seus respectivos tratados. Contudo, ter a responsabilidade e a obrigação de reparar danos ambientais atribuídas objetivamente é uma exceção. De modo geral, a responsabilidade depende da caracterização e da comprovação da violação de uma obrigação de direito internacional o que, em direito ambiental, tem os seus próprios desafios: desde a dificuldade de comprovar o dano, o nexo causal e a ação estatal, até a compensação pelos prejuízos causados ${ }^{107}$.

À medida que o direito internacional ambiental foi ganhando forma, alguns casos, hoje locus classicus na definição da responsabilidade, mostraram as primeiras direções a serem tomadas. Por exemplo, o princípio da responsabilidade internacional ambiental e a sua relação com o território e a soberania estatal ${ }^{108}$ surgiram da interpretação arbitral no caso «The Smelter Trail» ${ }^{109}$. Tal princípio definiu os limites da ação estatal para que ela não prejudique o meio ambiente de outros Estados. Outros casos demonstraram a importância da diligência devida estatal na prevenção de danos transfronteiriços (o caso do Lago Lanoux ${ }^{110}$; o caso dos

106 Em direito internacional, podem ser citados ainda outros casos de regras de responsabilidade objetiva relacionada a algum tipo de dano ambiental, como por exemplo, a responsabilidade na Convenção sobre Responsabilidade Internacional por Danos Causados por Objetos Espaciais, e na Convenção Internacional sobre a Responsabilidade Civil pelos Prejuízos devidos à Poluição por Hidrocarbonetos e a Convenção de Viena de 1963 sobre a Responsabilidade civil por Danos Nucleares.

107 BARBOZA, Julio. International liability for the injurious consequences of acts not prohibited by international law and protection of the environment. Boston: Brill, 1994. v.3. (Collected Courses of the Hague Academy of International Law, 247).

108 FINCK, François. L'imputabilité dans le droit de la responsabilité internationale. 2011. 452 f. (Doctorat en Droit) - École Doctorale Droit, Science Politique et Histoire, Universite de Strasboug. Strasbourgo , 2011, p. 15 ; COHN, M. G. La théorie de la responsabilité internationale. Boston : Brill, 1939. v. 2. Collected Courses of the Hague Academy of International Law, 68). p.209.

109 NAÇÕES UNIDAS. R.S.A.. Vol XXIX. Disponivel em: <http://untreaty.un.org/cod/riaa/cases/vol_XXIX/365-371. pdf $>$. Acesso em: 20 out. 2014; NAÇÕES UNIDAS, Trail smelter case (United States, Canada), 16 April 1938 and 11 March 1941, v.3, p. 1905-1982. Disponível em: < http://untreaty.un.org/cod/riaa/ cases/vol_III/1905-1982.pdf>. Acesso em: 20 out. 2014.

110 UNITED NATIONS. Affaire du lac Lanoux (Espagne, France). RSA, 16 November 1957, v.12, p. 317. Disponível em : <http:// untreaty.un.org/cod/riaa/cases/vol_XII/281-317_Lanoux.pdf $>$. Acesso em: 20 out. 2014. ensaios nucleares ${ }^{111}$, o caso Gabçikovo Nagymaros ${ }^{112}$; o caso das papeleiras ${ }^{113}$, entre outros).

A noção de diligência devida remonta a um princípio geral do direito que exige uma obrigação de comportamento da parte do sujeito de direito, o Estado. Trata-se da exigência de um comportamento estatal que permite controlar as consequências de suas ações em relação a um outro Estado. São, por exemplo, as obrigações de prevenção, assim como de notificação em caso de dano transfronteiriço, a fim de que as partes possam tomar as medidas necessárias para tratar das consequêncais em seus territórios ${ }^{114}$.

De modo geral, o exame da diligência devida estatal pode ser em vista de normas de procedimento e normas de fundo ${ }^{115}$. No primeiro caso, a diligência esperada diz respeito à ações de diálogo quando dois ou mais países se vêem em uma interface haja vista os efeitos de interdependência de suas ações. São exemplos de ações de diligência devida as consultas, notificações e negociações. $\mathrm{Na}$ ausência de ações desse tipo, já pode configurar fato ilícito causador de dano.

As normas de fundo, por sua vez, dizem respeito à criação e cumprimento do direito ambiental nacional como forma de cumprir com a diligência

111 Affaire des Essais Nucléaires, Australie c. la France, Arrêt du 20 décembre 1974. INTERNATIONAL COURT OF JUSTICE. 1974. Sentença 20 de December, Australia vs. France. Disponível em: <http://www.icj-cij.org/docket/files/58/6092.pdf>. Acesso em : 20 out. 2014 ; Affaire des Essais Nucléaire. INTERNATIONAL COURT OF JUSTICE. 1974. Sentença 20 de December, Nowvelle Zélande c. France. Disponível em: <http://www.icj-cij.org/docket/ files/59/9446.pdf. Acesso em: 20 out. 2014>.

112 INTERNATIONAL COURT OF JUSTICE. Affaire relative au Projet, 1997, Arrêt du 25 septembre 1997.. 1977. Sentença de 25 de Septembre, Gabcikovo-Nagymaros Disponível em: <http://www. icj-cij.org/docket/files/92/7374.pdf>. Acesso em: 20 out. 2014.

113 INTERNATIONAL COURT OF JUSTICE. Affaire relative à des usines de pâte à papier sur le fleuve Uruguay.. 2010. Sentença du 20 Avril du 2010, Argentine c. Uruguay. Disponível em: < http://www. icj-cij.org/docket/files/135/15878.pdf>. Acesso em: 20 out. 2014.

114 KOIVUROVA, Timo, Due Diligence. In: MAX Planck Encyclopedia of Public International Law. Disponível em: <http:// www.arcticcentre.org/loader.aspx?id=78182718-d0c9-4833-97b3b69299e2f127>. Acesso em: 20 out. 2014; SADELEER, Nicolas de. Comentários sobre o status no direito internacional de três princípios ambientais. In: VARELLA, Marcelo Dias; BARROSPLATIAU, Ana Flávia (Org). Proteção internacional do meio ambiente. Brasília: UniCEUB, 2009. p. 46.

115 Haja vista interpretação da Corte Internacional de Justiça no caso das papeleiras. Affaire relative à des usines de pâte à papier sur le fleuve Uruguay, Argentine c. Uruguay. INTERNATIONAL COURT OF JUSTICE. 2010. Sentença du 20 Avril du 2010, Argentine c. Uruguay. Disponível em: <http://www.icj-cij.org/ docket/files/135/15878.pdf $>$. Acesso em: 20 out. 2014. 
devida em relação à interface com um outro Estado. Nesse campo, outra esfera de omissões que podem ser responsabilizadas são omissões às medidas de prevenção e de controle nacional do Estado acerca das ações daqueles que agem em seu território ou sob o seu controle. São entendimentos oriundos de um suporte hermenêutico geral, faltando, contudo, uma base consolidada em um tratado com regras de direito internacional consolidadas sobre o tema.

Foi justamente com a intenção de uma regulamentação do tema, que a CDI elaborou o seu Projeto de artigos sobre responsabilidade, documento não ratificado dado interesse evasivo dos Estados na definição de regras nesse sentido. Os Estados tendem a preferir uma posição mais ampla acerca da responsabilidade por danos, haja vista os possíveis limites que cuidados com formas de prevenção podem ensejar no seu desenvolvimento nacional ${ }^{116}$. O projeto, embora não tenha o peso de um tratado, é um importante instrumento na orientação dos comportamentos e na harmonização da coerência entre as normas internaconais ${ }^{117}$.

O Parecer consultivo, pelo seu conteúdo hermenêutico, foi um passo importante na consolidação do entendimento construído pela via arbitral e pelo esforço interpretativo da CDI com o seu Projeto de artigos. Em diferentes momentos, o Parecer esclarece a importância do Projeto da CDI na interpretação da responsabilidade dos Estados, ressaltando ainda para a possibilidade do enquadramento de alguns de seus artigos como reflexos do costume no direito internacional, constituindo, portanto, fonte de direito:

\begin{abstract}
«Etant donné que l'article 139, paragraphe 2, de la Convention et l'article 304 de la Convention se réfèrent, respectivement, aux « règles du droit international » et à "l'application des règles existantes et [à] l'établissement de nouvelles règles concernant la responsabilité en vertu du droit
\end{abstract}

116 BOSSELMANN, Klaus. Jurisprudência das Cortes Internacionais em matéria ambiental: fazendo a sustentabilidade valer. In: DAIBERT, Arlindo (Org.). Direito ambiental comparado. São Paulo: Fórum, 2008. p. 338; LAFRANCHI, Marie-Pierre; MALJEAN-DUBOIS, Sandrine. Le contrôle juridictionnel sur le plan international. Le contrôle du juge international un jeu d'ombres et de lumières. In: MALJEAN-DUBOIS, Sandrine. L'effectivité $d u$ droit européen de l'environnement. Contrôle de la mise en ceuvre et sanction $d u$ non-respect. Paris: La documentation française, 2000. p. 248.

117 CHINKIN, C.M. The challenge of soft law: development and change in international law. International \& Comparative Law Qiartely, Cambrige, v. 38, n. 4, 1989. p. 851. international ", il convient de tenir compte de ces règles, en particulier à la lumière des Articles de la C.D.I. sur la responsabilité de l'Etat. Plusieurs de ces articles sont considérés comme reflétant le droit international coutumier ${ }^{118}$.

Outro aspecto relevante do Parecer foi a sua definição sobre obrigações primairas e secundárias para definir a forma de construção da responsabilidade doEstado e a sua obrigação de reparar danos internacionalmente ilícitos.

\section{Normas primárias e secundárias na responsabilidade internacional do Estado}

$\mathrm{Na}$ caracterização da responsabilidade, o Parecer esclarece as diferenças de significado dos termos « responsability » e « liability também com o auxílio do Projeto da CDI. Procurou deixar claro o entendimento sobre a construção da responsabilidade do Estado e a configuração da obrigação estatal de compensar dano causado por fato internacionalmente ilícito pela diferenciação entre obrigação primária e secundária de direito internacional.

Considerou que o termo " responsability », em português " responsabilidade ", se refere à obrigação primária ; enquanto que o termo «liability», que em português também poderia ser atribuído ao termo " responsabilidade » ou " obrigação de reparar », tem o significado de obrigação de compensar o dano ${ }^{119}$. A obrigação de compensar é secundária e se constitui na medida em que se tem violada uma obrigação primária de direito internacional, momento em que se caracteriza a sua responsabilidade. Nesse sentido:

\begin{abstract}
« La Chambre considère que dans les dispositions citées au paragraphe précédent, le terme « responsibility » se réfère à l'obligation primaire alors que le terme « liability » se réfère à l'obligation secondaire, à savoir aux conséquences de la violation d'une obligation primaire. »
\end{abstract}

118 Para a diferença entre os termos, consultar também: BARBOZA, Julio. International liability for the injurious consequences of acts not prohibited by international law and protection of the environment. The Hague Academy of International Law, Recueil des Cours, Volume 247 (1994-III), chapitre III et IV.

119 Câmara de Controvérsia dos Fundos Marinhos. Parecer consultivo de $1^{\circ}$ de fevereiro de 2011 sobre a Responsabilités et obligations des États qui patronnent des personnes et entités dans le cadre d'activités menées dans la Zone, p. 24. Disponível em: <http://www. itlos.org/fileadmin/itlos/documents/cases/case_no_17/adv_ op_010211_fr.pdf>. Acesso em: 20 out. 2014. 
A relação entre a violação de uma obrigação primária de direito internacional feita pelo Parecer condiz com o entendimento de responsabilidade do Projeto da $\mathrm{CDI}^{120}$. Sobre o tema, a relação entre normas primárias e secundárias não são formalmente um princípio geral de direito, mas compõem o processo ou a estrutura funcional do direito internacional ${ }^{121}$. Abre, pois, a possibilidade de instituição de uma arbitragem por violação de direito internacional, juntamente com a exigência de reparação de danos, quando presentes.

Ademais, no raciocínio do Projeto da CDI, existe uma relação de solidariedade ${ }^{122}$ na construção da responsabilidade, pois não é necessária a presença de um prejuízo, basta a violação a norma internacional. Trata-se de uma concepção civilista que considera a aplicação da responsabiolidade estatal pelo ponto de vista de uma sociedade internacional caracterizada por países soberanos, mas que devem respeito as obrigações internacionais que contratam.

Além disso, o Parecer procurou elaborar uma compreensão da relação entre normas gerais e especiais de responsabilidade, retratando a possibilidade de incluir o Projeto de artigo da CDI como fonte do que seriam as normas gerais sobre responsabilidade, enquanto que as regras contidas em outras normas resultariam em regras especiais, conforme segue a análise.

\section{Regras gerais e especiais de responsabilidade no direito internacional ambiental}

Ao procurar esclarecer as perguntas elaboradas pelo Conselho, especialmente no que diz respeito à responsabilização do Estado patrocinador perante a parte XI da Convenção (artigos 153 e 139), procurou considerar a incidência de regras especiais e gerais de responsabilidade resguardando a aplicação complementar do Projeto de artigos da CDI.

120 Conforme o artigo 2o e o artigo 31 do Projeto. CDI, Projets d'articles sur la responsabilité de l'état pour fait internationalement illicite et commentaires y relatifs, 2001.

121 CRAWFORD, James. The ILC's articles on responsibility of states for internationally wrongful acts: a retrospect. The american journal of international law, vol. 96, 2002, p. 876

122 DAILlIER, Patrick; FORTEAU, Mathia, PELLET, Alain, DINH, Ngyuen Quoc. Droit International Public. L.G.D.J., 8 édition, p. 850 ; OUEDRAOGO, Awalou. «L'évolution du concept de faute dans la théorie de la responsabilité internationale des États». Revue québécoise de droit international, vol 21, n.2-5, 2008, p.164.
De modo geral, os artigos mencionados determinam a responsabilidade do Estado pela falta cometida nos fundos marinhos por empresa estatal sob seu controle. A obrigação do Estado é de adotar medidas de prevenção e, em particular, de exigir dos exploradores (no caso, a empresa estatal), estudos de impacto e o respeito a outras regras de direito ambiental. A empresa tem o dever de obediência para com essas obrigações. Espera-se do Estado a adoção de medidas eficazes que garantam a obediência das ordens estatais, além da adoção de medidas de coerção e de implantação da obrigação de reparar o dano, em caso de desobediência.

Ao constatar a desobediência às regras veiculadas (dos artigos 153 e 139), tem-se a violação à Convenção do Mar, caracterizando, portanto, a constituição da responsabilidade internacional do Estado. A Convenção do Mar, por ter o seu próprio âmbito de incidência com suas próprias regras de responsabilidade e de reparação, abrange regras especiais de responsabilidade. E, para aquelas ações que ensejaram a responsabilidade, mas que não possuem direta relação com a Convenção do Mar, elas podem caracterizar a responsabilidade do Estado perante as regras gerais de responsabilidade, nos termos do Projeto de artigos da CDI.

A regra é dita especial em razão do domínio de aplicação, o Direito do Mar, e pode caracterizar a responsabilidade de modo diferenciado do que implica os princípios do Projeto de artigos da CDI. Aplica-se o entendimento geral de direito de que a regra especial prevalece sobre a regra geral. Pela regra especial da Convenção do Mar, o Estado possui uma obrigação de diligência devida de criar em seu quadro legislativo todas as medidas necessárias para assegurar o cumprimento das obrigações internacionais pelas entidades que possuem permissão de exploração nos fundos marinhos. Essas medidas devem estar legisladas, não basta um contrato com o explorador.

Além disso, para o artigo 139.2 da Convenção ${ }^{123}$, é necessário demonstrar não somente a falta de cumprimento da obrigação internacional, mas o nexo de causalidade entre a ação e o dano ao ambiente marinho. É preciso haver um dano, diferentemente do que postula as regras gerais de responsabilidade do Projeto de artigos da CDI. E é nesse sentido que a regra analisada se apresenta como regra especial :

123 CONVENÇÃO das Nações Unidas sobre o Direito do Mar. Disponível em: <http://www.un.org/Depts/los/convention_ agreements/texts/unclos/unclos_f.pdf>. Acesso em: 20 out. 2014. 
para o direito do mar, a responsabilidade do Estado é construída com a violação de uma obrigação, mas também com a existência de dano. Para o Projeto de artigos da CDI, conforme já mencionado, a mera violação de obrigação internacional é suficiente para caracterizar a responsabilidade. Todavia, as regras do Projeto de artigos da CDI não se excluem totalmente, pois podem ser aplicadas incidentalmente, em face dos prejuízos porventura não comptados pela Convenção do Mar, a fim de preencher suas lacunas.

Assim, por um lado, no domínio dos fundos marinhos, a responsabilidade do Estado se caracteriza com a presença de um dano material, nexo causal e violação à obrigação jurídica do direito do mar. Por outro lado, na presença de fato internacionalmente ilícito do Estado sem que haja um dano material caracterizado, aplica-se os princípios e regras do Projeto da CDI. Desta feita, o Parecer retrata uma interface complementar entre as regras de direito internacional ${ }^{124}$.

\section{A diligência devida perante um patrimônio comum da humanidade}

A diligência devida dos Estados, para a conservação dos fundos marinhos, fortalece os entendimentos subtraídos dos princípios oriundos dos já mencionados casos locus classicus do direito internacional ambiental. Consolida, pois, o entendimento da responsabilidade internacional ambiental, além da construção do direito nacional ambiental como medida de prevenção e de precaução aos riscos de danos. Além disso, reconhece a responsabilidade solidária pelos danos causados e a possibilidade de um efeito erga omnes das obrigações relacionadas aos fundos marinhos. Isso permite que qualquer Estado membro possa exigir a reparação do dano.

No que diz respeito à diligência devida, as obrigações dos envolvidos recaem sobre os princípios gerais de direito ambiental, permitindo um fortalecimento da eficácia destes na sua ligação com o direito internacional ambiental. Dentre as principais obrigações, estão: a obrigação do Estado patrocinador de ajudar a

124 Câmara de Controvérsia dos Fundos Marinhos. Parecer consultivo de $1^{\circ}$ de fevereiro de 2011 sobre a Responsabilités et obligations des États qui patronnent des personnes et entités dans le cadre d'activités menées dans la Zone, p INTERNATIONAL TRIBUNAL FOR THE LAW OF THE SEA. Chambre pour le règlement des différends relatifs aux fonds marins du Tribunal International du Droit de la Mer Disponível em: < http://www.itlos.org/fileadmin/ itlos/documents/cases/case_no_17/adv_op_010211_fr.pdf $>$. Acesso em: 20 out. 2014. autoridade competente no exercício do seu controle sobre as atividades executadas na zona, a obrigação de implementar uma perspectiva de precaução, a obrigação de aplicar as melhores práticas ecológicas, avaliação de impactos ambientais, constituição de medidas de urgência, obrigações de reparar e mecanismos de indenização dos danos causados. Nesse sentido:

"Parmi les plus importantes de ces obligations
directes qui incombent à l'Etat qui patronne
figurent l'obligation d'aider l'Autorité dans
l'exercice de son contrôle sur les activités menées
dans la Zone, l'obligation d'adopter une approche
de précaution, l'obligation d'appliquer les
meilleures pratiques écologiques, l'obligation de
prendre des mesures de garantie dans l'éventualité
de l'adoption, par l'Autorité, d'ordres en cas
d'urgence pour la protection du milieu marin,
l'obligation de garantir des voies de recours aux
fins de l'indemnisation des dommages causés
par la pollution et l'obligation de procéder à des
évaluations de l'impact sur le milieu marin."'125

Além disso, o Parecer reconhece a responsabilidade solidária dos envolvidos, assim como uma execução despersonalizada do dano salientado. Nesse sentido, considera a solidariedade de todos os envolvidos no dano, tanto o Estado patrocinador, quando a autoridade competente como a empresa executora da atividade, in verbis:

\begin{abstract}
"On peut concevoir que le dommage en question inclurait celui causé à la Zone et aux ressources qui sont le patrimoine commun de l'humanité et le dommage causé au milieu marin. Les sujets pouvant prétendre à réparation pourraient être, entre autres, l'Autorité, les entités engagées dans des activités minières relatives aux grands fonds marins, d'autres utilisateurs de la mer et les Etats côtiers." 126
\end{abstract}

125 Câmara de Controvérsia dos Fundos Marinhos. Parecer consultivo de $1^{\circ}$ de fevereiro de 2011 sobre a "Responsabilités et obligations des États qui patronnent des personnes et entités dans le cadre d'activités menées dans la Zone". INTERNATIONAL TRIBUNAL FOR THE LAW OF THE SEA. Chambre pour le règlement des différends relatifs aux fonds marins du Tribunal International du Droit de la Mer Disponível em: <http://www.itlos.org/fileadmin/ itlos/documents/cases/case_no_17/adv_op_010211_fr.pdf $>$. Acesso em: 20 out. 2014.

126 Câmara de Controvérsia dos Fundos Marinhos. Parecer consultivo de $1^{\circ}$ de fevereiro de 2011 sobre a "Responsabilités et obligations des États qui patronnent des personnes et entités dans le cadre d'activités menées dans la Zone". INTERNATIONAL TRIBUNAL FOR THE LAW OF THE SEA. Chambre pour le règlement des différends relatifs aux fonds marins du Tribunal International du Droit de la Mer Disponível em: < http://www.itlos.org/fileadmin/ 
Outra particularidade diz respeito à possibilidade de qualquer Estado membro poder entrar com uma reclamação face às violações das obrigações para com os fundos marinhos, justamente em razão de seu status de patrimônio comum da humanidade. Nesse sentido:"Tout Etat Partie pourrait également prétendre à réparation au vu du caractère erga omnes des obligations ayant trait à la préservation de l'environnement en haute mer et dans la Zone" ${ }^{127}$. Trata-se de um dano desterritorializado, responsabilizando o seu causador e o Estado responsável pela entidade causadora.

\section{Conclusão}

O Parecer tem sua importância na consolidação ${ }^{128}$ de um entendimento sobre a construção da responsabilidade internacional ambiental dos Estados. Considerou a presença de regras especiais e gerais sobre responsabilidade, ao tratar da Convenção do Mar como campo especial e do Projeto de artigos da CDI como regras gerais. Fortaleceu o status costumeiro do entendimento dos artigos da CDI e dos princípios oriundos de interpretações arbitrais em um conjunto de casos de direito internacional ambiental, contribuindo para a sua ponderação como fontes de direito internacional. Além disso, retratou a caracterização da responsabilidade perante a violação de obrigação primária e a caracterização de obrigação de compensar como obrigação secundária decorrente.

Ademais, deixou clara uma regra de responsabilidade solidária pelos danos causados nos fundos marinhos, zona enquadrada como patrimônio comum da humanidade. A diligência devida dos Estados exige a formação de seus direitos ambientais com base nos princípios gerais como a prevenção, precaução, instituição de estudos de impacto, regras de reparação, entre outros. Perante tal

itlos/documents/cases/case_no_17/adv_op_010211_fr.pdf $>$. Acesso em: 20 out. 2014.

127 Câmara de Controvérsia dos Fundos Marinhos. Parecer consultivo de $1^{\circ}$ de fevereiro de 2011 sobre a "Responsabilités et obligations des États qui patronnent des personnes et entités dans le cadre d'activités menées dans la Zone." INTERNATIONAL TRIBUNAL FOR THE LAW OF THE SEA. Chambre pour le règlement des différends relatifs aux fonds marins du Tribunal International du Droit de la Mer Disponível em: < http://www. itlos.org/fileadmin/itlos/documents/cases/case_no_17/adv_ op_010211_fr.pdf>. Acesso em: 20 out. 2014.

128 ARCARI, Maurizio, Le juge et la codification du droit de la responsabilité. In : BOSCHIERO, Nerina; SCOVAZZI, Tullio; PITEA, Cesare; RAGNI, Chiara (Ed). International Courts and the development of international law. Essays in honour of Tulio Treves, Springer, 2013. p.28-29. status de patrimônio comum, as obrigações que incidem nessa zona possuem caráter erga omnes e podem ser exigidas por qualquer Estado membro.

\section{Comentários ao caso m/v “Virginia " (Panamá c. Guiné- Bissau), 14 de abril de 2014}

Carina Costa de Oliveira* Natália da Silva Gonçalves**

\section{A) Apresentação do caso}

No dia 14 de abril de 2014, foi julgado o caso ${ }^{\circ}$ 19 chamado The $M / V$ "Virginia G" Case entre Panamá e Guiné-Bissau no Tribunal Internacional de Direito do Mar (International Tribunal for the Law of the Sea - ITLOS). O caso foi relevante por ter analisado duas questões de direito principais: a primeira, de admissibilidade, relacionada à existência ou não de um vínculo genuíno entre a embarcação $\mathrm{M} / \mathrm{V}$ Virginia G e o Panamá; a segunda, de substância, conectada à análise da liberdade de navegação em contraposição ao exercício da jurisdição compulsória pela Guiné-Bissau em sua Zona Econômica Exclusiva do Estado (ZEE). Para a melhor compreensão dos problemas jurídicos enfrentados pela Corte, é necessário apresentar os fatos dos principais problemas jurídicos julgados.

$\mathrm{O}$ caso envolve a apreensão da embarcação $\mathrm{M} / \mathrm{V}$ Virginia $\mathrm{G}$ registrada no Panamá cuja propriedade era da companhia Penn Lilac Trading S. $A^{131}$. A embarcação estava em conformidade com as exigências do Panamá para poder realizar as suas atividades. À época da apreensão, que ocorreu no dia 21 de agosto de 2009, o navio estava fretado para a empresa irlandesa Lotus Federation que atuava na venda e na distribuição de combustível para navios pesqueiros. Esse contrato foi fruto de uma parceria entre a Penn Lilac Trading S.A, proprietária do navio, e a empresa espanhola Gebaspe $S L$, que atuava como intermediária para o suprimento de combustível de navios pesqueiros. No momento da apreensão, o capitão do navio era o senhor Eduardo Blanco Guerrero, de nacionalidade cubana. Havia onze tripulantes a bordo, dos quais sete eram nacionais de Cuba, três do Gana e um do Cabo Verde.

\footnotetext{
* Professora adjunta, Universidade de Brasília; Doutora em Direito pela Universidade de Paris II, Panthéon-Assas.

** Mestranda em Direito, Centro Universitário de Brasília.

131 TRIBUNAL INTERNACIONAL O DIREITO DO MAR. 2012. Sentença de 03 de Março, Panamá vs Guiné-Bissau. Caso n. 19, M/V “Virginia G”. \$56.
} 
A embarcação M/V Virgínia G, fretada pela empresa Lotus, foi contratada pela empresa Balmar Pesquerías do Atlántico para distribuir combustível para as embarcações Amabal I, Amabal II, Rimbal I e Rimbal II. Esses navios eram de bandeira da Mauritânia e eram utilizados pela Balmar em sua atividade pesqueira ${ }^{132}$.

Em 14 de agosto de 2009, agentes da Balmar na Guiné-Bissau formularam um pedido de autorização para o Serviço Nacional de Fiscalização e Controle das Atividades de Pesca - FISCAP -, órgão do governo da Guiné-Bissau, requerendo autorização para abastecer seus navios na ZEE do referido país. A FISCAP autorizou o reabastecimento com a condição de que fossem indicadas as coordenadas de onde aconteceria o abastecimento, a data, o horário, o nome do navio responsável pela operação e o cumprimento das obrigações necessárias para obter a autorização ${ }^{133}$.

A Balmar entendeu ter prestado todas as informações requeridas pela FISCAP. Esta, por sua vez, informou que um dos documentos requeridos não tinha sido entregue pela Balmar, além da falta de pagamento da taxa exigida para a realização do serviço. Tratavase do certificado de que o navio M/V Virginia G detinha autorização para o tipo de operação que estava desenvolvendo na ZEE da Guiné-Bissau. A empresa, posteriormente representada pelo governo do Panamá, informou que o documento citado nunca havia sido requerido pelo órgão de fiscalização da Guiné-Bissau.

Em cumprimento às atividades contratadas, a embarcação realizou o reabastecimento dos navios Rimbal I e II, no dia 20 de agosto de 2009, e do Amabal II, no dia 21 de agosto na ZEE da Guiné-Bissau. Ao realizar o abastecimento do Amabal I, a M/V Virginia $G$ foi interceptada por fiscais da FISCAP que determinaram o seguimento da embarcação ao Porto de Bissau, onde chegou no dia 22 de agosto de 2009. Juntamente com essa embarcação, as embarcações Amabal I e Amabal II foram apreendidas e levadas ao porto, sendo que estas duas foram liberadas no dia 28 de agosto de $2009^{134}$.

132 TRIBUNAL INTERNACIONAL O DIREITO DO MAR. 2012. Sentença de 03 de Março, Panamá vs Guiné-Bissau. Caso n. 19, M/V "Virginia G”. \$58.

133 TRIBUNAL INTERNACIONAL O DIREITO DO MAR. 2012. Sentença de 03 de Março, Panamá vs Guiné-Bissau. Caso n. 19, M/V "Virginia G". \$64.

134 TRIBUNAL INTERNACIONAL O DIREITO DO MAR. 2012. Sentença de 03 de Março, Panamá vs Guiné-Bissau. Caso n. 19, M/V "Virginia G". \$71.
$\mathrm{Na}$ sequência, a $\mathrm{M} / \mathrm{V}$ Virginia $\mathrm{G}$ foi confiscada por uma decisão da Comissão Interministerial da Fiscalização Marítima da Guiné-Bissau (CIFM) em razão da venda não autorizada de combustível para navios pesqueiros na ZEE do Estado. A FISCAP notificou a Penn Lilac da referida decisão por meio de uma carta datada de 31 de agosto de 2009.

Penn Lilac então contatou a companhia Africargo, representante de seu navegador na Guiné-Bissau, e pediu o seu auxílio na recuperação da embarcação. A Africargo, por meio de uma carta, enviou ao coordenador da FISCAP um pedido de clarificação sobre quais procedimentos deveriam ser adotados para recuperar a embarcação e permitir a liberação da tripulação. Contudo, o coordenador da FISCAP afirmou que a decisão da CIFM foi legal, justa e adequada e que, portanto, as medidas permaneceriam vigentes.

Em uma nova tentativa, reiterou-se o pedido de recuperação da embarcação e de liberação de seus tripulantes e requereu-se informações sobre quais seriam os procedimentos administrativos cabíveis para a defesa do proprietário da embarcação. Entretanto, a resposta foi uma notificação que estabeleceu o prazo de 72 horas para que os representantes do proprietário da embarcação apresentassem manifestação pois, caso contrário, o navio com todos os seus bens seria vendido em hasta pública.

Após diversas tentativas de contato por parte da Africargo, a resposta da FISCAP foi de que os combustíveis encontrados no navio seriam vendidos em leilão e que a empresa seria convidada para participar da hasta pública.

Em resposta ao ocorrido, os donos da embarcação entraram com um pedido de medida provisória na Corte Regional da Guiné-Bissau para suspender a implementação das decisões da CIFM; o pedido foi deferido e executado. Contudo, o Procurador-Geral da Guiné-Bissau apelou da decisão e, apesar de a apelação ter sido rejeitada, foi enviada à Corte Superior da Guiné-Bissau em decorrência dos interesses políticos envolvidos ${ }^{135}$. O processo acabou não sendo apreciado, eis que a Corte afirmou que havia uma decisão do governo para liberar a embarcação. Diante disso, Procurador-Geral emitiu um parecer afirmando que a apreensão do navio e a utilização do combustível que ele

135 TRIBUNAL INTERNACIONAL O DIREITO DO MAR. 2012. Sentença de 03 de Março, Panamá vs Guiné-Bissau. Caso n. 19, M/V "Virginia G”. \$74. 
transportava tinham sido legais. Com base nesse parecer, o Secretário de Estado do Ministério das Finanças da Guiné-Bissau enviou uma carta ao comandante do navio afirmando que, com base na decisão da CIFM e não obstante a ordem judicial de suspensão da decisão, a Secretaria do Tesouro tinha ordenado a retirada de todo o combustível da embarcação ${ }^{136}$. A ordem foi cumprida e o proprietário do navio formulou um novo pedido de medidas provisórias na Corte Regional da Guiné-Bissau contra o Secretário; as medidas foram atendidas, determinando-se o retorno da carga ao navio $^{137}$.

Após um mês, o proprietário do navio promoveu uma ação de mérito contra a ordem do Secretário. Além dessa ação, a Penn Lilac propôs ações de mérito contra as decisões da CIFM. Contudo, ambas as ações não prosperaram por questões processuais, as quais, segundo o governo do Panamá, foram ilegítimas; ao passo que para o governo da Guiné-Bissau tratava-se de negligência do demandante.

Em 20 de setembro de 2010, por decisão da CIFM, a embarcação foi finalmente liberada ${ }^{138}$. Após o seu retorno, o navio passou por uma auditoria e voltou a operar depois de ter recebido reparos. Quanto à tripulação, todos tiveram seus passaportes inicialmente retidos e vários somente o receberam de volta quando da liberação da embarcação.

Diante desse contexto, a controvérsia em apreço foi levada ao ITLOS a partir de um acordo especial concluído por troca de cartas entre as partes ${ }^{139}$. Ambos os Estados ratificaram a Convenção da ONU sobre Direito do Mar. Entre os problemas decididos pelo tribunal, pode ser citada a admissibilidade do processo, com base na desvinculação de fato do proprietário da embarcação ao Estado do Panamá; e à questão substancial ligada ao confisco ilegal da embarcação. O tribunal entendeu que havia conexão entre a embarcação e o Panamá e, portanto, a controvérsia

136 TRIBUNAL INTERNACIONAL O DIREITO DO MAR. 2012. Sentença de 03 de Março, Panamá vs Guiné-Bissau. Caso n. 19, M/V "Virginia G”. \$76.

137 TRIBUNAL INTERNACIONAL O DIREITO DO MAR. 2012. Sentença de 03 de Março, Panamá vs Guiné-Bissau. Caso n. 19, M/V "Virginia G". \$79.

138 TRIBUNAL INTERNACIONAL O DIREITO DO MAR. 2012. Sentença de 03 de Março, Panamá vs Guiné-Bissau. Caso n. 19, M/V "Virginia G”. §82.

139 TRIBUNAL INTERNACIONAL O DIREITO DO MAR. 2012. Sentença de 03 de Março, Panamá vs Guiné-Bissau. Caso n. 19, M/V “Virginia G”. §86; \$92. poderia ser julgada pelo tribunal e que o confisco não tinha sido razoável no caso concreto.

\section{A) Comentário do caso}

A decisão situa-se em uma linha jurisprudencial clássica quanto aos aspectos processuais e substanciais, diferenciando-se da jurisprudência anterior do ITLOS por tratar, pela primeira vez, da natureza jurídica da atividade de abastecimento de navios pesqueiros na ZEE de um Estado.

A principal questão processual do caso referiu-se ao argumento trazido pela Guiné-Bissau de que inexistia um vínculo genuíno entre a embarcação $M / V$ Virginia G e o Panamá. Segundo a Guiné-Bissau, o Panamá não exercia uma efetiva jurisdição sobre o navio, o que pôde ser constatado pela completa desconexão entre o Estado citado, o dono do navio e a sua tripulação, nos termos do art. 91 da Convenção sobre o Direito do $\operatorname{mar}^{140}$. Segundo a Guiné-Bissau, o registro da bandeira do navio só poderia ser realizado quando o Estado tivesse efetiva jurisdição e controle sobre o proprietário ou o operador do navio ${ }^{141}$. Por esse motivo, a GuinéBissau entendeu que o Panamá não possuía o vínculo substancial para exercer a proteção diplomática da embarcação, nos termos da Convenção para Condições de Registro de Navios de 1986.

O Panamá, em sua réplica, afirmou que possuía e mantinha esse vínculo com a embarcação porque, além do reconhecimento desse fato pela própria GuinéBissau no momento dos contatos para obtenção de permissão para abastecimento em sua ZEE, a empresa proprietária da embarcação foi incorporada no Panamá, em conformidade com o art. 94 da Convenção sobre o Direito do $\mathrm{Mar}^{142}$. Além disso, afirmou possuir todos

140 TRIBUNAL INTERNACIONAL O DIREITO DO MAR. 2012. Sentença de 03 de Março, Panamá vs Guiné-Bissau. Caso n. 19, M/V "Virginia G". \. 102. O artigo 91 da Convenção sobre o Direito do Mar dispõe que: "Art. 91.Nacionalidade dos navios. 1. Os Estados devem estabelecer os requisitos necessários para a atribuição da sua nacionalidade a navios, para o registo de navios no seu território e para o direito de arvorar a sua bandeira. Os navios possuem a nacionalidade do Estado cuja bandeira estejam autorizados a arvorar. Deve existir um vínculo substancial entre o Estado e o navio; 2. Os Estados devem fornecer aos navios a que tenha concedido o direito de arvorar a sua bandeira os documentos pertinentes".

141 TRIBUNAL INTERNACIONAL O DIREITO DO MAR. 2012. Sentença de 03 de Março, Panamá vs Guiné-Bissau. Caso n. 19, M/V "Virginia G". \$103.

142 TRIBUNAL INTERNACIONAL O DIREITO DO MAR. 2012. Sentença de 03 de Março, Panamá vs Guiné-Bissau. Caso n. 
os certificados e as autorizações necessárias para o seu funcionamento nos termos das leis panamenhas aplicáveis. No que concerne à proteção diplomática, o Panamá respondeu alegando que o navio, a sua carga e a sua tripulação deveriam ser concebidos como uma única entidade para efeitos de proteção, tal como disposto no precedente M/V Saiga n ${ }^{\circ} 2^{143}$. Sendo assim, dado que a bandeira da embarcação era do Panamá, este detinha legitimidade para pleitear a reparação de danos a todos os envolvidos (do navio, do proprietário do navio, das pessoas e dos bens presentes no navio) independentemente da nacionalidade de cada pessoa física e jurídica presente.

O tribunal decidiu que existia o vínculo genuíno entre o Panamá e a embarcação eis que de fato a embarcação estava registrada no Panamá. De acordo com o tribunal, seguindo o precedente M/V Saiga $\mathrm{n}^{\circ} 2$ que interpretou o art. 91 da Convenção sobre Direito do $\mathrm{Mar}^{144}$, os Estados possuem competência exclusiva para determinar a possibilidade do registro de navios no âmbito nacional. O vínculo genuíno significa, para o tribunal ${ }^{145}$, que, uma vez que um navio estiver registrado em um Estado, este deve exercer o devido controle com a finalidade de assegurar a operação do navio de acordo com as normas nacionais e internacionais. Nesse sentido, afirmou que o Panamá observou todos os trâmites legais estabelecidos na sua própria legislação, estando esta em conformidade com as normas internacionais como a Convenção para Segurança da Vida no Mar (SOLAS 1974) e a Convenção para a prevenção de poluição por navios (MARPOL 73-78) ${ }^{146}$.

Observa-se que o tribunal foi reticente em analisar os elementos de fato da conexão entre a embarcação e o Estado de registro. Trata-se de uma posição conservadora, porém em conformidade com os

19, M/V "Virginia G". \$104-105.

143 TRIBUNAL INTERNACIONAL O DIREITO DO MAR. 2012. Sentença de 03 de Março, Panamá vs Guiné-Bissau. Caso n. 19, M/V “Virginia G”. \$120; Tribunal Internacional para o Direito do Mar. M/V Saiga n ${ }^{\circ}$ 2, Saint Vincent and the Grenadines v. Guiné, Relatório de 1999, paras. 106, 107.

144 TRIBUNAL INTERNACIONAL O DIREITO DO MAR. 1999. Sentença de 01 de Julho, Saint Vincent and the Grenadines v. Guiné. M/V Saiga n. 2. \$63, 82-83.

145 TRIBUNAL INTERNACIONAL O DIREITO DO MAR. 2012. Sentença de 03 de Março, Panamá vs Guiné-Bissau. Caso n. 19, M/V "Virginia G". \$113.

146 TRIBUNAL INTERNACIONAL O DIREITO DO MAR. 2012. Sentença de 03 de Março, Panamá vs Guiné-Bissau. Caso n. 19, M/V “Virginia G”. \$115-116. julgados anteriores sobre essa questão. Todavia, caberá ao tribunal se atentar aos elementos de fato de conexão entre o Estado de registro e a propriedade do navio para fins de incentivo às cautelas necessárias para a navegação marítima. Os danos que podem decorrer da navegação podem extrapolar os interesses das partes envolvidas, a exemplo de possíveis danos ambientais. A bandeira de conveniência é benéfica a empresas que pretendam obter vantagens fiscais e sociais para as suas operações, mas não pretendem se comprometer efetivamente com a tutela de bens como o meio ambiente ou os direitos humanos de trabalhadores em condições de vulnerabilidade. No entanto, como os fatos do caso estão conectados a um tema clássico do direito do mar — a liberação de embarcações —, não houve fatos diferentes que sustentassem a conexão substancial fática entre o registro da bandeira em um Estado e o proprietário ou do operador da embarcação.

A propósito da questão substancial, o Panamá alegou que a retenção e o confisco da embarcação tinham sido indevidos ${ }^{147}$. Os argumentos utilizados foram no sentido de que as regras elaboradas para a autorização das atividades da embarcação pelo governo da Guiné-Bissau violavam dispositivos da Convenção do $\mathrm{Mar}^{148}$. Segundo o demandante, o Decreto 6-A/200, formalizador da apreensão da embarcação, estabelecia a jurisdição compulsória da Guiné-Bissau diante de todas as atividades econômicas realizadas na ZEE do Estado. No entanto, segundo o Panamá, a atividade da $M / V$ Virginia $G$ deveria ser categorizada como navegação e não como atividade econômica passível de ser controlada, pois a sua função era acessória à atividade de pesca e de extração de recursos naturais na $\mathrm{ZEE}^{149}$. A atividade de bunkering exercida pela embarcação correspode ao abastecimento de embarcações que exerçam atividades econômicas no mar e, portanto, não poderia ser comparada à atividade de pesca em si, nos termos do artigo 56, parágrafo primeiro da Convenção sobre o Direito do $\operatorname{Mar}^{150}$. De acordo com o Panamá,

147 TRIBUNAL INTERNACIONAL O DIREITO DO MAR. 2012. Sentença de 03 de Março, Panamá vs Guiné-Bissau. Caso n. 19, M/V "Virginia G”. \$161.

148 Artigos 56, 58, e 73 parágrafo $1^{\circ}$ da Convenção sobre o Direito do Mar.

149 TRIBUNAL INTERNACIONAL O DIREITO DO MAR. 2012. Sentença de 03 de Março, Panamá vs Guiné-Bissau. Caso n. 19, M/V "Virginia G”. \$170.

150 TRIBUNAL INTERNACIONAL O DIREITO DO MAR. 2012. Sentença de 03 de Março, Panamá vs Guiné-Bissau. Caso n. 19, M/V "Virginia G”. \$167. 
essa jurisdição compulsória infringiu os direitos de livre navegação protegidos pelo artigo 58 , parágrafo primeiro da mesma Convenção ${ }^{151}$.

A Guiné-Bissau, por sua vez, afirmou que as restrições que empregava estavam dentro do limite mínimo necessário para garantir os direitos e a proteção de sua ZEE. A atividade de bunkering é considerada como uma atividade econômica relacionada à pesca pela legislação doméstica ${ }^{152} \mathrm{e}$, ainda, pela legislação de outros países da região ${ }^{153}$. Entre as condições para operar enquanto bunkering pode ser citada a cobrança de uma taxa que, segundo a Guiné-Bissau, não possui a natureza de imposto ${ }^{154}$. Um dos motivos do controle desta atividade seria a proteção ambiental da ZEE, no sentido de que a pesca deveria ser sustentável e, portanto, instrumentos regulatórios seriam necessários ${ }^{155}$. Isso porque a atividade de reabastecimento nessa área é uma atividade derivada da pesca e tem caráter econômico ${ }^{156}$, tendo inclusive a possibilidade de causar dano ambiental. Por este motivo seria conveniente a aplicação do princípio da precaução como base para a legislação doméstica ${ }^{157}$.

O tribunal manifestou-se da seguinte forma: primeiramente analisou se a Guiné-Bissau, no exercício de seus direitos soberanos de fiscalização da exploração dos recursos marinhos da ZEE, tem a competência de regular o reabastecimento de embarcações estrangeiras

151 TRIBUNAL INTERNACIONAL O DIREITO DO MAR. 2012. Sentença de 03 de Março, Panamá vs Guiné-Bissau. Caso n. 19, M/V “Virginia G”. \$170.

152 TRIBUNAL INTERNACIONAL O DIREITO DO MAR. 2012. Sentença de 03 de Março, Panamá vs Guiné-Bissau. Caso n. 19, M/V “Virginia G”. \$189.

153 TRIBUNAL INTERNACIONAL O DIREITO DO MAR. 2012. Sentença de 03 de Março, Panamá vs Guiné-Bissau. Caso n. 19, M/V "Virginia G". \$191.

154 TRIBUNAL INTERNACIONAL O DIREITO DO MAR. 2012. Sentença de 03 de Março, Panamá vs Guiné-Bissau. Caso n. 19, M/V “Virginia G”. \$178; \$204.

155 TRIBUNAL INTERNACIONAL O DIREITO DO MAR. 2012. Sentença de 03 de Março, Panamá vs Guiné-Bissau. Caso n. 19, M/V “Virginia G”. \$182; \$186.

156 TRIBUNAL INTERNACIONAL O DIREITO DO MAR. 2012. Sentença de 03 de Março, Panamá vs Guiné-Bissau. Caso n. 19, M/V “Virginia G”. \$177; \$185

157 TRIBUNAL INTERNACIONAL O DIREITO DO MAR. 2012. Sentença de 03 de Março, Panamá vs Guiné-Bissau. Caso n. 19, M/V “Virginia G”. \196; \199. Os artigos 61 e 62 da Convenção sobre o Direito do Mar são citados, bem como o caso M/V Saiga n. 2. TRIBUNAL INTERNACIONAL O DIREITO DO MAR. 1999. Sentença de 01 de Julho, Saint Vincent and the Grenadines v. Guiné. M/V Saiga n. 2. que pescam nessa zona; em seguida, observou se a forma pela qual o Estado regulou a atividade foi adequada. Destaca-se que a legislação nacional foi analisada com base em precedentes que já permitiram que os tribunais internacionais possam averiguar a conformidade das normas nacionais com as obrigações internacionais assumidas pelos Estados, apesar de as normas de direito interno serem, de modo geral, fato para o direito internacional ${ }^{158}$.

Com relação ao primeiro aspecto, o tribunal decidiu que a atividade de reabastecimento estava compreendida como parte integrante do processo de extração de recursos da ZEE, sendo, portanto, integrante da esfera de regulação da Guiné-Bissau. Assim, este Estado tem competência para regular o bunkering em razão da interpretação extensiva das obrigações de conservação e de gestão expressas nos artigos 56 e 61 a 68 da Convenção sobre Direito do Mar ${ }^{159}$. O tribunal citou diversas normas que demonstram a ligação direta entre a atividade de bunkering e a pesca, o que resulta na aplicação direta do art. 62 , parágrafo $4^{\circ}$ que trata da obrigação do Estado de gerir a pesca na sua $Z^{2} E^{160}$. Ademais, o tribunal analisou se a atividade de bunkering estaria abarcada pela liberdade de navegação nos termos do art. 58 da Convenção. A decisão foi no sentido de que o art. 58 não impede que o Estado costeiro regule a atividade de abastecimento de navios ${ }^{161}$, pois essa competência decorre do dever estabelecido no artigo 56 de conservar e de gerir os recursos da ZEE do Estado costeiro.

158 TRIBUNAL INTERNACIONAL O DIREITO DO MAR. 2012. Sentença de 03 de Março, Panamá vs Guiné-Bissau. Caso n. 19, M/V “Virginia G”. \$226. A decisão cita o precedente da Corte Permanente de Justiça, Certain German Interests in Polish Upper Silesia, Merits, Judgment n. 7, 1926, p. 19.

159 TRIBUNAL INTERNACIONAL O DIREITO DO MAR. 2012. Sentença de 03 de Março, Panamá vs Guiné-Bissau. Caso n. 19, M/V "Virginia G". \$212, 213. Ver especialmente o artigo 62, parágrafo 4 da Convenção sobre o Direito do Mar.

160 TRIBUNAL INTERNACIONAL O DIREITO DO MAR. 2012. Sentença de 03 de Março, Panamá vs Guiné-Bissau. Caso n. 19, M/V "Virginia G". \$216. O tribunal cita o seguinte tratado: "Agreement on Port State Measures to Prevent, Deter and Eliminate Illegal, Unreported and Unregulated Fishing (2009). Article 1, paragraph (d), of that agreement defines: "fishing related activities" as any operation in support of, or in preparation for fishing, including... the provisioning of personnel, fuel, gear and other supplies at sea"

161 TRIBUNAL INTERNACIONAL O DIREITO DO MAR. 2012. Sentença de 03 de Março, Panamá vs Guiné-Bissau. Caso n. 19, M/V “Virginia G”. \$222. 
Quanto à adequação da regulação do bunkering pela Guiné-Bissau, o tribunal afirmou que o Decreto-lei 6-A/2000, em especial os artigos 3 e 23 , estavam em conformidade com os artigos 56 e 62 da Convenção sobre o Direito do mar. A questão principal analisada pelo tribunal nesse ponto foi a de saber se a estipulação de pagamento de uma taxa, conforme aduziu a GuinéBissau, ou de um imposto, conforme argumentou o Panamá, seria lícita ${ }^{162}$. Nessa questão, o tribunal deu razão à Guiné-Bissau, no sentido de que, em conformidade com o precedente M/V Saiga (n.2) ${ }^{163}$, verificou-se que os Estados possuem a prerrogativa de fixar leis domésticas sobre a ZEE, a exemplo da previsão de taxas para a autorização de serviços naquela região. Igualmente, o tribunal verificou que a cobrança não era uma extensão de sua legislação tributária aos demais Estados, mas uma contraprestação pelos serviços prestados para a autorização necessária para o serviço de abastecimento ${ }^{164}$.

Assim, o trâmite estabelecido pela Guiné-Bissau para a concessão de autorização para serviços de abastecimento dentro de sua ZEE era legítimo. Todavia, as autoridades deveriam ter aplicado devidamente as regras que regiam o processo, motivo pelo qual o tribunal analisou se o processo de autorização das atividades da embarcação M/V Virginia $G$ tinha sido adequado $^{165}$.

As provas colhidas nos autos do processo demonstram que, de fato, a embarcação em questão não detinha a autorização por escrito necessária, conforme a legislação da Guiné-Bissau exigia, para realizar os abastecimentos $^{166}$. A partir dessa constatação, foi avaliado se a sanção foi adequadamente aplicada, conforme normas aplicáveis.

162 TRIBUNAL INTERNACIONAL O DIREITO DO MAR. 2012. Sentença de 03 de Março, Panamá vs Guiné-Bissau. Caso n. 19, M/V "Virginia G". \$230.

163 TRIBUNAL INTERNACIONAL O DIREITO DO MAR. 2012. Sentença de 03 de Março, Panamá vs Guiné-Bissau. Caso n. 19, M/V "Virginia G". \$127.

164 TRIBUNAL INTERNACIONAL O DIREITO DO MAR. 2012. Sentença de 03 de Março, Panamá vs Guiné-Bissau. Caso n. 19, M/V "Virginia G”. \$234.

165 TRIBUNAL INTERNACIONAL O DIREITO DO MAR. 2012. Sentença de 03 de Março, Panamá vs Guiné-Bissau. Caso n. 19, M/V "Virginia G". \$237.

166 TRIBUNAL INTERNACIONAL O DIREITO DO MAR. 2012. Sentença de 03 de Março, Panamá vs Guiné-Bissau. Caso n. 19, M/V "Virginia G”. \$248.
Ao analisar o conteúdo do artigo 52 do Decreto da Guiné-Bissau, combinado com a disposição do artigo 73 parágrafo $1^{\circ}$ da Convenção sobre Direito do Mar, percebe-se que o confisco de embarcações pesqueiras e aquelas que se apoiam em sua logística não é, por si só, uma violação da Convenção, eis que a legislação da Guiné-Bissau apresenta, em teoria, diversos mecanismos de flexibilização na aplicação das sanções e permite mecanismos jurídicos para enfrentar a medida de confisco $^{167}$. Por essa razão, o tribunal verificou se, no caso concreto, a ação de apreensão da embarcação tinha sido legal.

Para decidir sobre a conduta da Guiné-Bissau, o tribunal ponderou a razoabilidade das medidas adotadas pelo Estado que deveriam ser necessárias para assegurar a aplicação das normas ${ }^{168}$. Apesar de entender que houve uma violação grave perpetrada pela embarcação do Panamá por esta não possuir a devida autorização e não ter pago as taxas necessárias, havia fatores que atenuavam a conduta adotada pelos responsáveis pela embarcação. Podem ser citados, por exemplo, o fato de que a operação de abastecimento havia sido anteriormente informada, além do fato de que os demais barcos apreendidos com o M/V Virginia $G$ tinham recebido somente uma pena de multa, e não a pena de confisco, enquanto as embarcações Rimbal I e Rimbal II sequer foram multadas ${ }^{169}$.

O tribunal entendeu, portanto, que o fato de a embarcação não ter adquirido a autorização tinha sido fruto de uma má interpretação dos fatos, de um erro de comunicação entre os oficiais do governo e os responsáveis pela embarcação ${ }^{170}$. Sendo assim, não havia necessidade de se proceder ao confisco da embarcação e de seus bens, sendo a pena desproporcional ao delito, com base no princípio da razoabilidade ${ }^{171}$. Com isso,

167 TRIBUNAL INTERNACIONAL O DIREITO DO MAR. 2012. Sentença de 03 de Março, Panamá vs Guiné-Bissau. Caso n. 19, M/V “Virginia G”. \$253; \$255; \$257. A possibilidade de confisco pode ser observada no caso Tomimaru, Japan v. Russian Federation, Prompt Release, ITLOS Reports 2005-2007, paras. 72, 75, 76.

168 TRIBUNAL INTERNACIONAL O DIREITO DO MAR. 2012. Sentença de 03 de Março, Panamá vs Guiné-Bissau. Caso n. 19, M/V "Virginia G”. \$266.

169 TRIBUNAL INTERNACIONAL O DIREITO DO MAR. 2012. Sentença de 03 de Março, Panamá vs Guiné-Bissau. Caso n. 19, M/V "Virginia G”. \$268.

170 TRIBUNAL INTERNACIONAL O DIREITO DO MAR. 2012. Sentença de 03 de Março, Panamá vs Guiné-Bissau. Caso n. 19, M/V "Virginia G". \$269.

171 TRIBUNAL INTERNACIONAL O DIREITO DO MAR. 2007. Setença de 09 de Julho. Hoshinmaru, Japan v. Russian 
o tribunal considerou que o confisco da embarcação tinha violado o artigo 73 , parágrafo $1^{\circ} \mathrm{da}$ Convenção ${ }^{172}$.

Uma outra violação sustentada pelo Panamá, com base no artigo 73 parágrafo $3^{\circ}$ da Convenção, foi de que houve a detenção ilegal dos tripulantes da embarcação M/V Virginia $G$ por mais quatro meses, sem o devido processo legal e com a apreensão de seus passaportes. De acordo com o Panamá, não houve presença significativa dos tripulantes da embarcação na Guiné-Bissau que justificasse a reação realizada sem ter sequer existido o devido processo penal. Além disso, a empresa proprietária também argumentou, com base no parágrafo $2^{\circ}$ do art. 73 da Convenção, que não obteve uma tutela administrativa adequada no que tange à soltura da embarcação ${ }^{173}$.

Com relação aos tripulantes, o tribunal se posicionou a favor dos argumentos da Guiné-Bissau. Segundo o tribunal, o Decreto de regulação de proteção da ZEE não prevê, em nenhum momento, a pena de prisão para essa situação ${ }^{174}$; os membros da tripulação não foram retidos irregularmente, pois poderiam ter deixado o navio quando desejassem. Outrossim, é tolerável um atraso na devolução dos passaportes e isso não pode ser considerado equivalente ao encarceramento ${ }^{175}$.

No que tange à inadequação dos procedimentos relacionados à empresa proprietária da embarcação, o tribunal decidiu que não assiste razão ao Panamá, uma vez que o Decreto 6-A/2000 da Guiné-Bissau estabelece critérios, procedimentos e condições suficientes para que, no âmbito administrativo, a empresa proprietária da embarcação pudesse liberá-la administrativamente ${ }^{176}$.

O tribunal analisou, ainda, se a Guiné-Bissau tinha violado o artigo 73 , parágrafo $4^{\circ}$ da Convenção sobre

Federation. Prompt Release, Itlos Reports 2005-2007. §88.

172 TRIBUNAL INTERNACIONAL O DIREITO DO MAR. 2012. Sentença de 03 de Março, Panamá vs Guiné-Bissau. Caso n. 19, M/V “Virginia G”. \$269.

173 TRIBUNAL INTERNACIONAL O DIREITO DO MAR. 2012. Sentença de 03 de Março, Panamá vs Guiné-Bissau. Caso n. 19, M/V “Virginia G”. \$276-277.

174 TRIBUNAL INTERNACIONAL O DIREITO DO MAR. 2012. Sentença de 03 de Março, Panamá vs Guiné-Bissau. Caso n. 19, M/V "Virginia G". §306; \$308.

175 TRIBUNAL INTERNACIONAL O DIREITO DO MAR. 2012. Sentença de 03 de Março, Panamá vs Guiné-Bissau. Caso n. 19, M/V "Virginia G”. \$310.

176 TRIBUNAL INTERNACIONAL O DIREITO DO MAR. 2012. Sentença de 03 de Março, Panamá vs Guiné-Bissau. Caso n. 19, M/V “Virginia G”. \$296. o Direito do Mar ao não adotar os meios legais para a comunicação ao Panamá das sanções aplicadas ao navio de sua bandeira ${ }^{177}$. O tribunal considerou válida essa argumentação a despeito do argumento da GuinéBissau de que, pelo fato de não existirem nacionais do Panamá na tripulação, ela não estaria obrigada a informar àquele país sobre suas ações. Ocorre que o tribunal determinou, anteriormente, o vínculo genuíno entre o país e a embarcação. Assim, de acordo com a Convenção, o único elemento necessário para ensejar a responsabilização pelas comunicações é a caracterização da bandeira da embarcação, motivo pelo qual a Guiné-Bissau violou o artigo 73, parágrafo $4^{\text {o178 }}$.

Superada a análise desse artigo, o Panamá, em suas declarações finais, requereu ao tribunal que declarasse que a Guiné-Bissau violou também os princípios dos artigos 110 e 224, bem como os dispositivos 225 e 300 da Convenção sobre o Direito do Mar. Ademais, foi solicitada a declaração do uso excessivo de força e da violação dos princípios fundamentais de outros tratados ${ }^{179}$.

Ao fazer a análise dos princípios dos artigos 110 e 224, referentes ao direito de visita e ao poder de enforcement respectivamente, o tribunal percebeu que, não obstante os referidos artigos derivarem de costumes de direito internacional, eles não poderiam ser utilizados como princípios para a análise da ação da Guiné-Bissau, pois a Convenção permite discricionariedade do país para estabelecer métodos claros de apreensão de navios, como a Guiné-Bissau fez em seu Decreto 6-A/2000 ${ }^{180}$.

No que se refere ao uso excessivo de força, o tribunal observou que o precedente Saiga ${ }^{181}$ igualmente cobriu a questão, aduzindo que o uso de força é geralmente reconhecido pelo direito internacional

177 TRIBUNAL INTERNACIONAL O DIREITO DO MAR. 2012. Sentença de 03 de Março, Panamá vs Guiné-Bissau. Caso n. 19, M/V "Virginia G". \$312.

178 TRIBUNAL INTERNACIONAL O DIREITO DO MAR. 2012. Sentença de 03 de Março, Panamá vs Guiné-Bissau. Caso n. 19, M/V “Virginia G”. \$328.

179 TRIBUNAL INTERNACIONAL O DIREITO DO MAR. 2012. Sentença de 03 de Março, Panamá vs Guiné-Bissau. Caso n. 19, M/V “Virginia G”. \$329. O Panamá alega a violação da Convention for the Suppression of Unlawful Acts Against the Safety of Maritime Navigation (1988).

180 TRIBUNAL INTERNACIONAL O DIREITO DO MAR. 2012. Sentença de 03 de Março, Panamá vs Guiné-Bissau. Caso n. 19, M/V "Virginia G”. \$345.

181 TRIBUNAL INTERNACIONAL O DIREITO DO MAR. 1999. Sentença de 01 de Julho, Saint Vincent and the Grenadines v. Guiné. M/V Saiga n. 2. \$155-156. 
desde que obedeça padrões para sua utilização, como avisos e comunicação prévia. No caso, a abordagem feita pelas autoridades da Guiné-Bissau foi legítima, considerando que o uso de força restringiu-se somente ao mínimo necessário para a apreensão da embarcação, e as limitações sofridas, como a impossibilidade de comunicação, foram imediatamente cessadas quando do fim da captura. Por esse motivo, o entendimento foi pela não ocorrência do uso excessivo de força.

$\mathrm{Na}$ sequência foi avaliada a violação aos artigos 225 e da Convenção de Segurança na Navegação Marítima. Este artigo dispõe que nenhuma embarcação apreendida deve ser sujeitada a condições de navegação que possa trazer risco à embarcação. O Panamá alegou que essa regra foi violada porque as autoridades da Guiné-Bissau no momento da apreensão determinaram a navegação à noite e com baixa visibilidade por causa da chuva, além da proibição de usar instrumentos de comunicação $^{182}$. Além da violação desse dispositivo, o Panamá alegou que essa ação não era conforme aos propósitos da Convenção de Segurança na Navegação Marítima.

O tribunal, no entanto, aduziu que, diante das diferentes versões lançadas pelas partes e pela ausência de provas específicas que dessem suporte às alegações, não havia mecanismos para determinar a culpa da Guiné-Bissau na condução do navio de bandeira panamenha ${ }^{183}$. Igualmente, considerou que não seria possível aplicar a Convenção de Segurança na Navegação Marítima, pois esta se destina a coibir a prática de atos de terrorismo e não regular processos de condução de navios legais dentro da área de jurisdição de um Estado ${ }^{184}$.

Por fim, o tribunal passou à análise do artigo 300, que estabelece a necessidade de se proceder de boa-fé na condução das obrigações da Convenção, sem utilizar de maneira abusiva os direitos a ela inerentes ${ }^{185}$. O argumento do Panamá era de que a Guiné-Bissau faltou

182 TRIBUNAL INTERNACIONAL O DIREITO DO MAR. 2012. Sentença de 03 de Março, Panamá vs Guiné-Bissau. Caso n. 19, M/V "Virginia G”. \$365.

183 TRIBUNAL INTERNACIONAL O DIREITO DO MAR. 2012. Sentença de 03 de Março, Panamá vs Guiné-Bissau. Caso n. 19, M/V “Virginia G”. \$374.

184 TRIBUNAL INTERNACIONAL O DIREITO DO MAR. 2012. Sentença de 03 de Março, Panamá vs Guiné-Bissau. Caso n. 19, M/V “Virginia G”. \$376.

185 TRIBUNAL INTERNACIONAL O DIREITO DO MAR. 2012. Sentença de 03 de Março, Panamá vs Guiné-Bissau. Caso n. 19, M/V "Virginia G”. \$378. com a boa-fé ao proceder ao confisco da embarcação mesmo existindo uma ordem judicial que estipulava o contrário. O tribunal negou o argumento do Panamá por ser genérico, já que não se especificou nenhum compromisso na Convenção que tenha sido utilizado de maneira ilegal ou de modo abusivo, não sendo admissível uma proposição que considere o artigo 300 de maneira isolada ${ }^{186}$.

Tendo superado as questões apresentadas, o tribunal determinou quais seriam as reparações devidas. Considerando as duas condenações sofridas pela Guiné-Bissau, com base no artigo 73, parágrafos $1^{\circ}$ e $4^{\circ}$ da Convenção, o tribunal entendeu que o Panamá havia sofrido de fato danos. A reparação ao Panamá se limitou ao confisco da carga do navio e aos custos de reparo deste em consequência do confisco irrazoável. Nesse sentido, foi determinado o valor da carga para efeitos de reparação em US $\$ 388,506,00^{187}$. Outrossim, foi determinado, a título de reparos, o valor de US $\$ 146,080.80^{188}$. Os dois valores foram acrescidos de juros no valor de US\$2.862 compostos anualmente desde a data do confisco à data da decisão. No que se refere às custas processuais, o tribunal decidiu que cada parte deveria arcar com seus próprios custos.

Observa-se que a decisão foi razoável, mantendo a jurisprudência favorável à regulação doméstica de atividades acessórias à pesca que são também consideradas como atividades econômicas nos termos da Convenção sobre o Direito do Mar. A decisão é relevante pois interpreta a natureza da atividade de bunkering que ainda não havia sido interpretada pelo ITLOS. A atividade foi considerada como sendo econômica e, portanto, objeto de regulação pelo Estado costeiro. Além disso, é relevante sublinhar que um dos motivos pelos quais a atividade foi confirmada como objeto de regulação foi decorrente da obrigação dos Estados na busca pela pesca sustentável, o que

186 TRIBUNAL INTERNACIONAL O DIREITO DO MAR. 2012. Sentença de 03 de Março, Panamá vs Guiné-Bissau. Caso n. 19, M/V “Virginia G”. \$396; \$398. O tribunal já havia se manifestado sobre o tema no caso M/V Louisa Case, Saint Vincent and the Grenadines v. Kingdom of Spain, Julgamento de 28 de maio de 2013, TRIBUNAL INTERNACIONAL O DIREITO DO MAR . 2013. Setença de 28 de Maio, Saint Vincent and the Grenadines vs Kingdom of Spain. M/V Louisa Case. \$137.

187 TRIBUNAL INTERNACIONAL O DIREITO DO MAR. 2012. Sentença de 03 de Março, Panamá vs Guiné-Bissau. Caso n. 19, M/V "Virginia G". \$452.

188 TRIBUNAL INTERNACIONAL O DIREITO DO MAR. 2012. Sentença de 03 de Março, Panamá vs Guiné-Bissau. Caso n. 19, M/V "Virginia G”. \$452. 
requer a instrumentos regulatórios que possam atingir essa finalidade. Essa interpretação pode ser relevante para países que possuem uma movimentação grande de navios de abastecimento tanto para atividades como a pesca como para atividades de exploração de recursos naturais como o petróleo e os minérios. A proteção da pesca sustentável também foi um objetivo perquirido pela medida objeto da controvérsia, pois quando há abastecimento na zona econômica exclusiva a pesca é mais intensa do que quando o navio deve retornar à costa para ser abastecido. É relevante notar que a decisão não se estendeu para todas as atividades de bunkering, mas apenas para as que estiverem relacionadas à pesca ${ }^{189}$, o que deixa margem para a necessidade de outras interpretações com relação ao abastecimento de embarcações que realizem outras atividades no mar. Com relação às outras questões, houve, de modo geral, uma confirmação jurisprudencial da maior parte dos aspectos ligados à liberação e ao confisco de embarcações.

189 TRIBUNAL INTERNACIONAL O DIREITO DO MAR. 2012. Sentença de 03 de Março, Panamá vs Guiné-Bissau. Caso n. 19, M/V “Virginia G”. \$223. 


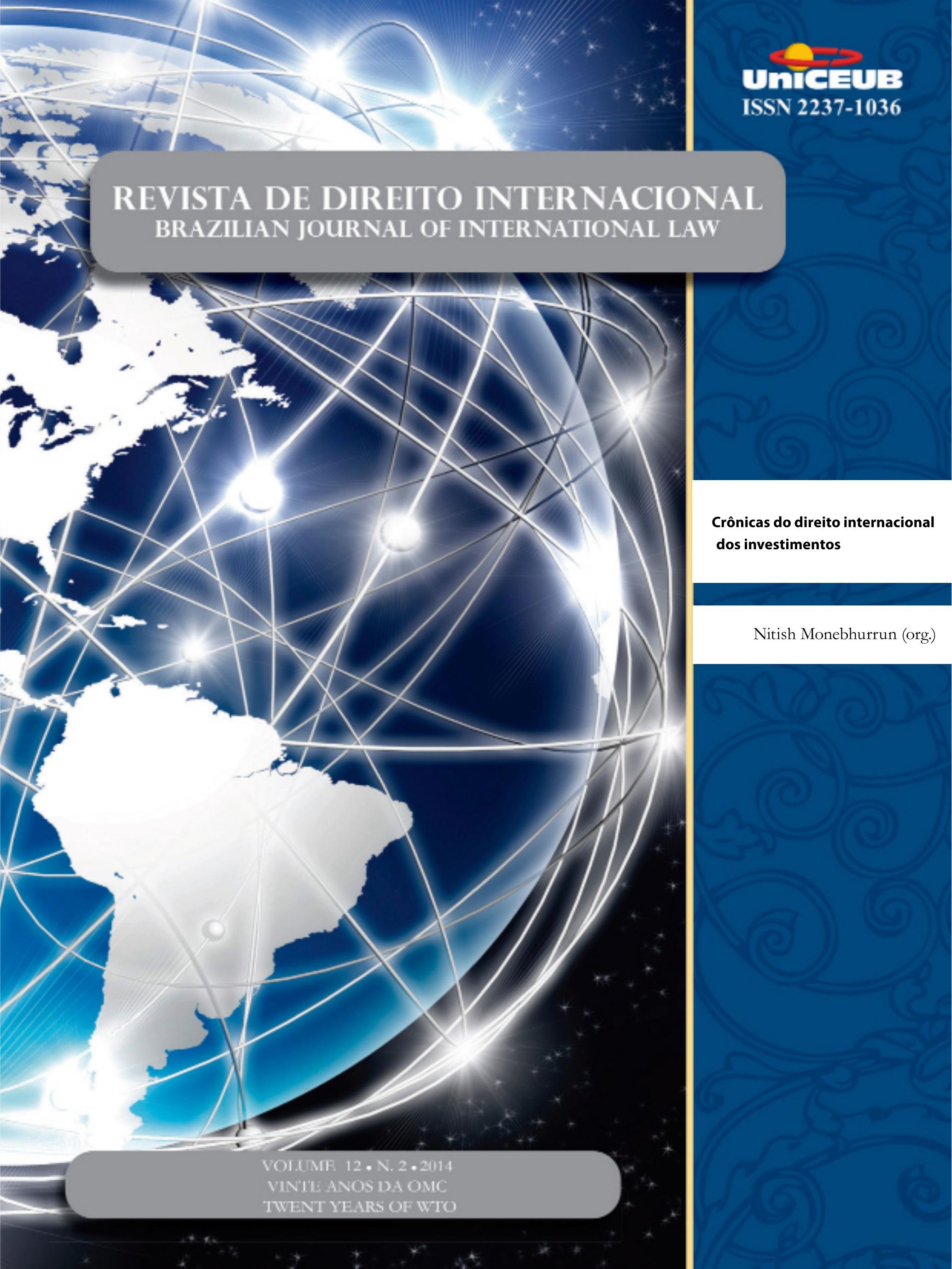




\title{
CRÔNICAS DO DIREITO INTERNACIONAL DOS INVESTIMENTOS
}

\author{
Nitish Monebhurrun*
}

\section{Tema 1: Reflexão sobre os (futuros) acordos brasileiros relativos à proteção dos investimentos: os acordos de cooperação e de facilitação de investimentos.}

\section{Introdução}

No cosmos jurídico peculiar do Direito Internacional dos Investimentos, o Brasil sempre teve uma postura sui generis: apesar de atrair muitos investimentos estrangeiros, o Estado brasileiro nunca ratificou os quatorzes tratados bilaterais ${ }^{1}$ sobreaproteçãoea promoçãodosinvestimentosporeleassinados.Estrategicamente, trata-se de uma escolha correta e pertinente. Essa postura nunca constituiu um obstáculo ao interesse dos investidores estrangeiros e tampouco ao recebimento efetivo de investimentos externos. O mercado brasileiro, a disponibilidade de recursos naturais ou humanos, a propensão à produção e à produtividade, ou a relativa estabilidade econômica, financeira e política são, entre outros, os fatores que atraem os investidores ao Brasil. A existência de tratados sobre a proteção dos investimentos poderia ser um fator a mais no caso brasileiro, porém não seria determinante. Deveras, não há uma relação direta entre esses acordos e a atração de investimentos estrangeiros. Comparado a outros países (em desenvolvimento), a postura do Brasil foi mais pragmática; o país analisou os tratados relativos aos investimentos com uma distância suficiente e inteligente para não seguir com cegueira à moda dos BITs (Bilateral Investment Treaties). Não que os BITs contenham um problema intrínseco: é apenas um meio para oferecer uma proteção jurídica aos investidores. O que pode ser criticado é a tendência que houve durante muito tempo na uniformização desses tratados: com algumas exceções e com algumas nuances, eram muito parecidos. Por exemplo, ao assinar os BITs, muitos países em desenvolvimento utilizaram apenas modelos que eles tinham com os países mais desenvolvidos. O modelo de tratado colombiano de 2007 é, nesse sentido e em muitos aspectos, uma cópia do modelo americano de 2004 (revisado em 2012). Até hoje, os interesses desses países em desenvolvimento aparecem pouco nos seus tratados. É, portanto, às vezes, um pouco burlesco quando alguns países descobrem depois (de suas celebrações) que os BITs oferecem uma proteção minuciosa aos investidores estrangeiros — conquanto poderiam tê-los negociado melhor para valorizar também os seus interesses nacionais. Outrossim, é por isso que alguns países como Equador ou Venezuela decidiram denunciar alguns de seus BITs. Essa configuração geral do regime dos BITs deve necessariamente ser considerada pelo Brasil nas negociações de seus futuros tratados.

O Brasil está atualmente negociando alguns acordos sobre a proteção dos

* Doutor em Direito Internacional Escola de Direito de Sorbonne, Paris; Professor Associado Centro Universitário de Brasília; Professor Visitante Programa de Mestrado da Universidad de la Sabana, Bogotá. nitish.monebhurrun@gmail.com investimentos com alguns de seus parceiros africanos ${ }^{2}$. Chamam-se de acordos

1 Tratados assinados com: França (1995), Holanda (1998), Cuba (1997), Portugal (1994), Chile (1994), Reino Unido (1994), Suíça (1994), Finlândia (1995), Dinamarca (1995), Itália (1995), Venezuela (1995), Corrêa (1995), Alemanha (1995), União Econômica Bélgica-Luxemburgo (1999). Todos os tratados relativos aos investimentos encontram-se no site da UNCTAD. Disponível em: $<$ http://investmentpolicyhub.unctad.org/IIA/AdvancedSearchBITResults>.

2 O autor obteve confirmação dessa informação durante um encontro com a coordenação- 
de cooperação e de facilitação de investimentos (ACFI) e tem como objetivos a gestão da governança institucional, a promoção e a proteção dos investimentos, a mitigação de riscos e a prevenção de disputas. Em si, essa (nova) decisão não é contraditória: o Estado inicialmente cético não se converteu necessariamente e repentinamente à religião dos BITs. Mais uma vez, é apenas uma decisão pragmática e estratégica. A maioria dos BITs que estão sendo negociados visam mormente à proteção dos investidores brasileiros no exterior. A conjuntura evoluiu para o Brasil, que se tornou um grande exportador de capitais e de investimentos. Estes necessitam, em alguns casos, de uma proteção jurídica nos Estados anfitriões. Implica-se, destarte, que o Estado brasileiro está se comportando como os países industrializados das décadas de 60-90, sabendo que os acordos assinados com os países africanos serão bilaterais na forma, mas unilaterais na realidade? Lembre-se, por exemplo, de que o Brasil tem mais investimentos (a proteger) em Angola que este no Brasil. Tudo dependerá do conteúdo dos tratados. É apenas o conteúdo dos futuros BITs brasileiros (2) que permitirá ao Brasil forjar uma identidade a estes, destacando-se - esperamos — do que sempre foi feito (3).

\section{Vislumbrando o conteúdo dos eventuais ACFIs brasileiros}

A negociação e a elaboração de um BIT ou de um ACFI hodierno deve necessariamente considerar a evolução do Direito internacional dos Investimentos e, para tanto, é preciso perscrutar a jurisprudência arbitral dessa área com o objetivo de conhecer todas as polêmicas e as problemáticas inerentes. Uma grande parte desse ramo do Direito Internacional foi desenvolvida pelos tribunais arbitrais: nas sentenças arbitrais encontram-se, por conseguinte, todos os conflitos, todas as contradições, todas as lacunas e todos os problemas jurídicos que devem ser entendidos e dominados antes de qualquer processo de negociação de um ACFI. O Direito Internacional dos Investimentos está mais maduro; um negociador em 2014 tem mais distância e mais técnicas para melhorar a formulação dos dispositivos mais importantes de um ACFI, se comparamos com os anos 60-90. Não seria razoável ignorar o histórico do desenvolvimento do Direito Internacional dos Investimentos durante esse

geral do Ministério do desenvolvimento, Indústria e Comércio Exterior. processo, ao risco de repetir erros que outros fizeram. Para o Brasil é uma oportunidade de considerar essa evolução ao celebrar os seus novos ACFIs. Será uma forma para antecipar qualquer futuro contencioso. Se a consideração das problemáticas clássicas da proteção dos investimentos estrangeiros consolidará, com certeza, esses acordos (A) serão, outrossim, bem-vindas considerações de interesse público — mais raras nesses tipos de acordos (B).

\section{A) Vislumbrando o conteúdo dos ACFIs brasileiros à luz das problemáticas recorrentes do Direito Internacional dos Investimentos}

Os comentários a seguir devem ser entendidos em relação ao contexto do ACFI, pois a capacidade de moldar as disposições do acordo dependerá do poder de negociação do Brasil — o que está relacionado, por sua vez, ao poder dos Estados parceiros. A capacidade de inflectir um acordo será, por exemplo, maior com a Angola que com a África do Sul, com Moçambique que com o Japão ${ }^{3}$. É com cuidado que devem ser firmados esses acordos para evitar todo arrependimento futuro como os suportados pelos países vizinhos, - como Argentina. Dessarte, utilizar um inventário dos problemas processuais, por um lado (i), e substancias (ii), por outro, facilitará a formulação dos objetivos visados em tais acordos.

(i) Moldando os ACFIs após um inventário das problemáticas processuais.

As problemáticas processuais a considerar são atinentes à própria definição dos investimentos (a) e à formulação da cláusula de resolução de controvérsias (b).

(a) Moldando a definição do conceito de investimento nos ACFIs

A definição deinvestimento éum passo fundamental, pois se trata do próprio objeto da proteção: apenas atividades caracterizadas como 'investimentos' são juridicamente protegidas. Normalmente os acordos sobre a proteção de investimentos não definem o conceito de investimento, mas propõem uma lista ilustrativa e não

3 A visita do Shinzo Abé (Primeiro-Ministro) do Japão no Brasil em agosto deste ano teve, entre outros, como objeto a negociação de acordos sobre o comércio e os investimentos (Ver: HAUBERT, Mariana. Dilma e primeiro-ministro do Japão firmam acordos bilaterais. Folha de São Paulo, São Paulo, 01 ago. 2014. Disponível em: <http://www1.folha.uol.com.br/mercado/2014/08/1494377dilma-e-primeiro-ministro-do-japao-firmam-acordos-bilaterais-parainvestimento.shtml> 
exaustiva de exemplos de investimentos ${ }^{4}$. As sentenças arbitrais elaboraram alguns critérios nesse processo de identificação de um investimento. O famoso caso Salini c. Marrocos (2001) apontou quatro critérios: uma contribuição, uma duração, um risco e uma contribuição ao desenvolvimento do país anfitrião ${ }^{5}$. Muitos tribunais utilizaram esses critérios conquanto outros se mostraram mais céticos em relação ao fator da contribuição ao desenvolvimento (Saba Fakes c. Turquia, 2010).

Com base no estado atual do direito, duas possibilidades existem ao negociar um ACFI. O primeiro é de seguir o caminho clássico e propor um projeto de acordo que contenha os mesmos exemplos de investimento que a grande maioria dos BITs. O outro implica na consideração da jurisprudência arbitral ao formular as disposições: essa jurisprudência será com certeza citada futuramente caso ocorra um contencioso envolvendo o Brasil ou um investidor brasileiro - e pode ser mais interessante antecipar algumas coisas nesse âmbito.

O elemento mais polêmico na definição dos investimentos no Direito Internacional dos Investimentos é aquele da contribuição ao desenvolvimento do Estado receptor. É possível considerar que a questão do desenvolvimento interessa todos os Estados. A definição do que constitui o seu desenvolvimento cabe a cada país. Portanto, se o Brasil quiser que os investimentos estrangeiros contribuam ao seu desenvolvimento e no mesmo sentido, se quiser participar do desenvolvimento dos parceiros (africanos), o ACFI pode ser um instrumento (humilde) para tais fins: juridicamente, é possível incluir — no corpo do

4 A título de exemplo, o BIT entre Brazil e Dinamarca (nunca ratificado) dispõe no seu artigo 1 (a): "o termo "investimento" significa todo o tipo de haveres e inclui, em particular, ainda que não exclusivamente:

i. bens tangíveis e intangíveis, móveis e imóveis e quaisquer outros direitos como concessões, hipotecas, penhoras, cauções, usufrutos, garantias e quaisquer outros direitos similares; ii. uma companhia ou empresa comercial, ou ações, títulos ou outras formas de participação em uma companhia ou empresa comercial, bem como títulos e dívidas de uma companhia ou empresa comercial; iii. rendas reinvestidas, títulos de crédito ou direitos em relação à execução de quaisquer atividades de acordo com um contrato com valor econômico; iv. direitos de propriedade intelectual, incluindo direitos autorais, patentes, marcas comerciais, tecnologia, marcas registradas, fundo de comércio, know-how e outros direitos similares; v. concessões ou outros direitos conferidos por lei ou por contrato, incluindo concessões para prospecção, cultivo, extração ou exploração de recursos naturais".

5 NITISH, Monebhurrun. A identificação dos investimentos internacionais no Direito Internacional dos Investimentos. Brazilian Journal of International Law, v. 11, n.1, p. 11-15, 2014. acordo ou em um anexo - algumas características que um investimento deve ter para ser compatível com o desenvolvimento do país anfitrião. Essas características devem ser determinadas pelos países signatários. Assim, uma atividade será qualificada de investimento e poderá se beneficiar de uma proteção jurídica pelo BIT/ACFI apenas se cumprir os requerimentos para o desenvolvimento. Será também uma forma de não deixar que um painel de árbitros decida no futuro o que é ou não uma contribuição ao desenvolvimento.

Usar esse critério implica obviamente discriminar atividades suscetíveis de receber o título de 'investimento’ e uma devida proteção em razão do seu aporte ao desenvolvimento, das outras. Alguns dirão que atuará como um limite à proteção dos investimentos, pois nem todas as atividades poderão ser protegidas. E está certo: referir-se ao critério de contribuição ao desenvolvimento significa proteger apenas as atividades favoráveis ao desenvolvimento; significaria definir o investimento em relação a sua propensão ao desenvolvimento. Tratar-se-á aqui de uma escolha dos Estados. Para tanto, o uso de peritos e especialistas do desenvolvimento pode ser útil para o entendimento técnico da relação entre investimentos e desenvolvimento - o que permitirá incluir uma paleta ampla de atividades sob a proteção do ACFI.

A este primeiro aspecto processual junta-se um outro de expressiva importância: a negociação das cláusulas de resolução de controvérsias.

(b) Moldando a cláusula de resolução de controvérsias

Duas questões devem ser examinadas aqui: o tribunal competente em casos de arbitragem internacional (b.1) e a extensão dessa competência pelo jogo da cláusula da nação mais favorecida na resolução de disputas (b.2).

(b.1) Escolher o tribunal competente em casos de arbitragem internacional

Deve ser lembrado que o Brasil não ratificou a Convenção de Washington que instituiu o Centro Internacional para a Resolução de Disputas relativas aos Investimentos (CIRDI / ICSID) em 18 de março de 1965. Mais uma vez, ao fazer o inventário do estado do direito, percebe-se que a maioria dos BITs prevê, entre outras possibilidades, a competência de tribunais constituídos sob a égide do CIRDI. Mesmo que seja uma tendência geral, não significa que essa convenção deva ser necessariamente ratificada pelo Brasil. Os investidores brasileiros podem ter acesso ao 
CIRDI sem essa ratificação. Para este propósito podem ser utilizadas as Additional Facility Rules do CIRDI cujo artigo 2 (a) permite um acesso à arbitragem aos investidores mesmo que os Estados de nacionalidade deles não tenham ratificado a Convenção de Washington. Isso pode ser previsto em um contrato ou pode ser o objeto de um compromisso de arbitragem; in fine, a decisão de admissibilidade caberá à SecretariaGeral do CIRDI. Além disso, os BITs podem prever o uso do regulamento da Comissão das Nações Unidas para o Direito Comercial Internacional (CNUDCI) em caso de controvérsias. Em todo caso, a mera ratificação da Convenção de Washington não despoja o Brasil de sua margem de manobra: a Convenção aplicar-se-á apenas se a cláusula de resolução de disputas dos ACFIs brasileiros referir-se à competência dos tribunais CIRDI. A ratificação não se equipara ao consentimento de submeter todas as disputas relativas aos investimentos aos tribunais CIRDI; o consentimento está consagrado na ratificação dos BITs que contêm a cláusula atinente a arbitragem CIRDI.

Ora, uma problemática relativa à cláusula de resolução de disputas apareceu - interessantemente —, no contencioso arbitral pelo jogo da cláusula da nação mais favorecida. Será recomendável que o Estado brasileiro cuide da formulação desta última cláusula.

(b.2) A problemática da inclusão da resolução de controvérsias no âmbito da cláusula da nação mais favorecida

Essa questão foi tratada de uma forma mais detalhada pelo presente autor nas crônicas da edição 2014.1 da mesma revista ${ }^{6}$. Em resumo, há um debate sobre a possibilidade de usar a cláusula da nação mais favorecida de um tratado assinado por um Estado para pedir o mecanismo de resolução de controvérsias previsto por outro tratado do mesmo Estado. Alguns tribunais consideraram que é juridicamente possível importar a cláusula de resolução de disputas por meio da cláusula da nação mais favorecida (Maffezini c. Espanba, 2000; Suez.c. Argentina, CIRDI, 2006; Gas Natural c. Argentina, CIRDI, 2005; Suez e Vivendi c. Argentina, CIRDI, 2006; RosInvest c. Rússia, SCC, 2010), enquanto outros mostraram-se mais céticos (Plama c. Bulgária, 2005; Salini c. Jordania, CIRDI, 2004; Berschader c. Rússia, SCC, 2006; Telenor c. Hungaria, CIRDI, 2006).

6 NITISH, Monebhurrun. O Uso da Cláusula da Nação Mais Favorecida no Direito internacional dos investimentos: de uma proteção substancial a uma proteção processual. Brazilian Journal of International Law, v. 11, n.1, p. 15-18, 2014.
O Brasil deve analisar onde se situa nesse debate, e até que ponto concorda com as duas tendências da jurisprudência arbitral. $\mathrm{Na}$ dúvida, a postura da Colômbia pode ser adotada: afirmar na própria cláusula da nação mais favorecida que esta não se estende- à resolução de disputas. O artigo IV (2) do modelo do BIT colombiano dispõe:

"The most favourable treatment to be granted in like circumstances referred to in this Agreement does not encompass mechanisms for the settlement of investment disputes [...]".

Claramente, essa decisão dependerá da outra parte signatária do ACFI. O Brasil pode ter uma postura mais liberal quando se tratar de um ACFI com um país principalmente importador de capital, pois, neste caso, o ACFI será mormente negociado para a proteção dos investidores brasileiros; haverá poucos riscos de casos contra o Estado brasileiro. Com Estados cujos investidores pretendam investir mais no Brasil (África do Sul, Japão), a formulação da cláusula da nação mais favorecida pode ser mais conservadora - excluindo a aplicação à resolução de controvérsias.

(ii) Moldando os ACFIs após um inventário das problemáticas substanciais

Situado entre o processo e os méritos, a umbrella clause (cláusula guarda-chuva) merece a atenção e a diligência do Estado brasileiro (a); será, outrossim, aconselhável considerar a evolução recente da interpretação da cláusula do tratamento justo e equitativo (b); e os limites a ser conferidos à cláusula relativa à expropriação (c).

(a) A inclusão ou não de uma umbrella clause

A cláusula, dita de guarda-chuva, permite que todas as obrigações do Estado vis-à-vis do investidor entrem no âmbito de proteção e de aplicação do $\mathrm{BIT}^{7}$. Isso significa, por exemplo, que as obrigações contratuais do Estado em relação a um determinado investimento podem ser regidas pelo BIT. Assim sendo, uma violação do contrato será internacionalizada em uma violação do BIT. Alguns tribunais arbitrais aceitaram esse princípio (por exemplo: Noble Ventures v. Romênia, 2005; Eureko v. Polônia, 2005), conquanto outros demonstram um ceticismo (por exemplo: SGS v. Pakistão, 2003).

7 A cláusula guarda-chuva do modelo do BIT da Alemanha dispõe (artigo 7.2): “ Each Contracting State shall fulfil any other obligations it may have entered into with regard to investments in its territory by investors of the other Contracting State". 
Outros ainda aceitaram a internacionalização de uma violação contratual apenas quando, sob o jus imperii, o Estado anfitrião atuou utilizando os seus poderes de polícia, as suas prérogatives de puissance publique (El Paso v. Argentina, 2006; Pan America v. Argentina, 2006).

A postura de negociação nesse caso segue a mesma lógica que a supramencionada: dependerá do outro Estado-parte ao ACFI. Muitos futuros ACFIs do Brasil terão como objeto e objetivo principal a proteção dos investidores brasileiros no exterior — sabendo já que os outros Estados signatários não mandarão tão cedo o mesmo número de investidores ao Brasil. Para esses tipos de ACFIs, a cláusula guarda-chuva oferecerá uma proteção maior aos investidores brasileiros. Malgrado, a postura pode ser mais conservadora nos BITs assinados com países que são também exportadores de capitais.

A próxima consideração substancial é atinente ao princípio do tratamento justo e equitativo.

(b) A formulação da cláusula relativa ao tratamento justo e equitativo.

Claramente, o objetivo aqui não é fazer um retrato completo desse princípio ${ }^{8}$, mas explicar uma tendência recente na sua interpretação. É sabido que o critério principal utilizado para identificar a violação da cláusula relativa ao tratamento justo e equitativo é aquele das expectativas legítimas. Uma frustração das expectativas legítimas é equiparada a uma violação da cláusula. Essa frustração ocorre, por exemplo, quando o Estado anfitrião não cumpre uma promessa explícita ou implícita feita ao investidor e na base da qual - confiando - ele se estabeleceu e começou a sua atividade. Comparando com os outros critérios do tratamento justo e equitativo ${ }^{9}$, as expectativas legítimas estão se tornando cada vez mais o critério cardinal e modelador. Três casos recentes estabeleceram que seria possível considerar as expectativas legítimas como um princípio geral de direito, segundo o artigo 38 do Estatuto da Corte Internacional de Justiça (Gold Reserve Inc. v. Venezuela, 2014; Toto Costruzioni Generali v Libano, 2012; Total v. Argentina, 2010). Essa tendência será seguramente confirmada no futuro. É indubitável que as expectativas legítimas constituem um dos princípios

8 Ver sobre esse assunto: NITISH, Monebhurrun; BARBOSA, Flávio Spaccaquerche. O Tratamento e a Proteção do Investimento Estrangeiro. Revista Brasileira de Arbitragem, ed. esp. p.107-144, set. 2011.

9 Por exemplo: a transparência, a coerência, a consistência, a estabilidade ou o devido processo legal. que oferece - e que tem oferecido - uma proteção ampla aos investidores em muitos casos.

Considerando essa evolução, não será chocante vêla expressis verbis em um BIT/ACFI — já que a linha de demarcação entre tratamento justo e equitativo e expectativas legítimas está em muitos casos muito tênue. Trata-se assim de outra possibilidade à disposição do Estado brasileiro: a redação da cláusula relativa ao tratamento justo e equitativo pode referir-se também às expectativas legítimas como sendo o seu indicador principal. Isso terá ao menos dois efeitos positivos: primeiramente, os Estados saberão sem ambiguidade o que é esperado deles e agirão de uma forma potencialmente mais diligente na sua relação com os investidores, o que é idôneo para prevenir futuros danos aos investimentos alheios; seguidamente, facilitará o trabalho hermenêutico dos tribunais. Por conseguinte, será um fulcro a mais no caminho da proteção dos investimentos, e da nitidez das normas aplicáveis para esses fins.

Dito isso, a precisão da norma pode acompanharse de sua flexibilização ${ }^{10}$ para que seja mais realista (e verdadeiramente justa e equitativa). A capacidade de oferecer tal tratamento depende em muitos casos dos recursos inatos de cada Estado. Ora, não será razoável esperar o mesmo nível de proteção de um país em desenvolvimento em comparação com um país altamente industrializado. Caso contrário, implicaria na obrigação de oferecer uma proteção absoluta ao investidor, escoimando-o de toda medida e dever de diligência - e, dessarte, infantilizando-o. Numa lógica intrínseca e em um espírito brasileiro de cooperação, especialmente com os países africanos, a cláusula sobre o tratamento justo e equitativo pode adequar a proteção esperada com os recursos dos Estados. O acordo sobre os investimentos de 2007 do Mercado Comum par a África do Leste e do Sul (COMESA) contém um dispositivo interessante a propósito. O artigo 14(3) do acordo dispõe:

\begin{abstract}
For greater certainty, Member States understand that different Member States have different forms of administrative, legislative and judicial systems and that Member States at different levels of development may not achieve the same standards at the same time. Paragraphs 1 and 2 of this Article do not establish a single international standard in this context.
\end{abstract}

10 Essa consideração aplica-se também à cláusula relativa à plena proteção e segurança. 
Para questões de cooperação, mas também de aperfeiçoamento do direito, será apreciável se o Brasil adotar uma formulação similar no seu ACFI. Essa mesma lógica de flexibilização pode aplicar-se à cláusula atinente à expropriação.

(c) Medindo a definição da expropriação.

Quão conturbada tornou-se hoje a questão da expropriação em razão notadamente da amplitude da definição da expropriação indireta? É uma das razões pelas quais a Alemanha é cética em relação à negociação de um Tratado Transatlântico entre os Estados Unidos e a União Europeia. Os tribunais arbitrais - e parte da jurisprudência arbitral — são acusados por alguns por esgarçar a margem de manobra do Estado e de seu poder regulador, pois, hoje me dia, muitas ações estatais equiparam-se a uma expropriação ${ }^{11}$. Exercer o poder regulador para a proteção ou a defesa dos interesses públicos pode, se o Estado se descuidar, violar os direitos protegidos dos investidores. Uma medida ambiental ou fiscal pode ser interpretada como sendo expropriatória. Essa problemática pode ser resolvida à montante, no próprio BIT/ACFI. Ao negociar o tratado e ao redigilo, é possível destacar quais atos e comportamentos do Estado não serão equiparados a uma expropriação. Nesse sentido, alguns modelos de BITs têm considerado que a regulação estatal para o interesse público - a proteção do meio ambiente, por exemplo —, não pode ser interpretada como uma expropriação indireta. $\mathrm{O}$ tratado colombiano dispõe nesse sentido:

\footnotetext{
Except in rare circumstances, such as when a measure or series of measures are so severe in the light of their purpose that they cannot be reasonably viewed as having been adopted and applied in good faith, non-discriminatory measures of a Party that are designed and appliedfor public purposes or social interest or with objectives such as public health, safety and environment protection, do not constitute indirect expropriation.
}

É um meio jurídico importante para proteger os poderes de polícia e a política interior do Estado. Formular a cláusula sobre a expropriação implica cautela: proteger os investimentos sem atravancar as prerrogativas de poder público do Estado. A confiança de ambos Estados e investidores no sistema deve ser mantida: isso é possível quando as regras são claras $a b$

11 O tema da expropriação é o objeto da segunda crônica desta edição. initio. No caso dos ACFIs brasileiros, será louvável se a proteção conferida aos investidores não ultrapassar os poderes soberanos dos Estados. É invocando questões de soberania que o Brasil nunca ratificou os BITs. Será hoje incôngruo se, para proteger os seus investidores, o Brasil propusesse um modelo de acordo - especialmente aos parceiros africanos —, que desconsiderasse o valor do poder soberano em alguns âmbitos estatais de interesse público.

\section{B) Vislumbrando o conteúdo dos ACFIs brasileiros à luz das problemáticas de interesse público.}

Os BITs / ACFIs têm como função principal a proteção dos investidores estrangeiros. Não obstante, nunca operam em um circuito fechado. Não se trata de uma coleção de normas visando apenas à proteção de interesses privados: ao menos, essa constatação decorre da evolução do Direito Internacional dos Investimentos. Para tanto, o Brasil fará um passo importante com o seu modelo de BIT se considerar questões de interesse público nos acordos (i), assim como elementos da responsabilidade social das empresas (ii).

(i) Articulando a proteção dos interesses privados com a proteção do interesse público nos BITs.

Essa colocação não é uma revolução; tampouco é anacrônica. Muitos modelos de BITs (americano, canadense, colombiano) e muitos dos novos acordos de livre-comércio (free trade agreements) já incluíram considerações ambientais, trabalhistas ou de saúde. O NAFTA de 1994 já continha tais considerações. Mais recentemente, o modelo do BIT canadense dispõe, por exemplo, no seu artigo 11:

The Parties recognize that it is inappropriate to encourage investment by relaxing domestic health, safety or environmental measures. Accordingly, a Party should not waive or otherwise derogate from, or offer to waive or otherwise derogate from, such measures as an encouragement for the establishment, acquisition, expansion or retention in its territory of an investment of an investor [...].

Numa lógica similar, os acordos de livre-comércio assinadospeloCanadá ${ }^{12}$ sãonormalmenteacompanhados de um acordo sobre a cooperação no âmbito ambiental e de outro sobre a cooperação trabalhista. Percebe-se que a referência ao desenvolvimento sustentável está

12 Ver por exemplo o acordo com Honduras que entrou em vigor em 1 de outubro de 2014. 
aparecendo cada vez mais nos acordos econômicos. É comumente admitido que a proteção dos investimentos estrangeiros não se faz em detrimento do interesse nacional. Se o Brasil deve proteger o interesse público nacional brasileiro, deve também mostrar-se disposto a ter o mesmo desempenho com os seus parceiros. Deve assegurar-se que os investimentos brasileiros não se implementem com desrespeito às considerações ambientais e sociais - mesmo que a legislação nacional dos Estados parceiros não seja tão rígida. O BIT / ACFI é o instrumento para prever e para estruturar esses aspectos dos investimentos. Deve ser traçada nitidamente nos acordos a linha de demarcação entre o poder regulador e a devida proteção ao investidor. As expectativas de ambos, Estado e investidor, devem ser protegidas para permitir um clima de confiança na cooperação econômica entre Estados por um lado, e entre Estados e investidores por outro. Por isso, não se pode negligenciar os interesses dos dois grupos. É nessa configuração que a proteção oferecida ao investidor deve ser formulada: para tanto, as negociações devem - sempre com a boa vontade e a participação séria e efetiva da parte mais influente - , apontar quais casos, fatos e atos de interesse público ${ }^{13}$ não se equiparam a uma violação do tratamento justo e equitativo, do tratamento nacional, da cláusula da nação mais favorecida, da plena proteção e segurança ou do dispositivo relativo à expropriação. Saindo novamente de uma visão apenas patológica do direito, a ideia é prevenir conflitos e disputas. Novamente a prevenção estrutura-se com regras claras definidas a montante.

Ainda nesse diálogo sobre o interesse público, outras regras podem ser coadunadas para incitar um comportamento responsável dos investidores na implementação e no exercício da sua atividade.

(ii) Considerando a responsabilidade social dos investidores na articulação entre a proteção do interesse privado e público.

Com certeza será aqui a parte mais ousada da presente crônica. Dizer que se trata de uma quebra de paradigma é um eufemismo. Isso porque invocar a responsabilidade social das empresas de uma forma séria - e jurídica — parece ser ainda um tabu. Dito isso, muitos tribunais arbitrais afirmaram que os BITs não são apólices de seguro para os investidores (Maffezzini v. Espanha, 2000; MTD Equity v. Chile, 2004); não podem prevalecer-se destes para pedir uma compensação ou

13 A definir pelos Estados. uma reparação de uma maneira absoluta - esperando que serão sempre e em todos os casos protegidos. Como supramencionados, o Direito Internacional dos Investimentos não infantiliza os investidores. Há casos nos quais o comportamento imprudente e pouco diligente do investidor foi levado em consideração pelos tribunais que não lhes acordaram a reparação requerida (Generation Ukraine v. Ucrânia, 2003; William Nagel v. República Checa, 2003; Alex Genin v. Estonia, 2001; MTD Equity v. Chile, 2004; Joseph Charles Lemire v. Ucrânia, 2011).

$\mathrm{O}$ investidor tem o dever de exercer o seu due diligence na sua relação com o Estado e deve também atuar conforme o princípio dos clean hands. O investidor que desrespeitou o direito nacional do Estado anfitrião e que investiu na desconsideração total das normas ambientais e/ou sociais não terá uma base sólida para atacar o Estado. Na configuração hodierna, na qual as empresas desenvolvem atividades cujo alcance é internacional e cuja cadeia de produção é também internacional, nessa configuração que tem revelado um desrespeito considerável das multinacionais com os princípios fundamentais do direito nacional dos países anfitriões, a questão da responsabilidade social dos investidores estrangeiros não pode mais manter-se no âmbito procrastinante da soft law.

Retirando toda ambiguidade, é preciso desde já assinalar que o BIT / ACFI não deve ter como objeto ou função a responsabilidade social das empresas. O princípio da responsabilidade social deve apenas aportar uma nuance à configuração complexa dos BITs / ACFIs. À vista disso, deve ser explicada a forma de incluir questões de responsabilidade social das empresas em um BIT / ACFI: os investidores devem, na realidade, demonstrar que merecem e podem juridicamente receber a esperada proteção do BIT / ACFI. Este deve, por conseguinte, conter alguns deveres que incumbam aos investidores: por exemplo, um dever de diligência nas esferas da corrupção, do meio ambiente, do respeito das normas trabalhistas, do respeito dos direitos humanos e das comunidades locais. Nesse sentido, o teor e a extensão da devida proteção ao investidor dependerá de como ele exerceu a sua diligência - o objetivo sendo de não (re)compensar a torpeza. Segundo o funcionamento dos mecanismos de resolução de controvérsias no Direito Internacional dos Investimentos, o Estado nunca é a parte requerente. Esse sistema pode ser mantido -, o Estado não podendo iniciar uma arbitragem contra um investidor. 
Entretanto, os elementos da responsabilidade social serão determinantes para avaliar a admissibilidade da demandadosinvestidores. Considerara responsabilidade social das empresas nos BITs / ACFIs não tem um objetivo repressivo, mas preventivo e comportamental. Auxiliará a moldar o comportamento dos investidores para que o investimento seja implementado de uma forma socialmente responsável. In fine, isto será apenas propício para consolidar a própria saúde da cooperação e do intercâmbio econômicos.

Atuando assim, o Brasil logrará forjar a sua identidade nos seus ACFIs.

3. Forjando os ACFIs com a identidade brasileira

A formulação dos BITs deixa transparecer a identidade do Estado, as suas preocupações, as suas políticas, os seus projetos, a sua integração nas relações internacionais, os seus valores. Mas, também a sua coerência. A título de exemplo, a política ambiental e social do Canadá não é apenas uma preocupação de fachada. O que se determina e o que se constrói na política interna desse país encontram-se também em espelho nas veias que sustentam as suas relações com outros Estados; o Canadá tenta agir da forma mais coerente na sua política global segundo a qual a economia é fundamental, porém não perdura sem a proteção de outros valores. Por isso, os seus BITs ou os seus acordos de livre-comércio salientam claramente a necessidade de oferecer uma proteção jurídica às relações econômicas, sem desconsiderar outros fatores sociais e ambientais.

Essa postura de coerência deve também ser apropriada pelo Brasil com o objetivo de projetar os seus valores em suas cooperações internacionais por meio dos seus futuros ACFIs. Seria realmente pouco razoável e extremamente maquiavélico se os modelos dos ACFIs brasileiros fossem apenas meras cópias dos BITs clássicos dos anos 60-90, ou seja, os mesmos que o Brasil rejeitou firmemente - e com razão. O mundo do Direito Internacional dos Investimentos - esse mundo enclausurado - está ansiosamente esperando que as cortinas se levantem para revelar o ACFI do Estado brasileiro. É para o Brasil uma oportunidade de entrar nesse mundo com identidade e originalidade, com realismo e com mensagens claras e fortes, com o objetivo de proteger os seus investidores sem negligenciar o interesse público. Considerando a sua posição e o seu peso no plano internacional, o Brasil, com toda a sua altivez, tem o dever de conduzir- se de uma forma responsável para projetar e oferecer um modelo, o seu modelo. Não se pode tornar-se uma China que, com frieza e ambições puramente materiais, decidiu colonizar o continente africano para insidiosamente dilacerá-lo.

Espera-se que o país celebre os seus ACFIs para destacar-se, talvez sem uma revolução coperniciana, porém com dispositivos novos para contribuir com a evolução do Direito Internacional dos Investimentos, para consolidá-lo - abrindo os seus horizontes para articular a proteção dos investimentos com os elementos supramencionados.

As propostas feitas nessa crônica visam regar a própria dialética dos negociadores brasileiros. São elementos de reflexão que podem ajudar a contemplar as negociações com outro olhar ou, pelo menos, com uma distância. Se é preciso cuidar da tecnicidade do Direito Internacional dos Investimentos, é justamente porque os raios de sua aplicação não se limitam apenas aos investidores internacionais.

\section{Tema 2: A desapropriação}

\section{Introdução}

As origens da desapropriação dos bens estrangeiros datam do estabelecimento dos estrangeiros - e dos seus negócios - em um território estrangeiro. A desapropriação dos bens das pessoas físicas ou jurídicas estrangeiras sempre foi um risco, um risco, aliás ligado à própria essência do investimento. Os exemplos mais recentes são as desapropriações mexicanas nos anos 20, a desapropriação (socialização) dos investimentos nos países da Europa central depois da segunda Guerra, as ondas de desapropriação decorrentes das descolonizações nos anos 60-70, e as desapropriações no Irã nos anos 80.

A desapropriação se define como uma transferência forçada da propriedade ou de um investimento privado ao Estado que se torna o novo dono do bem: implica uma transferência de propriedade, do privado ao público, tendo normalmente o interesse público como alvo. Pode haver uma desapropriação de bens e investimentos tangíveis ou intangíveis (SDMyers c. Canadá, 2000; Biloune c. Ghana, CNUDCI [1989]; CME c. República Checa, CNUDCI [2001]). A natureza da desapropriação depende da amplitude da definição do próprio investimento: se este é definido de uma 
maneira ampla, abrangente também será o âmbito da desapropriação.

Deveras, a liberalização dos fluxos dos investimentos internacionais acompanhou-se de vários casos de desapropriação, e, de uma forma paralela, do aperfeiçoamento do direito aplicável a esse problema jurídico. Hoje em dia, todos os acordos sobre a proteção dos investimentos preveem uma cláusula sobre o regime da desapropriação. Uma desapropriação é por definição legal, mas a legalidade embasa-se em condições específicas. A maioria dos casos perante os tribunais arbitrais internacionais contém uma questão relativa à desapropriação e a evolução do contencioso nesse campo sobrepujou várias formas de desapropriação, além da forma clássica. Os comportamentos do Estado e as medidas estatais são cada vez mais interpretados de uma maneira a encontrar casos de desapropriação em situações que, a primeira vista, não se equiparam a uma privação de propriedade. É a problemática da desapropriação indireta.

Para entender o regime jurídico aplicável a este fenômeno no Direito Internacional dos Investimentos, é preciso explicar as formas de desapropriação (2), o que prontificará o caminho para determinar os casos nos quais se torna possível afirmar a existência de uma desapropriação indireta (3).

\section{As formas de desapropriação}

São formas que seguem um formalismo prosaico: há desapropriações direitas por um lado (A), e indiretas, por outro (B).

\section{A) As desapropriações diretas}

Trata-se da forma clássica de desapropriação. É uma transferência de propriedade forçada e explícita: o Estado adota propositadamente uma medida (lei, decreto) para desapropriar um investimento. Há uma transferência clara da propriedade da pessoa privada à pessoa pública. Ao Estado são transferidos o usus e o abusus do investimento. Nos casos menos polêmicos, o contencioso - se houver - não é problemático, pois é apenas atinente à determinação da indenização. Uma desapropriação direita deve seguir alguns princípios: 1) um objetivo de interesse público; 2) a proporcionalidade da medida desapropriatória e; 3) uma compensação pronta, adequada e efetiva. Juridicamente, o Estado tem o direito de desapropriar ou de nacionalizar, sejam os bens nacionais ou estrangeiros: é um direito costumeiro (Topco c. Líbia, 1977). No entanto, o Estado pode limitar o seu próprio direito de desapropriar ou de nacionalizar, por exemplo, por meio contratual.

Disto isto, não é a forma de expropriação que colora principalmente o contencioso arbitral sobre os investimentos internacionais mais acostumados com o fenômeno da desapropriação indireta.

\section{B) A desapropriação indireta}

Há uma desapropriação indireta quando o Estado adota uma medida que a priori não é destinada ao investimento, mas que tem efeitos equiparados a uma desapropriação (direta). Teoricamente, o investidor mantém-se como o dono do seu investimento e da sua infra-estrutura, mas não pode mais usufruir destes, não pode mais frutificá-los. Trata-se, normalmente, de uma medida geral e impessoal - ou seja, não adotada apenas para o investidor como num caso de expropriação direta —, que visa à regulação de uma esfera específica do Estado e cuja implementação afeta drasticamente o investimento. Pode ser uma medida ambiental, uma política de revisão dos impostos ou uma política de autorização de construção. Em si, essas medidas se aplicam a todos, nacionais e estrangeiros; porém, ao ser aplicadas, os efeitos podem ser desapropriatórios — ou pelo menos, considerados como tal pelo investidor. A situação, portanto, é aquele na qual, sendo o dono da sua atividade e mantendo o abusus, o investidor não pode conduzir o seu investimento de uma maneira economicamente viável; ele perdeu o usus. Obviamente, o estudo da desapropriação indireta convida uma dose de subjetividade, pois é preciso sondar a veracidade dos efeitos desapropriatórios de uma medida atacada pelo investidor. Torna-se fundamental entender os casos e as condições que indicam a existência de uma desapropriação indireta.

\section{A existência de uma desapropriação indireta}

Uma desapropriação indireta pode ser convencional (A) ou contratual (B).

\section{A) A desapropriação indireta convencional.}

Quase todos os acordos sobre a proteção dos investimentos preveem uma proteção contra a desapropriação indireta. Embora tenha uma variedade de cláusulas sobre a questão (i), um debate existe sobre o âmbito da sua aplicação para saber, por exemplo, se a intenção do Estado importa ou se os únicos 
efeitos de uma medida bastam para determinar uma desapropriação indireta; é normalmente a teoria dos efeitos que predomina (ii) e os tribunais adotaram vários métodos e técnicas para medir o teor desses efeitos (iii).

\section{(i) As cláusulas sobre a desapropriação indireta.}

As formulações das cláusulas variam em função dos tratados; em geral, os tratados preveem um regime sobre ambas as desapropriações diretas e indiretas. $\mathrm{O}$ que foi supramencionado sobre as condições para poder desapropriar diretamente serve de base para entender os passos para concluir quanto à existência de uma desapropriação indireta. O tratado modelo dos EUA é com certeza o mais detalhado sobre as questões de expropriação e contém, por exemplo, um anexo (o Anexo B) apenas sobre essas questões. Este dispõe sobre a expropriação indireta da forma seguinte: essa forma de expropriação deve ser perscrutada caso a caso considerando os fatos próprios; um mero impacto econômico de uma medida não é automaticamente equiparado a uma expropriação; é preciso saber até que ponto o Estado interferiu nas expectativas do investidor; o caráter da ação estatal deve ser considerado; e finalmente, medidas não discriminatórias adotadas para a proteção do interesse público — como a proteção do meio ambiente, da saúde, da segurança pública não têm, em princípio um valor desapropriatório.

Os acordos normalmente não estabelecem um determinismo entre a ação estatal e a desapropriação, o que significa que os Estados têm uma margem de manobra e de apreciação razoável: uma medida não será equiparada a uma desapropriação se o Estado consegue justificar a sua utilidade e demonstrar o ser caráter não discriminatório e de utilidade pública, e se há uma compensação adequada.

Um elemento problemático ao analisar a problemática é entender se a intenção do Estado é determinante ao adotar uma medida cujos efeitos são potencialmente desapropriatórios.

\section{(ii) O predomínio da teoria dos efeitos sobre a intenção}

Em princípio, os tribunais concordam que são os efeitos de uma medida e não a intenção do Estado que a equiparam a uma desapropriação (Azurix c. Argentina, 2006). A forma da privação do investimento é menos importante que os efeitos da medida que conduz a essa privação (TECMED c. México, 2003). Aliás, essa conclusão é possível ao usar apenas os princípios de interpretação dos tratados da Convenção de Viena. Muitos tratados consideram, por exemplo, que uma desapropriação indireta é o resultado de uma medida cujo efeito - e não cuja intenção - é equiparado a uma desapropriação. Trata-se apenas dos efeitos, nitidamente explicitados nos acordos. Por conseguinte, como não há menção da intenção, não é preciso considerá-la. O tribunal de reclamação Irã-EUA já tinha afirmado esse ponto no caso Starrett Housing Corp. c. Irã (1987):

It is recognised in international law that measures taken by a State can interfere with propoerty rights to such an extent that these rights are rendered so useless that they must be deemed to have been expropriated, even though the State does not purport to have expropriated them and the legal title to the property formally remains with the original owner. (também, Tippetts c. Irã, 1984; Plama c. Bulgária, 2008).

Uma vez que aceitemos a teoria dos efeitos - sole effects doctrine - é preciso saber como se medem esses efeitos.

\section{(iii) As técnicas para medir os efeitos de uma medida desapropriatória}

Os tribunais examinam, normalmente, a interferência do Estado na capacidade do investidor a frutificar efetivamente o seu investimento, o que não implica que deve haver uma transferência de propriedade ou qualquer outro benefício ao Estado (a); no mesmo sentido, várias medidas estatais podem cumular-se e agregar-se para resultar em uma desapropriação (b); outrossim, o princípio da frustração das expectativas legítimas do investidor é, às vezes, usado para tais fins (c).

\section{(a) A interferência no usus do investimento.}

A desapropriação indireta é também conhecida como uma expropriação de facto, eis que, não há uma privação direta de propriedade, mas uma neutralização da capacidade de fruir e de usufruir do investimento (CME c. República Checa, 2001). Uma medida estatal pode ter uma interferência incidental com o usus e, assim sendo, tornar inútil a raison d'être do investimento, a sua razão de existir, o seu propósito (Starretts $c$. 
Irã, 1983; Metalclad c. México, 2000). No caso Sporrong c. Suécia (1982), a Corte européia sobre os direitos humanos sustentou que, nesses casos, os juízes devem ir além da aparência e investigar a realidade da situação para entender até que ponto os direitos da propriedade foram efetivamente neutralizados. Não se deve considerar apenas a natureza (por exemplo ambiental, fiscal) de uma medida, mas também os seus efeitos sobre os investimentos. A situação é aquela na qual os direitos intrinsecamente inerentes a um investimento - a capacidade de produzir para obter benefícios ou rendas, por exemplo - não existem mais por causa de uma medida estatal (TECMED c. México 2003). Outros tribunais afinaram ou amplificaram o entendimento da interferência estatal e os efeitos sobre os direitos rastejados: dizem eles que as medidas contenciosas devem ter um efeito substancial que reduz ou aniquila o direito de usufruir do investimento (RFCC c. Marrocos, 2003; CMS c. Argentina, 2005; Telenor c. Hungaria, 2006). A privação dos direitos deve ser substancial. Em muitos casos, a duração dos efeitos é também útil para medir o teor da interferência no investimento. Os efeitos equiparados aos de uma expropriação devem ser de longa duração, quase permanente, no sentido que se torna quase impossível para o investidor retomar as suas atividades (Wena Hotels c. Egito, 2000; LG\&E c. Argentina, 2006; SDMyers c. Canadá, 2000). Também, o Estado não deve necessariamente beneficiar-se de algo ou se enriquecer durante uma desapropriação indireta - como num caso de desapropriação direta no qual beneficia de uma nova propriedade (Tippetts; TECMED).

Para resumir: ao demonstrar uma desapropriação indireta, o investidor deve poder provar que, embora tenha e mantenha a propriedade do investimento, ele não pode mais se beneficiar deste como qualquer investidor pode in abstracto esperar fruir da sua atividade em termos de produção e de rendimento.

Ele pode, outrossim, demonstrar a existência de uma desapropriação progressiva - creeping expropriation.

\section{(b) A existência de uma desapropriação progressiva - creeping expropriation.}

Uma desapropriação progressiva se constata quando não apenas uma medida, mas uma série de medidas têm - progressivamente, ao longo do tempo, um efeito equivalente a uma desapropriação. Medidas estatais agregadas no tempo causam, nesse caso, uma erosão dos direitos do investidor em relação a sua capacidade de fruir da sua atividade (Generation Ukraine c. Ucrânia, 2003; Siemens c. Argentina, 2007; Starretts c Irã, 1987). O investido deve demonstrar que algumas medidas reguladores do Estado se agregaram de tal forma que impediram todo uso possível e razoável da sua atividade. Nesse caso, deveras, não terá necessidade de provar a existência de uma intenção de desapropriar.

Às vezes, alguns acordos preveem que a frustração das expectativas do investidor pode ser considerada ao avaliar uma expropriação.

\section{(c) A frustração das expectativas legítimas do investidor como indicador de uma desapropriação.}

As considerações das expectativas legítimas ao lidar com a desapropriação fazem parte do direito americano e alguns consideram que esse raciocínio foi importado pelos advogados americanos no contencioso arbitral internacional. São, aliás, os acordos americanos que dispõem sobre as expectativas legítimas do investidor ao averiguar a existência de uma desapropriação indireta (mas: ver também o modelo de tratado colombiano). Não se trata da expectativa de não ser expropriado, mas de poder fruir do investimento. No caso Metalclad, o tribunal arbitral afirmou que a desapropriação de facto é um:

$$
\begin{aligned}
& \text { covert or incidental interference with the use of } \\
& \text { property which has the effect of depriving the } \\
& \text { owner, in whole or in significant part, of the use } \\
& \text { or reasonably-to-be-expected economic benefit } \\
& \text { of property even if not necessarily to the obvious } \\
& \text { benefit of the host State. }
\end{aligned}
$$

A desapropriação priva o investidor do benefício que poderia esperar: nesse caso, é preciso verificar se a privação da propriedade e do usus constituíram um obstáculo ao rendimento da atividade. Por exemplo, no caso Occidental c. Ecuador, a expropriação não foi admitida em razão de uma recusa do Estado a reembolsar a IVA ao investidor, pois, segundo o tribunal, não houve uma "deprivation of the use or reasonably expected economic benefit of the investment". No caso TECMED, o tribunal ressaltou que "the Claimant's expectation was that of a longterm investment relying on the recovery of its investment and the estimated return through the operation of the Landfill during its entire useful life".

Até certo ponto, no entanto, a relação expectativas legítimas e desapropriação pode sercriticada. No caso de uma desapropriação direta, o investidor perde o usus 
e o abusus. Ele não é mais o dono, o proprietário, e não pode mais frutificar a atividade que foi transferida ao Estado. Ao analisar um caso de desapropriação indireta, a mesma lógica dever ser seguida. Primeiramente, é claro que não se trata de uma perda do abusus, porque o investidor mantém-se como o dono da empresa. Portanto, e em segundo lugar, são os efeitos sobre o usus que devem ser comparados e eventualmente equiparados. Os benefícios - e as expectativas de benefício - são apenas as consequências do usus, e podem ser realizados ou não, dependendo da conjuntura econômica da atividade. O que reflete melhor uma desapropriação de facto é a possibilidade do investidor de continuar em condições normais e razoáveis a sua atividade: deve ser verificado se continua como mestre do seu investimento. Para isso, não é necessário verificar as rendas esperadas; a capacidade de continuar a atividade do investimento basta amplamente. Pode ser comparado à influência e ao domínio que o investidor tinha sobre a sua atividade ao investir com a situação após uma determinada medida estatal. Focalizar sobre os benefícios equipara-se a falsificar a realidade de um investimento que não sempre conduz a lucro. O risco de uma perda é inerente a qualquer atividade econômica, como um investimento (CPJI, Oscar Chinn, 1934). Decorre, consequentemente, que uma incerteza desse tipo não pode se tornar critério de uma desapropriação indireta: é mais fácil pleitear a existência de expectativas para poder usar um bem ou um investimento que a existência de expectativas para obter benefícios deste.
Além dessa forma de expropriação convencional — decorrente de um tratado —, encontra-se outra forma de desapropriação: a forma contratual.

\section{B) A desapropriação contratual}

O instrumento jurídico relevante nesse caso é um contrato de investimento entre o investidor e o Estado, e a questão é de saber se uma violação contratual equipara-se à desapropriação. Desde já, é possível afirmar que uma mera violação de um contrato pelo Estado anfitrião não é uma desapropriação, pois nesse caso haverá uma banalização do sentido real da expropriação — e do seu teor de gravidade.

Uma violação contratual será equiparada a uma desapropriação apenas quando o Estado agiu com poderes e capacidade que apenas cabem à competência de uma pessoa pública; a intervenção dele deve ser feita com o uso das prérogatives de puissances publiques formalizadas em atos de autoridade pública. Por exemplo, o não pagamento da prestação devida ao investidor, o não pagamento de uma dívida não implica desapropriação, pois fazem parte do jus gestionis e não do jus imperii (Waste Water Management c. México, 2004; SGS c. Filipinas, 2004; Bureau Veritas c. Paraguay, 2009). Portanto, apenas a adoção de decretos, leis, atos e medidas executivas no âmbito dos poderes reguladores podem violar um contrato, sobrepujando a violação ao nível de uma desapropriação. 


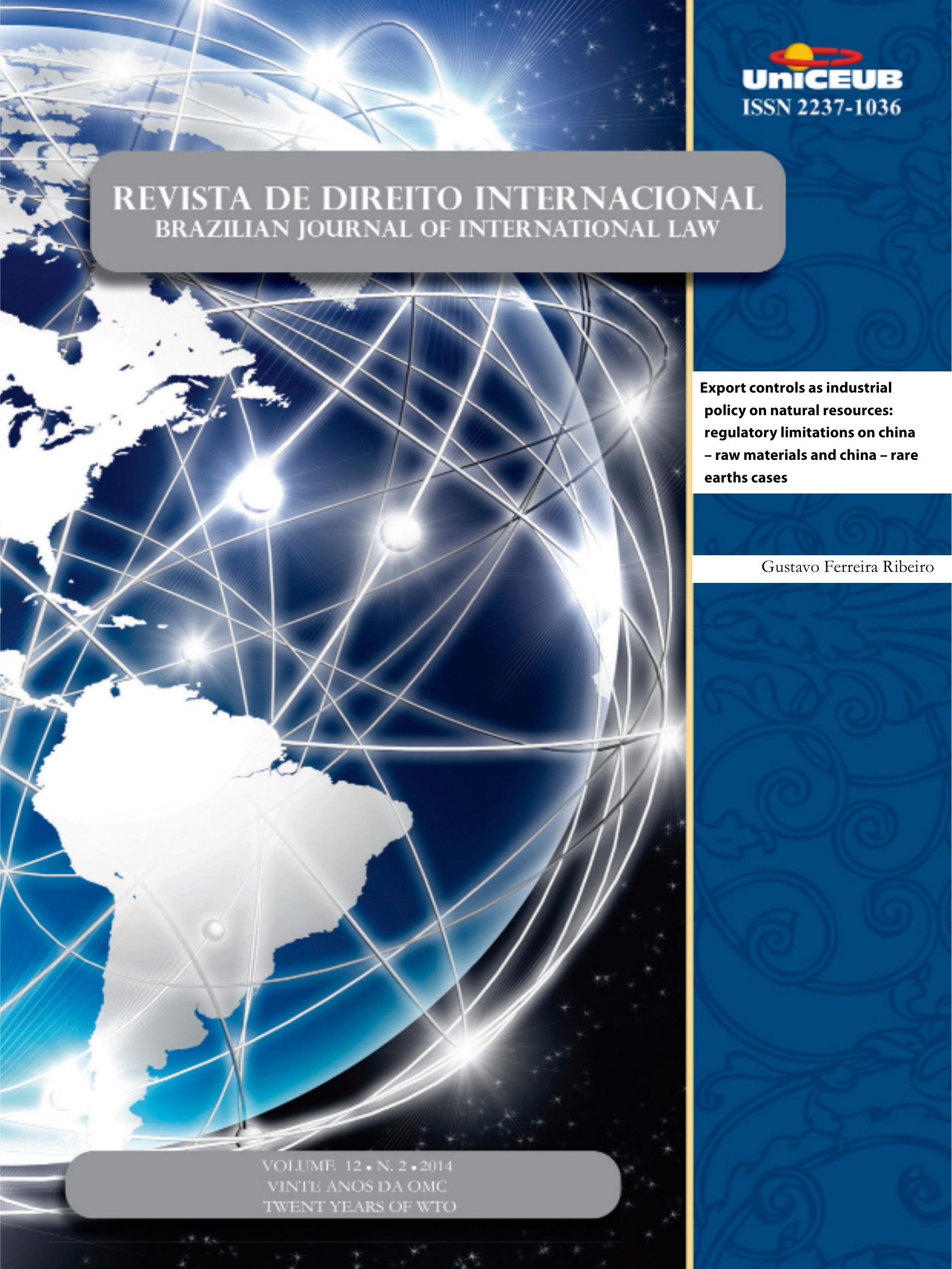




\title{
Export controls as industrial policy on natural resources: regulatory limitations on china - raw materials and china - rare earths cases*
}

Gustavo Ferreira Ribeiro**

\begin{abstract}
This paper evaluates the legal boundaries of export controls as industrial policies on natural resources, emphasizing articles XI, XX(i), and XX(j) of the GATT-94. The context comes from the concerned restrictions that led to the China - Raw Materials and China - Rare Earths cases at the WTO. Much of the literature has been focusing on systemic linkages: trade and environment/public health. Despite its importance, this paper innovates by focusing on the discretionary space of export controls as industrial policies that Members may adopt, without resorting to any environmental or public health arguments. Indeed, whether in Raw Materials the term industrial policy is not found in the dispute reports, in Rare Earths it appears at least thirty times in the Panel's report. After the analysis, this paper suggests distinct conformation of these spaces. Article XI of the GATT-94 would convey constricted space for export quotas due to time, substantive, and circumnstancial criteria. Article XI of the GATT-94, on the other hand, would provide considerable room for export duties; though Members with specific accession commitments (e.g. China), may have curtailed it, as interpreted by the Appellate Body. Finally, Articles XX(i) and XX(j) of the GATT-94 would rarely accommodate "ordinary" industrial policies. Their use attaches to stabilization plans and international emergencies, respectively. As the economics implications of the concerned measures were not analyzed, the paper also paves the way for future law and economics perspectives on this topic.
\end{abstract}

Keywords: Exports Controls. Industrial Policy. Raw Materials. Rare earths. WTO.

\section{Resumo}

Este artigo avalia as fronteiras legais de medidas de controles de exportação adotadas como parte de políticas industriais sobre recursos naturais, com ênfase nos Artigos XI, XX(i) e XX(j) do GATT-94. O contexto da discussão decorre de medidas desta natureza que culminaram com os casos China-Matérias-Primas e China - Terras-Raras na OMC. Muito da literatura relacionada aos casos foca questões sistêmicas: comércio e meioambiente/saúde pública. Apesar da importância dessas abordagens, este artigo inova ao analisar o espaço regulatório das medidas, sem qualquer recurso à retórica de meioambiente ou de saúde pública. De fato, se em Matérias-Primas o termo política industrial não é encontrado nos relatórios das decisões, em Terras-raras ele aparece pelo menos trinta vezes no Relatório do Painel. Após a análise, este artigo sugere conformações distintas de espaços regulatórios. O artigo XI do GATT-94 proporcionaria espaços restritos para o uso de cotas de exportação, em função de critérios temporais, substantivos e circunstanciais. Por outro lado, ofereceria espaços consideráveis para tarifas de exportação; embora Membros com compromissos específicos de acesso, como a China, podem tê-los diminuído, como interpretado pelo Órgão de Apelação. Finalmente, os Artigos XX(i) e XX(j) do GATT-94 dificilmente acomodariam políticas industriais convencionais. $\mathrm{O}$ uso destas exceções alude a planos de estabilização e emergências 
internacionais, respectivamente. Como as implicações econômicas destas medidas não foram analisadas, o artigo sugere pesquisas futuras no tema, com aportes jurídicos e econômicos.

Palavras-chave: Controles de Exportação. Política Industrial. Matérias-Primas. Terras-raras. OMC.

\section{Introduction}

Export controls on natural resources, adopted by China in the last decade, have sparked a complex discussion among WTO Members.

Measures of these nature - export controls on its own natural resources - are not unheard in the international trade history. In practice, they are observed since mercantilism (as a French law that prohibited gold exports in 1540), along the industrial revolution, between the Great Wars and also in the era of trade multilateralism.

However, the topic shall be revisited and expanded for at least two reasons: firstly, because the legal boundaries of export controls have been clarified ${ }^{1}$, though in distinct degrees; secondly, because it crosses a broad spectrum of economic interests, involving global chains and natural resources, and regulatory interests, related to industrial policy and environmental conservation.

Three situations illustrate the complexity of those interests: Brazil has mineral resources of different variety and strategic purposes, such as the elements called rare earths ${ }^{2}$. A specialized publication in the mining

1 Most of the time, when one observes the political debates and the cases brought to the WTO, they refer to Members controlling, restricting, or banning imports from other Members. Those measures take the form of taxes on imports, technical barriers, quotas, import licensing, among others. Those measures can be, sometimes, justified by the WTO exceptions. Export restrictions, as the name suggests, are measures taken on its own exports. They can also be employed in the form of taxes (export taxes), quotas (export quotas), or licensing procedures (export licensing). Normally, one assumes broader regulatory space on export controls.

2 As Serra suggests, in opposition to their name, rare earths are neither rare nor earth. The name accounts to the difficulty in separating them from other elements of the periodic table. Rare earths are numbered between 57 and 71 in the Periodic Table, with the most abundant being Cerium (Ce) and the less Thulium (Tu), though plentiful as silver. Their properties (magnetic, fluorescent and chemical) are useful for high aggregated products used by display, wind mill turbines, hybrid vehicles, photovoltaic cells, and optical fibers industries. SERRA, Osvaldo Antonio. Rare earths: Brazil x China. Journal of Brazilian Chemical Society, São Paulo, v. 22, n. 5, p. 811-812, mai 2011. p. 811. industry also reports that the Mexican government will fund, in the near future, efforts to locate new rare earths deposits, since the known ones under the West Coast Sea are hardly extracted. ${ }^{3}$ Yet, the expression raw materials diplomacy looms large in the international economic relations as a reference to the European Union articulation pro an international understanding to guarantee the supply of strategic raw materials. The visit of the Brazilian president in Germany, in 2012, was symptomatic. It was suggested, in that occasion, a strategic partnership with Brazil in raw materials, such as rare earths, aiming at stable supply, taking in consideration the implementation of the Chinese export restraint measures. ${ }^{4}$

In terms of international litigation, two recent cases brought to the WTO reveal more about the legal boundaries of export controls: China - Raw Materials and China Rare earths. Much of the literature about the cases has been focusing on the systemic issues and the trade and environmental linkages. Despite

3 JAMASMIE, Cecilia. Mexico's Government to Fund Rare Earth Exploration. Mining.com, 23 mai 2014. Available at: <http:// www.mining.com/mexicos-government-to-fund-rare-earthexploration-95877/>. Last access on: 27 jul. 2014.

4 Brazil may have an important role on rare earhts with estimates of reserves roughly at 3,5 billions of tons in places such as the Amazon and the Araxá-MG region, as reported in Brazilian papers. See RIBEIRO, G. F. Restrições à exportação de matérias-primas, multilateralismo e implicações para o Brasil. Pontes: informações e análises sobre comércio e desenvolvimento sustentável, v. 8, n. 3, p. 12-14, jun. 2012.

5 WORLD TRADE ORGANIZATION. Panel Reports. China: Measures Related to the Exportation of Various Raw Materials (China - Raw Materials). WT/DS394/DS395/DS398/R. 05 jul. 2011; WTO Appellate Body Reports. China: Measures Related to the Exportation of Various Raw Materials (China - Raw Materials). W'T/DS394/DS395/DS398/AB/R. 30 jan. 2012.

6 WORLD TRADE ORGANIZATION. Panel Reports. China: Measures Related to the Exportation of Rare Earths, Tungsten, and Molybdenum (China - Rare Earths). WT/ DS431/DS432/ DS433/R. 26 mar. 2014; WTO Appellate Body Reports. China Measures Related to the Exportation of Rare Earths, Tungsten, and Molybdenum (China - Rare Earths). WT/ DS431/DS432/DS433/ AB/R. 07 ago. 2014 (released after the paper was written).

7 See KARAPINAR, Baris. Defining the legal boundaries of export restrictions: a case law analysis. Journal of International Economic Law, Oxford, v. 15, n. 2, p. 443-479, jun. 2012 (covering, fundamentally, export quotas and article XI of GATT-94, the possibility of recourse to GATT-94 exceptions in relation to China's Accession Protocol, and environmental considerations). LIU, HanWei; MAUGHAN, John. China's rare earth export quotas: out of the China-Raw material gate, but past the WTO's finish line? Journal of International Economic Law, Oxford, v. 15, n. 4, p. 971-1005, dec. 2012 (scrutinizing the Chinese regime of export quotas and discussing environmental issues); CONDON, Bradly. Comentario sobre China: materias primas: informe del órgano de apelación. 
the relevance of those approaches, the cases also reveal the probable limits of industrial policies that Members may eventually adopt without any resort to the environmental rhetoric.

In fact, industrial policies ${ }^{8}$, as part of governmental action, can embrace import tariffs, subsidies, support for research and development, among others. This paper deals only, after a historical digression, with export controls (such as export quotas and export duties) as part of these policies and their likely justification under Articles XI, XX(i), XX(j) of GATT94. The paper suggests the conformations of different degrees of regulatory space for industrial policies on each of these articles.

\section{Development}

\subsection{The rebirth of export controls: from mercantilism to the multilateral system}

With the birth of the Nation-State it is possible to contextualize the first employment of export controls over natural resources. The mercantilism of the XVI and XVII centuries, for instance, promoted manufactured exports and raw materials imports, aiming at metal accumulation. At that time, metals were fundamentally payment means which accumulation was perceived as the source of power and wealth.

Douglas Irwin observes that, in theory, mercantilists would agree that is good to export manufactured and bad to import them; on the contrary, raw material imports is good and it is bad to export them. ${ }^{9}$ History also tells how the discovery, extraction and distribution of precious metals (gold, copper and, principally, silver, by then) made possible the rise of Portugal, Spain and the Netherlands, as opposing the Ottoman Empire, disaggregating the Muslim dominance in the African and Asia trade. ${ }^{10}$ It iss precisely from the mercantilism period that one can observe examples of exports

Revista de Derecho Económico Internacional, v. 2, n. 2, 2012 (analyzing procedural and substantive aspects decided by the Appellate Body).

8 This paper does not enter the wisdom or foolish of these policies in terms of economic consequences.

9 IRWIN, Douglas apud GODD, Walter. Dictionary of trade policy terms. 4. ed. London: CUP, 2002. p. 227.

10 ERLICHMAN, Howard. Conquest, tribute and trade: the quest for precious metals and the birth of globalization. New York: Prometheus, 2010. p. 10. restrictions on mineral resources, as a French law that prohibited gold exports (1540), among others. ${ }^{11}$

Interestingly, around four centuries later, article $\mathrm{XX}(\mathrm{c})$ of the GATT kept a text with the same purpose. Restrictive measures related to gold and silver imports or exports are justified. In this case, the rationale can be found in the contemporaneous role of gold and silver as monetary reserves. ${ }^{12}$

For focus, this paper does not develop the many details related to export controls on monetary issues - like the gold and silver crisis on the XVIII and XIX centuries, the emergency of the gold standard in the XX century, and the Great Wars and the Big Depression impacts on the overall discussion. ${ }^{13}$

The issue at stake in this paper is the recent flourish of natural resources export controls that are not related with monetary issues. An OCDE report informs, for example, three cases of export controls over molybdenum, chromite and rare earths; ${ }^{14}$ those elements are inputs to high technology industrial processing.

The report tells that, in 2007, China imposed a 10\% export duty on molybdenum concentrates and oxides and ferromolybdenum and a 15\% tax on molybdenum powder, among others. Yet, export quotas were implemented and had their levels reduced one year after. The main Chinese allegation related to environmental reasons (e.g. target residues from the mining industry) and the preservation of natural resources. ${ }^{15}$ Still in 2007 , India charged ad rem export duties on chromite, aiming

11 KELLENBENZ, Hermann. The rise of the european economy: an economic history of continental Europe 1500-1750. London: HM, 1976. p. 39.

12 It is reported that in the preparatory work of the International Conference on Trade and Employment (1947-1948), the Indian delegation accepted the exception in relation to gold, but considered that silver should be taken out of article $\mathrm{XX}(\mathrm{c})$ in the quality as a commodity. UNITED NATIONS. E/PC/T/C. II/54, 16 nov. 1946. p. 33.

13 For the historical aspects, see the third chapter of: NASCIMENTO, Marco Antônio Alcântara. Restrições às exportações no sistema multilateral de comércio: reflexões sobre desenvolvimento, soberania e liberalização do comércio. 2014. 224f. Dissertation (Master's Degree) - Programa de Mestrado e Doutorado em Direito, Centro Universitário de Brasília, Brasília, 2014.

14 KORINEK, Jane; KIM, Jeonghoi. Export restrictions on strategic raw materials and their impact on trade. OECD Trade Policy Working Papers, n. 95, 29 mar. 2010. paragraph 27.

15 KORINEK, Jane; KIM, Jeonghoi. Export restrictions on strategic raw materials and their impact on trade. OECD Trade Policy Working Papers, n. 95, 29 mar. 2010. paragraph 28. 
at increasing its supply for the domestic downstream industry ${ }^{16}$ Just to contextualize, the chromite price was globally increasing as a result of Chinese consumption. As a consequence of the Indian measures, China begun to import from South Africa which, on its turn, expressed worries and also considered implementing export restrictions on chromite. ${ }^{17}$ Finally, as to rare earths, it was China again that, at the end of 2006, among other measures, introduced a 10\% export duties and increased rates in the two following years. ${ }^{18}$

From the application of the Chinese measures, the discussion evolved at the WTO resulting in the aforementioned paradigmatic cases which are contextualized in the following section.

\subsection{The recent cases: China - raw materials and China - rare earths}

As introduced, the China - Raw Materials and China - Rare Earths are relatively recent. In the first, the consultation process began in June 2009 with the United States and European Union request to China. Mexico joined the consultations later on, in August. In November 2009, the United States, the European Union and Mexico asked for the establishment of panel which occurred by the deliberation of the Dispute Settlement Body (DSB) in the same month. Brazil, among other Members, joined as third party.

The Panel report circulated on July 05, 2011. Due to China's appeal, the Appellation Body circulated its decision seven months later, on January 30, 2012. The dispute involved Chinese export restraints related to nine products: bauxite, coke, fluorspar, magnesium, manganese, silicon carbide, silicon metal, yellow phosphorus, and zinc - which inspired the name of the case. Generally, the products are raw materials largely

16 KORINEK, Jane; KIM, Jeonghoi. Export restrictions on strategic raw materials and their impact on trade. OECD Trade Policy Working Papers, n. 95, 29 mar. 2010. paragraph 36.

17 KORINEK, Jane; KIM, Jeonghoi. Export restrictions on strategic raw materials and their impact on trade. OECD Trade Policy Working Papers, n. 95, 29 mar. 2010. paragraph 39-40. South Africa concerned on the long term effect of profitability on its processing industries.

18 KORINEK, Jane; KIM, Jeonghoi. Export restrictions on strategic raw materials and their impact on trade. OECD Trade Policy Working Papers, n. 95, 29 mar. 2010. paragraph 52. used in processing industry. The complaints identified as least for kinds of restrictions applied, in a variety of forms, by China: (i) export duties; (ii) export quotas; (iii) export licensing; and (iv) export minimum prices. In the DSB meeting, on January 28, 2013, China informed the promulgation of a new statute that would have removed the export duties and quotas on certain raw materials, which would have fully implemented the DSB recommendations. ${ }^{19}$

In China - Rare Earths, the United States requested consultations with China in March of 2012, pointing out many Chinese export restraints on rare earths, tungsten and molybdenum, similarly to the previous case. The European Union and Japan joined consultations later on. ${ }^{20}$ The Panel report circulated on March 26, 2014. By the time this paper was written, the case was under appeal, as requested by the United States and China. ${ }^{21}$

The referred disputes take on many issues. For instance, China's Accession Protocol (CAP) and its relation to the WTO agreements is invoked and analyzed, since China has assumed commitments related to export controls in the Protocol, covering quotas and export duties. The Chinese allegations that some measures contributed to the objective of protecting human, animal or plant life or health (article XX (b) of GATT-94) are also scrutinized. In the same token, the contribution of the measures to the conservation of exhaustible natural resources is also on the spot (article XX (g) of GATT-94), among other issues.

Notwithstanding those questions, the interest of this paper are the controversies involving the impact of the decisions on the discretionary power of industrial policies on natural resources, once export controls are used. Are those measures compatible with the multilateral trade system, when they do not have any

19 WORLD TRADE ORGANIZATION. China: measures related to the exportation of various raw materials. 28 jan. 2013. Available at: <http://www.wto.org/english/tratop_e/dispu_e/ cases_e/ds398_e.htm>. Last access on: 27 jul. 2014.

20 It is curious to acknowledge the absence of Mexico as a complainant or third party in this case, contrary to its complainant position in Raw Materials.

21 WORLD TRADE ORGANIZATION. China: measures related to the exportation of rare earths, tungsten and molybdenum. 29 aug. 2014. Available at: <http://www.wto.org/english/tratop_e/ dispu_e/cases_e/ds431_e.htm>. Last access on: 27 jul. 2014. 
appeal to environmental or public health concerns? Since, by definition, those measures are trade distorting, in which circumstances are they, if ever, allowed of justified?

\subsection{Export quotas and article XI of GATT-94}

Imagine that a Member imposes export quotas with the objective of raising the supply of product to their local industry. The Member is straightforward about the objective of the measure as a pillar of its industrial policy. Do those measures find comfort on the WTO rules?

As known, the general elimination of quantitative restrictions, according to article XI: 1 of the GATT94, deals not only with the eliminations on imports of products of other Members, but also on exports of products destined to other Members. This is a pacificied point that comes straightly from the text of the agreement. ${ }^{22}$

Until recently, less developed in the GATT and WTO jurisprudence were the exceptions to Article XI (such as article XI:2(a) of GATT-94) ${ }^{23}$ that could accommodate the imagined measure. Precisely, China invoked Article XI:2(a) as a defense to the applied quotas on refractory-grade bauxite, in tandem with other exceptions. ${ }^{24}$

China, in summary, raises the possibility of restricting exports because of strong foreign demand, physical exhaustibility, and/or domestic regulatory limits on access. China also mentions that the complainants themselves have recognized that refractory-grade bauxite is essential, necessary and critical to their economies. Moreover, complainants would have themselves applied prohibitions and restrictions on products that they deem essential for

22 Article XI:1 of the GATT-94: "No prohibitions or restrictions other than duties, taxes or other charges, whether made effective through quotas, import or export licences or other measures, shall be instituted or maintained by any contracting party on the importation of any product of the territory of any other contracting party or on the exportation or sale for export of any product destined for the territory of any other contracting party."

23 Artigo XI:2 of the GATT-94: “(a) Export prohibitions or restrictions temporarily applied to prevent or relieve critical shortages of foodstuffs or other products essential to the exporting contracting party [...]."

24 WORLD TRADE ORGANIZATION. China: measures related to the exportation of rare earths, Tungsten, and Molybdenum. WT/DS394/DS395/DS398/R, 05 jul. 2011. paragraph 7.227. downstream domestic industries, for periods exceeding decades. To illustrate this point, China mentions a US 43-year-old restriction and prohibition on the export of unprocessed timber harvested in US federal lands and a European 37-year prohibition and restriction on the export of various types of ferrous and non-ferrous metal waste and scrap. ${ }^{25}$

A plain reading of Article XI:2(a) of the GATT94 certainly suggests some room to justify those measures in the context of industrial policy, but under which limits? Once analyzed, the Panel divides the interpretation on the following terms: temporarily, essential, to prevent or relief critical shortages, ${ }^{26}$ which are revisited on appeal in the same case and barely changed in the Panel's interpretation in Rare Earths.

\subsubsection{Temporarily}

In China - Raw Materials, the Panel, by looking at the literal meaning in the three official languages of the WTO, observes that temporarily is for a time only and during a limited time. On its turn, limited time would mean appointed, fixed and circumscribed within definite limits, bounded, restricted. These definitions would suggest a fixed time-limit for the application of measures addressing critical shortages of products essential to the exporting Member. ${ }^{27}$

While referring to other $\mathrm{AB}$ decisions about the need to read all applicable provisions of a treaty in a way that gives meaning to all of them, harmoniously ${ }^{28}$, the Panel refers to the text of article $\mathrm{XX}(\mathrm{g})$ of GATT-94 that deals with the conservation of exhaustible natural. ${ }^{29}$ To the Panel, if a time-based distinction would have not been made, Members could resort indistinguishably to either Article XI:2(a) or XX(g) to address the problem

25 WORLD TRADE ORGANIZATION. China: measures related to the exportation of rare earths, Tungsten, and Molybdenum. WT/DS394/DS395/DS398/R, 05 jul. 2011. paragraph 7.241-7.242.

26 WORLD TRADE ORGANIZATION. China: measures related to the exportation of rare earths, Tungsten, and Molybdenum. WT/DS394/DS395/DS398/R, 05 jul. 2011. paragraph 7.250.

27 WORLD TRADE ORGANIZATION. China: measures related to the exportation of rare earths, Tungsten, and Molybdenum. WT/DS394/DS395/DS398/R, 05 jul. 2011. paragraph 7.255.

28 That the so-called principle of "effective-interpretation" or effectiveness in interpretation found in the international law doctrine.

29 WORLD TRADE ORGANIZATION. China: measures related to the exportation of rare earths, Tungsten, and Molybdenum. WT/DS394/DS395/DS398/R, 05 jul. 2011. paragraph 7.256-7.257. 
of an exhaustible natural resource. ${ }^{30}$ This would, one can infer, jeopardize the principle of effective interpretation. The Panel also rebates the Chinese allegation about the need to use supplementary means of interpretation (in accordance with article 32 of the Vienna Convention) $)^{31}$. China's argument comes from the fact that Australia, at the time of negotiating the GATT 1947, requested the application of an export ban on merino sheep for an extended period of time, in support of its view that measures may be applied under Article XI:2(a) for extended periods. The Panel, however, disagrees and sees no need to resort to article 32, since the interpretation is not ambiguous or obscure. $^{32}$

On appeal, the Appellate Body, also resorting to the dictionary meanings, posits that temporarily is defined as [l]asting or meant to last for a limited time only; not permanent; made or arranged to supply a passing need. ${ }^{33}$ Once played with applied, says the Appellate Body, the terms describes measures that are applied for a limited time, a measure taken to bridge a passing need, or measures that are applied in a interim. ${ }^{34}$ It should be noted that the Appellate Body agrees with the Panel's interpretation that the prohibitions or restriction, under the meaning of Article XI:2(a) have to do with a finite measure, that is, applied from a limited time. However, the Appellate Body disagrees with the Panel as to the necessity of fixing the duration in advance. ${ }^{35}$ In Rare Earths, on its

30 WORLD TRADE ORGANIZATION. China: measures related to the exportation of rare earths, Tungsten, and Molybdenum. WT/DS394/DS395/DS398/R, 05 jul. 2011. paragraph 7.257.

31 United Nations Convention on the Law of Treaties, Article 32 - Supplementary means of interpretation: "Recourse may be had to supplementary means of interpretation, including the preparatory work of the treaty and the circumstances of its conclusion, in order to confirm the meaning resulting from the application of article 31, or to determine the meaning when the interpretation according to article 31: (a) leaves the meaning ambiguous or obscure; or (b) leads to a result which is manifestly absurd or unreasonable."

32 WORLD TRADE ORGANIZATION. China: measures related to the exportation of rare earths, Tungsten, and Molybdenum. WT/DS394/DS395/DS398/R, 05 jul. 2011. paragraph 7.260.

33 WORLD TRADE ORGANIZATION. China: measures related to the exportation of rare earths, Tungsten, and Molybdenum. WT/DS394/DS395/DS398/AB/R, 30 jan. 2012. paragraph 323.

34 WORLD TRADE ORGANIZATION. China: measures related to the exportation of rare earths, Tungsten, and Molybdenum. WT/DS394/DS395/DS398/AB/R, 30 jan. 2012. paragraph 323.

35 WORLD TRADE ORGANIZATION. China: measures related to the exportation of rare earths, Tungsten, and Molybdenum. W'T/DS394/DS395/DS398/AB/R, 30 jan. 2012. paragraph 330331. See also CONDON, Bradly. Comentario sobre China: materias primas: informe del órgano de apelación. Revista de Derecho Económico Internacional, v. 2, n. 2, 2012. p. 105. KELLENBENZ, Hermann. turn, there are no further discussions on this issue. The Panel just refers to what the Appellate Body, in Raw Materials, has decided. ${ }^{36}$

\subsubsection{Essential}

China's assertion is that the appraisal of essentialness of a product to a Member, which would be confirmed by the WTO Preamble as a context of interpretation, is a function of the quantitative contribution of the product through its entire value chain. This contribution could have been made as to the gross domestic product, education, healthcare, infrastructure, technological progress, or scientific research. ${ }^{37}$ In addition, purportedly finding further support for this interpretation, a broad range of products could be considered essential: from serving basic consumptions needs to meeting economic needs (such as input needed for production). ${ }^{38}$ The European Union, on its turn, points out that such a broad interpretation would render other provisions redundant. This would be the case of Article XX(i) of the GATT-94 that deals with export restrictions on domestic materials necessary to ensure essential quantities of such materials to a domestic processing industry, in some circumstances ${ }^{39}$ (issue that this paper will tackle later).

The Panel, in Raw Materials, starts the analysis looking at the meaning of other products, which is qualified by essential to the exporting Member. ${ }^{40}$ As to the latter, extracting again the meaning from dictionaries, essential to means: affecting the essence of anything; material,

The rise of the european economy: an economic history of Continental Europe 1500-1750. London: HM, 1976. p. 8.

36 WORLD TRADE ORGANIZATION. China: measures related to the exportation of rare earths, Tungsten, and Molybdenum. WT/ DS431/DS432/DS433/AB/R, 07 ago. 2014. paragraph 7.453.

37 WORLD TRADE ORGANIZATION. China: measures related to the exportation of rare earths, Tungsten, and Molybdenum. WT/DS394/DS395/DS398/R, 05 jul. 2011. paragraph 7.263.

38 WORLD TRADE ORGANIZATION. China: measures related to the exportation of rare earths, Tungsten, and Molybdenum. WT/DS394/DS395/DS398/R, 05 jul. 2011. paragraph 7.264. This support would come from the Understanding on the Balanceof-Payments Provisions of GATT - 94, Article XXXVI:5 of the GATT-94 and its Ad Note.

39 WORLD TRADE ORGANIZATION. China: measures related to the exportation of rare earths, Tungsten, and Molybdenum. WT/DS394/DS395/DS398/R, 05 jul. 2011. paragraph 7.264.

40 WORLD TRADE ORGANIZATION. China: measures related to the exportation of rare earths, Tungsten, and Molybdenum. WT/DS394/DS395/DS398/R, 05 jul. 2011. paragraph 7.273. 
important; constituting, or forming part of, the essence of anything; and absolutely necessary, indispensably requisite. ${ }^{41}$ Later, by referring to the preparatory work of GATT-47, the Panel affirms that the reference to essential to the exporting Member, apparently, has been added to elucidate that the importance of any product should be judged in relation to the particular country concerned. ${ }^{42}$

However, the Panel also says that neither the terms of Article XI:2(a) of GATT-94 nor its negotiating history means that a Member can, on its own, determine whether a product is essential to it. ${ }^{43}$ The Panel brings up the national security exception of article XXI(b) of GATT-94, to develop its rationale. Article XXI(b) of GATT-94 states that nothing in GATT-94 shall be construed to prevent any Member from taking any action which it considers necessary for the protection of its essential security interests. Supposedly, the broader discretion as to essential in article $\mathrm{XXI}(\mathrm{b})$, and the lesser one, in article XI:2(a) of GATT-94 is the absence of it considers in the latter. ${ }^{44}$

In sum, the Panel asserts that a product may be essential when itis important, necessary, or indispensable to a particular Member and this can include a product that is an input to an important product or industry. However, the determination of essentialness must take into account "the particular circumstances faced by that Member at the time that a Member applied the restriction". ${ }^{45}$ One can infer that the Panel tells apart the essentialness analysis in two aspects: who detains

41 WORLD TRADE ORGANIZATION. China: measures related to the exportation of rare earths, Tungsten, and Molybdenum. WT/DS394/DS395/DS398/R, 05 jul. 2011. paragraph 7.275.

42 WORLD TRADE ORGANIZATION. China: measures related to the exportation of rare earths, Tungsten, and Molybdenum. WT/DS394/DS395/DS398/R, 05 jul. 2011. paragraph 7.275, footnote 465 .

43 WORLD TRADE ORGANIZATION. China: measures related to the exportation of rare earths, Tungsten, and Molybdenum. WT/DS394/DS395/DS398/R, 05 jul. 2011. paragraph 7.276.

44 WORLD TRADE ORGANIZATION. China: measures related to the exportation of rare earths, Tungsten, and Molybdenum. WT/DS394/DS395/DS398/R, 05 jul. 2011. paragraph 7.2767.277. In fact, this is one of the arguments since the Panel, when looking at essential, crosses other provisions, such as Article 4 of the BOP. The Panel, however, understands Article XI: 2(a) as broader than the BOP exception and does not use it to interpret essential. WORLD TRADE ORGANIZATION. China: measures related to the exportation of rare earths, Tungsten, and Molybdenum. WT/ DS394/DS395/DS398/R. 05 jul. 2011. paragraph 7.278-7.279.

45 WORLD TRADE ORGANIZATION. China: measures related to the exportation of rare earths, Tungsten, and Molybdenum. WT/DS394/DS395/DS398/R, 05 jul. 2011. paragraph 7.282. the powers to determine the essentialness - not left to a particular Member; and, as a corollary, what are the circumstances related to essentialness - taking into account the particular ones that the Member faced. Karapinar, on the last issue, criticizes the Panel decision since the benchmark used for asserting the essentialness of the concerned commodity is not clear. ${ }^{46}$

In Raw Materials, the Appellate Body develops the interpretation of essential as part of the full set of terms in Article XI:2(a). First, it overlaps with the Panel that essential is defined as absolutely indispensable or necessary. ${ }^{47}$ But read together, Article XI:2(a) of GATT94 would sound as critical shortages of foodstuffs or otherwise absolutely indispensable or necessary products. The inclusion of foodstuffs only indicates what can be considered essential for a Member, but not limiting the sense of essential products to foodstuff. ${ }^{48}$

In Rare Earths, likewise the interpretation of temporarily, the Panel does not provide further discussions on the topic. It just refers to what the Appellate Body has said, in Raw Materials. ${ }^{49}$

\subsubsection{To prevent or relieve critical shortages ${ }^{50}$}

At first, the Panel, in China - Raw Materials, and just as the previous methods of interpretation, construes the expression in accordance with its plain sense, in the following order: prevent, relieve, shortage, and critical. Among the available meanings, they would signify, respectively: to anticipate in action, to act in advance of; to ease or mitigate; deficiency in quantity; and of the nature of, or constituting, a crisis - as to the latter, the plain meaning would be a turning-point, a vitally important or decisive stage.

46 KARAPINAR, Baris. Defining the legal boundaries of export restrictions: a case law analysis. Journal of International Economic Law, Oxford, v. 15, n. 2, p. 443-479, jun. 2012. p. 10.

47 WORLD TRADE ORGANIZATION. China: measures related to the exportation of rare earths, Tungsten, and Molybdenum. WT/DS394/DS395/DS398/AB/R, 30 jan. 2012. paragraph 326.

48 WORLD TRADE ORGANIZATION. China: measures related to the exportation of rare earths, Tungsten, and Molybdenum. WT/DS394/DS395/DS398/AB/R, 30 jan. 2012. paragraph 326.

49 WORLD TRADE ORGANIZATION. China: measures related to the exportation of rare earths, Tungsten, and Molybdenum. WT/ DS431/DS432/DS433/R, 26 mar. 2014. paragraph 7.453.

50 As a Portuguese native speaker, this author recalls that the Brazilian official translation comes straightly from the French version of the GATT-94: pour prévenir une situation critique due à une Pénurie. In the English and Spanish versions the expression is more concise and corresponds, respectively, to para prevenir o remediar una escasez aguda and to prevent or relieve critical shortages. 
51 The Panel also agrees with the European assertion that temporarily contextually informs the notion of critical shortages. As a consequence, "if there is no possibility for an existing shortage ever to cease to exist, it will not be possible to 'relieve or prevent' it through an export restriction applied on a temporary basis". ${ }^{2}$

On appeal, the Appellate Body basically follows the ordinary meaning put forward by the Panel. ${ }^{53}$ It deepens the interpretation, however, by finding context of interpretation in the general or local short supply contained in Article XX(j) of GATT-94. In this sense, while Article XI:2(a) is qualified by critical, shortages (or short supply) of Article XX(j) of GATT-94 would not have been tempered in the same way. This textual distinction makes the Appellate Body, following the canons of effective interpretation, assert that the kind of shortages found in Article XI:2(a) of GATT-94 is more narrowly circumscribed than that of Article $\mathrm{XX}(\mathrm{j})$ of GATT- $94 .{ }^{54}$

The Appellate Body also takes on the Chinese appeal about incongruence and incoherence about the statement that if there is no possibility for an existing shortage ever to cease to exist, it will not be possible to relieve or prevent it through a temporary export restriction. The point is made since the Panel recognized before the possibility of alleviating or eliminating shortages of an exhaustible natural resource, as a result of advances in reserve detection or extraction techniques, or even that new technology or conditions might lessen demand. ${ }^{55}$ However, the Appellate Body maintains the Panel's view since the interpretation referred to an "if-condition" statement; when there is no possibility for an existing shortage ever to cease to exist. ${ }^{56}$

51 WORLD TRADE ORGANIZATION. China: measures related to the exportation of rare earths, Tungsten, and Molybdenum. WT/DS394/DS395/DS398/R, 05 jul. 2011. paragraph 7.294-7.296.

52 WORLD TRADE ORGANIZATION. China: measures related to the exportation of rare earths, Tungsten, and Molybdenum. WT/DS394/DS395/DS398/R, 05 jul. 2011. paragraph 7.297.

53 WORLD TRADE ORGANIZATION. China: measures related to the exportation of rare earths, Tungsten, and Molybdenum. WT/DS394/DS395/DS398/AB/R, 30 jan. 2012. paragraph 324.

54 WORLD TRADE ORGANIZATION. China: measures related to the exportation of rare earths, Tungsten, and Molybdenum. WT/DS394/DS395/DS398/AB/R, 30 jan. 2012. paragraph 325.

55 WORLD TRADE ORGANIZATION. China: measures related to the exportation of rare earths, Tungsten, and Molybdenum. WT/DS394/DS395/DS398/AB/R, 30 jan. 2012. paragraph 342.

56 WORLD TRADE ORGANIZATION. China: measures related to the exportation of rare earths, Tungsten, and Molybdenum.
Karapinar disapproves the Appellate Body upholding on the grounds that the Panel "was referring to a factual situation in relation to the very nature of exhaustible natural resources, namely their inevitable exhaustion, drawing a crucial conclusion that an export restriction would not relieve or eliminate their shortage in supply". The Panel conclusion would be incoherent once disregarding the idea of relative scarcity remediable - and looking only at absolute scarcity. ${ }^{57}$

The Panel, in Rare Earths does not develop the issue. As already pointed out in relation to temporarily and essential, it just refers to what the Appellate Body had said in Raw Materials. ${ }^{58}$

\subsubsection{Intermediate remarks}

Once the legal limits of Article XI:2(a) of GATT94 are disclosed, it appears to accommodate industrial policies dealing with natural resources; nonetheless, its utilization is circumscribed by time (temporarily), substantive (essential), and circumstantial limits (prevent or relieve shortages) sculpted by the jurisprudence.

Indeed, if in Raw Materials the term industrial policy is not found either in the Panel's or the Appellate Body's reports, in Rare Earths it appears at least thirty times in relation to export quotas. Moreover, the Panel not only admits Members rights to pursue industrial policies. ${ }^{59}$ It also acknowledges that "the GATT 1994 and other WTO covered agreements generally allow Members to adopt measures in pursuit of their industrial policy needs, and even recognize that, in certain circumstances, Members' industrial policy needs, and especially the imperative to protect vulnerable domestic industries, can override GATT obligations". ${ }^{60}$ Article XI:2(a) of GATT-94 is accordingly one of these circumstances.

WT/DS394/DS395/DS398/AB/R, 30 jan. 2012. paragraph 343.

57 KARAPINAR, Baris. Defining the legal boundaries of export restrictions: a case law analysis. Journal of International Economic Law, Oxford, v. 15, n. 2, p. 443-479, jun. 2012. p. 13-14.

58 WORLD TRADE ORGANIZATION. China: measures related to the exportation of rare earths, Tungsten, and Molybdenum. WT/ DS431/DS432/DS433/R, 26 mar. 2014. paragraph 7.453.

59 WORLD TRADE ORGANIZATION. China: measures related to the exportation of rare earths, Tungsten, and Molybdenum. WT/ DS431/DS432/DS433/R, 26 mar. 2014. paragraph 7.613, 7.804, 7.819, and 7.829.

60 WORLD TRADE ORGANIZATION. China: measures related to the exportation of rare earths, Tungsten, and Molybdenum. WT/ DS431/DS432/DS433/R, 26 mar. 2014. paragraph 7.453. 


\subsection{Export duties and article XI of the GATT-94}

Assume now that a Member imposes export duties on natural resource as part of its industrial policy to increase inputs for domestic markets. Would that measure be consistent under WTO Law?

The Panel report, in Raw material, may be understood as drawing two categories of Members at the WTO concerning the different regulatory space available to them to apply export duties. In the first (original membership and those whose terms of their accession protocols allows export duties), the space would be larger without prohibitions to use export duties. That discretion comes from the plain disposition of Article $\mathrm{XI}$ which excludes duties, taxes or other charges from its scope from its application. The second group would encompass acceding Members with specific export duties obligations in their Protocol of Access, such as China, in the paradigmatic cases. ${ }^{61}$

To the Panel, because of paragraph 11.3 of China's Accession Protocol (CAP), China would be constrained on the use of export duties. Importantly, it would also be limited to resort of GATT general exceptions, such as Article XX of the GATT-94. ${ }^{62}$ The Panel mindfully makes this distinction and asserts that the situation created by this interpretation, if solely taken, is imbalanced. However, the Panel affirms that cannot find in the CAP, or in any other part, legal ground to interpret paragraph 11.3 of $\mathrm{PAC}$ as allowing resort to Article XX of the GATT-94. ${ }^{63}$

The Appellate Body analyses in detail a handful of objections placed on: the terms of paragraph 11.3 of $\mathrm{PAC}^{64}$; the reference made to Annex 6 of the PAC (a list of products on which export duties could be applied); ${ }^{65}$ the reference made to Article VIII of the

61 WORLD TRADE ORGANIZATION. China: measures related to the exportation of rare earths, Tungsten, and Molybdenum. WT/DS394/DS395/DS398/R, 05 jul. 2011. paragraph 7.160.

62 Paragraph 11.3 of CAP: "China shall eliminate all taxes and charges applied to exports unless specifically provided for in Annex 6 of this Protocol or applied in conformity with the provisions of Article VIII of the GATT 1994."

63 WORLD TRADE ORGANIZATION. China: measures related to the exportation of rare earths, Tungsten, and Molybdenum. WT/DS394/DS395/DS398/R, 05 jul. 2011. paragraph 7.160.

64 WORLD TRADE ORGANIZATION. China: measures related to the exportation of rare earths, Tungsten, and Molybdenum. WT/DS394/DS395/DS398/AB/R, 30 jan. 2012. paragraph 279.

65 WORLD TRADE ORGANIZATION. China: measures related to the exportation of rare earths, Tungsten, and Molybdenum.
GATT; ${ }^{66}$ the right of China to regulate trade in light of environmental and public health considerations; among others. ${ }^{67}$ However, it upholds the Panel's decision for the absence of error in the interpretation. There would be no grounds in CAP, once a violation is found on the use of export duties, allowing the invocation of Article XX of the GATT-94. ${ }^{68}$

In China - Rare Earths, the Panel reenters the discussion on export duties, acknowledging the previous interpretation of the Appellate Body ${ }^{69}$. It recalls that, in 2012, China imposed export duties ranging from 5\% to $25 \%$ on 58 products of rare earths, 15 of tungsten, and 9 of molybdenum. As those products were not listed in Annex 6 of the CAP, the Panel points out the incompatibility of those measures with paragraph 11.3 of CAP. ${ }^{70}$

In an extended examination, the Panel reconsiders whether paragraph 11.3 of CAP is subject to further defense under Article XX of the GATT-94. ${ }^{71}$ Of core relevance, the Panel debates how to interpret silence in the PAC. Would the mere absence of reference in paragraph 11.3 of CAP, to Article XX of the GATT-94, be enough to refrain its application? China and Brazil - the later as a third party - recall the US - Carbon Steel case to respond negatively:

the task of ascertaining the meaning of a treaty provision with respect to a specific requirement does not end once it has been determined that the text is silent on that requirement ... [s]uch silence does

WT/DS394/DS395/DS398/AB/R, 30 jan. 2012. paragraph 281.

66 WORLD TRADE ORGANIZATION. China: measures related to the exportation of rare earths, Tungsten, and Molybdenum. WT/ DS394/DS395/DS398/AB/R, 30 jan. 2012. paragraph 288-292.

67 WORLD TRADE ORGANIZATION. China: measures related to the exportation of rare earths, Tungsten, and Molybdenum. WT/ DS394/DS395/DS398/AB/R, 30 jan. 2012. paragraph 300-306.

68 WORLD TRADE ORGANIZATION. China: measures related to the exportation of rare earths, Tungsten, and Molybdenum. WT/ DS431/DS432/DS433/R, 26 mar. 2014. paragraph 300-307.

69 WORLD TRADE ORGANIZATION. China: measures related to the exportation of rare earths, Tungsten, and Molybdenum. WT/ DS431/DS432/DS433/R, 26 mar. 2014. paragraph 7.35-7.40.

70 WORLD TRADE ORGANIZATION. China: measures related to the exportation of rare earths, Tungsten, and Molybdenum. WT/ DS431/DS432/DS433/R, 26 mar. 2014. paragraph 7.48.

71 WORLD TRADE ORGANIZATION. China: measures related to the exportation of rare earths, Tungsten, and Molybdenum. WT/ DS431/DS432/DS433/R, 26 mar. 2014. paragraph 7.54. The analysis starts by resuming the reports of Raw materials, as well as mentioning a request from China to a preliminar assessment of the issue, though denied. 
not exclude the possibility that the requirement was intended to be included by implication. ${ }^{72}$

The Panel, nonetheless, finds parallels rather than discrepancy between US - Carbon Steel and China - Raw Materials since, amongst five depicted points, the texts in both cases do not make any express reference to the provisions of the text intended to be applied. ${ }^{7}$

The sensitiveness of this finding is made known in the Panel's conclusion. The Panel emphasizes the limited implications of its findings, "in terms of China being able to adopt and maintain measures to protect the environment and the life and health of its population". ${ }^{74}$ Truly, the conundrum leads to a separate opinion stating that the obligations of paragraph 11.3 of the CAP are subject to the general exceptions (Article $\mathrm{XX}$ ) of the GATT-94. Yet, the dissenting opinion also remarks that the measures would not survive the

72 WORLD TRADE ORGANIZATION. China: measures related to the exportation of rare earths, Tungsten, and Molybdenum. WT/ DS431/DS432/DS433/R, 26 mar. 2014. paragraph 7.66.

73 WORLD TRADE ORGANIZATION. China: measures related to the exportation of rare earths, Tungsten, and Molybdenum. WT/ DS431/DS432/DS433/R, 26 mar. 2014. The five coincident points are: first, they deal with treaty interpretation and they discuss whether a provision (paragraph 9 of Article 11(9) of SCM / article XX of the GATT-94) applies to another provision (article 21(3) of the SCM / paragraph 3.11 of the CAP), being negative the response (paragraph 7.67). Second, both analyses begin by searching the allegdly references to which resort is sought, being negative the answer (paragraph 7.68). Third, both cases consider the importance of using the technic of introducing references in the concerned agreements (paragraph 7.69). Fourth, they both dealt with the lack of a reference that is not observed in subsequente paragraphs (paragraph 7.70). Finally, both cases would have explained the necessity of establishing an overall equilibrium between the rights and obligations of Members and the WTO agrements would not offer specific orientation on thi (paragraph 7.71).The Panel also debates the Chinese argument about the systemic relation between the CAP and the GATT-94 (paragraph 7.73-7.99); the terms nothing in this agreement contained in the chapeau of Article XX of the GATT-94 (paragraph 7.100-7.104); and the objective and purpose of the WTO Agreements (paragraph 7.105-7.114), though the Panel does not change its view about the inapplicability of Article XX of the GATT in relation to paragraph 3.11 of the CAP. About the later, the Panel, at the same time, agrees with China that an interpretation that left sovereign States legally aisled from adopting measures to protect human, animal or plant life or health would be probably incompatible with the objective and purpose of the Agreement. However, it disagrees with China that this would be a consequence of the Appellate Body's decision in Raw Materials (paragraph 7.114). In this sense, the Panel had previously quoted that China, in any moment, presented arguments to support the assumption that export duties were the only tool and way to face environmental and public health issues (paragraph 7.113).

74 WORLD TRADE ORGANIZATION. China: measures related to the exportation of rare earths, Tungsten, and Molybdenum. WT/ DS431/DS432/DS433/R, 26 mar. 2014. paragraph 7.117. scrutiny of the standards of Article XX(b) of the GATT and the chapean of Article XX of the GATT-94.

In sum, it is clear that the regulatory space to apply export duties as part of an industrial policy on natural resources relates, to begin with, to the quality of the membership and the terms of the protocol of access, in case of an acceding Member. In the case of China, due to its protocol of accession, the conformation of this space is still under construction, considering the separate opinion and the current appeal on Rare earths.

\subsection{Export restraints (in various types) and the downstream industry exception: article $\mathrm{XX}(\mathrm{i})$ of the GATT-94}

Take for granted, at this point, export restraints applied out of the XI:2(a) contours as regards export quotas and duties. Would they be justified by other exceptions?

As introduced, along the Raw Materials dispute, China struggles to make use of the exception of conservation of exhaustible natural resources to justify the imposition of export duties on its refractory bauxite and fluorite. China suggests that Article XX $(\mathrm{g})$ of the GATT-94 shall be interpreted in a manner that recognizes the sovereign Member rights on their natural resources. Additionally, inter alia, China points out that these rights must be exercised in the social and economic interest of the Members. ${ }^{76}$ On the contrary, the US and Mexican submissions contend that China looks to incorporate the idea of exercising rights over natural resources in its own social and economic interest into the term preservation, altering the meaning of Article XX $(\mathrm{g})$.

It is precisely in the context of interpretation of $\mathrm{XX}(\mathrm{g})$ that Article XX(i) of the GATT-94 comes into

75 WORLD TRADE ORGANIZATION. China: measures related to the exportation of rare earths, Tungsten, and Molybdenum. WT/ DS431/DS432/DS433/R, 26 mar. 2014. paragraph 7.119. The separate opinion tries to define the nature of paragraph 11.3 of the CAP. Whether the paragraph is part of the GATT-94, if it should be interpreted and applied as part of the Marraquesh Agreement, per se, or part of the WTO Agreement, but out of GATT-94. It concludes that it is part of China's obligations in trade of products, by adding to basic obligations of the GATT-94 related to border obligations (paragraph 7.138). Thus, once one cannot find an express rebuttal of Article XX in the CAP, the general exception should be applied in relation to paragraph 11.3 of the CAP.

76 WORLD TRADE ORGANIZATION. China: measures related to the exportation of rare earths, Tungsten, and Molybdenum. WT/DS394/DS395/DS398/R, 05 jul. 2011. paragraph 7.364. 
play. ${ }^{77}$ Before that, the provision had never been dealt with in disputes. It is reported that the US and Mexico understand that the provision could be invoked to justify measures taken in the interest of downstream industry, provided that some conditions are met. ${ }^{78}$ Inadvertently, while taking on the Chinese case over Article XX $(\mathrm{g})$ of the GATT-94, which has well known standards, the complainants add a point that China had not even raised.

But once raised, the Panel refers to Article XX(i) as context to interpret Article $\mathrm{XX}(\mathrm{g})$, indicating that Article XX(i) takes care of situations in which exports restraints are applied to help the affected domestic industry. But even in this situation, the Panel recognizes, Article XX(i) "ensures consideration of the interests of foreign producers". ${ }^{79}$ The Panel, thus, finds symmetries to interpret both articles as part of a nondiscriminatory system. That is to say:

Article $\mathrm{XX}(\mathrm{g})$, which provides an exception with respect to 'conservation', cannot be interpreted in such a way as to contradict the provisions of Article XX(i), i.e., to allow a Member, with respect to raw materials, to do indirectly what paragraph (i) prohibits directly. In other words, WTO Members cannot rely on Article $\mathrm{XX}(\mathrm{g})$ to excuse export restrictions adopted in aid of economic development if they operate to increase protection of the domestic industry. ${ }^{80}$

However, it sounds hard to find non-discrimination as a point of symmetry between the two provisions. At the same time that the Panel acknowledges that Article XX(i) cannot be imposed to increase the protection of the domestic industry, ${ }^{81}$ it had previously

77 Article $\mathrm{XX}(\mathrm{i})$ of the GATT-94: "involving restrictions on exports of domestic materials necessary to ensure essential quantities of such materials to a domestic processing industry during periods when the domestic price of such materials is held below the world price as part of a governmental stabilization plan; Provided that such restrictions shall not operate to increase the exports of or the protection afforded to such domestic industry, and shall not depart from the provisions of this Agreement relating to non-discrimination".

78 WORLD TRADE ORGANIZATION. China: measures related to the exportation of rare earths, Tungsten, and Molybdenum. WT/DS394/DS395/DS398/R, 05 jul. 2011. paragraph 7.368.

79 WORLD TRADE ORGANIZATION. China: measures related to the exportation of rare earths, Tungsten, and Molybdenum. WT/DS394/DS395/DS398/R, 05 jul. 2011. paragraph 7.384.

80 WORLD TRADE ORGANIZATION. China: measures related to the exportation of rare earths, Tungsten, and Molybdenum. WT/DS394/DS395/DS398/R, 05 jul. 2011. paragraph 7.386.

81 WORLD TRADE ORGANIZATION. China: measures admitted that Article $\mathrm{XX}(\mathrm{i})$ operates as to protect domestic industries. Article XX(i) seems to be, indeed, intrinsically discriminatory.

The argument is mitigated in practice for the very specific circumstances that Article XX(i) applies. In dicta, the Panel, turning to the scope of Articles XI:2(a) and XX(i) recalls that Article XX(i) applies in instances where a government 'as part of a government stabilization plan' holds the price below a benchmark world price. ${ }^{82}$ This paper calls the attention thus to the potential difficulty to give meaning to Article XX(i) in a manner that conciliates explicit protection to the local processing industry with non-discrimination principles.

One can find support for this perception in debates about the GATT-47, just after its signature. In the 1950s, a Working Group (WG) was created with the specific mandate of exploring the GATT-47 provisions dealing with quantitative restrictions on exports and imports. As to the first, while analyzing the restrictions aiming at promoting the processing domestic industry, the WG affirms that:

the exemption of export restrictions associated with governmental stabilization plans contained in paragraph I (i) of Article XX [now Article XX(i)] might, in certain circumstances, be difficult to interpret, since a stabilization plan which maintains the domestic price at a level below the world price inevitably afford some advantage to the domestic industry; paragraph (i) refers to an increase in the protection afforded to the industry by the export restriction, but it may be difficult in practice to distinguish between the effects of the stabilization plan and the effects of the restriction. ${ }^{83}$

The WG concludes and adds that:

the Agreement [GATT-47] does not authorize the imposition of restrictions upon the export of a raw material in order to protect or promote a domestic industry, whether by affording a price advantage to that industry for the purchase of its materials, or by reducing the supply of such materials available to

related to the exportation of rare earths, Tungsten, and Molybdenum. WT/DS394/DS395/DS398/R, 05 jul. 2011. paragraph 7.386.

82 WORLD TRADE ORGANIZATION. China: measures related to the exportation of rare earths, Tungsten, and Molybdenum. WT/DS394/DS395/DS398/R, 05 jul. 2011. paragraph 7.277, footnote. 466.

83 GATT. Working party "D" on quantitative restrictions: draft report to the contracting Parties. GATT/CP.4/D/5/Rev. 1, 21 march 1950. paragraph 11. 
foreign competitors, or by other means. However, it was Agreed that the question of the objective of any given export restriction would have to be determined on the basis of the facts in each individual case. ${ }^{84}$

The issue is not reexamined on appeal in Raw Materials. In Rare Earths it comes out in the relation between Articles XX(g) and XX(i), and the Chinese arguments about the reach of its conservation programs, sovereignty over natural resources, and the management of resources supply. The Panel makes the point that the right of Members to "adopt 'conservation programmes' does not permit the exercise of boundless discretion such that WTO Members may adopt GATT-inconsistent measures as they see fit". It would not be allowed, for instance, that Members apply measures based on Article XX $(\mathrm{g})$ in "a way that achieves indirectly what other subparagraphs of Article XX, including Article XX(i), prohibit directly". ${ }^{8}$

As noted, Article XX(i) offers room for regulation as part of a stabilization plan. This seems to demand, as a consequence, some event that has wobbled a Member. Hardly, an "ordinary" industrial policy containing export restrictions in any form, but out of the context of a de-stabilization event, could fit the exception. But shall the event happen, the non-discriminatory standard suggested by the Panel does not instruct much on how to conciliate industry protection and nondiscrimination in the exception.

\subsection{Export restraints and the general and local shortage exception conditioned by the equity partition obligation: article XX(j) of the GATT-94}

Finally, in accordance with Article $\mathrm{XX}(\mathrm{j})$ of the GATT-94, one must wonder about the design of measures that restrain exports in order to acquire or distribute products in general or local short supply; provided, inter alia, that these measures are consistent with the principle that all Member are entitled to an equitable share of the international supply of such products. Have the cases built on this provision? ${ }^{86}$

84 GATT. Working party " $D$ " on quantitative restrictions: draft report to the contracting Parties. GATT/CP.4/D/5/Rev. 1, 21 mar. 1950. paragraph 12 .

85 WORLD TRADE ORGANIZATION. China: measures related to the exportation of rare earths, Tungsten, and Molybdenum. WT/ DS431/DS432/DS433/AB/R, 07 ago. 2014. paragraph 7.269.

86 Article XX(i) of the GATT-94: "essential to the acquisition or distribution of products in general or local short supply; Provided that any such measures shall be consistent with the principle that
In Raw Materials, the debate on Article XX(j), similarly to what happened on Article XX(i), occurs in the interpretation context of Article $\mathrm{XX}(\mathrm{g})$. The European Union considers that the XX(j) exception, in the light of its equity share precept, would offer context of interpretation to the impartiality or even-handedness prescription found in Article XX $(\mathrm{g}){ }^{87}$ The Appellate Body, on its turn, makes use of the exception as the context to interpret Article XI:2(a), not Article XX(g). It refers specifically to the shortage issue. While the shortage of Article XI:2(a) is qualified by critical, Articles $\mathrm{XX}(\mathrm{j})$ 's shortage do not receive the same adjective; as a result, the shortage, in the contours of Article XI:2(a) would be more narrowly defined than that from Article $\mathrm{XX}(\mathrm{j}) .^{88}$

In Rare Earths, once more, the dialogue on Article $\mathrm{XX}(\mathrm{j})$ is indirect and related, initially, to Article $\mathrm{XX}(\mathrm{g})$ requirement of even-handedness. But differently from the Panel in Raw Materials, the Panel understands that the equity share precept does not contribute as context to interpret Article XX(g). The Panel makes two arguments: "the fact that the concept of equity is explicitly invoked in Article XX(j) of the GATT 1994 but is not used in Article XX $(\mathrm{g})$ leads to the Panel to conclude that this concept is not directly relevant in interpreting subparagraph (g)". Secondly, equity would not offer further orientation to the interpretation of even-handedness in Article XX $(\mathrm{g}) .{ }^{89}$

Along the analysis about the application of the chapean of Article XX, a little more on the history of Article XX(i) comes out. The Panel refers to the

all contracting parties are entitled to an equitable share of the international supply of such products, and that any such measures, which are inconsistent with the other provisions of the Agreement shall be discontinued as soon as the conditions giving rise to them have ceased to exist. Members shall review the need for this subparagraph not later than 30 June 1960." In the search made (July of 2014), the author has not found the referred examination.

87 This paper refers to prescription, since impartiality is a case law concept that arises for the first time in the Appellate Body report in US - Gasoline. The Appellate Body name impartiality the text of Article $\mathrm{XX}(\mathrm{g})$, in fine, "measures are made effective in conjunction with restrictions on domestic production or consumption". WORLD TRADE ORGANIZATION. China: measures related to the exportation of rare earths, Tungsten, and Molybdenum. WT/ DS394/DS395/DS398/R. 05 jul. 2011. paragraph 7.390.

88 WORLD TRADE ORGANIZATION. China: measures related to the exportation of rare earths, Tungsten, and Molybdenum. WT/DS394/DS395/DS398/AB/R, 30 jan. 2012. paragraph 325.

89 WORLD TRADE ORGANIZATION. China: measures related to the exportation of rare earths, Tungsten, and Molybdenum. WT/ DS431/DS432/DS433/AB/R, 07 ago. 2014. paragraph 7.323. 
summary of a meeting held in 1965 that tells the drafting circumstances of the provision: severe shortages caused by war and other emergencies. ${ }^{90}$ All of these would confirm that Article XX(j) should not be used as context to interpret Article XX $(\mathrm{g})$. Moreover, taken Articles XI:2, XIII (Non-Discriminatory Administration of Quantitative Restrictions), XXVIII (Modification of Schedules), and Article XX(i) of the GATT-94 together, the objective of the WTO rules would come clear on the table: "the overarching goal or concern [...] is to reduce distortion in trade flows caused by such restrictions and ensure that Members maintain the irrelative position vis-àvis each other with respect to their market shares and access to goods and materials". ${ }^{11}$

Similarly to the conclusions on Article $\mathrm{XX}(\mathrm{i})$, Article XX(j) seems to offer regulatory space for export restraints in very peculiar circumstance: the first, as part of a stabilization plan; the latter, as the drafting history indicates, in case of severe shortages caused by war and other emergencies. ${ }^{92}$ Industrial policies would barely be encompassed by the exception.

\section{Final remarks}

This paper aimed at exploring the legal boundaries for Members to adopt export restraint measures in

90 WORLD TRADE ORGANIZATION. China: measures related to the exportation of rare earths, Tungsten, and Molybdenum. WT/ DS431/DS432/DS433/AB/R, 07 ago. 2014. paragraph 7.359, footnote 551 .

91 WORLD TRADE ORGANIZATION. China: measures related to the exportation of rare earths, Tungsten, and Molybdenum. WT/ DS431/DS432/DS433/AB/R, 07 ago. 2014. paragraph 7.359.

92 Though, nowadays, one still can question it's raison d'être in the face of Article XXI (Security Exceptions) broader prescription. the context of industrial policies related to natural resources, without resorting to environmental or public health arguments. As observed, history is cyclic and the subject reemerges in two paradigmatic cases: China Raw materials and China - Rare earths.

On the menu of regulatory measures, and without any judgment about their economic wisdom, there are certainly other alternatives out (e.g. regulation of concession, royalties etc.) and within the WTO (e.g. export licensing) that may serve industrial policy objectives. Indeed, once a measure is chosen based on trade regulation as a way to promote domestic processing of higher value added products and increase of supply in local markets, inevitably, the debate shifts to the WTO arena.

The cases then become relevant to delineate the limits of these measures. Besides the higher discretion left to most of the Members to apply export duties ${ }^{93}$, the latest interpretation on Articles XI: 2(a), XX(i) and XX(j) of the GATT-94 points out to much less maneuver: in the first case, because of time (temporarily), substantive (essential), and circumstantial limits (prevent or relieve shortages) shaped by the cases; as to others, for the peculiar circumstances of stabilization plans and international emergency, respectively.

The polemic about the application of general exceptions in case of the wording of protocol accession remains open. With the current appeal on Rare earth, the relationship can be further clarified.

93 One could still wonder whether export duties would, in some circumstances, amount to a Non-Violation Complaints of the Type Described in Paragraph 1(b) of Article XXIII of GATT 1994. 


\section{References}

CONDON, Bradly. Comentario sobre China: materias primas: informe del órgano de apelación. Revista de Derecho Económico Internacional, Local, v. 2, n. 2, 2012.

ERLICHMAN, Howard. Conquest, tribute and trade: the quest for precious metals and the birth of globalization. New York: Prometheus, 2010.

GATT. Working party " $D$ ” on quantitative restrictions: $\mathrm{draft}$ report to the contracting Parties. GATT/CP.4/D/5/ Rev. 1, 21 mar. 1950.

GODD, Walter. Dictionary of trade policy terms. 4. ed. London: CUP, 2002.

JAMASMIE, Cecilia. Mexico's Government to Fund Rare Earth Exploration. Mining.com, 23 mai 2014. Available at: <http://www.mining.com/mexicos-governmentto-fund-rare-earth-exploration-95877/>. Last access on: 27 jul. 2014.

KARAPINAR, Baris. Defining the legal boundaries of export restrictions: a case law analysis. Journal of International Economic Law, Oxford, v. 15, n. 2, p. 443-479, jun. 2012.

KELLENBENZ, Hermann. The rise of the european economy: an economic history of Continental Europe 1500-1750. London: HM, 1976.

KORINEK, Jane; KIM, Jeonghoi. Export restrictions on strategic raw materials and their impact on trade. OECD Trade Policy Working Papers, n. 95, 29 mar. 2010.

LIU, Han-Wei; MAUGHAN, John. China's rare earth export quotas: out of the China-Raw material gate, but past the WTO's finish line? Journal of International Economic Law, Oxford, v. 15, n. 4, p. 971-1005, dec. 2012.
NASCIMENTO, Marco Antônio Alcântara. Restrições às exportações no sistema multilateral de comércio: reflexões sobre desenvolvimento, soberania e liberalização do comércio. 2014. 224f. Dissertation (Master's Degree) - Programa de Mestrado e Doutorado em Direito, Centro Universitário de Brasília, Brasília, 2014.

RIBEIRO, G. F. Restrições à exportação de matériasprimas, multilateralismo e implicações para o Brasil. Pontes: informações e análises sobre comércio e desenvolvimento sustentável, v. 8, n. 3, p. 12-14, jun. 2012.

SERRA, Osvaldo Antonio. Rare earths: Brazil x China. Journal of Brazilian Chemical Society, São Paulo, v. 22, n. 5, p. 811-812, mai 2011.

UNITED NATIONS. E/PC/T/C.II/54, 16 nov. 1946.

WORLD TRADE ORGANIZATION. China: measures related to the exportation of rare earths, Tungsten, and Molybdenum. WT/DS394/DS395/ DS398/R, 05 jul. 2011.

WORLD TRADE ORGANIZATION. China: measures related to the exportation of rare earths, Tungsten, and Molybdenum. WT/DS394/DS395/ DS398/AB/R, 30 jan. 2012.

WORLD TRADE ORGANIZATION. China: measures related to the exportation of rare earths, Tungsten, and Molybdenum. WT/ DS431/DS432/ DS433/R, 26 mar. 2014.

WORLD TRADE ORGANIZATION. China: measures related to the exportation of rare earths, Tungsten, and Molybdenum. WT/ DS431/DS432/ DS433/AB/R, 07 ago. 2014. 


\title{
O problema da espionagem econômica internacional: seria a Organização Mundial do Comércio o foro adequado para sua apreciação?
}

\author{
International economic espionage: Is the World \\ Trade Organization the proper forum for addressing \\ the problem?
}

\author{
Humberto A.Vasconcelos Lima** \\ Naiana Magrini Rodrigues Cunha***
}

\section{Resumo}

Valendo-se dos eventos que revelaram o programa de espionagem econômica cibernética conduzida pela China sobre os Estados Unidos, este trabalho tem por objetivo analisar criticamente, sob uma ótica puramente normativa, uma das soluções sugeridas para dirimir o problema, qual seja, submeter a questão ao Órgão de Solução de Controvérsias da Organização Mundial do Comércio (OMC). Para tanto, neste estudo se analisa a relação que se estabelece entre atividades de espionagem econômica e propriedade intelectual, e posteriormente entre esta e o comércio internacional. Posteriormente, o mérito da questão é enfrentado, quando se verifica conclusivamente que o sistema de solução de controvérsias da OMC comporta analisar atos de espionagem econômica entre membros caso haja violação direta ao artigo 39 do acordo TRIPS convertida em uma distorção concreta ao comércio internacional. A contribuição do trabalho consiste na crítica e reconstrução de conclusões extraídas em estudos anteriores a respeito do mesmo tema.

Palavras-Chave: Organização Mundial do Comércio. Espionagem econômica. Segredo de empresa. Propriedade intelectual.

\section{Abstract}

Taking, as a referential, the events that revealed China's economic cyber espionage program conducted over the United States, this work aims to analyze critically and from a purely normative perspective, one of the suggested alternatives to solve the problem: submit the matter to the Dispute Settlement Body of the World Trade Organization (WTO). To undertake this task, this study analyzes the relationship established between economic espionage activities and intellectual property, and subsequently between intellectual property rights and international trade. Later, the central question is faced, and we have concluded that the dispute settlement system of the WTO have the power to analyze acts of economic espionage between WTO members provided that a direct violation of Article 39 of the TRIPS agreement be converted into a concrete distortion on international trade. The contribution of this work consists in a critique and reconstruction of the conclusions reached in previous studies about the same subject matter.

Keywords: World Trade Organization. Economic espionage. Trade secret. Intellectual property.

*** Graduanda em Direito pela UFMG e Bolsista do CNPq, naianamagrinir@ gmail.com.
* Recebido em 09.19.2014

**Doutorando em Direito Internacional pela UFMG e Mestre em Inovação e Propriedade Intelectual pela UFMG, humbertoavlima@gmail.com. 


\section{Introdução}

Em outubro de 2011 o Office of The National Counterintelligence Executive encaminhou ao Congresso estadunidense relatório intitulado "Foreign Spies Stealing US Economic Secrets in Cyberspace". O documento alertava que tecnologias e informações econômicas sensíveis dos Estados Unidos eram alvo constante de espionagem estrangeira, principalmente conduzida pela China caracterizada no relatório como "Persistente Coletora" - e pela Rússia.

Reconhecendo as ameaças, o executivo estadunidense publica, em fevereiro do ano de 2013, o estudo "Administration Strategy on Mitigating the Theft of U.S. Trade Secrets" (Estratégia da Administração na Mitigação do Roubo de Segredos Comerciais dos Estados Unidos). ${ }^{2}$ Uma extensa lista de casos criminais que envolveram obtenção ilícita de segredo de empresa por chineses em companhias privadas (por exemplo: Dupont, General Motors, Ford, Cargill) e setores do governo dos Estados Unidos é anexada ao documento.

Evidências mais concretas permitiram associar a origem de atos de ataque cibernético ao território chinês. Uma companhia privada de segurança cibernética norte-americana, Mandiant, por conseguir rastrear a fonte de atividades de ciberespionagem com alvo nos Estados Unidos até instalações militares do Exército de Libertação Popular em Xangai (especificamente na “unidade 61398”- 61398部队), apresentou em relatório dados consistentes que permitiram concluir que o governo chinês conduz programas de ciberespionagem comercial. ${ }^{4}$ Setores estratégicos da economia norte-

1 OFFICE OF THE NATIONAL
COUNTERINTELLIGENCE EXECUTIVE (ONCIX). Foreign spies stealing US economic secrets in cyberspace: report to Congress on foreign economic collection and industrial espionage, out. 2011. Available at: <http://www.ncix.gov/publications/reports/fecie_ all/Foreign_Economic_Collection_2011.pdf $>$ Last access on: 09 aug. 2014. p. 1-5.

2 EXECUTIVE OFFICE OF THE PRESIDENT OF THE UNITED STATES. Administration strategy on mitigating the theft of U.S. trade secrets, feb. 2013. Available at: <http://www.whitehouse.gov/ sites/default/files/omb/IPEC/admin_strategy_on_mitigating_ the_theft_of_u.s._trade_secrets.pdf> Last access on: 09 aug. 2014.

3 EXECUTIVE OFFICE OF THE PRESIDENT OF THE UNITED STATES. Administration strategy on mitigating the theft of U.S. trade secrets, feb. 2013. Available at: <http://www.whitehouse.gov/ sites/default/files/omb/IPEC/admin_strategy_on_mitigating_ the_theft_of_u.s._trade_secrets.pdf> Last access on: 09 aug. 2014. Cf. o anexo do documento: "Summary of Department of Justice Economic Espionage and Trade Secret Criminal Cases".

4 MANDIANT. ATP1: exposing one of China's cyber espionage Units, 2013. Available at: <http://intelreport.mandiant. americana foram, segundo o relatório, alvos da espionagem chinesa, tais como empresas de jornalismo (The Wall Street Journal, The New York Times, Bloomberg), empresas de tecnologia (Google, Adobe, Yahoo), e a Coca-Cola. O então Diretor da National Security Agency (NSA), o General Keith Alexander, afirmou em 2012 que estes eventos representam a maior transferência de riqueza da história 5 . É importante considerar ainda os riscos que esse tipo de atividade implica para a segurança estadunidense, quando se sabe que empresas terceirizadas do ramo de defesa, como a Lockheed Martin, também foram alvo desses ataques.

Diante da massiva quantidade de evidências - em alguns casos provas diretas - da espionagem estatal chinesa, a reação do governo Obama para lidar com o problema evoluiu de medidas diplomáticas ${ }^{7}$, para o campo jurídico, quando cinco oficiais do exército chinês foram acusados perante o judiciário dos Estados Unidos por atos de ciberespionagem - a primeira vez que agentes de Estado estrangeiros foram acusados perante cortes do país por esse tipo de conduta, segundo o procurador-geral Eric Holder.

com/Mandiant_APT1_Report.pdf $>$ Last access on: 09 ago. 2014.

5 O General esclareceu que companhias norte-americanas perdem cerca de 250 bilhões de dólares por ano por "subtração" de propriedade intelectual, além de 114 bilhões perdidos anualmente com crimes cibernéticos. Cf. ROGIN, Josh. NSA chief: cybercrime constitutes the greatest transfer of wealth in history. Foreign Policy, 9 jul. 2012. Available at: <http://thecable.foreignpolicy.com/ posts/2012/07/09/nsa_chief_cybercrime_constitutes_the_ greatest_transfer_of_wealth_in_history> Last access on: 16 apr. 2014.

6 MANDIANT. ATP1: exposing one of China's cyber espionage Units, 2013. Available at: <http://intelreport.mandiant. com/Mandiant_APT1_Report.pdf> Last access on: 09 ago. 2014.

7 Negociações diplomáticas sobre a questão da ciberespionagem fracassaram em diálogos EUA-China que aconteceram em meados do ano de 2013. Cf. ROBERTS, Dan; GOLDENBERG, Suzanne. US-China summit ends with accord on all but cyber-espionage. The Guardian, 10 jun. 2013. Available at: <http://www.theguardian.com/ world/2013/jun/09/us-china-summit-barack-obama-xi-jinping > Last access on: 10 ago. 2014.

8 Os cinco oficiais chineses, Wang Dong, Sun Kailiang, Wen Xinyu, Huang Zhenyu, e Gu Chunhui, foram indiciados por um Grand Jury do Distrito Oeste da Pensilvânia com acusações associadas à ciberespionagem econômica, direcionadas contra as empresas Westinghouse, SolarWorld, U.S. Steel, ATI, USW e Alcoa Inc. Cf. THE UNITED STATES DEPARTMENT OF JUSTICE. U.S. charges five chinese military hackers for cyber espionage against U.S. corporations and a labor organization for commercial advantage, 19 mai 2014. Available $\quad$ at: <http://www.justice.gov/opa/pr/2014/May/14ag-528.html> Last access on: 10 aug. 2014. 
É fácil perceber que tais acusações guardam pretensões estritamente políticas ${ }^{9}$ pois uma condenação criminal dependeria da cooperação do governo chinês na extradição dos indiciados, o que não se espera que ocorra tendo em vista que suas autoridades negam enfaticamente ter patrocinado atividades de espionagem. Portanto, não se pretende que sejam solução efetiva para o problema. Por isso, paralelamente, o governo dos Estados Unidos considera outras opções. Vozes no congresso norte-americano ${ }^{10}$, na sociedade civil $^{11}$ e na academia $^{12}$ sugeriram que a adoção de uma medida mais grave consistiria em apresentar a questão da espionagem econômica chinesa ao Órgão de Solução de Controvérsias da Organização Mundial do Comércio (OMC).

Esse estudo tem por objetivo analisar a viabilidade jurídica dessa proposta, que será utilizada apenas como uma referência para a problematização; em outros termos: pretende verificar se as regras que regulamentam a solução de controvérsias, no âmbito da OMC, comportam a análise de demandas de tal natureza, não apenas no que se refere aos eventos de espionagem China-EUA. Não se pretende avaliar neste estudo, por outro lado, a viabilidade política de se apresentar consultas na OMC sobre matéria ligada à espionagem econômica, problema que conduziria a uma abordagem de outra natureza.

\section{Espionagem econômica, propriedade intelectual e comércio internacional}

Para que se possa responder à indagação "A OMC pode analisar casos de espionagem econômica entre Estados?", é preciso compreender o próprio sentido de se estabelecer a pergunta, ou seja, como há uma

9 Uma interessante análise dos reais objetivos das acusações pode ser lida em: CHABROW, Eric. The real aim of the U.S. indictment of chinese. Bank Info Security, 20 mai 2014. Available: $<$ http://www.bankinfosecurity.com/real-aim-us-indictmentchinese-a-6854/op-1> Last access on: 10 aug. 2014.

10 Em 22 de maio de 2014, o Senador Charles E. Schumer enviou uma carta ao U.S. Trade Representative, Michael Froman, solicitando que a questão da epsionagem econômica chinesa fosse apresentada à OMC. A carta pode ser lida em: < http:/ / www.schumer.senate.gov/ Newsroom/record.cfm?id=351779> Acesso em: 11 ago. 2014.

11 Cf. LEWIS, James A. Conflict and negotiation in cyberspace. Washington: Center for Strategic and International Studies, 2013. p. 49.

12 SKINNER, Christina Parajon. An international law response to economic cyber espionage. Connecticut Law Review, v. 46, n. 4, p. 1198-1199, 2014. associação teoricamente possível entre matéria comercial e atos de espionagem.

\subsection{Espionagem econômica como tema afeto à propriedade intelectual}

Uma primeira definição que se mostra relevante nessa tarefa é o conceito de espionagem com finalidades econômicas ou simplesmente "espionagem econômica". O conceito de espionagem não encontra definição técnica no Direito Internacional, mas pode ser ela compreendida como uma modalidade da atividade de inteligência de Estado. Por meio de agências especializadas, o Estado busca reunir informação relevante na maior quantidade e melhor qualidade possível, para que assim possa aprimorar seu processo decisório. ${ }^{13}$

Ocorre que os Estados não limitam suas atividades de inteligência apenas à utilização de mecanismos públicos e transparentes, exatamente por existirem informações que não podem ser obtidas por esse meio. Realmente, um serviço de inteligência que se limitasse à obtenção de informação pública se mostraria pouco relevante. Por essa razão, paralelamente, os Estados conduzem operações secretas de coleta de informações classificadas ou por outra forma ocultadas, no sentido de que são realizadas sem o conhecimento do público e, principalmente, do detentor da informação que a tem sob segredo. Ao fazê-lo, o Estado pratica espionagem, e nesse sentido é que pode-se dizer que a espionagem se apresenta como uma modalidade da inteligência, mais precisamente, uma forma clandestina de inteligência, qualificada pelo binômio (operação secreta de coleta + informação secreta a ser coletada).

O aparato de inteligência dos Estados pode ser voltado, então, sob a forma de espionagem, à obtenção de informações secretas de empresas ou órgãos públicos de outros Estados. Se esta informação for mantida sob segredo por razões econômicas estaremos diante de um segredo de empresa ${ }^{14}$, uma espécie de propriedade intelectual.

13 Sobre o papel das atividades de inteligência nas relações internacionais conferir: MCDOUGAL, Myres S.; LASSWELL, Harold D.; REISMAN, W. Michael. The intelligence function and world public order. Temple Law Quarterly, v. 46, n.3, p. 365-448, 1973.

14 Neste trabalho pressupõe-se que as expressões "segredo de empresa", "segredo de indústria", "segredo de comércio", "segredo de negócio", "segredo de fábrica", "trade secret", "informações confidenciais" (desde que com valor comercial), são sinônimas 
Explica-se: o detentor desse tipo de informação tem um interesse legítimo e juridicamente protegido em mantê-la sob segredo, pois, por possuir ela valor econômico, sua confidencialidade lhe garante vantagens concorrenciais. Pense-se, por exemplo, em uma empresa que desenvolve um novo combustível automotivo. Ela tem a opção, de um lado, de solicitar uma patente do produto - caso em que a tecnologia será publicada - e assim se beneficiar de um período limitado de exclusividade em sua exploração econômica ou mesmo licenciar, neste mesmo prazo, a tecnologia para concorrentes, como fonte de royalties. De outro lado, pode optar por manter a fórmula do combustível sob segredo de empresa indefinidamente e com isso auferir uma vantagem competitiva sobre outras empresas do mesmo setor enquanto for capaz de sustentar a confidencialidade, ou enquanto a mesma tecnologia não for desenvolvida por outros através de meios lícitos.

Sob esse espírito, no que diz respeito ao Direito Interno (por exemplo o do Brasil e o dos Estados Unidos), atos de espionagem econômica são proscritos, pois suas normas de proteção à concorrência desleal tutelam o segredo de empresa contra obtenções fraudulentas. Esse conjunto de normas geralmente carcaterizará como crime a exploração de informações confidenciais obtidas de forma clandestina. ${ }^{15}$

Todavia, quando se analisa a espionagem econômica a nível internacional, surgem dúvidas a respeito do alcance da proteção a segredos de empresas e sobre a maneira mais adequada de dirimir conflitos associados a tal tipo de atividade. Questiona-se: há uma proibição

e significam, conforme definido no Economic Espionage Act (EEA) dos Estados Unidos, de 1996, “[...] todas as formas e tipos de informação financeira, comercial, técnica, econômica ou de engenharia, incluindo-se padrões, planos, compilações, dispositivos de programa, fórmulas, desenhos, protótipos, métodos, técnicas, processos, procedimentos, programas ou códigos, tangíveis ou intangíveis, tanto estocado, quanto compilado ou memorizado, fisicamente, eletronicamente, graficamente, em fotografia, ou em escrita [...]". UNITED STATES OF AMERICA. Economic espionage act. Washington, 2 october 1996.

15 A Lei 9.279/96, a Lei Brasileira de Propriedade Industrial, tipifica como crime de concorrência desleal, em seu art. 195, incisos XI, XII, XIII e XIV, atos de divulgação, exploração ou utilização de segredos de empresa. BRASIL. Lei 9.279, de 14 de maio de 1996. Regula direitos e obrigações relativos à propriedade industrial. Disponível em: <http://www.planalto.gov.br/ccivil_03/leis/19279. htm>. Acesso em: 9 ago. 2014. no Direito Internacional de que Estados espionem uns aos outros com finalidades econômicas e, se sim, de onde vem essa proibição? Como resolver, juridicamente, casos de espionagem econômica entre Estados (como o caso China-EUA)?

Sabendo-se que espionagem econômica é tema relacionado à propriedade intelectual, possíveis respostas às perguntas acima propostas devem começar a ser construídas considerando-se as regras que disciplinam a propriedade intelectual a nível internacional. Essas regras foram ajustadas no acordo TRIPS (Trade-Related Aspects of Intellectual Property Rights) que é um dos instrumentos anexos ao GATT (General Agreement on Tariffs and Trade) de 1994, portanto, um sistema normativo da propriedade intelectual em um contexto maior de comércio internacional.

Logo, uma possível solução para o problema da espionagem econômica poderia residir na relação entre sistema internacional da propriedade intelectual e sistema do comércio internacional, que se consubstancia no acordo TRIPS. Entender o vínculo que existe entre esses dois domínios é essencial para evoluir na análise do problema.

\subsection{O vínculo entre propriedade intelectual $\mathrm{e}$ comércio internacional ${ }^{10}$}

Há uma relação material entre propriedade intelectual e comércio internacional que se estabelece quando a ausência de proteção à propriedade intelectual em determinado país representa uma barreira ao comércio de produtos originados de um segundo país em que esses direitos são protegidos. ${ }^{17}$ Isso ocorre porque produtos protegidos por propriedade intelectual naturalmente refletirão um preço mais elevado que produtos análogos que desempenham a mesma função mas não concentram os gastos com

16 Para uma análise detalhada do vínculo entre propriedade intelectual e comércio internacional conferir: LIMA, Humberto Alves de Vasconcelos. A construção do vínculo entre propriedade intelectual e comércio internacional e seus reflexos no Brasil. Revista Eletrônica Direito e Politica, v. 9, n. 2, 2014. Disponível em: < http:// www6.univali.br/seer/index.php/rdp/article/view/6033>. Acesso em: 9 ago. 2014.

17 MATSUSHITA, Mitsuo; SCHOENBAUM, Thomas J.; MAVROIDIS, Petros C. The World Trade Organization: law, practice and police. Oxford: Oxford University Press, 2006. p. 397. 
pesquisa e desenvolvimento, com criação de marca e com o patenteamento em relação ao que aqueles demandaram. Pense-se, por exemplo, em uma empresa canadense que desenvolva um medicamento inovador para o tratamento da hipertensão. $O$ preço desse medicamento irá refletir todos os gastos expendidos com a pesquisa e o desenvolvimento do composto, com a criação e registro da marca e com o patenteamento do produto (custos que aumentam em proporção direta ao número de países em que se pretende ver protegido o produto por propriedade intelectual). Agora suponhase que a empresa canadense pretenda vender seu produto em um país em que não são admitidas patentes sobre medicamentos. Ora, a empresa canadense não conseguirá competir com outras empresas que poderão produzir e comercializar o mesmo composto a preços inferiores, pois não precisarão amortizar os mesmos gastos que a primeira suportou.

Por perceberem essa relação, os países desenvolvidos - na posição de grandes exportadores de tecnologia e de produtos inovadores - buscaram inserir normas de proteção à propriedade intelectual no compromisso de liberação do comércio internacional, ao aprovarem o GATT de 1994 na Rodada de Negociações do Uruguai. Disto resultou a formalização do acordo TRIPS vínculo formal inédito entre propriedade intelectual e comércio internacional - ajustado no desejo de seus signatários de reduzir distorções e obstáculos ao comércio internacional, promover uma proteção eficaz e adequada dos direitos de propriedade intelectual e assegurar que as medidas e procedimentos destinados a fazê-los respeitar não se tornem, por sua vez, obstáculos ao comércio legítimo. ${ }^{18}$

$\mathrm{O}$ acordo TRIPS estabelece parâmetros mínimos de proteção à propriedade intelectual nas suas diversas modalidades (invenções, direitos de autor, marcas, indicações geográficas, desenho industrial, topografias de circuitos integrados, informações confidenciais e concorrência desleal), que devem ser aceitos pelos seus signatários (todos membros da OMC) e implementados por eles internamente em seus territórios. No que tange às informações confidenciais (ou segredos de empresa), o acordo TRIPS, em seu artigo 39, dispõe que detentores de informações secretas e de valor comercial terão a

18 ORGANIZAÇÃO MUNDIAL DO COMÉRCIO. Acordo sobre aspectos dos direitos de propriedade intelectual relacionados ao comércio, 1994. Disponível em: <http://www.fd.uc.pt/CI/CEE/OI/ OMC.GATT/OMC-Anexo_1C.htm>. Acesso em: 9 ago. 2014. Preâmbulo. possibilidade de evitar que informação legalmente sob seu controle seja divulgada, adquirida ou usada por terceiros, sem seu consentimento, de maneira contrária a práticas comerciais honestas. ${ }^{19}$

Sobre a invocação de tal regra, sustentam-se os principais argumentos que postulam a adequabilidade da submissão de litígios envolvendo espionagem econômica entre Estados ao Órgão de Solução de Controvérsias da OMC.

Estando demonstrado então que atividades de espionagem econômica dizem respeito à propriedade intelectual e que há um vínculo entre essa matéria e o comércio internacional, resta então enfrentar o problema central proposto no trabalho, que é o de verificar se o sistema de solução de controvérsias da OMC comporta a análise daquelas atividades.

\section{Espionagem econômica diante das normas do acordo TRIPS e do sistema de solução de controvérsias da OMC}

As normas e procedimentos sobre solução de controvérsias da OMC se aplicam a todos os acordos que compõem o GATT/1994 e ao acordo constitutivo da Organização (“Tratado de Marráquexe ${ }^{20 ")}$, como

19 Texto integral do artigo 39 do acordo TRIPS: "1. Ao assegurar proteção efetiva contra competição desleal, como disposto no Artigo 10bis da Convenção de Paris (1967), os Membros protegerão informação confidencial de acordo com o parágrafo 2 abaixo, e informação submetida a Governos ou a Agências Governamentais, de acordo com o parágrafo 3 abaixo. 2. Pessoas físicas e jurídicas terão a possibilidade de evitar que informação legalmente sob seu controle seja divulgada, adquirida ou usada por terceiros, sem seu consentimento, de maneira contrária a práticas comerciais honestas, desde que tal informação: (a) seja secreta, no sentido de que não seja conhecida em geral nem facilmente acessível a pessoas de círculos que normalmente lidam com o tipo de informação em questão, seja como um todo, seja na configuração e montagem específicas de seus componentes; (b) tenha valor comercial por ser secreta; e (c) tenha sido objeto de precauções razoáveis, nas circunstâncias, pela pessoa legalmente em controle da informação, para mantê-la secreta. 3. Os Membros que exijam a apresentação de resultados de testes ou outros dados não divulgados, cuja elaboração envolva esforço considerável, como condição para aprovar a comercialização de produtos farmacêuticos ou de produtos agrícolas químicos que utilizem novas entidades químicas, protegerão esses dados contra seu uso comercial desleal. Ademais, os Membros adotarão providências para impedir que esses dados sejam divulgados, exceto quando necessário para proteger o público, ou quando tenham sido adotadas medidas para assegurar que os dados sejam protegidos contra o uso comercial desleal." ORGANIZAÇÃO MUNDIAL DO COMÉRCIO. Acordo sobre aspectos dos direitos de propriedade intelectual relacionados ao comércio, 1994. Disponível em: < http://www.fd.uc.pt/CI/CEE/OI/OMC. GATT/OMC-Anexo_1C.htm>. Acesso em: 9 ago. 2014.

20 Optou-se pela grafia "Marráquexe" que é a recomendada para o português brasileiro. A palavra sem o acento agudo (Marraquexe) 
definido em seu Anexo 2 (Entendimento Relativo às Normas e Procedimentos sobre Solução de Controvérsias), Artigo 1 e Apêndice 1. Abrangem, portanto, o acordo TRIPS, de sorte que o órgão de solução de controvérsias é competente para apreciar litígios envolvendo propriedade intelectual. Com efeito, como observa John H. Jackson, "virtually every aspect of economic regulation and policy is touched upon at least potentially, if not actually [...]"21

Diante disso, é possível formular a seguinte premissa lógica: se um ato de espionagem econômica internacional viola uma ou mais normas do GATT, incluindo-se o acordo TRIPS, poderá ele ser objeto do sistema de solução de controvérsias da OMC. Note-se que isso não significa afirmar que somente poderão ser objetos do sistema de solução de controvérsias atos que violem diretamente normas do GATT. Com efeito, é possível que o órgão, atendidas algumas condições, aprecie condutas que não afetem diretamente obrigações do GATT, hipótese que será melhor analisada posteriormente.

\subsection{Atos de espionagem econômica violam obrigações assumidas no acordo TRIPS?}

Uma constatação que deve ser colocada antes da análise dessa questão é a de que não há norma no Direito Internacional positivo que proíba a prática da espionagem em tempos de paz $^{22}$, de forma genérica, entre os Estados. ${ }^{23} \mathrm{~A}$ ausência de qualquer tratado

é a utilizada no português oficial da União Europeia, enquanto as formas "Marrakech" e "Marraquesh" designam, respectivamente, a expressão no francês e no inglês.

21 JACKSON, John H. Sovereignty, the WTO and changing fundamentals of international law. Cambridge: Cambridge University Press, 2006. p. 135.

22 No que diz respeito à espionagem no contexto de um conflito armado internacional, a situação do espião está disciplinada no artigo 46 do Protocolo I Adicional às Convenções de Genebra de 1949 relativo à Proteção das Vítimas dos Conflitos Armados Internacionais. Afirma-se em seu item 1: “[...] o membro das forças armadas de uma Parte no conflito que cair em poder de uma Parte adversa enquanto se dedica a atividades de espionagem não terá direito ao estatuto de prisioneiro de guerra e poderá ser tratado como espião".

23 Cf. DEMAREST, Geoffrey B. Espionage in international law. Denver Journal of International Law and Policy, Glenn; YOO, John. Counterintuitive: intelligence operations and international law. Michigan Journal of International Law, v. 28, p. 625-638, 20062007; STONE, Julius. Legal problems of espionage in conditions of modern conflict. In: STANGER, Roland J. (Org.) Essays on espionage and international law. Athens: Ohio University Press, 1962. NORTH ATALNTIC TREATY ORGANIZATION. Tallin manual que proscreva a atividade é explicada em razão de que possuem os Estados interesses recíprocos em obter informações confidenciais uns dos outros. Ainda que cada qual possa fazê-lo com maior ou menor eficiência, a tolerância da prática contribuiria, em termos gerais e entre outras formas, para o monitoramento recíproco durante a execução de obrigações convencionais, especialmente em acordos de segurança global, exemplificativamente. ${ }^{24}$

É importante considerar ainda que o fato de os Estados se engajarem permanentemente em atividades de espionagem, não implica a conclusão de ter disso se derivado a formação de costume internacional que autorize a prática. Isso porque a perfeita configuração dessa fonte exige, além da verificação do elemento objetivo de generalidade da prática, o elemento subjetivo consubstanciado no reconhecimento do Estado de que a adoção de tal "postura" é obrigatória (opinio juris sive necessitatis). Comportamentos adotados pelos Estados, por qualquer outra razão que não seja a crença de se estar cumprindo com algo obrigatório perante o Direito Internacional, não geram costume internacional. ${ }^{25}$ No caso da espionagem, a evidência e a prática são adotadas por liberalidade e tolerância.

Se a espionagem, em sua forma genérica, mostrase como algo não proscrito pelo Direito Internacional, extrair automaticamente as mesmas conclusões para toda espécie de espionagem seria tarefa apressada e poderia conduzir a equívocos. Isso porque, no que se refere à espionagem econômica, como já afirmado anteriormente, há um dispositivo legal que possivelmente enquadraria a atividade, isso é, o art. 39 do acordo TRIPS (transcrito na seção 2.2$)^{26}$ que,

on the international law applicable to cyber warfare. Cambridge: Cambridge University Press, 2013. p 36; OPPENHEIM, Lassa. International law. 3. ed. London: Longmans, 1920. \455.

24 BAKER, Christopher D. Tolerance of international espionage: a functional approach. American University International Law Review, v. 19, n. 5, p. 1091-1113, 2003.

25 Como esclarece Malcolm Shaw, "The issue therefore is how to distinguish behaviour undertaken because of a law from behaviour undertaken because of a whole series of other reasons ranging from goodwill to pique, and from ideological support to political bribery. And if customary law is restricted to the overt acts of states, one cannot solve this problem". SHAW, Malcolm N. International law. 6. ed. Cambridge: Cambridge University Press, 2008. p. 75.

26 A única oportunidade em que o artigo 39 do TRIPS figurou em uma controvérsia apreciada na OMC foi na disputa DS 196, na qual os Estados Unidos questionavam dispositivos da legislação argentina que não conferiam proteção adequada às informações confidenciais relativas a testes prévios obrigatórios para comercialização de produtos farmacêuticos e químicos. Aqui 
ao impor uma obrigação aos membros de protegerem informação confidencial, em tese proibiria a prática de obtenção clandestina de segredo de empresa entre Estados.

Ocorre que as normas substantivas do acordo TRIPS foram construídas sob a ideia subjacente de que os parâmetros mínimos de proteção à propriedade intelectualaos quais devem os membros da OMCadequar sua legislação interna impõem-se territorialmente. Em regra, não destinam obrigações internacionais a serem adimplidas extraterritorialmente, como defende David Fidler:

One reason why WTO members have not used the WTO is the difficulty of formulating claims that economic espionage violates WTO agreements. WTO rules create obligations for WTO members to fulfill within their territories and do not generally impose duties that apply outside those limits. WTO members that covertly obtain intellectual property of nationals of other WTO members operating in their territories could violate WTO obligations to protect such property. However, the economic espionage of greatest concern-and especially acts of remotely conducted economic cyber espionage-involves governments obtaining information from private-sector companies located outside their territories. ${ }^{27}$

Reforçando a mesma ideia em outro texto, afirma o autor:

Nothing in the WTO generally or TRIPS specifically mandates that China (or any other WTO member) protect commercially valuable information found in the territories of other countries. TRIPS does not require WTO members to prohibit their nationals or companies from engaging in corporate espionage inside foreign nations, nor does TRIPS regulate governmentled economic espionage within other countries. Thus, the US cannot claim that China is violating TRIPS

se aplica o item 3 do artigo 39 do TRIPS, não havendo, no caso, qualquer ocorrência concreta de violação à confidencialidade de segredo de empresa. Cf. WORLD TRADE ORGANIZATION. Argentina: certain measures on the protection of patents and test data, 2002. Available: <http://www.wto.org/english/tratop_e/ dispu_e/cases_e/ds196_e.htm> Last access on: 29 aug. 2014.

27 FIDLER, David. P. Economic cyber espionage and international law: controversies involving government acquisition of trade secrets through cyber technologies. American Society of International Law Insights, v. 17, n. 10, 20 mar. 2013. Available at: <http://www.asil.org/insights/volume/17/issue/10/economiccyber-espionage-and-international-law-controversies-involving $>$ Last access on: 25 aug. 2014. with respect to Chinese economic cyber espionage the US fears is most damaging to US economic and commercial interests. Or, put another way, China has not made commitments under the WTO regarding espionage it conducts outside its territory, meaning the US cannot claim breach of legal obligations that justifies countermeasures involving trade restrictions against China. ${ }^{28}$

Insurgindo-se contra esta ideia - a de que as obrigações do acordo TRIPS não exigem de um signatário respeito à propriedade intelectual que se encontra extraterritório - Christina Parajon Skinner sugere uma interpretação que atenda aos fins do acordo e favoreça sua operabilidade e eficácia, como se pode extrair das seguintes considerações:

If a member state's actions taken from within its territory infringe on another member state's intellectual property rights, should not the WTO rules apply? That the harm is done in cyber space seems a poor reason to limit application of the TRIPS Agreement, which was, in any event, negotiated before the rise of cyber threats to trade and intellectual property rights. After all, the general goals of the TRIPS Agreement, found in its preamble, are to "reduce distortions and impediments to international trade ... [and] promote effective and adequate protection of intellectual property rights." In short, to remain relevant, the WTO Agreements must consider the possibility of cyber violations. ${ }^{29}$

A princípio, poder-se-ia acreditar que a dificuldade que se apresenta é de natureza hermenêutica, isto é, as disposições de um tratado devem ser interpretadas em um sentido conjuntural, prezando-se pela coerência sistêmica do acordo ou deve-se buscar uma interpretação que favoreça sua eficácia? No caso em exame: deve ser o art. 39 do acordo TRIPS interpretado segundo o contexto do tratado, cujas cláusulas estabelecem, eminentemente, obrigações territoriais ou deve-se optar pela interpretação que resulte na aplicação do dispositivo, para que "continue relevante", em atenção à sua finalidade?

28 FIDLER, David. P. Why the WTO is not an appropriate venue for addressing economic cyber espionage. Arms Control Law, $11 \mathrm{feb}$. 2013. Available at: <http://armscontrollaw.com/2013/02/11/whythe-wto-is-not-an-appropriate-venue-for-addressing-economiccyber-espionage/> Last access on: 30 aug. 2014.

29 SKINNER, Christina Parajon. An international law response to economic cyber espionage. Connecticut Law Review, v. 46, n. 4, p. 1198-1199, 2014. p. 1197. 
Todavia, esta seria uma forma precipitada de se formular o problema. Com efeito, é preciso analisar se, realmente, a posição exposta por David Fidler segundo a qual as regras ajustadas no acordo TRIPS impõem obrigações substantivas eminentemente territoriais, de sorte que uma interpretação contextual de seu art. 39 desaconselharia sua aplicação a atos conduzidos extraterritorialmente - é uma conclusão válida.

Em verdade, a perplexidade diante da questão se deve, em grande parte, ao fato de os atos de espionagem econômica serem conduzidos remotamente, por meio do ciberespaço - o que permite que oficiais do exército chinês posicionados na China obtenham segredos de empresa alocados em servidores no território estadunidense. Nesse quadro, um conceito de natureza física como o de territorialidade não se adequa com exatidão aos problemas relacionados à espionagem cibernética $^{30}$; na verdade compromete, inclusive, sua adequada compreensão. Com efeito, o acordo TRIPS foi elaborado em um momento em que não era possível a condução remota de espionagem na mesma dimensão em que o é atualmente, de sorte que, hoje, interpretar da sua natureza a característica da territorialidade das obrigações poderia conduzir a verdadeiros absurdos. Tome-se, por exemplo, o princípio do tratamento nacional (art. 3, item 1, acordo TRIPS) que determina, como regra, que "Cada Membro concederá aos nacionais dos demais Membros tratamento não menos favorável que o outorgado a seus próprios nacionais com relação à proteção da propriedade intelectual". Interpretando o dispositivo conforme uma acepção territorial das obrigações do acordo TRIPS - como sugere David Fidler - deveríamos concluir, por exemplo, que a China estaria, pelo princípio do tratamento nacional, obrigada a respeitar e tutelar o segredo de empresa (que pode consistir, e.g., tanto em técnicas industriais quanto em informações de mercado consumidor) mantido por fábricas da Ford em território chinês, mas não o estaria igualmente obrigada em relação às informações mantidas em servidores posicionados em unidades da empresa nos Estados Unidos, podendo obtê-los via espionagem cibernética. Trata-se de um resultado inadmissível pois implicaria em discriminação de proteção fundada simplesmente

30 Sobre as peculiaridades da espionagem conduzida no ciberespaço, conferir: WILLIAMS, Robert D. (Spy) game change: cyber networks, intelligence collection, and covert action. The George Washington Law Review, v. 79, n. 4, p. 1162-1200, 2011. p. 1183. na posição física e geográfica do segredo, e poderia consistir, inclusive, em uma medida protecionista para a indústria local. Portanto, certamente não se pode afirmar que as normas do acordo TRIPS não exigem respeito à propriedade intelectual que esteja fora dos limites territoriais de um Estado signatário.

Poresse motivo, assiste razão à objeção formulada por Christina Skinner, afirmando que o acordo TRIPS deve ser aplicado às atividades de espionagem cibernética. Todavia, a extensão da aplicabilidade do art. 39 deve ser balizada exatamente por uma interpretação teleológica do acordo. Como demonstrado anteriormente, a própria existência do acordo TRIPS se justifica e está sujeita ao contexto maior do comércio internacional, pois tem como principal norteador o objetivo de "reduzir distorções e obstáculos ao comércio internacional". Não se pode nunca perder de vista a natureza e a razão de ser desse vínculo. Em atenção a tal orientação, uma interpretação teleológica do art. 39 do acordo TRIPS evidencia que o dispositivo somente deve ser aplicado a situações em que a informação confidencial está associada diretamente ao comércio internacional.

Logo, atividades de espionagem econômica cibernética apenas irão violar o art. 39 do Acordo TRIPS, e assim poder ser objeto do procedimento de solução de controvérsias da OMC, se conduzirem a distorções concretas no comércio internacional, sendo que a mera obtenção clandestina da informação não seria suficiente para configurar uma infração à regra. Não está se afirmando com isso, frise-se, que a mera obtenção de segredo de empresa por espionagem cibernética não seja ilícita (tal análise não é objeto do presente estudo); apenas que, caso não venham a se converter em violação a regras e princípios do comércio internacional não poderão ser apreciadas na OMC, o que não impede que sejam dirimidas em outros foros internacionais.

\subsection{0 órgão de solução de controvérsias da OMC poderia apreciar atividades de espionagem econômica como uma violação a costume internacional?}

Outro argumento construído por Christina Skinner é o de que atividades de espionagem econômica internacional violam o costume internacional de não intervenção, em razão da obrigação de respeito à "soberania econômica" dos Estados. Sem definir o conteúdo do alegado princípio de "soberania econômica", mas, propondo seu argumento com base 
nele, conclui posteriormente a autora que poderia o Órgão de Solução de Controvérsias da OMC apreciar atividades de espionagem econômica internacional. ${ }^{3}$

Não há dúvidas de que o Direito do Comércio Internacional é parte do Direito Internacional e, portanto, reconhece as mesmas fontes de direitos e obrigações, notadamente os tratados, o costume internacional e os princípios gerais de direito para mencionar apenas fontes arroladas no art. 38 do Estatuto da Corte Internacional de Justiça. Foram diversas as oportunidades em que o Órgão de Solução de Controvérsias da OMC buscou suporte em elementos do Direito Internacional para fundamentar suas decisões. No caso United States - Gasoline, em que Brasil e Venezuela questionaram determinadas regras ambientais da legislação norte-americana a respeito do comércio de gasolina, o Órgão de Apelação reconheceu que princípios costumeiros influenciavam a interpretação de tratados, fazendo constantes menções às regras de interpretação presentes na Convenção de Viena sobre o Direito dos Tratados entre Estados (1969) como formalização da prática costumeira. ${ }^{32}$ Outros casos expressam outros pontos da relação "Comércio Internacional-Direito Internacional", como por exemplo: Japan - Alcoholic Beverages ${ }^{33}$; Korea - Government Procurement e United States - EC Hormones, neste último havendo invocação do princípio geral da boa-fé. ${ }^{34}$

31 Afirma a autora: "Customary international law also supports an expanded notion of sovereignty, which includes a concept of economic sovereignty that protects private sector actors that contribute to the nation's economic security [...] The economic corollaries of sovereignty and non-intervention - in addition to the well-recognized requirement to comply with one's treaty obligations in good Faith — should therefore give rise to a cognizable claim that economic cyber espionage violates TRIPS. On this view, the WTO agreements would not exclude a claim of economic cyber espionage simply because the conduct "involves governments obtaining information from private-sector companies located outside their territories." Arguably, it would be contrary to both the letter and spirit of the WTO agreements to fail to recognize such a claim". SKINNER, Christina Parajon. An international law response to economic cyber espionage. Connecticut Law Review, v. 46, n. 4, p. $1187-$ 1188, 2014.

32 JACKSON, John H. Sovereignty, the WTO and changing fundamentals of international law. Cambridge: Cambridge University Press, 2006. p. 165-166.

33 JACKSON, John H. Sovereignty, the WTO and changing fundamentals of international law. Cambridge: Cambridge University Press, 2006. p. 167-168.

34 SKINNER, Christina Parajon. An international law response to economic cyber espionage. Connecticut Law Review, v. 46, n. 4, p. 1198-1199, 2014.
Logo, refletindo tal consideração para o objeto deste estudo, não haveria problemas em se invocar o costume internacional ou princípios gerais de Direito Internacional para fundamentar uma decisão do Órgão de Solução de Controvérsias da OMC. A questão que se apresenta, contudo, é de natureza mais complexa: o Órgão de Solução de Controvérsias poderia extrair do costume internacional ou dos princípios gerais de Direito Internacional, além de elementos para fundamentação de suas decisões, obrigações autônomas em relação ao GATT que vinculariam os membros da OMC? Poderia uma noção imprecisa como a de "soberania econômica" - cuja existência é por si só questionável - ser fonte autônoma de obrigações para um membro e perante a qual a espionagem econômica internacional seria uma atividade contrária?

É certo que, do ponto de vista de uma teoria geral do Direito Internacional, os costumes, os tratados e os princípios gerais de Direito Internacional são fontes de direitos e obrigações em igual peso, não havendo relação de hierarquia entre as normas que impõem uns e outros. ${ }^{35}$ Todavia, a questão não é saber se um membro da OMC está vinculado a determinado princípio ou costume internacional - no caso o princípio da "soberania econômica". Trata-se, na verdade, de saber se ao Órgão de Solução de Controvérsias foi conferida, pela vontade convergente dos Membros, competência para apreciar obrigações impostas além dos acordos do GATT.

Sem que seja necessário investigar a real existência ou mesmo a extensão de um possível princípio de "soberania econômica", a resposta à indagação é negativa, isto é, o costume internacional não pode gerar obrigações autônomas para membros da OMC sem qualquer suporte em uma regra expressa do GATT. Como já afirmado anteriormente, o sistema de solução de controvérsias da OMC tem um âmbito restrito de competência, que é o de apreciar controvérsias envolvendo aplicação dos acordos que compõem o GATT 1994 e o próprio acordo constitutivo da Organização. Uma controvérsia que

35 ZEMANEK, Karl. The legal foundations of the international system: general course on public international law. Boston: Nijhoff, 1997. (Hague Academy Collected Courses, 266). p. 132; SHAW, Malcolm N. International law. 6. ed. Cambridge: Cambridge University Press, 2008. p. 123-124. Observe-se que a assertiva contrária à hierarquia foi formulada levando-se em conta apenas os tratados, os costumes e os princípios gerais de Direito Internacional. Obviamente, a questão se torna mais complexa se forem consideradas as normas jus cogens e as obrigações erga omnes. 
se fundamentasse em uma obrigação extraída de um costume internacional, sem correspondência expressa em um desses acordos, extrapolaria a competência que os membros concordaram em conferir ao Órgão de Solução de Controvérsias e, portanto, não poderia ser ali dirimida. Com efeito, uma das finalidades do sistema de solução de controvérsias é proporcionar previsibilidade e segurança às relações comerciais multilaterais $^{36}$, de sorte que a imposição de uma obrigação extraída apenas do costume internacional a um membro da OMC não satisfaria tais prudentes orientações.

\subsection{Mecanismo de apreciação de reclamações em situações de não violação (Non-violation complaints)}

Foi afirmado anteriormente que bastava que um ato estatal violasse alguma das obrigações assumidas no GATT para, em tese, ser objeto do sistema de solução de controvérsias da $\mathrm{OMC}$, o que não significa dizer que somente condutas que afrontassem diretamente tais obrigações poderiam ser ali apreciadas.

Com efeito, reconhece-se que, por mais detalhados que possam ser, os acordos que compõem o GATT eventualmente não cobrirão, por suas regras positivadas, todas as situações que se revelem prejudiciais aos compromissos comerciais. Há, de fato, lacunas no sistema, que devem ser supridas com um parâmetro genérico de reclamações entre os Membros.

Dessa forma, enquadraria-se nesta hipótese a conduta de algum membro que, mesmo sem violar diretamente umas das obrigações expressas no GATT, frustrasse um dos objetivos da Organização ou seus compromissos comerciais. ${ }^{37} \mathrm{O}$ Estado que deseja se

36 É dito no art. 3, item 2, do Anexo 2 do Acordo Constitutivo da OMC (Entendimento Relativo às Normas e Procedimentos sobre Solução de Controvérsias): "O sistema de solução de controvérsias da OMC é elemento essencial para trazer segurança e previsibilidade ao sistema multilateral de comércio. Os Membros reconhecem que esse sistema é útil para preservar direitos e obrigações dos Membros dentro dos parâmetros dos acordos abrangidos e para esclarecer as disposições vigentes dos referidos acordos em conformidade com as normas correntes de interpretação do direito internacional público. As recomendações e decisões do OSC não poderão promover o aumento ou a diminuição dos direitos e obrigações definidos nos acordos abrangidos." ORGANIZAÇÃO MUNDIAL DO COMÉRCIO. Acordo Constitutivo da Organização Mundial do Comércio, 1994. Disponível em: <http://www.mdic.gov.br/arquivo/secex/ omc/acordos/portugues/02estabeleceomc.pdf $>$. Acesso em: 9 ago. 2014. Anexo 2.

37 WORLD TRADE ORGANIZATION. Legal basis for a dispute: valer desse procedimento deve, portanto, demonstrar que suas expectativas foram frustradas pelas ações adotadas por outro Estado-Membro ou por qualquer outra situação que existir que provoque consequências de mesma natureza. ${ }^{38}$

$\mathrm{O}$ artigo XXIII do GATT define as diretrizes deste mecanismo: uma parte contratante que considere que alguma vantagem a que tem direito em decorrência do acordo, direta ou indiretamente, esteja sendo anulada ou reduzida, ou de que a realização de algum objetivo do acordo esteja sendo impedida, poderá formular representações escritas ou recomendações à outra parte contratante interessada, desde que tais efeitos sejam decorrência de: (a) do não cumprimento por outra parte contratante dos compromissos por ela assumidos em virtude do acordo; (b) da aplicação por outras partes contratante de uma medida, contrária ou não às disposições do acordo; ou (c) da existência de qualquer outra situação. ${ }^{39}$

O artigo 64.2 do acordo TRIPS sinaliza a possibilidade do aludido mecanismo ser utilizado para controvérsias, envolvendo propriedade intelectual, ainda que sua utilização estivesse sujeita a um prazo de 5 anos contados da data de entrada em vigor do Acordo Constitutivo da OMC. ${ }^{40} 41$

Seria possível, portanto, que a utilização das nonviolation complaints consista em via adequada para apreciação, na OMC, de atos que importem em obtenção clandestina de segredo de empresa.

Note-se ainda que a prática da espionagem para fins econômicos pode consistir em medida de desequilíbrio em negociações haja vista que, através da atividade,

types of complaints and required allegations in GATT, 1994. Available at: $<$ http://www.wto.org/english/tratop_e/dispu_e/disp_settlement_ cbt_e/c4s2p2_e.htm> Last access on: 02 set. 2014.

38 WORLD TRADE ORGANIZATION. Trips: non violation complaints: background and current situations, 3 december 2009. Available at: <http://www.wto.org/english/tratop_e/trips_e/ nonviolation_background_e.htm > Last access on: 02 set. 2014.

39 WORLD TRADE ORGANIZATION. General agreement on tariffs and trade. Geneva, jul. 1986. Available at: <http://www.wto. org/english/docs_e/legal_e/gatt47_e.pdf >. Last access on: 2 set. 2014. art. XXIII.

40 ORGANIZAÇÃO MUNDIAL DO COMÉRCIO. Acordo sobre aspectos dos direitos de propriedade intelectual relacionados ao comércio, 1994. Disponível em: <http://www.fd.uc.pt/CI/CEE/OI/ OMC.GATT/OMC-Anexo_1C.htm>. Acesso em: 9 ago. 2014. art. 64.2.

41 SKINNER, Christina Parajon. An international law response to economic cyber espionage. Connecticut Law Review, v. 46, n. 4, p. 1198-1199, 2014. p. 1202-1203. 
uma das partes poderia ter acesso a informações sigilosas de valor comercial, o que poderia favorecêla, indevidamente, no processo de negociação. Nessa hipótese, como não haveria, a princípio, violação direta a qualquer das obrigações assumidas no acordo TRIPS, a utilização do mecanismo das reclamações em situação de não violação seria o mais adequado.

Ainda que teoricamente possível, é preciso reconhecer algumas exigências que dificultariam a utilização das non-violation complaints para atividades de espionagem econômica cibernética. Ao apresentar uma reclamação com base nesta cláusula, o Estado-Membro deve construir uma justificativa apta a demonstrar: a) a existência de uma medida adotada por outro EstadoMembro; b) a existência de um benefício decorrente do acordo em questão; c) que a medida adotada pelo outro Estado-Membro anule o benefício de que o reclamante poderia se valer, ou seja, um nexo de causalidade entre a medida e a perda do benefício. ${ }^{42}$

Como se observa, a construção de uma justificativa aceitável para o uso da cláusula teria que superar requisitos vagos e de difícil demonstração. As poucas decisões referentes a essa cláusula sugerem que $\mathrm{O}$ "benefício" é algo referente ao acesso a mercados externos e que a "anulação" consistiria num efeito adverso e em "frustação de expectativas razoáveis", devendo-se evidenciar a relação de causalidade entre aquele e esta, não apenas provando-se uma diminuição no volume comercial. ${ }^{43}$

Por fim, mesmo diante de uma possibilidade remota de que as non-violation complaints sejam uma via adequada para dirimir problemas relacionados à espionagem econômica, a utilização do mecanismo para matéria relativa à propriedade intelectual nunca foi utilizada pelos $\mathrm{Membros}^{44}$, e está sob moratória até dezembro

42 WORLD TRADE ORGANIZATION. Legal basis for a dispute: types of complaints and required allegations in GATT, 1994. Available at: $<$ http://www.wto.org/english/tratop_e/dispu_e/disp_settlement_ cbt_e/c4s2p2_e.htm> Last access on: 02 set. 2014.

43 MATSUSHITA, Mitsuo; SCHOENBAUM, Thomas J.; MAVROIDIS, Petros C. The World Trade Organization: law, practice and police. Oxford: Oxford University Press, 2006.

44 WORLD TRADE ORGANIZATION. Trips: non violation complaints: background and current situations, 3 december 2009. Available at: <http://www.wto.org/english/tratop_e/trips_e/ nonviolation_background_e.htm> Last access on: 02 set. 2014.
2015, em virtude de decisão adotada na Conferência Ministerial em 2013. ${ }^{45}$

\section{Conclusão}

As recentes e graves revelações sobre o programa de ciberespionagem econômica chinesa aconselham avaliação de medidas que podem ser adotadas para solucionar ou ao menos mitigar o problema. Nesse contexto, o estudo crítico da proposta de uma dessas medidas, qual seja, endereçar o problema à Organização Mundial do Comércio, revelou que há sim a possibilidade de que o Órgão de Solução de Controvérsias aprecie tais atividades, dentro de balizas específicas.

Em uma avaliação puramente normativa, conclui-se que a espionagem econômica entre Estados-Membros da OMC viola o art. 39 do acordo TRIPS desde que implique em distorções concretas no comércio internacional - em atenção à finalidade do acordo sendo que a mera obtenção clandestina da informação não seria suficiente para configurar uma infração à regra.

Por outro lado, a construção de um argumento "às margens" das obrigações expressamente assumidas em um dos acordos que compõem o GATT, sustentada unicamente no costume internacional ou nos princípios gerais de direito internacional, não seria teoricamente adequada, pois os membros da OMC conferiram competência restrita ao Órgão de Solução de Controvérsias para apreciar demandas que envolvam obrigações que os vinculem apenas nos limites dos acordos do comércio internacional.

Por fim, o mecanismo de reclamações em situação de não violação (non-violation complaints) é, em tese, uma via adequada para apreciar atividades de espionagem econômica entre os membros, mas desde que sejam satisfeitos todos os requisitos impostos para o acionamento desse mecanismo - notadamente a existência de algum benefício comercial que seja anulado por outro Membro - o que na prática se revela extremamente difícil de se configurar.

45 SKINNER, Christina Parajon. An international law response to economic cyber espionage. Connecticut Law Review, v. 46, n. 4, p. 1198-1199, 2014. p. 1201-1202. 


\section{Referências}

BAKER, Christopher D. Tolerance of international espionage: a functional approach. American University International Law Review, v. 19, n. 5, p. 1091-1113, 2003.

BRASIL. Lei 9.279, de 14 de maio de 1996. Regula direitos e obrigações relativos à propriedade industrial. Disponível em: <http://www.planalto.gov.br/ ccivil_03/leis/19279.htm>. Acesso em: 9 ago. 2014.

CHABROW, Eric. The real aim of the U.S. indictment of chinese. Bank Info Security, 20 mai 2014. Available: $<$ http://www.bankinfosecurity.com/real-aim-usindictment-chinese-a-6854/op-1> Last access on: 10 aug. 2014.

DEMAREST, Geoffrey B. Espionage in international law. Denver Journal of International Law and Policy, v. 24, n. 2, p. 321-348, 1996

EXECUTIVE OFFICE OF THE PRESIDENT OF THE UNITED STATES. Administration strategy on mitigating the theft of U.S. trade secrets, feb. 2013. Available at: <http://www.whitehouse.gov/sites/default/files/ omb/IPEC/admin_strategy_on_mitigating_the_ theft_of_u.s._trade_secrets.pdf $>$ Last access on: 09 aug. 2014.

FIDLER, David. P. Economic cyber espionage and international law: controversies involving government acquisition of trade secrets through cyber technologies. American Society of International Law Insights, v. 17, n. 10, 20 mar. 2013. Available at: <http://www.asil.org/insights/ volume/17/issue/10/economic-cyber-espionage-andinternational-law-controversies-involving $>$ Last access on: 25 aug. 2014.

FIDLER, David. P. Why the WTO is not an appropriate venue for addressing economic cyber espionage. Arms Control Law, 11 feb. 2013. Available at: <http:// armscontrollaw.com/2013/02/11/why-the-wto-is-notan-appropriate-venue-for-addressing-economic-cyberespionage/> Last access on: 30 aug. 2014.

JACKSON, John H. Sovereignty, the WTO and changing fundamentals of international law. Cambridge: Cambridge University Press, 2006.

LEWIS, James A. Conflict and negotiation in cyberspace. Washington: Center for Strategic and International Studies, 2013.
LIMA, Humberto Alves de Vasconcelos. A construção do vínculo entre propriedade intelectual e comércio internacional e seus reflexos no Brasil. Revista Eletrônica Direito e Politica, v. 9, n. 2, 2014. Disponível em: $<$ http://www6.univali.br/seer/index.php/rdp/article/ view/6033>. Acesso em: 9 ago. 2014.

MANDIANT. ATP1: exposing one of China's cyber espionage Units, 2013. Available at: <http://intelreport. mandiant.com/Mandiant_APT1_Report.pdf $>$ Last access on: 09 ago. 2014.

MATSUSHITA, Mitsuo; SCHOENBAUM, Thomas J.; MAVROIDIS, Petros C. The World Trade Organization: law, practice and police. Oxford: Oxford University Press, 2006.

MCDOUGAL, Myres S.; LASSWELL, Harold D.; REISMAN, W. Michael. The intelligence function and world public order. Temple Law Quarterly, v. 46, n.3, p. 365-448, 1973.

NORTH ATALNTIC TREATY ORGANIZATION. Tallin manual on the international law applicable to cyber warfare. Cambridge: Cambridge University Press, 2013

OFFICE OF THE NATIONAL COUNTERINTELLIGENCE EXECUTIVE (ONCIX).ForeignspiesstealingUS economicsecretsincyberspace: report to Congress on foreign economic collection and industrial espionage, out. 2011. p. 1-5. Available at: $<$ http://www.ncix.gov/publications/reports/fecie_all/ Foreign_Economic_Collection_2011.pdf $>$ Last access on: 09 aug. 2014.

OPPENHEIM, Lassa. International law. 3. ed. London: Longmans, 1920.

ORGANIZAÇÃO MUNDIAL DO COMÉRCIO. Acordo Constitutivo da Organização Mundial do Comércio, 1994. Disponível em: <http://www.mdic.gov.br/arquivo/ secex/omc/acordos/portugues/02estabeleceomc.pdf $>$. Acesso em: 9 ago. 2014.

ORGANIZAÇÃO MUNDIAL DO COMÉRCIO. Acordo sobre aspectos dos direitos de propriedade intelectual relacionados ao comércio, 1994. Disponível em: <http:// www.fd.uc.pt/CI/CEE/OI/OMC.GATT/OMCAnexo_1C.htm>. Acesso em: 9 ago. 2014. 
ROBERTS, Dan; GOLDENBERG, Suzanne. USChina summit ends with accord on all but cyberespionage. The Guardian, 10 jun. 2013. Available at: <http://www.theguardian.com/world/2013/jun/09/ us-china-summit-barack-obama-xi-jinping $>$ Last access on: 10 ago. 2014.

ROGIN, Josh. NSA chief: cybercrime constitutes the greatest transfer of wealth in history. Foreign Policy, 9 jul. 2012. Available at: $<$ http://thecable.foreignpolicy.com/ posts/2012/07/09/nsa_chief_cybercrime_constitutes_ the_greatest_transfer_of_wealth_in_history> Last access on: 16 apr. 2014.

SHAW, Malcolm N. International law. 6. ed. Cambridge: Cambridge University Press, 2008.

SKINNER, Christina Parajon. An international law response to economic cyber espionage. Connecticut Law Review, v. 46, n. 4, p. 1198-1199, 2014.

STONE, Julius. Legal problems of espionage in conditions of modern conflict. In: STANGER, Roland J. (Org.) Essays on espionage and international law. Athens: Ohio University Press, 1962

SULMASY, Glenn; YOO, John. Counterintuitive: intelligence operations and international law. Michigan Journal of International Law, v. 28, p. 625-638, 2006-2007

THE UNITED STATES DEPARTMENT OF JUSTICE. U.S. charges five chinese military hackers for cyber espionage against U.S. corporations and a labor organization for commercial advantage, 19 mai 2014. Available at:<http:// www.justice.gov/opa/pr/2014/May/14-ag-528.html> Last access on: 10 aug. 2014.
UNITED STATES OF AMERICA. Economic espionage act. Washington, 2 october 1996.

WILLIAMS, Robert D. (Spy) game change: cyber networks, intelligence collection, and covert action. The George Washington Law Review, v. 79, n. 4, p. 1162-1200, 2011.

WORLD TRADE ORGANIZATION. Argentina: certain measures on the protection of patents and test data, 2002. Available: <http://www.wto.org/english/ tratop_e/dispu_e/cases_e/ds196_e.htm $>$ Last access on: 29 aug. 2014.

WORLD TRADE ORGANIZATION. General agreement on tariffs and trade. Geneva, jul. 1986. Available at: <http://www.wto.org/english/docs_e/legal_e/ gatt47_e.pdf $>$. Last access on: 2 set. 2014.

WORLD TRADE ORGANIZATION. Legal basis for a dispute: types of complaints and required allegations in GATT, 1994. Available at: <http://www.wto.org/english/ tratop_e/dispu_e/disp_settlement_cbt_e/c4s2p2_e. htm> Last access on: 02 set. 2014.

WORLD TRADE ORGANIZATION. Trips: non violation complaints: background and current situations, 3 december 2009. Available at: <http:// www.wto.org/english/tratop_e/trips_e/nonviolation_ background_e.htm> Last access on: 02 set. 2014.

ZEMANEK, Karl. The legal foundations of the international system: general course on public international law. Boston: Nijhoff, 1997. (Hague Academy Collected Courses, 266). 


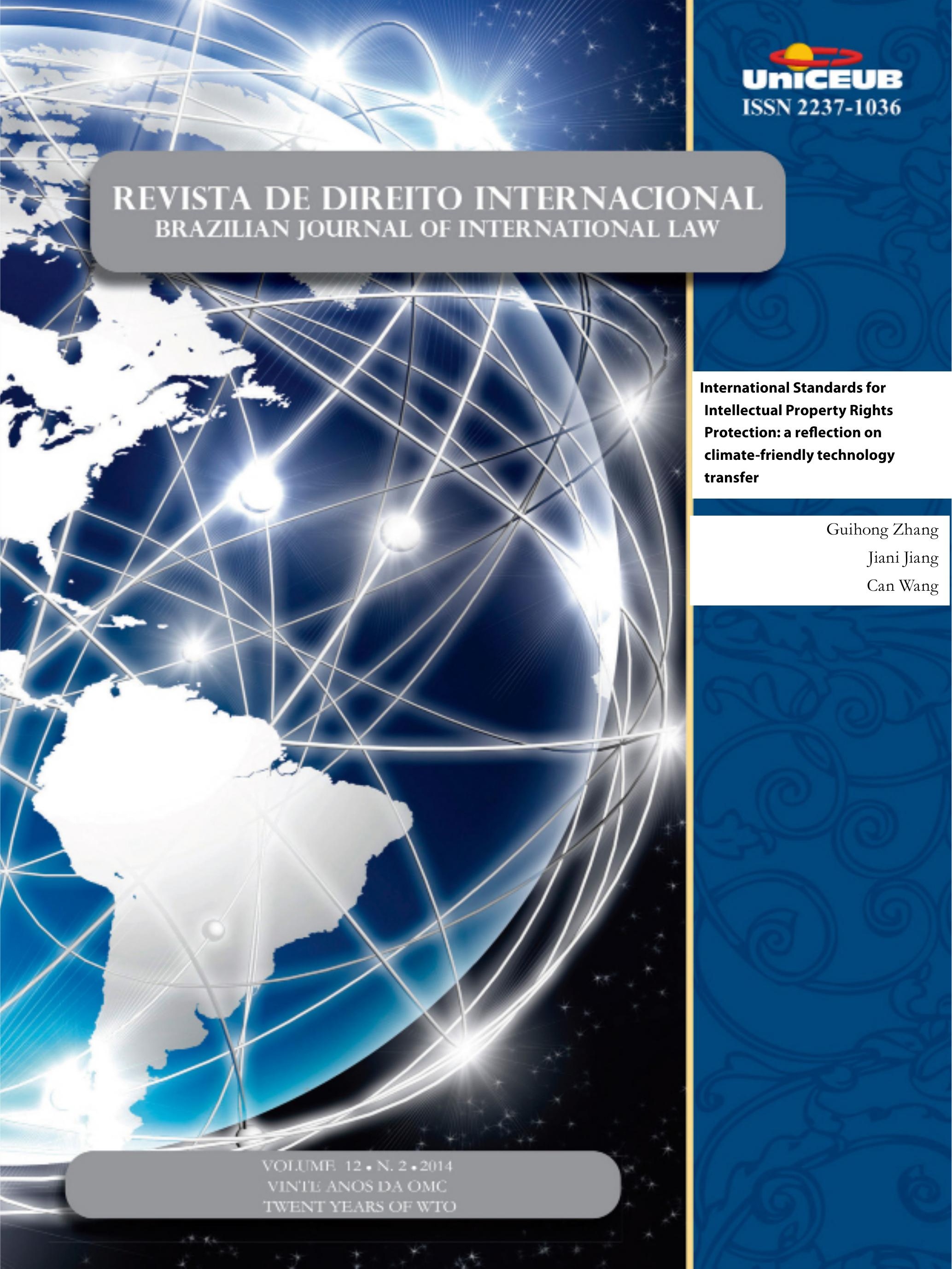




\title{
International Standards for Intellectual Property Rights Protection: a reflection on climate-friendly technology transfer*
}

\author{
Guihong Zhang ${ }^{* *}$ \\ Jiani Jiang ${ }^{* * *}$ \\ Can Wang ${ }^{* * * *}$
}

\begin{abstract}
An unsettled debate exists with regard to the role of intellectual property (IP) rights in international climate negotiation. This debate is based on premise that the international TRIPS Agreement set out minimum standards of protection, which presumably allow for unlimited extra protection. This study aims to address the question of whether a premise for minimum protection standards exists in the international IP system combined with climate-friendly technology transfer. First, the basic question of why international IP standards generate an impact on climate-friendly technology transfer is clarified. Second, three levels of arguments are applied to question this premise and examine the rationality of minimum protection standards. The three arguments are as follows: (1) Has TRIPS Agreement 1.1 provided unlimited minimal standards for IPR protection? (2) Is there no conflict between TRIPS Agreement-PLUS and the TRIPS Agreement? (3) How about the WTO dispute settlement panel report about this problem? The finding is that the dominant default policy, the IP protection standard, is the only minimum requirement in the case of uncertainty in legal provisions and practices. Therefore, the negative effects on the transfer of climate-friendly technology increase in terms of using flexible provision to promote import technologies. Third, this paper introduces China's current Patent Law and its practice in response to climate-friendly technology transfer. Lastly, this paper provides suggestions with regard to the need for comprehensive and explicit protection standards in the context of climatefriendly technology transfer.
\end{abstract}

Keywords: Climate-friendly technology. Minimum protection standards. International intellectual property rights. Developing countries. China. TRIPS Agreement. TRIPS-PLUS. DSB. Ceiling.

Environment, Tsinghua University, Areas of Specialization: Climate change policy and economics. Email: canwang@tsinghua.edu.cn. This research is funded by "Key Projects in the National Science \& Technology Pillar Program during the Twelfth Five-year Plan Period"(NO. 2012BAC20B04), the National Natural Science Foundation of China (No.71273153), and the China Scholarship Council (CSC) (NO. 201306040082).

\section{Introduction}

Climate-friendly technology requires high input and involves high risk and thus entails the establishment of a mechanism that encourages technological innovation and transfer. The patent system for climate-friendly technology is precisely built to realize this purpose. The patent system for climate-friendly technology aims to create, promote, and protect climate-friendly technology and facilitate its application. How to improve the patent system to facilitate climatefriendly technology innovation and transfer in the context of the depletion of petrochemical resources and global warming is an urgent problem. As pointed out by an ICTSD-EPO-UNEP report, after the Kyoto Protocol was passed in 1997, the number of patent applications in clean energy technology increases at an annual 
rate of approximately $20 \%$, which already exceeds that in the field of fossil fuel and nuclear energy. ${ }^{1}$ This phenomenon indicates that in the fight against climate change, IP legislation can definitely exert influence on climate-friendly technology innovation and transfer. Nonetheless, an unsettled debate exists regarding the role of the IP system in the development and transfer of climate-friendly technologies under the United Nations Framework Convention on Climate Change (UNFCCC) negotiation. In UNFCCC, developing parties contend that IPR impedes the diffusion of climate-friendly technologies and support evolutionary changes in the current international IP system to address climate change. ${ }^{2}$ Developed countries insist that IP promotes technology development and transfer and support an absolutely free market for climatefriendly technology transfer. They attempt to avoid references to IPR under UNFCCC. ${ }^{3}$

A recent stream of studies have addressed the role of IP in climate-friendly technology transfer. Briefly, three views exist with regard to the role of IP. In most cases, proponents of strong IP argue that patents foster climate-friendly technology development and transfer based on basic data analysis. They insist that a strong IP regime can guarantee sustained motivation for developed countries to invest in developing countries (BRANSTETTER, 2006; COPENHAGEN ECONOMICS, 2009; HOEKMAN, 2004; PUGATCH, 2010). Opponents of this view argue that the IP regime enhances many IP holders' paid-license rights but ignores the high price of the transfer. Thus, IP holders possess core technologies but are unwilling to transfer them to developing countries (ERI, 2009; LEWIS, 2006; MASKUS et al., 2005; WATAL, 1998). Other analysts observe that IP is not the only factor that impedes climate-friendly technology transfer

1 nited Nations Environment Programme (UNEP) Economics and Trade Branch, European Patent Office (EPO), International Centre for Trade and Sustainable Development (ICTSD), UNEP E P O. ICTSD. Patents and Clean Energy: Bridging the Gap Between Evidence and Policy: Final Report. Geneva, 2010. Available at:

$<$ http://www.epo.org/clean-energy $>$.

2 WN (Third Word Network), UNFCCC technology committee debates IPR issue, 2013. Available at:

<http://www.twnside.org.sg/title2/climate/info.service/2013/ climate130705.htm>.

3 CIED (The Coalition for Innovation, Employment and Development), Joint Resolution of BUSINESSEUROPE, IIPPF and the Global Intellectual Property Center on Climate Change, Technology, and Intellectual Property Rights, 2009. Available at:

<http://www.thecied.org/files / $2010 / 10 /$ FinalJointGreenTechnologiesClimateChangeStatementSept2809.pdf>.
(BARTON, 2007; OCKWELL, 2007; UNEPEPO-ICTSD, 2010). Although IP is a real challenge in climate-friendly technology transfer, it has not been formally recognized by UNFCCC despite the controversy. However, no firm evidence exists on how IP affects the diffusion of climate technologies. These studies show that IP is closely related to climate-friendly technology transfer and offers empirical analyses to clarify the role of IP in climate-friendly technology transfer. Nevertheless, literature has provided no coherent conclusion with regard to the effect of IP on climate-friendly technology because national policies make it difficult to determine the role of IP. Moreover, a few studies have explored the reason a controversy continues to exist between IP and climatefriendly technology transfer from the perspective of international laws.

Generally, in the field of international IP legislation, the IP system is believed to have been established based on minimum protection standards; no upper limit was set. This lack of upper limit serves as a legitimate basis for raising the standards of IP in signing bilateral or regional trade agreements and profoundly affects the judgment of the dispute settlement body (DSB). However, excessively high IP standards nullify the flexible clauses on the promotion of public interests set in the international IP system. With regard to actions that tackle climate change, developing countries propose refining such flexible clauses for climate-friendly technologies to become more easily transferrable. Numerous proposals have been introduced to the current international climate negotiation on technology to improve or establish a new international IP system that accommodates the transfer of climate-friendly technologies based on flexible clauses. ${ }^{4}$ Meanwhile, in the World Trade Organization (WTO) forum, the Doha Ministerial Conference agreed to establish a working group to examine the relationship between trade and technology transfer and possible recommendations for steps that may be implemented within the WTO mandate to increase the flows of technology to developing countries. The WTO's Trade-Related Aspects of Intellectual

4 In Cancun climate negotiation, Bolivia, which is one of the strongest opponents of the injustices derived from the TRIPS Agreement, insisted on weakening the IP system as a prerequisite to any climate deal. India issued a proposal for the inclusion of supplementary agenda items in the provisional agenda of COP 17 , including IP-related items, such as the treatment and delivery of climate technologies and their IPRs as a public good. 
Property (TRIPS Agreement) Council, in its first meeting for 2014, discussed the topic "Contribution of intellectual property (IP) to facilitate the transfer of environmentally rational technology." However, so far, limited advancement toward tackling climate change has been achieved. International efforts to promote climate-friendly technology innovation and transfer have not been able to transform into integrated forces because of the unresolved controversy between IP and technology transfer.

From the perspective of international laws, the essence of IP debates mainly arises from the conflicting opinions of all parties with respect to the relationship between IP level and IP protection standards. Developed countries contend that enhancing IP will facilitate technology innovation and transfer. Hence, current standards should specify only the minimum requirements and not the ceiling. By contrast, developing countries argue that enhancing IP does not necessarily facilitate technology innovation and transfer. Thus, existing protection standards should incorporate both the minimum and maximum requirements. Obviously, international IP agreements under the framework of the World Intellectual Property Organization (WIPO) and the TRIPS Agreement under WTO were set up based on the hypothesis that only minimum protection standards exist in the international IP system. ${ }^{5}$ Hitherto, TRIPS Agreement-Plus as an additional protection standard has been introduced in bilateral and regional trade agreements that involve or are dominated by developed countries. Such requirement imposes further restriction on the applicable range of the flexible clauses of the TRIPS Agreement. Thus, developing countries are likely to face a legislation challenge in terms of facilitating the transfer of climate-friendly technologies by taking advantage of the flexible clauses of the TRIPS Agreement.

As a major emitter of $\mathrm{CO}_{2}$, China has a strong demand for climate-friendly technology. China is also facing issues such as deficiency in independent research and development of climate-friendly technology and serious defects in climate-friendly technology patent transfer. Many reasons cause these problems. Such reasons include inadequate investment in research and development, inadequate infrastructures, and weak green patent consciousness. However, China must still

5 RUSE-KHAN, H. G. Time for a paradigm shift: exploring maximum standards in international intellectual property protection, 1. Trade L. \& Dev. 56, 2009. follow the above inherent assumptions ("minimum protection standards") as the starting point in establishing patent laws. These assumptions might urge the nation to increase IP protection standards while providing minimal emphasis on self-national conditions.

With these issues in mind, this paper focuses on several questions. First, why do international IP protection standards generate an impact on climatefriendly technology transfer? Second, is it true that only minimum protection standards are established by the existing international IP system? Third, what is the impact of minimum protection standards on China's climate-friendly technology patent legislation practices? Lastly, this paper provides two levels of alternative suggestions for perfecting IP legislation to enhance climate-friendly technology innovation and transfer.

\section{Transfer of climate-friendly technologies and minimum protection standards for IP}

\section{A. Definition of climate-friendly technologies}

The reform, transfer, and application of climatefriendly technology are the premises to realize the ultimate goal of climate change response described in Article 2 of UNFCCC. Article 2 of UNFCCC states the following:

The ultimate objective of this Convention and any related legal instruments that the Conference of the Parties may adopt is to achieve, in accordance with the relevant provisions of the Convention, stabilization of greenhouse gas concentrations in the atmosphere at a level that would prevent dangerous anthropogenic interference with the climate system. Such a level should be achieved within a time frame sufficient to allow ecosystems to adapt naturally to climate change, to ensure that food production is not threatened and to enable economic development to proceed in a sustainable manner.

Climate-friendly technologies, including solar photovoltaic and wind power generation technologies, are also known as environmentally sound, clean energy, and new energy technologies. The improvement of energy utilization efficiency and the development of climate-friendly technology create a bright prospect of $\mathrm{CO}_{2}$ emission reduction. These technologies can 
effectively lower the consumption of materials and energy and mitigate the negative impact on the environment. The important document Agenda 21 issued by United Nations Conference on Sustainable Development in 1992 provides a clear definition of climate-friendly technology; its Article 34.1 states that

Environmentally sound technologies protect the environment, are less polluting, use all resources in a more sustainable manner, recycle more of their wastes and products, and handle residual wastes in a more acceptable manner than the technologies for which they were substitutes.

Article 4.5 of UNFCCC further specifies the obligation of developed countries that sign the contract in transferring technology to developing countries.

The developed country Parties and other developed Parties included in Annex II shall take all practicable steps to promote, facilitate and finance, as appropriate, the transfer of, or access to, environmentally sound technologies and know-how to other Parties, particularly developing country Parties, to enable them to implement the provisions of the Convention. In this process, the developed country Parties shall support the development and enhancement of endogenous capacities and technologies of the developing country Parties. Other Parties and organizations in a position to do so may also assist in facilitating the transfer of such technologies.

However, no formal legal document that provides an explicit definition of climate-friendly technology and its transfer exists. The primary reasons for this condition include scientific uncertainty and rivalry in political views. Although an explicit, unified legal concept accepted by different countries is important to solve relevant problems, the absence of such concept does not mean that no international actions are possible before this concept is established. Scientific uncertainty and clash of interests make policies and regulations with significance to environmental risk control and sustainable development highly necessary. ${ }^{6}$ Post-event remedy is often too late considering the irreversibility of climate change. Article 3.3 in UNFCCC states that

The Parties should take precautionary measures to anticipate, prevent or minimize the causes of climate change and mitigate its adverse effects. Where there

6 GILROY, J. M. Justice and nature: kantian philosophy, environmental policy and the law, 45. Washington, DC: Georgetown University Press, 2011. are threats of serious or irreversible damage, lack of full scientific certainty should not be used as a reason for postponing such measures, taking into account that policies and measures to deal with climate change should be cost-effective so as to ensure global benefits at the lowest possible cost. To achieve this, such policies and measures should take into account different socio-economic contexts, be comprehensive, cover all relevant sources, sinks and reservoirs of greenhouse gases and adaptation, and comprise all economic sectors. Efforts to address climate change may be carried out cooperatively by interested Parties.

Climate-friendly technologies have three features. Technically, climate-friendly technologies cannot be completely separated from traditional ones. The transfer of climate-friendly technologies should be conducted according to the legal norms applicable to the transfer of common manufacturing technologies. Currently, the TRIPS Agreement under the WTO framework is the major legal norm that regulates the transfer of international technology. In terms of technical purpose, climate-friendly technologies, which are distinctive from ordinary manufacturing technologies, serve the interest of the public. Therefore, the provisions on the transfer of climatefriendly technologies in international trade should be differentiated from those on the transfer of ordinary technologies. The realization of the goals of addressing climate change should be prioritized. Most climatefriendly technologies are high technologies, in which developed countries take the lead. Ownership of patents on climate-friendly technologies throughout the world indicates that developed countries have a dominant advantage. ${ }^{8}$ Furthermore, the statistics on the flow of global technologies from the Organization for Economic Cooperation and Development indicate that most trades in climate-friendly technologies occur

7 For example, many technologies are versatile. They not only belong to the traditional technical classification but also mitigate and adapt to climate change.

8 A study by the European Patent Office in 2011 shows that the top six countries in clean energy technology patents, namely, Japan, USA, Germany, Korea, the United Kingdom, and France, account for $80 \%$ of the filings for global clean-energy technologies. See United Nations Environment Programme (UNEP) Economics and Trade Branch, European Patent Office (EPO), International Centre for Trade and Sustainable Development (ICTSD), UNEP E P O. ICTSD. Patents and clean energy: bridging the gap between evidence and policy: final report, 30. Geneva, 2010. Available at: <http://www.epo.Org/clean-energy.2014-2-20>. 
in developed countries.' Therefore, the international IP system related to the transfer of climate-friendly technologies must consider the interests of the developing countries as the major recipient of technologies.

\section{B. Transfer of climate-friendly technologies and IP}

The core issue of the debate in the negotiation on technology transfer under the framework of UNFCCC is whether IP impedes the transfer of climate-friendly technology to developing countries. The basis of the controversy on IP is the unclear relationship between IP and technology transfer. Most climate-friendly technologies exist in the form of patents and are actually transferred by IP licensing via commercial channels..$^{10}$ From the legal perspective, the relationship between IP and the transfer of climate-friendly technologies can be summarized as follows. First, IP is the object in legal relationships related to the transfer of climate-friendly technologies. IP as a property right is protected by laws. Exchange of interests is possible by demarcating the boundaries between the economic interests of different parties. Thus, IP can be exchanged because of its private attribute. An international system built for IP renders such an exchange controllable. For this reason, IP is the common target considered by two parties in the transfer of climate-friendly technologies. Second, the IP system provides a static legal premise for the transfer of climate-friendly technologies. The precondition for the smooth transfer of technologies is an explicitly established property system. What the IP system provides is the recognition and protection of the intangible assets of the owners, which is the static legal premise for the trade of climate-friendly technologies. The IP system profoundly affects the entire process: from the establishment of the ownership of climate-friendly technologies to the transfer of IP. It is a "regulator" of interest balance in the transfer of climate-friendly technologies between transferors and transferees.

\section{Current situation of "Minimum Protection Standards" for international IP}

9 HAŠČIČ, I. Climate policy and technological innovation and transfer: an overview of trends and recent empirical results, 12. OECD Publishing, 2010.

10 WANG S-P; WANG C; XU Y-M. Intellectual property right and climate change, 16. Sciences Academic Press (in Chinese), 2013.
In the contemporary international system of IP rights, the TRIPS Agreement plays the leading role and has incorporated IP protection into the international trade system for the first time. Thus, the legal relationship between IP and international technology transfer is formally established. Whether in developed countries or in developing countries, the criteria for international IP protection are closely connected to the basic obligations that should be fulfilled by the members who sign international agreements on IP. The TRIPS Agreement's preamble points out that

Recognizing the underlying public policy objectives of national systems for the protection of intellectual property, including developmental and technological objectives.

However, the articles of the TRIPS Agreement do not specify the means of promoting technology transfer through technology licensing. In fact, most of the articles of the Agreement only identify the goals of technology transfer to developing countries in an advocating manner. If no new measures are implemented to establish the role of IP in technology transfer, the IP factor will either directly or indirectly impede the transfer of climate-friendly technology from developed countries to developing countries in the battle against climate change. The obligations under the TRIPS Agreement refer to the fundamental requirements for all WTO members as indicated by the minimum protection standards. ${ }^{11}$ The minimum standards for international IP cannot be easily fulfilled by developing and least-developed countries. These countries need to enhance the intensity of IP protection to fulfill international agreements. Thus, the minimum protection standards established by the international IP system represent the extension of rights and the high-level protection of rights. Article 1.1 of the TRIPS Agreement generally defines only the minimum protection standards and not the maximum ones. It states that

Members shall give effect to the provisions of this Agreement. Members may, but shall not be obliged to, implement in their law more extensive protection than is required by this Agreement, provided that such protection does not contravene the provisions of this Agreement. Members shall be free to determine the

11 TAUBMAN, A. Rethinking TRIPS AGREEMENT: 'Adequate remuneration' for non-voluntary patent licensing, 927. Journal of International Economic Law, J.I.E.L, 970, 2008. 
appropriate method of implementing the provisions of this Agreement within their own legal system and practice.

Member states should not implement IP protection below the level required by the TRIPS Agreement but have the right to execute tighter IP protection. Moreover, the rules of the minimum protection standard are worded ambiguously. The TRIPS Agreement provides explicit provisions on the terms of protection, non-discriminatory treatment of foreign residents, and enforcement measures but fails to define in detail the standard of patentability. For instance, Article 27.1 of the TRIPS Agreement specifies that any invention in any field has to meet the following conditions to obtain a patent: novelty, usefulness, and originality. However, the Agreement does not provide the details of these three conditions. Each country has the right to define the denotation and connotation of these three conditions based on specific situations. Lastly, "minimum protection standards" increase the possibility of having abusive IP. ${ }^{12}$ In developed countries, enterprises that depend highly on IP, particularly those leading in the field of climatefriendly technology, are being challenged by emerging economies. They hope that these protection criteria can function as the bottom line, based on which a higher standard for IP protection can be demanded. In this manner, these enterprises can maintain a competitive edge in technology in the long term.

In summary, the transfer of climate-friendly technologies is regulated by the international IP system. Except for a few clauses that mention the concept of "public interest," no explicit provisions indicating that "addressing climate change" is the public interest that deserves special considerations exist in this system. As a component of the one-package protocol of the WTO, the TRIPS Agreement applies to exceptional environmental terms, namely, paragraphs (b) and (g) of Article XX of the General Agreement on Tariffs and Trade (GATT). With regard to the issue of climate-friendly technology transfer, the connection between the TRIPS Agreement and exceptional environmental terms and their application ranges is difficult to identify. In particular, existing exceptional environmental terms do not directly incorporate "the measures for facilitating the diffusion of climate-

12 Includes high licensing fees, refusal to deal, market control, and the permission of the licensor to own the majority of the company's shares. friendly technologies in response to climate change." Furthermore, minimum protection standards provide considerable protection for IP in developed countries that already have an advantage. Developed countries take advantage of this condition to constantly raise the standards of IP protection. However, developing countries hardly benefit from the system. Is it true that only minimum protection standards are established by the existing international IP system?

\section{Reflection on "Minimum Protection Standards" in the international IP system}

\section{A. Is "Minimum Protection Standard" equivalent to "Unlimited Strong Protection"?}

The minimum standard for IP protection was first formulated in Article 20 of the Berne Convention and later in Article 22 of the Rome Convention. Article 19 of the Paris Convention also contains similar provisions. The TRIPS Agreement unifies and defines "minimum protection standards." The above provisions contain necessary restriction requirements that neither special protocol nor condition should not "contravene" or be a violation of the existing protocols (particularly at the end of the first sentence in Article 1.1 of the TRIPS Agreement stating that "provided that such protection does not contravene the provisions of this Agreement"). Nevertheless, the clause of "minimum protection standard" in the TRIPS Agreement continues to create controversy in terms of its connotation. One point of view is that the heading of the first sentence of this clause should be emphasized, that is, the licensor has the right to introduce additional protection within the scope of the TRIPS Agreement. ${ }^{13}$ Another point of view is that the second sentence of this clause is equally important; its potential effect is to restrict the presence of TRIPS Agreement-Plus related to the nondiscriminatory principle of the TRIPS Agreement and the enforcement of IP because many clauses of the TRIPS Agreement imply that not only the lack of IP but also the abuse of IP will impede international trade. For example, in China-Measures Affecting the Protection and Enforcement of Intellectual Property Rights, part of criminal protection indicates that the panel holds that members have the right to decide on the legal system within its domain and the appropriate methods to implement

13 GERVAIS, D. J. The TRIPSTRIPS Agreement: drafting history and analysis. 3. ed. London: Sweet \& Maxwell, 2008. 
this protocol as specified by Article 1.1 in the TRIPS Agreement. However, the panel also holds the opinion that the amount of liberty granted to the members in this respect is only slightly considerable. The panel has the right to balance. ${ }^{14}$ Thus, Article 1.1 in the TRIPS Agreement does not allow for free discretion beyond the scope of minimum protection standards. Moreover, the TRIPS Agreement does not provide a complementary explanation for such uncertainty but reserves the discretion to the panel.

The pacta sunt servanda phrase in Article 26 of the Vienna Convention on the Law of Treaties (VCLT) indicates that the requirement of Article 1.1 in the TRIPS Agreement can be paraphrased as "the national law should respect the minimum standard for IP." The purpose of delineating the scope of Article 1.1 in the TRIPS Agreement is to establish a more extensive IP system. Any form of TRIPS-Plus should not contravene the TRIPS Agreement. Setting minimum standards for IP is sufficient to realize extensive IP. Thus, TRIPS-Plus, which is higher than the TRIPS Agreement, is allowed to take effect without restrictions and without risk of being contrary to the former agreement. However, this opinion deserves a thorough discussion. Article 1.1 in the TRIPS Agreement requires the national law to respect the minimum protection standard in the Agreement, which delineates the scope of obligations that a country should bear under the framework of the Agreement. Moreover, TRIPS-Plus contains coercive provisions on IP protection. If TRIPS-Plus is acquiesced to satisfy the minimum protection standard under the TRIPS Agreement, the scope of obligations that should be fulfilled by a country under the TRIPS Agreement will be broadened contrary to the purpose of the Agreement. Thus, the minimum protection standard under the TRIPS Agreement should not be considered unlimited. A ceiling on the scope of IP must be set.

\section{B. Is TRIPS-Plus in conflict with the "Minimum Protection Standard" under the TRIPS agreement?}

In the mid-1990s, the context for reaching the agreement on the protocols for international IP shifted from WIPO and WTO to free trade agreements (FTAs). Its relationship with the IP clauses presents a

14 CHINA. Measures affecting the protection and enforcement of intellectual property rights: WT/DS362/R. Report of the Panel, 115, 116, 2009. new feature, namely, the extension of TRIPS-Plus with FTAs as the major carrier. After the implementation of the TRIPS Agreement, the international IP system featured the co-existence of several international IP protocols by the TRIPS Agreement and WIPO under a multilateral trading system. In addition, the existing non-discriminatory global trade system and the "most favored nation" treatment principle became the pillars of the WTO. Article 24 of GATT and Article 5 of the General Agreement on Trade in Services (GATS) permit FTAs with a preferential nature because developed countries that have entered the WTO want developing countries to raise the level of IP to maintain their dominance in the technology trade. The extensive existence of TRIPS-Plus combined with the insufficient number of the "most favored nation" treatment principle and national treatment clauses under the TRIPS Agreement has conflated the desire of developed countries to raise IP standards in the international norm. Accordingly, the flexible clauses and policy space under the TRIPS Agreement are nullified by the obligations in TRIPS-Plus. Thus, disputes arise over the excessive restriction on national sovereignty, particularly in the fields of climate change, public health, and knowledge acquisition. ${ }^{15}$

The clauses of TRIPS Agreement do not emphasize "contravene." Article 31.1 of VCLT states that "a treaty shall be interpreted in good faith in accordance with the ordinary meaning to be given to the terms of the treaty in their context and in the light of its object and purpose." Article 7 of the TRIPS Agreement focuses on the balance of interest between the innovator and user, and Article 8 is mainly about public interest in important fields that can benefit the above judgment. Moreover, the declaration of the Doha round of the TRIPS Agreement and public health was passed in 2001. This declaration represents the consensus of WTO members in this field: "in applying the customary rules of the interpretation of public international law, each provision of the TRIPS Agreement shall be read in the light of the object and purpose of the Agreement as expressed, in particular, in its objectives and principles." This declaration can be included in the "other factors" considered in interpreting the context under Article 31.3 (a) of VCLT. Articles 7 and 8 of

15 MUSUNGU, S. F.; DUTFIELD, G. Multilateral agreements and a TRIPS AGREEMENT-plus world: the World Intellectual Property Organisation (WIPO). 26. Quaker United Nations Office (QUNO) 28, 2003. 
the TRIPS Agreement indicate that the provision in TRIPS-Plus under FTAs that allows the raising of the standards for the protection of IP by a single party is a violation of the essence of the minimum protection standard under the TRIPS Agreement. The former is only favorable to the protection of the interests of the innovator or right holder and ignores the interests of the user; it also blocks the realization of public interests, such as those in the environment and health.

The word "contravene" is explained as a type of "conflict with a right, principle, etc." in the Oxford dictionary. ${ }^{16}$ Pursuant to this definition, TRIPS-Plus and the TRIPS Agreement are in conflict with each other in terms of rights and principle. The question is, what is the "conflict" between norms? In the strictest sense, only direct incompatibility, that is, observing a necessary rule at the expense of other principles that constitutes a threat, can be regarded as true conflict. The Appellate Body of the WTO defines "conflict" in Guatemala - Definitive Anti-Dumping Measure on Grey Portland Cementfrom Mexico as a situation where adherence to the one provision leads to the violation of another. ${ }^{17}$ However, this opinion is not only about conflicting norms. The generalized understanding is that conflict also exists when the right to free choice provided by the protocol cannot be fulfilled because of the restriction and impediment imposed by other obligations in the protocol. ${ }^{18}$ Therefore, if TRIPS Agreement-Plus restricts the freedom of WTO members to implement the flexible clauses of the TRIPS Agreement, then it should be regarded as conflicting with the TRIPS Agreement.

\section{How did the panel of DSB interpret "Minimum Protection Standard"?}

In the WTO system, the Dispute Settlement Body (DSB) provides guarantee and predictability to the implementation of a multilateral trading system. To clarify the articles of the agreement, DSB provides a common, conventional interpretation as applied to national laws. Under DSB, the TRIPS Agreement

16 http://www.oxforddictionaries.com/us/definition/ american_english/contravene?q=contravene $>$.

17 The Dispute Settlement Body adopted the panel report on Guatemala: definitive anti-dumping measures on grey Portland cement from Mexico, 65 WT/DS156/R, 2000.

18 RAMANUJAN, Adarsh. Conflicts over "conflict": preventing fragmentation of international law. 1(1) 171 Trade L. \& Dev. 191, 2009. is by far the most extensive multilateral agreement concerning IP. It is subject to the following constraints: jurisdiction imposed by the appealing body, restrictive agreement of the DSB, and execution of a series of vindictive measures against non-compliance.

The cases related to the clauses of the TRIPS Agreementin DSB have given rise to many interpretations in the panel report where the "three-step test" was employed. ${ }^{19}$ The cases related to exceptional terms and restrictive clauses are the most remarkable. For instance, the panel utilized the three-step test in in Canada Patent Protection of Pharmaceutical Products to determine whether the exceptional clauses for patents apply. They dismantled the original clause into three independent conditions. Article 30 establishes three conditions, which can only be applied in combination. However, each condition is independent from one another and should be met. The requirements in Article 30 are not fulfilled when one condition is unmet. The conclusion obtained is that the clause favors the economic interests of the right holder. In fact, the "limited exception" in Article 30 is not altogether separable from the other two conditions. Nevertheless, the separation of the three conditions for the purpose of analysis is not entirely impossible. However, such separation is difficult to be implemented in practice. Article 30 provides the major international law basis for exceptional clauses for patents in international trade. Its purpose is to restrict the additional provisions imposed by WTO members on the exceptional clauses for patents. As indicated in the report by the panel, an attempt is made to dismantle Article 30 through the "three-step test." The steps are then performed one by one. Given that the condition of limited exception in the first step is found to be in conflict from the beginning, the panel directly concluded that the clause fails to fulfill the original intention and favors the right holder.

Thus, the TRIPS Agreement fails to provide an explicit provision on security and predictability related to whether it agrees with domestic exceptional clauses for IP. The reports by the panel only maintain the economic interests of the right holder through the "three-step test." WTO members are not well informed

19 WT/DS114/R. Panel report, Canada - Patent Protection of Pharmaceutical Products (Canada - Patents), 03/17/2000; WT/DS160/R. Panel Report, United States - Section 110 (5) of US Copyright Act (US - copyright), 06/15/2000; WT/DS/174R. Panel report, European Communities-Geographical Indications, 03/15/2005. 
on what to do but on what should not be done under a general context. These non-restrictive clauses assign a secondary place to the interests of the users. The only result is that TRIPS-Plus is an unlimited extension of IP at the expense of public interest. The ambiguity of the clauses and the requirement for the approval of the panel reduce the probability of a country to revise the new exceptional clauses according to the development level of the domestic economy, culture, and technology. This task is not difficult for developed countries that have a long history of establishing exceptional rights. This issue poses a real challenge for developing and least-developed countries where IP protection and enforcement have relatively low intensity. The situation is aggravated by the lack of counterbalancing by the competition law. The ambiguity of the clauses restricts developing and least-developed countries from adopting measures in the light of their needs. ${ }^{20}$

The minimum protection standard in the IP system does not necessarily mean the absence of an upper bound constraint. However, the assumption that the minimum protection standard is not equipped with an upper limit has long prevailed because of the absence of an explicit regulation on upper limit. It also gave rise to that check and balance and protection of the interests and rights of users in the international IP system are almost non-existent. Developed countries that possess an advantage in technology can actively push TRIPS-Plus forward to raise the standard for IP protection and increase the scope of protection. The room for free choice left by the TRIPS Agreement to developing countries is considerably compressed. In this situation, developing countries are unable to achieve the expected goal of improving social welfare and are severely restricted by developed countries in terms of technology innovation and transfer. Although no dispute has existed so far in direct relation to climatefriendly technology transfer owing to the flexible use of IP articles under WTO, we can obtain a general idea of the judgment by the expert panel from the case of a Canadian patented drug. However, this judgment remains unpredictable and gives rise to uncertainty in formulating policies related to climate-friendly technology transfer. Currently, some FTAs contain

20 KUR, A.; RUSE-KHAN, H. Grosse. Enough is enough: the notion of binding ceilings in international intellectual property protection, intellectual property in a fair world trade system: proposals for reform of TRIPS, 359. Edward Elgar Publishing Limited, 363, 2008. special clauses on promoting technology transfer for the purpose of tackling climate change. In particular, FTAs have clauses for promoting the development of clean energy technology, which is closely related to mitigating climate change. ${ }^{21}$ The negotiations on Trans-Pacific Partnership and Transatlantic Trade and Investment Partnership implement a high global standard for IP protection in terms of labor use and the environment. ${ }^{22}$ Thus, the use of flexible clauses in IP by developing countries to acquire climatefriendly technologies will be further restricted. Based on the assumption of the minimum protection standards in the TRIPS Agreement, Article 27.1 only provides a general provision on the three conditions for patent application and allows for discretion by the country. Such freedom can give rise to many rubbish patents or the patent thicket phenomenon for one specific patent. ${ }^{23}$ Developed countries usually draw on this clause to formulate low conditions for patent application to consolidate their technical dominance. If developing countries adopt similar conditions, the only consequence is that the number of patents filed in developed countries worldwide will increase given the technical dominance of these countries. Therefore, the entire patent system is monopolized by developed countries. Reflecting on the hazards brought about by the minimum protection standard, parties from developing countries in UNFCCC propose drawing on the flexibility clauses of the TRIPS Agreement to refine the provisions. However, WTO is yet to respond to these suggestions. As indicated in the discussion above, the efforts of developing countries to draw on the flexible clauses of the TRIPS Agreement face the huge risk of being crowded out by TRIPS-Plus. With respect to the issue of combating climate change and facilitating technology transfer, breaking the unreasonable assumption of the "minimum protection standards" for the international IP system will solve

21 BREWER, T. L. Climate change technology transfer: a new paradigm and policy agenda. 516. Climate Policy, 526, 2008.

22 USTR said the FTA can be more integrated into the global trade in intellectual property standards. Intellectual Property Protection in China. Available at: <http://www.ipr.gov.cn/ guojiiprarticle/guojiipr/guobiehj/gbhjnews/201311/1782549_1. html 2014-5-21>.

23 CORREA, C. M. Innovation and technology transfer of environmentally sound technologies: the need to engage in a substantive debate. 54. Review of European Community \& International Environmental Law, 61, 2013. 
the dilemma associated with the transfer of climatefriendly technologies.

\section{China's practice and patent laws}

The IP system is the main legal regulation that balances the interests of the transferor of climatefriendly technology and that of the transferee. The setting of the standard for IP protection reflects the value orientation in balancing the interests. The general belief in the past was that the IP system only specifies the minimum protection standard but imposes no upper limit constraint. Such misinterpretation favors the protection of the interests of the transferor at the expense of the interests of the transferee. As the largest developing country, China suffers from serious climatic disasters induced by global warming. China is currently undergoing rapid economic growth. With its huge population base and coal-dominated energy structure, China's greenhouse gas emissions will maintain an increasing trend for some time in the future. China's climate-friendly technology has developed rapidly in recent years owing to the optimization of the international environment and domestic policy support. China has reached a certain industrial scale in biomass, solar, and wind energy as well as in other technical fields. The climate-friendly technology industry in China is now booming. However, the application of climate-friendly technology in China is still in its infancy and is significantly different from that in Japan, the United States, Europe, and other developed countries and regions. Statistics show that among 110,000 patent applications for low-carbon technology for carbon capture and storage, $25 \%$ are from Japan, $20 \%$ are from the United States, and only $5 \%$ are from China. ${ }^{24}$ China possesses a large number of climate-friendly technology patents; however, the quality of these patents lags behind that in developed countries. China Human Development Report 2009/10: China and a Sustainable Future Towards a Low Carbon Economy \& Society point out that to achieve green development goals in the future, China requires the support of least 60 core technologies, most of which have not been mastered by China. ${ }^{25}$ Similar to other

24 GAO Yongyi; CHEN Kenan; SHENG Anquan. International patent analysis of low-carbon technologies. 44. Science Focus, 50, 2011.

25 UNDP. China, Remin University of China. China buman development report. 2009/10: China and a sustainable future: towards a low carbon economy and society, 46 (Zou Ji. Z.J, China. Translation and Publishing Corporation Beijing Gretchen Luchsinger, 2009. developing countries, China is a net importer of IP in the field of climate-friendly technology (particularly core technology). This condition reveals the low capacity of Chinese enterprises to research and develop low-carbon technology.

Since the negotiation on international climate, the legislation of patent protection in China has begun to comply with international standards and gradually reflects commitments to green development and environmental protection. This condition will provide a legal foundation for promoting the internationalization of China's climate-friendly technology patent protection and enhancement of industrial competitiveness. In recent years, climate-friendly technology has been guided by national macro-policies. The Outline of the Twelfth Five-Year Plan for National Economic and Social Development released in 2011 established the policy orientation of promoting green and low-carbon development and expressly set out the objectives and tasks of addressing climate change. China issued the Twelfth Five-Year National Strategic Emerging Industry Development Planning in 2012. The development of climate-friendly technologies has been included. In the same year, China also issued the Special National Science and Technology Development Scheme to Handle Climate Change during the $12^{\text {th }}$ Five-Year Plan (hereafter referred to as the Scheme); it emphasizes the reform of the economic growth pattern, the promotion of climate-friendly technology transfer, and the improvement of the IP strategy. The Scheme required a change in the existing unreasonable policy to improve the IP policy for advising and supporting Chinese businesses on low-carbon technology IP issues. The goals of the Promotion Plan for the Implementation of the National Intellectual Property Strategy in 2014 are to increase the pertinence and efficiency of IP creation, strengthen the connection between IP policies and industrial/regional policies, and promote IP in strategic emerging industries.

However, serious problems continue to exist in the current legal system for climate-friendly technology protection in China. Compared with the legislation in developed countries, the laws and regulations relating to climate-friendly technology patent and environmental protection in China are far from perfect. Laws and regulations that encourage the development of climate-friendly technology patent have not been established yet. The lag in legislative work seriously 
restricts the development of the climate-friendly technology industry. Considering that development based on climate-friendly technology patent is a new economic model, the traditional patent system still has many defects that limit the development of climate-friendly technology. Although China has established and repeatedly revised the Patent Law of the People's Republic of China (hereafter referred to as the Patent Law), no content in the Patent Law targets the development of climate-friendly technology in the aspects of patent application, examination, licensing, protection, and use. No complete and clear definition of climate-friendly technology patent has been established. Moreover, no complete system or practical provision has been established to address climate change. For example, Article 22 in the Patent Law indicates that

Any invention or utility model for which patent right may be granted must possess novelty, inventiveness, and practical applicability.

The article does not provide explicit environmental standards for patent application and cannot be utilized to effectively control and prevent non-climate-friendly technology from entering the field of green patents.

In addition, the Guidelines for Patent Examination (2010) in China provide several special requirements for patent licensing of climate-friendly technology. In its part II titled "Substantive Examination" (Chapter 4, Article 3.2.2), it regulates the "assessment of the notable progress" as follows:

When evaluating whether or not an invention represents notable progress, the examiner shall primarily consider whether or not the invention produces advantageous technical effects. Usually, an invention shall be regarded as producing advantageous technical effects and therefore representing notable progress in any of the following circumstances: (1) where, as compared with the prior art, the invention produces a better technical effect, such as quality improved, output increased, energy saving, and environmental pollution prevented or controlled. ${ }^{26}$

In its part II (Chapter 1, Article 3.1.3), the definition of "inventions/creations detrimental to public interest" is

26 State Intellectual Property Office of the People's Republic of China. Guidelines for patent examination 2010. 200. Intellectual Property Publishing House, 2010.
The expression "detrimental to public interest" means that the exploitation or use of an inventioncreation may cause detriment to the public or the society or may disrupt the normal order of the State and the society. Where the exploitation or use of an invention-creation may seriously waste energy or resources, disrupt ecological balance, or impair the health of the public, the invention-creation shall not be granted a patent right. ${ }^{27}$

Combining the two articles is in line with the goal of granting patents to technologies that combat climate change. However, in several recent revisions of the current patent law in China, the impact of and demand for low-carbon development were not specifically considered. Furthermore, promoting climate change was not directly included in the amendment scope of the patent law. The Patent Law and Patent Rules for Implementation of China currently have no clear patentability criteria to prevent high-carbon technology from obtaining patents.

Currently, China is not under direct pressure from the high protection standard in TRIPS-Plus. ${ }^{28}$ However, the raising of the protection standard has already resulted in the incompatibility between domestic climate-friendly technology innovation and actual demand for technology import. Investigations on China's renewable technology innovation and importation shows that the following problems usually exist in the practice of climate-friendly technology transfer to China: low level of public disclosure of patent information, long-term patent protection, large scope of patent protection that even extends into generic technologies, the patent holder monopolizing pricing, and restricting the ownership of rights associated with secondary inventions under the patent transfer contract. This situation indicates that balance in the IP system should be put into the schedule; otherwise, the dissemination of technological innovation would be affected. To balance the interests of the inventor and that of the public, specific reform measures should be resorted to. When it comes to formulating a reform plan, one issue to be clarified is the position of interests in the IP system. Breaking the traditional assumption

\section{Id. at $131,132$.}

28 The United States and the European Union have not yet signed an agreement with China. Thus, the Free Trade Agreements (FTAs) in which China is involved do not have problems related to the articles of TRIPS-Plus. However, China is likely to face pressure under the articles of TRIPS-Plus in contracting on FTAs later. 
would free us from the fixed pattern of thinking. Thus, we can focus more on urgent and most commonly shared interests and refrain from short-term egoism that prevents us from considering the fundamental interests of the development of human society.

China must promote the extensive application of climate-friendly technology, either introduced or developed independently, to curb the increasing trend of greenhouse gas emissions and reduce climate-related loss. For this purpose, a reflection on the Patent Law with respect to the starting point of system design is necessary to better serve the needs of climate-friendly technology development. On this basis, discarding the assumption of no upper limit constraint in protection standards and specifying a specific upper limit constraint will facilitate the introduction of foreign climate-friendly technology and the improvement of domestic and international legal environment with regard to IP. The main goal is to consolidate existing flexible articles on IP through restrictive regulations on the inside and on the outside. Hence, relevant laws will play a positive role in promoting the transfer of climate-friendly technology to developing countries. The IP system should properly balance the interests of the transferor and that of the transferee.

\section{Suggestions to Improve the Standards for IP Protection}

Patent legislation for the development of climate-friendly technology is determined by how the interaction between the patent system and the development of climate-friendly technology is considered. Climate-friendly technology development and innovation differ from that of traditional industrial technology in terms of origin. The former is grounded in the context of increasingly intensified environmental problems, whereas the latter stems from the pursuit of material life. Climate-friendly technology development is the optimization or renunciation of traditional technology. The modern patent system, aiming to fulfill the needs of climate-friendly technology development and dissemination, should start from the basic assumption about the values in adjusting this system. In this manner, the improved patent system will have an inherent mechanism that caters to the needs of low-carbon development and the fight against environmental problems. In response to climate change, encouraging climate-friendly technology innovation and dissemination should be the top priority in policy adjustment for patent systems both domestically and internationally.

Legal analysis of the "minimum protection standard" shows that the assumption that the international IP system only has "minimum standards of protection" does not hold. To popularize climatefriendly technologies and avoid the negative impact of raising the standards of IP protection by countries that have technological advantages, the inherent assumption that international IP protection only has "minimum standards" needs to be revoked. An upper limit should be set for the standard of protection on the international level and in national legislation. IP protection standards and related systems should be repositioned and improved.

The patent law for climate-friendly technology should not be adjusted following a traditional set of values but should simultaneously facilitate the protection of rights under the framework of patent law and climate-friendly technology innovation. Traditional values center on rights protection. In this case, the establishment of a patent law system and the balance in system design based on the consideration of social interests are no more than the check and balance of rights, whereas the consideration of public interests is placed in the center in the patent law that serves climate-friendly technology development. No hypothesis exists for minimum protection standards. The patent law formulated in this manner has an independent value and achieves balance between motivation for technology innovation and technology dissemination.

\section{A. International level}

To promote climate-friendly technology innovation and transfer, the exclusiveness of IP right as a private right must be balanced by the consideration of interests in the public domain. Therefore, an upper limit on the standard for IP protection should be set. Through this means, IP abuse can be prevented, and the interests of people other than the right owner will be protected (including the right of users, the right of free trade, and public interests).

First of all, the TRIPS Agreement should clarify the general provision that the public interest mentioned in this protocol includes combating climate change. The 
innovation, transfer, and spread of climate-friendly technologies should be incorporated into the general provision and public interest clause to legally support the unified international law related to the transfer of climate-friendly technologies in combating climate change. Doing so will also clarify the connection with GATT XX. The articles for promoting climate-friendly technology innovation, transfer, and dissemination should be incorporated into the general article and articles of public interests (Trips Agreement, Articles 7 and 8).

Second, a ceiling should be specified in Article 1.1. Article 1.1 of the TRIPS Agreement directly defines the minimum standards of IP protection. The first sentence indicates that IP protection in this Agreement is only required to comply with all the articles of this Agreement. The countries have no obligation to fulfill higher IP protection. However, it also affirms that all countries can carry out appropriate means allowed by the Agreement in accordance with their own circumstances, which suggests that all countries can handle issues flexibly. Flexibility may cause polarization. On the one hand, countries are provided autonomy to establish and obey protection standards that go beyond this Agreement. On the other hand, countries are provided autonomy, but no constraint is set in raising the standards of IP protection. The statement "as long as the protection does not contravene the articles of this Agreement" appears to be a restrictive provision and makes the content more ambiguous. Therefore, a clarification of this clause is necessary to set an upper limit for IP. Standards for IP protection laid down by nations that are above the present protocol cannot contravene the exceptional provisions set to serve the public's interests, such as combating climate change. IP protection standards formulated by national IP laws should meet the ceiling requirements. When the exclusive rights to IP are in conflict with the public's interests, priority should be explicitly given to the latter.

Lastly, the ceiling cannot be set by merely adjusting the clauses of the TRIPS Agreement. The assumption that IP protection standards provide only the baseline should be changed; however, this process takes time and not only involves the revision of the TRIPS Agreement by legislators but also the formulation of measures to impose the restriction on the ceiling through other means. Thus, the high standards laid down by TRIPS-
Plus also need to have a ceiling. The attitude of the DSB panel toward the standards for IP protection also needs to be changed. A preventive review mechanism for the transfer of climate-friendly technologies should be established as follows. First, a review mechanism should be set for TRIPS-Plus clauses under FTAs. According to the hypothesis of "minimum protection," the TRIPS Agreement does not place an upper limit on TRIPS-Plus' capability to raise the standards of IP protection among regions. However, the WTO has never reviewed the articles of TRIPS-Plus in the regional trade agreement. Although it was proposed to set an obligatory review mechanism for technology transfer in Hong Kong Ministerial Conference in 2003, the mechanism mainly targeted least-developed countries as mentioned in Article 66.1 in the TRIPS Agreement. In fact, such bilateral or regional trade agreements are often reviewed without allowing for the democratic input or a comprehensive assessment by the stakeholders. All of these participations should have preceded the formulation and revision of the Agreement. To protect climate-friendly technology, it was proposed in the WTO multilateral negotiations to establish a review mechanism for the terms of IP rights in bilateral or regional trade under the TRIPS Agreement. The focus is to assess the potential impact of climate-friendly technology transfer to developing countries under the articles of TRIPS-Plus. Second, in future dispute resolutions in DSB, independent assessment suggestions on whether any negative impact exists to promote climate-friendly technology development and transfer should be encouraged by environmental experts or NGOs, as friends of the court, for reference to the DSB panel. The main objective and measurement criteria are to determine whether the current interpretation of the environmental provisions is beneficial to the subsequent interpretation or at least provides an exact assessment of what can and should not be done. To increase predication auditing, if related cases occur in the future, it can play an important role in at least two aspects: (1) increasing the new legitimacy bases of the judgment and (2) the opinions of the existing panels may pass through the audit but are still biased or are apparently adverse to the interests of one party. At the least, a mechanism that can continue to improve clarity and predictability without making the problem worse should be established. 


\section{B. National level}

The hindrance to climate-friendly technology transfer brought about by the patent system is related to domestic patent protection in various countries. To fundamentally solve the conflict between climatefriendly technology transfer and patent protection, cooperation and functioning of domestic legislations are necessary. The effective implementation of international low-carbon development measures under the domestic framework of policies and legislations will in turn strengthens the confidence of the international society in climate-friendly technology development. This is a virtuous circle for global climate governance. Therefore, the adaptation ability of domestic policies should be considered in designing a plan for coordinating international conventions. Protecting IP rights of climate-friendly technology by passing laws can contribute to the development and dissemination of climate-friendly technology and will ultimately enhance China's industrial competitiveness. This is the only means for China to develop climatefriendly technology under the influence of global integration. From the domestic point of view, the values of the related IP protection system, on the one hand, should be consistent with the commitments to the protection of IP rights as China enters WTO; on the other hand, they should not blindly follow the high standards of IP protection. China should improve the domestic environment of the IP system to ensure the independent innovation of climate-friendly technology and the introduction of advanced technology from other countries. Specifically, the Patent Law in China directly relating to the transfer of climate-friendly technology provides the following recommendations.

First, the patent system should reflect the urgent demand in the fight against climate change. To control climate change and enhance China's ability to introduce and develop climate-friendly technologies, China's patent legislation should incorporate the ideas of sustainable development, environmental protection, and climate change response into the scope of public interests. Thus, support can be provided in terms of basic principles and values for incorporating the regulations on the transfer of climate-friendly technologies into the flexible term reserved for the benefit of public interests.

Second, the setting of an upper limit on the standards for IP protection does not exclude raising the minimum standard for IP protection. The purpose of limit setting is to safeguard the policy space of flexible terms that all countries can utilize for the sake of public interests. If countries can use flexible terms according to their respective actual situations to promote technological innovation and dissemination, it will conform to the intended goal of setting the upper limit for the standards of IP protection. Article 27.1 of the TRIPS Agreement leaves room for discretion on patents granted in each country. Given that the issue of climate change response has not been included in the amendment scope of patent law, China's Patent Law and Patent Rules for Implementation currently have no clear patentability criteria to prevent high-carbon technology from obtaining patents. As a result, many highcarbon technologies have acquired patent protection. Backward production capacity and technologies that should be eliminated have been legitimized. Assertion must be made that in determining the creativity and practicality of an invention, an invention shall not be patentable on any account if it does not comply with the environmental protection criteria provided by the Patent Law. Another proposal is to introduce "climatefriendliness" requirements into the Patent Law and the Patent Law Rules for Implementation as one of the criteria to assess patentability. Thus, China's Patent Law would mainly protect technologies that are higher in quality, more advanced, and more helpful in addressing climate change. Furthermore, it would prevent the phenomenon of "patent thickets" in the development of climate-friendly technologies.

\section{Conclusion}

In conclusion, setting a ceiling for the IP system is necessary but is not equivalent to denying that protection above the minimum protection level is unreasonable. Nevertheless, the prerequisite, at the least, is that the public interest of combating climate change can be realized with priority under the flexible clauses for IP protection. The setting of the ceiling remains risky. Thus, one-size-fits-all provisions should be avoided in international institutions. Advanced legislative techniques should be employed at both international and national scales. A systematic arrangement is required in terms of institutional value and content. The international controversy that "the IP system impedes the transfer of climate-friendly technologies" triggers a more thorough reflection on the international IP system. The presumption that 
the international IP system only provides minimum protection standards should be eliminated. Doing so is beneficial for establishing a more reasonable legal system for the transfer of climate-friendly technologies. Future studies should focus on whether international and national legislations, including the IP system, facilitate the transfer of climate-friendly technologies to developing countries. Another issue is how to establish and improve legislations for this purpose. The IP system is currently undergoing dynamic development, and the balance of interests involved in it also needs to be viewed from a dynamic perspective. The key to striking balance in the field of climate-friendly technology is to determine the baseline of the new balance. In the context of the common environmental problem for the entire human race, this baseline is different from that intended to motivate innovation. As one of the goals of the establishment of an IP system, climate-friendly technology should be given the highest priority in the fight against climate change. 


\section{Bibliography}

AGENDA 21. United Nations Conference on Environment and Development. Rio de Janeiro, 1992.

AGREEMENT on Trade-Related Aspects of Intellectual Property Rights (TRIPS). 1994.

BREWER, T. L. Climate change technology transfer: a new paradigm and policy agenda. 516. Climate Policy, 526, 2008.

CHINA. Measures affecting the protection and enforcement of intellectual property rights; WT/DS362/R, Report of the Panel. 115,116. 2009.

CHINA. Patent Law of The People's Republic of China. 2010.

CIE, The Coalition for Innovation, Employment and Development. Joint resolution of BUSINESSEUROPE, IIPPF and the Global Intellectual Property Center on Climate Change, Technology and Intellectual Property Rights, 2009. Available at: <http://www.thecied.org/ files /2010/10/FinalJointGreenTechnologiesClimateCh angeStatementSept2809.pdf>.

CORREA, C. M. Innovation and technology transfer of environmentally sound technologies: the need to engage in a substantive debate. 54. Review of European Community \& International Environmental Law, 61, 2013.

GAO Yongyi; CHEN Kenan; SHENG Anquan. International patent analysis of low-carbon technologies. 44. Science Focus, 50, 2011.

GERVAIS, D. J. The TRIPSTRIPS Agreement: drafting history and analysis. 3. ed. London: Sweet \& Maxwell, 2008.

GILROY, J. M. Justice and nature: kantian philosophy, environmental policy and the law, 45. Washington, DC: Georgetown University Press, 2011.

GUATEMALA. Definitive anti-dumping measures on grey Portland cement from Mexico; 65 WT/DS156/R, Report of the Panel. 65. 2000.

HAŠČǏ transfer: an overview of trends and recent empirical results. 12 OECD Publishing, 2010.

INTELLECTUAL PROPERTY PROTECTION IN CHINA. USTR said the FTA can be more integrated into the global trade in intellectual property standards. Available at:

KUR, A.; RUSE-KHAN, H. Grosse. Enough is enough: the notion of binding ceilings in international intellectual property protection. Intellectual property in a fair world trade system: proposals for reform of TRIPS, 359. Edward Elgar Publishing Limited. 363, 2008.

MUSUNGU, S. F.; DUTFIELD, G. Multilateral Agreements and a TRIPS AGREEMENT-plus world: the World Intellectual Property Organisation (WIPO). 26. Quaker United Nations Office (QUNO). 28. 2003.

RAMANUJAN, Adarsh. Conflicts over "conflict": preventing fragmentation of international law. 1(1) 171. Trade L. \& Dev., 191, 2009.

RUSE-KHAN, H. G. Time for a paradigm shift: exploring maximum standards in international intellectual property protection, 1 . Trade L. \& Dev., 56, 2009.

STATE INTELLECTUAL PROPERTY OFFICE OF THE PEOPLE'S REPUBLIC OF CHINA. Guidelines for Patent Examination 2010. 200. Intellectual Property Publishing House, 2010.

TAUBMAN,A. Rethinking TRIPS agreement: 'adequate remuneration' for non-voluntary patent licensing, 927. Journal of International Economic Law, J.I.E.L, 970, 2008.

TWN, Third Word Network. UNFCCC technology committee debates IPR issue, 2013. Available at: <http:// www.twnside.org.sg/title2/climate/info.service/2013/ climate130705.htm>.

UNDP. China, Remin University of China. China Human Development Report. 2009/10: China and a sustainable future: towards a low carbon economy and society. 46. Beijing: Zou Ji. Z.J, China Translation and Publishing Corporation; Gretchen Luchsinger, 2009.

\section{UNITED NATIONS ENVIRONMENT}

PROGRAMME (UNEP); Economics and Trade Branch; European PATENT OFFICE (EPO); International Centre for Trade and Sustainable Development (ICTSD). Patents and clean energy: bridging the gap between evidence and policy: final report. Geneva, 2010.

UNITED NATIONS. Framework Convention on Climate Change, 1992.

WANG S-P; WANG C; XU Y-M. Intellectual property right and climate change, 16. Sciences Academic Press (in Chinese), 2013.

<http://www.ipr.gov.cn/guojiiprarticle/guojiipr/ guobiehj/gbhjnews/201311/1782549_1.html 2014-5-21>. 


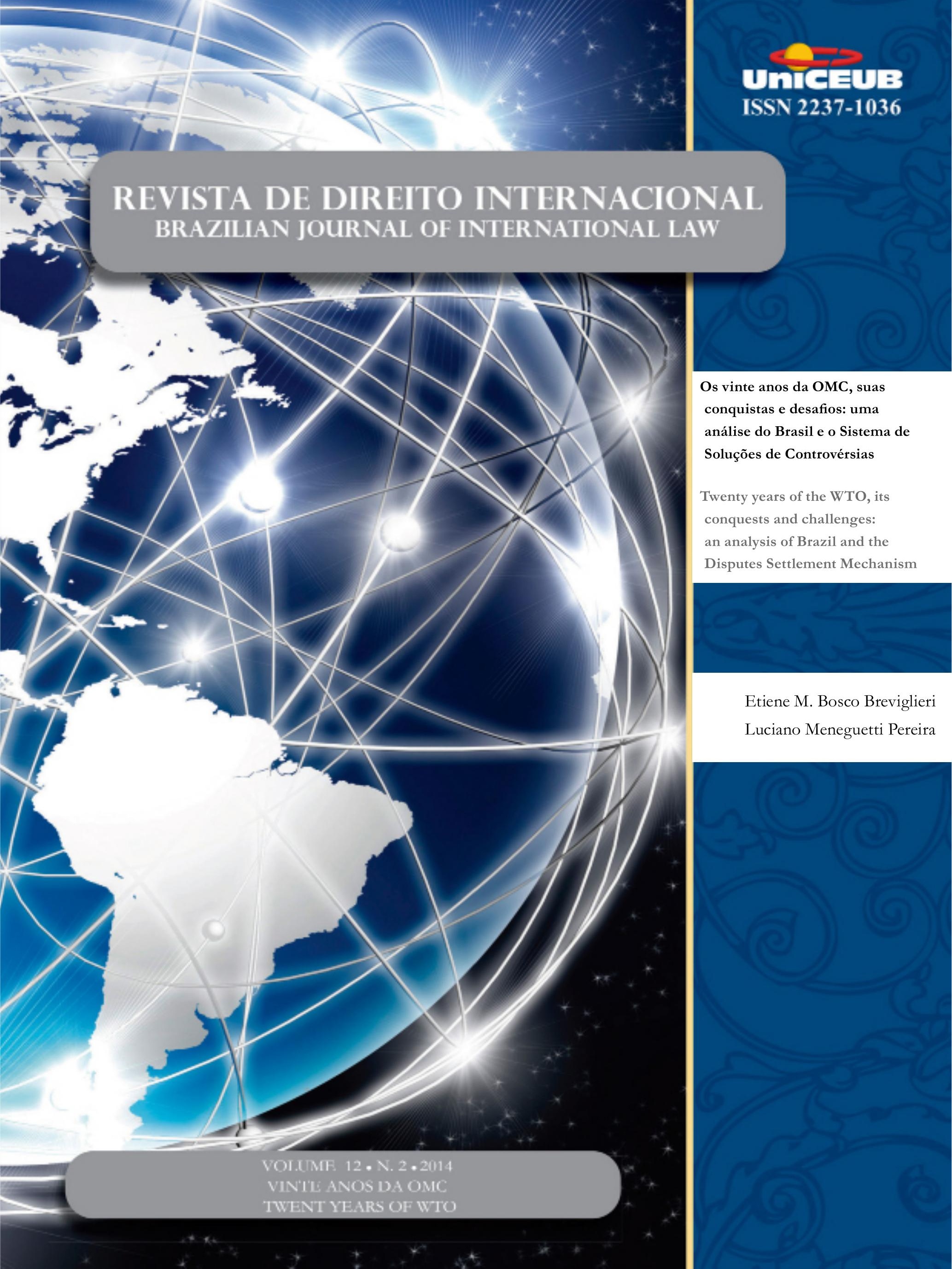




\title{
Os vinte anos da OMC, suas conquistas e desafios: uma análise do Brasil e o Sistema de Soluções de Controvérsias*
}

\author{
Twenty years of the WTO, its conquests and \\ challenges: an analysis of Brazil and the Disputes \\ Settlement Mechanism
}

Etiene M. Bosco Breviglieri** Luciano Meneguetti Pereira***

* Recebido em 18.10.2014

Aceito em 12.11.2014

** Pós-Doutoranda pela Università degli Studi di Messina (Itália); Doutora em Direito Civil Comparado pela PUC/SP; Mestre em Direito Internacional pela UNESP/Franca; Mestre em Letras pela UNESP/SJRP. Professora na Universidade Estadual de Minas Gerais (UEMG) - Campus de Frutal, na Universidade Paulista (UNIP) e no Instituto Municipal de Ensino Superior de Catanduva (IMES).

***Mestre em Direito Constitucional pelo Instituto Toledo de Ensino (ITE); Especialista em Direito Público com ênfase em Direito Constitucional pela Universidade Potiguar (UNP); Graduado em Direito pelo Centro Universitário Toledo (UNITOLEDO); Professor de Direito Internacional e Direitos Humanos no Centro Universitário Toledo (UNITOLEDO) e na Associação de Ensino do Mato Grosso do Sul (AEMS); Advogado, lmeneguetti@gmail.com.

\section{Resumo}

O objetivo desse artigo é analisar os aspectos mais importantes da atuação da OMC em seus vinte anos de existência. Diante da importância cada vez mais crescente da temática do comércio internacional nos arranjos globais das últimas décadas, diversos e importantes questionamentos têm sido levantados acerca da capacidade operacional da OMC, seus pressupostos teóricos e sua competência para desempenhar o papel para o qual foi concebida, isto é, ser a arquiteta e regente do comércio internacional no mundo. $\mathrm{O}$ artigo primeiramente apresenta a $\mathrm{OMC}$, seus objetivos, funções e estrutura. Em seguida são verificadas as principais conquistas obtidas pela organização ao longo de sua existência, para então serem abordados os principais problemas por ela enfrentados, assim como os desafios que deverão ser superados para que possa manter a sua relevância no contexto de um mundo globalizado e regionalizado. Ao final são abordados os principais aspectos do órgão de solução de controvérsias da organização, bem como o relacionamento do Brasil com esse órgão e as principais disputas ocorridas.

Palavras-chave: Comércio Internacional. Globalização. OMC. Sistema de Solução de Controvérsias. Brasil.

\begin{abstract}
The aim of this paper is to analyze the most important aspects of the performance of the WTO in its twenty years of existence. Given the everincreasing importance of the theme of international trade in global arrangements in the last few decades, several important questions have been raised about the operational capacity of WTO, its theoretical assumptions and its competence to perform the role for which it was designed, namely to be the architect and conductor of international trade in the world. The article first presents the WTO, its objectives, functions and structure. Next, are analyzed the main achievements obtained by the organization throughout its existence, to then be addressed the main problems faced by the organization as well as the challenges that must be overcome in order to WTO maintain its relevance in the context of a globalized and regionalized world. Finally, the main aspects of the dispute settlement body of the organization are addressed as well as the relations between Brazil and WTO and the major disputes occurred.
\end{abstract}

Keywords: International Trade. Globalization. WTO. Dispute Settlement System. Brazil. 


\section{Aspectos introdutórios}

Há vinte anos nascia a Organização Mundial do Comércio (OMC), exatamente em 15 de abril de 1994, com início de suas operações em $1^{\circ}$ de janeiro de 1995. Uma organização internacional concebida em meio a grandes expectativas para ser a arquiteta do comércio mundial. Nascia para ser uma instituição guia da globalização, com a missão de eliminar barreiras de negociação e acesso ao comércio internacional, limitar o protecionismo dos mercados internos, facilitando notadamente o ingresso dos países em desenvolvimento, dentre tantos outros obstáculos.

Passados vinte anos, o transcurso do tempo se encarregou de revelar que os obstáculos a serem vencidos pela organização seriam muito mais difíceis do que se esperava. É certo que muitas coisas foram conquistadas, mas as disputas políticas, a estrutura pouco ágil para o oferecimento de respostas rápidas, exigidas pela dinâmica evolutiva do comércio internacional no contexto de um mundo globalizado, o surgimento e o fortalecimento de blocos econômicos regionais e, notadamente algumas instituições da organização, como a regra do consenso, deram ensejo a uma lista de "fracassos" que a OMC não conseguiu evitar, o que acabou por colocar em xeque a sua credibilidade, sua capacidade para cumprir com os objetivos e funções estabelecidos em seu documento constitutivo, enfim, a sua relevância para o comércio internacional em pleno século XXI, não sendo desarrazoada a afirmação de que a $\mathrm{OMC}$ vive hoje uma crise existencial.

Nesses vinte anos que se passaram desde a sua criação, a OMC, oferecendo pioneiramente uma base jurídica sólida para o sistema de comércio multilateral, estabeleceu uma longa trajetória de inserção de diferentes Estados no mercado internacional, permitindo que alguns países membros tivessem mais segurança jurídica, estabilidade e previsibilidade nas intensas relações comerciais internacionais que se multiplicaram nas últimas duas décadas, o que certamente constitui uma das importantes conquistas da organização.

Diante da necessidade do estabelecimento de um processo de integração de normas capaz de permitir um fluxo contínuo e, na medida do possível, igualitário, entre os diferentes mercados presentes nas diversas regiões do planeta, uma tarefa árdua que apresentou e apresenta muitas dificuldades em razão dos inúmeros conflitos inerentes aos interesses contrastantes dos Estados-membros, criou-se também no âmbito da
OMC um órgão solucionador de controvérsias (OSC), também conhecido como Sistema de Solução de Controvérsias (SSC), o que também constituiu um grande avanço à época e contribuiu inicialmente de forma significativa para o alcance dos objetivos da organização.

Porém, no início de século XXI, no contexto de um mundo globalizado, em que a marca é o rápido e intenso relacionamento (global e regional) entre os países, notadamente na área da economia, a dinâmica das relações comerciais internacionais têm imposto à OMC a adoção de uma nova postura, principalmente no que tange ao oferecimento de respostas rápidas da organização para as questões comerciais entre os seus países-membros, v.g., aquelas situações de conflitos que se apresentam, decorrentes das relações comerciais entre os países; a necessidade do estabelecimento de acordos multilaterais globais que sejam efetivos etc. Surge para a OMC, até como uma condição sine qua non para a sua sobrevivência, a necessidade de se adaptar a uma nova tônica que vem sendo impressa no comércio internacional pela globalização, sobretudo, no tocante à necessidade de uma reestruturação organizacional e adaptação de suas regras aos novos desafios surgidos.

Nesse contexto, o presente texto em primeiro momento analisará de forma sucinta as principais conquistas obtidas pela OMC, bem como os principais problemas e desafios enfrentados desde a sua criação e que persistem atualmente. Em seguida serão tecidas considerações sobre o órgão solucionador de controvérsias da organização, analisando-se seus principais aspectos e sua atividade, para então verificar como tem sido o relacionamento do Brasil com a $\mathrm{OMC}$, notadamente no aspecto pertinente à solução de controvérsias ocorridas no âmbito da organização.

\section{A Organização Mundial do Comércio: conquistas e desafios}

Pode-se afirmar que, ao longo das últimas décadas, as necessidades comerciais de cada país aumentaram sobremaneira, fazendo intensificar-se o relacionamento comercial entre os diversos países do globo, fator que foi facilitado pelo avanço científico e tecnológico, notadamente nos meios de comunicação e transporte. Apenas para exemplificar um fenômeno de influência e modificação das relações comerciais globais, pode-se citar o crescimento vertiginoso da internet, que trouxe consigo uma nova espécie de economia: a economia digital, 
acarretando a formação de um mercado eletrônico (ou virtual) e o aparecimento das "ciberempresas", de matriz tecnológica. Concomitantemente, um fenômeno que se tem assistido é migração de empresas tradicionais para o mercado eletrônico, inclusive, com o abandono do ambiente físico por parte de muitas delas, para operarem apenas no ambiente virtual.

Esses e muitos outros fatores sem dúvida constituíram molas propulsoras para um intenso relacionamento comercial dos países em escala global e também facilitaram o relacionamento entre países por meio da criação de diversos blocos econômicos ou pelo aprimoramento daqueles já existentes mesmo antes do advento da era tecnológica, conforme se vê na atualidade, v.g., União Europeia (UE), Mercado Comum do Sul (MERCOSUL), Associação LatinoAmericana de Integração (ALADI), Tratado NorteAmericano de Livre Comércio (NAFTA), Associação de Nações do Sudeste Asiático (ASEAN) etc. É possível afirmar, portanto, que foi e é a necessidade de regras de intercâmbio, convivência e sobrevivência (no mundo físico e no mundo virtual) para esse mercado internacional, indispensáveis no contexto atual de globalização, que dá origem a organizações como a OMC e que também exigem a sua constante atualização para que possa acompanhar a dinâmica das relações comerciais internacionais.

\subsection{Entendendo a OMC}

A $\mathrm{OMC}^{1}$, com sede em Genebra, na Suíça, é uma organização com personalidade jurídica de Direito

1 A OMC foi criada a partir dos acordos e compromissos firmados em Marraqueche, como resultado da Rodada Uruguai (1990), objetivando-se, dentre outras coisas, interpretar e modificar substancialmente artigos específicos do tratado anterior regente da matéria, denominado GATT, que é Acordo Geral sobre Tarifas e Comércio (General Agreement on Tariffs and Trade), criado em 1947, visando harmonizar as políticas aduaneiras dos Estados signatários e que tornou-se a base da criação da Organização Mundial de Comércio. O GATT, ainda existente e parcialmente em vigor, é composto por um conjunto de normas e concessões tarifárias, criado com a função precípua de impulsionar a liberalização comercial e combater práticas protecionistas nas relações comerciais internacionais. No Brasil, a Ata Final da Rodada Uruguai, subscrita em Marraqueche, foi aprovada pelo Congresso Nacional por meio do Decreto Legislativo n. 30, de 15 de dezembro de 1994, e promulgada por meio do Decreto n. 1.355/94, de 30 de dezembro, assinado pelo então Presidente Itamar Franco, que estabeleceu sua vigência a partir de $1^{\circ}$ de janeiro de 1995. Disponível em: <http://www.planalto.gov.br/ccivil_03/decreto/1990-1994/ anexo/and1355-94.pdf>. Acesso em: 14 out. 2014.
Internacional, de natureza intergovernamental, conforme dispõe o art. $8^{\circ}$, 1 e 2, de seu Acordo Constitutivo. ${ }^{2}$ Aliás, nesse sentido reside um dos maiores diferenciais entre o sistema de regulação do comércio internacional anterior e a atual organização, pois enquanto o GATT foi apenas um acordo entre países, a OMC é uma organização dotada de personalidade internacional. Conforme explica Paulo Estivallet de Mesquita,

Os resultados da Rodada Uruguai foram amplos, profundos e, em boa medida, revolucionários. O sistema do GATT baseava-se em um acordo de status inferior a um tratado internacional (em virtude do Protocolo de Aplicação Provisória), limitado ao comércio de bens — e mesmo nesse caso, com setores excluídos —, com um mecanismo de solução de controvérsias que dependia do consentimento da parte reclamada e com um arranjo institucional precário. $\mathrm{O}$ acordo de Marraqueche, que estabeleceu a OMC, transformou o sistema de comércio multilateral de maneira radical. ${ }^{3}$

Ernest H. Preeg, discorrendo sobre a amplitude e importância da Rodada do Uruguai, que culminou com a criação da $\mathrm{OMC}$, afirma que

A Rodada Uruguai, iniciada em Punta del Este, Uruguai, em setembro de 1986, e concluída em Marrakesh, Marrocos, em março 1994, foi a mais importante e bem-sucedida das oito rodadas de negociações multilaterais do Acordo Geral sobre Tarifas e Comércio (GATT). Tarifas para o comércio não agrícola foram reduzidas de forma substancial e um quadro de liberalização do comércio para a agricultura foi adotado. Comércio de serviços e direitos de propriedade intelectual foram incorporados no sistema de negociações. Procedimentos de solução de controvérsias foram sobremaneira fortalecidos e quotas bilaterais de importação de têxteis foram eliminadas. Outros notáveis acordos foram alcançados, como medidas relacionadas ao comércio de

2 Os textos dos acordos da OMC podem ser consultados no sítio do Ministério das Relações Exteriores - Itamaraty: Disponível em: $\quad<$ http://www.itamaraty.gov.br/o-ministerio/conheca-oministerio/tecnologicos/cgc/solucao-de-controversias/maisinformacoes/texto-dos-acordos-da-omc-portugues $>$. Acesso em: 14 out. 2014.

3 MESQUITA, Paulo Estivallet de Mesquita. A Organização Mundial do Comércio. Brasília: FUNAG, 2013, e-book. 
investimentos, subsídios à exportação, antidumping, compras governamentais, salvaguardas, medidas sanitárias e fitossanitárias e barreiras técnicas ao comércio. E, embora não faça parte do mandato de negociação original, a Organização Mundial do Comércio (OMC) foi criada durante a fase final das negociações, que incorporou todos os elementos do Acordo da Rodada do Uruguai e as disposições de longa data do GATT. ${ }^{4}$

A OMC, portanto, constitui um organismo internacional com personalidade jurídica própria, distinta da de seus membros. Bernard M. Hoekmanis e Petros C. Mavroidis explicam que,

em poucas palavras, a OMC é tanto um mecanismo de troca (comércio) de compromissos de políticas comerciais como um acordo sobre um código de condutas.

Certamente a OMC constitui um organismo internacional que exerce papel fundamental na regulamentação do comércio internacional, atuando notadamente na solução de conflitos que, porventura, ocorrem entre os Estados-membros, que desde junho de 2014 totalizam 160 países. ${ }^{6}$

4 PREEG, Ernest. H. The Uruguay Round Negotiations and the Creation of the WTO. In: NARLIKAR, Amrita; DAUNTON, Martin; STERN, Robert M. The Oxford Handbook on the World Trade Organization. New York: Oxford University Press, 2012, e-book. "The Uruguay Round, launched at Punta del Este, Uruguay, in September 1986, and concluded at Marrakesh, Morocco, in March 1994, was the most important and successful of the eight General Agreement on Tariffs and Trade (GATT) rounds of multilateral negotiations. Tariffs on non-agricultural trade were reduced substantially and a trade liberalization framework for agriculture was adopted. Trade in services and intellectual property rights were incorporated within the trading system. Dispute procedures were strengthened greatly and bilateral import quotas for textiles were phased out. Other noteworthy agreements were reached for trade-related investment measures, export subsidies, anti-dumping, government procurement, safeguards, sanitary and phytosanitary measures, and technical barriers to trade. And, although not part of the original negotiating mandate, the World Trade Organization (WTO) was created during the final phase of the negotiations, which incorporated all elements of the Uruguay Round Agreement and the long-standing provisions of the GATT",

5 HOEKMAN, Bernard M.; MAVROIDIS, Petros C. The World Trade Organization: law, economics, and politics. Abingdon: Routledge, 2007, p. 15. "in a nutshell, the WTO is both a mechanism for exchanging (trading) trade policy commitments, and agreeing on a code of conduct"

6 A tabela de membros da OMC e seus detalhes pode ser consultada no sítio da própria WTO. Disponível em: <http://www. wto.org/english/thewto_e/whatis_e/tif_e/org6_e.htm>. Acesso em: 14 out. 2014
Em relação aos seus objetivos, conforme disposto no art. $2^{\circ}$ de seu tratado constitutivo, a "OMC constituirá o quadro Institucional comum para a condução das relações comerciais entre seus Membros". Conforme explica Pedro Talavera Déniz, a OMC nasceu com os seguintes objetivos: a) criar uma organização supranacional, capaz de administrar e regulamentar o comércio internacional; b) propiciar um maior e melhor acesso aos mercados, de modo a evitar as restrições protecionistas às importações; c) combater o comércio desleal nas exportações, evitando o crescimento artificial e desmedido de produtos não competitivos ou de mercadorias falsificadas; d) permitir aos países intervenientes o prévio conhecimento das normas regulamentares que afetem suas atividades; e) abarcar e disciplinar todas as transações internacionais, alcançando uma vasta gama de produtos, inclusive com regras específicas em relação à prestação de serviços; f) estabelecer um procedimento na solução de conflitos capaz de garantir aos seus membros o reconhecimento dos direitos negociados e o cumprimento das obrigações assumidas; e g) ser, em suma, um organismo de vocação universal. ' Seus objetivos, em síntese, resumem-se,

na intenção de desenvolver um sistema comercial multilateral integrado, mais viável e durável, baseado no GATT, nos resultados das rodadas de liberalização comercial anteriores e nos resultados da Rodada Uruguai. ${ }^{8}$

No tocante ao seu aspecto funcional, em síntese suas funções abrangem a administração dos acordos e dos mecanismos de solução de controvérsias e de revisão de políticas comerciais. Além disso, a Organização serve como fórum de negociações comerciais multilaterais?

conforme disposto no art. $3^{\circ}$ de seu documento constitutivo. $^{10}$

7 DÉNIZ, Pedro Talavera. La Regulación Del Comercio Internacional: del GATT a la OMC. Barcelona: Universitat de Barcelona, 1995, p. $45-46$.

8 MESQUITA, Paulo Estivallet de Mesquita. A Organização Mundial do Comércio. Brasília: FUNAG, 2013, e-book.

9 MESQUITA, Paulo Estivallet de Mesquita. A Organização Mundial do Comércio. Brasília: FUNAG, 2013, e-book.

10 “Artigo III - Funções da OMC. 1. A OMC facilitará a aplicação administração e funcionamento do presente Acordo e dos Acordos comerciais multilaterais e promoverá a consecução de seus objetivos e constituirá também o quadro jurídico para a aplicação, administração e funcionamento dos Acordos comerciais Plurilaterais. 2. A OMC será o foro para as negociações entre seus Membros acerca de suas relações comerciais multilaterais em assuntos tratados no quadro 
A estrutura institucional da OMC está prevista no seu art. $4^{\circ}$, sendo um tanto complexa. Funciona basicamente em quatro níveis organizacionais, em que há uma grande quantidade de comitês e grupos de trabalhos. ${ }^{11}$ Sua estrutura é composta precipuamente por seus membros, que são países ou "territórios aduaneiros". ${ }^{12}$ Mesquita explica que

A estrutura da OMC tem, no ápice, a Conferência Ministerial, que se reúne a cada dois anos. No dia a dia, o órgão decisório máximo é o Conselho Geral, integrado pelos Representantes Permanentes de todos os Membros. O Conselho Geral também se reúne como Órgão de Solução de Controvérsias e como Órgão de Revisão de Políticas Comerciais. Abaixo do Conselho Geral estão os Conselhos de Comércio de Bens, Comércio de Serviços e TRIPS. Abaixo destes, por sua vez, há cerca de quatro dezenas de Comitês, Subcomitês e Grupos de Trabalho, que administram acordos específicos ou mesmo aspectos distintos de um mesmo acordo. Essa estrutura é servida pelo Secretariado, dirigido por um Diretor-Geral. ${ }^{13}$

Conforme pode-se verificar, as Conferências Ministeriais (art. $\left.4^{\circ}, 1\right)$, conhecidas também como

dos acordos incluídos nos Anexos ao presente Acordo. A OMC poderá também servir de foro para ulteriores negociações entre seus Membros acerca de suas relações comercias multilaterais e de quadro Jurídico para a aplicação dos resultados dessas negociações secundo decida a Conferência Ministerial. 3. A OMC administrará o entendimento relativo às normas e procedimentos que regem a solução de controvérsias (denominado a seguir 'Entendimento sobre Solução de controvérsias' ou 'ESC') que figura no Anexo 2 do presente Acordo. 4. A OMC administrará o mecanismo de Exame das Políticas comerciais (denominado a seguir 'TPRM') estabelecido no anexo 3 do presente Acordo. 5. Com o objetivo de alcançar uma maior coerência na formulação das políticas econômicas em escala mundial, a OMC cooperará no que couber com o Fundo Monetário Internacional e com o Banco Internacional de Reconstrução e Desenvolvimento e com os órgãos a eles afiliados".

11 O organograma estrutural da OMC pode ser consultado no próprio sítio da organização na internet. Disponível em:

<http://www.wto.org/english/thewto_e/whatis_e/tif_e/utw_ chap7_e.pdf>. Acesso em: 14 out. 2014.

12 São territórios com capacidade jurídica para implementar acordos de comércio, mesmo não constituindo técnica $\mathrm{e}$ juridicamente Estados nacionais, v.g., Hong Kong, Taiwan e União Europeia.

13 MESQUITA, Paulo Estivallet de Mesquita. A Organização Mundial do Comércio. Brasília: FUNAG, 2013, e-book. "rodadas", configuram o primeiro e mais alto nível do processo de tomada de decisões da OMC, sendo que nelas são definidos os temas que serão tratados pelos Estados-membros em cada rodada de negociação, que deve ocorrer num prazo de até dois anos.

O segundo nível organizacional está representado por três organismos: o Conselho Geral, o Órgão de Solução de Controvérsias (OSC) e o Órgão de Revisão de Politica Comercial (ORPC).

O órgão mais expressivo é o Conselho Geral (art. $4^{\circ}$, 2), órgão permanente constituído por embaixadores ou chefes de delegações de todos os Estados-membros, cuja função precípua é zelar pelos acordos multilaterais, administrar as atividades diárias da OMC, bem como executar as decisões tomadas nas Conferências Ministeriais.

Os outros dois órgãos que se encontram no mesmo nível auxiliam o Conselho Geral no desempenho de suas tarefas. Um deles é o Órgão de Solução de Controvérsias OSC (art. $4^{\circ}, 3$ ), composto por todos os membros da organização, sendo a instituição máxima do sistema de solução de litígios no âmbito da organização e que será abordado mais adiante. O outro é o Órgão de Revisão de Politica Comercial - ORPC (art. $\left.4^{\circ}, 4\right)$, criado com o objetivo de estabelecer um cronograma anual de entrega de relatórios periódicos dos membros da OMC, com base nos acordos multilaterais de comércio, tem como incumbência verificar a consistência das políticas econômicas adotadas pelos países.

No terceiro nível dentro da estrutura orgânica da OMC, estão presentes três acordos: o GATT, O GATS e o TRIPS. O primeiro, Acordo Geral sobre Tarifas e Comércio (General Agreement on Tariffs and Trade - (GATT), que deu origem à $\mathrm{OMC}$, como já se deu notícia, atualmente está inserido no âmbito da organização para regular as tarifas e o comércio.

O segundo, Acordo Geral de Comércio de Serviços (General Agreement on Trade in Service - GATS), tem como finalidade estabelecer um quadro referencial multilateral de princípios e regras para o comércio internacional.

Por fim, o terceiro, denominado Acordo sobre Aspectos do Direito da Propriedade Intelectual Relacionados ao Comércio (Agreement on Trade-Related Aspects of Intellectual Property Rights - TRIPS), tem como escopo criar um ambiente para negociações multilaterais com base em princípios, regras e disciplina relacionados com os direitos de propriedade intelectual em disputa pelos países. 
O quarto e último nível organizacional da OMC é constituído por uma grande quantidade de comitês e grupos de trabalhos que tratam de temas diversos (v.g., o Comitê de Comércio e Desenvolvimento, o Comitê de Restrições por Balanço de Pagamentos, o Comitê de Assuntos Orçamentários, Financeiros e Administrativos etc.), como acesso a mercados, subsídios, e comitês permanentes que lidam com a administração, o orçamento e as finanças; comércio e meio ambiente; acordos regionais etc.

De um modo geral, essa estrutura organizacional tem sido objeto de críticas em razão de sua complexidade e inadequação para tratar de modo eficiente as questões do comércio internacional multilateral hodiernas que têm-se apresentado como desafios à $\mathrm{OMC}$, conforme tratado mais adiante.

\subsection{As conquistas da OMC}

Era comum o entendimento dos Estados-membros, quando da criação da OMC, de que as relações na esfera da atividade comercial e econômica deveriam objetivar a elevação dos níveis de vida, o pleno emprego, o aumento da produção e do comércio de bens e de serviços, permitindo simultaneamente a utilização ótima dos recursos mundiais de conformidade com o desenvolvimento sustentável, buscando-se proteger e preservar o meio ambiente bem como desenvolver os meios para fazê-lo, de maneira compatível com as respectivas necessidades e interesses de cada Estado, segundo os diferentes níveis de desenvolvimento econômico.

Os países também reconheciam naquele momento a necessidade de envidarem-se esforços positivos para que países em desenvolvimento, especialmente os de menor desenvolvimento relativo, pudessem obter uma parte do incremento do comércio internacional que correspondesse às necessidades de seu desenvolvimento econômico. Afirmavam naquele instante a intenção em contribuir para a consecução desses objetivos mediante a celebração de acordos destinados a obter, na base da reciprocidade e de vantagens mútuas, a redução substancial das tarifas aduaneiras e dos demais obstáculos ao comércio, assim como a eliminação do tratamento discriminatório nas relações comerciais internacionais. É, nesse contexto, nesse misto de otimismo e boas intenções e expectativas que nasceu a primeira organização regente do comércio internacional multilateral em âmbito mundial.

Conforme já se afirmou, a OMC foi pioneira no plano internacional em oferecer uma base jurídica sólida (Acordo de Estabelecimento da Organização Mundial de Comércio) para o sistema de comércio internacional multilateral, o que se deu por meio dos acordos firmados em Marraqueche, como resultados da Rodada Uruguai de Negociações Comerciais Multilaterais. Sem dúvida esse fato consiste numa grande conquista para os Estados-membros originários e para todos aqueles que puderam ingressar ulteriormente no mercado internacional, graças ao novo sistema instituído no âmbito da OMC. Afinal, a organização ainda é hoje o único fórum em que são definidas as regras para o comércio mundial, o que confere aos Estadosmembros maior segurança jurídica em suas relações, assim como maior estabilidade e previsibilidade nas relações comerciais internacionais desencadeadas.

Também como já se apontou, a OMC, ao longo dos vinte anos de sua existência, estabeleceu uma longa trajetória de inserção de diferentes Estados no mercado internacional. Certamente, a adesão de parceiros de peso como a China, a Arábia Saudita e a Rússia consistiram em importante conquista da organização.

O sistema de solução de controvérsias (OSC) da OMC possivelmente constitui o principal sucesso da organização. Com a sua instituição, passou a ser possível a resolução de disputas comerciais dentro de um procedimento de disputa regulamentado. Por essa razão, até mesmo os países em desenvolvimento conseguem ter êxito em disputas contra grandes potências industriais, a exemplo da União Europeia que já teve repetidas vezes que ajustar suas regras às determinações da OMC. Em relação ao mecanismo de administração de conflitos instituído no âmbito da organização, Celso Lafer pondera que

O mercado e a concorrência podem ser vistos como uma grociana luta de todos em prol de todos. Essa é a tese do doux commerce. Simmel observou que o mercado e a concorrência são, no entanto, simultaneamente uma hobbesiana guerra de todos contra todos [...]. Para evitar a confrontação bélica de uma concorrência desenfreada 'baseada no poder', a administração do conflito e da cooperação no mercado requer um enquadramento jurídico. A OMC prevê esse enquadramento através de um ordenamento 
jurídico, o single undertaking, concebido como um jogo de normas de fair play compartilhadas por todos os membros [...]. O sistema de solução de controvérsias da OMC representa não só codificação, mas um desenvolvimento progressivo do direito e da prática do GATT. ${ }^{14}$

Ainda que atualmente se deva admitir a necessidade de aperfeiçoamento do mecanismo de solução de controvérsias da $\mathrm{OMC}$ em diversos aspectos, não há dúvidas de que ele constituiu um avanço institucional de singular importância no campo das relações comerciais internacionais. Roberto Azevêdo, ao ressaltar a importância do OSC esclarece que

A adoção do chamado "consenso reverso",
segundo o qual decisões importantes como
o estabelecimento de painéis ou a adoção de
relatórios são automaticamente tomadas caso não
se verifique a oposição do conjunto dos membros
da OMC, trouxe maior previsibilidade ao sistema.
A criação de uma instância recursal, o Órgão de
Apelação, por sua vez, atribuiu maior juridicidade
à complexa tarefa de dirimir litígios comerciais
entre Estados soberanos. Por fim, a admissão do
direito de suspender concessões e obrigações na
hipótese de descumprimento de suas decisões
— ou seja, de "retaliar" — conferiu ao sistema
grau de atratividade e confiança que não encontra
paralelo em outras cortes internacionais.

Para o Brasil, o mecanismo de solução de controvérsias da OMC é considerado uma das principais realizações da Rodada Uruguai do GATT, pois, além de cumprir com a sua função precípua de resolver os conflitos comerciais ocorrentes entre os membros da OMC, o mecanismo tem-se revelado um instrumento fundamental no tocante à interpretação dos compromissos assumidos no âmbito dos acordos que conformam o sistema multilateral de comércio, bem como na criação de jurisprudência que, na prática, acaba por preencher lacunas e equacionar ambiguidades que não raras as vezes se fazem presentes nas disciplinas multilaterais do comércio. ${ }^{16}$

14 LAFER, Celso. AOMC e a regulamentação do comércio internacional: uma visão brasileira. Porto Alegre: Livraria do Advogado, 1998, p. 9.

15 AZEVÊDO, Roberto Carvalho de. O Brasil e o Mecanismo de Solução de Controvérsias da OMC. In: LIMA, Maria Lúcia Labate Mantovanini Padua; ROSENBERG, Barbara (Coords.). O Brasil e o contencioso na OMC. Tomo I. São Paulo: Saraiva, 2009, e-book.

16 AZEVÊDO, Roberto Carvalho de. O Brasil e o Mecanismo de Solução de Controvérsias da OMC. In: LIMA, Maria Lúcia Labate
A OMC também se mostrou capaz de desempenhar aquilo que talvez seja a sua principal tarefa que é limitar o protecionismo dos países em relação aos seus mercados internos. Esse fato ganha ainda mais relevo no contexto de uma crise financeira e econômica, como a que sobreveio sobre os EUA em 2008, pois, ao contrário de épocas anteriores, a crise não levou os Estados a fecharem seus mercados.

No entanto, em relação ao Brasil pesa atualmente um fator desfavorável nesse sentido. No início de 2014, o diretor-geral da OMC apresentou um relatório oficial em Genebra, que aponta o Brasil como campeão em medidas protecionistas no ano anterior (entre outubro de 2012 e novembro de 2013). . $^{17}$

De acordo com o documento, o Brasil "foi o país que mais adotou políticas contra produtos importados em todo o mundo" no ano de 2013, "com um total de 39 processos antidumping", conforme o relatório da organização ${ }^{18,}$ o que deu ao país o título de campeão em medidas protecionistas, o que reforça a sua imagem no exterior, notadamente na $\mathrm{EU}$, como um país que tem buscado medidas restritivas contra importações, v.g., elevando os impostos de importação (barreira tarifária) e concedendo isenção de impostos para empresas que fabriquem seus produtos dentro do mercado brasileiro.

No final de 2013, por ocasião de sua IX Conferência Ministerial, sob a direção geral do brasileiro Roberto Azevêdo, uma grande conquista da OMC foi conseguir concluir o primeiro acordo comercial global nos quase 20 anos de sua existência, na conferência realizada em Bali, na Indonésia. Embora o referido acordo consista num pacote modesto de medidas quando comparado às ambições iniciais da Rodada Doha ${ }^{19}$ (vide comentários

Mantovanini Padua; ROSENBERG, Barbara (Coords.). O Brasil e o Contencioso na OMC. Tomo I. São Paulo: Saraiva, 2009, e-book.

17 COLON, Leandro. OMC lista Brasil como líder em protecionismo. Londres. 2014. Disponível em: <http://www1. folha.uol.com.br/mercado/2014/02/1413705-omc-lista-brasilcomo-lider-em-protecionismo.shtml>. Acesso em 14: out. 2014.

18 VEJA. Brasil é o número $1 \mathrm{em}$ medidas protecionistas, diz OMC. 2014. Disponível em: < <ttp://veja. abril.com.br/noticia/economia/brasil-e-o-n-1-em-medidasprotecionistas-diz-omc>. Acesso em 14: out. 2014.

19 Em síntese, a Rodada Doha constitui atualmente o principal elemento do comércio mundial e também o seu grande desafio. Trata-se de exaustivas negociações iniciadas em 2001 no âmbito da OMC, entre os Estados-membros da organização, incluindo-se as maiores potências comerciais do mundo, visando a diminuição de barreiras comerciais, com foco no livre comércio. As negociações receberam o nome de Doha, capital do Qatar, pelo fato de ter sido nessa cidade que os países começaram a sua discussão. As conversas 
adiante), esse fato representou um significativo fôlego para a credibilidade da organização. $O$ acordo é importante porque constitui o primeiro realizado pela OMC desde o último acordo comercial global que havia sido realizado na Rodada do Uruguai, em 1994, ainda no âmbito do GATT, e pela primeira vez na história a organização chegou a um consenso, produzindo resultados.

Em síntese, o primeiro acordo global da organização envolve um esforço conjunto de 159 Estados-membros para simplificar os procedimentos para negócios internacionais. O pacote de Bali contém dez textos que estão divididos em três grandes temas: a desburocratização e facilitação do comércio, a agricultura e a promoção do desenvolvimento dos países mais pobres. ${ }^{20}$

Conforme notícia veiculada no jornal "Valor Econômico", de acordo com a Câmara Internacional de Comércio, o primogênito acordo tem o condão de gerar um incremento do comércio global de US\$ 1 trilhão e reduzir ainda entre $10 \%$ e $15 \%$ os custos de transação entre as empresas, podendo criar 21 milhões de empregos no planeta. ${ }^{21}$ No Brasil o acordo de Bali foi comemorado. Em nota oficial, o Ministério das Relações Exteriores afirmou que os resultados são "amplamente positivos" para o Brasil e terão a capacidade de permitir a implementação de "reformas" no país. ${ }^{22}$

\subsection{Os desarranjos e os desafios da OMC na atualidade}

No contexto de um mundo globalizado,

e negociações têm como ponto central a separação entre os países ricos e desenvolvidos e os maiores países em desenvolvimento (representados pelo G20), sendo os subsídios agrícolas o principal tema de controvérsia no âmbito das negociações, embora a agenda inicial da rodada conte com 21 temas amplos e complexos.

20 LANDIM, Raquel. É a hora de acabar com a utopia do consenso na OMC. Disponível em:

$<$ http://www1. folha.uol.com.br/colunas/raquellandim/2013/12/1382381-e-ahora-de-acabar-com-a-utopia-do-consenso-na-omc.shtml>. Acesso em: 15 out. 2014.

21 MOREIRA, Assis. OMC aprova em Bali primeiro acordo comercial global em décadas. Disponível em: < $<\mathrm{ttp}$ : / / w w . valor.com.br/internacional/3365324/omc-aprova-em-baliprimeiro-acordo-comercial-global-em-decadas $>$. Acesso em: 14 out. 2014.

22 BRASIL. Ministério das Relações exteriores. IX Conferência Ministerial da OMC. Disponível em:

$<\mathrm{h}$ t $\mathrm{t}$ p : / / www.itamaraty.gov.br/sala-de-imprensa/notas-a-imprensa/ixconferencia-ministerial-da-omc >. Acesso em: 14 out. 2014. a crescente internacionalização da economia decorrente principalmente da redução de barreiras ao comércio mundial, da maior velocidade das inovações tecnológicas e dos grandes avanços nas comunicações $^{23}$

tem gerado profundas mudanças no relacionamento comercial em âmbito mundial, demandando dos países mudanças efetivas na atuação no comércio internacional e como consequência exercendo pressão sobre a OMC, que hoje tem questionada a sua capacidade de promover entendimentos multilaterais e consequentemente cumprir os papéis para os quais foi vocacionada de maneira efetiva. ${ }^{24}$ Em verdade, há aqueles que vislumbram até um futuro esvaziamento da organização em razão do estado de coisas que se estabeleceu nos últimos anos.

Em um recente e sintético escrito intitulado "Desafios na OMC: discussão não deve ter influência ideológica" 25 , Rubens Barbosa aponta três desafios que os Estados-membros da OMC deverão enfrentar para recuperar a credibilidade e a relevância da organização para o comércio internacional: (i) retomar efetivamente as negociações da Rodada de Doha; (ii) tentar incluir

23 MARTINS, Eliane M. Octaviano. A sistemática de solução de controvérsias no âmbito da OMC. 2006. Disponível em:

<http://www.planalto.gov.br/ccivil_03/revista/Rev_40/artigos/ art_Eliane.html>. Acesso em 14 out. 2014.

24 A doutrina aponta que a OMC surgiu para enfrentar diversos problemas para os quais não foram encontradas soluções adequadas no âmbito do GATT: "a) a necessidade de efetiva integração de todos os países ao sistema proposto pelo GATT e demais Acordos Multilaterais; b) uma análise sobre o crescimento dos produtos de alta tecnologia e seus reflexos nos países excluídos; c) a questão da propriedade intelectual e das marcas e patentes internacionais ante o aumento da pirataria e da contrafação; d) a importância crescente dos subsídios à exportação como instrumento de política pública em determinados países; e) o enorme desenvolvimento do comércio de serviços, capaz de suplantar as transações entre mercadorias; f) as características peculiares do novo capital, a partir da globalização econômica, e a política de investimentos internacionais; g) a ausência de um ambiente permanente de negociações e de mecanismos de solução de controvérsias." (CAPARROZ, Roberto. Comércio internacional esquematizado. São Paulo: Saraiva, 2012, e-book).

25 BARBOSA, Rubens Antônio. Desafios da OMC. Disponível em: $<$ http://oglobo.globo.com/opiniao/desafios-na-omc-11702806>. Acesso em: 14 out. 2014. Rubens Antônio Barbosa foi embaixador do Brasil em Washington (1999-2004). É presidente do Conselho Superior de Comércio Exterior (Coscex) da Fiesp. É também articulista dos jornais "O Estado de São Paulo" e "O Globo", sendo também editor chefe da revista "Interesse Nacional". É autor dos livros "Panorama Visto de Londres", sobre política externa e econômica; "Integração Econômica da América Latina" e "The Mercosur Codes". 
na $\mathrm{OMC}$ os acordos regionais e bilaterais e suas regras; (iii) e reformar a governança da instituição.

Nos termos do artigo 28 do GATT, as partes contratantes podem realizar negociações com a finalidade de diminuir as tarifas de importação e promover a abertura dos mercados. No âmbito do GATT, foram realizadas pelos países membros, oito Conferências Comerciais Multilaterais, também conhecidas como "rodadas", sendo que a mais importante certamente foi a Rodada do Uruguai, que culminou com a criação da OMC, como já delineado.

Já no âmbito da OMC, as reuniões dos Estadosmembros em rodadas de negociações ocorrem por meio das Conferências Ministeriais, conforme já visto. A organização já realizou diversas rodadas e teve como divisor de águas e momento mais importante pós Rodada do Uruguai, o encontro promovido na cidade de Doha, capital do Qatar, em novembro de 2001. Porém, antes disso, três outras Conferências foram realizadas, com resultados variados (Cingapura - 1996; Genebra - 1998; Seattle - 1999). Acerca da Rodada de Doha, Caparroz explica que

O momento mais importante pós-Rodada Uruguai ocorreu em Doha, durante a Quarta Conferência Ministerial da Organização Mundial do Comércio, realizada entre 9 e 14 de novembro de 2001. Em meio à perspectiva de diminuição do crescimento das relações comerciais internacionais, agravada pela preocupação global causada pelos ataques terroristas em 11 de setembro, os países elegeram como ponto fundamental das negociações a necessidade de maior inserção dos países em desenvolvimento. $\mathrm{O}$ objetivo era a um só tempo essencial e ambicioso, pois precisava alcançar soluções para o acesso a mercados, regras mais balanceadas entre países desenvolvidos e menos desenvolvidos, assistência técnica contínua e financeiramente sustentável, além da necessidade de implantação de programas de capacitação efetivos para o desenvolvimento das economias mais frágeis. Tudo isso somado à eterna questão dos subsídios agrícolas, o grande nó das negociações multilaterais desde a criação do GATT. Ao término da conferência, foi produzida pelos signatários uma declaração ministerial que definiu a criação de uma nova rodada de negociações, a primeira no âmbito da $O M C$, que foi batizada de Rodada do Desenvolvimento. (grifo nosso) ${ }^{26}$

A atual rodada de negociações, denominada Rodada do Desenvolvimento é a primeira oficialmente conduzida sob os auspícios da OMC. Foi construída tendo como fundamento primordial a maior participação dos países em desenvolvimento no comércio internacional e o livre acesso ao mercado mundial a todos os participantes da organização, o que implica consequentemente a necessidade de alguns países, notadamente aqueles ricos e desenvolvidos, abrirem suas economias, a fim de superar-se o protecionismo dos mercados internos, v.g., por meio da redução de tarifas alfandegárias e outras barreiras comerciais. Manfred Elsig e Cédric Dupont explicam que

as negociações sobre questões distributivas são naturalmente caracterizadas por períodos de progresso e de estagnação. Portanto, não é incomum que, de tempos em tempos, apareçam impasses acerca das negociações sobre a maneira como os países abrem as suas economias ao comércio. ${ }^{27}$

A Rodada Doha contou com uma agenda inicial ambiciosa, que envolvia 21 temas amplos e complexos. Assim, diversos temas correlatos à temática principal são objeto dos debates e impasses no bojo dessa rodada de negociações (v.g., serviços, bens industriais, investimentos, políticas de concorrência, antidumping e subsídios, acordos comerciais regionais, solução de controvérsias, comércio e meio ambiente, comércio eletrônico etc.), sendo a agricultura certamente um dos aspectos mais espinhosos a serem enfrentados. ${ }^{28}$

26 CAPARROZ, Roberto. Comércio Internacional Esquematizado. São Paulo: Saraiva, 2012, e-book.

27 ELSING, Manfred; DUPONT, Cédric. Persistent Deadlock in Multilateral Trade Negotiations: The Case of Doha. In: NARLIKAR, Amrita; DAUNTON, Martin; STERN, Robert M. The Oxford Handbook on the World Trade Organization. New York: Oxford University Press, 2012, e-book. "Negotiations over distributive issues are naturally characterized by periods of progress and of stagnation. Therefore, it is not unusual that, from time to time, negotiations over the way countries open their economies to trade appear deadlocked".

28 Não há dúvidas de que um dos maiores pontos de discórdia nas discussões e negociações ocorridas no âmbito da OMC é a agricultura, assunto que acarretou uma divisão entre os países industrializados e as nações em desenvolvimento, tais como o Brasil. Apenas para se ter uma breve noção da problemática envolvendo a agricultura, algumas perguntas que constituem o núcleo dos 
Tudo isso acabou por transformar a Rodada de Doha na mais complexa negociação multilateral da história, o que explica, em parte, o fato de até o presente momento não se ter chegado a qualquer conclusão, estando praticamente paralisada desde então. ${ }^{29}$ Alguns especialistas em OMC, como o professor Simon J. Evenett, da Universidade St. Gallen, na Suíça, afirma que a Rodada Doha está morta, embora ninguém queira dizer isso em voz alta. ${ }^{30}$

Portanto, retomar de modo efetivo as negociações dessa rodada parece ser o primeiro grande obstáculo a ser enfrentado pela organização, principalmente diante do quadro atual de baixo crescimento econômico e do alto nível de desemprego na Europa, bem como em razão de acordos regionais e bilaterais que, de certo modo, propiciam uma zona conforto para os países desenvolvidos no âmbito de suas negociações comerciais, o que faz com que seus dirigentes manifestem certo desinteresse pelas negociações no domínio da OMC, como já demonstraram os dirigentes americanos e europeus.

De outro lado, países em desenvolvimento dificilmente tenderão a abrir mão de suas agendas de desenvolvimento e de interesses específicos, especialmente "quanto à redução ou eliminação dos

debates no âmbito da OMC são elucidativas: os países ricos devem abolir os subsídios que concedem a seus agricultores? Os países em desenvolvimento podem cobrar tarifas de importação para proteger seus próprios produtos? Conforme já indicou o atual ministro das Relações Exteriores, Luiz Alberto Figueiredo, para o Brasil, a retomada das negociações da Rodada Doha depende da inclusão na pauta das distorções comerciais na agricultura. Disponível em:

$<$ http://opiniao.estadao.com.br/noticias/geral,desafios-para-obrasil-na-omc-imp-,1134295>. Acesso em: 14 out. 2014.

Para um aprofundamento na temática da agricultura no contexto da OMC vide: RODRIGUES, Tatiana S. Fukuda; PAULA, Nilson M. de. A agricultura nas negociacõos multilaterais da Rodada Doba e suas implicações para o Brasil. Disponível em:

$<$ http://ojs.c3sl.ufpr.br/ojs/index.php/economia/article/ viewFile/12297/8514>. Acesso em: 14 out. 2014.

29 Para uma visão completa acerca dos impasses e dos impedimentos que têm paralisado a Rodada de Doha, sob uma perspectiva da Teoria dos Jogos, vide elucidativo escrito de Manfred Elsig e Cédric Dupont: Persistent Deadlock in Multilateral Trade Negotiations: The Case of Doha. In: NARLIKAR, Amrita; DAUNTON, Martin; STERN, Robert M. The Oxford Handbook on the World Trade Organization. New York: Oxford University Press, 2012, e-book.

30 EVENETT, Simon J. The Doha Round Impasse. 2012. Disponível em:<http://graduateinstitute.ch/files/live/sites/iheid/ files/shared/summer/WTO2012/protected/Evenett_Doha_ Round_Impasse_paper_March_2012\%20revised.pdf >. Acesso em: 14 out. 2014. créditos à produção e aos subsídios à exportação" 31 , havendo até quem afirma que a Rodada de Doha está morta.

Conforme delineado anteriormente, o segundo problema a ser enfrentado pela organização, uma vez retomadas as negociações, será trazer para o plano das negociações multilaterais os acordos comerciais que estão sendo discutidos e travados fora do âmbito da organização. Atualmente a OMC está sob forte pressão por estar enfrentando a concorrência de acordos bilaterais e mega-acordos regionais, articulados e concluídos no âmbito de países e blocos regionais específicos, a exemplo daqueles que têm sido constituídos entre EUA e países asiáticos e entre EUA e União Europeia. Desse modo, tentar trazer para o âmbito da organização estes acordos regionais e bilaterais e as suas regras, que para alguns vão "muito além das existentes hoje no âmbito da $\mathrm{OMC}^{\prime 32}$, é realmente um grande obstáculo a ser superado. Rubens Barbosa, comentando essa questão ressalta que

\begin{abstract}
Mais de 500 acordos regionais e bilaterais estão em discussão e 345 foram notificados à Organização e estão em vigor. A função de monitoramento desses acordos, um dos pilares da OMC, no entanto, não está sendo exercida por falta de condições técnicas e políticas. Como multilateralizar as concessões e as regras negociadas fora da entidade e que ultrapassam os limites hoje vigentes, como as chamadas de OMC plus (serviços, barreiras técnicas ou propriedade intelectual), bem assim as que tratam de temas que estão fora do marco da OMC, como investimento, concorrência, meio ambiente, padrões trabalhistas? As negociações de acordos preferenciais de comércio e dos megaacordos regionais não se restringem à redução de tarifas de importação, hoje muito reduzidas, mas focam um quadro regulatório que impacta diretamente o intercâmbio de bens e serviços, como barreiras técnicas, sanitárias e fitossanitárias, mudança climática, eficiência energética, direitos humanos, padrões (standards) e economia digital, entre outros. ${ }^{33}$
\end{abstract}

31 BARBOSA, Rubens Antônio. Desafios da OMC. Disponível em: $<$ http://oglobo.globo.com/opiniao/desafios-na-omc-11702806>. Acesso em: 14 out. 2014.

32 BARBOSA, Rubens. Desafios para o Brasil na OMC. Disponível em: <http://opiniao.estadao.com.br/noticias/geral,desafios-parao-brasil-na-omc-imp-,1134295>. Acesso em: 14 out. 2014.

33 BARBOSA, Rubens. Desafios para o Brasil na OMC. Disponível 
Verifica-se inclusive que a $\mathrm{OMC}$, enquanto órgão harmonizador do comércio internacional pretende ajudar os seus membros a seguirem padrões comerciais que satisfaçam seus interesses econômicos, enquanto, ainda que em segundo plano, produza a interação entre o comércio mundial e outras áreas como os direitos humanos e o meio ambiente. Portanto, um dos grandes desafios atuais da OMC está em alcançar um comércio livre, de acordo com os postulados do desenvolvimento sustentável, respeitando os diferentes níveis de desenvolvimento econômico dos Estados. Percebe-se assim que enquanto o antigo GATT tinha como um de seus objetivos principais incentivar ao máximo a utilização dos recursos mundiais, frutos da liberalização gradual do comércio internacional por meio da eliminação das barreiras comerciais, a OMC, conforme estabelecido em seu preâmbulo, inova ao incorporar novas temáticas ao comércio.

Como terceiro desafio, para enfrentar as questões relativas à retomada das negociações de Doha e a inclusão dos acordos e regras estabelecidos fora da OMC, prega-se a necessidade de reforma e modernização da organização para atender, de maneira satisfatória, às expectativas e reclamos de um comércio internacional intrincado e complexo.

É certo que as instituições internacionais como a OMC podem ser pensadas, concebidas e estruturadas sob diversas formas; contudo, o fator mais importante que se deve ter em mente é que essas instituições devem ter como objetivo principal a busca pela agregação dos interesses dos vários atores envolvidos nas negociações. Desde as preciosas contribuições de Keohane ${ }^{34}$ para a escola liberal, as instituições têm sido conceituadas como "plataformas que permitem a cooperação para ocorrerem" e, segundo o autor, essas instituições "existem porque delas poderia razoavelmente se esperar um aumento no bem-estar de seus criadores". ${ }^{35}$

É certo que o "bem-estar" dos Estados-membros da OMC depende da cooperação entre eles para a consecução de interesses comuns, mas, por outro lado,

em: <http://opiniao.estadao.com.br/noticias/geral,desafios-parao-brasil-na-omc-imp-,1134295>. Acesso em: 14 out. 2014.

34 KEOHANE, Robert O. After Hegemony: Cooperation and Discord in the World Political Economy. Princeton: Princeton University Press, 1984.

35 KEOHANE, Robert O. After Hegemony: Cooperation and Discord in the World Political Economy. Princeton: Princeton University Press, 1984, p. 80. "institutions exist because they could have reasonably been expected to increase the welfare of their creators" essa cooperação depende diretamente da satisfação (ou possibilidade de satisfação) dos interesses em jogo. Atualmente, para que a OMC seja capaz de promover de maneira satisfatória um ambiente onde interesses multilaterais diversos sejam convergidos para um denominador comum, precisa caminhar, no sentido de uma reorganização estrutural, bem como revisitar e modificar algumas de suas instituições tais como a regra da decisão por consenso (Art. IX, 1, do Acordo Constitutivo da OMC), o principio do single undertaking (Art. II, 2 e 3, do Acordo Constitutivo da OMC) e o tratamento especial e diferenciado para países em desenvolvimento (estabelecido no Art. XXVIII e na Parte IV do GATT - 1994). Em relação a esse ponto específico, Rubens Barbosa afirma que

Tal como funciona hoje, a OMC não está preparada para reagir às demandas da globalização, da evolução do comércio global e da revolução das cadeias produtivas, responsável por $56 \%$ do intercâmbio comercial e $72 \%$ dos serviços no mundo [...]. Com 160 países-membros, as decisões por consenso serão cada vez mais difíceis e formas alternativas para formar consenso pela maioria terão de ser encontradas; a manutenção do tratamento especial e diferenciado aos países em desenvolvimento já está sendo questionada pelos desenvolvidos para países como a China, o Brasil, a Índia e outros; o single undertaking está sendo um fator impeditivo de avanço, como se viu na Rodada Doha. Ao lado desses itens, a possibilidade de acordos plurilaterais (abertos ou restritos) terá de ser discutida para permitir que quem quiser participar possa fazê-lo sem esperar que todos venham a participar. Hoje existem dois acordos plurilaterais em negociação fora da OMC - que não permite esse tipo de negociação - o de Serviços e o de Tecnologia da Informação. O funcionamento de alguns órgãos da OMC terá de ser revisto para aumentar a eficiência e a aplicação das decisões. Um desses órgãos é o comitê que examina os acordos regionais. Caso haja um efetivo interesse em incorporar os acordos negociados fora da OMC, o comitê deverá ser transformado num conselho para aumentar seu peso político. Finalmente, em função da importância dos temas e de sua relevância para os operadores privados, deveria ser considerada a participação do setor privado. A OMC é uma instituição intergovernamental sem a presença 
de representantes empresariais, por isso alguma forma de participação privada será importante para influir no processo de negociação. ${ }^{36}$

Manfred Elsig e Cédric Dupont, ao comentarem a organização estrutural atual da OMC e suas instituições, explicam em feliz síntese que

As instituições tornam possíveis os acordos e lhes dão credibilidade. Uma vez que Estados obtém incentivos para se aproveitarem ou mesmo renunciarem a acordos anteriores, o projeto exato (e nível de legalização) faz-se importante para o entendimento do desejo ex ante e ex post de adesão. Pode-se também abordar as instituições internacionais por uma perspectiva realista. Em especial, os analistas que seguem a tradição do institucionalismo neorrealista focam em como regimes internacionais afetam a distribuição dos benefícios e custos da interação estatal. As instituições têm consequências distributivas e podem ser utilizadas como instrumentos para que sejam obtidos e mantidos os ganhos assimétricos. Elas podem ainda auxiliar mais amplamente no controle do comportamento de outros atores, domésticos e internacionais. Podemos diferenciar um número de explanações pela forma como diferentes tipos de "instituições" afetam os resultados. Primeiramente, encontramos explanações que têm o foco na forma como os procedimentos de negociação são definidos. Isso inclui as instituições que determinam quem tem direito a um assento à mesa nas discussões mais importantes relacionadas ao tema central e como os procedimentos de tomada de decisão (por votação ou consenso) devem ser aplicados. Um fator constituinte no contexto da OMC - em adição à busca de consenso - é o compromisso único, fator este em que todos os temas são ligados e "nada é acordado até que tudo seja acordado". A escolha de tais 'micro instituições' tem implicações importantes para as condições sob as quais as colisões são construídas e afetam integralmente as negociações. Além disso, o papel designado aos presidentes dos grupos de negociação ou ao Diretor Geral e ao Secretariado também pode ser importante. Em segundo lugar, as instituições internacionais podem repercutir no nível

36 BARBOSA, Rubens. Desafios para o Brasil na OMC. Disponível em: <http://opiniao.estadao.com.br/noticias/geral,desafios-parao-brasil-na-omc-imp-,1134295>. Acesso em: 14 out. 2014. doméstico. Trabalhos recentes têm dado atenção a como o processo de regulamentação no contexto da OMC tem afetado o equilíbrio entre forças de grupos de interesse nesse nível doméstico. Ademais, uma vez que a crescente regulamentação no âmbito da OMC afeta a aplicação da lei doméstica, as partes estão se tornando cada vez mais relutantes em assumir novos compromissos. A literatura mostra que algumas instituições são mais propensas a bloquear as negociações (v.g., formação de consenso versus votação majoritária), ao passo que mudanças institucionais (v.g., por meio da formação de coalisão e invenções processuais) possam acontecer como condição necessária para o avanço das negociações. Enquanto alguns podem considerar tais mudanças mais como sendo parte das táticas e estratégias dos atores do que fatores contextuais ou estruturais em si, nós as discutimos nessa sessão tendo em conta que os tipos de microinstituições mencionados acima são estáticos e não se alteram da noite para o dia.". 37

37 ELSING, Manfred; DUPONT, Cédric. Persistent Deadlock in Multilateral Trade Negotiations: The Case of Doha. In: NARLIKAR, Amrita; DAUNTON, Martin; STERN, Robert M. The Oxford Handbook on the World Trade Organization. New York: Oxford University Press, 2012, e-book. "Institutions make deals possible and credible. As states face incentives to free-ride or to renege on past agreements, the exact design (and level of legalization) is important for understanding ex ante and ex post willingness to commit. International institutions can also be approached within a realist perspective. In particular, analysts following the tradition of neorealist institutionalism focus on how international regimes affect the distribution of costs and benefits of state interaction. Institutions have distributional consequences, and can be used as devices to seek and maintain asymmetric gains. They can more broadly help control other actors' behaviour, both at home and abroad. We can differentiate a number of explanations as to how various types of 'institutions' affect outcomes. First, we find explanations that focus on the way negotiation procedures are defined. These include institutions that determine who has a seat at the table in the most important subject-related discussions and how the dominating modes of decision-making procedures (voting or consensus) are to be applied. A constituent feature in the WTO context - in addition to consensus-seeking - is the single undertaking, where all issues are linked and 'nothing is agreed until everything is agreed'. The choice of such 'micro-institutions' has important implications for the conditions under which coalitions are built, and affects overall negotiations. Furthermore, the role assigned to the chairs of the respective negotiation groups, or to the DG and the Secretariat staff, may also matter. Second, international institutions may reverberate at the domestic level. Recent work has focused on how legalization in the WTO context has affected the balance of interest group powers at home. Moreover, given that increasing legalization affects enforcement, parties are becoming more reluctant to commit to new obligations. The literature shows that some institutions are more likely to lead to deadlock (e.g. consensus decision-making versus 
O que se pode aferir é que um dos maiores problemas a serem enfrentados pela $\mathrm{OMC}$, no tocante à necessidade de uma restruturação organizacional, institucional e normativa, refere-se ao processo de tomada de decisões nas negociações (processo decisório). Como se sabe, a OMC manteve a prática de tomada de decisões por consenso que prevalecia no GATT, com direito a voto de todos os membros. ${ }^{38}$

Apesar da existência dos procedimentos de votação elaborados, a maioria das decisões do GATT é, na prática, tomada com base no consenso. Essa prática do GATT foi codificada no artigo IX. ${ }^{39}$, do Acordo que instituiu a OMC.40

Para os Estados-membros da OMC, a importância do consenso reside no fato de se possibilitar que todos os membros, mediante concessões recíprocas, possam alcançar um denominador comum.

majority voting), while institutional changes (e.g. through coalitionbuilding and procedural inventions) might act as a necessary condition for advancing negotiations. Whereas one could consider these changes to be part of actors' strategies and tactics rather than structural or contextual factors, we discuss them under this section given that the types of micro-institutions mentioned above are sticky and do not change overnight".

38 Dispõe o artigo $9^{\circ}, 1$, de seu documento constitutivo que "A OMC continuará a prática de processo decisório de consenso seguida pelo GATT 1947 (1). Salvo disposição em contrário, quando não for possível adotar uma decisão por consenso, a materna em questão será decidida por votação. Nas reuniões da Conferência Ministerial e do Conselho Geral cada Membro da OMC terá um voto. Quando as Comunidades Europeias exercerem seu direito de voto terão o número de votos correspondente ao número de seus Estados-Membros (2) que são membros da OMC. As decisões da Conferência Ministerial e do Conselho Geral serão tomadas por maioria de votos salvo disposição em contrário do presente Acordo ou do Acordo multilateral de comércio pertinentes (3)."

39 "A OMC manterá a prática da tomada de decisões por consenso seguida por força do GATT de 1947 (ver nota 1). Salvo disposição em contrário, nos casos em que não for possível chegar a uma decisão por consenso, a questão em causa será decidida por votação. Nas reuniões da Conferência Ministerial e do Conselho Geral, cada Membro da OMC disporá de um voto. Nos casos em que as Comunidades Europeias exerçam o seu direito de voto, disporão de um número de votos igual ao número dos seus Estados membros (ver nota 2) que sejam Membros da OMC. As decisões da Conferência Ministerial e do Conselho Geral serão adoptadas por maioria dos votos expressos, salvo disposição em contrário prevista no presente Acordo ou no acordo comercial multilateral pertinente (ver nota 3)."

40 NARLIKAR, Amrita. The World Trade Organization: a very short introduction. New York: Oxford University Press, 2005, p. 44. "Despite the existence of elaborate voting procedures, most decisions in the GATT were in practice taken on the basis of consensus. This GATT practice has been codified in Article IX.1 of the Agreement establishing the WTO."
Mesmo que não haja o consenso, determinadas questões podem ser resolvidas por votação, em que as decisões são acolhidas por maioria de votos emitidos, sendo que cada país representa um voto (art. $\left.9^{\circ}, 1\right) .^{41}$ Contudo, apesar da possibilidade de votação, é rara a ocorrência desse mecanismo no âmbito da OMC, assim como era à época do GATT. Isso porque é muito forte e prevalece entre os Estados-membros a ideia de consenso, uma vez que as partes contratantes são dotadas de soberania, e essa prerrogativa (de votação) não se coaduna com a noção democrática de se adotar decisões mediante maioria. Acerca da regra do consenso, Bernard M. Hoekmanis e Petros C. Mavroidis explicam que

o consenso não significa unanimidade. Significa
que nenhuma delegação representada em uma
reunião objetou a uma proposta. Chegar a um
consenso pode ser um processo complexo que vai
requerer ainterconexão de temas eassuntos. A regra
do consenso reforça as tendências conservadoras
no sistema. Propostas para mudança podem ser
adotadas apenas se não sofrerem oposição. Embora
possa potencializar a estagnação, o consenso ajuda
a realçar a legitimidade das decisões. ${ }^{42}$

Conforme se pode aferir pelas colocações dos autores, a regra do consenso é uma faca de dois gumes, pois, embora propicie maior legitimidade para as decisões tomadas pelos membros da OMC, ao mesmo tempo tem o potencial de travar as negociações, paralisar as discussões e impedir a elaboração de acordos multilaterais no âmbito da organização. Em

41 De acordo com o documento constitutivo da OMC, existem restrições quanto aos temas que podem ser objeto de votação, de modo que as grandes e importantes questões negociadas não podem ser decididas sem o devido consenso. Para quatro situações específicas, o Acordo Constitutivo da Organização Mundial do Comércio prevê votação: 1) adoção de uma interpretação para qualquer um dos acordos (maioria de $3 / 4$ dos membros); 2 ) isenção de uma obrigação (maioria de $3 / 4$ dos membros); 3 ) emenda das disposições do acordo geral (consenso ou maioria de $2 / 3$ dos membros), segundo a natureza da disposição considerada; 4) admissão de um novo membro (maioria de $2 / 3$ dos membros) na Conferência Ministerial.

42 HOEKMAN, Bernard M.; MAVROIDIS, Petros C. The World Trade Organization: law, economics, and politics. Abingdon: Routledge, 2007, p. 25. "Consensus does not mean unanimity. It signifies that no delegation represented in a meeting objects to a proposal. Achieving consensus can be a complex process, requiring issue linkages. Consensus reinforces conservative tendencies in the system. Proposals for change can be adopted only if unopposed. Although it creates the potential for paralysis, consensus helps enhance the legitimacy of decisions". 
verdade, esse tem sido o quadro que se pode verificar desde o início das negociações na Rodada de Doha, evidenciado, dentre tantos outros fatores, pelo fato de somente após quase 20 anos de existência, a OMC foi capaz de concluir o seu primeiro acordo multilateral, conforme já delineado anteriormente.

O que se verifica é que pela regra do consenso, um único país pode paralisar as negociações sobre determinado tema e isso compromete sobremaneira a margem de manobra da OMC, pois obter o consenso dos atualmente 160 Estados-membros que integram a organização é sem dúvida uma tarefa hercúlea. Para alguns a regra do consenso é uma utopia. Marcos Jank, diretor de relações com o mercado da BRF e um dos maiores especialistas brasileiros em negociações comerciais, afirma que

a OMC precisa abandonar a utopia de tomar decisões por consenso. 'No antigo Gatt (antecessor da OMC), um grupo pequeno de países tomava todas as decisões. Hoje é impossível colocar 160 países de acordo. O mundo mudou. ${ }^{43}$

Os efeitos produzidos pela regra do consenso sem dúvida reverberam larga e negativamente na imagem da organização e sua capacidade de gestão do comércio internacional multilateral, notadamente naquilo que toca à produção normativa internacional sobre essa temática, já que o que se nota nesse particular é que a legislação do comércio internacional não se desenvolveu significativamente nos últimos 20 anos, o que não pode ser dito em relação ao desenvolvimento do próprio comércio internacional.

Nesse ponto, o que se conclui é que a OMC precisa superar a regra do consenso, pois, dado o número cada vez maior de participantes, as decisões por esse caminho se tornarão cada vez mais difíceis, de modo que se torna imperioso para a organização buscar alternativas para a obtenção do consenso pela maioria.

Outro problema que se apresenta e que carece de uma devida atenção e reforma no âmbito da OMC diz respeito ao princípio do single undertaking (ou princípio do compromisso único). De acordo com ele, as negociações no âmbito da organização exigem concordância de todos os Estados-membros em relação

43 FOLHA DE SÃO PAULO. É a hora de acabar com a utopia do consenso na OMC. Disponível em: $<$ http://www1. folha.uol.com.br/colunas/raquellandim/2013/12/1382381-e-ahora-de-acabar-com-a-utopia-do-consenso-na-omc.shtml>. Acesso em: 15 out. 2014. aos temas propostos, sem possibilidade de escolhas ou adesões parciais. Conforme esse princípio, nada de "geral" será aprovado pela organização a menos que cada acordo individual esteja decidido. De acordo com Roberto Caparroz, o

single undertaking consiste na negociação de um pacote de metas; ou seja, enquanto não houver definição para qualquer dos pontos negociados, o acordo, como um todo, não se materializa. ${ }^{44}$

Praticamente todos os itens de uma negociação são parte de um todo indivisível e um pacote e não podem ser acordados separadamente. Assim, nada está acordado até que tudo esteja acordado.

Em tese, a ideia do single undertaking parece salutar, pois tem o condão de incentivar a obtenção de concessões mútuas e a reciprocidade de tratamento entre os membros da organização. Celso Lafer, tecendo comentários sobre a essencialidade das normas da OMC, afirma que o mercado internacional não opera no vazio, mas requer uma ordem normativa e explica que nesse sentido

$$
\begin{aligned}
& \text { o single undertaking de suas normas limita a } \\
& \text { competência discricionária das soberanias } \\
& \text { nacionais dos membros da OMC para promover } \\
& \text { o seu interesse comum, expandindo a produção } \\
& \text { e o comércio de bens e serviços, como se lê no } \\
& \text { preâmbulo do Acordo de Marraqueche. Essa } \\
& \text { expansão é concebida como propícia ao bem-estar } \\
& \text { geral e consequentemente vista como geradora de } \\
& \text { um bem público internacional. }
\end{aligned}
$$

Contudo, na prática, o que se tem verificado é que o princípio tem conduzido as negociações a um beco sem saída, já que se não houver uma definição para qualquer dos pontos negociados, acordos, como um todo, não se materializam, o que acaba também por travar as negociações multilaterais e a criação de uma legislação dinâmica para acompanhar relações comerciais internacionais também dinâmicas. De outro ângulo, o single undertaking também pode servir como uma espécie de subterfúgio para aqueles países que não vêm os seus interesses nas negociações atendidos, pois ao oporemse à negociação de um determinado tema, sabem que

44 CAPARROZ, Roberto. Comércio Internacional Esquematizado. São Paulo: Saraiva, 2012, e-book.

45 LAFER, Celso. A OMC e a regulamentação do comércio internacional: uma visão brasileira. Porto Alegre: Livraria do Advogado, 1998, p. 145. 
acabarão impedindo a conclusão de determinado acordo de um modo geral.

Conforme se afere, o princípio constitui, em verdade, um fator impeditivo de avanço nas negociações multilaterais e, portanto, é outro ponto que carece de uma reforma e exige superação por parte da OMC, pois os resultados de determinadas negociações não podem ficar adstritos ao sucesso ou fracasso de outras negociações. É preciso avançar com as negociações que se mostrem menos intrincadas e complexas, ainda que não se chegue a um acordo sobre aquelas que se apresentam mais problemáticas, postergando o tratamento dessas últimas para um momento ulterior.

Ao lado da regra do consenso e do princípio do single undertaking, outro instituto que merece atenção dentro do sistema normativo da OMC é o tratamento especial e diferenciado (SDT) para países em desenvolvimento (PEDs), ou seja, aqueles com grau de desenvolvimento inferior e, portanto, diversos dos países desenvolvidos.

No sistema internacional, essa discussão sempre teve grande relevância no comércio internacional, pois há muito tempo chegou-se à conclusão de que um tratamento normativo uniforme para todos os países, independentemente do seu grau de desenvolvimento, traz mais prejuízos do que benefícios ao sistema como um todo. Assim, o debate acerca da necessidade de um tratamento que encare os Estados-membros da OMC, de acordo com o seu grau de desenvolvimento, isto é, de modo diferenciado, flexibilizando o conceito de isonomia ${ }^{46}$, parece estar superado.

Nesse contexto, o tratamento especial e diferenciado foi concebido, ainda no âmbito do GATT, almejando a promoção do desenvolvimento daqueles países considerados mais atrasados, a fim de proporcionar a sua inserção no comércio internacional em um ambiente de relações comerciais mais maleáveis. Além disso, a Parte IV do GATT também beneficiou os países em desenvolvimento no sentido de possibilitar a adoção de medidas domésticas que possam apoiar seu desenvolvimento nacional. Também não há dúvidas de que esse mecanismo constitui um instrumento que

$46 \mathrm{Na}$ análise do princípio da isonomia no âmbito da OMC, especificamente sobre essa temática, deve ser analisado levandose em consideração as peculiaridades e diferenças geográficas, econômicas, históricas, sociais e culturais, dentre muitas outras, existentes entre os Estados que fazem parte do sistema multilateral de comércio internacional, de modo que não pode conceber exigências idênticas a todos os Estados quando estes guardam diferenças tão profundas entre si. auxilia os países em desenvolvimento a adquirirem capacidade legal e institucional para cumprir com suas obrigações de liberalização comercial. A cláusula da nação mais favorecida certamente é um reflexo desse tratamento.

Foge ao escopo do presente trabalho o estudo aprofundado dessa temática. ${ }^{47}$ No entanto, cumpre salientar que a aplicação dessa normativa consolidada no âmbito da organização não está livre de objeções e críticas. Um dos maiores problemas enfrentados nessa temática é a construção do conceito de tratamento especial e diferenciado, os limites de sua aplicação, bem como os impactos da sua efetivação para o desenvolvimento dos países e no sistema do comércio internacional de um modo geral. Quem são os países destinatários do tratamento especial e diferenciado? Como identificar dentro do conceito de diferenciação ou graduação, quem são os países que podem se beneficiar desse tipo de tratamento? Eduardo Saldanha explica que

O problema prático no sistema GATT/OMC é que
em toda a história nunca se alcançou um consenso
sobre uma definição de país em desenvolvimento, o
que leva a uma dificuldade de congregar os anseios
de todos quanto à possibilidade de diferenciação. ${ }^{48}$

Essa complexidade fatalmente leva à politização do debate entre os Estados-membros da OMC. Eduardo Saldanha exemplifica essa questão aduzindo que

países como México e República da Coreia, que se uniram recentemente à Organização para Cooperação e Desenvolvimento Econômico (OCDE), estão pouco dispostos a mudar a sua designação em razão da questão política associada ao status do país na OMC, estejam eles fazendo ou não uso do tratamento especial e diferenciado. ${ }^{49}$

47 Para um estudo aprofundado sobre a temática vide: SALDANHA, Eduardo. Desenvolvimento e Tratamento Especial e Diferenciado na $O M C$ : uma abordagem sob a perspectiva da doutrina do stare decisis - Parte II. Disponível em: < http:/ /www2.pucpr.br/ $\mathrm{reol} /$ index.php/direitoeconomico?dd99 $=$ pdf\&dd1 $=7547>$. Acesso em: 16 out. 2014.

48 SALDANHA, Eduardo. Desenvolvimento e Tratamento Especial e Diferenciado na $O M C$ : uma abordagem sob a perspectiva da doutrina do stare decisis - Parte II. Disponível em: < http:/ /www2.pucpr.br/ $\mathrm{reol} /$ index.php/direitoeconomico?dd $99=$ pdf\&dd $1=7547>$. Acesso em: 16 out. 2014.

49 SALDANHA, Eduardo. Desenvolvimento e Tratamento Especial e Diferenciado na OMC: uma abordagem sob a perspectiva da doutrina do stare decisis - Parte II. Disponível em: < http://www2.pucpr.br/ $\mathrm{reol} /$ index.php/direitoeconomico?dd99=pdf\&dd1 $=7547>$. Acesso em: 16 out. 2014 . 
Outro exemplo do que está a se falar é o questionamento por parte de países desenvolvidos acerca da manutenção do tratamento especial e diferenciado dispensado aos países em desenvolvimento como China, Brasil e Índia, dentre outros. ${ }^{50}$

Assim, embora seja nítido que o tratamento especial e diferenciado constitua uma tentativa de correção de assimetrias do comércio internacional, visando atenuar as disparidades econômicas existentes entre os países participantes da OMC, notadamente por meio da introdução de tratamentos preferenciais em favor das nações que ainda não atingiram um nível de desenvolvimento suficientemente elevado para fazer frente às grandes potências econômicas, uma reestruturação e reavaliação desse mecanismo pelos Estados-membros da organização deve ocorrer a fim de que se possa avançar com as negociações no âmbito da OMC.

Somando-se às questões tratadas até aqui, vale ainda destacar que, sob o ponto de vista de Bernard M. Hoekmanis e Petros C. Mavroidis, há outros três grandes desafios que os membros da OMC devem enfrentar:

(1) o alargamento da cooperação multilateral para o âmbito das políticas domésticas "intrafronteiras"; (2) a abordagem das preocupações dos países em desenvolvimento quanto ao fato de o sistema comercial ser "desequilibrado"; e (3) lidar com a proliferação de acordos preferenciais de comércio. Nenhum desses desafios são novos. ${ }^{51}$

Conforme se nota, os Estados-membros da OMC precisam envidarem seus esforços a fim de alargarem a cooperação multilateral para o âmbito das políticas domésticas dos Estados ("por trás das fronteiras". Os países desenvolvidos precisam dar atenção e abordarem de maneira responsável as preocupações dos países em desenvolvimento no tocante às alegações do desequilíbrio existente no sistema de negociação

50 GUPTA, Surupa. A ausência de unidade entre os países em desenvolvimento: a ruína de Bali? 2013. Disponível em: <http:// www.ictsd.org/bridges-news/pontes/news/a-aus\%C3\%AAnciade-unidade-entre-os-pa $\%$ C $3 \%$ ADses-em-desenvolvimento-aru\%C3\%ADna-de-bali>. Acesso em: 16 out. 2014.

51 HOEKMAN, Bernard M.; MAVROIDIS, Petros C. The World Trade Organization: law, economics, and politics. Abingdon: Routledge, 2007, p. 98. "(1) extending multilateral cooperation to domestic "behind the border" policies; (2) addressing concerns of developing countries that the trading system is "unbalanced"; and (3) dealing with the proliferation of preferential trade agreements. None of these challenges are new." multilateral e, por fim, precisam ainda lidar com a proliferação de acordos preferenciais de comércio, conforme já se mencionou anteriormente.

\section{0 órgão solucionador de controvérsias: conceituação e alcance}

Demonstradas, em síntese, as conquistas da OMC ao longo dos seus vinte anos de existência, bem como os problemas que enfrenta e os desafios a serem encarados no futuro pela organização, a partir desse momento serão tecidas considerações acerca de um dos seus mais importantes avanços dentro do sistema de comércio multilateral — o sistema de solução de controvérsias (OSC) - bem como serão abordados os principais aspectos do relacionamento do Brasil com a OMC, notadamente nas questões dirimidas pelo OSC.

O papel do Brasil, nesses últimos anos, numa postura que retrata sua intenção em encarar os desafios que lhe são propostos no cenário internacional vem intensificando a sua atuação diplomática frente às crises financeiras internacionais e seus reflexos no comércio. Por isso, especialmente desde a Rodada Doha, observase um aumento considerável do número de contenciosos comerciais, em especial no âmbito da Organização Mundial do Comércio (OMC). Hoje, como nunca antes, a atuação do Brasil no âmbito do mecanismo de solução de controvérsias da OMC tem permitido que o País não apenas defenda seus interesses comerciais, mas também contribua para a elaboração de normas justas de comércio multilateral.

Conforme já ressaltado, o mecanismo de solução de controvérsias (ou conflitos) é considerado o grande avanço da OMC, por estabelecer inovações entre as relações mantidas pelos Estados pertencentes a esta entidade. Esse órgão é composto por grupos que avaliam as reclamações dos Estados-membros e se propõe a solucionar as divergências havidas. Nesse avanço também está incluso o Órgão de Apelação, que pode ser concebido como uma "segunda instância" ou o "duplo grau de jurisdição" e que tem como objetivo principal garantir "uma solução positiva e pacífica para as controvérsias". ${ }^{52}$

Esse sistema consolidou uma visão mais legalista ${ }^{53}$ que o seu antecessor, o antigo GATT, mantendo

52 MELLO, Celso de Albuquerque. Curso de direito internacional público. Rio de Janeiro: Renovar, 2004, v. 2. p. 329.

53 CRETELLA NETO, José. Direito processual na Organização Mundial do Comércio. Rio de Janeiro: Forense, 2003, p. 61-62. 
ainda algumas regras anteriores, como as soluções negociadas diretamente entre os membros de forma diplomática. Havia ainda um único artigo sobre a solução de controvérsias (Artigo XXIII), que previa a possibilidade de investigação, recomendações ou determinações pelas partes contratantes, que poderiam suspender concessões negociadas entre as mesmas, se as circunstâncias fossem sérias o bastante para justificar tais medidas. A partir da criação do OSC salienta Seitenfus ${ }^{54}$ :

Para a OMC, os países membros que se encontrarem insatisfeitos devem se manifestar por meio do seu Órgão de Solução de Controvérsias (OSC) que irá analisar a existência de medidas restritivas ao comércio. Quanto a esse Sistema, no tocante às questões ambientais, convém ressaltar que o mesmo dá condições de os países membros utilizarem as regulamentações da própria organização para questionar as legislações ambientais nacionais ou regionais, o que pode trazer sérios prejuízos e controvérsias nas relações internacionais. Isso se deve ao fato de que "[...] seu sistema de solução de controvérsias quasejurisdicional [...] detém poder de sanção. O resultado é que se pode dotar de coercibilidade acordos que resultam de uma só abordagem: a do livre comércio.

Conforme já mencionado, a OMC também recebe críticas à medida que parece não se inteirar e encarar da maneira devida o chamado processo de "globalização" ou "mundialização", ou pior, só preocupar-se em analisar esse fenômeno do ponto de vista econômico comercial, desfazendo-se de outros importantes interesses transfronteiriços como a saúde e o meio ambiente.

Apesar disso o número de transações comerciais só vem crescendo e, como consequência, as controvérsias que são levadas à OMC. Desde a entrada em vigor do Entendimento Relativo às Normas e Procedimentos sobre Solução de Controvérsias da Organização Mundial do Comércio (OMC) $)^{55}$, em 1995, o Brasil tomou parte, como demandante ou demandado, em 41 dos 482 contenciosos iniciados na OMC até outubro

54 SEITENFUS, Ricardo Antônio Silva. Manual das organizações internacionais. 3. ed. Porto Alegre: Livraria do Advogado, 2003, p. 184.

55 Internalizado ao direito brasileiro por meio do Decreto $\mathrm{n}$. 1355/1994. de 2014 ${ }^{56}$, atrás apenas de Estados Unidos, União Europeia (UE), Canadá, China e Índia ${ }^{57}$.

Um outro aspecto positivo dessa participação brasileira está no fato de que o setor privado habilitouse, assim, a acompanhar as modificações que ocorreram na estrutura governamental e a interagir com o governo para a defesa de seus interesses na OMC. Os ministérios mais diretamente envolvidos no comércio internacional adequaram suas estruturas, capacitaram recursos humanos e aprimoraram a coordenação interministerial e com o setor privado, em particular após a criação da Câmara de Comércio Exterior (CAMEX) em 1995.

Em relação ao procedimento no âmbito do sistema de solução de controvérsias (OSC) se apontam as seguintes etapas de acordo com Entendimento Relativo às Normas e Procedimentos sobre Solução de Controvérsias ${ }^{58}$ :

Consulta: Cada Membro se compromete a examinar com compreensão a argumentação apresentada por outro membro e a conceder oportunidade adequada para consulta com relação a medidas adotadas dentro de seu território que afetem o funcionamento de qualquer acordo abrangido.

Painel (Grupos Especiais): É a primeira instância no procedimento para solução de controvérsias na OMC. São compostos por três indivíduos, que apresentam o relatório circunstanciado sobre a controvérsia e uma análise jurídica quanto ao fundamento da reclamação. Tem como competência: examinar a questão submetida e estabelecer conclusões que auxiliem o OSC a fazer recomendações ou emitir decisões. Antes de emitir uma decisão (relatório), o painel apresenta

56 WORLD TRADE ORGANIZATION. Brasil and the WTO. Disponível em: <http://www.wto.org/english/thewto_e/ countries_e/brazil_e.htm\#disputes>. Acesso em: 16 out. 2014.

57 A título de comparação e a fim de demonstrar o alto interesse dos Estados-membros por esse órgão em seus 20 anos de existência, vale ressaltar que, na Corte Internacional de Justiça, em seus 67 anos, são 153 casos demandados, e no Tribunal de Direito do Mar, estabelecido um após o OSC, apenas 21. Portanto, o órgão da OMC, sem dúvida, tem logrado êxito em sua atuação.

58 BRASIL. Ministério das Relações Exteriores. Entendimento Relativo às Normas e Procedimentos sobre Solução de Controvérsias (ESC). Disponível em:

$<$ http://www.itamaraty.gov.br/o-ministerio/conhecao-ministerio/tecnologicos/cgc/solucao-de-controversias/maisinformacoes/texto-dos-acordos-da-omc-portugues/2-anexo-2entendimento-relativo-as-normas-e-procedimentos-sobre-solucaode-controversias/view>. Acesso em: 16 out. 2014. 
um esboço descritivo, e um relatório provisório, ainda confidencial, que poderá ser objeto de comentários pelas partes na controvérsia. Após essa fase, o relatório do painel circula entre todos os Membros da OMC e é colocado à disposição no sítio eletrônico. Submetido o relatório ao OSC, será ele aprovado, a não ser que haja consenso reverso ou que uma das partes da controvérsia recorra ao OAp (Órgão Permanente de Apelação), o que geralmente ocorre.

Apelação: Diante da OAp, as partes apresentam seus argumentos escritos e em audiência. As deliberações dos juízes do OAp são confidenciais, e o relatório final aprovado, confirmando, modificando ou revogando o relatório do painel; é então remetido ao OSC, onde será aprovado. Com a aprovação pelo OSC do relatório do painel ou do OAp, encerra-se a fase jurisdicional do sistema de solução de controvérsias da OMC.

No relatório final aprovado, se concluir que a medida nacional reclamada é incompatível com os acordos da OMC, deverá recomendar que o membro torne a medida compatível com o acordo.

O Entendimento Relativo a Normas e Procedimentos sobre Solução de Controvérsias (ESC), Anexo 02, do Acordo Constitutivo da Organização Mundial do Comércio, é o resultado de uma longa evolução da solução de controvérsias no âmbito do Acordo Geral sobre Tarifas Aduaneiras e Comércio de 1947. Esse procedimento, que deixou de vigorar em 31 de dezembro de 1995, teve seus princípios preservados no novo procedimento, objeto do Anexo 02 do Acordo da OMC. Seu objetivo é o de manter a imparcialidade de julgamentos, garantindo uma previsibilidade legal dos julgamentos e facilitando o comércio internacional.

O êxito do órgão se deve, além da qualidade de seus julgados, à relativa rapidez das decisões proferidas. Há prazo de sessenta dias para a realização das consultas (Artigo 4.7 do Entendimento de Solução de Controvérsias (ESC), seis meses para a decisão do painel (Artigo 12.8 do ESC) e noventa dias para o Órgão de Apelação (OA) (Artigo 17.5 do ESC)). Prazos mais curtos podem, inclusive, ser estabelecidos, em casos excepcionais, conforme especificado nos Acordos pertinentes da OMC. Em média, um contencioso não deveria levar mais de dois anos entre o pedido de consultas e a adoção das recomendações pelo OSC, após recurso ao Órgão de Apelação; embora na prática existam casos que levaram mais tempo para serem solucionados.

Além das etapas acima definidas, outro ponto que influenciou substancialmente a estrutura do sistema de modo positivo foi o novo princípio do "consenso negativo". Agora, por esse princípio, para um painel seja bloqueado, é necessária a vontade de todos os Membros, inclusive do demandante, o que faz com que o novo procedimento seja quase automático, acarretando maior seriedade ao tema.

E mais, O ESC prevê uma pluralidade de procedimentos para solucionar as controvérsias no âmbito da OMC. Além do procedimento "central", desenvolvido pelo Grupo Especial (Painel) e pelo Órgão de Apelação, também não excluem-se os chamados, "procedimentos alternativos", que são os "bons ofícios", a "conciliação", a "mediação" e a "arbitragem".

\section{As soluções de controvérsias na OMC e o Brasil: efetivação do comércio e desenvolvimento de uma política econômico-diplomática}

Nas últimas décadas, o Brasil tem apresentado crescente participação em blocos econômicos, consequência de seu crescimento e diversidade comercial. Assim como outros países, apesar do aumento no volume de transações comerciais, o país encara também na OMC a difícil e problemática conceituação de "país em desenvolvimento" e seus efeitos.

Nessa seara, o processo de abertura e de desburocratização pelo qual tem passado a OMC nos últimos anos, tem favorecido países como o Brasil, especialmente, com a reformulação das formas de solução de conflito. Nesse sentido, o OSC atual permite uma participação mais justa e vantajosa ao comércio brasileiro.

O tratamento diferenciado/especial dado aos países em desenvolvimento desde a Rodada do Uruguai pode ser classificado em cinco grupos $^{59}: 1$ ) disposições destinadas a aumentar as oportunidades

59 YOSHIURA, Jackson Apolinário. Os países em desenvolvimento no sistema de solução de controvérsias da OMC. Boletim de Ciências Económicas, Coimbra, v. 53, 2010, p. 95-181, p. 117. Disponível em: $<$ https://digitalisdsp.uc.pt/bitstream/10316.2/24714/1/BoletimLIII_Artigo4.pdf>. Acesso em: 16 out. 2014. 
comerciais; 2) salvaguarda dos interesses dos países em desenvolvimento; 3) maior flexibilidade para os países em desenvolvimento nas normas do GATT; 4) período mais longo de transição para a adoção das obrigações provenientes das negociações; e 5) assistência técnica relacionada com o comércio.

A legislação brasileira mantém certa coerência com as regras multilaterais e faz com que os acordos da OMC tenham força de lei no ordenamento jurídico interno, isso reduz as vulnerabilidades no sistema de solução de controvérsias e se reflete no baixo número de controvérsias contra o Brasil que resultaram em necessidade de modificação, de alguma forma, da legislação brasileira. Para continuar esse processo, faz-se necessário que os formuladores de medidas de impacto na política comercial estejam conscientes das obrigações internacionais do Brasil, a fim de manter uma perspectiva positiva do país diante das formas de solução de controvérsias propostas pela OMC. Diante disso, pode-se afirmar que existe sempre uma necessidade de adequação dos Estados-membros. Sobre isso afirma Lafer $^{60}$ :

60 LAFER, Celso. A OMC e a regulamentação do comércio internacional:
O mercado e a concorrência podem ser vistos como uma grociana luta de todos em prol de todos. Essa é a tese do doux commerce. Simmel observou que o mercado e a concorrência são, no entanto, simultaneamente uma hobbesiana guerra de todos contra todos [...]. Para evitar a confrontação bélica de uma concorrência desenfreada baseada no poder, a administração do conflito e da cooperação no mercado requer um enquadramento jurídico. A OMC prevê esse enquadramento através de um ordenamento jurídico, o single undertaking, concebido como um jogo de normas de fair play compartilhadas por todos os membros [...] O sistema de solução de controvérsias da OMC representa não só codificação, mas um desenvolvimento progressivo do direito e da prática do GATT.

Os casos que envolveram o Brasil no OSC podem ser descritos no quadro abaixo:

\section{Quadro 1 - Casos de disputa envolvendo o Brasil ${ }^{61}$}

uma visão brasileira. Porto Alegre: Livraria do Advogado, 1998, p. 9. 61 WORLD TRADE ORGANIZATION. Disputing cases envolving

\begin{tabular}{|c|c|c|}
\hline DEMANDANTE & DEMANDADO & TERCEIRA PARTE \\
\hline 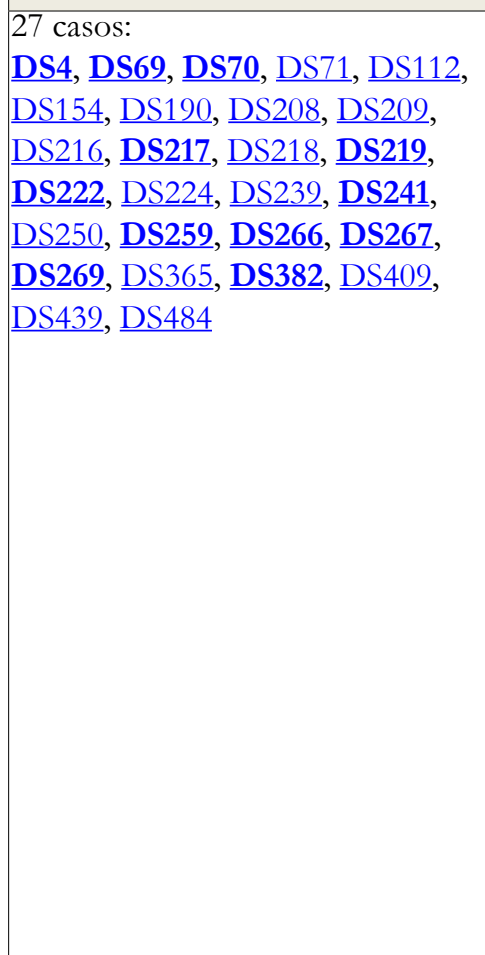 & 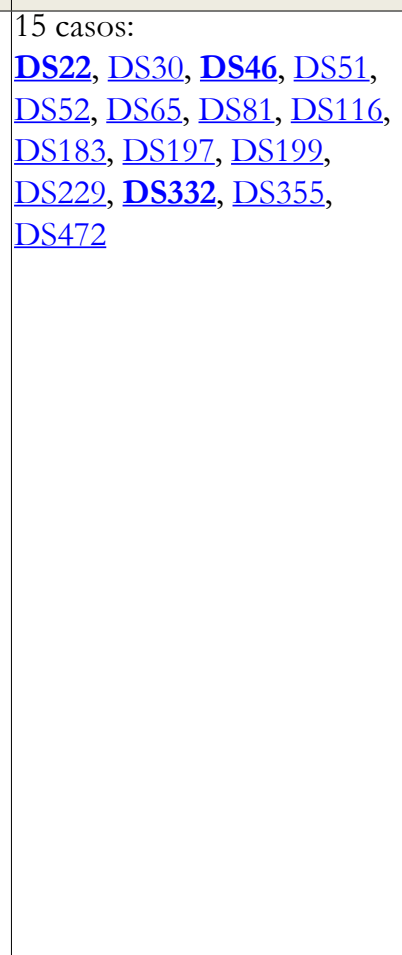 & 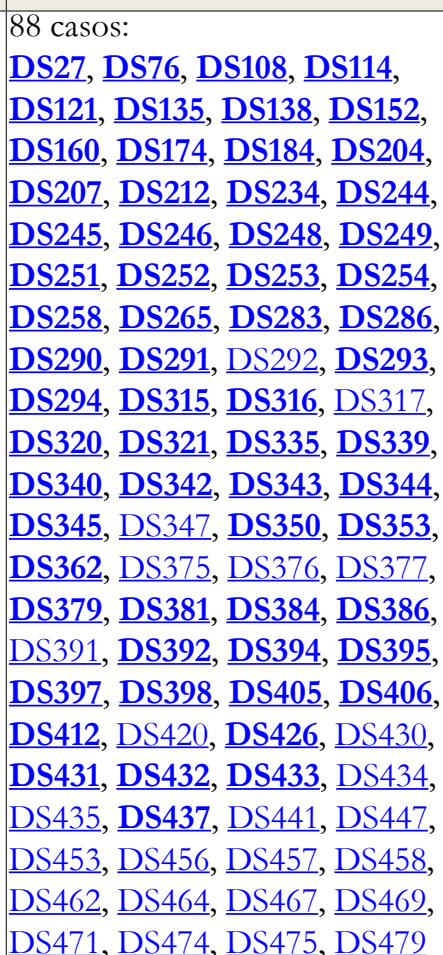 \\
\hline
\end{tabular}

Fonte: http://www.wto.org/english/thewto_e/countries_e/brazil_e.htm\#disputes 
Diante do grande número de casos, faz-se importante ressaltar os que revelam a estrutura e atividade do OSC e a atuação brasileira, cada vez mais especializada, ultrapassando seu caráter contencioso e criando novas páginas da política externa.

A atuação brasileira ocorreu especialmente em contenciosos que envolvem setores exportadores brasileiros dinâmicos, como o aeronáutico (Embraer vesus Bombardier); o siderúrgico (Emenda Byrd e salvaguardas americanas sobre certos produtos siderúrgicos); o de algodão (subsídios americanos à cotonicultura); o de açúcar (subsídios à exportação concedidos pela UE); o de frango salgado (reclassificação tarifária feita pela UE); o de suco de laranja (taxa de equalização americana); e o de bananas (arbitragem sobre regime de tarifa única europeu), dentre outros.

Também é importante ressaltar que a maneira de cada Estado-membro executar internamente uma decisão emanada do OSC pode variar. Os efeitos e alcance dessas decisões no ordenamento jurídico interno dos diferentes membros podem variar consideravelmente de acordo com a estrutura constitucional e o ordenamento jurídico de cada um deles, a quem cabe, em última instância, determinar sua hierarquia em relação ao direito interno e se esses atos podem ser arguidos em tribunais nacionais. No Brasil se pode vislumbrar o seguinte ${ }^{62}$ :

A situação no Brasil não difere muito. A Constituição Federal (CF) não contém nenhum dispositivo explícito sobre a interação dos atos emanados das OI com o ordenamento jurídico brasileiro. $\mathrm{O}$ texto constitucional limita-se a estabelecer, em seu artigo $4^{\circ}$ inciso IX, que o Brasil deverá balizar-se, nas suas relações internacionais, pela "busca da cooperação entre os povos", atribuindo à União, no artigo 21, a competência de "manter relações com Estados estrangeiros e participar de organizações internacionais". Não há, no entanto, na Constituição, nenhuma previsão específica sobre o alcance dos atos emanados dessas organizações, que tampouco figuram no rol de instrumentos legislativos estabelecidos no artigo 59 da CF. Tampouco há, no direito positivo brasileiro, elementos que permitam inferir de

62 BENJAMIM, Daniela Arruda. A aplicação interna das decisões do Órgão de Solução de Controvérsias da OMC na prática. In: BENJAMIM, Daniela Arruda (Org.). O Sistema de Solução de Controversias da OMC: uma perspectiva brasileira. Brasília: Fundação Alexandre de Gusmão, 2013. p. 586-587. forma inequívoca como, na prática, a integração desses atos no direito interno deveria se operar.

Por isso, cada Estado acabou por imprimir uma forma própria de implementação das decisões no que tange à receptação dessas normas em seu ordenamento. Resta claro que nosso país está apto a aplicar, no julgamento dos casos submetidos a sua apreciação, normas internacionais adotadas pelo Brasil. Nesse sentido, interessante o julgamento do STJ, no âmbito do Recurso Extraordinário n. 821-406, de 2007, que aplicou as Súmulas 20 e 71 do STJ e a Súmula 575 do STF, afirmando ser:

pacífica é a jurisprudência do STJ no sentido de que a mercadoria importada de país signatário do GATT é isenta de ICMS, quando contemplado com esse favor o similar nacional, em aplicação do princípio do tratamento nacional consagrado nos acordos da OMC. ${ }^{63}$

Portanto, é inegável que uma vez internalizada a Ata Final que aprova os Resultados da Rodada Uruguai de Negociações Comerciais (Decreto n. 1355/94), que estabeleceu a OMC, o Brasil conferiu aos acordos da OMC hierarquia de lei interna e estabeleceu, entre outras coisas, a obrigação de "garantir a conformidade de suas leis, regulamentos e procedimentos com os Acordos da OMC." ${ }^{4}$

\subsection{O Brasil nos Contenciosos da OMC: Aspectos Relevantes}

É importante apontar alguns elementos que marcaram a atuação brasileira ${ }^{65}$ nos contenciosos da OMC. Dado o volume de casos, salientam-se alguns que foram determinantes para condução da política externa brasileira junto ao comércio internacional.

63 BENJAMIM, Daniela Arruda. A aplicação interna das decisões do Órgão de Solução de Controvérsias da OMC na prática. In: BENJAMIM, Daniela Arruda (Org.). O Sistema de Solução de Controvérsias da OMC: uma perspectiva brasileira. Brasília: Fundação Alexandre de Gusmão, 2013. p. 589.

64 BENJAMIM, Daniela Arruda. A aplicação interna das decisões do Órgão de Solução de Controvérsias da OMC na prática. In: BENJAMIM, Daniela Arruda (Org.). O Sistema de Solução de Controvérsias da OMC: uma perspectiva brasileira. Brasília: Fundação Alexandre de Gusmão, 2013. p. 591.

65 Já em 1995, o país figurava como demandante, ao lado da Venezuela, em um dos primeiros contenciosos da OMC (caso USGasoline), 3 em que medidas ambientais foram avaliadas segundo as disciplinas multilaterais de comércio. 
Dentre os casos em que o Brasil foi demandante, podese citar: ${ }^{66}$

- DS 222 - Canadá - Créditos e garantias à indústria aeronáutica - "Embraer-Bombardier" (DS46/DS70/ DS222);

- DS 266 - Comunidades Europeias - Subsídios à Exportação de Açúcar (Brasil);

- DS 267 - Estados Unidos - Subsídios ao Algodão (Brasil);

- DS 269 - Comunidades Europeias - Classificação Aduaneira do Frango Desossado Congelado (Brasil);

\section{- $\quad$ DS 382 - Estados Unidos - Medidas Antidumping} sobre Suco de Laranja (Brasil).

A sucinta análise de alguns deles permite verificar como tem sido a atuação do Brasil junto ao OSC da OMC.

Um dos casos emblemáticos do Brasil junto ao OSC ficou conhecido como "Embraer-Bombardier" (DS46/ DS70/DS222) e se destacou pela discussão quanto ao uso de subsídios dos governos junto às empresas do setor aeronáutico (Acordo sobre Subsídios e Medidas Compensatórias - ASMC). A disputa iniciou-se em 1996 e colocava o Canadá contra o Brasil na discussão acerca das políticas usadas para comércio de aviões em dois processos paralelos a partir de 1998 (DS46 e DS70).

O Canadá questionava o programa "PROEX Equalização", considerado pela OMC como um programa de subsídios proibidos em sua versão original, enquanto o Brasil acentuava a ilegalidade de vários programas de subsídios (Export Development Canada e Technology Partnerships Canada).

Dentre suas principais decisões o OSC determinou que os parâmetros para concessão de créditos à exportação definidos no âmbito da Organização para a Cooperação e o Desenvolvimento Econômico (OCDE), organização internacional da qual o Brasil não é parte, eram aplicáveis a todos os membros da OMC, por

66 BRASIL. Ministério das Relações Exteriores. Brasil como demandante. Disponível em: $<$ http://www.itamaraty.gov.br/oministerio/conheca-o-ministerio/tecnologicos/cgc/solucaode-controversias/participacao-do-brasil-nos-contenciososdocumentos/brasil-como-demandante>. Acesso em: 18 out. 2014. força do segundo parágrafo da alínea "k" do Acordo sobre Subsídios e Medidas Compensatórias (ASMC). Com isso o Canadá recebeu o direito de retaliação ao Brasil em C \$344,2 milhões/ano. Apesar dessa primeira derrota, o caso provocou uma reviravolta na política externa do Brasil que soube aproveitar e implementar as mesmas medidas a seu favor posteriormente.

Assim, no DS 222, o Brasil foi autorizado a retaliar o Canadá em mais de US $\$ 247$ milhões, ao confirmar que programas federais e provinciais (Québec) canadenses subsidiaram fortemente operações de vendas da Bombardier em 2001, comprovando que o subsídio dado a cada avião no Canadá superava muito o adotado pelo Brasil. A fim de evitar maiores prejuízos, em 2007 foi aprovado um novo "Acordo Setorial sobre Créditos à Exportação para Aeronaves Civis", estruturado com grande participação do nosso governo. Assim pode ser resumido o quadro desse caso:

\section{Quadro 2- Resumo de disputa por data}

\begin{tabular}{|l|l|}
\hline Título: & $\begin{array}{l}\text { Canada - Aircraft Credits } \\
\text { and Guarantees }\end{array}$ \\
\hline Demandante: & Canad \\
\hline Demandado: & $\begin{array}{l}\text { Australia; European } \\
\text { Communities; India; United } \\
\text { States }\end{array}$ \\
\hline Terceiras partes: & $\begin{array}{l}\text { Subsidies and Countervailing } \\
\text { Measures: Art. } 1, \underline{3}\end{array}$ \\
\hline Acordos citados: & 22 Jan. 2001 \\
\hline Data de requerimento da \\
consulta:
\end{tabular}

Fonte: http://www.wto.org/english/tratop_e/ dispu_e/cases_e/ds222_e.htm

O próximo caso do qual o Brasil extraiu grande experiência ficou conhecido como "disputa do açúcar". Acerca dos subsídios europeus a esse produto, foi iniciado em 27/09/2002, com base no pedido de consultas formulado por Brasil (DS266) e Austrália (DS265). Em março de 2003, a Tailândia (DS283) apresentou pedido de consultas sobre o mesmo objeto, razão pela qual os três Estados-membros da OMC figuraram como codemandantes contra a Comunidade Europeia (CE) em painel uno para julgar esses contenciosos.

67 WORLD TRADE ORGANIZATION. Dispute settlement: Dispute ds222. Disponível em: <http://www.wto.org/english/ tratop_e/dispu_e/cases_e/ds222_e.htm >. Acesso em: 19 out. 2014 
O Brasil questionou na $\mathrm{OMC}$ o fato de que as exportações anuais subsidiadas de açúcar pela CE ultrapassavam os compromissos assumidos pelo bloco europeu perante aquela organização (já que a CE não computava nas vendas uma espécie de açúcar chamada de "açúcar C", driblando assim sua fiscalização). O Brasil conseguiu comprovar que a $\mathrm{CE}$ se beneficiava de subsídios cruzados, i.e., subsídios concedidos à produção do açúcar das quotas "A" e "B", os quais "transbordavam" para a produção do "açúcar C" (spillover effect). Mais uma vez o Brasil e demais demandantes venceram a questão. A CE foi obrigada a reformar seu regime açucareiro, o que de fato ocorreu em 1/7/2006, quando uma nova Organização Comum de Mercado (OCM) para o açúcar foi introduzida pelo Regulamento n. 318/2006.

Diante disso os europeus não somente deixaram de depreciar o produto provindo de outros Estados, como também tiveram que recalcular seus preços sem os subsídios, tornando o mercado mais competitivo, o que já proporcionou ao Brasil o dobro de exportações no ano seguinte à contenda. Sobre esse caso é possível apresentar o seguinte quadro:

\section{Quadro 3 - Resumo de disputa por data ${ }^{68}$}

\begin{tabular}{|c|c|}
\hline Título: & EC - Export Subsidies on Sugar \\
\hline Demandante: & Brasil \\
\hline Demandado: & European Communities \\
\hline Terceiras partes: & $\begin{array}{l}\text { Australia; Barbados; Belize; Canada; } \\
\text { China; Colombia; Cuba; Fiji; Guyana; } \\
\text { India; Jamaica; Kenya; Madagascar; } \\
\text { Malawi; Mauritius; New Zealand; } \\
\text { Paraguay; Saint Kitts and Nevis; } \\
\text { Swaziland; Tanzania; Thailand; } \\
\text { Trinidad and Tobago; United States; } \\
\text { Côte d'Ivoire }\end{array}$ \\
\hline Acordos citados: & $\begin{array}{l}\text { Agriculture: Art. } \underline{3.3}, \underline{8}, \underline{9.1}, \underline{10.1} \\
\text { GATT 1994: Art. } \underline{\mathrm{II}}: \underline{4}, \underline{\mathrm{XVI}} \\
\text { Subsidies and Countervailing } \\
\text { Measures: Art. } 1.1, \underline{3.1}, \underline{3.2}\end{array}$ \\
\hline $\begin{array}{l}\text { Data de } \\
\text { requerimento da } \\
\text { consulta: }\end{array}$ & 27 Sept. 2002 \\
\hline Data do Painel: & 15 Oct. 2004 \\
\hline Data da apelação: & 28 April 2005 \\
\hline $\begin{array}{l}\text { Relatório de } \\
\text { arbitragem (Artigo } \\
21.3 \text { c): }\end{array}$ & 28 Oct. 2005 \\
\hline
\end{tabular}

Fonte: https://www.wto.org/english/tratop_e/ dispu_e/cases_e/ds266_e.htm

O próximo caso constitui a pedra de toque das disputas e discussões havidas no âmbito da OMC. Diz respeito a um problema crucial enfrentado pelos países

68 WORLD TRADE ORGANIZATION.. Dispute settlement: Dispute ds266. Disponível em: < <ttps://www. wto.org/english/tratop_e/dispu_e/cases_e/ds266_e.htm>. Acesso em: 19 out. 2014 em desenvolvimento: os subsídios utilizados pelos países desenvolvidos na agricultura. Isso fez com que ao mesmo tempo em que se propusesse o caso do açúcar junto ao OSC, se fizesse o mesmo relativamente aos casos da agricultura, notadamente no caso do algodão.

Foi possível, por esse painel, analisar que, de 19992002, os EUA tinham concedido US $\$ 12,9$ bilhões em subsídios, o que equivalia a uma taxa de subsidiamento à produção de $89,5 \%$, em média. Dessa forma, sem essa arma, o algodão americano seria aproximadamente $9 \%$ mais caro. Foi o caso mais complexo enfrentado pelo Brasil e pela OMC até então, esgotando todos os procedimentos previstos no OSC: consultas, painel, apelação, painel de implementação (Artigo 21.5 do ESC), nova apelação e painel de retaliação (Artigo 22.6 do ESC).

O fundamental da análise desse caso está nas medidas comerciais tomadas pelo Brasil a partir dessa experiência contenciosa. Como exemplo, a implementação da política de retaliação ${ }^{69}$, autorizada pela OMC no caso do algodão americano, que culminou na Resolução no 15/2010 da CAMEX, com lista final contendo 102 bens sobre os quais incidiria a retaliação. Ainda sobre os efeitos desse caso, inclui-se a retaliação cruzada:

Em paralelo aos trabalhos na retaliação em bens, foram sendo delineadas as possíveis medidas a serem adotadas no campo da retaliação cruzada. [...] Antes de tudo, era necessário conferir o devido amparo legal à retaliação cruzada, particularmente no que tange à suspensão de direitos de propriedade intelectual. Para tanto, a CAMEX determinara, em agosto de 2007 — muito antes da instauração do procedimento de arbitragem da retaliação no contencioso do algodão, portanto o estabelecimento de subgrupo dentro do Grupo Interministerial de Propriedade Intelectual (GIPI) com vistas à revisão do arcabouço normativo existente e elaboração de uma proposta de legislação. $O$ trabalho culminou na edição da Medida Provisória 48213, que atribui à CAMEX competência para suspender diversos direitos de

69 Até então há um total de 8 casos que envolviam a temática da retaliação (incluindo o caso do algodão), num total de mais de 400 casos iniciados até hoje. Casos em que houve retaliação efetiva: 5. Membros da OMC que já retaliaram: EUA, EU, Canadá e Japão. Membros que foram autorizados, mas não retaliaram: Brasil (em 2 casos: Canada Aircraft e Byrd Amendment), Chile, Índia, Coréia, México, Equador e Antigua. 
propriedade intelectual conforme necessário para implementar uma retaliação cruzada. ${ }^{70}$

Esse processo de retaliação é a exceção que confirma a prioridade conferida pelo Brasil à proteção da propriedade intelectual. Como resultado, em junho de 2010, assinou-se um Acordo Quadro entre os dois países, solução momentânea que previu o pagamento da maior compensação financeira da história da OMC. Eis o quadro:

\section{Quadro 4 - Resumo de disputa por data ${ }^{7}$}

\begin{tabular}{|c|c|}
\hline Título: & US - Upland Cotton \\
\hline Demandante: & Brasil \\
\hline Demandado: & United States \\
\hline Terceiras Partes: & $\begin{array}{l}\text { Argentina; Australia; Benin; } \\
\text { Canada; Chad; China; Chinese } \\
\text { Taipei; European Communities; } \\
\text { India; New Zealand; Pakistan; } \\
\text { Paraguay; Venezuela, Bolivarian } \\
\text { Republic of; Japan; Thailand }\end{array}$ \\
\hline Acordos citados: & $\begin{array}{l}\text { Agriculture: Art. } \underline{3.3}, \underline{7.1}, \underline{8}, \underline{9.1} \text {, } \\
10.1 \\
\text { GATT 1994: Art. } \underline{\mathrm{III}}: 4, \underline{\mathrm{XVI}} \\
\text { Subsidies and Countervailing } \\
\text { Measures: Art. } \underline{3}, \underline{5}, \underline{6}\end{array}$ \\
\hline $\begin{array}{l}\text { Data do requerimento da } \\
\text { consulta: }\end{array}$ & 27 Sep. 2002 \\
\hline Data do painel: & 8 Sep. 2004 \\
\hline Data da apelação: & 3 March 2005 \\
\hline $\begin{array}{l}\text { Relatório do painel (Art. } \\
\text { 21.5): }\end{array}$ & 18 Dec. 2007 \\
\hline $\begin{array}{l}\text { Relatório da apelação } \\
\text { Art. 21.5: }\end{array}$ & 2 June 2008 \\
\hline $\begin{array}{l}\text { Relatório da arbitragem } \\
\text { (Art. 22.6): }\end{array}$ & 31 Aug. 2009 \\
\hline
\end{tabular}

Fonte: http://www.wto.org/english/tratop_e/ dispu_e/cases_e/ds267_e.htm

Após a experiência acumulada em alguns dos primeiros casos na OMC (Coco Ralado, Gasolina, Frangos e Aeronaves), a complexidade crescente dos assuntos discutidos nos painéis levou à melhor estruturação da participação brasileira, que, com o tempo, passou a basear-se nos seguintes quesitos: (i) Coordenação-Geral de Contenciosos no MRE (área criada em 10/10/2001); (ii) Delegação do Brasil em Genebra; e (iii) apoio, quando necessário, de escritório

70 SCHMIDT, Luiz Fellipe Flores. A construção da retaliação brasileira no caso do algodão: os desafios do pioneirismo. In: BENJAMIM, Daniela Arruda (Org.). O Sistema de Solução de Controvérsias da OMC: Uma perspectiva brasileira. Brasília: Fundação Alexandre de Gusmão, 2013, p.641

71 WORLD TRADE ORGANIZATION. Dispute settlement: Dispute ds267. Disponível em: <http://www.wto.org/english/ tratop_e/dispu_e/cases_e/ds267_e.htm>. Acesso em: 19 out. 2014 de advocacia especializado, além de interação constante com o setor privado.

Dessa forma o Brasil lutou pela inaplicabilidade de medidas que desfavorecem a concorrência entre os países e que implicam deliberadamente na política de proteção da indústria nacional, aplicada por vários Estados-membros e até mesmo na conceituação e aplicação de dumping (e de antidumping) pelos diferentes membros, como ocorreu no caso do frango (2003), dos pneus reformados (2005) e do suco de laranja (2008).

A atual temática do OSC vem contemplando novos temas como sustentabilidade ambiental, fontes renováveis de energia e exploração de recursos naturais, o que interessa sobremaneira ao Brasil, portanto, somente o acompanhamento de perto dessas questões e do seu deslinde poderá propiciar novas explanações e o delineamento dos novos contornos da atividade do OSC e da participação do Brasil nesse contexto.

\section{Considerações finais}

A OMC é uma das instituições multilaterais mais bem-sucedidas do período pós-1945. Apesar da ausência de uma autoridade central, a cooperação entre os seus Estados-membros tem sido sustentada por mais de 50 anos, apesar de suas imperfeições e lacunas, conforme se demonstrou no decorrer do presente trabalho. Apesar de todos os desafios que foram apresentados ao longo deste escrito, pode-se afirmar que o grau de comprometimento de seus membros para com a OMC é bastante alto, não havendo até o presente momento notícias de países considerem deixá-la.

Com um sistema de regras substancialmente mais desenvolvido e sofisticado do que aquele previsto no seu antecessor (GATT), a OMC conseguiu alcançar algumas conquistas importantes desde a sua criação, tais como o estabelecimento de uma base jurídica sólida para o sistema de comércio internacional multilateral; a projeção como único fórum onde são definidas as regras para o comércio internacional em escala mundial, propiciando maior segurança jurídica, estabilidade e previsibilidade para as relações comerciais multilaterais internacionais; a inserção de diferentes Estados no mercado internacional, inclusive trazendo para o âmbito da organização parceiros de peso; o estabelecimento de um sistema de solução de controvérsias dos mais avançados no mundo; em certa medida, a limitação do protecionismo dos países em 
relação aos seus mercados internos; e a conclusão de um primeiro acordo comercial em escala global.

No entanto, o lado negro da história também foi demonstrado no decorrer do texto, em que restaram evidenciados os maiores desafios que a organização terá que enfrentar nos próximos anos, consistentes na retomada efetiva das negociações da Rodada de Doha; na adequação de sua estrutura e normativa para tentar incluir os acordos regionais e bilaterais e suas regras; e na necessidade de uma reforma na governança da instituição. Certamente, para que a OMC possa recobrar fôlego e credibilidade como organismo internacional de gestão eficiente das relações comerciais internacionais multilaterais, os desafios apresentados ao logo do texto terão que ser superados.

Também se verificou a necessidade de uma atuação mais eficaz da OMC para que possa atender à dinâmica das relações internacionais hodiernas, que são complexas e desafiantes ao sistema inicialmente concebido pela organização. Para oferecer respostas rápidas e eficazes aos problemas que se apresentam, conforme visto, examinou-se a necessidade de uma reestruturação organizacional da instituição, bem como um repensar e um remodelar de alguns de seus institutos fundamentais, tais como a regra do consenso e o princípio do single undertaking.

Sem prejuízo de outras medidas e alternativas não vislumbradas no presente trabalho, sem que mudanças essenciais como as que aqui foram apontadas sejam tomadas, dificilmente a organização conseguirá sobreviver no cenário internacional, não como uma instituição proativa e eficiente na consecução dos resultados para os quais foi criada. A OMC não é uma obra acabada e concessões feitas pelos Estadosmembros a fim de torná-la um órgão que funcione serão essenciais.

Em relação ao sistema de solução de controvérsias, em cotejo com os casos em que o Brasil foi parte, diante dos contenciosos analisados e de outros tantos que já ocorreram e que estão por vir uma verdade é certa, o Brasil avançou e muito em suas negociações internacionais, passou a lutar por um posicionamento respeitável no comércio internacional e mais ainda, traçou caminhos dos quais não mais se distanciará.
Mais do que crescimento econômico o país alcançou uma maior maleabilidade na política externa que o possibilita trilhar novos mercados. Isso sem dúvida é o maior bem que se vislumbra após anos de criação do OSC da OMC.

Diante disso o quadro que se vê é extremamente positivo, principalmente se lembrarmos que as decisões precedentes estão servindo de modelo para outras e criando um condão fundamental para previsibilidade do comércio e confiabilidade junto à OMC. O Brasil ainda hoje é o país em desenvolvimento que mais acionou o mecanismo como parte demandante ou demandada, atuando em casos envolvendo setores estratégicos, mesmo quando o órgão de resolução se mantém ainda desafiador para países em desenvolvimento.

Por isso, há que se notar também a persistência de alguns pontos negativos no sistema de solução de controvérsias que ainda perecem à falta de melhoramento. São eles; a fragilidade ou dificuldade de defesa dos países em desenvolvimento; vez que para esses membros muitas vezes, a defesa junto ao órgão exige custos econômicos e de formação profissional elevados.

Outro aspecto que merece atenção é a alternância dos temas propostos ao logo dos anos. Se por um lado a dinâmica econômica exige constante adaptação dos países e da OMC, por outro, o surgimento de novas searas econômicas coloca todos em situação de despreparo, o que acarreta, na maioria das vezes, um atraso considerável para as decisões finais na OMC e o consequente aumento de custos para proposição das demandas junto ao OSC.

Resta a certeza de que tanto a OMC, como organização comercial, tanto seu órgão solucionador de controvérsias, OSC, encontram pela frente desafios que alternam com rapidez do mercado internacional e globalizado. A criação de fronteiras e limitações comerciais esbarra cada vez mais em valores que perpassam os interesses nacionais e vislumbram aspectos outrora fundamentais do jus gentium. Isso só demonstra que embora se crie novas fronteiras econômicas, a sociedade internacional cada vez mais se quedará a decisões que preferenciem a igualdade, a justiça e a manutenção dos bens e valores universais. 


\section{Referências}

ARAUJO, Leandro Rocha de; COSTA Valeria M.; PEREIRA, Celso de Tarso. 100 casos na OMC: a experiência brasileira em solução de controvérsias. Disponível em: $\quad<$ http://politicaexterna.com. br/384/100-casos-omc-experiencia-brasileira-solucaocontroversias/>. Acesso em: 16 out. 2014.

BARRAL, Welber (Org.). Tribunais Internacionais: mecanismos contemporâneos de solução de controvérsias. Florianópolis: Fundação Boiteux, 2004.

BENJAMIM, Daniela Arruda (Org.). O Sistema de Solução de Controvérsias da OMC: uma perspectiva brasileira. Brasília: Fundação Alexandre de Gusmão, 2013.

BRASIL. Ministério das Relações Exteriores. Entendimento Relativo às Normas e Procedimentos sobre Solução de Controvérsias (ESC). Disponível em: <http://www. itamaraty.gov.br/o-ministerio/conheca-o-ministerio/ tecnologicos/cgc/solucao-de-controversias/maisinformacoes/texto-dos-acordos-da-omc-portugues/2anexo-2-entendimento-relativo-as-normas-eprocedimentos-sobre-solucao-de-controversias/view>. Acesso em: 16 out. 2014.

BREVIGLIERI, Etiene M. B.; FIORATI, Jete Jane; RAUCCI, Regina Maciel. Direito do comércio internacional e meio ambiente: as exceções não comerciais e a OMC. Jaboticabal: FUNEP, 2010.

CAPARROZ, Roberto. Comércio internacional esquematizado. São Paulo: Saraiva, 2012.

COSTA, José Augusto Fontoura. Decidir e julgar: um estudo multidisciplinar sobre a solução de controvérsias na OMC. 2009. Tese (doutorado) - Departamento de Direito Internacional e Comparado, Faculdade de Direito, Universidade de São Paulo, São Paulo, 2009.

CRETELLA NETO, José. Direito processual na Organização Mundial do Comércio. Rio de Janeiro: Forense, 2003.

DÉNIZ, Pedro Talavera. La regulación del comercio internacional: del GATT a la OMC. Barcelona: Universitat de Barcelona, 1995.

EVENETT, Simon J. The Doha Round Impasse. Disponível em: <http://graduateinstitute.ch /files/live/sites/iheid/
files/shared/summer/WTO2012/protected/Evenett_ Doha_Round_Impasse_paper_March_2012\%20 revised.pdf>. Acesso em: 14 out. 2014.

HOEKMAN, Bernard M.; MAVROIDIS, Petros C. The World Trade Organization: law, economics, and politics. Abingdon: Routledge, 2007.

KEOHANE, Robert O. After hegemony: cooperation and discord in the world political economy. Princeton: Princeton University Press, 1984.

KLOR, Adriana Dreyzin de. et al. Solução de controvérsias: OMC, União Europeia e Mercosul. Rio de Janeiro: Konrad-Adenauer-Stiftung, 2004.

LAFER, Celso. A OMC e a regulamentação do comércio internacional: uma visão brasileira. Porto Alegre: Livraria do Advogado, 1998.

LANDIM, Raquel. É a bora de acabar com a utopia do consenso na OMC. Disponível em: <http://www1.folha. uol.com.br/colunas/raquellandim/2013/12/1382381e-a-hora-de-acabar-com-a-utopia-do-consenso-naomc.shtml>. Acesso em: 15 out. 2014.

LIMA, Maria Lúcia Labate Mantovanini Padua; ROSENBERG, Barbara (Coords.). O Brasil e o contencioso na OMC. São Paulo: Saraiva, 2009.

MACIEL, George Álvares. A dimensão multilateral: o papel do GATT na expansão da economia, a Rodada Uruguai e a criação da OMC em 1994. Boletim de Diplomacia Econômica, Brasília, n. 19, p. 130-146, 1995.

MARTINS, Eliane M. Octaviano. A sistemática de solução de controvérsias no âmbito da OMC. Disponível em: <http://www.planalto.gov.br/ccivil_03/revista/ Rev_40/artigos/ art_Eliane.htm>. Acesso em: 14 out. 2014.

MAZZUOLI, Valério de Oliveira; SILVA, Roberto Luiz (Orgs.). O Brasile os Acordos Econômicos Internacionais: perspectivas jurídicas e econômicas à luz dos acordos com o FMI. São Paulo: Revista dos Tribunais, 2003.

MELlO, Celso de Albuquerque. Curso de direito internacional público. Rio de Janeiro: Renovar, 2004. v. 2.

MESQUITA, Paulo Estivallet de. A Organização Mundial do Comércio. Brasília: FUNAG, 2013. 
NARLIKAR, Amrita. The World Trade Organization: a very short introduction. New York: Oxford University Press, 2005.

NARLIKAR, Amrita; DAUNTON, Martin; STERN, Robert M. The Oxford Handbook on the World Trade Organization. New York: Oxford University Press, 2012.

RODRIGUES, Tatiana S. Fukuda; PAULA, Nilson M. de. A agricultura nas negociações multilaterais da Rodada Doba e suas implicações para o Brasil. Disponível em: <http:// ojs.c3sl.ufpr.br/ojs/index.php/economia/article/ viewFile/12297/8514>. Acesso em: 14 out. 2014.

SALDANHA, Eduardo. Desenvolvimento e tratamento especial e diferenciado na OMC: uma abordagem sob a perspectiva da doutrina do stare decisis - Parte II. Disponível em: <http://www2.pucpr.br/reol/index. $\mathrm{php} /$ direitoeconomico?dd $99=\mathrm{pdf} \& \mathrm{dd} 1=7547>$. Acesso em: 16 out. 2014.

SEITENFUS, Ricardo Antônio Silva. Manual das organizações internacionais. 3. ed. Porto Alegre: Livraria do Advogado, 2003.
WORLD TRADE ORGANIZATION. Brasil and the WTO. Disponível em: <http://www.wto.org/english/ thewto_e/countries_e/brazil_e.htm\#disputes>. Acesso em: 16 out. 2014.

WORLD TRADE ORGANIZATION. Dispute settlement: Dispute ds222. Disponível em: <http://www. wto.org/english/tratop_e/dispu_e/cases_e/ds222_e. htm>. Acesso em: 19 out. 2014.

WORLD TRADE ORGANIZATION. Disputing cases envolving Brazil. Disponível em: <http://www. wto.org/english/thewto_e/countries_e/brazil_e. htm\#disputes>. Acesso em: 17 out. 2014.

YOSHIURA, Jackson Apolinário. Os países em desenvolvimento no sistema de solução de controvérsias da OMC. Boletim de Ciências Económicas, Coimbra, v. 53, 2010, p. 95-181. Disponível em: <https://digitalisdsp.uc.pt/bitstream/10316.2/24714/1/BoletimLIII_ Artigo4.pdf>. Acesso em: 18 out. 2014. 


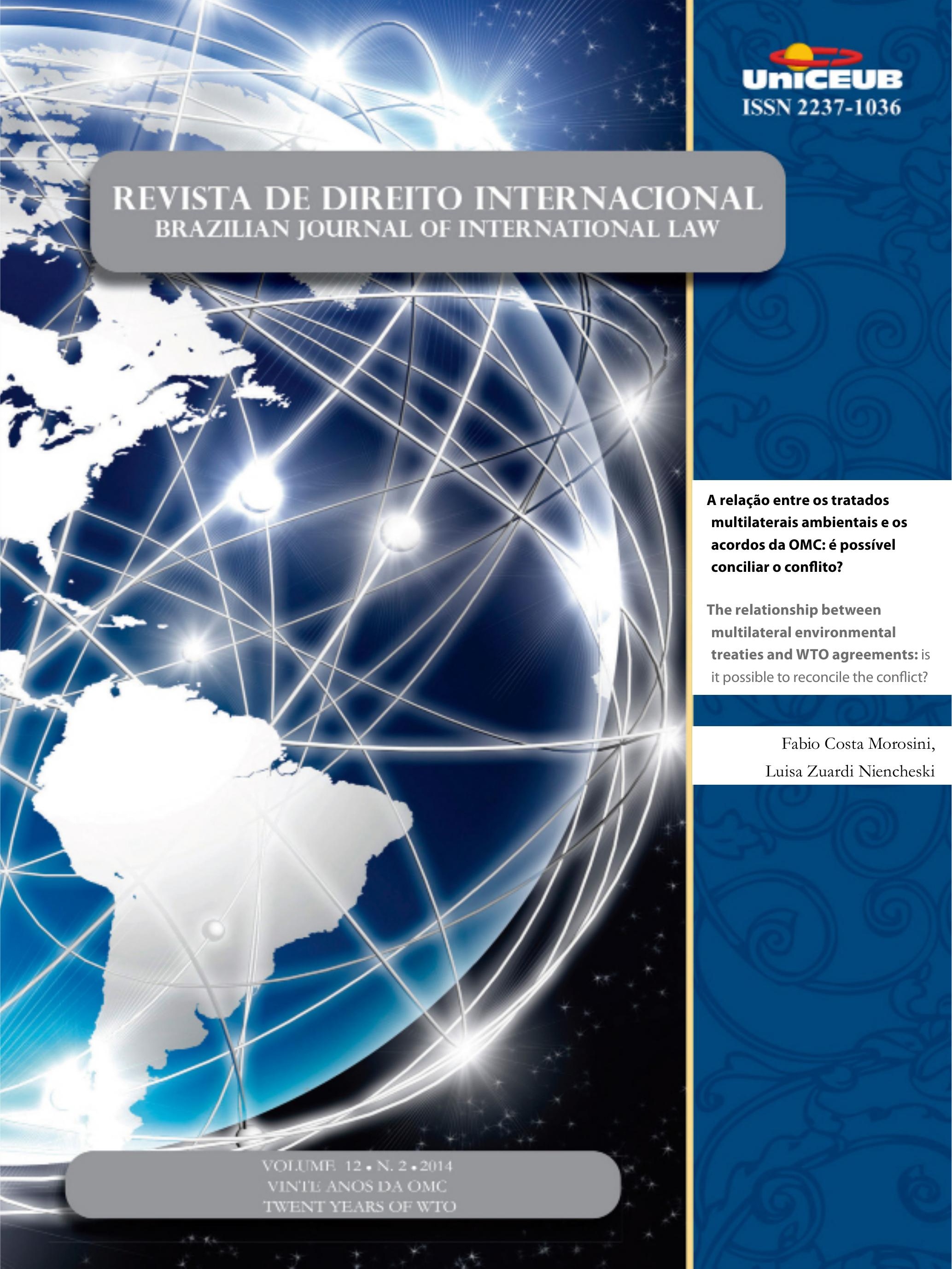




\title{
A relação entre os tratados multilaterais ambientais e os acordos da OMC: é possível conciliar o conflito?*
}

\author{
The relationship between multilateral \\ environmental treaties and WTO agreements: is it \\ possible to reconcile the conflict?
}

\author{
Fabio Costa Morosini, ${ }^{* *}$ \\ Luisa Zuardi Niencheski***
}

\section{Resumo}

A partir da repartição sistêmica interna do ordenamento jurídico internacional, consolidando-se de certa forma a independência dos regimes ambiental e comercial, potencializa-se a concorrência de jurisdições competentes para solucionar os conflitos, bem como a aplicação desconexa de diferentes normas que tutelam interesses comuns da sociedade. Nesse espectro, o presente artigo objetiva verificar o fenômeno que surge quando normas dos tratados multilaterais ambientais, que estipulam restrições comerciais, conflitam com a questão da ampliação do comércio internacional, mormente violando os princípios nucleares da OMC da cláusula da nação mais favorecida e do tratamento nacional. Assim, por meio da análise de tratados internacionais, de jurisprudência e de revisão bibliográfica, demonstrar-se-á que as disposições dos tratados ambientais e comerciais interagem no cenário jurídico internacional, denunciando que o sistema de livre-comércio inclina-se a adaptar a agenda ambiental entre as suas preocupações.

Palavras-chave: OMC. Tratados Multilaterais Ambientais. Conflito. Convenção de Viena sobre Direito dos Tratados. Artigo XX do GATT.

\footnotetext{
* Recebido em 22.10.2014

Aceito em 23.11.2014
}

\section{Abstract}

The internal systemic breakdown of the international legal order consolidates the independence of environmental and trade regimes and enhances competition of competent courts to resolve conflicts as well as imply the application of different rules that safeguard common interests of society. Thereby, the reading that follows aims to verify the phenomenon that arises when rules of multilateral environmental agreements stipulating trade restrictions conflict with the question of the expansion of international trade, especially because it violates the principles of the most favored nation and national treatment of WTO. Through the analysis of international law and treaties literature review, this study concludes that the provisions of environmental and trade agreements interact in the international legal scene, denouncing that the system of free trade is leaning to adapt the environmental agenda between their concerns.

Keywords: WTO. Multilateral Environmental Agreements. Conflict; Vienna Convention on the Law of Treaties. GATT Article XX. 


\section{Introdução}

A partir da especificação dos subsistemas ambiental e comercial, o processo de internacionalização do direito deflagrou a emergência de um fenômeno constatado quando normas dos tratados multilaterais ambientais entram em atrito com normas da OMC. A expansão de normas que ditam a lógica do comércio internacional e da proteção ao meio ambiente coexiste no espaço do direito internacional, mas, em circunstâncias particulares, revelam a probabilidade da disrupção de conflitos.

$\mathrm{O}$ risco de colisão entre situações que objetivam um sistema multilateral de comércio aberto, previsível, equitativo e não discriminatório sem conjugar os valores do desenvolvimento sustentável deve ser evitado ao extremo. No mesmo passo, tratados multilaterais ambientais deveriam enquadrar suas cláusulas de forma a promover a distribuição ótima da produção mundial consoante vantagens comparativa e beneficiando parceiros comerciais. Enquanto o sistema jurídico não garantir a certeza e a igualdade de tratamento à coexistência dessas normas incompatíveis, a proliferação de conflitos tende a agravar.

A fim de demonstrar que os órgãos jurisdicionais da OMC, Painel e Órgão de Apelação, podem utilizar outros instrumentos do direito internacional para realizar uma interpretação efetiva de suas decisões e, assim, evitar a concorrência normativa e jurisdicional entre os regimes ambiental e comercial, o artigo é dividido em 3 partes, cada qual comportando 2 subdivisões.

Desta forma, tendo como ponto de partida a definição do conceito de conflito e a incidência de seus tipos (conflito de jurisdições e conflito de normas), ${ }^{1}$ o artigo explica as interações entre as normas que compõem o subsistema do comércio e as do direito ambiental, verificando como o Painel e Órgão de Apelação podem incorporar disposições alienígenas aos acordos constitutivos da OMC. Nesse propósito, as regras de interpretação do artigo 31 da Convenção de Viena sobre Direito dos Tratados e aplicação de princípios, como o do desenvolvimento sustentável e da transparência, são pontos-chave nesta análise. Por derradeiro, com o intuito de ressaltar de que maneira é possível a coexistência mútua de tais normas, procede-

1 MARCEAU, Gabrielle. Conflicts of Norms and Conflicts of Jurisdictions: The Relationship between the WTO Agreement and MEAs and other Treaties. Journal of World Trade, Holanda, v. 35, n. 6, p. 1081-1131, 2001. se ao exame do artigo XX do GATT, exemplificandose o progresso do tratamento das causas ambientais por meio de casos levados a julgamento pelo GATT e, atualmente, pela OMC.

\section{Obstáculo para superação: análise do surgimento de conflitos}

\subsection{Conflito de normas}

As normas a respeito do comércio internacional e do meio ambiente apresentam finalidades muito específicas, dentro de seus regimes, e dependem de medidas que podem, muitas vezes apontar para direções conflitantes. No âmbito da presente discussão, a existência de um conflito condiciona-se ao estabelecimento de uma disposição nos acordos da OMC que terminantemente proíba uma obrigação expressa em tratado ambiental multilateral ou viceversa. A concorrência entre normas relaciona-se com situações em que obrigações dispostas em mais de um tratado não podem ser reconciliadas.

Isto porque diversos tratados ambientais passaram a dispor de sanções para prevenir a comercialização sobre alguns bens nocivos ao ambiente, autorizando certos Estados - a pretexto de salvaguardarem o meio ambiente - a discriminar produtos estrangeiros em comparação com os locais.

Essa atitude estaria por violar o princípio da não discriminação entre Estados membros da OMC, expresso nas cláusulas da nação mais favorecida e do tratamento nacional, tornando-se inegável o possível conflito entre esses tratados e os acordos da OMC. O princípio da nação mais favorecida (artigo I do GATT) ${ }^{2}$ proíbe a discriminação de um mesmo produto por parte dos diferentes países exportadores, enquanto que o princípio do tratamento nacional (artigo III do GATT) ${ }^{3}$

2 Especificamente, o artigo I:1 do GATT de 1994 dispõe que qualquer vantagem, benefício, privilégio ou imunidade concedida por qualquer membro a qualquer produto originado em ou destinado a qualquer outro país será conferido imediatamente e automaticamente aos produtos equivalentes originados em ou destinados aos territórios de todos os outros membros. O objetivo da obrigação de tratamento da nação mais favorecida é, então, assegurar igualdade de oportunidades para importar de ou exportar para todos os Membros da OMC. Nesse sentido, ver: UNITED NATIONS. Solução de Controvérsias. Conferência das Nações Unidas para o Comércio e Desenvolvimento. Nações Unidas, Nova Iorque e Genebra. 2003. Disponível em: <http://unctad.org/pt/docs/ edmmisc232add16_pt.pdf>. Acesso em: 18 jun. 2012.

3 O princípio do tratamento nacional, estipulado no artigo III 
proíbe discriminação entre produtos produzidos internamente e o mesmo tipo de produto importado, prevenindo práticas estatais para ilidir tributos e outras obrigações comerciais. Em algumas ocasiões, para que a norma seja eficiente, ocorre o afastamento com o que foi anteriormente previsto nos princípios gerais do direito internacional, questionando-se a unidade do ordenamento jurídico internacional.

Tal situação inicia-se quando medidas unilaterais são adotadas pelos Estados com o intuito de resguardar os recursos naturais e promover a preservação no contexto internacional. Algumas dessas medidas, constantes nos tratados multilaterais ambientais, dispõem sobre valores incompatíveis com o subsistema comercial, impondo suas normas mesmo a Estados não partes da OMC.

Em relação ao conflito de normas, Marceau ${ }^{4}$ explica que a existência de um conflito entre dois tratados depende de três condicionantes. Primeiro, que dois Estados assumam compromissos recíprocos em dois diferentes tratados. Em segundo, ambos os tratados devem ter pontos de contato, isto é, cobrirem o mesmo assunto, caso contrário não haveria nenhuma possibilidade de conflito. Terceiro, as disposições devem entrar em conflito no sentido de que devem impor obrigações mutuamente exclusivas.

Pauwelyn ${ }^{5}$, Kelly $^{6}$ e Bartels ${ }^{7}$ são adeptos da teoria de que conflito é sinônimo da incompatibilidade,

do GATT estabelece que "os membros reconhecem que tributos internos e outros encargos internos, e leis, regulamentos e requisitos que afetem a venda interna, oferta para venda, compra,transporte, distribuição ou uso de produtos, e regulamentações quantitativas internas que requeiram a mistura, processamento ou uso de produtos em quantidades ou proporções especificadas, não devem ser aplicados a produtos importados ou domésticos de modo a conferir proteção à produção doméstica". Dessa forma, o objetivo deste princípio é proibir a discriminação entre produtos domésticos e produtos importados similares. Nesse sentido, ver: UNITED NATIONS. Solução de Controvérsias. Conferência das Nações Unidas para o Comércio e Desenvolvimento. Nações Unidas, Nova Yorque e Genebra. 2003. Disponível em: <http://unctad.org/pt/docs/ edmmisc232add16_pt.pdf $>$. Acesso em: 18 jun. 2012.

4 MARCEAU, Gabrielle. Conflicts of norms and conflicts of jurisdictions: the relationship between the WTO agreement and MEAs and other treaties. Journal of World Trade, Holanda, v. 35, n. 6, p. 1084, 2001.

5 PAUWELYN, Joost. Conflict of norms in public international law: how wto law relates to other rules of international law. New York: Cambridge University Press, 2003. p. 169.

6 KELLY, Claire. The value vacuum: self-enforcing regimes and the dilution of the normative feedback loop. Michigan Journal of International Law. v. 22, p. 674, 2001.

7 BARTELS, Lorand. Jurisdiction and applicable law clauses: where does a tribunal find the principal norms applicable to the da inconsistência ou da contradição entre normas, designando também o conflito entre as disposições de um tratado ratificado posteriormente que viole o tratado anterior ou vice-versa. Segundo este viés mais amplo, ${ }^{8}$ tal situação de conflito ganha visibilidade quando, por exemplo, um tratado multilateral a mbiental concede a prerrogativa de impor restrições ao comércio de produtos específicos e que, em contrapartida, seria proibida em violação à cláusula da nação mais favorecida disposta no artigo III do GATT/OMC. O Painel da OMC, ao julgar o caso EC - Bananas $I I I,{ }^{9}$ expressou seu alinhamento ao enfoque não restrito de conflito, exigindo 2 situações para a instauração do conflito: haver o confronto de obrigações mutuamente exclusivas e haver uma norma que é proibida em um acordo, sendo permitida em outro.

A Comissão deDireito Internacional, acompanhando essa doutrina, examina o conceito de conflito sob as perspectivas do objeto, das questões jurídicas e das finalidades de um tratado de direito internacional. No relatório elaborado pela Comissão em 2006, afirma-se que uma definição ampla de conflito consiste em

uma situação em que duas regras ou princípios sugerem diferentes formas de lidar com um problema. Concentrar-se apenas em uma mera incompatibilidade lógica entre normas, acaba por descaracterizar o raciocínio jurídico como subsunção lógica. $\mathrm{Na}$ verdade, qualquer decisão envolve o processo de interpretação e escolha entre regras e significados alternativos que não podem ser suprimidos dentro do modelo de raciocínio lógico. ${ }^{10}$

case before it? In: BROUDE, T.; SHANY, Y. (eds). Multi-Sourced Equivalent Norms in International Law. Oxford: Hart, 2011. p. 123.

8 Cumpre ressaltar que Jenks, considerado precursor na seara do conflito internacional, define o conflito sob uma abordagem restrita como sendo a incompatibilidade direta de uma parte signatária de dois tratados adimplir obrigações constantes em ambos os instrumentos do direito internacional. Ver em: JENKS, Wilfred. The Conflict of Law-Making Treaties. 30 British Yearbook of International Law, 1953. p. 30.

9 Relatório do Painel European Communities - Regime for the Importation, Sale and Distribution of Bananas, WT/DS27 - R, adotado pelo Órgão de Solução de Controvérsias em 22 de maio de 1997. para. 7. 159.

10 Tradução nossa de: "This Report adopts a wide notion of conflict as a situation where two rules or principles suggest different ways of dealing with a problem. Focusing on a mere logical incompatibility mischaracterizes legal reasoning as logical subsumption. In fact, any decision will involve interpretation and choice between alternative rule-formulations and meanings that cannot be pressed within the model of logical reasoning." em CDI. Comissão de Direito Internacional da Organização das Nações 
Percebe-se uma evidente incidência do conflito de normas ambientais e comerciais ao se analisar os seguintes tratados multilaterais ambientais. Apesar de existirem mais de 250 tratados multilaterais ambientais, com membros que variam de pequenos grupos até o conjunto de 180 países, apenas 20 destes acordos incluem disposições que podem influenciar e afetar o comércio, ao dispor acerca de medidas que proíbam o comércio de determinada espécie ou produto ou que permitam aos países restringir o comércio em determinadas circunstâncias. Por exemplo, a CITES estabelece rígidas regras para as licenças de importação e exportação das espécies ameaçadas, que serão concedidas em circunstâncias excepcionais. ${ }^{11}$ A Convenção Internacional de Proteção Fitossanitária, por sua vez, com o objetivo de prevenir a introdução e disseminação de pragas, dispõe que as partes contratantes poderão impor e adotar medidas que proíbam a importação de plantas e produtos vegetais. ${ }^{12}$ O Protocolo de Montreal claramente ilustra a tensão que poderá surgir com normas comerciais. Contém medidas específicas proibindo a circulação de produtos que contenham substâncias prejudiciais à camada de ozônio com Estados que não sejam partes do Protocolo. ${ }^{13}$

Neste viés, a Convenção sobre Comércio Internacional de Espécies em Extinção da Fauna e da

Unidas. United Nations. Fragmentation of International Law: difficulties arising from the diversification and expansion of international law. Report of the Study Group of the International Law Commission. Finalized by Martti Koskenniemi. April, 2006. Disponível em: <http://untreaty. un.org/ilc/documentation/english/a_cn4_1682.pdf>. Acesso em: 17 abr. 2013. p. 19.

11 Colacionam-se alguns artigos da CITES que expressam a sujeição do comércio internacional de determinadas espécies às regras protetivas do meio ambiente. Artigo II, 4: As partes signatárias não devem permitir o comércio das espécies listadas no Anexo I, II e III, salvo se estiver de acordo com as disposições da presente Convenção. Artigo III, 2. A exportação de qualquer espécie incluída no Anexo I deve preceder a concessão e apresentação de uma licença de exportação. Uma licença de exportação só será concedida quando as algumas condições forem satisfeitas. Disponível em: <http:// www.cites.org/eng/disc/text.php\#II>. Acesso em: 21 out. 2014.

12 Artigo 7 da International Plant Protection Convention estabelece que as partes devem regulamentar estritamente a importação e exportação de vegetais e produtos vegetais, através de proibições, inspeções e destruição de partidas prejudicadas. Disponível em: <https://www.ippc.int/> . Acesso em: 21 out. 2014.

13 Artigo 4 do Protocolo de Montreal afirma que: "As partes que não fizeram objeções ao texto do anexo e estiverem de acordo com estes procedimentos, deverão proibir, dentro de um ano da entrada em vigor do anexo, a importação desses produtos de qualquer Estado que não seja Parte do presente Protocolo.” Disponível em: $<$ http://ozone.unep.org/new_site/en/Treaties/treaties_decisionshb.php?nav_id=19>. Acesso em: 21 out. 2014.
Flora Silvestre (CITES, sigla em inglês),aderida pelo Brasil em 1975, prevê medidas restritivas ao comércio em diferentes níveis de instâncias de decisões cujo objetivo é impor uma regulamentação rigorosa, a fim de não colocar em risco ainda mais a sobrevivência das espécies ameaçadas da fauna e flora silvestre, excepcionando o comércio em determinadas circunstâncias (reprodução em cativeiro, reprodução artificial, pesquisa científica) e desde que não seja voltado à obtenção de benefício econômico. ${ }^{14}$

Tendo em vista que a CITES utiliza medidas comerciais para sua implementação, recomenda-se a suspensão temporária do comércio com a parte que não cumpriu com suas obrigações, concedendo-lhe tempo para enquadrar-se aos compliance mechanisms, entre os quais destaca-se a apresentação de relatórios, a promulgação da legislação adequada, o combate e a redução do comércio ilegal e o atendimento às recomendações específicas. Assim, a suspensão do comércio é considerada uma forma de precaução, ilidindo a contínua violação da Convenção, prejudicial à sobrevivência das espécies ameaçadas.

Em igual sentido, a Convenção de Basileia sobre o Controle de Movimentos Transfronteiriços de Resíduos Perigosos e seu Depósito, ratificada pelo Brasil em 1993, fundamentada nos princípios da notificação e do consentimento prévio, estabelece no artigo 4 a proibição da exportação de resíduos perigosos e outros resíduos às partes que tenham proibido a importação de tais resíduos ou que tenham dado consentimento por escrito restringindo a importação. Ademais, consigna a vedação à exportação de resíduos perigosos a grupos de Estados que são Partes pertencentes a uma organização de integração política ou econômica e, particularmente, aos países em desenvolvimento se tiver motivos para acreditar que tais resíduos não serão geridos de forma ambientalmente segura. ${ }^{15}$ Essas restrições visam à redução do movimento de resíduos ao mínimo compatível com o manejo ambientalmente saudável e eficiente. ${ }^{16}$ As partes convencionaram na adoção de um

14 WORLD TRADE ORGANIZATION. Matrix on TradeRelated Measures Pursuant to Selected Multilateral Environmental Agreements. Committee on Trade and Environment. WT/CTE/W/160/Rev.5 of 15 june, 2011. p. 49.

15 Artigo $4^{\circ}$, alínea 2 , e da Convenção de Basileia sobre o Controle de Movimentos Transfronteiriços de Resíduos Perigosos e seu Depósito. Disponível em: < http://www.basel.int/Portals/4/ Basel\%20Convention/docs/text/BaselConventionText-e.pdf $>$. Acesso em: 21 out. 2014.

16 WORLD TRADE ORGANIZATION. Matrix on Trade- 
mecanismo flexível, não contecioso e não vinculativo que promova sua implementação e cumprimento.

Exatamente a contradição existente entre obrigações assumidas perante um sistema jurídico que diretamente influenciam compromissos acordados em outro é o objeto do presente estudo: a interação entre as normas $\mathrm{da} \mathrm{OMC}$ e as normas dispostas nos tratados ambientais que permitam a adoção de medidas restritivas ao comércio em prol da preservação dos ecossistemas.

Assim, conforme visto por tais tratados ambientais multilaterais, o subsistema ambiental impõe sua própria lógica, concretizando valores que busquem minimizar a consequência da liberalização do comércio. Através das cláusulas restritivas ao comércio, os tratados multilaterais ambientais são mecanismos que visam à proteção dos recursos naturais, fornecendo meios para a troca de conhecimentos científicos e informação entre os países-signatários. Sobretudo, caracterizamse por serem regulamentações e normas orientadas à concretização do desenvolvimento sustentável, em virtude de não apresentarem os riscos advindos dos acordos unilaterais e por serem capazes de atuar como soluções multilaterais para os problemas ambientais transfronteiriços, regionais e internacionais. Contudo, adeptos do sistema multilateral de comércio temem que estados protecionistas se utilizem de padrões ambientais para disfarçar as barreiras ao comércio e, também, que se valham de políticas com benefícios mínimos à saúde pública e ao meio ambiente para impor encargos injustificáveis ao comércio.

\subsection{Conflito de jurisdições}

De outro lado, a contrapartida do desenvolvimento de novas redes de responsabilidades e da multiplicação de normas específicas internacionais, impostas pelos subsistemas do direito internacional, também implica a criação de órgãos jurisdicionais capazes de implementar e controlar o cumprimento das obrigações ambientais e comerciais assumidas por parte dos Estados. Assim, percebe-se a emergência de diferentes tribunais internacionais aptos a julgar as controvérsias, surgindo também o conflito entre jurisdições.

Em poucos anos, o número de tratados, tribunais e, consequentemente, de jurisdições aumentou

Related Measures Pursuant to Selected Multilateral Environmental Agreements. Committee on Trade and Environment. WT/CTE/W/160/Rev.5 of 15 june, 2011. p. 64. dramaticamente, representando positivamente o aprimoramento na interpretação das normas, criando um corpo de julgadores mais eficientes e precisos. De fato, a proliferação de tais tribunais indica a edificação de uma ordem internacional fundamentada nos ideais de justiça, de independência e de legitimidade dos sistemas jurídicos.

Um conflito de jurisdição, no sentido de haver a sobreposição de tribunais ou diversos mecanismos de solução de controvérsias para julgar um mesmo fato, pode ser manejado quando um tratado ambiental préexistente à promulgação dos acordos da OMC em 1994 continua a ser relevante entre os membros da OMC os quais devem obedecê-lo. Da mesma forma, todos os novos tratados criados entre alguns ou todos os membros da OMC, posteriormente à conclusão dos acordos da OMC (diga-se, o Protocolo de Cartagena sobre Biossegurança ou as recentes Convenções das Nações Unidas), necessariamente, interagem com os direitos e obrigações dos membros da OMC vinculados ao novo tratado.

Assim, enquanto o desenvolvimento das relações internacionais conduziu a uma maior produção normativa e ao crescimento do número de organizações internacionais para tratar de questões técnicas, econômicas e sociais, consequentemente, abriu espaço para criação de novos sistemas de solução de controvérsias. ${ }^{17}$ A proliferação de tribunais, nesse sentido, vem a estimular a criatividade e a interação do direito através do diálogo entre diferentes áreas.

Todavia, a falta de coerência entre as técnicas de interpretação pode resultar em diferentes posicionamentos dos órgãos jurisdicionais internacionais, particularmente no momento do confronto entre o comércio e o meio ambiente.

$\mathrm{Na}$ presença de obrigações conflitantes dispostas em tratados diferentes, procura-se encontrar maneiras de coordenar simultaneamente os direitos assegurados em cada um dos subsistemas, mas não prorrogando a solução para o futuro, por meio de cláusulas condicionais. O Protocolo de Cartagena sobre Biossegurança, ao assegurar que tratados sobre comércio e meio ambiente amparam-se mutuamente com o fim de atingir o desenvolvimento sustentável, reconhece que conflitos devem ser instaurados e

17 KINGSBURY, Benedict. Is the proliferation of International Courts and Tribunals a Systemic Problem? The New York University Journal of International Law and Policy. v. 31, p. 681, 1999. 
resolvidos entre as partes, mas não pontua de forma clara como ocorrerão as negociações e procedimentos. ${ }^{18}$

São inúmeros os exemplos ${ }^{19}$ de tratados multilaterais ambientais que seguem essa mesma linha de indefinição quanto à resolução de conflitos, especialmente quando congregam partes de diferentes subsistemas, com também diferentes interesses e objetivos. A não ser que os Estados contratantes concordem previamente na escolha do foro competente para dirimir possíveis controvérsias, é visível a espécie de conflito entre diferentes jurisdições para o caso.

Face à ausência de uma organização mundial ambiental, com poder similar ao que a OMC exerce em matéria comercial, prevalece a descontinuidade e a competição em termos de escolha de jurisdição. De fato, por mais que essa diversidade auxilie a disseminar a efetividade das normas, parece que a multiplicidade de fóruns apropriados a julgar os litígios pode favorecer a primazia da lógica comercial. ${ }^{20}$

Isso abre precedentes para que o órgão escolhido, normalmente representativo de uma das partes e não um órgão terceiro imparcial, julgue o caso de acordo com as prioridades de seu regime, subsistema. Nesses casos, cláusulas ambíguas e abertas acobertam a atuação vantajosa e imparcial conferida a determinado regime em detrimento do outro.

Com efeito, quando em pauta a violação de uma obrigação ambiental ou comercial internacional, mecanismos de cumprimento ou de solução de controvérsias cumprem a função de reforçar os objetivos particulares dos tratados e obstar que a

18 O artigo 24 Protocolo de Cartagena sobre Biossegurança expressa, em complementação ao preâmbulo que reconhece que tratados sobre comércio e meio ambiente devem ser interpretados de maneira harmônica para alcançar o desenvolvimento sustentável, que movimentos transfronteiriços de organismos geneticamente modificados entre partes e partes não signatárias necessitam ser consistentes com o objetivo do presente protocolo, permitindo a celebração de acordos bilaterais, regionais e multilaterais. Para acessar o texto do Protocolo, ver: <http://bch.cbd.int/protocol/ text/>. Acesso em: 9 set. 2013.

19 Nesse sentido, a Convenção de Diversidade Biológica de 1992, a Convenção de Basileia de 1989 e o Tratado Internacional sobre os Recursos Fitogenéticos para a Alimentação e a Agricultura de 2002 também apresentam cláusulas que estabelecem cooperação mútua entre as diferentes partes contratantes, deixando, entretanto, espaço para interpretação ambígua quanto à apreciação e negociação. Ver: CDI, 2006, p. 140.

20 DELMAS-MARTY, Mireille. Comparative Law and International Law: methods for ordering pluralism. 2005. Disponivel em: $<$ http://w7.ens-lyon.fr/amrieu/IMG/pdf/Delmas-Marty_Comp_ Int_Law_10-05doc.pdf $>$.p. 12. parte transgressora reincida no descumprimento da obrigação. ${ }^{21}$ Isso porque uma correta interpretação quanto às obrigações estatais realiza-se de maneira que partes signatárias da OMC e dos tratados ambientais não procurem mecanismos de resolução de conflitos sem necessidade, dirigindo seus casos às instâncias mais apropriadas.

Portanto, a forma pela qual ocorrerá essa interpretação dos tratados é assunto da parte que segue, haja vista que as normas dos subsistemas ambiental ou comercial, codificadas em instrumento de tratado, podem ser interpretadas à luz do artigo 31 da Convenção de Viena sobre o Direito dos Tratados, a fim de estabelecer uma possível integração entre regimes integrantes do direito internacional, de forma a assegurar a coerência com o ambiente normativo.

\section{Interpretação e integração aplicáveis aos subsistemas do direito internacional}

\subsection{Convenção de Viena sobre o Direito dos Tratados: instrumentos à interpretação}

Não obstante a ocorrência de conflitos ser rechaçada pelo direito internacional, observa-se o crescente número de casos que trazem no seu bojo questões conflituais entre tratados. Em tese, não há hieraquia no direito internacional entre os acordos da OMC e os tratados multilaterais ambientais. Com exceção das normas jus cogens e das obrigações da Carta das Nações Unidas, nenhuma norma de direito internacional pode ser considerada mais importante do que outra. ${ }^{22}$

Visto que toda norma de direito internacional, de um modo ou de outro, deriva da mesma fonte, isto é, do consentimento do Estado, é indiferente a estipulação de uma hierarquia de fontes. $\mathrm{O}$ artigo 38 do Estatuto da Corte Internacional de Justiça, ao prever as fontes de direito internacional aplicáveis às controvérsias, não confere nenhuma ordem de preferência às convenções, aos costumes e aos princípios gerais de direito, expressando a mesma relevância jurídica de tais fontes. Similarmente ao artigo 38, os artigos 3.2 e 7 do ESC,

21 WEISS, Edith Brown et al. International environmental law and policy. Nova York: Aspen Publisher, 2007. p. 177.

22 PAUWELYN, Joost. The application of non-WTO rules of international law in WTO dispute settlement. In: MACRORY, Patrick; APPLETON, Arthur; PLUMMER, Michael (Ed.). The World Trade Organization: legal, economic and political analysis. United States: Springer, 2005. p. 1418. 
no âmbito da OMC, especificam que a controvérsia deve ser solucionada consoante as obrigações dispostas nos acordos constitutivos da OMC. O ESC engloba tão somente medidas que afetem o funcionamento de qualquer dos acordos-quadro dentro do território de um seus membros, incluindo medidas adotadas em nível local ou regional.

Entretanto, sob a análise do artigo 38 da CIJ, é possível asseverar que a OMC não descarta o sistema geral de direito internacional, aplicando princípios e regras aos seus litígios, fazendo-o em conformidade com o artigo 3.2 do ESC. ${ }^{23}$ Especificamente a abertura oferecida por esta disposição permite adequar a complexidade existente entre dois subsistemas do direito internacional, superando o antagonismo de normas que se encontravam fechadas e seladas ao seu próprio regime.

Justamente pela inexistência de hierarquia entre as normas que reside o desafio de encontrar o adequado equilíbrio entre direitos potencialmente conflitantes. Da indagação sobre se os órgãos jurisdicionais da OMC, Painel e Órgão de Apelação podem utilizar outros acordos que não sejam os promulgados pela $\mathrm{OMC}$, como os tratados multilaterais ambientais, responde-se em tom afirmativo pelas razões que seguem.

Quando as normas da OMC não excluam a aplicação de determinada regra, as demais normas de direito internacional continuam a ser aplicáveis. Através do recurso a regras gerais do direito internacional, restou comprovado que, no silêncio de um acordo da OMC, podem sim ser aplicadas as demais normas do direito internacional. ${ }^{24}$ A dizer, Painéis e Órgão de Apelação podem aplicar princípios gerais do direito internacional quando as normas da OMC não vedem expressamente sua aplicação. Afirmar o contrário, que a $\mathrm{OMC}$ não pode considerar normas que não estejam expressamente

23 O artigo 3.2 do ESC que confere comunicação entre as normas da $\mathrm{OMC}$ e as normas consuetudinárias do direito internacional prevê: “[...] Os Membros reconhecem que esse sistema é útil [...] para esclarecer as disposições vigentes dos referidos acordos em conformidade com as normas correntes de interpretação do direito internacional público. As recomendações e decisões do OSC não poderão promover o aumento ou a diminuição dos direitos $\mathrm{e}$ obrigações definidos nos acordos abrangidos." Disponível em: <http://www.wto.org/english/tratop_e/dispu_e/dsu_e.htm>. Acesso em: 17 out. 2013.

24 Nesse sentido, o caso Argentina - Footwear (parágrafo 67) e EC - Hormone (parágrafo 123) ilustram que o Órgão de Apelação não deveria limitar sua análise apenas aos Acordos da OMC, mas frente à ausência de regras de conflitos dispostas nos Acordos, aplicar regras de conflitos relacionadas ao direito internacional. referidas nos seus tratados, é ir contra o princípio básico de que as regras de direito internacional aplicam-se incondicionalmente aos tratados.

Dessa forma, reconhecendo que as normas da OMC são permeáveis às situações externas, tornase necessário analisar a incidência da Convenção de Viena sobre o Direito dos Tratados de 1969 (CVDT) na tentativa de conferir coerência à ordem jurídica internacional.

O texto da Convenção de Viena surge como método útil a fim de integrar os subsistemas ambiental ao comercial, oferecendo soluções para os conflitos aparentes entre normas e revelando a harmonização no ordenamento jurídico plural. Essa permissão é consequência da previsão do artigo 31.3 (c) da CVDT que, ao afirmar que a interpretação de um tratado deve levar em consideração "quaisquer regras pertinentes de direito internacional aplicáveis às relações entre as partes", abrange o escopo de normas possíveis de serem aplicadas pelo corpo jurídico da OMC, incluindo também as normativas dos tratados multilaterais ambientais. Esse artigo é um indicador de que as normas do direito internacional devem ser levadas em conta na interpretação das disposições de tratados específicos, como o da OMC. É considerado, também, como presunção de que os Estados não objetivam promulgar novas normas de direito internacional inconciliáveis com as já existentes.

Conforme observado durante os debates da Comissão de Direito Internacional, ${ }^{25}$ o grupo de estudos ressaltou que o artigo 31.3 (c) dá expressão ao objetivo de "integração sistêmica" do sistema jurídico internacional, descrevendo um processo de raciocínio legal em que elementos particulares terão maior ou menor importância, dependendo da natureza das disposições dos tratados postos à interpretação.

Assim, as regras de interpretação contidas nos artigos 30, 31 e 32 da Convenção de Viena são admitidas como "customary rules of interpretation of public international law" 26 e amplamente utilizadas no regime

25 CDI. Comissão de Direito Internacional da Organização das Nações Unidas. United Nations. Fragmentation of International Law: difficulties arising from the diversification and expansion of international law. Report of the Study Group of the International Law Commission. Finalized by Martti Koskenniemi. April, p. 208, 2006. Disponível em: <http://untreaty.un.org/ilc/documentation/ english/a_cn4_1682.pdf>.

26 Relatório do Painel no caso European Communities - Customs Classification of Frozen Boneless Chicken Cuts, WT/DS269/R, julgado em 30 de maio de 2005. parágrafo 7.88. Em igual sentido ver 
da OMC. Em que pese haver alguns membros da OMC que não sejam também partes-signatárias da Convenção de Viena sobre Direito dos Tratados de 1969, o Órgão de Apelação, seguindo precedentes da Corte Internacional de Justiça (Iran v. US, 2003, para. 4.1) declarou que a Convenção representa a codificação das regras de direito internacional consuetudinário, portanto, obrigatória para todas as partes signatárias dos acordos abrangidos da OMC.

Especificamente, tais artigos foram incorporados pelos acordos da OMC na seção relativa ao ESC. O artigo 3.2 do ESC, ao preservar direitos e obrigações de seus membros, dispõe que o Painel e Órgão de Apelação deve clarificar as disposições da OMC em consonância com as normas consuetudinárias de interpretação do direito internacional. O Órgão de Apelação, ao decidir o caso US - Continued Zeroing ${ }^{27}$ demonstrou como o referido dispositivo deve ser aplicado em conformidade com preceitos do processo interpretativo da Convenção de Viena. Ressalta-se que neste caso o Órgão de Apelação elucidou que os elementos para interpretação dos tratados dispostos nos artigos $31 \mathrm{e}$ 32 não expressam uma estrutura de hierarquia, pois são indistintamente partes integrantes e essenciais do processo interpretativo.

No entanto, vige a vedação ao acréscimo, diminuição ou alteração de direitos e obrigações nos acordos-quadro da OMC, obstando a extensão de competência do Órgão de Solução de Controvérsia, conforme previsto no final do art. 3.2 do ESC. A solução para este ponto é a de que a análise dos tratados multilaterais ambientais feita pelos Painéis não se estenda em determinar se a medida comercial violada enquadra-se nos termos do tratado ambiental. A análise deve repousar somente na verificação de se as partes signatárias do regime da OMC também o são do referido tratado multilateral ambiental e se o alegado tratado ambiental contém regras relevantes de direito internacional aplicáveis às partes.

Entretanto, de acordo com Trachman, ${ }^{28}$ as normas de direito internacional que não estão expressas nos

$\overline{\text { julgamento do Painel e Órgão de Apelação em casos como Japan }}$ - Alcobolic Beverages, Carbon Steel, US - Gasoline que reconheceram a funcionalidade dos artigos 31 e 32 da Convenção de Viena na estipulação de regras de interpretação ao direito internacional.

27 Relatório do Órgão de Apelação no caso United States Continued Existence and Application of Zeroing Methodology, WT/DS350/ $\mathrm{AB} / \mathrm{R}$, julgado em 4 de fevereiro de 2009. parágrafo 268 .

28 TRACHTMAN, Joel P. The Domain of WTO Dispute Resolution. acordos da OMC não deveriam ser utilizadas na interpretação das resoluções de controvérsias. Esta visão vai contra e distancia-se de diversas decisões proferidas pelo Painel e pelo Órgão de Apelação que fazem referência a normas contidas em outros tratados. No seu primeiro relatório do caso US-Gasoline $e^{29}$, o Órgão de Apelação ponderou que os acordos da OMC não devem ser interpretados em "clinical isolation" do direito internacional público.

Neste propósito, dizer que os órgãos da OMC possuem uma jurisdição limitada para interpretar e aplicar os acordos abrangidos não significa que as normas da OMC devam ser aplicadas de forma isolada do resto do direito internacional, ${ }^{30}$ reconhecendo, ademais, que os costumes internacionais aplicam-se aos acordos entre os Estados membros da OMC.

Tal como foi no caso US-Shrimp ${ }^{31}$, no qual o Órgão de Apelação recorreu ao auxílio de textos de outros tratados, como a CDB e a CITES, para interpretar termos próprios do comércio internacional. No referido caso, o Órgão de Apelação interpretou o termo "recursos naturais exauríveis" disposto no artigo XX (g) do GATT. Mais uma vez, se a resolução de litígios da OMC fosse somente restrita a cláusulas de seus tratados, esta referência aos tratados multilaterais ambientais não teria sido possível.

p. 5, 1999. Disponível em: <http://ssrn.com/abstract=149348>.

29 Ao explicar o artigo 31 da Convenção de Viena sobre Direito dos Tratados, o Órgão de Apelação consignou que: "That general rule of interpretation has attained the status of a rule of customary or general international law. As such, it forms part of the "customary rules of interpretation of public international law" which the Appellate Body has been directed, by Article 3(2) of the DSU, to apply in seeking to clarify the provisions of the General Agreement and the other "covered agreements" of the Marrakesh Agreement Establishing the World Trade Organization (the "WTO Agreement"). That direction reflects a measure of recognition that the General Agreement is not to be read in clinical isolation from public international law Relatório do Órgão de Apelação no caso United States - Standards for Reformulated and Conventional Gasoline, WT/ $\mathrm{DS} 2 / \mathrm{AB} / \mathrm{R}$, adotado pelo Órgão de Solução de Controvérsias em 22 de abril de 1996. p. 17.

30 MARCEAU, Gabrielle. A Call for Coherence in International Law: praises for the prohibition against "clinical isolation" In WTO Dispute Settlement. Journal of World Trade, Holanda, v. 33, n. 5, p. 131, 1999.

31 Trata-se de um caso postulado pela Índia, Paquistão, Tailândia e Malásia contra a atitude do governo dos Estados Unidos de proibir a importação de camarão em virtude dos métodos utilizados na sua captura, que ameaçavam a vida das tartarugas marinhas. Vide: Relatório do Órgão de Apelação no caso United States - Import Probibition of Certain Shrimp and Shrimp Products, WT/DS58/AB/R, 12 de outubro de 1998. 
Logo, encontrar a compatibilidade entre regimes plurais e dotados de objetivos antagônicos não é uma tarefa fácil, ainda mais diante da circunstância de um conflito entre disposições de tratados diferentes e tendo que determinar qual delas irá prepondar sobre a outra. Assim, verificou-se que a OMC pode recorrer a normas consuetudinárias e constantes em outros tratados para embasar sua decisão, desde que não implique no acréscimo ou restrição das obrigações de seus Estados membros, concluindo-se acerca da viabilidade de um Painel ou Órgão de Apelação poderem levar em consideração regras consideradas alienígenas, diferentes daquelas dispostas pelos acordos da OMC, de forma a melhor conceder a aplicação do direito internacional ao caso em concreto.

\subsection{Aplicação do desenvolvimento sustentável como diretriz interpretativa}

A partir do momento em que a OMC avocou maior número de competências para questões além das comerciais, seus mecanismos de resolução de controvérsias não poderiam mais interpretar todas obrigações por meio de "lentes" unicamente sensíveis ao compromisso da liberalização multilateral do comércio. ${ }^{32}$ Especialmente no que tange aos tratados ambientais, sugere-se que Painéis e o Órgão de Apelação façam uso, por exemplo, das ferramentas de interpretação dos tratados também por meio da aplicação do princípio do desenvolvimento sustentável.

Desenvolvimento sustentável aqui entendido como diretriz que se desenvolveu de uma aspiração meramente política para um conceito jurídico que considera as necessidades econômicas, sociais e ambientais da sociedade, tornando-se, assim, um princípio maleável de acordo com circunstâncias particulares. ${ }^{3}$

Depreende-se que a introdução do conceito de desenvolvimento sustentável é um facilitador para que as regras ambientais possam interagir com regras comerciais e expressa a manifestação de vontade dos membros de não limitar seus efeitos simplesmente às relações de comércio e meio ambiente. $\mathrm{Na}$ verdade, o

32 GUZMAN, Andrew T. Global Governance and the WTO. Harvard International Law Journal. v. 45, n. 2, p. 336, Summer, 2004.

33 MARCEAU, Gabrielle; MOROSINI, Fábio. The status of sustainable development in the law of the world trade organization. In: JUNIOR, Umberto Celli; BASSSO, Maristela; JUNIOR, Alberto Amaral (Coord.). Arbitragem e comércio internacional: estudos em homenagem a Luiz Olavo Baptista. São Paulo: Quartier Latin, 2013. p. 60 . meio ambiente tornou-se uma das correntes principais à efetiva integração do comércio. Essa referência claramente demonstra o intuito de não restringir os efeitos do comércio sobre o meio ambiente natural, evidenciando que o princípio do desenvolvimento sustentável está remodelando a interpretação da OMC acerca dos tratados internacionais. ${ }^{34}$

Nesse contexto, a referência ao desenvolvimento sustentável na decisão do Órgão de Apelação desponta como precedente de que o princípio concede "colour, texture and shading" ${ }^{35}$ aos direitos e obrigações dos Estados membros da OMC, ampliando a interpretação baseada nas circunstâncias do Acordo Geral da OMC. Trata-se de clara indicação ao reconhecimento do desenvolvimento sustentável como princípio informador das intenções dos membros em todos os acordos abrangidos da OMC.

De forma a acompanhar o caráter evolutivo ambiental e de maneira a atingir uma interpretação coerente com o desenvolvimento sustentável, o Órgão de Apelação precisou recorrer ao auxílio de alguns tratados e declarações multilaterais ambientais - mesmo que nem todos os Estados membros da OMC também o fossem de tais tratados e declarações. Os referidos diplomas ambientais - entre os quais está a Declaração sobre Desenvolvimento e Meio Ambiente do Rio de Janeiro, a CITES e a CDB - expressavam preocupações comuns dos governos.

Em especial, a referência à Declaração do Rio de Janeiro de 1992 foi feita por ocasião do julgamento do caso US - Shrimp, quando o Órgão de Apelação, analisando a adoção de medidas unilaterais por parte de seus membros, concluiu que a disposição do princípio 12 da Declaração do Rio seria o canal de justificação de certas ações unilaterais para proteger o ambiente externo à jurisdição nacional. Dessa forma, o Órgão de Apelação utilizou esse princípio como argumento para rebater a alegação americana, fazendo uso de "normas

34 MOROSINI, Fábio. Trade and Climate Change: unveiling the principle of common but differentiated responsibilities from the WTO Agreements. The George Washington International Law Review, Washington, v. 42, n. 4, p. 717, 2010.

35 O Órgão de Apelação no relatório do julgamento US Shrimp, em 1998, concluiu que a que a referência ao desenvolvimento sustentável no preâmbulo da OMC concede cor, textura e delineamento aos direitos e obrigações dos membros sob os Acordos da OMC. Relatório do Órgão de Apelação no caso United States - Import Probibition of Certain Shrimp and Shrimp Products, WT/ DS58/AB/R, 12 out. 1998. Disponível em: < http://www.wto.org/ english/tratop_e/dispu_e/58abr.pdf $>$. para. 155. 
ambientais - e não meramente comerciais - para discutir uma restrição ao comércio por outra norma ambiental". 36

Assim, a partir do julgamento desse mesmo caso (US - Shrimp), o Órgão de Apelação interpretou o termo "recursos naturais exauríveis" em harmonia com a exceção feita pelo artigo XX, alínea g do GATT, ampliando a interpretação concedida pelo Painel que havia definido o termo como recursos finitos, não incluindo os ecossistemas biológicos e renováveis. ${ }^{37}$ Nota-se, então, que a interpretação do Órgão de Apelação para estender o termo "recursos naturais não renováveis" de forma a abranger também outros organismos vivos demonstra seu posicionamento em conformidade com as diretrizes do desenvolvimento sustentável.

Além disso, a atividade dos órgãos jurisdicionais da OMC também é norteada consoante o princípio da transparência que subsidia diversos compromissos na área ambiental. A partir do efetivo compartilhamento de informações e da prestação de contas por parte de cada Estado membro, o alcance das políticas públicas comerciais com viés ambiental torna-se menos dispendioso do que o recurso a novas negociações. $\mathrm{O}$ princípio da transparência dita que as partes signatárias devem dar publicidade à negociação e à implementação das obrigações comerciais dispostas nos tratados multilaterais ambientais como forma de melhor examinar as regulamentações ambientais domésticas e seus impactos no comércio internacional. Inclusive, há quem $^{38}$ sustente que o sistema ambiental influenciou e

36 VARELLA, Marcelo Dias. Internacionalização do direito: direito internacional, globalização e complexidade. Brasília: UniCEUB, 2013. p. 238.

37 Nesse sentido, Morosini pondera que desenvolvimento sustentável lapidou a interpretação de diversos termos dos acordos da OMC inserindo a proteção ambiental na agenda comercial. Ver em: MOROSINI, Fábio. Taking into account environmental, social and cultural concerns through the objective of sustainable development: perspectives from the WTO Jurisprudence on General Exceptions In: HANANIA, Lilian Richieri (Org.). Effectiveness and normativity of the 2005 UNESCO Convention on the Protection and Promotion of the Diversity of Cultural Expressions. Londres: Routledge, 2014. p. 54.

38 Charnovitz assevera que o debate comércio e meio ambiente imprimiu amplo impacto nos procedimentos da OMC. Segundo a visão deste autor, a crítica dos ambientalistas e de ONGs foi fundamental para que, no início dos anos 90, a liderança dos burocratas comerciais concedessem abertura ao sistema de negociação como resposta à influência dos ambientalistas no sistema comercial. Nesse sentido, ver: CHARNOVITZ, Steve. Trade and the Environment in the WTO. GWU Legal Studies Research Paper n. 338. p.10, 2007. Disponível em: <http://ssrn.com/abstract=1007028>. exportou normas a favor da transparência organizacional à OMC, já que a solução de controvérsias do GATT carecia de certa quantidade de transparência. ${ }^{39}$

O glossário da OMC define transparência como o nível de abertura e previsibilidade estabelecido nas políticas e práticas comerciais. Tal previsibilidade refere-se ao conhecimento prévio de todas as medidas de defesa comercial que poderão ser utilizadas pelos membros da OMC, a exemplo de barreiras não tarifárias visíveis e mensuráveis. Destaca-se que a participação da sociedade é condição essencial para que as normas dos subsistemas comercial e ambiental sejam consideradas transparentes e confiáveis. Com efeito, a transparência, além de promover uma maior inserção da sociedade na elaboração de normas e na fiscalização de seu cumprimento, incentiva o aumento da eficácia dos acordos da OMC com os compromissos ambientais. ${ }^{40} \mathrm{O}$ princípio da transparência torna-se, então, corolário para o desenvolvimento sustentável, incentivando procedimentos com tomadas de decisões democráticas e com responsabilidade financeira. ${ }^{41}$ Esta transparência é uma oportunidade para acomodar as medidas comerciais de acordo com as obrigações ambientais, partindo do pressuposto de que a maior concessão de informações é capaz de induzir o governo a modificar sua política e superar os obstáculos a partir de sua clara identificação.

Frente a essa percepção, os tratados multilaterais ambientais tornam-se uma via natural de regulação em conjunto com as normas dispostas pela OMC que, em razão de ter incluído a preservação do meio ambiente entre as diretrizes de seu sistema, continua a avançar em harmonia com a promoção do desenvolvimento sustentável.

Desse modo, uma forma apropriada para solucionar os conflitos entre sistemas normativos díspares em reflexo à complexidade da ordem internacional ocorre por meio da integração de regras e conceitos articulados em tais regimes, autônomos e ao mesmo tempo complementares, considerando seus compromissos, na

39 JACKSON, John H. World Trade Rules and Environmental Policies: congruence or conflict? Washington and Lee Law Review. v. 49, n. 4, p. $1255,1992$.

40 HALLE, Mark; WOLFE, Robert. A new approach to transparency and accountability in the WTO. Entwined. Issue Brief 6, 2010. p. 3.

41 SEGGER, Marie-Claire Cordonier; KHALFAN, Ashfaq. Sustainable Development in Policy and in Law: principle, practices and prospects. USA: Oxford University Press, 2005. p. 101. 
devida medida, com o desenvolvimento sustentável. Resta saber, então, se o regime jurídico da OMC está realmente acompanhando esse padrão ambientalmente sustentável e de que forma excepciona e compatibiliza os objetivos ambientais com o direito internacional comercial, assunto que será pormenorizadamente abordado no próximo ponto.

\section{Conciliando medidas restritivas do comércio e objetivos ambientais}

\subsection{Premissas do artigo XX do GATT 1994}

A exemplo de um regime associado à fragmentação do direito internacional, a OMC, em período relativamente recente, tem promovido esforços para demonstrar que a relação entre os objetivos da salvaguarda de um sistema multilateral de comércio aberto e não discriminatório pode e deve se apoiar mutuamente com o viés da proteção do meio ambiente e da promoção do desenvolvimento sustentável. Realiza essa tarefa, em grande parte, por meio das restrições comerciais estabelecidas no artigo XX que concede o equilíbrio entre a eliminação das barreiras alfandegárias e a liberdade concedida pelos Estados para tomar decisões que protejam interesses sensíveis à população nacional - como são os problemas ambientais.

A redação do artigo $\mathrm{XX}$ foi pensada quando da formação da Organização Internacional do Comércio e seu dispositivo, especificamente ao que se refere às alíneas (b) e (g), manteve idêntica forma, prevendo que, "desde que não sejam aplicadas de forma a constituir quer um meio de discriminação arbitrária, ou injustificada, entre os países onde existem as mesmas condições, quer uma restrição disfarçada ao comércio internacional, disposição alguma do presente capítulo será interpretada como impedindo a adoção ou aplicação, por qualquer parte contratante, das medidas: b) necessárias à proteção da saúde e da vida das pessoas e dos animas e à preservação dos vegetais; g) relativas à conservação dos recursos naturais esgotáveis, se tais medidas forem aplicadas conjuntamente com restrições à produção ou ao consumo nacionais." Ressalva-se, entretanto, a ponderação proposta pelo Brasil e adotada na Conferência de Genebra em agosto de 1947 para excluir a expressão ${ }^{42}$ que levava

42 A referida expressão da precedente leitura do artigo XX (g) era "taken pursuant to international agreements". Nesse sentido, em consideração tratados internacionais disposta na alínea (g), afastando a exigência de qualquer requisito relativo à conformidade de tais medidas com tratados multilaterais ambientais.

$\mathrm{O}$ artigo XX, então, estabelece a aplicação de medidas ambientais contidas em outros instrumentos do direito internacional, mesmo que restritivas ao comércio. Elenca exceções às regras sobre a liberalização comercial "com o intuito de permitir a execução de políticas governamentais que promovam a realização de finalidades essenciais para as sociedades domésticas." ${ }^{\not 3}$ Por isso, o artigo XX fornece isenções no que tange aos aspectos de grande relevância, como a moralidade pública, saúde humana, vegetal ou animal e a defesa dos recursos naturais.

Apesar de nem mencionar a palavra meio ambiente, visto que, na época de sua redação, em 1947, a degradação ambiental não era motivo de preocupação pública, a função do artigo XX é favorecer o diálogo com os demais subsistemas do direito internacional, designadamente, os tratados multilaterais ambientais. De fato, a proteção do meio ambiente, por meio das sanções dispostas nos tratados multilaterais ambientais, realiza-se quer por intermédio da letra (b) quer pelo recurso à letra $(\mathrm{g})$.

Com efeito, em primeiro lugar, é preciso identificar se o objetivo levado a cabo por meio da medida restritiva comercial se insere no âmbito das políticas previstas nas alíneas do artigo XX do GATT 1994. Isso inclui verificar se os elementos jurídicos elencam-se em algumas das alíneas que visam perseguir objetivos de saúde pública e de preservação dos recursos naturais exauríveis. ${ }^{44}$ Em segundo lugar, procede-se à

CHARNOVITZ, Steve. Exploring the Environmental Exceptions in GATT Article XX. Journal of World Trade, Geneva, v. 3, n. 5, p. 41, 1991. Para uma melhor compreensão da interpretação dos termos do artigo XX e do quadro regulatório da OMC, ver: THORSTENSEN, Vera; OLIVEIRA, Luciana Maria de (Org.). Releitura dos Acordos da OMC como Interpretados pelo Órgão de Apelação. São Paulo: VT Assessoria Consultoria e Treinamento Ltda, 2013.

43 AMARAL JUNIOR, Alberto do. A solução de controvérsias na OMC. São Paulo: Atlas, 2008. p.191.

44 Essa foi a sequência de passos estabelecidos de forma pioneira pelo Painel na decisão US - Tuna II, conhecido como threestep analysis. Em primeiro lugar, o Painel examinou se o objetivo da política ambiental enquadrava-se nas exceções do artigo XX. Após, considerou se a medida vinculava-se à alínea (b) ou $(\mathrm{g})$ do referido artigo. Preenchidas as 2 primeiras etapas, então, passou a verificar se a medida atendia à conformidade do caput do artigo. Ver em: Relatório do Painel no caso United States - Restriction on Imports of Tuna II, DS29/R, julgado em 16 de junho de 1994. Parágrafo 5.12. 
verificação quanto ao caput do Artigo XX, analisando se a medida não conduz a uma discriminação arbitrária ou injustificável entre países ou uma restrição disfarçada ao comércio internacional. ${ }^{45}$

Assim, uma medida alternativa que também pode ser adequada às exceções do artigo XX deve preencher 3 requisitos: ser capaz de alcançar o grau de proteção genuinamente estipulado pelo país que está invocando a exceção; não ser uma medida teórica, mas que possa ser posta em prática e que não imponha ônus indevidamente a outra parte. ${ }^{46}$

Não obstante certos tratados multilaterais ambientais realmente confrontarem tais obrigações consideradas pilares dos acordos da OMC, a aplicação das exceções do artigo XX possibilita considerar os tratados ambientais como consistentes com o regime comercial.

Em essência, o artigo XX progrediu com o fim de representar um mecanismo que permitisse exceções às regras comerciais, contanto que políticas com fins de proteção ambiental e de saúde pública não fossem utilizadas como barreiras ao livre-comércio internacional. Sem sombras de dúvidas, é possível afirmar que, atualmente, quase todas as decisões proferidas pelos órgãos jurisdicionais da OMC que se referem a disputas ambientais têm aproveitado os conhecimentos técnicos científicos e, assim, as decisões mais recentes demonstram um viés ambientalmente favorável.

\subsection{Incidência prática das exceções ao sistema multilateral comercial}

$\mathrm{Na}$ maioria dos casos levados à apreciação e julgamento de Painéis e Órgão de Apelação, as medidas expressas nos tratados ambientais são justificadas

45 Quanto à ordem de verificação da alínea (b), após a fixação da análise em 3 etapas, todos os demais casos da OMC observaram a mesma sistemática, examinando primeiro a conformidade com a alínea, para depois analisar o caput do artigo XX. A exceção se faz pelo caso US - Shrimp no qual o Painel iniciou a análise pelo caput, não chegando a proceder a verificação das alíneas. Já na ordem de verificação da alínea (g), a decisão do caso US - Taxes on automobiles, no mesmo ano do julgamento do US - Tuna II, adotou a análise em 3 etapas, metódico que se seguiu no regime da OMC. Ver: Relatório do Painel no caso United States - Taxes on automobiles, DS31/R, em 11 de outubro de 1994. parágrafo 5.56

46 Relatório do Painel e Órgão de Apelação no caso United States - Standards for Reformulated and Conventional Gasoline, WT/DS2/R, em 29 de janeiro de 1996. p. 17. Nesse sentido, ver: MOROSINI, Fábio. Trade and Climate Change: unveiling the principle of common but differentiated responsibilities from the WTO Agreements. The George Washington International Law Review, Washington, v. 42, n 4, p.716, 2010. ao abrigo das exceções da OMC relacionadas à saúde e ao meio ambiente. As alíneas (b) e (g) são as mais contestadas pelo mecanismo de solução de controvérsias da OMC, comprovando-se pela vasta jurisprudência acerca das medidas sobre saúde pública, sanções e proteções normativas compatíveis com o regime comercial e relativas à conservação dos recursos naturais exauríveis.

Durante o regime estipulado pelas regras do GATT, 6 painéis envolvendo questões ambientais foram instaurados (US - Canadian Tuna; Canada - Salmon and Herring; Thailand - Cigarettes; US - Tuna IMexico; US TunaII; US - Automobiles). Percebe-se que, nesse período, as causas submetidas à apreciação do mecanismo de solução de controvérsias do GATT eram julgadas desfavoravelmente à preservação dos recursos naturais ou até mesmo disposições sobre a proteção da natureza não eram sequer consideradas.

Exatamente no caso US - Tuna I também conhecido como caso Atum-Golfinho I, o Painel conferiu prioridade às regras do livre-comércio sobre as normas de proteção ambiental, considerando que a manutenção da solidez de um sistema multilateral de comércio seria mais importante do que a necessidade de proteger os recursos naturais de qualquer país. O caso retratou o embargo americano sobre o atum proveniente do México, envolvendo acidentalmente uma significante captura de golfinhos no momento da pesca do peixe. A legislação dos Estados Unidos, Marine Mammal Protection Act, requeria que os pescadores norte-americanos ajustassem suas práticas pesqueiras para evitar a morte dos golfinhos e proibiu a importação de atum dos países nos quais o índice de mortalidade dos golfinhos superasse em vinte e cinco por cento o de atuns. ${ }^{47} \mathrm{Em}$ decorrência do banimento à importação do atum de seus países, México e Venezuela, em 1990, levaram a disputa ao GATT, obtendo decisão favorável em prol de seus objetivos comerciais em 1991. Isso porque o Painel afirmou que a alegação da conduta americana ter sido motivada na preservação de seus recursos naturais não foi suficiente comprovada para se enquadrar nas exceções do artigo XX, uma vez que a medida não era "destinada principalmente à" conservação, bem como não "relacionava-se com" a conservação e preservação dos recursos naturais, requisitos específicos do artigo $\mathrm{XX}(\mathrm{g})$.

47 Relatório do Painel United States - Restriction on Imports of Tuna, DS21/R - 39S/155, julgado em 3 setembro de 1991. Parágrafo 2.4. 
O Painel também ponderou que os Estados Unidos não poderiam usar as exceções do artigo XX para regular recursos naturais para além de suas fronteiras, expressando a vontade das partes contratantes do GATT, como terceiros interessados, de que o texto do Acordo Geral não poderia sofrer ampliação, permitindo medidas unilaterais. ${ }^{48}$ Caso fosse esta a intenção das partes, deveriam alterar suas normas diretamente através do processo legislativo, por meio de emendas às provisões do Acordo Geral ou de renúncias às correspondentes obrigações, mas não por meio da interpretação do artigo $\mathrm{XX}{ }^{49}$

Assim, enquanto o relatório do Painel no caso US - Tuna I rejeitou o argumento norte-americano para aplicação extraterritorial das exceções (b) e (g), no caso US - Tuna $I I^{50}$ promovido pelas Comunidades Europeias contra os Estados Unidos no ano de 1992, observou-se que o artigo XX (g) sobre conservação de recursos naturais exauríveis não limita a localização das fontes que devem ser preservadas, permitindo, assim, a aplicação da jurisdição extraterritorial. O progresso deste julgamento centrou-se na possibilidade concreta de que uma política de conservação ambiental adotada em determinado país e com difusão de seus efeitos para outras nações possa recair no âmbito das exceções previstas no artigo XX.

Entretanto, as decisões do mecanismo de controvérsias do GATT demonstravam ser tão controversas que muitas não eram adotadas e perseguidas pelas partes, a exemplo das decisões dos casos citados acima. Em análise a esses julgados, pondera-se que, apesar da não obtenção de êxito dos Estados Unidos em justificar suas medidas ambientais

48 Parágrafo 5. 32: "The Panel considered that if the extrajurisdictional interpretation of Article XX(g) suggested by the United States were accepted, each contracting party could unilaterally determine the conservation policies from which other contracting parties could not deviate without jeopardizing their rights under the General Agreement. The considerations that led the Panel to reject an extrajurisdictional application of Article XX (b) therefore apply also to Article XX (g)." Ver também: JACKSON, John H. World Trade Rules and Environmental Policies: congruence or conflict? Washington and Lee Law Review. v. 49, p. 123, 1992.

49 SANTOS, Alvaro. Carving Out Policy Autonomy for Developing Countries in the World Trade Organization: the experience of Brazil and Mexico. In: TRUBEK, David M.; GARCIA, Helena Alvair; COUTINHO, Diogo R et al (ed.) Law and the New Developmental State: The Brazilian Experience in Latin American Context. Cambridge: Cambridge University Press, 2013. p. 193.

50 Relatório do Painel no caso United States - Restriction on Imports of Tuna, DS29/R, julgado em 16 de junho de 1994. nos ditames do artigo XX (g), eis que realmente encontravam-se em violação com as normas do regime comercial, conseguiu avançar em termos de políticas domésticas ambientais. Justamente pelo fato dos Estados Unidos ser considerado ator com reiterada participação no procedimento de solução de controvérsias, desfruta dos benefícios da expertise, do conhecimento rebuscado sobre o funcionamento do sistema judicial e da capacidade de barganha que lhes permitiu alcançar a melhor alternativa para a solução de seu interesse. ${ }^{51}$

A partir da estipulação de novos padrões no mecanismo de solução de controvérsias da OMC, percebeu-se uma positiva e environmental-friendly linha divisória com a precedente jurisprudência do GATT. Desde então, o órgão de solução de controvérsias já foi instado a indiretamente se pronunciar acerca de uma série de disputas envolvendo medidas comerciais relacionadas ao meio ambiente.

O primeiro caso que desafiou as normas da OMC com fundamento na violação da preservação do meio ambiente foi o US - Gasoline. In casu, Brasil e Venezuela contestaram a validade da legislação Fuels and Fuel Additives - Reformulated and Conventional Gasoline da Parte 80 do Título 40 da Legislação Federal Clean Air Act que impôs condições diferenciadas à venda e ao acesso da gasolina importada. Segundo os Estados Unidos, a medida visava ao controle da poluição tóxica causada pela combustão da gasolina fabricada por outros países e sua atitude estaria amparada na exceção da aliena (b) do artigo XX, uma vez que medidas voltadas à promoção da qualidade do ar influenciariam a preservação do meio ambiente.

O Painel concluiu que o artigo XX poderia ser aplicado se os Estados Unidos comprovassem não haver outra medida de igual eficiência e menor efeito restritivo ao comércio que levasse aos mesmos objetivos da emenda ao Clean Air Act - de redução dos poluentes advindos da combustão da gasolina. Os Estados Unidos, no entanto, não conseguiram provar a essencialidade de tal medida, motivo pelo qual o Painel postulou pelo não enquadramento aos

51 SANTOS, Alvaro. Carving Out Policy Autonomy for Developing Countries in the World Trade Organization: the experience of Brazil and Mexico. In: TRUBEK, David M.; GARCIA, Helena Alvair; COUTINHO, Diogo R et al (Ed.) Law and the New Developmental State: The Brazilian Experience in Latin American Context. Cambridge: Cambridge University Press, 2013. p. 188. 
requisitos do Artigo XX e pela violação ao princípio da igualdade de tratamento, tendo em vista que os produtos importados tinham tratamento diferenciado dos nacionais. O Órgão de Apelação chegou à conclusão de que a medida era incompatível com as obrigações assumidas pelos Estados Unidos perante a OMC por constituir discriminação injustificável, mas discordou do relatório do Painel que afirmou que a legislação do Clean Air Act não se enquadrava nos termos do Artigo XX (g). ${ }^{52}$ De fato, a análise do caráter arbitrário e injustificável da medida contestada não está na hierarquização comércio/meio ambiente; apoiase, na ausência de iniciativas e negociações por parte dos Estados Unidos que objetivavam nada além de "favorecer suas próprias indústrias, utilizando o meio ambiente como desculpa." 53

Logo, consagrou-se o entendimento de que medidas voltadas à preservação da natureza podem se expandir para o âmbito extraterritorial, porém a responsabilização apenas recai sobre os nacionais do Estado promulgador da medida. Dessa forma, tendo os Estados Unidos falhado ao demonstrar a necessidade da legislação aos seus nacionais, comprovaram a discriminação a países terceiros, justificando que não poderiam aplicar medidas restritivas à gasolina brasileira.

Já no julgamento em 1998 do caso US - Shrimp ${ }^{54}$ o Órgão de Apelação fixou que os elementos jurídicos da alínea (g) deveriam passar pela análise dos seguintes requisitos: verificar se a medida objetiva ou preocupa-se com a conservação dos recursos naturais; se a medida relaciona-se com a conservação dos recursos naturais exauríveis e se a medida é efetivada em conjunto com restrições à produção ou ao consumo nacional. Ademais, concretizou-se o entendimento de que uma inversão na ordem de primeiro analisar os parágrafos para depois proceder ao estudo do caput do artigo XX poderia conceder interpretação errônea ao WTO Agreement, diminuindo a importância das restrições

52 Relatório do Órgão de Apelação no caso United States Standards for Reformulated and Conventional Gasoline, WT/DS2/AB/R, adotado pelo Órgão de Solução de Controvérsias em 22 de abril de 1996. p. $29-30$.

53 VARELLA, Marcelo Dias. Direito internacional econômico ambiental. Belo Horizonte: Del Rey, 2003. p. 268.

54 Relatório do Órgão de Apelação no caso United States - Import Probibition of certain shrimp and shrimp products, WT/DS58/AB/R, adotado pelo Órgão de Solução de Controvérsias em 6 de novembro de 1998. Parágrafo 127. estabelecidas e desequilibrando direitos e obrigações dos Estados membros. ${ }^{55}$

O referido caso versava sobre o embargo americano imposto à importação de camarões e seus derivados em virtude dos métodos utilizados na sua captura, que ameaçavam a vida das tartarugas marinhas. Por meio da promulgação da Seção 609 da Lei Pública 101-162, os Estados Unidos estabeleceram normas aplicáveis a todos os barcos de pesca de camarão para que utilizassem outros dispositivos além da rede de arrasto de forma a não prejudicar as tartarugas. Segundo o governo dos Estados Unidos, essa medida exigia que todo camarão importado pelos Estados Unidos estivesse em conformidade com a certificação da Seção 609 e, em última análise, era necessária à preservação dos recursos naturais exauríveis, entre os quais se enquadram as tartarugas marinhas. Os países exportadores de camarão como Índia, Paquistão, Tailândia e Malásia insurgiram-se contra a atitude do governo dos Estados Unidos, alegando que tal medida não estaria justificada sob o abrigo do Artigo XX (b) e (g), uma vez que o histórico da produção legislativa da restrição americana demonstrava que o objetivo da medida era tão somente proteger sua indústria pesqueira. Ainda, tais países questionavam o porquê de os Estados Unidos não terem recorrido primeiramente aos instrumentos de política de proteção ambiental, como os meios diplomáticos, atestando sua predisposição em não negociar ou ao menos tentar chegar a um acordo seriamente com os países que exportavam camarão.

O Painel decidiu que a alegação americana não preenchia os requisitos do Artigo XX, além da Seção 609 claramente impor restrições quantitativas aos direitos de exportação, demonstrando ser incompatível com o Artigo XI. Já o Órgão de Apelação, por meio do teste de meios e fins, verificou que o embargo realmente objetivava a conservação das tartarugas, justificando-se a utilização da exceção do Artigo XX (g) $\cdot{ }^{56}$ Entretanto, os Estados Unidos erraram ao ter adotado medidas de conservação às tartarugas marinhas de maneira unilateral e, quanto a esse aspecto, o Órgão de Apelação

55 Relatório do Órgão de Apelação no caso United States - Import Probibition of certain shrimp and shrimp products, WT/DS58/AB/R, adotado pelo Órgão de Solução de Controvérsias em 6 de novembro de 1998. Parágrafo 119.

56 Relatório do Órgão de Apelação no caso United States - Import Probibition of certain shrimp and shrimp products, WT/DS58/AB/R, adotado pelo Órgão de Solução de Controvérsias em 6 de novembro de 1998. Parágrafo. 137 e 142. 
entendeu que os Estados Unidos agiram de modo discriminatório.

Nesse julgado, o Órgão de Apelação teve a oportunidade de estabelecer os parâmetros para a interpretação do Artigo XX, revendo as conclusões auferidas no emblemático caso US - Gasoline. Asseverou não haver hierarquia entre as duas exceções ambientais contidas nas letras (b) e (g) e os artigos I e III do GATT, entendendo que não há, no plano interpretativo, primazia das regras comerciais sobre as exceções concebidas para garantir a preservação do meio ambiente.

Delineando um paralelo a partir do julgamento do caso US - Tuna I até o relatório do Órgão de Apelação em US - Shrimp, é possível perceber o crescimento do número de litígios nos quais questões ambientais são confrontadas com o regime comercial. Isso é reflexo de uma maior inquietação quando o assunto da liberalização do comércio possa tornar mais difícil aos países a manutenção de rigorosos requisitos ambientais.

Portanto, acredita-se que, devido à natureza permissiva do artigo XX, na maior parte dos casos, medidas restritivas dispostas em tratados multilaterais ambientais são compatíveis com as normas da OMC, possibilitando a comunicação e o inter-relacionamento entre os dois regimes que coexistem no ordenamento jurídico internacional. Por essa razão, o artigo XX autorizaria tais restrições. O Órgão de Apelação ${ }^{57}$ afirmou que, na avaliação da interpretação e aplicação do artigo XX, há a necessidade de manter um "equilíbrio" entre as disposições referentes ao meio ambiente e ao comércio, contrabalanceando os direitos e as obrigações dos membros de ambos os subsistemas. Em igual sentido, o Órgão de Apelação ${ }^{58}$ asseverou que

57 Parágrafo 145: “[...] We consider that it embodies the recognition on the part of WTO Members of the need to maintain a balance of rights and obligations between the right of a Member to invoke one or another of the exceptions of Article XX [...]" Relatório do Órgão de Apelação no caso United States - Import Probibition of certain shrimp and shrimp products, W'T/DS58/AB/R, adotado pelo Órgão de Solução de Controvérsias em 6 de novembro de 1998.

58 No caso US-Gasoline, como visto anteriormente, Venezuela e Brasil alegaram que um regulamento dos Estados Unidos discriminava a importação de gasolina e estaria em violação aos princípios da nação mais favorecida e do tratamento nacional, dispostos nos artigos I e III do GATT. Em 1996, o Órgão de Apelação através de uma interpretação teleológica inovadora decidiu que os Estados membros tem autonomia para determinar suas próprias políticas ambientais, circunscrita somente a necessidade de respeitar as exigências do GATT. Nesse sentido ver: < http://www. os acordos da OMC não podem ser entendidos sem levar em consideração o direito internacional público.

\section{Conclusão}

A sustentação de que os múltiplos subsistemas dialogam entre si e com o sistema jurídico internacional permite, então, a compreensão de que o conflito entre as diversas instâncias jurisdicionais deve buscar, no que for compatível, a flexibilidade entre os mecanismos de solução de controvérsias com vistas ao alcance do desenvolvimento sustentável. Fundamentalmente, prevalece o entendimento de que os métodos para fazer referência a regras não pertencentes ao regime da OMC são também diretrizes para normas dos tratados multilaterais ambientais. Nesse sentido, é possível sustentar que a interpretação dos acordos-quadro da $\mathrm{OMC}$ reivindica referência às normas evolutivas do direito internacional. Tais normas, originariamente não componentes do corpo normativo da OMC, são hábeis a auxiliar na solução da controvérsia envolvendo o comércio internacional.

Assim, de forma a melhor responder às consequências impostas pela complexidade do direito internacional, é incontroverso que os acordos da OMC sejam interpretados consoante os ditames dos tratados multilaterais ambientais. Compreende-se que o artigo 3.2 do ESC orienta o caminho para interpretação das decisões do Painel e do Órgão de Apelação, aceitando a incidência dos métodos interpretativos dispostos na Convenção de Viena de 1969, possibilitando o diálogo e a comunicação entre os subsistemas. Além do mais, percebe-se a relevância de realizar uma interpretação fundamentada no conceito e nos objetivos primordiais do desenvolvimento sustentável que deve ser perseguida em todas as circunstâncias, e não apenas nas situações de conflitos, permeadas pela dúvida e obscuridade.

Com efeito, não obstante a interpretação da OMC acerca desse assunto tão polêmico estar longe de ser definitiva, variando de acordo com circunstâncias particulares, nota-se uma forte tendência de diálogo por parte do organismo internacional comercial com os interesses ambientais, evidenciado a partir da aplicação em caráter evolutivo do artigo XX.

wto.org/english/tratop_e/dispu_e/cases_e/ds2_e.htm>. Acesso em: 7 jun. 2012. 


\section{Referências}

AMARALJUNIOR, Alberto do. A solução de controvérsias na OMC. São Paulo: Atlas, 2008.

BARTELS, Lorand. Jurisdiction and Applicable Law Clauses: Where does a Tribunal find the principal norms Applicable to the Case before it? In: BROUDE, T.; SHANY, Y. (Ed). Multi-Sourced Equivalent Norms in International Law.Oxford: Hart, 2011. p. 115-141.

CDI. Comissão de Direito Internacional da Organização das Nações Unidas. United Nations. Fragmentation of International Law: difficulties arising from the diversification and expansion of international law. Report of the Study Group of the International Law Commission. Finalized by Martti Koskenniemi. April, 2006. Disponível em: <http:// untreaty.un.org/ilc/documentation/english/a_cn4_1682. pdf $>$. Acesso em: 17 abr. 2013.

CHARNOVITZ, Steve. Trade and the Environment in the WTO. GWU Legal Studies Research Pape. n. 338 p. 1-30, 2007. Disponível em: <http://ssrn.com/ abstract $=1007028>$.

DELMAS-MARTY, Mireille. Comparative Law and International Law: methods for ordering pluralism. 2005. Disponivel em: <http://w7.ens-lyon.fr/amrieu/IMG/ pdf/Delmas-Marty_Comp_Int_Law_10-05doc.pdf $>$.

GUZMAN, Andrew T. Global Governance and the WTO. Harvard International Law Journal. v. 45, n. 2, p. 303-351, Summer, 2004.

HALLE, Mark; WOLFE, Robert. A new approach to transparency and accountability in the WTO. Entwined. Issue Brief 6, 2010. p. 1-8.

INTERNATIONAL COURT OF JUSTICE (ICJ). Case concerning Oil Platforms - Islamic Republic of Iran v. United States of America, judment of 6 November, 2003. ICJ Rep 161, para. 4.1. Disponível em: <http:// www.icj-cij.org $/$ docket $/$ sum $=634 \&$ code $=$ op $\& p 1=3 \& p$ $2=3 \&$ case $=90 \& \mathrm{k}=0 \mathrm{a} \& \mathrm{p} 3=5>$. Acesso em: 24 jun. 2013.

JACKSON, John H. World Trade Rules and Environmental Policies: congruence or conflict? Washington and Lee Law Review. v. 49, n. 4, 1992.

KELLY, Claire. The value vacuum: self-enforcing regimes and the dilution of the normative feedback loop. Michigan Journal of International Law. v. 22, p. 673731, 2001.
KINGSBURY, Benedict. Is the proliferation of International Courts and Tribunals a Systemic Problem? The New York University Journal of International Law and Policy, v. 31, p. 679-696, 1999.

MARCEAU, Gabrielle. A Call for Coherence in International Law: praises for the prohibition against "clinical isolation". In WTO Dispute Settlement. Journal of World Trade. Holanda, v. 33, n. 5, p. 87-152, 1999.

MARCEAU, Gabrielle. Conflicts of Norms and Conflicts of Jurisdictions: The Relationship between the WTO Agreement and MEAs and other Treaties. Journal of World Trade. Holanda, v. 35, n. 6, p. 1081-1131, 2001.

MARCEAU, Gabrielle; MOROSINI, Fábio. The Status of Sustainable Development in the Law of the World Trade Organization. In: CELLI JUNIOR, Umberto; BASSSO, Maristela; AMARAL JUNIOR, Alberto (Coord.). Arbitragem e comércio internacional: estudos em homenagem a Luiz Olavo Baptista. São Paulo: Quartier Latin, 2013. p.59-91.

MOROSINI, Fábio. Trade and Climate Change: unveiling the principle of common but differentiated responsibilities from the WTO Agreements. The George Washington International Law Review. Washington, v. 42, n. 4, p. 713-748, 2010.

MOROSINI, Fábio. Taking into account environmental, social and cultural concerns through the objective of sustainable development: Perspectives from the WTO Jurisprudence on General Exceptions In: HANANIA, Lilian Richieri (Org.). Effectiveness and normativity of the 2005 UNESCO Convention on the Protection and Promotion of the Diversity of Cultural Expressions. Londres: Routledge. p. 54-67.

PAUWELYN, Joost. Conflict of Norms in Public International Law: how wto law relates to other rules of international law. New York: Cambridge University Press, 2003.

PAUWELYN, Joost. The application of non-WTO rules of international law in WTO dispute settlement. In: MACRORY, Patrick; APPLETON, Arthur; PLUMMER, Michael (Ed.). The World Trade Organization: legal, economic and political analysis. United States: Springer, 2005. p. 1405-1425.

SANTOS, Alvaro. Carving out policy autonomy for developing countries in the world trade organization: the experience of Brazil and Mexico. In: TRUBEK, David M.; GARCIA, Helena Alvair; COUTINHO, Diogo R et al (Ed.) Law and the New Developmental State: the brazilian experience in latin american context. 
Cambridge: Cambridge University Press, 2013. p. 167 -245 .

STONEHOUSE, Peter D. A review of WTO and environmental issues. Journal of Agricultural and Environmental Ethics. v. 13, n. 1, p. 121-144, 2000. Disponível em: <http://www.springerlink.com/ content/j4544018955738u9/fulltext.pdf $>$. Acesso em: 22 maio 2012.

THORSTENSEN, Vera; OLIVEIRA, Luciana Maria de. (Org.). Releitura dos Acordos da OMC como interpretados pelo órgão de apelação. São Paulo: VT Assessoria Consultoria e Treinamento Ltda, 2013.

TRACHTMAN, Joel P. The Domain of WTO Dispute Resolution. 1999. p. 1-44. Disponível em: <http://ssrn. com/abstract $=149348>$.

VARELLA, Marcelo Dias. Direito internacional econômico ambiental. Belo Horizonte: Del Rey, 2003.

VARELLA, Marcelo Dias. Internacionalização do direito: direito internacional, globalização e complexidade. Brasília: UniCEUB, 2013.

WEISS, Edith Brown et al. International environmental law and policy. Nova York: Aspen Publisher, 2007.

WORLD TRADE ORGANIZATION. Relatório do Painel no caso European Communities - Customs Classification of Frozen Boneless Chicken Cuts, WT/ DS269/R, julgado em 30 de maio de 2005. Disponível em: <http://www.wto.org/english/ tratop_e/dispu_e/cases_e/ds269_e.htm>. Acesso em: 7 out. 2014.

WORLD TRADE ORGANIZATION. Relatório do Painel European Communities - Regime for the Importation, Sale and Distribution of Bananas, WT/DS27 - R, adotado pelo Órgão de Solução de Controvérsias em 22 de maio de 1997. Disponível em: <http://www. wto.org/english/tratop_e/dispu_e/cases_e/ds27_e. htm>. Acesso em :14 out. 2014.

WORLD TRADE ORGANIZATION. Relatório do Painel no caso United States - Restriction on Imports of Tuna I, DS21/R - 39S/155, julgado em 3 setembro de 1991. Disponível em: < http://www.worldtradelaw.net/ reports/gattpanels/tunadolphinI.pdf $>$. Acesso em: 12 out. 2014.
WORLD TRADE ORGANIZATION. Relatório do Painel no caso United States - Restriction on Imports of Tuna II, DS29/R, julgado em 16 de junho de 1994. Disponível em: $<$ http://www.worldtradelaw.net/reports/gattpanels/ tunadolphinII.pdf>. Acesso em: 12 out. 2014.

WORLD TRADE ORGANIZATION. Relatório do Órgão de Apelação no caso Argentina - Safeguard Measures on Imports of Footwear, WT/DS 121/AB/R, julgado em 14 de dezembro de 1999. Disponível em: <http://www. wto.org/english/tratop_e/dispu_e/cases_e/ds121_e. htm>. Acesso em: 9 set. 2014.

WORLD TRADE ORGANIZATION. Relatório do Órgão de Apelação no caso European Communities Measures Concerning Meat and Meat Products (Hormones), WT/DS26/AB/R, WT/DS48/AB/R, julgado em 16 de janeiro de 1998. Disponível em: <http://www.wto. org/english/tratop_e/dispu_e/cases_e/ds26_e.htm>. Acesso em: 11 out. 2014.

WORLD TRADE ORGANIZATION. Relatório do Órgão de Apelação no caso United States - Continued Existence and Application of Zeroing Methodology, WT/ DS350/AB/R, julgado em 4 de fevereiro de 2009. Disponível em: <http://www.worldtradelaw.net/ reports/wtoab/us-continuedzeroing(ab).pdf $>$. Acesso em: 12 out. 2014.

WORLD TRADE ORGANIZATION. Relatório do Órgão de Apelação no caso United States - Import Probibition of Certain Shrimp and Shrimp Products, WT/DS58/AB/R, 12 de outubro de 1998. Disponível em: <http://www. wto.org/english/tratop_e/dispu_e/58abr.pdf $>$. Acesso em: 10 out. 2014.

WORLD TRADE ORGANIZATION. Relatório do Órgão de Apelação no caso United States - Standards for Reformulated and Conventional Gasoline, WT/DS2/AB/R, adotado pelo Órgão de Solução de Controvérsias em 22 de abril de 1996. Disponível em: <http://www.wto. org/english/tratop_e/dispu_e/cases_e/ds2_e.htm>. Acesso em: 18 out. 2014.

WORLD TRADE ORGANIZATION. Matrix on TradeRelated Measures Pursuant to Selected Multilateral Environmental Agreements. Committee on Trade and Environment. WT/ CTE/W/160/Rev.5 of 15 june, 2011. 


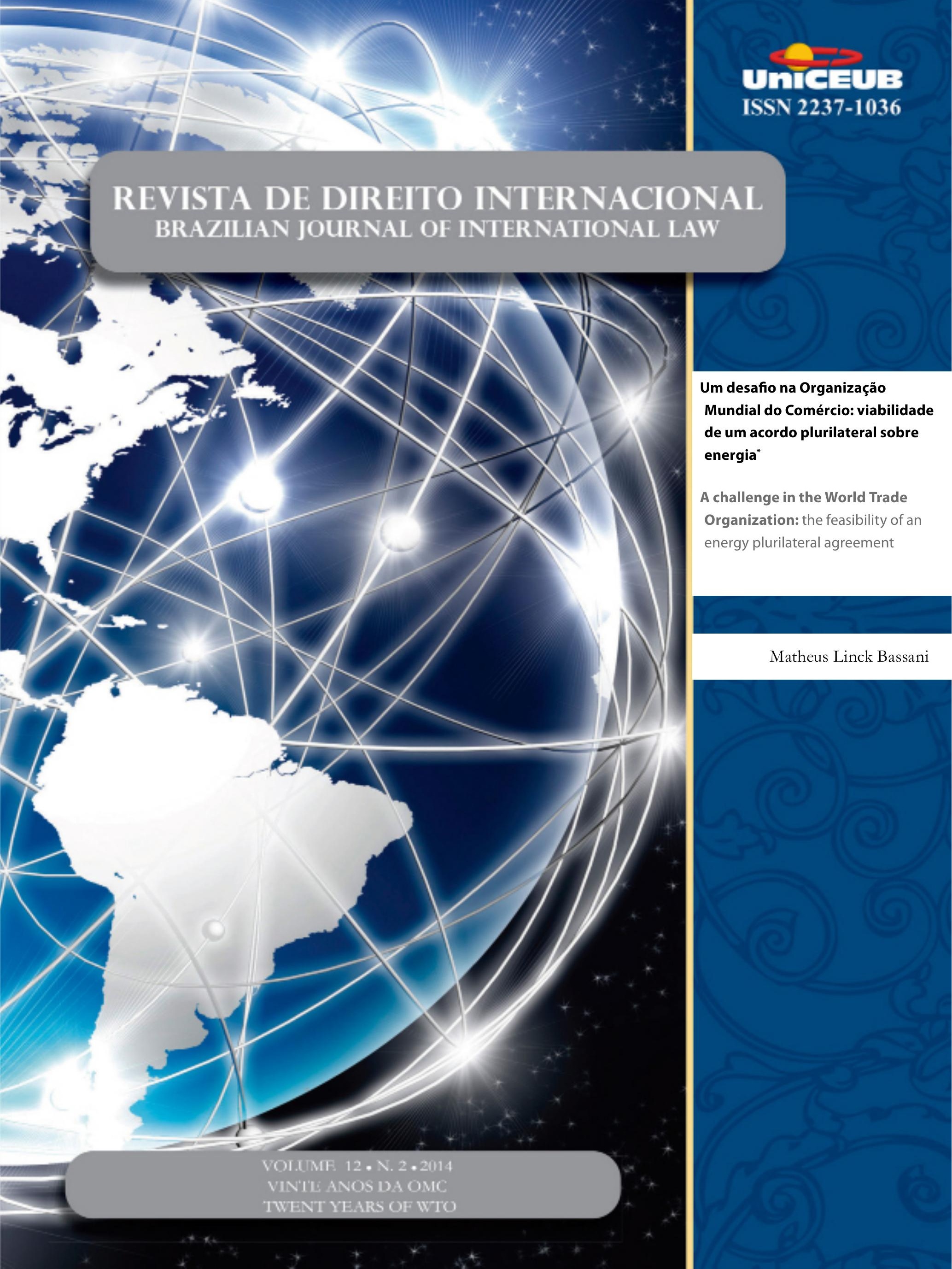




\section{Um desafio na Organização Mundial do Comércio: viabilidade de um acordo plurilateral sobre energia*}

\section{A challenge in the World Trade Organization: the feasibility of an energy plurilateral agreement}

Matheus Linck Bassani**

\section{Resumo}

O presente artigo propõe um Acordo Plurilateral sobre o tema energético no âmbito da Organização Mundial do Comércio (OMC). Utiliza-se do método dedutivo e análise doutrinária, considerando-se relevante o resultado da pesquisa em razão da sua originalidade, especificidade e da abordagem temática, pouco explorada na área de Direito Internacional Público. Na primeira parte, identificam-se desafios, envolvendo o comércio de energia em face da incidência dos dispositivos normativos multilaterais, relacionados aos assuntos como tarifas, restrições, tributação, subsídios, trânsito, meio ambiente, investimentos e disputas relacionadas com energia, como os casos US - Reformulated Gasoline e os mais recentes com energia renovável. Na segunda parte, diante dos desafios apresentados, analisa-se a viabilidade de um Acordo Plurilateral sobre Energia no intuito de estabelecer melhor tratamento ao tema. Conclui-se que as normas da OMC poderiam ser atualizadas, mas as iniciativas são obstaculizadas pela regra do consenso. Um acordo plurilateral de energia para facilitar e acelerar os fluxos de energia de forma sustentável é uma solução mais viável, por facultar a adesão dos membros da própria OMC.

Palavras-chave: Energia. Organização Mundial do Comércio (OMC). Acordo Plurilateral. Multilateralismo. Energia Renovável. Sustentabilidade.

\section{Abstract}

This paper proposes an Energy Plurilateral Agreement in the World Trade Organization (WTO), through doctrine analysis and using the deductive method. It evaluates major contribution of this research due its originality, specificity and thematic approach, underexplored in the area of Public International Law. In the first part, challenges involving energy trade are identified regarding multilateral rules relating to the matters as tariffs, restrictions, taxation, subsidies, transit, environment, investment and energy conflicts related as US - Reformulated Gasoline and the latest renewable energy cases. In the second part, the feasibility of an Energy Plurilateral Agreement is analyzed in order to establish the best treatment to the subject. The conclusion is that WTO rules could be updated, but initiatives are hampered by the consensus rule. An Energy Plurilateral Agreement to facilitate the energy trade flow in a sustainable way is a more viable solution by providing the faculty of accession by the members of the WTO.

Keywords: Energy. World Trade Organization (WTO). Plurilateral Agreement. Multilateralism. Renewable Energy. Sustainability. 


\section{Introdução}

Tratar de energia no comércio internacional requer uma análise precisa de um quadro multifacetado e complexo, por envolver diversas áreas, como meio ambiente e investimentos. Hoje, a Organização Mundial do Comércio (OMC) aborda o tema da energia como um bem, e, a partir dos entraves identificados, emerge a proposta para um Acordo específico.

Para se avaliar a confirmação ou não do problema trazido neste trabalho, ou seja, da viabilidade de se estabelecer um Acordo Plurilateral, utilizar-se-á do método dedutivo, mediante análise doutrinária, nacional e estrangeira, além de base de dados científicos.

A OMC regula o comércio de bens, serviços e propriedade intelectual, e, apesar de não incluir regras específicas ao comércio de energia, ela estabelece normas que são relevantes para o setor. Nesse artigo não serão abordados aspectos históricos, princípios gerais, e funcionamento estrutural da $\mathrm{OMC}$, em face da especificidade do tema. O intuito é ater-se somente aos aspectos que efetivamente impactam o comércio de energia.

A importância da organização vem crescendo em relação ao tema da energia, no momento que países estratégicos (produtores e consumidores) têm aderido ao sistema multilateral, como Equador, Oman, Arábia Saudita (2005), China (2001), Ucrânia (2008) e recentemente a Rússia, em 2012. Outros como Irã, Iraque, Cazaquistão, Líbia e Argélia ainda são observadores e negociam a acessão.

De qualquer sorte, inúmeros dispositivos normativos influem diretamente no comércio internacional, como no moderno mercado dos equipamentos para geração de energia renovável, e, consequentemente, emerge a necessidade de uma interpretação doutrinária e jurisprudencial para solucionar eventuais conflitos, em face da lacuna jurídica sobre determinados aspectos que incidem sobre o campo energético.

Diante desse contexto, serão apresentados, na primeira parte, aspectos relativos ao comércio de energia na OMC, como tarifas, restrições, tributação, subsídios, trânsito, meio ambiente, investimentos e disputas; e, na segunda parte, será analisada a viabilidade de um Acordo Plurilateral sobre Energia, o que se considera uma alternativa viável e acessível diante do atual conturbado cenário da Organização Multilateral.

\section{Desafios no comércio de energia na Organização Mundial do Comércio}

Nesta primeira parte, serão analisadas algumas das principais questões da OMC em relação ao setor de energia, de forma específica, no intuito de identificar o tratamento atual do setor.

\subsection{Tarifas e outras medidas aduaneiras afetando importação de bens}

\subsubsection{Tarifas de importação}

O objetivo da OMC é reduzir gradualmente as tarifas e eliminar outras barreiras de importação. Questões relativas às tarifas de importação e outras obrigações conexas estão localizadas no art. II:2, do GATT (Lista de Concessões)

Os membros negociam as tarifas máximas para cada produto, e essas tarifas máximas são indicadas num programa para cada membro. Os membros não podem aplicar tarifas superiores a este programa acordado. Poderiam aplicar tarifas inferiores, desde que respeitado o princípio da não discriminação. Todos os outros encargos e deveres impostos ou em conexão com importação são proibidos, exceto se houver reserva prevista no programa acordado.

Tarifas de importação de produtos energéticos são relativamente baixas em relação a outros produtos. O World Trade Report (2010) identificou que a média tarifária (entre 146 países) para importação de combustíveis é de $25,3 \%$, sendo que a taxa média praticada por países desenvolvidos é de 1,5\% e dos países em desenvolvimento é de $27,5 \%$. Mas existe um fator externo ao comércio que determina um aumento ou redução das tarifas, que é a segurança energética, influenciando nos preços. ${ }^{2}$

Em relação aos biocombustíveis, particularmente o etanol, os EUA têm cobrado 54 centavos de dólar por galão além da tarifa de $2,5 \%$ ad valorem. A UE tarifa entre 39\% e 63\%. No caso do etanol, ele está

1 YANOVICH, Alan. WTO rules and the energy sector. In: SELIVANOVA, Yulia (Org.). Regulation of energy in international trade law: wto, nafta and energy charter. Kluwer Law International, 2011. p. 4.

2 ORGANIZAÇÃO MUNDIAL DO COMÉRCIO. World Trade Report 2010. Disponível em: <http://www.wto.org/english/res_e/ publications_e/wtr10_e.htm>. Acesso em: 10 nov. 2012. p. 115. 
classificado no capítulo 22 do sistema harmonizado, sendo tratado como um produto agrícola disciplinado no Acordo para Agricultura.

Outra questão é em relação a equipamentos utilizados para geração de energia renovável. Mais de $93 \%$ da produção de energia eólica está concentrada entre as empresas com base em sete países: Dinamarca, EUA, Espanha, Alemanha, Índia, China e Japão. ${ }^{4}$

Até 2009, a maioria dos membros da OMC impõe tarifas de importação sobre turbinas eólicas, painéis solares e turbinas a gás de grande porte (> $5 \mathrm{MW})$. Para as turbinas de vento, as tarifas são cobradas em quase 60\% (91 dos 156) dos países, com uma tarifa média de $7,4 \%$. Os painéis solares têm uma tarifa em quase $43 \%$ (65 de 156) dos países, com uma tarifa média de 8,8\%. Grandes turbinas a gás enfrentam tarifas em mais de $55 \%$ dos países (85 de 156), com uma tarifa média de $6,6 \%$

Apesar de existir uma tendência de favorecer bens ambientalmente favoráveis no âmbito da $\mathrm{OMC}^{6}$, a grande porcentagem de países que tarifam os geradores de energia pode significar: (i) uma conduta protecionista em relação à indústria doméstica; (ii) um meio de buscar receita; ou (iii) dificultar investimentos no setor, o que não é salutar para o incremento de geração de energia por meio sustentável.

3 YANOVICH, Alan. WTO rules and the energy sector. In: SELIVANOVA, Yulia (Org.). Regulation of energy in international trade law: wto, nafta and energy charter. Kluwer Law International, 2011. p. 5.

4 BURNS, Thaddeus J. The liberalization of environmental goods and services (EGS) trade and the need for a distinct EGS agreement. In: PAUWELYN, Joost. Global Challenges at the intersection of trade, energy and the environment. Genebra: The Graduate Institute, Center for Trade and Economic Integration, 2010. p. 96. Disponível em: <http://graduateinstitute.ch/ctei/publications_list/global. html> Acesso em: 15 nov. 2012.

5 BURNS, Thaddeus J. The liberalization of environmental goods and services (EGS) trade and the need for a distinct EGS agreement. In: PAUWELYN, Joost. Global Challenges at the intersection of trade, energy and the environment. Genebra: The Graduate Institute, Center for Trade and Economic Integration, 2010. p. 96-97. Disponível em: <http://graduateinstitute.ch/ctei/publications_ list/global.html>. Acesso em: 15 nov. 2012.

6 VOSSENAAR, Rene. Climate-related Single-use Environmental Goods, ICTSD. Issue Paper 13, September/2010. International Centre for Trade and Sustainable Development, Geneva, Switzerland. Disponível em: <http://ictsd.org/downloads/2011/12/climaterelated-single-use-environmental-goods.pdf $>$. Acesso em: 16 dez. 2012.

\subsubsection{Restrições de importação}

Proibição de restrições quantitativas: o art. XI do GATT dispõe que não serão permitidas proibições ou restrições instituídas ou mantidas por qualquer parte contratante sobre a importação de qualquer produto do território de outra parte contratante ou à exportação ou venda para exportação de qualquer produto destinado ao território de outra parte contratante, exceto que não sejam impostos, taxas ou outros encargos, se efetivada por meio de cotas de importação ou de exportação ou outras medidas.

Essa restrição quantitativa é prejudicial para o comércio de bens e serviços, e por isso deve ser eliminada no contexto comercial. Uma questão pode surgir na hipótese de ausência de proibição expressa da quantidade, mas a entrada do produto somente é permitida sob determinadas condições. No caso da energia, essas restrições são menos problemáticas no comércio internacional.7

\subsection{Medidas que afetam a exportação}

$\mathrm{O}$ art. XI do GATT pró́be restrições quantitativas de importação e exportação, mas permite a imposição de impostos, taxas ou outros encargos, se efetivada por meio de cotas de importação ou de exportação ou outras medidas.

Alguns países exportadores de recursos naturais têm utilizado dessa faculdade, como meio de geração de renda. Conforme o relatório World Trade Report-2014, emitido pela OMC, baseado em dados da OECD, em média, estima-se que $5 \%$ do total das exportações se referem a taxas de exportação, aumentando para $11 \%$ quando se trata especificamente de exportação de recursos naturais. ${ }^{8}$ Uma consequência do uso massivo de taxas de exportação e de outras restrições à exportação de recursos naturais é o uso do denominado Investimento Estrangeiro Direto (IED) como forma de contornar as medidas.

7 YANOVICH, Alan. WTO rules and the energy sector. In: SELIVANOVA, Yulia (Org.). Regulation of energy in international trade law: wto, nafta and energy charter. Kluwer Law International, 2011. p. 6-7.

8 ORGANIZAÇÃO MUNDIAL DO COMÉRCIO. World Trade Report 2014. Disponível em:<http://www.wto.org/english/ res_e/booksp_e/world_trade_report14_e.pdf $>$. Acesso em: 17 nov. 2014. p. 12. 
A primeira forma de contornar as restrições à exportação ocorre por meio de aquisição ou fusões com empresas estrangeiras envolvidas no setor de recursos naturais (empresas petrolíferas, empresas de mineração, etc.). Especificamente, as empresas de países importadores podem optar por investir no setor de recursos naturais no país exportador — por exemplo, mudando algumas partes do processo de produção como uma forma de evitar as restrições à exportação dos recursos naturais. ${ }^{?}$

Os investimentos diretos em recursos naturais, como a terra, em países estrangeiros podem, em parte, ter motivações semelhantes. Esse fenômeno tem atraído grande atenção recentemente. Esses investimentos frequentemente tomam a forma de arrendamentos de longo prazo, compras diretas, ou contratos agrícolas. Em muitos casos, a área adquirida é dedicada ao cultivo de plantações para alimento ou biocombustível. ${ }^{1011}$

Os investidores tendem a ser de países onde a terra arável e com água é particularmente escassa ou de economias com uma crescente demanda por alimentos, energia e matérias-primas. Os investimentos são frequentemente direcionados para países da África (como a Etiópia, Moçambique, Sudão) e no Sudeste da Ásia (Camboja, Indonésia, Filipinas), mas também em outros mais desenvolvidos e ricos em recursos, como a Ucrânia e Rússia. ${ }^{12}$

O valor das fusões transfronteiriças e aquisições no setor de recursos naturais (mineração, pedreiras e petróleo) atingiu mais de US\$ 83 bilhões dólares em 2008, representando cerca de um oitavo do valor total de fusões e aquisições daquele ano. ${ }^{13}$ Logicamente, existem certos riscos. Nesse contexto, estão sendo

9 ORGANIZAÇÃO MUNDIAL DO COMÉRCIO. World Trade Report 2010. Disponível em: <http://www.wto.org/english/res_e/ publications_e/wtr10_e.htm>. Acesso em: 10 nov. 2012. p. 117.

10 ORGANIZAÇÃO MUNDIAL DO COMÉRCIO. World Trade Report 2010. Disponível em:<http://www.wto.org/english/res_e/ publications_e/wtr10_e.htm>. Acesso em: 10 nov. 2012.p. 117.

11 ORGANIZAÇÃO MUNDIAL DO COMÉRCIO. World Trade Report 2014. Disponível em: $<$ http://www.wto.org/english/ res_e/booksp_e/world_trade_report14_e.pdf $>$. Acesso em: 17 nov. 2014. p. 141.

12 ORGANIZAÇÃO MUNDIAL DO COMÉRCIO. World Trade Report 2010. Disponível em:<http://www.wto.org/english/res_e/ publications_e/wtr10_e.htm>. Acesso em: 10 nov. 2012. p. 117.

13 UNCTAD. Conferência das Nações Unidas sobre Comércio e Desenvolvimento (UNCTAD), 2009. Apud ORGANIZAÇÃO MUNDIAL DO COMÉRCIO. World Trade Report 2010. Disponível em:<http://www.wto.org/english/res_e/publications_e/wtr10_e. htm>. Acesso em: 10/11/2012. p. 117. consideradas medidas para que os investimentos sejam realizados de forma sustentável, mediante políticas públicas de longo prazo, com esforços para países menos desenvolvidos. ${ }^{14}$

Ainda no aspecto da exportação, existe a questão das cotas de produção, que podem ser prejudiciais ao comércio, principalmente no tocante à exportação de petróleo, em que a OPEP tem a faculdade de limitar a produção, o que pode gerar distorções no preço do produto. Nesse caso, existem posições para ambos os lados: (i) de que a produção de cotas da OPEP está limitada ao art. XI:1 (proibição de restrições quantitativas, e (ii) outros consideram que decisões de quanto um recurso deve ser extraído recai sobre o princípio da soberania sobre os recursos naturais, e que poderia se enquadrar no art. XX (h) GATT por ser uma commodity. ${ }^{15}$ Ocorre que a OPEP não poderia ser condenada, por ser uma organização internacional não membro; cogitar-se-ia tão-somente a hipótese dos países membros da OPEP serem condenados, caso membros também da OMC.

\subsection{Tributação interna e regulação}

É tratado no art. III do GATT, e considerado como imposto sobre consumo ou venda. Diferentemente das tarifas, não houve limitação ou imposição de um teto das exigências tributárias internas que podem se aplicar aos produtos importados

Da mesma forma, o art. III do GATT permite ao Estado membro ampla discricionariedade para regular as vendas internas, ofertas, compras, transporte e distribuição de um produto importado. O que o art. III não permite é uma discriminação fiscal (art. III:2) ou regulatória (art. III:4) entre o produto importado e o semelhante doméstico, o que violaria o princípio do tratamento nacional e, se concedido um tratamento diferenciado a outro país membro em relação ao mesmo

14 UNCTAD. World Investment Report 2014. Disponível em: $<$ http://unctad.org/en/PublicationsLibrary/wir2014_overview_ en.pdf>. Acesso em: 17 nov. 2014. p. 24-40.

15 WORIKA, Ibibia L. Production, Management, OPEC and the WTO. In: PAUWELYN, Joost. Global Challenges at the intersection of trade, energy and the environment. Genebra: The Graduate Institute, Center for Trade and Economic Integration, 2010. p. 87-93. Disponível em: <http://graduateinstitute.ch/ctei/publications_ list/global.html>. Acesso em: 15 nov. 2012. 
produto, poder-se-ia identificar violação ao princípio da nação mais favorecida, previsto no art. I do GATT.

Alguns países exigem tributos sobre consumo de combustíveis substancialmente superiores aos tributos sobre importação do mesmo produto. Aqueles que não são produtores de combustíveis têm uma tendência maior de impor essa exigência, sendo considerado por uma perspectiva econômica o mesmo que impor tarifas de importação. ${ }^{17}$

Nesse quesito é necessário conceituar o que seria um produto semelhante (likeness) que causaria a violação dos referidos dispositivos. Brevemente, a determinação de likeness tem sido conduzida a partir de quatro (4) critérios $^{18}$ : (i) as propriedades, natureza e qualidade do produto; (ii) as finalidades de uso do produto; (iii) gosto e hábitos do consumidor e (iv) a classificação tarifária do produto. ${ }^{19}$

\subsection{Subsídios}

O Acordo SCM (Agreement on Subsidies and Countervailing Measures) define subsídio como uma contribuição financeira por um governo que confere um benefício (Art. 1.1). Essa contribuição pode se dar na forma de transferência direta de fundos, subvenção, empréstimo ou injeções de capital; na renúncia de receita pelo governo; ou concessão de bens e serviços outros que não de infraestrutura. ${ }^{20}$

O subsídio deve ser específico a uma empresa ou indústria, ou um grupo de empresas ou indústrias, sob pena de não se enquadrar na hipótese do SCM (art.

16 YANOVICH, Alan. WTO rules and the energy sector. In: SELIVANOVA, Yulia (Org.). Regulation of energy in international trade law: wto, nafta and energy charter. Kluwer Law International, 2011. p.11-12.

17 YANOVICH, Alan. WTO rules and the energy sector. In: SELIVANOVA, Yulia (Org.). Regulation of energy in international trade law: wto, nafta and energy charter. Kluwer Law International, 2011. p. 11-12.

18 Ver decisão do Órgão de Apelação da OMC do caso JapanTaxes on Alcoholic Beverages. Disponível em: <http://www.wto.org/ english/tratop_e/dispu_e/cases_e/ds8_e.htm>. Acesso em: 28 jan. 2014.

19 YANOVICH, Alan. WTO rules and the energy sector. In: SELIVANOVA, Yulia (Org.). Regulation of energy in international trade law: wto, nafta and energy charter. Kluwer Law International, 2011. p. 11-12.

20 ORGANIZAÇÃO MUNDIAL DO COMÉRCIO. Acordo SCM. Disponível em: <http://www.wto.org/english/docs_e/ legal_e/24-scm.pdf>. Acesso em: 10 out. 2012.
2). Diferentes disposições são aplicadas a diferentes espécies de subsídios conforme o grau de distorção do mercado internacional. Subsídios para exportação e subsídios condicionados ao uso de bens domésticos são proibidos. Outros subsídios são acionáveis, o que significa que outros membros da OMC podem tomar medidas contra eles somente na hipótese de causar efeitos adversos. ${ }^{21}$

Duas medidas podem ser tomadas contra os subsídios proibidos ou acionáveis: (i) um membro pode aplicar deveres adicionais de importação (countervailing duties) aos bens importados subsidiados, desde que demonstrado o prejuízo. (ii) Outra opção é recorrer ao OSC, quando os subsídios causarem ou ameacem causar prejuízos à indústria doméstica do reclamante, mas também onde o uso dos subsídios causem outros efeitos adversos, como deslocando ou impedindo as exportações para um mercado de terceiro país, efeitos nos preços (preço abaixo do mercado, supressão ou depressão, ou vendas perdidas), ou aumentando a fatia do mercado do membro subsidiante. ${ }^{22}$

Em relação ao tema da energia, estima-se que os subsídios podem estar promovendo um consumo superior ao necessário de combustíveis fósseis, contribuindo para a mudança climática. A Agência Internacional de Energia calculou que os subsídios nesse setor poderiam exceder US $\$ 550$ bilhões por ano. Se eles fossem zerados, o mundo deixaria de consumir até 2020850 milhões de toneladas de petróleo, o que representa o consumo de Japão, Coreia do Sul, Austrália e Nova Zelândia juntos. ${ }^{23}$

Outra preocupação é que os subsídios podem ser necessários para o desenvolvimento e implantação de energia renovável. No caso, o art. $8^{\circ}$, que determinava a exceção para subsídio não acionáveis, ou seja, para atividades de pesquisas, assistência para regiões carentes e assistência para promover adaptação às

21 YANOVICH, Alan. WTO rules and the energy sector. In: SELIVANOVA, Yulia (Org.). Regulation of energy in international trade law: wto, nafta and energy charter. Kluwer Law International, 2011. p. 17.

22 YANOVICH, Alan. WTO rules and the energy sector. In: SELIVANOVA, Yulia (Org.). Regulation of energy in international trade law: wto, nafta and energy charter. Kluwer Law International, 2011. p. 17.

23 YANOVICH, Alan. WTO rules and the energy sector. In: SELIVANOVA, Yulia (Org.). Regulation of energy in international trade law: wto, nafta and energy charter. Kluwer Law International, 2011. p. 17. 
novas necessidades ambientais, não foi renovado e não vigora mais. Uma saída seria a aplicação do art. XX do GATT, mas que poderia ser questionada por se tratar de matéria de outro acordo (SCM), e não do GATT, como dispõe seu caput. ${ }^{24}$

Os recentes casos apresentados ao OSC da OMC (vide Anexo II) têm como fundamento, entre outros, a violação do acordo SCM, pelo fato de promover a exportação e condicionar as aquisições de equipamento mediante o requisito de conteúdo doméstico. No entanto, mesmo os casos sendo relacionados com energia renovável, não houve até a presente data qualquer alegação de aplicação da exceção do art. XX, do GATT, pelos reclamados.

Conforme Thorstensen os subsídios para o setor de energia são conferidos a produtores e indústrias mediante:

[...] pagamentos diretos para financiar a produção; subsídios relacionados à tributação; políticas para redução do custo de insumos; subsídios relacionados a investimentos (como empréstimos a juros preferenciais, remissão de dívidas, empréstimos de garantias, entre outros); e políticas que geram transferência de preços por meio do mercado. ${ }^{25}$

Os conceitos do Acordo SCM foram criados focando para o comércio de bens, e não podem ser aplicados diretamente aos investimentos, pois se referem aos fluxos de bens, que ocorrem depois que o investimento tiver sido feito. Os efeitos adversos estabelecidos no Acordo estão definidos como distorções do fluxo comercial dos bens subsidiados, ou seja, na medida em que os subsídios aumentam o nível de exportação ou reduzem nível de importação do país que subsidia e, assim, prejudicam os produtores de produtos similares em outro país. ${ }^{26}$

Isso demonstra a distinção entre subsídio e investimento. $\mathrm{O}$ subsídio, mesmo podendo ser

24 PEAT, Daniel. The Wrong Rules for the Right Energy: the wto scm agreement and subsidies for renewable energy. Environmental law and management. n. 3, 2012. p. 14-15. Disponível em: <http:// ssrn.com/abstract $=1998240$ or http://dx.doi.org/10.2139/ ssrn.1998240>. Acesso em: 16 maio 2012.

25 THORSTENSEN, Vera; et. al. A regulação do comércio internacional de energia: combustíveis e energia elétrica. São Paulo: FIESP, 2013. p.99.

26 THORSTENSEN, Vera. A OMC - Organização Mundial do Comércio e as negociações sobre investimentos e concorrência. Revista Brasileira de Política Internacional, Brasília, v. 1, n. 41, p. 57-89, 1998. p. 69-70. Disponível em: <http://www.scielo.br/pdf/rbpi/ v41n1/v41n1a04>. Acesso em: 06 fev. 2014. uma contribuição financeira, não é considerado um investimento em si, pelo simples fato de ser o meio pelo qual o investimento será realizado.

\subsection{Trânsito}

A OMC considera a ocorrência de trânsito quando há uma passagem de um produto por um território de um membro, sendo esse local de passagem não o seu destino final. Inclusive, se considera que a passagem em territórios outros que não o seu destino final é como se o produto tivesse sido transportado diretamente, como se jamais tivesse passado por outro território

O tema do trânsito de energia é complexo, uma vez que a OMC coloca como se fosse trânsito de bens (considerando que trânsito de energia é algo bem mais complexo, podendo ser por oleodutos, gasodutos, sem citar a questão da energia elétrica por redes).

No que diz a esse respeito, o artigo V do GATT de 1994 fornece um conjunto relativamente limitado de regulamentos e alguns estudiosos chegam a argumentar que ainda é discutível se o artigo V do GATT é aplicável ao trânsito de energia.

No entanto, questiona-se se o trânsito previsto no art. V se aplica a transportes móveis, como embarcações, ou se aplica ao trânsito por estruturas fixas, como tubulações. A expressa exclusão de aeronaves no art. V:7 e a ampla definição de "tráfego no trânsito" no art. $\mathrm{V}: 1$, apoia a posição que o trânsito via tubulações ou outras estruturas de redes fixas é matéria aplicável pelo art. V, do GATT. $^{27}$

Considerando-se que o art. V se aplica somente a Estados membros, outras questões podem surgir: se as estruturas são de propriedade de entes privados, qual extensão pode ser aplicado o art. V, do GATT? E, como ficam as estruturas de propriedade de empresas estatais? ${ }^{28}$

A Ucrânia, que é um país chave na passagem de gás e petróleo da Eurásia para a Europa, e cobra por isso, se

27 THORSTENSEN, Vera. A OMC - Organização Mundial do Comércio e as negociações sobre investimentos e concorrência. Revista Brasileira de Política Internacional, Brasília, v. 1, n. 41, p. 57-89, 1998. Disponível em: <http://www.scielo.br/pdf/rbpi/v41n1/ v41n1a04>. Acesso em: 06 fev. 2014.

28 SELIVANOVA, Yulia. The WTO and Energy WTO Rules and Agreements of Relevance to the Energy Sector. International Centre for Trade and Sustainable Development - ICTSD. Disponível em: <http://ictsd. org/downloads/2008/05/the20wto20and20energy.pdf $>$. Acesso em: 24 out. 2011. 
comprometeu no momento das negociações à acessão a respeitar o art. V do GATT, submetendo suas normas e demais regulamentos. Esse tema é tão relevante para aquele país que o compromisso firmado se refere especificamente à energia, e cobre não somente leis e regulamentos relativos ao trânsito, mas também outras medidas. $^{29}$

Por exemplo, na questão do trânsito, alguns membros manifestaram a sua preocupação no que diz respeito às taxas cobradas para o trânsito de produtos energéticos por meio de gasodutos quando definido em um ambiente não competitivo, não transparente, contrário ao Artigo V, do GATT. Outros argumentaram que as diferentes taxas de transporte em diferentes rotas de trânsito de petróleo conflitam com as disposições de liberdade de trânsito do artigo V, do GATT.

Considerando-se as práticas vigentes na indústria de energia, em que tubulações são, em sua maioria, construídas e geridas por empresas estatais ou empresas com monopólio, e considerando-se a inaplicabilidade do artigo $\mathrm{V}$ do GATT em entidades privadas, verificase certa inadequação da OMC em lidar com o trânsito no comércio de energia. ${ }^{30}$

\subsection{Serviços}

O GATS é aplicável a todos os serviços, exceto serviços fornecidos no exercício de autoridade governamental (art. I:3(b)) e direitos e serviços de tráfico aéreo diretamente ligado ao exercício desses direitos (Anexo do GATS relativo a transporte aéreo)

Foram definidos quatro modos de fornecimento de serviços (art. I:2, GATS):

Do território de um Estado-Membro para o território de qualquer outro membro; (cross-border trade);

No território de um membro para o consumidor de serviços de qualquer outro membro; (consumption abroad);

29 MARCEAU, Gabrielle. The WTO in the Emerging Energy Governance Debate. In: PAUWELYN, Joost. Global Challenges at the intersection of trade, energy and the environment. Genebra: The Graduate Institute, Center for Trade and Economic Integration, 2010. p. 32. Disponível em: <http://graduateinstitute.ch/ctei/publications_ list/global.html>. Acesso em: 15 nov. 2012.

30 SHIH, Wen-chen. Energy Security, GATT/WTO and Regional Agreements. SIEL, n. 10. 2008. p. 41.
Por um prestador de serviços de um membro por meio da presença comercial no território de qualquer outro membro (commercial presence);

Por um prestador de serviços de um Membro, por meio da presença de pessoas físicas de um membro no território de qualquer outro membro (presence of natural persons).

O GATS estabelece, entre outras, obrigações de acesso ao mercado, não discriminação (tratamento nacional e NMF) e transparência. As obrigações de acesso ao mercado (art. XVI) e o tratamento nacional (art. XVII) se aplicam somente em setores e modos de fornecimento que cada Estado membro havia especificado no seu programa de compromissos específicos. $\mathrm{Na}$ ausência desses compromissos, o GATS impõe obrigações gerais mais limitadas, como a NMF.

A classificação setorial de serviços (MTN/ GNS/w/120) que foi usada como base para programar os compromissos sob o GATS não incluiu a energia como um setor. Somente incluiu três subsetores em relação ao setor de energia:

- Serviços de mineração;

- Serviços de distribuição de energia;

- Transporte de combustíveis.

Deve-se relembrar o que foi referido no início desse estudo, que é a dificuldade em se identificar onde classificar determinado serviço, por exemplo. Pode-se até questionar se o trânsito de energia não seria um serviço.

Como exemplo, já houve a discussão no tema da extração de petróleo: para a OMC, a perfuração é um serviço incidente sobre mineração se estiver baseado numa relação contratual e realizado por uma entidade distinta; mas pode constituir um valor adicionado se o produto é extraído pelo próprio proprietário do petróleo. E isso pode se aplicar a liquefação de gás, refino de petróleo e regasificação. ${ }^{31}$

31 YANOVICH, Alan. WTO rules and the energy sector. In: SELIVANOVA, Yulia (Org.). Regulation of energy in international trade law: wto, nafta and energy charter. Kluwer Law International, 2011. p. 32. 


\subsection{Conservação ambiental}

A OMC reconhece que a expansão da produção e do comércio deve permitir e promover a otimização do uso dos recursos naturais mundiais conforme o princípio do desenvolvimento sustentável

Em abril de 1987, a Comissão Brundtland, como ficou conhecida, publicou um relatório inovador denominado "Nosso Futuro Comum", que traz o conceito de desenvolvimento sustentável para o discurso público: “o desenvolvimento sustentável é o desenvolvimento que encontra as necessidades atuais sem comprometer a habilidade das futuras gerações de atender suas próprias necessidades." 32

Em primeiro lugar, é entendimento generalizado que a OMC não se aplica a recursos naturais no seu estado natural, como petróleo e carvão, ou seja, antes da extração (critério). No entanto, uma previsão governamental concedendo incentivos à madeira plantada (em pé) para uma empresa privada que remunerará o governo por menos que o considerado adequado no mercado, pode constituir subsídios no sentido do Agreement on Subsidies and Countervailing Measures (SCM Agreement). ${ }^{33}$

Ressalta-se a opinião da própria OMC, no World Trade Report 2010:

Visões têm sido alteradas ao longo do tempo questionando se os recursos naturais são uma bênção ou uma maldição para o desenvolvimento econômico. Muitos economistas entendem que o legado dos recursos naturais é essencial como uma vantagem comparativa dos países, mas crítico para o crescimento econômico, enquanto outros alegam que a dependência da exportação dos recursos naturais podem prender países em estado de subdesenvolvimento. ${ }^{34}$ (tradução nossa)

32 ORGANIZAÇÃO DAS NAÇÕES UNIDAS. Comissão Brundtland "Nosso Futuro Comum". Disponível em: <http:// www.onu.org.br/a-onu-em-acao/a-onu-e-o-meio-ambiente/>. Acesso em: 05 out. 2012.

33 YANOVICH, Alan. WTO rules and the energy sector. In: SELIVANOVA, Yulia (Org.). Regulation of energy in international trade law: wto, nafta and energy charter. Kluwer Law International, 2011. p. 3.

34 ORGANIZAÇÃO MUNDIAL DO COMÉRCIO. World Trade Report 2010. Disponível em: <http://www.wto.org/english/ res_e/publications_e/wtr10_e.htm>. Acesso em: 10 nov. 2012.
Ainda, as regras da OMC não são competentes para regular propriedade dos recursos naturais, incluindo recursos energéticos, seja entre Estados, seja entre Estados e privados. Isso porque ela vincula os governos estatais, e somente indiretamente os privados.

$\mathrm{O}$ art. XX dispõe sobre as exceções gerais. Nada neste acordo deve ser interpretado para impedir a adoção ou a aplicação por qualquer parte contratante de medidas:

(b) necessárias para proteger humana, animal ou vegetal saúde;

(g) para a conservação de recursos naturais esgotáveis, se tais medidas forem aplicadas juntamente com restrições à produção ou ao consumo nacionais.

Mas as medidas devem cumprir os critérios do Chapeau do art. XX, exigindo que não sejam aplicadas de forma a constituírem um meio de discriminação arbitrária ou injustificável entre países onde prevalecem as mesmas condições, ou uma restrição disfarçada ao comércio internacional.

O GATS confere exceção no art. XIV, mas não inclui conservação de recursos naturais exauriveis, o que seria uma total incoerência. ${ }^{35}$ Isso levantou a questão se poderia ser aplicado o art. XX, do GATT, ao SCM Agrement.

O primeiro caso apreciado pelo OSC da OMC, e coincidentemente ligado ao tema da energia, foi o caso US - Reformulated Gasoline, que foi paradigmático ao permitir a análise do art. XX do GATT. Nesse caso, os Estados Unidos da América (EUA) aprovaram o Clean Air Act e suas regras de implementação, como a Gasoline Rule, no intuito de reduzir a poluição do ar.

Para tanto, em áreas de alto grau de poluição do ar, somente uma gasolina especial, reformulada, poderia ser vendida, e em demais áreas foi permitida a venda de gasolina não mais "suja" que as vendidas nos anos 1990. A Gasoline Rule foi destinada às refinarias, petroquímicas e importadores, e determinava requisitos com certas características químicas, numa média anual, com níveis definidos. Alguns níveis eram expressamente definidos pelo regulamento, mas outros indicavam critérios de não degradação para que fosse comercializada.

35 MARCEAU, Gabrielle; WYATT, J. Trade and the environment: the WTO's efforts to balance economic and sustainable development. p. 231. Apud YANOVICH, Alan. WTO rules and the energy sector. In: SELIVANOVA, Yulia (Org.). Regulation of energy in international trade law: wto, nafta and energy charter. Kluwer Law International, 2011. p. 36. 
Para demonstrar a base individual dos níveis de "pureza" da gasolina, conforme os critérios estabelecidos, as empresas deviam comprovar a qualidade do produto no ano de 1990 (método 1), e, se não fosse possível, após essa data (método 2 e 3). Os importadores também deveriam provar, mas somente poderiam utilizar como prova a gasolina no ano de 1990, e não posteriormente (método 1). Se não fosse possível, os critérios seriam conforme uma presunção legal estabelecida pelos EUA.

Por se sentirem prejudicados, Venezuela e Brasil reclamaram na OMC, invocando violação ao princípio do tratamento nacional, uma vez que a gasolina produzida era inferior aos standards da Gasoline Rule.

Objetivamente, o Órgão de Apelação julgou inconsistente a Gasoline Rule, pelo fato que a alegação pelos EUA de que os critérios seriam para evitar um dano ambiental, fundamentado na exceção do art. $\mathrm{XX}$, g, do GATT, não satisfez o teste do Chapeau do art. XX, que dispõe que a medida não deve ser uma discriminação injustificada ou uma restrição disfarçada, não cumprindo o teste de necessidade, além de que poderia ter sido utilizada outra medida menos restritiva e menos inconsistente com o GAT'T para a proteção ambiental. ${ }^{36}$

O Órgão de Apelação entendeu que os EUA não levaram em consideração os interesses e os custos das refinarias estrangeiras quando houve a implementação dos métodos restritivos, além de que poderiam ter promovido uma cooperação entre os governos interessados, estendendo os mesmos métodos utilizados no âmbito interno. Houve uma restrição à importação de certa qualidade de gasolina, incorrendo em medida restritiva de comércio, e violou um dos núcleos fundamentais do GATT, que é o princípio do tratamento nacional.

Além disso, a obrigação de um membro em considerar os custos de uma medida sobre outros membros pode ser compreendido como uma aplicação objetiva do desenvolvimento sustentável, considerando os princípios do uso sustentável, igualitário e integrado. Em relação ao primeiro, deve ser levado em consideração que o estágio de desenvolvimento de um país define

36 NAPPERT, Sophie; ORTINO, Federico. International resolution of energy trade and investment dispute. In: SELIVANOVA, Yulia (Org.). Regulation of energy in international trade law: wto, nafta and energy charter. Kluwer Law International: 2011. p. 313 . sua capacidade técnica para adotar medidas. No caso concreto, Brasil e Venezuela não tinham as mesmas capacidades técnicas que os EUA, o que impediria a adoção das regras impostas. ${ }^{37}$

O princípio do uso igualitário implica que o uso de determinado recursos por um país (no caso os EUA) deve levar em conta a necessidade de outros países (Brasil e Venezuela), o que não ocorreu. E, por fim, as medidas ambientais impostas pelos EUA nunca consideraram a integração com outras questões afins, como o nível de desenvolvimento econômico dos países afetados, afrontando o princípio da integração. ${ }^{38}$

Apesar do Clean Air Act possuir um objetivo de reduzir as emissões de poluentes atmosféricos, esse discurso não convenceu o Órgão de Apelação, principalmente pelo fato de que outras medidas poderiam ser adotadas com o mesmo efeito, sem, contudo, prejudicar os outros membros da OMC. Esse argumento é substantivo para análise de futuros casos a serem apreciados.

\subsection{Investimento}

A OMC não inclui acordos específicos sobre investimento. O TRIMS não trata de proteção do investimento, mas proíbe os membros de imporem níveis particulares de aquisições locais por uma empresa (local content requirements) ou requisitando que uma empresa restrinja o volume ou valor das importações ao montante relacionado ao nível de produtos exportados (trade balancing requirements). Esse acordo aplica-se a medidas de investimento relacionadas somente ao comércio de bens.

\subsection{Disputas}

Um fator que merece uma atenção especial é que os conflitos no comércio de energia são caracterizados

37 MOROSINI, Fábio Costa; MARCEAU Gabrielle. The status of sustainable development in the law of the World Trade Organization. p. 59-92. In: CELLI JUNIOR, Umberto; BASSO, Maristela; AMARAL JUNIOR, Alberto do. (Coord.). Arbitragem e comércio internacional: estudos em homenagem a Luiz Olavo Baptista. São Paulo: Quartier Latin, 2013. p. 81.

38 MOROSINI, Fábio Costa; MARCEAU Gabrielle. The status of sustainable development in the law of the World Trade Organization. p. 59-92. In: CELLI JUNIOR, Umberto; BASSO, Maristela; AMARAL JUNIOR, Alberto do. (Coord.). Arbitragem e comércio internacional: estudos em homenagem a Luiz Olavo Baptista. São Paulo: Quartier Latin, 2013. p. 81. 
pela presença de obstáculos para a fluidez dos produtos energéticos pelas fronteiras dos países. Como já referido no início do trabalho, um sistema de solução de controvérsias foi criado no âmbito da OMC para solucionar eventuais disputas comerciais.

A OMC constituiu um Entendimento de Solução de Controvérsias (ESC - Dispute Settlement Understanding - DSU), que é o grande diferencial em relação ao GATT/1947, cabendo a aplicação das normas ao Órgão de Solução de Controvérsias (OSC).

Conforme Celso Lafer, como principal característica, verifica-se o "adensamento de juridicidade" das decisões do Órgão, que vinculam as partes ao seu cumprimento. Ou seja, o ESC visa mais do que o cumprimento de uma mera "obrigação de comportamento", a ser seguida de boa-fé, como no caso de transparência (art. 2(3) da Carta da ONU). Objetiva uma "obrigação de resultado", como medida de construção da confiança (confidence building measure), tutelando segurança e previsibilidade do sistema multilateral de comércio ${ }^{39}$

As disputas iniciam quando um membro requer uma consulta por que considera que benefícios estão sendo prejudicados direta ou indiretamente em face da violação dos acordos por outro membro. Se as consultas não resultarem em um acordo amigável, um Painel é estabelecido, composto por três julgadores. Da decisão do painel cabe apelação ao Órgão de Apelação.

O OSC administra o procedimento, e tem a função de autorizar as contramedidas adjudicantes, se for o caso. E nesses casos podem ocorrer disputas em razão de medidas governamentais que restringem (i) a exportação de produtos de energia (taxas e obrigações alfandegárias de exportação, podendo incluir cotas de produção); (ii) importação de produtos de energia (tributação e regulação interna, incluindo medidas sobre câmbio climático), e (iii) trânsito em energia (condução por monopólios estatais e empresas de comércio estatais que operam a infraestrutura de energia). Ainda, os conflitos no setor do comércio podem ocorrer em face da prestação de serviços de energia. ${ }^{40}$

39 LAFER, Celso. A OMC e a regulamentação do comércio internacional: uma visão brasileira. Porto Alegre: Livraria do Advogado, 1998. p. 31-32.

40 NAPPERT, Sophie; ORTINO, Federico. International resolution of energy trade and investment dispute. In: SELIVANOVA, Yulia (Org.). Regulation of energy in international trade law: wto, nafta and energy charter. Kluwer Law International: 2011. p. 304.
Dentro desse contexto, segue-se para uma análise do mecanismo para solução de controvérsias em relação ao setor energético no âmbito da OMC, com breves comentários comparativos com o do ECT.

Conforme art. 23.1 do DSU, a jurisdição é compulsória e exclusiva por natureza, com exclusão de qualquer outro sistema. ${ }^{41}$ Apenas para complementar a questão jurisdicional, o Energy Charter Treaty (ECT) refere que no caso de comércio, se os Estados judicantes também forem ambos membros da OMC, o caso será levado ao OSC..$^{42}$ Em relação a disputas decorrentes do trânsito de energia, o ECT dispõe de um mecanismo especializado de conciliação, permitindo maior rapidez com menor formalidade no procedimento (art. 7(7) ECT), e o OSC nada dispõe sobre esta matéria específica. ${ }^{43}$

Surge o questionamento das causas e/ou razões de reduzidos conflitos no setor energético na OMC. Mesmo compreendendo uma relevante parcela do comércio internacional, o tema não foi objeto de reclamações ao OSC. Numa análise quantitativa de disputas em comércio de energia, poucos casos foram identificados em comparação com o número total de conflitos apreciados pelo OSC.

Em primeiro lugar, isso se deve ao fato que muitos exportadores de energia não são membros da $\mathrm{OMC}$, como Argélia, Azerbaijão, Irã, Iraque, Cazaquistão, Líbia e Turcomenistão, e outros recém se tornaram membros, como Rússia (2012) e Arábia Saudita (2005). Outra questão é que no setor de energia, em regra, as restrições ou barreiras ao fluxo de produtos são estabelecidas por países exportadores, e não importadores, e essas restrições caem sob a disposição do art. XI do GATT, não tão visado pelo sistema multilateral. ${ }^{44}$

41 BOSSCHE, Peter Van Den. The law and policy of the world trade organization: text, cases and materials. 2 ed. Cambridge: Cambridge University Press, 2010. p. 180.

42 SELIVANOVA, Yulia. The Energy Charter Treaty and the international energy governance. In: SELIVANOVA, Yulia (Org.). Regulation of energy in international trade law: WTO, nafta and energy charter. Kluwer Law International, 2011. p. 378.

43 NAPPERT, Sophie; ORTINO, Federico. International resolution of energy trade and investment dispute. In: SELIVANOVA, Yulia (Org.). Regulation of energy in international trade law: WTO, nafta and energy charter. Kluwer Law International: 2011. p. 308.

44 NAPPERT, Sophie; ORTINO, Federico. International resolution of energy trade and investment dispute. In: SELIVANOVA, Yulia (Org.). Regulation of energy in international trade law: WTO, nafta and energy charter. Kluwer Law International: 2011. p. $314-315$. 
Numa comparação entre os reduzidos casos de energia na OMC com os casos relacionados a investimentos em energia baseados em tratados internacionais de investimento, alguns fatores devem ser enfatizados.

Primeiro, os tratados internacionais de investimento, representados pelos Bilateral Investment Treaties (BITs) e pelo próprio Energy Charter Treaty (ECT), dispõem sobre garantias de proteção ao investimento que não são cobertos pela OMC. Esses tratados contêm previsões impondo ao Estado hospedeiro uma obrigação (i) de compensar o investidor estrangeiro no caso de expropriação, (ii) de tratar o investidor estrangeiro de maneira justa e equitativa e (iii) de garantir ao investidor estrangeiro proteção integral e segurança; (iv) além de respeitar qualquer obrigação assumida em relação ao investimento estrangeiro. ${ }^{45}$

Os investimentos em energia são peculiares, pois envolvem, na maioria dos casos, volumosas transferências de capital, em tese sempre com uma concessão governamental do Estado hospedeiro; e uma natureza politicamente sensível de várias operações de energia, quando se relaciona com recursos naturais e que pode gerar renda para vários Estados. E esses tratados são base crucial para promover e garantir o investimento estrangeiro no setor energético. Apesar de existir no sistema da OMC dispositivos sobre investimento, como o TRIMS e GATS, eles não preveem qualquer garantia e proteção ao investidor, pois sua função é promover a liberalização do comércio de bens e serviços, eliminando medidas protecionistas e restrições quantitativas em serviços. ${ }^{46}$

Em segundo lugar, o fato que somente Estados são legítimos a reclamarem ao OSC da OMC é um fator que pode justificar o baixo índice de casos nesta matéria. Ao se comparar casos Estado versus Estado e Investidor versus Estado no âmbito dos tratados multilaterais como regionais e bilaterais, incluindo ECT e NAFTA, verifica-se que (i) é complicado o investidor convencer o Estado a assumir sua causa perante o sistema 45 NAPPERT, Sophie; ORTINO, Federico. International resolution of energy trade and investment dispute. In: SELIVANOVA, Yulia (Org.). Regulation of energy in international trade law: WTO, nafta and energy charter. Kluwer Law International: 2011. p. 316.

46 NAPPERT, Sophie; ORTINO, Federico. International resolution of energy trade and investment dispute. In: SELIVANOVA, Yulia (Org.). Regulation of energy in international trade law: WTO, nafta and energy charter. Kluwer Law International: 2011. p. 316. multilateral e (ii) apesar de haver uma preocupação do investidor em demandar um Estado, por "fechar a porta" para futuros negócios (principalmente quando se trata de recursos naturais), há forte interesse do investidor ser restituído. ${ }^{47}$

Terceiro lugar, o investidor tem pleno controle do procedimento arbitral, e dos recursos disponíveis, com uma participação direta e podendo receber a compensação na forma de danos, em contraposição a sanções previstas na OMC. Quarto lugar, em regra os contratos estabelecidos entre o investidor e o Estado hospedeiro preveem cláusula de estabilização, recurso ao tribunal estabelecido pela Convenção da ICSID (se cabível), e demais disposições que são reflexos ou se assemelham aos tratados internacionais celebrados. ${ }^{48}$

Esses fatores podem explicar o porquê que poucos casos envolvendo o tema energético foram trazidos à apreciação da OMC.

Após a decisão do caso US - Reformulated Gasoline, desde 2010, a OMC tem recebido consultas e painéis no tema de energia renovável, o que propõe que o comércio desse setor tem sido disputado com forte concorrência internacional, devido a alguns fatores, como o forte investimento em equipamentos para geração de energia elétrica por fontes limpas, principalmente eólica e solar. E também pela constante preocupação na redução de emissão de poluentes, além do gradual aumento da demanda global por energia.

Isso demonstra que existe uma evolução tecnológica, criou-se um mercado em expansão, em decorrência do investimento nesse tipo de tecnologia. Logicamente, os agentes econômicos investiram quantias consideráveis para produzir seus equipamentos, e agora desejam também protegê-los.

Os Estados protegem sua indústria mediante regulamentos domésticos, sem se preocupar com os acordos firmados no âmbito multilateral. $O$ ponto é se as medidas protetivas violam ou não os acordos da OMC. Com exceção do caso biodiesel, os demais se

47 NAPPERT, Sophie; ORTINO, Federico. International resolution of energy trade and investment dispute. In: SELIVANOVA, Yulia (Org.). Regulation of energy in international trade law: WTO, nafta and energy charter. Kluwer Law International: 2011. p. 316.

48 NAPPERT, Sophie; ORTINO, Federico. International resolution of energy trade and investment dispute. In: SELIVANOVA, Yulia (Org.). Regulation of energy in international trade law: WTO, nafta and energy charter. Kluwer Law International: 2011. p. 317. 
referem a equipamentos para geração de energia, mas todos são considerados como produtos, sujeitos aos mesmos tratamentos.

Abaixo seguem os casos identificados em relação a essa matéria. Salienta-se que os casos são recentes, e estão pendentes de decisão, com exceção dos casos canadenses (julgados de forma conjunta), em que houve a condenação do reclamado por proteger a indústria de equipamentos para geração de energia fotovoltaica da província de Ontario, mediante regras de conteúdo local. No Anexo II, estão sinteticamente demonstrados todos os dispositivos supostamente violados alegados pelos Estados requerentes. ${ }^{49}$

São eles: (i) DS 412 - Canadá - Certain measures affecting the renewable energy generation sector e DS 426 Canadá - Measures relating to the feed-in tariff program (ii) DS 419 - China - Measures concerning wind power equipment; (iii) DS 443 - UE e Espanha - Biodiesel; (iv) DS452 - UE, Grécia e Itália - Certain measures affecting the renewable energy generation sector e (v) DS 456 - Índia Certain measures relating to solar cells and solar modules.

Os casos trazidos para esse estudo demonstram que até o presente momento não houve decisão apreciando o art. XX, do GATT 1994, no setor de energia renovável. Tanto é que no caso DS 412/DS 419, os reclamantes não contestaram os objetivos do Canadá com o programa FIT, que é reduzir a emissão de carbono e promover a geração de energia elétrica por fontes renováveis.

O Japão afirmou que não se trata de disputas entre comércio e meio-ambiente, mas sim de comércio e investimento, pelo fato de promover as indústrias de produção de equipamento locais em detrimento de outras estrangeiras. Conforme o Painel, o Canadá não contestou a alegação que as medidas são relacionadas com comércio e investimento, afetando a importação de equipamentos de geração de energia por fonte renovável. Os casos estão diretamente relacionados aos equipamentos para geração de energia elétrica, como turbinas eólicas, placas solares, que são utilizados para gerar eletricidade, e não energia em si mesmo, como os combustíveis ou energia elétrica.

Dessa forma, o caso US - Reformulated Gasoline ainda poderá ser utilizado como parâmetro para eventual

49 Todas as informações das disputas foram obtidas no site da ORGANIZAÇÃO MUNDIAL DO COMÉRCIO. Disponível em: $<$ http://www.wto.org/english/tratop_e/dispu_e/dispu_status_e. htm>. Acesso em: 15 fev. 2013. apreciação de casos que envolvam a exceção prevista no art. XX, g, do GATT 1994.

A OMC, portanto, é uma organização extremamente relevante no sentido de regulamentar o comércio internacional de bens e serviços, estabelecendo parâmetros, que sempre foi seu principal objetivo. No entanto, ela acaba sendo o palco de intenso conflito de interesses dos seus membros, dificultando sua atualização. Como consequência, sua abordagem em determinados assuntos, como energia, acaba não evoluindo como deveria.

\section{Viabilidade de um acordo plurilateral sobre energia}

Em se tratando de comércio internacional de energia, inequívoca a necessidade de avaliar a possibilidade de um acordo específico sobre energia na Organização Mundial do Comércio.

Em razão de que poucos países possuem recursos naturais capazes de gerar energia e em face de, em regra, quase todos os países dependerem dela, o comércio de combustíveis (especialmente o petróleo) foi fundamental para satisfazer as necessidades globais. Há mais comércio internacional em petróleo do que qualquer outro produto. Isso se explica pela quantidade ou volume, pelo seu valor, ou a capacidade de transporte necessária para mover uma mercadoria. Uma estimativa conservadora coloca o comércio de energia em aproximadamente $20 \%$ do comércio total de mercadorias, e a metade do comércio mundial em serviços é intensamente dependente de energia. ${ }^{50}$

O jurista Arghyrios Fatouros expõe um fator complicador: que os recursos naturais, que são as principais fontes de energia, como petróleo, carvão ou gás natural, em regra, são extraídos em locais distintos de onde serão utilizados. Como exemplo, ele afirma que a Europa produz menos de $10 \%$ do petróleo no mundo, mas consome mais de $22 \%$. Os Estados Unidos da América (EUA) produzem menos de 20\% de petróleo mundial e consome mais de 30\%. Se forem contabilizadas as reservas de petróleo, essa diferença aumenta ainda mais. A Europa possui $2 \%$, os EUA $8 \%$, enquanto o Oriente Médio possui mais de $65 \% .^{51}$

50 PAUWELYN, Joost. Global Challenges at the intersection of trade, energy and the environment. Genebra: the graduate institute, center for trade and economic integration, 2010. p. 3-4. Disponível em: $<$ http://graduateinstitute.ch/ctei/publications_list/global.html> Acesso em: 15 nov. 2012.

51 FATOUROS, Arghyrios A. an international legal framework 
Isso demonstra que os atores que consomem energia têm que adquirir os recursos daqueles que produzem em localidade distinta, gerando forte fluxo de produtos e divisas, caracterizando-se como um forte comércio internacional. No entanto, estranhamente, a OMC não tem historicamente se preocupado com o comércio de energia.

Gabrielle Marceau afirma que as regras da OMC não foram inicialmente projetadas para resolver problemas de energia em si mesmo. Ao mesmo tempo, essa falta de interesse pode ser explicada de forma relativamente fácil. ${ }^{52}$

O sistema de comércio é focado em convencer os países a reduzir as restrições de importação. Quando se trata de energia, no entanto, restrições de importação não é o problema (poucos países impõem deveres de importação sobre petróleo). Em vez disso, o que importa é gestão da produção e estabilidade de preços para exportadores de energia, e acesso a produtos estrangeiros (ou de produção, exportação e restrições de trânsito) para os importadores de energia. ${ }^{5 .}$

De fato, o setor de energia parece incluir tanto aspectos de comércio de bens e de serviços. A jurisprudência da OMC é clara que uma única atividade comercial e até mesmo uma única medida podem estar cobertas pelas regras tanto do GATT quanto do Acordo Geral sobre o Comércio de Serviços.

Fica a questão de que, apesar das disciplinas do GATT serem geralmente aplicáveis a todos os produtos (enquanto todas as disciplinas do GATS não são aplicáveis a todos os serviços), é preciso esclarecer quais os aspectos do comércio de energia são abrangidas pelas regras desses e de outros acordos da OMC. ${ }^{54}$

for energy, collected courses of The Hague Academy of International Law. Martinus Nijhoff Publishers, The Hague, v. 332, p. 355-446, 2008.

52 MARCEAU, Gabrielle. The WTO in the Emerging Energy Governance Debate. In: PAUWELYN, Joost. Global Challenges at the intersection of trade, energy and the environment. Genebra: the graduate Institute, Center for Trade and Economic Integration, 2010. p. 25. Disponível em: <http://graduateinstitute.ch/ctei/publications_ list/global.html> Acesso em: 15 nov. 2012.

53 PAUWELYN, Joost. Global Challenges at the intersection of trade, energy and the environment. Genebra: The Graduate Institute, Center for Trade and Economic Integration, 2010. p. 3-4. Disponível em: $<$ http://graduateinstitute.ch/ctei/publications_list/global.html> Acesso em 15 nov. 2012.

54 MARCEAU, Gabrielle. The WTO in the Emerging Energy Governance Debate. In: PAUWELYN, Joost. Global Challenges at the intersection of trade, energy and the environment. Genebra: The Graduate Institute, Center for Trade and Economic Integration, 2010. p. 26. Disponível em: <http://graduateinstitute.ch/ctei/publications_
Não se pode evitar mencionar que o aspecto ambiental, compreendendo poluição, alterações climáticas e outros problemas decorrentes, deve também ser analisado pela OMC nesse tipo de comércio, principalmente em razão da utilização de fontes fósseis como base para a geração de energia.

O setor de energia é uma indústria de capital intensivo que exige investimentos significativos em infraestrutura. O Acordo TRIMS não lida com política de investimento por si só, e somente dispõe sobre a obrigação de tratamento nacional e proibição de restrições quantitativas em relação a determinadas medidas de investimento, tais como conteúdo local e requisitos relacionados à troca comercial. É proibido impor medidas de investimento que exigem as empresas a comprar uma determinada quantidade de mercadorias de origem nacional ou condicionar importações sobre o montante das exportações. ${ }^{55}$

Vale salientar que, há 60 anos, a demanda por energia era uma fração do que é hoje, e da mesma forma os preços praticados. Por isso a liberalização da energia não foi uma prioridade para os países na celebração do GATT/1947. Além disso, a energia sempre foi um monopólio estatal e o comércio internacional, quando existia, estava concentrado em poucas companhias multinacionais. ${ }^{56}$

Hoje, não vivemos mais sem energia, sendo considerada uma necessidade básica para a manutenção da sociedade e da vida das pessoas. Tanto é que existe uma crescente preocupação em relação ao tema, tendo sido inclusive discutido na conturbada Rodada Doha, pois se tornou um elemento importante do comércio internacional.

Inclusive, existe o questionamento do enfraquecimento do órgão multilateral em face dos blocos regionais, tema que objeto de discussão na própria $\mathrm{OMC}^{57}$, mas que poderá ser objeto de outro estudo com maior aprofundamento.

list/global.html> Acesso em: 15 nov. 2012.

55 SELIVANOVA, Yulia. The WTO and energy wto rules and agreements of relevance to the Energy Sector. International Centre for Trade and Sustainable Development - ICTSD. Disponível em: < http://ictsd. org/downloads/2008/05/the20wto20and20energy.pdf $>$. Acesso em: 24 out. 2011.

56 COTTIER, Thomas et al. Energy in WTO law and policy. World Trade Organization. p. 1. Disponível em: <http://www.wto.org/ english/res_e/publications_e/wtr10_forum_e/wtr10_7may10_e. pdf $>$. Acesso em: 24 abr. 2011.

57 WORLD TRADE ORGANIZATION. Disponível em: <http://www.wto.org/english/forums_e/public_forum12_e/ 
Diante desse contexto, é possível visualizar alguns desafios que merecem atenção no âmbito da OMC, tais como:

Unificação da regulamentação do tema da energia para promover condições de competição igualitária e justa entre os diversos setores, quais sejam, combustíveis fósseis e não fósseis; energia incluindo óleo, gás, térmica, madeira, eletricidade e energia atômica; fontes de energia renovável para geração de energia elétrica (solar, eólica, ondas e marés) e biocombustíveis, ${ }^{58}$

Reforma da classificação dos serviços de energia, evitando que, por exemplo, transporte de óleo combustível seja classificado na categoria de serviços de transporte; ${ }^{59}$

A questão dos subsídios concedidos por países nos casos de energia renovável, como, por exemplo, os Estados Unidos no tratamento favorecido à produção de milho para produção de etanol, abordando o Art. XX, b, do GATT; ${ }^{60}$

O controle de produção versus a restrição de exportação, que pode ser visualizado no contexto do petróleo, em que países membros da OPEP desejam manter sua prática comercial sob o regulamento específico, e não desejam aplicar o Art. XI do GATT, que proíbe as restrições quantitativas; ${ }^{61}$

A propriedade industrial de tecnologias de produção, armazenamento ou transmissão de energia, por meio de patentes, e pagamento de royalties é outro aspecto que provavelmente tornar-se-á tema de discussão na OMC.

Portanto, é possível identificar o entrelaçamento de inúmeros temas em torno da questão energética, que surge como o ponto em comum para uma nova perspectiva normativa no âmbito da OMC,

public_forum12_e.htm>. Acesso em 04 jun. 2012.

58 COTTIER, Thomas et al. Energy in WTO law and policy. World Trade Organization. p. 8. Disponível em: <http://www.wto.org/ english/res_e/publications_e/wtr10_forum_e/wtr10_7may10_e. pdf $>$. Acesso em: 24 abr. 2011.

59 COTTIER, Thomas et al. Energy in WTO law and policy. World Trade Organization. p. 9. Disponível em: <http://www.wto.org/ english/res_e/publications_e/wtr10_forum_e/wtr10_7may10_e. pdf>. Acesso em: 24 abr. 2011.

60 COTTIER, Thomas et al. Energy in WTO law and policy. World Trade Organization. p. 11. Disponível em: <http://www.wto.org/ english/res_e/publications_e/wtr10_forum_e/wtr10_7may10_e. pdf $>$. Acesso em: 24 abr. 2011.

61 COTTIER, Thomas et al. Energy in WTO law and policy. World Trade Organization. p. 16. Disponível em: <http://www.wto.org/ english/res_e/publications_e/wtr10_forum_e/wtr10_7may10_e. pdf>. Acesso em: 24 abr. 2011. principalmente em função de ser um elemento potencial de conflitos entre países.

A importância da energia para o comércio se reflete no volume que ele representa. Apesar da relevância, a OMC trata o setor igual a qualquer outro, sem distinção. O comércio de serviços é consideravelmente menos liberalizado que o comércio de bens, dadas as peculiaridades das operações de serviços transfronteiriços. Reitera-se que inexiste entendimento pacífico de como a eletricidade deve ser negociada, se deve ser classificada como um bem ou um serviço. ${ }^{62}$

Uma transição da energia fóssil para renovável aumentará a importância das redes elétricas, que deverá ser usada para distâncias mais longas. Isso é mais um argumento para a criação de um comércio multilateral específico de energia. Nesse panorama, questiona-se se a OMC é o fórum adequado para criar um acordo-quadro sobre o comércio de energia? Ou seria mais viável adicionar disposições relacionadas com a energia nas regras atuais da OMC, o que evitaria o complexo processo de ratificação de um novo acordo internacional? Embora a OMC não discrimine energia, ela permite abordar algumas questões já tratadas nesse estudo, principalmente em relação à conservação dos recursos naturais, a proteção do meio ambiente, da saúde humana, animal ou vegetal, como exceção à regra geral. ${ }^{63}$

O ex-diretor da OMC Sr. Pascal Lamy afirmou que a organização mediante suas regras, transparência, comitês de discussão e seu mecanismo de rule-oriented pode e deve contribuir para uma governança global de energia, mas que a contribuição da OMC poderia ser reforçada através de uma abordagem mais holística para a energia, que atinge o equilíbrio entre as necessidades dos países exportadores e importadores de energia. ${ }^{64}$

62 LEAL-ARCAS, Rafael; FILIS, Andrew. The fragmented governance of the global energy economy: a legal-institutional analysis. The Journal of World Energy Law \& Business, 2013. Disponível em: <http://jwelb.oxfordjournals.org/content/early/2013/07/19/ jwelb.jwt011.abstract>. p. 21.

63 LEAL-ARCAS, Rafael; FILIS, Andrew. The fragmented governance of the global energy economy: a legal-institutional analysis. The Journal of World Energy Law \& Business, 2013. Disponível em: <http://jwelb.oxfordjournals.org/content/early/2013/07/19/ jwelb.jwt011.abstract>. p. 21.

64 ORGANIZAÇÃO MUNDIAL DO COMÉRCIO. Lamy calls for dialogue on trade and energy in the WTO. 2013. Disponivel em: <http://www.wto.org/english/news_e/sppl_e/sppl279_e.htm>. Acesso em: 14 nov. 2013. 
Ele ainda salientou que a OMC oferece aos seus membros a oportunidade única de se envolver em um diálogo para o futuro sobre a rápida expansão de uma interface entre energia e comércio. Isso pode ser útil para ajudar a traçar um caminho comum rumo a um maior apoio mútuo e coerente entre o comércio e os objetivos de política energética. Considerou que essa complementaridade e coerência são características essenciais de um sistema de governança global de energia eficiente e eficaz. ${ }^{65}$

Apesar das declarações otimistas - e políticas —, o que é salutar, no caso, o sistema geral da OMC não fornece uma governança global de energia suficiente. Além disso, as regras da OMC carecem de especificidade, tratando o comércio de energia de forma igual a bens e serviços. Uma solução seria discutir o tema já na Rodada de Doha, iniciada em 2001, mas que precisa do consenso de todos os membros para aprovar qualquer aditivo contratual. ${ }^{66}$

Outra possibilidade seria desenvolver um acordo plurilateral de comércio (Plurilateral Trade Agreements), que poderia fazer parte do Tratado da OMC ao ser adicionado ao anexo 4 do Acordo da OMC. Conforme artigo II.3 do Acordo OMC, tais acordos plurilaterais fazem parte do Acordo da OMC somente para os membros que as aceitaram. No entanto, os acordos plurilaterais não criam obrigações nem direitos para os membros que não as aceitaram.

Conforme artigo X.9 do Acordo da OMC, a Conferência Ministerial, mediante requerimento dos membros, pode acrescentar ou deletar um acordo ao Anexo 4, por consenso; e conforme artigo X.10, aditivos a esse acordo plurilateral deverão ser negociados conforme a previsão no próprio acordo plurilateral.

$\mathrm{O}$ acordo plurilateral pode ser considerado como uma obrigação WTO-plus, ou seja, se comprometer além do mínimo necessário que se exige para ser membro. Dois acordos plurilaterais de comércio foram implementados e tem sido efetivos para a redução de barreiras, como o

65 ORGANIZAÇÃO MUNDIAL DO COMÉRCIO. Lamy calls for dialogue on trade and energy in the WTO. 2013. Disponível em: <http://www.wto.org/english/news_e/sppl_e/sppl279_e.htm>. Acesso em: 14 nov. 2013.

66 BACCHUS, James. A way forward for the WTO. International Centre for Trade and Sustainable Development - ICTSD. Disponível em: < http://ictsd.org/downloads/2012/02/james-bacchus-a-wayforward-for-the-wto.pdf $>$. Acesso em: 10 out. 2013. de compras governamentais (GPA) e o de tecnologia da informação (ITA) da OMC. ${ }^{6}$

De certa forma, os acordos plurilaterais são positivos no sentido de que eles podem ser aderidos por todos os outros membros da OMC, a qualquer tempo. A não adesão não vincula quaisquer membros. $\mathrm{E}$ isso torna a organização mais flexível e torna um fórum muito mais eficaz para tratar de temas, como energia sustentável, ligados ao comércio mas que não estão sendo adequadamente cobertos pelas regras atuais, e não faz parte, ou não suficientemente parte, da agenda de negociações da Rodada Doha. ${ }^{68}$

Para exemplificar, seguem alguns temas urgentes de interesse comercial internacional que poderiam ser objeto de acordos plurilaterais adicionais: investimento, concorrência, energia verde, comércio digital, práticas cambiais, serviços, propriedade intelectual, harmonização regulatória, normas e regulamentações técnicas, facilitação do comércio, segurança do produto.

E se surgirem conflitos em decorrência desses acordos, deve-se aplicar o DSU? Absolutamente, pois essa seria uma grande vantagem em conceber um acordo dentro da estrutura jurídica da OMC, a exemplo dos acordos GPA e ITA. Caso contrário, à todo acordo celebrado fora do escopo da OMC teria que se criar todo um sistema novo de solução de controvérsias. Portanto, essa é uma oportunidade de criar um Sustainable Energy Trade Agreement para eliminar barreiras ao comércio e investimento das novas tecnologias da economia verde, no intuito de promover um desenvolvimento sustentável.

A agenda de negociações da OMC é sempre determinada pelos seus membros, com base em suas prioridades políticas e econômicas. Uma vez que se atinge um consenso numa agenda, as negociações podem iniciar. E essa regra se aplica também para o comércio de energia, que, apesar de estar longe de ter um acordo específico, o tema aparece nas negociações de Doha lançadas em 2001. ${ }^{69}$

67 BACCHUS, James. A Way Forward for the WTO. International Centre for Trade and Sustainable Development-ICTSD. Disponível em: <http://ictsd.org/downloads/2012/02/james-bacchus-a-wayforward-for-the-wto.pdf $>$. Acesso em: 10 out. 2013..

68 BACCHUS, James. A Way Forward for the WTO. International Centre for Trade and Sustainable Development - ICTSD. Disponível em: <http://ictsd.org/downloads/2012/02/james-bacchus-a-wayforward-for-the-wto.pdf $>$. Acesso em: 10 out. 2013.

69 ORGANIZAÇÃO MUNCIAL DO COMÉRCIO. Doba Round will benefit energy trade: Lamy. 2007. Disponível em: <http:// www.wto.org/english/news_e/sppl_e/sppl80_e.htm>. Acesso em: 
Isso se deve ao fato que a energia não foi devidamente abordada na Rodada Uruguai, aliás, jamais foi prioridade desde o GATT, em 1947. Como resultado, os membros da OMC assumiram compromissos limitados para abrir seus mercados aos operadores estrangeiros nos serviços de energia, como os serviços relacionados com a extração de petróleo e gás, serviços relacionados com a distribuição de gás e eletricidade e transporte de combustíveis por dutos.

A primeira área na agenda de Doha em que se trata de energia está nas negociações de serviços. Pela primeira vez os membros estão discutindo a energia como um setor de serviços específicos, cobrindo uma ampla gama de atividades relevantes para as empresas de energia e abrangendo todas as fontes de energia, incluindo as energias renováveis. Compromissos são procurados em atividades como a perfuração, engenharia, testes e análises técnicas, trabalhos de construção de gasodutos de curta e longa distância, e serviços de comércio por atacado e varejo de combustíveis. ${ }^{70}$

A segunda área relevante da Rodada de Doha se relaciona com tecnologia limpa, visando abrir os mercados para bens e serviços ambientais, facilitando a promoção da eficiência energética, matéria prima para a produção de energia renovável, gestão de aquecimento e controle de poluição. Os equipamentos para geração de energia renovável incluem turbinas eólicas, painéis solares, sensores de energia geotérmica, células de combustível e medidores de energia elétrica. Os serviços ambientais incluem as negociações sobre serviços para reduzir GEE e melhorar a qualidade do ar, serviços de proteção da natureza ou serviços para a reabilitação de sítios de mineração.

A terceira área trata de facilitação de comércio, mediante negociação nos temas de melhorias e esclarecimentos ao trânsito de energia, obrigação contida nas regras do GATT/1947 que obrigam os membros permitir a passagem de mercadorias em trânsito por meio de seus territórios. Na atual Rodada de Doha, as propostas foram apresentadas para esclarecer

14 nov. 2013.

70 ORGANIZAÇÃO MUNCIAL DO COMÉRCIO. Doha Round will benefit energy trade: Lamy. 2007. Disponível em: <http:// www.wto.org/english/news_e/sppl_e/sppl80_e.htm>. Acesso em: 14 nov. 2013.

71 ORGANIZAÇÃO MUNCIAL DO COMÉRCIO. Doba Round will benefit energy trade: Lamy. 2007. Disponível em: <http:// www.wto.org/english/news_e/sppl_e/sppl80_e.htm>. Acesso em: 14 nov. 2013. o significado dessa obrigação e se inclui as instalações fixas, tais como gasodutos e oleodutos. ${ }^{72}$

Propostas sobre os impostos de exportação e subsídios de energia devem ser objeto de discussão, focando para as restrições à exportação de bens energéticos e outras matérias primas, porque essas restrições são mais predominantes nessa área do que no comércio em geral, além de preocupar os países importadores dependentes dos insumos. A questão dos subsídios na forma de produtos de energia de baixo preço, especialmente o gás natural, tem recorrentemente agitado os debates entre os membros da OMC e também faz parte das negociações em curso. ${ }^{73}$

No caso, o gás natural abaixo do preço praticado, ou mais barato que o praticado no âmbito internacional, estaria funcionando como uma espécie de vantagem comparativa, cujos efeitos se alastram para todos os produtos que utilizam esses recursos, desequilibrando o comércio internacional, afetando mais precisamente a concorrência.

Por fim, os biocombustíveis deveriam ser regulados de forma específica (vide caso DS 443 - biodiesel - promovido pela Argentina contra UE e Espanha) por permitir enfrentar a mudança climática, segurança energética e desenvolvimento rural. A delicadeza nesse tema se deve ao fato que acaba se inserindo em negociações sobre agricultura, para redução de tarifas e subsídios, setor considerado sempre como prioridade para a UE e EUA.

\section{Conclusão}

O que se verifica é que inexiste uma classificação abrangente e universalmente aceita de serviços de energia, incluindo serviços de energia sustentável na OMC. Negociações para a liberalização desses serviços vão envolver diversos setores, como engenharia, construção, manutenção e consultoria, podendo levar a distorções na abordagem. Atualmente, negociações de serviços têm progredido de forma lenta. Questões que estavam originalmente na mesa de negociações, como investimento, política de concorrência e transparência 72 ORGANIZAÇÃO MUNCIAL DO COMÉRCIO. Doha Round will benefit energy trade: Lamy. 2007. Disponível em: <http:// www.wto.org/english/news_e/sppl_e/sppl80_e.htm>. Acesso em: 14 nov. 2013.

73 ORGANIZAÇÃO MUNCIAL DO COMÉRCIO. Doba Round will benefit energy trade: Lamy. 2007. Disponível em: <http:// www.wto.org/english/news_e/sppl_e/sppl80_e.htm>. Acesso em: 16 nov. 2013. 
nas compras governamentais foram retiradas da agenda de negociações da Rodada de Doha, pela falta de um "consenso explícito" na Conferência Ministerial da OMC em Cancun, em 2003. ${ }^{74}$

A Rodada de Doha como um todo está praticamente estagnada, depois de uma falta de acordo em uma série de áreas críticas, tais como acesso a mercados não agrícolas (NAMA), ou seja, bens manufaturados. O sistema de single-undertaking da OMC, em que nada está acordado até que tudo esteja acordado, torna difícil nas atuais circunstâncias tratar de questões relacionadas com energia como parte de um conjunto amplo e abrangente de negociações comerciais multilaterais. ${ }^{75}$

A conduta recente da Índia em se opor à adoção do Pacote de Bali, de dezembro de 2013, para facilitação de

74 ICTSD. Fostering Low Carbon Growth: the case for a sustainable energy trade agreement. Disponível em: < http://ictsd.org/ downloads/2012/05/ fostering-low-carbon-growth-the-case-for-asustainable-energy-trade-agreement1.pdf> Acesso em: 13 nov. 2013.

75 ICTSD. Fostering Low Carbon Growth: the case for a sustainable energy trade agreement. Disponível em: <http://ictsd.org/ downloads/2012/05/ fostering-low-carbon-growth-the-case-for-asustainable-energy-trade-agreement1.pdf > Acesso em: 13 nov. 2013. comércio, alegando a necessidade de armazenamento de alimentos face à segurança alimentar, demonstra uma desvantagem do sistema de consenso. Recentemente, EUA e Índia estabeleceram um acordo com o compromisso que não haverá disputas referentes ao subsídio doméstico para venda de alimentos até que seja o tema amplamente discutido. ${ }^{76}$

Portanto, as normas da OMC poderiam ser revistas e atualizadas, mas as iniciativas são obstaculizadas pela regra do consenso. Um Acordo Plurilateral de Energia tende a ser um caminho viável para facilitar e acelerar os fluxos de energia, primeiro, por facultar a adesão dos interessados membros da própria organização multilateral, evitando longas negociações num tema de extrema sensibilidade. Segundo, por estabelecer um marco regulatório atualizado e acessível, que possa servir como base para geração de energia por meio sustentável.

76 NEW YORK TIMES. U.S. India Agreement on Stockpiles of Food Revives a Trade Deal. Disponível em: < http://www.nytimes. com/2014/11/14/business/international/us-india-agreement-clearsway-for-global-trade-deal.html?_r=0>. Acesso em: 17 nov. 2014. 


\section{Referências}

ALVAREZ, José E. The public international law regime governing international investment. The Hague: Brill Nijhoff, 2011.

AMARALJÚNIOR, Alberto do. A solução de controvérsias na OMC. São Paulo: Atlas, 2007.

ARIBOGAN, D U; BILGIN, M. New Energy Order Politics Neopolitics: From Geopolitics to Energeopolitics. Uluslar, Iliskiler, v. 5, n. 20, p. 109-131, 2009.

BACCHUS, James. A way forward for the WTO. International Centre for Trade and Sustainable Development - ICTSD. Disponível em: <http://ictsd.org/ downloads/2012/02/james-bacchus-a-way-forwardfor-the-wto.pdf.> Acesso em: 10 out. 2013.

BARNETT, Michael; FINNEMORE, Martha. Rules for the world: international organizations in global politics. London: Cornell University Press, 2004.

BARRAL, Welber de Oliveira (Org.). O Brasil e a Organização Mundial do Comércio. 2. ed. Curitiba: Juruá, 2002.

BHATTACHARYYA, Subhes C. Energy access programmes and sustainable development: a critical review and analysis. Energy for Sustainable Development, v. 16, n. 3, p. 260-271, 2012. Disponível em: <http://linkinghub.elsevier.com/retrieve/pii/ S0973082612000245>. Acesso em: 14 out. 2013.

BHATTACHARYYA, Subhes C. Financing energy access and off-grid electrification: a review of status, options and challenges. Renewable and Sustainable Energy Reviews, v. 20, n. 0, p. 462-472, 2013. Disponível em: $<$ http://www.sciencedirect.com/science/article/pii/ S1364032112007046>.

BHATTACHARYYA, Subkes C. Energy Economics. Part 1. London: Springer-Verlag Limited, 2011.

BOSSCHE, Peter Van Den. The law and policy of the world trade organization: text, cases and materials. 2 ed. Cambridge: Cambridge University Press, 2010.

BOSSELMAN, Fred et al. Energy, economics and the Environment: cases and Materials. December 21, 2008.
Foundation Press, 2006. Disponível em: <http://ssrn. com/abstract $=1319022>$. Acesso em: 07 out. 2012.

BRASIL. Decreto n. 7030/2009. Convenção de Viena sobre Direito dos Tratados. Disponível em: <http://www2. mre.gov.br/dai/dtrat.htm>. Acesso em: 10 abr. 2012.

BRITISH PETROLEUM. Statistical Review of World Energy. June 2012. Disponível em: <http:// www.bp.com/content/dam/bp/pdf/StatisticalReview-2012/statistical_review_of_world_ energy_2012.pdf>. Acesso em: 26 jul. 2013.

BURNS, Thaddeus J. The liberalization of environmental goods and services (EGS) trade and the need for a distinct EGS agreement. In: PAUWELYN, Joost. Global Challenges at the intersection of trade, energy and the environment. Genebra: The Graduate Institute, Center for Trade and Economic Integration, 2010. Disponível em: <http://graduateinstitute.ch/ctei/publications_ list/global.html> Acesso em: 15 nov. 2012.

BUSSE, Matthias; GRÖNING, Steffen. The resource curse revisited: governance and natural resources. Public Choice, Germany, v. 154, n. 1-2, p. 1-20, may/jul. 2013.

COELHO, Suani T; GOLDEMBERG, José. Energy access: Lessons learned in Brazil and perspectives for replication in other developing countries. Energy Policy, v. 61, n. 0, p. 1088-1096, 2013. Disponível em: <http://www.sciencedirect.com/science/article/pii/ S030142151300414X>.

COTTIER, Thomas et al. Energy in WTO law and policy. Disponível em: <http://www.wto.org/ english/res_e/publications_e/wtr10_forum_e/ wtr10_7may10_e.pdf>. Acesso em: 24 abr. 2011.

ENERGY CHARTER TREATY. Investor-State disputes. Disponível em: <http://www.encharter.org/index. php?id=213>. Acesso em: 01 fev. 2014.

ENERGY CHARTER TREATY. The energy charter treaty and related documents: a legal framework for international energy cooperation. Disponível em: $<$ http://www.encharter.org/fileadmin/user_upload/ document/EN.pdf>. Acesso em: 10 jan. 2013.

FATOUROS, Arghyrios A. An international legal framework for energy, collected courses of The Hague Academy 
of International Law. The Hague: Martinus Nijhoff Publishers, p. 355-446, 2008. v. 332.

FERREIRA, Lier Pires. Direito internacional, petróleo e desenvolvimento: políticas de produção petrolífera em áreas inativas com acumulações marginais. São Paulo: Saraiva, 2011.

FIORILLO, Celso Antônio Pacheco; FERREIRA, Renata Marques. Curso de direito da energia: tutela jurídica da água, do petróleo, do biocombustível, dos combustíveis nucleares e do vento. 2 ed. São Paulo: Saraiva, 2010.

GOLDTHAU, Andreas; WITTE, Jan Martin. Global Energy Governance: the new rules of the game. Washington: Brooking Press, 2010.

GUZMAN, Andrew T. Why LDCs sign treaties that hurt them: explaining the popularity of bilateral investment treaties. Journal of International Law, Virginia, v.38, n. 639, p. 639-688, jan. 1998.

GUZMAN, Andrew T.; PAUWELYN, Joost H. B. International trade law. New York: Wolters Kluwer-Aspen Publishers, 2009.

HOBÉR, Kaj. Investment Arbitration and the Energy Charter Treaty. Journal of International Dispute Settlement, Oxford, v. 1 , n. 1 , p. 153-190, 2010.

ICTSD. Aževêdo Extends WTO Negotiating Deadline in Bid to Secure Bali Deal. 2013. Disponível em: <http://ictsd. org/i/news/bridgesweekly/178924/\#sthash.sx4cqiV9. dpuf $>$. Acesso em: 14 nov. 2013.

ICTSD. Fostering Low Carbon Growth: the case for a sustainable energy trade agreement. Disponível em: http://ictsd.org/downloads/2012/05/fostering-lowcarbon-growth-the-case-for-a-sustainable-energytrade-agreement1.pdf Acesso em: 13 nov. 2013.

\section{INTERNATIONAL RENEWABLE ENERGY} AGENCY - IRENA. Members. Disponível em: <http:// www.irena.org/menu/index.aspx?mnu=cat\&PriMenu $\mathrm{ID}=46 \&$ CatID=67>. Acesso em: 13 nov. 2013.

INTERNATIONAL RENEWABLE ENERGY AGENCY - IRENA. Statute. Disponível em: <http:// www.irena.org/documents/uploadDocuments/ Statute/IRENA_FC_Statute_signed_in_
Bonn_26_01_2009_incl_declaration_on_further_ authentic_versions.pdf $>$. Acesso em: 13 nov. 2013.

KARNS, Margaret P.; MINGST, Karen A. International organizations: the politics and processes of global governance. 2 ed. Boulder: Lynne Rienner Publishers, 2010.

KHATIB, Hisham. IEA World Energy Outlook 2011-A comment. Energy Policy, v. 48, p. 737-743, 2012. Disponível em: <http://linkinghub.elsevier. com/retrieve/pii/S0301421512005149>. Acesso em: 26 maio 2013.

KONOPLYANIK, Andrei; WALDE, Thomas. Energy Charter Treaty and its Role in International Energy. Journal of Energy \& Natural Resources Law, v. 24, n. 4, p. 523-558, 2006.

KOSKENNIEMI, Martti; LEINO, Päivi. Fragmentation of International Law? Postmodern Anxieties. Leiden Journal of International Law, p. 553-579, 2002, Kluwer Law International.

LAFER, Celso. A OMC e a regulamentação do comércio internacional: uma visão brasileira. Porto Alegre: Livraria do Advogado, 1998.

LAMY, Pascal, Global Governance: From Theory to Practice, Journal of International Economic Law, v. 15, n. 3, p. 721-728, 2012.

LEAL-ARCAS, Rafael; FILIS, Andrew. The fragmented governance of the global energy economy: a legal-institutional analysis. The Journal of World Energy Law \& Business, 2013. Disponível em: <http://jwelb. oxfordjournals.org/content/early/2013/07/19/jwelb. jwt011.abstract>.

LYSTER, Rosemary; BRADBROOK, Adrian. Energy Law and Environment. Cambridge: Cambridge University Press, 2006.

MARCEAU, Gabrielle. The WTO in the Emerging Energy Governance Debate. In: PAUWELYN, Joost. Global Challenges at the intersection of trade, energy and the environment. Genebra: The Graduate Institute, Center for Trade and Economic Integration, 2010. p. 25. Disponível em: <http://graduateinstitute.ch/ctei/publications_list/ global.html> Acesso em: 15 nov. 2012. 
MELLO, Celso Duvivier de Albuquerque. Direito Internacional Econômico. Rio de Janeiro: Renovar, 1993.

MOROSINI, Fábio Costa. Globalização e novas tendências em filosofia do direito internacional: a dicotomia entre público e privado na cláusula de estabilização. In: MARQUES, Claudia Lima; ARAÚJO, Nadia de (Org.). O novo direito internacional: estudos em homenagem a Erik Jayme. Rio de Janeiro: Renovar, 2005. p. 549-572.

MOROSINI, Fábio Costa. Repensando estratégias regulatórias internacionais: a interação entre o setor elétrico e o meio ambiente na América do Norte. In: GUERRA, Sidney; FERREIRA JUNIOR, Lier Pires. $O$ direito internacional ambiental e do petróleo. Rio de Janeiro: Lumen Juris, 2009. p. 111-138.

MOROSINI, Fábio Costa; Gabrielle Marceau. The status of sustainable development in the law of the World Trade Organization. p. 59-92. In: CELLI JUNIOR, Umberto; BASSO, Maristela; AMARAL JUNIOR, Alberto do. (Coord.). Arbitragem e comércio internacional: estudos em homenagem a Luiz Olavo Baptista. São Paulo: Quartier Latin, 2013.

NAPPERT, Sophie; ORTINO, Federico. International resolution of energy trade and investment dispute. In: SELIVANOVA, Yulia (Org.). Regulation of energy in international trade law: WTO, nafta and energy charter. Kluwer Law International: 2011.

NEW YORK TIMES. U.S.-India Agreement on Stockpiles of Food Revives a Trade Deal. Disponível em: <http://www. nytimes.com/2014/11/14/business/international/ us-india-agreement-clears-way-for-global-trade-deal. html?_r=0>. Acesso em: 17 nov. 2014.

\section{ORGANIZAÇÃO DAS NAÇÕES UNIDAS.} Comissão Brundtland "Nosso Futuro Comum". Disponível em: <http://www.onu.org.br/a-onu-em-acao/a-onu-eo-meio-ambiente/>. Acesso em: 05 out. 2012.

ORGANIZAÇÃO MUNDIAL DO COMÉRCIO. Decisão Painel DS-426. Disponível em: <http://www. wto.org/english/tratop_e/dispu_e/cases_e/ds426_e. htm.> Acesso em 15 jan. 2013.

ORGANIZAÇÃO MUNDIAL DO COMÉRCIO. Disponível em: <http://www.wto.org/english/ forums_e/public_forum12_e/public_forum12_e. htm>. Acesso em: 04 jun. 2012.

ORGANIZAÇÃO MUNDIAL DO COMÉRCIO. Disputes. Disponível em: <http://www.wto.org/english/ tratop_e/dispu_e/find_dispu_cases_e.htm\#results $>$. Acesso em: 10 nov. 2012.

ORGANIZAÇÃO MUNDIAL DO COMÉRCIO. Doba Round will benefitenergy trade: Lamy. 2007. Disponível em: <http://www.wto.org/english/news_e/sppl_e/ sppl80_e.htm>. Acesso em: 14 nov. 2013.

ORGANIZAÇÃO MUNDIAL DO COMÉRCIO. GATT/1994. Disponível em: <http://www.wto. org/english/res_e/booksp_e/analytic_index_e/ gatt1994_05_e.htm>. Acesso em: 10 nov. 2012.

ORGANIZAÇÃO MUNDIAL DO COMÉRCIO. Lamy calls for dialogue on trade and energy in the WTO. 2013. Disponível em: <http://www.wto.org/english/ news_e/sppl_e/sppl279_e.htm>. Acesso em: 14 nov. 2013.

ORGANIZAÇÃO MUNDIAL DO COMÉRCIO. World Trade Report 2010. Disponível em: <http://www. wto.org/english/res_e/publications_e/wtr10_e.htm>. Acesso em: 10 nov. 2012.

ORGANIZAÇÃO MUNDIAL DO COMÉRCIO. World Trade Report 2013. Disponível em: <http:// www.wto.org/english/res_e/booksp_e/world_trade_ report13_e.pdf>. Acesso em: 18 jul. 2013.

ORGANIZAÇÃO MUNDIAL DO COMÉRCIO. World Trade Report 2014. Disponível em: <http:// www.wto.org/english/res_e/booksp_e/world_trade_ report14_e.pdf $>$. Acesso em: 17 nov. 2014.

PACHAURI, Shonali. Reaching an international consensus on defining modern energy access. Current Opinion in Environmental Sustainability, v. 3, n. 4, p. 235240, 2011. Disponível em: <http://www.sciencedirect. com/science/article/pii/S1877343511000625>.

PACHAURI, Shonali; CHERP, Aleh. Energy security and energy access: distinct and interconnected challenges. Current Opinion in Environmental Sustainability, v. 3, n. 4, p. 199-201, 2011. Disponível em: <http:// www.sciencedirect.com/science/article/pii/ S1877343511000637>. 
PAUWELYN, Joost (Org.). Global Challenges at the intersection of trade, energy and the environment. Genebra: The Graduate Institute, Center for Trade and Economic Integration, 2010. p. 25. Disponível em: <http:// graduateinstitute.ch/ctei/publications_list/global. html> Acesso em: 15 nov. 2012.

PEAT, Daniel. The Perfect FIT: Lessons for Renewable Energy Subsidies in the World Trade Organization. LSU Journal of Energy Law and Resources. 2012. Disponível em: <http://ssrn.com/abstract=2128654>. Acesso em: 18 nov. 2012.

PEAT, Daniel. The Wrong Rules for the Right Energy: The WTO SCM Agreement and Subsidies for Renewable Energy. Environmental Law and Management. n. 3, 2012. p. 14-15. Disponível em: <http://ssrn. com/abstract=1998240 or http://dx.doi.org/10.2139/ ssrn.1998240>. Acesso em: 16 maio 2012.

PEREIRA, Ana Cristina Paulo (Org.). Direito internacional do comércio: mecanismo de solução de controvérsias e casos concretos na OMC. Rio de Janeiro: Lúmen Júris, 2003.

PETERSMANN, Ernst-Ulrich. Constitutional Problems of Multilevel Judicial Governance in Trade and Investment Regulation. March 1, 2012. EUI Working Papers LAW, n.2012/08. Available at SSRN: <http://ssrn. com/abstract $=2069916$ or http://dx.doi.org/10.2139/ ssrn.2069916>

PINTO JUNIOR, Helder Queiroz et al. Economia da energia: fundamentos econômicos, evolução histórica e organização industrial. Rio de Janeiro: Elsevier, 2007.

PRAZERES, Tatiana Lacerda. A OMC e os blocos regionais. São Paulo: Aduaneiras, 2008.

RUBINI, Luca. the subsidization of renewable energy in the WTO: issues and perspectives. Disponível em: $<$ http://papers.ssrn.com/sol3/papers.cfm?abstract $\underline{\mathrm{id}=1933863>}>$. Acesso em: 31 out. 2011.

SAKMAR, Susan L. Bringing energy trade into the WTO: the historical context, current status, and potential implications for the middle east region (2008), Indiana International \& Comparative Law Review, v. 18, n. 1, p. 89, 2008. Disponível em: <http://ssrn.com/ abstract $=1995896>$ Acesso em: 25 nov. 2011.
SELIVANOVA, Yulia (Org.). Challenges for multilateral energy trade regulation: WTO and Energy Charter. Disponível em: <http://papers.ssrn.com/sol3/papers. cfm?abstract_id=1632557>. Acesso em: 31 out. 2011.

SELIVANOVA, Yulia (Org.). Regulation of energy in international trade law: WTO, nafta and energy charter. Kluwer Law International: 2011.

SELIVANOVA, Yulia (Org.). The WTO and energy WTO rules and agreements of relevance to the Energy Sector. International Centre for Trade and Sustainable Development - ICTSD. Disponível em: <http://ictsd. org/downloads/2008/05/the20wto20and20energy. pdf> Acesso em: 24 out. 2011.

SHIH, Wen-chen. Energy Security, GATT / WTO and Regional Agreements. SIEL, n. 10. 2008. p. 41.

SIMPSON, Robin. Energy: sustainable access for all. Consumer Policy Review, v. 16, n. 2, p. 66-74, 2006. Disponível em: <http://search.ebscohost.com/login. aspx?direct $=$ true $\& d b=$ buh $\& A N=20847488 \&$ site $=$ eho st-live \&scope $=$ site $>$.

SUSSMAN, Edna. A multilateral energy sector investment treaty: is it time for a call for adoption by all nations? International Lawyer, v. 44, n. 3, p. 939, 2010. Disponível em: <http://go.galegroup.com/ps/i.do?id= GALE $\mid$ A $248263440 \& v=2.1 \& u=$ capes $58 \&$ it $=r \& p=A$ $\mathrm{ONE} \& \mathrm{sw}=\mathrm{w}>$.

TEIXEIRA, Anderson Vichinkeski. Teoria pluriversalista do direito internacional. São Paulo: WMF Martins Fontes, 2011.

THORSTENSEN, Vera. A OMC: Organização Mundial do Comércio e as negociações sobre investimentos e concorrência. Revista Brasileira de Política Internacional, Brasília, v. 1, n. 41, p. 57-89, 1998. p. 6970. Disponível em: <http://www.scielo.br/pdf/rbpi/ v41n1/v41n1a04>. Acesso em: 06 fev. 2014.

THORSTENSEN, Vera. Organização Mundial do Comércio: as regras do comércio internacional e a nova rodada de negociações multilaterais. 2. ed. São Paulo: Aduaneiras, 2001.

THORSTENSEN, Vera; et. al. A regulação do comércio internacional de energia: combustíveis e energia elétrica. São Paulo: FIESP, 2013. 
TRINDADE, Antônio Augusto Cançado. Direito das organizações internacionais. 5. ed. rev. atual e ampl. Belo Horizonte: Del Rey, 2012.

UNCTAD. World Investment Report 2014. Disponível em: $<$ http://unctad.org/en/PublicationsLibrary/wir2014_ overview_en.pdf $>$. Acesso em: 17 nov. 2014.

WORIKA, Ibibia L. Production, management, OPEC and the WTO. In: PAUWELYN, Joost. Global Challenges at the intersection of trade, energy and the environment. Genebra: The Graduate Institute, Center for Trade and Economic Integration, 2010. p. 87-93. Disponível em: $<$ http://graduateinstitute.ch/ctei/publications_list/ global.html> Acesso em: 15 nov. 2012.

YANOVICH, Alan. WTO rules and the energy sector. In: SELIVANOVA, Yulia (Org.). Regulation of energy in international trade law: wto, nafta and energy charter. Kluwer Law International: 2011. p. 1-48. 


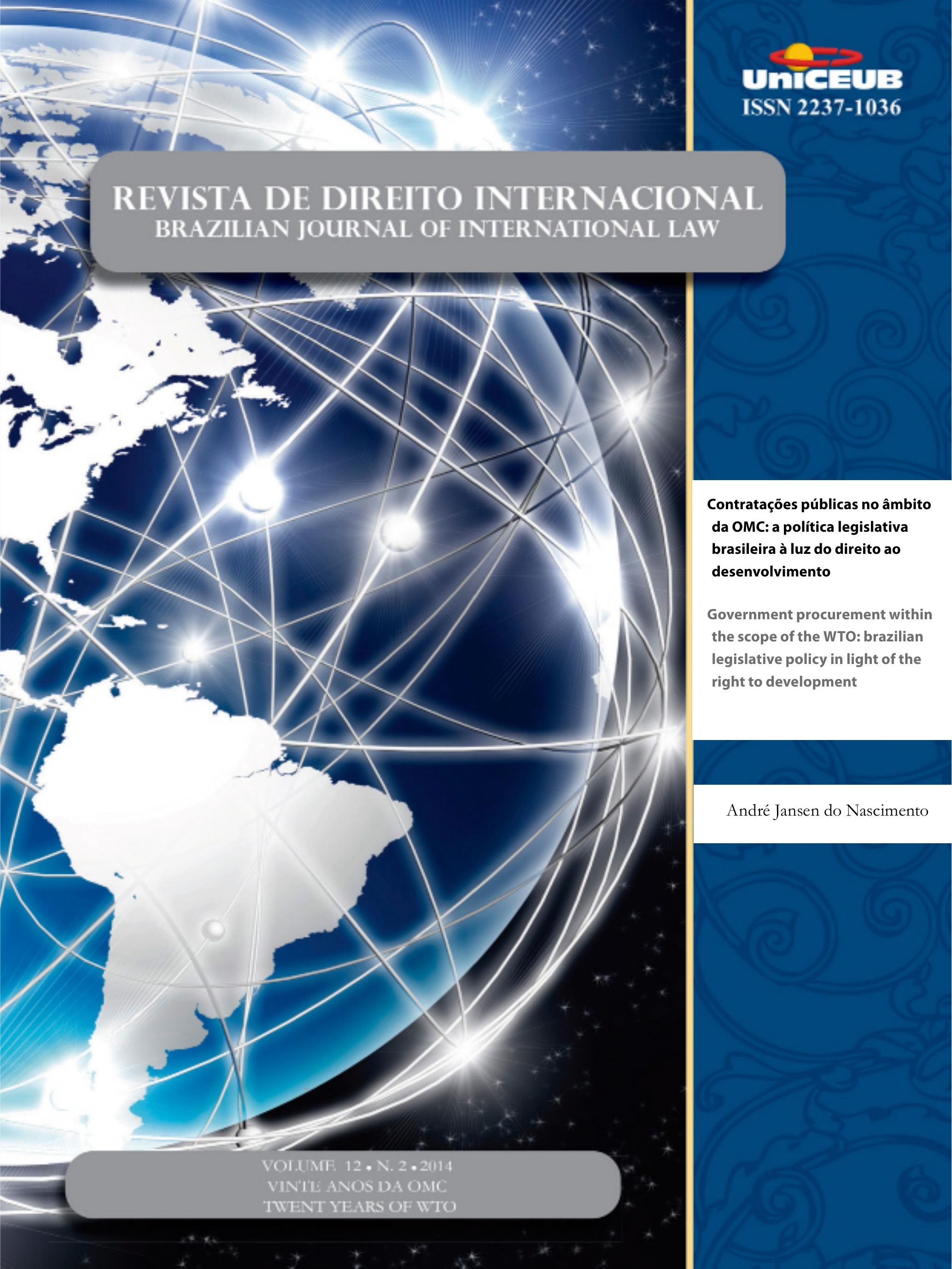




\title{
Contratações públicas no âmbito da OMC: a política legislativa brasileira à luz do direito ao desenvolvimento*
}

\author{
Government procurement within the scope of the \\ WTO: brazilian legislative policy in light of the right \\ to development
}

André Jansen do Nascimento**

\section{Resumo}

O tema comércio internacional e direito ao desenvolvimento, sob a perspectiva das compras governamentais, tem sido objeto de discussões importantes, principalmente no que diz respeito à adesão dos países em desenvolvimento às regras existentes no âmbito do Acordo sobre Compras Governamentais (GPA, ou Government Procurement Agreement) da OMC, que em 2014 completou vinte anos de sua assinatura. O presente artigo tem por objetivo apresentar um estudo jurídico acerca da postura política legislativa brasileira no plano das compras governamentais, diante de um aparente conflito de interesses normativos no Direito Internacional e à luz das normas e princípios contidos na Declaração sobre o Direito ao Desenvolvimento da ONU e no GPA, a fim de verificar se há uma tendência legislativa protecionista de mercado das compras públicas nacionais ou se o Brasil privilegia a liberalização comercial no setor público. Para tanto, o estudo desenvolveu-se por meio do método comparativo, no qual, em um primeiro momento, analisou-se o direito fundamental ao desenvolvimento, nos planos normativos internacional e nacional. Em seguida, explorou-se o GPA sob o prisma das iniciativas propostas nas Reuniões Ministeriais, desenvolvidas ao longo dos seus vintes anos, bem como o de sua flexibilização. Posteriormente, investigou-se a política legislativa de compras governamental brasileira, destacando-se a intensa utilização da licitação como instrumento de políticas públicas econômicas, sociais e ambientais. Conclui-se que, ao não aderir ao GPA, o Brasil adotou uma postura de política protecionista do mercado de compras públicas, em que atualmente é questionada a efetividade do mecanismo da margem de preferência, bem como se esta se encontra sob pressão em razão da aproximação de parceiros comerciais ao Acordo da OMC. Em relação à temática do artigo, pode-se afirmar que o assunto é inquietante e dinâmico e que o ponto de vista apresentado é inédito e valioso, quando se considera o estudo das compras governamentais sob a lente do aparente conflito de normas e princípios basilares do Direito Internacional.

Palavras-chaves: Comércio internacional. OMC. Desenvolvimento. Compras governamentais. Políticas discriminatórias.

* Recebido em: 25.10.2014

Aceito em: 30.11 .2014

** Mestre em Direito pelo UniCeub, andre.wdc@hotmail.com.

\section{Abstract}

The theme of international trade and the right to development, from the perspective of government procurement, has been the subject of many important discussions. In particular, there has been much debate about the adherence 
of developing countries to the existing rules under the WTO Agreement on Government Procurement (GPA), which in 2014 marked 20 years since its signing. The purpose of this paper is to present a legal analysis of Brazilian legislative policy regarding government procurement in response to an apparent conflict of interests of normative international law and in light of the rules and principles contained in the Declaration on the Right to Development of the UN and the GPA. This analysis verified if there is a trend towards protectionist legislation in national public procurement or if Brazil privileges trade liberalization in the public sector. To this end, the study was developed using a comparative method, in which it first analyzed the fundamental right to development in international and national regulatory plans. We then explored the GPA through the prism of the initiatives proposed at ministerial meetings, developed over its 20 years of existence, in addition to its flexibility. Subsequently, the legislative policy of Brazilian government purchases was investigated, with special emphasis to the intense use of public procurement as a tool for economic, social and environmental policies. In conclusion, it was determined that by not joining the GPA, Brazil adopted a protectionist policy regarding the government procurement market. Nowadays, this attitude has been questioned as to the effectiveness of the margin of preference mechanism and is under pressure due to the approximation of commercial partners to the WTO agreement. Regarding the theme of this article, it can be stated that the subject matter at hand is an instigating and dynamic one and that the view presented here is novel and can contribute to the study of government procurement, through the lens of the apparent conflict of regulations and basic principles of international law.

Keywords: International trade. WTO. Development. Government procurement. Discriminatory policies.

\section{Introdução}

A temática das compras governamentais estáinserida em um campo de pesquisa dinâmico, no qual diversas questões jurídicas, econômicas, de políticas públicas e de relações comerciais formam uma combinação que é complexa para ambos os setores, o público e o privado. Para o primeiro, as questões relacionadas às compras e sua regulação podem ser instrumentos de efetivação de políticas públicas, quer sejam econômicas, sociais ou ambientais. Para o segundo, significam a maior ou uma das maiores oportunidades de negócios, em razão dos valores envolvidos e da visão de que o Estado é o mais importante cliente na maioria das economias ao redor do mundo.

A compreensão do fenômeno jurídicoadministrativo da contratação pública não pode prescindir da análise de sua necessária correspondência com o contexto político, econômico, social e cultural, verificável e real, em que opera de modo dinâmico, em movimento e realização, e que se circunscreve historicamente em sua concretização.

De caráter bastante atual, a presente pesquisa tem por finalidade contribuir para a consolidação do entendimento de que as relações comerciais entre as nações causam impactos, na efetivação dos direitos humanos e nas possibilidades de desenvolvimento dos Estados e das pessoas, devendo haver uma aproximação desses três temas: direitos humanos, relações comerciais e desenvolvimento.

Assim, por muito tempo, o direito ao desenvolvimento foi interpretado, pelos Estados em desenvolvimento ou menos desenvolvidos, ${ }^{1}$ como um proeminente direito relacionado a obrigações externas a esses grupos, no qual os países desenvolvidos teriam o dever de promover o desenvolvimento daqueles menos favorecidos. Obviamente, um direito fundamentado somente em obrigações de terceiros tornar-se-ia um direito político, sendo efetivado apenas por acordos de "boas intenções" em decisões políticas. Assim, o conceito de direito ao desenvolvimento deveria ser ampliado, exigindo ações pragmáticas e atribuindo, da mesma forma, aos países em desenvolvimento e menos desenvolvidos, responsabilidades de promoção do desenvolvimento, por meio de políticas públicas domésticas. $^{2}$

Simultaneamente aos fenômenos da ampliação do conceito de desenvolvimento e da consolidação dos direitos humanos, em meados da década de 1990, as compras governamentais tiveram seu paradigma modificado de atividade secundária e instrumental, com

1 O Acordo Geral de Tarifas e Comércio (GATT) inicialmente se referia a dois grupos de países: os desenvolvidos e os menos desenvolvidos. Os países em desenvolvimento passaram a constituir um novo grupo a partir da criação da Cláusula de Habilitação, em 1979.

2 SALDANHA, Eduardo. Desenvolvimento e tratamento especial diferenciado na OMC: uma abordagem sob a perspectiva da doutrina do stare decisis - Parte II. Revista de Direito Econômico Socioambiental, Curitiba, v. 3, n. 2, jul./dez. 2012. p. 310. 
o fim de atender uma demanda imediata do Estado, para instrumento de desenvolvimento econômico, em razão dos valores empregados na atividade contratual estatal. Dessa percepção, diversos marcos internacionais foram estabelecidos por organismos e blocos internacionais de importante representação, como, por exemplo, Organização Mundial do Comércio (OMC), United Nations Commission on International Trade Law (UNCITRAL) e North American Free Trade Agreement (NAFTA), a fim de reconhecer a importância do Estado como contratante.

Estabelecida a aproximação dos temas direitos humanos, relações comerciais e desenvolvimento, posteriormente faz-se necessária a análise da internação do plano normativo internacional das compras públicas, com ênfase no Acordo sobre Compras Governamentais da OMC (Government Procurement Agreement- GPA), que completa vinte anos, no plano jurídico internacional.

No sistema policêntrico ${ }^{4}$ de produção do direito, no qual não há somente a fonte estatal, não se pode mais considerar o Poder Legislativo como o titular do monopólio de sua produção. $\mathrm{Na}$ pluralidade normativa, tem-se a incorporação de ditames locais, regionais, nacionais, comunitárias e internacionais. Por conseguinte, atualmente, o regime de compras governamentais é regulado em três ordens: $i$ ) interno (nacional e local); ii) internacional (produto de pactos, acordos e convenções); e iii) o concreto particular, no âmbito de cada contrato celebrado. ${ }^{5}$

Partindo-se da premissa de que problemas globais requerem soluções globais, a internacionalização da questão da regulação das compras públicas apresenta desafios que se referem a obstáculos práticos à competição, transparência e igualdade de tratamento, entre outras questões, ou que implica outros aspectos como a harmonização de normas, o adequado uso de

3 HERNANDEZ-GARCIA, Roberto. Introduction: the global challenges of international public procurement. In:

International Public Procurement. London: Globe Law and Business, 2009. p. 10.

4 Sistema jurídico que tem por característica a capacidade de substituir "a coerção pelo consenso, o comando pela negociação, a decisão imperativa pela persuasão, a intervenção controladora por mecanismos descentralizados de auto direção e, por fim, a responsabilização individual pela organizacional, nas condutas potencialmente comprometedoras do equilíbrio sistêmico da sociedade." Segundo FARIA, José Eduardo. O direito na economia globalizada. São Paulo: Malheiros, 1999. p. 194.

5 DROMI, Roberto. Licitación pública. 4. ed. Buenos Aires: Hispania Libros, 2010. p. 2. tecnologia, a luta contra a corrupção, a sustentabilidade ambiental e a defesa da competição nas contratações públicas contra qualquer forma de distorção.

Diante do problema posto, o artigo tem por objetivo confirmar a hipótese de que o legislador brasileiro, ao estabelecer o plano normativo nacional de compras governamentais e segundo o conceito de policy space, harmonizou a norma brasileira ao Direito Internacional ao adotar e privilegiar o direito fundamental ao desenvolvimento econômico, com verdadeiro status de norma jus cogens, ${ }^{8}$ disposto na Declaração sobre o Direito ao Desenvolvimento da Organização das Nações Unidas - ONU (1986). Ao mesmo tempo, optou por não aderir ao GPA (1994), da OMC, pois, fazendo isso, em tese poderia contrariar o Princípio da Não-Discriminação, ao

6 HERNANDEZ-GARCIA, Roberto. Introduction: the global challenges of international public procurement. In:

International Public Procurement. London: Globe Law and Business, 2009.p. 9.

$7 \quad$ Policy Space trata da liberdade de escolha, conferida aos países em desenvolvimento, para optar pela melhor combinação de políticas possíveis para alcançar um desenvolvimento econômico sustentável e equitativo, segundo o seu único e individual caráter social, político, econômico e condições ambientais. Ele se refere ao espaço para políticas nacionais, especialmente nas áreas de comércio, investimento e desenvolvimento industrial e reflete a ideia de que os governos devem ter flexibilidade para avaliar o tradeoff entre os benefícios de aceitar regras internacionais e as restrições impostas pela perda de espaço político. Disponível em: <http://www.eldis.org/vfile/upload/1/document/0708/ DOC20476.pdf > . Acesso em: 30 set. 2014.

8 Dispõem o artigo 53 da Convenção de Viena sobre Direito dos Tratados de 1969 que: "A norma do jus cogens é aquela norma imperativa de Direito Internacional geral, aceita e reconhecida pela sociedade internacional em sua totalidade, como uma norma cuja derrogação é proibida e só pode sofrer modificação por meio de outra norma da mesma natureza". Já para o Dicionário Diplomático, jus cogens significa o direito taxativo, ou seja, o conjunto de normas inderrogáveis mediante consentimento das partes e que não admitem pacto contrária dada à natureza do bem que tais normas tutelam: a ordem pública. A tais normas designadas por imperativas, opõemse outras que dependem da vontade das partes, ou seja, normas dispositivas.

9 O Artigo III: 1 e 2 do GPA dispõe sobre o princípio fundamental de Não-Discriminação. Primeiramente, uma Parte do GPA deve estabelecer tratamento "não menos favorável" a produtos, serviços e fornecedores de outras Partes do GPA do que o tratamento dado aos produtos, serviços e fornecedores domésticos. Além disso, uma Parte do GPA deve tratar os produtos, serviços ou fornecedores de uma Parte do GPA não menos favoravelmente do que o tratamento determinado a qualquer outra Parte do GPA (não-discriminação entre Partes estrangeiras do GPA). Ademais, o GPA obriga as Partes a garantir que as entidades governamentais não discriminem entre fornecedores locais devido à participação 
adotar privilégios aos produtos e empresas nacionais, por meio do afastamento do processo licitatório e da aplicação da margem de preferência, para adjudicação do contratado. Para atingir tal objetivo, o autor utiliza-se do método comparativo ao analisar os planos normativos internacionais (OMC e ONU) e nacionais (Constituição Federal de 1988 e legislação infraconstitucional de compras governamentais).

Inicialmente, o artigo tratará do direito fundamental ao desenvolvimento no Direito Internacional e na Constituição de Federal de 1988 e, posteriormente, abordará o plano normativo sobre compras governamentais da OMC, especificamente no que se refere ao Acordo sobre Compras Governamentais, com ênfase no Princípio da Não-Discriminação. Em seguida, será estudada a internação do direito ao desenvolvimento na legislação brasileira de compras governamentais, destacando-se a aplicação da margem de preferência aos produtos nacionais. $\mathrm{Da}$ análise dos planos normativos, dos princípios e do direito fundamental, o artigo concluirá sobre a postura política adotada pelo Brasil em matéria de compras governamentais. Adverte-se que, pela dimensão e importância do tema, não se tem o intuito e nem a possibilidade de exploração plena do assunto; todavia, tem-se por objetivo contribuir para a discussão acadêmica ao levantar mais um ponto de vista sobre essa temática, de característica tão dinâmica quanto instigante.

\section{Plano normativo da ONU e o direito fundamental ao desenvolvimento}

O presente tópico iniciar-se-á com o seguinte questionamento: qual é a relação entre o direito internacional e o desenvolvimento econômico? Certamente, pode haver diversas respostas e de natureza bem diferente, se essa questão for posta a um país desenvolvido ou a um país em desenvolvimento ou de menor desenvolvimento relativo. Assim, a

estrangeira ou afiliação, e que tais entidades não discriminem entre entidades locais devido ao local de produção do bem ou serviço fornecido, sob a condição de que as Regras de Origem do Artigo IV do GPA sejam respeitadas. Esse dispositivo dá ao princípio da NãoDiscriminação uma aplicação mais efetiva, uma vez que visa às ações individuais das entidades governamentais e evita a discriminação individual. Para garantir o princípio da Não-Discriminação, o Artigo III é complementado por outros dispositivos constantes do Acordo, que enfatizam os procedimentos para assegurar transparência das leis, regulamentos, procedimentos e práticas relacionadas às Compras Governamentais. resposta somente pode ser dada pelo próprio direito internacional, ${ }^{10}$ e resta uma afirmação provocativa de Paul Samuelson, em 1976, de que "nenhum esclarecimento foi oferecido até hoje para explicar por que os países pobres são pobres e os países ricos são ricos." $" 11$

Considerando o direito como estratégico para o desenvolvimento, aquele passou a ser visto como instrumento destinado à regulação das relações entre agentes privados e Estado com vistas a aumentar a eficiência econômica. Dessa maneira, o direito seria responsável por proporcionar um ambiente de garantia da transparência e da segurança nas relações econômicas mediante a proteção ao direito de propriedade, edição de normas contratuais e societárias, que garantissem segurança e fluidez, e manutenção de um sistema judicial efetivo. ${ }^{12}$

O direito ao desenvolvimento envolve conflitos distributivos que precisam ser analisados sob a luz da conexão de distribuição e justiça, afastando-se a ideia das relações não somente no plano econômico, mas também nas possíveis reflexões normativas pertinentes ao direito contemporâneo. Sob a lente econômica, o desenvolvimento não tem qualquer compromisso prévio com uma concepção jurídica ou moral de desenvolvimento. Colocado em perspectiva de sua natureza jurídica, desperta questionamentos como, por exemplo, se esse é realmente um direito ou um princípio e se ele pode ser utilizado como padrão para as decisões judiciais. ${ }^{13}$

Com as ideias colocadas por John Keynes, que propôs um aumento da intervenção estatal na economia como modo de corrigir os malefícios gerados pelo sistema capitalista de produção, o direito

10 COSTA, Ligia Maura. OMC e direito internacional do desenvolvimento sustentável. São Paulo: Quartier Latin, 2013. p. 243.

11 LANDES, David S. A riqueza e a pobrez̧a das nações: por que algumas são tão ricas e outras tão pobres. Rio de Janeiro: Campus, 1998.

12 CUNHA, Luciana Gross; LANGENEGGER, Natalia. Litígio de interesse público e desenvolvimento. O direito ao desenvolvimento sob a perspectiva do pensamento jurídico contemporâneo. In: SILVEIRA, Vladmir Oliveira da; NASPOLINI SANCHES, Samyra; COUTO, Monica Benetti. (Org.). Direito e desenvolvimento no Brasil no século XXI. Brasília: IPEA; CONPEDI, 2013. p. 93.

13 DIAS, Jean Carlos. O direito ao desenvolvimento sob a perspectiva do pensamento jurídico contemporâneo. In: SILVEIRA, Vladmir Oliveira da; NASPOLINI SANCHES, Samyra; COUTO, Monica Benetti. (Org.). Direito e desenvolvimento no Brasil no século XXI. Brasília: IPEA; CONPEDI, 2013. p. 32. 
ao desenvolvimento apresenta-se como uma dimensão dos direitos humanos econômicos, nivelando seu campo de interesse de livre mercado e de justiça social, com a intervenção dirigente do poder público, que observa o comportamento dos agentes do setor e de sua correspondência com os valores concernentes ao primado dos direitos humanos. Como desdobramento destes, o direito ao desenvolvimento constitui-se em uma prerrogativa inerente à natureza humana, surgindo daí a necessidade estatal de elaborar e consagrar políticas públicas voltadas para sua concretização. ${ }^{14}$

No direito internacional, o direito ao desenvolvimento foi situado nos diversos acordos e tratados internacionais, que têm por finalidade regulamentar as condições mínimas e vitais para a humanidade. A primeira referência ao respectivo direito foi disposta na Carta das Nações Unidas, de 26 de junho de 1946, no artigo $1^{\circ}$, que trata dos objetivos das Nações Unidas, em seu parágrafo $3^{\circ}$, ao estipular que seja realizada a cooperação internacional, com a resolução dos problemas internacionais de caráter econômico, social, cultural ou humanitário, promovendo e estimulando o respeito pelos direitos do homem e pelas liberdades fundamentais para todos, sem distinção de raça, sexo, língua ou religião. Para realizar tal objetivo, no mesmo diploma, no capítulo X, foi criado o Conselho Econômico e Social, estabelecendo funções e atribuições que são exercidas por meio de suas comissões e que têm como escopo o estudo de questões econômicas e sociais e a proteção dos direitos humanos.

Em 1948, a Declaração Universal dos Direitos Humanos (DUDH), considerada como um documento marco na história dos direitos humanos, por ter sido elaborada por representantes de diferentes origens jurídicas e culturais de todas as regiões do mundo, estabeleceu a proteção universal dos direitos humanos pela primeira vez. A Declaração foi proclamada pela Assembleia Geral das Nações Unidas, em Paris, em 10 de dezembro de 1948, por meio da Resolução 217 A (III) da Assembleia Geral. Assim como na Carta das Nações Unidas, na DUDH está disposto no seu artigo XXI que todo ser humano, como membro da sociedade,

14 SILVEIRA, Vladmir Oliveira da; NASPOLINI SANCHES, Samyra. Direito e desenvolvimento no Brasil do século XXI: uma análise da normatização internacional e da Constituição Brasileira. In: SILVEIRA, Vladmir Oliveira da; NASPOLINI SANCHES, Samyra; COUTO, Monica Benetti. (Org.). Direito e desenvolvimento no Brasil no século XXI. Brasília: IPEA; CONPEDI, 2013. p. 124. tem direito à segurança social, à realização pelo esforço nacional, pela cooperação internacional e de acordo com a organização e recursos de cada Estado, dos direitos econômicos, sociais e culturais indispensáveis à sua dignidade e ao livre desenvolvimento da sua personalidade.

A fim de complementar as diretrizes contidas na DUDH, foi assinado o Pacto Internacional sobre Direitos Econômicos, Sociais e Culturais (PIDESC), adotado pela Assembleia Geral da ONU, em 1966, constituindo-se no principal instrumento internacional deproteção dos Direitos Econômicos, Sociais e Culturais e consolidando uma série de direitos já declarados na DUDH. O PIDESC, ao lado da Declaração e do Pacto dos Direitos Civis e Políticos, configura-se como instrumento da denominada Declaração Internacional de Direitos Humanos.

Atualmente, as mais importantes declarações e resoluções pertinentes ao direito do desenvolvimento utilizados no direito internacional são: $i$ ) Resolução $n^{\circ}$ 2.626 - estratégia Internacional do Desenvolvimento; ii) Resolução no 3.201 - Declaração da Nova Ordem Econômica Internacional; iii) Resolução no 3.202 Declaração do Programa de Ação; e iv) Resolução n ${ }^{\circ}$ 3.291 - Carta dos Direitos e deveres Econômicos dos Estados. $^{15}$

Como assinalado no primeiro dos Princípios Linburg, ${ }^{16}$ os direitos econômicos, sociais e culturais, como instrumentos fundamentais ao desenvolvimento, formam parte integral do direito internacional dos direitos humanos, sendo esse direito objeto de obrigações específicas contratadas no contexto de vários

15 SILVEIRA, Vladmir Oliveira da; NASPOLINI SANCHES, Samyra. Direito e desenvolvimento no Brasil do século XXI: uma análise da normatização internacional e da Constituição Brasileira. In: SILVEIRA, Vladmir Oliveira da; NASPOLINI SANCHES, Samyra; COUTO, Monica Benetti. (Org.). Direito e desenvolvimento no Brasil no século XXI. Brasília: IPEA; CONPEDI, 2013. p. 126.

16 Um grupo de especialistas de destaque no campo do direito internacional, convocado pela Comissão Internacional sobre Juristas, da Faculdade de Direito Universidade de Limburg (Maastricht, Países Baixos) e do Instituto de Direitos Urban Morgan Humana da Universidadede Cincinnati (Ohio, EUAAmerica), reuniu-se em Masstricht, no período de 2 a 6 de junho 1986, com o propósito de analisar a natureza e a extensão das obrigações dos Estados Partes no âmbito do Pacto Econômico Internacional, Social e Culturais. Do encontro, surgiram os princípios Linburg. Disponível em: <http:// www.derechoshumanos.unlp.edu.ar/assets/files/documentos/losprincipios-de-limburg-sobre-la-aplicacion-del-pacto-internacionalde-derechos-economicos-sociales-y-culturales-2.pdf $>$. Acesso em: 26 ago. 2014. 
instrumentos internacionais, especialmente o PIDESC. No mesmo documento, no princípio de número onze, ressalta-se a importância da participação de todos os setores, em especial da participação popular, em cada etapa do processo, incluindo a formulação, aplicação e revisão de políticas nacionais, com o objetivo de realização dos direitos acima citados. ${ }^{1}$

Não obstante os documentos normativos já citados, o direito ao desenvolvimento se consagra definitivamente como direito fundamental, quando da aprovação da Declaração sobre o Direito ao Desenvolvimento, da ONU, em 14 de dezembro de 1986, adotada pela resolução no 41/128 da Assembleia Geral das Nações Unidas. Com um extenso preâmbulo e dez artigos, a Declaração firma o entendimento de desenvolvimento como um processo econômico, social, cultural e político abrangente, que visa à melhoria constante do bem-estar de toda a população e de todos os indivíduos com base na sua participação ativa, livre e significativa no processo de desenvolvimento e na justa distribuição dos benefícios dele derivados.

A Declaração proclama, no primeiro eixo, que o direito ao desenvolvimento é inalienável em virtude do fato de que todos os seres humanos e todos os povos têm o direito de participar, de contribuir e de gozar do desenvolvimento econômico, social, cultural e político, de forma que todos os direitos humanos e liberdades fundamentais se possam plenamente realizar. No segundo eixo, o respectivo direito humano implica também a plena realização do direito dos povos à autodeterminação, o qual inclui, sem prejuízo das disposições pertinentes de ambos os Pactos Internacionais sobre Direitos Humanos, o exercício do seu direito inalienável à plena soberania sobre todas as suas riquezas e recursos naturais.

Portanto, os Direitos Humanos e, entre eles, o direito ao desenvolvimento, compreendido como direito de terceira geração e de caráter difuso, devem ocupar uma posição hierarquicamente superior aos demais tratados internacionais com verdadeiro status de norma jus cogens, para que se garanta o cumprimento de todas as normas

17 UNIVERSIDAD NACIONAL DE LA PLATA. Los principios de Limburg sobre la aplicación del pacto internacional de derechos económicos, sociales y culturales. Disponível em: $<$ http:// www.derechoshumanos.unlp.edu.ar/assets/files/documentos/losprincipios-de-limburg-sobre-la-aplicacion-del-pacto-internacionalde-derechos-economicos-sociales-y-culturales-2.pdf $>$. Acesso em: 26 ago. 2014. garantidoras do desenvolvimento sem que se olvide dos critérios estruturantes de transformação social.

Não mais sendo discutível a natureza do direito ao desenvolvimento como direito fundamental e jus cogens, faz-se necessário classificá-lo. Pelo seu caráter difuso, reconhecido pela indivisibilidade dos bens que tutela, o direito ao desenvolvimento pode ser classificado, como dito, como pertencente à terceira geração, de natureza difusa, sendo considerado como um "direito de solidariedade".

$$
\begin{aligned}
& \text { Os indivíduos, nessa acepção, são os destinatários } \\
& \text { reais dos benefícios, mas somente o são } \\
& \text { mediatamente, uma vez que - notadamente - } \\
& \text { sobrepõe-se o interesse coletivo ao individual. }{ }^{18}
\end{aligned}
$$

Por fim, conclui-se parcialmente que, com a exposição do plano internacional sobre o direito ao desenvolvimento, fica assim disposto que o Estado passa a ser o sujeito passivo dessa relação e o principal responsável em criar as condições favoráveis ao desenvolvimento supranacional e interno dos povos e dos indivíduos. ${ }^{19}$ Em seguida, será analisado o direito fundamental ao desenvolvimento no âmbito da Constituição Federal do Brasil de 1988.

\section{O direito fundamental ao desenvolvimento na Constituição Federal de 1988}

Como analisada no tópico anterior, a Declaração sobre o Direito ao Desenvolvimento de 1986 vem sendo considerada parte integrante da Carta Internacional dos Direitos Humanos, ao lado da Carta de São Francisco, da Declaração Universal dos Direitos Humanos e dos dois Pactos Internacionais de Direitos de 1966: o Pacto Internacional sobre Direitos Econômicos, Sociais e Culturais; e o Pacto dos Direitos Civis e Políticos. $\mathrm{Na}$ Declaração de 1986, está previsto no artigo $6^{\circ}$, item 2, que "todos os direitos humanos e liberdades fundamentais são indivisíveis e interdependentes; atenção igual e consideração urgente devem ser dadas

18 PEIXINHO, Manoel Messias; FERRARO, Suzani Andrade. Direito ao desenvolvimento como direito fundamental. In: CONGRESSO NACIONAL DO CONPEDI. p. 6952-6971. Disponível em: <http://www.conpedi.org.br/manaus/arquivos/anais/bh/ manoel_messias_peixinho.pdf $>$. Acesso em: 26 ago. 2014.

19 SILVEIRA, Vladmir Oliveira da; NASPOLINI SANCHES, Samyra. Direito e desenvolvimento no Brasil do século XXI: uma análise da normatização internacional e da Constituição Brasileira. In: SILVEIRA, Vladmir Oliveira da; NASPOLINI SANCHES, Samyra; COUTO, Monica Benetti. (Org.). Direito e desenvolvimento no Brasil no século XXI. Brasília: IPEA; CONPEDI, 2013. p. 127-128. 
à implementação, promoção e proteção dos direitos civis, políticos, econômicos, sociais e culturais".

Como signatário dos principais tratados e pactos internacionais sobre a questão do desenvolvimento, o Brasil estabeleceu em sua Constituição Federal de 1988 alguns dispositivos constitucionais no sentido de promover tal direito fundamental, como veremos a seguir. Não obstante, há um intenso debate na doutrina e na jurisprudência em relação à incorporação dos tratados internacionais de direito humanos (TIDH) no ordenamento jurídico brasileiro, no qual se destacam quatro linhas de pensamento, quanto ao reconhecimento da natureza e hierarquia dos TIDH em relação ao direito pátrio: $i$ ) corrente que reconhece a natureza supranacional; ii) corrente que reconhece a natureza constitucional; iii) corrente que reconhece a natureza de lei ordinária; e iv) corrente que reconhece a natureza supralegal. ${ }^{20}$

No presente trabalho, adota-se o entendimento segundo o qual os tratados de Direitos Humanos possuem estatura constitucional, assegurando a essas normas a aplicabilidade imediata em nível nacional e internacional desde o ato de ratificação, escusando intermediações legislativas, em face do seu caráter especial em relação aos tratados internacionais sobre as demais matérias. Sob a lente utilizada, os conflitos emergentes entre o tratado e a Constituição devem ser solucionados pela aplicação da norma mais favorável à vítima da violação do direito humano, titular do direito, tarefa hermenêutica de incumbência dos tribunais nacionais e dos órgãos de aplicação do Direito. ${ }^{21}$

$\mathrm{Na}$ vigente Constituição Federal, a interpretação sistêmica de seus dispositivos leva-nos a concluir

20 EMERIQUE, Lilian Balmant; GUERRA, Sidney. A incorporação dos tratados internacionais de direitos humanos na ordem jurídica brasileira. Revista Jurídica, Brasília, v. 10, n. 90, p.01-34, abr./maio, 2008. Ed. Esp. Disponível em: < http://www.planalto.gov. br/ccivil_03/revista/Rev_90/Artigos/PDF/SidneyGuerra_Rev90. pdf>. Acesso em: 30 ago. 2014. Sobre a relação entre os tratados internacionais de direitos humanos e a Constituição Federal Brasileira, os autores entendem que a hierarquia dos tratados é estabelecida conforme o atendimento de requisitos dispostos no $\$ 3^{\circ}$, do art. $5^{\circ}$, da $\mathrm{CF}$, ou não. No primeiro caso, conforme o $\$ 3^{\circ}$, os tratados e convenções internacionais sobre direitos humanos que forem aprovados, em cada Casa do Congresso Nacional, em dois turnos, por três quintos dos votos dos respectivos membros, serão equivalentes às emendas constitucionais. No segundo caso, o entendimento jurisprudencial é de que se trata de normas supralegais (STF).

21 PIOVESAN, Flávia. A Constituição Brasileira de 1988 e os tratados internacionais de proteção dos direitos humanos. In: Temas de direitos humanos. 2. ed. São Paulo: Max Limonad, 2003. p. 44-56. sobre a prevalência do princípio da compatibilização do interesse privado com o coletivo e difuso, não podendo os últimos oprimir os interesses individuais. Assim, o interesse coletivo deve ser compatibilizado com a livre iniciativa e com o princípio da liberdade econômica, em virtude de que a liberdade privada não pode ser suprimida em um sistema capitalista. ${ }^{22}$ Não se pode pensar num Estado comprometido com o desenvolvimento nacional, fundamentado somente no critério econômico, mas sim aliado a critérios estruturantes de transformação social.

O texto da Carta Magna de 1988 estabeleceu expressamente a garantia ao desenvolvimento nacional, como um dos objetivos fundamentais da República do Brasil, no inciso II do artigo $3^{\circ}$, bem como reconheceu, em seu elenco de direitos fundamentais, o denominado direito ao desenvolvimento. O reconhecimento desse direito tem por consequência o dever do Estado em intervir na esfera privada, por meio de incentivo, fomento e condução do desenvolvimento, principalmente nas etapas de formulação e implementação de políticas públicas que tenham por finalidade a efetivação dos direitos sociais, econômicos, culturais e ambientais. ${ }^{23}$

Em outra passagem, no preâmbulo da Constituição, o direito ao desenvolvimento restou consolidado ao dispor que, ao instituir o Estado Democrático, cabe assegurar, entre outros valores supremos de uma sociedade fraterna, pluralista e sem preconceitos, o desenvolvimento. Assim, tanto o governo como a Administração Pública devem agir para a concretização desse desiderato.

No que tange o direito ao desenvolvimento como direito fundamental, não há expressamente na Constituição disposição nesse sentido. Não obstante, pode-se afirmar que o respectivo direito enquadra-se na regra disposta pelo $\int 2^{\circ}$, do artigo $5^{\circ}$, que enuncia que os direitos e garantias expressos na Constituição não excluem outros decorrentes do regime e dos princípios

22 SILVEIRA, Vladmir Oliveira da; NASPOLINI SANCHES, Samyra. Direito e desenvolvimento no Brasil do século XXI: uma análise da normatização internacional e da Constituição Brasileira. In: SILVEIRA, Vladmir Oliveira da; NASPOLINI SANCHES, Samyra; COUTO, Monica Benetti. (Org.). Direito e desenvolvimento no Brasil no século XXI. Brasília: IPEA; CONPEDI, 2013. p. 131.

23 OLIVEIRA, Gustavo Henrique Justino de. Direito ao Desenvolvimento na Constituição Brasileira de 1988. Revista Eletrônica de Direito Administrativo Econômico, Salvador, n.16, nov./ dez./jan., p. 2. Disponível em: <http://www.direitodoestado. com/revista/REDAE-16-NOVEMBRO-2008-GUSTAVO $\% 20$ JUSTINO.pdf $>$. Acesso em: 30 set. 2014. p. 2. 
por ela adotados, ou dos tratados internacionais em que a República Federativa do Brasil seja parte. Logo, os direitos fundamentais fora do catálogo podem ser escritos, se presentes na Lei Maior ou em tratados internacionais, ou não escritos, decorrentes do regime e dos princípios. Faz-se necessário, para serem assim qualificados, que os direitos fundamentais fora de catálogo preencham os critérios de conteúdo (substância) e importância (relevância), para que possam ser equiparados aos direitos integrantes do elenco do Título dos Direitos e Garantias Fundamentais da Constituição Federal de $1988 .{ }^{24}$

Da defesa de que o direito ao desenvolvimento é um direito fundamental e da previsão da dignidade da pessoa humana, como fundamento da República (artigo $1^{\circ}$, III, CF), do qual todos os demais princípios derivam e que norteia todas as regras jurídicas, o Estado contemporâneo tem o papel indutor, promotor e garantidor do desenvolvimento nacional, tendo como norteador de suas ações a pessoa humana. Assim, é dever estatal "exercer ações em número, extensão e profundidade suficientes para bem desincumbir-se da obrigação constitucional de realizar um dos valores que fundamentam a República Federativa do Brasil: a dignidade da pessoa humana". ${ }^{25}$

Da mesma forma, a dignidade da pessoa humana é novamente abordada, quando da elaboração da Constituição econômica, na qual está inserida a ordem econômica brasileira, nos artigos 170 e seguintes da Constituição Brasileira vigente. No caput do artigo 170 está disposto que, a fim de assegurar a todos uma existência digna, conforme os ditames da justiça social, a ordem econômica brasileira deve ser fundada na valorização do trabalho e na livre iniciativa. $O$ constituinte brasileiro evidencia dessa forma que na Carta Magna de 1988 há o direito civil e empresarial, que regula os interesses individuais, e o direito econômico, que regula o direito difuso e o coletivo.

Para se atingir o fim de assegurar a todos a existência digna, o Estado tem a possibilidade de intervir na esfera econômica sempre que julgar necessário para se

24 SARLET, Ingo Wolfgang. A eficácia dos direitos fundamentais. 3. ed. Porto Alegre: Livraria do Advogado, 2003. p. 99.

25 OLIVEIRA, Gustavo Henrique Justino de. Direito ao Desenvolvimento na Constituição Brasileira de 1988. Revista Eletrônica de Direito Administrativo Econômico, Salvador, n. 16, nov./ dez./jan., p. 2. Disponível em: <http://www.direitodoestado. $\mathrm{com} /$ revista/REDAE-16-NOVEMBRO-2008-GUSTAVO $\% 20$ JUSTINO.pdf>. Acesso em: 30 set. 2014. p 10. alcançar os fins constitucionais e proteger e viabilizar os princípios por ela estabelecidos. A ordem econômica brasileira, por meio dos seus nove princípios, sistematiza o campo das atividades lucrativas e, ao mesmo tempo, "compatibiliza o seu desenvolvimento com a efetividade das políticas de redução das desigualdades sociais e erradicação da pobreza". ${ }^{26}$

Conclui-se que o direito ao desenvolvimento, entre os direitos econômicos, é um direito de intervenção na ordem econômica, considerando que a Constituição, embora reconheça o poder econômico, reconhece também que este pode ser exercido de forma contrária à efetivação de direitos sociais, cabendo nesses casos a intervenção estatal. Nesse sentido, a Constituição Brasileira outorga ao Estado a atividade de regulação da economia, no seu artigo 174, caput, atribuindo um papel de agente normativo e regulador da atividade econômica, por meio da execução de funções como fiscalizar, regular e planejar a economia, sendo essa última indicativa para o setor privado e determinante para o público.

Por fim, afirma-se que a atividade regulatória e normativa estatal tem por finalidade essencial a realização dos valores fundamentais da República, dispostos nos artigo $1^{\circ}$ e $3^{\circ}$ da Carta Magna, não fundamentando, portanto, suas ações estatais somente nos princípios da ordem econômica, arrolados no artigo constitucional 170. ${ }^{27}$ A seguir, serão explorados os principais fatos e considerações sobre o Government Procurement Agreement, ao longo dos seus vinte anos de vigência.

\section{Os vinte anos do Agreement on Government Procurement (GPA)}

Até o fim da década de 1980, as compras governamentais não eram reconhecidas como uma distinta e separada disciplina, sendo entendidas como um conjunto de regras puramente internas, utilizadas pelo Estado para contratar com o setor

26 SILVEIRA, Vladmir Oliveira da; NASPOLINI SANCHES, Samyra. Direito e desenvolvimento no Brasil do século XXI: uma análise da normatização internacional e da Constituição Brasileira. In: SILVEIRA, Vladmir Oliveira da; NASPOLINI SANCHES, Samyra; COUTO, Monica Benetti. (Org.). Direito e desenvolvimento no Brasil no século XXI. Brasília: IPEA; CONPEDI, 2013. p. 135.

27 FERRAZ, Luciano. Função regulatória da licitação. Revista Eletrônica de Direito Administrativo Econômico (REDAE), Salvador: Instituto Brasileiro de Direito Público, n. 19, ago./set./out., 2009. Disponível em: <http://www.direitodoestado.com/revista/ REDAE-19-AGOSTO-2009-LUCIANO-FERRAZ.pdf>. Acesso em: 30 set. 2014. 
privado a fim de satisfazer necessidades públicas. Todavia, essa visão foi sendo modificada no sentido de visualizar o Government procurement como um instrumento de ampliação de demandas, estimulação de desenvolvimento econômico, criação de empregos e desenvolvimento regionais. Paralelamente à mudança de paradigma descrita, instituições e novas regras de comércio internacional surgiram e dominaram a arena global, valorizando as compras governamentais como parte vital para uma nova ordem econômica. ${ }^{28}$

Nesse sentido, em meados dos anos 1990, importantes marcos internacionais foram estabelecidos no cenário mundial, como o Government Procurement Agreement (GPA) da OMC; o Law on Procurement of Goods, Construction and Services da United Nations Commission on International Trade Law (UNCITRAL), ${ }^{29}$ e outros instrumentos internacionais que envolviam o tema como, por exemplo, North America Free Trade Agreement (NAFTA), de 1994. Logo, ficou claro que o tema das compras governamentais havia se tornado uma questão de interesse internacional, e que foram estabelecidos princípios fundamentais para a sua regulamentação, como: eficiência, efetividade, justiça, abertura aos estrangeiros, competição, transparência, controle e adequado gerenciamento de conflitos. ${ }^{30}$

As compras governamentais (government procurement, em inglês) referem-se ao processo de compras, leasing, arrendamentos e contratações realizados por entidades ou agências governamentais.

$\mathrm{Na}$ OMC, o GPA, que regulamenta esta modalidade, faz parte dos chamados acordos

28 HERNANDEZ-GARCIA, Roberto. Introduction: the global challenges of international public procurement. In: International Public Procurement. London: Globe Law and Business, 2009. p. 9.

29 Órgão judicial principal do sistema das Nações Unidas no campo do direito comercial internacional. Corpo jurídico com a adesão universal, dedicado à reformada legislação societária em todo o mundo há mais de 40 anos. O papel da UNCITRAL é modernizar e harmonizar as regras do comércio internacional. Em 2011, foi editada uma nova versão da Lei Modelo de Contratações Públicas. Disponível em: <http://www.uncitral.org/uncitral/es/uncitral_ texts/procurement_infrastructure/2011Model.html>. Acesso em: 15 out. 2014.

30 HERNANDEZ-GARCIA, Roberto. Introduction: the global challenges of international public procurement. In: International Public Procurement. London: Globe Law and Business, 2009. p. 10. plurilaterais, ${ }^{31}$ negociados na Rodada de Tóquio $^{32} \mathrm{e}$ renegociado na Rodada Uruguai (entre os anos de 1986 e 1994), contendo direitos e obrigações para as partes signatárias. Seu objetivo principal é estender às compras governamentais de um país os princípios basilares da Nação Mais Favorecida ou Most-Favoured Nation (MFN) ${ }^{33}$ e o do tratamento nacional ou nation and National Treatment (NT), ${ }^{34}$ ou seja, a concessão de tratamento não menos favorável do que o concedido aos produtores e fornecedores nacionais. O GP $A$ foi renovado em 15 de abril de 1994, mesma data de criação da OMC, tendo entrado em vigor em $1^{\circ}$ de janeiro de 1996 e sendo vigente até os dias atuais.

Logo, o estabelecimento do GPA teve por escopo a superação do paradigma presente em quase todo o século XX, no qual as contratações públicas permitiriam alcançar objetivos de bem-estar nacional, aplicandose mecanismos de discriminação que privilegiariam a "aquisição doméstica" ou "preferencial", como forma de estímulo à indústria nacional e de concentração de ganhos nas empresas nacionais. ${ }^{35}$ Em sentido contrário, o GPA parte do pressuposto segundo o qual as políticas discriminatórias prejudicam o bem-estar mundial, de forma que a liberalização da contratação pública seria uma consequência necessária para garantir o bemestar. $^{36}$

Cabe destaque para a análise do período no qual o GPA foi negociado, o ano de 1994, por meio da Rodada Uruguai. Portanto, o Acordo "nasceu em um contexto neoliberal, onde a integração de mercados e a vislumbrada eliminação de barreiras ao livre comércio significavam a ordem do dia'. Seu objetivo, portanto, seria o da liberalização, estando quaisquer outros objetivos relegados à condição de exceções." ${ }^{37}$ Logo,

31 A OMC, segundo seu acordo constitutivo, tem o encargo de administrar dois tipos de acordos, os multilaterais e os plurilaterais. Os primeiros são vinculantes para todos os membros da OMC, enquanto os plurilaterais são de decisão voluntária. Os acordos multilaterais estão dispostos nos anexos 1, 2 e 3 do Acordo Constitutivo da OMC, e os plurilaterais, em seu anexo 4.

32 O primeiro Acordo sobre compras governamentais foi assinado em 1979, entrando em vigor em 1981, e foi a seguir emendado em 1987. As emendas entraram em vigor em 1988.

33 GATT 1947, artigo I.1.

34 GATT 1947, artigo III.4.

35 RODRIGUES, Nuno Cunha. A contratação pública como instrumento de política econômica. Coimbra: Almedina, 2013. p 29-30.

36 McAFEE, Preston; McMILLAN, John. Government procurement and international trade. Journal of International Economics. v. 26, 1989. p. 292.

37 VIEIRA, Andréia Costa. A OMC e o policy space dos 
as questões ligadas ao desenvolvimento pareciam estar bloqueadas nos foros econômicos e comerciais, olvidando-se de que a importância cada vez maior dos direitos humanos, na ordem internacional, estava vinculada aos temas econômicos. ${ }^{38}$

Outra questão relevante refere-se aos Estadosmembros que aderiram ao GPA no primeiro momento, em $1^{\circ}$ de janeiro de 1996, data em que o Acordo passou a vigorar. ${ }^{39}$ Dos 21 países aderentes ao Acordo de Compras Governamentais, oito estavam entre as dez maiores economias do mundo (Brasil e China estavam entre as dez, mas não aderiram),$^{40} \mathrm{o}$ que sugere que $\mathrm{o}$ GPA, pelo menos no primeiro momento, parecia mais atrativo aos países desenvolvidos e economicamente mais fortes. Pelo fato de o acordo ser plurilateral e de adesão não obrigatória, conclui-se, da mesma forma, que os países em desenvolvimento e menos desenvolvidos se posicionaram segundo a lógica de que quanto menos compromissos assumidos, melhor para esses Estados, pois teriam maior flexibilidade para a regulamentação interna de políticas públicas (policy space). ${ }^{41}$

Os governos, ao aderir ao GPA e abdicar de políticas domésticas discriminatórias, procuravam alcançar duas finalidades: ) a redução da despesa pública possibilitada pela concorrência internacional, que resultaria da abertura da contratação pública; e ii) o incremento das exportações, diante da conquista de novos mercados resultante da reciprocidade associada à liberalização da contratação pública. ${ }^{42}$

Ainda na década de 1990, mais cinco países aderiram ao GPA: República da Coreia, Hong Kong (China),

Estados: questões de flexibilidade, desenvolvimento sustentável e políticas públicas no GATT e GATS. In: AMARAL JUNIOR, Alberto do; CELLI JUNIOR, Umberto (Org.). A OMC: desafios e perspectivas. São Paulo: Aduaneiras, 2014. p 65.

38 PERRONE-MOISÉS, Cláudia. Direito ao desenvolvimento e investimentos estrangeiros. São Paulo: Oliveira Mendes, 1998. p. 69.

39 WORLD TRADE ORGANIZATION. Parties, observers and accessions. Disponível em: <http://www.wto.org/english/tratop_e/ gproc_e/memobs_e.htm>. Acesso em: 30 set. 2014.

40 Canadá, Estados Unidos, Japão, Alemanha, Espanha, França, Itália, Reino Unido, Áustria, Bélgica, Dinamarca, Noruega, Suíça, Finlândia, Israel, Grécia, Irlanda, Luxemburgo, Países Baixos, Portugal e Suécia (em negrito, os países que estavam entre as dez maiores economias do mundo, em 1995).

41 SALDANHA, Eduardo. Desenvolvimento e tratamento especial diferenciado na OMC: uma abordagem sob a perspectiva da doutrina do stare decisis - Parte II. Revista de Direito Econômico Socioambiental, Curitiba, v.3, n. 2. jul./dez. 2012. p. 311.

42 RODRIGUES, Nuno Cunha. A contratação pública como instrumento de política econômica. Coimbra: Almedina, 2013. p. 30.
Liechtenstein, Países Baixos, com respeito a Aruba, e Singapura. Já nos anos 2000, mais dezesseis países se associaram ao GPA: Armênia, Taipei (China), Islândia, Chipre, Eslovênia, Estônia, Hungria, Letônia, Lituânia, Malta, Polônia, República Checa y República Eslovaca, Bulgária, Romênia e Croácia. Da lista apresentada, não se vislumbra nenhuma grande potência econômica, que pudesse proporcionar uma nova dinâmica ou dimensão ao Acordo.

Atualmente, o GPA possui 43 membros signatários da OMC, com destaque à adesão total dos 28 membros da União Europeia, dos Estados Unidos da América e do Japão. Outros 27 membros e quatro organizações internacionais participam como observadores no Comitê de Contratação Pública do GPA. Dez desses membros, ${ }^{43}$ com destaque à China, que estão na situação de observador, se encontram em processo de adesão ao Acordo. ${ }^{44} \mathrm{O}$ GP $A$ revisado cria novas possibilidades comerciais de até US\$100 bilhões para as empresas dos Estados membros participantes do acordo, incluindo EUA, União Europeia e Japão, que representam mais de $60 \%$ da economia global. ${ }^{45}$

Como o objetivo de regular as compras governamentais em um nível multilateral mais amplo, iniciativas foram tomadas ao longo do tempo, a fim de ampliar e consolidar o GPA. A primeira delas foi o estabelecimento de um mandato ao Grupo de Trabalho sobre Transparência em Compras Governamentais, na Primeira Reunião Ministerial da OMC, ocorrida em Cingapura, no ano de 1996, que tinha por finalidade "conduzir um estudo sobre transparência nas práticas de compras governamentais, levando em consideração políticas nacionais, e, baseado neste estudo" e no trabalho de outras organizações internacionais relevantes sobre a simplificação dos procedimentos comerciais "desenvolverem elementos para a inclusão em um Acordo negociado." 46

43 China, Nova Zelândia, Montenegro, Albânia, Geórgia, Jordânia, Quirguistão, Moldova, Oman e Ucrânia.

44 WORLD TRADE ORGANIZATION. Parties, observers and accessions. Disponível em: <http://www.wto.org/english/tratop_e/ gproc_e/memobs_e.htm>. Acesso em: 30 set. 2014.

45 MOREIRA, Assis. OMC revisa acordo de compra governamental; Brasil prefere não aderir. 15 dez. 2011. Valor Econômico, São Paulo. Disponível em: <http://www.valor.com. $\mathrm{br} /$ internacional/1141028/omc-revisa-acordo-de-compragovernamental-brasil-prefere-nao-aderir\#ixzz3GiEEYTZg>. Acesso em: 30 set. 2014.

46 WORLD TRADE ORGANIZATION. Singapore WTO Ministerial 1996: Ministerial Declaration wt/min(96)/dec. Artigo 21 - Transparency in Government Procurement. Disponível em: 
Em 1998, num cenário em que as economias de alguns Membros da OMC experimentavam dificuldades como consequência das perturbações do mercado financeiro, foi realizada a Segunda Reunião Ministerial da OMC, em Genebra, que teve, basicamente, como objetivo as negociações sobre telecomunicações e serviços financeiros e marcou o início da vigência do Acordo sobre Tecnologia da Informação, não sendo tratados assuntos relacionados às compras governamentais. ${ }^{47}$ Da mesma forma, em dezembro de 1999, na Terceira Reunião Ministerial da OMC, em Seattle, as disposições relativas às compras governamentais não sofreram alterações.

Após duas Reuniões Ministeriais da OMC sem abordagem do tema das Compras Governamentais, na Quarta Reunião Ministerial de Doha, em 2001, ele retornou à agenda, exatamente abordando e restringindo a negociação ao escopo da transparência, e afirmando que essas negociações deveriam ser baseadas no progresso do Grupo de Trabalho, estabelecido em Singapura. Em outras palavras, ficaram definidas em Doha, as seguintes proposições: i) as negociações só teriam início, depois da quinta Conferência Ministerial de 2003, se houvesse um consenso explícito nessa reunião sobre as modalidades de negociação (não houve tal consenso); ii) as negociações se limitariam à transparência e não incluiriam questões de acesso ao mercado; e iii) um acordo multilateral sobre transparência nas compras governamentais levaria a uma exigência de assistência técnica e fomento à capacitação nos países mais pobres. ${ }^{48}$

A Quinta Reunião Ministerial da OMC ocorreu em Cancun, em setembro de 2013, e teve por missão principal realizar um balanço dos progressos realizados nas negociações e outros trabalhos no marco estabelecido no Programa de Doha para o Desenvolvimento. No texto Ministerial de Cancun, no seu artigo 16, considerando os trabalhos desenvolvidos pelo Grupo de Trabalho sobre a Transparência da Contratação pública, decidiu-se iniciar as negociações

<http://www.wto.org/english/thewto_e/minist_e/min96_e/ wtodec_e.htm >.Acesso em: 01 set. 2014.

47 WORLD TRADE ORGANIZATION. Geneva WTO Ministerial 1998: Ministerial Declaration. Disponível em: <http:// www.wto.org/english/thewto_e/minist_e/min98_e/mindec_e. htm>. Acesso em: 01 set. 2014.

48 WORLD TRADE ORGANIZATION. Doba WTO Ministerial 2001: Ministerial Declaration. Disponível em: <http:// www.wto.org/english/thewto_e/minist_e/min01_e/mindecl_e. htm>. Acesso em: 01 set. 2014. sobre a base das modalidades estabelecidas no anexo $\mathrm{D}$ do documento, que trata das seguintes questões: i) as negociações relativas a um acordo multilateral sobre transparência da contratação pública se basearão no parágrafo 26, da Declaração de Doha; ii) fica acordado que os contratos abrangidos pelo GPA podem extrapolar a esfera nacional de contratação e que haveria um limite mínimo do valor dos contratos a ser abrangidos pelo GPA; e iii) reafirma-se que nas negociações se levaria em conta as prioridades de desenvolvimento dos participantes, especialmente as dos países menos desenvolvidos. ${ }^{49}$

A Sexta Reunião Ministerial da OMC, realizada em Hong Kong, em dezembro de 2005, e a Sétima Reunião, em Genebra, em dezembro de 2009, não trouxeram nenhuma novidade ou abordagem sobre o tema das Compras Governamentais.

A Oitava Conferência Ministerial também foi realizada em Genebra, em dezembro de 2011. Foram realizadas três sessões de trabalho com os seguintes temas: "importância do Sistema Multilateral de Comércio e a OMC", "Comércio e Desenvolvimento" e "Desenvolvimento de Doha". Como fato importante da Conferência, destaca-se a aprovação da adesão da Rússia ao Organismo. Em relação às compras governamentais, a Conferência marcou a finalização das negociações do GPA, no primeiro dia do evento, com 42 países signatários, negociação que estava há dez anos em curso, em razão de divergências envolvendo principalmente União Europeia, Estados Unidos e Japão. Conclui-se que, com a aprovação, um novo mercado de US $\$ 100$ bilhões de contratos públicos, além dos US $\$ 50$ bilhões iniciais, estaria aberto aos países aderentes ao GPA, com a ampliação da cobertura do Acordo para agências governamentais e ministérios. ${ }^{50}$

Da mesma forma que a Sexta e a Sétima Reuniões da OMC não apresentaram abordagens sobre as compras públicas, a Nona Reunião Ministerial realizada em Bali, em dezembro de 2013, adotou a mesma postura, concentrando seus trabalhos na ampliação

49 WORLD TRADE ORGANIZATION. Anexos Del proyecto de Texto Ministerial de Cancún. Disponível em: <http://www.wto.org/spanish/thewto_s/minist_s/min03_s/ draft_decl_annex_rev2_s.htm >. Acesso em: 03 set. 2014.

50 INTERNATIONAL CENTRE FOR TRADE AND SUSTAINABLE DEVELOPMENT (ICTSD). Acordo sobre compras governamentais inangura Ministerial da OMC. Disponível em: $<\mathrm{http}: / /$ www.ictsd.org/bridges-news/pontes/news/acordo-sobrecompras-governamentais-inaugura-ministerial-da-omc $>$. Acesso em: 30 set. 2014. 
das questões que formam parte das negociações mais amplas da Rodada de Doha, resultando no documento denominado Pacote de Bali.

Da análise das nove Reuniões Ministeriais da OMC, ao longo desses vinte anos, pode se concluir que a transparência foi o único tema a entrar na pauta da OMC, deixando de ser abordadas nas negociações, questões de relevância como, por exemplo, o acesso ao mercado e o direito ao desenvolvimento social, econômico e ambiental, pelos países em desenvolvimento e menos desenvolvidos, por meio das compras governamentais. Todavia, existe uma percepção de que, ao focar na transparência, pode se avançar um passo na direção de converter o GPA num acordo multilateral, obrigando os Estados-membros a aderirem a ele, não mais permitindo que a adesão seja um ato voluntário.

Nesse sentido, a transparência está voltada para a efetivação de exigências no sentido de divulgação de informações, normas de aquisições e termos contratuais pelos governos aderentes, não tangenciando assuntos importantes e centrais, como acessos mais livres por empresas estrangeiras, por meio da efetivação de princípios, como do tratamento nacional dos fornecedores, independentemente da propriedade, da filiação ou da origem do produto ou do serviço. Logo, as futuras negociações no âmbito do GPA deverão abordar assuntos relacionados à maior acessibilidade ao mercado pelas empresas estrangeiras, sob o prisma do direito fundamental ao desenvolvimento.

Atualmente, no plano internacional, o GPA estabelece, para os países signatários, uma estrutura de direitos e obrigações à qual as partes devem se adaptar quanto a sua legislação nacional, regulamentos, procedimentos e práticas relacionadas às compras governamentais. Dentre os aspectos relevantes, destacam-se principalmente matérias relativas à transparência, à integridade e ao acesso aos mercados nacionais de compras públicas, em razão da representatividade expressiva das compras públicas, que representam entre 10 a $15 \%$ do PIB das economias nacionais, constituindo num mercado significativo e um aspecto importante do comércio internacional. ${ }^{51}$

Conforme mencionado, os acordos assinados durante a Rodada Uruguai são classificados em: Acordos Multilaterais (anexos 1, 2 e 3), de adesão obrigatória;

51 WORLD TRADE ORGANIZATION. WTO and Government Procurement. Disponível em: <http://www.wto.org/english/ tratop_e/gproc_e/gproc_e.htm>. Acesso em: 30 set. 2014. e Plurilaterais (anexo 4),,$^{52}$ de adesão opcional. Dos quatro acordos plurilaterais, o Brasil assinou somente o Acordo Internacional sobre Carne Bovina e, como a maior parte dos países em desenvolvimento, não é signatário do GPA,,$^{53}$ segundo o argumento de que o país não considera interessante a adesão ao Acordo, porque prefere privilegiar empresas do Mercosul na aquisições de bens e serviços pelo governo.

Esse posicionamento brasileiro vai ao encontro da negociação do Protocolo de Contratações Públicas do Mercosul, estabelecido por Brasil, Argentina, Paraguai e Uruguai, que tem por finalidade assegurar tratamento não discriminatório aos bens, serviços e obras públicas originárias fornecidas por provedores e prestadores dos Estados Partes do bloco. O Protocolo de Contratações Públicas, que foi ratificado apenas pela Argentina e não chegou a entrar em vigor, está sendo revisto desde 2010, com negociações que abrangem o marco normativo e seus anexos e que deverão ser concluídas antes que o novo texto do Protocolo seja ratificado e internalizado pelo Brasil e pelos demais Estados Partes do Mercosul. ${ }^{54}$

Todavia, o argumento brasileiro para não adoção do GAP, baseado no critério da preferência regionalista por produtos de empresas do Mercosul, parece não ter sustentação na produção legislativa, nos últimos vinte anos. O Brasil tem consciência de que possui ampla vantagem no que se refere às compras governamentais em relação aos outros membros do Mercosul e, como será visto em detalhe no próximo tópico, adota uma postura de proteção às suas próprias empresas nacionais, conforme a disposição contida no $\int 5^{\circ}$ do artigo $3^{\circ}$ do Estatuto de Licitações e Contratos (Lei $\left.n^{\circ} 8.666 / 93\right)$, alterado pela Lei no $12.349 / 2010$, na qual se estabelece de forma indubitável a preferência para

52 Anexos: 4A - Acordo sobre Comércio de Aeronaves Civis, 4B - Acordo sobre Compras Governamentais, 4C- Acordo Internacional de Produtos Lácteos e 4D- Acordo Internacional sobre Carne Bovina

53 MOREIRA, Assis. OMC revisa acordo de compra governamental; Brasil prefere não aderir. Valor Econômico, São Paulo, 15 dez. 2011. Disponível em: < http://www.valor.com. $\mathrm{br} /$ internacional/1141028/omc-revisa-acordo-de-compragovernamental-brasil-prefere-nao-aderir\#ixzz3GiEEYTZg>. Acesso em: 30 set. 2014.

54 BRASIL. Ministério do Desenvolvimento, Indústria e Comércio Exterior. Negociações internacionais de compras governamentais. Disponível em: <http://www.mdic.gov.br//sitio/interna/interna. php?area $=5 \&$ menu $=3542>$. Acesso em: 01 out. 2014. 
produtos manufaturados e para serviços nacionais que atendam a normas técnicas brasileiras.

Outros argumentos são levantados no sentido da não necessidade de adesão brasileira ao GPA, como por exemplo: $i$ ) a similitude das regras previstas no GPA e na legislação brasileira, que garante um procedimento célere e isonômico; ii) a não adesão ao GPA garante a produção normativa que assegura a preferência a produtos nacionais, diretriz disposta na Constituição Federal sobre a promoção do desenvolvimento nacional; e iii) as regras previstas no ordenamento nacional já preveem maneiras eficazes de igualar os participantes, sejam eles nacionais ou estrangeiros. ${ }^{55}$

Em contrapartida, a OMC defende que o GPA traz benefícios potenciais ao Brasil, como: $i$ ) ganho comercial baseado no acesso juridicamente garantido às licitações realizadas pelos governos dos países participantes; ii) manutenção do mercado aberto; iii) aumento da confiança no sistema de compras; e $i v$ ) melhora do value for Money, ${ }^{56}$ pela elevação da concorrência e uso mais eficiente e efetivo dos recursos públicos. Mercados atraentes de contratações públicas, como da China, por exemplo, estão sendo abertos parcialmente para os membros do GPA, com a estimativa de US\$ 1,1 trilhão. No entanto, há manifestações por parte de comissários da União Europeia, ${ }^{57}$ no sentido de que, sem a adesão ao GPA ou acordo bilateral com a UE, empresas brasileiras não terão a garantia jurídica de participar de licitações de compras pelos governos europeus. ${ }^{58}$

55 SANCHES MONASSA, Clarissa Chagas; LEONELLI, Aubrey de Oliveira. É interessante para o Brasil aderir ao acordo sobre compras governamentais da OMC? Revista de Direito Internacional, Brasília, v. 10, n. 1, p. 72-84. 2013.

56 É um termo usado para avaliar se uma organização obteve ou não o máximo de benefício dos produtos e serviços, dentro dos recursos disponíveis para isso. Alguns elementos podem ser subjetivos, difíceis de medir, intangíveis e incompreendidos. Ele não só mede o custo de bens e serviços, mas também tem em conta o mix de qualidade, custo, utilização de recursos e adequação ao uso.

57 A União Europeia espera celebrar um acordo bi-regional com o Mercosul e, com isso, ter acesso às compras públicas do governo federal, tanto para o executivo, como para empresas estatais, como a Petrobras. Em TACHINARDI, Maria Helena. Sensibilidades no acordo União Europeia-Mercosul. São Paulo: Instituto de Estudos do Comércio e Negociações Internacionais.

58 MOREIRA, Assis. OMC revisa acordo de compra governamental; Brasil prefere não aderir. Valor Econômico, São Paulo, 15 dez. 2011. Disponível em: <http://www.valor.com. $\mathrm{br} /$ internacional/1141028/omc-revisa-acordo-de-compragovernamental-brasil-prefere-nao-aderir\#ixzz3GiEEYTZg>. Acesso em: 30 set. 2014.
Da composição dos argumentos favoráveis e desfavoráveis à a doção do GPA, surge o questionamento sobre qual seja o equilíbrio entre a política de livre comércio estabelecida no Acordo da OMC, fundamentada no Princípio da Não Discriminação, e a flexibilidade e o policy space dos Estados-Membros, e a consequente margem de manobra para a efetivação de políticas públicas voltadas a um processo de inclusão social e de redistribuição de riquezas.

Não se pode olvidar de que, ao fim do século XX e início do XXI, tem sido reclamado um novo intervencionismo estatal por um cenário que configura a urgência de implantação de políticas públicas, principalmente para a garantia de direitos humanos, entre os quais o direito ao desenvolvimento, objeto deste artigo, e de uma proteção do meio ambiente. Logo, as normas internacionais que controlam o comércio internacional, incluindo o GPA, não podem perder o foco na questão do desenvolvimento, devendo ser instrumento para tal propósito. Sendo assim, dada a assimetria entre os Estados que se tornaram parceiros dentro do sistema da OMC, é "necessário garantir-lhes uma margem de atuação (policy space) para a promoção de políticas públicas voltadas ao desenvolvimento sustentável dentro de seus territórios." ${ }^{59}$

A flexibilidade ou policy space do Estado nas compras governamentais possui três eixos na aplicação das regras de liberalização que auxiliam a entender as limitações aplicáveis ao acordo e mitigação do princípio da Não Discriminação: $i$ ) a segregação do mercado; ii) a identificação das situações às quais as regras se aplicam; e iii) a explícita indicação de situações admitidas como exceções. $^{60}$

Em relação à segregação do mercado, considerase que as compras governamentais podem incluir tanto o comércio de bens quanto o de serviços. Quanto ao segundo eixo, pretende-se a delimitação da abrangência do escopo da contratação, em relação ao alcance dos níveis da administração pública

59 VIEIRA, Andréia Costa. A OMC e o policy space dos Estados: questões de flexibilidade, desenvolvimento sustentável e políticas públicas no GATT e GATS. In: AMARAL JUNIOR, Alberto do; CELLI JUNIOR, Umberto (Org.). A OMC: desafios e perspectivas. São Paulo: Aduaneiras, 2014. p 43-74.

60 DAWAR, K.; EVENETT, S. Government procurement. In: CHAUFFOUR, J. P.; MAUR, J. C. Preferential trade agreement policies for development: a handbook. Washington: World Bank, 2011, p. 375. Disponível em: <https://openknowledge.worldbank.org/ bitstream/handle/10986/2329/634040PUB0Pref00Box0361517B0 PUBLIC0.pdf?sequence=4>. Acesso em: 01 out. 2014. 
(federal, estadual, municipal, empresas estatais) e ao valor mínimo de compras ou contratos alcançáveis, em razão da onerosidade dos baixos contratos. O terceiro eixo de preocupação nos capítulos sobre compras governamentais, que para o presente artigo é o mais relevante, "está em como reconhecer nas suas disposições a importância do Estado e de suas instituições como um agente econômico — no caso do comprador - na implementação ou no fortalecimento de determinadas políticas públicas." Os dispositivos relacionados a esse eixo são enquadrados em três grupos: " $i$ ) offsets ou condicionalidades; ii) set-asides ou preferências; e, em algumas situações, iii) exceções stricto sensu nos capítulos de compras governamentais, que podem incluir tanto o comércio de bens quanto o de serviços." ${ }^{\prime 1}$

Como se pode constatar, tais provisões podem objetivar tanto a preservação, ou sua proibição, da possibilidade de definição de condicionalidades para participar de um processo de compras, com vistas a promover o desenvolvimento econômico e social, quanto a proteção a determinados grupos, como favorecimento à implementação de outras políticas públicas, como as ambientais, no caso das exceções.

Concluindo parcialmente, defende-se que a flexibilidade aos princípios gerais de livre-comércio, que visa a não discriminação entre nacionais ou estrangeiros ou o tratamento nacional, está regulamentada por dispositivos que estabelecem margens de preferência, condicionalidades (offsets ou acordos de compensação), regras de origem, especificações técnicas, exclusões e exceções, cujo conjunto de normas assegura o necessário policy space aos Estados-Membros aderente ao GPA, principalmente aos países em desenvolvimento e os menos desenvolvidos, para a efetivação de políticas públicas que realizem o direito humano econômico e fundamental ao desenvolvimento econômico, social e ambiental. No próximo tópico, será abordada a política legislativa das compras governamentais brasileira, sob a perspectiva da utilização da licitação como instrumento regulatório e realizador do direito ao desenvolvimento.

61 SANCHEZ BADIN, Michelle Ratton; AZEVEDO, Milena da Fonseca. A Regulação de Compras Governamentais nos Acordos Preferenciais de Comércio. In: OLIVEIRA, Ivan Tiago Machado; SANCHEZ BADIN, Michelle Ratton. (Org.). Tendências regulatórias nos acordos preferenciais de comércio no século XXI: os casos de Estados Unidos, União Europeia, China e Índia. Brasília: IPEA, 2013. p. 243-245. Disponível em: < http://www.ipea.gov.br/ agencia/images/stories/PDFs/livros/livros/livro_tendencias_ regulatorias1.pdf> Acesso em: 02 out. 2014.

\section{A política legislativa das compras governamentais brasileira: a licitação como instrumento regulatório e realizador do direito ao desenvolvimento}

A licitação, com sua característica procedimental, desde sempre, foi vista como uma atividade de caráter instrumental e secundária, pois visava única e exclusivamente atender a uma necessidade imediata: a aquisição de um bem ou a prestação de um serviço. ${ }^{62}$ $\mathrm{Na}$ nova concepção, segundo as normas de direito internacional e do ordenamento jurídico nacional, há uma finalidade material adicional ou extraordinária, de forma indireta e mediata, no sentido de satisfazer outros interesses também reconhecidos como relevantes pelo Direito, agrupados em objetivos secundários, que não se confundem com a finalidade material direta $\mathrm{e}$ imediata. ${ }^{63}$

A licitação, que tem a adjudicação e a assinatura do contrato administrativo como o resultado do seu processo, inaugura a implementação da regulação contratual, quando da elaboração do seu edital, com a definição de critérios de participação no certame, que podem ser de ordem econômica, social, ambiental ou tecnológica, como, por exemplo, e escolha do contratado. Em outras palavras, a Administração regula quem participará da licitação. Da mesma forma, a Administração não é livre para a escolha de tais critérios, pois está vinculada constitucionalmente a um conjunto de regras e princípios que também regulamentam o Estado contratante. Assim, ela utilizase do seu poder de contratação ou de compra para regular o mercado, ao definir o formato do contrato desejado. ${ }^{64}$

Nesse sentido, a discricionariedade na elaboração do edital licitatório envolve o exercício de uma competência regulatória, por interferir na estrutura do mercado, devendo ser técnica, em razão de que os aspectos políticos, geralmente inseridos numa determinada política pública, são definidos em leis,

62 Desde a Lei Federal $\mathrm{n}^{\circ} 4.536 / 1922$ e o Decreto $\mathrm{n}$. $15.783 / 1922$, a legislação previa a concorrência prévia para a contratação administrativa e para a alienação de bens, conforme MEIRELLES, Hely Lopes. São Paulo: Revista dos Tribunais, 1964. p. 244. Todavia, no presente trabalho, será abordada a exigência prévia somente em relação ao contrato administrativo.

63 FERREIRA, Daniel. A licitação pública no Brasil e sua finalidade legal: a promoção do desenvolvimento nacional sustentável. Belo Horizonte: Fórum, 2012. p. 35.

64 SOUTO, Marcos Juruena Villela. Direito administrativo regulatório. 2. ed. Rio de Janeiro: Lumen Juris, 2005. p. 307-308. 
acordos comunitários e tratados internacionais. Nessa ideia, cita-se como exemplo a atribuição de margens de preferências para determinados setores da indústria ou da sociedade ou a restrição a participação de estrangeiros em certames nacionais, no exercício do denominado policy space. Por competência regulatória técnica, entende-se a edição de regras que possam restringir a formação de monopólios, concentrações e dominações de mercados, que, por outro lado, sacrificam a competição desejada, como a previsão das denominadas cláusulas de barreira, que têm amparo constitucional no art. $173, \int 4^{\circ} .{ }^{65}$

Diante desse movimento regulatório e desregulatório nas contratações públicas, com ênfase na fase de licitação, importante se faz o exame cuidadoso desse movimento pendular, no contexto da regulamentação geral do Estado, a fim de se verificar se tal fenômeno é uma política isolada ou se está contida num plano maior estatal. Essa oscilação entre os extremos da regulação insuficiente e excessiva é produzida, em parte, pelos custos reais que estão associados às duas práticas, sendo potencializados por reformas legislativas que visam combater abusos ou escândalos que ganhem atenção política, mas que podem não ser representativas do funcionamento característico do sistema de compras e de funcionamento de determinado mercado. Em suma, pelo fato de que há custos reais associados tanto com regulação como com não regulamentação, na função de compras governamentais, em um sistema de compras ideal será necessário encontrar o equilíbrio entre os custos de excesso de regulamentação e os custos da regulação insuficiente. ${ }^{66}$

Stephen Breyer, ao trabalhar na desregulamentação da indústria aérea nos Estados Unidos na década de 1970, afirma que as características centrais recomendadas para a regulação das contratações governamentais seguem as seguintes premissas: $\imath$ ) em primeiro lugar, nenhum regulamento é apropriado, a menos que "o mercado não esteja regulamentado e que possua defeitos graves para que a regulamentação venha oferecer uma cura"; ii) em segundo lugar, quando a regulação é justificada, deve se empregar a

65 SOUTO, Marcos Juruena Villela. Direito administrativo regulatório. 2. ed. Rio de Janeiro: Lumen Juris, 2005. p 310-313.

66 SCWARTZ, Joshua I. Regulation and Deregulation in Public Procurement Law Reform in the United States. In:

Advancing public procurement experiences: experiences, innovation and knowledge sharing. Boca Raton, PrAcademics Press, 2006, p 1-28. Disponível em: <http://www.ippa.ws/IPPC2/BOOK/Chapter_9. pdf>. Acesso em: 04 out. 2014. menos restritiva alternativa, utilizando-se da regulação clássica, apenas quando os meios menos restritivos não vão funcionar; e iii) entre as alternativas menos restritivas para a regulação clássica a ser considerada são abordagens baseadas em incentivos, tais como redução de impostos e criação de regimes de direitos especiais de mercado, as exigências e requisitos de divulgação e a aproximação nas negociações. A palavra de ordem primordial é preservar, na medida do possível, as vantagens inerentes dos mercados competitivos. ${ }^{67}$

Tradicionalmente, no direito brasileiro ena respectiva doutrina e jurisprudência, a licitação possuía dois objetivos fundamentais ou finalidades legais, que eram preconizados no artigo $3^{\circ}$, caput da Lei $n^{\circ}$ 8.666/1993: a garantia da observância do princípio constitucional da isonomia e a seleção da proposta mais vantajosa para a administração. Com o advento da Lei no 12.349/2010, uma nova finalidade legal foi acrescida às outras duas existentes: a promoção do desenvolvimento econômico sustentável. Logo, a proposta mais vantajosa mitigou a importância do critério econômico da seleção e atribuiu relevância àquelas que possam garantir benefícios sociais, ambientais e econômicos, derivados do direito fundamental ao desenvolvimento, modificando toda política de contratação governamental, ao utilizar o seu poder de compra para implementar políticas públicas novas e desenvolver aquelas já existentes.

Com a nova finalidade legal estabelecida, o processo licitatório passou a ser visto sob uma ótica constitucional, "de consagração de valores pluralísticos, de onde deixou de ser tida como mero instrumento de compra do governo para se tornar mais um vetor de garantia dos interesses coletivos e do desenvolvimento nacional", manifestando-se a função regulatória da licitação, com mecanismos que privilegiem aqueles licitantes que exerçam suas atividades empresariais, com objetivos além do lucro, com ações que contribuam com o desenvolvimento econômico sustentável nacional. ${ }^{68}$

Para ser considerado o desenvolvimento como plenamente sustentável, existem três vieses de abordagem: o econômico, o social e o ambiental. $\mathrm{O}$ econômico leva em consideração a necessidade mínima

67 BREYER, Stephen G. Regulation and Its Reform. Cambridge, MA: Harvard University Press, 1982. p. 184-188.

68 ACOCELLA, Jéssica; RANGEL, Juliana Cabral Coelho. $O$ papel regulatório e de fomento das licitações públicas, 2013. Disponível em: <http://www.migalhas.com.br/dePeso/16,MI182325,71043-O+ papel+regulatorio $+\mathrm{e}+\mathrm{de}+$ fomento + das + licitacoes + publicas $>$. Acesso em: 01 set. 2014. 
de sistemas econômicos que assegurem, de forma contínua, o aumento do Produto Interno Bruto (PIB) e do PIB per capita (PPC), retroalimentando a economia e surtindo efeitos positivos na sociedade. O social se funda em valores de democracia e equidade, contribuindo para a expansão das capacidades humanas e da qualidade de vida, reforçando a sustentabilidade econômica e viceversa. Já o ambiental vem numa relação simbiótica com o social e econômico, pois não há como imaginar qualidade de vida em um ambiente degradado, com a ameaça da condição e da sobrevivência dos seres vivos. Da mesma forma, há de se ter equilíbrio entre crescimento econômico e degradação ambiental, não justificando qualquer crescimento que possa trazer a inviabilidade da existência humana. ${ }^{69}$

A partir da visão constitucionalizada da licitação, entende-se possível a edição de medidas legislativas e administrativas ativas, como, por exemplo, a Lei $n^{\circ}$ 12.349/2010, com o objetivo de repudiar, incentivar ou direcionar as atividades dos entes privados, quando da contratação pública, e de realizar preferências pelo Estado para o desenvolvimento de determinado tipo de segmento econômico. ${ }^{70}$

$\mathrm{Na}$ própria Lei no 8.666/1993, há uma forma de interferência direta do Estado no domínio econômico, por conta da regra do art. 24 , VI, que dispõe que a licitação será dispensável, quando a União tiver que intervir no domínio econômico para regular preços ou normalizar o abastecimento.

Nessa hipótese, não há acordo de vontades, mas desapropriação regulada pela ordem econômica constitucional, instituída, em especial, pelos artigos $173, \sqrt{ } 4^{\circ}$, da $\mathrm{CF}$, e no artigo 170 , III, que estabelece o Princípio da Função Social da Propriedade. Notase que o dispositivo, neste caso, tem por finalidade a formatação de um mercado livre, utilizando-se da função regulatória da licitação, cuja competência em normatizar é da União, por se tratar de caso de dispensabilidade da licitação. Todavia, nada impede que estados e municípios, por força do artigo 174, CF, possam, por via da regulação, promover e defender

69 FERREIRA, Daniel. A licitação pública no Brasil e sua finalidade legal: a promoção do desenvolvimento nacional sustentável. Belo Horizonte: Fórum, 2012. p. 52-55.

70 FERRAZ, Luciano. Função Regulatória da Licitação. Revista Eletrônica de Direito Administrativo Econômico (REDAE), Salvador: Instituto Brasileiro de Direito Público, n. 19, ago./set./out., 2009. Disponível em: <http://www.direitodoestado.com/revista/ REDAE-19-AGOSTO-2009-LUCIANO-FERRAZ.pdf>. Acesso em: 30 set. 2014. seus mercados, como, por exemplo, o fomento à participação de pequenos agricultores e cooperativas. ${ }^{71}$

Nesse mesmo sentido, defende-se que o dispositivo vincula-se à tentativa de a União influenciar o mercado de bens e serviços, por meio da oferta ou aquisição de bens ou serviços, a fim de restabelecer o equilíbrio do mercado. A União, atuando para normalizar o abastecimento ou regular preços, efetivará contratações em igualdade com os particulares, intervindo no mercado para incrementar a oferta ou a procura. "A intervenção da União se tornaria ineficaz se fosse precedida de licitação, porque não influenciaria a oferta e a demanda".72

Assim, a evolução histórica do procedimento licitatório no Brasil está estritamente ligada à atuação da Administração Pública na consecução do interesse público, que sofreu uma readequação substancial ao longo dos anos, em razão das constantes transformações políticas, sociais e econômicas e com a inserção do Estado brasileiro como agente condutor da economia e da aquisição de bens e serviços. ${ }^{73}$

Partindo-se da ideia de que o dever de licitar traduzse numa política pública, na medida em que pressupõe ser a disputa seletiva isonômica aquela que habilita o Estado à consecução da melhor prestação contratual, ${ }^{74}$ o seu afastamento ou mitigação, por meio de regras de preferência ${ }^{75}$ ou proteção de grupos econômicos, deve

71 SOUTO, Marcos Juruena Villela. Direito administrativo contratual. Rio de Janeiro: Lumen Juris, 2004, p. 104-105. No mesmo sentido, NIEBUHR, Joel de Menezes. Dispensa e inexigibilidade de licitação pública. 3. ed. Belo Horizonte: Fórum, 2011. p. 257. Em sentido oposto, PEREIRA JUNIOR, Jessé Torres. Comentários à lei de licitações e contratações da administração pública. 6. ed. Rio de Janeiro: Renovar, 2003. p. 271. "Somente à União cabe intervir no domínio econômico para regular preços ou normalizar o abastecimento, podendo fazê-lo mediante aquisições ou alienações de gêneros ou produtos, inclusive no Exterior, que dispensarão a prévia licitação dada a índole peculiar da intervenção."

72 JUSTEN FILHO, Marçal. Comentários à lei de licitaçoes e contratos administrativos. 13. ed. São Paulo: Dialética, 2009. p. 302.

73 GUEDES, Aloysio Neves. O procedimento licitatório como microssistema jurídico: apontamentos e Reflexões in Rio de Janeiro (Estado). Tribunal de Contas. Revista do Tribunal de Contas do Estado do Rio de Janeiro, Rio de Janeiro, v. 2, n. 5, jan./jun. 2013. p. 41.

74 PEREIRA JUNIOR, Jessé Torres; DOTTI, Marinês Restelatto. Politicas públicas nas licitações e contratações administrativas. 2 ed. rev. atual. e ampl. Belo Horizonte: Fórum, 2012. p. 33.

75 McAFEE, R. P., McMiLlAN, J. Auctions and Bidding. Journal of Economic Literature, v. 25, p. 699-738. 1987. p. 716. O objetivo da adoção de margem de preferência em uma licitação é igualar as condições de competição quando os licitantes possuem assimetrias estruturais de custos que impedem a eficiência de uma licitação. Do ponto de vista da teoria econômica, o valor da margem 
ser analisada sob a ótica de política governamental. Até o presente momento, o legislador brasileiro sinalizou quais são os setores a serem desenvolvidos, em razão de 14 decretos específicos editados pelo Governo Federal, por meio da Comissão Interministerial de Compras Públicas, instituída pelo decreto $\mathrm{n}^{\circ}$ 7.546/2011, atribuindo a margem de preferência a produtos nacionais, conforme segue: ${ }^{76}$

i) Decreto $\mathrm{n}^{\mathrm{o}} 7.709 / 2012$ - motoniveladoras e retroescavadeiras;

ii) Decreto $n^{\circ} 7.713 / 2012$ - fármacos e medicamentos;

iii) Decreto $n^{\circ} 7.756 / 2012$ - confecções e calçados;

iv) Decreto $n^{\circ} 7.767 / 2012$ - equipamentos médicohospitalares;

v) Decreto $n^{\circ} 7.810 / 2012$ - papel moeda;

de preferência deve ser o suficiente para equiparar assimetrias competitivas que levam a diferenças na utilidade (para o comprador) entre a melhor oferta estrangeira e a melhor oferta nacional.

76 BRASIL. Ministério do desenvolvimento, Indústria e Comércio. Relatório de acompanhamento da medidas sistêmicas: junho de 2014. Disponível em:<http://www.abdi.com.br/Estudo/ Medidas\%20Sist $\%$ C3\%AAmicas\%20PBM $\% 20-\% 20$ Rel $\% 20 \% 20$ de $\% 20$ Acomp $\% 20$ junho\%2014.pdf>. Acesso em: 15 out. 2014. vi) Decreto $\mathrm{n}^{\circ} 7.812 / 2012$ - veículos para vias férreas;

vii) Decreto $n^{\circ} 7.816 / 2012$ - caminhões, furgões, e implementos rodoviários;

viii) Decreto $n^{\circ} 7.843 / 2012$ - disco para moeda;

ix) Decreto no $7.840 / 2012$ - perfuratriz e patrulha mecanizada;

x) Decreto $n^{\circ} 7.903 / 2013$ - equipamentos de tecnologia e comunicação;

xi) Decreto no $8.002 / 2013$ - pás carregadoras, tratores de lagarta e produtos afins;

xii) Decreto $n^{\circ}$ 8.186/2014 - licenciamento de uso de programas de computador e serviços correlatos;

xiii) Decreto ${ }^{\circ}$ 8.185/2014 - brinquedos, jogos, artigos para divertimento ou para esporte; e

xiv) Decreto $n^{\circ} 8.224 / 2014$ - máquinas e equipamentos especificados no decreto.

Além da Lei $\mathrm{n}^{\circ} 8.666 / 1993$, alterada pela Lei $\mathrm{n}^{\circ}$ 12.349/2010, diversas outras medidas legislativas dispõem ou regulamentam o direito ao desenvolvimento, como forma de regulação de mercado, todavia com ênfase na implementação de políticas publicas sociais, ambientais e econômicas, conforme Quadro 1, a seguir: 
Quadro 1: Políticas públicas nas licitações

\begin{tabular}{|c|c|c|c|}
\hline Legislação & Política Pública efetivada & $\begin{array}{l}\text { Dispositivo na Lei } n^{\circ} \\
8.666 / 1993\end{array}$ & Dispositivos em outras normas \\
\hline Legislação & Política Pública efetivada & $\begin{array}{l}\text { Dispositivo na Lei } n^{\circ} \\
8.666 / 1993\end{array}$ & Dispositivos em outras normas \\
\hline \multirow{10}{*}{ Lei 8.666/93 } & Preservação ao meio ambiente & $\begin{array}{l}\text { Inciso } \mathrm{X} \text {, art } 6^{\circ} \mathrm{e} \\
\text { IncisoVII art } 12\end{array}$ & $\begin{array}{l}\text { Art. 170, VI CF/88 e Portaria } n^{\circ} \\
61 / 2008 \text { MMA }\end{array}$ \\
\hline & Política Fundiária & $\begin{array}{l}\text { Art. } 17 \text { - licitação } \\
\text { dispensada }\end{array}$ & \\
\hline & $\begin{array}{l}\text { Preservação do patrimônio } \\
\text { histórico }\end{array}$ & Inc. XV, art. 24 & $\int 1^{\circ}$ art. $216 \mathrm{CF}$ \\
\hline & $\begin{array}{l}\text { Geração de emprego e } \\
\text { inclusão social }\end{array}$ & Inc. XXVII, art. 24 & Lei n ${ }^{\circ} 11.445 / 2007$ \\
\hline & $\begin{array}{l}\text { Reequipamento das Forças } \\
\text { Armadas e Defesa nacional }\end{array}$ & $\begin{array}{l}\text { Incisos XVIII, XIX, } \\
\text { XXVIII, art. } 24\end{array}$ & \\
\hline & Participação em Força de Paz & Inciso XXIX, art. 24 & $\begin{array}{l}\text { Lei no } 11.783 / 2008 \text { inseriu o } \\
\text { inciso }\end{array}$ \\
\hline & Apoio ao deficiente físico & Inciso XX, art. 24 & Art. 203, IV, CF/88 \\
\hline & Ciência e tecnologia & Inciso XXI, art. 24 & Art. 218, CF/88 \\
\hline & $\begin{array}{l}\text { Proteção ao trabalho do } \\
\text { menor (infantil) }\end{array}$ & Inciso $\mathrm{V}$, art. 27 & Lei no $9.854 / 1999$ \\
\hline & $\begin{array}{l}\text { Incentivo à produção de bens } \\
\text { e serviços de informática (PPB } \\
\text { Nacional) }\end{array}$ & $\begin{array}{l}\text { Art45, } \int 4^{\circ}, \text { Lei } n^{\circ} 8.666 \\
\text { Decreto } n^{\circ} 7.174 / 2010\end{array}$ & $\begin{array}{l}\text { Lei no } 11.077 / 2004 \text { (acesso ao } \\
\text { pregão) }\end{array}$ \\
\hline \multicolumn{4}{|c|}{ Políticas Públicas nas leis extravagantes } \\
\hline Legislação & Política Pública efetivada & \multicolumn{2}{|c|}{ Dispositivos em outras normas } \\
\hline $\begin{array}{l}\text { Lei } \mathrm{n}^{\circ} \\
8.248 / 1991- \\
\text { Lei nacional de } \\
\text { informática }\end{array}$ & $\begin{array}{l}\text { Preferência na contratação de } \\
\text { bens e serviços de informática } \\
\text { e automação nacionais }\end{array}$ & \multicolumn{2}{|l|}{ Decreto $n^{\circ} 7.174 / 2010$} \\
\hline LC n ${ }^{\circ} 123 / 2006$ & $\begin{array}{l}\text { Favorecimento às } \\
\text { Microempresas e Empresas de } \\
\text { Pequeno Porte }\end{array}$ & \multicolumn{2}{|l|}{ Art. 170 e 179 da CF/88 } \\
\hline $\begin{array}{l}\text { Lei } \mathrm{n}^{\mathrm{o}} \\
11.284 / 2006\end{array}$ & $\begin{array}{l}\text { Gestão de florestas } \\
\text { (terceirização) }\end{array}$ & \multicolumn{2}{|c|}{ Decreto n ${ }^{\circ} 6.063 / 2007$ - artigos 29 a 43} \\
\hline $\begin{array}{l}\text { Lei n } 12.305 \\
/ 2010 \text { - Política } \\
\text { Nacional de } \\
\text { Resíduos Sólidos }\end{array}$ & $\begin{array}{l}\text { Promoção do consumo } \\
\text { sustentável pela administração } \\
\text { pública (art. } 7^{\circ} \text {, inciso XI da } \\
\text { Lei) }\end{array}$ & \multicolumn{2}{|c|}{$\begin{array}{l}\text { Inciso I, do artigo 44, do Decreto n }{ }^{\circ} 7404 / 2010 \text { - } \\
\text { contratação de cooperativas de catadores de material } \\
\text { reciclável. }\end{array}$} \\
\hline
\end{tabular}




\begin{tabular}{|c|c|c|}
\hline $\begin{array}{l}\text { Lei } n^{\circ} \\
12.349 / 2010\end{array}$ & $\begin{array}{l}\text { Desenvolvimento Econômico } \\
\text { Sustentável (fomento } \\
\text { econômico, social e ambiental) } \\
\text { Estabelece margem de } \\
\text { preferência para produtos } \\
\text { manufaturados e para serviços } \\
\text { nacionais, com objetivo } \\
\text { de desenvolver a indústria } \\
\text { nacional }\end{array}$ & $\begin{array}{l}\text { Regulamentada pelo Decreto } n^{\circ} 7.546 / 2011 \text { e mais onze } \\
\text { decretos específicos. }\end{array}$ \\
\hline $\begin{array}{l}\text { Lei } n^{\circ} \\
12.440 / 2010\end{array}$ & $\begin{array}{l}\text { Proteção ao trabalhador - } \\
\text { Exigência da CNDT para } \\
\text { contratar com o poder público }\end{array}$ & Estabelece a Certidão Negativa de Débitos Trabalhistas \\
\hline $\begin{array}{l}\text { Lei } n^{\circ} \\
12.598 / 2012\end{array}$ & $\begin{array}{l}\text { Estabelece normas } \\
\text { especiais para as compras, } \\
\text { as contratações e o } \\
\text { desenvolvimento de produtos } \\
\text { e de sistemas de defesa. }\end{array}$ & Decretos $n^{\circ} 7.970 / 13$ e no $8.122 / 2013$ (Retid Defesa) \\
\hline $\begin{array}{l}\text { Portaria } \mathrm{n}^{\circ} \\
837 / 2012 \text { do } \\
\text { Ministério da } \\
\text { Saúde }\end{array}$ & $\begin{array}{l}\text { Objetivo de redução de preços } \\
\text { de produtos estratégicos para } \\
\text { saúde }\end{array}$ & $\begin{array}{l}\text { Estabelece Parcerias para o Desenvolvimento Produtivo } \\
\text { (PDP) }\end{array}$ \\
\hline
\end{tabular}

Fonte: Elaboração do autor.

Após a apresentação dos dados do Quadro 1 e da análise do plano normativo que regula as compras governamentais brasileiras, a primeira conclusão é de que a postura da política de contratação pública nacional está na utilização intensiva da licitação, no sentido de efetivar as políticas públicas econômicas, sociais e ambientais no Brasil, políticas essas distribuídas em, no mínimo, uma lei complementar, sete leis ordinárias, dezenas de decretos e portarias, caracterizando uma verdadeira inflação legislativa ${ }^{77}$ no tema.

A segunda conclusão evidente, resultado da excessiva produção legislativa, é que o Brasil adota uma posição protecionista e está preocupado em garantir o mercado de contratação pública para as empresas brasileiras, principalmente aquelas relacionadas ao Plano Brasil Maior (PBM) ${ }^{78}$ e ao Plano de Aceleração

77 Segundo Carnelutti, a expressão inflação legislativa refere-se à produção em massa de leis, também chamada por ele de "hipertrofia da lei”, que decorria de certo fascínio que a sociedade moderna tem pelas leis, não percebendo que à medida que "cresce o número das leis jurídicas, diminui a possibilidade de sua formação cuidadosa e equilibrada". CARNELUTTI, Francesco. A morte do direito. Belo Horizonte: Líder, 2003, p. 9-10.

78 O Plano Brasil Maior é a política industrial, tecnológica e de comércio exterior do Governo Federal. O desafio do Plano Brasil Maior é: 1) sustentar o crescimento econômico inclusivo num contexto econômico adverso; e 2) sair da crise internacional ao Crescimento (PAC). ${ }^{79}$ Ao mesmo tempo, tem ciência da dificuldade em ingressar em mercados de compras governamentais de países desenvolvidos. Logo, é natural que o Governo Federal não queira assinar, no momento, o GPA, que se apresenta totalmente oposto à decisão política protecionista da legislação brasileira, a qual, por sua vez, se utilizando do policy space, busca a efetivação do direito fundamental ao desenvolvimento.

Da comparação das exigências do GPA com a legislação nacional, reside a questão central de saber se a política discriminatória constitui um mecanismo eficiente de alcançar objetivos que não reflete, de forma imediata, uma natureza financeira ou, ainda, se essas metas podem ser realizadas de forma não discriminatória. Assim, o governo e o legislador

em melhor posição do que entrou, o que resultaria numa mudança estrutural da inserção do país na economia mundial. Disponível em: $<$ http://www.brasilmaior.mdic.gov.br/conteudo/128>. Acesso em: 15 out. 2014.

79 A Lei $n^{\circ} 12.745 / 2012$ permite que o Governo Federal exija percentual mínimo de produtos e serviços nacionais nas obras do PAC, e o Decreto $\mathrm{n}^{\circ} 7.888 / 2013$ inaugurou o novo instrumento determinando que $80 \%$ do custo financeiro associado às obras de mobilidade urbana do PAC sejam destinados aos produtos nacionais elencados na Portaria Interministerial MP/MDIC $\mathrm{n}^{\circ}$ 95, de 3 abr. 2013. 
brasileiro põem-se diante do dilema do prisioneiro, ${ }^{80}$ em que o Brasil atua isoladamente, prosseguindo políticas discriminatórias que afetam o interesse global, dado que há a opção de cooperar (fazendo parte do GPA) ou não cooperar (ficando excluído do GPA). Ao mesmo tempo, existe a pressão que os beneficiados pela discriminação exercem sobre as autoridades, a fim de maximizar seus ganhos. ${ }^{81}$

$\mathrm{Na}$ esfera da OMC, a estratégia na área de compras governamentais brasileira tem reforçado três pontos:

“i) o entendimento de que a agenda da OMC já é demasiadamente extensa para incorporar novos temas, o que o inibiria de assumir novos compromissos junto à organização; ii) o de que o Brasil aceita discutir apenas princípios de transparência nas suas licitações, respeitando-se a circunscrição apenas às atividades do governo central; e iii) o entendimento de que pretende manter o seu espaço para o desenvolvimento de políticas públicas, garantindo o tratamento discriminatório a empresas e prestadores de serviços brasileiros e, eventualmente, do Mercosul." 82

Todavia, dois aspectos estão colocando as orientações protecionistas da política brasileira em xeque: o primeiro refere-se à crescente adesão de outros parceiros comerciais às regras em compras governamentais, como o Chile e a Argentina, que hoje se encontram na situação de observadores do GPA/OMC; e, segundo, a participação brasileira, em processos de negociação mais complexos, como a retomada das negociações para um acordo bi-

80 O Dilema dos Prisioneiros foi inventado em 1950 por Merrill Flood e Melvin Dresher, e foi adaptado e divulgado por A.W.Tucker. O dilema do prisioneiro é um problema da teoria dos jogos e trata da natureza da cooperação. Neste problema supõe-se que cada jogador, de modo independente, quer aumentar ao máximo a sua própria vantagem sem lhe importar o resultado do outro jogador. O dilema prova que quando cada um de nós, individualmente, escolhe aquilo que é do seu interesse próprio, pode-se gerar um resultado pior do que ficaria se tivesse sido feita uma escolha que fosse do interesse coletivo.

81 RODRIGUES, Nuno Cunha. A contratação pública como instrumento de política econômica. Coimbra: Almedina, 2013, p. 36.

82 SANCHEZ BADIN, Michelle Ratton; AZEVEDO, Milena da Fonseca. A Regulação de Compras Governamentais nos Acordos Preferenciais de Comércio. In: OLIVEIRA, Ivan Tiago Machado; SANCHEZ BADIN, Michelle Ratton. (Org.). Tendências regulatórias nos acordos preferenciais de comércio no século XXI: os casos de Estados Unidos, União Européia, China e Índia. Brasília: IPEA, 2013. p. 243245. Disponível em: <http://www.ipea.gov.br/agencia/images/ stories/PDFs/livros/livros/livro_tendencias_regulatorias1.pdf $>$. Acesso em: 02 out. 2014. regional entre União Europeia e Mercosul, no qual o Brasil oferece uma pequena margem, de $3 \%$, para os produtores europeus, em relação a preços de países de fora do bloco sul-americano.

Outra questão relacionada à política de adoção da margem de preferência a produtos nacionais é a efetividade da política, que, para a sua análise, necessita de indicadores de desempenho econômicos e sociais. Dados levantados pelo Ministério do Planejamento, Orçamento e Gestão, a pedido da gerência-executiva de política industrial da Confederação Nacional da Indústria (CNI), afirmam que, mesmo favorecidas por margens de preferência que permitem vencer licitações do setor público, cobrando preços até $25 \%$ maiores que os concorrentes estrangeiros, ${ }^{83}$ as empresas nacionais perderam, para fornecedores de outros países, a chance de abastecer compras do governo brasileiro equivalentes a R\$ 965 milhões, entre abril de 2012 e outubro de 2013. Nem com permissão para preços mais altos as empresas nacionais se mostraram competitivas em setores como fármacos, medicamentos e equipamentos médicos, uma das áreas prioritárias para o governo, e desejadas por fornecedores americanos e europeus. ${ }^{84}$

Ao adotar a política de compras públicas por meio de margens de preferência, o governo calculava atingir $\mathrm{R} \$ 15$ bilhões em compras, sendo que o índice atingido ficou em apenas 14\% desse valor, tanto em 2012 quanto no ano passado, até o mês de outubro. Causas como a falta de competitividade do produtor nacional, ou a ausência de fabricantes no país, levaram os estrangeiros a aumentar sua participação no fornecimento de fármacos, medicamentos e equipamentos médicos, de 2012 para 2013. No caso dos fármacos e remédios, os fabricantes garantiram o fornecimento de apenas $10 \%$ do total de produtos comprados pelo governo. Além disso, em 95\% dos casos nos quais a margem mínima poderia ser usada, ela foi insuficiente para beneficiar fornecedores nacionais, porque os concorrentes

83 EMPRESA BRASILEIRA DE COMUNICAÇÃO. O governo unificou em 25\% a margem de preferência para as compras públicas: 0 percentual será aplicado até 2020 nas licitações federais para produtos manufaturados e serviços nacionais. Brasília, 2014. Disponível em: <http://www.ebc.com.br/noticias/economia/2014/06/margemde-preferencia-para-compras-do-governo-sera-estendida-para-25>. Acesso em: 16 out. 2014.

84 LEO, Sérgio. Menos R\$ 1 Bi em vendas ao Governo. Valor Econômico, São Paulo, 17 mar. 2014. Disponível em: <http:// www.valor.com.br/brasil/3481592/menos-r-1-bi-em-vendas-aogoverno>. Acesso em: 16 out. 2014. 
estrangeiros apresentaram preços pelo menos 25\% menores que os dos laboratórios no país. ${ }^{85}$

$\mathrm{Da}$ análise dos dados, pode-se concluir que o mecanismo de privilégio aos nacionais pode gerar resultados positivos, se bem operados, ou negativos, se mal gerenciados. Com pouco lapso temporal para análise do caso brasileiro, não há condições de averiguar tendências positivas ou negativas, se a margem de preferência está fomentando a diversificação industrial, agregando valor e promovendo o desenvolvimento tecnológico, ou se está gerando custos desnecessários para o Estado, para a própria indústria, para os consumidores e para os contribuintes. Apesar de não conclusivos em relação a tendências, os dados apresentados no estudo da CNI são um bom indicador para questionamentos em relação à eficácia da medida.

Em sede de conclusão parcial, a última questão levantada nesse tópico refere-se a disputas de arenas por possíveis grupos beneficiados pela regulamentação por meio da aplicação da margem de preferência. Partindo-se das considerações realizadas por Lowi, pode-se afirmar que a implementação de políticas públicas, por meio da aplicação de preferências nas licitações, enquadra-se na categoria das políticas públicas regulatórias, em razão da utilização do mercado e do poder de compras estatal, para alcançar objetivos e executar ações estratégicas nas áreas de políticas públicas econômicas e sociais. Obviamente que na arena distributiva haverá uma multiplicidade de grupos organizados em torno de relações de interesses setoriais com a finalidade de inserção do respectivo setor econômico nas políticas governamentais e consequente inserção na condição de favorecido da política. Logo, resta o questionamento sobre quais setores industriais serão beneficiados em maior ou menor escala. Todavia há a certeza de que serão estabelecidas arenas de políticas públicas, com atores disputando o ingresso na agenda desenvolvimentista estatal. ${ }^{86}$ Realizada a conclusão parcial, nesse momento serão feitas as considerações finais do presente artigo.

85 LEO, Sérgio. Menos R\$ 1 Bi em vendas ao Governo. Valor Econômico, São Paulo, 17 mar. 2014. Disponível em: <http:// www.valor.com.br/brasil/3481592/menos-r-1-bi-em-vendas-aogoverno>. Acesso em: 16 out. 2014.

86 LOWI, Theodore J. Distribution, regulation, redistribution: the functions of government. In: Public Policies and Their Politics. Ripley, W.W. Norton e Company Inc. New York: 1996. p. 7.

\section{Considerações finais}

O presente artigo buscou apresentar a consolidação e a aproximação de três temas inter-relacionados entre si: os direitos humanos, as relações comerciais e econômicas e o direito ao desenvolvimento. Assim, a partir da análise desenvolvida no trabalho, procurou-se estabelecer a inter-relação entre regras, compromissos e obrigações sobre os temas, contidos no âmbito do Direito Internacional, com destaque aos documentos elaborados pela ONU e pela OMC, e do Direito interno.

Para tanto, apresentou-se, por um lado, o direito ao desenvolvimento como direito fundamental econômico, de caráter difuso, de terceira geração, consagrado como inalienável pela Declaração sobre o Direito ao Desenvolvimento da ONU (1986) e insculpido em diversas passagens da Constituição Federal de 1988. De outro, a liberdade à concorrência, com o princípio basilar da Não Discriminação, englobando a Cláusula da Nação Mais Favorecida e o Princípio do Tratamento Nacional, os quais proíbem tratamento discriminatório em relação a produtos e países contratantes do Government Procurement Agreement (GPA), da OMC, que completa vinte anos, no plano jurídico internacional.

No mesmo sentido, verificou-se que o Brasil, ao não aderir ao GPA, adotou uma postura política de promoção do desenvolvimento nacional sustentável, atribuindo uma terceira finalidade legal à licitação, por meio da Lei $\mathrm{n}^{\circ} 12.349 / 2010$, utilizando-se da flexibilidade em normatizar ou do denominado policy space. A partir dessa diretriz e com a finalidade de operacionalizar a política estabelecida, um conjunto expressivo de normas correlatas à Lei no 8.666/93 foi editado, caracterizando o que Carnelutti denominou de inflação legislativa, na área das compras governamentais.

Tal conjunto de normas concebe privilégios aos produtos e aos serviços nacionais, em detrimento dos concorrentes estrangeiros, com a disposição do Estado nacional em pagar até $25 \%$ mais caro por aqueles produtos, por meio do mecanismo da margem de preferência, que é adotado por diversos países, principalmente os em desenvolvimento. Todavia, os dados levantados no primeiro ano de vigência da regulamentação da Lei no 12.349/2010 não sinalizaram de maneira satisfatória, acendendo a primeira luz de alerta sobre a eficiência do referido mecanismo no desenvolvimento de políticas públicas econômicas, sociais e ambientais. 
Aliado à possibilidade de ineficiência do mecanismo da margem de preferência adotada, dois outros aspectos pressionam a política estatal de compras governamentais brasileira, em relação à adesão ao GPA, colocando em dúvida a consequente harmonização da produção normativa nacional com as normas de direito internacional: a aproximação de parceiros do Mercosul ao GPA, na condição de observadores, como o Chile e a Argentina, e os processos de negociação mais complexos, dos quais o Brasil faz parte, como a retomada das negociações para um acordo bi-regional entre União Europeia e Mercosul, sobre o referido tema.

Diante do todo exposto, conclui-se que, mesmo o Brasil não sendo signatário do GPA, o sistema de compras governamentais brasileiro assemelha-se muito ao Acordo da OMC, em matéria de transparência e procedimento. Todavia, a adoção de margem de preferência e de privilégios aos nacionais nos contratos públicos atinge frontalmente, no primeiro momento, o princípio basilar do Direito do Comércio Internacional da Não Discriminação. Da mesma forma, a política protecionista das compras governamentais brasileira está sob pressão em razão de questões internas (dúvidas sobre a eficiência do mecanismo e condições dos produtores nacionais em se beneficiar do privilégio) e internacionais (aproximação de parceiros comerciais ao GPA e negociações de acordos mais complexos). 


\section{Referências}

ACOCELLA, Jéssica; RANGEL, Juliana Cabral Coelho. O papel regulatório e de fomento das licitações públicas, 2013. Disponível em: <http://www.migalhas.com.br/ dePeso/16,MI182325,71043-O+papel+regulatorio+e+ $\mathrm{de}+$ fomento + das + licitacoes + publicas $>$. Acesso em: 01 set. 2014.

BRASIL. Ministério do Desenvolvimento, Indústria e Comércio Exterior. Negociações Internacionais de Compras Governamentais. Disponível em: <http://www.mdic.gov. $\mathrm{br} / /$ sitio/interna/interna.php?area $=5 \& \mathrm{menu}=3542>$. Acesso em: 01 out. 2014.

BRASIL. Ministério do desenvolvimento, Indústria e Comércio. Relatório de acompanhamento das medidas sistêmicas: junho de 2014. Disponível em: <http://www.abdi.com.br/Estudo/Medidas $\% 20$ Sist $\%$ C3\%AAmicas\%20PBM $\% 20-\% 20$ Rel $\% 20 \% 20$ de $\% 20$ Acomp $\% 20$ junho\%2014.pdf>. Acesso em: 15 out. 2014.

BRASIL. Ministério do desenvolvimento, Indústria e Comércio. Plano Brasil Maior. Disponível em: <http:// www.brasilmaior.mdic.gov.br/conteudo/128>. Acesso em: 15 out. 2014.

BREYER, Stephen G.. Regulation and its reform. Cambridge, MA: Harvard University Press, 1982.

CARNELUTTI, Francesco. A morte do direito. Belo Horizonte: Líder, 2003.

COSTA, Ligia Maura. OMC e direito internacional do desenvolvimento sustentável. São Paulo: Quartier Latin, 2013.

CUNHA, Luciana Gross; LANGENEGGER, Natalia. Litígio de interesse público e desenvolvimento. O direito ao desenvolvimento sob a perspectiva do pensamento jurídico contemporâneo. In: SILVEIRA, Vladmir Oliveira da.; NASPOLINI SANCHES, Samyra; COUTO, Monica Benetti. (Org.). Direito $e$ desenvolvimento no Brasil no século XXI. Brasília: IPEA; CONPEDI, 2013.

DAWAR, K.;EVENETT, S. Government procurement. In: CHAUFFOUR, J. P.; MAUR, J. C. Preferential trade agreement policies for development: a handbook. Washington: World Bank, 2011.
DIAS, Jean Carlos. O direito ao desenvolvimento sob a perspectiva do pensamento jurídico contemporâneo. In: SILVEIRA, Vladmir Oliveira da; NASPOLINI SANCHES, Samyra; COUTO, Monica Benetti. (Org.). Direito e desenvolvimento no Brasil no século XXI. Brasília: IPEA; CONPEDI, 2013.

DROMI, Roberto. Licitación pública. 4. ed. Buenos Aires: Hispania Libros, 2010.

ELDIS. Policy Space. Disponível em: <http://www. eldis.org/vfile/upload/1/document/0708/DOC20476. pdf $>$.Acesso em: 30 set. 2014.

EMERIQUE, Lilian Balmant; GUERRA, Sidney. A incorporação dos tratados internacionais de direitos humanos na ordem jurídica brasileira. Revista Jurídica, Brasília, v. 10, n. 90, p. 01-34, abr./maio, 2008. Ed. Esp. Disponível em: <http://www.planalto. gov.br/ccivil_03/revista/Rev_90/Artigos/PDF/ SidneyGuerra_Rev90.pdf>. Acesso em: 30 ago. 2014.

EMPRESA BRASILEIRA DE COMUNICAÇÃO. O governo unificon em $25 \%$ a margem de preferênciapara as compras públicas: o percentual será aplicado até 2020 nas licitações federais para produtos manufaturados e serviços nacionais. Brasília, 2014. Disponível em: <http://www. ebc.com.br/noticias/economia/2014/06/margem-depreferencia-para-compras-do-governo-sera-estendidapara-25>. Acesso em 16 out. 2014.

FERRAZ, Luciano. Função Regulatória da Licitação. Revista Eletrônica de Direito Administrativo Econômico (REDAE), Salvador, n. 19, ago./set./out. 2009. Disponível em: <http://www.direitodoestado.com/ revista/REDAE-19-AGOSTO-2009-LUCIANOFERRAZ.pdf $>$. Acesso em: 30 set. 2014.

FERREIRA, Daniel. A licitação pública no Brasil e sua finalidade legal: a promoção do desenvolvimento nacional sustentável. Belo Horizonte: Fórum, 2012.

GUEDES, Aloysio Neves. O procedimento licitatório como microssistema jurídico: apontamentos e Reflexões in Rio de Janeiro (Estado). Tribunal de Contas. Revista do Tribunal de Contas do Estado do Rio de Janeiro, Rio de Janeiro, v. 2, n. 5, jan./jun. 2013.

HERNANDEZ-GARCIA, Roberto. Introduction: the global challenges o international public procurement. 
In: International Public Procurement. London: Globe Law and Business, 2009.

INTERNATIONAL CENTRE FOR TRADE AND SUSTAINABLE DEVELOPMENT (ICTSD). Acordo sobre compras governamentais inangura Ministerial da OMC. Disponível em: <http://www.ictsd.org/bridges-news/ pontes/news/acordo-sobre-compras-governamentaisinaugura-ministerial-da-omc>. Acesso em: 30 set. 2014.

JUSTEN FILHO, Marçal. Comentários à lei de licitações $e$ contratos administrativos. 13. ed. São Paulo: Dialética, 2009.

LANDES, David S. A riqueza e a pobreza das naçôes: por que algumas são tão ricas e outras tão pobres. Rio de Janeiro: Campus, 1998.

LEO, Sérgio. Menos R \$ $1 \mathrm{Bi}$ em vendas ao Governo. Valor Econômico, São Paulo, 17 mar. 2014. Disponível em: $<$ http://www.valor.com.br/brasil/3481592/menos-r-1bi-em-vendas-ao-governo>. Acesso em: 16 out. 2014.

LOWI, Theodore J. Distribution, regulation, redistribution: the functions of government. In: Public Policies and Their Politics. Ripley, W.W.

Norton e Company Inc. New York: 1996.

McAFEE, Preston; McMILLAN, John. Government procurement and international trade. Journal of International Economics, v. 26, 1989.

McAFEE, R. P., McMILLAN, J. Auctions and Bidding. Journal of Economic Literature. v. 25, p. 699-738, . 1987.

MOREIRA, Assis. OMC revisa acordo de compra governamental; Brasil prefere não aderir. Valor Econômico, São Paulo, 15 dez. 2011. Disponível em: $<$ http://www.valor.com.br/internacional/1141028/ omc-revisa-acordo-de-compra-governamental-brasilprefere-nao-aderir\#ixzz3GiEEYTZg>. Acesso em: 30 set. 2014.

NIEBUHR, Joel de Menezes. Dispensa e inexigibilidade de licitação pública. 3. ed. Belo Horizonte: Fórum, 2011.

OLIVEIRA, Gustavo Henrique Justino de. Direito ao Desenvolvimento na Constituição Brasileira de 1988. Revista Eletrônica de Direito Administrativo Econômico, Salvador, n. 16, nov./dez./jan. Disponível em: <http:// www.direitodoestado.com/revista/REDAE-16-
NOVEMBRO-2008-GUSTAVO\%20JUSTINO.pdf>. Acesso em: 30 set. 2014, p. 2.

PEIXINHO, Manoel Messias; FERRARO, Suzani Andrade. Direito ao desenvolvimento como direito fundamental. Disponível em: <http://www.conpedi.org.br/manaus/ arquivos/anais/bh/manoel_messias_peixinho.pdf $>$. Acesso em: 26 ago. 2014.

PEREIRA JUNIOR, Jessé Torres. Comentários à lei de licitações e contratações da administração pública. 6 . ed. Rio de Janeiro: Renovar, 2003.

PEREIRA JUNIOR, Jessé Torres; DOTTI, Marinês Restelatto. Políticas públicas nas licitações e contratações administrativas. 2 ed. rev. atual. e ampl. Belo Horizonte: Fórum, 2012.

PERRONE-MOISÉS, Cláudia. Direito ao desenvolvimento e investimentos estrangeiros. São Paulo: Oliveira Mendes, 1998.

PIOVESAN, Flávia. A Constituição brasileira de 1988 e os tratados internacionais de proteção dos direitos humanos. In: Temas de Direitos Humanos. 2. ed. São Paulo: Max Limonad, 2003.

RODRIGUES, Nuno Cunha. A contratação pública como instrumento de politica econômica. Coimbra: Almedina, 2013.

SALDANHA, Eduardo.Desenvolvimento etratamento especial diferenciado na OMC: uma abordagem sob a perspectiva da doutrina do stare decisis - Parte II. Revista de Direito Econômico Socioambiental, Curitiba, v. 3, n. 2, jul./dez. 2012.

SANCHES MONASSA, Clarissa Chagas; LEONELLI, Aubrey de Oliveira. É interessante para o Brasil aderir ao acordo sobre compras governamentais da OMC? Revista de Direito Internacional, Brasília, v. 10, n. 1, p. 7284. 2013.

SANCHEZ BADIN, Michelle Ratton; AZEVEDO, Milena da Fonseca. A Regulação de Compras Governamentais nos Acordos Preferenciais de Comércio. In: OLIVEIRA, Ivan Tiago Machado; SANCHEZ BADIN, Michelle Ratton. (Org.). Tendências regulatórias nos acordos preferenciais de comércio no século XXI: os casos de Estados Unidos, União Europeia, China e Índia. Brasília: IPEA, 2013. p. 243-245. Disponível 
em: <http://www.ipea.gov.br/agencia/images/stories/ PDFs/livros/livros/livro_tendencias_regulatorias1. pdf> Acesso em: 02 out. 2014.

SARLET, Ingo Wolfgang. A eficácia dos direitos fundamentais. 3. ed. Porto Alegre: Livraria do Advogado, 2003.

SCWARTZ, Joshua I. Regulation and Deregulation in Public Procurement Law Reform in the United States. In: ______. Advancing public procurement experiences: experiences, innovation and knowledge sharing. Boca Raton, PrAcademics Press, 2006, cap. 9, p 1-28. Disponível em: <http://www.ippa.ws/IPPC2/BOOK/ Chapter_9.pdf >. Acesso em: 04 out. 2014.

SILVEIRA, Vladmir Oliveira da; NASPOLINI SANCHES, Samyra. Direito e desenvolvimento no Brasil do século XXI: uma análise da normatização internacional e da Constituição Brasileira. In: SILVEIRA, Vladmir Oliveira da; NASPOLINI SANCHES, Samyra; COUTO, Monica Benetti. (Org.). Direito e desenvolvimento no Brasil no século XXI. Brasília: IPEA; CONPEDI, 2013.

SOUTO, Marcos Juruena Villela. Direito administrativo contratual. Rio de Janeiro: Lumen Juris, 2004.

SOUTO, Marcos Juruena Villela. Direito administrativo regulatório. 2. ed. Rio de Janeiro: Lumen Juris, 2005.

UNCITRAL.LeiModelode ContrataçõesPúblicas.Disponível em: <http://www.uncitral.org/uncitral/es/uncitral_ texts/procurement_infrastructure/2011Model.html>. Acesso em: 15 out. 2014.

UNIVERSIDAD NACIONAL DE LA PLATA. Los principios de Limburg sobre la aplicación del pacto internacional de derechos económicos, sociales y culturales. Disponível em: <http:// www.derechoshumanos.unlp.edu.ar/assets/files/ documentos/los-principios-de-limburg-sobre-laaplicacion-del-pacto-internacional-de-derechos- economicos-sociales-y-culturales-2.pdf $>$. Acesso em: 26 ago. 2014.

VIEIRA, Andreia Costa. A OMC e o policy space dos Estados: questões de flexibilidade, desenvolvimento sustentável e políticas públicas no GATT e GATS. In: AMARAL JUNIOR, Alberto do; CELLI JUNIOR, Umberto (Org.). A OMC: desafios e perspectivas. São Paulo: Aduaneiras, 2014.

WORLD TRADE ORGANIZATION. Anexos del proyecto de texto ministerial de Cancún. Disponível em: $<$ http://www.wto.org/spanish/thewto_s/minist_s/ min03_s/draft_decl_annex_rev2_s.htm>. Acesso em: 03 set. 2014.

WORLD TRADE ORGANIZATION. Doba WTO Ministerial 2001: Ministerial Declaration. Disponível em: $<$ http://www.wto.org/english/thewto_e/minist_e/ min01_e/mindecl_e.htm>. Acesso em: 01 set. 2014.

WORLD TRADE ORGANIZATION. Geneva WTO Ministerial 1998: Ministerial Declaration. Disponível em: $<$ http://www.wto.org/english/thewto_e/minist_e/ min98_e/mindec_e.htm>. Acesso em: 01 set. 2014.

WORLD TRADE ORGANIZATION. Parties, observers and accessions. Disponível em: <http://www.wto.org/ english/tratop_e/gproc_e/memobs_e.htm>. Acesso em: 30 set. 2014.

WORLD TRADE ORGANIZATION. Singapore WTO Ministerial 1996: Ministerial Declaration wt/ min(96)/dec. Artigo 21 - Transparency in Government Procurement. Disponível em: <http://www.wto.org/ english/thewto_e/minist_e/min96_e/wtodec_e.htm >.Acesso em: 01 set. 2014.

WORLD TRADE ORGANIZATION. WTO and Government Procurement. Disponível em: <http://www. wto.org/english/tratop_e/gproc_e/gproc_e.htm>. Acesso em: 30 set. 2014. 


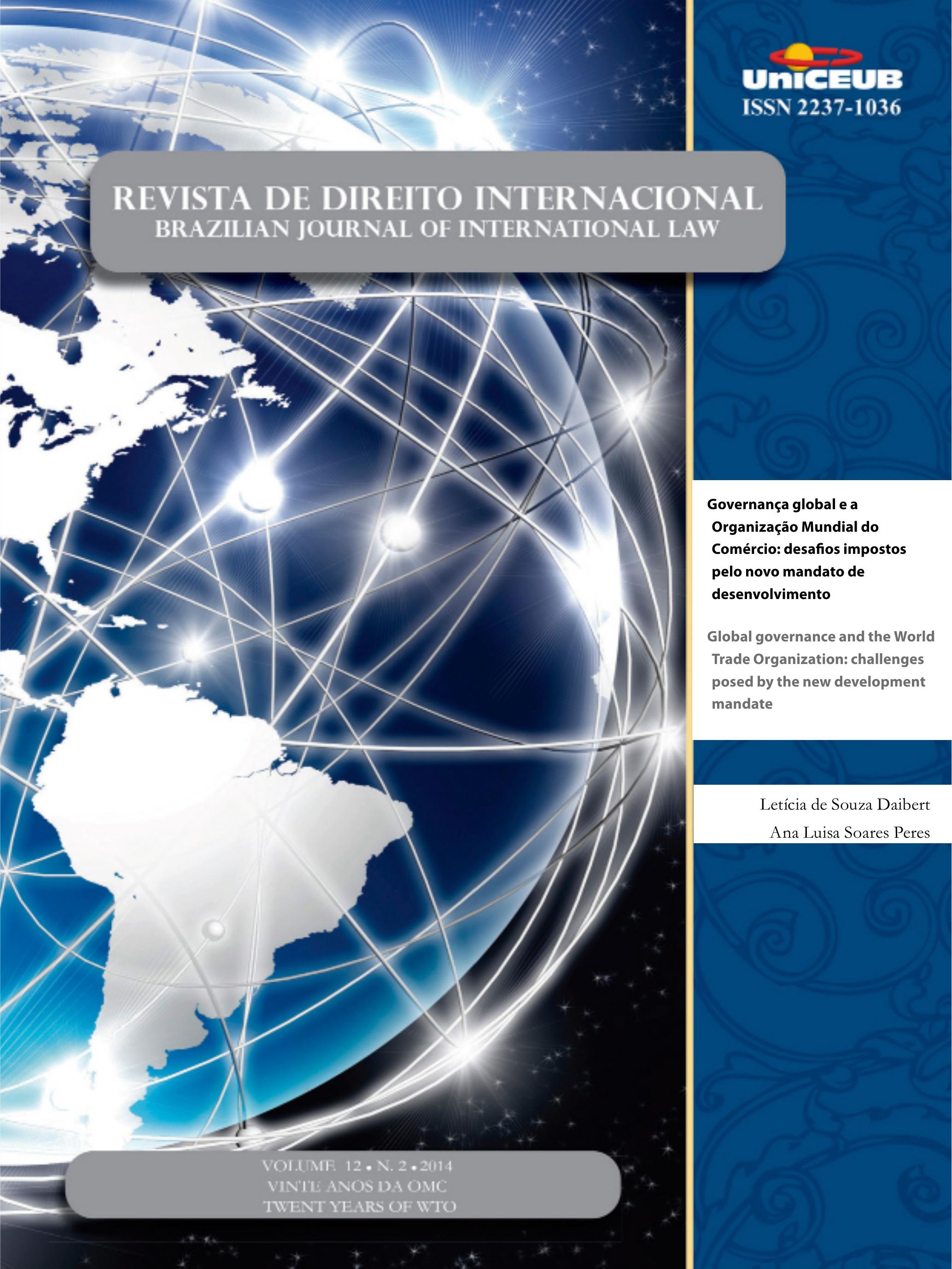




\title{
Governança global e a Organização Mundial do Comércio: desafios impostos pelo novo mandato de desenvolvimento*
}

\author{
Global governance and the World Trade \\ Organization: challenges posed by the new \\ development mandate
}

\footnotetext{
* Recebido em 30.10.2014

Aceito em 02.12.2014
}

** Professora voluntária de Direito Internacional Público na UFMG. Mestranda em Direito Internacional pela Universidade Federal de Minas Gerais e Graduada em Direito pela mesma instituição. Especialista em Estudos Diplomáticos pela Faculdade de Direito Milton Campos. Bolsista da FAPEMIG, leticiadaibert@gmail.com.

*** Mestranda em Direito Internacional pela Universidade Federal de Minas Gerais e Graduada em Direito pela mesma instituição. Bolsista da CAPES, nabrescia87@gmail.com.

\author{
Letícia de Souza Daibert** \\ Ana Luísa Soares Peres*** \\ "As pessoas estão a unir-se, em todo o mundo, numa luta comum: \\ participar livremente nos acontecimentos e processos que condicionam \\ as suas vidas". Mahbub ul Haq
}

\section{Resumo}

O presente trabalho propõe uma abordagem das normas da Organização Mundial do Comércio (OMC), especialmente de seus princípios e objetivos, baseada no conceito de governança global. Apresentam-se, de forma sucinta, algumas características fundamentais da governança global contemporânea para, em seguida, analisarem-se aspectos pontuais relacionados com a atuação da $\mathrm{OMC}$ como fórum de promoção de práticas de boa governança. Reconhece-se que a intensificação do processo de integração econômica reafirmou a interdependência entre os atores da sociedade internacional, e levou ao surgimento de desafios cuja solução ultrapassa a capacidade dos Estados individualmente considerados. A necessidade de se conferir legitimidade a essas soluções gera a demanda pelo estabelecimento de boa governança. Analisa-se, posteriormente, a importância de uma interpretação extensiva das normas da OMC, que inclua os preâmbulos de seus acordos, de modo a identificar valores e propósitos comuns a todos os Membros. Por meio desses interesses compartilhados, ressaltam-se os benefícios da participação dos Estados em desenvolvimento e de menor desenvolvimento relativo nas atividades da OMC, em um contexto de governança global, que enfatiza a coordenação e o diálogo entre os diversos atores. Por fim, considera-se a reforma do sistema de tomada de decisão da OMC, com o intuito de garantir a participação efetiva dos Membros em desenvolvimento e de menor desenvolvimento relativo. Para tanto, sugere-se a adoção de um modelo de democracia discursiva, segundo o qual se deve considerar todos os argumentos levantados pelas partes, a fim de alcançar uma decisão adequada que seja fruto de um consenso fundamentado.

Palavras-chave: OMC. Desenvolvimento. Governança Global. Participação deliberativa. Democracia.

\section{Abstract}

This paper suggests an approach to rules of the World Trade Organization (WTO), especially its principles and objectives, based on the concept of global governance. Some key features of contemporary global governance are briefly 
presented, and then specific aspects related to the performance of the WTO as a forum for promoting good governance practices are analyzed. It recognizes that the intensification of the economic integration reaffirmed the interdependence among actors in international society and led to the emergence of challenges that exceed the capacity of solution of problems by States individually considered. The need to confer legitimacy to such solutions generates a demand for the establishment of good governance. Subsequently, the importance of an extensive interpretation concerning the WTO's rules is analyzed, including its agreements preambles, in order to identify values and purposes common to all Members. Through these shared interests, the benefits of developing and least developed States participation in WTO activities are highlighted in a context of global governance, which emphasizes the coordination and the dialogue among the different actors. Finally, the reform of the WTO decision-making process is considered, aimed at ensuring the effective participation of developing and least developed Members. To this end, the adoption of a discursive democracy model is suggested, according to which all the arguments raised by the parties should be taken into account, to achieve a proper decision that is the result of a reasonable consensus.

Keywords: WTO. Development. Global governance. Deliberative participation. Democracy.

\section{Introdução}

O comércio não é um fim em si mesmo, mas um mecanismo de promoção do crescimento e do desenvolvimento. Esse é o princípio subjacente ao papel desempenhado pela Organização Mundial do Comércio (OMC) e pelo arcabouço normativo regulando o sistema multilateral de liberalização do comércio e cooperação econômica internacional ${ }^{1}$.

A existência de um regime multilateral de comércio crível e legítimo, apto a promover a governança econômica e o desenvolvimento, deve necessariamente passar pelo reconhecimento dos interesses comerciais, financeiros e sociais de todos os atores envolvidos, especialmente os países em desenvolvimento e de menor desenvolvimento relativo, de forma a permitir

1 PANITCHPAKDI, Supachai. The WTO, global governance and development. In: SAMPSON, Gary P. (Ed.). The WTO and global governance: future directions. Tóquio: United Nations University Press, 2008. p. 187. que eles maximizem os seus ganhos e minimizem as suas perdas na participação no comércio internacional.

O presente artigo conta com cinco seções, além deste primeiro item introdutório. No segundo item, a governança global será analisada como mecanismo facilitador da cooperação entre atores internacionais. $\mathrm{O}$ terceiro item explora o contexto histórico de surgimento das organizações internacionais de propósito específico no século XX e a relação deste fenômeno com a consolidação de práticas de boa governança na arena global. No item quatro, analisa-se a forma de atuação da OMC como agente ativo da promoção de práticas de boa governança global. O quinto item demonstra a existência de uma agenda comum relacionada com o desenvolvimento econômico em diferentes fóruns de debate internacional e apresenta indícios da demanda dos Estados pela consolidação de práticas de boa governança sobre comércio internacional. O sexto item versa sobre a necessidade de reforma do processo de tomada de decisão da OMC, de modo a garantir uma participação efetiva dos Membros em desenvolvimento e de menor desenvolvimento relativo, em consonância com os princípios de boa governança. Nas considerações finais, reforçam-se as impressões derivadas das análises das transformações do sistema multilateral de comércio e das tendências para a consolidação de um ambiente mais equilibrado de negociações.

O estudo desenvolvido fundamenta-se na revisão de extensa bibliografia específica sobre o tema, bem como na interpretação teleológica dos acordos que integram o âmbito normativo da OMC e na análise de casos levados ao Órgão de Solução de Controvérsias (OSC). A partir dessa pesquisa inicial, elaboram-se propostas que favoreçam o fortalecimento da estrutura de governança global dentro da Organização, de modo a promover os interesses e as necessidades relacionados ao desenvolvimento.

\section{Relevância da governança global para o funcionamento das organizações internacionais}

O aumento da interdependência global é um dos principais desafios contemporâneos. O processo de tomada de decisões é atualmente conduzido com ampla participação de vários atores internacionais e frequentemente transcende as fronteiras nacionais. Esse fenômeno requer o estabelecimento de uma estrutura de governança global que facilite a cooperação, mas que também reconheça os limites desta mesma governança no nível supranacional. 
Uma governança global eficaz pressupõe a habilidade de se administrar a interdependência de maneira a fomentar a cooperação em dada arena política, levando em consideração as diferenças em competitividade, os valores e as expectativas daqueles envolvidos nas negociações ${ }^{2}$.

Para que as organizações internacionais possam ser vistas como verdadeiros fóruns de governança global, investidos de mecanismos legítimos e de autoridade para conduzir negociações, elas devem demonstrar a sua capacidade de reconhecimento e de gerenciamento das diferenças, especialmente entre interesses nacionais e internacionais.

Nesse contexto, as organizações internacionais criam estruturas institucionais equivalentes ao aparato estatal de seus membros, tanto em forma quanto na função ${ }^{3}$, que terminam por facilitar o surgimento de redes governamentais de coleta e disseminação de informações dentro das próprias organizações ${ }^{4}$.

Anne-Marie Slaughter, em sua obra $A$ New World Order, identifica que

[o] desafio para os arquitetos destas redes (que poderiam ser os próprios membros das instituições nacionais e supranacionais participantes) será o de promover o equilíbrio adequado entre funções e responsabilidades nacionais e supranacionais. (Tradução nossa). ${ }^{5}$

As redes governamentais existem dentro e paralelamente às organizações formalmente constituídas como sujeitos de direito internacional. Elas são formadas por representantes dos governos nacionais e muitas vezes facilitam que as várias demandas da sociedade internacional sejam consideradas nas negociações ${ }^{6}$.

2 ESTY, Daniel C. Governing at the trade-environment interface. In: SAMPSON, Gary P. (Ed.).The WTO and global governance: future directions. Tóquio: United Nations University Press, 2008. p. 118.

3 SLAUghter, Anne-Marie. A New World Order. Princeton: Princeton University Press, 2004. p. 16.

4 Slaughter, Anne-Marie. A New World Order. Princeton: Princeton University Press, 2004. p. 153.

5 The trick for the architects of these networks (which could be the participating national and supranational government institutions themselves) will be to strike the right balance between national and supranational functions and responsibilities. SLAUGHTER, Anne-Marie. A New World Order. Princeton: Princeton University Press, 2004. p. 133.

6 SLAughter, Anne-Marie. A New World Order. Princeton: Princeton University Press, 2004. p. 58.
Essas redes são parte de um sistema de governança global que busca institucionalizar a cooperação e conter a escalada de conflitos, de maneira a permitir que haja um aumento mundial da paz e da prosperidade, com a melhoria dos níveis de vida de todos. Desse modo, uma vez que a sociedade internacional é caracterizada pela inexistência de hierarquia, de um governo central absoluto, as relações desenvolvidas em seu meio devem ser fundamentadas em um processo de diálogo e em vínculos de coordenação.

A OMCéa entidade cujo mandato cobre o mais amplo espectro de temas relacionados com a globalização e também a que congrega os mais diferentes pontos de vista sobre o fenômeno. A crescente integração de mercados e interdependência econômica entre os países fizeram com que temas relativos ao comércio internacional passassem a ser centrais nos processos de elaboração de políticas públicas ${ }^{7}$. Nesse cenário, a OMC emergiu como o principal fórum de articulação dos interesses envolvidos com o comércio. As redes formadas dentro da Organização desempenham um papel facilitador desta articulação de interesses.

Para que a OMC possa desempenhar adequadamente as suas funções e se fortalecer como ambiente preponderante de construção de um regime global de interdependência econômica, ela deve ser capaz de reconhecer e de reforçar os princípios e objetivos sobre os quais a Organização foi constituída, enquanto promove a liberalização do comércio. São exatamente esses princípios e objetivos que possibilitam a acomodação das diferenças entre seus Membros dentro do arcabouço normativo da entidade e fomentam as práticas de boa governança. Nesse sentido, a boa governança pode ser definida com base em cinco conjuntos de princípios: i) legitimidade, que envolve a participação e o consenso; ii) direção, de modo a se construir uma visão estratégica ampla e que considere o todo; iii) performance, que implica as ideias de eficiência e efetividade; iv) responsabilidade, na medida em que os tomadores de decisão devem ser responsáveis perante aqueles que representam, os quais, por sua vez, devem ter acesso às informações necessárias, o que ressalta a importância da transparência; e v) justiça, relacionada à equidade e ao estado de direito ${ }^{8}$.

7 LAMY, Pascal. The WTO's contribution to global governance. In: SAMPSON, Gary P. (Ed.). The WTO and global governance: future directions. Tóquio: United Nations University Press, 2008. p. 39.

8 GRAHAM, John; AMOS, Bruce; PLUMPTRE, Tim. Principles for Good Governance in the 21st Century. August 2003. Ottaw: Institute 
3 Desenvolvimento das organizações internacionais de finalidade específica no século xx: governança e mudanças paradigmáticas motivadas pelo adensamento das relações internacionais

A Grande Depressão (1929) ${ }^{9}$ transformou as relações comerciais internacionais no período entre guerras, alterando o paradigma da antiga economia liberal. Os Estados iniciaram um processo de isolamento, com o soerguimento de barreiras comerciais cada vez maiores para proteger seus mercados internos e as suas respectivas moedas contra os efeitos das crises mundiais.

O tratamento não discriminatório entre produtos, serviços e parceiros comerciais nacionais e estrangeiros, conhecido como princípio da nação mais favorecida, foi eliminado em $60 \%$ dos 510 acordos comerciais celebrados entre 1931 e 1939, permanecendo nos demais com limitação de escopo. Este fato é exemplificativo do processo de progressivo isolamento dos Estados, que enfraquecia as bases de florescimento de um sistema multilateral de comércio de longo prazo. Em decorrência disto, o comércio mundial caiu $60 \%$ em quatro anos $(1929-32)^{10}$.

Após a Segunda Guerra Mundial, as potências aliadas concluíram que o isolacionismo econômico dos

of Governance, 2003. (Policy Brief, n. 15). Disponível em: < http:// unpan1.un.org/intradoc/groups/public/documents/UNPAN/ UNPAN011842.pdf>. Acesso em: 12 out. 2014.

9 Em primeiro lugar, a extrema violência da depressão deve ser percebida. Nas três potências industriais líderes do mundo - Estados Unidos, Grã-Bretanha e Alemanha - 10.000.000 de trabalhadores ficaram ociosos. Há poucas indústrias em qualquer parte gerando lucro suficiente para a sua expansão - o que é um teste para a verificação do progresso. Ao mesmo tempo, nos países de produção primária, a renda obtida com a mineração e a agricultura é auferida com a venda, no caso de quase todas as commodities importantes, a um preço que, para muitos ou para a maioria dos produtores, não cobre os seus custos. [...] não há exemplo na história moderna de uma queda de preços tão grande e tão rápida [...]. Eis a magnitude da catástrofe. (Tradução nossa). First of all, the extreme violence of the slump is to be noticed. In the three leading industrial countries of the world - the United States, Great Britain, and Germany-10,000,000 workers stand idle. There is scarcely an important industry anywhere earning enough profit to make it expand - which is the test of progress. At the same time, in the countries of primary production the output of mining and of agriculture is selling, in the case of almost every important commodity, at a price which, for many or for the majority of producers, does not cover its cost. [...] there is no example in modern bistory of so great and rapid a fall of prices [...]. Hence the magnitude of the catastrophe. KEYNES, John Maynard. The Great Slump of 1930. Londres: The Nation \& Athenæum, 1930. Part 1. Disponível em: $<$ http://www.gutenberg.ca/ebooks/keynes-slump/keynes-slump00-h.html>. Acesso em: 29 out. 2014.

10 HOBSBAWN, Eric. The age of extremes: the short twentieth century (1914-1991). Londres: Abacus, 1994. p. 94.
Estados teria sido uma das mais proeminentes causas para o aprofundamento da Grande Depressão e para a eclosão do conflito.

De fato, a coerência entre políticas trabalhistas, financeiras e comerciais era um ponto central do sistema multilateral de nações que se constituía após o arrefecimento da guerra. A Organização Internacional do Trabalho (OIT), o Fundo Monetário Internacional (FMI), o Banco Internacional para Reconstrução e Desenvolvimento (BIRD) e a Organização Internacional do Comércio (OIC) seriam as entidades investidas do mandato para coordenar estas esferas da política internacional ${ }^{11}$.

A Conferência de Bretton Woods resultou na criação de duas organizações internacionais, a saber: o FMI, com atribuição de promover a estabilidade do sistema financeiro internacional; e o BIRD, cuja principal atribuição inicial foi a de financiar a reconstrução dos países europeus no pós-guerra ${ }^{12}$.

Os Estados Unidos da América (EUA) propuseram, em 1945, a instituição da OIC, cujo mandato estaria vinculado à regulamentação das relações comerciais internacionais, das relações de emprego e das práticas negociais. A organização, entretanto, não chegou a ser criada. A recusa do Congresso dos EUA em aprovar a carta instituidora da OIC, em dezembro de 1950, levou ao fim definitivo das negociações ${ }^{13}$.

Nesse contexto, entrou em vigor o Acordo Geral sobre Tarifas e Comércio(GATT/47), com o propósito de regular a progressiva redução de tarifas aduaneiras e de outras restrições comerciais. Como a Carta de Havana $^{14}$ nunca entrou em vigor, criou-se um vazio institucional relacionado com a normatização do comércio internacional. Para suprir esta lacuna, o GATT/47 foi aplicado de forma "provisória" por quarenta e sete anos.

11 SOMAVIA, Juan. Promoting policy coherence in the global governance of trade and employment. In: SAMPSON, Gary P. (Ed.). The WTO and global governance: future directions. Tóquio: United Nations University Press, 2008. p. 130.

12 PALMETER, David; MAVROIDS, Petros C. Dispute settlement in the World Trade Organization: practice and procedure. 2. ed. Cambridge: Cambridge University Press, 2004. p. 1.

13 PALMETER, David; MAVROIDS, Petros C. Dispute settlement in the World Trade Organization: practice and procedure. 2. ed. Cambridge: Cambridge University Press, 2004. p. 2.

14 Nome atribuído ao tratado que, se entrasse em vigor, viria a instituir a Organização Internacional do Comércio. 
O GATT/47 passou a desempenhar, então, as funções que seriam próprias da OIC. Para tanto, foram atribuídos ao acordo alguns aspectos institucionais. O que seria apenas um tratado internacional voltado para a liberalização do comércio se converteu em uma organização de fato. As estruturas institucionais foram sendo criadas e ajustadas conforme as necessidades dos seus Estados membros, identificadas no curso de suas relações comerciais ${ }^{15}$.

Merece destaque o fato de que os mandatos das organizações internacionais criadas no pós-guerra têm natureza complementar, e não exclusiva. Todas são responsáveis, em alguma medida, pela promoção da coesão das políticas internacionais sobre trabalho, finanças e comércio. Veja-se, a título exemplificativo, um dos objetivos da OIT, previsto no Anexo Declaração Referente aos Fins e Objetivos da Organização Internacional do Trabalho, da Constituição da Organização Internacional do Trabalho (1944): II $[\ldots]$

d) compete à Organização Internacional do Trabalho apreciar, no domínio internacional, tendo em vista tal objetivo, todos os programas de ação e medidas de caráter econômico e financeiro, ${ }^{16}$ (Grifo nosso).

O Convênio Constitutivo do Fundo Monetário Internacional apresenta outro exemplo da sobreposição de mandatos entre as organizações internacionais criadas no período:

Artigo I
Objetivos
Os objetivos do Fundo Monetário Internacional
são:[...]
(ii) Facilitar a expansão e o crescimento equilibrado
do comércio internacional e contribuir, assim,
para o estabelecimento e manutenção de níveis

15 HOEKMAN, Bernard M.; MAVROIDIS, Petros C. The World Trade Organization: law, economics and politics. Nova Iorque: Routledge, 2007. p. 7-8.

16 BRASIL. Decreto n. 25.696, de 20 de Outubro de 1948. Constituição da Organização Internacional do Trabalho (OIT) e seu Anexo (Declaração de Filadélfia), aprovada na $26^{a}$ reunião da Conferência (Filadélfia - 1944), conforme incorporado ao ordenamento jurídico brasileiro. elevados de emprego e de rendimento real e para o desenvolvimento dos recursos produtivos de todos os membros, como objetivos primordiais da política econômica ${ }^{17}$.

Os exemplos acima apresentados demonstram que a agenda internacional ampliou-se de forma considerável após a Segunda Guerra Mundial, abarcando inclusive temas antes restritos ao âmbito de competência interna dos Estados, como comércio e trabalho. O surgimento e fortalecimento de organizações internacionais, bem como o desenvolvimento de instrumentos normativos internacionais, contribuíram para a consolidação de uma complexa rede de interdependência pautada em arranjos regulatórios e de colaboração.

A criação das organizações no período pós-guerra é, certamente, uma das facetas do fenômeno da governança global. A preocupação em se construir um sistema multilateral de cooperação que perdurasse no longo prazo e fosse capaz de fomentar a manutenção da paz e da segurança mundial, ao mesmo tempo em que auxiliasse na manutenção da estabilidade econômica, renovaram a necessidade de se estabelecerem políticas globalmente coesas relacionadas com uma grande variedade de temas ${ }^{18}$, incentivando a participação de atores em vários níveis.

O adensamento do contexto de interdependência decorrente da globalização introduziu profundas modificações na forma de atuação e da formulação de políticas pelos Estados, ao pleitear tanto a criação de normas, como o exercício de governança para além das próprias fronteiras.

Ressalte-se que

$[\mathrm{g}]$ overnança global não é apenas um projeto
inspirado em princípios normativos. Ao contrário,
trata-se de uma realidade emergente. Admitir
a existência de uma governança no âmbito
internacional, ainda que incipiente, implica
reconhecer que os Estados soberanos
encontram-se atualmente imersos em uma
vasta teia de organizações, instituições

17 Convênio Constitutivo do Fundo Monetário Internacional FMI. BRASIL. Decreto n. 21.177, de 27 de maio de 1946. Convênio constitutivo do Fundo Monetário Internacional - FMI, de 22 de julho de 1944. Disponível em: <http://data.worldbank.org/ indicator/SP.URB.TOTL.IN.ZS> Acesso em: 12 maio 2014.

18 SOMAVIA, Juan. Promoting policy coherence in the global governance of trade and employment. In: SAMPSON, Gary P. (Ed.). The WTO and global governance: future directions, Tóquio: United Nations University Press, 2008. p. 131. 
e regimes internacionais que exercem autoridade e regulam uma série de atividades, envolvendo também diversos atores, dentre os quais se destacam, por sua relativa novidade, organizações não governamentais e as corporações multinacionais ${ }^{19}$.

Governança global, neste contexto de desenvolvimento das organizações internacionais, adquire o sentido de "[...] exercício de autoridade política na gestão de recursos para o desenvolvimento econômico e social." ${ }^{20}$. O fortalecimento da capacidade de os países formularem e executarem políticas públicas consistentes, e com vistas à promoção do crescimento e do desenvolvimento econômico também em âmbito internacional, passou a fazer parte da agenda global.

\section{A OMC como agente fomentador de uma governança global em matéria de comércio internacional e desenvolvimento econômico}

O Acordo de Marraqueche constituindo a OMC foi assinado em 12 de abril de 1994 e entrou em vigor em $1^{\circ}$ de janeiro de 1995 (BRASIL, Decreto n ${ }^{\circ}$ 1.355, de 30 de dezembro de 1994, 1994.) A estrutura da Organização foi planejada de acordo com as experiências acumuladas pelos Estados ao longo dos quarenta e sete anos de vigência do GATT/47.

Da mesma forma que o GATT/47, a OMC apresenta, entre seus objetivos, o fomento ao bem-estar de todas as nações, por meio da expansão da produção mundial e do intercâmbio comercial, a utilização plena dos recursos naturais e a expansão da produção e do comércio de bens. Ela funciona como um mecanismo para que os governos reduzam as suas barreiras comerciais e discutam políticas relacionadas com o comércio internacional ${ }^{21}$.

19 BENTO, Leonardo Valles. Governança global: uma abordagem conceitual e normativa das relações internacionais em um cenário de interdependência e globalização. 2007. Tese (Doutorado)-Curso de Pós-Graduação em Direito, Universidade Federal de Santa Catarina, Florianópolis, 2007. p. 192.

20 BENTO, Leonardo Valles. Governança global: uma abordagem conceitual e normativa das relações internacionais em um cenário de interdependência e globalização. 2007. Tese (Doutorado)-Curso de Pós-Graduação em Direito, Universidade Federal de Santa Catarina, Florianópolis, 2007. p. 135.

21 HOEKMAN, Bernard M.; MAVROIDIS, Petros C. The World Trade Organization: law, economics and politics. Nova Iorque: Routledge, 2007. p. 1.
A assinatura de tratados mutualmente benéficos, envolvendo a redução de tarifas e outras barreiras ao comércio, bem como a eliminação do tratamento discriminatório no comércio internacional, é apresentada como instrumento que contribuiria para a realização destes propósitos. A liberalização do comércio, portanto, não é um fim em si mesmo, mas um meio para a realização dos objetivos da Organização ${ }^{22}$.

Todos os acordos da OMC são aplicáveis a todos os seus $\mathrm{Membros}^{23}$. A instituição de um sistema de solução de controvérsias, dotado de meios para a execução de suas decisões, é uma de suas características mais relevantes. Sob a OMC, a formação de painéis, a adoção das decisões, bem como a autorização para retaliar, só são impedidas pelo consenso negativo, ou seja, caso todos os Membros da OMC votem negativamente à formação de painel, à adoção de decisão ou à retaliação de determinado Estado.

Cada um dos signatários dos acordos da OMC tem vOz e participa ativamente dos processos de tomada de decisões na Organização, sendo que a cada um é atribuído um voto de igual valor. Uma vez que a maior parte das deliberações é feita por consenso, até mesmo Estados menores têm a oportunidade de se fazerem ouvir no curso das negociações. Além disto, o fato de a Organização ser composta por um ordenamento jurídico cujas normas podem ser efetivadas por meio de um sistema de solução de controvérsias possibilita que o Membro menos expressivo demande as maiores potências mundiais.

Podem-se identificar exemplos do maior engajamento de países em desenvolvimento e de menor desenvolvimento relativo nas recentes reuniões ministeriais. As negociações de Seattle (1999) não progrediram, principalmente, pela recusa daqueles em aceitar a agenda imposta por alguns países desenvolvidos, relacionada com a inclusão de padrões mínimos de proteção de direitos trabalhistas nas normas da $\mathrm{OMC}^{24}$. Em Cancun (2003), as negociações foram interrompidas em razão da recusa dos países mais pobres em aceitar o lançamento de negociações sobre

22 HOEKMAN, Bernard M.; MAVROIDIS, Petros C. The World Trade Organization: law, economics and politics. Nova Iorque: Routledge, 2007. p. 14.

23 Princípio conhecido como single undertaking.

24 Os países em desenvolvimento e de menor desenvolvimento relativo entendem que a inclusão de padrões mínimos de proteção de direitos trabalhistas nas normas da OMC reduziria a competitividade da indústria intensiva em mão de obra desses mesmos países. 
as Questões de Singapura ${ }^{25}$ - concorrência, política de investimento e transparência em compras públicas ${ }^{26}$.

$\mathrm{Na}$ prática, a maior parte das negociações reflete as relações de poder existentes. Os países com maior poder econômico acabam exercendo maior influência no resultado das negociações. Não obstante, a característica que diferencia a $\mathrm{OMC}$ das experiências anteriores é a passagem de um sistema em que a implementação das esparsas normas existentes se dava de forma eminentemente voluntária e em que as disputas eram resolvidas por meios diplomáticos; para um sistema mais igualitário, em que as normas vigentes e as decisões exaradas pelo órgão de solução de controvérsias são juridicamente vinculantes. Isso permite um real engajamento dos países mais pobres nas negociações, ao promover a confiança - fator estruturante das relações internacionais - entre os membros.

Assim, as regras do sistema multilateral de comércio, em um contexto de governança global, são essenciais para assegurar a eficiência, previsibilidade e transparência das relações comerciais internacionais, de modo a manter e intensificar os fluxos de trocas entre os países. A existência de tal estabilidade favorece a integração dos membros em desenvolvimento na OMC, uma vez que fornece garantias de que a Organização não será um instrumento para a imposição dos interesses dos membros mais fortes. Constata-se, pois uma evolução do processo de tomada de decisão da OMC, que deixa de ser power oriented, para se transformar em rule oriented.

Fazer parte da Organização implica limitar a autonomia interna em quatro áreas principais: comércio de bens, comércio de serviços, proteção aos direitos de propriedade intelectual e solução de conflitos. Implica, ainda, submeter as políticas comerciais nacionais à avaliação periódica. Em contrapartida, os Membros recebem a segurança jurídica e um ambiente propício para a acomodação das demandas tanto dos países desenvolvidos, como dos países em desenvolvimento e de menor desenvolvimento relativo ${ }^{27}$.

25 Existe um temor por parte dos países em desenvolvimento e de menor desenvolvimento relativo de que a inclusão das Questões de Singapura levaria a uma grande redução da autonomia política dos Estados, ao aumento de custos das operações comerciais e à adoção de regras contrárias aos seus próprios interesses.

26 HOEKMAN, Bernard M.; MAVROIDIS, Petros C. The World Trade Organization: law, economics and politics. Nova Iorque: Routledge, 2007. p. 5.

27 HOEKMAN, Bernard M.; MAVROIDIS, Petros C. The World Trade Organization: law, economics and politics. Nova Iorque:
A OMC, nesse cenário, é um ator internacional que exerce governança global com relação a um amplo espectro de temas. Ela não só possibilita a cooperação, ao proporcionar um ambiente horizontal de troca de compromissos políticos comerciais e de debates para o estabelecimento de normas de conduta comuns, como também exerce efetiva autoridade sobre as normas jurídicas e sobre a política interna de seus membros. A conformação de um sistema eficiente de governança global relacionada com comércio é essencial para a consecução dos objetivos internacionais de desenvolvimento.

Com razão, nos ensinamentos de Lawrence $\mathrm{S}$. Finkelstein:

Governança Global é governar, sem autoridade soberana, relações que transcendem fronteiras nacionais. Governança Global é fazer internacionalmente o que governos fazem em casa. (Tradução nossa) ${ }^{28}$

$\mathrm{Na}$ OMC, ao longo de sua história, houve a progressiva solidificação de um sistema de normas e regulamentos que demandam efetiva ação governamental. O seu papel não é o de uma autoridade soberana e superior aos seus membros, mas o de conformação de um ambiente que favorece debates democráticos, entre Estados com igual poder de voto e de representação.

\subsection{Interpretação dos acordos da OMC: reconhecimento da existência de valores compartilhados pelos membros da organização}

A interpretação de toda norma jurídica tem início na análise do seu texto, sendo este apenas o primeiro método ao qual deve recorrer o operador do direito para esclarecer o seu sentido. A compreensão das normas jurídicas, todavia, não se esgota na interpretação textual ou literal de seu texto. O texto, o contexto histórico, os objetivos e propósitos para os quais a norma foi instituída devem ser entendidos como uma única regra de interpretação.

Os dispositivos de um tratado devem receber interpretação conforme seu sentido original. O objeto

Routledge, 2007. p. 15.

28 Global Governance is governing, without sovereign authority, relationships that transcend national frontiers. Global governance is doing internationally what governments do at home. FINKELSTEIN, Lawrence S. What is global governance? Global Governance, v. 1, n. 3, p. 367-373, sept./dec. 1995. p. 369. 
e os propósitos do dispositivo legal também devem ser levados em consideração ao se estabelecer o sentido de uma norma.

É exatamente esta interpretação sistemática das normas contidas nos acordos que formam o conjunto normativo da OMC que cria a possibilidade de se acomodarem os interesses de países em desenvolvimento e de menor desenvolvimento relativo e possibilita o efetivo exercício de governança global em matéria comercial. A análise das normas em conjunto permite ao aplicador do direito identificar quais os valores são compartilhados pelos Membros daquela Organização. Os valores compartilhados e objetivos comuns são o fundamento último da cooperação entre os Estados e, por isso, formam as bases para uma verdadeira governança global.

O Artigo 3.2 do Entendimento, relativo às Normas e Procedimentos sobre Solução de Controvérsias (ESC), determina que o Órgão de Apelação busque o real sentido das normas da OMC de acordo com o que determina as regras costumeiras sobre intepretação do Direito Internacional.

Artigo 3

Disposições Gerais [...]

2. O sistema de solução de controvérsias da OMC é elemento essencial para trazer segurança e previsibilidade ao sistema multilateral de comércio. Os Membros reconhecem que esse sistema é útil para preservar direitos e obrigações dos Membros dentro dos parâmetros dos acordos abrangidos e para esclarecer as disposições vigentes dos referidos acordos em conformidade com as normas correntes de interpretação do direito internacional público. As recomendações e decisões do OSC não poderão promover o aumento ou a diminuição dos direitos e obrigações definidos nos acordos abrangidos ${ }^{29}$.

O Órgão de Solução de Controvérsias da OMC (OSC) ratificou este entendimento, ao reconhecer os Artigos 31 e 32 da Convenção de Viena sobre o Direito

29 Anexo II ao Acordo Constitutivo da Organização Mundial Do Comércio - Entendimento relativo às Normas e Procedimentos sobre Solução de Controvérsias. Conforme incorporado ao ordenamento jurídico brasileiro. BRASIL. Decreto n. 1.355, de 30 de dezembro de 1994. dos Tratados de 1969 (Convenção de Viena) como normas gerais de interpretação. Referidas normas, conforme decisão do OSC no caso Japan - Alcoholic Beverages II, têm observância obrigatória, por terem adquirido status de costume internacional em matéria de direito dos tratados ${ }^{30}$ :

Artigo 31

Regra Geral de Interpretação

1. Um tratado deve ser interpretado de boafé segundo o sentido comum atribuível aos termos do tratado em seu contexto e à luz de seu objetivo e finalidade.

Artigo 32

Meios Suplementares de Interpretação

Pode-se recorrer a meios suplementares de interpretação, inclusive aos trabalhos preparatórios do tratado eàs circunstâncias de sua conclusão, a fim de confirmar o sentido resultante da aplicação do artigo 31 ou de determinar o sentido quando a interpretação, de conformidade com o artigo 31:

a) deixa o sentido ambíguo ou obscuro; ou

b) conduz a um resultado que é manifestamente absurdo ou desarrazoado ${ }^{31}$.

O OSC confirmou, em várias oportunidades, a aplicação desse costume às disputas submetidas à sua apreciação. Na primeira lide decidida pelo Órgão de Apelação, em relação ao caso US-Gasoline, reconheceuse, expressamente, que o Artigo 31 da Convenção de Viena havia atingido o status de costume em Direito Internacional.

O painel, no caso Canada - Pharmaceutical Patents, referiu-se expressamente ao preâmbulo como contexto jurídico de interpretação das normas previstas no TRIPS:

30 WORLD TRADE ORGANIZATION. Japan: taxes on alcoholic beverages: report of the appellate body. (Japan Alcoholic Beverages II), WT/DS8/AB/R; WT/DS10/AB/R; WT/DS11/AB/R. 4 October 1996. Como adotado em 1 de novembro de 1996. p 12.

31 BRASIL. Decreto n. 7.030, de 14 de dezembro de 2009. Convenção de Viena sobre Direito dos Tratados, de 23 de maio de 1969. . 
[...] o contexto ao qual o Painel pode recorrer para fins de interpretação de determinados dispositivos do TRIPS [...] não está restrito ao texto, Preâmbulo e Anexos ao TRIPS, mas também inclui tanto os dispositivos de outros instrumentos internacionais sobre propriedade intelectual incorporados ao TRIPS, quanto qualquer outro acordo celebrado entre as partes relativos aos citados instrumentos internacionais, à luz do Art. 31(2) da Convenção de Viena sobre Direito dos Tratados. (Tradução nossa) ${ }^{32}$.

O painel, portanto, não só reconheceu o preâmbulo e os anexos ao TRIPS como componentes do contexto interpretativo, como acrescentou que disposições contidas em outros instrumentos internacionais sobre propriedade intelectual também podem contribuir para o esclarecimento do conteúdo normativo do tratado em questão, ampliando as possibilidades de instrumentos aos quais se poderia recorrer para elucidar o sentido de uma norma.

Uma conclusão fundamental derivada do Artigo 31 da Convenção de Viena é o princípio da efetividade. De fato, em United States - Standards for Reformulated and Conventional Gasoline, o Órgão de Apelação estabeleceu que:

[...] um dos corolários da regra geral de interpretação da Convenção de Viena é que a interpretação deve dar sentido e eficácia a todos os termos do tratado. O intérprete não é livre para adotar uma leitura que resultaria em reduzir cláusulas ou parágrafos inteiros de um tratado à redundância ou à inutilidade. (Tradução nossa) $)^{33}$.

$32[\ldots]$ the context to which the Panel may have recourse for purposes of interpretation of specific TRIPS provisions, $[\ldots]$ is not restricted to the text, Preamble and Annexes of the TRIPS Agreement itself, but also includes the provisions of the international instruments on intellectual property incorporated into the TRIPS Agreement, as well as any agreement between the parties relating to these agreements within the meaning of Article 31(2) of the Vienna Convention on the Law of Treaties. WORLD TRADE ORGANIZATION. Canada: term of patent protection AB-20007: report of the appellate body. WT/DS170/AB/R 18 September 2000. Conforme adotado em 18 de setembro de 2000. Para. 7.26.

33 One of the corollaries of the "general rule of interpretation" in the Vienna Convention is that interpretation must give meaning and effect to all the terms of a treaty. An interpreter is not free to adopt a reading that would result in reducing whole clauses or paragraphs of a treaty to redundancy or inutility. WORLD TRADE
A análise da Carta da OMC, a qual estabelece os objetivos e propósitos da Organização, bem como do preâmbulo de alguns de seus acordos constitutivos, são essenciais para a compreensão das normas contidas nos acordos da OMC. Com razão, qualquer sistema jurídico deve ser compreendido como um todo, sendo impossível se conhecer o real sentido de uma norma isoladamente ao ordenamento no qual se encontra inserida.

O preâmbulo do Acordo Geral Sobre Tarifas Aduaneiras e Comércio (GATT/1947), como o dos demais acordos que compõem o arcabouço normativo da OMC, apresenta os objetivos dos Estados contratantes quando da adoção do tratado. É possível se inferir do texto as distintas posições trazidas à negociação pelas partes, com clara sobreposição dos interesses dos países desenvolvidos em face dos em desenvolvimento e de menor desenvolvimento relativo.

\section{ACORDO GERAL SOBRE TARIFAS ADUANEIRAS E COMÉRCIO}

[...] Reconhecendo que suas relações no domínio comercial e econômico devem ser orientadas no sentido de elevar os padrões de vida, de assegurar o emprego pleno e um alto e sempre crescente nível de rendimento real e de produção efetiva, para a mais ampla exploração dos recursos mundiais e a expansão da produção e das trocas de mercadorias;

Almejando contribuir para a consecução desses objetivos, mediante a conclusão de acordos recíprocos e mutuamente vantajosos, visando à redução substancial das tarifas aduaneiras e de outras barreiras às permutas comerciais e à eliminação do tratamento discriminatório, em matéria de comércio internacional;

Por intermédio de seus representantes, convieram no seguinte ${ }^{34}$

É razoável se afirmar que os propósitos mais relevantes do GATT/47 à época de sua redação eram o

ORGANIZATION. United States: standards for reformulated and conventional gasoline. WT/DS2/9 20 may 1996. Conforme adotado em 20 de maio de 1996. p. 23.

34 Acordo Geral sobre Tarifas Aduaneiras e Comércio (GATT/1947). BRASIL. Decreto 313, de 30 de julho de 1948, 1948. 
de garantir a paz mundial, fomentar o desenvolvimento e o bem-estar econômico de todas as nações ${ }^{35}$.

O GATT/47 foi concebido tendo como fim o estabelecimento de mudanças nas legislações internas das partes contratantes para que fossem progressivamente reduzidas as barreiras ao comércio existentes. A interferência se dava, portanto, no âmbito de discricionariedade dos Estados e não na relação entre eles.

No texto do Acordo, é concedido enfoque particular à progressiva liberalização do comércio, conforme defendem os países desenvolvidos. Não obstante, o preâmbulo também apresenta como uns dos principais objetivos do GATT/47, a melhoria dos padrões de vida e a garantia do pleno emprego, o que retrata uma preocupação dos países em desenvolvimento com relação às implicações econômicas que poderiam advir da liberalização do comércio e que corresponde aos objetivos gerais da OMC.

Com efeito, o preâmbulo do Acordo Constitutivo da OMC inclui a maioria dos objetivos do GATT/47, ampliando-os:

As Partes do presente Acordo,

Reconbecendo que as suas relações na esfera da atividade comercial e econômica devem objetivar a elevação dos níveis de vida, o pleno emprego e um volume considerável e em constante elevação de receitas reais e demanda efetiva, o aumento da produção e do comércio de bens e de serviços, permitindo ao mesmo tempo a utilização ótima dos recursos mundiais em conformidade com o objetivo de um desenvolvimento sustentável e buscando proteger e preservar o meio ambiente e incrementar os meios para fazê-lo, de maneira compatível com suas respectivas necessidades e interesses segundo os diferentes níveis de desenvolvimento econômico,

Reconhecendo ademais que é necessário realizar esforços positivos para que os países em desenvolvimento, especialmente os de menor desenvolvimento relativo, obtenham uma parte do incremento do comércio

35 JACKSON, John Howard. Sovereignty, the WTO and changing fundamentals of international law. Cambridge: Cambridge University Press, 2006. p. 85-86. internacional que corresponda às necessidades de seu desenvolvimento econômico,

Desejosas de contribuir para a consecução desses objetivos mediante a celebração de acordos destinados a obter, na base da reciprocidade e de vantagens mútuas, a redução substancial das tarifas aduaneiras e dos demais obstáculos ao comércio, assim como a eliminação do tratamento discriminatório das relações internacionais,

Resolvidas, por conseguinte, a desenvolver um sistema multilateral de comércio integrado, mais viável e duradouro, que compreenda o Acordo Geral sobre Tarifas Aduaneiras e Comércio, os resultados de esforços anteriores de liberalização do comércio e os resultados integrais das Negociações Comerciais Multilaterais da Rodada Uruguai,

Decididas a preservar os princípios fundamentais e a favorecer a consecução dos objetivos que informam este sistema multilateral de comércio,

Acordam o seguinte: [...] (Grifo nosso) ${ }^{36}$

Ressalte-se que o preâmbulo de um tratado constitui importante ferramenta para sua interpretação, elucidando seu contexto, mas não impõe, por si, obrigações aos Estados-parte, como demonstrado pela própria conotação recomendatória dos verbos empregados. O dever de os tratados serem interpretados à luz de seus objetivos e propósitos é norma costumeira de Direito Internacional, conforme visto na seção 2.1.

A preocupação dos países em desenvolvimento e de menor desenvolvimento relativo no que tange às implicações econômicas decorrentes da liberalização do comércio encontra reflexo na afirmação de que todos os Membros devem cooperar para que aqueles obtenham uma parte dos ganhos do comércio internacional que corresponda às necessidades de seu próprio desenvolvimento econômico.

Nesse sentido, Amartya Sen, em sua obra Desenvolvimento como Liberdade ${ }^{37}$, propõe um conceito de desenvolvimento que se contrapõe à mera análise de fatores como o produto interno bruto, renda per capta,

36 Acordo Constitutivo da Organização Mundial Do Comércio. BRASIL. Decreto n. 1.355, de 30 de dezembro de 1994.

37 SEN, Amartya. Desenvolvimento como liberdade. Tradução: Laura Teixeira Motta. São Paulo: Companhia das Letras, 2010. p. 55. 
nível de industrialização e grau de desenvolvimento tecnológico de uma nação. Muito embora todos os fatores mencionados anteriormente contribuam para a expansão da capacidade de os indivíduos exercerem e usufruírem das suas liberdades, entende-se que o crescimento econômico, que é possibilitado pelo aumento dos fluxos comerciais internacionais, não pode ser considerado um fim em si mesmo, ele deve necessariamente estar associado com a melhoria dos padrões de vida de todos e, especialmente com a expansão das liberdades individuais.

A ideia de desenvolvimento como liberdade é oposta ao modelo clássico de desenvolvimento como aumento de renda real. A expansão das liberdades substantivas, como o aumento do acesso à educação, saúde e alimentação, é tida como resultado direto do processo de desenvolvimento econômico e está alinhada ao posicionamento adotado pelos países em desenvolvimento e de menor desenvolvimento relativo no seio da OMC.

O arcabouço normativo da OMC, especialmente quando se considera o preâmbulo dos seus acordos constitutivos, e os princípios e objetivos que regem a Organização, reflete valores que são partilhados por seus Membros: a busca do crescimento econômico não como um fim em si mesmo, mas como mecanismo que possibilite a expansão e o exercício pleno das liberdades individuais. Governança global se traduz, em última análise, em ações pautadas por valores compartilhados entre os vários atores, que podem ou não derivar de obrigações legalmente prescritas ${ }^{38}$. A Organização, portanto, exerce governança global, na medida em que funciona como um meio para que seus Membros busquem a realização de objetivos comuns.

\subsection{A boa governança na OMC}

Como anteriormente mencionado, a prática de boa governança dentro de uma Organização Internacional implica a observância de determinados princípios. $\mathrm{Na} \mathrm{OMC}$, tais princípios se correlacionam e podem ser encontrados em diversos acordos e aspectos institucionais da Organização. Há, contudo, melhorias que poderiam ser feitas de modo a reforçar o comprometimento da OMC com esses elementos basilares, o que promoveria o fortalecimento

38 ROSENAU; James N., CZEMPIEL, Ernst-Otto. Governance without government: order and change in world politics. Cambridge: Cambridge University Press, 2000. p. 4. da Organização e a satisfação do mandato de desenvolvimento assumido na Rodada Doha.

O primeiro desses princípios, o da legitimidade, será tratado com mais detalhes posteriormente, na análise da necessidade de reforma do sistema de tomada de decisão da OMC. A legitimidade pressupõe

$$
\begin{aligned}
& \text { especialidade e promessa de ganhos de bem-estar } \\
& \text { social; ordem e estabilidade; freios e contrapesos; } \\
& \text { diálogo político e um devido processo de } \\
& \text { formulação de decisão. (Tradução nossa) }{ }^{39} \text {. }
\end{aligned}
$$

Nesse sentido, esse conceito está intimamente relacionado às negociações e decisões delas decorrentes. Na OMC, a necessidade do consenso e da participação de todos os 160 membros nos fóruns de discussão evidencia a preocupação com a legitimidade do processo, de forma a garantir a estabilidade da Instituição, a persecução de seus objetivos e a excelência de suas atividades.

A direção, por sua vez, refere-se à consideração das diferentes perspectivas e fatores que influenciam as negociações sobre o comércio internacional. Nesse contexto, a noção de representatividade torna-se central. As iniciativas da OMC, como a realização de fóruns públicos, que aproximam a Organização da sociedade civil demonstram os esforços da OMC em identificar os interesses de uma esfera pública mais ampla. As redes verticais, ao desempenharem um papel de ponte, coordenando as negociações da OMC aos interesses e necessidades das unidades de governo dos membros e das sociedades civis internas de cada um deles, também se destacam como instrumentos essenciais para assegurar que um vasto leque de possibilidades e pontos de vistas sejam apreciados nas negociações.

A performance, por sua vez, abarca os conceitos de eficiência e eficácia. A eficiência relaciona-se com o tempo, recursos e custos envolvidos nas negociações e tomada de decisão. Já a eficácia envolve a observância dos acordos e das decisões da OMC por seus membros e a adequação desses instrumentos aos propósitos da Organização. A Rodada Doha apresenta-se como um desafio para esses dois aspectos. A dificuldade em se alcançar um consenso nos temas mais importantes da

39 expertise and the promise of social welfare gains; order and stability; checks and balances; political dialogue and a 'right process' for decision-making. ESTY, Daniel C. Good Governance at the World Trade Organization: building a foundation of administrative law. Journal of International Economic Law, v.10, n. 3, p. 509-527, 2007. p. 511. 
agenda, em uma negociação que se estende por treze anos, revela os problemas da OMC no que concerne a sua eficiência. Quanto à eficácia, o sistema de solução de controvérsias da Organização é um importante elemento para garantir que os seus membros cumpram as normas multilateralmente acordadas. Os obstáculos nesse ponto estão em assegurar a completa realização dos objetivos assumidos em seu acordo constitutivo, os quais, como anteriormente mencionado, envolvem o desenvolvimento e o bem-estar de todos os membros. O avanço desse princípio, assim como o da legitimidade, depende da reforma do processo da tomada de decisão da OMC, de modo a tornar o sistema realmente democrático e ativo no sistema multilateral do comércio.

No tocante à responsabilidade, as redes verticais na OMC também trariam benefícios para a solidificação desse princípio, pois facilitariam a responsabilização dos oficiais na Organização, de modo a garantir que eles atuem em consonância com as necessidades e interesses da sociedade internacional. A ligação, por meio de canais de comunicação e trabalho conjunto, entre os representantes eleitos internamente e os oficiais da OMC, permitiria a aproximação destes das realidades dos membros. As posturas assumidas nas negociações multilaterais seriam assim mais representativas e vinculadas aos padrões ali observados. A fiscalização, possibilitada pelo princípio da transparência, resultaria em um sistema de tomada de decisão mais congruente, com a necessidade de justificação das ações adotadas e das políticas aprovadas pela OMC.

Por fim, a justiça é um princípio que possui um elemento procedimental, relacionado ao devido processo e a oportunidade de ser ouvido, o que o aproxima muito do conceito de legitimidade, e um elemento substantivo, que pondera se os benefícios e encargos são equitativamente distribuídos ${ }^{40}$. $\mathrm{Na} \mathrm{OMC}$, o aspecto procedimental ainda necessita de maior atenção e a possibilidade de implementação de uma democracia deliberativa, como proposta no presente trabalho, apresenta-se como imprescindível para a sua completa realização. O caráter material de tal princípio é ressaltado nos diversos dispositivos estudados a seguir, que concedem tratamento especial e diferencial para os membros em desenvolvimento e de menor desenvolvimento relativo, de forma que estes não

40 ESTY, Daniel C. Good Governance at the World Trade Organization: building a foundation of administrative law. Journal of International Economic Law, v.10, n. 3, p. 509-527, 2007. p. 523. precisem arcar com um fardo maior na liberalização comercial.

\section{Países em desenvolvimento e a OMC}

Como abordado na seção anterior, são objetivos da OMC a melhoria dos padrões de vida, o pleno emprego, a promoção do desenvolvimento sustentável e ações afirmativas com o intuito de assegurar que os países em desenvolvimento e, especialmente, os de menor desenvolvimento relativo possam ter uma participação no crescimento do comércio mundial proporcional às suas necessidades de desenvolvimento econômico.

Acesso a mercados e crescimento de fluxos comerciais não necessariamente se convertem em desenvolvimento econômico efetivo, como se infere da lição de Amartya Sen:

É importante notar que opulência econômica e liberdade, ainda que não sejam dissociadas, podem frequentemente divergir. (Tradução nossa) ${ }^{41}$

A política comercial e, especialmente, a liberalização do comércio inevitavelmente provocam mudanças nas economias internas dos países afetados por tais políticas. Um comércio mais livre incentiva a expansão da atividade econômica, o que pode se traduzir em industrialização e aumento do consumo de recursos naturais, alterando o modelo de desenvolvimento até então adotado internamente. Este processo só estaria incluído no escopo da OMC, se fossem levados em conta o contexto interpretativo e os objetivos de seus acordos, na medida em que resultem na elevação dos padrões de vida, em formas de se assegurar o pleno emprego e em um alto e sempre crescente nível de rendimento real e de produção efetiva. Com razão,

[o] resultado básico sobre a eficiência do mercado pode, nesse sentido, ser estendido à perspectiva das liberdades substantivas. Mas esses resultados de eficiência nada dizem sobre a equidade das situações decorrentes, ou sobre a equidade na distribuição das liberdades ${ }^{42}$.

41 It is important to note that economic opulence and substantive freedom, while not unconnected, can frequently diverge. SEN, Amartya. The idea of justice. Cambridge: The Belknap Press of Harvard University Press, 2009. p. 226.

42 SEN, Amartya. Desenvolvimento como liberdade. Tradução: Laura Teixeira Motta. São Paulo: Companhia das Letras, 2010. p. 159-160. 
A rápida industrialização chinesa após a sua entrada na OMC exemplifica esta tendência. A transferência do excedente de mão de obra do setor agrícola, de baixa produtividade, para os setores secundários e terciários da economia, de alta produtividade, criou as bases para o rápido crescimento econômico do país, verificado na primeira década dos anos $2000^{43}$. Esse fenômeno resultou no aumento da população urbana, de 37.7\% em 2001, para $52 \%$ em $2013^{44}$. A opulência econômica, no entanto, não se converteu automaticamente em desenvolvimento humano.

A esse respeito, as considerações do Relatório do Desenvolvimento Humano de 2013:

\begin{abstract}
A ascensão do Sul abarca experiências de países muito distintos, mostrando que existem múltiplas formas de alcançar e manter o desenvolvimento humano. Os países foram pragmáticos na adoção de políticas adequadas às suas circunstâncias específicas: por exemplo, entre 1979 e 1989, nada mais nada menos que $40 \%$ da regulamentação nacional chinesa foi considerada de caráter experimental. Foram também amplamente partilhadas abordagens comuns. Verificou-se, na maioria dos países em rápido desenvolvimento do Sul, uma abertura ao exterior no domínio do comércio, investimento e tecnologia. Contudo, essa abertura não garantiu, por si só, o êxito. [...].

Uma liderança ativa por parte dos governos foi fundamental para acelerar o pregresso econômico e minimizar os conflitos sociais. [...] A China pôs igualmente em evidência a importância desta abordagem na sua procura estratégica de uma 'sociedade harmoniosa's .
\end{abstract}

O imperativo de se incorporarem as necessidades dos países em desenvolvimento e de menor desenvolvimento relativo ao sistema multilateral de

43 CHEN, Chunlai. China's integration with the global Economy: WTO accession, foreign direct investment and international trade. Cheltenham: Edward Elgar, 2009. p. 2.

44 DADOS do Banco Mundial. Disponível em: < http://data. worldbank.org/indicator/SP.URB.TOTL.IN.ZS>. Acesso em: 12 maio 2014

45 PROGRAMA DAS NAÇÕES UNIDAS PARA O DESENVOLVIMENTO - PNUD. Relatório do desenvolvimento humano 2013: a ascensão do sul: progresso humano num mundo diversificado. Disponível em: <http://www.un.cv/files/ HDR2013\%20Report\%20Portuguese.pdf> . Acesso em: 14 maio 2014. p. 18. comércio foi bem explicitado pelo relatório do Painel no caso EC - Tariff Preferences:

Durante a segunda sessão da UNCTAD, em 26 de março de 1968, uma Resolução sobre a "Expansão e Diversificação de Exportações e Manufaturas e SemiManufaturas em Países em Desenvolvimento" foi adotada (Resolução 21 (II)). Nesta resolução, a UNCTAD concordou com a "rápida criação de um sistema mutuamente aceitável de preferências generalizadas, não recíprocas e não discriminatórias, que seriam benéficas para os países em desenvolvimento" e estabeleceu uma Comissão Especial de Preferências como um órgão subsidiário do Conselho de Comércio e Desenvolvimento, com um mandato para decidir os detalhes de arranjos sobre Regime Generalizado de Preferências (RGP). Em 1970, a Comissão Especial de Preferências da UNCTAD aprovou as Conclusões Acordadas estabelecendo os detalhes acordados do regime SPG. O Conselho de Comércio e Desenvolvimento anotou estas Conclusões Acordadas em 13 de janeiro de 1970. De acordo com as Conclusões Acordadas, certos Membros desenvolvidos do GATT requereram a isenção do RGP perante o Conselho do GATT. O GATT concedeu uma isenção de 10 anos em 25 de junho de 1971. Antes de terminar o período de isenção, as Partes adotaram uma decisão em "Tratamento Diferencial e mais Favorável, Reciprocidade e Participação de Países em Desenvolvimento" (a "Cláusula de Habilitação”), em 28 de novembro de 1979. (Tradução nossa) ${ }^{46}$.

46 During the Second Session of UNCTAD, on 26 March 1968, a Resolution was adopted on "Expansion and diversification of Exports and Manufactures and Semi-manufactures of Developing Countries" (Resolution 21 (II)). In this Resolution, UNCTAD agreed to the "early establishment of a mutually acceptable system of generalized, non-reciprocal and non-discriminatory preferences which would be beneficial to the developing countries" and established a Special Committee on Preferences as a subsidiary organ of the Trade and Development Board, with a mandate to settle the details of the GSP arrangements. In 1970, UNCTAD's Special Committee on Preferences adopted Agreed Conclusions which set up the agreed details of the GSP arrangement.

UNCTAD's Trade and Development Board took note of these Agreed Conclusions on 13 January 1970. In accordance with the Agreed Conclusions, certain developed GATT contracting parties sought a waiver for the GSP from the GATT Council. The GATT granted a 10-year waiver on 25 June 1971. Before the expiry of this waiver, the CONTRACTING PARTIES adopted a decision on "Differential and More Favorable Treatment, Reciprocity and Fuller Participation of Developing Countries" (the "Enabling Clause") on 28 November 1979. EUROPEAN COMMUNITIES. Conditions 
A Cláusula de Habilitação, que permite que distorções geradas pela aplicação da Cláusula da Nação Mais Favorecida (MFN) sejam corrigidas com relação a países em desenvolvimento e de menor desenvolvimento relativo, é um dos instrumentos utilizados para se reduzirem as desigualdades verificadas entre os Membros. Ela se tornou um traço permanente tanto do GATT/47, quanto da OMC.

O tratamento preferencial, concedido sob a Cláusula de Habilitação, tem sido usado como forma de auxílio ao desenvolvimento, cujo objetivo final seria o de promover a expansão e a diversificação das exportações. A história, no entanto, sugere que o tratamento diferenciado, apesar de gerar incentivos à exportação, não é suficiente para superar os entraves internos à produção ${ }^{47}$.

Esse é um exemplo de como a consolidação de um regime comercial forte, fundamentado em regras jurídicas vinculantes, pode contribuir para a consolidação de um modelo abrangente de governança global no mercado mundial. $\mathrm{Na}$ ausência de hierarquia e de um poder central, são as normas que possibilitam a harmonia e a legitimação do sistema multilateral de comércio, por estimularem a inclusão de todos os atores em tal sistema. A Cláusula de Habilitação é um instrumento que oferece uma oportunidade para a correção dos desequilíbrios relacionados com a liberalização do comércio e o acesso a mercados.

Os acordos da OMC contêm aproximadamente cento e cinquenta e cinco dispositivos regulando o tratamento especial e diferenciado para países em desenvolvimento. Além da Cláusula de Habilitação, há exceções às regras gerais, metas reduzidas de diminuição de tarifas e de subsídios agrícolas, períodos mais extensos para a implementação interna das normas, regras procedimentais favoráveis e assistência técnica. Estes mecanismos são parte integrante dos acordos da OMC e são coerentes com os seus princípios e objetivos ${ }^{48}$. A correta aplicação destas regras contribui para a redução das assimetrias e fomento do desenvolvimento, sendo essenciais para o fortalecimento de uma verdadeira governança econômica global.

for the Granting of Tariff Preferences to Developing Countries (DS246), conforme adotado em 20 de abril de 2004.

47 HOEKMAN, Bernard M.; MAVROIDIS, Petros C. The World Trade Organization: law, economics and politics. Nova Iorque: Routledge, 2007. p. 95.

48 PANITCHPAKDI, Supachai. The WTO, global governance and development. In: SAMPSON, Gary P. (Ed.). The WTO and global governance: future directions. Tóquio: United Nations University Press, 2008. p. 188.
O reconhecimento de que o comércio pode servir como uma ferramenta de crescimento econômico, desenvolvimento e erradicação da pobreza também é encontrado na Declaração do Milênio das Nações Unidas:

\section{Declaração do Milênio das Nações Unidas}

[...] 12. Em consequência, decidimos criar condições propícias, a nível nacional e mundial, ao desenvolvimento e à eliminação da pobreza.

13. A realização destes objetivos depende, entre outras coisas, de uma boa governação em cada país. Depende também de uma boa governação no plano internacional e da transparência dos sistemas financeiros, monetários e comerciais. Propugnamos um sistema comercial e financeiro multilateral aberto, equitativo, baseado em normas, previsível e não discriminatório ${ }^{49}$.

Ao atrair investimentos domésticos e estrangeiros, incentivar o empreendedorismo e a produção, o aumento dos intercâmbios mercantis pode se converter, indubitavelmente, em desenvolvimento. Ao gerar renda, o comércio contribui para a criação de empregos, para o aumento da renda das populações, bem como para o aumento dos níveis de bem-estar de todos. No entanto, a realização destes objetivos não é automática. Depende da elaboração de políticas públicas que reconheçam a existência de assimetrias entre os atores e criem mecanismos para reduzi-las.

O fato de a Declaração do Milênio reconhecer que a boa governança em matéria comercial é essencial para a realização dos objetivos de promoção do desenvolvimento e de erradicação da pobreza é bastante significativo e demonstra que essa agenda não está circunscrita à OMC.

A chave para a realização das metas de desenvolvimento internacionalmente estabelecidas está na consolidação não apenas de um modelo de governança global, mas também de práticas de boa governança econômica global. A liberalização do comércio e aumento de acesso a mercados, por si só, não são suficientes para que haja efetiva melhoria no bem-estar de todos.

49 Declaração do Milénio das Nações Unidas é um documento histórico para o novo século. Aprovada na Cimeira do Milénio realizada de 6 a 8 de Setembro de 2000, em Nova Iorque. Disponível em: <https://www.unric.org/html/portuguese/uninfo/DecdoMil. pdf $>$. Acesso em: 14 maio 2014. 
6 A rodada Doha e a necessidade de reforma da OMC

As transformações observadas na sociedade internacional nas últimas décadas demonstram que não é mais possível ignorar a presença e o peso dos países em desenvolvimento na economia e políticas mundiais. A OMC tem tentado adaptar-se a esse contexto, de modo a abarcar os interesses e as necessidades deste grupo de Estados em suas atividades.

A Rodada Doha ${ }^{50}$ é a primeira rodada de negociações desde a instituição da OMC. Ela possui um propósito ambicioso, qual seja, o de revisar as normas já existentes e de ampliar o escopo regulatório da Organização, com a celebração de novos acordos. O tópico desenvolvimento tornou-se central nas discussões e passou a ser o fundamento para todas as negociações realizadas no âmbito da Rodada. Busca-se com isso amenizar os desequilíbrios decorrentes da Rodada do Urugua $^{51}$, pois, em razão da desproporcionalidade da capacidade negocial entre os países desenvolvidos e aqueles em desenvolvimento, os acordos resultantes desta Rodada acabaram por favorecer a prevalência dos interesses dos Estados economicamente mais fortes.

A conscientização dos Membros em desenvolvimento e de menor desenvolvimento relativo sobre o seu papel no sistema multilateral de comércio resultou na mudança da postura negocial desses países e, consequentemente, na evolução da dinâmica das negociações no interior da OMC. Observa-se uma posição mais incisiva e ativa desse grupo de Estados, que quer introduzir seus interesses e suas necessidades nas pautas de discussão.

Alguns dos Membros em desenvolvimento e de menor desenvolvimento relativo, temendo o desvio no propósito dos debates da Rodada Doha, decidiram se articular em uma coalizão, criando, em 2003, o G-20 comercial $^{52}$. O G-20 confere a esses países

50 Também conhecida como Rodada do Milênio, teve seu início em 2001, com um mandato voltado para o desenvolvimento.

51 Última Rodada de Negociações do GATT/47 que se estendeu de 1986 a 1994 e resultou na criação da OMC.

52 Grupo de países em desenvolvimento criado em 20 de agosto de 2003, na fase final da preparação para a V Conferência Ministerial da OMC, realizada em Cancun, entre 10 e 14 de setembro de 2003. O Grupo tem uma vasta e equilibrada representação geográfica, sendo atualmente integrado por 23 Membros: 5 da África (África do Sul, Egito, Nigéria, Tanzânia e Zimbábue), 6 da Ásia (China, Filipinas, Índia, Indonésia, Paquistão e Tailândia) e 12 da América Latina (Argentina, Bolívia, Brasil, Chile, Cuba, Equador, Guatemala, México, Paraguai, Peru, Uruguai e Venezuela), e concentra sua atuação em agricultura, o tema central da Agenda de Desenvolvimento de Doha. um maior poder de manobra e de persuasão, com o objetivo principal de proteger os compromissos sobre desenvolvimento assumidos na Agenda da Rodada Doha.

Desse modo, os Membros em desenvolvimento e de menor desenvolvimento relativo buscam alternativas para participar do sistema multilateral de comércio e para ter voz nas discussões e negociações, de forma a serem integrantes, de facto, da estrutura de cooperação fomentada pela governança global.

\subsection{Reforma do processo de tomada de decisão}

A OMC, a fim de solidificar, tanto em sua estrutura quanto em suas atividades, os princípios da boa governança mencionados nas seções anteriores, necessita rever o seu processo de tomada de decisões.

A regra que orienta esse processo é a do consenso. $\mathrm{O}$ grande problema no tocante a tal prática é que ela pode resultar em um impasse, o que, em algumas situações, leva à paralização nas negociações, como observado durante a Rodada Doha. As discussões sobre as formas de aprimorar esse método são muitas, mas nenhum resultado concreto foi alcançado. O consenso continua, assim, como a melhor alternativa para assegurar a legitimidade democrática das decisões, em especial quando comparado com o sistema de votos com pesos diferentes adotados, por exemplo, pelo Banco Mundial e pelo FMI. Depreende-se, pois, que deve necessariamente haver um acordo de vontades entre os Estados economicamente mais fortes e os Membros em desenvolvimento e de menor desenvolvimento relativo para que se alcance uma decisão na OMC..$^{53}$

A principal questão a ser analisada no tocante ao processo de tomada de decisão da OMC é como garantir aos Membros de menor poder político e econômico as oportunidades para manifestar seus interesses e necessidades. Torna-se necessário que esse grupo de países possa participar nas negociações de forma efetiva e seja capaz de influenciar as decisões que delas decorram.

A democratização do processo de tomada de decisão da OMC apresenta-se como um elemento necessário para a evolução da Organização e possui um contexto favorável para ser realizada, em razão

53 JACKSON, John H. Sovereignty, the WTO and changing fundamentals of international law. Cambridge: Cambridge University Press, 2006. p. 113-116. 
da ênfase concedida atualmente à governança global. A governança pressupõe a existência de negociações constantes, de modo a permitir a concordância sobre ações e regras comuns para responder a problemas também comuns ${ }^{54}$. A atuação conjunta, fundamental para a governança, apenas é possível quando todos os atores envolvidos no processo tenham as mesmas chances e os mesmos recursos para debater e para alcançar o resultado final, isto é, quando há a efetiva democratização do sistema.

A OMC é composta, atualmente, por cento e sessenta Membros, os quais, segundo as regras do consenso e do single undertaking, devem participar de todas as discussões e aceitar todas as regras multilateralmente acordadas. Percebe-se, assim, o desafio de assegurar a todos os países papel ativo nas negociações dentro da Organização.

Alguns autores sugerem como alternativa para superar esse problema a criação de grupos consultivos, de um comitê executivo, ou de um órgão consultivo ${ }^{55}$. Todas essas propostas possuem a mesma essência - a formação de um subgrupo, constituído por um número limitado de Membros, que atuaria como um órgão de apoio para as negociações, realizando estudos e análises técnicas sobre os temas debatidos no fórum multilateral. A despeito do temor de alguns Estados, tal subgrupo não seria um instrumento de exclusão, uma vez que emitiria pareceres recomendatórios e não decisões vinculatórias, suas atividades seriam imparciais e transparentes, e haveria uma rotação periódica dos participantes, o que garantiria a sua representatividade e diversidade. O propósito seria fornecer substrato material para as discussões, como forma de ajudar na construção de argumentos dos Membros.

54 LAMY, Pascal. The WTO's Contribution to Global Governance. In: SAMPSON, Gary P. (Ed.). The WTO and global governance: future directions. Tóquio: United Nations University Press, 2008. p. 41.

55 Nesse sentido, conferir: OSTRY, Sylvia. The WTO, global governance and policy options. In: SAMPSON, Gary P. (Ed.). The WTO and global governance: future directions. Tóquio: United Nations University Press, 2008; SUTHERLAND, Peter; SEWELL, John; WEINER David. Challenges Facing the WTO and Policies to Address Global Governance. In: SAMPSON, Gary P. (Ed.). The Role of the World Trade Organization in global governance. Tóquio: United Nations University Press, 2001; BLACKHURST, Richard; HARTRIDGE, David. Improving the Capacity of WTO Institutions to Fulfil Their Mandate. Journal of International Economic Law, v.7, n. 3, p. 705-716, 2004.
A teoria da democracia discursiva ${ }^{56}$ apresenta-se como a mais adequada para a governança global, em que há uma reafirmação dos países em desenvolvimento na sociedade internacional. A aplicação dessa teoria significaria oestabelecimento de mecanismosdefomento a uma atuação coordenada dos Membro na OMC, de modo a promover um consenso fundamentado ${ }^{57}$. O fato de haver reconhecimento, respeito e igualdade de todas as partes como integrantes da ação comunicativa não nega a assimetria de poder entre elas, mas salienta que os aspectos relacionados ao poder, coerção e força devem ser colocados em segundo plano, priorizando-se os argumentos e os melhores fundamentos ${ }^{58}$.

Dessa forma, é possível

[...] avaliar reflexivamente e coletivamente as reinvindicações válidas sobre normas e padrões de comportamento estabelecidos. Como resultado, argumentação e persuasão constituem ferramentas de "direção branda" que podem melhorar tanto os problemas de legitimidade da governança global, por prover oportunidades para os diversos interessados em expressar sua voz, quanto a capacidade de solução de problemas das instituições de governança por intermédio da deliberação (Tradução nossa) ${ }^{59}$.

O objetivo final da democratização do processo de tomada de decisões é conseguir um sistema legítimo,

56 A democracia discursiva, ou democracia deliberativa, é uma teoria desenvolvida a partir dos estudos de Habermas, que se baseia na argumentação e na ação comunicativa. Diferentemente da democracia representativa, na qual há o enfoque no voto por cabeça, a democracia discursiva enfatiza os discursos dos atores e a institucionalização de processos para garantir que esses discursos sejam externalizados e considerados na tomada de decisão. Uma decisão adequada, legítima e democrática será, segundo essa corrente, aquela que aprecia todas as perspectivas apresentadas pelos diferentes discursos e é justificada pelos melhores argumentos. Desse modo, a democracia discursiva ressalta a pluralidade das partes e favorece a integração de diferentes realidades.

57 HABERMAS, Jürgen. The theory of communicative action: Reason and the rationalization of society. Boston: Beacon Press, 1984. p. 285-286.

58 RISSE, Thomas. Global governance and communicative action. Government and Opposition, v. 39, n. 2, p. 288-313, 2004. p. 296.

$59[\ldots]$ can reflexively and collectively assess the validity claims of norms and standards of appropriate behavior. As a result, arguing and persuasion constitute tools of 'soft steering' that might improve both the legitimacy problems of global governance by providing voice opportunities to various stakeholders and the problem-solving capacity of governance institutions through deliberation. RISSE, Thomas. Global governance and communicative action. Government and Opposition, v. 39, n. 2, p. 288-313, 2004. p. 288-289. 
que produza decisões igualmente legítimas, mas que seja eficaz, capaz de superar os entraves das negociações.

Nesse mesmo contexto, é imprescindível aprimorar a transparência e a participação dos Membros nas atividades desenvolvidas no seio da Organização.

A transparência é um princípio que norteia a atuação da OMC e está presente em seus acordos, constituindo-se uma via de mão dupla: os Membros devem publicar suas políticas relacionadas ao comércio internacional e a Organização deve tornar públicas as suas decisões e todo trabalho relacionado às negociações. Assim, os documentos produzidos no interior da $\mathrm{OMC}$, tanto por seus funcionários quanto por representantes governamentais, devem ser públicos e práticas que tentem burlar esse princípio, como por exemplo, conceder caráter não oficial a documentos que são, de fato, oficiais, devem ser coibidas. Além disso, questiona-se o fato de o Sistema de Solução de Controvérsias não ser aberto aos outros Membros que não estejam envolvidos na disputa, e a dificuldade dos comitês e grupos de trabalho em tornarem suas reuniões mais transparentes ${ }^{60}$.

A participação, por sua vez, está atrelada ao princípio da transparência e implica mais que a mera presença de alguns representantes governamentais junto à sede da OMC em Genebra. Ela é condição essencial para a garantia de legitimidade da OMC, uma vez que uma decisão da Organização será legítima se produzida por um sistema inclusivo que permita aos Membros uma contribuição em igual medida e o acesso às informações necessárias para a construção de suas perspectivas. Um passo importante para assegurar a efetiva participação dos Membros é o fornecimento de expertise e condições materiais adequadas, com destaque para o princípio da cooperação, que permite a capacitação técnica dos países em desenvolvimento e de menor desenvolvimento relativo.

Dessa forma, investir em aspectos como transparência, participação e cooperação favorecem a imparcialidade, a representatividade e a legitimidade das decisões, na medida em que esses princípios são essenciais para assegurar o acesso às informações e ao conhecimento. Esses elementos são necessários para o equilíbrio de poder entre os Membros, bem como

60 JACKSON, John H. Sovereignty, the WTO and Changing fundamentals of international law. Cambridge: Cambridge University Press, 2006, p. 118-120. para o desenvolvimento de posições e a articulação de interesses no decorrer das negociações.

Os fóruns de discussão existentes na OMC são uma característica que singulariza esta Organização perante as demais, mas é mandatório que o formato deles seja repensado, com base em uma teoria democrática discursiva, de modo a apreciar todos os pontos de vista apresentados pelos países. Nesse mesmo processo, devem-se considerar os princípios de boa governança e realçar a noção de comunidade que sustenta a estrutura da OMC e que é o alicerce para o êxito da Organização. A exposição das diferentes posições permite a persuasão por meio dos melhores argumentos e assegura que a decisão adotada será aquela mais bem fundamentada e que ofereça maiores benefícios para o sistema multilateral de comércio, ao mesmo tempo em que promova o desenvolvimento.

\section{Conclusão}

Os temas de governança econômica global, relacionados com o desenvolvimento, devem considerar os problemas dos países emergentes e as suas implicações para o sistema multilateral de comércio. A credibilidade e a viabilidade de um sistema multilateral de comércio durável estão intrinsecamente relacionadas com a capacidade de as normas sobre comércio internacional e a própria OMC preencherem o seu potencial de atuarem como instrumentos de promoção do desenvolvimento.

Como visto, a melhoria pura e simples dos indicadores econômicos não é suficiente para a criação de um ambiente internacional capaz de fomentar o desenvolvimento e o crescimento econômico sustentável. Nesse cenário, o fortalecimento dos elementos fundamentais da governança global econômica pode desempenhar um papel central na criação das bases para esse desenvolvimento e crescimento econômico sustentável.

Por um lado, a instituição da OMC e de normas uniformes sobre comércio contribuíram para $O$ aumento dos intercâmbios mercantis, por meio da progressiva remoção das barreiras ao comércio, do aumento da transparência e da previsibilidade das normas comerciais.

Por outro lado, é imprescindível que os acordos da OMC sejam interpretados de forma a incentivar o desenvolvimento, colocando as necessidades e 
interesses dos países em desenvolvimento e de menor desenvolvimento relativo no centro das negociações.

É verdade que as negociações comerciais tendem a refletir as relações de poder existentes, favorecendo a conclusão de negociações referentes a temas afetos à agenda dos países desenvolvidos, como o estabelecimento de exceções à liberalização do comércio em áreas nas quais são pouco eficientes, como agricultura e têxteis.

Não obstante todos esses desafios, a recente Rodada de Negociação oferece a oportunidade para a correção dos desequilíbrios verificados ao longo dos vinte anos da celebração dos Acordos de Marraqueche. Os esforços no sentido de redução das assimetrias e fomento do desenvolvimento são essenciais para o fortalecimento de uma verdadeira governança econômica global.

O desafio que se apresenta para os formuladores de políticas públicas e legisladores é como incentivar o desenvolvimento inclusivo, que não apenas se manifeste na forma de ingresso de receitas, mas também de melhoria dos índices de desenvolvimento humano da população envolvida no processo; e, ao mesmo tempo, preservar as características principais do já estabelecido sistema multilateral de comércio, para que ele perdure para além dos ciclos de expansão e de recessão da economia.

A importância da OMC e do sistema que se constituiu sob os seus auspícios é inquestionável. Os acordos e regras em vigor, ao lado de um sistema efetivo e bem estabelecido de solução de controvérsias, asseguram a sua relevância para um mundo de economia globalizada. Seu caráter universal, confirmado pela acessão da China (2001) e, recentemente, da Rússia (2012), confere ainda maior legitimidade à Organização.

A responsabilidade pela construção de um sistema equilibrado e efetivamente integrado, dotado da flexibilidade necessária para que haja espaço na arena política para que os países em desenvolvimento e de menor desenvolvimento relativo possam sustentar o seu crescimento é de todos os seus Membros e, especialmente, das economias mais avançadas. Sempre que estas demonstram vontade política, a conclusão das negociações se dá de maneira mais fácil. 


\section{Referências}

BENTO, Leonardo Valles. Governança global: uma abordagem conceitual e normativa das relações internacionais em um cenário de interdependência e globalização. 2007. Tese (Doutorado)-Curso de PósGraduação em Direito, Universidade Federal de Santa Catarina, Florianópolis, 2007.

BLACKHURST, Richard; HARTRIDGE, David. Improving the Capacity of WTO Institutions to Fulfil Their Mandate. Journal of International Economic Law, v.7, n. 3, p. 705-716, 2004.

BRASIL. Decreto 313, de 30 de julho de 1948. Acordo geral sobre tarifas e comércio, de 15 de abril de 1994.

BRASIL. Decreto n. 1.355, de 30 de dezembro de 1994.

BRASIL. Decreto n. 21.177, de 27 de maio de 1946. Convênio constitutivo do Fundo Monetário Internacional - FMI, de 22 de julho de 1944. Disponível em: <http://data. worldbank.org/indicator/SP.URB.TOTL.IN.ZS>. Acesso em: 12 maio 2014.

BRASIL. Decreto n. 25.696, de 20 de Outubro de 1948. Constituição da Organização Internacional do Trabalho (OIT).

BRASIL. Decreto n. 7.030, de 14 de dezembro de 2009. Convenção de Viena sobre Direito dos Tratados, de 23 de maio de 1969.

BRASIL. Decreto no 1.355 , de 30 de dezembro de 1994. Entendimento da OMC sobre regras e procedimentos para a solução de controvérsias, de 15 de abril de 1994.

CHEN, Chunlai. China's integration with the global Economy: WTO accession, foreign direct investment and international trade. Cheltenham: Edward Elgar, 2009.

ESTY, Daniel C. Good Governance at the World Trade Organization: building a foundation of administrative law. Journal of International Economic Law, v.10, n. 3, p. 509-527, 2007.

ESTY, Daniel C. Governing at the trade-environment interface. In: SAMPSON, Gary P. (Ed.). The WTO and global governance: future directions. Tóquio: United Nations University Press, 2008.
FINKELSTEIN, Lawrence S. What is global governance? Global Governance, v. 1, n. 3, p. 367-373, sept./dec. 1995.

GRAHAM, John; AMOS, Bruce; PLUMPTRE, Tim. Principles for Good Governance in the 21st Century. August 2003. Ottaw: Institute of Governance, 2003. (Policy Brief, n. 15). Disponível em: <http://unpan1. un.org/intradoc/groups/public/documents/UNPAN/ UNPAN011842.pdf>. Acesso em: 12 out. 2014.

HABERMAS, Jürgen. The theory of communicative action: reason and the rationalization of society. Boston: Beacon Press, 1984.

HOBSBAWN, Eric. The age of extremes: the short twentieth century (1914-1991). Londres: Abacus, 1994.

HOEKMAN, Bernard M.; MAVROIDIS, Petros C. The World Trade Organization: law, economics and politics. Nova Iorque: Routledge, 2007.

INSTITUTO BRASILEIRO DE MINERAÇÃO - IBRAM. Informações e Análise da Economia Mineral Brasileira. 7. ed. Dez. de 2012. Disponível em: <http:// www.ibram.org.br/sites/1300/1382/00002806.pdf>. Acesso em: 14 maio 2014.

INSTITUTO BRASILEIRO DE MINERAÇÃO IBRAM. Relatório Anual IBR AM: julho 2012 - junho 2013. Disponível em: <http://www.ibram.org.br/ sites $/ 1400 / 1457 / 00000383$.pdf $>$. Acesso em: 14 maio 2014.

JACKSON, John Howard. Sovereignty, the WTO and changing fundamentals of international law. Cambridge: Cambridge University Press, 2006.

KEYNES, John Maynard. The Great Slump of 1930: part 1. Londres: The Nation \& Athenæum, 1930. Disponível em: <http://www.gutenberg.ca/ebooks/ keynes-slump/keynes-slump-00-h.html>. Acesso em: 29 out. 2014.

LAMY, Pascal. The WTO's Contribution to Global Governance. In: SAMPSON, Gary P. (Ed.). The WTO and global governance: future directions. Tóquio: United Nations University Press, 2008.

NAÇÕES UNIDAS. Declaração do Milénio. Aprovada na Cimeira do Milénio. Realizada de 6 a 8 de setembro de 
2000, em Nova Iorque. Disponível em: <https://www. unric.org/html/portuguese/uninfo/DecdoMil.pdf $>$. Acesso em: 14 maio 2014.

OSTRY, Sylvia. The WTO, Global Governance and Policy Options. In: SAMPSON, Gary P. (Ed.). The WTO and global governance: future directions. Tóquio: United Nations University Press, 2008.

PALMETER, David; MAVROIDS, Petros C. Dispute Settlement in the World Trade Organization: practice and procedure. 2. ed. Cambridge: Cambridge University Press, 2004.

PANITCHPAKDI, Supachai. The WTO, global governance and development. In: SAMPSON, Gary P. (Ed.). The WTO and global governance: future directions. Tóquio: United Nations University Press, 2008.

PROGRAMA DAS NAÇÕES UNIDAS PARA O DESENVOLVIMENTO - PNUD. Relatório do desenvolvimento bumano 2013: a ascensão do sul: progresso humano num mundo diversificado. Disponível em: <http://www.un.cv/files/HDR2013\%20Report $\% 20$ Portuguese.pdf $>$. Acesso em: 14 maio 2014.

RISSE, Thomas. Global governance and communicative action. Government and Opposition, v. 39, n. 2, p. 288-313, 2004.

ROSENAU; James N., CZEMPIEL, Ernst-Otto. Governance without government: order and change in world politics. Cambridge: Cambridge University Press, 2000.

SEN, Amartya. Desenvolvimento como liberdade. Tradução: Laura Teixeira Motta. São Paulo: Companhia das Letras, 2010.
SEN, Amartya. The idea of justice. Cambridge: The Belknap Press of Harvard University Press, 2009.

SLAUGHTER, Anne-Marie. A new world order. Princeton: Princeton University Press, 2004.

SOMAVIA, Juan. Promoting policy coherence in the global governance of trade and employment. In: SAMPSON, Gary P. (Ed.). The WTO and global governance: future directions. Tóquio: United Nations University Press, 2008.

SUTHERLAND, Peter; SEWELL, John; WEINER David. Challenges Facing the WTO and Policies to Address Global Governance. In: SAMPSON, Gary P. (Ed.). The Role of the World Trade Organization in global governance. Tóquio: United Nations University Press, 2001.

WORLD TRADE ORGANIZATION. Canada: term of patent protection $\mathrm{AB}-2000-7$ : report of the appellate body. WT/DS170/AB/R 18 September 2000. Conforme adotado em 18 de setembro de 2000.

WORLD TRADE ORGANIZATION. Japan: taxes on alcoholic beverages: report of the appellate body. (Japan - Alcoholic Beverages II), WT/DS8/AB/R; WT/DS10/AB/R; WT/DS11/AB/R. 4 October 1996. Como adotado em 1 de novembro de 1996.

WORLD TRADE ORGANIZATION. United States: standards for reformulated and conventional gasoline. WT/DS2/9 20 may 1996. Conforme adotado em 20 de maio de 1996. 


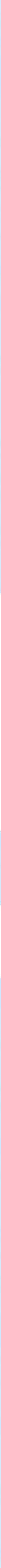




\section{Vinte Anos de Crise para a África? Poder, Assimetrias e a Abordagem Liberal da OMC*}

\section{Twenty Years' Crisis for Africa? Power, Asymmetries and the Liberal Approach to the WTO}

Igor Abdalla Medina de Souza**

\section{Resumo}

O artigo parodia o título da conhecida obra de Edward Carr, que critica o tratamento liberal da Liga das Nações vinte anos após sua a criação, para desafiar a abordagem liberal da Organização Mundial do Comércio. Duas décadas após o nascimento do atual regime de comércio, investiga-se a OMC com base no conceito de poder institucional. Em contraposição à visão liberal de soma positiva das instituições criada desde os anos 1980, em referência ao GATT 1947, desdobra-se o poder institucional nas dimensões da mudança de fórum e rolo compressor para argumentar-se que a OMC traz perdas absolutas para a África. Os acadêmicos liberais deixam de analisar as assimetrias do Acordo da $\mathrm{OMC}$ e afirmam erroneamente que a natureza mais juridicizada do mecanismo de solução de controvérsias reduz o viés em favor dos países poderosos. As estimativas apontam que os países africanos sofrem perdas associadas a royalties e monopolização advindos da maior proteção à propriedade intelectual, decréscimos em termos de PIB, exportações e medidas de bem-estar econômico, bem como vultosos custos de ajuste e implementação. Os Estados Unidos e as Comunidades Europeias valeram-se do seu poder de mercado para prover liberalização seletiva, mudar o fórum da propriedade intelectual e impor aos países africanos a escolha entre aderir ou arcar com custos proibitivos de exclusão da OMC, que mantém fechadas áreas de interesse dos países de menor desenvolvimento relativo, como agricultura.

Palavras-Chave: OMC. Liberalismo. Rodada Uruguai. DSU. Poder Institucional. África

\section{Abstract}

The article draws on the title of Edward Carr's well-known criticism directed against liberal internationalists 20 years after the creation of the League of Nations to challenge the liberal approach to the WTO two decades after it came into being. The aim of the article is to investigate the World Trade Organization

* Recebido em 30.10.2014 Aceito em 04.12.2014

** Diplomata de carreira e PhD em Ciências Políticas e Sociais pelo Instituto Universitário Europeu (Florença, Itália). As opiniões expressas no artigo são exclusivas do autor e não guardam relação com sua filiação institucional. igor.souza@itamaraty.gov.br. from the standpoint of the concept of institutional power. Against the liberal positive-sum view on institutions created in reference to the GATT 1947 from the 1980s, we break down institutional power into the dimensions of forum-shifting and go-it-alone to argue that the WTO brings absolute losses to Africa. Liberal scholars refrain from analyzing the asymmetries of the WTO and erroneously assume that the more juridicized nature of the new dispute settlement mechanism reduces the bias towards powerful countries. Existing estimates indicate that Africa undergoes absolute losses associated to royalties and monopolization derived from higher intellectual property protection, decrease in terms of GDP, 
exports and economic welfare measures, as well as high implementation and adjustment costs. The United States and the European Communities employed their market power to provide selective liberalization, shift the forum in charge of intellectual property and impose on poorer countries a choice between accepting the WTO and bearing prohibitive costs of exclusion from the trade regime, which refrains from liberalizing areas of interest to least developed countries, such as agriculture.

Keywords: WTO. Liberalism. Uruguay Round. DSU. Institutional Power. Africa.

\section{Introdução}

Vinte anos após a criação da Liga das Nações, o historiador britânico Edward Carr proferiu célebre crítica aos internacionalistas liberais, que não apreendiam os efeitos do poder na instituição criada em 1919. ${ }^{1}$ Este artigo parodia o título do livro-manifesto de Carr para proceder à investigação interdisciplinar da Organização Mundial do Comércio do ponto de vista do poder. Argumenta-se que alguns dos países mais pobres do mundo na África sofrem perdas absolutas com as normas acordadas na Rodada Uruguai (1986-1994). Desde que o estudo das instituições internacionais aproximou teóricos de Relações Internacionais (RI) e do Direito Internacional (DI) nos estertores da Guerra Fria,${ }^{2}$ internacionalistas liberais enfocaram o do Acordo Geral de Tarifas e Comércio (GATT) para conceber os arranjos normativos como mecanismos que permitem a Estados obter ganhos mútuos. David Kennedy tem argumentado com propriedade que a convergência de juristas e teóricos liberais da política internacional, após a Guerra Fria, agrava os seus pontos cegos e reduz o espaço do politicamente contestável. ${ }^{3}$ Kennedy acrescenta que o mapa mental dos internacionalistas liberais, para os quais a economia preexiste à política, enquanto esta preexiste ao Direito, não permite que os

1 CARR, Edward W. The twenty years' crisis, 1919-1939: an introduction to the study of international relations. Londres: Macmillan, 1939.

2 SOUZA, Igor A. Medina de. Dom Quixote reencontra Sancho Pança: guerra fria, relações internacionais e direito internacional. Rio de Janeiro: Apicuri, 2014.

3 KENNEDY, David. The disciplines of international law and policy. Leiden Journal of International Law,v.12, n.1, p. 9-133, jan./mar. 1999. juristas enxerguem como normas e discursos jurídicos (re)produzem assimetrias no sistema internacional. ${ }^{4}$

Philip Alston sustenta que, apesar de participarem ativamente da construção da "globalização", os juristas têm deixado de problematizar a ordem global, o que tem resultado em agendas restritas. ${ }^{5}$ Como indica o volume especial do periódico International Organization sobre a "legalização", 6 que congregou teóricos de DI e $\mathrm{RI}$, os internacionalistas liberais assumem que a OMC traz ganhos a todos os membros e limitam suas análises ao Entendimento relativo às Normas e Procedimentos sobre Solução de Controvérsias (DSU). Ainda que o desenvolvimento da abordagem liberal para o regime de comércio tenha coincidido com a transformação do GATT 1947 na OMC, os liberais não questionam em que medida o Acordo que Estabelece a OMC (doravante, Acordo da OMC) abre mercados em setores nos quais os países poderosos têm vantagens comparativas, mantendo fechadas áreas nas quais os países mais pobres tendem a ser competitivos, como agricultura. Após lidarem com amplas divergências no setor agrícola, os Estados Unidos (EUA) e as Comunidades Europeias (CE) mudaram o fórum da propriedade intelectual, deixaram o GATT 1947 e impuseram aos países em desenvolvimento a escolha entre aderir à OMC ou arcar com os custos de exclusão do regime de comércio. ${ }^{8}$ À medida que os países aderiam à OMC, criou-se dinâmica de rolo compressor que aumentava os custos de exclusão a países recalcitrantes, que se veriam em desvantagem em termos de acesso aos mercados desenvolvidos.

4 KENNEDY, David. The dark sides of virtue: reassessing international humanitarianism. Princeton: Princeton University Press, 2004. p.19.

5 ALSTON, Philip. The Myopia of the Handmaidens: International Lawyers and Globalization. European Journal of International Law, Oxford, v.8, n.3, p.435-448, 1997.

6 International Organization, Cambridge, v.54, n.3, jul./set. 2000.

7 As Comunidades Europeias foram a entidade jurídica que representou o processo de integração europeu na Rodada Uruguai, tornando-se membro da OMC ao final das negociações. Desde 2009, entretanto, a União Europeia é oficialmente reconhecida como membro da OMC.

8 STEINBERG, Richard. In the shadow of law or power? Consensus-based bargaining and outcomes in the GATT/ WTO. International Organization, Cambridge, v.56, n.2, p. 33974, abr./jun. 2002. p. 360; OSTRY, Sylvia. The Uruguay round north-south grand bargain: implications for future negotiations. In: KENNEDY, Daniel; SOUUTHWICK, James (Org.). The political economy of international Trade Law: essays in honor of Robert E. Hudec. New York: Cambridge University Press, 2002. p. 285-300. 
A atitude padrão, mesmo entre instituições comprometidas com os países pobres, transforma perdedores absolutos em ganhadores a partir de racionalizações a posteriori da decisão de aderir à OMC. O Overseas Development Institute argumenta que "perdedores aparentes" na África anuíram com a OMC devido a ganhos em termos de "certeza". A UNCTAD reconhece perdas para os países africanos, mas recorre à abstração para professar que perdedores absolutos ganharão no "longo prazo". ${ }^{10} \mathrm{O}$ jurista liberal ErnstUlrich Petersmann propõe que, após a terminação do GATT 1947, as Partes Contratantes "enfrentaram escolha entre aderir à $\mathrm{OMC}$ ou ficar de fora do sistema mundial de comércio, sem acesso legal seguro a mercados estrangeiros". ${ }^{11}$ Petersmann assume que o Acordo da OMC gera benefícios a todos os membros e considera a manobra de terminar o GATT 1947 para forçar a entrada na OMC como necessária para evitar "carona", limitando ganhos aos países-membros. A deficiência dessas abordagens é bastante evidente, pois elas simplesmente assumem o que deveriam explicar — a saber, que perdedores absolutos são, na verdade, vencedores.

O objetivo deste artigo é investigar a OMC a partir do conceito de poder institucional criado pelos teóricos Michael Barnett e Raymond Duvall, com referência a "casos em que Estados desenham instituições internacionais que operam de acordo com os seus interesses de longo prazo e em detrimento dos interesses de outros". ${ }^{12}$ Argumenta-se que este é justamente o caso da OMC à medida que "perdedores aparentes" na África nada mais são do que perdedores absolutos. Diferentes estimativas indicam que os países africanos sofrem perdas em termos de PIB e exportações, medidas de bem-estar econômico, custos de ajuste e implementação. O contínuo suporte dos países ricos ao setor agrícola e a perda de preferências comerciais na Rodada Uruguai deprimem a renda em países africanos. A África une-

9 OVERSEAS DEVELOPMENT INSTITUTE. Developing countries in the WTO. Londres: Overseas Development Institute, 1995. p. 3-4.

10 UNCTAD. Trade and Development Report. Genebra: UNCTAD, 1994. p. 161.

11 PETERSMANN, Ernst-Ulrich. The GATT/WTO dispute settlement system: international law, international organizations and dispute settlement. Londres: Kluwer Law International, 1997. p. 50-51.

12 BARNETT; Michael; DUVALL. Raymond, Power in Global Governance. In: BARNETT; Michael; DUVALL, Raymond (Org.). Power in Global Governance. Cambridge: Cambridge University Press, 2005. p. 1-32. se ao mundo em desenvolvimento nas perdas oriundas de royalties e monopolização criados pelo Acordo sobre Aspectos dos Direitos de Propriedade Intelectual Relacionados ao Comércio (TRIPS). Dada a notória falta de capacidade legal dos países africanos, mesmo os supostos benefícios advindos de maior "certeza" se transformam em fardos adicionais: país africano algum jamais iniciou uma causa na OMC.

\section{GATT 1947: referência para a visão liberal das instituições}

Nos anos finais da Guerra Fria, o estudo das instituições atraiu estudiosos de RI e do DI, estes interessados em transcender o período que Martti Koskenniemi classificou como "decadência" na disciplina. ${ }^{13}$ Como afirmou Charlotte $\mathrm{Ku}$, “juristas internacionais, como cientistas sociais, começaram a perguntar 'como' e 'por que' e mostravam-se insatisfeitos com as respostas providas pela dogmática jurídica. Quais instituições funcionam e por quê? Quais normas funcionam e por quê? Como isso tudo acontece?". ${ }^{14}$ Paralelamente, teóricos de RI, dispostos a superar a negligência dos elementos normativos típica do período da Guerra Fria, convergiram em torno do conceito de "regimes", definidos como "os conjuntos, implícitos ou explícitos, de princípios, normas, regras e procedimentos de tomada de decisão em torno dos quais convergem as expectativas dos atores em uma determinada área das relações internacionais". ${ }^{15} \mathrm{O}$ conceito de regimes tinha como referência o GATT 1947..$^{16}$ O GATT 1947 codificou regras em período particularmente auspicioso para o intercâmbio comercial entre os países capitalistas, que cresceu cerca de dez vezes entre 1948 e 1973. Com base na tradição liberal da Economia Política, acredita-se que a eliminação das barreiras comerciais traz ganhos agregados a todos os países, a partir da teoria ricardeana

13 KOSKENNIEMI, Martti. Gentle civilizer of nations: the rise and the fall of International Law. Port Chester: Cambridge University Press, 2002.

$14 \mathrm{KU}$, Charlotte. International Law, international relations and global governance. Nova York: Routledge, 2012. p.13.

15 KRASNER, Stephen. Regimes and the limits of realism: regimes as autonomous variables. International Organization, Cambridge, v.36, n.1, p. 1-21, jan./mar. 1982. p.2.

16 KRATOCHWIL, Friedrich; RUGGIE, John. International Organization: a state of the art on an art of the State. International Organization, Cambridge, v. 40, n.4, p. 753-775, out./dez. 1986. p. 769. 
das vantagens comparativas. ${ }^{17}$ Ocorre que, apesar dos ganhos agregados, alguns grupos domésticos perdem com a abertura comercial. ${ }^{18}$ Esses grupos exercem pressão sobre os governos contra a liberalização comercial. Como forma de proteger produtores locais poderosos e arranjos políticos domésticos, os governos liberalizarão áreas em que a produção do país é relativamente eficiente, de forma a aumentar as exportações e, eventualmente, manter barreiras em setores relativamente ineficientes.

Se todos os governos agirem dessa forma, o nível de liberalização será mínimo e, em que pese o potencial de cooperação, o resultado é que haveria espaço para a obtenção de ganhos para os países considerados em sua totalidade. $\mathrm{O}$ estabelecimento de um regime para o comércio pode impedir que o comportamento individual dos Estados fizesse decrescer o bem-estar social, reduzindo o espaço para que os países protejam setores ineficientes. O regime do GATT, com o seu sistema de solução de controvérsias, diminuía as chances de trapaça - ou seja, a proteção dos setores mais ineficientes contra as regras do regime - com vistas a atingir maior liberalização comercial. As regras do regime de comércio, entretanto, acabavam por conferir alguma margem de manobra aos governos, como forma de lidar com as pressões políticas domésticas. O enfoque tipicamente economicista sobre a eficiência não permitia investigações sobre distribuição de ganhos e perdedores absolutos. Ademais, a abordagem dos regimes caracterizou-se por uma "egrégia" de referências à literatura jurídica. Apesar de saltar aos olhos a proximidade entre o conceito de "regimes espontâneos" criada por Oran Young ${ }^{20}$ e o estudo dos costumes no DI, Young acaba por recorrer à onipresente literatura econômica para formular hipóteses sobre as origens dos regimes espontâneos. Essa omissão é ainda

17 RICARDO, David. On the principles of political economy and taxation. Londres: John Murray, 1817.

18 Os efeitos distributivos e a possibilidade de haver perdedores com a abertura comercial foram elaborados em teorias posteriores às vantagens comparativas, como o modelo de Heckscher-Ohlin. Ver KRUGMAN, Paul; OBSTFELD, Maurice. Economia internacional. São Paulo: Makron Books, 2001.

19 KRATOCHWIL, Friedrich. Thrasymmachos revisited: on the relevance of norms and the study of law for International Relations. Journal of International Affairs, New York, v.37, n.1, p.353-356, jan/mar. 1983.

20 YOUNG, Oran. Regime dynamics: the rise and fall of international regimes. International Organization, Cambridge, v.36, n.1, p. 277-297, jan./mar. 1982. mais surpreendente quando se observa que Young é um dos teóricos de RI versados em Direito, ou, a partir da expressão que ele próprio cunhou, "fluente em ambas as linguagens", ${ }^{21}$ quando se referia às desconexões entre os jargões de RI e DI.

\subsection{Institucionalismo liberal}

O estudo clássico de Robert Keohane sobre as instituições lançou a pedra angular da teoria institucionalista. $^{22}$ As instituições conduzem os estados a resultados eficientes ao reduzir os custos de transação em contexto de repetidas interações, bem como as incertezas criadas pela distribuição assimétrica de informação. Keohane admitiu mais recentemente, no prefácio da nova edição de After Hegemony (2005), que o seu institucionalismo generaliza a experiência do GATT. O institucionalismo forneceu bases de justificação excepcionalmente perspicazes para a manutenção dos regimes criados pelos EUA, como o GATT, em momento no qual a hegemonia estadunidense era desafiada pela ascensão de novos polos no mundo capitalista, em especial, o Japão e a Europa, que se integrava sob a liderança da Alemanha. Em última instância, prevalecia o objetivo político da manutenção da ordem - que traria, em tese, ganhos a todos os atores - em detrimento de outros fins, como a justiça distributiva. Conforme apontou Susan Strange, os teóricos liberais "tendiam a tomar como dada a forma como a economia internacional de mercado era gerida, sem perguntar muito sobre as razões que fizeram que certos princípios, normas e regras prevalecessem e não outros". ${ }^{23}$ Os acadêmicos liberais dos anos 1980, de fato, não questionavam como o regime internacional de comércio instituído pelo GATT lograra obter, gradualmente, razoável liberalização comercial em produtos manufaturados, nos quais os países desenvolvidos tendiam a ter

21 A criação dessa expressão por Oran Young é relatada no artigo escrito por Anne-Marie Slaughter, Andrew Tulumello e Stepan Wood. SLAUGTER, Anne-Marie; TULUMELLO, Andrew; WOOD, Stepan. International Law and International Relations theory: a new generation of interdisciplinary scholarship. American Journal of International Law, Washington DC, v. 92, n.3, p. 367-397, jul. 1998.

22 KEOHANE, Robert. After hegemony: cooperation and discord in the world political economy. Princeton: Princeton University Press, 1984-2005.

23 STRANGE, Susan. States and markets. Londres: Pinter Publishers, 1988. p.21. 
vantagens comparativas, enquanto excluía setores em que os países em desenvolvimento poderiam ser competitivos, em especial agricultura e têxteis.

Da mesma forma, os institucionalistas não problematizam como o novo regime da Organização Mundial de Comércio contêm regras fortes em áreas como propriedade intelectual e serviços financeiros, nos quais predominam interesses de agentes econômicos localizados no mundo desenvolvido, e ínfima liberalização nas áreas de interesse dos países em desenvolvimento - não somente agricultura e têxteis, mas também setores manufaturados e de serviços selecionados, como construção naval. Essa omissão é ainda mais contundente quando se constata que a Rodada Uruguai (1986-1994) desenrolou-se ao mesmo tempo em que o próprio institucionalismo. Repetindo a abordagem dos regimes, se os teóricos institucionalistas caminharam na direção de estudos interdisciplinares, não foi na direção do Direito Internacional, mas, sim, da Economia, com a consequência de que "a compreensão da relação entre política e direito nas relações internacionais permaneceu limitada". ${ }^{24}$ A transformação do GATT em uma organização formalmente a cargo do regime multilateral de comércio incrementou as possibilidades de cooperação entre juristas e teóricos de RI. Se, de um lado, a OMC atrai óbvio interesse em RI, de outro, como observaram Abram e Antonia Chayes, "uma organização internacional é uma criatura do Direito". ${ }^{25}$

\subsection{Liberalismo pós-guerra fria}

O final da Guerra Fria intensificou o caráter ideológico das obras dos autores liberais. ErnstUlrich Petersmann propôs a incorporação dos direitos humanos e a constitucionalização do Acordo da OMC, considerado um marco no caminho para a liberdade e a paz democrática. ${ }^{26}$ Petersmann, que desempenhou

24 REUS-SMIT, Chris. The politics of international law. In: REUS-SMIT, Chris (Org.). The Politics of International Law. Nova York: Cambridge University Press, 2004. p.14-44. p. 19.

25 CHAYES, Abram; CHAYES, Antonia. The new sovereignty: compliance with international regulatory agreements. Cambridge: Harvard University Press, 1995. p.125.

26 PETERSMANN, Ernst-Ulrich. The GATT/WTO dispute settlement System: International Law, international organizations and dispute settlement. Londres: Kluwer Law International, 1997. p. 4; PETERSMANN, Ernst-Ulrich. The WTO Constitution and Human Rights. Journal of International papel-chave na burocracia do GATT durante a Rodada Uruguai, personifica a proposição de Philip Alston de que os juristas internacionais participam da construção da globalização ao mesmo tempo em que abdicam de problematizar as suas assimetrias. Nesse caso, Petersmann legitima academicamente a globalização de altos padrões de proteção da propriedade intelectual, ${ }^{27}$ bem como avança visão dos direitos humanos que o próprio Alston classificou como "domesticada", 28 pois reduzida, em última instância, ao direito de propriedade. Em RI, Andrew Moravcsik produziu nova versão da teoria liberal concentrada na política doméstica e nos atores transnacionais, ${ }^{29}$ bem como nova visão da integração europeia que absorveu o papel dos grupos de interesse na formação das instituições. ${ }^{30}$ Moravcsik lançou luz sobre parte do jogo de poder por detrás das instituições; entretanto, definidas as preferências estatais, as instituições levavam novamente a melhoras de Pareto. Em artigo clássico para o debate interdisciplinar DI RI, Slaughter propôs agenda dual, que contemplava o institucionalismo liberal e o liberalismo proposto por Moravcsik como fontes de cooperação acadêmica. ${ }^{31} \mathrm{~A}$ agenda dual concretizou-se quando Slaughter e Moravcsik se uniram a Keohane na edição do periódico International Organization dedicada à "legalização", conceito derivado da teoria de H.H.Hart,

Economic Law, New York, v.3, n.1, p. 19-25 jan-mar, 2000; PETERSMANN, Ernst-Ulrich. Time for a United Nations 'Global Compact' for integrating Human Rights into the law of Worldwide Organizations: lessons from the European Integration. European Journal of International Law, Cambridge, v.13, n.3, p. 621-650, jul./set, 2002.

27 SELL, Susan. Private power, public law: the globalization of Intellectual Property Rights. Cambridge: Cambridge University Press, 2003.

28 ALSTON, Philip. Resisting the merger and acquisition of Human Rights by Trade Law: a reply to Petersmann. European Journal of International Law, Oxford, v.13, n. 4, p.815844, out./dez., 2002.

29 MORAVCSIK, Andrew. Liberalism and International Relations theory. Cambridge: Harvard University, 1992; MORAVCSIK, Andrew. Taking preferences seriously: a liberal theory of international politics. International Organization, Cambridge, v. 51, n. 4, p.513-553. out./dez, 1997.

30 MORAVCSIK, Andrew. The choice for Europe: social purpose and state power from Messina to Maastricht. New York: Cornell University Press, 1998.

31 SLAUGHTER, Anne-Marie. International Law and International Relations theory: a dual agenda. American Journal of International Law, New York, v. 87, n. 2, p. 205-239, abr./jun, 1993. 
que se decompôs nas dimensões da obrigação, da delegação e da precisão para categorizar os arranjos internacionais entre os extremos do Direito duro e da anarquia.

Quadro I - Formas de Legalização Internacional

\begin{tabular}{|c|c|c|c|c|}
\hline TIPO & OBRIGAÇÃO & PRECISÃO & ELEGAÇÃO & EXEMPLOS \\
\hline \multicolumn{5}{|c|}{$\begin{array}{l}\text { Tipo Ideal: } \\
\text { Direito duro }\end{array}$} \\
\hline I & Alto & Alto & Alto & $\begin{array}{l}\text { UE;OMC-TRIPS; Convenção } \\
\text { Europeia de Direitos Humanos; } \\
\text { TPI }\end{array}$ \\
\hline II & Alto & Baixo & Alto & $\begin{array}{l}\text { UE-Antitruste, Art.85-6; OMC- } \\
\text { Tratamento Nacional }\end{array}$ \\
\hline III & Alto & Alto & Baixo & $\begin{array}{l}\text { Tratados de Controle de Armas } \\
\text { EUA-URSS; Protocolo de } \\
\text { Montreal }\end{array}$ \\
\hline IV & Baixo & Alto & Alto (moderado) & $\begin{array}{l}\text { Comitê da ONU para } \\
\text { Desenvolvimento Sustentável } \\
\text { (Agenda 21) }\end{array}$ \\
\hline V & Alto & Baixo & Baixo & $\begin{array}{l}\text { Convenção de Viena sobre } \\
\text { Ozônio; Convenção Europeia } \\
\text { sobre Minorias Nacionais }\end{array}$ \\
\hline VI & Baixo & Baixo & Alto (moderado) & $\begin{array}{l}\text { Agências Especializadas da ONU; } \\
\text { Banco Mundial }\end{array}$ \\
\hline VII & Baixo & Alto & Baixo & $\begin{array}{l}\text { Ata Final de Helsinque; Princípios } \\
\text { Não Vinculantes; Padrões } \\
\text { Técnicos }\end{array}$ \\
\hline VIII & Baixo & Baixo & Baixo & $\begin{array}{l}\text { Grupo dos 7; Esferas de } \\
\text { Influência; Balança de Poder }\end{array}$ \\
\hline
\end{tabular}

Tipo Ideal:

Anarquia

Fonte: ABBOT'T, Kenneth et al. The Concept of Legalization. International Organization, Cambridge, v. 54, n.3, p.401-419, jul./set. 2000. p. 406.

Embora o TRIPS seja considerado próximo ao tipo ideal do Direito duro, o enfoque aparentemente neutro na aplicabilidade (enforceability) não permite a investigação das assimetrias do acordo sobre a proteção da propriedade intelectual. Martha Finnemore e Stephen Toope habilmente observaram que o conceito do Direito dos teóricos liberais é demasiadamente concentrado nos seus aspectos regulatórios e burocráticos, em detrimento do seu papel criativo no sistema internacional, incluindo a definição dos direitos de propriedade. ${ }^{32} \mathrm{Em}$ consequência, ao lidarem com a OMC, os teóricos liberais tendem a limitar-se ao DSU, em desfavor de questões distributivas

32 FINNEMORE, Martha; TOOPE, Stephen. Alternatives to 'Legalization': Richer Views of Law and Politics. International Organization, Cambridge, v.55, n.3, p. 743-758, jul./set., 2001. 
derivadas das assimetrias do Acordo da OMC. Eles erroneamente sustentam que a natureza mais legalizada do novo sistema reduz o viés em favor dos países mais poderosos. Mais fundamentalmente, os liberais não investigam como países poderosos inseriram a proteção da propriedade intelectual no Acordo da OMC, levando a perdas em países pobres. Tampouco problematizam a razão da liberalização negligenciável em áreas nas quais os países em desenvolvimento tendem a ser mais competitivos, como agricultura.

\section{Poder institucional}

Michael Barnett e Raymond Duvall constataram que o discurso liberal omite como instituições resultam do poder e reproduzem assimetrias. Barnett e Duvall conceituaram poder institucional em referência às situações em que um ator controla outros ao empregar "as instituições formais e informais que mediam $\mathrm{A}$ e $\mathrm{B}$, pois $\mathrm{A}$, trabalhando por meio das regras e procedimentos que definem essas instituições, guia, dirige e constrange as ações (ou inações) e condições de existência de outros". ${ }^{33}$ Os resultados da Rodada Uruguai são consistentes com a relação estabelecida entre poder institucional e agência. Enquanto os EUA e as $\mathrm{CE} / \mathrm{UE}$ dirigiram as negociações e hoje são os maiores beneficiários da $\mathrm{OMC}$, os países de menor desenvolvimento relativo, que tiveram, na melhor das hipóteses, participação bastante limitada, incorrem em perdas absolutas. Os países africanos, com delegações de recursos humanos e materiais ínfimos em Genebra, foram responsáveis por menos de 3\% dos documentos circulados nas negociações até $1990 .{ }^{34}$ Subdividiremos, em seguida, o poder institucional nas dimensões da mudança de fórum e rolo compressor.

\subsection{Mudança de fórum}

A Rodada Uruguai foi inicialmente moldada pelos eventos do começo dos anos 1980. Companhias transnacionais sediadas nos EUA, como a Pfizer,

33 BARNETT; Michael; DUVALL. Raymond, Power in global governance. In: BARNETT; Michael; DUVALL, Raymond (Org.). Power in global governance. Cambridge: Cambridge University Press, 2005. p. 1-32. p. 15.

34 OYEJIDE, T. Ademola. The participation of developing countries in the Uruguay round: an African perspective. World Economy, v.13, n.3, p. 427-444, jul./set., 1990. criaram redes para angariar o apoio do governo dos EUA para a causa da proteção da propriedade intelectual internacionalmente. ${ }^{35}$ Essas redes serviram de base para a criação de grupos de especialistas, cujos esforços teóricos acabaram por nortear a formulação de política. ${ }^{36} \mathrm{O}$ representante de comércio dos EUA, William Brock, veiculou, em 1981, apelo para a reforma do regime de comércio, com enfoque nos "temas do futuro". ${ }^{37}$ A ênfase em produtos falsificados pavimentou o caminho para estratégia de mudança de fórum destinada a transferir o tema da propriedade intelectual da Organização Mundial da Propriedade Intelectual para o GATT. Após os EUA terem bloqueado o tema na UNCTAD e na UNESCO (retiraram-se dessa instituição em 1984), o GATT era o fórum mais atrativo porque os países poderosos historicamente controlavam o regime.

O fim da Guerra Fria permitiu atitude mais agressiva dos EUA e o Departamento de Estado retirou a sua oposição a estratégias de coerção econômica aberta contra os chamados "linhas-duras" - países em desenvolvimento, liderados por Brasil e Índia, que opunham resistência ao TRIPS. Antes do desafio colocado pela entrada da China na OMC em 2001 e o contínuo ganho de influência de Brasil e Índia após a Rodada Uruguai, o tamanho combinado dos mercados dos EUA e das CE, que respondiam por $40 \%$ das exportações e 50\% do PIB do mundo em 1994, permitiu-lhes dominar o regime de comércio. Os EUA, que respondiam por mais da metade das exportações da América Latina e um terço da Ásia do Leste, ${ }^{38}$ usaram o seu poder de mercado para empregar coerção econômica aberta destinada a promover a proteção da

35 DRAHOS, Peter. Expanding Intellectual Property's Empire: the role of FTAs. Canberra: Australian National University, 2003.

36 DRAKE, William; KALYPSO, Nicolaidis. Ideas, interests, and institutionalization: trade in services and the Uruguay round. International Organization, Cambridge, v. 46, n. 1, p. 37-100, jan./mar. 1992; PRAKASH, Adam; SELL, Susan. Using ideas strategically: the contest between business and NGO networks in Intellectual Property Rights. International Studies Quarterly. v. 48, n. 1, p. 143-175 jan./mar. 2004.

37 PREEG, Ernest. Traders in a brave new world: the Uruguay Round and the future of the international trading system. Chicago: The University of Chicago Press, 1995. p. 30.

38 SELL, Susan. Intellectual Property protection and antitrust in the developing world: crisis, coercion and choice. International Organization, Cambridge, v. 49, n. 2, p. 315-349, abri./jun. 1995. p. 322. 
propriedade intelectual em países em desenvolvimento que incluíram o Egito. Países não diretamente afetados pela coerção, como Hong Kong, anteciparam a ameaça e reformaram seus sistemas de propriedade intelectual. ${ }^{39}$

Quadro 2 - Coerção dos EUA contra países em desenvolvimento 1988-1993

\begin{tabular}{|c|c|}
\hline $\begin{array}{l}\text { Países em Desenvolvimento integrantes dos linhas- } \\
\text { duras ou ativos no grupo } 10+10 \text { de negociação do } \\
\text { TRIPS }\end{array}$ & $\begin{array}{l}\text { Anos em que um país em desenvolvimento foi } \\
\text { submetido à petição, listado como investigado ou } \\
\text { sofreu penalidade sob o Ato de Comércio (1974) } \\
\text { ou Sistema Geral de Preferências }\end{array}$ \\
\hline Argentina & 1988-1993 \\
\hline Brasil & 1988-1993 (1988*) \\
\hline Chile & 1988-1993 \\
\hline \multicolumn{2}{|l|}{ Cuba } \\
\hline Egito & 1989-1993 \\
\hline \multicolumn{2}{|l|}{ Hong Kong } \\
\hline Índia & 1989-1993 (1992*) \\
\hline Indonésia & 1989,1990 \\
\hline Malásia & 1989, 1990, 1993 \\
\hline \multicolumn{2}{|l|}{ Nicarágua } \\
\hline \multicolumn{2}{|l|}{ Nigéria } \\
\hline Peru & 1992,1993 \\
\hline \multicolumn{2}{|l|}{ Cingapura } \\
\hline \multicolumn{2}{|l|}{ Tanzânia } \\
\hline Tailândia & $1989-1993(1989 *)$ \\
\hline \multicolumn{2}{|l|}{ Uruguai } \\
\hline Venezuela & 1989-1993 \\
\hline Iugoslávia & 1989-1991 \\
\hline
\end{tabular}

* Ano em que penalidades foram impostas

Fonte: DRAHOS, Peter. Developing countries and international intellectual property standard-setting. Londres: Commission on Intellectual Property Rights, 2002. (Study Paper, 8). p. 15.

\subsection{Rolo compressor}

Segundo Lloyd Gruber, quando Estados poderosos concordam em criar uma nova instituição, eles apresentam um fato consumado a potenciais membros. ${ }^{40}$ Agindo em "coalizão habilitadora", Estados poderosos (A e B na figura 1) mudam o conjunto de escolhas do Estado perdedor (C), que, descartada a escolha pelo status quo, decide entre a adesão e a marginalização da nova instituição. O Estado perdedor racional e voluntariamente aderirá caso os custos de exclusão superem os custos de pertencer à nova instituição. Como afirmaram Gerard e Victoria

39 DRAHOS, Peter. Developing countries and international intellectual property standard-setting. Londres: Commission on Intellectual Property Rights, 2002. (Study Paper, 8). p. 15.

40 GRUBER, Lloyd. Ruling the world: power politics and the rise of supranational institutions. Princeton: Princeton University Press, 2000. 
Curzon: "[s]e é claro que os Estados Unidos e sua legislação doméstica ditavam os cronogramas das rodadas do GATT, era a interação dos interesses comerciais dos Estados Unidos e europeus que determinava os temas envolvidos". ${ }^{41}$ Os EUA foram os iniciadores da Rodada Uruguai, mas divergências em agricultura geradas pela Política Agrícola Comum europeia ameaçavam a formação da coalizão habilitadora clássica EUA-CE do GATT. Após negociações bilaterais que incluíram o Acordo de Blair House em 1992, EUA e CE diluíram a liberalização agrícola e asseguraram normas que refletiam interesses comuns em outras áreas, como propriedade intelectual.

Figura 1 - Cooperação como Jogo de Vencedores e Perdedores, Estágio 1

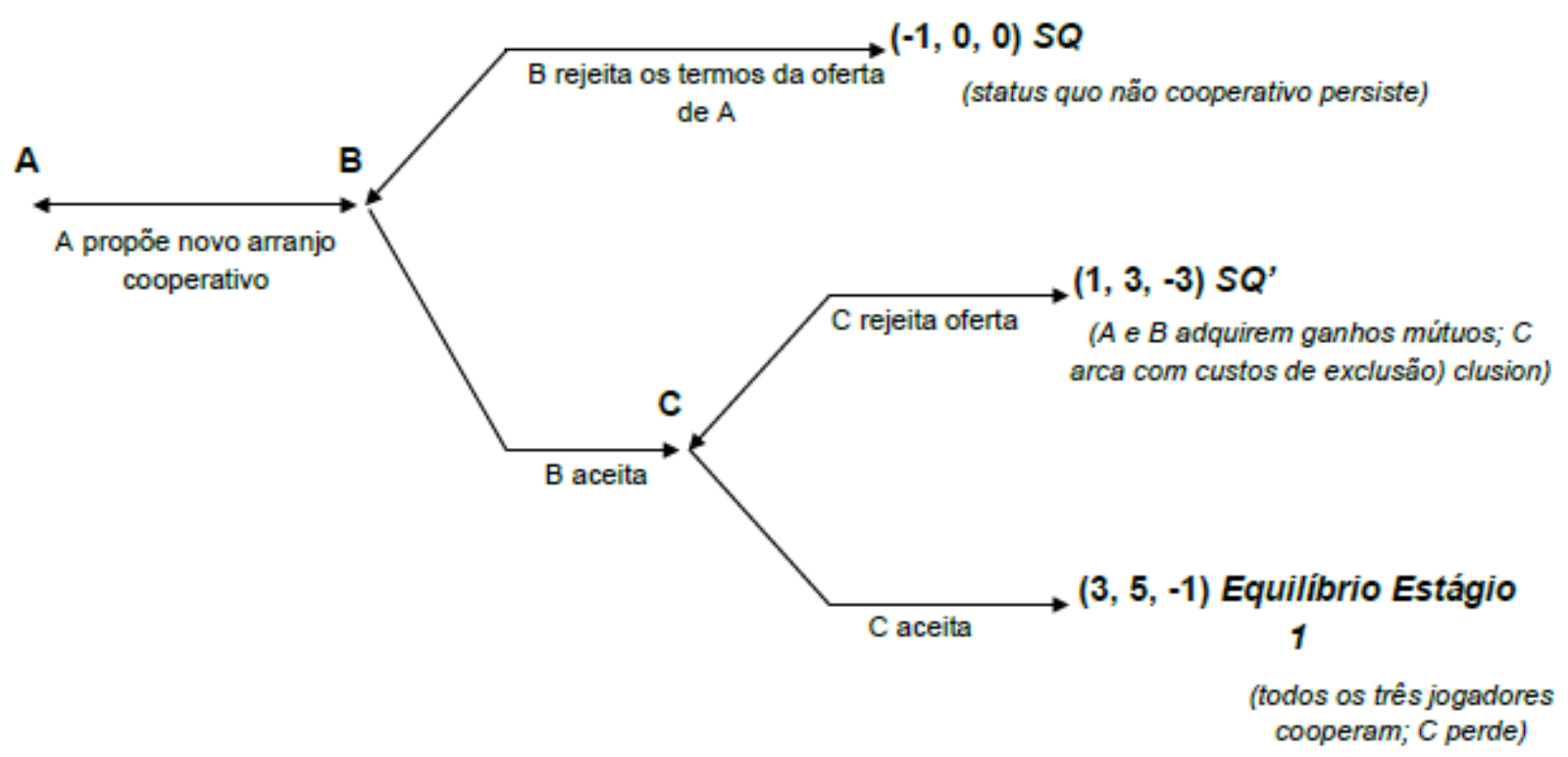

Fonte: GRUBER, Lloyd. Ruling the world: power politics and the rise of supranational institutions. Princeton: Princeton University Press, 2000. p. 44.

41 CURZON, Victoria; CURZON, Gerard. GATT: trader's club. In: COX, Robert; JACOBSON, Harold (Org.). The anatomy of influence: decision making in international organisation. New Haven: Yale University Press, 1973. p. 314-315.

A adesão de outros Estados aumenta os custos de exclusão. ${ }^{42}$ Durante a Rodada Uruguai, as negociações transcorriam em círculos concêntricos que se iniciavam com acertos EUA-CE, incluindo, em seguida, outros países desenvolvidos e, posteriormente, os maiores países em desenvolvimento. Quando os pacotes negociadores eram, enfim, apresentados aos países de menor desenvolvimento relativo, os custos econômicos e diplomáticos de exclusão eram grandes a ponto de compeli-los a aderir, ainda que

42 GRUBER, Lloyd. Power politics and the free trade bandwagon. Comparative Political Studies, New York, v. 34, n. 7, p. 703-741, set. 2001. já não houvesse ambiguidade de que o acordo lhes trazia perdas absolutas. Ao final das negociações da Rodada Uruguai, em dezembro de 1993, os EUA e as CE terminaram suas obrigações no GATT 1947, que deixou formalmente de existir ao final de 1994, com a OMC nascendo oficialmente em $1^{\circ}$ de janeiro de 1995. Esse gesto personificou a remoção do status quo do conjunto de escolhas dos outros países, aumentandolhes os custos de exclusão, que cresciam ainda mais à medida que outros países aderiam. De acordo com o single-undertaking, a recusa de qualquer dos acordos multilaterais da OMC implicava custos proibitivos de exclusão do regime de comércio. 


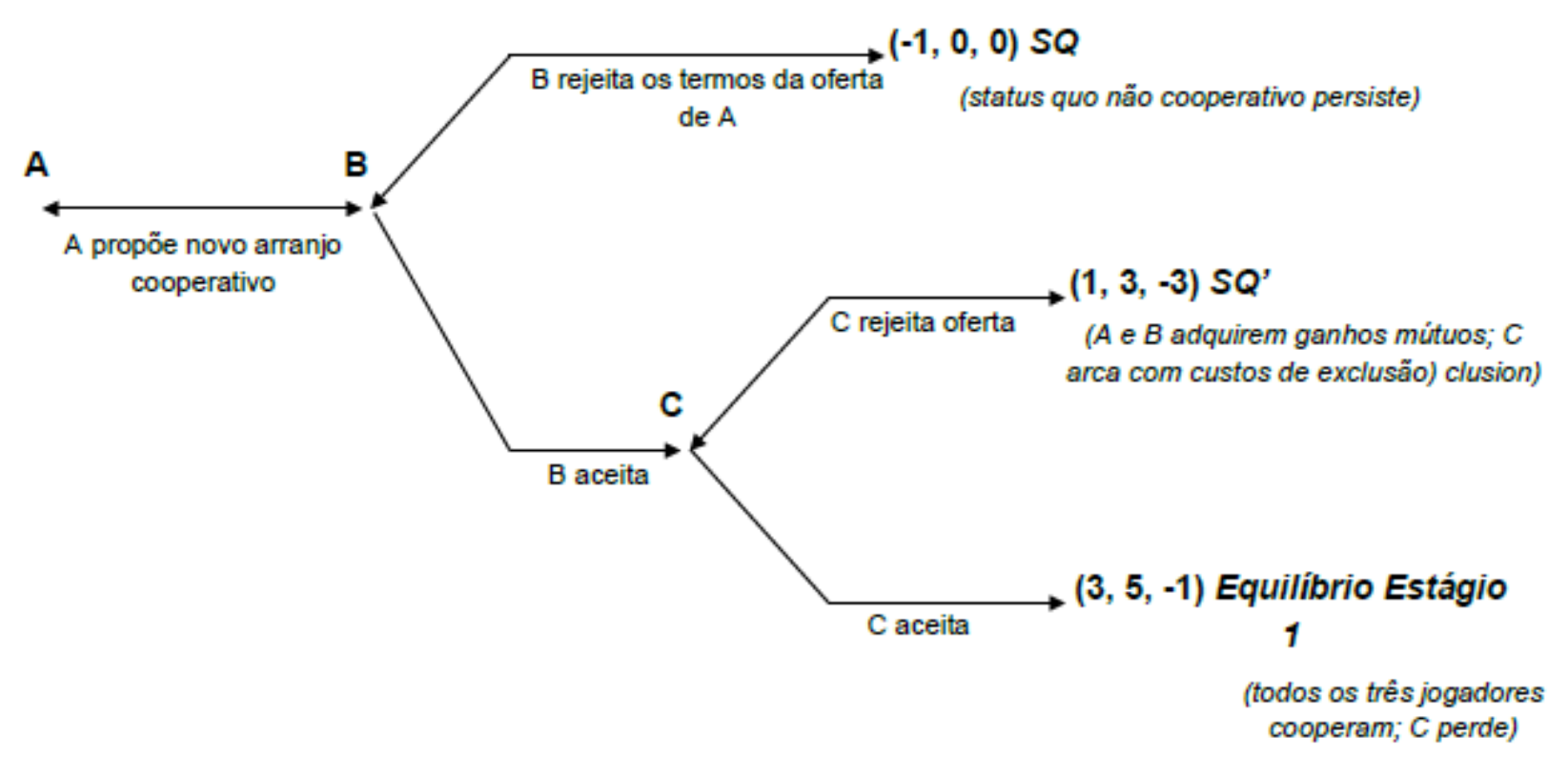

Fonte: GRUBER, Lloyd. Ruling the world: power politics and the rise of supranational institutions. Princeton: Princeton University Press, 2000. p. 49.

\section{Estimativas de perdas absolutas para a Africa}

Os liberais empregam a proverbial constatação de que o DSU representa a joia da coroa da OMC para argumentar que a sua natureza legalizada reduz a tendência de beneficiar os países mais poderosos. ${ }^{43}$ À primeira vista, os países em desenvolvimento têm sido ativos, propondo cerca de $40 \%$ das causas registradas no DSU. Os números absolutos, entretanto, mascaram que "a vasta maioria dos países em desenvolvimento está amplamente ausente do processo" 44 ou "não

43 PETERSMANN, Ernst-Ulrich. The GATT/WTO dispute settlement system: international law, international organizations and dispute settlement. Londres: Kluwer Law International, 1997; GOLDSTEIN, Judith; MARTIN; Lisa. Legalization, trade liberalization, and domestic politics: a cautionary note. International Organization, Cambridge, v.54, n.3, p. 603-632, jul./set. 2000; KEOHANE, Robert; MORAVCSIK, Andrew; SLAUGHTER; Anne-Marie. Legalized dispute resolution: interstate and transnational. International Organization, Cambridge, v. 54, n. 3, p. 457-488, jul./set. 2000.

44 NOTTAGE, Hunter. Developing countries in the WTO dispute settlement system. Oxford: Global Economic Governance Programme, 2009.(Working Paper, 47). p. 2. participa de forma alguma". ${ }^{45}$ Nenhum país africano iniciou qualquer das cerca de 500 causas registradas até hoje no DSU, embora Egito e África do Sul tenham sido acionados oito vezes. Gregory Shaffer propõe que a maior participação dos Estados Unidos (70\%) e da UE $(65 \%)$ permite seja aplicado poder institucional de segunda ordem para moldar a jurisprudência do sistema de solução de controvérsias da OMC.46

Os liberais, de fato, não compreendem que o poder é frequentemente exercido não a despeito do Direito, mas, sim, por meio dele. A possibilidade de contratar melhores advogados é apenas a vantagem mais óbvia dos litigantes abastados. As assimetrias são exacerbadas na litigação internacional porque o fórum jurídico é distante, os processos políticos mais complexos e a expertise legal menos difundida e, portanto, mais

45 EVANS, David; SHAFFER, Gregory. Introduction. In: SHAFFER, Gregory; MELÉNDEZ-ORTIZ, Ricardo (Org.). Dispute settlement at the WTO: the developing country experience. Cambridge: Cambridge University Press, 2010. p. 1-18. p. 2-3.

46 SHAFFER, Gregory. Power, governance, and the WTO: a comparative institutional approach. In: BARNETT, Michael; DUVALL, Raymond (Org.). Power in global governance. Cambridge: Cambridge University Press, 2005. p. 130-160. 
custosa. As causas na OMC chegam a custar 10 milhões de dólares. Países pobres deixam de acionar nações poderosas, entre outros fatores, pelos custos processuais e pela ausência de poder de mercado, que importa incapacidade de retaliar efetivamente. Os liberais, cuja abordagem formalista exagera o papel da adjudicação, não enxergam que muitas das ações de maior consequência no DSU têm lugar à sombra do Direito, ${ }^{47}$ em negociações ou mudanças do fórum da OMC. Em qualquer caso, na análise empírica mais bem feita do DSU até hoje, Marc Bush e Eric Reinhardt demostraram que, estatisticamente, não somente as nações desenvolvidas estão significantemente mais aptas a assegurar resultados que desejam, mas também o número de ações contra os países em desenvolvimento aumentou dramaticamente. Como concluíram Busch e Reinhardt: ${ }^{48}$

A nova exigência de capacidade legal do DSU é menos custosa para os Estados industriais mais avançados, que geralmente mantêm grandes e dedicadas equipes permanentes de juristas e economistas a cargo da OMC... Para os países mais pobres, esse movimento simplesmente substitui (ou acrescenta) a (à) tradicional fonte de fraqueza - a saber, o mercado reduzido, e, portanto, a falta de poder de retaliação — uma nova: capacidade legal.

Slaughter tratou de "um importante problema de política atual ... que reforma, se alguma, deve ser feita no DSU?". Slaughter vale-se do trabalho de Richard Shell, ${ }^{50}$ que se baseou na agenda dual para propor reformas no DSU, com o intuito de defender o acesso de atores privados ao sistema. Seguindo-se o insight de

47 BUSCH, Marc; REINHARDT, Eric. Bargaining in the shadow of the law: early settlement in GATT/WTO disputes. Fordham International Law Journal, New York, v.24, n.1, p.158-172. 2000.

48 BUSCH, Marc; REINHARDT, Eric. Developing countries and general agreement on tariffs and trade/world trade organization dispute settlement. Journal of World Trade, New York, v. 37, n. 4, p. 719-735, out./dez. 2003. p. 721-722.

49 SLAUGHTER, Anne-Marie. International law and international relations: millennial lectures. Hague: Academy of International Law, 2000. p.152.

50 SHELL, Richard. Trade legalism and international relations theory: an analysis of the World Trade Organization. Duke Law Journal, Durham, v.44, n. 5, p. 829-927; SHELL, Richard. The trade stakeholders model and participation by nonstate parties in the World Trade Organization. University of Pennsylvania Journal of International Economic Law, Philadelphia, v. 17, n. 1, p. 359-381, 1996.
Martti Koskenniemi, ${ }^{51}$ a agenda dual invisivelmente se transforma em uma agenda liberal a partir da oposição retórica entre o Estado, em referência ao enfoque estadocêntrico do institucionalismo, e a defesa do bem-estar dos indivíduos, associada ao liberalismo tal como proposto por Moravcsik. Como acrescentou Koskenniemi sobre a agenda de Slaughter, "a proposta de estudos interdisciplinares não pode ser dissociada dos tipos de sociologia e ética que são advogados", porque "a sociologia é sempre carregada normativamente, e carregada de forma a subscrever uma constelação produzida anteriormente pelo poder". ${ }^{52}$ Nesse caso, as parcerias entre atores públicos e privados são precisamente uma das razões do prevalecimento dos países poderosos no DSU. ${ }^{53}$ Ao contrário dos inúmeros analistas que manifestam preocupação com os prospectos distributivos do DSU, a proposta de Slaughter e Shell para a reforma do sistema caminha na direção do agravamento das atuais assimetrias observadas na solução de controvérsias da OMC. Como as companhias mais ricas do mundo, que têm interesses concentrados e recursos, tendem a ser sediadas nos países desenvolvidos, a construção de parcerias público-privadas é fonte primordial de poder institucional de segunda ordem para os EUA e a UE no DSU.

Mais fundamentalmente, os acadêmicos liberais não problematizam os efeitos do exercício de poder institucional de primeira ordem na criação das regras substantivas da OMC, que traz regulações frouxas em agricultura, liberalização seletiva em manufaturados e serviços e normas draconianas em propriedade intelectual. Glenn Harrison, Thomas Rutherford e David Tarr estimaram que o mundo como um todo ganha substancialmente com as reformas da Rodada Uruguai, mas os ganhos são concentrados no mundo desenvolvido. Enquanto os Estados Unidos, a União Europeia e o Japão ganham, respectivamente, US\$ $13,{ }^{54} 39$ e 17 bilhões, com ganhos residuais para os

51 KOSKENNIEMI, Martti. Gentle Civilizer of nations the rise and the fall of International Law. Port Chester: Cambridge University Press, 2002. p. 441.

52 KOSKENNIEMI, Martti. Gentle civilizer of nations: the rise and the fall of International Law. Port Chester: Cambridge University Press, 2002. p. 448-449.

53 SHAFFER, Gregory. Defending interests: public-private partnerships in WTO litigation. Washington D.C.: Brookings Institution Press, 2003.

54 Jeffrey Schott apresenta estimativas de incremento do 
maiores países em desenvolvimento, "a conclusão mais importante do nosso estudo é que deverá haver alguns perdedores da Rodada Uruguai" - a África Subsaariana, que congrega a esmagadora maioria dos países de menor desenvolvimento relativo no mundo, sofre perdas de bem-estar econômico..$^{55}$ Sheila Page e Michael Davenport previram perdas em termos de PIB, índices de renda real e bem-estar econômico para a África. ${ }^{56}$ Page e Davenport calcularam que o valor

PIB anual dos EUA que vão desde 14,8 a 128 bilhões de dólares. SCHOTT, Jeffrey. The Uruguay round: an assessment. Washington D.C: Institute for International Economics, 1994.

55 HARRISON, G.; RUTHERFORD, T; TARR, D. Quantifying the Uruguay Round. In: WILL, Martin; WINTERS, Alan. (Org.). The Uruguay round and the developing economies. Washington, D.C: Banco Mundial, 1995. p. 216-252. p. 216.

56 DAVENPORT, Michael; PAGE, Sheila. World Trade reform: do developing countries gain or lose? Londres: das exportações do continente africano decresce 1,5\% por causa do Acordo da OMC. No caso de países como Etiópia, Malawi e Moçambique, a queda varia entre 4,6 e 5,9\% de todas as receitas anuais de exportação. Lionel Fontagné e Nicolas Péridy calcularam que o Norte da África perde 2,3\% de sua renda real após a implementação do Acordo da OMC. ${ }^{57}$ Thomas Hertel, William Masters e Aziz Elbehri estimaram que a região Norte da África/Oriente Médio e a África Subsaariana sofrem perdas absolutas em termos de renda e bemestar econômico. $^{58}$

Overseas Development Institute, 1994. p. 60, 68.

57 FONTAGNÉ, Lionel; PÉRIDY, Nicolas. Uruguay Round et PVD: le cas de l'Afrique du Nord. Revue économique, v. 46, n. 3, 1995. p. 703-15.

58 HERTEL, Thomas; MASTERS, William; ELBEHRI, Aziz. the Uruguay round and Africa: a global, general equilibrium analysis. Journal of African Economies, Oxford, v. 7 , n. 2, p. 208-234. 1998. p. 228.

Quadro 3 - Estimativas dos anos 1990 de perdas absolutas para a África

\begin{tabular}{|c|c|}
\hline Estudo & Perdas \\
\hline Page e Davenport (1994) & $\begin{array}{c}\text { PIB, Renda Real e Bem-Estar } \\
\text { Econômico }\end{array}$ \\
\hline Goldin e Mensbrugghe (1995) & Renda \\
\hline Fontagné e Péridy (1995) & $\begin{array}{c}\text { Renda Real } \\
\text { (Norte da África) }\end{array}$ \\
\hline Harrison, Rutherford e Tarr (1995) & $\begin{array}{c}\text { Bem-Estar Econômico } \\
\text { (África Subsaariana) }\end{array}$ \\
\hline PNUD (1997) & $\begin{array}{c}\text { Renda } \\
\text { (África Subsaariana) }\end{array}$ \\
\hline Hertel, Masters e Elbehri (1998) & Bem-Estar Econômico \\
\hline
\end{tabular}

Fonte: Do Autor

Como afirmou T. N. Srinivasan, "quase todas as estimativas de ganhos [da Rodada Uruguai] sugerem que a África Subsaariana, na verdade, poderá perder ao invés de ganhar". ${ }^{59}$ O Programa das Nações Unidas para o Desenvolvimento estima que a África Subsaariana perca 1,2 bilhão de dólares anualmente por causa do Acordo da OMC. ${ }^{60}$ Stiglitz e Charlton relataram que os

59 SRINIVASAN, T. N. Developing countries and the multilateral trading system: from the GATT to the Uruguay round and the future. Boulder: Westview Press, 1998. p. 100.

60 PNUD. Human Development Report. Nova York: PNUD, 1997. p. 82.
48 países de menor desenvolvimento relativo do mundo sofrem perdas líquidas anuais da ordem de 600 milhões de dólares. ${ }^{61}$ Sobre a Rodada Uruguai, Michael Finger e Ludger Schuknecht observaram que "a maior parte do que os países em desenvolvimento concedeu produz efeitos imediatos, a maior parte do que receberão não será dada até 2005 ou ainda precisa ser negociada". ${ }^{62} \mathrm{O}$

61 STIGLITZ, Joseph; CHARLTON, Andrew. Fair trade for all: how trade can promote development. Oxford: Oxford University Press, 2005. p. 47.

62 FINGER, Michael; SCHUKNECHT, Ludger. Market access advances and retreats since the Uruguay round 
fim do Acordo Multifibras para negociação de quotas em têxteis não aconteceu antes de 2005 e a redução do suporte doméstico à agricultura nos países da OCDE ainda deve ser negociada. A agricultura é o único setor em que persistem subsídios às exportações e anomalias como as megatarifas, que chegam a $200 \%$. Hathway e Ingco observaram que "o acordo final foi moldado, em grande medida, pelo fato de que foi negociado entre os EUA e a UE ... com a exceção do Japão, os mercados altamente protegidos da OCDE foram liberalizados pouco ou nada". ${ }^{63}$ Ian Goldin e Van der Mensbrugghe estimaram que a perda de preferências comerciais e o aumento nos preços dos alimentos gera perda de 2 bilhões de dólares para a África a partir de 2002. ${ }^{64}$

Não bastasse a menor rigidez das regras agrícolas, os países desenvolvidos frequentemente violam suas obrigações legais. Apenas os subsídios para o algodão nos EUA reduzem entre 1-2\% da renda de países africanos como Benin, Burkina Faso, Chad e Mali. ${ }^{65}$ Os subsídios aumentam artificialmente a produção nos EUA, deprimem o preço do algodão no mercado internacional e diminuem a produção na África. Com a Rodada Doha paralisada, quase $50 \%$ do orçamento da UE ainda é gasto com a Política Agrícola Comum. Os EUA negociam bilateralmente com membros do G20

agreement. Washington D.C.: The World Bank Development Research Group, 1999. (Working Paper, 2232). p. 1-2.

63 HATHWAY, Dale; INGCO, Merlinda. Agricultural liberalization and the Uruguay round. In: MARTIN, Will; WINTERS, Alan (Org.). The Uruguay round and the developing economies. Washington D.C: World Bank, 1995. p. 15-37. p. 23.

64 GOLDIN, Ian; MENSBRUGGHE, Dominique. The Uruguay round: an assessment of economy wide and agricultural reforms. In: MARTIN, Will; WINTERS, Alan. (Org.). The Uruguay round and the developing economies. Washington D.C: World Bank, 1995. p.37-69. p. 50-53.

65 STIGLITZ, Joseph; CHARLTON, Andrew. Fair trade for all: how trade can promote development. Oxford: Oxford University Press, 2005. p. 62. para diluir a nova coalizão para a liberalização agrícola. ${ }^{66}$ Em termos de manufaturados, tarifas agregadas baixas em países da OCDE escondem picos e escaladas que prejudicam exportações africanas de produtos processados. ${ }^{67}$ As perdas dos países africanos são ainda maiores em razão dos custos de ajuste e implementação, que não foram cobertos pelas estimativas dos anos 1990. A liberalização no mercado de castanha de caju levou à dispensa de 85\% dos trabalhadores do setor em Moçambique. ${ }^{68}$ Com frequência, funcionários com baixo nível educacional não encontram ocupações alternativas. Ademais, as amplas consequências redistributivas dos ajustes solapam ganhos hipotéticos de eficiência. ${ }^{69}$ Segundo Michael Finger e Phillip Schuler, a implementação do Acordo da OMC custa, em média, 150 milhões de dólares anuais a cada um dos países em desenvolvimento, soma que supera todo o orçamento destinado ao desenvolvimento na maioria dos países de menor desenvolvimento relativo. Finger e Schuler descartam que as reformas tornem as economias mais eficientes, pois "as regulações da OMC refletem pouca consciência dos problemas do desenvolvimento e pouca apreciação das capacidades dos países de menor desenvolvimento relativo".70

66 SHAFFER, Gregory. Power, governance, and the WTO: a Comparative Institutional Approach. In: BARNETT, Michael; DUVALL, Raymond (Org.). Power in Global Governance. Cambridge: Cambridge University Press, 2005. p. 130-60, 135.

67 OYEJIDE, T. Ademola. The participation of developing countries in the Uruguay round: an African perspective. World Economy. v.13, n. 3, p. 427-444, 1990.

68 STIGLITZ, Joseph; CHARLTON, Andrew. Fair trade for all: how trade can promote development. Oxford: Oxford University Press, 2005. p. 175.

69 RODRIK, Dani. Why is trade reform so difficult in Africa? Journal of African Economies, Oxford, v.7, p. 10-36, 1998. suplemento 1.

70 FINGER, Michael; SCHULER, Philip. Implementation of Uruguay round commitments: the development challenge. World Economy, v. 24, n. 4, p. 511-525, 2000. p. 511. 
Quadro 4 - Estimativas dos anos 2000 de perdas adicionais para a África

\begin{tabular}{|c|c|}
\hline Estudo & Área das Perdas \\
\hline Finger e Schuler (2000) & Custos de Implementação \\
\hline Maskus (2000) & Propriedade Intelectual \\
\hline Banco Mundial (2001) & Propriedade Intelectual \\
\hline Busch e Reinhardt (2003) & $\begin{array}{c}\text { Mecanismo de Solução de } \\
\text { Controvérsias }\end{array}$ \\
\hline Stiglitz e Charlton (2005) & \begin{tabular}{c} 
Custos de Ajuste \\
\hline Nottage (2009)
\end{tabular} \\
\hline $\begin{array}{c}\text { Mecanismo de Solução de } \\
\text { Controvérsias }\end{array}$ \\
\hline
\end{tabular}

Fonte: Do Autor

As estimativas de perdas absolutas da década de 1990 são ainda mais significativas porque elas tampouco incluem os chamados novos temas: propriedade intelectual, serviços e investimentos. Em oposição ao discurso pró-liberalização da OMC, a defesa da propriedade intelectual conecta-se, historicamente, ao protecionismo comercial e a formas não competitivas de mercado. $\mathrm{Na}$ área da propriedade intelectual, a clivagem entre países desenvolvidos e em desenvolvimento, que são importadores líquidos de tecnologia, é "teórica e empiricamente válida". ${ }^{71}$ As perdas para os países em desenvolvimento são duplas, porque o TRIPS não apenas impõe transferências diretas de renda, mas também cria monopólios que disparam os preços domésticos e limitam o acesso a bens essenciais, como produtos farmacêuticos. Keith Maskus calculou que o TRIPS cria transferências da ordem de 5,8 bilhões de dólares todos os anos dos países em desenvolvimento aos EUA. ${ }^{72} \mathrm{O}$ Banco Mundial estimou que as provisões relativas a patentes do TRIPS implicam pagamentos anuais de royalties de 19 bilhões de dólares a empresas dos EUA. ${ }^{73}$ A África do Sul, por exemplo, desembolsa 11 milhões de dólares anuais em

71 PUGATCH, Meir Perez. The international political economy of Intellectual Property Rights. Cambridge: Edward Elgar Publishing, 2004. p. 47.

72 MASKUS, Keith. Intellectual Property Issues for the New Round. In: SCHOTT, Jeffrey (Org.). The WTO after Seattle. Washington D.C: Institute for International Economics, 2000. p. 137-58. p.142.

73 BANCO MUNDIAL. Global Economic prospects and the developing countries. Washington, D.C: The World Bank, 2001. p. 133. royalties. $\mathrm{O}$ aumento nos preços dos remédios contra o HIV/AIDS na África, causado pela monopolização da oferta local, desencadeou ultraje global. O TRIPS impõe padrões de proteção de propriedade intelectual consideravelmente maiores do que aqueles aplicados pelos países desenvolvidos de hoje em estágios pregressos similares aos dos atuais países em desenvolvimento. ${ }^{74}$ Após a Rodada Uruguai, os EUA têm mudado o fórum da OMC para impor condições ainda mais draconianas na forma de cláusulas "TRIPSPlus" em acordos bilaterais celebrados com numerosos países em desenvolvimento. ${ }^{75}$ O GATS contempla apenas áreas de interesse de países desenvolvidos, como serviços financeiros. Não houve liberalização efetiva em setores como construção, serviços de navegação e saúde, nos quais os países em desenvolvimento têm vantagens comparativas. ${ }^{76}$

\section{Considerações finais}

Assim como Carr criticou a cegueira dos internacionalistas liberais do seu tempo com relação ao poder vinte anos após a criação da Liga das Nações, pode-se afirmar, duas décadas após a criação da $\mathrm{OMC}$, que os liberais contemporâneos negligenciam

74 CHANG, Ha-Joon. Kicking away the ladder: development strategy in historical perspective. Londres: Anthem Press, 2003.

75 SELL, Susan. TRIPS was never Enough: vertical forum shifting, FTAS, ACTA, AND TPP. Journal of Intellectual Property Law, Athens, n.18, p. 447-475, 2011.

76 STIGLITZ, Joseph; CHARLTON, Andrew. Fair trade for all: how trade can promote development. Oxford: Oxford University Press, 2005. p. 52. 
os aspectos relacionados ao poder no novo regime de comércio. O regime insculpido no Acordo da OMC reflete o exercício de poder institucional e, ocasionalmente, coerção econômica por parte dos parceiros transatlânticos, que impuseram perdas absolutas à África na Rodada Uruguai. O argumento deste artigo desafia normativamente os teóricos liberais contemporâneos, que tomam como dado que a OMC traz ganhos a todos os membros e deixam de analisar as profundas assimetrias (re)produzidas pela organização. A visão de soma positiva dos arranjos internacionais cria barreira ideológica que cega acadêmicos liberais de RI e DI para a realidade de que instituições são, com frequência, apresentadas como ofertas que os países em desenvolvimento não podem recusar. ${ }^{77}$

Dadas as assimetrias da OMC, não surpreende que protestos antiglobalização em todo o mundo tenham sido iniciados no contexto de uma reunião da organização (Seattle 1999). As assimetrias do Acordo

77 SOUZA, Igor A. Medina de. An offer developing countries could not refuse: how powerful countries created the World Trade Organisation. Journal of International Relations \& Development, Basingstoke, n. 18, p.1-27, 9 ago. 2013. DOI: 10.1057 jird.2013. da OMC não devem, entretanto, levar ao abandono da via multilateral; ao contrário, aumentam a necessidade de reforma do arcabouço normativo da organização na Rodada Doha. Isso porque somente negociações multilaterais podem trazer ganhos mais amplos aos países de menor desenvolvimento relativo, que não têm condições de barganhar vantagens bilateralmente. Além de abrangente liberalização agrícola e em produtos primários, com a eliminação de todas as formas de subsídios às exportações, é imperativo que o TRIPS seja reformado para reequilibrar a relação entre exportadores e importadores de propriedade intelectual. Deve-se prover maior assistência aos países menos poderosos para que o sistema de consenso não funcione como instância de "hipocrisia organizada" 78 e, também, para que os países mais pobres não sejam sobrecarregados com custos de ajuste e implementação, bem como participem efetivamente do mecanismo de solução de controvérsias.

78 STEINBERG, Richard. In the Shadow of Law or Power? Consensus-based bargaining and outcomes in the GATT/WTO. International Organization, Cambridge, v. 56, n.2, p. 339-374, abr./jun. 2002. 


\section{Referências}

ABBOTT, Kenneth et al. The concept of legalization. International Organization, Cambridge, v. 54, n.3, p.401419, jul./set. 2000.

ALSTON, Philip. Resisting the merger and acquisition of Human Rights by Trade Law: a reply to Petersmann. European Journal of International Law, Oxford, v.13, n.4, p.815-844, out./dez. 2002.

ALSTON, Philip. The Myopia of the Handmaidens: International Lawyers and Globalization. European Journal of International Law, Oxford, v.8, n.3, p.435-448, 1997.

BANCO MUNDIAL. Global economic prospects and the developing countries. Washington, D.C: The World Bank, 2001.

BARNETT, Michael; DUVALL, Raymond. Power in global governance. In: BARNETT, Michael; DUVALL; Raymond. (Org.). Power in global governance. Cambridge: Cambridge University Press, 2005. p.1-32.

BUSCH, Marc; REINHARDT, Eric. Bargaining in the shadow of the law: early settlement in GATT/WTO disputes. Fordham International Law Journal, New York, v.24, n.1, p.158-172, 2000.

BUSCH, Marc; REINHARDT, Eric. Developing countries and general agreement on tariffs and Trade/ World Trade Organization dispute settlement. Journal of World Trade, v. 37, n. 4, p. 719-735, out./dez. 2003.

CHANG, Ha-Joon. Kicking away the ladder: development strategy in historical perspective. Londres: Anthem Press, 2003.

CHAYES, Abram; CHAYES, Antonia. The new sovereignty: compliance with international regulatory agreements. Cambridge: Harvard University Press, 1995.

CURZON, Victoria; CURZON, Gerard. GATT: Trader's Club. In: COX, Robert; JACOBSON, (Org.) Harold. The anatomy of influence: decision making in International Organisation. New Haven: Yale University Press, 1973. p.298-333.

DAVENPORT, Michael; PAGE, Sheila. World Trade reform: do developing countries gain or lose? Londres: Overseas Development Institute, 1994.
DRAHOS, Peter. Developing countries and international Intellectual Property standard-setting. Londres: Commission on Intellectual Property Rights, 2002. (Study Paper, 8).

DRAHOS, Peter. Expanding Intellectual Property's empire: the role of FTAs. Canberra: Australian National University, 2003.

DRAKE, William; KALYPSO, Nicolaidis. Ideas, interests, and institutionalization: trade in services and the Uruguay round. International Organization, Cambridge, v. 46, n. 1, p. 37-100, jan./mar. 1992.

EVANS, David; SHAFFER, Gregory. Introduction. In: SHAFFER, Gregory; MELÉNDEZ-ORTIZ. (Org.) dispute settlement at the WTO: the developing country experience. Cambridge: Cambridge University Press, 2010. p.1-18.

FINGER, Michael; SCHUKNECHT, Ludger. Market access advances and retreats since the Uruguay round agreement. Washington D.C.: The World Bank Development Research Group, 1999. (Working Paper, 2232).

FINGER, Michael; SCHULER, Philip. Implementation of Uruguay round commitments: the development challenge. World Economy, v. 24, n. 4, p. 511-525, out./dez. 2000.

FINNEMORE, M; TOOPE, S. Alternatives to 'Legalization': Richer Views of Law and Politics. International Organization, Oxford, v. 55, n. 3, p. 743-758, jul./set.2001.

FONTAGNÉ, Lionel; PÉRIDY, Nicolas. Uruguay Round et PVD: le cas de l'Afrique du Nord. Revue économique, v. 46, n. 3, p. 703-715, jul./set. 1995.

GOLDIN, Ian; MENSBRUGGHE, Dominique. The Uruguay round: an assessment of economy wide and agricultural reforms. In: MARTIN, Will; WINTERS, Alan.(Org.). The Uruguay round and the developing economies. Washington D.C: World Bank, 1995. p. 37-69.

GOLDSTEIN, Judith; MARTIN, Lisa. Legalization, trade liberalization, and domestic politics: a cautionary note. International Organization, Cambridge, v. 54, n. 3, p. 603-632, jul./set. 2000.

GRUBER, Lloyd. power politics and the free trade bandwagon. Comparative Political Studies, New York, v. 34, n. 7, p. 703-741, set. 2001. 
GRUBER, Lloyd. Ruling the world: power politics and the rise of supranational institutions. Princeton: Princeton University Press, 2000.

HARRISON, G.; RUTHERFORD, T; TARR, D. Quantifying the Uruguay round. In: WILL, Martin; WINTERS, Alan.(Org.) The Uruguay round and the developing economies. Washington D.C.: World Bank, 1995. p. 216-252.

HATHWAY, Dale; INGCO, Merlinda. Agricultural liberalization and the Uruguay round. In: MARTIN, Will; WINTERS, Alan. (Org.) The uruguay round and the developing economies. Washington D.C: World Bank, 1995. p. 15-37.

HERTEL, Thomas; MASTERS, William; ELBEHRI, Aziz. The Uruguay round and Africa: a global, general equilibrium analysis. Journal of African Economies, Oxford, v. 7, n. 2, p. 208-234, abr./jun. 1998.

KEOHANE, Robert. After hegemony: cooperation and discord in the world political economy. Princeton: Princeton University Press, 1984/2005.

KEOHANE, Robert; MORAVCSIK, Andrew; SLAUGHTER; Anne-Marie. Legalized Dispute Resolution: Interstate and Transnational. International Organization, Cambridge, v. 54, n. 3, p. 457-488, jul./set. 2000.

KOSKENNIEMI, Martti. Gentle civilizer of nations: the rise and the fall of International Law. Port Chester: Cambridge University Press, 2002.

KRASNER, Stephen. Regimes and the limits of realism: regimes as autonomous variables. International Organization, Cambridge, v.36, n. 1, p. 1-21, jan./mar. 1982.

KRATOCHWIL, Friedrich. Thrasymmachos revisited: on the relevance of norms and the study of law for International Relations. Journal of International Affairs, New York, v. 37, n. 1, p. 434-456, jan./mar. 1983.

KRATOCHWIL, Friedrich; RUGGIE, John. International Organization: a state of the art on an art of the state. International Organization, Cambridge, v. 40, n. 4, p. 753-775, out./dez. 1986.

KRUGMAN, Paul; OBSTFELD, Maurice. Economia Internacional. São Paulo: Makron Books, 2001.
$\mathrm{KU}$, Charlotte. International law, international relations and global governance. Nova York: Routledge, 2012.

MASKUS, Keith. Intellectual property issues for the new round. In: SCHOTT, Jeffrey. (Org.).The WTO after seattle. Washington D.C: Institute for International Economics, 2000. p. 137-158.

MORAVCSIK, Andrew. Liberalism and international relations theory. Cambridge: Harvard University, 1992. (Working Paper).

MORAVCSIK, Andrew. Taking preferences seriously: a liberal theory of international politics. International Organization, Cambridge, v.51, n.4, p.513-553, out./ dez.1997.

MORAVCSIK, Andrew. The choice for Europe: social purpose and state power from Messina to Maastricht. Nova York: Cornell University Press, 1998.

NOTTAGE, Hunter. Developing countries in the WTO dispute settlement system. Oxford: Global Economic Governance Programme, 2009. (Working Paper, 47)

OSTRY, Sylvia. The Uruguay round north-south grand bargain: implications for future negotiations. In: KENNEDY, Daniel; SOUTHWICK, James. (Org.). The political economy of International Trade Law: essays in honor of Robert E. Hudec. Nova York: Cambridge University Press, 2002. p. 285-300.

OVERSEAS DEVELOPMENT INSTITUTE. Developing Countries in the WTO. Londres: Overseas Development Institute, 1995.

OYEJIDE, T. Ademola. The participation of developing countries in the Uruguay Round: an African perspective. World Economy, v.13, n.3, p. 427-444, jul./ set. 1990.

OYEJIDE, T. Ademola. Trade policy and sustainable development in Africa. Genebra: UNCTAD, 1999.

PETERSMANN, Ernst-Ulrich. The Gatt/Wto dispute settlement system: international law, international organizations and dispute settlement. Londres: Kluwer Law International, 1997.

PETERSMANN, Ernst-Ulrich. The WTO Constitution and Human Rights. Journal of International Economic Law, v.3, n.1, p.19-25, jan./mar, 2000. 
PETERSMANN, Ernst-Ulrich. Time for a United Nations 'Global Compact' for integrating Human Rights into the Law of Worldwide Organizations: Lessons from the European Integration. European Journal of International Law, Cambridge, v.13, n.3, p. 621-650, jul./set. 2002.

PNUD. Human Development Report. Nova York: PNUD, 1997.

PRAKASH, Adam; SELL, Susan. Using ideas strategically: the contest between business and NGO networks in Intellectual Property rights. International Studies Quarterly, v. 48, n. 1, p. 143-175, jan./mar. 2004.

PREEG, Ernest. Traders in a brave new world: the Uruguay round and the future of the international trading system. Chicago: University of Chicago Press, 1995.

PUGATCH, Meir Perez. The international political economy of Intellectual Property Rights. Cambridge: Edward Elgar Publishing, 2004.

REUS-SMIT, Chris. The politics of International Law. In: REUS-SMIT, Chris (Org.) The politics of International Law. Nova York: Cambridge University Press, 2004. p.14-44.

RICARDO, David. On the principles of political economy and taxation. Londres: John Murray, 1817.

RODRIK, Dani. Why is trade reform so difficult in Africa? Journal of African Economies, Oxford, v.7, p.10-36, 1998. Suplemento 1.

SCHOTT, Jeffrey. The Uruguay round: an assessment. Washington D.C: Institute for International Economics, 1994.

SELL, Susan. Intellectual Property protection and antitrust in the developing world: crisis, coercion and choice. International Organization, v. 49, n. 2, p. 315-349, abr./jun. 1995.

SELL, Susan. Private power, public law: the globalization of Intellectual Property Rights. Cambridge: Cambridge University Press, 2003.

SELL, Susan. TRIPS was never Enough: vertical forum shifting, FTAS, ACTA, AND TPP. Journal of Intellectual Property Law, Athens, v.18, p. 447-475, 2011.
SHAFFER, Gregory. Defending interests: public-private partnerships in WTO litigation. Washington D.C.: Brookings Institution Press, 2003.

SHAFFER, Gregory. Power, governance, and the WTO: a comparative institutional approach. In: BARNETT, Michael; DUVALL, Raymond. (Org.). Power in global governance. Cambridge: Cambridge University Press, 2005. p. 130-160.

SHELL, Richard. The trade stakeholders model and participation by nonstate parties in the World Trade Organization. University of Pennsylvania Journal of International Economic Law, Cambridge, v.17, n.1, p. 359-381,1996.

SHELL, Richard. trade legalism and International Relations theory: an analysis of the World Trade Organization. Duke Law Journal, Durham, v. 44, n.5, p. 829-927, 1995.

SOUZA, Igor A. Medina de an offer developing countries could not refuse: how powerful countries created the World Trade Organisation. Journal of International Relations \& Development, Basingstoke, v. 18, p.1-27, ago. 2013. DOI: 10.1057 jird.2013

SOUZA, Igor A. Medina de. Dom Quixote reencontra Sancho Pança: guerra fria, relações internacionais e direito internacional. Rio de Janeiro: Apicuri, 2014.

SRINIVASAN, T.N. Developing countries and the multilateral trading system: from the GATT to the Uruguay round and the future. Boulder: Westview Press, 1998.

STEINBERG, Richard. In the shadow of law or power? consensus-based bargaining and outcomes in the GATT/WTO. International Organization, Cambridge, v. 56, n. 2, p. 339-374, abr./jun. 2002.

STIGLITZ, Joseph; CHARLTON, Andrew. Fair trade for all: how trade can promote development. Oxford: Oxford University Press, 2005.

UNCTAD. Trade and development report. Genebra: UNCTAD, 1994.

YOUNG, Oran. Regime dynamics: the rise and fall of international regimes. International Organization, Cambridge, v. 36, n.1, jan./mar. 1982. p. 277-297. 


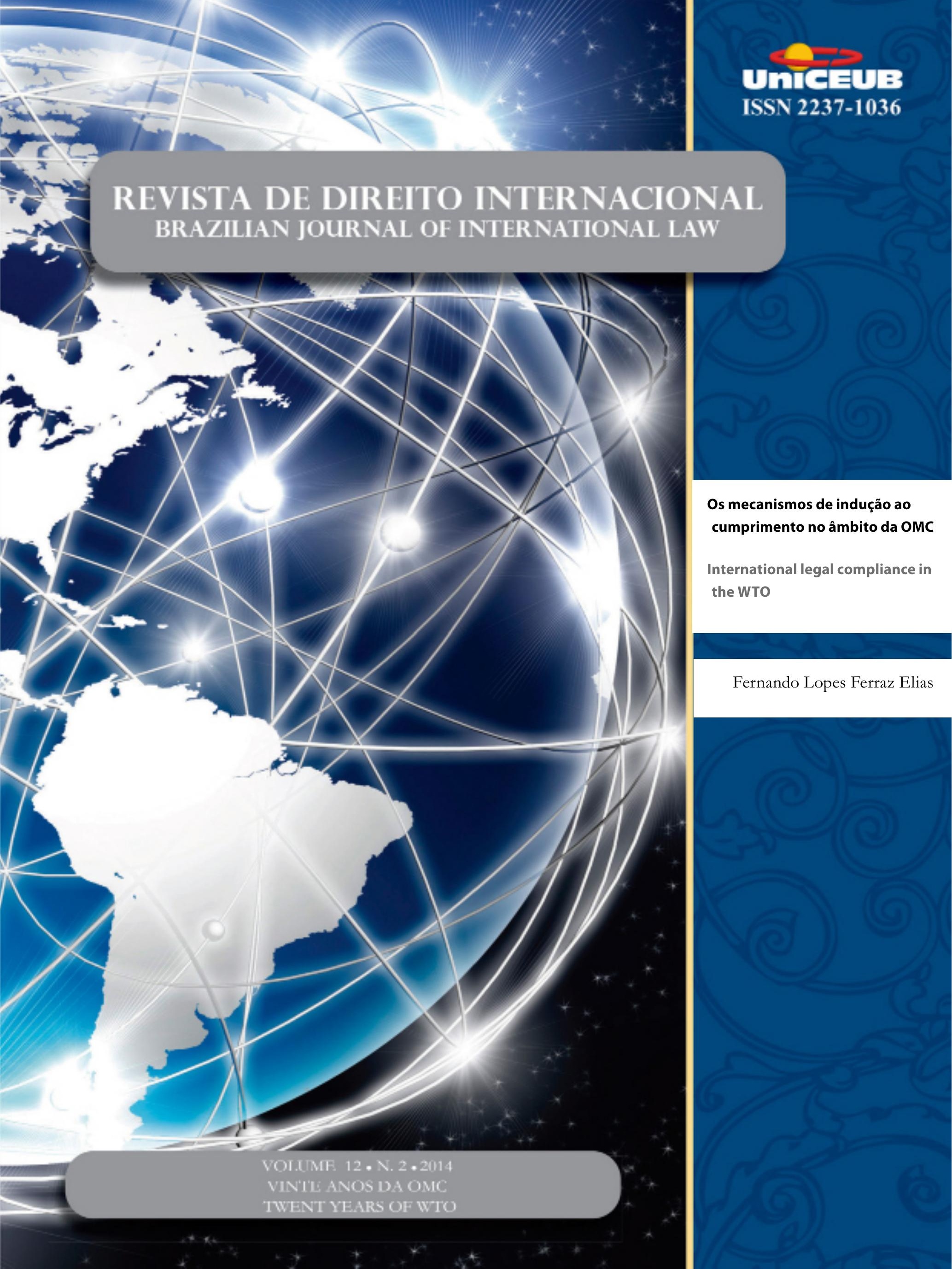




\title{
Os mecanismos de indução ao cumprimento no âmbito da OMC*
}

\author{
International legal compliance in the WTO
}

\author{
Fernando Lopes Ferraz Elias**
}

\section{Resumo}

O presente artigo visa investigar os mecanismos de indução ao cumprimento no âmbito da OMC. Primeiramente, contextualizamos, política e juridicamente, a questão da implementação das regras e decisões da OMC. Em seguida, examinamos os fatores que influenciam o descumprimento das regras e das decisões da OMC pelos países desenvolvidos, em desenvolvimento e de menor desenvolvimento relativo. Adiante, destacamos as formas de descumprimento das regras e das decisões da OMC e analisamos dados e estatísticas do sistema. Por fim, propomos mudanças para o aprimoramento do cumprimento das decisões da OMC. Concluímos que a questão da conformidade é central para o funcionamento das instituições internacionais, com a OMC na vanguarda. A eficácia do regime jurídico da OMC depende da sua capacidade de indução ao cumprimento das decisões dos painéis e do órgão de apelação. Hoje, a solução de litígios comerciais internacionais é tanto o resultado de ingerências políticas quanto de um verdadeiro interesse em aprimorar as condições do comércio internacional. Destarte, é fundamental perscrutarmos em que extensão os atuais níveis de descumprimento das obrigações comerciais podem constituir uma ameaça a um regime jurídico relativamente bem organizado, e até agora, em parte, efetivo; ou, ao contrário, são necessários para a sua operação contínua em um sistema de comércio multilateral marcado por acentuadas assimetrias de poder. Portanto, o presente estudo é dotado de originalidade e, despido de pretensões de exaurir o tema, utiliza fontes de documentação direta e indireta nacional, internacional e estrangeira, a exemplo de leis, jurisprudências, livros e artigos científicos.

Palavras-chave: Mecanismos de indução ao cumprimento. Acordo Geral de Tarifas e Comércio (GATT). Organização Mundial do Comércio (OMC). Países desenvolvidos, em desenvolvimento e de menor desenvolvimento relativo.

\section{Abstract}

The aim of this paper is to investigate the international legal compliance in the WTO. First, we contextualize, politically and legally, the issue of WTO rules and decisions' implementation. Next, we examine the factors that influence noncompliance with the rules and decisions of the WTO by developed countries, developing countries and less developed countries. Forward, we highlight the forms of noncompliance with the rules and decisions of the WTO and we analyze data and statistics of the system. Finally, we propose changes to improve compliance with WTO rulings. We conclude that the issue of compliance is central to the functioning of international institutions, the WTO at the forefront. The effectiveness of the legal framework of the WTO depends on its ability to

\footnotetext{
* Recebido em 30.10.2014

Aceito em 27.11.2014

** Bacharel em Direito e Relações Internacionais pela PUC-SP, Mestre em Relações Internacionais pela UNISUL, Doutorando em Direito pelo UNICEUB, flfe@ig.com.br.
} 
induce compliance with the decisions of panels and the appellate body. Today, the settlement of international commercial disputes is the result of political interference and a genuine interest in improving the conditions of international trade. Thus, it is essential we scrutinize in what extent the current levels of noncompliance with trade obligations may constitute a threat to a relatively well-organized legal system, and so far, partly effective; or, conversely, are necessary for its continued operation in a multilateral trading system that is defined by sharp power asymmetries. Therefore, this study is endowed with originality and, without pretensions to exhaust the subject, uses sources of direct and indirect documentation national, international and foreign, like laws, jurisprudence, books and scientific articles.

Keywords: International legal compliance. General Agreement on Tariffs and Trade (GATT). World Trade Organization (WTO). Developed countries, developing countries and less developed countries.

\section{Introdução}

Uma das mais importantes questões recentemente suscitadas no âmbito da OMC é a do respeito às regras e decisões dos painéis e do órgão de apelação do sistema de solução de controvérsias. Uma vez que uma decisão foi proferida, como pode uma parte reclamante garantir que a parte reclamada irá fielmente implementá-la? Que recurso está disponível para o autor da denúncia, se o réu de uma disputa altamente politizada recusar-se a cumpri-la?

No direito internacional, de modo geral, é difícil tomar medidas coercitivas quando os estados não cooperam. Na OMC, especificamente, é diferente, em razão da estrutura do OSC, com destaque para a possibilidade de imposição de medidas retaliatórias ao membro que descumpre as regras e decisões da organização. Contudo, descontextualizado dos interesses dos atores políticos, esse expediente não tem sido suficiente para resolver as deficiências pertinentes ao cumprimento, uma vez que não é possível estabelecer uma relação direta entre a natureza coercitiva da norma comercial internacional e o comportamento dos estados. Não podemos olvidar que a OMC foi constituída como uma criatura híbrida, tanto jurídica quanto diplomática. Por isso, devemos questionar quem serve melhor aos objetivos econômicos do sistema de comércio internacional, se a lei ou a negociação.
A importância do poder político e econômico emoldura o contexto no qual se podem compreender os principais fatores que influenciam a conformidade às regras e às decisões da $\mathrm{OMC}$ por parte dos países desenvolvidos, em desenvolvimento e de menor desenvolvimento relativo, a ponto de se repensar a própria viabilidade do ESC como um mecanismo idôneo para a resolução de disputas comerciais internacionais, supedâneo de um sistema baseado no direito ao invés de um sistema baseado no poder. Por um lado, destaca-se a dificuldade do OSC de induzir o cumprimento das regras da OMC, bem como de suas decisões, aos países desenvolvidos diante de: (i) situações de ausência de pressão da comunidade internacional; (ii) aspectos estruturais do sistema de solução de controvérsias; (iii) receio de perda de soberania. Por outro, as decisões do painel e do órgão de apelação da OMC, em relação aos dos países em desenvolvimento e de menor desenvolvimento relativo, são incapazes de minimizar a desconformidade frente: (i) à influência dramática da força política e econômica dos países desenvolvidos sobre o processo de solução de controvérsias; (ii) ao descumprimento das decisões da OMC pelos países desenvolvidos; (iii) aos aspectos técnicos do sistema de solução de controvérsias da OMC; (iv) à impossibilidade dos países em desenvolvimento de utilizarem o mecanismo da retaliação; (v) à falta de capacidade técnica e de recursos financeiros aos países em desenvolvimento.

A não conformidade dos membros da OMC, geralmente, materializa-se das seguintes maneiras: (i) descumprimento prévio; (ii) descumprimento temporário; (iii) morosidade; e (iv) descumprimento, aberto e disfarçado. $\mathrm{Na}$ maioria dos casos, entretanto, a maioria dos membros - tanto os maiores como os menores — implementa a maior parte dos relatórios do painel e do órgão de apelação, principalmente, a fim de se assegurar a legitimidade de um sistema baseado em regras. Isso faz com que a taxa de cumprimento no âmbito da OMC seja muito boa. Contudo, vista mais de perto, se considerados os números dos casos de cumprimento não integral somados aos casos de morosidade persistente até o pleno cumprimento, isto é, qualidade e tempo de cumprimento, respectivamente, chega-se a um índice de descumprimento muito superior ao do antigo GATT, o que recomenda reformas na $\mathrm{OMC}$, desde que não sejam meramente legalistas e atendam aos interesses peculiares dos seus membros. 


\section{Entre a política e o direito, a implementação das regras e das decisões da OMC}

Não há dúvida de que o mais convincente fator para o cumprimento de uma diretriz ${ }^{1}$ relativa ao comércio internacional é que ela decorra de um processo legal. ${ }^{2} \mathrm{~A}$ judicialização das disputas comerciais e o trabalho consistente dos juízes têm potencializado a força normativa dos acordos e promovido um regime de comércio internacional baseado em regras. Essa visão é reforçada pela taxa de êxito dos demandantes entre 80 e 90 por cento das disputas, resultado de uma interpretação judicial dos textos da OMC a partir de uma visão liberal de livre comércio. ${ }^{3}$ Sistemas de regulação baseados em regras são preferidos pelos países porque: (i) apresentam mais e melhores recursos para a solução dos conflitos; (ii) são a maneira mais eficaz de negociar e capturar mudanças políticas desejadas em passos incrementais possíveis; (iii) criam as condições mais previsíveis para as decisões das empresas; (iv) ajudam a cimentar as próprias políticas liberais de comércio contra as pressões políticas internas protecionistas. ${ }^{4}$

Em última instância, as regras do comércio internacional são estabelecidas para aumentar o bem-estar nacional e mundial por meio do uso mais eficiente dos recursos. Parece pouco provável que uma abordagem mais orientada para o poder elevaria o bem-estar nacional ou mundial. A ameaça de guerras comerciais cresceria, particularmente, no caso de

1 É importante distinguir o cumprimento das obrigações primárias da OMC - a promoção do que é o objetivo final do ESC - do cumprimento das decisões e recomendações do OSC. Conquanto este seja certamente relevante para aquele e o influencie direta e indiretamente, ambos não são a mesma coisa. Decisões e recomendações do OSC são, necessariamente, produtos de controvérsias não resolvidas por meio de consultas e mediações. De fato, menos da metade desses casos são submetidos ao OSC. Portanto, são, naturalmente, os casos mais difíceis, do ponto de vista jurídico ou político. VAZQUEZ, Carlos M.; IACKSON, John H. Some reflections on compliance with WTO dispute settlement decisions. Law and Policy in International Business, v. 33, n. 4, p. 555-568. 2002.

2 BRIMEYER, Benjamin L. Bananas, beef, and compliance in the world trade organization: the inability of the WTO dispute settlement process to achieve compliance from superpower nations. Minnesota Journal of Global Trade, v. 10, p. 166, 2001.

3 COLARES, Juscelino F. Thelimits of WTO adjudication: is compliance the problem? Journal of International Economic Law, v. 14, n. 2, p. 403-436, 2011.

4 HUDEC, Robert E. The new WTO dispute settlement procedure: an overview of the first three years. Minnesota Journal of Global Trade, v. 8, n. 1, p. 10, 1999. disputas entre países poderosos. Além disso, reduziria a previsibilidade e a estabilidade do sistema, exigências das empresas privadas, prejudicando a alocação de recursos por parte delas. E, ainda, o poder poderia ser exercido para interesses particulares e fins protecionistas. Portanto, os interesses dos consumidores, bem como o bem-estar dos cidadãos, aumentariam mesmo na hipótese em que o país deles viesse a ser derrotado em um litígio no âmbito da OMC.

Uma análise dos mecanismos de solução de controvérsias mostra que, embora a OMC estabeleça um regime mais orientado para o direito, ainda lhe falta o poder de impor o cumprimento das suas decisões. ${ }^{6} \mathrm{~A}$ politização das disputas torna o Entendimento sobre Solução de Controvérsias (ESC) inoperante para a implementação dos seus direitos. A inexistência de um cumprimento coercitivo envenena a relação entre os países. Ir ao OSC não se traduz no automático cumprimento de suas decisões, sendo este o verdadeiro desafio para a $\mathrm{OMC}^{\top} \mathrm{A}$ aplicação efetiva das decisões do OSC é essencial para garantir a integridade contínua do sistema de solução de controvérsias da OMC. No entanto, é evidente que a tão anunciada "automaticidade" tem suas limitações. A aceitação automática dos relatórios do painel e do órgão de apelação, bem como dos pedidos de retaliação, não é garantia de cumprimento automático.

Em contraponto, não há uma relação direta entre o caráter obrigatório de determinada norma e o incentivo a certa conduta, sem considerar o contexto em que ambos estão insertos. Portanto, devemos analisar quais mecanismos produzem um maior respeito às normas e em quais circunstâncias o cumprimento das normas é algo verdadeiramente útil. A lei é imprecisa e

5 SCHAEFER, Matthew. National review of WTO dispute settlement reports: in the name of sovereignty or enhanced WTO rule compliance? St. John's Journal of Legal Commentary, v. 11, n. 2, p. 335-336, 1996.

6 KHANSARI, Azar M. Searching for the perfect solution: international dispute resolution and the new world trade organization. Hastings International and Comparative Law Review, v. 20, n. 1, p. 189, 1996.

7 IERLEY, Douglas. Defining the factors that influence developing country compliance with and participation in the WTO dispute settlement system: another look at the dispute over bananas. Law and Policy in International Business, v. 33, p. $627,2002$.

8 MCGIVERN, Brendan P. Seeking compliance with WTO rulings: theory, practice and alternatives. International Lanyer $(A B A)$, v. 36, n. 1, p. 157, 2002. 
imperfeita, como nossa sociedade e nós mesmos. Não devemos imaginar que a condição natural da lei seja o seu cumprimento, ao contrário, sistemas jurídicos devem ser avaliados por sua maturidade, ou seja, se oferecem uma ampla variedade de opções sociais que permitem decisões políticas flexíveis em situações específicas.

No âmbito europeu, essa discussão do cumprimento do direito da OMC pode dar razão para o otimismo ou o pessimismo por parte daqueles que desejam melhores padrões de conformidade. Por um lado, os otimistas podem argumentar que a legislação da OMC impactou a forma como a Comunidade Europeia (CE) lida com o processo de restrição do comércio. De modo geral, a criação da OMC reforça o cumprimento da lei do comércio internacional. Por outro lado, os resultados podem encorajar o pessimismo entre aqueles desejosos de que a conformidade não dependa das conveniências políticas dos estados membros, mas sim de mecanismos coercitivos. É duvidoso que os acordos internacionais possam alcançar este tipo de cumprimento institucionalmente garantido. No final, o cumprimento será sempre o resultado de um cálculo político além das regras da OMC ou da possibilidade de retaliação. O cumprimento é estimulado ou desestimulado de acordo com os interesses dos atores políticos domésticos. Ao mesmo tempo, isso não reduz a questão da conformidade a uma questão de conveniência política doméstica, um bem desenhado projeto das instituições internacionais pode de fato aumentar a probabilidade de cumprimento, como o fez a OMC. O fortalecimento de um sistema de resolução de litígios pode contribuir para tornar mais difícil o descumprimento, ou seja, as instituições internacionais podem estruturar processos políticos que conduzam ao cumprimento de tal modo que a conformidade torna-se mais ou menos provável. É na interação entre direito e política que a conformidade é finalmente promovida. ${ }^{10}$

$\mathrm{O}$ efeito direto das decisões quer dizer que os Judiciários dos estados membros podem dar efeito imediato a uma medida tomada no âmbito da OMC. Entretanto, de acordo com a relação entre o direito nacional e o direito internacional em cada país, essa

9 TRACHTMAN, Joel P. Bananas, direct effect and compliance. European Journal of International Law, v. 10, n. 4, p. 656-657, 677, 1999.

10 PRINCEN, Sebastiaan. EC compliance with WTO law: the interplay of law and politics. European Journal of International Law, v. 15, n. 3, p. 555-574, 2004. mudança seria tão atraente para estados que optam pela prevalência dos tratados sobre as leis internas, mesmo posteriores aos compromissos firmados internacionalmente, quanto poderia significar a ineficácia do sistema nos estados em que esta relação não é tão clara, como no Brasil, uma vez que a vigência do tratado poderia ser considerada suspensa (ou mesmo revogada) à luz da norma interna posterior. Assim, a efetividade das decisões ficaria refém do grau de monismo ou dualismo de cada estado membro e o sistema todo contaminado pela insegurança jurídica e pela falta de agilidade dos Judiciários nacionais, cujos processos internos são, na maioria das vezes, muito mais morosos do que no âmbito multilateral, a exemplo do contencioso Comunidades Europeias - Pneus, cuja medida se tornou ineficaz pela própria morosidade do Judiciário brasileiro em proferir em tempo razoável uma decisão definitiva. ${ }^{11}$

A mais importante questão quanto à implementação é determinar se o efeito direto é adequado ao nível e ao tipo da força normativa obrigatória desejada. O efeito direto deve ser concebido em termos de preferência e não como uma teoria abstrata descontextualizada das instituições políticas. Essa é uma avaliação e um envolvimento que cabe aos atores políticos, consoante os interesses públicos. Certamente os EUA teriam rejeitado a Rodada Uruguai se as normas da OMC exigissem a produção de efeitos diretos. Trata-se de uma questão política que deve ser respondida em termos políticos. A falta de efeito direto deve ser vista como um mecanismo que reforça a legitimidade democrática dos estados, conquanto favoreça os mais poderosos e reduza o cumprimento das normas. Portanto, não há problemas no ESC, senão a necessidade de direito e política coexistirem. O nirvana do cumprimento perfeito é uma quimera. ${ }^{12}$

Se os membros tivessem desejado um cumprimento perfeito, poderiam ter fornecido sanções duras pelo descumprimento e criado um equivalente internacional a uma força policial coercitiva. Os membros não o fizeram, nem há possibilidade de que o façam. Sem dúvida, isso reflete, em certa medida, o fato de que

11 VARELLA, M. D. Efetividade do Órgão de Solução de Controvérsias da Organização Mundial do Comércio: uma análise sobre os seus doze primeiros anos de existência e das propostas para seu aperfeiçoamento. Revista Brasileira de Politica Internacional, v. 52, n. 2, p. 19, 2009.

12 TRACHTMAN, Joel P. Bananas, directeffectandcompliance. European Journal of International Law, v. 10, n. 4, p. 676-678, 1999. 
os membros não desejavam o cumprimento perfeito, pois não estavam dispostos a pagar o preço, em termos de soberania, por um regime que alcançaria esse grau de cumprimento. Contudo, isso não significa que eles queriam apenas o cumprimento daquilo com que concordam. ${ }^{13}$ No final, uma eventual alteração do ESC para produzir uma maior conformidade com as normas primárias é tanto uma questão política quanto técnica. Depende da vontade dos membros e eles podem preferir remédios menos invasivos. ${ }^{14}$

A estrutura jurídica da OMC fornece aos membros uma flexibilidade intra e extracontratual, tanto no âmbito dos limites da negociação quanto além dele, para garantir que, num primeiro momento, estados soberanos permaneçam dispostos a entregar grande parte da sua liberdade de ação em questões comerciais ao aderir à $\mathrm{OMC}$, e, num segundo momento, participem, no futuro, de rodadas de liberalização do comércio. Mais importante ainda, todas as iniciativas de atribuir ao processo de solução de controvérsias da OMC sanções mais duras, a fim de forçar os membros que se encontram em estado de violação à imediata conformidade, podem ser perfeitamente compatíveis com a natureza jurídica da solução de controvérsias bem como das obrigações internacionais. No entanto, elas ignoram completamente que o mecanismo de execução, aparentemente fraco, da OMC, por exemplo, permissivo ao descumprimento temporário das obrigações e decisões do órgão, serve como uma valiosa válvula de segurança sistêmica. Ademais, constata-se que esse expediente — baseado no regime de renegociação e alteração unilateral de tarifas e serviços, sob os artigos XXVIII do Acordo Geral de Tarifas e Comércio (GATT) de 1994 e XXI do Acordo Geral sobre Comércio de Serviços (GATS), que é parte explícita do acordo da OMC — tem sido utilizado pelos países membros apenas em circunstâncias verdadeiramente excepcionais. ${ }^{15}$

13 VAZQUEZ, Carlos M.; IACKSON, John H. Some reflections on compliance with WTO dispute settlement decisions. Law and Policy in International Business, v. 33, n. 4, p. 555568, 2002.

14 HUDEC, Robert E. Broadening the scope of remedies in WTO dispute settlement. In: WEISS, Friedl (Coord.). Improving WTO dispute settlement procedures: issues and lessons from the practice of other international courts and tribunals. London: Cameron May, 2000. p. 345-376.

15 ZIMMERMAN, Claus D. Toleration of temporary noncompliance: the systemic safety valve of WTO dispute settlement revisited. Trade, Law and Development, v. 3, n. 2, p. 382-406, 2011.
O aumento da coerção e de seu monitoramento tem como premissa o fortalecimento das obrigações normativas prescritas nos acordos comerciais. Essa visão ingenuamente pressupõe que os membros podem ser forçados a cumprir, mesmo quando o cumprimento é contrário aos seus próprios interesses. Finalmente, o cumprimento imperfeito não constitui nenhuma ameaça para o regime comercial. Ao invés disso, é essencial uma válvula de escape num sistema impulsionado pela crescente judicialização e ativismo jurídico. Vista dessa perspectiva mais flexível, a não conformidade aparece como um último recurso, acomodando os fortes interesses políticos e econômicos dos membros que já não podem contar com a flexibilidade diplomática do antigo GATT. Consequentemente, em vez de ameaçar a normatividade do sistema de comércio, tais desvios raros permitem a sua operação contínua enquanto as suas regras não podem constranger economias fortes, tampouco minimizar assimetrias de poder do sistema multilateral. ${ }^{16}$

Ademais, o adensamento de juridicidade poderia ser ruim para o crescimento do multilateralismo econômico, edificado sobre negociações mais políticas do que jurídicas. ${ }^{17} \mathrm{O}$ descumprimento persistente não implica sequer uma mudança permanente de direitos, uma vez que, de acordo com as regras do ESC, o direito da OMC é melhor analisado como sendo uma regra de propriedade e não uma regra de responsabilidade. Destarte, acomoda, de uma maneira muito equilibrada, flexibilidade extracontratual e segurança jurídica. Isso permite uma crescente liberalização do comércio mundial, beneficiando os membros e as pessoas físicas. ${ }^{18}$

Nesse sentido, os membros não são obrigados a cumprir as disposições dos acordos, caso lhes seja mais conveniente violá-los e sofrerem a suspensão das concessões nos termos do artigo 22 do ESC. Todavia, é difícil de entender como o ESC poderia promover a previsibilidade na $\mathrm{OMC}$ se a única responsabilidade

16 COLARES, Juscelino F. Thelimits of WTO adjudication: is compliance the problem? Journal of International Economic Law, v. 14, n. 2, p. 403-436, 2011.

17 VARELLA, M. D. Efetividade do Órgão de Solução de Controvérsias da Organização Mundial do Comércio: uma análise sobre os seus doze primeiros anos de existência e das propostas para seu aperfeiçoamento. Revista Brasileira de Política Internacional, v. 52, n. 2, p. 06, 2009.

18 ZIMMERMAN, Claus D. Toleration of temporary noncompliance: the systemic safety valve of WTO dispute settlement revisited. Trade, Law and Development, v. 3, n. 2, p. 382-406, 2011. 
dos membros é a de manterem um equilíbrio entre benefícios e ônus, ou seja, se os membros estão livres para agirem de forma inconsistente com as disposições dos acordos, desde que estejam dispostos a sofrerem a suspensão das concessões equivalentes. Esse sistema parece mais adequado para um regime que tem por finalidade simplesmente facilitar a resolução de litígios individuais, mas parece incompatível com um regime jurídico que visa produzir segurança e certeza para os membros. Portanto, se para o sistema é indiferente, se as leis dos seus membros estão em conformidade com as da organização ou se preferem suportar a suspensão das concessões, esta se convolou em obrigação primária dos membros. ${ }^{19}$

Diante disso, seria necessário conceber o direito da OMC como um conjunto de regras internacionais vinculativas, capaz de engendrar a responsabilidade internacional do estado e, assim, a obrigação de reparação do ato ilícito, nos termos dos princípios internacionalmente aceitos nesta matéria. Essa é a única forma de aumentar a segurança e a previsibilidade das relações comerciais, eliminando os incentivos existentes para a inobservância do sistema e fortalecendo suas regras para a implementação das obrigações. ${ }^{20}$

Por um lado, sem coação, as partes, inevitavelmente, não seguirão as suas decisões. ${ }^{21}$ Esse problema resulta, em parte, da mudança de um sistema baseado no poder para um sistema baseado em regras. Contudo, a "legalização" das disputas sob os auspícios da OMC termina quando o não cumprimento começa. ${ }^{22}$ Por outro lado, se a natureza jurídica da organização evoluir muito rápido, há o risco de afastar seus membros, o que poderia diminuir a confiança no regime internacional, mormente, caso a parte transgressora seja uma nação economicamente poderosa e, portanto, essencial para o

19 VAZQUEZ, Carlos M.; JACKSON, John H. Some reflections on compliance with WTO dispute settlement decisions. Law and Policy in International Business, v. 33, n. 4, p. 555568, 2002.

20 NGANGJOH, Yenkong; RIOS-HERRAN, Roberto. WTO dispute settlement system and the issue of compliance: multilateralizing the enforcement mechanism. Manchester Journal of International Economic Law, v. 1, n. 3, p. 15-30, 2004.

21 KHANSARI, Azar M. Searching for the perfect solution: international dispute resolution and the new world trade organization. Hastings International and Comparative Law Review, v. 20, n. 1, p. 189, 1996.

22 PAUWELYN, Joost H. Enforcement and countermeasures in the WTO: rules are rules - toward a more collective approach. American Journal of International Law, v. 94, p. 338, 2000. funcionamento do sistema de comércio mundial. Está muito claro que a OMC depende das boas intenções das partes. A Rodada Uruguai deu significativos passos na direção da criação de um efetivo tribunal internacional, com base no art. 23 do ESC. Entretanto, não obstante deva se desenvolver nesse sentido, a OMC é e continuará sendo, em um futuro próximo, uma criatura híbrida, tanto jurídica quanto diplomática em sua constituição. ${ }^{23}$ Consequentemente, um sistema orientado ao direito pode também trazer efeitos opostos aos desejados. Dessa maneira, admitindo-se que o cumprimento das obrigações será melhor para o sistema do que o não cumprimento, a questão é saber o que será mais eficaz na garantia do cumprimento, a adjudicação ou a negociação. ${ }^{24}$

\section{Fatores que influenciam o descumprimento das regras e das decisões da OMC pelos países desenvolvidos}

Vários fatores são responsáveis por uma maior desconformidade entre o comportamento dos países desenvolvidos e as regras da OMC, bem como pela incapacidade do OSC em determinar o cumprimento das suas decisões, quando esses países figuram na condição de partes perdedoras nas disputas: (i) situações de ausência de pressão da comunidade internacional; (ii) aspectos estruturais do sistema de solução de controvérsias; (iii) receio de perda de soberania..$^{25}$

Desde o antecessor da OMC, o GATT, cujo procedimento jurídico não era obrigatório, governos demandados sempre estiveram suscetíveis à pressão por parte da comunidade internacional, quando se chegava a um consenso de que a decisão era correta. ${ }^{26}$ Todavia, não há pressão internacional pelo cumprimento de uma decisão se um consenso não puder ser alcançado quanto à justiça dessa decisão. Dessa maneira, a descrença no processo pode tanto reduzir as pressões internacionais

23 DILLON JUNIOR., Thomas J. The World Trade Organization: a new legal order for world trade? Michigan Journal of International Law, v. 16, n. 2, p. 398, 1995.

24 DILLON JUNIOR, Thomas J. The World Trade Organization: a new legal order for world trade? Michigan Journal of International Law, v. 16, n. 2, p. 401. 1995.

25 BRIMEYER, Benjamin L. Bananas, beef, and compliance in the world trade organization: the inability of the WTO dispute settlement process to achieve compliance from superpower nations. Minnesota Journal of Global Trade, v. 10, p. 164, 2001.

26 HUDEC, Robert E. The new WTO dispute settlement procedure: an overview of the first three years. Minnesota Journal of Global Trade, v. 8, n. 1, p. 09, 1999. 
por seu cumprimento, quanto a aceitação pela comunidade internacional de um processo baseado em regras aumentar a conformidade a ele. ${ }^{2}$

A OMC foi criada para corrigir problemas gerados pela falta de um coeso conjunto de leis do GATT $^{28}$, especialmente frustrante para as partes contratantes. Os autores da OMC projetaram-na cuidadosamente para resolver essas deficiências organizacionais do GATT $^{29}$, cujas falhas no mecanismo de solução de controvérsias prejudicavam a coordenação do comércio internacional. Problemas processuais, inconsistências nas decisões do painel e um descompasso entre a conduta dos países e a legislação do GATT estimularam na comunidade internacional o desejo de um novo mecanismo de regulação comercial. ${ }^{30}$ De toda maneira, a mudança do GAT'T à OMC destinava-se a reforçar os princípios existentes, não a alterá-los, na esperança de se melhorar os níveis de cumprimento das regras e reduzir o uso de medidas comerciais unilaterais ${ }^{31}$, posto que se espalhou uma crença de que algumas regras do GAT'T não eram observadas e a aplicação de outras era imprópria. ${ }^{32}$

Uma das mais significativas diferenças entre os mecanismos de resolução de litígios da OMC e do GATT envolve a criação de painéis e a adoção de suas decisões. Cada sistema de solução de controvérsias começa com consulta e negociação entre as duas partes. Findo esse processo, se não houver êxito, ambos os sistemas permitem a formação de painéis para resolver a disputa. No âmbito do GAT'T, as partes tinham o

27 BRIMEYER, Benjamin L. Bananas, beef, and compliance in the world trade organization: the inability of the WTO dispute settlement process to achieve compliance from superpower nations. Minnesota Journal of Global Trade, v. 10, p. 166, 2001.

28 Pondera-se que, não há precisão na avaliação da eficácia de um sistema, no caso o GATT, sobre o qual não há dados suficientes quanto ao cumprimento de suas decisões. HUDEC, Robert E. The GATT legal system and world trade diplomacy . 2. ed. New York: Praeger Publishers, 1990. p. 95.

29 DILLON JUNIOR, Thomas J. The World Trade Organization: a new legal order for world trade? Michigan Journal of International Law, v. 16, n. 2, p. 355, 1995.

30 KHANSARI, AzarM. Searching for the perfect solution: international dispute resolution and the new world trade organization. Hastings International and Comparative Law Review, v. 20, n. 1, p. 189, 1996.

31 PRINCEN, Sebastiaan. EC compliance with WTO law: the interplay of law and politics. European Journal of International Law, v. 15, n. 3, p. 555-574, 2004.

32 MORA, Miquel Montana I. A GATT with teeth: law wins over politics in the resolution of international trade disputes. Columbia Journal of Transnational Law, v. 31, n. 1, p. 121, 1993. poder de bloquear a formação do painel ou impedir a adoção da decisão do painel, cuja adoção se dava apenas pelo voto unânime das partes envolvidas. Esse procedimento mudou no âmbito da OMC. Uma parte em uma controvérsia não pode mais bloquear a abertura de um painel ou vetar a adoção de uma decisão, que se tornou obrigatória. Assim que uma queixa é feita contra uma parte, esta pode evitar o painel por meio de negociação, porém não pode mais bloqueá-lo. ${ }^{33}$ Obviamente, o caráter vinculativo do procedimento de resolução de conflitos da OMC teve fortes efeitos. $\mathrm{O}$ objetivo principal em atribuir força jurídica às decisões do painel foi o de eliminar a morosidade e a falta de cumprimento. Contudo, sem a capacidade de bloquear uma decisão adversa, a morosidade e o não cumprimento tornaram-se alternativas jurídicas viáveis aos derrotados. Enquanto, por um lado, a nova natureza vinculativa do OSC serve para trazer mais negociações e menos painéis, por outro, pode resultar em maior descumprimento pelas partes perdedoras. ${ }^{34}$

Propostas de um mecanismo de apelação imbuído da retificação das decisões "fundamentalmente falhas" do painel ou da revisão de relatórios "errados" ou "incompletos" opunham-se aos temores de que causariam decisões finais ainda mais demoradas. ${ }^{35} \mathrm{Se}$ um governo violou um acordo: (i) ele sabe perfeitamente bem que houve uma violação; e (ii) ele o fez por causa de pressões políticas internas, as mesmas que atuarão sobre ele para que recorra ao tribunal de segunda instância, mesmo quando ele não deveria fazê-lo. É precisamente isso que preocupa em um sistema de solução de conflitos com um mecanismo de apelação: o estímulo ao recurso, materializado na revisão da decisão de cada painel. ${ }^{36}$

33 BRIMEYER, Benjamin L. Bananas, beef, and compliance in the world trade organization: the inability of the WTO dispute settlement process to achieve compliance from superpower nations. Minnesota Journal of Global Trade, v. 10, p. 164, 2001.

34 BRIMEYER, Benjamin L. Bananas, beef, and compliance in the world trade organization: the inability of the WTO dispute settlement process to achieve compliance from superpower nations. Minnesota Journal of Global Trade, v. 10, p. 165, 2001.

35 JOERGENS, Konstantin J. True appellate procedure or only a two-stage process? A view of the appellate body under the WTO dispute settlement understanding. Law and Policy in International Business, v. 30, n. 2, p. 195, 1999.

36 HORLICK, Gary. Dispute resolution mechanism: will the United States play by the rules? Journal of World Trade, v. 29, n. 2, p. $169,1995$. 
No caso de uma decisão negativa do painel, a parte pode interpor recurso. Se o recurso não for bemsucedido, a parte terá três opções: (i) o cumprimento da decisão da OMC; (ii) manutenção da prática ilegal, compensando a outra parte pelas perdas; ou (iii) completa desconsideração da decisão. A título de exemplo, os litígios carne e a bananas demonstram que, mesmo sem a capacidade de bloquear as decisões do painel, as partes vencidas optaram por criar longos atrasos e, depois, ignorar a decisão da OMC. Uma das razões para a criação do processo de apelação foi a de aliviar os efeitos da adoção automática das decisões do painel, todavia duas grandes preocupações foram observadas: (i) imprecisão e falta de especificidade da decisão; (ii) inconsistência e contradição na argumentação. Tais problemas com o processo de apelação podem minar a fé de uma das partes no sistema e, assim, tornar a não conformidade uma solução mais atraente. Dessa maneira, o processo de apelação também produziu um maior incumprimento. ${ }^{3}$

Um bom número de inconsistências resulta do raciocínio contraditório do órgão de apelação, às vezes, dentro do mesmo relatório. Dois casos ilustram o problema. No litígio Estados Unidos - Normas para gasolina modificada e convencional, a divisão do órgão de apelação, depois de ter afirmado a importância dos significados diferentes das palavras usadas no artigo XX do GATT, não fez a mesma distinção ao interpretar o caput desse artigo, afirmando que "discriminação arbitrária", "discriminação injustificável" e "restrição disfarçada" podem, consequentemente, ser lidos como sinônimos. No litígio Índia proteção de patente para produtos químicos farmacêuticos e agrícolas, o Órgão de Apelação afirmou que a Índia deveria suportar os efeitos dos direitos e obrigações consagrados no artigo 70.9 do TRIPS, a partir da data da entrada em vigor do Acordo Constitutivo da OMC (01 de janeiro de 1995), o que é, no mínimo, questionável se o órgão de apelação aplicou corretamente o artigo 31 da Convenção de Viena, por não considerar a sua remissão ao artigo 70.8, que prevê especificamente um período de transição para países em desenvolvimento. Esse dispositivo fica sem sentido sob essa interpretação. A jurisprudência revela que o órgão de apelação, por vezes, não

37 BRIMEYER, Benjamin L. Bananas, beef, and compliance in the world trade organization: the inability of the WTO dispute settlement process to achieve compliance from superpower nations. Minnesota Journal of Global Trade, v. 10, p. 165-166, 2001. conseguiu alcançar o desejado grau de consistência em sua análise. ${ }^{38}$

Outra questão das mais controversas no debate sobre a implementação dos acordos da Rodada Uruguai foi a dos possíveis efeitos sobre a soberania dos estados. ${ }^{39}$ Desde a criação da OMC, os países membros têm se preocupado com o fato de o sistema representar um risco para a soberania, ou seja, para o poder de agirem em nome dos seus cidadãos. Isso significa delegar a burocratas a capacidade de determinarem se as leis de um país violam a política internacional, impedindo os países de bloquear essa decisão e, ainda, retirando deles a capacidade de impor sanções unilaterais. Essas preocupações acabam, invariavelmente, por justificar o incumprimento de decisões contrárias, sob a alegação de que a parte vencida sente que sua soberania foi violada, remanescendo como única opção a não conformidade. Se os países virem a OMC não como um meio de resolver disputas, mas de infringir suas soberanias, o não cumprimento pode se tornar uma opção aceitável e os países membros simplesmente optarão por suportar as sanções, expressão do fracasso do órgão em ajudá-los a resolver disputas. De fato, se as nações poderosas preferirem as sanções ao cumprimento das decisões, a OMC revelará pouca serventia na arena de resolução de disputas. O litígio hormônio de carne viu a apreensão sobre a soberania se concretizar. A União Europeia afirmou que a decisão da OMC infringia o seu direito de determinar o nível de proteção que considera adequado para os seus próprios cidadãos. Em virtude dessa discordância, optou por um expediente de implementação responsável por atrasos no cumprimento e, por fim, pelo descumprimento da decisão. ${ }^{40}$

\section{Fatores que influenciam o descumprimento das regras e das decisões da omc pelos países em desenvolvimento}

O aumento dos acordos comerciais no âmbito da OMC, a necessidade do órgão resolver equitativamente disputas entre os países membros com grandes

38 JOERGENS, Konstantin J. True appellate procedure or only a two-stage process? A view of the appellate body under the WTO dispute settlement understanding. Law and Policy in International Business, v. 30, n. 2, p. 218-219, 1999.

39 HORLICK, Gary. WTO dispute settlement and the Dole commission.Journal of World Trade, v. 29, n. 6, p. 45-46, 1995.

40 BRIMEYER, Benjamin L. Bananas, beef, and compliance in the world trade organization: the inability of the WTO dispute settlement process to achieve compliance from superpower nations. Minnesota Journal of Global Trade, v. 10, p. 133-168, 2001. 
diferenças de poder político e econômico e os trabalhos do OSC, marcados pela transparência e neutralidade, contribuíram para o respeito às regras da organização e a expansão substancial do número de demandas, em relação ao regime anterior, envolvendo os países em desenvolvimento. ${ }^{41}$

Contudo, há diversos fatores que influenciam a desconformidade dos países em desenvolvimento às decisões do painel e do órgão de apelação da OMC: (i) a influência dramática da força política e econômica dos países desenvolvidos sobre o processo de solução de controvérsias; (ii) o descumprimento das decisões da OMC pelos países desenvolvidos; (iii) os aspectos técnicos do sistema de solução de controvérsias da OMC; (iv) a impossibilidade dos países em desenvolvimento de utilizarem o mecanismo da retaliação; (v) a falta de capacidade técnica e de recursos financeiros aos países em desenvolvimento. ${ }^{42}$

A primeira questão a ser considerada numa disputa é se o país envolvido é uma economia forte ou fraca. As disputas chegam até o ponto em que se define qual parte é a politicamente mais poderosa, o que desencoraja os países em desenvolvimento a demandarem os países membros do "Quad" — os EUA, a UE, o Japão e o Canadá - cujos interesses prevalecem. Há para os países em desenvolvimento uma frustração, quanto ao sistema de solução de controvérsias da $\mathrm{OMC}^{43}$, em virtude da tensão entre a preponderância do poder político, na prática, e a igualdade das regras, na teoria. Isso faz com que, na prática, o regime da OMC seja composto por estruturas "baseadas no poder", ditadas pelo "império

41 IERLEY, Douglas. Defining the factors that influence developing country compliance with and participation in the WTO dispute settlement system: another look at the dispute over bananas. Law and Policy in International Business, v. 33, p. 615652, 2002.

42 IERLEY, Douglas. Defining the factors that influence developing country compliance with and participation in the WTO dispute settlement system: another look at the dispute over bananas. Law and Policy in International Business, v. 33, p. 615652, 2002.

43 Ademais, os países em desenvolvimento sempre foram excluídos das discussões sobre o comércio internacional. O poder econômico também se desenrola em termos socioeconômicos, pois o impacto de uma disputa comercial entre um país desenvolvido e um país em desenvolvimento é certamente maior para este IERLEY, Douglas. Defining the factors that influence developing country compliance with and participation in the WTO dispute settlement system: another look at the dispute over bananas. Law and Policy in International Business, v. 33, p. 615652, 2002. da força”. Dois casos de destaque, Estados Unidos restrições às importações de algodão e Comunidade Europeia - regime de importação, venda e distribuição de bananas, em 2008, esclarecem as questões mais importantes e ilustram o que a participação no sistema de solução de controvérsias da OMC oferece aos países em desenvolvimento: por um lado, a possibilidade de processos contra um país desenvolvido, cujas práticas violam as regras do comércio internacional em seu próprio benefício; por outro, o fracasso do sistema de solução de controvérsias para resolver conflito. ${ }^{44} \mathrm{No}$ caso bananas, evidenciou-se a força do poder político e econômico dos EUA e da UE, que intimidaram e pressionaram a comunidade internacional, a fim de obterem uma decisão que lhes favorecesse. Dessa forma, os interesses das verdadeiras partes do litígio nações da América Latina, da África, do Caribe e do Pacífico - tornaram-se secundários e não apareceram na decisão final do painel da OMC. ${ }^{45}$

A despeito do estabelecimento de mais políticas de implementação no âmbito da $\mathrm{OMC}$, as nações menos desenvolvidas ainda enfrentam dificuldades, quando não falham por completo, em forçar as nações mais desenvolvidas a agirem em conformidade com as regras do comércio internacional. ${ }^{46}$ No entanto, a possibilidade de descumprimento por parte dos países em desenvolvimento surge, muitas vezes, como uma reação ao descumprimento dos países desenvolvidos. Sem o bom exemplo dos países desenvolvidos, os países em desenvolvimento ficam, naturalmente, menos relutantes em descumprir. O descumprimento dos países desenvolvidos estabelece um precedente muito ruim que incentiva o descumprimento dos países em desenvolvimento. ${ }^{47}$

44 IERLEY, Douglas. Defining the factors that influence developing country compliance with and participation in the WTO dispute settlement system: another look at the dispute over bananas. Law and Policy in International Business, v. 33, p. 615652, 2002.

45 KHANSARI, AzarM. Searching for the perfect solution: international dispute resolution and the new world trade organization. Hastings International and Comparative Law Review, v. 20, n. 1, p. 183-206, 1996.

46 KHANSARI, AzarM. Searching for the perfect solution: international dispute resolution and the new world trade organization. Hastings International and Comparative Law Review, v. 20, n. 1, p. 183-206, 1996.

47 IERLEY, Douglas. Defining the factors that influence developing country compliance with and participation in the WTO dispute settlement system: another look at the dispute over bananas. Law and Policy in International Business, v. 33, p. 615-652, 2002. 
Outrossim, há críticas técnicas ao sistema jurídico da OMC, cada vez mais sobrecarregado com questões com as quais ele não é capaz de lidar e que são desinteressantes aos países em desenvolvimento, a exemplo de propriedade intelectual, investimentos, entre outras. Ademais, o processo é muitas vezes visto como demorado e complicado, sendo necessárias reformas para acelerá-lo. E, ainda, suas decisões são consideradas demasiado legalistas para as necessidades reais das pessoas do mundo em desenvolvimento. Basta questionar, quem está se beneficiando com o sistema? ${ }^{48}$

Em certa medida, sem dúvida, a estrutura da OMC encoraja o cumprimento de suas decisões, por exemplo, por meio do mecanismo da retaliação cruzada. ${ }^{49} \mathrm{O}$ cumprimento das decisões do OSC é considerado um importante, talvez o mais importante, dado na avaliação da eficácia do ESC. ${ }^{50}$ Entretanto, a prática de retaliações comerciais autorizadas por mecanismos jurisdicionais, como instrumento de política comercial internacional é foco de críticas à efetividade e ao modo de funcionamento do OSC..$^{51}$

A imposição de sanções, geralmente, fere os interesses comerciais de ambas as partes, por consequência, a capacidade desse mecanismo de induzir o cumprimento está longe de ser certa..$^{52} \mathrm{~A}$ retaliação nunca foi aplicada sob as regras do GATT e, no âmbito da OMC, em apenas quatro contenciosos: Comunidade Europeia regime de importação, venda e distribuição de bananas; Comunidade Europeia Hormônios; Estados Unidos Tratamento tributário para "venda de corporações estrangeiras"; Estados Unidos Lei de 2000, sobre dumping e compensação de

48 IERLEY, Douglas. Defining the factors that influence developing country compliance with and participation in the WTO dispute settlement system: another look at the dispute over bananas. Law and Policy in International Business, v. 33, p. 615652, 2002.

49 HORLICK, Gary. WTO dispute settlement and the Dole commission. Journal of World Trade, v. 29, n. 6, p. 45-48, 1995.

50 VAZQUEZ, Carlos M.; IACKSON, John H. Some reflections on compliance with WTO dispute settlement decisions. Law and Policy in International Business, v. 33, n. 4, p. 555568. 2002.

51 VARELLA, M. D. Efetividade do Órgão de Solução de Controvérsias da Organização Mundial do Comércio: uma análise sobre os seus doze primeiros anos de existência e das propostas para seu aperfeiçoamento. Revista Brasileira de Política Internacional, v. 52, n. 2, p. 05-21, 2009.

52 MCGIVERN, Brendan P. Seeking compliance with WTO rulings: theory, practice and alternatives. International Lawyer $(A B A)$, v. 36, n. 1, p. 141-158, 2002. subsídio. A retaliação no caso Hormônios não mudou a política comercial europeia. E, mesmo nos outros três casos, conquanto seja indiscutível que a retaliação teve algum efeito sobre a resolução desses conflitos, é difícil identificá-la como o fator principal. ${ }^{53}$

Especificamente, é questionável se a retaliação cruzada seria um mecanismo eficaz para garantir o cumprimento nos casos em que o demandado é um país grande e rico e o demandante é um país pequeno e pobre, cujo total de importações corresponda a uma parte insignificante do comércio internacional, destarte, uma retaliação cruzada pode representar nada mais do que "a picada de um mosquito em um elefante", em outras palavras, não é suficientemente eficaz no sentido de encorajar o país violador a adaptar suas medidas em conformidade com as regras internacionais. ${ }^{54}$ Por exemplo, na visão do Departamento de Comércio dos EUA (USTR), se os norte-americanos perdem um painel, podem cumprir as regras de resolução de disputas da OMC, aceitando a retaliação. Sem dúvida, se a OMC considerou que houve violação, há uma contínua obrigação, todavia, com a retaliação, também há uma mitigação, é claro. A título de comparação, um relatório do General Accounting Office (GAO) afirma que, com as exceções importantes da UE, do Japão e do Canadá, nenhum membro do antigo GATT tinha força econômica para retaliar unilateralmente os EUA. Isso explica, do ponto de vista do GAO, por que, com frequência, os países simplesmente aceitavam o descumprimento norte-americano, em vez de retaliá-lo. ${ }^{55}$

De sua banda, muitos países em desenvolvimento não têm sequer a opção de escolherem o descumprimento das recomendações do OSC, pois suas fracas economias não suportariam retaliar as economias dos países desenvolvidos. O exercício do mecanismo da retaliação pelos países em desenvolvimento, economicamente frágeis, como meio principal de se determinar a conformidade dos países desenvolvidos, não é uma opção prática. O custo econômico da retirada de concessões comerciais, dada a relevância das importações e o potencial aumento

53 DAVEY, William J. Compliance problems in WTO dispute settlement. Cornell International Law Journal, v. 42, n. 1, p. 119-128, 2009.

54 DILLON JUNIOR, Thomas J. The World Trade Organization: a new legal order for world trade? Michigan Journal of International Law, v. 16, n. 2, p. 349-402, 1995.

55 HORLICK, Gary. Dispute resolution mechanism: will the United States play by the rules? Journal of World Trade, v. 29, n. 2, p. 163-172, 1995. 
dos custos, tornam inevitáveis os danos à economia dos países em desenvolvimento que tomam medidas de retaliação. Além disso, há dificuldades quanto à escolha dos produtos e ao nível de retaliação. ${ }^{56} \mathrm{Em}$ que pese seja eficaz quando usada por um membro importante da OMC, a retaliação não é um remédio adequado para os países pequenos, e, certamente, por isso, nunca a utilizaram, mesmo quando autorizados pela OMC. ${ }^{57}$

Portanto, a verdadeira questão para o mundo em desenvolvimento, incluindo as economias em transição, é saber o que mais interessa. Considerar expedientes gerados pelos acordos celebrados no âmbito da OMC, a exemplo da retaliação cruzada, como benéficos a esses países é algo controverso. ${ }^{58}$

Ademais, o direito à retaliação cruzada concedido a um país em desenvolvimento pelo êxito em uma demanda sob os auspícios da OMC, a exemplo do que se deu com o Equador no caso Bananas, é uma vitória jurídica que se transforma em um problema político para os países em desenvolvimento, qual seja, o risco dos países desenvolvidos responderem à retaliação cruzada retirando o Sistema Geral de Preferências (SGP). ${ }^{59} \mathrm{O}$ medo de contramedidas não autorizadas ou maquiadas, materializadas na suspensão do SGP, é um dos principais motivos da não utilização de todas as medidas possíveis e autorizadas pelo ESC. ${ }^{60}$

De acordo com os artigos 22.1 - 22.2 do ESC, a compensação - embora também não produza diretamente o cumprimento - é uma alternativa à retaliação, no prazo de vinte dias após expirado o

56 IERLEY, Douglas. Defining the factors that influence developing country compliance with and participation in the WTO dispute settlement system: another look at the dispute over bananas. Law and Policy in International Business, v. 33, p. 615652, 2002.

57 DAVEY, William J. Compliance problems in WTO dispute settlement. Cornell International Law Journal, v. 42, n. 1, p. 119-128, 2009.

58 DILLON JUNIOR, Thomas J. The World Trade Organization: a new legal order for world trade? Michigan Journal of International Law, v. 16, n. 2, p. 349-402, 1995.

59 IERLEY, Douglas. Defining the factors that influence developing country compliance with and participation in the WTO dispute settlement system: another look at the dispute over bananas. Law and Policy in International Business, v. 33, p. 615652, 2002.

60 VARELLA, M. D. Efetividade do Órgão de Solução de Controvérsias da Organização Mundial do Comércio: uma análise sobre os seus doze primeiros anos de existência e das propostas para seu aperfeiçoamento. Revista Brasileira de Política Internacional, v. 52, n. 2, p. 05-21, 2009. período de tempo razoável. Destacam-se os seguintes contenciosos notificados de solução mutuamente aceitável: Japão impostos sobre bebidas alcoólicas, 1998 (o Japão compensou comercialmente o Canadá); Turquia Restrições sobre produtos têxteis e roupas importadas, 2001 (a Turquia compensou comercialmente a Índia); Acordo sob o artigo 21.3 (b) do ESC, Estados Unidos medidas de salvaguarda definitivas sobre as importações de tubulação de carbono soldado de alta qualidade da Coreia, 2002 (os Estados Unidos compensaram comercialmente a Coreia); Estados Unidos - Seção 110 (5) da Lei de Direitos Autorais norte-americana, 2003 (os Estados Unidos ofereceram compensação monetária pelos três anos de não implementação). ${ }^{61}$

Em que pesem esses problemas, é inegável que o regime de comércio internacional da OMC deu um passo decisivo em direção ao legalismo, com destaque para o importante papel desempenhado pelos mecanismos de resolução de litígios, portanto uma adequada assistência jurídica em disputas comerciais tornou-se essencial. Ser capaz de resolver questões que incidem sobre os seus direitos é a única maneira do estado desempenhar um papel e beneficiar-se do complexo regime de comércio internacional. ${ }^{62}$ Não há dúvida de que é necessário capacitar os representantes dos países em desenvolvimento e estimulá-los a participarem ainda mais ativamente desse sistema como a única forma de aumentarem suas experiências e ganharem as disputas. Há países que sequer possuem um ministério dedicado aos assuntos do comércio internacional. Sem saber como a OMC funciona, como os painéis realizam audiências e tomam decisões, é impossível tirar proveito do seu sistema de solução de controvérsias, nem mesmo compreender os benefícios do ESC. Ademais seria importante para alavancar os países em desenvolvimento para um novo ciclo de reforma do ESC. A falta de capacidade técnica está diretamente relacionada à incapacidade de identificar violações comerciais e iniciar casos, afetando posições de negociação em disputas. A mera ameaça de utilizar o sistema já aumenta o poder de barganha desses países. ${ }^{63}$

61 DAVEY, William J. Compliance problems in WTO dispute settlement. Cornell International Law Journal, v. 42, n. 1, p. 119-128, 2009.

62 MCBRIDE, Thaddeus. Rejuvenating the WTO: Why the U.S. must assist developing countries in trade disputes. International Legal Perspectives, v. 11, n. 1, p. 6-102, 1999.

63 IERLEY, Douglas. Defining the factors that influence developing country compliance with and participation in the 
O direito da OMC também pode ter efeitos sem uma decisão formal ou mesmo sem que um caso seja levado ao OSC. A ameaça de recurso ao sistema pode assegurar o cumprimento antes de surgir efetivamente um litígio. De fato, a conformidade com a legislação da OMC será mais pronunciada nos casos em que uma decisão não formal é emitida, isto é, o cumprimento da legislação do GATT / OMC é menos provável em casos que envolvem uma sentença. ${ }^{64} \mathrm{Na}$ conclusão da Rodada Uruguai, muitos funcionários estavam otimistas de que a simples ameaça de retaliação automática serviria como uma ferramenta poderosa para forçar as partes recalcitrantes a cumprirem com suas obrigações. No entanto, houve disputas em que a ameaça de utilização da retaliação ou o seu efetivo uso não foram suficientes, em que pese o pequeno número de $\operatorname{casos}^{65} \mathrm{O}$ uso pelos governos das reclamações legais como tática de negociação, sem a intenção de realmente litigar, é, ademais, uma das razões por que o novo procedimento no âmbito da OMC resultou em um menor número de painéis. ${ }^{66} \mathrm{Nessa}$ perspectiva, as críticas às deficiências de conformidade seriam insensatas, pois a suspensão de concessões raramente ocorre, já que são raros os casos de incumprimento após o curso completo do litígio e, mesmo nesses casos, o contencioso favorece os reclamantes durante as negociações comerciais. ${ }^{67}$

Não obstante a importância de uma representação jurídica capacitada, permanece difícil para os países em desenvolvimento arcar com essa assistência. Destarte, uma substancial assistência jurídica deve lhes ser fornecida, caso contrário, as nações desenvolvidas permanecerão sendo as principais beneficiárias do comércio mundial ${ }^{68}$. E, por isso, esse grupo de elite é

WTO dispute settlement system: another look at the dispute over bananas. Law and Policy in International Business, v. 33, p. 615652, 2002.

64 PRINCEN, Sebastiaan. EC compliance with WTO law: the interplay of law and politics. European Journal of International Law, v. 15, n. 3, p. 555-574, 2004.

65 MCGIVERN, Brendan P. Seeking compliance with WTO rulings: theory, practice and alternatives. International Lanyer $(A B A)$, v. 36, n. 1, p. 141-158, 2002.

66 BRIMEYER, Benjamin L. Bananas, beef, and compliance in the world trade organization: the inability of the WTO dispute settlement process to achieve compliance from superpower nations. Minnesota Journal of Global Trade, v. 10, p. 133-168, 2001.

67 COLARES, Juscelino F. Thelimits of WTO adjudication: is compliance the problem? Journal of International Economic Law, v. 14, n. 2, p. 403-436, 2011.

68 Será interessante observar ao longo do tempo se os dados empíricos confirmam a suspeita de que esse comportamento o que mais tem a perder. Se não agir rapidamente para ajudar o mundo em desenvolvimento, eles só terão a si mesmos para culpar por suas perdas.$^{69}$ Por essas razões, a resolução de litígios internacionais tem se revelado como o resultado mais de manobras políticas do que de uma verdadeira preocupação em melhorar as condições do comércio internacional. ${ }^{70}$ Diante disso, podem ser endereçadas críticas à $\mathrm{OMC}$ e aos países desenvolvidos por seus parcos esforços para atender as necessidades de assistência técnica dos países em desenvolvimento, a começar pela ausência da questão nos próprios acordos da OMC. ${ }^{71}$ Dentro das obrigações claras que o Acordo da OMC cria para estados, a parte pertinente aos países em desenvolvimento deve ser revitalizada. ${ }^{72}$

Intimamente ligada à capacidade técnica está a questão dos recursos financeiros, ou seja, fundos para iniciar investigações sobre violações comerciais. Muitas vezes, é o setor privado desses países que ajuda a cobrir os custos associados a ações judiciais da OMC. O custo é o fator mais importante, representa a maior dificuldade para a participação no sistema de solução de controvérsias e é responsável por muitos países em desenvolvimento somente atuarem no processo de disputa quando forçados.?

tornou-se discriminatório, ficando os países ricos — aqueles mais capazes de arcar com o custo interno ou externo de se defenderem em litígios no âmbito da OMC — em uma melhor posição do que os países pobres HORLICK, Gary; COLEMAN, Judith. The compliance problems of the WTO. Arizona Journal of International and Comparative Law, v. 24, n. 1, p. 141-148, 2007.

69 MCBRIDE, Thaddeus. Rejuvenating the WTO: Why the U.S. must assist developing countries in trade disputes. International Legal Perspectives, v. 11, n. 1, p. 6-102, 1999.

70 KHANSARI, AzarM. Searching for the perfect solution: international dispute resolution and the new world trade organization. Hastings International and Comparative Law Review, v. 20, n. 1, p. 183-206, 1996.

71 IERLEY, Douglas. Defining the factors that influence developing country compliance with and participation in the WTO dispute settlement system: another look at the dispute over bananas. Law and Policy in International Business, v. 33, p. 615652, 2002.

72 MCBRIDE, Thaddeus. Rejuvenating the WTO: Why the U.S. must assist developing countries in trade disputes. International Legal Perspectives, v. 11, n. 1, p. 6-102, 1999.

73 IERLEY, Douglas. Defining the factors that influence developing country compliance with and participation in the WTO dispute settlement system: another look at the dispute over bananas. Law and Policy in International Business, v. 33, p. 615652, 2002. 
Por outro lado, em que pese os países apresentarem capacidades e recursos díspares, o que implica o ESC ser muito menos eficaz para os países em desenvolvimento do que para os países desenvolvidos, a alegação da sua ilegitimidade por conta dessa disparidade de poder negligencia o fato de que, na sua ausência, essa desigualdade seria ainda maior. A falha do ESC não reside na criação de um sistema pautado na igualdade de tratamento dos membros - a propósito, uma importante medida da legitimidade de um sistema jurídico - ao contrário, reside em não ir além e não buscar reduzir a desigualdade de fato reinante no plano internacional. Nações poderosas terão mais poder de violar suas obrigações internacionais com impunidade, enquanto exigem das demais o cumprimento delas. Sistemas jurídicos procuram diminuir tais disparidades de poder ou, pelo menos, minimizar sua importância na distribuição e execução de direitos e deveres, e, mesmo em sistemas domésticos, as disparidades nunca são totalmente neutralizadas. ${ }^{74}$

\section{Formas de descumprimento das regras e das decisões da OMC}

Todos os dias, os governos de todo o mundo agem em conformidade com a OMC e, antes dela, provavelmente até com mais frequência, agiam de acordo com o GATT. No entanto, nas ocasiões raras em que governos nacionais decidem, ao contrário, não cooperar, a OMC tem se mostrado um instrumento fraco. Essa não-conformidade tende a assumir, pelo menos, quatro formas: (i) descumprimento prévio; (ii) descumprimento temporário; (iii) morosidade; e (iv) descumprimento, aberto e disfarçado. ${ }^{75}$

A julgar a partir da amostra oferecida pelos casos levados ao mecanismo de solução de controvérsias da OMC, praticamente todos os principais membros adotaram medidas inconsistentes com as regras da organização, considerando que, na pior das hipóteses, seriam condenados por uma decisão definitiva do órgão de apelação, em um litígio que duraria de três a quatro anos, antes de terem de cumprir o que previamente acordaram. Isso tanto foi feito pelos maiores como

74 VAZQUEZ, Carlos M.; ذACKSON, John H. Some reflections on compliance with WTO dispute settlement decisions. Law and Policy in International Business, v. 33, n. 4, p. 555568. 2002.

75 HORLICK, Gary; COLEMAN, Judith. The compliance problems of the WTO. Arizona Journal of International and Comparative Law, v. 24, n. 1, p. 141-148, 2007. pelos menores atores. Com efeito, a Carta da OMC foi reescrita diante da não aplicação das obrigações do órgão por um período de três a quatro anos. O exemplo mais óbvio é o caso "zerar", envolvendo a Índia contra a Comunidade Europeia, decidido em favor da Índia pelo órgão de apelação em $2001 .^{76}$

Embora os mecanismos de solução de controvérsias da OMC não tenham sido concebidos para incentivar violações, o sistema existente acomoda, de facto, pelo menos, o descumprimento temporário. $\mathrm{O}$ atual modelo do mecanismo de solução de controvérsias da OMC, operando temporariamente como um sistema de "violação e compensação", cumpre um papel crucial como válvula de segurança sistêmica para raros cenários em que é impossível os membros da OMC cumprirem as recomendações e decisões do OSC dentro do "prazo razoável de tempo", conforme previsto no artigo 21.3 do ESC. Mesmo ao término desse período marcado por circunstâncias excepcionais, o cumprimento não deve se dar a qualquer custo e o país membro pode "comprar" um tempo adicional. Essa regra, todavia, certamente não tem impedido alguns membros da OMC de apresentarem dezenas de relatórios contendo poucas novidades sobre o progresso da implementação doméstica, a exemplo do $107^{\circ}$ relatório apresentado pelo EUA, em 14 de outubro de 2011, sobre a disputa EUA - Seção 211 Lei de Recursos dos Ônibus, de 1998, em que, de maneira similar aos relatórios anteriores, os EUA simplesmente afirmam que continuam trabalhando na busca de uma solução para a questão.

Os estudiosos do direito internacional devem abandonar a ilusão de um mundo regido por leis obrigatórias proibitivas de barreiras comerciais. A existência de barreiras comerciais revela exceções de conteúdo e atenuações de procedimentos das leis que as proíbem. No mundo real há circunstâncias em que um cumprimento integral não é sequer desejado. ${ }^{78}$

Mesmo admitindo, caridosamente, que todos os membros da OMC ajam de boa-fé no cumprimento de suas obrigações e que, portanto, eles só descobrem que

76 HORLICK, Gary; COLEMAN, Judith. The compliance problems of the WTO. Arizona Journal of International and Comparative Law, v. 24, n. 1, p. 141. 2007.

77 ZIMMERMAN, Claus D. Toleration of temporary noncompliance: the systemic safety valve of WTO dispute settlement revisited. Trade, Law and Development, v. 3, n. 2, p. 382-406, 2011.

78 TRACHTMAN, Joel P. Bananas, direct effect and compliance. European Journal of International Law, v. 10, n. 4, p. 655-678, 1999. 
estão em violação depois de uma decisão do órgão de apelação, há inúmeros casos em que o processo posterior a essa decisão estende-se por anos. Mais uma vez, isso não envolve poucos países membros. É óbvio que vários governos decidiram burlar o sistema e estender o descumprimento por tanto tempo quanto possível. E isso sem considerar os numerosos atrasos nos processos judiciais antes das decisões do órgão de apelação é assustador ouvir advogados dos países membros afirmarem, claramente, que estão procrastinando o processo o máximo que podem..$^{7}$ De fato, empresas têm identificado a não conformidade e os atrasos como razões para não usar o sistema de solução de controvérsias da OMC, o que levanta sérias preocupações futuras. ${ }^{80}$

Há, ainda, um número crescente de decisões em que os membros, abertamente, escolheram correr o risco de serem retaliados ao invés de cumpri-las, por exemplo, no caso Comunidade Europeia - Hormônios, de 1998, em que nem mesmo a retaliação levou à conformidade, tampouco compensou (e nem poderia) os exportadores prejudicados pelas medidas europeias consideradas incompatíveis com as regras da OMC. Nenhum outro descumprimento poderia ser assim tão aberto. ${ }^{81}$

A seu turno, a título de exemplo de descumprimento disfarçado, o site da OMC relaciona como um sucesso o caso EUA chumbo e bismuto, posto que, em síntese, o órgão de apelação decidiu e o país demandado cumpriu. Todavia, não registra em nenhum lugar o pagamento de milhões de dólares à companhia envolvida. ${ }^{82}$ Em outro

79 HORLICK, Gary; COLEMAN, Judith. The compliance problems of the WTO.Arizona Journal of International and Comparative Law, v. 24, n. 1, p. 141-148, 2007.

80 DAVEY, William J. Compliance problems in WTO dispute settlement. Cornell International Law Journal, v. 42, n. 1, p. 119-128, 2009.

81 Todavia, não se deve olvidar que, conquanto a responsabilidade de um membro em relação às obrigações da OMC pareça mais limitada do que a de um estado sob o direito internacional geral, indiscutivelmente, a conformidade às regras e decisões da OMC configura uma obrigação de direito internacional VAZQUEZ, Carlos M.; JACKSON, John H. Some reflections on compliance with WTO dispute settlement decisions. Law and Policy in International Business, v. 33, n. 4, p. 555568. 2002. Com base na linguagem do ESC, na prática do GATT e nos trabalhos preparatórios das negociações da Rodada Uruguai, é possível dizer que a recomendação de um relatório de um painel constitui uma obrigação jurídica internacional JACKSON, John H. The WTO dispute settlement understanding: misunderstandings on the nature of legal obligation. The American Journal of International Law, v. 91, n. 1, p. 60-64, 1997.

82 HORLICK, Gary; COLEMAN, Judith. The compliance exemplo, a disputa entre Canadá e Brasil, sobre os subsídios dos jatos, revela potenciais problemas com os cálculos das contramedidas, porque a intenção declarada de tais medidas não era punir ou compensar, mas induzir o cumprimento. Nesse papel, entretanto, essas medidas preventivas não foram bem-sucedidas. Esse caso também pode forçar a OMC a encarar a espinhosa questão de saber se o ESC foi concebido para fornecer um sistema verdadeiramente vinculativo, posto que, no final do litígio, restou um grave problema, a tentativa das partes evitarem o cumprimento das decisões do OSC pela "reestruturação" de seus programas de subsídio e a continuação da concessão dos subsídios no âmbito dos programas "novos", sob a alegação de que são compatíveis. ${ }^{83} \mathrm{~A}$ avaliação da eficácia do ESC deve levar em conta a indução ao cumprimento das decisões dos painéis e do órgão de apelação, responsável pela clareza das obrigações dos membros, bem como pela redução dos conflitos internacionais, em última instância. ${ }^{84}$

\section{Análise de dados e estatísticas pertinentes ao cumprimento das regras e das decisões da OMC}

Uma pesquisa ${ }^{85}$ realizada em 2007, sobre as respostas dos países membros às decisões da $\mathrm{OMC}$, aponta que, das 98 decisões finais, proferidas desde 1996, o painel ou o órgão de apelação entendeu que houve violações às regras da $\mathrm{OMC}$ em 85 casos $(85,8 \%)$. Isso quer dizer que não foram encontradas violações em 13 casos. Dos 85 casos de violações, o prazo para o cumprimento ainda não havia se exaurido em 6 deles, e o estado de conformidade de 2 não era claro, deixando 77 casos para a continuação da análise. Dos 77 casos, 53 (68,8\%) terminaram em aparente cumprimento, o que inclui o cumprimento após ameaças de retaliação. Em 19 casos (24,6\%), o país transgressor fez gestos de cumprimento: cumprimento parcial (revisão de algumas, mas não de

problems of the WTO.Arizona Journal of International and Comparative Law, v. 24, n. 1, p. 141-148, 2007.

83 SULLIVAN, Helena D. Regional Jet Trade Wars: Politics and Compliance in WTO Dispute Resolution. Minnesota Journal of Global Trade, v. 12, p. 71-108, 2003.

84 VAZQUEZ, Carlos M.; JACKSON, John H. Some reflections on compliance with WTO dispute settlement decisions. Law and Policy in International Business, v. 33, n. 4, p. 555568. 2002.

85 Para uma descrição mais detalhada dos casos e membros envolvidos, consultar: HORLICK, Gary; COLEMAN, Judith. The compliance problems of the WTO. Arizona Journal of International and Comparative Law, v. 24, n. 1, p. 141-148, 2007. 
todas as medidas) em 8 casos; cumprimento discutível (em que o país demandado alega ter cumprido, mas o demandante contesta o cumprimento) em 6 casos; acordos tíbios em 5 casos (dos quais 4 estão relacionados à pendência entre EUA e Canadá sobre as madeiras coníferas. Finalmente, 6 dos casos $(6,1 \%)$ resultaram em descumprimento descarado, tolerado, a contragosto, em todos eles, exceto no litígio Comunidade Europeia - Hormônios. ${ }^{86}$

Em outro trabalho sobre os mesmos doze primeiros anos de existência da OMC, chega-se ao índice de cumprimento de $83 \%$ dos contenciosos. Todavia, os $17 \%$ restantes são interpretados de maneira diferente, como contenciosos anteriores à criação da OMC, sendo o novo sistema utilizado para tentar reverter situações já consolidadas nos estados. A título de exemplo, os contenciosos sobre o regime de importação de bananas, pertinente a dezenas de países membros e polêmico desde os anos 1970; e sobre os hormônios na carne bovina norte-americana, cuja implementação da decisão da OMC nos estados-membros da União Europeia tornou-se politicamente inoportuna devido às crises sanitárias. ${ }^{87}$

O índice de cumprimento no âmbito da OMC é muito bom para um sistema internacional de solução de controvérsias entre estados ${ }^{88}$. Os bons números são devidos, principalmente, à boa-fé e ao desejo dos membros de verem o sistema de solução de controvérsias funcionar de forma eficaz. Os usuários mais ativos do sistema são os atores que se repetem tanto como demandantes quanto como demandados. Portanto, é do interesse deles que o sistema funcione eficazmente e, na maioria dos casos, ele realmente funciona. ${ }^{89} \mathrm{Em}$ termos gerais, o nível de cumprimento das decisões

86 HORLICK, Gary; COLEMAN, Judith. The compliance problems of the WTO. Arizona Journal of International and Comparative Law, v. 24, n. 1, p. 141-148, 2007.

87 VARELLA, M. D. Efetividade do Órgão de Solução de Controvérsias da Organização Mundial do Comércio: uma análise sobre os seus doze primeiros anos de existência e das propostas para seu aperfeiçoamento. Revista Brasileira de Política Internacional, v. 52, n. 2, p. 05-21, 2009.

88 A título de comparação, nos contenciosos da Corte Internacional de Justiça (CIJ), o percentual de cumprimento das decisões é de 68\% GINSBURG, Tom; MCADAMS, Richard H. Adjudicating in anarchy: an expressive theory of international dispute resolution. William and Mary Law Review, v. 45, n. 4, p. 1229-1340, 2004.

89 DAVEY, William J. Compliance problems in WTO dispute settlement. Cornell International Law Journal, v. 42, n. 1, p. 119-128, 2009. da OMC tem sido muito bom. A maioria dos países, na maioria dos casos, implementou a maior parte dos relatórios do painel e do órgão de apelação, devido ao interesse dos membros em promover a integridade de um sistema baseado em regras, mesmo que isso signifique, de vez em quando, aceitar e implementar uma decisão desagradável. ${ }^{90}$

Uma taxa de 6,1\% de não conformidade não parece mesmo nada ruim. Porém, a maior parte é cumulativa, ou seja, a maioria dos casos não desaparece, o que significa um crescente descumprimento. ${ }^{91} \mathrm{~A}$ título de comparação, no âmbito do GATT ${ }^{92}$, o sistema de solução de controvérsias não funcionou em 12\% dos 207 casos registrados, o que foi suficiente para abalar a credibilidade do Acordo e pavimentar as contundentes mudanças produzidas na Rodada Uruguai. ${ }^{93}$ Nesse contexto, os $25 \%$ de cumprimento não integral somados aos atrasos para se atingir o pleno cumprimento, em outros casos, sugerem a necessidade de reformas na OMC. ${ }^{94}$

Em contraponto, é temerário comparar a eficácia do regime de solução de controvérsias da OMC com o regime anterior - cujas decisões eram proferidas somente pelos painéis de solução de controvérsias porquanto a existência de um sistema de solução de controvérsias mais rigoroso pode incentivar os membros a litigarem, possibilidade que antes não tinham..$^{95}$

De toda maneira, o quadro não é assim tão róseo se olharmos além das estatísticas gerais e considerarmos a "qualidade do cumprimento", isto é, a forma como

90 MCGIVERN, Brendan P. Seeking compliance with WTO rulings: theory, practice and alternatives. International Lawyer $(A B A)$, v. 36, n. 1, p. 141-158, 2002.

91 HORLICK, Gary; COLEMAN, Judith. The compliance problems of the WTO. Arizona Journal of International and Comparative Law, v. 24, n. 1, p. 141-148, 2007.

92 O GATT revelou-se um fórum adequado para as disputas. Prova disso é que, mesmo no âmbito do Acordo EUA - Canadá, dotado de mecanismos formais de resolução de conflitos, ambos os países, em várias ocasiões, preferiram ir ao GATT HORLICK, Gary. WTO dispute settlement and the Dole commission. Journal of World Trade, v. 29, n. 6, p. 45-48, 1995.

93 HUDEC, Robert E. Enforcing international trade law: the evolution of the modern GATT legal system. Salem, N. H.: Butterworth Legal Publishers, 1993.

94 HORLICK, Gary; COLEMAN, Judith. The compliance problems of the WTO. Arizona Journal of International and Comparative Law,v. 24, n. 1, p. 141-148, 2007.

95 VAZQUEZ, Carlos M.; JACKSON, John H. Some reflections on compliance with WTO dispute settlement decisions. Law and Policy in International Business, v. 33, n. 4, p. 555-568. 2002. 
a decisão da OMC foi implementada e se a violação cessou e não foi modificada ou substituída por outra medida, e o "tempo de cumprimento", ou seja, se a ação de execução foi feita dentro de um razoável período de tempo fixado para a execução e se o tempo decorrido no painel e no órgão de apelação respeitou os padrões especificados no ESC..$^{96}$ De modo geral, na primeira década de resolução de litígios, no âmbito da OMC, o cumprimento das decisões foi tempestivo, respeitando-se o tempo razoável para a implementação definida, entretanto, muitas vezes, o processo levou tanto tempo que a implementação não foi muito significativa em termos práticos ${ }^{97}$. Em $75 \%$ dos casos de defesa comercial, o resultado foi a modificação da medida contestada, todavia depois de um longo decurso temporal. Os países que menos cumpriram as decisões em tempo hábil foram a UE, o Canadá, o Japão, a Austrália e, principalmente, os EUA, a uma taxa de $50 \%$, enquanto os países em desenvolvimento atingiram um índice de mais de $80 \%{ }^{98}$

\section{Propostas e perspectivas de aprimoramento do cumprimento das decisões da OMC}

Diante dos registros do sistema de solução de controvérsias da OMC, há um espaço considerável para a melhoria da conformidade existente. ${ }^{99}$ Uma diluição da soberania poderia facilitar o cumprimento. Se as negociações comerciais fossem realizadas em bloco não com base no interesse exclusivo de cada um dos países, senão esse interesse como parte de um grupo as decisões poderiam ser tomadas fora dos domínios da soberania, ou seja, os interesses econômicos colocados à

96 DAVEY, William J. Compliance problems in WTO dispute settlement. Cornell International Law Journal, v. 42, n. 1, p. 119-128, 2009.

97 Ademais, o grau de cumprimento tende a ser melhor em disputas exclusiva ou principalmente comerciais. Problemas de implementação são mais propensos a surgir em casos que também envolvem preocupações não comerciais. Por exemplo, o compromisso da CE de desenvolver a economia das de excolônias europeias na África, no Caribe e no Pacífico (ACP) dificultou o cumprimento integral das decisões da OMC na disputa Bananas MCGIVERN, Brendan P. Seeking compliance with WTO rulings: theory, practice and alternatives. International Lawyer (ABA), v. 36, n. 1, p. 141-158, 2002.

98 DAVEY, William J. Compliance problems in WTO dispute settlement. Cornell International Law Journal, v. 42, n. 1, p. 119-128, 2009 .

99 DAVEY, William J. Compliance problems in WTO dispute settlement. Cornell International Law Journal, v. 42, n. 1, p. 119-128, 2009. frente dos políticos. ${ }^{100}$ Nessa esteira, o poder da própria OMC em demandar, aplicar retaliações multilaterais e fiscalizar os países mais poderosos pode revelar-se mais eficaz. ${ }^{101} E$ certamente verdade que os países em desenvolvimento têm muito menos poder prático para induzir o cumprimento pelos países desenvolvidos do que o contrário. Destarte, para minimizar esse problema, merece séria consideração o estabelecimento de um mecanismo que, por exemplo, permita contramedidas impostas coletivamente. ${ }^{102}$ A possibilidade de medidas defensivas coletivas no contexto da OMC certamente teria um efeito positivo em termos da melhoria do grau e do tempo em que as recomendações e decisões do OSC são implementadas. Além disso, teria um efeito positivo sobre a eliminação de alguns dos incentivos existentes para o não cumprimento, quando o poder de retaliação bilateral de uma parte não é grande. ${ }^{103}$

A noção de "retaliação coletiva" foi levantada pela primeira vez no âmbito do GATT, em meados da década de 1960, quando uma série de países em desenvolvimento argumentou que eles não tinham a capacidade de infligir comercialmente retaliação significativa nas economias dos países desenvolvidos. Portanto, propugnaram a adoção de um novo sistema que permitisse a todos retaliar. Desde então, a ideia da retaliação coletiva levanta uma série de problemas, incluindo o estabelecimento de um sistema para garantir que as sanções aplicadas por todos os membros não excedam a quantidade autorizada. Além disso, desvios de comércio poderiam ocorrer, caso um país, apesar de suas obrigações, se recusasse a retaliar. Direto ao ponto, seria necessária uma alteração do ESC, a fim de se implementar o princípio da retaliação coletiva, e muitos países não concordariam em impor prejuízos

100 IERLEY, Douglas. Defining the factors that influence developing country compliance with and participation in the WTO dispute settlement system: another look at the dispute over bananas. Law and Policy in International Business, v. 33, p. 615652, 2002.

101 DILLON JUNIOR, Thomas J. The World Trade Organization: a new legal order for world trade? Michigan Journal of International Law, v. 16, n. 2, p. 349-402, 1995.

102 VAZQUEZ, Carlos M.; JACKSON, John H. Some reflections on compliance with WTO dispute settlement decisions. Law and Policy in International Business, v. 33, n. 4, p. 555568. 2002.

103 NGANGJOH, Yenkong; RIOS-HERRAN, Roberto. WTO dispute settlement system and the issue of compliance: multilateralizing the enforcement mechanism. Manchester Journal of International Economic Law, v. 1, n. 3, p. 15-30, 2004. 
comerciais às suas economias para resolver uma disputa comercial que não lhes diz respeito. ${ }^{104}$

De modo geral, há várias mudanças práticas que poderiam melhorar a implementação das decisões da OMC, particularmente: (i) substituição da suspensão das concessões por multas; (ii) retroatividade, de modo a encorajar a conformidade dentro do período de tempo razoável; e (iii) mecanismo de ajuste para aumentar o nível de sanções, ao longo do tempo, e evitar que o incumprimento torne-se uma opção viável. ${ }^{105}$

Primeiro, o possível remédio mais óbvio é permitir que uma parte escolha entre a suspensão das concessões e o recebimento de um pagamento monetário periódico. Todavia, como variam as capacidades financeiras dos membros da OMC, o sistema teria de ser ajustado a elas, a fim de ser efetivo tanto aos ricos quanto aos pobres. ${ }^{106}$ Assim, os prejuízos monetários poderiam induzir o cumprimento de forma mais eficaz do que a retaliação comercial, porque os governos teriam que arcar com os custos, em vez de simplesmente transferi-los. ${ }^{107}$

Segundo, a natureza prospectiva dos recursos da OMC não incentiva os países ao pronto cumprimento, ao contrário, encoraja a morosidade. Para minimizar esse problema, qualquer que seja o remédio (retaliação ou pagamento em dinheiro) deve ser calculado a partir de uma data anterior à prevista para implementação (por exemplo, data de aprovação do relatório em causa ou data de constituição do painel ou mesmo antes), assim, afastando a regra atual que possibilita o incumprimento dentro do período de tempo razoável. ${ }^{108}$ Conquanto um processo rápido não possa ser substituído pela aplicação retroativa dos custos aos infratores, esta ajuda a diminuir os danos causados ${ }^{109}$.

104 MCGIVERN, Brendan P. Seeking compliance with WTO rulings: theory, practice and alternatives. International Lawyer $(A B A)$, v. 36, n. 1, p. 141-158, 2002.

105 DAVEY, William J. Compliance problems in WTO dispute settlement. Cornell International Law Journal, v. 42, n. 1, p. 119-128, 2009.

106 DAVEY, William J. Compliance problems in WTO dispute settlement. Cornell International Law Journal, v. 42, n. 1, p. 119-128, 2009

107 CHARNOVITZ, Steve. Rethinking WTO trade sanctions. American Journal of International Law, v. 95, n. 4, p. 792- 832, 2001.

108 DAVEY, William J. Compliance problems in WTO dispute settlement. Cornell International Law Journal, v. 42, n. 1, p. 119-128, 2009 .

109 NGANGJOH, Yenkong; RIOS-HERRAN, Roberto. WTO dispute settlement system and the issue of compliance:
Terceiro, o aumento das sanções ao longo do tempo ajudaria a evitar a percepção de que o pagamento de multas ou danos é simplesmente uma alternativa para o cumprimento. Em certo sentido, a Comunidade Europeia utilizou este conceito no caso do FSC quando impôs um imposto sobre uma longa lista de produtos dos EUA que começou em $5 \%$ e foi aumentado em $1 \%$ ao mês. O reajuste, ainda que mensalmente pequeno, elevou a sanções do FSC para a ordem de 4 bilhões de dólares, criando um incentivo para a mudança de comportamento. Dessa forma, o mesmo conceito poderia ser usado em outros casos para incentivar uma implementação mais rápida. Por outro lado, sanções crescentes ao longo do tempo aumentariam o custo da não conformidade, pois aumentariam a oposição política à implementação. Disputas da OMC são demasiado complexas, de modo que algumas medidas poderiam ser vistas pelos membros como uma forma mais drástica e menos aceitável de mudança, produzindo efeitos contrários aos pretendidos, por exemplo, paralisando o comércio. ${ }^{110}$

Ademais, outros expedientes podem ser alinhavados: (i) arbitragem, diante das dificuldades em se modificar as legislações domésticas, como um meio mais rápido e menos caro de se resolverem os conflitos comerciais internacionais; (ii) permissão de levarem novos casos à OMC apenas aos países que cumpriram integralmente as decisões; (iii) participação de terceiras partes no processo de disputa; (iv) compensação, como o melhor remédio, tanto em si mesmo, quanto como uma possível resposta ao descumprimento por parte dos países desenvolvidos. ${ }^{111}$

A sugestão mais promissora no sentido de facilitar a compensação envolve o estabelecimento de um procedimento para definir o nível de prejuízo, conferindo uma base mais clara para a realização de negociações de compensação, dentro de um tempo determinado. Contudo, a parte transgressora ainda teria que concordar com a compensação. Consequentemente,

multilateralizing the enforcement mechanism. Manchester Journal of International Economic Law, v. 1, n. 3, p. 15-30, 2004.

110 DAVEY, William J. Compliance problems in WTO dispute settlement. Cornell International Law Journal, v. 42, n. 1, p. 119-128, 2009.

111 IERLEY, Douglas. Defining the factors that influence developing country compliance with and participation in the WTO dispute settlement system: another look at the dispute over bananas. Law and Policy in International Business, v. 33, p. 615652, 2002 . 
ideias de compensação "obrigatória” são difíceis de serem implementadas quando o demandado é recalcitrante. ${ }^{112}$ Por outro lado, conquanto a compensação esteja sempre sujeita à concordância da parte infratora, a longo prazo, é vantajosa não só para as partes envolvidas, mas também para todos os membros da OMC. Por isso, por que não tornar a compensação obrigatória e automática como as contramedidas atualmente o são? Sem a necessidade de aprovação de ambas as partes, o OSC poderia, então, aprovar um pedido de compensação - sob a forma de, por exemplo, menor tarifa de importação, maior quota de importação ou acesso ao mercado ${ }^{113}$ - a ser concedido à parte prejudicada. Em caso de litígio sobre o montante da indenização pedida, a arbitragem obrigatória disponível para contramedidas poderia ser utilizada. Além disso, o atual regime de contramedidas, que visa induzir o cumprimento em vez de compensá-lo, poderia ser mantido. ${ }^{114}$ Expandir o uso da compensação seria particularmente desejável para os países em desenvolvimento que se encontram em uma situação em que a implementação não vai ocorrer e a ação de retaliação não é uma possibilidade prática, como é normalmente o caso. Mesmo que isso equivalha aos países ricos "comprarem" suas obrigações, no cômputo geral, seria um requisito útil. ${ }^{115}$ Apesar de amplamente aceita como preferível à retaliação, a compensação tem sido pouco utilizada, e quando utilizada, suas negociações têm sido sem sucesso. Isso porque as partes podem ter ideias muito diferentes sobre o que constitui uma adequada compensação. A solução pode vir de um precedente interessante e construtivo: no caso Lei de Direitos Autorais, EUA e CE realizaram uma arbitragem especial sobre o nível de perdas e danos

112 DAVEY, William J. Compliance problems in WTO dispute settlement. Cornell International Law Journal, v. 42, n. 1, p. 119-128, 2009 .

113 Na compensação sob a forma de maior acesso ao mercado, a parte demandada poderia, por exemplo, concordar em reduzir tarifas de produtos específicos enquanto se aguarda a retirada da medida ilegal. Fa-lo-ia com base no princípio da nação mais favorecida, o que teria a vantagem de expandir o comércio, ao invés de restringi-lo por meio de sanções MCGIVERN, Brendan P. Seeking compliance with WTO rulings: theory, practice and alternatives. International Lawyer $(A B A)$, v. 36, n. 1, p. 141-158, 2002.

114 PAUWELYN, Joost H. Enforcement and countermeasures in the WTO: rules are rules - toward a more collective approach. American Journal of International Law, v. 94, p. 335-347, 2000.

115 DAVEY, William J. Compliance problems in WTO dispute settlement. Cornell International Law Journal, v. 42, n. 1, p. 119-128, 2009. durante o período de implementação, o que facilitou a subsequente negociação de um acordo de compensação temporária entre as partes. ${ }^{116}$

De maneira específica, é possível, ainda, melhorar a capacidade técnica dos países em desenvolvimento, a partir de vários cenários: o estabelecimento de um corpo de voluntários jurídicos internacionais responsáveis pela formação de pessoal; a formação de funcionários de comércio internacional em vinte países por ano, por iniciativa da OMC; o oferecimento de sessões interativas na OMC; o oferecimento de cursos profissionalizantes nas universidades dos países desenvolvidos como parte dos pacotes de ajuda externa; e o estabelecimento pela Secretaria da OMC de centros regionais de suporte contínuo aos países em desenvolvimento. Todavia, entre essas iniciativas, afasta-se a ideia de se utilizarem escritórios particulares de advocacia, em virtude de seus custos, seus interesses em prolongar as disputas para obterem mais honorários e, principalmente, por não capacitarem os funcionários dos países em desenvolvimento, gerando um ciclo de dependência. ${ }^{117}$ Enfim, apoiar centros de assistência jurídica independente é, tanto por razões políticas quanto jurídicas, a única maneira das nações desenvolvidas honrarem suas obrigações autoimpostas de auxílio aos regimes de comércio das nações em desenvolvimento. ${ }^{118}$

Antes e acima de tudo, questões relacionadas ao cumprimento devem ser examinadas numa perspectiva mais ampla, que transcenda a análise estritamente legalista do regime de comércio e considere os interesses multifacetados $\mathrm{e}$ as diferenças entre os membros da OMC, sob pena de uma eventual reforma do sistema torná-lo demasiadamente rígido e inflexível, o que empurraria seus membros mais poderosos para o bilateralismo puro e simples. ${ }^{119}$

116 MCGIVERN, Brendan P. Seeking compliance with WTO rulings: theory, practice and alternatives. International Lawyer $(A B A)$, v. 36, n. 1, p. 141-158, 2002.

117 IERLEY, Douglas. Defining the factors that influence developing country compliance with and participation in the WTO dispute settlement system: another look at the dispute over bananas. Law and Policy in International Business, v. 33, p. 615652, 2002.

118 MCBRIDE, Thaddeus. Rejuvenating the WTO: Why the U.S. must assist developing countries in trade disputes. International Legal Perspectives, v. 11, n. 1, p. 6-102, 1999.

119 COLARES, Juscelino F. Thelimits of WTO adjudication: is compliance the problem? Journal of International Economic Law, v. 14 , n. 2, p. 403-436, 2011. 


\section{Considerações Finais}

A questão do cumprimento efetivo das regras e das decisões do sistema de solução de controvérsias da OMC tem estado, nos últimos anos, no centro das atenções acadêmicas. Por um lado, uma decisão construída juridicamente sob os auspícios de uma instituição internacional é, de forma evidente, mais bem aceita do que outra imposta pela força. Por outro, recorrer ao OSC não implica o cumprimento automático de suas decisões, pois o sistema é carente de mecanismos coercitivos eficazes, ou seja, imunes aos cálculos políticos de seus membros. Diante disso, a questão da conformidade é tão contestada que serve, a um só tempo, tanto aos defensores do regime jurídico da OMC, quanto aos seus detratores. O mesmo raciocínio aplica-se à questão do cumprimento perfeito, tantas vezes tomado como se fosse a quintessência. $\mathrm{O}$ fato de que os membros não tenham buscado sanções mais duras, quando da construção da OMC, não significa anuência a um mero cumprimento arbitrário. Por exemplo, a flexibilidade dos mecanismos de execução do regime jurídico da OMC funciona como uma importante válvula de segurança sistêmica. Portanto, esses problemas somente podem ser adequadamente compreendidos na intersecção entre as esferas jurídica e política.

O escopo principal de se constituir a OMC como um sistema baseado no direito foi o de diminuir o descumprimento das regras e decisões concernentes ao comércio internacional, ou mesmo a morosidade em cumpri-las. Contudo, por vezes, alguns membros utilizam o sistema como forma de adiar o cumprimento de uma decisão do painel ou do órgão de apelação: é a não conformidade materializada em morosidade. Além disso, é preocupante que a comunidade internacional comece a ver a organização como uma ferramenta incapaz de resolver equitativamente as disputas comerciais internacionais. A não ser que todas as partes num litígio sejam bem representadas, é improvável que resultados justos e eficazes sejam atingidos. Instrumentos jurídicos, a exemplo das sanções, são, no mínimo, contrários aos interesses comerciais de seus membros e à própria natureza da instituição internacional. Especificamente para as economias fracas, o recurso à retaliação não constitui sequer uma opção prática.

Diante disso, aventam-se algumas propostas para se aperfeiçoar um complexo sistema de solução de controvérsias. De modo geral, a título de exemplo, ressaltamos: (i) contramedidas comerciais coletivas, (ii) substituição da suspensão das concessões por multas; (iii) retroatividade das decisões; (iv) mecanismo de ajuste do nível de sanções, ao longo do tempo; (v) arbitragem; (vi) impedimento da apresentação de novos casos aos países que não cumpriram integralmente decisões anteriores; (vii) participação de terceiras partes no processo de disputa; (viii) compensação. De maneira específica aos países em desenvolvimento, destacamos, por exemplo: (i) estabelecimento de um corpo de voluntários jurídicos internacionais responsáveis pela formação de pessoal; (ii) formação de funcionários de comércio internacional em vinte países por ano, por iniciativa da OMC; (iii) oferecimento de sessões interativas na OMC; (iv) oferecimento de cursos profissionalizantes nas universidades dos países desenvolvidos como parte dos pacotes de ajuda externa; (v) estabelecimento pela Secretaria da OMC de centros regionais de suporte contínuo aos países em desenvolvimento.

Todavia, é preciso questionar se essas propostas seriam adequadas e se funcionariam em termos práticos, ou seja, se os países ricos aceitariam a substituição de remédios jurídicos que concedem aos países pobres direitos que eles não podem exercitar por outros verdadeiramente efetivos. Se as nações poderosas considerarão seus interesses de longo prazo e abdicarão de suas capacidades de se desviarem de suas obrigações internacionais, será talvez a questão mais importante para se determinar o quanto a OMC pode se aproximar de um sistema verdadeiramente jurídico, caracterizado pelo cumprimento de suas regras e decisões. 


\section{Referências}

BRIMEYER, Benjamin L. Bananas, beef, and compliance in the world trade organization: the inability of the WTO dispute settlement process to achieve compliance from superpower nations. Minnesota Journal of Global Trade, v. 10, p. 133- 168, 2001.

CHARNOVITZ, Steve. Rethinking WTO trade sanctions. American Journal of International Law, v. 95, n. 4, p. 792- 832, 2001.

DAVEY, William J. Compliance problems in WTO dispute settlement. Cornell International Law Journal, v. 42, n. 1, p. 119-128, 2009.

COLARES, Juscelino F. Thelimits of WTO adjudication: is compliance the problem? Journal of International Economic Law, v. 14, n. 2, p. 403-436, 2011.

DILLON JUNIOR, Thomas J. The World Trade Organization: a new legal order for world trade? Michigan Journal of International Law, v. 16, n. 2, p. 349402, 1995.

GINSBURG, Tom; MCADAMS, Richard H. Adjudicating in anarchy: an expressive theory of international dispute resolution. William and Mary Law Review, v. 45, n. 4, p. 1229-1340, 2004.

HORLICK, Gary. Dispute resolution mechanism: will the United States play by the rules? Journal of World Trade, v. 29, n. 2, p. 163-172, 1995.

HORLICK, Gary. WTO dispute settlement and the Dole commission.Journal of World Trade, v. 29, n. 6, p. 45-48, 1995.

HORLICK, Gary; COLEMAN, Judith. The compliance problems of the WTO. Arizona Journal of International and Comparative Law, v. 24, n. 1, p. 141-148, 2007.

HUDEC, Robert E. Broadening the scope of remedies in WTO dispute settlement. In: WEISS, Friedl (Coord.). Improving WTO dispute settlement procedures: issues and lessons from the practice of other international courts and tribunals. London: Cameron May, 2000. p. 345-376.

HUDEC, Robert E. Enforcing international trade law: the evolution of the modern GATT legal system. Salem, N. H.: Butterworth Legal Publishers, 1993.
HUDEC, Robert E. The GATT legal system and world trade diplomacy. 2. ed. New York: Praeger Publishers, 1990.

HUDEC, Robert E. The new WTO dispute settlement procedure: an overview of the first three years. Minnesota Journal of Global Trade, v. 8, n. 1, p. 01-54, 1999.

IERLEY, Douglas. Defining the factors that influence developing country compliance with and participation in the WTO dispute settlement system: another look at the dispute over bananas. Law and Policy in International Business, v. 33, p. 615-652, 2002.

JACKSON, John H. The WTO dispute settlement understanding: misunderstandings on the nature of legal obligation. The American Journal of International Law, v. 91, n. 1, p. 60-64, 1997.

JOERGENS, Konstantin J. True appellate procedure or only a two-stage process? A view of the appellate body under the WTO dispute settlement understanding. Law and Policy in International Business, v. 30, n. 2, p. 193 $-230.1999$.

KHANSARI, AzarM. Searching for the perfect solution: international dispute resolution and the new world trade organization. Hastings International and Comparative Law Review, v. 20, n. 1, p. 183-206, 1996.

MAVROIDIS, Petros C. Remedies in the WTO legal system: between a rock and a hard place. European Journal of International Law, v. 11, n. 4, p. 763-814, 2000.

MCBRIDE, Thaddeus. Rejuvenating the WTO: Why the U.S. must assist developing countries in trade disputes. International Legal Perspectives, v. 11, n. 1, p. 6-102, 1999.

MCGIVERN, Brendan P. Seeking compliance with WTO rulings: theory, practice and alternatives. International Lawyer (ABA), v. 36, n. 1, p. 141-158, 2002.

MORA, Miquel Montana I. A GATT with teeth: law wins over politics in the resolution of international trade disputes. Columbia Journal of Transnational Law, v. 31, n. 1, p. 103- 180, 1993.

NGANGJOH, Yenkong; RIOS-HERRAN, Roberto. WTO dispute settlement system and the issue of compliance: multilateralizing the enforcement 
mechanism. Manchester Journal of International Economic Law, v. 1, n. 3, p. 15-30, 2004.

PAUWELYN, Joost H. Enforcement and countermeasures in the WTO: rules are rules - toward a more collective approach. American Journal of International Law, v. 94, p. 335-347, 2000.

PRINCEN, Sebastiaan. EC compliance with WTO law: the interplay of law and politics. European Journal of International Law, v. 15, n. 3, p. 555-574, 2004.

SCHAEFER, Matthew. National review of WTO dispute settlement reports: in the name of sovereignty or enhanced WTO rule compliance? St. John's Journal of Legal Commentary, v. 11, n. 2, p. 307-350, 1996.

SULLIVAN, Helena D. Regional Jet Trade Wars: Politics and Compliance in WTO Dispute Resolution. Minnesota Journal of Global Trade, v. 12, p. 71-108, 2003.
TRACHTMAN, Joel P. Bananas, direct effect and compliance. European Journal of International Law, v. 10, n. 4, p. 655- 678, 1999.

VARELLA, M. D. Efetividade do Órgão de Solução de Controvérsias da Organização Mundial do Comércio: uma análise sobre os seus doze primeiros anos de existência e das propostas para seu aperfeiçoamento. Revista Brasileira de Politica Internacional, v. 52, n. 2, p. 0521, 2009.

VAZQUEZ, Carlos M.; JACKSON, John H. Some reflections on compliance with WTO dispute settlement decisions. Law and Policy in International Business, v. 33, n. 4, p. 555-568. 2002.

ZIMMERMAN, Claus D. Toleration of temporary non-compliance: the systemic safety valve of WTO dispute settlement revisited. Trade, Law and Development, v. 3, n. 2, p. 382-406, 2011. 


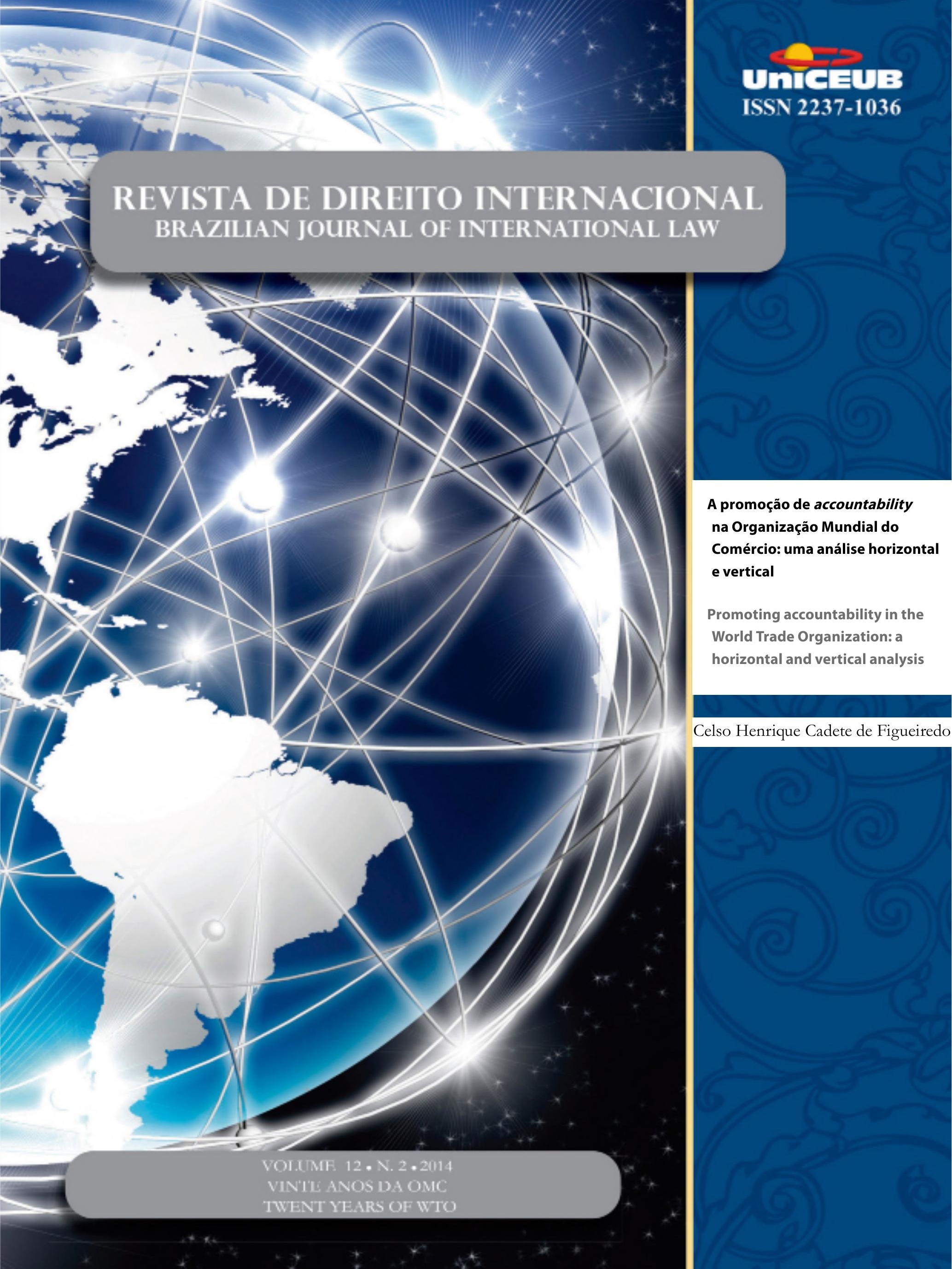




\title{
A promoção de accountability na Organização Mundial do Comércio: uma análise horizontal e vertical*
}

\author{
Promoting accountability in the World Trade \\ Organization: a horizontal and vertical analysis
}

Celso Henrique Cadete de Figueiredo**

\section{Resumo}

O objetivo deste artigo é investigar se, na atual governança global, a Organização Mundial do Comércio (OMC) consegue promover accountability no seu âmbito de atuação. Primeiramente, serão apresentados conceitos e elementos básicos de accountability e expostas as dificuldades de transplantá-los diretamente para o âmbito global, vez que não existe uma sociedade global definida. Posteriormente, sob duas linhas teóricas, a intergovernamental e a supranacional, serão definidos os atores aos quais a OMC pode promover accountability $3 / 4$ respectivamente, os países membros e a sociedade civil organizada. Nessas linhas, será avaliada se no âmbito interno da OMC é possível identificar a presença de três elementos chaves da accountability $3 / 4$ padrões, informações e sanções $3 / 4$ tanto numa perspectiva horizontal de accountability, isto é, entre os próprios países membros, ou sob uma perspectiva vertical, com a OMC e os países membros em uma ponta e a sociedade civil em outra. Tal análise leva a conclusão de que se encontram satisfatoriamente todos os elementos de accountability numa perspectiva horizontal, porém, verticalmente não se pode afirmar que a OMC consiga promover accountability. A pesquisa teve que limitar tanto a abrangência do termo accountability a um contexto que possibilitasse a atual análise, como o escopo de sociedade civil particularmente às ONGs devido à própria prática da $\mathrm{OMC}$ de considerá-las representações sociais mais aptas de participação. Por fim, a originalidade deste trabalho tem o intuito de reforçar o diálogo em volta de sugestões para promover accountability verticalmente, e consequentemente debater a legitimidade da OMC.

* Recebido em 30.10 .2014

Aceito em 10.12.2014

** Mestre em Direito Econômico pela Universidade Federal da Paraíba. Especialista em Direito Tributário pela Universidade Paulista. Graduado em Direito pela Universidade Federal da Paraíba. Graduado em Relações Internacionais pela Universidade Estadual da Paraíba. Atualmente é Consultor Jurídico em Comercio Internacional pela GO Associados. henriquecadete@yahoo.com.br
Palavras-chave: OMC. Governança Global. Accountability. Países membros. ONGs.

\section{Abstract}

The aim of this paper is to investigate whether, in the current global governance, the World Trade Organization (WTO) can promote accountability within its operations. First, it will be presented basic concepts and elements of accountability and then it will be exposed the difficulties of transplanting them directly into the global context, since there is no defined global society. Subsequently under two theoretical lines, intergovernmental and supranational, the actors of which the WTO can promote accountability will be defined respectively the member states and civil society organizations. Under these lines it will be evaluated within WTO whether is possible to identify the presence of three key elements of accountability - standards, information and penalties 
- both a horizontal perspective of accountability, that is, between the member countries themselves, or from the perspective vertical, between WTO member countries on a point and civil society on another. Such analysis leads to the conclusion that all the elements of accountability in a horizontal perspective are satisfactorily meet, however, vertically one cannot say that the WTO promotes accountability. The research had to limit both the term accountability to a context that enabled the current analysis, and the scope of civil society, particularly to NGOs, due to the practice of the WTO to consider them more apt to participate as social representations. Finally, the originality of this work aims to enhance dialogue around suggestions for promoting accountability vertically, and therefore debate the legitimacy of the WTO.

Keywords: WTO. Global Governance. Accountability. Member Countries. NGOs.

\section{Introdução}

A Organização Mundial do Comércio (OMC), criada em 1995, evoluiu e se fortaleceu ao longo desses vinte anos em paralelo às mudanças na forma pela qual a governança global ${ }^{1}$ em si é ordenada. De forma resumida, a atual governança global pode ser identificada como um complexo de regras e instituições

1 Uma das conceituações mais famosas tentando traduzir as mudanças correntes nas interações políticas, sociais e jurídicas no mundo atual foi emitida pela Comissão sobre a Governança Global que tentou reconceitualizar a governança global da seguinte forma: "[...] a soma das várias maneiras em que os indivíduos e instituições, pública e privada, gerenciam seus interesses comuns. É um contínuo processo através dos quais conflitos ou interesses diversos podem ser acomodados e, ações cooperativas podem ser tomadas. Incluem-se instituições formais e regimes autorizados para aplicar a observância, tanto quanto arranjos informais na qual pessoas e instituições também tenham acordado para, ou entendidas como sendo do seu interesse. [...] A nível global, governança vem sendo vista primariamente como relações intergovernamentais, mas deve ser entendida agora como também por envolver organizações não governamentais (ONGs), movimentos de cidadãos, corporações multinacionais e o mercado de capital global [...] não existe um simples modelo ou forma de governança global, nem existe uma singular estrutura ou um conjunto de estruturas. É um processo complexo, dinâmico e amplo de interativas tomadas de decisões que está constantemente evoluindo e respondendo as circunstâncias mutatórias". Em: COMISSÃO SOBRE GOVERNANÇA GLOBAL. Nossa Comunidade Global: o relatório da Comissão sobre Governança Global. Rio de Janeiro: Editora FGV, 1996, p. 4. regulatórias que se aplicam a jurisdições transnacionais e constituições sociais ${ }^{2}$.

De forma mais profunda, a atual governança global, vai além da governança produzida pelas Organizações Internacionais (OIs), uma vez que estas são entendidas em termos de relações entre Estados Nações, envolvendo, portanto outros tipos de atores tais como empresas, associações da sociedade civil, governos locais e agências regulatórias ${ }^{3}$.

A priori desenhada para atuar como uma Organização Internacional Intergovernamental que funcionasse nos moldes de uma arena de produção de regras, na qual os países membros teriam a oportunidade de negociar os acordos comerciais que regeriam as suas relações comerciais e, também como uma agência administrativa para cuidar da adequação e aplicação dessas regras ${ }^{4}$, a OMC testemunhou o crescimento do interesse de atores não estatais e, sua atuação, em virtude, por exemplo, da regulamentação de temas de interesse público, tais como a proteção ao meio ambiente, a saúde humana e animal.

De forma mais clara, é possível encontrar na própria aplicação de alguns padrões regulatórios estabelecidos pela OMC $3 / 4$ tais como padrões fitossanitários contidos no Acordo de Medidas Sanitárias e Fitossanitárias $(\mathrm{SPS})^{5} 3 / 4$ a atuação de algumas organizações híbridas ${ }^{6}$, como por exemplo, a Codex Alimentarius, ou por vezes privadas, tal como a International Standartization

2 SCHOLTE, Jan Aart. Global governance, accountability and civil society. In: SCHOLTE, Jan Aart (Ed.). Building global democracy: civil society and global governance. Cambridge: Cambridge University Press, 2011.

3 SCHOLTE, Jan Aart. Global governance, accountability and civil society. In: SCHOLTE, Jan Aart (Ed.). Building global democracy: civil society and global governance. Cambridge: Cambridge University Press, 2011. p. 10.

4 CHARNOVITZ, Steve. Transparency and participation in the World Trade Organization. GWU Law School Public Law Research Paper, Washington, n. 142, 2004. p. 16-21.

5 No caso do SPS tal relação fica mais palpável, uma vez que no anexo A do acordo está institucionalizada a adoção de padrões providos pelas "três irmãs" (Codex Alimentarius, Escritório Internacional de Epizootias, e Convenção Internacional sobre Proteção Vegetal.

6 Que mantém uma Administração híbrida intergovernamental-privada, sendo entendidos como órgãos que combinam atores privados e governamentais e assumem formas diferentes e cada vez mais relevantes. KINGSBURY, Benedict; KRISCH, Nico; STEWART, Richard B. The emergence of global administrative law. Law and Contemporany Problems. North Carolina, v. 68, n. 3-4, p. 15-62, 2005. 
Organization (ISO) $3 / 4$ que estabelece padrões de qualidades por vezes adotados para solução de disputas concernentes ao Acordo de Barreiras Técnicas (TBT).

Dessa forma, resta cada vez mais claro que o processo de tomada de decisões, administração e aplicação de medidas na OMC acaba envolvendo uma série de atores estatais e mesmo não estatais, dentro de uma variedade de mecanismos, que não se conformam em uma noção tradicional de governança intergovernamental onde apenas os países membros teriam voz?

Por fim, uma vez que as regras estabelecidas no âmbito da OMC perpassam a esfera internacional e atingem a legislação doméstica de vários países, e concorrentemente a vida das pessoas de forma direta, resta difícil negar a amplitude de interesses que possam permear a atuação da OMC.

É, portanto, no ínterim desse amplo debate sobre a governança global que passou-se a discutir a existência ou a necessidade de criação de ferramentas que promovam accountability, como forma de garantia de legitimidade das organizações internacionais, em particular a OMC, para com os seus membros, mas também para aqueles atores não estatais que integram este novo sentido de governança.

As demandas por accountability dentro da OMC partem, principalmente, de dois setores, dos países em desenvolvimento, ávidos por manter uma maior influência na organização com vistas a terem consideradas as suas agendas e, a sociedade civil, em especial as ONGs, que demandam um canal que possa manter os rumos da organização atrelados ao interesse público global ${ }^{8}$.

Uma vez que a accountability é vista por ter um papel central de legitimidade no atual contexto de governança global no qual se encontram presentes uma variedade de atores interessados, que não apenas os países membros, o presente trabalho pautou seu objetivo principal na seguinte questão: a OMC promove accountability?

Porém, responder a pergunta a respeito de a OMC promover accountability, perpassa primeiramente por definir o que se entende por accountability na perspectiva da atual governança global e, em segundo lugar, para

7 MITCHELL, Andrew D.; SHEARGOLD, Elizabeth. Global governance: the World Trade Organization's contribution. Alberta Law Review, Alberta, v. 46, p. 1061-1080, jan. 2010.

8 CHARNOVITZ, Steve. Transparency and participation in the World Trade Organization. GWU Law School Public Law Research Paper, Washington, n. 142, 2004. quem a OMC deve promover accountability e, de que forma se está, ou não, sendo accountable. É com base nesse desafio que estão estabelecidos os objetivos específicos do presente trabalho: primeiramente perseguir um entendimento do termo accountability na perspectiva da governança global, em segundo lugar, investigar de que forma esse parâmetro pode ser aplicado no âmbito da OMC, ou seja, identificando os potenciais account holders, para enfim fazer uma análise e promover uma reflexão acerca da questão da accountability no âmbito da OMC

Nesse sentido, o presente trabalho foi dividido em quatro seções (sendo a primeira seção a própria introdução) a segunda seção será destinada a introduzir o leitor ao conceito de accountability $3 / 4$ este primeiramente designado para explicar uma relação de poder e legitimidade constante no ambiente político doméstico $3 / 4$ que correntemente é bastante invocado em debates sobre governança global, quando se questiona a adoção de processos ou mecanismos de accountability para avaliar a legitimidade da atuação de Organizações Internacionais. Nesta seção o leitor entenderá os três elementos chave do processo de accountability (padrões, informação e sanção), e de que forma a interação destes três elementos formam o processo ou criam mecanismos de accountability.

$\mathrm{Na}$ terceira seção, se debruçará especificamente para quem a OMC deve ser accountable, uma vez que se fazem presentes duas vertentes que defendem posições distintas sobre tal questão, uma abordagem intergovernamentalista, que enxerga apenas os países membros como detentores do direito de manter as regras da OMC accountable, e uma abordagem supranacionalista que enxerga na sociedade civil o destinatário final das normas da OMC e por isso entendem que estes são os detentores do direito de manter a OMC, e em ultima instancia os países membros, accountable.

$\mathrm{Na}$ quarta seção será analisada a existência de elementos chave de accountability dentro de uma perspectiva intergovernamental da OMC, partindose do pressuposto que os detentores de poder e os encarregados de cumprir as normas da OMC são os próprios países membros, em uma relação de poder horizontal. Dessa forma, serão verificados quais institutos e ferramentas institucionais dentro da OMC permitem aos membros estabelecerem padrões, se informarem sobre o cumprimento das normas pelos outros países e, por fim, estabelecerem sanções em caso de descumprimento. 
$\mathrm{Na}$ quinta seção, será analisada a existência de elementos chave de accountability dentro de uma perspectiva supranacional, estabelecendo-se a sociedade civil organizada, em particular ONGs, como destinatária final das normas da OMC e, desta forma, dentro de uma relação vertical. Da mesma forma, serão verificados institutos e ferramentas institucionais dentro da OMC que permitam à sociedade civil utilizar dos três elementos chave da accountability.

Por fim, serão feitas as considerações finais que, ressaltadas as dificuldades metodológicas (como, por exemplo, definir accountability e sociedade civil) e algumas limitações do objeto a ser perseguido, firmarão algumas impressões do presente estudo. Em primeiro lugar reconhecendo que, embora não seja utilizada de forma igual por todos os países membros, a OMC, em uma perspectiva horizontal, fornece de forma satisfatória os três elementos chave na promoção de accountability. Porém, apesar de tentar estreitar os vínculos com a sociedade civil organizada, no que diz respeito a disponibilização de ferramentas de formulação de regras e estabelecimento de sanções, a sociedade civil não encontra espaço para tornar a OMC, e ultimamente, os seus países membros, accountable.

O desenvolvimento do presente trabalho se deu com base em uma considerável pesquisa bibliográfica, que se fundamentou, em referenciais teóricos, tanto da governança global, como de accountability e OMC. Para tanto, além da doutrina sedimentada em obras físicas, como livros e revistas, foram utilizadas bases bibliográficas de portais como o Institute for International Law and Justice, Social Science Research Network, Jstor e Scielo, assim como as publicações e documentos oficiais contidos na base de dados disponibilizados pelo site da OMC.

A relevância da pesquisa reside no desbravamento de um tema atual, qual seja, accountability na governança global. Nesse aspecto, toma-se o enfoque da promoção de accountability em uma das Organizações Internacionais mais importantes do mundo, a OMC. Portanto, através do presente trabalho, espera-se fortalecer a gama de trabalhos sobre governança global e OMC.

\section{As dificuldades da aplicação da accountability na governança global}

Accountability é um termo originalmente designado para descrever uma relação de poder entre dois entes num ambiente doméstico, no qual um detentor de poder deve prestar contas das suas ações aos administrados de forma a evitar abusos de poder ou mesmo déficits de legitimidade.

Embora o termo accountability tenha sido pensado primeiramente ligado à ideia de responsabilidade, posteriormente passou a ser utilizado como um conceito a parte, não obstante a manutenção do grande peso que a responsabilidade tem para a accountability em termos de importância e escopo?.

A partir da década de 80 , com as reformas do New Public Management, o termo accountability passou a ter utilização mais ampla, e o seu estudo passou a ser abordado pelo direito administrativo, relações internacionais e pela administração tanto do setor público, como também em corporações provadas e mesmo no mercado financeiro.

De forma geral accountability pode ser entendido como uma relação específica ou um mecanismo que envolva a obrigação de explicar e justificar uma conduta, ou, na concepção de "a process of being called to account to some authority for one's actions" ${ }^{10}$. Isto implica na relação entre um accountee, ou mesmo agente, de um lado, e, de um fórum, account holder, accountor, ou principal do outro lado, onde o primeiro ator deve justificar e prestar conta das suas condutas ao segundo. Em outras palavras, o accountee é aquele agente ao qual foi transferida a incumbência de agir em nome de outrem, ou subordinado a outrem, ou mesmo em nome de determinada regra estabelecida por terceiros. Estes terceiros seriam os detentores do poder de cobrar que a conduta do accountee esteja de acordo com aquilo que havia sido estabelecido, os detentores de poder seriam, assim, account holders.

9 MULGAN, Richard. One cheer for hierarchly: accountability in disjointed governance. Political Science, v. 55 n. 2, p.6-18, 2003.

10 MULGAN, Richard. One cheer for hierarchly: accountability in disjointed governance. Political Science, v. 55, n. 2, p.6-18, 2003. p. 555. 


\section{TABELA 1 - Atores componentes da relação de accountability}

Ator que detém o poder de agir representando outrem sob o respeito de padrões/normas previamente estabelecidas:

\begin{tabular}{|l|l|}
\hline Accountee & Account bolder/Accountor \\
\hline Detentor de Poder/Delegado & Constituinte/Fórum/ Outorgante \\
\hline Agente & Principal \\
\hline
\end{tabular}

Fonte: Formatação própria

Apesar de diversos autores enfatizarem vários modelos de accountability, tais como, a accountability hierárquica ${ }^{11}$, a accountability legal ${ }^{12}$, a accountability política ${ }^{13}$ e a accountability profissional $^{14} 3 / 4$ sendo cada um desenhado para refletir uma fonte maior e legítima de expectativas para o comportamento administrativo e as diferentes relações dentro de um ambiente democrático $3 / 4$ de forma geral vislumbra-se em todos esses modelos de accountability três elementos chaves que tornam tais mecanismos susceptíveis

11 As relações de accountability hierárquica são aquelas amplamente aceitas pelo público em geral uma vez que se baseia em critérios de supervisão apurada e conjunto com o cumprimento com diretivas. Em: DUBNICK, Melvin J.; ROMZEK, Barbara. Accountability. In: SHAFRITZ, Jay M. (Org.). The International Encyclopedia of Public Policy and Administration. Westview Press, 1998. v. 1.

12 As relações accountability legal emergem de uma arena onde as autoridades têm a expectativa que os agentes oficiais tomem conta das suas atividades de acordo com as obrigações legais, constitucionais, contratuais e mesmo principiais. In: DUBNICK, Melvin J.; ROMZEK, Barbara. Accountability. In: SHAFRITZ, Jay M. (Org.). The International Encyclopedia of Public Policy and Administration. Westview Press, 1998. v. 1.

13 As relações de accountability observa-se na relação entre os oficiais eleitos e os seus constituintes eleitores como uma relação de accountability política que preza pela responsividade, uma vez que não sendo responsivos, os oficiais eleitos se tornam de forma crescente insusceptíveis de serem mantidos ou reeleitos no cargo. Em: DUBNICK, Melvin J.; ROMZEK, Barbara. Accountability. In: SHAFRITZ, Jay M. (Org.). The International Encyclopedia of Public Policy and Administration. Westview Press, 1998. v. 1.

14 As relações de accountability profissional se desenvolvem em ambientes de trabalho, onde se enxerga a responsabilidade de um administrador em manter a sua discrição, conduta e desempenho de uma maneira compatível com as melhores práticas profissionais. Em: DUBNICK, Melvin J.; ROMZEK, Barbara. Accountability. In: SHAFRITZ, Jay M. (Org.). The International Encyclopedia of Public Policy and Administration. Westview Press, 1998. v. 1.
Ator que é representado e tem o direito de manter accountable aquele que o representa através de processos de transparência/consultas, com a possibilidade de aplicação de sanções:

Constituinte/Fórum/ Outorgante

de serem efetivos. São eles: padrões (Standards), informação (information) e, sanção (sanction) ${ }^{15}$.

Essa estrutura tridimensional é bastante reproduzida ${ }^{16}$, de forma que, basicamente, o processo de accountability pressupõe um relacionamento entre os encarregados do poder e aqueles que os mantém accountable, num cenário onde se verifica a existência de um reconhecimento geral de legitimidade dos padrões operacionais para accountability e da autoridade das partes para o relacionamento, ou seja, um exercendo o poder particular e o outro tentando manter o primeiro accountable ${ }^{17}$.

Esses elementos formam um processo constituído de quatro fases, em que a primeira fase cuida de estabelecer quais os padrões os detentores de poder ou accountees devem seguir. O estabelecimento de tais padrões (normas, regras, procedimentos, etc.) pode ser feito de forma conjunta entre os account holders e os detentores de poder, ou somente pelos account holders sendo reconhecidos posteriormente pelos accountees.

$\mathrm{Na}$ segunda fase, os account bolders adquirem informações sobre o cumprimento, ou não, dos padrões estabelecidos. Nesse sentido, os detentores de poder devem explicar que: (a) eles cumpriram com os padrões; (b) que eles não cumpriram, mas por uma justificativa compreendida nos padrões; (c) que eles de

15 RUBENSTEIN, Jennifer. Accountability in an unequal world. Journal of Politics, v. 69, n. 3, p. 616-632, ago. 2007.

16 Tal definição também é utilizada por: STEWART, Richard B. Accountability and the discontents of globalization: US and EU models for regulatory governance. In: University Hauser Colloquium on Globalization and its Discontents, Discussion Draft, Nova Iorque, 2006; e, DYZENHAUS, David. Accountability and the concept of (global) administrative law. IILJ Working Paper, Nova Iorque, n. 7, 2008.

17 GRANT, Ruth W.; KEOHANE, Robert O. Accountability and abuses of power in world politics. American Political Science Review, v. 99, n. 1, fev. 2005. 
forma injustificada não cumpriram, mas existe uma desculpa para tal descumprimento, ou; (d) que eles não cumpriram e falta uma justificação, assim como uma desculpa para tanto ${ }^{18}$.

Destarte, com base na informação adquirida, uma decisão é tomada acerca da implementação, ou não, de uma sanção ao detentor de poder. É este componente repressivo do processo que dá dentes à accountability, e, assim, distingue-o de responsabilidade, que, em resumo é capacidade de resposta e deliberação ${ }^{19}$. Portanto, o propósito da fase de sanção é pressionar o detentor de poder a cumprir com os padrões relevantes e, para a sanção servir a este propósito, o detentor de poder deve estar a par tanto dos padrões como do potencial da sanção que lhe possa atingir.

A quarta e última fase acontece quando os padrões aos quais os accountees (detentores de poder de agir) estão atrelados mudam com o tempo. Claro que tais mudanças podem sofrer resistência por parte dos accountees, fato pelo qual pode incorrer em desfechos distintos dependendo da força de imposição do constituinte/account holder, podendo a regra ser imposta, ser aberto um processo de negociação entre as partes, ou mesmo de substituição dos accountees $^{20}$. De forma esquematizada podemos visualizar o processo de accountability da seguinte forma:
Em resumo, para se haver accountability, é necessária a presença de regras ou padrões a serem seguidos, um canal que permita a informação do cumprimento ou não dos padrões por aqueles que detém o poder ou o dever de administrar e, por último, a possibilidade de punir os account holders quando não verificado o cumprimento dos padrões ou quando detectado abuso de poder por parte deste.

Dentro de um ambiente doméstico, é possível enxergar quais os tipos de accountability que se desenvolvem e quais são os atores dessa relação. Neste sentido, Ruth W. Grant e Robert O. Keohane construíram uma matriz que parece descrever bem quais tipos de accountability se desenvolvem dentro de um ambiente doméstico democrático. Tal relação pode se dividir em dois conceitos básicos: accountability por delegação e accountability por participação. A diferença entre os dois modelos se encontra basicamente na resposta à seguinte pergunta: "Quem é intitulado a manter o poder accountable?". Enquanto no modelo de participação o desempenho dos detentores de poder (agentes) é avaliado por aqueles que são afetados pelas suas ações (principais), no modelo de delegação o desempenho é avaliado por aqueles que confiaram o poder a terceiros (outorgantes) ${ }^{21}$.

\section{FIGURA 1 - Fases do processo de accountability}

\begin{tabular}{|l|l|l|l|l|}
\hline $\begin{array}{l}\text { 1. Os account holders } \\
\text { criam e os detentores de } \\
\text { poder reconhecem os } \\
\text { padrões. }\end{array}$ & $\begin{array}{l}\text { 2. Os account holders recebem } \\
\text { informações sobre } \\
\text { cumprimento detentores de } \\
\text { poder em relação aos padrões. }\end{array}$ & $\begin{array}{l}\text { 3. Os account holders } \\
\text { aplicam, ou não as } \\
\text { sanções nos detentores } \\
\text { de poder. }\end{array}$ \\
\hline
\end{tabular}

Fonte: RUBENSTEIN, Jennifer. Accountability in an unequal world. Journal of Politics, v. 69, n. 3, p. 616-632, ago. 2007. p. 618.

18 RUBENSTEIN, Jennifer. Accountability in an unequal world. Journal of Politics, v. 69, n. 3, p. 616-632, ago. 2007.

19 RUBENSTEIN, Jennifer. Accountability in an unequal world. Journal of Politics, v. 69, n. 3, p. 616-632, ago. 2007. p. 619.

20 RUBENSTEIN, Jennifer. Accountability in an unequal world. Journal of Politics, v. 69, n. 3, p. 616-632, ago. 2007. p. 619620.
Percebe-se, portanto, que em um contexto doméstico democrático, os mecanismos de accountability quaisquer eles que sejam, acabam se tornando ferramentas de controle de poder e, consequentemente, acabam se tornando um filtro de legitimidade, onde aqueles detentores de poder que são accountable são legítimos aos olhos dos account holders.

21 GRANT, Ruth W.; KEOHANE, Robert O. Accountability and abuses of power in world politics. American Political Science Review, v. 99, n. 1, fev. 2005. 
No entanto, quando tais concepções de accountability são transpostas para um cenário de governança global, na tentativa de analisar para quem a OMC deve ser accountable, resta intangível uma resposta exata.

Isto porque ao contrário de antigamente onde o debate se simplificava na lógica do sistema internacional westfaliano, somente os Estados deveriam ter obrigações de accountability uns aos outros de forma horizontal, e verticalmente com relação às Organizações Internacionais, o atual cenário de governança global convergiu para uma multiplicidade de atores não estatais que tanto passaram a ocupar posições reguladoras e administrativas, como também se inserirem na posição de regulado.

Tal debate é, hoje, de fundamental importância na academia, uma vez que a legitimidade de vários atores internacionais, e em particular a OMC, é questionada diante da caracterização de déficits democráticos, uma vez que as elites políticas internacionais, mormente não são formadas de representantes eleitos pelo povo e, segundo, não existe uma identidade coletiva compartilhada e nem uma cultura de suporte comum às instituições internacionais ${ }^{22}$.

E, quando se analisa o destinatário final das normas e tomadas de decisões permeadas no âmbito global, percebe-se que, na maioria das vezes, o indivíduo ou a sociedade como um todo são atingidas, ou seja, sofrem o impacto das normas. É nesse sentido que, nos últimos anos, vem crescendo a demanda tanto por parte da academia, como por parte das organizações da sociedade civil organizada, e mesmo de indivíduos, para o estabelecimento de critérios capazes de amenizar o asseverado déficit de legitimidade oriundo da falta de um adequado ambiente democrático a nível global, em especial, mecanismos de accountability. Legitimidade aqui entendida no sentido normativo de se ter o direito de regular. No contexto internacional, a legitimidade se apresenta conceituada tanto de forma relacional, uma vez que é construída por relações dialéticas entre organizações globais e atores externos, e, por relações contestadas, tendo em vista que diferentes atores irão desacordar sobre o que se requere para que uma organização global seja legítima ${ }^{23}$.

22 NANZ, Patricia; STEFFEK, Jens. Global governance, participation and the public sphere. In: HELD, David; KOENIG-ARCHIBUGI, Matias. (Ed.). Global governance and public accountability. Chichester: Wiley-Blackwell, 2005, p. 190-211.

23 PEDRAZA-FARINA, Laura G. Conceptions of civil society in international law-making and implementation: a
Em termos gerais, é possível vislumbrar dois tipos de accountability na governança global, a accountability interna, que seria aquela que envolve controle por parte dos constituintes que tem o poder de autorização ou de suporte, e a accountability externa, considerada como mecanismos que privilegiam pessoas de fora da entidade atuante as quais as vidas são afetadas ${ }^{24}$.

No entanto, a partir do momento em que se torna impossível caracterizar uma sociedade pública global uníssona, que possa ser constituída como account holder da governança global, cria-se um déficit de legitimidade das tomadas de decisões e regulações adotadas globalmente, uma vez que estas não perpassaram por uma escolha democrática e não encontram mecanismos de accountability para restringir abusos de poder.

Diante da referida ausência de uma demos global, uma figura vem se tornando bastante popular, como forma de se tentar preencher a lacuna de accountability externa gerada pela maioria das organizações multilaterais globais e mesmo atividades de organismos globais híbridos e privados: a denominada sociedade civil.

Inclusive, no âmbito da OMC, esse debate é bastante acirrado, uma vez que restam argumentos sedimentados sobre para quem a OMC deve ser accountable, se para os países membros, ou mesmo para a sociedade civil, conforme será exposto na próxima seção.

\section{Para quem a OMC deve promover accountability?}

Segundo Marc Williams ${ }^{25}$, existem visões conflitantes sobre os atores aos quais a OMC deveria ser accountable ou promover accountability, tendo em vista que, argumentar sob perspectivas na qual a OMC encontra padrões contemporâneos de accountability constitui uma importante característica do relacionamento entre a OMC os seus membros e a sociedade civil. Dois grandes posicionamentos são discerníveis neste debate: um, que pode ser denominado de abordagem intergovernamental e, o outro, denominado abordagem supranacional.

theoretical framework. Michigan Journal of International Law, Michigan, v. 34, n. 3, p. 101-173, 2013.

24 KEOHANE, Robert O. Global governance and democratic accountability. In: HELD, David; KOENIGARCHIBUGI, Mathias (Eds.). Taming globalization: frontiers of governance. Cambridge: Polity Press: 2002.

25 WILLIAMS, Mark. Civil society and the WTO: contesting accountability. In: SCHOLTE, Jan Aart (Ed.). Building global democracy: civil society and global governance. Cambridge: Cambridge University Press, 2011. 
Os analistas, que adotam uma abordagem estritamente intergovernamental da OMC, negam qualquer requerimento para a OMC ser accountable a atores outros que governos nacionais. Eles argumentam que a OMC segue um club model governance, que, basicamente defende que, a legitimidade das organizações da governança global é inteiramente derivada da constituição formal dos seus membros, o que no caso da OMC se limita aos Estados. De acordo com essa perspectiva, os Estados se engajam na governança global sob a base de autoridade legítima delegada a eles pelos seus cidadãos, assim, qualquer verificação de accountability da governança global por parte dos cidadãos reside nos governos nacionais ${ }^{26}$.

A OMC basicamente pode ser enxergada uma agência administrativa na qual os países membros tomam as decisões chaves e inovam legalmente. Ela estaria limitada a supervisionar a ordem legal concebida pelos Estados. Vista por esse angulo, a OMC deve ser accountable aos seus membros, demandando, portanto, uma accountability exercida internamente ${ }^{27}$.

Marc Williams coloca que, de uma perspectiva intergovernamentalista, questões de accountability poderiam surgir de duas formas na OMC: em um primeiro sentido, um déficit de accountability pode emergir se os mecanismos institucionais evitam que algum Estado Membro colha os benefícios integrais da participação. Uma segunda forma de déficit de accountability pode surgir como resultado do impacto das políticas da OMC em populações específicas. (Ex. o caso do acesso a remédios para grandes populações carentes). Ainda assim, os intergovernamentalistas negam que os déficits de accountability devam requerer a intervenção da sociedade civil $^{28}$. A resposta, para eles, seria melhorar os procedimentos de tomadas de decisão dentro da OMC, para permitir maior equidade entre os Estados Membros.

Já os que enxergam a OMC como uma organização supranacional defendem que o impacto da atuação da

26 WILLIAMS, Mark. Civil society and the WTO: contesting accountability. In: SCHOLTE, Jan Aart (Ed.). Building global democracy: civil society and global governance. Cambridge: Cambridge University Press, 2011. p. 110.

27 KEOHANE, Robert O.; NYE, Joseph S. Power and interdependence. Boston: Scott, Foresman and Company, 2001.

28 WILLIAMS, Mark. Civil society and the WTO: contesting accountability. In: SCHOLTE, Jan Aart (Ed.). Building global democracy: civil society and global governance. Cambridge: Cambridge University Press, 2011. p. 111.
OMC na economia global transcende uma abordagem isoladamente intergovernamental e que, portanto, a OMC deveria promover accountability àqueles afetados pelas suas políticas. Eles se baseiam em três principais pontos: primeiro, a Rodada Uruguai, que resultou em uma significante transformação da forma pela qual se gerencia o comércio mundial. Em comparação com o GATT, o regime da OMC é muito mais extensivo (incluindo novos setores e novas questões, como propriedade intelectual e meio ambiente) e mais intrusivo em seu impacto em políticas, práticas e regulações domésticas ${ }^{29}$.

Em segundo lugar, clama-se que a OMC desenvolveu processos de supervisão, que redefiniram a forma pela qual se gerenciam o sistema comercial global, por meio do Mecanismo de Revisão de Política Comercial e o Mecanismo de Solução de Controvérsias que limitam a autoridade dos governos nacionais. Nesse ângulo, tem sido arguido que a OMC é um órgão administrativo supranacional emergente, uma vez que não é simplesmente mais um sistema baseado no consenso, reciprocidade e balanceamento de concessões, mas um sistema de regras que refletem na realidade do Estado administrativo ${ }^{30}$.

Terceiro, a posição supranacional argumenta que o poder normativo da OMC efetivamente subverte a tomada de decisões políticas no âmbito nacional. A OMC incorpora uma série de compromissos específicos, facilita uma abertura do sistema de comércio global e uma desregulação das economias nacionais através da insistência de que os Estados removam as suas barreiras comerciais. Este processo pode, potencialmente, atropelar a legislação doméstica aprovada para preservar, por exemplo, valores culturais, recursos ambientais e padrões trabalhistas ${ }^{31}$.

Por isso, de acordo com uma perspectiva supranacionalista, todos os três processos dão base ao surgimento de déficits de accountability na OMC que

29 WILLIAMS, Mark. Civil society and the WTO: contesting accountability. In: SCHOLTE, Jan Aart (Ed.). Building global democracy: civil society and global governance. Cambridge: Cambridge University Press, 2011. p. 111.

30 WILLIAMS, Mark. Civil society and the WTO: contesting accountability. In: SCHOLTE, Jan Aart (Ed.). Building global democracy: civil society and global governance. Cambridge: Cambridge University Press, 2011. p. 112.

31 WILLIAMS, Mark. Civil society and the WTO: contesting accountability. In: SCHOLTE, Jan Aart (Ed.). Building global democracy: civil society and global governance. Cambridge: Cambridge University Press, 2011. p. 113. 
os Estados sozinhos não podem corrigir. Ademais, essas mudanças no regime de comércio global trazem a OMC em engajamento direto com grupo como consumidores, fazendeiros ou mesmo trabalhadores. Nessas bases, atores da sociedade civil poderiam ter um papel legítimo na governança da OMC e esta deveria ser accountable a sociedade civil da mesma forma que é para os Estados.

Com base no trabalho de Robert Wolfe é possível afirmar que uma visão intergovernamental leva ao exercício de uma accountability interna de dimensão horizontal onde os membros se mantêm accountable uns aos outros em um tipo de processo de revisão por pares. Ele entende que, os membros da OMC são muito mais confortáveis dentro de uma visão horizontal de accountability dada a sua crença profundamente interiorizada que a OMC é uma organização "memberdriven", portanto apenas aos próprios membros podem manter as regras da organização em voga e cobrar uns aos outros ${ }^{32}$.

Ao passo que, numa perspectiva supranacional, a OMC sendo accountable à sociedade civil se dá numa dimensão vertical, na qual as decisões tomadas no interior da organização $3 / 4$ seja pelos países membros, seja pela administração da OMC $3 / 4$ devem ser responsivas ao público afetado pela formulação de regras, padrões e tomadas de decisões estabelecidas em seu âmbito.

Restaria, portanto, saber de que forma se exerceriam as duas perspectivas (horizontal e vertical) de accountability, uma vez que a OMC não detém um órgão administrativo específico para manter os seus agentes accountable aos seus principais.

Tomando emprestado a leitura feita pelos professores Richard Stewart e Michelle Ratton Sanchez ${ }^{33}$, é possível identificar que em uma dimensão interna de atuação da OMC existe a presença de três componentes decisórios, sendo esses elementos básicos de accountability, quais sejam: a produção de regras e padrões originadas particularmente por meio de Conferências Ministeriais; o processo de informação e transparência com vistas a identificar a consonância das políticas e regras

32 WOLFE, Robert. Who is accountable at the World Trade Organization?: anatomy of a trilemma within a dilemma. Kingston, p. 1-19, (no prelo).

33 STEWART, Richard B.; SANCHEZ BADIN, Michelle Ratton. The World Trade Organization and global administrative law. NYU School of Law Public Law Research Paper, Nova Iorque, n. 09-71, p. 1-31, 2009. domésticas com os acordos multilaterais, em especial, por meio do Mecanismo de Revisão de Políticas Comerciais; e a possibilidade de aplicação de sanções em quando verificada a adoção de uma prática ou política comercial destoante com os padrões comerciais do sistema multilateral, através do Órgão de Solução de Controvérsias.

As próximas seções procurarão, assim, investigar se, dentro da dimensão interna de atuação da OMC, pode ser verificado o funcionamento dos três elementos fundamentais para a aplicação de mecanismos de accountability existentes ao nível global $3 / 4$ padrões, informações e sanções $3 / 4$ correlatos ao funcionamento dos componentes legislativo, administrativo e judiciário da OMC sob as dimensões, horizontal e vertical, de accountability e, neste sentido, tentar responder se na OMC se promove accountability.

\section{Elementos de accountability no plano horizontal}

A partir de uma visão intergovernamental da OMC, na qual esta deve ser accountable estritamente aos membros que a compõem e, partindo do artigo IX do Acordo Constitutivo da OMC, que estabelece a igualdade de seus membros, em função da regra de um país, um voto, o controle de abuso de poder dos seus membros tem que ser praticado de uma forma horizontal por meio de um processo de accountability de pares. Resta saber se a OMC fornece, de forma satisfatória, aos seus países membros os três elementos de consecução do processo de accountability, quais sejam: o estabelecimento de padrões, meios de supervisão do cumprimento dos padrões e possibilidade de sanção quando verificado o descumprimento.

\subsection{O componente legislativo como elemento de estabelecimento de padrões}

Conforme estatui o artigo VI:1 do Acordo que Constituiu a $\mathrm{OMC}^{34}$, o principal processo de criação de regras no âmbito desta se dá através das Conferências Ministeriais, que ocorrem, geralmente, a cada dois anos e, ao passo que a OMC se constitui uma organização

34 Acordo Constitutivo da Organização Mundial do Comércio. In: BRASIL. Decreto 1.355 de 30 de dezembro de 1994. Promulgo a Ata Final que Incorpora os Resultados da Rodada Uruguai de Negociações Comerciais Multilaterais do GATT. Presidência da República. Brasília, 30 dez. 1994. 
member-driven, demandam uma votação consensual para que novos acordos sejam estabelecidos.

Segundo Van den Bossche ${ }^{35}$, a Conferência Ministerial é o órgão supremo da OMC. É composto por representantes dos membros em grau de ministério e tem o poder de tomada de decisão sobre todas as matérias, sob qualquer um dos acordos multilaterais. Além desse poder decisório amplo, à Conferência Ministerial é garantida, com base no Acordo Constitutivo da OMC, uma série de outros poderes específicos, como: adotar interpretações dos acordos da OMC (artigo XI:2); derrogar a obrigação de um Membro sobre determinado acordo (artigo XI:3); adotar emendas nos acordos (artigo X); decisões sobre ascensão de novos membros (artigo XII); e indicação do Diretor-Geral e adoção de regulações do seu respectivo estafe (artigos VI:2 e VI:3).

À Conferência Ministerial também cabe fazer o lançamento das rodadas de negociações multilaterais. A última rodada lançada foi na Conferência Ministerial de Doha em 2001 e que, até hoje, resta inconclusa.

Com relação ao processo de tomada de decisões no âmbito da Conferência Ministerial, verifica-se uma dualidade de interesses entre a efetividade de formulação de novas regras e o princípio da transparência disposto como premissa de uma eficaz accountability, tendo em vista a dificuldade de se atingir o consenso dentro uma negociação ${ }^{36}$. Por isso, mecanismos alternativos chegaram a ser desenvolvidos durante a Rodada Uruguai para garantir que os acordos saíssem do papel, tal como a tão criticada sala verde ${ }^{37}$.

Diante das duras críticas que os países, em particular os PEDs, teceram ao processo de tomada de decisões na Rodada Uruguai, que foram repetidos durante

35 BOSSCHE, Van den. The law and policy of the World Trade Organization. Cambridge: Cambridge University Press, 2005. p. 123.

36 STEWART, Richard B.; SANCHEZ BADIN, Michelle Ratton. The World Trade Organization and global administrative law. NYU School of Law Public Law Research Paper, Nova Iorque, n. 09-71, p. 1-31, 2009. p. 4-5.

37 Um dos aspectos mais criticados em relação à transparência das negociações da OMC é a chamada Green Room ou Sala Verde, que significa um sistema de reuniões informais estabelecidas durante a Rodada Uruguai, nomeado a partir da cor da sala do Diretor-Geral, que à época que era verde. Nessas reuniões, um pequeno número de países com interesse no assunto a ser negociado se reuniam para a um acordo prévio sobre determinado tema, para depois apresentar um texto formado, a ser ratificado por consenso por todos os países membros. a Conferência Ministerial de Seattle, o lançamento da Rodada Doha levou à articulação de uma série de princípios e práticas para guiar as negociações, sintonizadas no estabelecimento de um Comitê de Negociações Comerciais, em inglês Trade Negotiations Committee (TNC) ${ }^{38}$.

No entanto, apesar dos esforços em tornar a Rodada Doha mais transparente e inclusiva, a forma de organização dos comitês específicos de negociações sofreu críticas por não ter dado oportunidade a todos os membros de colocarem seus interesses em questão ${ }^{39}$.

Apesar disso, é possível afirmar que, os descontentamentos dos países com relação à transparência interna nos processos de tomadas de decisões no âmbito da Conferência Ministerial vêm sendo amenizado ${ }^{40}$.

Prova disso foi o atingimento de um minipacote de acordos inéditos ${ }^{41}$ alcançados durante a última Conferência Ministerial em Bali, após um processo delongado de consultas e reuniões com todos os membros durante meses, culminando no consenso requerido, que permitiu que a OMC entregasse o primeiro acordo multilateral em quase vinte anos de existência.

Apesar de existirem outros dois meios, nos quais podem ser estabelecidos determinados padrões, como no caso dos conselhos e comitês especializados e, em certos aspectos, por meio de interpretação legal por painéis e Órgão de Apelação do Órgão de Solução de Controvérsias da OMC, o mandato de ambos estão previamente definidos nas regras estabelecidas pelos países membros por meio da Conferência Ministerial.

Dessa forma, por meio da Conferência Ministerial, intenta-se fornecer aos seus membros um canal

38 PEREZ-ESTEVE, Maria. WTO rules and practices for transparency and engagement with civil society organizations. Staff Working Paper ERSD, Genebra, v. 14, p. 1-28, 2012. p. 6.

39 STEWART, Richard B.; SANCHEZ BADIN, Michelle Ratton. The World Trade Organization and global administrative law. NYU School of Law Public Law Research Paper, Nova Iorque, n. 09-71, p. 1-31, 2009. p. 4-5.

40 PEREZ-ESTEVE, Maria. WTO rules and practices for transparency and engagement with civil society organizations. Staff Working Paper ERSD, Genebra, v. 14, p. 1-28, 2012. p. 6.

41 Este minipacote alcançou acordos na área de facilitação de barreiras burocráticas alfandegárias, de agricultura - relativo a programas de segurança alimentar - e de incentivos ao desenvolvimento da capacidade estrutural dos países membros menos desenvolvidos. 
democrático de formulação de regras e criações de padrões necessários para a criação de um ambiente comercial multilateral mais legalizado e igualitário.

\subsection{O Mecanismo de Revisão de Políticas Comerciais como cerne no monitoramento e na difusão de informações através da transparência}

Segundo a descrição oficial do site da OMC o Mecanismo de Revisão de Políticas Comerciais 3/4 Trade Policy Review Mechanism (TPRM) 3/4 foi provisoriamente estabelecido em Dezembro de 1988 ainda durante a Rodada Uruguai e foi agregado permanentemente à OMC através do artigo III do Tratado de Marrakesh, entrando em vigor em 1995 (WTO, 2014b). O anexo 3 do Acordo de Marrakesh estabelece como objetivos do TPRM: "facilitar o bom funcionamento do sistema multilateral de comércio, aumentando a transparência das políticas comerciais dos membros" $"$.

O TPRM fornece uma apreciação e avaliação regular coletiva de todas as práticas e políticas comerciais dos membros, assim como os relativos impactos sobre o funcionamento do sistema multilateral de comércio. O seu propósito é atingir ampla transparência e entendimento das políticas e práticas comerciais dos membros e contribuir, nesse sentido, para aumentar a aderência de todos os membros às regras, disciplinas e compromissos feitos sob os acordos da $\mathrm{OMC}^{43}$.

OTPRM também funciona como um mecanismo de supervisão, com uma implicação de aplicação de regras, baseado em uma pressão político-diplomática por parte dos pares, que expõe a responsabilidade da instituição em organizar e manter a vigilância multilateral contra aqueles que intencionam agir em "free riding", enquanto a função de transparência expressa a responsabilidade dos membros em tornar disponíveis as informações sobre as políticas comerciais nacionais em detrimento do seu autointeresse $e^{44}$.

42 BRASIL. Decreto 1.355 de 30 de dezembro de 1994. Promulgo a Ata Final que Incorpora os Resultados da Rodada Uruguai de Negociações Comerciais Multilaterais do GATT. Presidência da República. Brasília, 30, dez. 1994.

43 BOSSCHE, Van den. The law and policy of the World Trade Organization. Cambridge: Cambridge University Press, 2005. p. 94-95.

44 FROESE, Marc D. Between surveillance and transparency: trade policy review and north american dispute settlement at the WTO. Canadian University College, Lacombe, Paper, p. 1-39, abr.
O processo pode ser resumidamente vislumbrado da seguinte forma: os comentários são conduzidos pelo Órgão de Revisão de Políticas Comerciais 3/4 Trade Policy Review Body (TPRB) 3/4 com base em uma declaração política dos Estados que estão sob análise e, um relatório preparado por economistas da Divisão de Revisão de Política Comercial do Secretariado. O debate do TPRB é estimulado por dois examinadores previamente selecionados para este fim. Ao elaborar o seu relatório, o Secretariado busca a cooperação dos Estados, mas tem a responsabilidade pelos fatos apresentados e pontos de vista ${ }^{45}$.

Ressalte-se que o funcionamento do TPBR é meramente administrativo, tendo o mesmo sido concebido com vistas ao exercício político/diplomático de debates e emissões de relatórios que, embora confrontem as políticas comerciais com a legislação da OMC, não podem ser utilizadas de base para o cumprimento de obrigações específicas no âmbito dos acordos ou para procedimentos de resolução de litígios, ou impor novos compromissos políticos sobre membros $^{46}$.

As prerrogativas funcionais do TPRB, portanto, são impostas no sentido de reforçar e legitimar institucionalmente a própria OMC, pois prezam pela observância de princípios como: o da transparência, quando se dá aos membros a oportunidade de conhecer, tecer comentários e, mesmo, questionar as políticas comerciais que vem adotando os seus pares; o da participação, uma vez que todos os membros tem o direito de participar das reuniões do TPBR e; da revisão, tendo em vista que é dada a oportunidade aos membros de analisar diplomaticamente, em conjunto com o Secretariado da OMC e os demais membros, a melhor forma de promover aderência de sua política comercial doméstica às regras comerciais multilaterais, disciplinas e compromissos assumidos no âmbito dos acordos comerciais multilaterais e, quando aplicável, os acordos comerciais plurilaterais. Destacando-se o fato de que vários membros tem tido de revisar sua legislação nacional, adaptando essas às regras da OMC,

2012. p. 7.

45 WTO. Trade policy reviens: brief introduction. Genebra. Disponível em:

$<$ http://wto.org/english/tratop_e/tpr_e/tp_int_e. $\mathrm{htm}>$. Acesso em: 14 fev. 2014a.

46 WTO. Understanding the WTO. Genebra: WTO Publications, 2008. p. 53-55. 
na oportunidade dos seus respectivos relatórios de revisão de política comercial ${ }^{47}$.

O TPRM, no entanto, não perfaz como o único mecanismo de transparência disponível na OMC. Na realidade, a um nível abaixo do TPRM existe a atuação de três conselhos especializados (alguns divididos em comitês) que auxiliam no trabalho de aprimorar a transparência na OMC e promover a vigilância das regras comerciais. São eles: o Conselho para Comércio de Bens; o Conselho para o Comércio de Serviços e o Conselho de TRIPS. O Conselho de Bens é responsável pelo trabalho dos comitês, grupos de trabalho e working parties dos setores de atividade cobertos pelo acordo do GATT, são eles: Agricultura; Acesso ao mercado de bens; Medidas sanitárias e fitossanitárias; Subsídios e medidas de compensação; Antidumping; Avaliação aduaneira; Regras de origem; Licenças de importação; Investimento; Salvaguardas; Empresas comerciais do Estado (grupo de trabalho); e, Acordo de tecnologia da informação ${ }^{48}$.

Além de auxiliar como um mecanismo de supervisão e transparência, os conselhos e comitês também provêm assistência técnica para países em desenvolvimento implementarem seus compromissos da $\mathrm{OMC}^{49}$.

Por último, em resposta à crise financeira global de 2008, o DG Pascal Lamy estabeleceu uma "Força Tarefa sobre a Crise Financeira" dentro do secretariado da OMC, no qual uma das principais tarefas seria a preparação de relatórios sobre o desenvolvimento de políticas relacionadas com o comércio que fossem associadas à crise financeira. A tal iniciativa foi denominada de trade monitoring $g^{50}$.

$\mathrm{Na}$ atual descrição contida no website da OMC dispõe-se que o trade monitoring correntemente produz

47 CHAISSE, Julien; CHAKRABORTY, Debashis. Implementing WTO rules through negotiations and sanction: the role of Trade Policy Review Mechanism and Dispute Settlement System. University of Pennsylvania Journal of International Economic Law, Philadelphia, v. 28, n. 1, 2007.

48 WTO. Understanding the WTO. Genebra: WTO Publications, 2008. p. 101-104.

49 STEWART, Richard B.; SANCHEZ BADIN, Michelle Ratton. The World Trade Organization and global administrative law. NYU School of Law Public Law Research Paper, Nova Iorque, n. 09-71, p. 1-31, 2009. p. 7-8.

50 PAUWELYN, Joost; BERMAN, Ayelet. Emergency action by the WTO director-general: global administrative law and the WTO's initial response to the 2008-09 financial crisis. International Organizations Law Review. v.6, p.499-512, 2009. dois tipos de relatórios de monitoramento de comércio: 1- amplos relatórios sobre a evolução relacionados com o comércio cobrindo todos os membros da OMC e observadores e; 2- relatórios com a Organização para a Cooperação e Desenvolvimento Econômico (OCDE) e da Conferência das Nações Unidas sobre Comércio e Desenvolvimento (UNCTAD) em medidas de investimento e comércio tomadas pelo G-20 $0^{51}$.

Com relação ao princípio da transparência, resta claro que o Diretor Geral estatuiu nesse ponto que o propósito do monitoramento é aumentar a transparência e a pressão dos pares entre os membros de modo a evitar uma mudança em direção ao protecionismo ${ }^{52}$.

Por fim, sempre é possível aos membros acessarem o site oficial da OMC que, conforme será discutido posteriormente, é um ótimo canal de transparência, uma vez que por meio dele os documentos oficiais da OMC são disponibilizados ao público em geral.

Em suma, pode se afirmar que a OMC mune os seus membros com vários mecanismos de transparência e monitoramento para expor aqueles que por ventura estiverem adotando medidas contrárias aos acordos e padrões internacionais. Promove-se, portanto, um sistema de informação eficaz, capaz de identificar abusos ou transgressões do poder que cada membro detém na formulação e regulação das suas respectivas políticas comerciais, tornando possível que este, por conta própria, reconfigure as medidas adotadas para se conformar com os padrões da OMC, ou seja alvo de alguma contenda no sistema de solução de controvérsias, que é o mecanismo capaz de aplicar sanções aos transgressores.

\section{3 Órgão de Solução de Controvérsias como elemento de aplicação de sanções}

É de amplo conhecimento que as negociações da Rodada Uruguai se converteram no sentido de atribuir uma maior independência e autoridade ao antigo sistema de solução de disputas do GATT. A adoção

51 WTO. Trade monitoring. Genebra. Disponível em: < http:// www.wto.org/english/tratop_e/tpr_e/trade_monitoring_e. htm>. Acesso em: 02 mar. 2014b.

52 PAUWELYN, Joost; BERMAN, Ayelet. Emergency action by the WTO director-general: global administrative law and the WTO's initial response to the 2008-09 financial crisis. International Organizations Law Review. v.6, p.499-512, 2009. p. 509. 
do Entendimento sobre a Solução de Controvérsias ${ }^{53}$ (ESC), com o objetivo de indicar à organização os procedimentos do Órgão de Solução de Controvérsias (OSC), teve a intenção de dar um "adensamento da juridicidade" ao novo sistema de solução de controvérsias da OMC, transformando este em um órgão quasi-judicia ${ }^{4}$.

O objetivo básico do Órgão de Solução de Controvérsias da OMC está definido no art. 3.2 do ESC, onde dita que "O sistema de solução de controvérsia da OMC é elemento essencial para trazer segurança e previsibilidade ao sistema multilateral de comércio" 55 .

Uma das características mais marcantes sistema da OMC é a tomada de uma orientação menos conciliatória se comparado ao GATT, apesar de a oportunidade de conciliação ser possível em qualquer fase do processo.

Ademais, é imperioso destacar a criação de um Órgão de Apelação (OA), mecanismo que, além de reforçar o devido processo legal e estabelecer um duplo grau de jurisdição nos conflitos da OMC, permite a interpretação das normas contidas na OMC, produzindo, em cada caso, decisões que solidificam a instituição e dão diretrizes aos membros em futuros litígios.

Nesse sentido, a atuação do OSC é capaz de apontar abusos praticados pelos países em nível de legislação administrativa doméstica, que estejam em desacordo com os princípios e regras do sistema multilateral. O caso mais famoso a tratar esse tipo de situação foi o WT/DS58, US - Shrimp-turtles ${ }^{56}$, em que Índia, Malásia, Paquistão e a Tailândia alegavam que a legislação americana, em relação à Seção 609, proibia a importação de camarões não certificados pelo Turtle Excluder Devices (TEDs), era uma ilegítima extensão da

53 Abreviação de Entendimento Relativo às Normas e Procedimentos sobre Solução de Controvérsias, ou simplesmente o Entendimento sobre a Solução de Controvérsias (ESC) - em inglês: Understanding on rules and procedures governing the settlement of disputes, ou simplesmente Dispute Settlement Understanding.

54 LAFER, Celso. A OMC e a regulamentação do comércio internacional: uma visão brasileira. Porto Alegre: Livraria do Advogado, 1998.

55 Ver: Anexo 2 - Entendimento Relativo às Normas e Procedimentos sobre Solução de Controvérsias. In: BRASIL. Decreto 1.355 de 30 de dezembro de 1994. Promulgo a Ata Final que Incorpora os Resultados da Rodada Uruguai de Negociações Comerciais Multilaterais do GATT. Presidência da República. Brasília, 30, dez. 1994. p. 447.

56 Abreviação de United States — Import Prohibition of Certain Shrimp and Shrimp Products. jurisdição extraterritorial americana e, dessa forma, violava os artigos I, XI e XIII do GATT 1994.

Nesse caso, a decisão final do OA considerou que, embora a medida protetiva ambiental americana fosse válida segundo as normas da OMC, as regras procedimentais que exigiam o TED, no entanto, negava o direito ao devido processo para os países afetados. Em resposta a tal situação, os EUA se tornaram mais flexíveis, passando a prover uma notificação aos países que não se adequassem as exigências do certificado e convidando tais países a prover informações adicionais.

Nessa perspectiva, na visão de Sanchez e Stewart (2009, p. 3) esse mais legalizado sistema de resolução de disputas atraiu um grande volume de negócios e elevou o sistema de solução de controvérsias da OMC a uma posição de liderança entre os tribunais e cortes internacionais.

Porém, o grande trunfo do sistema de resolução de conflitos da OMC é a sua capacidade de impor sanções (também denominada retaliação), algo que restava irrelevante no sistema do GATT, isto porque na época deste último, para se aplicar uma sanção comercial era necessário um consenso positivo, isto é, de todos os membros do GATT. Já na OMC ocorreu uma mudança na forma de composição e adoção das decisões dos painéis do $\mathrm{OA}$, que passaram a ser por consenso negativo, ou seja, somente a rejeição de todos os membros impede a imposição de sanções - conforme artigo 17.14 do $\mathrm{ESC}^{57}$.

A permissão para aplicar uma sanção comercial só ocorre quando verificado que determinado membro falhou no objetivo de mudar a sua política ou legislação comercial, restando esta em dissonância com os acordos da OMC. Assim, se comprovadamente falhar neste aspecto, o membro que foi reclamado deverá compensar o reclamante, na forma de concessões, como, por exemplo, por meio de isenção tributária. $\mathrm{Na}$ falta de uma compensação, o reclamante pode suspender a concessão relativa ao acordo específico que tenha sido ferido, ou na impossibilidade de tal, pode suspender alguma concessão relativa a outro acordo da OMC, neste caso denominada retaliação cruzada.

57 Ver: Anexo 2 - Entendimento Relativo às Normas e Procedimentos sobre Solução de Controvérsias. In: BRASIL. Decreto 1.355 de 30 de dezembro de 1994. Promulgo a Ata Final que Incorpora os Resultados da Rodada Uruguai de Negociações Comerciais Multilaterais do GATT. Presidência da República. Brasília, 30, dez. 1994. p. 461. 
Um dos casos mais emblemáticos de aplicação de sanções comerciais envolve o Brasil e os EUA, no caso US - Subsidies on Upland Cotton (WT/DS267), no qual o Brasil desafiou a legalidade dos subsídios agrícolas americanos destinados à produção e exportação de algodão. Nesse caso, após longos anos de litígio, no dia 22 de agosto de 2009, o "Brasil recebera o direito de aplicar mais de US\$ 800 milhões em retaliação, dos quais mais de US\$200 milhões poderiam tomar a forma de 'retaliação cruzada" 58 .

A possibilidade de aplicar uma retaliação, nos bens e serviços americanos, parece ter sido a única forma de forçar os mesmos a negociarem medidas que pudessem atender as expectativas brasileiras, em direção ao saneamento dos prejuízos causados com os mencionados subsídios. Neste ponto, é importante ressaltar que a retaliação pode ser mais válida como um poder de barganha em si, que seja capaz de forçar o país infrator a negociar as suas políticas, do que uma medida de cunho indenizatório para amenizar prejuízos.

Em função do exposto, na autoavaliação da OMC, o sistema de solução de controvérsias representa um grande sucesso, quebrando paradigmas existentes na época do GATT, fortalecendo a instituição através da formulação da jurisprudência do OA impedindo o congelamento das regras e atribuindo segurança e previsibilidade ao comércio internacional. No entanto, se admite que a participação dos PEDs não seja satisfatória ${ }^{59}$ devido as custas judiciais, por medo de represália dos países desenvolvidos ou até por incapacidade de impor medidas de compensação à violação sofrida ${ }^{60}$.

Assim, resta patente que com a promoção de um sistema de solução de controvérsias dotado de um processo caracterizado pela juridicidade, que promova a observância de princípios administrativos, como

58 SCHMIDT, Luis Felipe Flores. A construção da retaliação brasileira no caso algodão: os desafios do pioneirismo. In: BENJAMIN, Daniela Arruda (Org.). O sistema de Solução de Controvérsias da OMC: uma perspectiva brasileira. Brasília: FUNAG, 2013. p. 631.

59 Ainda assim, se comparado ao GATT, nos 10 primeiros anos de funcionamento do OSC da OMC, os PEDs incrementaram sua participação no sistema de solução de controvérsias da OMC, uma vez que no antigo sistema, 30\% das demandas foram apresentadas exclusivamente por PEDs e na OMC, esta cifra elevou-se para 39\%.

60 WTO. The future of the WTO: addressing institutional challenges in the new millennium. Genebra: WTO publications, 2004. transparência, participação, decisão motivada e revisão, e, que assegure aos países membros a imposição de retaliações comerciais, uma vez que se comprove uma prática comercial abusiva, pode ser identificado como um eficaz elemento de aplicação de sanções.

Portanto, com base em todo exposto, de forma geral é factível identificar que, numa perspectiva intergovernamental, além de notadamente atuar como um fórum de negociações internacionais e um órgão administrativo internacional, a OMC também carrega todos os elementos que a caracterizam como um mecanismo per si de promoção de accountability interna do regime de comércio internacional - estabelecimento de padrões por meio da Conferencia Ministerial, ampla difusão de informações e aplicação eficaz de sanções pelo OSC - de forma a corroborar a promoção de transparência, participação nos processos de tomadas de decisões e regulação e aplicação de mecanismos de revisão. Nestes termos, pode-se confirmar que o exercício de accountability horizontal da OMC é sólido e, por isso o seu sistema é funcional e legítimo.

\section{Elementos de accountability na OMC sob uma perspectiva vertical}

Conforme foi descrito na sessão anterior, a OMC também pode ser entendida em sua dimensão interna como um mecanismo per si de accountability horizontal. Entretanto, quando adotada uma abordagem supranacionalista da atuação da OMC, elenca-se a sociedade civil como o destinatário final dos processos de estabelecimento de regras e padrões e tomadas de decisões no âmbito do comércio internacional. Em virtude disso, constrói-se um argumento em prol da promoção de canais de participação, transparência e de consultas junto à sociedade civil no intuito de promover a accountability e, dessa forma, superar os déficits de legitimidade apontados na organização.

Nesse quesito, existem questionamentos acerca da possibilidade de criação de um mecanismo de accountability independente na OMC, voltado à sociedade civil, nos moldes estabelecidos pelos bancos de desenvolvimento, em particular o Painel de Inspeção do Banco Mundial, com vistas permitir que os atores não membros tenham a oportunidade de questionar $o$ cumprimento das suas políticas operacionais ${ }^{61}$.

61 LESTER, Simon. Accountability at the WTO. International Economic Law and Policy Blog. 13 dez. 2009. Disponível em: <http://worldtradelaw.typepad.com/ielpblog/2009/12/ 
No entanto, diferentemente do Banco Mundial, que age como um verdadeiro "ator no mercado de capitais" 62 $3 / 4$ semelhante a um banco privado, na medida em que promove um serviço, que diretamente afeta a vida de uma população inteira $3 / 4$ as iniciativas da OMC partem de sua lógica member-driven e, portanto, não são independentes como as do Banco Mundial. Reitera-se, portanto, o caráter de fórum e agência administrativa da OMC em função dos seus membros.

Porém, desde a sua criação, a OMC vem intensificando as formas de aproximação e engajamento junto à sociedade civil, em particular as ONGs que atuam nas áreas contempladas pela OMC e que se baseiam em Genebra.

Assim, uma vez insusceptível a criação de um mecanismo de accountability próprio direcionado a sociedade civil, nas próximas sessões se analisará, de forma análoga a qual foi feita na accountability horizontal, a existência, ou não, dos elementos de accountability, que porventura sejam capazes de atender aos requerimentos da promoção de uma accountability vertical.

\subsection{A participação da sociedade civil na OMC}

Primeiramente, é importante destacar que, tanto na literatura acadêmica relativa à OMC, como nos documentos oficiais da OMC, falar de sociedade civil é quase sinônimo de se falar em $\mathrm{ONGs}^{63}$. Podese depreender que isso ocorre devido ao maior interesse dessa parcela da sociedade civil, que trabalha ativamente em temas relacionados ao comércio internacional, tais como direitos humanos, direitos trabalhistas, meio ambiente e desenvolvimento. E, em função deste interesse mais sobressaliente por parte das ONGs, conforme será exposto abaixo, as disposições oficiais da OMC relativas ao seu engajamento com a sociedade civil, em sua grande maioria fazem referência especificamente às ONGs.

accountability-at-the-wto.html>. Acesso em: 15 jan. 2014.

62 BAIMU, Evarist; PANOU, Aristeidis. Responsibility of International Organizations and the World Bank Inspection Panel: parallel tracks unlikely to converge? In: CISSE, Hassane; BRADLOW, Daniel D.; KINGSBURY, Benedict. The World Bank legal review: international financial institutions and global legal governance. Washington: The World Bank, 2012. v. 3.

63 Ver por exemplo: HALLE, Mark; WOLFE, Robert; BEATON, Christopher. Looking back, looking forward: civil society contributions to WTO accountability. ENTWINED Issue Brief, n. 8, 2011.
A esse respeito, Craig Vangrasstek ${ }^{64}$ exalta o reconhecimento das ONGs como atores nas relações internacionais é anterior à OMC e mesmo ao GATT, tendo-se, como exemplo, o artigo 71 da Carta das Nações Unidas, que autorizou o Conselho Econômico e Social a adotar as diligências necessárias para a consulta com organizações não governamentais que se ocupem de assuntos de sua competência. Mesmo a Carta de Havana, da idealizada International Trade Organization (ITO), similarmente previa consultas com ONGs, de acordo com o artigo 87.2, que estatuía: "The Organization may make suitable arrangements for consultation and co-operation with non-governmental organizations concerned with matters within the scope of this Charter" ${ }^{65}$. Porém, uma vez que a ITO não teve êxito em se estabelecer e, ao seu substituto, o GATT, não foi incluída nenhuma previsão legal de estabelecimento de relações com as organizações da sociedade civil, a estas nunca foi dado acesso direto as atividades daquela.

Todavia, o estabelecimento da OMC tratou de corrigir a ausência de uma previsão legal concernente à relação com a sociedade civil, estabelecendo em seu Acordo Constitutivo no Artigo V:2, que se refere as Relações com Outras Organizações, que "O Conselho Geral poderá tomar as providências necessárias para manter consultas e cooperação com organizações não governamentais dedicadas a assuntos relacionados com os da OMC" ${ }^{\prime 6}$.

No entanto, ao passo que o Artigo V:1 estabelece que "O Conselho Geral tomará as providências necessárias para estabelecer cooperação efetiva com outras organizações intergovernamentais que tenham áreas de

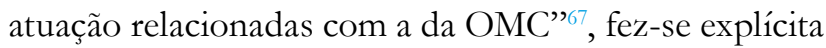

64 VANGRASSTEK, Craig. The history and the future of the World Trade Organization. Genebra: WTO Publications, 2013.

65 UNITED NATIONS CONFERENCE ON TRADE AND EMPLOYMENT. Final Act and Related Documents. Interim Comission for the International Trade Organization: Lake Success, abr. 1948. p. 85.

66 Acordo Constitutivo da Organização Mundial do Comércio. In: BRASIL. Decreto 1.355 de 30 de dezembro de 1994. Promulgo a Ata Final que Incorpora os Resultados da Rodada Uruguai de Negociações Comerciais Multilaterais do GATT. Presidência da República. Brasília, 30, dez. 1994.

67 Acordo Constitutivo da Organização Mundial do Comércio. In: BRASIL. Decreto 1.355 de 30 de dezembro de 1994. Promulgo a Ata Final que Incorpora os Resultados da Rodada Uruguai de Negociações Comerciais Multilaterais do GATT. Presidência da República. Brasília, 30 dez. 1994. 
a opção pela organização de ter como preferência a relação com outras organizações intergovernamentais em detrimento das $\mathrm{ONGs}^{68}$.

Conforme classificação observada pela Professora Michelle Ratton Sanchez Badin ${ }^{69}$, em geral, as formas de participação em fóruns intergovernamentais podem ser classificadas em quatro categorias: (1) informação, (2) consulta, (3) cooperação, e (4) deliberação. No Acordo Constitutivo da OMC, estão expressamente discriminadas as formas de consulta e cooperação com as ONGs. No entanto, ficam ausentes critérios de deliberação, uma vez que os países membros detêm o monopólio deste e, em termos de informação, esta é parte do princípio da transparência, um dos pilares da organização e, portanto destinados a todos de forma erga omnes.

Porém, uma vez que apenas essa passagem legal, contida no Acordo Constitutivo, não promovia um direcionamento explícito sobre quais procedimentos a OMC deveria tomar em relação ao seu engajamento com a sociedade civil $^{70}$, em 1996 foi adotado pelo Conselho Geral as Linhas Gerais para Arranjos sobre Relações com Organizações Não governamentais - em inglês, Guidelines for arrangements on relations with NonGovernmental Organizations (WT/L/162 de 23 de Julho de 1996) - de agora em diante referida apenas como Linhas Gerais de 1996.

Conforme resume Peter Van den Bossche, nas Linhas Gerais de 1996, foi acordado que a interação com as ONGs deveria ser desenvolvida por meio de vários meios como: a organização de simpósios para ONGs em questões específicas relacionadas à $\mathrm{OMC}$; arranjos informais que permitam receber informações das ONGs devendo essas informações serem disponíveis a consultas por delegações interessadas; a continuação da prática passada do secretariado da OMC em responder a requerimentos por informações gerais e briefings sobre a OMC, e; a participação dos presidentes de conselhos

68 VANGRASSTEK, Craig. The history and the future of the World Trade Organization. Genebra: WTO Publications, 2013. p. 181.

69 SANCHEZ BADIN, Michelle Ratton. Breves considerações sobre os mecanismos de participação para ONGs na OMC. Revista Internacional de Direitos Humanos, n. 4, ano 3, p. 102-125, 2006. p. 105.

70 PEREZ-ESTEVE, Maria. WTO rules and practices for transparency and engagement with civil society organizations. Staff Working Paper ERSD, Genebra, v. 14, p. 1-28, 2012. p. 10. e comitês da OMC em discussões e encontros com ONGs em seus próprios estabelecimentos ${ }^{71}$.

Por outro lado, as Linhas Gerais de 1996 também delimitaram o alcance do envolvimento das ONGs. No parágrafo de conclusão, o conselho geral ser refere ao caráter especial da OMC que é legalmente vinculada aos membros por um tratado intergovernamental de direitos e obrigações e como um fórum de negociações e, portanto, existe uma clara visão de que não é possível para as ONGs estarem diretamente envolvidas nos trabalhos da OMC ou suas reuniões, apesar de ser aconselhável a utilização de consultas e outras formas de cooperação com estas ${ }^{72}$.

Em resumo, apesar de estabelecer regras que passaram a conduzir o relacionamento da OMC com as ONGs $3 / 4$ e, em função disso reconhecer o importante papel que as podem ter em tornar o público mais lúcido com relação às práticas observadas na $\mathrm{OMC}^{3} / 4$ as Linhas Gerais de 1996 estabeleceram limites para a referida relação da OMC com as ONGs. Maria Perez-Esteve elenca três limites para a supracitada relação: primeiro, as Linhas Gerais de 1996 explicitamente se referem ao caráter especial da OMC de ser, ao mesmo tempo, um tratado intergovernamental, legalmente vinculante, de direitos e obrigações entre os seus membros, e, um fórum de negociações; em segundo lugar, reconhece a difundida visão entre os membros que não seria possível para as ONGs estarem diretamente envolvidas no trabalho da OMC ou suas reuniões, e; por último, é especificado que uma consulta e uma cooperação próxima com as ONGs também podem ser construtiva no contexto doméstico entre os governos dos países membros e a sociedade civil, uma vez que é neste nível que se encontra a responsabilidade primária de levar em conta os diferentes elementos do interesse público ${ }^{73}$.

É importante ressaltar que os princípios estabelecidos nas Linhas Gerais de 1996 não foram

71 BOSSCHE, Van den. The law and policy of the World Trade Organization. Cambridge: Cambridge University Press, 2005. p. 158.

72 WTO. WT/L/162. Guidelines for arrangements on relations with Non-Governmental Organizations. Genebra, 23 jul. 1996. Disponível em:

<http://www.wto.org/english/forums_e/ngo_e/ guide_e.htm>. Acesso em: 20 fev. 2014.

73 PEREZ-ESTEVE, Maria. WTO rules and practices for transparency and engagement with civil society organizations. Staff Working Paper ERSD, Genebra, v. 14, p. 1-28, 2012. 
alterados e permanecem até hoje em vigor. Assim, para uma participação da sociedade civil para além do que já foi estabelecido, é necessário encontrar alternativas dentro da estrutura organizacional da OMC baseada nos acordos já estabelecidos, ou alcançar a decisão consensual de todos os países membros, para uma regra mais direta de inclusão das ONGs.

\subsection{Estabelecimento de padrões}

Conforme foi visto anteriormente, o estabelecimento de regras na OMC se dá por meio das Conferências Ministeriais, nas quais os países membros detêm a exclusividade de negociar novos acordos comerciais por meio do consenso. A sociedade civil não pode participar diretamente da parte deliberativa das Conferências Ministeriais, mas isso não a impede de tentar exercer algum tipo de influência nas negociações.

A partir do estabelecimento das Linhas Gerais de 1996, toda ONG ou entidade da sociedade civil organizada que demonstrasse estar à frente de alguma questão relacionada à OMC, poderia pedir o credenciamento para integrar uma lista montada previamente a conferência, que era submetida ao Conselho Geral para a aprovação. Após isso, a tendência geral foi de aumento no número de participantes da sociedade civil nas Conferências Ministeriais, embora a localização do encontro também influenciasse nos níveis de participação.

Neste sentido, com exceção da Conferência Ministerial de Doha, que se envolveu uma série de restrições devido ao atentado de 11 de setembro, a organização das Conferencias Ministeriais tem anotado um grande interesse e participação da sociedade civil ${ }^{74}$.

\footnotetext{
74 Na Conferência de Singapura, em 1996, 108 grupos da sociedade civil participaram (cada um sendo permitido até 3 representantes). Esse número subiu para 128 associações na Conferência Ministerial de Genebra 1998, e 737 organizações na Reunião Ministerial de Seattle no final de 1999. O número caiu para 366 para a conferência da (relativamente remota) Doha, que, aliás, foi convocada em meio as reduções de viagens aéreas após 9/11 e envolveu uma série de restrições burocráticas que complicaram a participação da sociedade civil. No encontro em Cancún, registraram-se 902 organizações, e 812 grupos participaram da Conferência Ministerial de Hong Kong em 2005. Em: WILLIAMS, Mark. Civil society and the WTO: contesting accountability. In: SCHOLTE, Jan Aart (Ed.). Building global democracy: civil society and global governance. Cambridge: Cambridge University Press, 2011. p. 105-127.
}

Neste aspecto, conforme expõe Peter Van den Bossche apesar de terem sido convidadas a presenciarem as sessões plenárias da primeira Conferência Ministerial pós-criação da OMC, e terem a oportunidade de participarem de workshops organizados pela OMC que ocorreram paralelamente à conferência, as ONGs não tiveram reconhecido o status de observador e, muito menos, a elas foi permitido fazer qualquer tipo de declaração ${ }^{75}$. Ademais, conforme fora colocado, elas só poderiam atender as sessões plenárias, que representam apenas a parte mais formal da Conferência Ministerial, sendo proibidas de participarem das negociações.

Uma segunda onda de melhorias aconteceu em abril de 2001, quando o secretariado da OMC lançou uma nota de informações aos membros, denominada $W T O$ Secretariat Activities with NGOs, expondo uma nova gama de iniciativas em empreendimentos com ONGs para a preparação da quarta Conferência Ministerial em Doha. Conforme expõe Michelle Ratton Sanchez Badin, dentre as formas de atividades possíveis, destacam-se: “(1) os briefings, em Genebra, pelo Secretariado após as reuniões entre os Membros; (2) as pequenas mesas de debate; (3) a organização de grupos de trabalho; e (4) a possibilidade de aceitação pelo Secretariado de posições por escrito" 7 .

A intenção do novo programa de atividades era facilitar e incentivar discussões substantivas e responsáveis com as ONGs sobre as questões abrangidas pelo mandato da OMC. Nesta perspectiva, desde 2001 a OMC tem facilitado a realização de um simpósio ou de um fórum público anual ${ }^{77}$. Esses eventos geralmente

75 BOSSCHE, Van den. The law and policy of the World Trade Organization. Cambridge: Cambridge University Press, 2005.

76 SANCHEZ BADIN, Michelle Ratton. Breves considerações sobre os mecanismos de participação para ONGs na OMC. Revista Internacional de Direitos Humanos, n. 4, ano 3, p. 102-125, 2006. p. 110.

77 Os Fóruns Públicos da OMC em ordem cronológica decrescente: 2013: 1-3 October "Expanding Trade through Innovation and the Digital Economy"; 2012: 24-26 September "Is Multilateralism in Crisis?"; 2011 "Seeking answers to global trade challenges"; 2010 "The Forces Shaping World Trade"; 2009 "Global Problems, Global Solutions: Towards Better Global Governance"; 2008 "Trading into the Future"; 2007 "How the WTO can help harness globalization?"; 2006 "What WTO for the XXIst Century?". The Public Forum was previously known as the Public Symposium, which was first held in 2001: 2005 "WTO After 10 Years: Global Problems and Multilateral Solutions"; 2004 "Multilateralism at a crossroads"; 2003 "Challenges Ahead on the Road to Cancún"; 2002 "The Doha Development Agenda and beyond"; 2001 "Symposium on 
servem para a exposição dos pontos de vista das ONGs, mas sem a existência de um compromisso que leve a um diálogo significante. Ademais, a participação limitada dos oficiais dos membros da OMC indica que estes eventos não são efetivos no exercício de consultas substantivas $^{78}$.

Um canal adicional de consulta junto à sociedade é provido por meio de reuniões informais entre ONGs e oficiais da OMC. Outrossim, desde 1996 a Divisão de Relações Externas da OMC vem mantendo contato com ONGs e distribuindo briefings regulares a estas. $\mathrm{Na}$ ausência de acesso da sociedade civil às deliberações do Conselho Geral e outros órgãos, os briefings acabam sendo uma importante fonte de informação.

Por último, ocorreram três tentativas de um contato mais sistemático entre o Diretor Geral e membros da sociedade civil, em especial representantes de ONGs. A primeira foi com o Diretor Geral Renato Ruggiero, que introduziu a prática de manter reuniões informais regulares com diferentes representantes de $\mathrm{ONGs}^{79}$. Em 2003, o Diretor Geral Supachai Panitchpadki estabeleceu um Informal NGO Advisory Body e um Informal Business Advisory Body, mas não resta claro se estes mecanismos consultivos tiveram alguma consequência política, sem contar que estes expiraram com o término do mandato de Supachai Panitchpadki, sem terem sido renovados ${ }^{80}$. A terceira tentativa foi estabelecida junto com o Diretor Geral Pascal Lamy, no qual ele comunicou ao estafe da OMC a sua intenção de ampliar as práticas de engajamento e transparência junto as ONGs e a sociedade civil por meio de um relatório perene às $\mathrm{ONG}$ e ao público em geral com a explicação das regras e atividades da $\mathrm{OMC}^{81}$.

Após os programas delineados pelo Diretor Geral, o número de práticas de engajamento da OMC junto à

issues confronting the world trading system".

78 WILLIAMS, Mark. Civil society and the WTO: contesting accountability. In: SCHOLTE, Jan Aart (Ed.). Building global democracy: civil society and global governance. Cambridge: Cambridge University Press, 2011. p. 117.

79 PEREZ-ESTEVE, Maria. WTO rules and practices for transparency and engagement with civil society organizations. Staff Working Paper ERSD, Genebra, v. 14, p. 1-28, 2012. p. 14.

80 BOSSCHE, Van den. The law and policy of the World Trade Organization. Cambridge: Cambridge University Press, 2005.

81 PEREZ-ESTEVE, Maria. WTO rules and practices for transparency and engagement with civil society organizations. Staff Working Paper ERSD, Genebra, v. 14, p. 1-28, 2012. sociedade civil aumentou ${ }^{82}$, no entanto, nenhum modelo desenhado implicou uma inclusão direta da sociedade civil no processo de tomada de decisões e produção de regras. Por outro lado, pode-se inferir que quanto mais envolvimento e contato a sociedade civil passar a ter com a OMC, mais conhecimento esta agregará voltado a pressionar, não só a OMC como organização, mas, em especial, os Estados que a compõem e que procuram estabelecer regras em desacordo com os intuitos das respectivas representações da sociedade civil.

\subsection{Transparência na prática de difusão de informações}

É possível identificar na OMC dois tipos distintos de transparência: a transparência interna e a transparência externa. A interna diz respeito às práticas de transparência dos países membros entre si e, entre os países membros e o corpo administrativo componente da OMC. Já a transparência externa se refere à prática de manter o público em geral informado das atividades e trabalhos da OMC.

A transparência entre os membros sempre foi um requisito básico desde a época do GATT ${ }^{83}$, porém, este requisito foi expandido na OMC, uma vez que todos os acordos da OMC requerem que os governos notifiquem ao Secretariado da OMC, medidas comerciais ao nível nacional, novas ou modificadas, antes de estas serem implementadas:

Conforme já foi visto, a prática central para assegurar a transparência entre os membros da OMC ocorre por meio do exercício de revisão de pares em comitês e órgãos que atuem nessa área. Notadamente, o mecanismo de supervisão regular das políticas comerciais nacionais é o TPRM, que estabelece revisões periódicas de todos os membros.

Outra forma de incrementar a transparência interna se dá, por meio da notificação cruzada, meio pelo qual um membro notifica a OMC de uma medida que não foi notificada por outro membro. Isto é possível sob o Acordo de Medidas de Salvaguarda e Direitos Compensatórios e no Mecanismo de Transparência do Regional Trade Agreement.

82 PEREZ-ESTEVE, Maria. WTO rules and practices for transparency and engagement with civil society organizations. Staff Working Paper ERSD, Genebra, v. 14, p. 1-28, 2012.

83 Contida no artigo $\mathrm{X}$ do GATT sobre Publicação e Administração de Regulações Comerciais. 
Conforme explicita Michelle Ratton Sanchez Badin, o primeiro documento da OMC em que se pode identificar a garantia da transparência externa é o WT/L/160/Rev.1 de 1996, relativa aos procedimentos para circulação e liberalização dos documentos na organização, uma vez que existia diferença com relação ao tempo de liberação de documentos caso a transparência fosse interna ou externa, na qual os documentos da OMC, só poderiam ser liberados ao público seis meses após serem discutidos e negociados entre os Membros nos Conselhos e Comitês ${ }^{84}$. Ainda assim, o referido documento não garantiu uma plena liberação de documentos oficiais da OMC uma vez que este princípio foi, na época, sujeito a exceções importantes, tais como a liberação de Atas de reuniões do Secretariado da OMC só poderem ser liberados após o decurso de oito a nove meses ${ }^{85}$.

No entanto, um fato teve importância marcante no rumo pelo qual a OMC passaria a ter com a sociedade civil, em especial as ONGs: o fiasco da Conferência Ministerial de Seattle. Um ano após a denominada batalha de Seattle ${ }^{86}$, o Conselho Geral manteve intensivas reuniões informais com os países membros com a intenção de debater a sua transparência externa, especificamente a questão da participação da sociedade civil e ONGs no trabalho da OMC, dando início aos trabalhos de revisão da WT/L/160/Rev.1.

84 SANCHEZ BADIN, Michelle Ratton. Breves considerações sobre os mecanismos de participação para ONGs na OMC. Revista Internacional de Direitos Humanos, n. 4, ano 3, p. 102-125, 2006.

85 BOSSCHE, Van den. The law and policy of the World Trade Organization. Cambridge: Cambridge University Press, 2005.

86 A batalha de Seattle foi a denominação dada para a série de manifestações que ocorreram durante a Conferência Ministerial de Seattle, na qual se estima que mais de quarenta mil pessoas, saíram as ruas para manifestar contra a forma pela qual a OMC estava guiando questões de interesse a humanidade, tais como saúde, desenvolvimento e meio ambiente. As manifestações direcionadas contra a OMC foram incrementadas por outras manifestações que ocorriam concomitantemente em Seattle, em especial de trabalhadores grevistas, resultando em um aumento significativo do número de manifestantes. A par disso, a atuação de black blocs e outros grupos radicais transformaram as manifestações em motim O resultado foi a classificação de estado de sítio, que fez com que o Departamento de Polícia e a Guarda Nacional acabassem usando de repreensão excessiva contra manifestantes e mesmo equipes jornalísticas, transformando o que antes eram manifestações em um cenário de guerra. Para um aprendizado mais interativo sobre o tema, ver o filme: BATTLE of Seattle. Direção: Stuart Townsend. Hyde Park International, 2007.
Em 2002 foi, então, aprovada a Decisão $\mathrm{WT} / \mathrm{L} / 452$, que revisou a WT/L/160/Rev.1 e atenuou o descompasso entre os períodos de tempo para a liberação dos documentos, definindo como regra geral que os documentos da OMC seriam automaticamente liberados ao público ${ }^{87}$.

O principal canal de transparência entre a OMC e a sociedade civil vem sendo feito através do website da OMC. O uso deste como ferramenta de transparência remete as linhas gerais de 1996 e, posteriormente, a decisão do Conselho Geral, em 2002, sobre os procedimentos para a circulação e liberação de documentos da OMC, onde foi permitido que mais documentos fossem acessíveis ao público e de forma mais rápida. Desde 1998, o website tem também mantido uma sessão especial para ONGs, o qual contém informações gerais sobre as atividades da OMC, relações com as aquelas, participação da sociedade civil nas Conferências Ministeriais e documentos recebidos de representações da sociedade civil.

$\mathrm{O}$ acesso às notificações, que contém informações sobre as políticas e práticas comerciais dos membros, fornece às empresas do setor privado estabilidade e previsibilidade para conduzir os seus negócios, ao mesmo tempo em que fornece, ao público geral e às ONGs envolvidas em comércio internacional, informações que possam ser usadas para manter os governos accountable por suas ações ${ }^{88}$.

Desta forma, pode-se afirmar que o uso do website da OMC, como forma de incrementar a transparência externa da organização, junto às ONGs, sociedade civil e público em geral, vem sendo bem-sucedido, uma vez que a disseminação de documentos via website na OMC foi uma história de sucesso na qual o volume de documentos e o fácil acesso levaram de 15 a 20 milhões de acessos por mês e downloads de mais de 25 milhões de páginas ${ }^{89}$.

87 SANCHEZ BADIN, Michelle Ratton. Breves considerações sobre os mecanismos de participação para ONGs na OMC. Revista Internacional de Direitos Humanos, n. 4, ano 3, p. 102-125, 2006.

88 PEREZ-ESTEVE, Maria. WTO rules and practices for transparency and engagement with civil society organizations. Staff Working Paper ERSD, Genebra, v. 14, p. 1-28, 2012.

89 SMYTHE, Elizabeth; SMITH, Peter J. Legitimacy, transparency, and information technology: the World Trade Organization in an era of contentious trade politics. In: Global governance: a review of multilateralism and international organizations, v. 12 , n. 1, p. 31-53, jan. 2006. 
Ocorre que, com relação ao TPRM, que é o principal órgão promotor da transparência interna na OMC, nem a sociedade civil organizada, muito menos o público em geral tem acesso as suas reuniões. Da mesma forma ocorre com relação ao trabalho quotidiano dos Conselhos e Comitês da OMC. "Para nenhum dos órgãos envolvidos na aplicação de regras há a previsão de participação de ONGs nos documentos oficiais da OMC"

Na visão da Professora Michelle Sanchez Badin, podem ser levantadas pelo menos três hipóteses para explicar a falta de um debate mais amplo sobre a inclusão da sociedade civil no TPRM e comitês da OMC: "(1) pouca demanda; (2) menor responsividade da OMC quanto a essa forma de regulamentação; e/ ou (3) uma certa conveniência da informalidade para ONGs mais influentes" ".1. Com base em suas pesquisas, a referida autora afirma que todas as três hipóteses podem ser confirmadas.

\subsection{A participação da sociedade civil no processo de enforcement das regras pelo Órgão de Solução de Controvérsias}

A participação da sociedade civil nos processos de resolução de conflitos no âmbito do Órgão de Solução de Controvérsias da OMC foi construída em torno de um grande debate acerca da aceitação, ou não, das submissões provenientes dos denominados amicus curiae, ou em português, "amigo da corte" ${ }^{92}$.

90 SANCHEZ BADIN, Michelle Ratton. Breves considerações sobre os mecanismos de participação para ONGs na OMC. Revista Internacional de Direitos Humanos, n. 4, ano 3, p. 102-125, 2006. p. 111.

91 SANCHEZ BADIN, Michelle Ratton. Breves considerações sobre os mecanismos de participação para ONGs na OMC. Revista Internacional de Direitos Humanos, n. 4, ano 3, p. 102-125, 2006. p. 111-112.

92 "Desde o início do século XX, o instituto jurídico denominado Amicus Curiae ("Amigo da Corte") é adotado na Suprema Corte norte-americana, objetivando proteger direitos coletivos (de grupos identificados) ou de proteger direitos difusos (da sociedade em geral). Sua função é chamar a atenção dos julgadores para alguma matéria que poderia, de outra forma, escapar-lhe ao conhecimento. Um memorial de amicus curiae é produzido, assim, por quem não é parte no processo, com vistas a auxiliar a Corte para que esta possa proferir uma decisão acertada, ou com vistas a sustentar determinada tese jurídica em defesa de interesses públicos e privados de terceiros, que serão indiretamente afetados pelo desfecho da questão". SILVA, Luiz Fernando Martins da. Amicus Curiae: direito e ação afirmativa. Revista Jurídica, Brasília, v. 7, n. 76, p.70-78, 2006. p. 70.
$\mathrm{Na}$ OMC, a primeira vez que se lidou com as submissões de amicus curiae foi no caso US-Gasoline (WT/DS2), no entanto, o painel decidiu seguir os procedimentos do antigo GAT'T, e não considerou os briefs. Foi somente no caso US-Shrimp (WT/DS58), em que Índia; Malásia; Paquistão e Tailândia questionavam a política americana de importação de camarões, que o debate sobre a participação da sociedade civil organizada, através de documentos não solicitados, entrou em pauta no Órgão de Solução de Controvérsias da OMC, muito em função da grande repercussão que este caso teve perante ONGs de cunho ambiental ${ }^{93}$.

Nessa oportunidade, o painel entendeu que embora detivesse a permissibilidade do artigo 13 do ESC para buscar informações, quando necessário, de qualquer fonte relevante, a aceitação de documentação por parte de entidades não integrantes da OMC não haveria de ser permitida, na oportunidade de não solicitação de sua submissão por parte do painel. No entanto, o painel ressaltou que os documentos de amicus curiae que fossem integrados às petições dos membros, passavam a ser parte desta e, portanto, deveriam ser aceitas em sua completude ${ }^{94}$

Apesar de ter concordado com o posicionamento do painel, de que só os países membros poderiam ser partes legítimas na solução de conflitos, o Órgão de Apelação reverteu o entendimento daquele com relação às documentações não solicitadas, oriundas de terceiros não membros da OMC, ampliando o entendimento da palavra buscar, permitindo que em virtude da possibilidade de iniciativa própria do painel em auferir informações adicionais, este poderia também se utilizar, se bem entendesse proveniente, das documentações dos amicus curiae ${ }^{95}$.

93 Foram apresentados documentos por diversas ONGs, como, por exemplo, a WWF, reiterando a ameaça da pesca predatória de camarão às tartarugas marinhas e expondo políticas e leis nacionais, regionais e internacionais relacionada à preservação da espécie. Outras submissões foram feitas pelo Centro de Direito Ambiental Internacional e pelo Centro de Preservação Marinha. Ver: PALMER, Alice. Observando de fora: participação da sociedade civil no Sistema de Solução de Controvérsias da OMC. In: BAPTISTA, Luiz Olavo; CELLI JUNIOR, Umberto; YANOVICH, Alan (Orgs.). 10 anos de OMC: uma análise do Sistema de Solução de Controvérsias e perspectivas. São Paulo: Aduaneiras, 2007. p. 223-258.

94 MAVROIDIS, Petros C. Amicus curiae briefs before the WTO: much ado about nothing. Jean Monnet Working Paper, v. 2, n. 1, p. 1-18, 2002.

95 WTO. WT/DS58/AB/R - United States - Import Probibition of Certain Shrimp and Shrimp Products. Genebra, 12 out. 1998, p. 38. 
No caso US - Carbon Steel (WT/DS138)96, o OA reconheceu que a oportunidade dos amicus curiae de submeterem suas petições e documentos se dava tanto na fase de painel, quanto na fase de apelação, uma vez que a permissividade contida no artigo 13.2 do ESC, se estendia a este último.

Posteriormente, no caso EC - Abestos (WT/ DS135 $)^{97}$, o OA promoveu o desenvolvimento de alguns procedimentos específicos para o recebimento dos documentos submetidos pelos amicus curiae, tomando como base o artigo 16(1) do seu Working Procedures ${ }^{98}$.

Nesse caso, ficou institucionalizada a possibilidade de participação da sociedade civil nos procedimentos de solução de controvérsias da OMC, por meio de um processo burocrático, que acabou por instrumentalizar, mas ao mesmo tempo dificultar, a aceitação de briefs dos amicus curiae ${ }^{99}$. O estabelecimento de procedimentos adicionais por parte do OA causou grande discordância por parte de vários PEDs, tanto que resultou na convocação de uma Reunião Especial do Conselho Geral o (WT/GC/M/60) no dia 22 de novembro de 2000, na qual foi debatida a atitude do OA.

O OA ainda decidiu, no caso WT/DS231 EC Trade Description of Sardines, que aos países membros também era assegurada a possibilidade de submeter documentos na forma de amicus curiae, atendendo a um pedido da delegação ${ }^{100}$.

96 WTO. WT/DS138/AB/R. United States - Imposition of Countervailing Duties on Certain Hot-Rolled Lead and Bismuth Carbon Steel Products Originating in the United Kingdom. Genebra, 10 maio 2000. (Também conhecido como US Bismuth ou US - British Steel).

97 WTO. WT/DS135/AB/R. European Communities - Measures Affecting Asbestos and Products Containing Asbestos. Genebra, 12 mar. 2001.

98 Conjunto de regras que definem a forma de atuação do Órgão de Apelação no Sistema de Solução de Controvérsias.

99 Nesse caso o OA recebeu 17 pedidos de terceiros não partes para a aplicação de suas briefs, no entanto todas elas foram rejeitadas. Seis delas devido ao fato de terem sido consideradas intempestivas, porém o restante dos pedidos foram negados sem um motivo específico, apenas com a declaração do OA que não havia satisfeito todos os requerimentos dos procedimentos adicionais. Ver: PALMER, Alice. Observando de fora: participação da sociedade civil no Sistema de Solução de Controvérsias da OMC. In: BAPTISTA, Luiz Olavo; CELLI JUNIOR, Umberto; YANOVICH, Alan (Orgs.). 10 anos de OMC: uma análise do Sistema de Solução de Controvérsias e perspectivas. São Paulo: Aduaneiras, 2007. p. 223-258.

100 UNCTAD. Curso de solução de disputas em comércio internacional, investimento e propriedade intelectual. Modulo 3.3: apelação. Nova Iorque e Genebra: ONU, 2003.
Até o ano passado, foram feitas um total de 34 submissões em 20 casos na fase de painel, na qual 17 foram aceitas para consideração e, 39 submissões em 15 casos na fase de apelação, na qual foram aceitas 21 para consideração ${ }^{101}$. Porém, após serem aceitas, a forma pela qual são estas são utilizadas continua ambígua, uma vez que nem a sociedade civil nem os próprios membros da OMC são capazes de obter uma visão clara sobre a forma como as submissões amicus podem realmente estar influenciando o resultado de disputas ${ }^{102}$.

Por isso, é arguido que para não ser considerada apenas um aceno simbólico em direção à sociedade civil organizada, o OSC poderia informar que tipo de informação e assistência proveniente da sociedade civil seria do interesse deste ${ }^{103}$.

Outro ponto de destaque, sobre a participação direta de ONGs no sistema de solução de controvérsias, é a demanda por uma abertura das audiências ao público em geral (SANCHEZ BADIN, 2006). A primeira transmissão pública ocorreu nos casos US - Continued Suspension of Obligations e Canada - Continnued Suspension of Obligation, vez que ambas as partes envolvidas nos dois casos requisitaram tal abertura. O painel decidiu a favor da transmissão com base no artigo 12.1 do ESC que prevê que os painéis seguirão os working procedures do Apêndice 3, em conjunto com o artigo 18.2 do ESC que estatui que nenhuma das disposições do ESC deverá impedir uma das partes em controvérsia de publicar suas próprias posições.

O Órgão de Apelação, da mesma forma permitiu a abertura das suas audiências referentes aos casos citados, não obstante o artigo 17.10 do ESC, que exprime que os procedimentos do OA devem ser confidenciais. Particularmente, diante do artigo 18.2 do ESC, o OA relativizou a confidencialidade em função da vontade dos membros ${ }^{104}$. No entanto, apesar de já

101 MARCEAU, Gabrielle; HURLEY, Mikaella. Transparency and public participation in the WTO: a report card on WTO transparency mechanisms. Trade, Law and Development, v. 4, n. 1, p. 19-44, 2012.

102 MARCEAU, Gabrielle; HURLEY, Mikaella. Transparency and public participation in the WTO: a report card on WTO transparency mechanisms. Trade, Law and Development, v. 4, n. 1, p. 19-44, 2012.

103 MARCEAU, Gabrielle; HURLEY, Mikaella. Transparency and public participation in the WTO: a report card on WTO transparency mechanisms. Trade, Law and Development, v. 4, n. 1, p. 19-44, 2012.

104 Ver: Anexo 2 - Entendimento Relativo às Normas e Procedimentos sobre Solução de Controvérsias. In: BRASIL. 
terem sido transmitidos 19 procedimentos no OSC, entre painel e $\mathrm{OA}$, e de não terem sido concretizadas as preocupações que tais iniciativas transformariam as práticas em um circo midiático, o interesse do público em geral tem sido abaixo das expectativas da OMC, em especial a participação das ONGs, uma vez que a maior parte dos interessados é proveniente da comunidade acadêmica $^{105}$.

Em resumo, é possível afirmar que, apesar de não ser assegurado às representações da sociedade civil direitos de participação ativa, da mesma forma dos países membros, hoje em dia existe um canal aberto de participação por meio da possibilidade de submissão das suas petições e documentos de duas formas: ou anexadas nas petições de algum Estado membro envolvido em uma disputa, ou por meio de submissões avulsas de acordo com os procedimentos estabelecidos pelo OA. Constatou-se, por último, ser possível a transmissão ao público das audiências do $\mathrm{OA}$, desde que os países membros envolvidos na disputa assim permitam.

\section{Considerações finais}

O presente artigo procurou responder se a OMC é accountable, e para tanto procedeu na análise do próprio termo aplicado a uma perspectiva de governança global, no qual se encontram dificuldades de definir quem é o detentor do poder de manter a OMC accountable.

Primeiramente, ao invés de trabalhar na transfusão de modelos ou de tipos gerais de accountability, constatou-se ser mais importante focar na identificação dos três elementos de composição da accountability dentro das instituições de governança global para, consequentemente, responder se estas são accountable, ou promovem a accountability e, assim, trabalhar em cima do aprimoramento de cada uma delas quando necessário.

Ademais, diante das dificuldades de se transpor o conceito de accountability para a governança global, foi identificado neste trabalho dois parâmetros de análise.

Decreto 1.355 de 30 de dezembro de 1994. Promulgo a Ata Final que Incorpora os Resultados da Rodada Uruguai de Negociações Comerciais Multilaterais do GATT. Presidência da República. Brasília, 30, dez. 1994, p. 461.

105 MARCEAU, Gabrielle; HURLEY, Mikaella. Transparency and public participation in the WTO: a report card on WTO transparency mechanisms. Trade, Law and Development, v. 4, n. 1, p. 19-44, 2012.
Em primeiro lugar, constatando-se a não definição da figura do cidadão global, como meio viabilizador de uma democracia, tanto o meio acadêmico, como as próprias OIs têm se valido da figura da sociedade civil como possível substituta, ainda que de forma não perfeitamente concebida, da demos global.

Uma vez que a OMC foi elencada por este trabalho como objeto de pesquisa, analisar a promoção de accountability em seu âmbito, perpassou, primeiramente, na identificação de quem seriam os sujeitos destinatários finais do estabelecimento de normas e padrões regulatórios que emanam da sua atuação. E, em um segundo momento, na verificação dos elementos gerais de composição da accountability, em sua arquitetura institucional.

Partiu-se de duas visões conflitantes: (i) a abordagem intergovernamental, que, restritamente, enxerga apenas os Estados membros como detentores do direito de se utilizarem de mecanismos accountability na OMC, em um plano horizontal, de prestação de contas e aplicação de sanções entre si; (ii) e a abordagem supranacional, que visualiza a atuação da OMC para além de sua abordagem intergovernamental, ao reconhecer na sociedade civil, o destinatário final das ações desta, demandando, portanto uma análise sob uma perspectiva vertical de promoção de elementos de accountability.

No plano horizontal, foi possível verificar a existência e funcionalidade de todos os três elementos de accountability quais sejam: o estabelecimento de padrões, por meio das Conferências Ministeriais, que estipula o consenso como método de adoção de novas regras e padrões; processos de informação por meio de mecanismos de transparência tal como o TPRM, conselhos, comitês e mesmo o site da OMC; e, a aplicação de sanções por meio do braço judiciário da OMC, com base em princípios do devido processo legal, duplo grau de jurisdição e decisões motivadas, que permitem o constrangimento de práticas abusivas no regime multilateral de comércio.

Neste caso, é possível, portanto, concluir que a OMC, se tomada em seu aspecto intergovernamental, representa um caso de promoção de accountability, fazendo com que o direito estabelecido em seu âmbito seja formulado dentro de um processo legítimo, ao menos aos olhos dos seus membros.

Por outro lado, verificou-se no plano vertical, que é possível vislumbrar a presença de alguns princípios fortalecedores da accountability relativa à sociedade civil, 
como forma de políticas promotoras de responsividade, tal como a transparência e participação (não decisória). Contudo, não é possível afirmar seguramente que a OMC promove accountability em relação à sociedade civil. Isto porque: (i) em termos de transparência, a OMC, apresenta duas facetas: uma em termos de difusão de informações (publicidade), que é amplamente aberto ao público, e a outra com relação à participação nos mecanismos de transparência da OMC, como por exemplo o TPRM, que é de participação exclusiva dos países membros; (ii) com relação à participação da sociedade civil nos processos de construção legal e estabelecimento de regras e padrões, disposto nas Conferências Ministeriais, restou exposto que o nível de abertura é bastante tímido, de forma a não permitir que a sociedade civil tenha, concretamente, uma influência nas tomadas de decisões ocorrentes no ínterim das negociações, privilegiando-se, portanto, o modelo member-driven da OMC - neste sentido, a participação da sociedade civil se dá apenas de forma não decisória; (iii) por último, à sociedade civil foi possibilitada um importante canal de participação no processo de enforcement das regras da OMC através do OSC, pois, conforme foi explicado, são permitidas submissões na forma de amicus curiae, tanto na fase de painel como na fase de apelação. Este é um caminho fundamental para tornar as práticas e medidas políticas adotadas pelos membros da OMC accountable às perspectivas da sociedade civil, apesar de, não restar claro a forma pela qual as submissões são aproveitadas, quando apresentadas de forma isolada, ou seja, sem estarem anexadas à petição de uma das partes do litígio.

Ou seja, apesar de serem promovidas importantes ferramentas para um maior engajamento da OMC junto à sociedade civil, tais como a transparência pelo site da OMC, a participação-não decisória nas Conferências Ministeriais e a possibilidade de submissão de petições na forma de amicus curiae no processo de solução de controvérsias, resta ainda fortalecer alguns elementos da accountability, tal como a inclusão da agenda da sociedade civil no plano da tomada de decisões e a possibilidade de esta ter acesso a outros mecanismos de transparência, tal como o TPRB, conselhos e comitês.
Neste plano de análise, é possível se chegar a duas vertentes conclusivas distintas: a primeira indicando que a OMC é uma organização que parcialmente promove a accountability à sociedade civil, justamente por ter aberto a possibilidade de participação desta, naquele que é considerado como os "dentes" dos processos accountability, qual seja, a aplicação de sanções por meio do OSC, permitindo sua influência sobre casos que envolvam, ao seu critério, abusos de poder que desafiem o interesse público, ressaltando-se, no entanto, a necessidade de uma melhor definição procedimental na forma pela qual as submissões isoladas podem ser aproveitadas.

A segunda conclusão, por outro lado, indicando que, de forma geral, a OMC não pode ser reconhecida como uma organização que promove a accountability no plano horizontal, uma vez que esta estabelece apenas determinados mecanismos de responsividade, o que pode gerar questionamentos sobre a legitimidade de suas ações e, consequentemente das suas regras e padrões.

De uma forma ou de outra, não é possível afirmar que a promoção de accountability em relação à sociedade civil se dá em pés de igualdade ao que ocorre em relação aos países membros. A discussão, portanto, gira em torno da gradação a qual se exercem os mecanismos de promoção de accountability, podendo ser entendido que a promoção acontece de uma forma satisfatória, ou que apenas de uma forma circunstancial e marginal.

Por isso, em suma, apesar de ser plausível confirmar a evolução da OMC em termos de fortalecimento de princípios de participação, transparência direcionados à solidificação da promoção de accountability à sociedade civil, permitindo, inclusive, a participação desta no processo de sanção das regras comerciais. Numa perspectiva vertical, não é possível chegar à mesma conclusão que verificada na perspectiva horizontal, qual seja, a de que a OMC promova accountability direcionado à sociedade civil, pois, apesar de promover diversos canais de engajamento com esta, a OMC está presa a sua natureza intergovernamental e member-driven de produção de regras. 


\section{Referências}

BAIMU, Evarist; PANOU, Aristeidis. Responsibility of International Organizations and the World Bank Inspection Panel: parallel tracks unlikely to converge? In: CISSE, Hassane; BRADLOW, Daniel D.; KINGSBURY, Benedict. The World Bank legal review: international financial institutions and global legal governance. Washington: The World Bank, 2012. v. 3.

BATTLE of Seattle. Direção: Stuart Townsend. Hyde Park International, 2007.

BOSSCHE, Van den. The law and policy of the World Trade Organization. Cambridge: Cambridge University Press, 2005.

BR ASIL. Decreto 1.355 de 30 de dezembro de 1994. Promulgo a Ata Final que Incorpora os Resultados da Rodada Uruguai de Negociações Comerciais Multilaterais do GATT. Presidência da República. Brasília, 30 dez. 1994.

CHAISSE, Julien; CHAKRABORTY, Debashis, Implementing WTO rules through negotiations and sanction: the role of Trade Policy Review Mechanism and Dispute Settlement System. University of Pennsylvania Journal of International Economic Law, Philadelphia, v. 28, n. 1, 2007.

CHARNOVITZ, Steve. Transparency and participation in the World Trade Organization. GWU Law School Public Law Research Paper, Washington, n. 142, 2004.

COMISSÃO SOBRE GOVERNANÇA GLOBAL. Nossa comunidade global: o relatório da Comissão Sobre Governança Global. Rio de Janeiro: FGV, 1996.

DUBNICK, Melvin J.; ROMZEK, Barbara. Accountability. In: SHAFRITZ, Jay M. (Org.). The International Encyclopedia of Public Policy and Administration. Westview Press, 1998. v. 1.

FROESE, Marc D. Between surveillance and transparency: trade policy review and north american dispute settlement at the WTO. Canadian University College: Lacombe Paper, p. 1-39, abr. 2012.

GRANT, Ruth W.; KEOHANE, Robert O. Accountability and abuses of power in world politics. American Political Science Review, v. 99, n. 1, fev. 2005.
HALLE, Mark; WOLFE, Robert; BEATON, Christopher. Looking back, looking forward: civil society contributions to WTO accountability. ENTWINED Issue Brief, n. 8, 2011.

KEOHANE, Robert O.. Global governance and democratic accountability. In: HELD, David; KOENIG-ARCHIBUGI, Mathias (Eds.). Taming globalization: frontiers of governance. Cambridge: Polity Press: 2002.

KEOHANE, Robert O.; NYE, Joseph S. Power and interdependence. Boston: Scott, Foresman and Company, 2001.

KINGSBURY, Benedict; KRISCH, Nico; STEWART, Richard B. The emergence of global administrative law. Law and Contemporany Problems, North Carolina, v. 68, n. 3-4, p. 15-62, 2005.

LAFER, Celso. A OMC e a regulamentação do comércio internacional: uma visão brasileira. Porto Alegre: Livraria do Advogado, 1998.

LESTER, Simon. Accountability at the WTO. International Economic Law and Policy Blog. 13 dez. 2009. Disponível em: <http://worldtradelaw.typepad.com/ ielpblog/2009/12/accountability-at-the-w to.html>. Acesso em: 15 jan. 2014.

MARCEAU, Gabrielle; HURLEY, Mikaella. Transparency and public participation in the WTO: a report card on WTO transparency mechanisms. Trade, Law and Development, v. 4, n. 1, p. 19-44, 2012.

MAVROIDIS, Petros C. Amicus curiae briefs before the WTO: much ado about nothing. Jean Monnet Working Paper, v. 2, n. 1, p. 1-18, 2002.

MITCHELL, Andrew D.; SHEARGOLD, Elizabeth. Global governance: the World Trade Organization's contribution. Alberta Law Review, Alberta, v. 46, p. 10611080, jan. 2010.

MULGAN, Richard. One cheer for hierarchly: accountability in disjointed governance. Political Science, v. 55 , n. 2 , p.6-18, 2003.

NANZ, Patricia; STEFFEK, Jens. Global governance, participation and the public sphere. In: HELD, David; KOENIG-ARCHIBUGI, Matias. (Ed.). Global 
governance and public accountability. Chichester: WileyBlackwell, 2005. p. 190-211.

PALMER, Alice. Observando de fora: participação da sociedade civil no Sistema de Solução de Controvérsias da OMC. In: BAPTISTA, Luiz Olavo; CELLI JUNIOR, Umberto; YANOVICH, Alan (Org.). 10 anos de OMC: uma análise do Sistema de Solução de Controvérsias e perspectivas. São Paulo: Aduaneiras, 2007.

PAUWELYN, Joost; BERMAN, Ayelet. Emergency action by the WTO director-general: global administrative law and the WTO's initial response to the 2008-09 financial crisis. International Organizations Law Review. v.6, p.499-512, 2009.

PEDRAZA-FARINA, Laura G. Conceptions of civil society in international law-making and implementation: a theoretical framework. Michigan Journal of International Law, Michigan, v. 34, n. 3, p. 101-173, 2013.

PEREZ-ESTEVE, Maria. WTO rules and practices for transparency and engagement with civil society organizations. Staff Working Paper ERSD, Genebra, v. 14, p. 1-28, 2012.

RUBENSTEIN, Jennifer. Accountability in an unequal world. Journal of Politics, v. 69, n. 3, p. 616-632, ago. 2007.

SANCHEZ BADIN, Michelle Ratton. Breves considerações sobre os mecanismos de participação para ONGs na OMC. Revista Internacional de Direitos Humanos, n. 4, ano 3, p. 102-125, 2006.

SCHMIDT, Luis Felipe Flores. A construção da retaliação brasileira no caso algodão: os desafios do pioneirismo. In: BENJAMIN, Daniela Arruda (Org.). O sistema de Solução de Controvérsias da OMC: uma perspectiva brasileira. Brasília: FUNAG, 2013.

SCHOLTE, Jan Aart. Global governance, accountability and civil society. In: SCHOLTE, Jan Aart (Ed.). Building global democracy: civil society and global governance. Cambridge: Cambridge University Press, 2011.

SILVA, Luiz Fernando Martins da. Amicus curiae: direito e ação afirmativa. Revista Jurídica, Brasília, v. 7, n. 76, p. 70-78, 2006.
SMYTHE, Elizabeth; SMITH, Peter J. Legitimacy, transparency, and information technology: the World Trade Organization in an era of contentious trade politics. Global governance: a review of multilateralism and international organizations, v. 12, n. 1, p. 31-53, jan. 2006.

STEWART, Richard B.; SANCHEZ BADIN, Michelle Ratton. The World Trade Organization and global administrative law. NYU School of Law Public Law Research Paper, Nova Iorque, n. 09-71, p. 1-31, 2009.

UNCTAD. Curso de solução de disputas em comércio internacional, investimento e propriedade intelectual. Modulo 3.3: Apelação. Nova Iorque e Genebra: ONU, 2003.

UNITED NATIONS CONFERENCE ON TRADE AND EMPLOYMENT. Final act and related documents. Interim Comission for the International Trade Organization: Lake Success, abr. 1948.

VANGRASSTEK, Craig. The history and the future of the World Trade Organization. Genebra: WTO Publications, 2013.

WILLIAMS, Mark. Civil society and the WTO: contesting accountability. In: SCHOLTE, Jan Aart (Ed.). Building global democracy: civil society and global governance. Cambridge: Cambridge University Press, 2011.

WOLFE, Robert. Who is accountable at the World Trade Organization?: anatomy of a trilemma within a dilemma. Kingston, p. 1-19, (no prelo).

WTO. $W T / L / 162$ : Guidelines for arrangements on relations with Non-Governmental Organizations. Genebra, 23 jul. 1996. Disponível em: <http://www. wto.org/english/forums_e/ngo_e/guide_e.htm>. Acesso em: 20 fev. 2014.

WTO. WT/DS58/AB/R: United States - Import Prohibition of Certain Shrimp and Shrimp Products. Genebra, 12 out. 1998.

WTO. $W T / D S 138 / A B / R$ : United States - Imposition of Countervailing Duties on Certain Hot-Rolled Lead and Bismuth Carbon Steel Products Originating in the United Kingdom. Genebra, 10 mai. 2000. 
WTO. $W T / G C / M / 60$ : minutes of meeting Held in the Centre William Rappard on 22 November 2000. Genebra, 23 jan. 2001.

WTO. WT/DS135/AB/R: European Communities Measures Affecting Asbestos and Products Containing Asbestos. Genebra, 12 mar. 2001.

WTO. The future of the WTO: addressing institutional challenges in the new millennium. Genebra: WTO Publications, 2004.

WTO. Understanding the WTO. Genebra: WTO Publications, 2008.
WTO. The WTO agreements series: sanitary and phytosanitary measures. Genebra: WTO Publications, 2010. Disponível em: <http://wto.org/english/res_e/booksp_e/ agrmntseries4_sps_e.pdf>. Acesso em: 12 dez. 2014.

WTO. Trade policy reviews: brief introduction. Genebra. Disponível em: <http://wto.org/english/tratop_e/ tpr_e/tp_int_e.htm>. Acesso em: 14 fev. 2014a.

WTO. Trade monitoring. Genebra. Disponível em: <http://www.wto.org/english/tratop_e/tpr_e/trade_ monitoring_e.htm>. Acesso em: 02 mar. 2014b. 


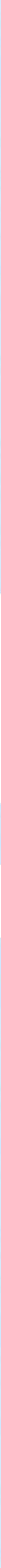




\title{
La OMC y el proceso de globalizacion de la regulación alimentaria*
}

\section{The WTO and the food law globalization process}

\author{
Maria Eugenia Marichal**
}

\section{Resumen}

Este artículo pretende explorar el papel de la OMC en la conformación del régimen jurídico global de los alimentos y el modo en que incidió en el diseño y expansión de ciertas tecnologías de estandarización tendientes a facilitar el comercio internacional de alimentos. Se utilizan nociones de G. Teubner acerca de los regímenes globales parciales, y algunos conceptos de los estudios de política de la ciencia y tecnología (S. Jasanoff). En primer lugar, exploramos sintéticamente la constitución de los procesos globales de regulación alimentaria contemporáneos y la "reinvención" del Codex Alimentarius luego de la creación de la OMC, por su estricta base en el conocimiento científico que logró articularse con las pretensiones de objetividad de esta última. Luego reconstruimos el modo en que se fue configurando la base científica subyacente al complejo OMC \& Codex Alimentarius a través del análisis de directrices y principios de aplicación de su normativa. En tercer lugar, describimos dos tecnologías globales de estandarización del control de los alimentos: la difusión de metodologías del análisis de riesgos alimentarios y los Sistemas Nacionales de Control Alimentario, que implican una progresiva homogenización de la regulación a través de la implantación de agencias de expertos entrenados en la gramática dominante del discurso científico, así como la privatización y descentralización del control estatal. Finalmente, apuntamos algunos problemas y límites del régimen. El estudio aporta a la comprensión del modo en que los presupuestos teóricos de la OMC engendran asimetrías de poder en el sistema de intercambios comerciales de alimentos.

Palabras claves: Régimen global alimentario. Codex Alimentarius. Regulación basada en Ciencia. Sistemas Nacionales de Control Alimentario.

\section{Abstract}

This paper aims to explore the role of WTO in the conformation of a global food regime and the way in which it influenced the design and expansion of certain standardization technologies to facilitate the international food trade.

* Recebido em 31.10.2014

Aceito em 04.12.2014

** Magíster en Ciencia, Tecnología y Sociedad (Universidad Nacional de Quilmes). Doctora en Derecho (Universidad Nacional del Litoral). Docente de la Facultad de Ingeniería y Ciencias Hídricas, y de la Facultad de Ciencias Jurídicas y Sociales (Universidad Nacional del Litoral). E-mail: marichal@ffjs.unl.edu.ar.
We use G. Teubner partial global regimes ideas and some concepts from science and technology political studies (S. Jasanoff). First, we briefly explore the contemporary global food regulation process and the "reinvention" of the Codex Alimentarius after the WTO creation, due to its strictly scientific knowledge base that manages to articulate with WTO pretensions of objectivity. Then, we rebuild the way in which this scientific knowledge base underlying the $O M C$ \& $\mathrm{d}$ dex Alimentarius complex was shaped through application guidelines and principles of its regulations. Third, we describe two global standardization technologies for food control: the spread of food risk analysis methodologies and National Food 
Control Systems. These systems imply a progressive legal standardization through the establishment of agencies with experts trained in the dominant grammar of scientific discourse, as well as food control privatization and de-centralization. Finally, we highlight some problems and limitations of the regime. The study contributes to the understanding of the way in which some WTO theoretical assumptions produce power asymmetries in international food trade.

Keywords: Global Food Regime. Codex Alimentarius. Science Based regulation. National Food Control Systems.

\section{La emergencia de un régimen alimentario global}

En este trabajo intentaremos explorar el papel de la OMC en la conformación del régimen jurídico global de los alimentos y el modo en que éste incidió en el diseño y expansión de ciertas tecnologías de estandarización tendientes a facilitar el comercio internacional de los alimentos. Enmarcamos la emergencia de una regulación de la cuestión alimentaria a nivel global dentro de un proceso general de globalización jurídica ${ }^{1}$. En efecto, la cuestión alimentaria representa una de las problemáticas ejemplares de dicho proceso ${ }^{2}$.

1 Entendemos por globalización, la intensificación de los intercambios de capital, información y personas a nivel planetario, proceso operado a fines del pasado siglo, que muchos autores identifican como un fenómeno histórico diferenciado, con características propias. Dentro de las características de este proceso se incluye la progresiva pérdida de capacidad del Estado Nacional como agente productor de regulaciones sobre diversas cuestiones del propio ámbito nacional. BECK, Ulrich. ¿Qué es la globalización?: Falacias del globalismo, respuestas a la globalización. Paidós, 2008. BECK, Ulrich; GIDDENS, Anthony; LASH, Scott. Modernización reflexiva: Política, Tradición y Estética en el Orden Social Moderno. Alianza Editorial, 1997. FARÍA, José Eduardo. El Derecho en la Economía Globalizada. Trotta, 2001. FARIÑAS DULCE, María José. Globalización, Ciudadanía y Derechos Humanos. Dykinson, 2000. GIDDENS, Anthony. Consecuencias de la Modernidad. Alianza Editorial, 2007. SANTOS, Boaventura de Sousa. La globalización del derecho: los nuevos caminos de la regulación y la emancipación. Colombia: Universidad Nacional de Colombia, 1998. SASSEN, Saskia. Una sociología de la globalización. Katz Editores, 2007. SKLAIR, Leslie. Sociología Del Sistema Global: El Impacto Socioeconómico y Político de Las Corporaciones Transnacionales. Gedisa, 2003. Entenderemos que la globalización trasciende la dimensión puramente económica y se trata de un "un proceso policéntrico, en el que diversos ámbitos vitales superan sus límites regionales y constituyen respectivamente sectores globales autónomos". TEUBNER, Gunther. El derecho como sistema autopoiético de la sociedad global. Bogotá: Centro de Investigación en Filosofía del Derecho de la Universidad Externado de Colombia, 2005, p. 72.

2 Así es reconocido tanto en documentos políticos de ciertos organismos internacionales, como por ejemplo, en documentos
A nivel conceptual, para identificar la emergencia de tal régimen, seguiremos algunas nociones claves de la teoría socio- jurídica de G. Teubner ${ }^{3}$ acerca de la conformación de regímenes globales parciales. Ante ciertas tendencias de regulación global, tales como el régimen de los derechos humanos o los conflictos por la regulación del ciberespacio, el mencionado autor señala que la posibilidad de emergencia de "una" constitución global capaz de reglamentar la totalidad de los complejos problemas que acucian a la sociedad global, es discutible. Afirma que en lugar de una única constitución global -al estilo de las constituciones nacionales- lo que está emergiendo es un "cúmulo de constituciones civiles"'.

En esta línea, entendemos que la construcción global de una regulación para el control, la garantía de inocuidad y el comercio mundial de alimentos se compone de reglas de carácter constitucional y tiende a la progresiva conformación de una "constitución global parcial”. Dado que la cuestión de la seguridad alimentaria se configura como un terreno político complejo que involucra una variedad de intereses, sobre una variedad de temas y disciplinas, este régimen global parcial involucra tanto organizaciones gubernamentales, intergubernamentales como no gubernamentales (ONG) que actúan "a distintos niveles en la formulación de

de la FAO ("La adopción del Codex Alimentarius como fuente de normas alimentarias internacionales porparte de la OMC en su Acuerdo MSF, en el año 1995 (...) bien podría considerárse un reconocimiento a la creciente globalización de la producción y del comercio de alimentos (...) desde principios del siglo XXI es imprescindible tener en cuenta el marco juridico internacional a la bora de configurar las politicas nacionales o regionales, debido a su creciente importancia y a la dimensión global de los asuntos alimentarios". FAO. Directrices En Materia de Legislación Alimentaria (nuevo Modelo de Ley de Alimentos Para Países de Tradición Jurídica Romano-Germánica). Estudio Legislativo. Roma: FAO, 2006, p. 22. Así como en la literatura académica:

BOUTRIF, Ezzeddine. The New Role of Codex Alimentarius in the Context of WTO/SPS Agreement. Food Control, v. 14, p.8188, 2003. HERWING, Alexia. Trasnational Governance Regime for Foods Derived from Bio-Technology and Their Legitimacy. In: JOERGES, Christian et. al. Transnational Governance and Constitutionalism. Hart Publishing, 2004. p 199-222. VEGGELAND, Frode; BORGEN, Svein. Negotiating International Food Standards: The World Trade Organization's Impact on the Codex Alimentarius Commission. Governance, v. 18, n. 4, p. 675-708, 2005.

3 TEUBNER, Gunther. El Derecho Como Sistema Autopoiético de La Sociedad Global. Bogotá: Universidad Externado de Colombia, 2005.

4 Siguiendo un esquema luhmanniano, aclara que la constitución de la sociedad global "no se hace realidad exclusivamente en las instituciones representantes de la política internacional, tampoco puede acontecer en una constitución global que abarque todos los ámbitos sociales, sino que se genera por incremento en la constitucionalización de una multiplicidad de subsistemas autónomos de la sociedad mundial". 
normas alimentarias y en la búsqueda de soluciones para los problemas mundiales en la materia".

$\mathrm{La}$ OMC, junto con la FAO y la OMS, constituyen los principales organismos internacionales que determinan la producción de la normativa alimentaria internacional que regula el comercio internacional y el modo de resolución de cualquier cuestión controvertida acerca de la aplicación de los acuerdos, directrices y demás normas del régimen 5 .

Estos sectores globales se caracterizan por la emergencia de nuevas fuentes del derecho, más allá de los tradicionales mecanismos del Derecho Internacional:

los nuevos fenómenos de una juridificación global también implican la posibilidad de que los procesos de constitucionalización tengan a su turno lugar fuera de las instituciones estatales y política ${ }^{6}$

Pero en el caso del régimen global alimentario hay una tendencia al liderazgo de la OMC en el establecimiento de los principios y directrices centrales.

Si bien en principio los países son libres de sentar sus propios estándares de control de los alimentos, su autonomía en el proceso de regulación de la seguridad alimentaria se ve constreñida por las normas resultantes de un espacio de regulación global y en cierta medida por la normativa regional, que en algunos casos (como el de la Unión Europea) puede estar en tensión con la regulación global?

5 Este sistema contiene también sus propias reglas procedimentales para resolver los conflictos. La producción de normas jurídicas para resolver conflictos no sólo acontece en los tribunales nacionales e internacionales sino también las instancias de solución de conflictos sociales no políticas, regímenes contractuales, de cortes de arbitraje, instancias de mediación, comisiones de ética, etc.

6 TEUBNER, Gunther. El derecho como sistema autopoiético de la sociedad global. Bogotá: Universidad Externado de Colombia, 2005. p. 55. Existen sistemas mundiales que se autorreproducen en la economía, la ciencia, la cultura, la tecnología, el sistema de salud, el sector militar, los transportes, los medios de comunicación y el turismo, todos los cuales logran competir exitosamente con la política de los estados nación. Mientras que el proceso político ha alcanzado sólo una "proto-globalización en las relaciones internacionales (relaciones intersistémicas entre unidades nacionales con algunos débiles elementos transnacionales)" el resto de subsistemas sociales ya comienzan a formar una "multitud fragmentada de diversas sociedades globales". TEUBNER, Gunther. Global Law without a State. Dartmouth, 1997.

7 LINDNER, Line Friis. Regulating Food Safety: The Power of Alignment and Drive towards Convergence. The European Journal of Social Science Research, v. 21, n. 2, p. 133-43, 2008. Por un lado, el poder de alineamiento mundial de los estándares del Codex Alimentarius -en tanto reglas aceptadas por la OMC para resolución de los conflictos comerciales- y por el otro, la tracción hacia una
En siguiente apartado, nos detenemos en el análisis del Codex Alimentarius, una agencia que, en principio, responde a la acción conjunta de FAO y OMS, pero que tiene claras conexiones con la OMC. En un tercer apartado, analizaremos el núcleo del discurso de estos organismos internacionales en relación al comercio internacional de alimentos: la conformación de una regulación basada en conocimiento científico acreditado. Luego, veremos cómo se implementa instrumentalmente esta lógica a través de la juridización de dos tecnologías globales de estandarización del control de los alimentos: la adopción de decisiones a través del análisis de los riesgos alimentarios y la implementación de Sistemas Nacionales de Control Alimentario (SNCA). Observaremos el modo en que este tipo de sistemas implican una progresiva homogenización de la regulación alimentaria a través de la implementación de agencias de expertos entrenados en la gramática dominante del discurso científico, así como a la adopción de métodos tendientes a la privatización y descentralización del control estatal. Estas tecnologías funcionales al comercio internacional hegemónico impactan diferencialmente en el diseño e implementación de la regulación de la seguridad alimentaria de los Estados. Finalmente, y a modo de breve conclusión, esbozaremos algunos problemas y límites de este régimen global, especialmente el modo en que los presupuestos teóricos de la OMC engendran asimetrías de poder en el sistema de intercambios comerciales de alimentos, no sólo entre los distintos Estados nacionales.

\section{El Codex Alimentarius y su articulación con la OMC}

El término Codex Alimentarius proviene del latín y significa literalmente "código de los alimentos". Se trata de

\begin{abstract}
Una colección de estándares de alimentos desarrollados y presentados en una manera unificada, codificada, junto con material asociado, tal como códigos de higiene y buenas prácticas de manufactura (BPM); reconocidos métodos de análisis y muestreo; principios generales y guías ${ }^{8}$.
\end{abstract}

convergencia bilateral o regional según los estándares desarrollados por, o con, los socios comerciales.

8 BOUTRIF, Ezzeddine. The New Role of Codex Alimentarius in the Context of WTO/SPS Agreement. Food Control, v. 14, p. 81, 2003. 
Nace como una recopilación ordenada de la regulación alimentaria que la comunidad científica y técnica en la materia postulaba para la identificación, elaboración, control, etc. de los alimentos?.

La Comisión del Codex Alimentarius fue establecida en 1961 como un cuerpo subsidiario de la Organización Mundial de la Salud (OMS) y la FAO para la formulación de propuestas a los Directores Generales de la ONU y de los órganos rectores de ambas organizaciones. Al poco tiempo, se agregó la finalidad de actuar como órgano de consulta para todas las cuestiones relativas a la ejecución del Programa Conjunto FAO/OMS sobre Normas Alimentarias ${ }^{10}$.

La Comisión del Codex Alimentarius elabora diferentes tipos de instrumentos normativos: estándares, códigos de prácticas, directrices y otras recomendaciones. Los estándares pueden estar relacionados con todas o sólo algunas de las características de los productos alimenticios o bien pueden referirse a métodos de análisis y muestreo. Los códigos de prácticas (e higiene) recomiendan prácticas de producción, procesamiento, manufactura, transporte y almacenamiento de alimentos. Las directrices pueden ser sobre principios que establecen políticas en determinados ámbitos fundamentales (suelen estar incorporados a las normas y códigos de prácticas, como en el caso de los aditivos alimentarios), o directrices para la interpretación de esos principios o normas generales del Codex (por ejemplo, sobre etiquetado de los alimentos) ${ }^{11}$.

9 La lógica que subyace al Codex Alimentarius de FAO/ OMS proviene de un sistema de códigos alimentarios utilizado en el Imperio Astro- Húngaro entre 1897 y 1911, que inspiraron el nombre de Codex a la regulación de 1961. Este sistema "establecía una colección de standards y descripciones de productos para una amplia variedad de alimentos. Fue conocido como el Códex Alimentarius Austriacus. A pesar de su falta de verdadera fuerza legal, este sistema fue ampliamente utilizado como una fuente de referencia por las cortes para determinar los tipicos standards para identificar una particular sustancia alimenticia”. MAC MAOLÁIN, Caoimhín. EU Food Law: Protecting Consumers and Health in a Common Market. Hart, 2007. p. 51.

10 Programa creado en 1963 para "proteger la salud de los consumidores y asegurar prácticas equitativas en el comercio de los alimentos" y "promover la coordinación de todos los trabajos sobre normas alimentarias emprendidos por las organizaciones internacionales gubernamentales y no gubernamentales" (art. 1 de los Estatutos de la Comisión del Codex Alimentarius). ORGANIZACIÓN DE LAS NACIONES UNIDAS PARA LA AGRICULTURA Y LA ALIMENTACION. ¿Qué Es El Codex Alimentarius? Roma: FAO, 2006. p. 22.

11 ORGANIZACIÓN DE LAS NACIONES UNIDAS PARA LA AGRICULTURA Y LA ALIMENTACION. ¿Qué Es El Codex Alimentarius? Roma: FAO, 2006. p. 22.'
Los códigos de prácticas, directrices y recomendaciones tienen el valor de consejos:

algunos de estos textos son muy generales y otros muy específicos. Algunos contienen requisitos detallados sobre un alimento $\mathrm{O}$ grupos de alimentos; otros tienen por objeto el funcionamiento y la gestión de procesos de producción o el funcionamiento de sistemas de reglamentación pública de la inocuidad de los alimentos y la protección de los consumidores ${ }^{12}$.

La elaboración de esta regulación se produce al interior de Comisión del Codex Alimentarius, mediante el trabajo de Comités. Existen Comités de Asuntos Generales, que estudian una materia o materias generales para todo tipo de alimentos (de "naturaleza horizontal") ${ }^{13}$ y Comités de Productos, que estudian cuestiones específicas a los alimentos dentro de una misma clase (de "naturaleza vertical") ${ }^{14}$. Los Comités de Asuntos Generales pueden solicitar asesoramiento de expertos, consultando a especialistas internacionalmente reconocidos o a comités de expertos independientes de la FAO y la OMS ${ }^{15}$.

La Comisión del Codex Alimentarius se considera la

Única organización internacional que reúne científicos, expertos técnicos, entes reguladores gubernamentales y organizaciones, tanto de

12 ORGANIZACIÓN DE LAS NACIONES UNIDAS PARA LA AGRICULTURA Y LA ALIMENTACION. ¿Qué Es El Codex Alimentarius? Roma: FAO, 2006. p. 22.

13 Por ejemplo, el Comité del Codex sobre Contaminantes de los Alimentos, Comité del Codex sobre Aditivos Alimentarios, Comité del Codex sobre Etiquetado de los Alimentos, etc. Disponível em: <http://www.codexalimentarius.org/committees\&-task-forces/es/>.

14 Por ejemplo, el Comité del Codex sobre Frutas y Hortalizas Frescas, Comité del Codex sobre Grasas y Aceites, Comité del Codex sobre Azúcares, etc. Disponível em: <http://www. codexalimentarius.org/committees- $\&$-task-forces/es/>.

15 Actualmente, entre los Comités de expertos Mixtos FAO/ OMS más importantes puede mencionarse al Comité de Expertos en Aditivos Alimentarios (JECFA), el Comité de Expertos sobre Residuos de Plaguicidas (JMPR) y el Comité de Expertos sobre Evaluación de Riesgos Microbiológicos (JEMRA). El asesoramiento científico de estos comités mixtos de expertos, así como los resultados de las consultas de expertos ad hoc, conforman la base de las normas elaboradas por los Comités del Codex “...estos comités de expertos y consultas no son parte de la Comisión del Codex Alimentarius, pero son entidades autónomas, establecidos por la FAO y la OMS para proporcionar asesoramiento especializado a la Comisión del Codex Alimentarius y sus órganos subsidiarios, así como a los gobiernos miembros" Disponível em: <http:// www.codexalimentarius.org/bases-cientificas-para-el-codex/es/>. 
consumidores como industriales, con el fin de establecer normas alimentarias ${ }^{16}$.

Representa un ejemplo paradigmático de administración híbrida privada-intergubernamental, uno de los cinco tipos de "espacios administrativos globales" que clasifica la reciente literatura del derecho administrativo global, en la medida que

adopta estándares de seguridad alimenticia a través de un proceso de decisión que hoy en día incluye una amplia participación tanto de actores no-gubernamentales como de representantes gubernamentales, y que produce estándares que adquieren un efecto cuasi-obligatorio a través del Acuerdo sobre Medidas Sanitarias y Fitosanitarias (MSF) de la $\mathrm{OMC}^{17}$.

Es evidente que la adopción de normas alimentarias uniformes acarrea beneficios para la liberalización del comercio mundial de alimentos. Por ello, si bien el Codex Alimentarius es una agencia global de FAO y OMS, su vinculación con la OMC es estrecha, cumpliendo un importante rol instrumental en el cumplimento de sus acuerdos.

Los Estados parte de la OMC firmaron dos tratados sobre seguridad, comercio y normalización de los alimentos: el Acuerdo de Medidas Sanitarias y Fitosanitarias (en adelante, AMSF) y el Acuerdo de Obstáculos Técnicos al Comercio (AOTC). En ambos se reconoce a la Comisión del Codex Alimentarius como organismo de referencia para la adopción de medidas sanitarias (expresamente en el AMSF e implícitamente en el AOTC). Desde estos Acuerdos, se impulsa a los países miembros a participar en la labor de la Comisión del Codex Alimentarius y de basar sus medidas sanitarias y fitosanitarias en las normas, directrices y recomendaciones de dicho Codex.

16 ORGANIZACIÓN DE LAS NACIONES UNIDAS PARA LA AGRICULTURA Y LA ALIMENTACION. Directrices En Materia de Legislación Alimentaria (nuevo Modelo de Ley de Alimentos Para Países de Tradición Jurídica Romano-Germánica). Estudio Legislativo. Roma: FAO, 2006. p. 24.

17 KINGSBURY, Benedict; KRISCH, Nico; RICHARD, Steweart. El Surgimiento Del Derecho Administrativo Global. Rev. Pública Argentina, v. 30, 2007. Kingsbury distingue cinco tipos: una administración de las organizaciones internacionales formales, administración basada en la acción colectiva de redes transnacionales de acuerdos de cooperación; administración distribuida por reguladores nacionales bajo tratados u otros regímenes; administración por acuerdos híbridos intergubernamentales públicoprivados; y administración por instituciones privadas con funciones reguladoras.
Desde la referencia en estos acuerdos de la OMC, las normas internacionales y recomendaciones de la Comisión del Codex Alimentarius

$$
\begin{aligned}
& \text { se han convertido en puntos de referencia } \\
& \text { internacionales por los que pueden evaluarse las } \\
& \text { medidas y reglamentos alimentarios nacionales con } \\
& \text { arreglo a los parámetros jurídicos de los Acuerdos } \\
& \text { de la Organización Mundial del Comercio }{ }^{18} \text {. }
\end{aligned}
$$

En los últimos años, el Codex pasó de ser un cuerpo "invisible" de establecimiento de estándares a convertirse en una agencia regulatoria global y consagrar el acreditado discurso de "análisis de riesgo" que articula conocimiento y poder ${ }^{19}$. Aunque la conformidad con los estándares del Codex no es, en principio, una imposición obligatoria para los Estados miembros de la OMC, la mayoría de los académicos coinciden en señalar que los estándares sentados por la Comisión del Codex Alimentarius se han convertido en puntos de referencia fundamentales para los requerimientos nacionales debido a su influencia directa e indirecta en el establecimiento de las regulaciones alimentarias ${ }^{20}$.

18 ORGANIZACIÓN DE LAS NACIONES UNIDAS PARA LA AGRICULTURA Y LA ALIMENTACION. ¿Qué Es El Codex Alimentarius? Roma: FAO, 2006. p. 6.

19 WINICKOFF, David E.; BOUSHEY, Douglas. Science and Power in Global Food Regulation: The Rise of the Codex Alimentarius. Science, Technology, \& Human Values, v. 35, n. 3, p. 356$381,2010$.

20 BRONCKERS, Marco; SOPRAMANIEN, Ravi. The Impact of WTO Law on European Food Regulation. European Food \& Feed Law Review, v. 6, p. 361-375, 2008. POLI, Sara. The European Community and the Adoption of the International Food Standards within the Codex Alimentarius Comission. European Law Journal, v. 10, n. 5, p. 613-30, 2004. LEE, Richard. Agri-Food Governance and Expertise: The Production of International Food Standards. Sociologia Ruralis, v. 49, n. 4, p. 415-431, 2009. MILLESTONE, Erik; VAN ZWANENBERG, Patrick. The Evolution of Food Safety Policy-Making Institutions in the UK, EU and Codex Alimentarius. Social Policy e Administration, v. 36, n. 6, p. 593-609, 2002. MANSOUR, Mark. One World for All: International Harmonization of Food Regulations. Codex Alimentarius and the Treatment of Foods Deriver from Biotechnology as a Case Study. Journal of Food Science, v. 69, n. 4, 2004. Los estándares del Codex ejercen una influencia directa cuando los Estados miembros optan por seguir la recomendación de la OMC y basan sus medidas en los estándares internacionales. Tienen una influencia indirecta como puntos de referencia cuando los Estados eligen sus propios niveles de protección previendo la amenaza de disputa (en caso de que un miembro aplique un estándar más restrictivo al comercio de lo necesario para alcanzar el nivel de protección requerido) que se presenta como un incentivo hacia el alineamiento de los estándares domésticos de seguridad alimentaria con los desarrollados por la Comisión del Codex Alimentarius. LINDNER, Line Friis, Regulating Food Safety: The Power of Alignment and Drive towards Convergence. The European Journal of Social Science Research, v. 21, n. 2, p. 133-43, 2008. 
A continuación, intentaremos explicar el modo en que ciertas reglas, criterios y herramientas institucionales promovidas desde las instancias productoras de la regulación alimentaria global, se han convertido en normas constitucionales que tienden a una intensa estandarización de la normativa y las instituciones nacionales -y regionales- para el control de los alimentos. Se trata de dispositivos normativos que funcionan como tecnologías globales de control de los alimentos, las cuales, por fuerza del comercio internacional logran disciplinar las regulaciones nacionales hacia la unificación global tras esos estándares internacionalmente aceptados.

\section{El sustento científico subyacente a la regulación alimentaria del complejo OMC e Codex Alimentarius}

El régimen alimentario global emergente al compás de la regulación de los tres organismos internacionales (FAO, OMS, OMC) y de las fuerzas del comercio internacional de alimentos, se nutre especialmente del discurso científico y técnico, es decir, de la información formal y especializada que brinda el subsistema científico $^{21}$. Con esa base científica, las mencionadas organizaciones promueven una racionalización del régimen jurídico que se manifiestan en el carácter dominante del cálculo instrumental -como única racionalidad reconocida en todos los ámbitos- y la organización burocrática mediante la

extensión de organizaciones formales,
estructuradas jerárquicamente y provistas de
conocimientos expertos como titulares de la
racionalidad formal ${ }^{22}$.

El conocimiento experto ha ocupado desde siempre un rol central en el discurso de FAO/OMS, articulando conocimientos de distintas disciplinas abocadas o vinculadas al estudio de los alimentos ${ }^{23}$.

21 Los nuevos derechos globales fragmentados (constituciones globales parciales) que van emergiendo ya no se nutren de tradiciones (como podría interpretarse desde las clásicas teorías sobre pluralismo jurídico que intentaban explicar fenómenos como el colonialismo) sino de la continua autoreproducción de redes globales de naturaleza económica, técnica, cultural, académica o tecnológica. Se trata de redes altamente técnicas, especializadas y a menudo formalmente organizadas y estrechamente definidas. TEUBNER, Gunther. Global Law without a State. Dartmouth, 1997.

22 TEUBNER, Gunther. El Derecho como sistema autopoiético de la sociedad global. Bogotá: Universidad Externado de Colombia, 2005.

23 Se publicita el trabajo de la Comisión del Codex Alimentarius como "un punto de convergencia para todas las investigaciones cientificas relacionadas con los alimentos" y a la propia Comisión como "un centro
Si bien el Codex Alimentarius existe desde la década de 1960 y ha funcionado con una base científica desde sus comienzos, como establecimos, su importancia ha aumentado considerablemente desde la existencia del AMSFS como resultado de la Ronda de Uruguay en 1995.

Ya a inicios de la década de 1990, en un clima de controversias sobre los intercambios internacionales de alimentos entre los EEUU y Europa, por los debates en torno a la utilización de ciertas hormonas de crecimiento en animales y el cultivo de vegetales transgénicos ${ }^{24}$, los negociadores del acuerdo precisaban criterios "neutrales" para poner fin a los debates y avanzar en el trabajo de armonización internacional. Para uniformar la regulación alimentaria en un modo que fuera aceptado por todas las partes involucradas, confiaron en la autoridad de la ciencia. Al indagar en el subsistema científico por reservorios de conocimiento acreditado, hallaron los contenidos en el Codex Alimentarius, por entonces una simple oficina de la FAO y la OMS que venía produciendo standards alimentarios de aplicación voluntaria, y decidieron adoptarla como una de las tres organizaciones internacionales cuyos estándares los países miembros deberían tener en cuenta ${ }^{25}$.

internacional de extrema importancia para el intercambio de información científica sobre los alimentos". ORGANIZACIÓN DE LAS NACIONES UNIDAS PARA LA AGRICULTURA Y LA ALIMENTACION. ¿Qué Es El Codex Alimentarius? Roma: FAO, 2006. p. 10.

24 SADELEER, Nicolas de. The Precautionay Principle in EC Health and Environmental Law. European Law Journal, v. 12, n. 2, p. 139-172, 2006. FORSMAN, Zeynep Kivilcim. Community Regulation of Genetically Modified Organisms: A Difficult Relationship Between Law and Science. European Law Journal, v. 10, n. 5, p. 580-94, 2004. RECUERDA GIRELA, Miguel Dangerous Interpretations of the Precautionary Principle and the Foundational Values of European Union Food Law: Risk Versus Risk. Food Law \& Policy, v. 4, n. 1, p. 1-44, 2008.

25 En relación a la inocuidad alimentaria, el AMSFS recomienda a los países miembros fundar sus medidas en la regulación adoptada por la Comisión del Codex Alimentarius. Además del repertorio de disposiciones sobre requisitos sanitarios para el comercio internacional de los alimentos establecidos en el Codex Alimentarius, existen una variedad de estándares internacionales que los países importadores pueden exigir, como los procedimientos de verificación de la calidad de productos o procesos productivos (análisis HACCP o las normas ISO). LARACH, María Angélica. El Acuerdo Sobre La Aplicación de Medidas Sanitarias Y Fitosanitarias: Contenido Y Alcance Para América Latina Y El Caribe. Comercio Internacional, Santiago, v. 39, 2003. Sobre salud y vida animal y vegetal, se recomienda la regulación de la Oficina Internacional de Epizootias (OIE) y la Convención Internacional de Protección Fitosanitaria (CIPF). Dichos organismos regulan sus ámbitos de aplicación también elaborando Códigos, Código Sanitario para los Animales Terrestres y Código Sanitario para los Animales Acuáticos, conocidos como "Código Terrestre" y "Código Acuático", 
La mutua construcción de una autoridad legal y epistémica a través de la actuación estas organizaciones internacionales (OMC, FAO, OMS) ha sido fundamental para la constitución y estabilización del régimen global de la seguridad alimentaria. Este proceso ha generado un marco para el análisis del riesgo que reclama para sí la mayor "rigurosidad científica" pero que incorpora, sin embargo, particulares elecciones de valor sobre salud y ambiente ${ }^{26}$.

La presencia e integridad de la base científica se convierte en "el principal criterio para determinar la legitimidad de muchos esfuerzos regulatorios nacionales encaminados a asegurar la integridad ambiental o salvaguardar la salud pública”. Los actuales acuerdos multilaterales y regionales de comercio (como los resultantes de la Ronda de Uruguay o el NAFTA) invitan a la aplicación de la ciencia en dos puntos críticos: en el establecimiento de los estándares regulatorios nacionales y en el casi adjudicatorio panel de resolución de controversias ${ }^{27}$.

El AMSFS es una muestra acerca de cómo la ciencia se ha convertido en un "recurso ideologico primario" para alcanzar la racionalización y armonización de los estándares de control de alimentos entre los distintos países $^{28}$. Porque si bien el AMSFS permite a sus Estados miembros mantener o introducir medidas que impliquen estándares más rigurosos que los establecidos por los organismos internacionales reconocidos (art. 3.3 AMSFS) tales medidas se permiten sólo "si existe una justificación científica" o cuando "ello es consecuencia del nivel de protección sanitaria o fitosanitaria que el Miembro de que se trate determine adecuado", según la metodología de evaluación del riesgo y la determinación del nivel de protección reglamentados en el Acuerdo.

En una nota al pie de dicho artículo tercero del acuerdo, se aclara que "existe una justificación científica si, sobre la base de un examen y evaluación de la información científica disponible en conformidad

respectivamente.

26 WINICKOFF, David E.; BOUSHEY, Douglas. Science and Power in Global Food Regulation: the Rise of the Codex Alimentarius. Science, Technology, \& Human Values, v. 35, n. 3, p. 356-81, 2010.

27 WIRTH, David. The Role of Science in the Uruguay Round and NAFTA Trade Disciplines. Cornell International Law Journal, v. 27, p. 820, 1994.

28 WINICKOFF, David E.; BOUSHEY, Douglas. Science and Power in Global Food Regulation: the Rise of the Codex Alimentarius. Science, Technology e Human Values v. 35, n. 3, p. 35681, 2010. con las disposiciones pertinentes del presente Acuerdo, un Miembro determina que las normas, directrices o recomendaciones internacionales pertinentes no son suficientes para lograr su nivel adecuado de protección sanitaria o fitosanitaria". En cualquier caso, las medidas adoptadas nunca podrán ser incompatibles con otra disposición del Acuerdo.

En las últimas décadas, dado el reposicionamiento estratégico del Codex Alimentarius desde la entrada en vigencia del AMSFS (y aún antes, durante su negociación) se rediscutieron y positivizaron -en distintos documentos de la organización- los lineamientos para la articulación del conocimiento científico en la regulación alimentaria global.

Cuando en 1991 era claro que el Codex se convertiría en un engranaje fundamental del régimen comercial de alimentos que se estaba negociando en el seno de la OMC, los grandes miembros estuvieron de acuerdo en la necesidad de formalizar la base científica de la regulación de seguridad alimentaria y observaron que el procedimiento para el establecimiento de estándares del Codex necesitaba ser más consistente, transparente y científicamente fundado ${ }^{29}$.

En marzo de 1995 -unos pocos meses después del nacimiento de la OMC- era evidente que el nuevo estatus de la regulación de la OMC había transformado al Codex Alimentarius de una organización de standards voluntarios a una agencia global. Ese año, mediante una decisión general, la Comisión del Codex Alimentarius aprobó cuatro

Declaraciones de principios referentes a la Función que Desempeña la Ciencia en el Proceso Decisorio del Codex y la Medida en que se tienen en Cuenta otros Factores ${ }^{30}$.

29 JUKES, David. The Role of Science in International Food Standards. Food Control, v. 11, n. 3, p. 181-94, 2000. Esta discusión se dio en el marco de las controversias sobre las hormonas del crecimiento en bifes, cuando en 1991 la Comisión del Codex Alimentarius rechazó cuatro hormonas recibiendo una crítica respuesta de la delegación de los EEUU, que reclamaba que todas las propuestas de estándares recomendados por la Comisión debían estar basadas en la evaluación científica del JEFCA y ser universalmente adoptadas, a menos que nueva evidencia científica presentada ponga en cuestión la validez del estándar. FRANK,

30 ORGANIZACIÓN DE LAS NACIONES UNIDAS PARA LA AGRICULTURA Y LA ALIMENTACION. Decisión de la Comisión del Codex Alimentarius en su $21^{\circ}$ periodo de sesiones de 1995. Disponível em: <http://www.fao.org/docrep/W5975S/ w5975s0l.htm\#TopOfPage $>$. Sin embargo, la inclusión de estas declaraciones entre los principios generales del Codex Alimentarius no los transformaba en reglas formales para el trabajo de la comisión, 
La primera de estas Declaraciones establece que

las normas alimentarias, directrices y otras recomendaciones del Codex Alimentarius se basarán en el principio de un profundo análisis y testimonio científico, que comporte el examen exhaustivo de toda la información pertinente, a fin de que las normas aseguren la calidad e inocuidad de los suministros alimentarios ${ }^{31}$.

Se reconoce al discurso científico un rol central en el proceso de toma de decisiones de la Comisión. Asumiendo un carácter pretendidamente objetivo y neutral, se lo sitúa en el lugar de árbitro de los intereses políticos- económicos en juego de los de diferentes los países miembros, como único agente capaz de garantizar la calidad e inocuidad de los alimentos por encima o al margen de esos intereses.

A continuación, la segunda Declaración parece abrir una posibilidad a la invocación a otras formas de conocimientos o razones no basadas en la Ciencia, al establecer que "en la elaboración de las normas alimentarias y la adopción de decisiones al respecto, el Codex Alimentarius tendrá en cuenta, cuando corresponda, otros factores válidos que atañen a la protección de la salud de los consumidores y al fomento de prácticas equitativas en el comercio de alimentos". Luego la tercera Declaración establece que

a este respecto, se toma nota de que el etiquetado
de los alimentos juega un papel importante en la
promoción de estos objetivos ${ }^{32}$. por lo cual, fueron incorporadas como Apéndice del Manual de Procedimientos del Codex Alimentarius, según se resolviera en la $22^{\circ}$ sesión de la Comisión, en junio de 1997, y fueron incluidos a partir de la $10^{\circ}$ edición del Manual de Procedimientos -que se publicó ese mismo año-. FAO \& OMS. Comisión Del Codex Alimentarius: Manual de Procedimiento. 10. ed. Roma: FAO/OMS, 1997.

31 ORGANIZACIÓN DE LAS NACIONES UNIDAS PARA LA AGRICULTURA Y LA ALIMENTACION. Comisión Del Codex Alimentarius: manual de procedimiento. 10. ed. Roma: FAO/OMS, 1997.

32 La cuarta y última Declaración incorpora un principio procedimental: "si se plantea la situación de que los miembros del Codex están de acuerdo sobre el grado de protección de la salud pública que se necesita, pero tienen opiniones diferentes sobre otros aspectos, los miembros podrán abstenerse de aceptar la norma en cuestión, sin ello que impida necesariamente al Codex adoptar su decisión". ORGANIZACIÓN DE LAS NACIONES UNIDAS PARA LA AGRICULTURA Y LA ALIMENTACION. Comisión Del Codex Alimentarius: manual de procedimiento. 10. ed. Roma: FAO/ OMS, 1997. p. 25. Esto se debió a cierto temor que había suscitado la referencia del AMSFS al Codex Alimentarius en el sentido de que podía llegar a profundizar los conflictos de intereses y el planteo de mayores disidencias entre los países miembros en el proceso decisorio de la propia Comisión del Codex -que hasta entonces había funcionado por unanimidad. WINICKOFF, David E.; BOUSHEY,
La frase "otros factores válidos" generó varias discusiones. Cabe aclarar que el desarrollo de la terminología del Codex no está sujeto al escrutinio de entrenados asesores legales (como sí sucede con la redacción de los Acuerdos de la OMC), y las palabras o frases son a menudo acordadas por consenso. Y aunque a veces las delegaciones en las reuniones del Codex no están completamente de acuerdo con un término, lo aceptan igual para arribar a la decisión, y el significado preciso de la frase queda abierto a las diferentes interpretaciones de las distintas delegaciones ${ }^{33}$.

Debido a diversos problemas de interpretación suscitados, unos años más tarde se establecen Criterios para tomar en Cuenta los otros Factores Mencionados en la Segunda Declaración de Principios ${ }^{34}$. En línea con la representación de la ciencia como eje central en el proceso de toma de decisiones que atraviesa todo el régimen alimentario global, se aclara que el

examen de otros factores no debe afectar al fundamento científico del análisis de riesgos; en este proceso se debe respetar la separación entre la evaluación de riesgos y la gestión de riesgos con miras a garantizar la integridad científica de la evaluación de riesgos.

A continuación, se enuncia que se debe admitir que algunas preocupaciones
legítimas manifestadas por los gobiernos
cuando establecen sus legislaciones nacionales
no son en general aplicables o pertinentes en el
plano internacional [...] en el marco del Codex,
solamente se pueden tomar en consideración los
otros factores que puedan ser aceptados en el

Douglas. Science and Power in Global Food Regulation: the Rise of the Codex Alimentarius. Science, Technology, \& Human Values, v. 35, n. 3, p. 356-81, 2010.

33 JUKES, David. The Role of Science in International Food Standards. Food Control, v. 11, n. 3, p. 181-94, 2000. Esto contrasta con la situación respecto a los textos de la OMC, incluyendo el AMSFS. En el marco de las disputas de la OMC, son considerados por un panel de expertos legales entrenados en determinar con precisión la interpretación de los derechos y obligaciones de los estados miembros.

34 Las Declaraciones de principios fueron enmendadas en 2001 para incluirlos (Decisión tomada en la $24^{\circ}$ sesión de la Comisión del Codex Alimentarius de 2001). El primero de estos criterios establece que cuando se trate de cuestiones relacionadas con la salud y la inocuidad, se deben seguir las mencionadas Declaraciones de principios referentes a la función que desempeña la Ciencia y las Declaraciones de Principios relativos a la función de la evaluación de riesgos respecto de la inocuidad de los alimentos. 
plano mundial, o en el plano regional cuando se trata de normas y textos afines regionales.

De esta manera, se impide la invocación de cualquier cuestión de diversidad cultural que pueda ser alegada por un país para adoptar una medida (de repercusión internacional) amparándose en los mencionados "otros factores", con lo cual se neutraliza el potencial aparentemente contenido en el segundo principio.

En los Criterios..., se indica además que el examen de estos "otros factores" debe estar documentado y con la correspondiente justificación para incorporarlos, caso por caso. Finalmente, se aclara que "la integración de otros factores legítimos en la gestión de riesgos no debe crear trabas injustificadas al comercio", indicando al pie de la frase "con arreglo a los principios de la OMC y teniendo en cuenta las disposiciones específicas de los Acuerdos MSF y OTC" ${ }^{35}$. Es decir, sin enunciar cuales podían ser estos "otros factores" válidos, la aclaración contenida en los Criterios simplemente vino a reforzar el papel central del conocimiento científico oficial, y evacuar cualquier duda respecto a la posibilidad de que bajo la invocación de factores no basados en conocimiento científico sean utilizados como argumento para proteger ciertos valores culturales, la diversidad biológica, etc. evitando cualquier obstáculo al comercio internacional.

\section{Las tecnologías de estandarización global}

\subsection{La metodología de análisis de riesgos alimentarios}

Acordada la importancia de una adecuada base científica para el establecimiento de los estándares de la Comisión del Codex Alimentarius, se hizo necesario contar con una metodología general formalizada y consensuada entre todos los países para gobernar los riesgos alimentarios.

Si bien el análisis del riesgo no era un concepto nuevo para la Comisión, durante la década de 1990 las negociaciones del comercio internacional en el marco de la creación de la OMC empujaron hacia su expansión y estandarización como herramienta

35 En este criterio se agrega que "se debe prestar una atención especial a las repercusiones que podría tener en los países en desarrollo la incorporación de esos otros factores". ORGANIZACIÓN DE LAS NACIONES UNIDAS PARA LA AGRICULTURA Y LA ALIMENTACION. Comisión Del Codex Alimentarius: manual de procedimiento. 20. ed. Roma: FAO/OMS, 2011. institucionalizada en el Codex. En 1995 la Comisión del Codex Alimentarius convocó una Consulta experta Mixta FAO/OMS sobre la Aplicación del Análisis del Riesgo a los Estándares Alimentarios. Los expertos consultados recomendaron numerosos cambios en las prácticas del Codex para avanzar hacia un acercamiento consistente con la evaluación del riesgo basada en la ciencia. En función de estas observaciones, en 1997 se completa las cuatro Declaraciones de Principios sobre el Rol de la Ciencia de 1995 con "Declaraciones de Principios Relativos a la Función de la Evaluación de Riesgos respecto de la Inocuidad de los Alimentos" 36 .

La necesidad de formalizar y procedimentalizar el análisis de evolución de riesgos en materia alimentaria también se aceleró como resultado de su inclusión en los documentos de la OMC. El uso del análisis de riesgo se impuso en el AMSFS". Las "Declaraciones de Principios Relativos a la Función de la Evaluación de Riesgos respecto de la Inocuidad de los Alimentos" de 1997 establecían que "los aspectos sanitarios y de inocuidad de los alimentos de las decisiones y recomendaciones del Codex deben basarse en la evaluación de riesgos". La evaluación de riesgos tiene que basarse en "sólidos conocimientos cientificos" debiendo comprender "las cuatro fases del proceso de evaluación de riesgos" y "estar documentada de manera transparente". Se explicita que

36 Decisión de la Comisión en su $22^{\circ}$ período de sesiones de 1997. El Anexo del Acuerdo contiene un listado de definiciones en el cual se establece la evaluación de riesgos como la "evaluación de la probabilidad de entrada, radicación o propagación de plagas o enfermedades en el territorio de un Miembro importador según las medidas sanitarias o fitosanitarias que pudieran aplicarse, asi como de las posibles consecuencias biológicas y económicas conexas; o evaluación de los posibles efectos perjudiciales para la salud de las personas y de los animales de la presencia de aditivos, contaminantes, toxinas u organismos patógenos en los productos alimenticios, las bebidas o los piensos" (punto 4 del Anexo A, AMSFS).

37 Los estados miembros "se asegurarán de que sus medidas sanitarias o fitosanitarias se basen en una evaluación, adecuada a las circunstancias, de los riesgos existentes para la vida y la salud de las personas y de los animales o para la preservación de los vegetales, teniendo en cuenta las técnicas de evaluación del riesgo elaboradas por las organizaciones internacionales competentes" (artículo 5.1 AMSFS). Se indica luego qué puntos deberán tener en cuenta los Estados al realizar esta evaluación del riesgo (art. 5.2, 5.3 y 5.4 del AMSFS) y se reitera la advertencia que aparece a lo largo de todo el texto del Acuerdo acerca de que, al aplicar medidas de protección ante riesgos detectados, los miembros evitarán "distinciones arbitrarias o injustificables en los niveles que considere adecuados en diferentes situaciones, si tales distinciones tienen por resultado una discriminación o una restricción encubierta del comercio internacional" (artículo 5.5. del Acuerdo SFS) y que estas medidas "no entrañen un grado de restricción del comercio mayor del requerido para lograr su nivel adecuado de protección sanitaria o fitosanitaria, teniendo en cuenta su viabilidad técnica y económica" (artículo 5.6). 
debe haber una separación práctica entre la evaluación de riesgos y la gestión de riesgos, aunque se reconoce que cierto grado de interacción es indispensable para la adopción de criterios pragmáticos ${ }^{38}$.

La $20^{\circ}$ edición del Manual de Procedimientos del Codex Alimentarius incluye una sección dedicada al Análisis de Riesgos (Sección IV) que
contiene las directrices sobre el análisis de riesgos para la Comisión del Codex Alimentarius y sus órganos auxiliares que se ocupan de la protección de la salud del consumidor y de las consultaciones de los órganos expertos FAO/OMS ${ }^{39}$.

Se incorporan allí los principios mencionados (Principios de aplicación práctica para el análisis de riesgos aplicables en el marco del Codex Alimentarius), definiciones de los términos del análisis de riesgos relativos a la inocuidad de los alimentos y una serie de Principios y Políticas para casos, sustancias o situaciones específicas.

En el mencionado Manual, el análisis de riesgos se divide en tres componentes: evaluación de riesgos, gestión de riesgos y comunicación de riesgos ${ }^{40} . \mathrm{Al}$ acentuar que el análisis del riesgo es un proceso interactivo entre sus tres componentes, estos principios del Codex sobre los riesgos evitan una separación conceptual tajante entre las fases técnica y política del análisis del riesgo, la cual puede tender a un ocultamiento de las bases valorativas

38 ORGANIZACIÓN DE LAS NACIONES UNIDAS PARA LA AGRICULTURA Y LA ALIMENTACION. Comisión Del Codex Alimentarius: Manual de Procedimiento. 10. ed. Roma: FAO/OMS, 1997.

39 ORGANIZACIÓN DE LAS NACIONES UNIDAS PARA LA AGRICULTURA Y LA ALIMENTACION. Comisión Del Codex Alimentarius: Manual de Procedimiento. 20. ed. Roma: FAO/ OMS, 2011. En el año 2003 la Comisión del Codex Alimentario aprueba una "Declaración completa de Principios de Aplicación Práctica para el Análisis de Riesgos en Materia de Inocuidad de los Alimentos y Salud" que es incorporada al Manual de Procedimiento de la Comisión del Codex Alimentarius. En 2007 se completan los "Principios prácticos sobre el análisis de riesgos para la inocuidad de los alimentos aplicables por los gobiernos" (CAC/GL 62-2007).

40 El Manual de Procedimientos del Codex establece (entre los Principios de aplicación práctica para el análisis de riesgos...) que "entre la evaluación de los riesgos y su gestión debe existir una separación funcional a fin de garantizar la integridad cientifica de la evaluación de riesgos, evitar la confusión entre las funciones que deben desempeñar los evaluadores de riesgos y los encargados de la gestión de los mismos, y atenuar cualquier conflicto de intereses. No obstante, se admite que el análisis de riesgos es un proceso iterativo y que, para su aplicación práctica es esencial que exista una interacción entre los encargados de la gestión de riesgos y los evaluadores de riesgos" ORGANIZACIÓN DE LAS NACIONES UNIDAS PARA LA AGRICULTURA Y LA ALIMENTACION. Comisión Del Codex Alimentarius: Manual de Procedimiento. 20. ed. Roma: FAO/OMS, 2011. que sustentan las decisiones al interior de la fase de evaluación. Sin embargo, la división entre evaluación y gestión permanece y esto puede obscurecer aún algunas particulares elecciones de valor ${ }^{41}$.

La aplicación del análisis de riesgos se convierte en "la base de todo sistema de inocuidad de los alimentos" según FAO que promueve su implementación también al interior de las estructuras nacionales de control de los alimentos, pues

ofrece a los gobiernos un marco para evaluar,
gestionar y comunicar con eficacia los riesgos
relativos a la inocuidad de los alimentos en
colaboración con las distintas partes interessadas. ${ }^{42}$

El poder del régimen comercial y su delegación de autoridad en la Comisión del Codex Alimentarius por parte de la $\mathrm{OMC}$, le permitió a éste definir parámetros de ciencia adecuados para la regulación comercial. En un movimiento circular que se retroalimentaba, mientras

la OMC se encargó de su problema de legitimidad
jurídica y económica identificando una base de
confianza común en el rigor científico y en la
expertise internacional existente, el Codex se
encargó de las cuestiones difíciles sobre el rol de
la ciencia en el proceso regulatorio mediante la
legitimación recibida de la OMC. ${ }^{43}$

La formación de un nuevo régimen de riesgos alimentarios formalizado significó una estrategia de purificación y delimitación que el Codex necesitaba para sustentarse con su nueva autoridad otorgada por los acuerdos de $\mathrm{OMC}^{44}$. Esta demarcación de límites

41 WINICKOFF, David E.; BOUSHEY, Douglas. Science and Power in Global Food Regulation: the Rise of the Codex Alimentarius. Science, Technology, \& Human Values, v. 35, n. 3, p. 356-81, 2010.

42 ORGANIZACIÓN DE LAS NACIONES UNIDAS PARA LA AGRICULTURA Y LA ALIMENTACION. Fortalecimiento de Los Sistemas Nacionales de Control de Los Alimentos: Directrices Para Evaluar Las Necesidades de Fortalecimiento de La Capacidad. Roma: FAO, 2007.

43 WINICKOFF, David E.; BOUSHEY, Douglas. Science and Power in Global Food Regulation: The Rise of the Codex Alimentarius. Science, Technology, \& Human Values, v. 35, n. 3, p. 35681, 2010. p. 362.

44 En relación a la nociones de purificación y "boundry work", los autores se remiten a la obra de Jasanoff. JASANOFF, Sheila. The fifth branch: science advisers as policymakers. Harvard: Harvard University Press, 1994. Pueden verse también interesantes explicaciones en LATOUR, Bruno. Nunca fuimos modernos: Ensayo de antropología simétrica. Buenos Aires: Siglo XXI, 2007. También en LEIGH STAR, Susan; GRIESEMER, James. Institutional Ecology, 'Translations' and Boundary Objects: Amateurs and Professionals in 
ayudó a estabilizar su postura sobre las relaciones de política científica, facilitando la rápida formulación de los estándares.

\subsection{La implementación de Sistemas Nacionales de Control Alimentario}

La otra tecnología de estandarización que compone el régimen global alimentario es la noción de Sistema Nacional de Control Alimentario (SNCA). Se trata de una técnica de homogenización de las legislaciones de control de alimentos promovida por organismos internacionales -fundamentalmente FAO y OMS- que desarrollan acciones para la uniformización de los parámetros de control de alimentos en las estructuras institucionales de gobierno nacionales encargadas de la administración y fiscalización alimentaria. Así, FAO considera que

\footnotetext{
para garantizar la inocuidad de los alimentos y proteger a los consumidores es imprescindible que haya sistemas nacionales de control de los alimentos que sean eficaces, con una base oficial y de carácter obligatorio ${ }^{45}$.
}

Se ha puesto especial interés en la producción de indicaciones y consejos sobre la instalación y fortalecimiento de estos sistemas especialmente para países latinoamericanos y del Caribe, mediante una serie de publicaciones (manuales, guías y directrices) que detallan los pasos para evaluar las necesidades de fortalecimiento de la capacidad del sistema, con claves y sugerencias para la instalación de las herramientas de política, gestión, evaluación, etc. En estas guías y recomendaciones ${ }^{46}$ se precisan los componentes mínimos que debe tener un sistema de control de

Berkeley's Museum of Vertebrate Zoology, 1907-39. Social Studies of Science, v. 19, n. 3, p. 387-420, 1989.

45 ORGANIZACIÓN DE LAS NACIONES UNIDAS PARA LA AGRICULTURA Y LA ALIMENTACION. Sistemas de control alimentario. Disponível em: <http://www.rlc.fao.org/es/ temas/inocuidad/sistemas-de-control-alimentario/>. Se explica la necesidad de los países de crear o fortalecer sus sistemas de control de los alimentos por dos razones fundamentales: las obligaciones impuestas por el "entorno mundial del comercio de productos alimenticios", y un "interés sin precedentes" de los consumidores acerca de la producción, elaboración y comercialización de los alimentos. Los sistemas de control de alimentos se presentan como "decisivos" pues, de acuerdo a este discurso global, son los únicos capaces de garantizar la inocuidad y la calidad de los alimentos destinados al comercio internacional y a la vez asegurar a cada país que los alimentos importados se atienen a los requisitos nacionales.

46 ORGANIZACIÓN DE LAS NACIONES UNIDAS PARA LA AGRICULTURA Y LA ALIMENTACION alimentos: 1) legislación alimentaria, 2) inspección de los alimentos, 3) análisis (practicados en laboratorios oficiales), 4) gestión del control de los alimentos, e 5) información, educación y comunicación.

Dos piezas fundamentales en la arquitectura de los SNCA son las agencias de asesoramiento e investigación científica y la proliferación de ciertas metodologías de autocontrol por parte de los sujetos obligados a cumplir con la normativa alimentaria. Las agencias alimentarias, tales como la AESA Autoridad Europea de Seguridad Alimentaria-, la FDA norteamericana-Food and Drug Administration -, la brasilera ANVISA -Agencia Nacional de Vigilância Alimentaria- o la argentina ANMAT- Administración Nacional de Medicamentos, Alimentos y Tecnología Médica- son organismos que pueden cumplir un amplio rango de funciones, pero generalmente se caracterizan por brindar el asesoramiento experto para la toma de decisiones estatales en la etapa de evaluación del riesgo alimentario.

A pesar de ser comúnmente utilizado en relación a las administraciones nacionales, el término "agencia" es ambiguo. En el caso de las agencias alimentarias, puede referir a cuerpos de inspección y policía, otras proveen principalmente consejo a otras instituciones gubernamentales y/o realizan investigaciones científicas y evaluaciones de riesgo, además, pueden tener diferentes relaciones con el gobierno central, poder sancionador, poder legislador, etc. Por ello, el mero uso del término agencia no significa que se trate del mismo tipo de instituciones, a pesar que sean similares ${ }^{47}$.

A través de la expansión y desarrollo del Codex Alimentarius

muchos estados han reconocido la necesidad de crear agencias alimentarias domésticas para supervisar la implementación de las mejores prácticas, o al menos, una aceptable versión de las mismas. ${ }^{48}$

Si embargo, mientras que a los países en desarrollo se les difunden rigurosos catálogos prediseñados conteniendo los "moldes" a que deben ajustarse los instrumentos, herramientas, criterios, etc. necesarios para instalar o fortalecer su SNCA, los países desarrollados crean o modifican sus instituciones de

47 HELLEBO RYKKJA, Lise. Food Safety at Stake - the Establishment of Food Agencies. Working Paper. Stein Rokkan Centre for Social Studies. Unifob AS, 2004.

48 MAC MAOLÁIN, Caoimhín. EU Food Law: Protecting Consumers and Health in a Common Market. Hart, 2007. p.152. 
control alimentario libremente y a la medida de sus propias necesidades (las cuales más tarde suelen servir de modelo que recogen los manuales y recomendaciones de los organismos internacionales). Así, los EE.UU., los países de la Unión Europea y la propia Unión Europea como bloque supranacional han modificado sus estructuras institucionales de control alimentario en respuesta a crisis alimentarias que pusieron en evidencia irregularidades en el modo de control de los alimentos, generando una desconfianza generalizada y un reclamo público por seguridad 4 . Pero las "nuevas" regulaciones e instituciones de control responden criterios endógenos en tanto los gobiernos de países desarrollados tienen la capacidad de diseñar (y aplicar) las reformas einstituciones a la medida de las experiencias sufridas y con el objetivo de resolver problemas locales, moldeados por factores culturales, económicos, sociales, geopolíticos, etc.

Así, mientras la regulación norteamericana recientemente modificada (Food Safety Modernization Act, sancionada en 2010) prioriza la seguridad nacional y alza como objetivo central a la prevención y persecución del "bioterrorismo" ${ }^{50}$, la Unión Europea construyó su política alimentaria con el objetivo de recuperar la confianza de la población europea en los mecanismos de control a nivel supranacional ${ }^{51}$. Una de las mayores innovaciones institucionales que se diseñaron como consecuencia de los reclamos post crisis fue la creación de una Agencia Europea de Seguridad Alimentaria, que respondía a la necesidad de separación de la intervención de "ciencia" y la decisión "política" en el proceso de toma de decisiones sobre el riesgo alimentario. ${ }^{52}$ La regulación alimentaria surgida

49 LIN, Ching-Fu. Global Food Safety: Exploring Key Elements for an International Regulatory Strategy. Virginia Journal of International Law, v. 51, n. 3, p. 637, 2011.

50 COATES, Allison; BOUKHMAN TROUNCE, Milana. FDA Food Safety Modernization Act: Is It Enough?”. Journal of Bioterrorism and Biodefens, v. 2, p. 119, 2011. FORTIN, Neal D. The United States FDA Food Safety Modernization Act: The Key New Requirements. European Food \& Feed Law Review, v. 5, p. 260-68, 2011. STRAUSS, Debra. An Analysis of the FDA Food Safety Modernization Act: Protection for Consumers and Boon for Business. Food and Drug Law Journal, v. 66, n. 3, p. 353-76, 2011.

51 Además, la UE reconoce expresamente en la regulación legal alimentaria al polémico principio precautorio. ALEMANNO,

52 BOOTH, Simon. Conflicting Approaches to Risk Management: Recent Trends in the BSE Crisis. Journal of Contingencies and Crisis Management, v. 6, n. 4, p. 214-23, 1998. MARICHAL, María Eugenia. Las Crisis Como 'catalizadoras' Del Derecho: El Caso de Las Recientes Crisis Alimentarias En La Unión Europea Y La Instauración Del Concepto de Seguridad Alimentaria. Revista Crítica de Derecho Privado. La Ley Uruguay, 2010. p.7. NOT the Last Word on the BSE Crisis. Nature, v. 389, p. 423, 1997. VINCENT, Keith. Mad Cows en Europa luego de haber atravesado un período de crisis alimentarias se ha convertido en uno de los modelos de regulación cuyos dispositivos se exportan, algunos a través de las imposiciones de esa región a sus socios comerciales (convergencia).

La segunda pieza estratégica de los SNCA (además de las agencias) que pueden encontrarse en las Directrices de FAO y OMS es la integración de las tradicionales disposiciones obligatorias del control de los alimentos con "estrategias preventivas y educativas que protejan toda la cadena alimentaria", a través de métodos preventivos como el mundialmente conocido sistema HACCP, por sus siglas en el idioma inglés "Hazard Analysis of Critical Control Points", que se traduce como "Análisis de Riesgos y de los Puntos Críticos de Control". Este tipo de métodos suponen dispositivos integradores de todos los agentes que participan de la cadena alimentaria, desde "la granja a la mesa". ${ }^{54}$

and Eurocrats -Community Responses to the BSE Crisis. European Law Journal, v. 10, n. 5, p. 499-517, 2004. RECUERDA GIRELA, Miguel. Dangerous Interpretations of the Precautionary Principle and the Foundational Values of European Union Food Law: Risk Versus Risk. Food Law \& Policy, v. 4, n. 1, p. 1-44, 2008. RODRIGUEZ FONT, Mariola. Régimen Jurídico de la Seguridad Alimentaria: De la Policía Administrativa a la Gestión de Riesgos. Marcial Pons, 2007.

53 Un claro ejemplo de esta exportación es el dispositivo de la trazabilidad, una herramienta de gestión que facilita la retirada de alimentos, permite a los consumidores tener información más precisa y promueve el comercio justo entre los operadores. Por ejemplo, la trazabilidad de las carnes vacunas, la miel o los cítricos está regulada en Argentina para los productos de exportación, debido a exigencias del mercado Europeo (Reglamento 178/2000). La Resolución 231/2002 de la Secretaría de Agricultura, Ganadería, Pesca y Alimentos crea el "Sistema Argentino de Trazabilidad para el Sector Agroalimentario, orientado a identificar mediante registros escritos o electrónicos el origen o el estado sanitario de un producto o producción agropecuaria nacionaly dar conformidad a los alimentos resultantes". Dicha resolución reconoce en sus considerandos "...que los paises competidores o compradores de nuestros productos han promovido la actualización de los sistemas de identificación, identidad preservada y trazabilidad", por lo cual "la competitividad de los productos agroalimentarios se puede ver afectada por disposiciones de países compradores que estipulan que los procedimientos y criterios en los países de origen deben ser equivalentes a los fijados en el país comprador, siendo un caso claro y objetivo las exigencias impuestas por Unión Europea para la carne bovina". Sobre trazabilidad alimentaria en Argentina ver, entre otros: VICTORIA, Adriana. Producción Alimentaria, Aspectos Ambientales, Técnicos Y Jurídicos. Santiago del Estero: UNSE, 2006. VICTORIA, Adriana. Trazabilidad de La Carne de Vacuno En Argentina Y El Derecho Comparado. Revista Del Instituto de Derecho Agrario de Rosario, 2002. BONET DE VIOLA, Ana María. De La Marca de Fuego Al Chip. Genealogía de La Trazabilidad Como Sistema de Seguimiento de Los Productos de Consumo. Papeles Del Centro de la Facultad de Ciencias Jurídicas y Sociales, v. 3, n. 10, p. 7-22, 2013. p. 3.

54 La FAO aconseja la incorporación de estos mecanismos preventivos mediante reglamentos complementarios (directrices relativas a la inspección) y no a través de la legislación general. La implementación de este tipo de control en los establecimientos requiere grandes inversiones, tanto en equipos como en recursos humanos. Estos costos se justifican en el caso de grandes empresas, sobre todo aquellas que exporten a países que exigen estos sistemas de 
El sistema HACCP fue diseñado por expertos de las agencias de control sanitario de los Estados Unidos para aumentar la seguridad alimentaria en la manipulación y tratamiento de la carne vacuna en los $90^{55}$. Fueron incorporados al Codex Alimentarius a propuesta de su Comité de Higiene de los Alimentos (CCFH). Los principios del HACCP se institucionalizaron globalmente a través de las directrices del Comité del Codex sobre Higiene de los Alimentos que adoptaron esta estructura creada para identificar y controlar riesgos transmitidos por alimentos ${ }^{56}$.

Se entiende que la actividad de control desde el Estado, por sí sola, no puede alcanzar plenamente los objetivos de la seguridad alimentaria, lo que torna imprescindible la "cooperación y participación activa de todas las partes interesadas, por ejemplo, los agricultores, la industria y los consumidores"57. Con lo cual se promueve una progresiva privatización y descentralización del control alimentario, estrategia de base neoliberal, acompañada por tendencia a descargar la responsabilidad también en el propio consumidor, limitando la actividad protectoria del Estado y el mercado a brindar una información adecuada (por medio de un correcto etiquetado, fundamentalmente) lo cual se asume suficiente dado que se entiende que éste elegirá racionalmente. ${ }^{58}$

control (por lo cual su adopción se convierte en vinculante) pero no es conveniente imponer el sistema en forma obligatoria a pequeñas y medianas empresas, pues la dificultad de absorber esos altos costos las colocaría en una situación de desventaja respecto de las empresas de mayor magnitud. FAO \& OMS. Garantía de La Inocuidad Y Calidad de Los Alimentos: Directrices Para El Fortalecimiento de Los Sistemas Nacionales de Control de Los Alimentos. Estudio FAO/OMS: Alimentación y Nutrición, 2003. p.76.

55 HULEBAK, Karen; SCHLOSSER, Wayne. Hazard Analysis and Critical Control Point (HACCP) History and Conceptual Overview. Risk Analysis, v. 22, n. 3, p. 547-52, 2002.

56 Codex Alimentarius. Directrices Para La Aplicación Del Sistema de Análisis de Riesgos Y de Los Puntos Críticos de Control (HACCP). Anexo de CAC/RCP 1-1969, 1997.

57 Este enfoque "ha conseguido que el sector privado asuma una mayor responsabilidad de los riesgos para la inocuidad de los alimentos y de su control". Según la FAO, esto "facilita una mayor protección del consumidor, estimula eficazmente la agricultura y el sector de la elaboración de los alimentos y promueve el comercio nacional e internacional de alimentos". ORGANIZACIÓN DE LAS NACIONES UNIDAS PARA LA AGRICULTURA Y LA ALIMENTACION. Garantía de La Inocuidad Y Calidad de Los Alimentos: Directrices Para El Fortalecimiento de Los Sistemas Nacionales de Control de Los Alimentos. Estudio FAO/OMS. Alimentación y Nutrición, 2003. p. 76.

58 Esta tendencia hacia un derecho alimentario "reflexivo" parece promover una mayor atribución de libertad y poder a los individuos, lo cual en principio podría pensarse como un proceso democratizador. Sin embargo, dado que en los contextos de países periféricos (a diferencia de los procesos operados en los países centrales) la tendencia hacia la racionalidad reflexiva se
Estas tendencias en la regulación alimentaria, hacia un derecho reflexivo ${ }^{59}$ hacia formas de autorregulación y co-regulación son comprensibles como traducciones en el campo del derecho de las formas regulatorias que promueve una agencia global (Comisión del Codex Alimentarius) que es un caso ejemplar de gobernanza global ${ }^{60}$.

\section{Algunas problemas y límites del régimen global alimentario}

La normativa global alimentaria actúa como un poderoso instrumento de estandarización que opera silenciosamente a través de las recomendaciones, directrices, estándares, normas y códigos de prácticas construidos, difundidos y promovidos por el aparato experto de la Comisión del Codex Alimentarius, que desde la creación de la OMC y la existencia del Acuerdo MSFS (1995) se ha convertido en una agencia regulatoria global. Con un respaldo de legitimidad científica (dado por sus propia estructura, funcionamiento y proceso de toma de decisiones basado en la ciencia) necesaria para sortear las dificultades políticas que presentaba el AMSFS, el Codex Alimentarius fue señalado como uno de los puntos de referencia para determinar la legalidad de las medidas sanitarias y fitosanitarias. A su vez, la explícita indicación del Codex Alimentarius en el AMSFS dotó a la normativa elaborada por la Comisión del Codex de una legitimidad política que aumentó el interés de los países miembros en la participación en el proceso de toma de decisiones, en el cual se han filtrado valores e intereses políticos, sociales y económicos.

La regulación del AMSFS (junto con otros acuerdos vinculados a la cuestión alimentaria) contiene los elementos constitucionales básicos del régimen global alimentario. Junto a él, y por directa referencia a sus

manifiesta casi exclusivamente en una orientación procedimental de los Sistemas nacionales de control de alimentos que incorporan herramientas procedimentales con el objeto de facilitar la apertura al comercio internacional de alimentos.

59 TEUBNER, Gunther. Global Bukowina: Legal Pluralism in the World Society in Global Law without a State. Dartmouth, 1997. p. 3-28. TEUBNER, Gunther. Elementos Materiales Y Reflexivos En El Derecho Moderno. In: La Fuerza Del Derecho. Colombia: Uniandes, 2000.

60 Siguiendo a Lima, entendemos que los conceptos de derecho reflexivo, pluralismo jurídico, co-rregulación y autorregulación reflejan la noción de gobernanza global, traduciendo sus significados al lenguaje jurídico. LIMA, Gabriela. Reflexões epistemológicas de teoria das relações internacionais e teoria do direito: governança global, regimes jurídicos, legitimidade, efetividade, direito reflexivo, pluralismo jurídico, coregulação e autoregulação. Revista de Direito Internacional, v. 11, n. 1, p. 215-28, 2014. 
guías, directrices y recomendaciones, la regulación del Codex Alimentarius completa ese régimen, reuniendo los caracteres de constitución global de un sector fragmentado: la regulación de los alimentos, vinculada a los subsistemas social, científico y económico.

La normativa global alimentaria constituye un caso de constitución global parcial indica los actores y grupos de actores más relevantes, entrona un discurso y un lenguaje específicos (la ciencia) para el gobierno del sector regulado (los alimentos) tomando de allí, del entorno del derecho, la base para la regulación positivizada.

Indagar las características más relevantes del régimen constitucional global alimentario y las estrategias de armonización normativa de los organismos internacionales permite evaluar el margen de autonomía que resta a los Estados nacionales en el diseño y aplicación de sus políticas y regulaciones de la cuestión alimentaria.

La adopción del riesgo como única gramática dominante en la regulación global de los alimentos opera como factor limitante, no sólo del poder de los Estados nacionales, sino de algunos grupos sociales que pueden tener intereses legítimos en la regulación de la cuestión alimentaria ${ }^{61}$. El discurso del riesgo implícitamente "empodera" algunas personas consideradas expertos, mientras que margina a otras considerándolas irrelevantes ${ }^{62}$. Los países en desarrollo y los consumidores son los dos grandes grupos a los cuales les es muy difícil "expresar sus intereses en el discurso del riesgo". Los primeros, "... debido a la falta de acceso a equipos de medición y otras tecnologias de cuantificación", que les impiden investigar y documentar el riesgo según los exigentes parámetros de la comunidad experta internacional de modo de poder plantear situaciones endógenas en los foros internacionales de producción normativa o en caso de conflicto, en las cortes arbitrales

61 El principio de armonización impulsado por la OMC genera diversas opiniones "entre quienes pugnan por la liberalización del comercio, por un lado, y grupos ambientalistas y de consumidores, por el otro". Mientras que "los primeros ven las políticas reglamentarias nacionales como posibles obstáculos al libre comercio. Los últimos, en cambio, cuestionan que la armonización limita la soberanía política en materia de reglamentación nacional, dificultando la adopción de normas más estrictas que las vigentes en los países exportadores en áreas tales como protección ambiental e inocuidad alimentaria". LEAVY, Sebastián; SÁEZ, Francisco. Debilidades en la armonización de medidas sanitarias y fitosanitarias en el MERCOSUR. Densidades, n. 5, p. 22, 2010. .

62 JASANOFF, Sheila. Risk Management and Political Culture: A Comparative Study of Science in the Policy Context. Russell Sage Foundation. 1986. JASANOFF, Sheila. Relating Risk Assessment and Risk Management. EPA Journal, v. 19, n. 1, p. 35, 1993. de la OMC. Además, esta escasez de recursos los coloca en una situación de cautivos de las recetas y modelos difundidos por los organismos internacionales en lo que respecta al diseño de su institucionalidad (SNCA). En relación a los consumidores,

debido a la dificultades para encuadrar preocupaciones culturales, religiosas y de otros tipos no estrictamente relacionadas a la seguridade. ${ }^{63}$

La adopción del marco del análisis de riesgo tiende a suplantar otros encuadramientos posibles y ha marginalizado potenciales factores en la regulación alimentaria tales como los ambientales u económicos ${ }^{64}$.

El gran riesgo del régimen global alimentario es que su forma de operar y su lógica subyacente pueden limitar las "posibilidades de preservar en el plano internacional los valores sociales, culturales y ambientales" ${ }^{\prime \prime}$. Esta exclusión de lo cultural en la escena del régimen global alimentario es grave si consideramos que, tal como los estudios antropológicos de los alimentos desde largo tiempo han demostrado ${ }^{66}$ la alimentación es, esencialmente, un hecho social.

63 WINICKOFF, David E.; BOUSHEY, Douglas. Science and Power in Global Food Regulation: The Rise of the Codex Alimentarius. Science, Technology, \& Human Values, v. 35, n. 3, p. 356-381, 2010. p. 364.

64 SHIVA, Vandana. Derecho a La Alimentación, Libre Comercio Y Fascismo. In: GIBNEY, Matthew. La Globalización de Los Derechos Humanos. Crítica. España, 2003.

65 Las decisiones del Órgano de Solución de Diferencias de la OMC dan testimonio de "la impermeabilidad del sistema jurídico internacional a los valores no comerciales invocados por los miembros y, principalmente, por la Unión Europea", lo cual se advierte puede conducir al "rechazo de este sistema jurídico mundial, puramente comercial, por parte de las poblaciones y engendrar así, tensiones, conflictos y violencia(s)". COLLART-DUTILLEUL, Francois. El nuevo derecho agroalimentario europeo a la luz de las problemáticas de la seguridad alimentaria, del desarrollo durable y del comercio internacional. $7^{\circ}$ Programa-Marco. IDEES, 2008. Esta exclusión de lo cultural en la escena del régimen global alimentario es grave si consideramos que, tal como los estudios antropológicos de los alimentos desde largo tiempo han demostrado, la alimentación es esencialmente un hecho social. AGUIRRE, Patricia. La construcción social del gusto en el comensal moderno. In: KATZ, Mónica; BRUERA, Matías; AGUIRRE, Patricia. Comer: Puentes entre la alimentación y la cultura. Libros del Zorzal, 2009. p. 15-60. FISCHLER, Claude. Gastro-Nomía Y Gastro-Anomía. Sabiduría Del Cuerpo Y Crisis Biocultural de La Alimentación Moderna. Gazeta de Antropologia, n. 26, 2010. GOODY, Jack. Cocina, cuisine y clase: estudio de sociología comparada. Gedisa, 1995.

66 AGUIRRE, Patricia. La construcción social del gusto en el comensal moderno. In: KATZ, Mónica; BRUERA, Matías; AGUIRRE, Patricia. Comer: Puentes entre la alimentación y la cultura. Libros del Zorzal, 2009. p. 15-60. FISCHLER, Claude. Gastro-Nomía Y GastroAnomía. Sabiduría Del Cuerpo Y Crisis Biocultural de La Alimentación Moderna. Gazeta de Antropología, n. 26, 2010. GOODY, Jack. Cocina, cuisine y clase: estudio de sociología comparada. Gedisa, 1995. 


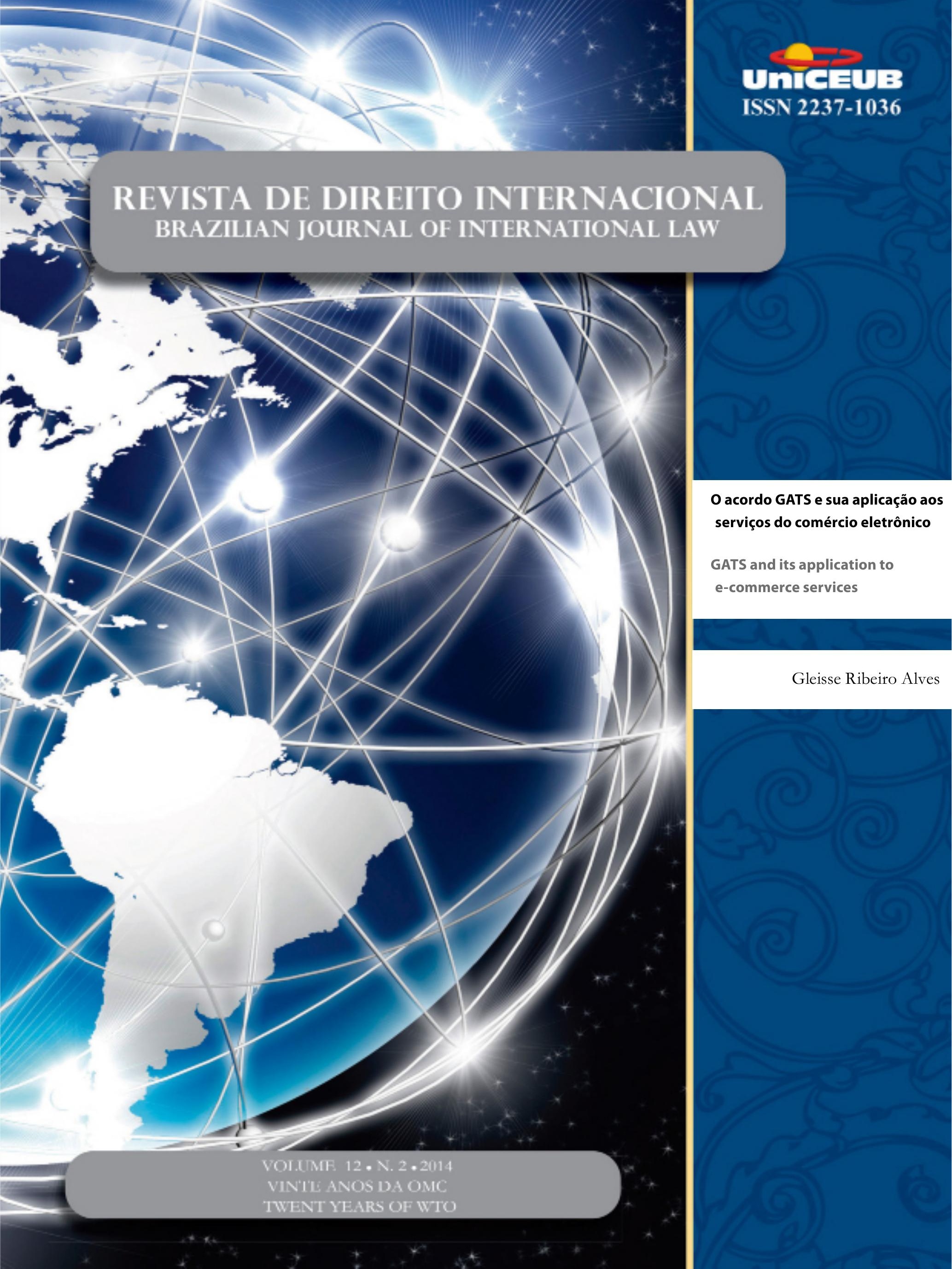




\title{
O acordo GATS e sua aplicação aos serviços do comércio eletrônico*
}

\section{GATS and its application to e-commerce services}

\author{
Gleisse Ribeiro Alves**
}

\section{Resumo}

O Objetivo do presente artigo é verificar a aplicação do Acordo de Serviços (GATS) da Organização Mundial do Comércio (OMC) às atividades realizadas no ambiente eletrônico. Dessa forma, primeiro abordaremos como o tema comércio eletrônico foi analisado pela OMC e quais dispositivos legais da OMC são aplicáveis ao comércio eletrônico. Apresentaremos as conclusões dos Grupos de Trabalho da OMC definindo que o GATS é o Acordo que possui maior ligação com os temas relacionados ao comércio na internet. Em seguida, demonstraremos a aplicação dessas conclusões apresentando as decisões emanadas pelo Órgão de Solução de Controvérsias (OSC) da OMC que aplicaram o GATS aos serviços do comércio eletrônico, tais como os casos EUA-Jogos (DS285); China-Publicações eletrônicas e serviços audiovisuais (DS363); China-Serviços de pagamento eletrônico (DS413). Embora ainda se tenha poucos litígios envolvendo temas do ambiente eletrônico, é possível inferir e concluir que a maioria dos dispositivos legais da OMC são adaptados para o ambiente eletrônico. Contudo, como também ocorre nas demais áreas, a implementação das decisões é altamente dependente da ação dos Estados, que necessitam de tempo para negociar. Também é possível concluir que existe, no âmbito dos litígios no ambiente eletrônico, um comprometimento dos Estados na implementação das decisões emanadas pelo Órgão de solução de controvérsias, em suma, os Estados preferem respeitar as decisões do OSC e manter a legitimidade do sistema como um todo. Dessa forma, o presente artigo é inovador ao demonstrar as adaptações e aplicações dos dispositivos da OMC aos serviços do comércio eletrônico.

Palavras-chave: Acordo de Serviços (GATS); Serviços do comércio eletrônico; Órgão de Solução de Controvérsias (OSC).

\section{Abstract}

This article aims at verifying the suitability of World Trade Organization's (WTO) General Agreement on Trade in Services (GATS) to activities performed within the electronic environment. Therefore, first topic to be considered is how the so-called e-commerce has been analyzed by WTO and which of its legal provisions are applicable to such commerce. There will be presented, herein, some WTO Working Groups' conclusions reporting that GATS is the most suitable agreement for e-commerce and related topics in internet. In the sequence, the employment of such conclusions will be demonstrated by upholding decisions issued by the WTO's Dispute Settlement Body (DSB). This board has set GATS to e-commerce's services - as seen in cases such as EUA - a Gambling (DS285); China - Publications and Audiovisual Products (DS363); China - Electronic Payment Services (DS413). Although there are only a few disputes on electronic

\footnotetext{
** Doutora em Direito (Université Nancy 2). Professora do Programa de Mestrado em Ciência Política do Centro Universitário e do Centro Universitário de Brasília. CV Lattes: http://lattes. cnpq.br/2226009228595251; gleisse@ yahoo.com

yahoo.com
}

* Recebido em 31.10.2014 Aceito em 03.12.2014 
environment matters, it is possible to infer and conclude that most of WTO's legal provisions are adapted for the electronic environment. Nonetheless, as it also occurs in other areas, implementation of decisions is highly dependent on the action of country leaders, who require more time to negotiate. It is also possible to conclude that, concerning electronic environments, governments are committed to implement DSB decisions. In short, they prefer to uphold DSB's verdicts and maintain the system legitimacy. On these considerations, this article is an innovative piece of work as it demonstrates how to adapt and to apply WTO's rules to e-commerce services.

Keywords: General Agreement on Trade in Services (GATS); E-commerce Services; Dispute Settlement Body (DSB)

\section{Introdução}

$\mathrm{Na} \mathrm{OMC}$ não existe uma regra específica sobre o comércio eletrônico. Para a OMC, a primeira referência ao comércio eletrônico ocorreu na Conferência Ministerial em Genebra em 1998, onde foi estabelecido um Grupo de Trabalho sobre Comércio Eletrônico. Esse Grupo, ao longo dos anos, tem se dedicado às questões relativas a este tipo de negócio, tais como a aplicação dos aspectos técnicos, econômicos, políticos e jurídicos no ambiente eletrônico'. De acordo com a OMC, o termo "comércio eletrônico" envolveu uma ampla gama de atividades diferentes: como "meios de produção, distribuição, comercialização, venda ou entrega de bens e serviços por meios eletrônicos"”.

No âmbito do Grupo de Trabalho sobre Comércio Eletrônico, os países membros chegaram a um consenso de que os vários acordos da OMC com todos os seus direitos, obrigações e compromissos específicos são aplicáveis ao comércio eletrônico, porque eles não diferenciam o meio pelo qual os produtos são entregues. Os países membros, em particular, descobriram que os diversos temas relacionados ao comércio eletrônico

1 O Grupo de Trabalho sobre comércio eletrônico organizou em 2013 workshop para fomentar as discussões e estudos sobre os temas discutidos no grupo. Mais detalhes ver: Workshop on Electronic Commerce, Geneva, 17-18 june 2013. Disponível em: <http://www.wto.org/english/tratop_e/serv_e/wkshop_ june13_e/wkshop_june13_e.htm>.

2 Work programme on electronic commerce. Adopted by the General Council on 25 September 1998 - WT/L/274 (30/09/1998). Disponível em: <https://docsonline.wto.org/dol2fe/Pages/ FormerScriptedSearch/directdoc.aspx?DDFDocuments/t/ WT/L/274.DOC.> têm ligação com os vários acordos e grupos de trabalho da OMC. Outro aspecto importante do Grupo de Trabalho sobre Comércio Eletrônico foi a determinação da moratória digital de modo que seja mantida a não imputação de tarifas, quotas ou regulamentos discriminatórios sobre o comércio eletrônico.

Os membros da OMC não chegaram a um acordo sobre a classificação do tipo de comércio realizado pela internet: se ele é classificado como bem ou serviço. É importante estabelecer essa resposta, tendo em vista que essa definição identificará se o comércio realizado estará sujeito ao GATT (bens), ou GATS (serviços). Além da aplicação dos Acordos GATT e GATS $^{3}$, alguns membros da $\mathrm{OMC}^{4}$ defendem que o comércio na internet deve ser regulamentado também pelo Acordo TRIPS porque deve-se regulamentar a propriedade do bem e não a forma como o produto chegará ao consumidor. Para fomentar mais discussões e estudos sobre o comércio eletrônico, a OMC tem realizado diversas cooperações e estudos com outras organizações internacionais, como por exemplo, a OCDE $^{5}, \mathrm{UNCITRAL}^{6}, \mathrm{OMPI}^{7}$.

Dessa forma, vários estudos sobre o comércio eletrônico foram organizados no âmbito da OMC para

3 O GATS, resultado das negociações multilaterais comerciais do Ciclo do Uruguai, quando entrou em vigor em 1995, foi o primeiro acordo multilateral sobre o comércio de serviços. O GATS é produto de uma negociação longa e difícil, realizada entre um grande número de países, tanto desenvolvidos como em desenvolvimento. Assim, trata-se de um acordo complexo e detalhado. O GATS abrange um amplo campo de aplicação, na medida em que a maioria das medidas impostas pelos governos - nacional, regional e local- que afetam o comércio de serviços, com exceção dos serviços prestados no exercício da autoridade governamental e certos setores específicos, como o serviço de transporte aéreo, são cobertas pelo Acordo. Entretanto, são poucas as obrigações dirigidas a todas as medidas que afetam o comércio de serviços, destacam-se entre elas a obrigação de tratamento MFN e obrigações de transparência. Outras obrigações fundamentais, como por exemplo acesso à mercado e tratamento nacional, se aplicam somente para os Membros que se comprometeram em suas listas de compromissos específicos relativos à um setor de serviços particular. Cf. STEGER, Debra. Curso de Solução de Controvérsias em Comércio Internacional, Investimento e Propriedade Intelectual: módulo 3.13 GATS. Genebra, Nações Unidas (UNCTAD), 2003, p.3 [Online]. Disponível em : < http://unctad.org/pt/docs/edmmisc232add31_ pt.pdf. $>$ Acesso em: 21 set. 2014.

4 Por exemplo Cingapura e Indonésia.

5 ORGANIZAÇÃO PARA COOPERAÇÃO DESENVOLVIMENTO ECONÔMICO.

6 COMISSÃO DAS NAÇÕES UNIDAS PARA O DIREITO DO COMÉRCIO INTERNACIONAL.

7 ORGANIZAÇÃO MUNDIAL DE PROPRIEDADE INTELECTUAL. 
verificar, entre os acordos constitutivos da organização, qual o mais adequado para regular o comércio eletrônico. Cada Conselho e Grupo de Trabalho analisou os aspectos do comércio eletrônico de acordo com os seus documentos específicos. O Conselho para o Comércio de Bens (GATT) analisou os aspectos de acesso a mercados, regras de origem, barreiras técnicas ao comércio, entre outros. O Conselho para o Comércio de Serviços (GATS) está trabalhando na análise de obrigações e disciplinas gerais, mas também sobre os compromissos específicos em matérias de acesso a mercados e tratamento nacional, conforme especificados em cada uma das Listas de compromissos específicos dos Estados membros. Os copyrigths e novas tecnologias relacionadas com a internet são analisados pelo Conselho de direitos de propriedade intelectual relacionados com o comércio (TRIPS).

As pesquisas desenvolvidas pelos Grupos de Trabalhos defendem o argumento de que o Acordo GATS é o mais aplicável à regulamentação do comércio eletrônico, uma vez que as transações realizadas na internet são, na maioria dos casos, caracterizadas por serviços e que, entre os acordos constitutivos da OMC, o Acordo de Serviços - GATS é o mais adaptável. Essas pesquisas evoluíram principalmente depois de 2003 litígio Estados-Unidos-Jogos ${ }^{8}$, quando houve o primeiro conflito entre Estados membros envolvendo aspectos relacionados ao ambiente eletrônico. Dessa forma, pela primeira vez, um tema do ambiente virtual foi analisado pelo Órgão de Solução de Controvérsias da OMC (OSC).

Dessa forma, primeiro abordaremos como o tema comércio eletrônico foi analisado pela OMC, qual a classificação dos serviços do comércio eletrônico e quais dispositivos legais da OMC são aplicáveis ao comércio eletrônico (Parte I). Apresentaremos as conclusões dos Grupos de Trabalho da OMC, definindo que o GATS é o Acordo que possui maior ligação com os temas relacionados ao comércio na internet. Em seguida, demonstraremos a aplicação dessas conclusões apresentando as decisões emanadas pelo Órgão de Solução de Controvérsias (OSC) da OMC que aplicaram o GATS no comércio eletrônico (Parte II).

\section{A classificação dos serviços do comércio eletrônico}

8 (Estados Unidos - Jogos), Estados Unidos - Medidas que afetam o fornecimento transfronteiriço de serviços de jogos e apostas, Grupo Especial, WT/DS285/R adotado 10 novembro 2004, modificado em 2005 pelo Órgão de Apelação WT/DS285/ $\mathrm{AB} / \mathrm{R}$ e adotado dia 7 abril 2005.
A globalização do comércio de serviços tem promovido uma expansão dos meios de serviços de produção ${ }^{9}$ e, sobretudo, permitiu aos países a expansão de seu comércio e de mercados consumidores. Dessa forma, a classificação e harmonização dos serviços tornaram-se uma prioridade para as organizações internacionais. Nas últimas décadas, com o desenvolvimento das tecnologias de informação e comunicação, essa classificação tem-se tornado cada vez mais necessária para assim se atingir a harmonização dos tipos de serviços fornecidos no mercado. São esses estudos que irão orientar os comerciantes "na negociação de compromissos específicos sobre o comércio de serviços e, em seguida, no monitoramento do cumprimento destes compromissos resultantes para cada tipo de prestação de serviço. [...] As empresas privadas também precisam de informações para estar cientes das oportunidades oferecidas pela liberalização do comércio" ${ }^{10}$.

Para atingir este projeto, em 1970, os países concordaram com a necessidade de se criar uma classificação padrão dos produtos e serviços presentes no comércio internacional para assim se facilitar o intercâmbio internacional de bens e serviços. Em 1973, após a Conference of European Statisticians - CES tivemos uma primeira fase de harmonização com o desenvolvimento do sistema harmonizado (doravante “HS”). Em 1974, a Comissão de Estatística do Conselho Econômico e Social das Nações Unidas ${ }^{11}$

9 Vários dispositivos eletrônicos são utilizados, por exemplo, em campanhas eleitorais e políticas. Mais detalhes ver: BORGES, Helena. Manipulados pela internet. Isto é, v. 38, n. 2328, p. 64-69, 9 jul. 2014; TANG, Min; HUHE, Narisong. Alternative framing: the effect of the internet on political support in authoritarian China. International Political Science Review. v. 35, n. 5, p.559-576, nov. 2014; STEIN, Michael; TRENT, John. Electronic Democracy. Toronto: Barbara Budrich Publishers, 2012. NATIONAL BOARD OF TRADE. E-commerce - New Opportunities, New Barriers: a survey of e-commerce barriers in countries outside the EU, November 2012. Disponível em: <http://www.wto.org/english/tratop_e/serv_e/ wkshop_june13_e/ecom_national_board_e.pdf $>$

10 Manuel des Statistiques du commerce international des services, p. 13. Mais detalhes ver: OCDE. Commerce électronique engagements existants dans le cadre de l'AGCS pour la fourniture de services en ligne. 2000. Td/Tc/Wp(99)37/Final; MAMDOUH, Hamid. Services liberalization, negotiations and regulation: some lessons from the GATS experience. In: LIM, Aik Hoe; MEESTER, Bart De. WTO domestic regulation and services trade: puting principles into practice. New York: Cambridge University Press, 2014. p. 325-331.

11 The Statistical Commission oversees the work of the United Nations Statistics Division (UNSD) is a Functional Commission of the UN Economic and Social Council. Cf. <http://unstats.un.org/ unsd/statcom/commission.htm> 
utilizou o "HS" para estabelecer uma classificação dos produtos e serviços e assim criou-se o sistema de Classificação Central de Produtos (CPC) ${ }^{12}$. Em 1977, o Serviço de Estatística do Secretariado das Nações Unidas e o Serviço de Estatística das Comunidades Europeias $^{13}$ estabeleceram um grupo de trabalho conjunto. Esse grupo desenvolveu um sistema integrado de classificação das atividades comerciais e, assim, a Europa adotou o CPC como base para o desenvolvimento da Classificação Europeia dos Produtos por Atividade ${ }^{14}$, sendo mais detalhada, porém compatível com o $\mathrm{CPC}^{15}$.

A OMC também usou o CPC para a criação das Listas de compromissos que integram o GATS essencialmente o documento MTN.GNS/W/120 ${ }^{16}$. Essas Listas incluem

12 A Classificação Central de Produtos das Nações Unidas (Central Product Classification - CPC) é uma classificação detalhada de produtos e serviços e tem como objetivo fornecer um quadro harmônico de classificação de produtos e serviços que permita a realização de comparação. $\mathrm{Na}$ CPC todos os bens e serviços são abrangidos e são mutuamente exclusivos (um bem ou serviço específico só pode ser classificado em uma categoria do CPC). A CPC é dividido em "seções" (10) "Divisões (69) "grupos" (295), "Classes" (1050) e "subclasses" (1811). Cf. WT/DS285/AB/R $\$ 172$.

13 EUROSTAT (Office statistique des Communautés européennes) é o serviço de estatística da Comissão Europeia.

14 European Classification of Products by Activity (CPA).

15 Compatível também como a CPC e o GATS éa Nomenclatura Brasileira de Serviços, Intangíveis e Outras Operações que Produzam Variações no Patrimônio (NBS) e as respectivas Notas Explicativas (NEBS), aprovadas pelo Decreto no 7.708, de 02 de abril de 2012. A NBS e a NEBS integram o Sistema do Siscoserv (Sistema Integrado de Comércio Exterior de Serviços, Intangíveis e Outras Operações que Produzam Variações no Patrimônio). O Siscoserv é um sistema informatizado, desenvolvido pelo Governo Federal como ferramenta para o aprimoramento das ações de estímulo, formulação, acompanhamento e aferição das políticas públicas relacionadas a serviços e intangíveis bem como para a orientação de estratégias empresariais de comércio exterior de serviços e intangíveis. O Siscoserv conta com dois Módulos: Venda e Aquisição. No MóduloVenda são registrados os serviços, intangíveis e outras operações que produzam variações no patrimônio, vendidos por residentes ou domiciliados no País a residentes ou domiciliados no exterior. Este módulo abrange também o registro das operações realizadas por meio de presença comercial no exterior. No Módulo Aquisição são registrados os serviços, intangíveis e outras operações que produzam variações no patrimônio, adquiridos por residentes ou domiciliados no País de residentes ou domiciliados no exterior. Mais detalhes ver: MDIC; SRF. Siscoserv: Manual informatizadoMódulo aquisição, 8. ed, 2013. Disponível em: < http://www.mdic. gov.br/arquivos/dwnl_1404481411.pdf>.

16 Le MTN.GNS/W/120 é um documento da OMC sobre a Classificação Setorial de serviços do GATS. Teve origem em maio de 1991, por meio da distribuição de uma nota informal contendo um projeto de Lista de classificação setorial de serviços que formariam o Acordo GATS. O documento consiste em uma tabela de duas colunas. a divisão de serviços em doze grandes setores listados a seguir: 1. Serviços prestados às empresas; 2. Os serviços de comunicação; 3. Construção e serviços de engenharia; 4. Serviços de Distribuição; 5. Os serviços educativos; 6. Serviços Ambientais; 7. Serviços Financeiros; 8. Serviços de saúde; 9. Serviços relacionados com turismo e viagens; 10 . Serviços recreativos; 11 . Serviços de transporte; 12. Outros serviços. O cerne da questão consiste em saber se os serviços eletrônicos podem ser inseridos nas áreas de classificação de serviços já preestabelecidas internacionalmente ou, se existe a necessidade de rever o sistema de classificação para se adicionar outra categoria mais específica para os serviços eletrônicos.

Dessa forma, houve a necessidade de reorganizar essa classificação de serviços para atender os serviços eletrônicos. Atualmente, os especialistas ${ }^{17}$ descobriram que os serviços do e-commerce podem ser classificados em quatro grupos:

Grupo I - Bens de tecnologia da informação (Information technology goods) : incluem semicondutores, computadores e outras tecnologias de banda larga (bens de alta tecnologia) que fazem parte da infraestrutura física necessária para acessar a Internet / intranets e para operar o comércio eletrônico. Muitos desses produtos têm abrangência no âmbito do Acordo ITA (Information Technology Agreement):

Grupo II - Serviços de Infraestrutura de Internet $^{18}$ (Electronically Traded Services): existem vários serviços que fazem parte da infraestrutura virtual necessária para acessar a Internet / intranet e para operação do e-commerce. Estes incluem serviços de telecomunicações de base, serviços de telecomunicações de valor adicionado;

A coluna da esquerda é chamada de "setores e sub-setores", é uma lista ordenada de serviços em doze setores de serviços, cada um dividido em vários sub-setores (mais de 150 no total). A coluna da direita é intitulado "correspondência com o CPC (Classificação Central dos Produtos das Nações Unidas). Cf. WT/DS285/AB/R \ 172.

17 Esses especialistas são formados por representantes da OMC, OMPI, UNCTAD, Markle Foundation, OCDE.

18 OCDE. La libéralisation des services d'infrastructure de résean et l'AGCS. 2006, TD/TC/WP(2004)51/FINAL. 
Grupo III - $\underline{\text { Serviços eletronicamente }}$ comercializados (Electronically Trade Services): vários serviços podem ser comercializados eletronicamente, incluindo os serviços audiovisuais, serviços empresariais, serviços financeiros, serviços de viagens e turismo e outros serviços relacionados com o aspecto profissional.

Grupo IV - $\underline{\text { Produtos Digitais }}^{19}$ (Digital Products): estes são produtos como software, livros, música, filmes e jogos que podem ser negociados na forma física, como vídeo cassete ou CD. E agora eles têm a oportunidade de serem ofertados eletronicamente através da internet $^{20}$.

No presente artigo, a pesquisa vai se concentrar em serviços classificados de acordo com os Grupos $I I I$ e $I V$, tendo em vista que os dois primeiros grupos estão relacionados aos aspectos de infraestrutura que permitem a operacionalização do comércio eletrônico. O comércio de serviços eletrônicos pode, na grande maioria, ser classificado como comércio de "serviços eletronicamente comercializados" ou de "produtos digitais". Esses dois grupos de serviços têm suscitado discussões como: qual a classificação dentro do CPC aplicada aos produtos digitais? Pergunta-se se tais produtos devem ser classificados como bens ou serviços, porque essa classificação definirá se os Estados-Membros serão obrigados, no âmbito dos produtos digitais a seguir as regras do GAT'T para bens ou do GATS para serviços.

Para melhor identificar quais são os serviços eletrônicos classificados de acordo com esses dois Grupos III (Serviços eletronicamente comercializados) e IV (Produtos Digitais), nós utilizamos, para o presente artigo, a classificação estabelecida pelos GATS da OMC. De acordo com essa classificação, há quatro modos de prestação de serviços, a saber: Modo 1 - Prestação entre fronteiras (Comércio
Transfronteiriço): a possibilidade de os prestadores
de serviços não residentes em um Estado prestar

19 Manuel des statistiques du commerce international des services, 2001 (publicação conjunta da OMC, Comissão Europeia, FMI, OCDE, UNCITRAL, 'ONU). Disponível em: <http://www.wto.org/ french/res_f/statis_f/its_manual_f.htm $>$.

20 Cf. WUNSCH-VINCENT, Sacha; MCINTOSH, Joanna. WTO, E-commerce, and Information Technologies: from the Uruguay Round through the Doha Development Agenda. New York: United Nations, 2004. A Report for the UN ICT Task Force, 2004. p. 6. serviços além-fronteira no território de um outro Estado membro da OMC; Tem-se como exemplo: empresa de um Membro, prestando serviço de transporte de material desperdiçado de um determinado Membro, sendo transportado para outro território com objetivo de vendê-lo ou utilizá-lo ${ }^{21}$.

Modo 2 - Consumo no exterior: a liberdade que o residente de um país membro tem para viajar e consumir um serviço no território de outro Membro. Como exemplo tem-se o serviço de turismo.

Modo 3 - Presença comercial: a possibilidade que os fornecedores de serviços estrangeiros possuem para se estabelecer, operar ou expandir a sua presença comercial no território de outro Estado membro da OMC, como uma sucursal, agência ou filial;

Modo 4 - Movimento temporário de pessoas físicas: permite que os fornecedores de serviços de um Estado membro tenham a oportunidade de entrada e permanência temporária no território de um outro país membro. Assim, os prestadores de serviços de um Membro viajam para o território do outro Membro para prestar o serviço, por exemplo, pode ser o caso do médico de um país que viaja para o território de outro Membro, para operar o paciente ${ }^{22}$.

Há um consenso, por parte dos especialistas, que, dos "quatro modos de fornecimento de serviços" presentes no Acordo GATS, apenas dois possuem ligação com a prestação de serviços eletrônicos. São eles, o Modo 1 (prestação transfronteiriça de serviços sem movimentação física do prestador de serviços) e Modo 2 (consumo de serviços no exterior). E de acordo com esses modos de prestação de serviços verifica-se que dos doze setores analisados no Acordo GATS, sete tipos de setores poderiam ser fornecidos por via eletrônica, a saber: a) Setor 1 - Serviços prestados às empresas; b) Setor 2 - Serviços de Comunicação; c)

21 STEGER Debra. Curso de Solução de Controvérsias em Comércio Internacional, Investimento e Propriedade Intelectual: módulo 3.13 GATS. Genebra: Nações Unidas (UNCTAD), 2003. p. 3. Disponível em: $<$ http://unctad.org/pt/docs/edmmisc232add31_pt.pdf>. Acesso em: 21 set. 2014. p. 10.

22 STEGER Debra. Curso de Solução de Controvérsias em Comércio Internacional, Investimento e Propriedade Intelectual : módulo 3.13 GATS. Genebra: Nações Unidas (UNCTAD), 2003, p. 3. Disponível em : $<$ http://unctad.org/pt/docs/edmmisc232add31_pt.pdf $>$. Acesso em: 21 set. 2014. p. 11. 
Setor 4 - Serviços de distribuição; d) Setor 5 - Serviços de Educação; e) Setor 7 - Serviços Financeiros; f) Setor 9 - Serviços relacionados a turismo e viagens; g) Setor 10 - Recreativa, cultural e desportivo.

A fim de contribuir para uma melhor compreensão desses sete setores de serviços, detalharemos a seguir os tipos de serviços que poderão ser fornecidos via eletrônica ${ }^{23}$ :

Setor 1 - Serviços prestados às empresas

São classificados nesse Setor:

Serviços de contabilidade, auditoria: a empresa-mãe no país B emprega um auditor do país A para controlar as contas de uma de suas filiais localizada no país A. Este, por sua vez, transfere os resultados da controladoria por meio eletrônico utilizando um software desenvolvido no país A e exportado para ser utilizado no país B.

Serviços de arquitetura e engenharia: graças aos avanços dos sistemas de comunicação, projetos, plantas, estudos podem ser transmitidas eletronicamente e consultas a técnicos podem ser realizadas online.

Serviços médicos: entrega de exames médicos;

Serviços de Publicidade: serviços de planejamento, criação de publicidade; serviços para venda ou locação de espaço ou tempo para publicidade para jornais, periódicos e estações de televisão. Como sublinha um especialista ${ }^{24}$, nesse tipo de serviços estão as mais famosas formas de publicidade virtuais: uso de banners, páginas web, sistema de referenciamento por motores de busca, hyperlinks, e-mail, fórum de discussão.

Serviços jurídicos: incluem serviços de consultoria e representação, bem como todas as atividades relacionadas à administração da justiça. O comércio transfronteiriço de serviços jurídicos pressupõe o envio de documentos ou aconselhamento jurídico, por meio do correio eletrônico e até de métodos de resolução de litígios online ${ }^{25}$ são um bom exemplo de um novo serviço jurídico oferecido por meio da internet.

23 L'Organisation Mondiale du Commerce (OMC). Guide sur l'AGCS: aperçu des questions relatives à la poursuite de la libéralisation du commerce des services. Québec : Kluwer Law International, 2005.

24 Ver tópico: Les formes de publicité sur l'internet. VERBIEST, Thibault ; WÉRY, Étienne. Le droit de l'internet et de la société de l'information: droits européen, belge et français. Bruxelles : Larcier, 2001. p. 261.

25 CACHARD, O. Les modes électroniques de règlement des litiges (MERL). Revue mensuelle LexisNexis JurisClasseur. Communication. Commerce électronique, n. 30, p. 22-26, déc. 2003.
Setor 2-este setor inclui serviços de comunicação, serviços audiovisuais [produção e distribuição de filmes; Rádio e televisão e outros];

Setor 4 - setor composto pelos serviços de distribuição, quatro categorias de serviços: serviços de corretagem, serviços de atacado e varejo, franchising. Serviços de varejo são fornecidos principalmente por meio da presença de franquias comerciais. Estão presentes nesse Setor as lojas online nos diversos domínios: jornais, revistas, música, filmes, flores, livros, carros, computadores e software, e outros.

Setor 5 - serviços de educação: incluem serviços de educação primária, secundária, superior, serviços educacionais para adultos (para a educação de adultos, dentro e fora do sistema de ensino regular). O ensino à distância é um dos serviços online que testemunharam grande dinamismo e crescimento com as novas tecnologias de informação e comunicação.

Setor 7 - serviços financeiros: serviços de seguros de vida, automóveis, empréstimos

Setor 9 - serviços relacionados com o turismo e viagens: os Sistemas informatizados de reservas são utilizados para se verificar a disponibilidade de voos, fazer reservas, e, muitas vezes, para emitir bilhetes de passagens. Eles também podem ser usados para reservas de hotéis, aluguel de carros e outros.

Setor 10 - serviços recreativos, culturais e esportivos: jogos ou apostas on-line; serviços de entretenimento, como teatro, espetáculos; serviços de biblioteca; arquivos; museus e outros serviços culturais.

É importante identificar a classificação dos serviços prestados por via eletrônica, para se localizar nas "Listas de compromissos específicos" o tipo de serviço e o respectivo nível de obrigação assumido pelo país membro sobre a liberalização promulgada pelo GATS.

\section{A implementação efetiva das recomendações e decisões do OSC no domínio dos serviços do comércio eletrônico}

A imensa maioria das 486 denúncias, recebidas pela Secretaria do Órgão de Solução de Controvérsias (OSC), entre 1 de janeiro de 1995 e 5 de novembro de 2014, foi relacionada a disputas relativas às mercadorias. Dessas, apenas vinte e três casos mencionaram o GATS, ou seja, ocorreram reivindicações com base no Acordo GATS. Dez 
$\operatorname{casos}^{26}$ não resultaram em processos judiciais, tendo em vista que a solução do litígio deu-se por meio de acordo mútuo entre as partes ${ }^{27}$. Em outro caso, a denúncia foi transferida para outro tribunal, nesse caso à Corte Internacional de Justiça ${ }^{28}$.

26 DS38 (Estados Unidos - Lei para a liberdade e a solidariedade democrática em Cuba) - 03 de maio de 1996, a Comunidade Europeia solicitou consultas com os Estados Unidos sobre a Lei para a Liberdade e Solidariedade Democrática em Cuba e outras provisões para sanções comerciais contra Cuba; DS45 (Japão-Medidas que afetam os serviços de distribuição) - em 13 junho de 1996, os Estados Unidos apresentaram uma queixa contra o Japão alegando algumas medidas tomadas por esse país serem incompatíveis com o artigo III (transparência) e artigo XVI (acesso ao mercado) do GATS; DS117 (Canadá-Medidas visando os serviços de distribuição de filmes) - em 20 de janeiro de 1998, a Comunidade Europeia solicitou abertura de Consultas com o Canadá para analisar medidas canadenses sobre a distribuição de filmes; DS188 e DS201 (Nicarágua- Medidas visando algumas importações oriundas de Honduras e da Colômbia) - em 17 janeiro de 2000 a Colômbia apresentou uma queixa contra Nicarágua e em 26 de junho de 2000, Honduras também solicitou abertura de Consultas com Nicarágua. Esses dois países alegaram que a lei nicaraguense sobre imposição de taxas sobre bens e serviços originários de Honduras e da Colômbia era incompatível com obrigações nicaraguenses acordadas no âmbito do GATT et GATS; DS237 (Turquia - Certos procedimentos sobre importação de frutas frescas) - em 31 de agosto de 2001, o Equador solicitou abertura de Consultas com a Turquia devido à uma medida turca que criou um obstáculo à entrada de bananas frescas. Equador alegou ser essa medida incompatível com diversos Acordos da OMC como por exemplo GATS artigos: VI (regulamentação interna/ nacional) et XVII (Tratamento nacional); DS309 (China - Taxa de valor adicionado incidindo sobre circuitos integrados) - 18 de março de 2004 os Estados Unidos iniciaram um processo contra a China. Eles alegaram que a medida chinesa do direito à restituição parcial do imposto TVA sobre circuitos integrados produzidos na China consistia num tratamento mais favorável aos produtos chineses e uma discriminação incompatível com o Acordo GATS. Cf. OMC. OSC, < http://www.wto.org/french/tratop_f/dispu_f/ dispu_status_f.htm>, consultado 22 outubro 2014 ; DS 378China - Medidas que afetam os serviços de informação financeira e os fornecedores financeiros estrangeiros (Demandante: Canadá); DS373 China - Medidas que afetam os serviços de informação financeira e os fornecedores financeiros estrangeiros (Demandante: Estados Unidos); DS 372 China - Medidas que afetam os serviços de informação financeira e os fornecedores financeiros estrangeiros (Demandante: Comunidade Europeia).

27 Os casos DS45, DS80, DS168, DS177 foram finalizados na fase de Consultas e os casos DS38, DS237, DS309 as partes no conflito chegaram a um acordo antes da decisão final do Painel.

28 Casos DS188 et DS201 Nicarágua - medidas visando as importações provenientes de Honduras e da Colômbia. Honduras apresentou a queixa ao OSC no dia 26 de junho de 2000 devido à imposição de uma taxa nicaraguense incidindo sobre bens e serviços provenientes de Honduras e Colômbia. Honduras considerou que essa taxa era incompatível com as obrigações da Nicarágua decorrentes do GATT de 1994 e dos artigos II et XVI do Acordo GATS. O conflito havia também sido iniciado na Corte Internacional de Justiça em dezembro de 1999. A CIJ examinou questões sobre as delimitações marítimas entre Nicarágua e Honduras no mar do Caribe e proferiu sua decisão em 8 de outubro de 2007. Cf. CIJ. (Nicarágua c. Honduras),
Dos vinte três casos que citam o GATS, três merecem maiores comentários, conforme a seguir, por causa de seu interesse e suas circunstâncias particulares ligadas aos serviços do comércio eletrônico.

\section{A. Caso EUA - Jogos (DS285) ${ }^{29}$}

Esse caso $^{30}$, primeiro envolvendo serviços do comércio eletrônico, opôs os Estados Unidos e o Estado de Antígua e Barbuda (modesta república situada entre o mar do Caribe e o Oceano Atlântico) e referia-se à prestação transfronteiriça de serviços de jogo e apostas. Antígua e Barbudas queixaram-se de certas restrições impostas pelos Estados Unidos por meio de leis federais ou estaduais, tendo em vista que essas restrições acabaram por proibir o fornecimento de serviços transfronteiriços de jogos e apostas a partir do território de Antígua. Antígua e Barbuda alegaram que esta proibição era contrária às obrigações assumidas pelos Estados Unidos decorrentes do Acordo de Serviços GATS.

O reclamante argumentou que essa proibição era contrária às obrigações do Acordo de Serviços assumidas pelos EUA porque na Lista ${ }^{31}$, norte-americana

1999. Disponível em: < http://www.icj-cij.org >. Acesso em: 24 out. 2014.

29 Texto resumido do site da OMC litígio: Estados Unidos Medidas visando o fornecimento transfronteiriço de serviços de jogos e apostas. Disponível em: <http://www.wto.org/french/ tratop_f/dispu_f/cases_f/ds285_f.htm >

30 Estados Unidos- Medidas visando o fornecimento transfronteiriço de serviços de jogos e apostas, Órgão de Apelação, WT/DS285/AB/ Radotado 20 abril 2005 pelo OSC. Comentários ver BARRAL, Welber Oliveira. Comércio Internacional. Belo Horizonte: Del Rey, 2007. MANARA, Cédric. Commerce électronique: première décision de l'Organe de règlement des différends de l'OMC, Recueil Dalloz, p. 3122; TENENBAUM, Aline, Les jeux d'argent sur l'Internet facilités dans le cadre de l'Organisation mondiale du commerce: réflexions à propos de la décision de l'organe d'appel de l'OMC du 7 avril 2005, Revue mensuelle LexisNexis JurisClasseur. Communication. Commerce électronique, n. 9 Études 31, p. 15-18. ORTINO Federico, Treaty interpretation and the WTO appellate body report in USGambling: a critique, JIEL, v. 9, n. 1, p. 117-148. WUNSCHVINCENT Sacha, The Internet, cross-border trade in services, and the GATS: lessons from US-Gambling, World Trade Review, nov. v. 5, n. 3, p. 319-355. DELIMATSIS, Panagiotis. Don't Gamble with GATS - The interaction between articles VI, XVI, XVII and XVIII GATS in the light of the US-Gambling case, Journal of world trade, v. 40, n. 6, p. 1059-1080. THOMAS, Emeline. Les jeux et Paris en ligne: approches nationales, communautaire et internationale. Mémoire Master 2 - Juriste d'affaires européen, Faculté de droit, sciences économiques et gestion, Nancy: Université de Nancy 2, 2006.

31 Nas Listas são detalhados os compromissos específicos assumidos pelos Membros no âmbito do GATS. A extensão 
de compromissos do GATS havia compromissos específicos referentes aos serviços de jogo e apostas. Em continuação, argumentou que os Estados Unidos haviam escrito na Lista " compromissos sem limitação » e que portanto se comprometiam a não aplicar limitação em termos de acesso ao mercado e tratamento nacional. Dessa forma, a manutenção das medidas restritivas

dos compromissos, as suas condições, o acesso a mercados e a obrigação do tratamento nacional contida na Parte II do GATS, se aplicam aos setores individuais de qualquer Membro, podendo ser avaliadas apenas pelas referências às inscrições na Lista deste Membro. Tais Listas são anexadas ao GATS, e formam partes integrantes do tratado. A parte geral das Listas de Compromissos de qualquer Membro do GATS tem aparência de itens organizados em quatro colunas, especificando em cada caso: i) o setor sujeito ao compromisso; ii) os termos, as limitações e as condições de acesso ao mercado para cada setor inscrito designados por modos de prestação; iii) as condições e limitações ao tratamento nacional para cada setor inscrito designadas por modos de prestação; iv) as inscrições relativas aos compromissos adicionais e se houver, quando apropriado, o período de implementação para cada compromisso; v) e a data de entrada em vigor de cada compromisso. A parte setorial da Lista de Compromissos do Membro é precedida por "compromissos horizontais", ou seja, uma lista de compromissos e limitações que geralmente se aplicam à todos os setores inscritos. Muitos dos compromissos horizontais estão relacionados com derrogações no acesso a mercados e obrigação de tratamento nacional, em relação a módulos particulares de prestação, tais como "presença de pessoas físicas". Por exemplo, a maioria dos Membros inscrevem os compromissos horizontais como forma de limitar a movimentação de pessoas físicas em todos os setores de serviços inscritos, incentivando as transferências entre empresas, dificultando a entrada de pessoas essenciais ou de visitantes desempregados que permaneceram por pouco tempo no país. Nas inscrições em cada setor, ficam indicadas, a natureza e extensão dos compromissos que cada Membro acordou em firmar. Sob cada setor designado, os compromissos são inscritos separadamente para cada um dos quatro módulos de prestação de serviço. $\mathrm{Na}$ Listas de Compromissos podem ser quatro os tipos de termos que indicam os níveis de compromissos :"Compromisso Integral" : a palavra "nenhuma" é adicionada na lista ao lado de determinado módulo de prestação do serviço. Isto significa que o Membro garante acordar acesso integral a mercados e direito ao tratamento nacional, sem qualquer condição, limitação ou qualificação para serviços e prestadores de serviços de outros Membros. "Compromisso com Limitação" : o Membro adiciona limitações, condições e qualificações que limitam o acesso a mercados e o compromisso de tratamento nacional. Geralmente os Membros inscrevem medidas específicas que seriam, de outra maneira, inconsistentes com as obrigações de acesso a mercados e tratamento nacional. "Sem compromisso" : as palavras "Não vinculado" são adicionadas na Lista ao lado do modo de prestação correspondente ao setor de serviços. Isto indica que o membro é livre para impor qualquer medida inconsistente com as obrigações de tratamento nacional e acesso a mercados. "Sem compromisso tecnicamente viável" : o Membro indica no setor em questão que a prestação de serviços não será possível através de determinado módulos de prestação. STEGER, Debra. Curso de solução de controvérsias em comércio internacional, investimento e propriedade intelectual: módulo 3.13 GATS. Genebra, Nações Unidas (UNCTAD), 2003. Disponível em : < http://unctad.org/pt/docs/edmmisc232add31_ pt.pdf $>$. Acesso em: 21 set. 2014. p. 36-37. em questão decorrentes de leis federais ou estaduais era incompatível com as obrigações decorrentes do artigo VI (regulamentação interna), XI (Pagamentos e Transferências), XVI (acesso ao mercado) e XVII (tratamento nacional) do GATS.

$\mathrm{Na}$ falta de acordo entre os dois países, um painel foi constituído pelo OSC, em 2003 que afirmou a incompatibilidade da lei dos Estados Unidos com o Acordo GATS, uma decisão confirmada em recurso. Em 2005, foi então concedido um prazo razoável, a pedido dos Estados Unidos para adequar a sua legislação em conformidade com as recomendações do OSC. O caso arrastou-se e, a pedido de Antígua, um novo painel concluiu que os Estados Unidos não tinham realizado as alterações necessárias nas suas legislações nacionais. Assim, Antígua ganhou o direito de usar a retaliação, tanto no âmbito do GATS e do Acordo de Propriedade Intelectual (TRIPS). Descontentes, os Estados Unidos recorreram em 23 de julho de 2007, contestando o valor das medidas de retaliação, o que provocou a intervenção de um árbitro que estabeleceu finalmente US\$21 milhões por ano como valor montante da retaliação (decisão de 21 de dezembro de 2007).

$\mathrm{Na}$ reunião do OSC, de 28 de janeiro de 2013, Antígua e Barbuda solicitaram a autorização do Órgão para suspender concessões e obrigações para os Estados Unidos no que diz respeito aos direitos de propriedade intelectual. OSC concordou com o pleito.

Nesse caso, o OSC analisou três questões: em primeiro lugar, se na lista anexa ao GATS pelos Estados Unidos, havia a inclusão de compromissos específicos sobre jogos de azar e apostas; segundo, se a proibição da oferta de jogos e apostas online é uma medida de limitação do acesso aos mercados, o que é incompatível com as obrigações do GATS; o terceiro ponto analisado, se a proibição americana é considerada necessária para se proteger a moral e ordem pública dos Estados Unidos (medida válida nos termos do artigo XIV do GATS).

O Painel interpretou a Lista de compromissos dos Estados Unidos e classificou os serviços de jogos e apostas online no sub-setor $10 . D^{32}$, mas os Estados

32 Subsetor 10.D trata de outros serviços recreativos (com exclusão dos serviços esportivos). Referente aos modos 1 e 2 de prestação de serviços, na coluna referente à limitação de acesso ao mercado aparece o termo "nenhum". Isso significa que o Membro garante acordar acesso integral a mercados e direito ao tratamento nacional, sem qualquer condição, limitação ou qualificação para serviços e prestadores de serviços de outros Membros. Assim, ele não pode impor limite de 
Unidos apelaram desta conclusão. A alegação americana se fundamentou na classificação realizada pelo OSC de classificar a prestação de serviço no sub-setor 10.D. De acordo com os Estados Unidos, o significado do termo Sporting deve incluir jogos e apostas online. Dessa forma, a alegação norte-americana foi de que o painel errou ao não considerar essa interpretação o que levaria a classificar de jogos e apostas online no subsetor 10 . $E$, setor sem compromissos específicos dos Estados Unidos $^{33}$.

Em relação à limitação do acesso ao mercado, o OSC concluiu que a proibição do fornecimento transfronteiriço de serviços de jogo e apostas online é caracterizada como uma limitação aos prestadores de serviços, na acepção do artigo XVI: 2, ponto a) do GATS. Tal proibição é também uma limitação do número total de operações de serviços ou da quantidade total de serviços produzidos, na acepção do artigo XVI: 2, ponto c) do Acordo. Consequentemente, os Estados Unidos agiram de forma inconsistente com as obrigações assumidas no âmbito do Acordo GATS.

Para o avanço das regras sobre o comércio eletrônico, o caso EUA-Jogos (DS285) pouco contribuiu. A análise realizada pelo OSC foi limitada porque as questões fundamentais relacionadas ao comércio no ambiente virtual permaneceram sem resposta, tais como: prática de não impor direitos aduaneiros sobre transmissões eletrônicas; a definição e classificação de produtos digitais; a difícil regulamentação dos artigos VI (regulamentação interna) e XVI (acesso ao mercado) ${ }^{34}$.

A maior contribuição desse caso foi a conclusão da possibilidade de se aplicar os acordos da OMC para os serviços eletrônicos ${ }^{35}$. O Painel e o Órgão de Apelação não afirmaram esta opinião de forma direta,

acesso ao mercado. Mais detalhes ver: MTN.GNS/W/164 (3 setembro 1993) parágrafo 24; Lignes directrices pour l'établissement des listes d'engagements spécifiques dans le cadre de l'AGCS adoptées le 23 mars 2001. S/L/92 (28 mars 2001), paragraphe 42. Voir aussi Affaire Telmex WT/DS204/ R S 7.73, p.180.

\section{Ver WT/DS285/AB/R S 162, 183.}

34 WUNSCH-VINCENT, Sacha. The WTO, the Internet and trade in digital products: EC-US perspectives. Oregon: Oxford, 2006. p. 174. 35 Para os Membros da OMC essa aplicação tem ocorrido pelas decisões emanadas pelo OSC. Cf. WUNSCH-VINCENT, Sacha. Trade rules for digital age. In: PANIZZON, Marion; POHL, Nicole; SAUVÉ, Pierre (Ed.). GATS and the Regulation of International Trade in Services. Cambridge: Cambridge University Press, 2008. p. 499. HUFBAUER, Gary; STEPHENSON, Sherry. Services trade: past liberalization and future challenges, JIEL, v. 10, n. 3, p. 605-630. mas ambas as decisões aplicaram o Acordo GATS no serviço fornecido no âmbito eletrônico ${ }^{36}$.

Alguns autores ressaltam ${ }^{37}$ que essas interpretações do OSC não criaram um precedente vinculativo, porque eles usam como guia, os acordos da OMC e a Convenção de Viena sobre o Direito dos Tratados ${ }^{38}$, e, por conseguinte, a interpretação é específica para cada caso $^{39}$. Dessa forma, não podemos dizer que a posição final da OMC é a adoção de todos Acordos da OMC serem aplicados aos serviços do comércio eletrônico. No entanto, a prática no OSC tem demonstrado, na maioria dos casos, que os relatórios emitidos pelo Órgão de Solução de Controvérsias podem e tem fornecido indicações para negociações e litígios subsequentes sobre o mesmo assunto.

\section{B. Caso China-Publicações eletrônicas e serviços audiovisuais (DS363) (0) $^{40}$}

Por um longo tempo, a China manteve-se estranha à OMC o que a impediu de ser questionada perante o OSC, em particular, do Acordo GATS. Desde que a China não estava vinculada por convenções internacionais da OMC que protegem as empresas de propriedade intelectual $^{41}$ estabelecidas na China, ela poderia se utilizar de forma desonesta de patentes industriais e de pesquisadores estrangeiros, e, assim, desenvolver suas indústrias e laboratórios nacionais. Somente em 2002 a China anunciou a sua adesão à OMC, aceitando, assim, as exigências da adesão e também as obrigações

36 WUNSCH-VINCENT, Sacha. The WTO, the Internet and trade in digital products: EC-US perspectives. Oregon: Oxford, 2006. p. 175 37 MATSushita, Mitsuo, SCHOEnBAuM, Thomas J. C. MAVROIDIS Petros. The World Trade Organization: law, practice and policy. New York: Oxford University Press, 2006.

38 Artigo 31 : um tratado deve ser interpretado de boa fé segundo o sentido comum atribuível aos termos do tratado em seu contexto e à luz de seu objetivo e finalidade.

39 Deve-se notar que as interpretações adotadas pelo OSC vinculam apenas as partes no litígio e não criam necessariamente um precedente vinculativo para os litígios posteriores.

40 Texto resumido do site da OMC litígio: China - Publicações eletrônicas e serviços audiovisuais. Disponível em: <http://www. wto.org/french/tratop_f/dispu_f/cases_f/ds363_f.htm $>$.

41 Sobre direito de propriedade intelectual ver : PIOTRAUT, Jean-Luc. La propriété intellectuelle et droit international et comparé. Paris : Lavoisier, 2007 ; MARINHO, Maria. Les processus d'internationalisation du droit des brevets : a la recherche d'un droit commun pluraliste. Allemagne: Éditions universitaires européennes, 2010. 
relacionadas às regras internacionais de propriedade intelectual ${ }^{42}$.

Nesse litígio, os Estados Unidos questionaram a China na OMC, e Austrália, União Europeia, Japão, Coreia do Sul e Taiwan participaram do conflito como terceiros países. Por falta de acordo durante os procedimentos de consultas, foi instalado um painel em 10 de outubro de 2007. Nesse painel várias medidas chinesas foram questionadas, pois acabavam por impor restrições ou limitações discriminatórias aos fornecedores estrangeiros de vídeos em DVD, gravações de som e publicações, tais como livros, revistas e publicações eletrônicas. O painel, na verdade, afirmou a incompatibilidade das medidas chinesas com as obrigações decorrentes do GATT e GATS (artigo XVI- Acesso a mercados e XVII - Tratamento Nacional). O Órgão de Apelação confirmou a incompatibilidade das medidas chinesas em 21 de dezembro de 2009 e, relatório foi adotado em 19 de janeiro de $2010^{43}$.

Após esse procedimento, a China buscou e obteve um prazo razoável, fixado em 14 meses encerrados em 19 de março de 2011, para implementar a decisão do OSC.

Na reunião do OSC, de 23 de março de 2012, a China informou a plena implementação das recomendações e decisões do OSC, com exceção daqueles referentes aos filmes relacionados para lançamento nos cinemas. No que diz respeito às medidas relativas a filmes para lançamento nos cinemas, a China informou estar mantendo discussões com os Estados Unidos para a conclusão de um acordo para resolver a questão, o que seria assinado e notificado ao OSC. Até o momento presente, os Estados Unidos não concordam com o argumento chinês da plena aplicação das recomendações do OSC. Estados Unidos alegam que a China ainda não realizou a implementação integral, pois ainda restavam áreas sem o cumprimento por parte da China das decisões emanadas pelo OSC.

Na reunião do OSC, de 24 de maio de 2012, a China informou ter assinado com Estados Unidos acordo para resolver o conflito. Os Estados Unidos disseram

42 Cf. Challenges n. 229, 21 octobre 2010, p. 11.

43 Essas constatações são observadas nos parágrafos 4 e 5 do artigo 7: Règle sur la sous-distribution des publications. Chine - Services audiovisuels, Rapport du Groupe spécial, WT/DS363/R distribué le 12/08/2009, \$88.2.3 a) vii); \$7.1142. que o Acordo era importante, mas que não poderia ser ainda considerado uma solução final ao litígio.

\section{Caso China-Serviços de pagamento eletrônico $(\mathrm{DS} 413)^{44}$}

Esse litígio opôs os Estados Unidos e a China e em 15 de setembro de 2010 foi instalado um Painel para analisar se certas restrições e exigências mantidas pela China em matéria de serviços de pagamento eletrônico (SPE) eram contrárias aos dispositivos do GATS.

Os Estados Unidos alegaram que a China somente autorizava uma entidade chinesa (China Union Pay CUP) para fornecer serviços de pagamento eletrônico dentro do território chinês. Prestadores de serviços de outros Estados membros só poderiam fornecer esses serviços para transações com cartão de pagamento liquidadas em moeda estrangeira. A China também exige que todos os dispositivos de transação de cartão de pagamento eletrônico sejam compatíveis e possuam logotipo do sistema CUP.

Além disso, a entidade chinesa garante a todos os comerciantes chineses o acesso e os equipamentos necessários para pagamento com cartão eletrônico, enquanto que os fornecedores de outros Estados membros que queiram prestar esse serviço de pagamento eletrônico devem negociar o acesso com os estabelecimentos comerciais. Os Estados Unidos afirmaram, portanto, que essas medidas da China eram incompatíveis com as suas obrigações assumidas nos termos dos artigos XVI (Acesso a mercados) e XVII (Tratamento Nacional) do GATS.

Em março de 2011, o OSC estabeleceu um painel tendo a Austrália, a Coreia do Sul, a Guatemala, o Japão, a União Europeia, o Equador e a Índia, como terceiros participantes. Somente em 6 de julho de 2012, o Relatório do Painel foi distribuído aos Membros. Os Estados Unidos afirmaram que a China havia contraído compromissos no âmbito do GATS em matéria de acesso ao mercado e tratamento nacional referente aos modos 1 e 3 de prestação de serviços. Os Estados Unidos consideraram que os serviços de pagamento eletrônico estão classificados no subsetor $7 \mathrm{~B}$, item d) do GATS, que especifica os seguintes serviços: “o pagamento e as transferências monetárias, incluindo os

44 Texto resumido do site da OMC litígio: China - Certas medidas que afetamos serviços de pagamento eletrônico. <http:// www.wto.org/french/tratop_f/dispu_f/cases_f/ds413_f.htm $>$ 
serviços de pagamento por cartão de crédito e similares, cheques de viagem e saques".

O Painel começou a analisar se os serviços em causa (SPE) para transações com cartão de pagamento estavam na Lista de compromissos da China classificados no subsetor $7 \mathrm{~B}$, item d $)^{45}$ do GATS. Dessa análise o painel rejeitou o argumento americano com relação ao modo 1 de prestação de serviço transfronteiriço.

No entanto, o painel considerou que a lista da China continha um compromisso de acesso a mercado para os fornecedores estrangeiros do serviço de SPE que queiram prestar o serviço através da presença comercial na China (modo 3), desde que preencham certos requisitos para transações em moeda local (RMB).

Além disso, o painel concluiu que a Lista de compromissos da China continha um compromisso total em tratamento nacional para a prestação transfronteiriça (modo 1) do SPE, e um compromisso de tratamento nacional para o modo 3 (também sujeito a determinados requisitos para as transações em moeda local - RMB).

O Painel rejeitou por falta de provas, as alegações sobre acesso ao mercado e de tratamento nacional dos Estados Unidos de que a China mantinha a CUP como um fornecedor monopolista para o tratamento de todas as transações com cartões de pagamento no mercado interno chinês. No entanto, o painel concluiu que a China manteve a CUP como fornecedor monopolista para impedir certos tipos de transações com pagamentos em cartões. Dessa forma havia monopólio nas operações de pagamento com cartões emitidos em moeda local (RMB) na China e utilizados em Hong Kong, China e Macau, China, ou cartões de pagamento em RMB emitidos em Hong Kong, China e Macau, e utilizados na China. O Painel ressaltou que o Artigo XVI, item 2) do GATS exige que os membros, que tenham assumido compromissos de acesso ao mercado, não limitem o número de prestadores de serviços. Dessa forma, o Painel concluiu que a China agiu de forma inconsistente com o compromisso de acesso ao mercado em modo 3 nos termos do artigo XVI: 2) do GATS, ao conceder à China UnionPay - CUP, o monopólio para transações com cartão de crédito de pagamento em moeda local. O Painel não encontrou

45 Os serviços referidos na Seção 7B da lista de serviços da China classificados como serviços bancários e outros serviços financeiros, incluem: d) Todos os serviços de pagamento e de transferências monetárias, incluindo cartões de crédito e de débito, cheques de viagem e ordens de pagamento bancárias. nenhuma incompatibilidade com os compromissos da China em matéria de tratamento nacional.

No que concerne às outras alegações americanas de incompatibilidade: i) exigência chinesa de que todos os cartões de pagamento emitidos na China devem portar o logo "Yin Lian" e "Union Pay" e serem capazes de permitir a interoperabilidade com o rede local e, ii) exigência chinesa de que todos os estabelecimentos mantenham afixados estampas com o logotipo"Yin Lian" e "Union Pay" indicando que são capazes de aceitar todos os cartões de crédito com o logotipo em questão, o Painel concluiu que cada um desses requisitos é incompatível com as obrigações da China ao tratamento nacional para o modo 1 e modo 3 nos termos do artigo XVII do GATS. O OSC, no relatório de 31 agosto de 2012, observou que a China, por meio desses regulamentos, alterou as condições de livre concorrência e deu favorecimento à China Union Pay - CUP e, assim, a China não ofereceu um tratamento nacional aos provedores de serviços de pagamento eletrônico (SPE) de outros membros, alteração portanto, contrária aos compromissos assumidos pela China.

Na reunião do OSC, de 28 de setembro de 2012, a China declarou a intenção de implementar as recomendações e decisões do OSC. Ela acrescentou, no entanto, que precisaria de um prazo razoável para o fazer. Em 22 de novembro de 2012, a China e os Estados Unidos informaram ao OSC que eles haviam acordado um período de 11 meses, a partir da data de adoção do relatório do painel, para que a China implemente as recomendações e decisões do OSC. Esse prazo expirou em 31 de julho de 2013 e a China declarou ter integralmente implementado as decisões do OSC. Contudo, os Estados Unidos não concordaram com essa afirmação, e disseram que iriam monitorar as ações da China.

\section{Conclusão}

No âmbito do Grupo de Trabalho sobre Comércio Eletrônico, os países membros chegaram a um consenso de que os vários acordos da OMC com todos os seus direitos, obrigações e compromissos específicos são aplicáveis ao comércio eletrônico, porque eles não diferenciam o meio pelo qual os produtos são entregues. Eles, em particular, descobriram que os diversos temas relacionados ao comércio eletrônico, tem ligação com os vários acordos e grupos de trabalho da OMC. Outro 
aspecto importante do Grupo de Trabalho sobre Comércio Eletrônico foi a determinação da moratória digital. Ou seja, a não imputação de tarifas, quotas ou regulamentos discriminatórios sobre o comércio eletrônico.

Embora ainda se tenha poucos litígos envolvendo temas do ambiente eletrônico, é possível inferir e concluir que a maioria dos dispositivos legais da OMC e do GATS são adaptados para o ambiente eletrônico. Contudo, como também ocorre nas demais áreas, a implementação das decisões é altamente dependente da ação dos Estados, que necessitam de tempo para negociar. Também é possível inferir que existe, no âmbito dos litígios e no ambiente eletrônico, um comprometimento dos Estados na implementação das decisões emanadas pelo Órgão de solução de controvérsias, em suma, os Estados membros da OMC preferem respeitar as decisões do OSC e manter a legitimidade do sistema como um todo. 


\section{Referências}

BARRAL, Welber Oliveira. Comércio Internacional. Belo Horizonte: Del Rey Editora, 2007.

CACHARD O. Les modes électroniques de règlement des litiges (MERL). Revue mensuelle LexisNexis JurisClasseur. Communication. Commerce électronique, n. 30, p. 22-26, déc. 2003.

DELIMATSIS Panagiotis. Don't Gamble with GATS - The interaction between articles VI, XVI, XVII and XVIII GATS in the light of the US-Gambling case, Journal of world trade, v. 40, n. 6, p. 1059-1080.

HUFBAUER Gary; STEPHENSON Sherry. Services trade: past liberalization and future challenges, JIEL, v. 10, n. 3, p. 605-63.

MANARA Cédric, Commerce électronique: première décision de l'Organe de règlement des différends de l'OMC, Recueil Dalloz, p. 3122ss.

LIM, Aik Hoe; MEESTER, Bart De. WTO domestic regulation and services trade: puting principles into practice. New York: Cambridge University Press, 2014.

MAMDOUH, Hamid. Services liberalization, negotiations and regulation: some lessons from the GATS experience. In: LIM, Aik Hoe; MEESTER, Bart De. WTO domestic regulation and services trade: puting principles into practice. New York: Cambridge University Press, 2014. p. 325-331.

MATSUSHITA, Mitsuo; SCHOENBAUM, Thomas J. C. MAVROIDIS, Petros. The World Trade Organization: law, practice and policy. New York: Oxford University Press, 2006.

MDIC. SRF. Siscoserv: Manual informatizado - Módulo aquisição. 8. ed. 2013. Disponível em: < http://www. mdic.gov.br/arquivos/dwnl_1404481411.pdf>.

NATIONAL BOARD OF TRADE. E-commerce - New Opportunities, New Barriers: a survey of e-commerce barriers in countries outside the EU, November 2012. Disponível em: <http://www.wto.org/english/tratop_ e/serv_e/ wkshop_june13_e/ecom_national_board_e.PDF>.

ORGANISATION DE COOPÉRATION ET DE DÉVELOPPEMENT ÉCONOMIQUES. Commerce électronique - engagements existants dans le cadre de l'AGCS pour la fourniture de services en ligne. 2000. Td/tc/wp(99)37/ final.

ORGANISATION DE COOPÉRATION ET DE DÉVELOPPEMENT ÉCONOMIQUES. La libéralisation des services d'infrastructure de résean et l'AGCS. 2006, Td/Tc/Wp(2004)51/Final.

ORGANIZAÇÃO MUNDIAL DO COMÉRCIO. OMC/OSC. DS 285: Estados Unidos - Medidas visando o fornecimento transfronteiriço de serviços de jogos e apostas, Órgão de Apelação, Painel, WT/ DS285/R adotado 10 novembro 2004 e modificado em 2005 pelo Órgão de Apelação WT/DS285/AB/R adotado 7 abril 2005.

WORLD TRADE ORGANIZATION. OMC; FMI; OCDE; UNCITRAL; ONU. Manuel des statistiques du commerce international des services, 2001, consultado em 22 outubro de 2014, Disponível em: <http://www.wto. org/french/res_f/statis_f/its_manual_f.htm>.

\section{L'ORGANISATION MONDIALE DU}

COMMERCE. Guide sur l'AGCS: aperçu des questions relatives à la poursuite de la libéralisation du commerce des services. Québec : Kluwer Law International, 2005.

ORTINO, Federico. Treaty interpretation and the WTO appellate body report in US-Gambling: a critique, JIEL, v. 9, n. 1, p. 117-148.

PIOTRAUT, Jean-Luc. La propriété intellectuelle et droit international et comparé. Paris : Lavoisier, 2007.

STEGER, Debra. Curso de solução de controvérsias em comércio internacional, investimento e propriedade intelectual : módulo 3.13 GATS. Genebra, Nações Unidas (UNCTAD), 2003. Disponível em: <http://unctad.org/pt/docs/ edmmisc232add31_pt.pdf> Acesso em: 21 set. 2014.

STEIN, Michael; TRENT, John. Electronic Democracy. Toronto: Barbara Budrich Publishers, 2012.

TENENBAUM Aline, Les jeux d'argent sur l'Internet facilités dans le cadre de l'Organisation mondiale du commerce: réflexions à propos de la décision de l'organe d'appel de l'OMC du 7 avril 2005, Revue mensuelle LexisNexis JurisClasseur. Communication. Commerce électronique, n. 9 Études 31, p. 15-18. 
TANG, Min; HUHE, Narisong. Alternative framing: the effect of the internet on political support in authoritarian China. International Political Science Review. v. 35 , n. 5, p.559-576, nov. 2014,

THOMAS, Emeline. Les jeux et Paris en ligne: approches nationales, communautaire et internationale. Mémoire Master 2 - Juriste d'affaires européen, Faculté de droit, sciences économiques et gestion, Nancy: Université de Nancy 2, 2006.

VERBIEST Thibault ; WÉRY Étienne. Le droit de l'internet et de la société de l'information: droits européen, belge et français. Bruxelles : Larcier, 2001.

WUNSCH-VINCENT, Sacha; MCINTOSH, Joanna. WTO, E-commerce, and Information Technologies: from the Uruguay Round through the Doha Development
Agenda. New York: United Nations, 2004. A Report for the UN ICT Task Force, 2004.

WUNSCH-VINCENT, Sacha. The Internet, crossborder trade in services, and the GATS: lessons from US-Gambling, World Trade Review, nov. v. 5, n. 3, p. 319355.

WUNSCH-VINCENT, Sacha. The WTO, the Internet and trade in digital products: EC-US perspectives. Oregon: Oxford and Portland, 2006.

WUNSCH-VINCENT, Sacha. Trade rules for digital age. In: PANIZZON, Marion; POHL, Nicole; SAUVÉ, Pierre. (Ed.). GATS and the Regulation of International Trade in Services. Cambridge: Cambridge University Press, 2008. 


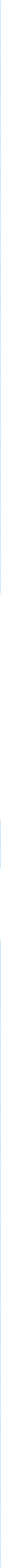




\title{
A OMC e o regionalismo do século XXI: estratégia de imposição de modelos normativos?*
}

\author{
WTO and regionalism in the $21^{\text {st }}$ century: strategy to \\ impose normative models?
}

Camilla Capucio**

\section{Resumo}

O objetivo central do artigo é recontextualizar a temática do regionalismo em sua relação com o sistema multilateral de comércio, passados vinte anos de criação da OMC. O trabalho se baseia numa nova geração de estudos, que identifica na proliferação de Acordos Regionais de Comércio pós-Rodada de Doha interesses diversos daqueles manifestados anteriormente, relacionados contemporaneamente à tentativa de imposição de um modelo regulatório-normativo, com futuros impactos na formulação de esquemas regulatórios globais. A metodologia consiste em análise bibliográfica da evolução do tratamento da temática pelas diversas gerações de estudiosos, em face das características peculiares do fenômeno em suas respectivas realidades, com destaque para essa nova "faceta". A conclusão central do trabalho, na qual subsiste seu principal valor, é a percepção de que, diante das novas complexidades do regionalismo no século XXI, iniciativas atuais buscam preencher o espaço de regulamentação de temas deixados pelo congelamento da Rodada de Doha. Conclui-se que a sistemática de negociação passa a circular não mais em função de barganhas para o acesso a mercados por meio de cortes tarifários, mas em torno da capacidade de expansão de modelos regulatórios, e que essa normatividade resultante dos novos acordos regionais tende a se cristalizar, exatamente devido à tipologia dos compromissos abarcados, que importam implicações jurídico-institucionais domésticas duradouras.

Palavras-chave: Acordos regionais de comércio. OMC. Sistema multilateral de comércio. Regionalismo. Multilateralismo.

\section{Abstract}

This paper is aimed to recontextualize the theme of regionalism in its relationship with the multilateral trading system, after twenty years of creation of the WTO.

* Recebido em 31.10.2014

Aceito em 01.12.2014

** Doutora em Direito Internacional (Faculdade de Direito da USP) e Mestre em Direito (Faculdade de Direito da UFMG). Pesquisadora do Núcleo de Estudos em Tribunais Internacionais (NETI-USP) e do Grupo de Pesquisa Empresa, Mercado e Desenvolvimento Social (UNA). Professora (Centro Universitário UNA).E-mail: ccapucio@usp.br
It is based on a new generation of studies, which identifies the proliferation of Regional Trade Agreements post-Doha Round with interests different from those expressed before, contemporaneously related to the attempt to impose a regulatory-normative model, with future impacts in formulating schemes of global regulation. The methodology consists on bibliographic analysis of the evolution of the treatment of the subject by several generations of scholars, in view of the peculiar characteristics of the phenomenon in their respective realities, especially in this new aspect. The central conclusion of the work, in which remains its main value, is the perception that, given the complexities of the new regionalism in the XXI century, current initiatives seek to fill the space left by the regulations of freezing issues in the Doha Round. The paper concludes that trade negotiation 
is focused no more in bargain for market access through tariff cuts, but mainly in the ability to expand regulatory models, and that the normativity that today seems diluted tends to crystallize.

Keywords: Regional trade agreements. WTO. Multilateral trading system. Regionalism. Multilateralism.

\section{Introdução: a OMC e o regionalismo}

A temática do regionalismo exige uma análise histórica do fenômeno, tendo em vista não apenas os diferentes aspectos que caracterizam as respectivas "ondas" do regionalismo observadas nas relações internacionais, mas principalmente as diversas perspectivas teóricas e pragmáticas construídas para entender as dimensões de sua relação com o Sistema Multilateral de Comércio.

Assim, diante de novas complexidades e novas características apresentadas pelo fenômeno do regionalismo no século XXI, é perceptível a insuficiência de análises clássicas limitadas à percepção de compatibilidades e/ou incompatibilidades estáticas dos Acordos Regionais de Comércio face ao sistema multilateral de comércio. Passados vinte anos de criação da OMC, é tarefa urgente recontextualizar a temática do regionalismo, tendo em vista a mudança de interesses buscados com a construção de arranjos regionais na atualidade, e os potenciais impactos sob o sistema multilateral de comércio.

Desse modo, o artigo se desenrola por meio da análise histórico-evolutiva das diferentes fases da relação entre o regionalismo e o sistema multilateral de comércio, com ênfase na perspectiva mais recente de percepção dos arranjos regionais como tentativa de expansão de modelos regulatórios, buscando preencher o espaço de regulamentação de temas deixados pela agenda multilateral.

Inicialmente é necessário explicitar que, embora o regionalismo fosse existente já à época do GATT 1947, a proliferação dos blocos regionais é fenômeno que se relaciona diretamente com as modificações da sociedade internacional nas últimas décadas do século XX. A nova conformação das forças políticas após a queda do Muro de Berlim trouxe mudanças que propiciaram a ascensão dos blocos regionais como alternativa à satisfação de interesses de atores no interior dos Estados, diante da globalização e de tentativas de contraposição a este fenômeno.

1 LAFER, Celso. Comércio, desarmamento e direitos bumanos: reflexões sobre uma experiência diplomática. São Paulo: Paz e Terra,
Aquela reconfiguração do cenário internacional significou uma alteração substancial nos paradigmas econômico, comercial, político e social, afetando intensamente a estrutura e o papel do Estado-nação, que, ao perder sua centralidade tradicional enquanto unidade privilegiada de condução ou controle dos fluxos de pessoas, bens, capitais ou ideias, se mostra então insuficiente para responder às novas necessidades da sociedade internacional. ${ }^{2,}$,

Observa-se, ainda, que o regionalismo tem abarcado, desde sua origem, diferentes modos deinstitucionalização, de acordo com os interesses dos Estados participantes na integração, e essa diversidade tem se manifestado de forma marcante na atualidade. ${ }^{4}$ A complexidade da temática consiste na dimensão política do processo de integração, que não pode ser dissociada dos aspectos jurídico e econômico, vez que a estratégia e o nível de aprofundamento dependem necessariamente da vontade política dos Estados que decidem se aproximar.

A partir da década de 1980, contudo, o fenômeno do regionalismo demonstrou não apenas novo fôlego, mas inovadora configuração. ${ }^{67} \mathrm{O}$ então "novo regionalismo" se diferencia substancialmente, por ultrapassar a pauta das questões tarifárias, incorporando novas temáticas ${ }^{8}$ e relacionando-se com a mudança na geografia do poder mundial em sentido mais amplo.

Por um lado, o novo regionalismo é identificado, de modo geral, com o regionalismo aberto, por sua interação com o mercado exterior e com a liberalização multilateral. ${ }^{9}$ Sob tal perspectiva, haveria uma tendência

1993. p. 33.

2 MENEZES, Wagner. Ordem global e transnormatividade. Ijui: Unijui, 2005.

3 SILVA, Roberto Luiz. Direito comunitário e da integração. Porto Alegre: Síntese, 1999. p. 23.

4 AMARAL JÚNIOR, Alberto do. A solução de controvérsias na OMC. São Paulo: Atlas, 2008. p. 29.

5 CELLI JUNIOR, Umberto. Teoria geral da integração: em busca de um modelo alternativo. In: MERCADANTE, Araminta de Azevedo; CELLI JUNIOR, Umberto; ARAÚJO, Leandro Rocha de (Orgs.). Blocos econômicos e integração na América Latina, África e Ásia. Curitiba: Juruá, 2003. p. 19.

6 HURRELL, Andrew. On global order: power, values and the constitution of international society. New York: Oxford University Press, 2007. p. 241.

7 FAWCETT, Louise. Regionalism in historical perspective. In: FAWCETT, Louise; HURRELL, Andrew. Regionalism in world politics. Oxford: Oxford University Press, 1995. p. 9.

8 HORN, Henrik; MAVROIDIS, Petros C.; SAPIR, André. Beyond the WTO?: an anatomy of EU and US preferential trade agreements. Brussels: Bruegel, 2009.

9 PRAZERES, Tatiana Lacerda. A OMC e os blocos regionais. São 
de conjugação dos Acordos Regionais de Comércio com a abertura econômica multilateral, ${ }^{10}$ como mecanismo mediante o qual os governos conduziriam sua inserção econômica mantendo relativa autonomia política. ${ }^{11}$ Por outro lado, contudo, a nova agenda do regionalismo bem como a sua arquitetura diferenciada - trouxe novas complexidades ao seu relacionamento com o sistema multilateral de comércio.

Assim, sob a nomenclatura de Acordos Regionais de Comércio (ARC), ou Acordos Preferenciais de Comércio (APC), ${ }^{12}$ identificaram-se, nessa onda de regionalismos, em face do sistema multilateral de comércio, quatro tendências principais: (i) o protagonismo desses Acordos nas políticas comerciais da maior parte dos Estados, superando a primazia do sistema multilateral; (ii) o crescente nível de sofisticação, nas áreas de normatividade e nos parceiros não necessariamente em contiguidade geográfica; (iii) o aumento dos acordos Norte-Sul, entre países desenvolvidos e em desenvolvimento; e (iv) a expansão e consolidação de um crescente número de ARC bilaterais entre blocos regionais de comércio de dimensão continental. ${ }^{1}$

Destaca-se, pois, que não é recente a preocupação de estudiosos com o futuro do sistema multilateral de comércio, face a essa proliferação dos Acordos Regionais. A percepção, entretanto, de que a formação de tais acordos tem se dado de forma livre e com regulamentação pouco efetiva, tem levado a doutrina a vislumbrar uma inversão nas relações econômicas internacionais, na qual o regionalismo perde seu caráter de exceção, constituindo uma regra, em potencial

Paulo: Aduaneiras, 2008. p. 150-151.

10 DEVLIN, Robert; ESTEVADEORDAL, Antoni. What's new in the new regionalism in the Americas? In: BULMERTHOMAS, Victor (Ed.). Regional integration in Latin America and the Caribbean: the political economy of open regionalism. London: Institute of Latin American Studies, University of London, 2001. p. 22.

11 CEPAL. Regionalismo abierto: un examen del concepto a la luz de las experiencias de América Latina y Asia y el Pacífico. In: _. Panorama de la inserción internacional de América Latina y el Caribe. LC/G.2085-P. Santiago: Naciones Unidas, 2001. p. 208.

12 Assim como os autores do estudo desenvolvido no âmbito da $\mathrm{OMC}$, as nomenclaturas são adotadas neste trabalho como termos intercambiáveis, embora existam outros autores que estabeleçam diferenças entre os ARC e os APC. Cf: FIORENTINO, Roberto; VERDEJA, Luis; TOQUEBOEUF, Christelle. The changing landscape of regional trade agreements: 2006 Update. WTO Discussion Paper n. 12. Geneva: WTO, 2007.

13 FIORENTINO, Roberto; VERDEJA, Luis; TOQUEBOEUF, Christelle. The changing landscape of regional trade agreements: 2006 Update. WTO Discussion Paper n. 12. Geneva: WTO, 2007. ameaça ao multilateralismo, exigindo mudanças dos Estados e/ou do sistema multilateral.

A fraca disciplina do tema, a dificuldade em se atingir um consenso e o interesse individual de parte dos Estados em deixar a questão livre de impedimentos nas relações internacionais contribuem para a erosão da não-discriminação no comércio internacional, ${ }^{15}$ bem como apontam para um risco de imposição assimétrica das regras do comércio internacional, como discutiremos adiante.

\section{Desenvolvimento}

\subsection{A dicotomia superada: stumbling blocs e building blocs}

Em uma visão global da literatura nesta temática, é possível reconhecer uma evolução, de modo correlato às ondas de acordos regionais de comércio, consubstanciada em três gerações distintas na doutrina. ${ }^{16}$

A primeira geração corresponde aos estudos originados a partir de Jacob Viner, que elabora os conceitos de criação de comércio (trade creation) e desvio de comércio (trade divertion), que compõem uma análise econômica dos efeitos dos acordos regionais face à liberalização multilateral. ${ }^{17} \mathrm{O}$ teste do desvio e criação de comércio formulado nessa primeira geração continua como ponto de partida relevante da análise dos efeitos econômicos da formação

14 O relatório acerca do futuro da OMC, elaborado com vistas a explorar os desafios institucionais da organização no novo milênio, denominado Sutherland Report em referência ao seu ccordenador, destaca a inversão ocorrida: "Yet nearly five decades after the founding of the GATT, MFN is no longer the rule; it is almost the exception. Certainly, much more trade between the major economies is still conducted on an MFN basis. However, what has been termed the "spaguetti bowl" of custom unions, common markets, regional and bilateral free trade areas, preferences and an endless assortment of miscellaneous trade deals has almost reached the poit where MFN treatment is exceptional treatment. Certainly the term might now be better defined as LFN, Least-Favored-Nation treatment. Does it matter? We belive it matters profoundly to the future of the WTO." CONSULTATIVE BOARD to the WTO Director-General. The Future of the WTO: Advancing Institutional Challenges in the New Milenium. (Sutherland Report). Geneva: WTO, 2004. p. 19.

15 MAVROIDIS, Petros. If you don't do someone else will (or won't): testing compliance of preferential trade agreements with the multilateral rules. Journal of World Trade. v. 40, n. 1, p. 187-214, 2006. p. 9.

16 THORSTENSEN, Vera. O multissistema da regulação do comércio global: proposta de novo referencial teórico e nova metodologia de análise. Revista Tempo do Mundo, Brasília, v. 3, n. 1. p. 89-115, 2011.

17 VINER, Jacob. The customs union issue. Washington DC: Anderson Kramer Associates, 1961. p. 44. 
de blocos, embora as críticas e refinamentos tenham levado a uma análise dos efeitos em uma perspectiva mais ampla pelos estudos que se seguiram.

A segunda geração de estudos nesta temática polarizou a discussão entre a identificação desses acordos como blocos de contenção $3 / 4$ stumbling blocs $3 / 4 \mathrm{da}$ liberalização do comércio multilateral, em uma relação de antagonismo, a percepção dos acordos regionais de comércio como building blocs, em complementariedade ao sistema multilateral. Essa dicotomia, embora tenha partido da geração anterior dos estudos econômicos, incorporou à discussão outros fatores não diretamente econômicos.

Sob o ponto de vista da tensão entre os Acordos Regionais e a OMC, criticam-se os efeitos do que Jagdish Bhagwati denominou spaguetti bowl, ${ }^{19}$ em referência ao emaranhado de regulamentações comerciais sobrepostas e inconsistentes entre si, que ameaçaria a transparência e a previsibilidade no comércio internacional, e resultaria no aumento dos custos de transação através dessa complexa arquitetura.

Ademais, afirma-se que os ARC podem desviar a atenção das negociações multilaterais, por motivos de recursos financeiros e humanos limitados destinados a negociações comerciais, e por razão da mudança de foco e perda de interesse político no sistema multilateral. ${ }^{20}$ A primeira hipótese é claramente o caso de países menos desenvolvidos, que não detêm corpo diplomático e recursos materiais suficientes para a participação simultânea em negociações regionais e multilaterais. A segunda hipótese se confunde com a observada perda de interesse de certos países no avanço das negociações multilaterais, resultado também dos entraves não solucionados da Rodada de Doha.

Por fim, alega-se que o tratamento de temas 'sensíveis' pelos sistemas regionais poderia prejudicar o consenso nas regras do comércio unilateral, por antecipar a percepção das dificuldades geradas por meio da adoção regional de regras em temas não diretamente comerciais (non trade issues).

18 MANSFIELD, Edward D.; MILNER, Helen V. The political economy of regionalism. New York: Columbia University Press, 1997. p. 22.

19 BHAGWATI, Jagdish. Preferential trade agreements: the wrong road. Law and Policy in International Business, v. 27, p. 865-890, 1996.

20 FIORENTINO, Roberto; VERDEJA, Luis; TOQUEBOEUF, Christelle. The changing landscape of regional trade agreements: 2006 Update. WTO Discussion Paper n. 12. Geneva: WTO, 2007. p. 11.
Por outro lado, sob a perspectiva da compatibilidade entre os acordos regionais e o sistema multilateral, afirma-se que os Acordos Regionais, devido ao número reduzido de participantes, conseguiriam alcançar liberalizações mais profundas que o sistema de negociações multilaterais. Assim, ao promoverem a liberalização regional, tem-se que os Acordos Regionais favorecem o caminho ao livre comércio, objetivo basilar do sistema multilateral.

Ademais, os arranjos regionais com frequência aprofundam os compromissos já acordados, ou incluem compromissos em áreas ainda não abrangidas pelas obrigações da OMC. O estabelecimento de compromissos mais profundos $3 / 4$ WTO-plus $3 / 4,{ }^{21}$ e de compromissos que ultrapassam as áreas atualmente disciplinadas $3 / 4$ WTO-extra $3 / 4,22$ ao mesmo tempo em que são apresentados por alguns como prejudiciais ao consenso na OMC, pois escancaram as dificuldades de implementação e malefícios por parte dos países em desenvolvimento, são também interpretados como antecedentes positivos às negociações multilaterais. ${ }^{23}$

A perspectiva nesse ponto parte da ideia de que os compromissos regionais representam consensos parciais entre os membros da OMC, oferecendo precedente útil às negociações multilaterais, também por meio da formação de alianças e fortalecimento das relações entre parceiros comerciais. Embora haja a possibilidade, em temas como direitos trabalhistas e meio ambiente, de regulamentações divergentes $e$ discriminatórias a partir da multiplicidade de arranjos regionais, as demandas do mercado e os custos da aplicação de diversas regulamentações diferentes empurrariam os membros para a convergência, através da harmonização e unificação das regras. ${ }^{24}$

Além do precedente ao consenso, o tratamento pelos Acordos Regionais de temas além das obrigações

21 A expressão WTO-plus é utilizada na doutrina em referência a Acordos que tratam de temas previstos na OMC, mas estabelecem compromissos mais onerosos que a disciplina do sistema multilateral.

22 A expressão WTO-extra é utilizada na doutrina em referência a Acordos que tratam de temas ainda não disciplinados pelo sistema multilateral.

23 CEPAL. Regionalismo abierto: un examen del concepto a la luz de las experiencias de América Latina y Asia y el Pacífico. In: _. Panorama de la inserción internacional de América Latina y el Caribe. LC/G.2085-P. Santiago: Naciones Unidas, 2001. p. 210.

24 FIORENTINO, Roberto; VERDEJA, Luis; TOQUEBOEUF, Christelle. The changing landscape of regional trade agreements: 2006 Update. WTO Discussion Paper n. 12. Geneva: WTO, 2007. p. 8. 
da OMC poderia oferecer experiências concretas de implementação que conseguem auxiliar o sistema multilateral a regulamentar esses temas de maneira menos "traumática" aos Estados. Nesse aspecto, os Acordos Regionais funcionariam como uma experiência preliminar, na qual a negociação e implementação de regras em temas "sensíveis" poderia ensinar aos negociadores multilaterais, expondo o melhor caminho para a inclusão desses novos temas na agenda da OMC.

Contudo, em superação desta dicotomia, a geração atual de estudos se concentra no aspecto concreto e real da temática, propondo análises específicas dos principais Acordos Regionais existentes, exames de compatibilidade de regras determinadas com a normativa multilateral e mecanismos concretos de multilateralização das regras regionais. ${ }^{25}$

A superação da dicotomia clássica por essa nova geração de estudos é resultado, pois, de mudanças concretas na arquitetura das relações econômicas internacionais observadas nos últimos anos. ${ }^{26}$ Não se pode ignorar, ainda, que a recente crise econômica mundial e o fracasso nas negociações de novos compromissos na OMC conferiram combustível adicional à conclusão de Acordos Regionais pelos principais atores das relações internacionais. Esse quadro acaba por extremar as previsões, levando à percepção de objetivos implícitos de exportação de um modelo regulatório na conclusão de pacotes de Acordos Regionais, como veremos adiante.

\subsection{O regionalismo do século XXI como vetor para imposição de modelos normativos}

$\mathrm{Na}$ atualidade, verifica-se a necessidade de uma revisão substancial e global do tratamento do regionalismo em relação ao sistema multilateral, de modo a preencher o espaço existente entre o regionalismo do Século XXI e as regras do Século XX. ${ }^{27}$ Por suas características únicas, o regionalismo deste século exige uma rearquitetura de regras e estratégias existentes.

25 BALDWIN, Richard. Multilateralizing regionalism: spaguetti bowls as building blocks on the path to global free trade. The World Economy, v. 29, n. 11, p. 1451-1518, 2006.

26 BALDWIN, Richard. 21th century regionalism: filling the gap between 21th century trade and 20th century rules. Geneva: World Trade Organization, Economic Research and Statistics Division, 2011.

27 BALDWIN, Richard. 21th century regionalism: filling the gap between 21 th century trade and 20th century rules. Geneva: World Trade Organization, Economic Research and Statistics Division, 2011.
Como bem destaca Richard Baldwin, a revolução tecnológica-informacional-comunicacional promoveu uma real internacionalização das cadeias produtivas, que trouxe a imbricação entre (i) o comércio; (ii) os investimentos e (iii) os serviços ao centro do comércio internacional. Essa nova configuração exige normas complexas para sua regulação, que abarquem tais temáticas. ${ }^{28}$

O autor complementa sua teoria da multilateralização do regionalismo, com um estudo no qual, após evidenciar novas complexidades da relação entre o multilateralismo e o regionalismo, clama por um novo quadro regulatório do comércio internacional. O nexo entre (i) comércio, (ii) investimentos e (iii) serviços passou a ser elemento central e característica distintiva do comércio internacional no Século XXI.

Como consequência, as principais barreiras ao comércio neste século não são as tarifárias, mas aquelas relacionadas à defesa da concorrência, ao trânsito de capitais, aos direitos de propriedade intelectual e à segurança de investimentos. Estes são, pois, temas que já foram implementados no interior dos Estados desenvolvidos, mas ainda necessitam de regulamentação doméstica nos demais Estados. Deste modo, o regionalismo atual passaria a preencher, através de Acordos Regionais "profundos", o espaço de regulamentação desses temas, juntamente com reformas unilaterais e Tratados Bilaterais de Investimentos. ${ }^{30}$

Desse modo, o regionalismo do século XXI é direcionado por forças políticas e econômicas interessadas em reformas regulatórias internas, diferentemente das forças interessadas no acesso a mercados que dirigiam o regionalismo do século XX. A regulação segundo certos interesses passa a ser o objetivo buscado e, neste ponto, o regionalismo poderia ameaçar o papel da OMC como locus de formulação multilateral de regras do comércio internacional.

28 BALDWIN, Richard. 21th century regionalism: filling the gap between 21 th century trade and 20th century rules. Geneva: World Trade Organization, Economic Research and Statistics Division, 2011. p. 5.

29 BALDWIN, Richard. 21th century regionalism: filling the gap between 21 th century trade and 20th century rules. Geneva: World Trade Organization, Economic Research and Statistics Division, 2011. p. 10.

30 BALDWIN, Richard. 21th century regionalism: filling the gap between 21 th century trade and 20th century rules. Geneva: World Trade Organization, Economic Research and Statistics Division, 2011. p. $10-25$. 
Nessa perspectiva, toda a sistemática de negociação $3 / 4$ regional ou multilateral $3 / 4$ passa a circular não mais em função de barganhas para o acesso a mercados através de cortes tarifários, mas em torno da capacidade de expansão do modelo regulatório ao qual um polo já esteja vinculado. A função dos grupos de interesse interno assume força determinante da política comercial, ao exercer influência substancial sob as negociações nas diferentes esferas $3 / 4$ multilateral, regional e unilateral. ${ }^{3}$

É assim também que Vera Thorstensen propõe uma visão integrada da regulação do comércio global, que passaria por uma análise transversal das dimensões normativas relacionadas ao comércio internacional, visando a uma melhor compreensão dos efeitos cruzados entre o sistema multilateral-plurilateral, os sistemas preferenciais, e os sistemas nacionais de comércio externo. ${ }^{32}$

A autora também destaca a relevância central de uma análise atenta do mapeamento dos acordos preferenciais negociados por um certo parceiro, uma vez que a concentração de países com acordos em torno de um eixo evidencia padrões de regras que depois serão levadas às instâncias multilaterais. E, assim, se um número significativo de países adotar certo modelo regulatório, o grau de liberdade possível para a negociação multilateral ou a posterior inclusão de outros países no grupo será limitada. ${ }^{33}$ Assim, a formação de acordos regionais de

31 BALDWIN, Richard. 21th Century Regionalism: Filling the gap between 21th century trade and 20th century rules. Geneva: World Trade Organization, Economic Research and Statistics Division, 2011. p. 23-25.

32 Assim a autora explicita: "Uma visão integrada da regulação do comércio global, sob essa ótica, passa a abranger não apenas a análise em sequência dos diferentes sistemas de regulação que

definem o comércio internacional - incluindo temas diretamente ligados ao comércio, temas relacionados ao comércio e temas

que afetam o comércio -, mas também, e sobretudo, uma maior compreensão dos efeitos cruzados entre os diversos sistemas: i) o sistema multilateral-plurilateral, criado por meio de negociações internacionais entre membros de organizações internacionais e/ ou tratados internacionais negociados por uma parcela significativa de países; ii) os sistemas preferenciais (regionais, bilaterais, não recíprocos), negociados pelas partes de acordos comerciais de diferentes níveis de integração econômica; e iii) os sistemas nacionais de comércio externo, negociados internamente pelos principais parceiros internacionais, e definidos por suas políticas de comércio externo." THORSTENSEN, Vera. O multissistema da regulação do comércio global: proposta de novo referencial teórico e nova metodologia de análise. Revista Tempo do Mundo, Brasília, v. 3, n. 1. p. 89-115, 2011. p. 93-94.

33 THORSTENSEN, Vera. O multissistema da regulação do comércio global: proposta de novo referencial teórico e nova metodologia de análise. Revista Tempo do Mundo, Brasília, v. 3, n. 1. p. 89-115, 2011. p. 98. comércio com compromissos regulatórios para além da disciplina multilateral pode influenciar na capacidade de um Estado em tornar-se um agente de construção da governança do comércio internacional. ${ }^{34}$

É nesse sentido que o regionalismo assume novo papel nas relações internacionais, polarizando modelos normativos que paulatinamente tendem a se cristalizar, trazendo uma pressão à sua adoção pelos demais países, e privilegiando interesses dos Estados centrais que iniciaram o respectivo polo. Este contexto exige, portanto, uma postura crítica e proativa dos Estados em desenvolvimento $3 / 4$ e dos países latino-americanos $3 / 4 \mathrm{sob}$ o risco de diluírem-se na corrente normativa, e acabarem importando modelos regulatórios que lhes desfavoreçam.

\subsection{Os modelos normativos europeus e norte- americanos}

Partindo desse novo contexto, Henrik Horn, Petros Mavroidis e André Sapir desenvolveram pesquisa empírica com o objetivo de mapear os Acordos Regionais de Comércio sob a perspectiva da 'profundidade' de seus compromissos em face dos Acordos da OMC. Tendo em vista que o emaranhado de Acordos Regionais seguindo um padrão próprio é estratégia adotada há décadas pela União Europeia ${ }^{35}$ e Estados Unidos $3 / 4$ seguida bem mais recentemente pelo Japão $3 / 4{ }^{36}$, a pesquisa focou sua análise sob os dois primeiros agentes.

34 THORSTENSEN, Vera; et al. A multiplicação dos acordos preferenciais de comércio e o isolamento do Brasil. 2013. Disponível em: $<$ http://retaguarda.iedi.org.br/midias/artigos/51d18e9168afa9d0. pdf $>$. Acesso em: 30 nov. 2014.

35 Na pesquisa em questão utiliza-se do termo "Comunidade Europeia" para se referir à atuação da União Europeia na sociedade internacional. Não se pretende adentrar na eventual distinção conceitual entre ambas as expressões, limitando-se à destacar que esta discussão perde sentido desde a ratificação do Tratado de Lisboa, que prevê textualmente que a União Europeia substituiu e sucedeu à Comunidade Europeia. Neste sentido, a nomenclatura adotada nos documentos oficiais da OMC passou a ser "União Europeia".

36 Pesquisas recentes apontam também o papel da China, que buscaria crescentemente também construir um modelo próprio para seus arranjos regionais, seguindo a tendência dos outros global players. Cf: SANCHEZ BADIN, Michelle Ratton. Compromissos assumidos por grandes e médias economias em Acordos Preferenciais de Comércio: o contraponto entre União Europeia e Estados Unidos e China e Índia. Brasília: IPEA, 2012. p. 14.

37 HORN, Henrik; MAVROIDIS, Petros C.; SAPIR, André. Beyond the WTO?: an anatomy of EU and US preferential trade agreements. Brussels: Bruegel, 2009. 
Após análise detida dos Acordos Regionais então registrados perante o Secretariado da OMC que tinham como parte respectivamente a União Europeia e os Estados Unidos, os autores concluíram que estes escolheram estratégias notadamente distintas em relação à tipificação das cláusulas além da normatividade consolidada no âmbito multilateral.

Primeiramente, foi detectada uma "inflação normativa" nos Acordos direcionados pela União Europeia, que continham o quádruplo do número de dispositivos WTO-extra, mas muitos deles continham obrigações não exigíveis juridicamente. Dentre os temas inovadores, os acordos direcionados pela UE continham disposições relativas às políticas de concorrência e os acordos dos EUA continham dispositivos relacionados a padrões trabalhistas e ambientais.

Embora entendam que o estudo não permitiria apontar diferenças precisas nestas estratégias, os autores explicitam a percepção de que estes dispositivos que expressam uma 'inflação normativa' são disposições relacionadas à temática do desenvolvimento, o que sugeriria uma necessidade da UE em posicionar seus Acordos regionais como não puramente ligados a interesses comerciais. Este aspecto pode se relacionar, ainda, a uma falta de consenso entre os estados-membros da UE sobre os objetivos principais desses acordos.

A segunda conclusão principal do estudo explicita que os dispositivos de fato exigíveis juridicamente são poucos tanto nos Acordos centralizados na UE quanto nos Acordos centralizados nos EUA, e se referem majoritariamente a áreas já existentes nos Acordos da $\mathrm{OMC}$, tais como investimentos, trânsito de capitais e propriedade intelectual (WTO-plus).

A conclusão final do estudo se refere à constatação de que as disposições existentes em áreas inovadoras têm um caráter claramente regulatório, o que sugere que os acordos capitaneados pela UE e EUA se prestam a atuar como meios para que os dois polos exportem e expandam seus respectivos modelos regulatórios a seus parceiros de acordos regionais. E, assim, chamam a atenção ao potencial dano à justiça das relações comerciais internacionais:

Este estudo não nos permite tirar conclusões sobre os custos e os benefícios desta situação para os "hubs and spokes", mas a nossa impressão é que ele atende principalmente os interesses dos dois "reguladores do mundo". Esta impressão é baseada no fato de que as disposições OMC-extra juridicamente vinculantes incluídas nos acordos da CE e dos EUA foram todos objeto de tentativas anteriores, mas mal sucedidas, por parte da UE e / ou dos EUA para incorporá-las em regras da OMC, contra os desejos dos países em desenvolvimento. Na medida em que nossa conclusão é correta, ela apoia a visão acima mencionada que APC são fontes de preocupação com a injustiça nas relações comerciais ${ }^{38}$

O Secretariado da OMC aplicou metodologia similar em pesquisa com um universo mais amplo de acordos regionais, destacando o novo foco dos ARC em formação. ${ }^{39}$ Este segundo estudo reforça a tendência de aprofundamento dos novos acordos regionais de comércio em matérias além das disciplinadas multilateralmente, o que aponta o caráter regulatório dos compromissos assumidos e sua crescente relevância para a disciplina do comércio global. ${ }^{40}$

38 Tradução livre do original em língua inglesa: "This study does not permit us to draw conclusions about the costs and benefits of this situation for the hubs and the spokes, but our impression is that it primarily serves the interests of the two 'regulators of the world'. This impression is based on the fact that the legally enforceable WTO-X provisions included in EC and US agreements have all been the subject of earlier, but failed, attempts by the EU and/or the US to incorporate them into WTO rules, against the wishes of developing countries. To the extent that our conclusion is correct, it supports the above-mentioned view that PTAs are breeding concern about unfairness in trade relations." HORN, Henrik; MAVROIDIS, Petros C.; SAPIR, André. Beyond the WTO?: an anatomy of EU and US preferential trade agreements. Brussels: Bruegel, 2009. p. 7.

39 Assim, o estudo indica: "As preferential agreements have evolved over time, however, the lowering of tariffs is no longer the main focus of PTAs. Agreements now cover a wider number of issues - beyond tariffs - and involve more structured institutional arrangements. Traditional theories about PTAs fail to explain these new developments, both in terms of the causes and consequences of "deep" agreements. In particular, traditional theories are silent on the relationship between the growth of international production networks and the formation of deeper policy arrangements among countries. While the above discussion has shed some light on the causes and the structure of deep integration agreements - a discussion that falls mostly outside the domain of trade economics

- there is clearly a need for further research in this area. WORLD TRADE ORGANIZATION. World Trade Report 2011. The WTO and preferential trade agreements: from co-existence to coherence. Geneva: WTO, 2011. p. 114.

40 O estudo confirma a hipótese dos autores Horn, Mavroidis e Sapir: "The pattern between developed and developing countries observed in the portion of Figure D.9 dealing with WTO-X provisions is consistent with the argument made by HMS that developed countries are seeking to "export" their regulatory regimes to developing countries. WORLD TRADE ORGANIZATION. World Trade Report 2011. The WTO and preferential trade agreements: from co-existence to coherence. Geneva: WTO, 2011. p. 132. 


\subsection{Em busca de um modelo latino-americano}

Enquanto os EUA e a União Europeia desenvolvem seus respectivos modelos normativos, e promovem a sua crescente expansão em um contexto de diminuição de esforços no âmbito multilateral, os países da América Latina adotam perspectivas difusas sobre a temática. ${ }^{41}$

Alguns países, como México e Chile, têm buscado o estabelecimento de Acordos Regionais de Comércio com padrões regulatórios similares ao NAFTA, o que lhes situa mais fortemente na zona de influência do modelo regulador norte-americano. Os aparentes frutos econômicos surgidos a esses países estimularam outros a seguirem esta estratégia de celebração de ARC mais recentemente, tais como Colômbia, Peru e Equador. No caso do Chile, que há algumas décadas adota a formação de Acordos Bilaterais como estratégia de inserção internacional, houve inclusive a substituição de acordos anteriormente formados com parceiros da América Latina por outros no modelo no NAFTA, o que poderia sugerir uma concreta replicação do modelo norte-americano como expressão da primazia desses interesses. ${ }^{42}$

De modo geral, os demais países da América Latina seguem apostando em esquemas regionais anteriormente constituídos 3/4 ALADI e MERCOSUL $3 / 4$, não se atentando para o valor de outros ARC em termos de participação na construção do modelo regulatório internacional. Ademais, é preciso destacar que, devido ao nível de consolidação jurídica-

41 Embora não seja objeto deste estudo, cumpre destacar que o conceito de América Latina é relativo, e a expressão, como categoria classificadora de povos com diversas culturas, merece reflexão. De modo geral, o conceito se relaciona ao compartilhamento do sentido da exploração colonial, embora com inegáveis variáveis próprias da colonização portuguesa e hispânica, que seria, portanto, uma característica comum às atuais ex-colônias tropicais na América, nas quais diversos autores visualizam uma identidade contemporânea de subdesenvolvimento.

42 Os autores fazem este diagnóstico: "A maioria desses acordos são TLCs de natureza semelhante à do NAFTA, sendo que este formato de acordo tem substituído anteriores ACEs que o Chile havia feito com alguns países latino-americanos na década de 1990, como no caso de Peru e Colômbia. Isso porque, segundo Sáez e Valdés (1999), o governo chileno tem estimulado a inclusão das distintas dimensões do comércio, reflexo da maior complexidade das relações econômicas, o que não está presente nos ACEs. Além disso, Kuwayama e Kuwayama (2002) sugerem que o fato de o Chile fazer TLC no modelo NAFTA seria uma forma de reduzir os problemas de coordenação que podem surgir com o grande número de acordos bilaterais." p. 670 CARVALHO, Carlos Eduardo; LOPES, Renata Rossetto. Acordos bilaterais de comércio como estratégia de inserção regional e internacional do Chile. Contexto Internacional, v. 32, n. 2, p. 643-693, jul/dez. 2010. institucional alcançado por estes esquemas, há obstáculo formal à celebração de novos ARC pelos países em separado, exigindo-se uma negociação em bloco com os demais parceiros, o que por si só pode dificultar a formação desses novos ARC e a construção de um modelo normativo latino-americano.

No tocante ao Brasil, é possível identificar um verdadeiro "isolamento" do país no contexto da formação desses novos ARC, e potencialmente na construção do modelo regulatório global, uma vez que o país sempre privilegiou a esfera multilateral para negociações comerciais, o que tem resultado na inexistência de construção um modelo de acordo embasado nos interesses brasileiros. ${ }^{43}$

Em estudo que traça claramente este diagnóstico, Vera Thorstensen et al identificam no diminuto número de ARC celebrados pelo país, os vetores regional e extrarregional. $\mathrm{O}$ vetor regional encontra-se polarizado pelo MERCOSUL, que por sua vez insere-se no âmbito da ALADI. ${ }^{44}$ No vetor extrarregional, os acordos existentes foram celebrados pelo país em conjunto com os demais parceiros do MERCOSUL, e o maior destaque é conferido ao acordo em negociação com a UE. ${ }^{45}$ Em ambos os vetores, contudo, as regras contidas nestes APC inovam pouco em relação à normatividade multilateral, apresentando principalmente uma retomada de regras dos acordos da OMC. ${ }^{46}$

43 THORSTENSEN, Vera; et al. A multiplicação dos acordos preferenciais de comércio e o isolamento do Brasil. 2013. Disponível em: $<$ http://retaguarda.iedi.org.br/midias/artigos/51d18e9168afa9d0. pdf>. Acesso em: 30 nov. 2014.

44 Assim enumeram os autores: "Nesse contexto, foram celebrados acordos entre os membros do Mercosul e: (i) Chile; (ii) Bolívia; (iii) México (geral); (iv) México (setor automotivo); (v) Peru; (vi) Colômbia, Equador e Venezuela; e (vii) Cuba. O Brasil também assinou acordos com: (i) Guiana e (ii) Suriname (apenas arroz)." THORSTENSEN, Vera; et al. A multiplicação dos acordos preferenciais de comércio e o isolamento do Brasil. 2013. Disponível em: $<$ http://retaguarda.iedi.org.br/midias/artigos/51d18e9168afa9d0. pdf $>$. Acesso em: 30 nov. 2014.

45 Assim explicitam os autores: "No âmbito extraregional, o Brasil, em conjunto com o Mercosul, é signatário de APCs com: (i) Índia, (ii) Israel; (iii) União Aduaneira do Sul da África - SACU ; (iv) Egito; e (v) Palestina, dos quais apenas dois primeiros estão em vigor. Destaca-se, também, a atual negociação de um APC entre Mercosul e União Européia." THORSTENSEN, Vera; et al. A multiplicação dos acordos preferenciais de comércio e o isolamento do Brasil. 2013. Disponível em: <http://retaguarda.iedi.org.br/midias/ artigos/51d18e9168afa9d0.pdf>. Acesso em: 30 nov. 2014.

46 A este respeito, confira-se: "Finalmente, em novos temas, pouca regulamentação é de fato encontrada nos acordos constitutivos e também naqueles assinados entre Brasil ou Mercosul e outros parceiros. Em grande parte, a regulamentação se restringe a acordos mais específicos dentro de cada área, que são regulados eminentemente no Mercosul, com exceção da temática de meio ambiente, também 
A estagnação na celebração de novos acordos pelo país pode levar não somente à perda relativa de preferências tarifárias pelo Brasil em relação a outros países da América Latina que continuem negociando com outros parceiros, mas principalmente pode abrir espaço para o fortalecimento do modelo norteamericano no continente. Isso pois a Aliança do Pacífico $3 / 4$ formada entre Chile, Colômbia, Peru e México $3 / 4-$ tem a potencialidade de constituir-se como um centro replicador do modelo de integração postulado pelos ARC com padrão regulatório norte-americano e em defesa de seus respectivos interesses. ${ }^{47}$

Diante deste quadro, Vera Thorstensen et al concluem:

Com a necessidade de atualização das regras da OMC e do impasse nas negociações da Rodada Doha, a regulação do comércio se dará, sobretudo, no âmbito dos APCs. Desse modo, o Brasil deverá intensificar o processo de integração tanto no vetor regional quanto no extraregional, além de definir as regras que julgue necessárias negociar para esse novo cenário comercial, tais como regras de origem, medidas não tarifárias, serviços e investimentos, dentre outros. Apenas assim o Brasil poderá garantir sua posição como um rule maker e não um rule taker na governança do comércio internacional. ${ }^{48}$

Assim, compartilha-se a compreensão explicitada pelo estudo supracitado de que o Brasil deve assumir um papel proativo na construção de novos acordos, que busquem construir um modelo regulatório que esteja mais diretamente ligado aos interesses nacionais, e que possam contribuir para um modelo regulatório latino-americano.

regulada pela Aladi. O Mercosul possui regulamentação nas áreas de concorrência, compras governamentais, meio ambiente e cláusula social, sendo que apenas estas duas últimas estão em vigor." p. 65. SANCHEZ BADIN, Michelle Ratton; CARVALHO, Marina Amaral Egydio de; RORIZ, João Henrique Ribeiro. Os acordos regionais e preferenciais de comércio do Brasil com o seu entorno. In: BAUMANN, Renato; OLIVEIRA, Ivan Tiago Machado (Orgs.). Os BRICS e seus vizinhos: comércio e acordos regionais. Brasília: Ipea, 2014. p. 55-101.

47 MENEZES, Roberto Goulart. A Aliança do Pacífico e a estratégia de integração Sul-Americana do Brasil. IX Encontro da ABCP. Política Internacional. Brasília, ago. 2014. Disponível em: <http://www.encontroabcp2014.cienciapolitica.org.br/ resources/anais/14/1403747928_ARQUIVO_Aestrategia deintegracaoregionalbrasileiraeaAliancadoPacificoABCP2014. pdf $>$ Acesso em: 30 nov. 2014.

48 HORSTENSEN, Vera; et al. A multiplicação dos acordos preferenciais de comércio e o isolamento do Brasil. 2013. Disponível em: <http:// retaguarda.iedi.org.br/midias/artigos/51d18e9168afa9d0.pdf > . Acesso em: 30 nov. 2014.

\section{Comentários finais: desafios e perspectivas}

Conforme se verificou, se por um lado a UE e os EUA têm construído suas redes regulatórias, utilizando-se de sua influência para garantir parceiros em seus Acordos Regionais, e pressionado para que os padrões que lhes interessam sejam impostos, os países da América Latina não possuem posicionamento sólido neste aspecto relevante das relações comerciais internacionais na contemporaneidade. Assim, embora alguns países tenham escolhido vincular-se ao polo norte-americano, os demais países da América Latina permanecem vinculados aos respectivos esquemas regionais consolidados, conferindo atenção secundária à formação de novos acordos regionais, o que seria uma possibilidade de participar desta paulatina construção da normatividade internacional.

Contudo, essa nova configuração da rede de Acordos Regionais impõe novos desafios à participação dos países latino-americanos no cenário internacional, e exige novos paradigmas de tratamento da temática do regionalismo por esses Estados. Desse modo, diante do diagnóstico da polarização entre os Acordos Regionais sob os eixos norte-americano e europeu, a partir de seus respectivos moldes e interesses, ${ }^{49}$ há um chamamento à participação mais efetiva e consciente dos países emergentes $3 / 4 \mathrm{e}$ especialmente do Brasil $3 / 4$ na construção dessa arquitetura institucional regulatória, pois a normatividade que hoje parece diluída tende a se cristalizar, exatamente devido à tipologia dos compromissos abarcados, que importam implicações jurídico-institucionais domésticas duradouras.

O novo desafio que o regionalismo coloca, portanto, ao sistema multilateral é sutil, ao ameaçar a legitimidade do sistema em sua capacidade de congregar distintos interesses e construir entendimentos. Nesse sentido, não se trata apenas de promover a multilateralização do regionalismo, mas de que maneira isto será concretizado. A multilateralização de um modelo hegemônico, que favoreça apenas os Estados desenvolvidos, parece se distanciar dos objetivos globais que vislumbramos no sistema multilateral de comércio. Esses objetivos não se limitam à promoção do livre comércio, mas incluem a manutenção da paz, a promoção do desenvolvimento econômico e do bem-estar mundial, o alcance do desenvolvimento sustentável e a proteção ambiental, a redução da pobreza e a gerência de crises econômicas globais. ${ }^{50}$

49 HORN, Henrik; MAVROIDIS, Petros C.; SAPIR, André. Beyond the WTO?: an anatomy of EU and US preferential trade agreements. Brussels: Bruegel, 2009. p. 7.

50 JACKSON, John. H. Sovereignty, the WTO, and changing fundamentals of international law. Cambridge: Cambridge University Press, 2006. p. 86. 


\section{Referências}

AMARALJÚNIOR, Alberto do. A solução de controvérsias na OMC. São Paulo: Atlas, 2008.

BALDWIN, Richard. 21th century regionalism: filling the gap between 21th century trade and 20th century rules. Geneva: World Trade Organization, Economic Research and Statistics Division, 2011.

BALDWIN, Richard. Multilateralizing regionalism: spaguetti bowls as building blocs on the path to global free trade. The World Economy, v. 29, n. 11, p. 1451-1518, 2006.

BHAGWATI, Jagdish. Preferential Trade Agreements: the wrong road. Law and policy in international business, v. 27, 1996, p. 865-90, 1996.

CARVALHO, Carlos Eduardo; LOPES, Renata Rossetto. Acordos bilaterais de comércio como etratégia de inserção regional e internacional do Chile. Contexto Internacional, v. 32, n. 2, p. 643-693, jul/dez. 2010.

CELLI JUNIOR, Umberto. Teoria geral da integração: em busca de um modelo alternativo. In: MERCADANTE, Araminta de Azevedo; CELLI JUNIOR, Umberto; ARAÚJO, Leandro Rocha de (Orgs.). Blocos econômicos e integração na América Latina, Africa e Ásia. Curitiba: Juruá, 2003.

CEPAL. Regionalismo abierto: un examen del concepto a la luz de las experiencias de América Latina y Asia y el Pacífico. In: - Panorama de la inserción internacional de América Latina y el Caribe. LC/G.2085-P. Santiago: Naciones Unidas, 2001.

CONSULTATIVE BOARD to the WTO DirectorGeneral. The future of the WTO: advancing institutional challenges in the new milenium. (Sutherland Report). Geneva: WTO, 2004.

DEVLIN, Robert; ESTEVADEORDAL, Antoni. What's new in the new regionalism in the Americas? In: BULMER-THOMAS, Victor (Ed.). Regional integration in Latin America and the Caribbean: the political economy of open regionalism. London: Institute of Latin American Studies, University of London, 2001.

FAWCETT, Louise. Regionalism in historical perspective. In: FAWCETT, Louise; HURRELL,
Andrew. Regionalism in world politics. Oxford: Oxford University Press, 1995.

FIORENTINO, Roberto; VERDEJA, Luis; TOQUEBOEUF, Christelle. The changing landscape of regional trade agreements: 2006 update. Geneva: WTO, 2007.

HORN, Henrik; MAVROIDIS, Petros C.; SAPIR, André. Beyond the WTO?: an anatomy of EU and US preferential trade agreements. Brussels: Bruegel, 2009.

HURRELL, Andrew. On global order: power, values and the constitution of international society. New York: Oxford University Press, 2007.

JACKSON, John. H. Sovereignty, the WTO, and changing fundamentals of international law. Cambridge: Cambridge University Press, 2006.

LAFER, Celso. Comércio, desarmamento e direitos humanos: reflexões sobre uma experiência diplomática. São Paulo: Paz e Terra, 1993.

MANSFIELD, Edward D.; MILNER, Helen V. The political economy of regionalism. New York: Columbia University Press, 1997.

MAVROIDIS, Petros. If you don't do someone else will (or won't): testing compliance of preferential trade agreements with the multilateral rules. Journal of World Trade, v. 40, n. 1, p. 187-214, 2006.

MENEZES, Roberto Goulart. A Aliança do Pacifico e a estratégia de integração Sul-Americana do Brasil. IX Encontro da ABCP. Política Internacional. Brasília, 2014. Disponível em: < http://www.encontroabcp2014. cienciapolitica.org.br/resources/anais/14/1403747928_ ARQUIVO_Aestrategiadeintegracaoregionalbrasileir aeaAliancadoPacificoABCP2014.pdf> Acesso em: 30 nov. 2014.

MENEZES, Wagner. Ordem global e transnormatividade. Ijui: Unijui, 2005.

PRAZERES, Tatiana Lacerda. A OMC e os blocos regionais. São Paulo: Aduaneiras, 2008.

SANCHEZ BADIN, Michelle Ratton. Compromissos assumidosporgrandes e médias economias em acordospreferenciais 
de comércio: o contraponto entre União Europeia e Estados Unidos e China e Índia. Brasília: Ipea, 2012.

SANCHEZ BADIN, Michelle Ratton; CARVALHO, Marina Amaral Egydio de; RORIZ, João Henrique Ribeiro. Os acordos regionais e preferenciais de comércio do Brasil com o seu entorno. In: BAUMANN, Renato; OLIVEIRA, Ivan Tiago Machado (Orgs.). Os BRICS e seus vizzinhos : comércio e acordos regionais. Brasília: Ipea, 2014.

SILVA, Roberto Luiz. Direito comunitário e da integração. Porto Alegre: Síntese, 1999.

THORSTENSEN, Vera. O Multissistema da Regulação do Comércio Global: proposta de novo referencial teórico e nova metodologia de análise. Revista Tempo do Mundo, Brasília, v. 3, n. 1. p. 89-115, 2011.

THORSTENSEN, Vera et al. A multiplicasão dos acordos preferenciais de comércio e o isolamento do Brasil. 2013. Disponível em: <http://retaguarda.iedi.org.br/midias/ artigos/51d18e9168afa9d0.pdf>. Acesso em: 30 nov. 2014.

VINER, Jacob. The customs union issue. Washington DC: Anderson Kramer Associates, 1961.

WORLD TRADE ORGANIZATION. World Trade Report 2011. The WTO and preferential trade agreements: from co-existence to coherence. Geneva: WTO, 2011. 


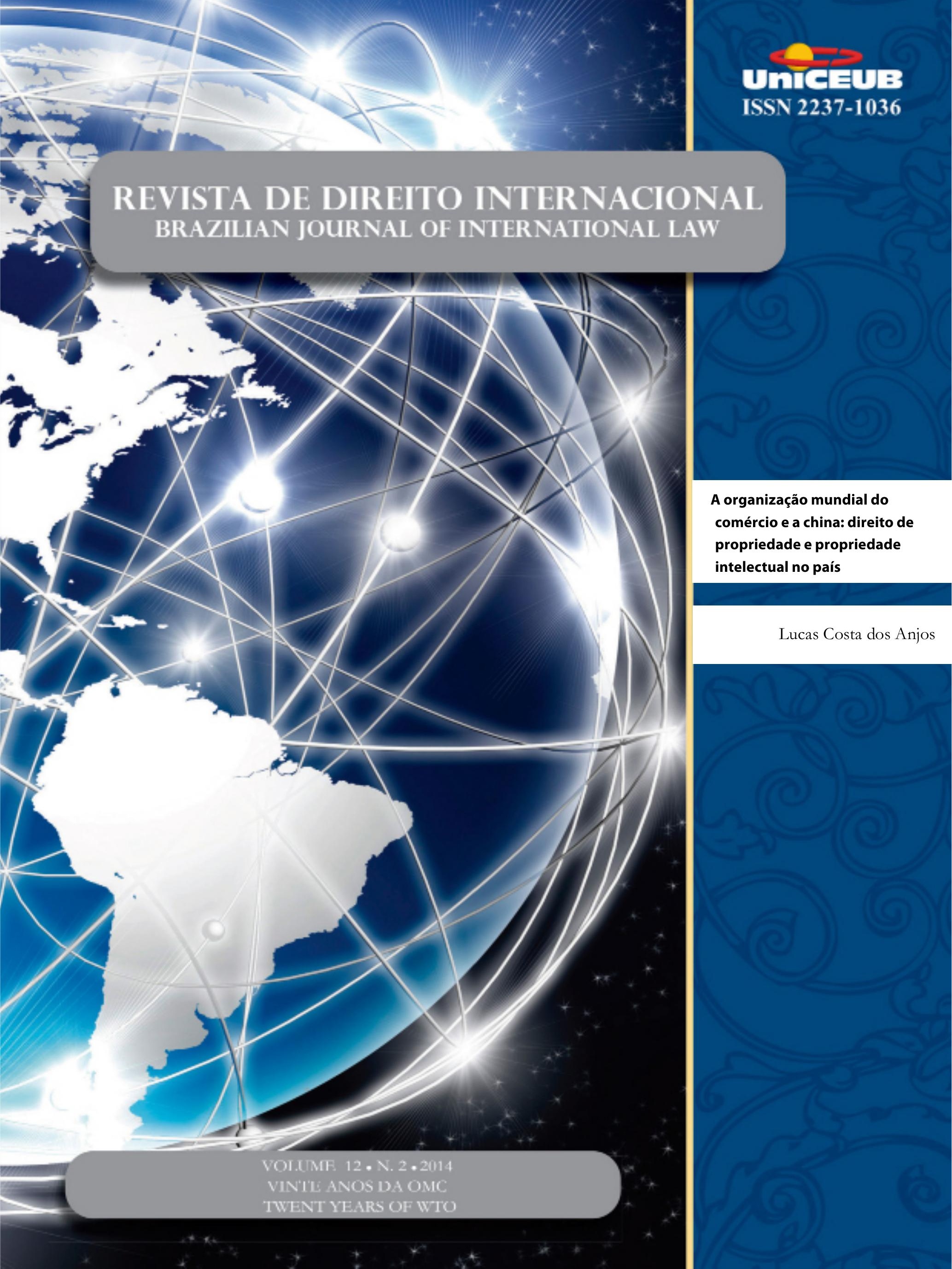




\author{
A ORGANIZAÇÃO MUNDIAL DO COMÉRCIO E A \\ CHINA: DIREITO DE PROPRIEDADE E PROPRIEDADE \\ INTELECTUAL NO PAÍS*
}

\section{The World Trade Organisation and China: Property Rights and Intellectual Property in the State}

Lucas Costa dos Anjos**

\footnotetext{
* Recebido em 09.11.2014

Aceito em 16.12.2014
}

\footnotetext{
** graduado pela Faculdade de Direito da UFMG e mestrando no Programa de Pós-Graduação em Direito da UFMG, com ênfase de pesquisa nas áreas de Direito Internacional Público, Direito Internacional Privado e Propriedade Intelectual. lucascostaanjos@gmail.com
}

\section{Resumo}

O presente artigo pretende analisar o escopo e a abrangência das recentes reformas do direito interno chinês no sentido de criar um marco legal para a ascensão do país à Organização Mundial do Comércio, especialmente no que diz respeito ao direito de propriedade e aos direitos de propriedade intelectual. A relevância do país para essa temática evidencia-se por meio do tamanho de sua economia (mercado consumidor interno e produção exportadora) e de sua parcela de participação no comércio internacional. Além disso, o país é hoje polo de inovação tecnológica e de disseminação de técnicas de produção. As recentes transformações legais, principalmente as reformas na Constituição de 1982 e a Lei de Propriedade de 2007, serão analisadas sob esse contexto. Além disso, observar-se-ão as principais categorias de propriedade intelectual na China, por meio de estudo comparativo com outros regimes normativos do mundo. O mercado chinês ainda é muito pouco estudado, principalmente na língua portuguesa, o que justifica a escolha por títulos de língua inglesa e francesa sobre o tema, bem como ressalta a originalidade e o valor dessa temática para o âmbito acadêmico no Brasil.

Palavras-chave: Propriedade intelectual. Propriedade privada. China. Organização Mundial do Comércio. Acordo TRIPS.

\section{Abstract}

With regard to intellectual property rights, China's transition from world forger of commercial goods in the 1980s and 1990s to a hub of scientific innovation and technology in the 2000s is supported by abundant governmental incentives in research and development. Over the last two decades, due to its accession to the World Trade Organization, China implemented legal reforms that increased the scope of its protection to private property, raising guarantees for foreign investors in the country. In reality, private investments are still subjected to regulations and to political conditionalities from the government, which points out the legal insecurity and the entrepreneurial risks involved in doing business in the country. This article analyzes property law under China's legal system,

1 O presente artigo é resultado de pesquisas e debates desenvolvidos na disciplina Temas de direito internacional público - O direito chinês contemporâneo: diálogos entre cultura, direito comparado e relações internacionais; ministrada pelo Prof. Dr. Fabrício Bertini Pasquot Polido e pelo Prof. Dr. Marcelo Maciel Ramos, no Programa de Pós-Graduação em Direito da Universidade Federal de Minas Gerais, entre fevereiro e julho de 2014. 
by means of contextualizing it according to the 1982 Constitution and the Property Law of 2007. Intellectual property will also be analyzed as a category of private property, especially with regard to recent legal reforms under the TRIPS agreement. The main categories of intellectual property in China will be studied and compared to other national regimes, from different countries. On the final remarks, recent transformations in the country will be taken into consideration, as well as the challenges that property law still faces in China, in addition to new trends for the country in the context of intellectual property. The theme is especially relevant for Brazilian academia, due to the fact that there are not many studies of the subject in Portuguese.

Keywords: Intellectual property. Property law. China. World Trade Organization. TRIPS Agreement.

\section{Considerações iniciais}

Segundo estudos da Organização para a Cooperação e Desenvolvimento - OCDE, a China conseguiu, entre 2005 e 2012: aumentar sua renda per capta de US\$ 4.950 para US\$10.924; crescer sua economia em $10 \%$ ao ano, em média; quadruplicar os investimentos estrangeiros no país; mais que dobrar suas exportações no setor de comunicação e tecnologia; reduzir pela metade a taxa de mortalidade infantil, entre outros impressionantes indicadores de desenvolvimento ${ }^{2}$.

Atualmente, devido a seu crescimento econômico e social, a China desempenha papel de destaque nos principais foros mundiais, desde discussões sobre desenvolvimento sustentável no âmbito do Programa das Nações Unidas para o Meio Ambiente - PNUMA ${ }^{3}$, até questões de coordenação e de regulação financeira, no contexto do Fundo Monetário Internacional ${ }^{4}$. Independentemente da área de atuação, é cada vez mais necessário que países e demais atores internacionais

2 ORGANIZATION FOR ECONOMIC CO-OPERATION AND DEVELOPMENT. Country statistical profile: China, 2005 a 2012. Available at: <http://www.oecd-ilibrary.org/economics/ country-statistical-profile-china_csp-chn-table-en>. Last access on: 03 nov. 2014.

3 UNITED NATIONS ENVIRONMENTAL PANNEL. China's pathway to a green economy. Available at: <http://www.unep. org/greeneconomy/AdvisoryServices/China/tabid/56270/ Defaultaspx >. Last acces on: 01 nov. 2014.

4 SWANSON, Ana. Will China fund the world's next round of economic expansion? Forbes, 26 october 2014. Available at: <http://www.forbes.com/sites/ anaswanson/2014/10/26/willchina-fund-the-worlds-next-round-of-economic-expansion/>. Last access on: 01 nov. 2014. dialoguem com o corpo diplomático e com o empresariado chinês para atingir consensos, para firmar acordos e para coordenar políticas.

$\mathrm{Na}$ área de propriedade intelectual, segundo relatório da Thomson Reuters ${ }^{5}$, a China tornou-se, em 2011, o país que mais depositou pedidos de patente no mundo, superando assim os tradicionais mercados norteamericano e japonês ${ }^{6}$. Ainda que esse fato indique maior incentivo à inovação no país e sugira forte tendência de transformação do made in China para o designed in China, não se superou completamente a reputação de falsificadora mundial de bens de consumo?

Essa temática é particularmente relevante no contexto atual do comércio internacional, em que a China é a segunda economia do mundo ${ }^{8}$ e exerce considerável influência sobre os fluxos internacionais financeiros e de mercadorias. No que diz respeito à propriedade intelectual, a transição de falsificadora de bens de consumo, nas décadas de 1980 e 1990, para polo mundial de inovação científica e tecnológica, a partir dos anos 2000, é corroborada por abundantes incentivos governamentais na área de pesquisa e desenvolvimento.

Nas duas últimas décadas, a China empreendeu reformas legais que aumentaram o escopo de proteção à propriedade privada, ampliando as garantias dadas a investidores estrangeiros no país, apesar de o setor público exercer fundamental papel no cenário econômico nacional. Em termos práticos, ainda há sujeição dos investimentos privados às regulações e condicionalidades políticas do governo, o que denota

5 YEE, Lee Chyen. China tops U.S, Japan to become top patent filer. Reuters, 11 december 2011. Available at: <http:// www.reuters.com/article/2011/12/21/us-china-patentsidUSTRE7BK0LQ20111221>. Last access on: 16 apr. 2014.

6 Segundo esse mesmo relatório, foram 314.000 pedidos de patente protocolados em 2010. Ainda assim, é importante notar que o número de patentes concedidas a requerentes chineses ainda é menor que os números do Japão e dos Estados Unidos. Além disso, a maioria dos pedidos diz respeito a patentes de modelos de utilidade, o que denota, de forma geral, menor grau inovador das patentes chinesas. YEE, Lee Chyen. China tops U.S, Japan to become top patent filer. Reuters, 11 december 2011. Available at: <http://www.reuters.com/article/2011/12/21/us-china-patentsidUSTRE7BK0LQ20111221>. Last access on: 16 apr. 2014.

7 RAPOZA, Kenneth. In China, why is piracy here to stay. Forbes, 22 july 2012. Available at: <http://www.forbes.com/sites/ kenrapoza/2012/07/22/in-china-why-piracy-is-here-to-stay/>. Last access on: 16 apr. 2014.

8 GDP (current US\$). The World Bank. Available at: < http:// data.worldbank.org/indicator/NY.GDP.MKTP.CD>. Last access on: 16 apr. 2014. 
a insegurança jurídica e o risco do empreendimento ao investir no país. Assim como em outras áreas jurídicas na China, o direito de propriedade, seja ela real ou intangível, tenta superar o confronto entre privado e público.

Como proposta de análise dessas questões centrais de investigação, o presente artigo conta com quatro seções. Além desse item de introdução, no próximo item, o direito de propriedade será analisado sob a perspectiva do Direito Chinês, por meio de sua contextualização segundo os princípios da Constituição (1982) e da Lei de Propriedade (2007) ${ }^{9}$. No item seguinte, explora-se a propriedade intelectual como espécie de direito de propriedade, notadamente quanto às recentes reformas legais empreendidas no país. No item posterior, analisam-se as principais espécies de propriedade intelectual na China e suas particularidades em relação aos regimes de proteção de outros países. Nas considerações finais, reforçam-se impressões de análise das recentes transformações legais, das tendências de crescimento da inovação tecnológica no país, dos desafios ainda enfrentados na aplicação dos direitos de propriedade e das perspectivas para o futuro da China no contexto da propriedade intelectual.

\section{Direito de propriedade na China}

Sobre essa temática, cabe ressaltar os ensinamentos de Jianfu Chen sobre a terminologia utilizada:

Ao examinar o direito de propriedade na China, é necessário distinguir dois termos, 'suo-you-zhi' ( 所有制) e 'cai-chan suo-you-quan' (财产 所有权). Esses dois termos remontam a duas diferentes definições do termo 'propriedade', como utilizado em outros países socialistas. 'Suo-you-z̧hi’ significa, literalmente, o sistema de propriedade. Esse termo refere-se ao sistema político-econômico do Estado, como as propriedades coletivas dos trabalhadores e a propriedade estatal. 'Cai-chan suo-you-quan' significa, literalmente, direitos de propriedade. Esse termo denota os direitos do proprietário, conforme estabelecidos em lei ${ }^{10}$.

9 A Lei de Propriedade entrou em vigor em $1^{\circ}$ de outubro de 2007 e foi um marco histórico na China. Pela primeira vez, foi concedida igual proteção legal a propriedades públicas e privadas, o que significa uma relativização da tradicional primazia dos interesses públicos sobre os privados em relação aos direitos de propriedade no país.

10 Tradução livre do trecho: "In examining property law in the PRC, two different terms, 'suoyouzhi' and 'caichan suoyouquan', have to be distinguished. These two terms are reminiscent of the two
Nos milênios que antecederam o século $\mathrm{XX}$, o poder do Imperador determinava o destino e o uso de todas as formas de propriedade na China. Assim como as liberdades individuais, os objetos e as terras eram propriedade do Imperador, cuja supremacia impedia o desenvolvimento dos conceitos de propriedade privada $^{11}$. Segundo Mo Zhang:

\begin{abstract}
Historicamente, a China era um país onde o "poder imperial", ou o "poder do imperador", era a autoridade suprema da nação. De acordo com o Confucionismo, governar um país seria como governar uma família na qual o pai tem poder absoluto para decidir tudo, e cada indivíduo deve subordinar seus interesses pessoais aos interesses familiares. Assim, era fundamental que houvesse unidade familiar e que todos os indivíduos se sujeitassem a ela ${ }^{12}$.
\end{abstract}

O governo de Chiang Kai-Shek tentou implementar um Código Civil em 1930, mas as disputas militares com o Japão dificultaram sua efetiva aplicação. O Partido Comunista, ao chegar ao poder em 1949, anulou o Código Civil e restringiu ao máximo quaisquer direitos privados e individuais. A Revolução Cultural buscou instaurar o sentimento de que direitos individuais e a propriedade privada seriam diametralmente contrários aos princípios socialistas, favorecendo assim as propriedades coletivas e as propriedades estatais ${ }^{13}$.

different definitions of the term 'ownership' as used in other socialist countries. The term 'suoyouzhi', literally meaning ownership system, refers to the politico-economic system of the state, e.g. ownership by the whole people and the collective ownership of the working people. The term 'caichan suoyouquan', literally meaning rights of property ownership, denotes property rights of the property owner as provided by the law". CHEN, Jianfu. Civil law: property. In: Chinese law: context and transformation. Leiden; Boston: Martinus Nijhoff, 2008. p. 363-388. p. 367.

11 ZHANG, Mo. From public to private: the newly enacted Chinese property law and the protection of property rights in China. Berkeley Business Law Journal, v. 5, 2008. Available at: <http://ssrn. com/abstract $=1084363>$. Last access on: 16 apr. 2014.

12 Tradução livre do trecho: "Historically, China was a country where the 'imperial power' or the 'power of emperor' was the supreme authority of the land. Pursuant to Confucianism, to rule a country is like to rule a family where the father has absolute power to decide everything for the family, and each individual member in the family must subordinate his or her own interest to the family interest. Therefore, it was imperative that the family was held together and all individuals were subject to if'. ZHANG, Mo. From public to private: the newly enacted Chinese property law and the protection of property rights in China. Berkeley Business Law Journal, v. 5, 2008. Available at: < http:// ssrn.com/abstract=1084363>. Last access on: 16 apr. 2014.

13 ZHANG, Mo. From public to private: the newly enacted Chinese property law and the protection of property rights in China. Berkeley Business Law Journal, v. 5, 2008. Available at: <http://ssrn. 
O marco inicial dos direitos de propriedade privada na China ocorreu na década de 1980, com a abertura parcial do país nas Zonas Econômicas Especiais, principalmente no Sudeste do território. Além disso, houve uma série de reformas econômicas, sob o comando de Deng Xiaoping ${ }^{14}$. O objetivo dessas transformações era o de transformar a economia rigidamente planificada pelo governo em uma economia de mercado, ainda que de forma controlada e setorizada, de acordo com os interesses do Partido Comunista (economia socialista de mercado).

Embora as reformas empreendidas por Deng Xiaoping permitissem práticas capitalistas em áreas específicas, tentou-se unificar política e ideologicamente o país sob o comando do Partido Comunista, por intermédio da declaração dos Quatro Princípios Cardinais $^{15}$, os valores centrais que a China deveria observar durante a modernização:
a. Devemos nos manter no caminho socialista.
b. Devemos apoiar a ditadura do proletariado.
c. Devemos apoiar a liderança do Partido Comunista.
d. Devemos apoiar o Marxismo-Leninismo e o Pensamento de Mao Zedong.

Reformas no sistema de propriedade foram necessárias para a modernização e iniciaram-se, efetivamente, por meio da Constituição (1982, e emendas) e dos Princípios Gerais de Direito Civil (1986).

No que diz respeito à Constituição chinesa, a proteção à propriedade é estabelecida nos artigos $12 \mathrm{e}$ 13, que tratam, respectivamente, da propriedade estatal e da propriedade privada:

Artigo 12. A propriedade pública socialista é sagrada e inviolável. O Estado protege a propriedade pública socialista. Apropriação ou dano a propriedades

com/abstract $=1084363>$. Last access on: 16 apr. 2014.

14 Essas reformas representam o início de uma revolução silenciosa que, concomitantemente à inserção internacional da China em termos econômicos, tem aberto o país às influências sociais estrangeiras, aos costumes ocidentais e às práticas jurídicas consagradas pelos sistemas de Civil Law e Common Law, quando cabíveis.

15 "1.We must keep to the socialist road; 2. We must uphold the dictatorship of the proletariat; 3. We must uphold the leadership of the Communist Party; 4. We must uphold Marxism-Leninism and Mao Zedong Thought' (tradução livre). XIAOPING, Deng. Uphold the four cardinal principles (excerpts), 1979 Available at: <http://academics. wellesley.edu/Polisci/wj/China/Deng/principles.htm $>$. Last access on: 20 apr. 2014. estatais ou coletivas, por organizações ou indivíduos, é proibida em todas as suas formas ${ }^{16}$.

Artigo 13. O Estado protege o direito de propriedade dos cidadãos em relação a sua renda, suas economias, seus domicílios e outras formas legais de propriedade. O Estado protege, legalmente, o direito dos cidadãos de herdar propriedades privadas ${ }^{17}$.

Cumpre ressaltar que, somente em 2004, por meio de uma emenda à Constituição de 1982, foi expressamente reconhecida a proteção à propriedade privada na China. A emenda de 1988, por exemplo, permitia "a existência do setor econômico privado e seu desenvolvimento de acordo com os limites legalmente prescritos", mas não utilizava, de forma literal, o termo "propriedade privada" ${ }^{18}$.

Apesar dessa proteção, o artigo $6^{\circ}$ da Constituição afirma ser a propriedade pública "a base do sistema econômico socialista da República Popular da China" e que o sistema de propriedades públicas "tem primazia sobre o sistema de exploração do homem pelo homem" ${ }^{\prime 1}$. Além disso, o artigo $7^{\circ}$ caracteriza a economia socialista como a "principal força econômica nacional, cuja consolidação e crescimento serão assegurados pelo Estado" 20.

16 "Article 12. Socialist public property is sacred and inviolable. The state protects socialist public property. Appropriation or damage of state or collective property by any organization or individual by whatever means is probibited" (tradução livre). CHINA. Constitution of the People's Republic of China. Available at: <http://english.people.com.cn/constitution/ constitution.html>. Last access on: 19 apr. 2014.

17 "Article 13. The state protects the right of citizens to own lawfully earned income, savings, houses and other lawful property. The state protects by law the right of citizens to inherit private property" (tradução livre). CHINA. Constitution of the People's Republic of China. Available at: <http:// english.people.com.cn/constitution/constitution.html>. Last access on: 19 apr. 2014.

18 ZHANG, Mo. From public to private: the newly enacted Chinese property law and the protection of property rights in China. Berkeley Business Law Journal, v. 5, 2008. Available at: <http://ssrn. com/abstract $=1084363>$. Last access on: 16 apr. 2014.

19 "Article 6. The basis of the socialist economic system of the People's Republic of China is socialist public ownership of the means of production, namely, ownership by the whole people and collective ownership by the working people. The system of socialist public ownership supersedes the system of exploitation of man by man; it applies the principle of 'from each according to his ability, to each according to his work." (tradução livre). CHINA. Constitution of the People's Republic of China. Available at: <http:// english.people.com.cn/ constitution/constitution.html>. Last access on: 19 apr. 2014.

20 "Article 7. The state economy is the sector of socialist economy under ownership by the whole people; it is the leading force in the national economy. The state ensures the consolidation and growth of the state economy" 
Esses artigos denotam que, não obstante a proteção legal à propriedade privada, há supremacia das formas coletivas e estatais de propriedade no país, o que indica certa incompatibilidade entre dispositivos constitucionais que versam sobre a propriedade.

Os Princípios Gerais de Direito Civil da China, em seu quinto capítulo (Direitos Civis), discorrem sobre direitos de propriedade, direitos de propriedade intelectual, direitos acessórios aos direitos de propriedade, obrigações e direitos pessoais ${ }^{21}$. Segundo o artigo 71, “'direito de propriedade' significa o direito do proprietário de, nos termos da lei, possuir, utilizar, fruir livremente de e dispor de sua propriedade" ${ }^{22}$. Essa autonomia do proprietário para dar destinação à coisa decorre de influência do modelo capitalista de organização produtiva, cuja implementação no âmbito chinês pode acarretar conflitos com as atuais instituições do sistema de propriedades da República Popular da China.

Quanto aos direitos de propriedade intelectual, a lei cita a possibilidade de proteção a direitos autorais, de patentes, de marcas e de descobertas, mas não discorre sobre o tempo e as condições de proteção. $\mathrm{O}$ diploma concentra-se, efetivamente, nas hipóteses de propriedade estatal e de propriedade coletiva. Ainda assim, a aplicabilidade desses princípios era restrita e raramente colocada em prática ${ }^{23}$.

Em 2007, entrou em vigor a Lei da Propriedade, cuja singularidade e importância recaem sobre o fato de que, pela primeira vez, não se observa a supremacia da proteção de propriedades estatais e coletivas sobre propriedades privadas. Em seu artigo primeiro ${ }^{24}$, são

(tradução livre CHINA. Constitution of the People's Republic of China. Available at: <http://english.people.com.cn/ constitution/ constitution.html>. Last access on: 19 apr. 2014.

21 CHEN, Jianfu. Civil law: property. CHINESE Law: context and transformation. Leiden; Boston: Martinus Nijhoff, 2008. p. 372.

22 'Property ownership' means the owner's rights to lawfully possess, utilize, profit from and dispose of his property" (tradução livre). CHINA. General principles of the civil law of the People's Republic of China. Available at: <http://www.china.org.cn/china/ LegislationsForm2001-2010/2011-02/11/content_21898337. htm>. Last access on: 19 apr. 2014.

23 CHEN, Jianfu. Civil law: property. In: Chinese law: context and transformation. Leiden; Boston: Martinus Nijhoff, 2008. p. 363-388. p. 373.

24 "This Law is formulated with a view to maintaining the national basic economic system and the economic order of the socialist market, clarifying the ownership of property, giving full effect to the meaning of property, $[\ldots]$ in accordance with the Constitution" (tradução livre). CHINA. Constitution of the People's Republic of China. Available at: <http://english.people.com. delimitados os objetivos desse dispositivo legal e sua sujeição à Constituição:

Essa lei é formulada com o objetivo de manter o sistema econômico básico nacional e a ordem econômica do mercado socialista, esclarecendo o direito de propriedade, atribuindo completa efetividade ao significado de propriedade, [...] de acordo com a Constituição.

Nesse sentido, o artigo $3^{\circ}$ dessa lei determina que "o Estado implementa a economia socialista de mercado, assegurando a todos os agentes do mercado igualdade de status legal e de direito de desenvolvimento" ${ }^{25}$. Além disso, segundo o artigo $4^{\circ}$, "os direitos de propriedade coletivos, do Estado, individuais e relacionados a outras obrigações serão protegidos por leis e não serão infringidos por nenhum instituto ou indivíduo" ${ }^{26}$. Esses dispositivos confirmam tendência, ao menos legislativa, de aumentar o escopo de proteção à propriedade privada no país.

A Lei de Propriedade estabelece, entre diversos dispositivos, que somente serão válidas as obrigações e direitos de propriedade estabelecidos por lei. Essa regra diminui a autonomia individual na criação de relações contratuais relacionadas à propriedade. Além disso, ela determina que "terrenos urbanos, terrenos rurais e terrenos de subúrbio pertencem ao Estado e, de acordo com a lei, serão propriedade do Estado" ${ }^{27}$. Isso significa que não existe direito de propriedade sobre a terra na China.

Os direitos de usufruto do terreno e dos imóveis é que são transacionados em relações que envolvem bens imóveis. Essa confusão entre os conceitos de posse e de propriedade refretem o confronto entre o âmbito cn/constitution/constitution.html>. Last access on: 19 apr. 2014.

25 "The State implements the socialist market economy, ensuring equal legal status and right for development of all market players" (traducão livre). CHINA. Constitution of the People's Republic of China. Available at: $<$ http://english.people.com.cn/ constitution/constitution.html $>$. Last access on: 19 apr. 2014.

26 "The property rights of the State, collective, individual and other obligees shall be protected by laws and shall not be infringed by any institute or individuals" (tradução livre). CHINA. Constitution of the People's Republic of China. Available at: <http://english.people.com.cn/ constitution/constitution.html>. Last access on: 19 apr. 2014.

27 "The urban lands are owned by the State. Such rural land and the land on the outskirt of the city as belonging to the State according to law shall be owned by the State" (tradução livre). CHINA. Property law of the People's Republic of China. Available at: <http://www. lehmanlaw.com/resource-centre/laws-and-regulations/general/ property-rights-law-of-the-peoples-republic-of-china.html>. Last access on: 18 apr. 2014 
público e o âmbito privado ${ }^{28}$, cuja prevalência ainda está por ser desenvolvida no cotidiano dos tribunais chineses. Dessa forma, a ingerência do Estado sobre os direitos individuais ocorre, também, por meio dos direitos de propriedade, que são limitados.

Cenário comum no atual contexto urbano chinês são as nail houses (casas-prego, tradução livre), edificações urbanas antigas, de moradores que se recusam a abdicar seus direitos de usufruto. Como a maioria dos residentes vizinhos cede às pressões do governo, é frequente encontrar grandiosos projetos de desenvolvimento imobiliário e urbano instalados ao redor dessas casas, que se destacam como "pregos" em meio àqueles imóveis ${ }^{29}$.

Muitas normas e regulamentos existentes atualmente ainda devem ser modificados para que estejam em concordância com essa lei. Em linhas gerais, a Lei de Propriedade representa um avanço para o sistema jurídico chinês, a base de uma verdadeira economia de mercado, ainda que sua aplicação exija maior efetividade no futuro ${ }^{30}$. Como afirma Jianfu Chen:

28 Sobre esse tema, Peter Ho afirma que "a questão é até que ponto a privatização conseguirá prosseguir sem corromper os princípios Marxistas-Leninistas de propriedade estatal e coletiva. Legislar sobre direito de propriedade constitui, então, uma alternância entre a restrição de práticas que excedem os limites legais e a concessão de espaço para a experimentação, por meio da formulação de políticas e leis intencionalmente confusas". Tradução livre do trecho: "the question is how far privatization can proceed before corrupting the Marx-Leninist principles of state and collective land ownership. Land and policy-making is, therefore, an alternation of restraining practices that exceed legal boundaries and giving space to experimentation by formulating intentionally unclear policies and laws". HO, Peter. Who owns China's land?. The China Quaterly, n. 166, p. 394-421, jun. 2001. Available at: $<$ http://www.jstor.org/ discover/10.2307/3451163?uid=36438255 1 \&uid $=3737664$ \&uid $=5909624$ \&uid $=2$ \&uid $=3$ \&uid $=37572 \&$ uid $=$ 67\&uid $=62 \&$ sid $=21104041677947>$. Last access on: 19 mai 2014 .

29 MOORE, Malcom. China moves to calm unrest over property seizures. The Telegraph, 29 january 2010. Available at: <http://www.telegraph.co.uk/news/worldnews/ asia/ china/7103231/China-moves-to-calm-unrest-over-propertyseizures.html>. Last access on: 21 apr. 2014.

30 A rápida urbanização e desenvolvimento econômico têm aumentado o número de apropriações pelo governo. Em sua maioria, a tomada de terras e imóveis tem o objetivo de expandir estruturas urbanas e de criar conjuntos habitacionais com maior capacidade residencial. NOBLE, Jarret. Land Seizures in The People's Republic of China: protecting property while encouraging economic development. Pacific McGeorge Global Business \& Development Law Journal, v. 22, n. 2, p. 355, jan. 2010. Available at: <https://litigationessentials.lexisnexis.com/webcd/app?action $=$ DocumentDisplay\&c rawlid $=1 \&$ doctype $=$ cite \&docid $=22+$ Pac. $+\mathrm{McGeorge}+\mathrm{Global}+\mathrm{Bu}$ s. $+\% 26+$ Dev. + L.J. $+355 \&$ srctype $=$ smi\&srcid $=3$ B $15 \&$ key $=$ bddae 3 d7800eb02fa8f15498f96aad66>. Last access on: 21 abr. 2014
Não obstante certos percalços, o Direito agora estabelece um esboço e uma estrutura dos princípios legais que regem os direitos de propriedade (especialmente no que tange à noção de usufruto), permitindo que ocorra mais desenvolvimento. Mais que isso, o Direito agora estabelece, de forma abrangente e firme, a noção de "direitos de propriedade" no sistema legal chinês. Em um país socialista, isso representa, no mínimo, uma revolução em termos de pensamento jurídico e de desenvolvimento legal ${ }^{31}$.

\section{Propriedade intelectual na China}

Primeiramente, cumpre salientar que o direito de propriedade recai sobre bens materiais (res corporalis) e imateriais (res incorporalis). A propriedade intelectual é bem imaterial, fruto do intelecto, seja ele de cunho artístico, científico, literário ou industrial. De acordo com uma concepção tradicional, por meio da concessão do direito de exclusividade e, portanto, do monopólio temporário de exploração de determinada ideia, garantese ao criador a faculdade de fruir economicamente de sua criação e, consequentemente, possibilita-se a obtenção de retorno financeiro em contrapartida pelo trabalho inventivo realizado, fomentando assim o desenvolvimento do mercado.

$\mathrm{Na}$ China, o desenvolvimento da proteção à propriedade intelectual ocorreu, principalmente, a partir da década de 1980, como parte das reformas empreendidas pelo país no sentido de se inserir na economia de mercado internacional. Assim como o Brasil, que enfrentava dificuldades na atração de capital e de investimentos diretos no país, a China resistia à necessidade de aumentar o escopo de proteção aos detentores de patentes e de direitos autorais. Temiase que a concessão de direitos de exclusividade a estrangeiros prejudicasse a indústria nacional, mas a instalação de empresas estrangeiras nas Zonas Econômicas Especiais e o desenvolvimento da

31 "Despite certain shortcomings, the Law now lays down an outline and a structure of legal principles governing property rights (especially in the general notion of usufruct), allowing further development to occur. Most importantly, the Law now firmly and comprehensively establishes the notion of 'property rights' in the Chinese legal system. This, in a nominally socialist country, represents no less than a revolution in legal thought and legal development?" (tradução livre). CHEN, Jianfu. Intellectual property law. In: __ Chinese law: context and transformation. Leiden; Boston: Martinus Nijhoff, 2008. p. 565-617. p. 389. 
indústria tecnológica nacional dependiam de padrões mínimos de defesa à propriedade intelectual.

Dessa forma, foi promulgada, em 1979, a Lei sobre Joint Ventures Sino-estrangeiras. Em 1980, a China tornou-se membro da Organização Mundial da Propriedade Intelectual (OMPI). No ano de 1982, promulgou-se a Lei de Marcas, e a Lei de Patentes entrou em vigor em 1985. Leis sobre a proteção de softwares e direitos autorais entraram em vigor no início da década de 1990. Apesar da robusta produção legislativa, países Ocidentais (especialmente os Estados Unidos e a União Europeia) ${ }^{32}$ ainda criticavam o país devido à proteção pouco efetiva no âmbito interno, que contribuía para a caracterização da China, no âmbito internacional, como falsificadora mundial ${ }^{33}$.

O que se percebe é que, apesar da adequação legislativa empreendida principalmente nas décadas de 1980 e 1990, o governo chinês dava pouca efetividade a esses dispositivos. De certa forma, essa foi uma maneira de o mercado interno chinês se adaptar aos novos padrões de proteção mundial. Por essa razão, empreendedores ainda buscavam absorver novas formas de produção, técnicas modernas de inovação e capacitação de pessoal para os setores de pesquisa e desenvolvimento de suas indústrias incipientes.

Em resposta à crescente pressão ocidental, bem como às necessidades do dinamismo comercial do crescente mercado interno, emendas foram feitas às leis patentárias, de marcas e criminal (tornando a contrafação crime), em 1992 e 1993. O país também ratificou o Acordo de Madri (1981) ${ }^{34}$ e a Convenção de Berna (1886, seguida de revisões e emendas) ${ }^{35}$,

32 Segundo Peter K. Yu, "no final dos anos 1980, os Estados Unidos empreenderam, contra a China, agressiva política externa de proteção à propriedade intelectual. Repetidamente, a China foi ameaçada por meio de sanções, guerras comerciais, não renovação do status de nação mais favorecida e oposição a sua entrada na OMC". Tradução livre do trecho "in the late 1980s, the United States pursued a very aggressive foreign intellectual property policy toward China. It repeatedly threatened the country with economic sanctions, trade wars, nonrenewal of most-favored-nation status, and opposition to entry into the WTO". YU, Peter K. From pirates to partners (episode II): protecting intellectual property in post-WTO China. American University Law Review, v. 55, p. 901-1000, 2006. Available at: <http://ssrn.com/abstract= 578585>. Last access on: 16 apr. 2014.

33 CHEN, Jianfu. Intellectual property law. In: Chinese law: context and transformation. Leiden; Boston: Martinus Nijhoff, 2008. p. 565-617. p. 567.

34 Esse acordo versa sobre o registro internacional de marcas.

35 Essa convenção versa sobre direitos autorais referentes a obras literárias e artísticas. entre outros tratados internacionais. A adoção desses instrumentos denota a intenção do país, em meados da década de 1990, de melhor se adequar à estrutura normativa internacional sobre propriedade intelectual.

Varas e tribunais especializados foram instaurados na década de 1990, com o objetivo de assegurar maior efetividade às legislações recém-promulgadas. Nesse mesmo sentido, órgãos internos, como o State Intellectual Property Office (SIPO), uma espécie de Instituto Nacional da Propriedade Industrial (INPI), foram criados para realizar o exame e a manutenção de pedidos de patentes, marcas, direitos autorais, entre outros. Desde então, esses pedidos têm aumentado exponencialmente.

Esses esforços de adequação e de adaptação foram ampliados quando o país pleiteou, nos anos 2000, a condição de membro da Organização Mundial do Comércio (OMC), o que pressupunha a adoção do Acordo sobre os Aspectos dos Direitos de Propriedade Intelectual Relacionados ao Comércio (TRIPS, da sigla em inglês $)^{36}$. A necessidade de compatibilidade com as normas do Acordo TRIPS ensejou nova onda de reformas legislativas e revisão das normas de proteção intelectual no país. Nesse sentido, a ascensão da China ao quadro normativo da OMC representou verdadeiro marco transitório para o país, principalmente no que diz respeito à sua participação no quadro do comércio internacional.

Inserida no âmbito da OMC, a China se sujeita aos procedimentos de solução de controvérsias da organização. É interessante notar que o sistema de soluções de controvérsias da OMC também prevê a resolução de demandas na área de propriedade intelectual, visto que o TRIPS encontra-se entre os tratados sujeitos ao single undertaking, do grupo de tratados multilaterais da organização.

Em 2007, os Estados Unidos solicitaram a abertura de painel de consultas à OMC, devido à insuficiência das medidas implementadas pela China em relação à proteção de direitos de propriedade intelectual ${ }^{37}$. Os Estados Unidos tiveram a maioria de suas alegações confirmadas pelo painel ${ }^{38}$.

36 WORLD TRADE ORGANIZATION. Trade related aspects of intellectual property rights, 1994. Available at: < http://www.wto.org/ english/docs_e/legal_e/27-trips_01_e.htm>. Last access on: 20 apr. 2014.

37 LIEGSALZ, Johannes. The economics of intellectual property rights in China: patents, trade, and foreign direct investment. Ute Wrasmann: Gabler Verlag, 2010. p. 144.

38 UNITED STATES TRADE REPRESENTATIVE. United 
Nessa demanda, diversas incongruências da proteção à propriedade intelectual da China tiveram que ser adequadas aos padrões mínimos requeridos pelo TRIPS. As decisões do Órgão de Solução de Controvérsias foram adotadas pela China, mas o país precisava de um período razoável para colocá-las em prática. Junto aos Estados Unidos, acordou-se um prazo de 12 meses para que isso ocorresse, até março de 2010. Um dia antes de vencer o prazo, a China informou aos Estados Unidos que sua Assembleia Popular Nacional havia aprovado alterações nas regras de direito autoral e que o Conselho de Estado iria rever o Regulamento de Proteção Aduaneira dos Direitos de Propriedade Intelectual.

A adesão da China à OMC é também uma das principais causas de o fluxo internacional de mercadorias ter aumentado nas últimas décadas, tanto em termos de exportação, quanto em termos de importação ${ }^{39}$. Cabe ressaltar, no entanto, que o fortalecimento de relações comerciais no âmbito externo foi acompanhado de ferramentas de garantias para o cumprimento de regras internacionais, como no caso das regras da $\mathrm{OMC}$ e da adesão chinesa a seu sistema de solução de controvérsias. Sobre essa temática, Peter K. Yu adverte que:

Legisladores estão, portanto, explorando ativamente opções que induzam a China a jogar de acordo com as regras da OMC, especialmente aquelas que dizem respeito às regras de propriedade intelectual sob a égide do Acordo TRIPS. Ao explorar essas opções, é importante que os países tenham cuidado quanto à forma de engajar a China no processo, especialmente em um período no qual o país ainda aprende a observar a variedade de requerimentos da OMC. [...] Ainda que seja benéfico ter a China jogando pelas mesmas regras que outros países, um infortúnio desse país emergente tem o potencial de arruinar todo o sistema internacional de comércio $^{40}$.

States wins WTO dispute over deficiencies in China's intellectual property rights laws, 2009. Available at: <http://www.ustr.gov/about-us/ press-office/press-releases/2009/january/united-states-wins-wtodispute-over-deficiencies-c >. Last access on: 20 apr. 2014.

39 LIEGSALZ, Johannes. The economics of intellectual property rights in China: patents, trade, and foreign direct investment. Ute Wrasmann: Gabler Verlag, 2010. p. 87.

40 "Policymakers, therefore, are actively exploring options to induce China to play by the WTO rules, in particular those concerning protection of

\section{Categorias de propriedade intelectual na China}

O quadro legal estabelecido pela legislação chinesa e pela adesão da China ao sistema da OMC garante cenário protetivo bastante similar ao de países em desenvolvimento e, em alguns casos, até de países desenvolvidos, como será explanado nos itens seguintes. Resta saber se o rápido amadurecimento chinês, em termos legais, será acompanhado de efetiva proteção desses direitos de propriedade intelectual e, consequentemente, incentivo à pesquisa, desenvolvimento e inovação tecnológica no país. Nos próximos itens, serão analisadas algumas espécies de propriedade intelectual no âmbito nacional, não exaustivamente, mas de forma a ressaltar as principais particularidades do país em relação a esses instrumentos de proteção.

\subsection{Marcas e nomes de domínio}

Reformas recentes na Lei de Marcas do país instauraram proteção a marcas coletivas, marcas de certificação e marcas de renome internacional ${ }^{41}$. No mercado interno, ainda restam questões controversas, como o fato de que não é necessário registrar uma marca para comercializar bens na China, exceto no caso de tabaco e de produtos farmacêuticos, que são regulados pelo governo. Produtos sem distinção de marca devem, entretanto, conter rótulos com o nome e o endereço do vendedor ${ }^{42}$.

intellectual property rights under the TRIPs Agreement. In exploring these options, countries need to be careful about how they engage China in the process, especially at a time when the country is still learning how to comply with the different demanding requirements of the WTO. [... WW bile it is beneficial to have China playing by the same rules like all other countries, a blunder by this emerging trading power could ruin the entire international trading system" (tradução livre). YU, Peter K. From pirates to partners (episode II): protecting intellectual property in post-WTO China. American University Law Review, v. 55, p. 901-1000, 2006. Available at: < http:// ssrn.com/abstract $=578585>$. Last access on: 16 apr. 2014.

41 Marcas coletivas são usadas para identificar produtos ou serviços provindos de membros de uma determinada entidade. Marcas de certificação são as que se destinam a atestar a conformidade de um produto ou serviço a determinadas normas ou especificações técnicas, notadamente quanto à qualidade, natureza, material utilizado e metodologia empregada. Marcas de renome internacional são as que atingiram tamanho grau de projeção no território nacional, que, independentemente de sua ligação com o segmento originário, são reconhecidas pelo público em geral, transcendendo todas as categorias de produtos ou serviços e conservando o poder de distinção ainda que desvinculados da sua função originária.

42 CHEN, Jianfu. Intellectual property law. In: Chinese 
Essa falta de proteção aos registros de marcas pode gerar efeitos concorrenciais adversos, como a contrafação e a concorrência desleal, por meio da desinformação entre consumidores sobre a origem e a qualidade de certos produtos. Além disso, a falta de distinção entre marcas de produtos semelhantes acarreta menor preocupação dos agentes de mercado em aumentar a competitividade de seus produtos, principalmente por meio de inovações tecnológicas.

No que diz respeito aos nomes de domínio, existem restrições quanto a seu conteúdo, visto que não podem ser registrados nomes que violem os princípios da Constituição, que revelem segredos de Estado, que atentem contra a ordem pública, que sejam contrários à unidade e aos interesses nacionais, entre outros fatores $^{43} \mathrm{e} 44$.

\subsection{Patentes}

O escritório nacional de registro e manutenção de patentes, o State Intellectual Property Office (SIPO), é também o órgão governamental responsável pela cooperação internacional em matéria de propriedade intelectual. Isso sugere o caráter da atuação do país em termos de política externa no âmbito da propriedade intelectual, mais voltada para questões técnicas e de viés eminentemente tecnológico e econômico, como no caso do registro de patentes.

Inicialmente, a Lei de Patentes impedia o registro de produtos alimentícios, de bebidas, de condimentos, de fármacos e de substâncias químicas. As reformas de 1992 alteraram esses dispositivos e aumentaram o escopo da proteção, tanto em termos temporais, quanto em termos dos produtos e processos patenteáveis ${ }^{45}$. Essa mudança legislativa sugere tendência do país em relação

law: context and transformation. Leiden; Boston: Martinus Nijhoff, 2008. p. 565-617. p. 577.

43 CHEN, Jianfu. Intellectual property law. In: Chinese law: context and transformation. Leiden; Boston: Martinus Nijhoff, 2008. p. 565-617.p. 578.

$44 \mathrm{O}$ fato de a China restringir a atribuição de nomes de domínio dessa forma e segundo esses critérios evidencia a tentativa do governo de reduzir os parâmetros de liberdade na rede mundial de computadores. Em outros países, as restrições aos nomes de domínio referem-se a hipóteses de nomes que induzam erro ou confusão sobre sua titularidade (concorrência desleal) e de palavras ou expressões contrárias à ordem pública e aos bons costumes.

45 CHEN, Jianfu. Intellectual property law. In: Chinese law: context and transformation. Leiden; Boston: Martinus Nijhoff, 2008. p. 565-617. p. 583. ao aumento da proteção e, consequentemente, dos incentivos à inovação tecnológica no país. Garantindose maior proteção patentária no setor de fármacos, por exemplo, os setores de pesquisa e desenvolvimento terão maior propensão a investir em inovação no país.

$\mathrm{Na}$ China, o período de proteção para patentes de invenções é de 20 anos, enquanto o período para modelos de utilidade é de 10 anos, o que denota compatibilidade com a legislação praticada em outros países $^{46}$. Desde 2001, o país também protege novas espécies vegetais, em conformidade com o TRIPS e com a Convenção para a Proteção de Novas Variedades Vegetais (1978).

\subsection{Direitos de autor e programas de computador}

A Lei de Direitos Autorais chinesa determina a proteção de obras literárias, musicais, arquitetônicas, fotográficas, cinematográficas, de programas de software, entre outros. Assim como em outros países, a maioria dos direitos de autor é protegida durante sua vida e, após a sua morte, pelo prazo de 50 anos. Apesar de haver proteção para produtos audiovisuais, a realidade é que a pirataria de CDs e DVDs constitui um dos mais graves problemas de violação aos direitos de propriedade intelectual na China ${ }^{47}$.

A proteção a programas de software possui particularidades quanto à nacionalidade de seus desenvolvedores. Os programas desenvolvidos por nacionais são protegidos, independentemente de registro e publicação ${ }^{48}$. Softwares estrangeiros, no entanto, só serão protegidos em território chinês se seu país de origem ou residência for parte de acordos multilaterais ou bilaterais com a China nesse sentido. Em 2013, houve reforma da regulamentação nacional sobre a proteção de softwares ${ }^{49}$, cujo artigo

46 UNITED STATES PATENT AND TRADEMARK OFFICE. Office of policy and international affairs: protecting intellectual property rights (ipr) overseas. Available at: < http://www.uspto.gov/ ip/iprtoolkits.jsp>. Last access on: 07 mai 2014.

47 CHEN, Jianfu. Intellectual property law. In: __ Chinese law: context and transformation. Leiden; Boston: Martinus Nijhoff, 2008. p. 565-617. p. 595.

48 CHINA. Regulations on Computer Software Protection. Article 5: "Chinese citizens, legal entities or other organizations enjoy, in accordance with these Regulations, copyright in the software which they have developed, whether published or not'. Disponível em: < http://www.ccpit-patent.com.cn/ references/ regulations_on_computer_software_protection.htm $>$. Acesso em: 07 maio 2014.

49 CHINA. Regulation on computers software protection, 
24 expandiu as hipóteses de infração ao direito de autor dos programas de computador. Além disso, estabelece multas e compensações cabíveis em casos de pirataria ${ }^{50}$.

A violação de direitos autorais é uma das principais queixas contra a China no âmbito internacional ${ }^{51}$. Para combater essas práticas crescentes, instituiuse a Comissão Antipirataria, em 2002, responsável por conduzir investigações, estabelecer alianças de combate à pirataria e iniciar ações judiciais a pedido de detentores de direitos autorais ${ }^{52}$.

2011. Available at: <http://www.wipo.int/wipolex/en/details. jsp?id=13396> . Last access on: 07 mai 2014.

50 CHINA. Regulations on Computer Software Protection. Article 22: "Except where otherwise provided in the Copyright Law of the People's Republic of China, these Regulations, or other laws or administrative regulations, anyone who, without the authorization of the software copyright owner, commits any of the following acts of infringement shall, in light of the circumstances, bear civil liability by means of ceasing infringements, eliminating ill effects, making an apology, or compensating for losses; where such act also prejudices the public interest, the copyright administration department may order to cease infringements, confiscate illegal income, confiscate or destroy the infringing copies, and may impose a fine concurrently; where the circumstances are serious, the copyright administration department may confiscate the material, tools and equipment mainly used to produce infringing copies; and where the act violates the Criminal Law, criminal liability shall be investigated for the crime of infringing upon copyright or selling infringing copies in accordance with the provisions of the Criminal Law: (1) to reproduce, wholly or in part, a piece of software of the copyright owner; (2) to distribute, rent or communicate to the public through information network a piece of software of the copyright owner; (3) to knowingly circumvent or sabotage technological measures used by the copyright owner for protecting the software copyright; (4) to knowingly remove or alter any electronic rights management information attached to a copy of a piece of software; or (5) to transfer, or authorize another person to exploit, the software copyright of the owner. Whoever commits the act referred to in item (1) or (2) of the preceding paragraph may be concurrently fined 100 Yuan for per copy or not more than 5 times of the value of the products; and, those who commits the act referred to in item (3), (4) or (5) of the preceding paragraph may be fined not more than 50, 000 Yuan concurrently.". Disponível em: < http://www.ccpitpatent.com.cn/references/ regulations_on_computer_software_ protection.htm>. Acesso em: 07 maio 2014.

51 É importante notar que a falsificação pode envolver, simultaneamente, a violação de direitos autorais, patentários e de marcas. Segundo Ned Levin, "A China é notoriamente conhecida como um ponto de partida para falsificações. De acordo com a Organização Mundial Alfandegária, 75\% dos produtos falsificados aprendidos, entre 2008 e 2010, vieram da China". "China is well-known as a major counterfeiting hub. According to the World Customs Organisation, 75 per cent of counterfeit goods seized worldwide in 2008 to 2010 came from China" (tradução livre). LEVIN, Ned. China's counterfeits in the spotlight. Financial Times, 26 november 2013. Available at: <http:// www.ft.com/cms/s/0/8ab95c8e-4c7c-11e3-923d-00144feabdc0. html\#axzz2zdnSSAQl>. Last access on: 21 apr. 2014.

52 CHEN, Jianfu. Intellectual property law. In: Chinese law: context and transformation. Leiden; Boston: Martinus Nijhoff, 2008. p. 565-617. p. 591.

\subsection{Indicações geográficas}

Dispositivos legais específicos para a proteção de indicações geográficas foram adotados pelo governo somente a partir de 2005 e decorrem, em grande parte, de esforços bilaterais empreendidos junto à União Europeia $^{53}$. Assim como em outros regimes jurídicos nacionais, a proteção a indicações geográficas decorre também das regras do Direito Concorrencial, que vedam a utilização de falsas representações de origem no comércio de bens.

Ao contrário de o que ocorre no Brasil, não há certificação de serviços por meio de indicações geográficas, apenas de produtos. As principais indicações geográficas do país são o Vinho Amarelo Shaoxing (绍兴黄酒) e o Chá Longjing (龙井茶), que já foi objeto de falsificação no país ${ }^{54}$.

\section{Considerações finais: implementação de padrões mínimos de proteção, adequação internacional e inovação na China}

Apesar das diversas reformas legislativas empreendidas pela China desde os anos 1980, ainda existem desafios quanto à efetiva aplicação e execução desses dispositivos legais. Assim como em outros países emergentes, as circunstâncias econômicas, políticas e sociais do país têm se transformado com igual rapidez e acarretam outra série de questões, que nem sempre são adequadamente respondidas por meio de reformas legislativas. Muitas vezes, o próprio mercado econômico cuida de regular essas questões.

As dificuldades enfrentadas pela China na superação de seu passado de contrafação e de intervencionismo estatal envolvem, também, diferenças culturais entre o Ocidente e o Oriente. O país busca se adequar a sistemas políticos e jurídicos criados pela comunidade internacional, sendo o principal deles o sistema normativo da Organização Mundial do Comércio, mas também mantém, efetivamente, práticas orientais tradicionais, como as apropriações de imóveis e a substancial regulação do cenário econômico interno.

53 XIAOBING, Wang. Q\&A manual: China legislation on geographical indications, 2011. Available at: <http://www.ipr2.org/ storage/Q\&A_Manual_Chinese_legislation_on_GIs1012.pdf $>$. Last access on: 21 apr. 2014.

54 DON'T be fooled by the "fake" Longing tea. China Daily, 28 march 2007. Available at: <http://www.china.org.cn /archive/2007-03/28/ content_1205169.htm>. Last access on: 22 apr. 2014. 
Independentemente do significado da expressão "economia socialista de mercado", o aumento do fluxo de comércio do país tornou suas práticas econômicas, tanto no âmbito interno quanto externo, fundamentais para a comunidade internacional. Em termos pragmáticos, os riscos de não estabelecer relações comerciais com a China e de ignorar seu vasto mercado consumidor são maiores do que aqueles de não empreender efetiva cooperação com o país para o desenvolvimento de políticas públicas e privadas, especialmente na área de proteção à propriedade intelectual. Nesse contexto, a participação do país na OMC tende a aumentar, seja no sistema de solução de controvérsias, seja na negociação de novos acordos no âmbito da Rodada Doha.

É importante considerar as particularidades regionais e o breve espaço de tempo que a China teve para assimilar e implementar as transformações legislativas recentes. Nesse sentido, o reconhecimento e a ampliação de direitos de propriedade, seja ela real ou intangível, representam maior esforço político no sentido de construir ordem jurídica mais adequada aos padrões contemporâneos da comunidade internacional.

Esses esforços têm garantido bons resultados à China, ainda que seja necessária maior efetividade na aplicação dessas leis ao mercado. Os resultados econômicos e a virada tecnológica pela qual passa o país atualmente comprovam efetiva tendência de crescimento nos setores de pesquisa, desenvolvimento e inovação tecnológica. Além de ser um dos principais mercados consumidores do mundo hoje (em franca expansão, aliás), a China tem consolidado rapidamente seu espaço na ordem do comércio internacional como polo de inovação e de produtividade intelectual. 


\section{Referências}

CHEN, Jianfu. Civil law: property. In: Chinese law: context and transformation. Leiden; Boston: Martinus Nijhoff, 2008. p. 363-388.

CHEN, Jianfu. Intellectual property law. In: Chinese law: context and transformation. Leiden; Boston: Martinus Nijhoff, 2008. p. 565-617.

CHINA. Constitution of the People's Republic of China. Available at: <http://english.people.com.cn/ constitution/constitution.html>. Last access on: 19 apr. 2014.

CHINA. General principles of the civil law of the People's Republic of China. Available at: <http://www.china.org. cn/china/LegislationsForm2001-2010/2011-02/11/ content_21898337.htm>. Last access on: 19 apr. 2014.

CHINA. Property law of the People's Republic of China. Available at: <http://www.lehmanlaw.com/resourcecentre/laws-and-regulations/general/property-rightslaw-of-the-peoples-republic-of-china.html>. Last access on: 18 apr. 2014.

CHINA. Regulation on computers software protection, 2011. Available at: <http://www.wipo.int/wipolex/en/ details.jsp?id=13396> . Last access on: 07 mai 2014.

DON'T be fooled by the "fake" Longjing tea. China Daily, 28 march 2007. Available at: <http://www.china. org.cn/archive/2007-03/28/content_1205169.htm>. Last access on: 22 apr. 2014.

GDP (current US\$). The World Bank. Available at: <http://data.worldbank.org/indicator/NY.GDP. MKTP.CD>. Last access on: 16 apr. 2014.

HO, Peter. Who owns China's land?. The China Quaterly, n. 166, p. 394-421, jun. 2001. Available at: <http://www. jstor.org $/$ discover $/ 10.2307 / 3451163$ ?uid $=364382551$ \&uid $=3737664$ \&uid $=5909624$ \&uid $=2 \&$ uid $=3 \&$ uid $=3$ 7572 \&uid $=67 \&$ uid $=62 \&$ sid $=21104041677947>$. Last access on: 19 mai 2014.

LEVIN, Ned. China's counterfeits in the spotlight. Financial Times, 26 november 2013. Available at: <http:// www.ft.com/cms/s/0/8ab95c8e-4c7c-11e3-923d00144feabdc0.html\#axzz2zdnSSAQl>. Last access on: 21 apr. 2014.
LIEGSALZ, Johannes. The economics of intellectual property rights in China: patents, trade, and foreign direct investment. Ute Wrasmann: Gabler Verlag, 2010.

LIU, Sida. Globalization as boundary-blurring: international and local law firms in China's corporate law market. Law and Society Review, v.42, n.4, p. 771-804, 2008.

MOORE, Malcom. China moves to calm unrest over property seizures. The Telegraph, 29 january 2010. Available at: <http://www.telegraph.co.uk/news/ worldnews/asia/china/7103231/China-moves-tocalm-unrest-over-property-seizures.html $>$. Last access on: 21 apr. 2014.

NOBLE, Jarret. Land Seizures in The People's Republic of China: protecting property while encouraging economic development. Pacific McGeorge Global Business \& Development Law Journal, v. 22, n. 2, p. 355, jan. 2010. Available at: <https://litigation-essentials.lexisnexis. $\mathrm{com} / \mathrm{webcd} /$ app?action $=$ DocumentDisplay\&crawlid $=$ $1 \&$ doctype $=$ cite $\&$ docid $=22+$ Pac.+ McGeorge + Global + Bus. $+\% 26+$ Dev. + L.J. $+355 \&$ srctype $=$ smi\&srcid $=3 \mathrm{~B}$ 15\&key $=$ bddae3d7800eb02fa8f15498f96aad66>. Last access on: 21 abr. 2014.

ORGANIZATION FOR ECONOMIC COOPERATION AND DEVELOPMENT. Country statistical profile: China, 2005 a 2012. Available at: $<$ http://www.oecd-ilibrary.org/economics/countrystatistical-profile-china_csp-chn-table-en>. Last access on: 03 nov. 2014.

RAPOZA, Kenneth. In China, why is piracy here to stay. Forbes, 22 july 2012. Available at: <http://www. forbes.com/sites/kenrapoza/2012/07/22/in-chinawhy-piracy-is-here-to-stay/>. Last access on: 16 apr. 2014.

SWANSON, Ana. Will China fund the world's next round of economic expansion? Forbes, 26 october 2014. Available at: <http://www.forbes.com/sites/ anaswanson/2014/10/26/will-china-fund-the-worldsnext-round-of-economic-expansion/> . Last access on: 01 nov. 2014.

UNITED NATIONS ENVIRONMENTAL PANNEL. China's pathway to a green economy. Available at: $\quad<$ http://www.unep.org/greeneconomy/ AdvisoryServices/China/tabid/56270/Default.aspx>. Last acces on: 01 nov. 2014. 
UNITED STATES TRADE REPRESENTATIVE. United States wins WTO dispute over deficiencies in China's intellectual property rights laws, 2009. Available at: <http://www.ustr.gov/about-us/press-office/pressreleases/2009/january/united-states-wins-wto-disputeover-deficiencies-c >. Last access on: 20 apr. 2014.

UNITED STATES PATENT AND TRADEMARK OFFICE. Office of policy and international affairs: protecting intellectual property rights (ipr) overseas. Available at: <http://www.uspto.gov/ip/iprtoolkits.jsp>. Last access on: 07 mai 2014.

WORLD TRADE ORGANIZATION. Trade related aspects of intellectual property rights, 1994. Available at: <http://www.wto.org/english/docs_e/legal_e/27trips_01_e.htm>. Last access on: 20 apr. 2014.

XIAOBING, Wang. Q\&A manual: China legislation on geographical indications, 2011. Available at: < http://www. ipr2.org/storage/Q\&A_Manual_Chinese_legislation_on_ GIs1012.pdf>. Last access on: 21 apr. 2014.
XIAOPING, Deng. Uphold the four cardinal principles (excerpts), 1979 Available at: <http://academics. wellesley.edu/Polisci/wj/China/Deng/principles. htm >. Last access on: 20 apr. 2014.

YEE, Lee Chyen. China tops U.S, Japan to become top patent filer. Reuters, 11 december 2011. Available at: <http://www.reuters.com/article/2011/12/21/ us-china-patents-idUSTRE7BK0LQ20111221>. Last access on: 16 apr. 2014.

YU, Peter K. From pirates to partners (episode II): protecting intellectual property in post-WTO China. American University Law Review, v. 55, p. 901-1000, 2006. Available at: $<$ http://ssrn.com/abstract $=578585>$. Last access on: 16 apr. 2014.

ZHANG, Mo. From public to private: the newly enacted Chinese property law and the protection of property rights in China. Berkeley Business Law Journal, v. 5, 2008. Available at: <http://ssrn.com/abstract $=1084363>$. Last access on: 16 apr. 2014. 


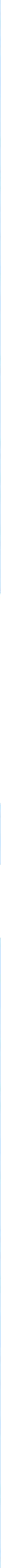




\section{Dos contenciosos na OMC com enfoque em restrições às exportações da China*}

\section{WTO cases focusing on restrictions of importations of China}

Marco Antônio Alcântara Nascimento**

\section{Resumo}

Este artigo tem como objetivo examinar o tratamento do tema restrições às exportações como um novo (e velho) desafio ao Sistema Multilateral de Comércio (SMC). A partir do exame de dois contenciosos na Organização Mundial do Comércio (casos China-Matérias-Primas e China-Terras-Raras), com desdobramentos entre 2011 e 2014, em que a China defendeu a adoção de medidas dessa natureza, baseada em argumentos de soberania sobre recursos naturais e/ou o direito ao desenvolvimento de sua indústria de processamento, propõe-se uma reflexão crítica sobre como o Órgão de Solução de Controvérsias buscou harmonizar esses princípios inseridos no Acordo Constitutivo da OMC, bem como a partir de considerações da doutrina sobre as decisões proferidas para estes contenciosos. Sugere-se a necessidade de ainda se buscar um balanço adequado entre liberalização do comércio, soberania sobre recursos naturais e desenvolvimento sustentável.

Palavras-chave: Restrições às exportações. Organização Mundial do Comércio. China. Recursos naturais. Soberania. Desenvolvimento.

\section{Abstract}

This study aims at examining the treatment of the export restrictions as a new (and old) challenge to the Multilateral Trading System (MTS). From the examination of two disputes in the World Trade Organization (China-Raw Materials and China-Rare-Earths), with developments between 2011 and 2014, when China supported the adoption of such measures based on arguments of sovereignty over natural resources and / or the right to develop its processing industry, this article proposes a critical reflection on how the Dispute Settlement Body sought to harmonize these principles enshrined in the WTO Agreement, as well as from considerations of the doctrine over the judgment given for these litigious. It is suggested the need for still seek an appropriate balance between trade liberalization, sovereignty over natural resources and sustainable development.

* Recebido em 09.11.2014

Aceito em 16.12.2014

** Mestre em Direito pelo Centro Universitário de Brasília. Assessor para o Programa de Financiamento às Exportações (PROEX), do Governo Federal, no Banco do Brasil S/A. academico.marco@gmail.com
Keywords: Export restrictions. World Trade Organization. China. Natural resources. Sovereignty. Development.

1 Este artigo reúne as principais ideias desenvolvidas na dissertação, com o mesmo título, recentemente defendida no Centro Universitário de Brasília (UniCEUB). Dessa forma, agradeço às importantes contribuições dos professores Gustavo Ribeiro, Paulo Roberto de Almeida e Leandro Rocha de Araújo para o texto final. 


\section{Introdução}

A eliminação gradativa das restrições quantitativas, a aceitação da proteção tarifária como a forma mais transparente de proteção do mercado interno e o disciplinamento das restrições não tarifárias: eis três dos principais desafios que mobilizaram os esforços da sociedade internacional ${ }^{2}$, em prol do avanço da liberalização comercial, nas últimas seis décadas.

Em torno desses desafios, usualmente o Sistema Multilateral de Comércio (SMC) voltou suas atenções para eliminar barreiras tarifárias e não tarifárias às importações. Via de regra, os países desejam aumentar os seus fluxos de exportação e diminuir, na medida do possível, os seus fluxos de importações, perseguindo uma balança comercial favorável ${ }^{3}$, com geração de divisas internacionais.

Mas e quando os países restringem as suas exportações, impondo controles de diversas formas? Estamos diante das restrições às exportações que, quando examinadas, exigem uma "inversão da lógica" de análise, pois usualmente tende-se a discutir sobre as medidas discriminatórias de um membro controlando, restringindo ou banindo importações provenientes de outros países, e não impondo barreiras às suas próprias exportações.

Hoje, as medidas restritivas às exportações são definidas pela OMC como "medidas de fronteira em que uma regulamentação de Governo limita expressamente a quantidade de exportações e/ou define condições explícitas para que as exportações sejam permitidas", ou "que assume a forma de uma taxa imposta com objetivo claro de limitar a quantidade de exportações"`.

2 Antes sob coordenação do General Agreement on Tariffs and Trade (GATT-1947) e, mais recentemente, da Organização Mundial do Comércio (OMC).

3 Esta meta tende a ser perseguida pelos países na busca da manutenção de um balanço de pagamentos favorável também. Deve se destacar que inclusive consignou-se no GATT-1947 um compromisso no Artigo XII de que as Partes Contratantes poderiam adotar medidas restritivas às importações para assegurar sua "posição financeira externa" e seu "balanço de pagamentos", desde que observadas uma série de condições ali também constantes. Este compromisso foi mantido no GATT-1994 (Anexo 1A do Acordo de Marraqueche), com novas condições estabelecidas na seção intitulada Understanding on The Balance-of-Payments Provisions of the General Agreement on Tariffs and Trade 1994.

4 A definição é uma tradução livre, utilizada na disputa Canadá contra Estados Unidos. Referência no OSC: DS194 (2000). Disponível em: <http://www.wto.org/english/tratop_e/dispu_e/ cases_e/ds194_e.htm>. Acesso em: 20 abr. 2012. Ressalte-se apenas que não se confundem com as restrições voluntárias às exportações
É possível perguntar: esse assunto foi tratado ou observado com a mesma atenção pelo SMC? Nos últimos anos, a discussão sobre as chamadas medidas restritivas às exportações ou controles às exportações ${ }^{5}$ tornou-se tema frequente entre lideranças políticas e diplomáticas e, também, no meio acadêmico.

De modo geral, verifica-se que o assunto ganhou mais destaque nas academias estrangeiras, com a publicação de vários papers, sob enfoques diferenciados, especialmente em relação aos contenciosos abertos na Organização Mundial do Comércio (OMC): o caso China-Matérias-Primas (CMP) e o caso China-TerrasRaras (CTR), que tiveram todos os seus desdobramentos nos últimos três anos, e que "lançaram os holofotes" do SMC ao tema de controles de exportações.

Ambos os casos trazem a China para o centro de análise. Como de conhecimento, aquele país tornouse um fenômeno mundial de crescimento nas últimas décadas, adotando um modelo essencialmente baseado na importação de recursos naturais e partes, peças e acessórios para montagem final, com posterior exportação de produtos finais. Em relação aos recursos naturais ali existentes, como seria de se esperar, a China se tornou uma ávida consumidora do que passou a extrair ${ }^{6}$. Além de ser grande consumidora, a China alcançou uma condição privilegiada no fornecimento de matérias-primas consideradas estratégicas, e com destaque para as terras-raras ${ }^{8}$.

(voluntary export restrictions (VER)), que se configuram quando um país concorda em limitar as suas exportações para outro país em certos produtos sensíveis. As VERs são vedadas no Artigo XI do Acordo de Salvaguardas da OMC.

5 Trataremos "medidas restritivas às exportações" e "controle às exportações" como sinônimos neste artigo.

6 COXHEAD, Ian; JAYASURIYA, Sisira. China, India and the commodity boom: economic and environmental Implications for lowincome countries. The World Economy, 2010. p. 526.

7 A condição estratégica dos minerais que serão tratados a seguir está diretamente relacionada à cinco requisitos: 1) importância para o desenvolvimento sustentável; 2) crescimento da demanda; 3) receitas e lucros gerados; 4) criticidade geológica; e 5) concentração da oferta. Conforme LIMA, Paulo César Ribeiro. Terras-raras: elementos estratégicos para o Brasil. Brasília: Câmara dos Deputados - Consultoria Legislativa, 2012. A China, em 2011, ocupava o primeiro posto na produção em relação ao mundo em relação aos seguintes minerais: fluorita, magnésio, manganês (metal), carbeto de silício, silício, fósforo amarelo, zinco e terras-raras, com percentuais oscilando de $25 \%$ a $95 \%$ do total da produção mundial (Seminário do MRE "Solução de Controvérsias: O Sistema da OMC e os casos do Brasil", realizado no UniCEUB, em agosto de 2012).

8 As terras-raras (TRs), que foram objeto da segunda disputa na OMC, são insumos extraídos de minérios e minerais, utilizados em produtos de alta tecnologia e tecnologia limpa, tais como aparelhos 
As medidas restritivas às exportações adotadas pela China, em relação às matérias-primas, que vieram ser contestadas na OMC, apenas serviram para exacerbar os efeitos da escassez das commodities em disputa e, em última instância, descortinaram a "luta global" por recursos naturais e o delicado balanço das cadeias produtivas globais, nas quais o acesso às matériasprimas se tornou de crucial importância?

É importante, neste momento inicial, também contextualizar as disputas que se desenrolaram na OMC: as questões sistêmicas relacionadas com o regime de restrições às exportações da $\mathrm{OMC}$ não atraíram muita atenção até quando a demanda global por recursos naturais (e produtos baseados nestes) cresceu significativamente nos últimos 10-15 anos ${ }^{10}$. O resultado prático foi o surgimento destes casos (CMP e CTR), que ganharam destaque a partir de 2011, quando se deram os primeiros desdobramentos.

Essa nova relação com o tema ficou evidenciada no estudo realizado pelo International Centre for Trade

celulares, automóveis híbridos, turbinas eólicas, bem como produtos de aplicação em defesa militar. Não se tratam de insumos raros. $\mathrm{Na}$ verdade, são abundantes, contudo, por conta de propriedades geoquímicas, os depósitos não estão concentrados de forma suficiente para serem explorados economicamente. Ademais, os métodos de extração e processamento ainda são complexos e custosos, dificultando a exploração comercial. Finalmente, as propriedades únicas das TRs fazem sua aplicação muito específica e muito valiosa em segmentos de ponta, como comentado acima. O fato é que, nas últimas duas décadas, houve um aumento exponencial na demanda destes materiais, tendo em vista o aumento de novas tecnologias que fazem uso destas propriedades únicas. Atualmente, a China detém cerca de $95 \%$ da oferta global, tendo suplantado os Estados Unidos durante a década de 1980. Este é um aspecto importante, pois esta condição privilegiada foi alcançada com uma estratégia de inovação tecnológica em manufaturados, baseados em TRs, como um de seus elementos essenciais. Paralelamente, o aumento da demanda global motivou mais foco nestes materiais. Baseado em KIM, Jeonghoi; KORINEK, Jane. Export restrictions on strategic raw materials and their impact on Trade and Global Supply. OECD, Trade Policy Paper, n. 95, 2010; JEBE, Ruth; LEE, Yong-Shik; MAYER, Don. China's export restrictions of raw materials and rare earths: a new balance between free trade and environmental protection. The George Washington International Law Review, v. 44, p. 580-642, 2012; LIU, HanWei; MAUGHAN, John J. China's rare earths export quotas: out of the China-raw materials gate, but past the WTO's finish line? Journal of International Economic Law, v. 15, n. 4, 21 nov. 2012.

9 LIM, C. L.; SENDUK, J. H. You don't miss your water til your river runs dry: regulating industrial supply shortages after China-raw materials. Stanford Journal of Law, Business, and Finance, v. 18, n. 1, 23 apr. 2013; University of Hong Kong Faculty of Law Research Paper, n. 2013/016, p. 92.

10 QIN, Julia Ya; Reforming WTO discipline on export duties: sovereignty over natural resources, economic development and evironmental protection. Wayne State University Law School Research Paper, n. 2012-04, 28 mar. 2012). and Sustainable Development (ICTSD) ${ }^{11}$, em que destacou entre os novos desafios do SMC para o século XXI, a necessidade de um "repensar" sobre as restrições às exportações, em duas vertentes — alimentos e matériasprimas $^{12}$-, bem como a preparação institucional (ou não) da OMC para enfrentar estes e outros desafios.

Posto isso, os casos CMP e CTR são de grande relevância para o SMC e, em especial, aos países ricos em recursos naturais, entre eles o Brasil. Basta recordar que somos detentores de importantes jazidas de minerais estratégicos para as economias mundiais, assim como a China, ainda que com reconhecidos problemas de várias naturezas (marco regulatório atrasado, infraestrutura e logística ineficientes, pesquisa e desenvolvimento incipientes, entre outros aspectos) para melhor utilização deste potencial. Assim, uma pergunta que pode ser colocada também para análise nas próximas páginas: quais são as lições que os contenciosos enfrentados pela China podem trazer para os formuladores de política pública brasileira?

Os casos citados, que foram tratados no Órgão de Solução de Controvérsias (OSC) da OMC, parecem indicar o seguinte posicionamento institucional: os controles às exportações adotados pela China (mas poderia ser qualquer outro país), baseado puramente em argumentos de soberania e desenvolvimento, fragilizam a liberalização do comércio. Ficam, então, evidenciados os três aspectos que merecem atenção na análise do tema controle às exportações, como tratado hoje no SMC, no sentido de uma concatenação de "forças": liberalização do comércio, de um lado; soberania e desenvolvimento, de outro lado.

11 O ITCSD é uma organização não-lucrativa, sediada em Genebra, Suíça, que tem como missão envidar esforços no fortalecimento do tema desenvolvimento sustentável no contexto do sistema internacional de comércio. Entre os programas desenvolvidos pelo ITCSD, destacamos o de "políticas econômicas globais e instituições", que produziu, em 2012, uma importante coletânea de ensaios sob o título The Future and the WTO: Confronting the Challenges.

12 As exportações mais afetadas hoje pelas medidas de controle são as exportações de alimentos e de matérias-primas, e estes têm sido o foco de debate tanto na OMC quanto em outros foros internacionais. Contudo, para fins deste artigo, buscarse-á concentrar sobre as restrições às exportações de matériasprimas, com destaque para minerais. Reconhece-se que há lógicas diferenciadas nas exportações de alimentos, relacionadas, por exemplo, à sazonalidade da produção. Também se entende da existência de disciplinas diferenciadas para alimentos e matériasprimas dentro da OMC, uma vez que a produção agrícola tem um capítulo à parte de tratamento na Organização, no caso o Acordo de Agricultura, que não será objeto de nossa exposição. 
Surge, então, a proposta deste artigo: examinar os principais aspectos substantivos destes contenciosos (seção 4), verificando, em especial, como o OSC buscou concatenar tais princípios consagrados nos Acordos Constitutivos da OMC nas decisões proferidas pelos painelistas e o Órgão de Apelação (OAp). Contudo, antes de alcançar os contenciosos, julgamos importante realizar uma abordagem sobre o tratamento do tema dos controles às exportações no sistema multilateral de comércio, a partir do advento do GATT-1947 (seção 2) e passar pelos antecedentes recentes dos contenciosos (seção 3). Já na conclusão (seção 5), sintetizamos os principais aspectos jurídicos trazidos pelos contenciosos e, também, enveredamos por uma reflexão de caráter mais político-estratégico e desafios ao Brasil diante o tema.

\section{Restrições às exportações no Sistema Multilateral de Comércio: um novo (velho) tema a ser enfrentado}

O tratamento dado às medidas restritivas às exportações, no âmbito do SMC, se deu a partir do GATT-1947 $7^{13}$. Assim, é possível partir do pressuposto de que o SMC não deixou de tratar do assunto restrição às exportações, como uma leitura menos atenta possa sugerir.

Tanto a escalada tarifária ${ }^{14}$ quanto os impostos aplicados às exportações seriam objeto do Acordo GATT de 1947, constando disciplina sobre o assunto nos drafts iniciais. Havia uma preocupação à época de que as exportações das indústrias de processamento de matérias-primas pudessem ser afetadas por impostos aplicados às importações em outros países, e, como resultado, os países prejudicados pudessem recorrer à

13 Ainda que este artigo foque-se no SMC configurado a partir do GATT-1947, há de se ter em mente que a discussão sobre restrições às exportações é muito anterior. No período entre guerras, foram construídas várias propostas para facilitar o acesso a recursos naturais, utilizando acordos internacionais e aparatos institucionais, como revelam autores como Andre Istel, Herbert Feis e Jacob Viner. O momento histórico salutar conduziu para reflexões deste tipo, como o ciclo recessivo experimentado nos primeiros anos da década de 1930, levando ao colapso de preço de várias matériasprimas de modo tão profundo que se exigiu a intervenção pública para resgate dos setores agrícola e mineral, especialmente; ou, ainda, a deflagração da Segunda Guerra Mundial, que resultou na "quebra" de várias linhas de oferta, em prol da sustentação do esforço de guerra, que exigiu também intervencionismo estatal.

14 A escalada tarifária se manifesta numa estrutura de proteção em que as tarifas aumentam à medida que se caminha pelo estágio de processamento. Ou seja, quanto menos processado, menos tarifa; quanto mais processado, mais tarifa. adoção de impostos sobre as exportações de matériasprimas in natura ${ }^{15}$.

Apesar da estrutura legal que cerca o tema das restrições às exportações ${ }^{16}$, o entendimento entre estudiosos do assunto foi de que houve um tratamento mais brando em relação a esse tema em comparação com a disciplina estabelecida para as restrições às importações. Dessa forma, a questão fundamental foi que não se estabeleceram tetos para aplicação, ou ainda limites temporais para aplicação ou aumento de direitos aduaneiros sobre exportações, como se fizeram para as importações ${ }^{17}$.

Contudo, não se pode negar que o controle às exportações esteve presente de forma perene nas discussões nos foros próprios do GATT. Ainda nos primeiros anos de GATT-1947, um Relatório de Grupo de Trabalho (The Use of Quantitative Restrictions for Protective and Other Commercial Purposes) explicitou algo importante para os contenciosos que examinaremos: o entendimento de que nenhuma das exceções previstas no GATT (especialmente Artigo XI: 2(a) e (b), e Artigo $\mathrm{XX}(\mathrm{g}),(\mathrm{h})$, (i) e (j)) tivessem sido desenhadas para promover a indústria doméstica; assim, não se permitiria que a imposição de restrições sobre as exportações de matérias-primas fosse feita para proteger ou promover uma indústria doméstica, assegurando uma vantagem de preço para a indústria doméstica na compra desses materiais ou reduzindo a oferta desses insumos para competidores estrangeiros, ou ainda outras formas possíveis.

Após alguns anos sem desdobramentos importantes, o fim da Rodada Tóquio (1973-1979) marcou uma reinserção do tema na agenda de discussão novamente. Os Membros declararam a necessidade de fazer uma abordagem das medidas restritivas às exportações no contexto do SMC, considerando as necessidades

15 LATINA, Joelle; PIERMARTINI, Roberta; RUTA, Michele. Natural resources and non-cooperative trade policy. World Trade Organization Economic Research and Statistics Division Staff Working Paper, n. ERSD-2011-06, p. 4, 1 mar. 2011.

16 Especificamente, os Artigos I (princípio da nação mais favorecida), X (princípios da transparência e legalidade), XI (princípio da eliminação de restrições quantitativas ou princípio da tarificação), XII (restrições para salvaguardas no balanço de pagamentos), XIII (administração não discriminatória das restrições quantitativas) e XX (exceções gerais) do GATT-1947 consubstanciam compromissos entre as partes para arrefecer e/ou eliminar as medidas restritivas às exportações, inclusive com as exceções admitidas. São princípios de caráter instrumental que, em última instância, buscam promover a liberalização comercial no plano multilateral.

$17 \quad$ Vide nota 15. 
financeiras e comerciais em prol do desenvolvimento das economias menos desenvolvidas, como um dos itens prioritário da agenda multilateral de negociações (documento GATT/MTN/FR/W/20, 1978). Esse é um aspecto muito importante, pois foi neste contexto que o princípio da soberania permanente sobre recursos naturais (SPRN) foi trazido para o cerne do debate dentro do GATT, tendo sido utilizado como defesa da China nos contenciosos que examinaremos adiante ${ }^{18}$.

Quando do início da Rodada Uruguai (1986-1994), um Subgrupo de negociações para o comércio de bens baseados em recursos naturais (Negotiating Group on Natural Resource-Based Products) foi criado dentro do Grupo de Negociações para Bens (documento GATT/MTN.GNG/NG3/1, 1987). Em seguida, o Subgrupo estabeleceu uma agenda de negociações, que incluía, entre outros aspectos, restrições (quantitativas) às exportações, impostos aplicados às exportações e escalada tarifária, considerando reivindicações das delegações da Coreia do Sul, dos Estados Unidos, da Comunidade Europeia (CE), do Japão e dos países nórdicos (documento GATT/ MTN.GNG/NG3/2/3, 1987).

Um dos encaminhamentos iniciais deste Subgrupo foi de propor que estes aspectos fossem levados para a mesa de negociações da Rodada Uruguai como um dos objetivos a cumprir (documento GATT/MTN.GNG/ NG3/W/8/Rev. 1, 1988). Entretanto, na sequência de trabalhos, pareceu haver uma divisão clara de posições: de um lado, países em desenvolvimento (PED) e países de menor desenvolvimento relativo (PMRD) demonstraram interesse de um foco maior na escalada tarifária ${ }^{19}$, enquanto países desenvolvidos, especialmente a Comunidade Europeia (CE),

18 O princípio da SPRN foi tratado, em suas origens, como um pré-requisito para o desenvolvimento econômico e, dessa forma, um princípio fundamental do DI contemporâneo, reconhecido entre as nações, apesar das críticas existentes, que se direcionaram para a tentativa de resposta jurídica para problemas eminentemente políticos e econômicos. É sugerido que isto talvez seja provavelmente a maior causa para explicar porque até agora concordâncias doutrinárias sobre o conteúdo preciso e parâmetros deste princípio fundamental não tenham sido alcançados; em suma, há validade neste princípio, mas falta ainda a definição de sua condição entre as demais fontes de DIP. Baseado em PERREZ, Franz Xavier. The relationship between permanent sovereignty and the obligation not to cause transboundary environmental damage. Environmental Law, n. 26, p. 1191-1192, 1996; e VARELLA, Marcelo Dias. Direito internacional econômico ambiental. Belo Horizonte: Del Rey, 2004. p. 18. 19 Cite-se, por exemplo, a defesa feita em declaração conjunta de Camarões, Costa do Marfim, Senegal e Zaire, consignada no documento GATT/MTN.GNG/NG3/W/10, 1988. enfatizaram a necessidade de regular as medidas adotadas sobre as exportações de produtos baseados em recursos naturais, com uma ampliação do debate além da escalada tarifária ${ }^{20}$.

A CE, em particular, advogou nessa fase de negociações que escalada tarifária e medidas restritivas poderiam ser trabalhadas num enfoque conjunto: no seu ponto de vista, os PED e PMRD adotariam medidas restritivas às suas exportações, argumentando pelo desenvolvimento de sua indústria doméstica de processamento; contudo, ao fazer isso, poderiam estar induzindo outros países a aplicar ou manter impostos mais elevados na importação de materiais processados (escalada tarifária), causando um círculo vicioso que nada contribuiria para a construção de práticas comerciais mais liberais (GATT/MTN.GNG/ NG3/W/37, 1990).

Ademais, a $\mathrm{CE}$ defendeu que as restrições às exportações conjugadas com a prática de fornecimento de matérias-primas a preços menos elevados para a indústria doméstica resultavam em uma política de "preço duplo" (double-pricing), com efeito similar ao subsídio, que deveria ser combatida pelo SMC. A solução passaria por medidas paralelas e coerentes do ponto de vista de acesso do mercado exportador e de acesso do mercado importador. Assim, do ponto de vista dos mercados exportadores, todas as proibições deveriam ser eliminadas em um primeiro momento; ademais, todas as demais restrições deveriam ser examinadas quanto à sua adequação às exceções legais; finalmente, as medidas que fossem julgadas incompatíveis deveriam ser eliminadas ou postas em conformidade com as normas aceitas; também, as medidas deveriam ser "tarificadas" para ocorrer uma negociação em paralelo com o acesso aos mercados importadores. Estes compromissos seriam anexados ao Acordo de Bens do GATT e seriam governados pelos Artigos II, XXIII e XXVIII. Do ponto de vista dos mercados importadores, a escalada tarifária deveria ser negociada em paralelo.

Durante a realização da Rodada Uruguai, enquanto ocorriam esses desdobramentos nos bastidores de negociação, houve a atuação do sistema de solução de controvérsias do GATT em uma disputa ambiental, envolvendo restrições às exportações. Tratouse de Painel (sob referência BISD 35S/98), com

20 Cite-se, por exemplo, a defesa feita em declaração da CE, consignada no documento GATT/MTN.GNG/NG3/W/11, 1988. 
desdobramentos entre 1986 e 1988, em que o Canadá foi investigado em relação a medidas tomadas nas exportações de salmões e arenques não processados ${ }^{21}$.

Apesar de todas as tentativas para um tratamento adequado ao tema das restrições às exportações, o fato é que a Rodada Uruguai foi concluída em 1994 sem que se tenha chegado a um consenso sobre a melhor forma de abordar o problema.

A partir de 1995, a OMC iniciou seus trabalhos, passando a coordenar os esforços para aperfeiçoamento do SMC. Basicamente, se partiu do mesmo quadro já existente no GATT-1947: os Acordos da OMC distinguem entre dois tipos de restrições às exportações: impostos e outras formas. A aplicação de impostos, de forma geral, é permitida, contudo pode ser restringida em casos especiais, como nos Protocolos de Acessão. Já as restrições quantitativas, como a adoção de cotas, são proibidas com base no dispositivo do Artigo XI do GATT. Contudo, o Artigo XI é relativizado por exceções previstas no próprio Acordo, tais como, por exemplo, uma crise de abastecimento de matériasprimas; ou para fins de proteção da vida humana, animal ou vegetal; ou, ainda, para conservar recursos naturais exauríveis ${ }^{22}$.

Uma novidade em relação ao GATT-1947 foi que, apesar de não haver uma definição ou a obrigação de

21 Nesse caso, os Estados Unidos alegaram a violação ao Artigo XI do GATT diante das medidas restritivas às exportações impostas pelo Canadá, que, por sua vez, justificava a imposição destas medidas com base no Artigo XX (g) (exceções gerais à cláusula da nação mais favorecida, com base na alegação da conservação de recursos naturais) e também o Artigo XI(2) (b) (exceção à eliminação das restrições quantitativas necessárias para aplicação de padrões ou regulações de classificação e comercialização de commodities no comércio internacional). A decisão final do Painel foi de que o Canadá deveria ajustar suas medidas para passar a estar em conformidade com as obrigações assumidas junto aos demais Membros do GATT, não encontrando amparo nas exceções que alegou (Artigo XI.2(b) e $\mathrm{XX}(\mathrm{g})$ ). O principal aspecto neste caso, ainda à época do sistema de solução de controvérsias do GATT-1947, que foi trazido para o caso Estados Unidos-Gasolina (WT/DS 2) e, também, para os casos CMP e CTR, a serem examinados adiante, diz respeito à interpretação feita à expressão "made effective in conjunction with" no Artigo XX(g). Ou seja, os controles de exportações, justificados na proteção de recurso exaurível, somente são admitidos para a OMC, quando também são impostos à produção e ao consumo domésticos. A recente decisão no caso CMP confirma o entendimento já trazido no caso CanadáPescados de que o Artigo XX não pode ser usado para justificar uma política que privilegie o desenvolvimento econômico doméstico. Assim, configurou-se nesse caso Canadá-Pescados um importante teste legal trabalhado nos casos CMP e CTR.

22 Vide respectivamente, Artigo XI:2(a), XX (b) e XX (g). Há outras possibilidades previstas no próprio Artigo XX, mas, para termos do presente trabalho, estas são exceções que serão enfocadas. se definir um cronograma de desgravação de impostos aplicados às exportações, como ocorreu com as importações, o Comitê de Negociação Comercial, no âmbito da OMC, incluiu um Procedimento de Notificação que estabelecia uma lista indicativa de medidas que podiam ser notificadas, que incluía os impostos sobre as exportações, como forma de aumentar a transparência aos Membros.

Posteriormente, uma decisão do Conselho do Comércio em Bens estabeleceu um procedimento de notificações bienais em relação às restrições quantitativas, a partir de janeiro de 1996 (documento G/L/59, 1996). Também estabeleceu a possibilidade da notificação reversa, a fim de permitir que os Membros pudessem indicar medidas não tarifárias utilizadas por outros Membros (documento G/L/60, 1996).

Em seguida, a Rodada Doha foi a primeira rodada comercial iniciada a partir da criação da OMC, com o início dos trabalhos em 2001. A Declaração Ministerial (documento WT/MIN(01)/DEC/1, 2001) que determinava a abertura das negociações, inseriu no mandato da Rodada a discussão sobre a eliminação de barreiras não tarifárias, entre elas, as restrições quantitativas. Nesse aspecto, era possível esperar uma retomada das negociações sobre controles às exportações.

Todavia, partindo-se do mesmo "ambiente dividido" (países desenvolvidos versus PED e PMDR) em que se deram as negociações realizadas na Rodada Uruguai, avanços concretos não foram alcançados até o momento para pacificar o assunto. Ademais, é pouco provável que se avance neste sentido no curto e médio prazos, dada à existência de outros temas prioritários na agenda.

Não obstante, com o aumento do uso dos controles às exportações nos últimos anos, tanto em termos de escalada quantitativa quanto em termos de amplitude de razões alegadas para a adoção destas medidas há uma preocupação latente com o tema. Uma declaração do ex-comissário de Comércio da União Europeia, Peter Mandelson, em discurso para o Parlamento Europeu em 2008, deu a tônica de mais um assunto por tratar: "estivemos envolvidos por seis décadas com a criação de um mundo aberto ao comércio, focando na derrubada das taxas sobre as importações de bens, apenas para vermos hoje as restrições às exportações colocarem esses ganhos em risco" ${ }^{23}$. Na mesma linha, o

23 Tradução livre do discurso de Mandelson em LAUSTER, 
ex-Diretor-Geral da OMC, Pascal Lamy, destacou, no primeiro semestre de 2011, que avançaram a tomada de medidas restritivas às exportações, especialmente sobre alimentos e matérias-primas e minerais, cujos preços internacionais estariam numa escala ascendente ${ }^{24}$.

Assim, com a pouca possibilidade de que a Rodada Doha consiga fortalecer disciplinas no tocante aos controles de exportações, permanecendo, então, um quadro de "regulamentação folgada" ${ }^{25}$, as interpretações do OSC sobre o tema tendem a ocupar um papel relevante para o disciplinamento das políticas públicas dos Membros. Dessa forma, antes de examinar os contenciosos envolvendo a China, será feita uma abordagem (necessária) sobre os antecedentes destes.

\section{Antecedentes recentes dos contenciosos da China: a construção da "diplomacia das matérias-primas", com atuação destacada Organização para Cooperação e Desenvolvimento Econômico ${ }^{26}$}

Foi visto na seção anterior que, à época do GATT1947 e mais acentuadamente a partir da Rodada Uruguai (1986-1994), bem como nos primeiros anos da OMC, a CE (posteriormente União Europeia - UE) se tornou uma defensora ativa do tratamento do tema das restrições às exportações no SMC, tendo também os Estados Unidos um "parceiro de preocupações".

Gitta; ANNIKA, Mildner Stormy. Settling trade disputes over natural resources: limitations of international trade law to tackle export restrictions. Goetttingen Journal of International Law, v. 3, n. 1, p. 251-281, 2011. p. 253.

24 "Talvez porque as disciplinas da OMC são mais frágeis em relação às exportações do que às importações, as restrições às exportações não tem sido um tema habitual ou significativo para a gestão do sistema de comércio no passado, mas aumenta a possibilidade a criar obstáculos sérios ao comércio em nossa economia mundial cada vez mais integrada. Há o perigo de que, diante da falta de disciplinas multilaterais mais claras, os governos se sintam tentados a usar as restrições às exportações para modificar em seu benefício o preço relativo de suas exportações ou aumentar a produção de suas indústrias nacionais a expensas da produção estrangeira". Tradução livre de discurso proferido no Órgão de Revisão de Políticas Comerciais. Disponível em: <http://www.wto. org/spanish/news_s/sppl_s/sppl196_s.htm>. Acesso em: 30 jan. 2012.

25 Termo utilizado em LATINA, Joelle; PIERMARTINI, Roberta; RUTA, Michele. Natural resources and non-cooperative trade policy. World Trade Organization Economic Research and Statistics Division Staff Working Paper, n. ERSD-2011-06, 1 mar. 2011. p. 7.

26 Outros foros multilaterais também passaram a se preocupar com o tema, tais como a Conferência das Nações Unidas para o Comércio e o Desenvolvimento (UNCTAD) ou o G-20. Contudo, para fins deste artigo, destacaremos a OCDE, que debruçou-se sobre o tema de forma mais contundente.
É possível sugerir que houve uma canalização da discussão iniciada pelas principais economias mundiais, com destaque para a UE, sobre o "acesso justo e equitativo" às matérias-primas mundiais, na $\mathrm{OCDE}^{27}$, que se tornou, consequentemente, a porta-voz oficial dessas reivindicações, numa abordagem pragmática. Há, então, um contraponto ao princípio da SPRN, já tratado anteriormente neste artigo.

Dentro do Comitê de Comércio da OCDE, um grupo de trabalho para discutir as denominadas medidas não tarifárias foi criado em 2001. Ao abordar este assunto, de destacar que a Organização produziu dois importantes documentos, tratando sobre os impostos aplicados às exportações e sobre as restrições às exportações ${ }^{28}$, em que se verifica um encadeamento expresso entre os mesmos. Os estudos demonstraram ser tentativas de mapeamento das medidas existentes, do impacto sobre o comércio, da extensão de seu uso, das justificativas apresentadas pelos países adotantes, dos temores trazidos pelos países importadores e, também, da análise da disciplina estabelecida no âmbito da OMC de cada um dos assuntos relacionados, bem como em outras organizações internacionais e em acordos de integração regionais e bilaterais.

Uma leitura conjunta dos dois estudos permite trazer alguns pontos para reflexão:

Os controles sobre exportações, quer na forma de impostos (admitidos nos Acordos da $\mathrm{OMC}^{29}$ ), quer na forma de medidas restritivas (vedadas nos Acordos da OMC), são justificados com "objetivos políticos legítimos e defensáveis", tais como: a) o aumento da arrecadação estatal; b) o abastecimento adequado à indústria local; c) o desenvolvimento da indústria de

27 A OCDE foi criada em 1960, contando hoje com 33 membros. O Secretariado da OMC reconhece a existência de áreas de trabalhos conjuntos com o Secretariado da OCDE, sendo que pesquisas e estudos desta última são regularmente usadas pela OMC para, por exemplo, providenciar os relatórios do Trade Policy Review. Vide: <http://www.wto.org/english/thewto_e/coher_e/wto_ oecd_e.htm>. Acesso em: 20 mar. 2014.

28 Respectivamente, ORGANIZAÇÃO PARA COOPERAÇÃO E DESENVOLVIMENTO ECONÔMICO (OCDE), Working Party of the Trade Committee. Analysis of non-tariff measures: the case of export duties, 2002. (Ref. TD/TC/ WP(2002)54/FINAL); e Analysis of non-tariff measures: the case of export restrictions, 2003. (Ref. TD/TC/WP(2003)7/FINAL).

29 Apesar de admitidos, são tratados como medidas não tarifárias tanto na OMC quanto em acordos regionais. Na OMC especificamente, a lista indicativa de medidas notificáveis anexada à Decisão sobre Notificação de Procedimentos adotada na conclusão da Rodada Uruguai colocou os tributos sobre exportações na categoria de medidas não tarifárias. 
processamento e como resposta à escalada tarifária; d) a adoção de mecanismos de controle de qualidade da produção exportada $a^{30}$; e) a promoção do investimento externo direto. Há ainda as justificativas baseadas na necessidade de cumprimento de "obrigações internacionalmente reconhecidas", tais como: a) $\mathrm{o}$ respeito às obrigações assumidas em acordos internacionais de commodities (açúcar, café, petróleo cru, para fins de aplicação de cotas); b) o atendimento às exceções trazidas nos Acordos de Têxteis e Vestuário da OMC; c) o atendimento às exceções trazidas nos Artigos XX e XXI do GATT-1947 (segurança, proteção ao meio ambiente, saúde pública, interesse social ou religioso, etc.).

Quanto aos impostos aplicados às exportações, não haveria disciplinas suficientes, uma vez que o princípio da nação mais favorecida (Artigo I) e o requisito geral de transparência (Artigo X), ambos contidos no GATT1994, não permitiriam o combate adequado a tais medidas. Nenhum país tinha assumido voluntariamente, até então, um cronograma de desgravação tarifária ou mesmo a notificação de impostos aplicados às exportações. Já as medidas restritivas, em suas variadas formas $^{31}$, de forma individual ou de forma concertada, são explicitamente vedadas pelo Artigo XI do GATT1994:

Entretanto, deve se chamar a atenção para "um quadro de amplas exceções e justificativas baseadas em razões não econômicas", estabelecidas nos Artigo XX e XXI do mesmo Acordo, que "minariam a eficácia" do Artigo XI. Assim, em contraste com as regulações sobre as importações, em que houve um encorajamento à tarificação das restrições quantitativas durante as várias negociações comerciais realizadas sob a vigência do GATT-1947, as restrições às exportações não foram discutidas como prioridade ${ }^{32}$, sendo que

\begin{abstract}
talvez isto reflita a dificuldade de lidar com itens como soberania nacional sobre recursos naturais e/ou políticas de controle da inflação, que controlam o nível adequado de oferta doméstica de produtos chaves.
\end{abstract}

\footnotetext{
30 Relembre-se, por exemplo, do caso Canadá - Pescados, já examinado na seção anterior.

31 As proibições à exportação ou embargos, cotas, licenças, preços mínimos, cartéis, restrições voluntárias às exportações e monopólios estatais, são as formas reconhecidas pela OCDE.

32 Com exceção das restrições voluntárias às exportações, vedadas explicitamente no Artigo 11 do Acordo de Salvaguardas.
}

Mesmo os procedimentos de notificação de restrições quantitativas, que serviriam para aumentar a transparência do processo, não estariam sendo eficazes, na medida em que os Membros não eram obrigados a submeter notificações.

Paralelamente a esses aspectos jurídicos, a OCDE buscou destacar as consequências políticoeconômicas claras. Inicialmente, as restrições às exportações distorcem os fluxos de comércio e afetam negativamente o bem-estar dos parceiros comerciais, sendo que, quando implementadas por países grandes, permitem ganhos apenas no curto prazo, sendo que, em longo prazo, os efeitos de aumento de preços limitam tais ganhos, uma vez que os compradores tradicionais tendem a buscar fontes alternativas para suas aquisições de insumos. Ademais, a busca por fontes alternativas gera aumento da demanda e, consequentemente, uma escalada de preços no plano internacional. Diante do fato de que nenhuma economia é totalmente suficiente na produção de cada matéria-prima, passou-se a estar diante de um desafio global, com especial chamada à reflexão dos PED e PMRD ${ }^{33}$.

Assim, com esse tipo de manifestação, a OCDE buscou assumir uma posição marcadamente contrária às medidas restritivas às exportações adotadas pelos países, evidenciando, numa abordagem pragmática, aspectos econômicos e de caráter mais técnico, que deveriam conduzir aos gestores de políticas públicas a refletir sobre efeitos distorcivos de medidas eventualmente encaminhadas.

$\mathrm{Na}$ visão daquela Organização, para combater tanto os impostos às exportações quanto as outras medidas não tarifárias, o fortalecimento das disciplinas multilaterais seria o caminho adequado, algo que deveria buscar inspiração nos Acordos regionais/ bilaterais de comércio e nos Protocolos de Acessão à OMC.

Os Acordos regionais e bilaterais, sob o "guardachuva" do Comitê de Acordos Regionais e Preferenciais de Comércio, estariam proibindo a aplicação de impostos sobre exportações. Os Acordos Regionais mais expressivos e alguns Acordos Bilaterais já determinavam a proibição do uso de medidas restritivas ou proibitivas às exportações, bem como tributos aplicados às exportações, mas também com um quadro de exceções definido. Entre os acordos regionais, as

33 OCDE. The economic impact of export restrictions on raw material. OECD Publishing, 2010. 
inspirações poderiam estar no regime adotado pela União Europeia, pela Associação Europeia para o Livre Comércio (EFTA), pela Cooperação Econômica da Ásia e do Pacífico (APEC), pelo Tratado NorteAmericano de Livre Comércio (NAFTA), pelo Mercado Comum do Sul (Mercosul) e pela Comunidade do Caribe (Caricom). Já entre os acordos bilaterais, as inspirações seriam trazidas dos acordos Canadá-Chile, Canadá-Costa Rica, Austrália-Nova Zelândia, JapãoCingapura, União Europeia-México ${ }^{34}$.

Já os Protocolos de Acessão, em negociação ou já negociados, previam a assunção a obrigações específicas para os controles às exportações, como no caso da China, sendo que variaram bastante o escopo e a natureza destes compromissos $^{35}$. De modo geral, os antigos Membros exigiram que os pleiteantes identificassem todas as medidas existentes, determinando o compromisso de que fossem removidas aquelas restrições não admitidas como excepcionalidades (medidas temporárias para prevenir ou aliviar o abastecimento limitado de gêneros alimentícios e outros produtos essenciais; para proteger os tesouros nacionais; para conservar recursos naturais exauríveis (desde que a produção ou consumo doméstico seja também restringido)). No caso da China, foi dado um "passo além" em relação às obrigações dos países originalmente signatários, quando se definiu a eliminação de todos os impostos às exportações, exceto para um grupo de 84 itens, que foram colocados num cronograma de desgravação tarifária ${ }^{36}$.

34 LIM, C. L.; SENDUK, J. H. You don't miss your water til your river runs dry: regulating industrial supply shortages after China-raw materials. Stanford Journal of Law, Business, and Finance, v. 18, n. 1, 23 apr. 2013.; University of Hong Kong Faculty of Law Research Paper, n. 2013/016.

35 Podemos citar outros Protocolos de Acessão em que foram previstos compromissos em relação às medidas restritivas às exportações, inclusive impostos aplicados às exportações: Mongólia (1997), Letônia (1999), Croácia (2000) Arábia Saudita (2005), Vietnã (2007), Ucrânia (2008), Montenegro (2012) e Rússia (2012).

36 Essa condição assumida pela China e outros países, sob este enfoque, deve ser vista dentro do processo tipicamente utilizado pela OMC para assegurar que os novos Membros construam compromissos específicos com os principais Membros e, num segundo momento, promovam a multilateralização, evidenciando assunção de "compromissos um pouco mais rigorosos", algo que torna a OMC objeto de questionamentos permanentes quanto à equidade real dos Membros no SMC. Vide CHARNOVITZ, Steve. Mapping the law of WTO accession. The George Washington University Law School. Public Law and Legal Theory Working Paper; Legal Studies Research Paper, n. 237, nov. 2006. p. 9. Em relação ao regime de adoção de impostos de exportações, seria possível pensar em quatro tipos de membros da OMC: a) bloco de mais de 140 membros que gozariam de liberdade para aplicar impostos às exportações; b) Austrália e Rússia, que se comprometeram a não elevar seus
A partir destas experiências (positivas, aos olhos da OCDE) dos Protocolos de Acessão e dos Acordos regionais/ bilaterais, a Organização recomendava o estabelecimento de cronogramas para liberalização das exportações, da cobertura de produtos abrangidos, da cobertura dos países abrangidos, dos patamares e tetos para os impostos aplicados e do período de implementação. Os compromissos poderiam ser gerais ou, alternativamente, avançar por setoriais (agricultura, minerais, couros, florestais, pesca) ou na base caso a caso, mesmo que com concessões de tratamento especial e diferenciado. $O$ foro adequado para a continuação das negociações seria o Grupo de Negociação de Acesso ao Mercado (Non Agricultural Access Market - NAMA), no âmbito da agenda da Rodada Doha.

Em conjunto, o aumento da transparência deveria ser fomentado. A atuação do TPR, como foco nas restrições às exportações, deveria ser intensificada, na visão da OCDE. Isto, de fato, acabou por ocorrer em relação à China, em especial. O país, no período de transição para sua acessão à $\mathrm{OMC}$, foi objeto de dezenas de consultas quanto a controles às exportações adotados. Os Estados Unidos, o Japão e a EU, por exemplo, fizeram questionamentos reiterados para compreender melhor as restrições às exportações adotadas pela China, na forma de licenças, cotas, proibições e impostos, para matérias-primas (bauxita, carvão, coque, metais não ferrosos, terras-raras, entre outros). Via de regra, buscou-se entender como a China compreendia que seu regime de comércio exterior estava adequado às normas da OMC. Nas poucas vezes em que se manifestou, a China respondeu que mantinha um regime administrado de exportações em torno de alguns poucos produtos com o objetivo de proteger o interesse público, conservar recursos naturais ou cumprir com obrigações derivadas de outros tratados internacionais, em conformidade com o Artigo XX do GATT-1994. Contudo, os países consultantes entendiam que a excepcionalidade não era cabível na medida em que a China não estaria adotando medidas

impostos além dos níveis definidos em seus cronogramas, mas mantêm o direito de invocar as exceções do GATT; c) Ucrânia e Vietnã, que inseriram compromissos de eliminar impostos, mas com o direito de usar as exceções; e d) Arábia Saudita, Letônia, Mongólia, Montenegro e, também, China, que se obrigaram a eliminar impostos de exportações, mas que não podem invocar exceções. Criou-se, então, um quadro desequilibrado de direitos e obrigações entre os membros. Conforme QIN, Julia Ya. Reforming WTO discipline on export duties: sovereignty over natural resources, economic development and environmental protection. Wayne State University Law School Research Paper, n. 2012-04, p. 14-15. 28 mar. 2012. 
restritivas para a produção doméstica, como alguns dados demonstravam, inclusive indicando o oposto com a liderança chinesa na produção de várias das matérias-primas tratadas. Dessa forma, solicitavam que o país indicasse prazos para adequação de seu regime administrado.

\section{Dos contenciosos na OMC: casos China-Matérias- Primas (CMP) e China-Terras-Raras (CTR)}

Todo o quadro relatado na seção anterior serviu de contexto para os contenciosos. Assistimos à construção de uma "diplomacia das matérias-primas", tendo como países/blocos mais atuantes os Estados Unidos, o Japão e a UE, que buscaram fazer um discurso articulado tanto no âmbito da OMC quanto em outros foros internacionais, especialmente na OCDE. Num primeiro momento, o assunto das restrições às exportações da China, que se tornou um grande produtor e exportador de matérias-primas estratégicas para a indústria de transformação mundial, foi encaminhado dentro do mecanismo do TPR, para então, diante da falta de argumentos sólidos deste país, migrar para o OSC, em torno de dois contenciosos tratados a seguir.

Vale ressaltar que trataremos apenas dos argumentos trazidos nos Painéis, uma vez que o Órgão de Apelação em ambos os casos referendou, de modo geral, as decisões emanadas daqueles. Em outras palavras, em ambos os casos, as principais decisões proferidas pelos Painéis foram ratificadas pelo Órgão de Apelação, ensejando a derrota das teses chinesas.

\subsection{Painel CMP (WT/DS394, WT/DS395 e WT/DS398)}

A disputa teve como cerne a acusação dos reclamantes de que a reclamada estaria adotando medidas restritivas à exportação de várias matériasprimas (bauxita, coque, fluorita, magnésia, manganês, carbeto de silício, silício metálico, fósforo amarelo e zinco). Todos esses materiais têm significativa utilização na indústria de transformação.

Os reclamantes alegaram o uso de quatro espécies de medidas pela reclamada: (i) imposto de exportação; (ii) cotas de exportação; (iii) licenças de exportação; e (iv) preços mínimos de exportação (WT/DS394/R, Parágrafo. $\left.2 \cdot 3^{37}\right)$. Nestas espécies, os reclamantes

37 Daqui em diante, se fará referência apenas ao(s) número(s) do(s) Parágrafo(s) do caso WT/SD394/R. haviam identificado cerca de 40 composições diferentes (Parágrafo 2.4).

\section{A) Artigo XX do GATT: uma cláusula de defesa diante das obrigações do PAC?}

A China alegou a adoção de medidas temporárias em relação a alguns dos metais e minerais objetos da disputa $^{38}$ com base no Artigo XX(b) e (g) do GATT (Parágrafo 7.108). Caberia, então, ao Painel examinar se as exceções do Artigo XX poderiam justificar as medidas chinesas.

O Painel partiu da premissa que o PAC era parte integrante dos Acordos da $\mathrm{OMC}^{39}$ e deveria ser interpretado, dessa forma, de acordo com as normas consuetudinárias de interpretação de DIP previstas nos Artigos 31, 32 e 33 da Convenção de Viena do Direito dos Tratados (CVDT). Reconhecido este aspecto, as partes divergiam sobre o direito chinês de invocar as defesas do Artigo XX: para a China, o texto do Parágrafo 11.3 do PAC e o Parágrafo 170 do RGTAC permitiam uma interpretação favorável a esta possibilidade de defesa, enquanto os reclamantes advogaram que aquele país não poderia recorrer ao Artigo XX uma vez que o Parágrafo 11.3 do PAC não estaria fazendo referência à excepcionalidade contida neste Artigo (Parágrafos 7.110-115).

Fazendo referência ao Relatório do OAp no caso China-Audiovisual (WT/DS363/AB/R), em que o Parágrafo 5.1 do PAC foi interpretado de uma maneira a incorporar as justificativas do Artigo $\mathrm{XX}^{40}$, o Painel cogitou uma análise similar neste novo caso. No entanto, o Painel observou que o texto contido no Parágrafo 11.3, objeto de análise, revelava outra linguagem, que devia ser interpretada de forma singular. Assim, esclarecia que o Parágrafo em tela não incluía qualquer referência ao Artigo XX, ou outros dispositivos do GATT de forma mais geral. Ademais, o Parágrafo 11.3 do PAC não trazia expressão semelhante ou similar àquela registrada no Parágrafo 5.1. Finalmente, o Parágrafo 11.3 do PAC mencionava exceções específicas, que

38 Restos de metais não ferrosos de zinco, manganês e magnésio; coque, metal de manganês e metal de magnésio; e, finalmente, fluorita.

39 Com base no Parágrafo 1.2 do PAC.

40 A expressão utilizada no Parágrafo 5.1 do PAC é ora reproduzida: "Without prejudice to China's right to regulate trade in a manner consistent with the WTO Agreement, [...]" 
constariam do Anexo 6 ou cobertas no Artigo VIII do GATT (Parágrafos 7.116-120, 7.124-129 e 7.149-154).

Passando então a analisar o Relatório do Grupo de Trabalho de Acessão da China (RGTAC), o Painel examinou se a alegação chinesa, de que o Parágrafo 170 deste documento permitiria uma justificativa das violações, concluindo que não seria possível concordar com esta tese. A conclusão era de que não havia qualquer dispositivo explícito ou implícito que autorizasse a China a invocar as exceções gerais do Artigo XX (Parágrafos 7.147-148).

Um último ponto analisado foi o argumento chinês de que a prerrogativa para estabelecer impostos sobre a exportação podia ser encontrada em um direito inerente e soberano (das nações) em regular o comércio (grifo nosso), apesar da condição estabelecida no Parágrafo 11.3 do PAC. O Painel observou que o direito de regular o comércio foi colocado em exercício pelos Membros da OMC e a China quando, por exemplo, negociaram seus termos de acessão à Organização. Assim, não havia qualquer contradição entre este direito e os termos negociados no Parágrafo 11.3 (Parágrafos 7.155-157).

Em suma, o Painel concluiu que o texto e o contexto do Parágrafo 11.3 do PAC não autorizariam a China a invocar o Artigo XX do GATT para justificar as violações ao mencionado Parágrafo (Parágrafos 7.158-159).

\section{B) Artigo XX (g) do GATT: cotas de exportação e impostos de exportação ${ }^{4}$}

Baseado nas invocações da China ao Artigo XX(g) para justificar a adoção de cotas e impostos de exportação de minerais em disputa, o Painel também avaliou se as restrições sobre as exportações especificamente de bauxita refratária e fluorita encontrariam amparo no Artigo XX(g).

De acordo com a China, essas matérias-primas eram recursos naturais exauríveis, escassos e sem substitutos eficazes, devendo ser administrados e protegidos pelo Estado. O país também alegou que nada devia interferir na soberania sobre seus recursos naturais. Ademais, em seu entendimento, os PED precisavam fazer um uso ótimo de seus recursos na busca por mais desenvolvimento,

41 WT/DS394/R, Parágrafo 7.235. Esta análise foi feita pelo Painel, ainda que a conclusão já manifestada pelo mesmo foi de que a China não poderia recorrer ao Artigo XX por conta dos termos trazidos no Parágrafo 11.3 do PAC, como visto no tópico A acima. da forma que considerassem mais apropriado, inclusive no tocante ao seu processamento (grifo nosso) (Parágrafo 7.356).

O Painel empreendeu uma análise, partindo das duas condições estabelecidas no Artigo XX(g): as medidas restritivas adotadas deveriam estar relacionadas à conservação de recursos naturais exauríveis, e, também, serem conjugadas com restrições à produção ou consumo doméstico (Parágrafo 7.360-361).

Em relação ao primeiro aspecto, um ponto pacífico entre reclamantes e reclamada era de que os recursos naturais eram exauríveis; todavia, discordavam quanto à adequação das medidas restritivas a um programa de conservação do Estado chinês. O Painel, então, ponderou alguns aspectos que utilizaria em sua investigação: a) a definição literal de conservação de recursos naturais; b) as considerações trazidas no Preâmbulo do Acordo Constitutivo da OMC, em atendimento ao Artigo 31(2) da $\mathrm{CVDT}^{42}$, em relação ao propósito dos Membros em perseguir o desafio de administrar os recursos naturais de uma maneira sustentável, de forma a assegurar a proteção e conservação do meio ambiente e, paralelamente, promover o desenvolvimento econômico (Parágrafos 7.373-375); e c) o princípio da soberania sobre os recursos naturais, reconhecido como um princípio do DI (com referência direta às Resoluções AGNU 626 e 1803), que autorizava os Estados nacionais a usarem de modo livre e explorarem suas riquezas naturais e recursos em prol de seu progresso e desenvolvimento econômico (grifo nosso) (Parágrafos 7.377-383) ${ }^{43}$.

Tomando por base esses aspectos, a conclusão do Painel foi de que os Membros da OMC não poderiam se amparar no Artigo XX (g) para justificar a adoção de controles às exportações na busca pelo desenvolvimento econômico, caso estas contribuíssem para aumentar a proteção à indústria doméstica. Assim, o Artigo XX(g) não poderia contradizer os termos do Artigo XX(i),

42 O Artigo estabelece que o contexto de um Tratado inclua seu texto, incluindo Preâmbulo e Anexos.

43 O Painel, neste caso, se fundamentou no Artigo 31(3)(c) da Convenção de Viena. Recordou também que o assunto estaria pacificado em torno de alguns outros casos tratados no OSC, relacionados à preservação de recursos naturais, que foram citados em nota do Parágrafo 7.377, tais como US - Shrimp (Vietnam) (DS404); US - Tuna II (Mexico) (DS381); US - Customs Bond Directive (DS345 and DS343 ); Argentina -Hides and Leather (DS155); EC Asbestos (DS135); US - Shrimp (DS58); Brazil - Desiccated Coconut (DS22); US - Gasoline (DS2 and 4). 
que fazia exatamente esta ressalva destacada pelo Painel (Parágrafos 7.384-386).

Em relação ao segundo aspecto trazido pelo Artigo $\mathrm{XX}(\mathrm{g})$, a China fez referência ao Artigo XXXVI:5 (meta de diversificação econômica), no sentido de que deveria ser utilizado na interpretação do Artigo XX(g). Desse modo, a China alegava que, no caso da indústria do aço, o país precisava restringir suas exportações de insumos (como a bauxita refratária) para ajudar na diversificação na medida em que o crescimento da indústria do aço estimularia o desenvolvimento do setor de infraestrutura do país, que, por sua vez, permitiria um crescimento de todos os demais setores da economia nacional (Parágrafos 7.399-400).

O Painel, ainda que tenha reconhecido o argumento da China em relação ao seu direito de desenvolvimento econômico e o exercício de sua soberania sobre os recursos naturais, foi claro na observação de que ambos os pontos não estariam em conflito com os direitos e obrigações enquanto Membro da OMC (grifo nosso) (Parágrafos 7.403-404).

Em suma, o Painel afirmou que o Artigo XX(g) poderia ser utilizado para justificar medidas restritivas, desde que se aplicassem também para os produtores domésticos na conservação de recursos naturais, a fim de que não criasse um cenário desequilibrado em termos de competitividade internacional (Parágrafo 7.408).

Já indo ao ponto manifestado no início deste tópico (examinar se as restrições sobre as exportações de bauxita refratária e fluorita estariam baseadas no Artigo XX(g)), o entendimento do Painel foi de que não era possível encontrar provas conclusivas de que as cotas e os impostos de exportação adotados estariam relacionados com a conservação dos recursos naturais supostamente protegidos (Parágrafos 7.419, 7.426-28 e 4.430-435).

Entretanto, ainda restava examinar o aspecto da conjugação de medidas restritivas às exportações com medidas de contenção junto à produção ou consumo doméstico. O Painel deu o parecer de que não era possível identificar evidências de que a China havia adotado medidas neste sentido (Parágrafos 7.437, 7.453458 e 7.463-465).

Posto isso, o Painel concluiu que, ainda que a China pretendesse fazer uso do Artigo XX $(\mathrm{g})$ como forma de justificar suas medidas restritivas, o país não tinha demonstrado que as cotas de exportação impostas sobre a bauxita refratária ou os impostos aplicados na exportação de fluorita podiam ser, de fato, justificadas neste dispositivo (Parágrafos 7.467-468).

\subsection{Painel CTR (WT/DS431, WT/DS432 e WT/DS433)}

O Relatório do Painel CTR foi aguardado com grande expectativa. O caso anterior (CMP) já havia repercutido bastante entre lideranças políticas/técnicas, bem como no meio acadêmico, revelando a necessidade de uma retomada mais intensa do tema na agenda internacional. Assim, o caso CTR foi visto como uma oportunidade para confirmação ou reformulação de teses jurídicas trabalhadas no caso CMP.

O objeto da disputa foram, novamente, medidas chinesas como impostos de exportação, cotas de exportação e administração e alocação de cotas de exportação para os elementos terras-raras, o tungstênio e o molibdênio (WT/DS431/R, Parágrafos 2.2 a $\left.2.16^{44}\right)$. As violações da China seriam: a) os impostos de exportação estariam em desacordo com as obrigações assumidas pela China no Parágrafo 11.3 do PAC; b) as cotas de exportação estariam em desacordo com o Artigo XI:1 do GATT-1994, bem como com o Parágrafo 1.2 do PAC, que, por sua vez, incorporaram compromissos dos Parágrafos 162 e 165 do RGTAC; e c) a administração e a alocação de cotas de exportação estariam em desacordo com o Parágrafo 1.2 e 5.1 do PAC, que incorporaram compromissos dos Parágrafos 873 e 84 do RGTAC (Parágrafo 3.1/a/b/c).

A defesa chinesa se deu pelas seguintes vias: a) alegou a aplicação das exceções gerais do Artigo XX(b) do GATT-1994 como forma de defesa para uma potencial violação do Parágrafo 11.3 do PAC; e b) tentou explicar a imposição de cotas de exportações justificadas no Artigo $\mathrm{XX}(\mathrm{g})$; e c) afirmou que os compromissos do Parágrafo 5.1 do PAC e dos Parágrafos 83 e 84 do RGTAC não impediriam o uso do critério de performance de exportação prévia ou de exigência de capital mínimo registrado para administrar as cotas de terras-raras e molibdênio (Parágrafo 3.2/a/b/c).

44 Daqui em diante, se fará referência apenas ao(s) número(s) do(s) Parágrafo(s) do caso WT/DS431/R, quando for o caso. 


\section{A) Adoção de cotas de exportação em violação ao Artigo XI:1 do GATT-1994 e Parágrafos 162 e 165 do RGTAC}

Os reclamantes expuseram que a China adotou restrições quantitativas, inclusive cotas, em relação às terras-raras, tungstênio e molibdênio, algo inconsistente com as obrigações assumidas face ao Artigo XI:1 do GATT-1994 e os Parágrafos 162 e 165 do RGTAC.

A China reconheceu que as suas cotas eram uma violação aos instrumentos citados, contudo invocou o Artigo XX(g), uma vez que as cotas teriam sido estabelecidas para a conservação de recursos naturais exauríveis e seriam adotadas em conjunção com restrições à produção e consumo domésticos. O Painel recordou que, ao buscar o Artigo XX(g), cabia à China a obrigação de reunir provas suficientes para convencimento dos painelistas e dos reclamantes ${ }^{46}$.

Após fazer uma extensa explicação sobre o regime de cotas de exportação na China, com as principais autoridades envolvidas, bem como as aplicações efetivas de cotas e requerimentos para empresas manufatureiras e distribuidoras dos minerais em exame, o Painel decidiu por proceder da mesma forma como feita pelo Painel do caso CMP e, assim, apresentar conclusões e recomendações a respeito da legislação chinesa em todos os seus níveis. Contudo, antes de fazer isto, era necessário verificar se havia lugar para a defesa chinesa, com base no Artigo XX(g) do GATT-1994.

\section{B) Aplicabilidade do Artigo XX(g) como forma de defesa às cotas de exportação47}

A análise do Painel considerou duas vias de investigação: a) as medidas deveriam obedecer aos requisitos do Artigo XX(g); e b) deveriam obedecer aos requisitos do caput do Artigo XX. Em atendimento ao Artigo 3.2 do ESC e ao Artigo 31 da CVDT, também houve preocupação em se definir os termos utilizados no Artigo XX, caput e parágrafo (g).

Em relação ao aspecto "conservação", a China explicou que adota uma política ampla de conservação para proteger e racionalizar o uso das suas reservas de

45 Este tópico foi baseado na leitura dos parágrafos 7.197 a 7.235 do Relatório do Painel CTR.

46 Nesta oportunidade, diferentemente do que fez no caso CMP, a China não recorreu à exceção prevista no Artigo XI:2 (a) para justificar a adoção de suas cotas de exportações, e sim apenas ao Artigo XX, item " $\mathrm{g}$ ".

47 Esse tópico foi baseado na leitura dos parágrafos 7.236 a 7.261, e 7.362 a 7.970 do Relatório do Painel CTR. minerais estratégicos com ações concretas a partir do ano da década de 1990. A sua política contemplaria: a) o controle de acesso à indústria de minerais; b) medidas de taxação; c) combate aos danos causados pela mineração e produção de terras-raras, por exemplo; d) controle quantitativo de extração, produção e restrições às exportações, sendo os três mecanismos interconectados; e e) aplicação rigorosa de leis e regulações relacionadas com a indústria de minerais.

Em seguida, a China buscou convencer os painelistas de que este objetivo de conservação deveria ser visualizado num contexto maior: além da preservação de recursos naturais exauríveis, englobaria a gestão de recursos em linha com o desenvolvimento econômico sustentável dos Membros, sugerindo entendimentos trazidos no Painel CMP. Alegou, em especial, que o Painel daquele caso reconheceu que o princípio da SPRN permite aos Membros utilizar seus recursos naturais para promover seu próprio desenvolvimento enquanto regulam o uso de seus recursos para assegurar o desenvolvimento sustentável, reconhecendo que a conservação e o desenvolvimento econômico devem "operar em harmonia".

Os reclamantes rejeitaram a tese acima, apresentando uma série de argumentos. Com destaque, defenderam que não se poderia ampliar a noção de conservação para incorporar o desenvolvimento econômico do país-membro. Na visão destes, a China teria buscado no Preâmbulo do Acordo Constitutivo da OMC uma leitura seletiva para ampliar o sentido de "conservação", indicando uma tentativa de quebrar o equilíbrio geral de valores salientado no próprio Preâmbulo e fomentando o protecionismo. Ademais, recorreram ao caso CMP para relembrar que a exceção do parágrafo (g) do Artigo XX não poderia ser ampliada para não conflitar com o parágrafo (i) do mesmo Artigo, gerando possibilidade concreta de quebra de sistematicidade deste dispositivo. Finalmente, os reclamantes recordaram que, no caso CMP, houve o alerta para que o princípio da SPRN seja instrumentalizado de forma consistente com as obrigações assumidas pelos Membros junto à OMC.

Como o OAp ainda não tinha se manifestado sobre o significado expresso do termo "conservação"

48 É perceptível, fazendo uma comparação do Painel deste caso com o do caso CMP, uma preocupação em se aprofundar mais sobre estes aspectos, antes de partir para os testes legais. Ficou evidenciado, também, que o Painel desejava poder partir de premissas mais claras, tanto na conceituação de "conservação" como de "recursos naturais exauríveis", algo que seria de incumbência do OAp da OMC. 
Painel destacou a necessidade de se ter em mente o caráter evolucionário, e não estático, deste conceito, que deveria ser buscado nas normas consuetudinárias de DI. Tendo em conta o conceito ordinário (literal), passou-se para o exame do contexto de produção do Artigo XX $(\mathrm{g})^{49}$. Levando em consideração o Preâmbulo do Acordo Constitutivo da OMC, o Painel inferiu que o objetivo de desenvolvimento sustentável era relevante para a interpretação do Artigo XX $(\mathrm{g})$; contudo, não poderia ser invocado como base para um desvio dos requisitos definidos no Artigo XX $(\mathrm{g})$.

Indo adiante, nos termos do Artigo 31(3)(c) da CVDT, o Painel ponderou que, além do contexto, deveria se considerar toda norma pertinente de DI aplicável às relações entre as partes. Dessa forma, recorreu ao princípio da SPRN e do desenvolvimento sustentável, que, no seu entendimento, deveriam ser considerados para interpretação do Artigo XX (g), nesse momento "chamando para debate" as Resoluções nrs. 626/1952, 1803/1962 e 2158/1966 da ONU, bem como a Declaração do Rio de Janeiro sobre Meio Ambiente e Desenvolvimento de 1992 (Princípios 2 e 4).

A partir de uma leitura desses acordos internacionais, o Painel concordou com a China de que o termo conservação, como usado no Artigo XX(g), não poderia ser limitado à mera preservação de recursos naturais, ao considerar o princípio da SPRN como relevante princípio do DI. Aceitando este pressuposto, o Painel entendeu que há margem para que os Membros tenham objetivos próprios e metas para as suas políticas implementadas, incluindo o desenvolvimento econômico e sustentável. Contudo, isso não poderia ser visto como um direito geral para regular e controlar o mercado de recursos naturais e, em última instância, desvelando uma busca pelo controle do mercado internacional. Ademais, a gestão de recursos, citada pela China, deveria se dar de forma consistente com o DI e as normas da OMC, afastando, por exemplo, a vedação trazida pelo dispositivo do Artigo XX(i).

Outro ponto a se atestar, na visão do Painel, é que o exercício de soberania se manifesta quando determinado Estado ratifica tratados internacionais. Assim, os Membros não perderam a sua SPRN ao ingressar na OMC, ou mesmo desistiram do direito

49 Nos termos do Artigo 31(2) da CVDT, o contexto inclui texto, Preâmbulo e Anexos. Trata-se, também, de entendimento confirmado no OAp do caso Estados Unidos-Camarões (WT/DS 58) de adotar cotas de exportação ou outra medida para alcançar a conservação dos recursos naturais; todavia, concordaram em exercitar seus direitos em conformidade com as normas da OMC e respeitar os dispositivos dos Acordos quando implementam políticas para conservar seus recursos naturais exauríveis. Enfim, a soberania permanece, o policy space, definitivamente, não no mesmo nível.

Cumprida a tarefa de examinar cada aspecto do caput e do parágrafo (g) do Artigo XX, o Painel passou à tarefa de verificar in loco a possibilidade de se excepcionalizar as cotas de exportação aplicadas aos minerais em exame.

No entendimento chinês, as cotas de exportações atualmente existentes no quadro legal daquele país, além de proporcionar a conservação de recursos naturais exauríveis (ponto central de sua argumentação), eram utilizadas para cumprir diversas finalidades, entre elas permitir uma alocação entre consumidores estrangeiros e domésticos, no exercício de sua soberania sobre recursos naturais, de forma a distribuir o comércio de produtos de terras-raras, de maneira que haja uma aproximação entre demanda doméstica e estrangeira. Nesse ponto, a China ressaltou que sua condição de atual fornecedora de mais de $90 \%$ das terras-raras consumidas no mundo traz uma "responsabilidade" de fazer uma adequada gestão destes recursos naturais exauríveis $^{50}$. Ademais, no entendimento daquele país, tratou-se de algo completamente inerente ao exercício de sua SPRN, de forma a utilizar e explorar seus recursos livremente e obter progresso e desenvolvimento econômico. Aliás, se os Membros da OMC dotados de recursos não tivessem esse direito de alocar recursos, a acessão à OMC teria significado a renúncia a essa norma fundamental.

Percebe-se, então, a tentativa chinesa de ampliar o sentido de conservação de recursos naturais no seguinte sentido: a reclamada alegou contribuição material das cotas para a conservação de recursos naturais exauríveis, e, também, para o exercício da soberania sobre estes minerais, sem que haja intenção de beneficiar a indústria doméstica. Em outras palavras, conclui-se que a China buscou trazer ao debate a necessidade de uma interpretação mais ampla à necessidade de conservação de recursos naturais exauríveis.

50 Em relação ao tungstênio, a China ressaltou dispor de 61\% das reservas, contudo produz $83 \%$ da oferta atual (Parágrafo 7.685). Em relação ao molibdênio, teria $43,9 \%$ das reservas conhecidas, produzindo $38 \%$ do total consumindo no mundo (Parágrafo 7.850). 
Por sua vez, o Painel decidiu que caberia à China, tendo o ônus da prova ao alegar a exceção do Artigo $\mathrm{XX}$, ter demonstrado de forma adequada a relação pretendida, sendo que as referências textuais à conservação nos instrumentos legais chineses foram inconclusivas. Por exemplo, a citação no Preâmbulo de um documento legal não poderia afastar a análise do objetivo real de uma medida, observando a forma como a medida está construída. Recorreu, também, para a explicação de que o objetivo de conservação do Artigo XX(g) do GATT permitiria aos Membros tomar em conta o seu desenvolvimento sustentável quando adotam uma determinada política, bem como no desenho e nos instrumentos que serão utilizados para implementá-la. No entanto, na visão do Painel, a China teria interpretado de forma equivocada as considerações trazidas pelo Painel do caso CMP: naquela oportunidade, não se quis manifestar que $\mathrm{o}$ desenvolvimento sustentável deve ser buscado sobre a rubrica da "conservação". Assim, os Membros deveriam fazer uma diferenciação bem clara das medidas que objetivam a promoção do desenvolvimento econômico, que são medidas de política industrial, de fato, das medidas de conservação.

Outro ponto muito relevante foi defendido pelo Painel: uma vez que o recurso natural é extraído, não caberia ao país-membro onde se extraiu o recurso se tornar "responsável" ou ter o direito de alocar os recursos disponíveis entre diferentes consumidores, pois uma vez extraídos e inseridos no mercado, tais recursos passariam a estar sujeitos às normas da OMC. Dessa forma, para combater distorções de mercado, como demandas especulativas, as medidas de salvaguardas temporárias, como estabelecidas no Artigo XI:2 do GATT, e não as cotas de exportações, seriam as ferramentas adequadas para utilização.

Assim, após a análise dos fatos, o Painel manifestou que, apesar de menções indiretas na legislação chinesa sobre metas de conservação com a aplicação de cotas, não foi munido de explicações de como as medidas são desenhadas de modo a assistir ao programa de conservação da China, não permitindo estabelecer, então, o requisito da relação estabelecido no Artigo $\mathrm{XX}(\mathrm{g})$. Ademais, outras situações fragilizam a posição chinesa, tais como o fato de que as distribuições.

O Painel destacou também que não concordava com a China de que o exercício da SPRN autorize um controle dos mercados internacional e doméstico e a alocação internacional e distribuição de terras-raras. Novamente: poderia haver controle sobre a extração, mas, uma vez extraído e inserido no mercado, o recurso passa a estar sujeito às normas da OMC, que proíbem cotas a menos que justificadas pelas exceções.

Em relação ao caput do Artigo XX, o Painel também concluiu que a China não demonstrou como o seu sistema de cotas sobre as terras-raras não foi aplicado de modo a se configurar como uma medida arbitrária ou injustificada, ou uma restrição velada ao comércio internacional. Chamou atenção, também, que os reclamantes sugeriram medidas alternativas e consistentes com as obrigações assumidas na OMC, que poderiam ser utilizadas para conservar recursos naturais, inclusive apenas com o fortalecimento de medidas já tomadas pela própria China, como restrições à produção, sistema de licenciamento, ou mesmo desenvolver novas formas, como um sistema de cotas para vendas domésticas, ao que a China não ofereceu maiores explicações.

Tomando como base essas conclusões, a China não poderia excepcionalizar sua conduta com base no Artigo XX(g) ou no caput do Artigo, o que conduziria à constatação de que o sistema de cotas de exportações de terras-raras, tungstênio e molibdênio é inconsistente com o Artigo XI:1 do GATT-1994 e os Parágrafos 162 e 162 do RGTAC.

\section{Conclusão}

Como pode ser examinado, o caso CMP é um caso de vanguarda no âmbito do OSC: a interseção de normas da OMC com normas de DIP já havia sido explorada em outros contenciosos e na literatura; contudo, tratou-se de uma das primeiras oportunidades em que os painelistas tiveram de lidar com o princípio da SPRN e do (direito ao) desenvolvimento sustentável, diante da alegação da China de que, ao adotar controles de exportações, buscava exercer o seu direito de regular as exportações de recursos naturais como uma questão de soberania e de desenvolvimento ${ }^{51}$.

$\mathrm{Na}$ sequência, o Painel do caso CTR confirmou teses jurídicas trabalhadas no caso CMP: ao tempo que reconheceu a importância destes princípios no DIP, privilegiou a interpretação literal (restritiva) dos termos

51 ROLLAND, Sonia Elise. China-raw materials: WTO rules on chinese natural resources export dispute. ASIL Insights, v. 16, n. 21, 19 June 2012; Northeastern University School of Law Research Paper, n. 96-2012. 
de acessão da China à OMC. Posto isso, e acrescidas as fragilidades dos argumentos de defesa da China (ônus da prova), ficou afastada a possibilidade de excepcionalizar o comportamento deste país com base nos Artigos $\mathrm{XI}: 2(\mathrm{a})$ e $\mathrm{XX}(\mathrm{g})$. Ou seja, prevaleceram as normas da OMC diante de outros princípios de DIP por aspectos técnicos-interpretativos assumidos pelo OSC.

Enfim, uma das principais conclusões dos casos CMP e CTR diz respeito ao fato de ter sido estabelecido a forma como a OMC entendeu como as exceções trazidas nas proibições às restrições às exportações previstas no GATT estão relacionadas com os princípios gerais de DI relacionados com a soberania sobre recursos naturais e o direito ao desenvolvimento. Ainda que tenha feito uma interpretação restritiva, o Painel nos casos CMP e CTR partiu da constatação de que a SPRN e o desenvolvimento sustentável eram princípios basilares do DI e deveriam ser ponderados no trabalho de análise da proposta chinesa de conservação de recursos naturais.

Entretanto, é possível refutar que estes princípios desempenhem, hoje, a função de "metaprincípios vinculantes", competentes a orientar os Estados e as Organizações Internacionais a aplicarem normas potencialmente conflitantes ${ }^{52}$. Ainda que o OAp tenha reconhecido que os princípios do desenvolvimento sustentável e da soberania devam ser empregados com o propósito de dar "cor e consistência" à interpretação dos Acordos da OMC, percebeu-se um cuidado no exame dos casos CMP e CTR para que a alegação de que a soberania sobre recursos naturais e o desenvolvimento sustentável não se configurassem uma prática velada capaz de distorcer o comércio.

Assim, apesar da vitória das teses dos reclamantes, trata-se do momento oportuno para trazer à cena um dos trechos do Relatório do Painel CTR, que desvela a tônica do desafio ainda a se enfrentar na OMC:

o Painel considera que toda a análise precedente sugere uma necessidade de se balancear os objetivos da liberação comercial, soberania e desenvolvimento sustentável, ainda que não seja indicado precisamente como tal balanço

52 Vide RODRIGUES JÚNIOR, Edson Beas. O princípio do desenvolvimento sustentável como princípio geral do direito: origem histórica e conteúdo normativo. Revista dos Tribunais, ano 103 , v. 940 , p. $334-335$, fev. 2014. São argumentos que tratam da natureza normativa do princípio do desenvolvimento sustentável, e que ora se estendem para o princípio da SPRN. poderia ou deveria ser atingido (tradução livre do Parágrafo 7.276).

Esse desafio está relacionado diretamente com as exceções trazidas na interpretação do Artigo XX do GATT e, mais, especificamente, na necessidade de refinar a cláusula da conservação tratada no parágrafo (g) deste Artigo ${ }^{53}$.

A necessidade de construção deste balanço adequado, inclusive, foi trazida para a Declaração Ministerial de Doha. Ao menos formalmente, a OMC colocou as necessidades e os interesses dos PED em seu centro, a fim de capacitá-los a erradicar a pobreza e a dotar de seus povos dos meios essenciais para se autodeterminarem e, assim, promover um SMC que efetivamente viabilize o desenvolvimento sustentável de todos os seus Membros. Trata-se, em última instância, da manifestação explícita do princípio da inter-relação ou integração, ou por princípio da potenciação mútua, complementariedade e não subordinação, com a finalidade de obrigar os Estados a interpretarem e aplicarem normas potencialmente conflitantes, de modo a harmonizá-las, conservando íntegros seus direitos e obrigações frente a outros Estados ${ }^{54}$.

Apesar de desejável (em especial para a OCDE, como visto), o fortalecimento das disciplinas multilaterais sobre controles às exportações dificilmente será alcançado no curto ou médio prazos, dado à abertura e complexidade dos itens que serão tratados.

53 Vide LIM, C. L.; SENDUK, J. H. You don't miss your water til your river runs dry: regulating industrial supply shortages after China-raw materials.). Stanford Journal of Law, Business, and Finance, v. 18, n. 1, 23 apr. 2013.; University of Hong Kong Faculty of Law Research Paper, n. 2013/016, p. 99-100; 110-112. A China defendeu que, longe de ser o objetivo final dos Acordos de Marraqueche, a liberalização comercial foi concebida e regulada dentro do SMC, coordenada pela OMC, como ferramenta "para aumentar os padrões de vida", meta a ser perseguida constantemente, "proporcionando o uso ótimo dos recursos mundiais" e "de acordo com o objetivo de desenvolvimento sustentável, buscando concomitantemente proteger e preservar o meio ambiente", todos estes objetivos inseridos no Preâmbulo do Acordo em tela. Sob esta visão, os compromissos de liberalização comercial não seriam disciplinados como obrigações e proibições absolutas, impossíveis de serem derrogados, mas como obrigações que podem ser contornadas a fim de perseguir os valores não comerciais contemplados em várias normas da OMC, particularmente nas cláusulas de exceções gerais, respeitando todos os requisitos e o equilíbrio entre necessidades conflitantes e preocupações expressadas por aquelas provisões multilaterais.

54 Vide RODRIGUES JÚNIOR, Edson Beas. O princípio do desenvolvimento sustentável como princípio geral do direito: origem histórica e conteúdo normativo. Revista dos Tribunais, ano 103, v. 940, p. 335-336, fev. 2014. 
Por outro lado, não se pode ignorar que os problemas podem se ampliar. Há focos de tensões claros. As medidas tomadas pela China foram destacadas neste artigo, mas podem ser citados outros eventos, tais como a tensão entre Rússia, que recentemente também ingressou na OMC, e a União Europeia, no tocante ao fornecimento de carvão e gás, desde 2004; ou medidas tomadas pela Índia, adotando impostos de exportação sobre o crómio, em 2007, que direcionou os ávidos importadores chineses da matéria-prima para o mercado sul-africano, que ficou também próximo de adotar medidas de proteção para sua indústria de processamento do ferro-crómio; ou, finalmente, o regime de exportação de gás de xisto nos Estados Unidos, que também tem sido alvo de questionamentos ${ }^{55}$. Ademais, corre-se o risco também de que as decisões nos contenciosos abertos contra a China façam avançar sentimentos nacionalistas de oposição, que em nada contribuam para uma solução razoável dos problemas de fornecimento e, ao contrário, apenas aumentem medidas de cunho protecionista e retaliações na mesma proporção.

Voltando ao ponto original, não é possível ainda dizer se o uso dos controles às exportações é uma reação temporária (ou, talvez, intermitente) à volatilidade de preço no mercado global de commodities ou se devem se tornar mais frequentes nas políticas comerciais por razões estruturais ${ }^{56}$. Queremos crer, contudo, que fica evidenciado que, ainda nos próximos anos, permanecerá um foco de tensão entre os "países ricos em recursos" e os "países pobres em recursos". Desta vez, por suas dimensões continentais, os PED parecem

55 BELLMANN, Cristophe; WILKE, Marie. Trade policies for resource security: rethinking export restrictions. In: ICTSD. The future and the WTO: confronting the challenges: a collection of short essays. Geneva, Switzerland: ICTSD Programme on Global Economic Policy and Institutions, 2012. p. 197-198.; BRONCKERS, Marco, MASKUS, Keith E. China raw materials: a controversial step towards evenhanded exploitation of natural resources. 27 aug. 2013. p. 1415. Available at SSRN: <http://ssrn.com/abstract $=2321018>$. or $<$ http://dx.doi.org/10.2139/ssrn.2321018>.

56 Por exemplo, o crescimento rápido e sustentado de economias dos emergentes pode gerar uma demanda maior por matérias-primas e energia para assegurar oferta para as indústrias domésticas, colocando as fontes de abastecimento sobre pressão constante. Nas palavras de Julia Ya Qin (p. 6), "o aumento da demanda em um mundo de recursos finitos causou uma disseminação da ansiedade em torno da segurança pelo acesso de recursos naturais" (tradução livre). QIN, Julia Ya. Reforming WTO discipline on export duties: sovereignty over natural resources, economic development and environmental protection. Wayne State University Law School Research Paper, n. 2012-04, 28 mar. 2012. ter uma vantagem comparativa em relação aos países desenvolvidos.

Do ponto de vista prático, se as normas atualmente existentes restringem, ao menos teoricamente ou formalmente, as restrições às exportações, poderia haver perigo que medidas desse tipo, utilizadas por países individuais, se tornassem um padrão de comportamento no SMC? O que seria indicado, então, para o fim da "guerra comercial" que teria se começado a travar? Estas são perguntas que podem orientar a reflexão do ponto de vista político, inclusive com a indicação de alguns caminhos a seguir, que não podem ser vistos de forma exclusiva ou exaustiva.

É possível se verificar que existem mercados relativamente livres para algumas commodities, cujos preços se formam pelo equilíbrio entre oferta e demanda. Contudo, há muitas matérias primas que são reguladas por acordos amplos, ou contratos de fornecimento. Uma solução política passaria por uma composição como esta, envolvendo a China, Estados Unidos, União Europeia e Japão, num primeiro momento.

A construção de arranjos comerciais no plano bilateral seria um primeiro caminho então. Citese, por exemplo, a iniciativa da UE em propor, nas suas negociações bilaterais ou multilaterais, com destaque para as tratativas com o Chile e a Coreia do Sul ou no processo de acessão da Rússia, algumas disciplinas sobre controles às exportações, sendo que, até mesmo os impostos de exportação são utilizados de forma excepcional, por razões ambientais ou para implementação de políticas de desenvolvimento. Há também iniciativas individuais dentro da UE, como a Alemanha, que assinou acordo bilateral com o Cazaquistão, que assegurou às empresas alemãs o direito de exploração de matérias-primas, incluindo terras-raras em troca de investimento e tecnologia "verde", inclusive fortalecendo uma política de proteção ambiental e promoção de indústrias domésticas ${ }^{57}$.

Outra possibilidade é o fortalecimento da transparência. Podem ser citadas como avanços neste sentido algumas ações, tais como a preocupação do TPR sobre o assunto, a criação da base de dados da OCDE especificamente sobre o controle às exportações

57 BELLMANN, Cristophe; WILKE, Marie. Trade policies for resource security: rethinking export restrictions. In: ICTSD. The future and the WTO: confronting the challenges: a collection of short essays. Geneva, Switzerland: ICTSD Programme on Global Economic Policy and Institutions, 2012. p. 200. 
ou, ainda, o fortalecimento do procedimento de notificação e consultas já previstas no GATT-1994.

No âmbito da OMC, na busca de disciplinas multilaterais mais robustas, que não deve se conseguir tão rapidamente, deve se pensar numa forma integrada: de um lado, alguns países desenvolvidos clamam por mais tarificação e menos restrições quantitativas às exportações; de outro lado, os PED citam o problema da escalada tarifária como uma das origens do problema das restrições às exportações, uma vez que alguns países têm dificuldades de inserir produtos de maior valor agregado em terceiros mercados e, com isto, restringem ou taxam suas exportações de matérias-primas ${ }^{58}$.

Assim, há um ponto de partida em comum, que poderia tornar o debate sobre controle às exportações dentro de uma abordagem mais ampla sobre recursos naturais, que permitiria uma discussão mais profunda sobre os efeitos e relações entre várias políticas comerciais, tais como escalada tarifária, subsídios distorcivos e medidas não tarifárias, "abrindo às portas" para a troca de informação, o desenvolvimento de linhas de ações cooperativas, a sugestão de notas interpretativas sobre as normas da OMC, entre outros aspectos. Esses autores citam, por exemplo, a possibilidade de retomadas dos trabalhos realizados pelo "Grupo de Negociações de Produtos baseados em Recursos Naturais", que atuou fortemente ao longo da Rodada Uruguai ${ }^{59}$.

Alguns estudiosos também advogam a possibilidade de se utilizar um mecanismo de dumping reverso para combater os efeitos dos controles às exportações ${ }^{60}$. Também há defensores de que os controles às exportações possam ser abordados dentro do Acordo de Subsídios ${ }^{61}$, algo refutado pelos PED. Finalmente,

58 Cite-se, por exemplo, o Grupo de Cairns, que contempla um grupo de países com interesse específico nas negociações agrícolas.

59 BELLMANN, Cristophe; WILKE, Marie. Trade policies for resource security: rethinking export restrictions. In: ICTSD. The future and the WTO: confronting the challenges: a collection of short essays. Geneva, Switzerland: ICTSD Programme on Global Economic Policy and Institutions, 2012. p. 203.

60 O dumping reverso é uma ideia não testada, tratando os controles às exportações como um subsídio ilegal, algo que desperta novas questões conceituais. Contudo, não existe qualquer orientação sobre o assunto na jurisprudência do GATT. Para aprofundamento, vide Vide LIM, C. L.; SENDUK, J. H. You don't miss your water til your river runs dry: regulating industrial supply shortages after China-raw materials. Stanford Journal of Law, Business, and Finance, v. 18, n. 1, 23 apr. 2013.; University of Hong Kong Faculty of Law Research Paper, n. 2013/016. p. 113.

61 Ainda que haja decisão no Painel do caso Estados Unidos- para outros analistas, é possível que, enquanto não se construam consensos amplos dentro da OMC, uma forma de se avançar seria a adoção dos acordos plurilaterais, algo que, por exemplo, poderia se aplicar para um tratamento das restrições às exportações entre os países que assim desejem fazer ${ }^{62}$.

Comenta-se, também, sobre a possibilidade de que a China, diante dos desdobramentos verificados nos casos CMP e CTR, assuma, de fato, o papel de grande player dentro do processo de produção de normas na OMC e inicie um movimento, coordenado inicialmente com os demais Membros que ingressaram recentemente na Organização, para reformar o regime de impostos de exportações no quadro dos Acordos da Organização, com um reforço à "tarificação das restrições quantitativas às exportações" ${ }^{63}$.

Restrições às Exportações (DS 194), por exemplo, que manifeste que os controles às exportações não podem se configurar como subsídios, há posições na doutrina que não entendem da mesma forma e defendem que o Acordo de Subsídios possa combater estes comportamentos que afetam a competitividade de empresas estrangeiras. Vide LIM, C. L.; SENDUK, J. H. You don't miss your water til your river runs dry: regulating industrial supply shortages after China-raw materials. Stanford Journal of Law, Business, and Finance, v. 18, n. 1, 23 apr. 2013.; University of Hong Kong Faculty of Law Research Paper, n. 2013/016. p. 114.

62 Há possibilidade de um enfrentamento à questão do single undertaking. Este princípio teria tomado uma feição de obrigação legal e estaria "cegando" os países quanto às possibilidades dos acordos plurilaterais, como saída possível para o desenvolvimento mais rápido da OMC. Contudo, para alguns países, os acordos plurilaterais representariam riscos para a construção de um SMC pleno. MENDOZA, Miguel Rodriguez. Toward plurilateral "plus" agreements. In: BELLMAN, Christophe et al. The future and the WTO: confronting the challenges. Geneva: ICTSD, 2012.

63 Julia Ya Qin propõe que o uso dos impostos de exportação seja tratado da mesma forma que os impostos de importação (ou seja, obrigatoriedade do uso dos impostos de exportação, com a aplicação dos mesmos princípios e regras que se aplicam aos impostos de importação), algo que aumentaria a transparência e a segurança nas relações comerciais, afastando, também, as indesejadas restrições quantitativas. Assim, uma disciplina efetiva sobre impostos de exportação poderia beneficiar PEDs e países desenvolvidos de forma similar, tratando o problema "de frente". A solução não seria eliminar os impostos de exportação (como se propôs para alguns membros em seus Protocolos de Acessão), mas sim fortalecer o conhecimento sobre o seu uso legítimo. Outro ponto importante seria fazer com que os compromissos assumidos pelos países que acederam à OMC fossem incorporados ao GATT, com a criação de uma Parte $\mathrm{V}$, que tratasse especificamente do cronograma de concessões de cada país, como se procedeu na acessão da Rússia, especificamente, criando uma uniformidade de tratamento para todos os membros, e não categorias de países. Vide QIN, Julia Ya. Reforming WTO discipline on export duties: sovereignty over natural resources, economic development and environmental protection. Wayne State University Law School Research Paper, n. 2012-04, p. 29-35. 28 mar. 2012. 
Em suma, o desafio permanecerá nos próximos anos como agenda aberta dentro da OMC. Soluções políticas são altamente desejáveis, inclusive criando o quadro favorável para soluções jurídicas, baseadas em novas normas para tratar de assunto tão crítico para as economias mundiais. Entendemos que os casos na OMC geraram uma massa crítica instigante para reflexão, e, inclusive, de novas frentes de investigação, não se esgotando aqui.

Indo adiante, as decisões do OSC revelaram a relativização do policy space dos Membros diante das obrigações assumidas na OMC: uma vez extraídos, os recursos devem estar disponíveis aos demais Membros. Essa leitura nos indica que, aos países detentores de reservas expressivas de minerais importantes para a indústria de transformação, entre eles o Brasil, os casos da China na OMC revelam condicionalidades para a definição de um plano de ação estratégico e, num segundo momento, para a implementação de políticas públicas que possam ser tomadas ${ }^{64}$. Hoje, aliás, a dimensão internacional não deve ignorada na definição de implementação de qualquer política pública.

O nosso país seguramente pode vir a ocupar posição de destaque, tendo em vista que estimativas da Agência Serviços Geológico Norte-Americano (USGS, sigla em inglês) apontam que as reservas brasileiras podem chegar a 3,5 bilhões de toneladas de terras raras. Isso alçaria o país ao primeiro posto entre os detentores de reservas $^{65}$.

Em termos de movimentação do setor público brasileiro para o assunto, houve um marco importante quando da divulgação do Plano Nacional de Mineração 2030 (PNM-2030), em maio de 2011, que propôs uma série de medidas para alavancar o setor mineral brasileiro $^{66}$. $\mathrm{Na}$ contextualização de desafios, em

64 Nos contenciosos examinados, fortaleceu-se a tese jurídica de que a soberania permanece, mas a liberdade para o exercício das políticas públicas em áreas que afetem os compromissos e obrigações sob o SMC foi definitivamente afetada.

65 INSTITUTO DE PESQUISAS TECNOLÓGICAS (IPT). Terras Raras. Seção Imprensa, IPT na Mídia, 15 jul. 2011.

66 O documento cita alguns objetivos estratégicos e ações, tais como assegurar a governança pública eficaz do setor mineral; garantir a ampliação do conhecimento geológico do território nacional; estabelecer diretrizes para materiais estratégicos; ampliar o conteúdo de pesquisa, desenvolvimento e investimento nas atividades de geologia, mineração e transformação mineral; promover a produção sustentável do setor mineral; e estimular a agregação de valor na cadeia produtiva de bens minerais com competitividade, entre outros aspectos. Vide BRASIL, Ministério de Minas e Energia. Plano Nacional de Mineração 2030 (PNM-2030). Brasília: MME, 2010. p. 121-132. relação aos minerais estratégicos, este documento oficial chamou a atenção para três aspectos principais: a) a dependência brasileira por importações de minerais, para suprimento de setores vitais de sua economia ${ }^{67}$, com possibilidades de impactos fortes na balança comercial; b) em contrapartida, a existência de minerais em que o país produz e exporta com destaque (minério de ferro e nióbio, por exemplo), apresentando vantagens comparativas naturais; e c) o crescimento da importância de minerais aplicados em produtos de alta tecnologia, entre eles as terras-raras. Em especial, em relação às terras-raras, o mesmo documento destacava que a estratégia preconizada iria muito além da descoberta e produção destes minerais no país, mas sim na necessidade da adoção de programas específicos coordenados entre governo e setor privado para o desenvolvimento de processos e produtos em cadeias produtivas de alto valor agregado, eventualmente atuando em determinados nichos, em um ambiente de intensa competitividade internacional ${ }^{68}$.

Entre as ações estratégicas estabelecidas no PNM2030, ficou definido que o Serviço Geológico do Brasil (CPRM), vinculado ao Ministério de Minas Energia (MME) iniciaria a realização de levantamento geológico de áreas potenciais para minerais estratégicos "carentes" e "portadores do futuro". Assim, iniciou-se, naquele mesmo ano de publicação do PNM-2030, o projeto denominado de Avaliação do Potencial dos Minerais Estratégicos do Brasil, que busca identificar novas áreas em todo o território brasileiro onde pode haver ocorrência de terras-raras, com previsão de conclusão em $2014^{69}$.

Por outro lado, no ensejo da apreciação da proposta do Novo Código de Mineração (Projeto Legislativo $n^{\circ} 5807 / 2013$, em tramitação no Congresso Nacional, algumas propostas feitas pela frente de trabalho do Centro de Estudos e Debates Estratégicos da Câmara dos Deputados (CEDE), que passou a se envolver de forma regular com o tema, para inserção de itens julgados importantes para o desenvolvimento da

67 Por exemplo, a produtividade do setor agrícola está condicionada à produção de fertilizantes, que, por sua vez, têm entre seus insumos alguns minerais importados pelo Brasil, como o potássio, o nitrogênio e o fósforo, em que o índice de dependência do exterior varia entre $50 \%$ e $90 \%$. Vide BRASIL. Ministério de Minas e Energia. Plano Nacional de Mineração 2030 (PNM-2030). Brasília: MME, 2010. p. 64.

68 BRASIL. Ministério de Minas e Energia. Plano Nacional de Mineração 2030 (PNM-2030). Brasília: MME, 2010. p. 121-132; p. 63-65.

69 SIMÕES, Janaína. Brasil tem uma das maiores reservas de terras raras do planeta. Inova Unicamp, 24 maio 2011. 
produção de minerais estratégicos e terras-raras no Brasil serão levadas para debate parlamentar.

A partir de um comparativo entre os marcos regulatórios no setor elétrico, petrolífero e mineral, é possível demonstrar que este último estaria um passo atrás dos demais, em termos de estruturação, coordenação, investimentos, pesquisa e desenvolvimento, algo que seria incompatível com as possibilidades reais oferecidas pelo setor para a economia brasileira. Diante disso, algumas propostas foram apontadas para permitir avanços do setor mineral, e que não estariam contempladas no PL em tramitação, tais como a assinatura de contratos de concessão com cláusulas de investimento em pesquisa e desenvolvimento; o estabelecimento de parcelas das receitas das minas de extração de alta rentabilidade com destinação aos programas de pesquisa e desenvolvimento, ou, alternativamente, a destinação de recursos dos setores elétrico e petrolífero para o setor mineral; e, também, a criação de um novo modelo institucional ${ }^{70}$.

Entendemos que a integração às cadeias produtivas mundiais pode se tornar o melhor caminho, ao invés da tomada de medidas de natureza protecionista. Quanto à possibilidade de exploração da cadeia produtiva de terras-raras ${ }^{71}$, ainda ressentimos de uma política pública

70 LIMA, Paulo César Ribeiro. Terras-raras: elementos estratégicos para o Brasil. Brasília: Câmara dos Deputados Consultoria Legislativa, 2012.

71 A integração da cadeia produtiva de terras-raras consiste, via clara nesse sentido, ainda que reconheça importantes iniciativas sendo conduzidas pelo território brasileiro ${ }^{72}$ : o passo adiante seria representando não apenas pela produção de mais uma mercadoria mineral para exportação, mas sim pela inclusão de atividades de pesquisa e desenvolvimento e de processamento das terras-raras, com o objetivo de constituir uma indústria de alta tecnologia e de alto valor agregado no Brasil, a exemplo do que ocorreu na China; ou, indo além, na integração desta indústria com área que fornecem insumos ou produzem materiais compostos, ou áreas que possivelmente produzirão nos próximos anos, em esquemas de consórcios e joint ventures ${ }^{73}$.

de regra, nos encadeamentos dos seguintes processos: mineração, trituração, moagem, concentração, separação, refino de óxidos, refino para metais, combinação em ligas e fabricação de peças e dispositivos (aplicação efetiva). Assim, quanto mais se anda na cadeia, mais se agrega valor.

72 Lima (p. 38-50) detalha projetos sendo desenvolvidos em Araxá e Patrocínio, em Minas Gerais, e em Pitinga, no Amazonas. Vide LIMA, Paulo César Ribeiro. Terras-raras: elementos estratégicos para o Brasil. Brasília: Câmara dos Deputados - Consultoria Legislativa, 2012.

73 O Departamento de Energia dos Estados Unidos destacava em 2010 algumas áreas que podem iniciar a produção nos próximos anos: Mount Weld (Austrália); Mountain Pass (Estados Unidos); Nolans Bore (Austrália); Nechalacor (Canadá); Domng Pao (Vietnã); Hoidas Lake (Canadá); e Dubbo Zirconia (Austrália). Vide LIMA, Paulo César Ribeiro. Terras-raras: elementos estratégicos para o Brasil. Brasília: Câmara dos Deputados - Consultoria Legislativa, 2012. p. 19 


\section{Referências}

BARONCINI, Elisa. Uma relação impossível? O artigo XX do GATT e o Protocolo de Acessão da China no caso das matérias-primas. Pontes Quinzenal, v. 8, n. 7, nov. 2012.

BELLMANN, Cristophe; WILKE, Marie. Trade policies for resource security: rethinking export restrictions. In: ICTSD. The future and the WTO: confronting the challenges: a collection of short essays. Geneva, Switzerland: ICTSD Programme on Global Economic Policy and Institutions, 2012. Disponível em: <www.ictsd.org>.

BRASIL. Ministério de Minas e Energia. Plano Nacional de Mineração 2030 (PNM-2030). Brasília: MME, 2010.

BRONCKERS, Marco; MASKUS, Keith E. China raw materials: a controversial step towards evenhanded exploitation of natural resources. 27 aug. 2013. Available at SSRN: $<$ http://ssrn.com/abstract $=2321018>$. or $<$ http://dx.doi.org/10.2139/ssrn.2321018>.

CHARNOVITZ, Steve. Mapping the law of WTO accession. The George Washington University Law School. Public Law and Legal Theory Working Paper; Legal Studies Research Paper, n. 237, nov. 2006.

COMPANHIA DE PESQUISA DE RECURSOS MINERAIS (CPRM). CPRM pesquisa áreas potenciais para minerais denominados "terras raras". Seção Notícias, 18 ago. 2011.

COXHEAD, Ian; JAYASURIYA, Sisira. China, India and the commodity boom: economic and environmental implications for low-income countries. The World Economy, 2010. Doi: 10.1111/j.1467-9701.2009.01232.

Documentos da OMC (disponível na base de documentos no site da OMC: <https://docs.wto.org/ dol2fe/Pages/FE_Search/FE_S_S001.aspx>.):

Documentos do GATT (disponível na base de documentos do GATT no site da OMC: <http://www. wto.org/english/docs_e/gattdocs_e.htm>.):

FEIS, Herbert. Raw materials and foreign policy. Foreign Affairs, v. 16, n. 4, p. 574-586, July 1938.

GATT/MTN.GNG/NG3/1. Uruguay Round. Group of Negotiations on Goods. Negotiating Group on Natural Resource-Based Products. Meeting of 11 February 1987. Note by the Secretariat, 26 feb. 1987.
GATT/MTN.GNG/NG3/2. Uruguay Round. Group of Negotiations on Goods. Negotiating Group on Natural Resource-Based Products. Meeting of 29 April 1987. Note by the Secretariat, 26 feb. 1987.

GATT/MTN.GNG/NG3/W/10. Uruguay Round. Group of Negotiations on Goods. Negotiating Group on Natural Resource-Based Products. Communication from Senegal, Cameroon, Cote D'Ivoire and Zaire, 2 feb. 1988.

GATT/MTN.GNG/NG3/W/11. Uruguay Round. Group of Negotiations on Goods. Negotiating Group on Natural Resource-Based Products. Communication from The European Communities, 12 feb. 1988.

GATT/MTN.GNG/NG3/W/37. Uruguay Round. Group of Negotiations on Goods. Negotiating Group on Natural Resource-Based Products. Submission by The European Communities. 25 june 1990.

GATT/MTN.GNG/NG3/W/8/Rev.1. Uruguay Round. Group of Negotiations on Goods. Summary of Statements and Proposals made concerning negotiations on natural resourcebased products. Note by the Secretariat, 14 jan.1988.

GATT/MTN/FR/W/20. Multilateral trade negotiations: group "Framework". Note by the Acting Chairman of Group, 11 dec. 1978.

GENERAL AGREEMENT ON TARIFFS AND TRADE. The use of quantitative restrictions for protective and other commercial purposes. Geneva: General Agreement on Tariffs and Trade, 1950.

INSTITUTO DE PESQUISAS TECNOLÓGICAS (IPT). Terras raras. IPT na Mídia, Seção Imprensa, 15 jul. 2011.

ISTEL, Andre. Equal access to raw materials. Foreign Affairs, v. 20, n. 3, p. 450-465, apr. 1942.

JACKSON, John Howard. The world trading system: law and policy of international economic relations. 2. ed. Cambridge: MIT Press, 1997.

JEBE, Ruth; LEE, Yong-Shik; MAYER, Don. China's export restrictions of raw materials and rare earths: a new balance between free trade and environmental protection. The George Washington International Law Review, v. 44, p. 580-642, 2012. 
KIM, J. Recent trends in export restrictions on raw materials In: OECD. The economic impact of export restrictions on raw materials. OECD Publishing, 2010. Doi: 10.1787/9789264096448-4-en.

KIM, Jeonghoi; KORINEK, Jane. Export restrictions on strategic raw materials and their impact on trade and global supply. OECD, Trade Policy Paper n. 95, 2010.

LAMY, Pascal. Recommitting to commodity sector development as an engine of economic growth and poverty reduction. Geneva, Switzerland: UNCTAD, Global Commodities Forum, 2013.

LATINA, Joelle; PIERMARTINI, Roberta; RUTA, Michele. Natural resources and non-cooperative trade policy. World Trade Organization Economic Research and Statistics Division Staff Working Paper, n. ERSD-2011-06, 1 mar. 2011.

LAUSTER, Gitta; ANNIKA, Mildner Stormy. Settling trade disputes over natural resources: limitations of international trade law to tackle export restrictions. Goetttingen Journal of International Law, v. 3, n. 1, p. 251-281, 2011.

LIM, C. L.; SENDUK, J. H. You don't miss your water til your river runs dry: regulating industrial supply shortages after China-raw materials. Stanford Journal of Law, Business, and Finance, v. 18, n. 1, 3 apr. 2013; University of Hong Kong Faculty of Law Research Paper, n. 2013/016.

LIMA, Paulo César Ribeiro. Terras-raras: elementos estratégicos para o Brasil. Brasília: Câmara dos Deputados - Consultoria Legislativa, 2012. Disponível em:<http://www2.camara.leg.br/a-camara/ altosestudos/temas/temas-2013-2014/terras-raras/Est udoMineraisEstratgicoseTerrasRaras.pdf $>$.

LIU, Han-Wei; MAUGHAN, John J. China's rare earths export quotas: out of the China-raw materials gate, but past the WTO's finish line? Journal of International Economic Law, v. 15, n. 4, 21 nov. 2012.

MENDOZA, Miguel Rodriguez. Toward plurilateral "plus" agreements. In: BELLMAN, Christophe et al. The future and the WTO: confronting the challenges. Geneva: ICTSD, 2012.
OCDE. The economic impact of export restrictions on raw materials. OECD Publishing, 2010. Available at: <http://dx.doi.org/10.1787/9789264096448-en>.

ORGANIZAÇÃO MUNDIAL DO COMÉRCIO. Órgão de Revisão de Políticas Comerciais. Las restricciones comerciales van em aumento. Disponível em: $<$ http://www.wto.org/spanish/news_s/sppl_s/ sppl196_s.htm>. Acesso em: 30 jan. 2012.

ORGANIZAÇÃO MUNDIAL DO COMÉRCIO. Órgão de Revisão de Políticas Comerciais. China: measures related to the exportation of various raw materials. Reports of the Panel. WT/DS394/R, WT/DS395/R and WT/DS398/R, 5 july 2011.

ORGANIZAÇÃO MUNDIAL DO COMÉRCIO. WT/ACC/CHN/49. Report of the working party on the accession of China. 1 oct. 2001.

ORGANIZAÇÃO MUNDIAL DO COMÉRCIO. WT/L/432. Protocol of accession of the People's Republic of China. 23 nov. 2001.

ORGANIZAÇÃO MUNDIAL DO COMÉRCIO. WT/TPR/S/230/Rev.1. Trade policy review. Report of Secretariat: China. 5 july 2010.

ORGANIZAÇÃO PARA COOPERAÇÃO E DESENVOLVIMENTO ECONÔMICO (OCDE). Analysis of non-tariff measures: the case of export restrictions. 2003. (Ref. TD/TC/WP(2003)7/FINAL).

ORGANIZAÇÃO PARA COOPERAÇÃO E DESENVOLVIMENTO ECONÔMICO (OCDE). Working party of the trade committee: analysis of non-tariff measures: the case of export duties. 2002. (Ref. TD/ TC/WP(2002)54/FINAL).

PERREZ, Franz Xavier. The relationship between permanent sovereignty and the obligation not to cause transboundary environmental damage. Environmental Law, n. 26, p. 1190-1211, 1996.

QIN, Julia Ya. Reforming WTO discipline on export duties: sovereignty over natural resources, economic development and environmental protection. Wayne State University Law School Research Paper, n. 2012-04, 28 mar. 2012. 
RODRIGUES JÚNIOR, Edson Beas. O princípio do desenvolvimento sustentável como princípio geral do direito: origem histórica e conteúdo normativo. Revista dos Tribunais, ano 103, v. 940, fev. 2014.

ROLLAND, Sonia Elise. China-raw materials: WTO rules on chinese natural resources export dispute. ASIL Insights, v. 16, n. 21, 19 june 2012; Northeastern University School of Law Research Paper, n. 96-2012. Available at SSRN: <http://ssrn.com/abstract=2095078>.
SIMÕES, Janaína. Brasil tem uma das maiores reservas de terras raras do planeta. Inova Unicamp, 24 maio 2011.

VARELLA, Marcelo Dias. Direito internacional econômico ambiental. Belo Horizonte: Del Rey, 2004.

VINER, Jacob. National monopolies of raw materials. Foreign Affairs, v. 4, n. 4, p. 585-600, july 1926. 


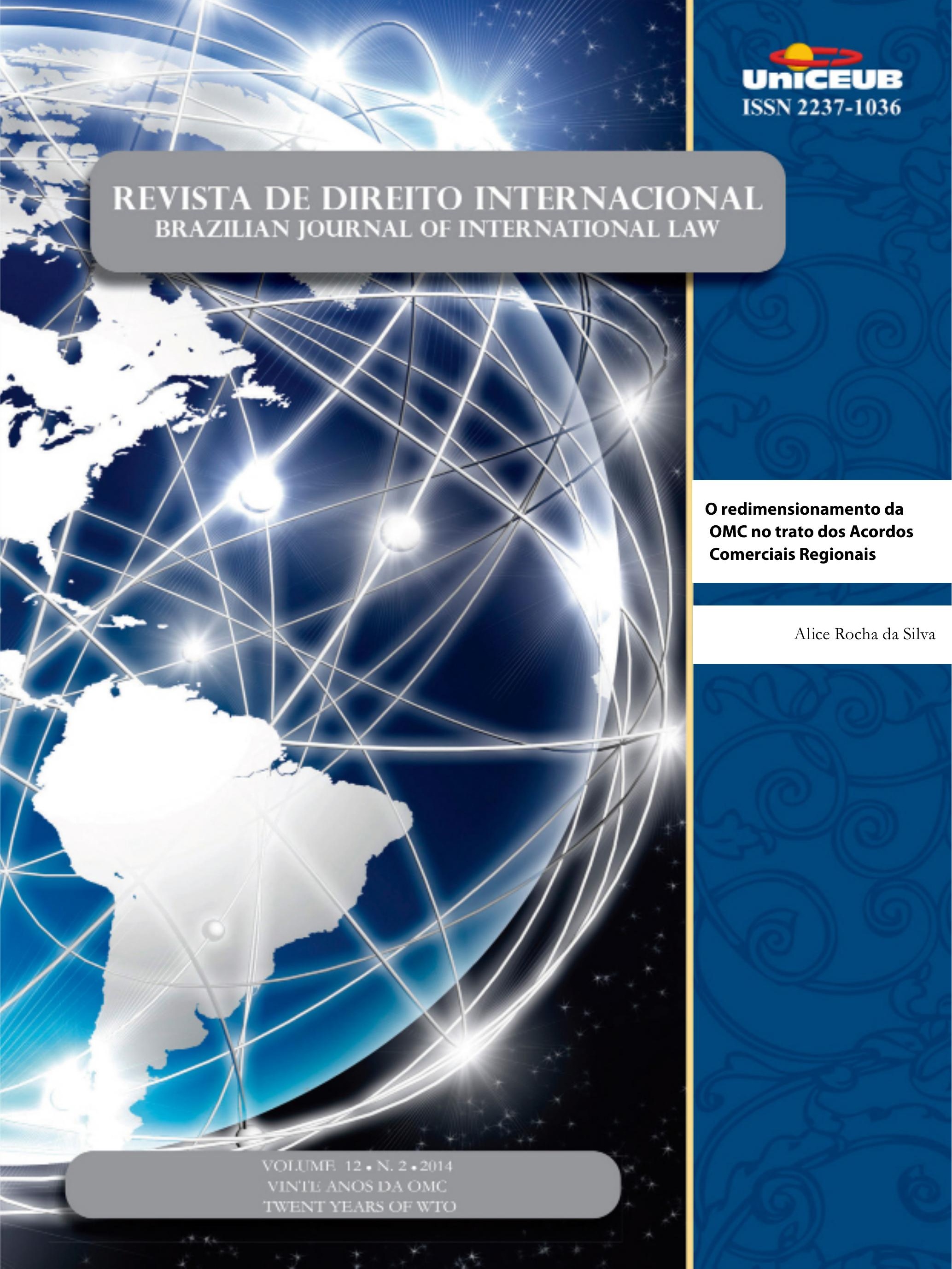




\title{
O redimensionamento da OMC no trato dos Acordos Comerciais Regionais*
}

\section{Redimensioning the WTO in Regional Trade Agreements}

\author{
Alice Rocha da Silva**
}

\section{Resumo}

A complexa articulação entre os acordos comerciais regionais e o direito da OMC pode ser facilitada a partir de instrumentos jurídicos presentes na teoria do Direito Internacional Público. A prática corrente demonstra a possibilidade de sucesso na utilização dessas ferramentas. No entanto, mesmo que tal utilização se revele fraca ou ineficaz, este trabalho visa proporcionar pistas de reflexão para a solução da interação entre regionalismo e multilateralismo. A ação em duas frentes (normativa e jurisdicional) parece permitir uma análise do conjunto que pode resultar em uma melhor interação entre eles. Nesse sentido, começamos nosso trabalho, analisando o fortalecimento do regionalismo comercial e, em seguida, verificaremos os efeitos desse fenômeno sobre o multilateralismo da OMC. A partir da análise proposta, podemos constatar que atualmente os acordos comerciais regionais constituem um elemento essencial na vida comercial dos Estados em todo o mundo e continuarão a coexistir com o sistema da OMC. Assim, a melhor solução seria a de aceitá-los não como um obstáculo aos objetivos da OMC, mas como uma alternativa dada aos Estados para fortalecer ainda mais a liberalização do comércio e encontrar a melhor maneira de articular as relações entre eles no contexto internacional.

Palavras-chave: Articulação. Acordos comerciais regionais. Direito da OMC.

\section{Abstract}

The complex articulation between regional trade agreements and WTO law can be facilitated from legal instruments present in the theory of public international law. The practice demonstrates the possibility of success in using these tools. However, even if such use proves weak or ineffective, this study aims to provide food for thought for the solution of the interaction between regionalism and multilateralism. The action on two fronts (normative and jurisdictional) seems to permit an analysis of the joint which can result in better interaction between them. In this sense, we start our work by analyzing the strengthening of trade regionalism and then see the effects of this phenomenon on the multilateralism of the WTO. From the proposed analysis, we note that currently the regional trade agreements are a key element in the commercial life of states around the world and will continue to coexist with the WTO system. Thus, the best solution would be to not accept them as an obstacle to the objectives of the WTO, but as an alternative given to states to further strengthen trade liberalization and find the best way to articulate the relationship between them in the international context.

Keywords: Articulation. Regional trade agreements. WTO law.

\footnotetext{
* Recebido em: 10.12 .2014

Aceito em: 15.12.2014

** Professora do Programa de Mestrado e Doutorado em Direito do Centro Universitário de Brasília (UniCEUB) e da graduação da Faculdade Processus. Doutora em Direito Internacional Econômico pela Aix-Marseille Université, França. Mestre em Direito das Relações Internacionais pelo UniCEUB. Graduada em Direito pelo UniCEUB e Graduada em Relações Internacionais e Ciência Política pela Universidade de Brasília-UnB. Email: rochaalice@ yahoo.com.br.
} 


\section{Introdução}

Partindo da premissa de que o direito da OMC autoriza e limita a formação de acordos comerciais regionais (ACR), constata-se que, apesar dessas limitações, nas últimas duas décadas, o sistema jurídico internacional tem conhecido uma verdadeira proliferação de ACR. Relações cada vez mais complexas entre regionalismo e multilateralismo são então estabelecidas, sendo necessário o desenvolvimento de instrumentos jurídicos que contribuam para a compreensão da articulação entre os ACR e o direito da OMC.

O direito da OMC oferece aos seus Membros a possibilidade de celebrar ACR, ou seja, permite a formação de tais acordos, desde que preencham os critérios determinados em seus dispositivos legais. Esses critérios são utilizados para limitar os efeitos de desvio de comércio que podem ser causados pela formação de acordos regionais. Vale ressaltar que, desde o início, “[...] o verdadeiro objetivo do GATT era de controlar e limitar a discriminação, não de eliminá-la."1

Nesse sentido, a formação de ACR, entre os Membros da OMC, é possível, mas limitada pelos critérios e procedimentos projetados especificamente para essa finalidade. Esses critérios estão previstos essencialmente no artigo XXIV do GATT, mas também no artigo V do Acordo Geral sobre Comércio de Serviços (GATS do inglês General Agreement on Trade in Services) para tratar os ACR que afetam o comércio de serviços e na Cláusula de Habilitação ${ }^{2}$ para os ACR compostos por países em desenvolvimento, que têm direito a um tratamento diferenciado e mais favorável.

No entanto, as limitações impostas pela OMC para a formação desses ACR não são efetivas e as tentativas de análise de compatibilidade dos ACR com esses critérios foram abandonados pelo Comitê de Acordos Comerciais Regionais (CRTA do inglês Committee on Regional Trade Agreements) que preferiram adotar uma estratégia que favorece uma maior transparência sobre tais acordos ${ }^{3}$. Além disso, se a compatibilidade dos ACR

1 HUDEC, R. E. The Gatt legal system and world trade diplomacy. Salem: Butterworth Legal Publishers, 1990.

2 GATT, Traitement Difference et Plus Favorable Reciprocite et Participation Plus Complete des Pays en Voie de Developpement: Décision du 28 novembre 1979 (Clause d'habilitation), L/4903, 03 décembre 1979.

3 OMC. Mécanisme pour la transparence des accords pudesse eventualmente ser examinada pela Orgão de Solução de Controvércias (OSC) da $\mathrm{OMC}^{4}$, na prática, esse exame seria improvável de acontecer e os Estados temeriam que essas práticas discriminatórias no contexto dos ACR fossem colocadas em questão pelos demais Membros da OMC. Assim, as dificuldades na aplicação desses limites impostos pela OMC, associadas às constantes dificuldades de negociações no campo multilateral, levaram os Estados a tomarem um atalho utilizando a via regional para a defesa de seus interesses.

Nesse sentido, percebe-se que a capacidade operacional da OMC em controlar tais acordos é questionada não só pelas relações de poder e assimetria que sempre existiram, mas também pelas novas dimensões de governança internacional, com redes de regulação e coordenação entre políticas públicas nacionais e globais. A proliferação dos ACR significa a multiplicação desses espaços regulatórios que muitas vezes vão além dos temas tratados pela $\mathrm{OMC}$, podendo ser uma perspectiva de oportunidade para novos negócios, mas também de conflito aos interesses do sistema multilateral. Sendo assim, podemos propor uma avaliação do papel da OMC para a governança internacionals dessas interelações que se formam entre o regionalismo e o multilateralismo, apontando instrumentos jurídicos de articulação entre ambos.

\section{Estabelecimento de precisões conceituais}

Primeiramente, temos de apresentar algumas definições utilizadas na presente análise. Este estudo define o "direito da OMC", como sendo, de um lado, o conjunto de regras contidas no Acordo constitutivo da OMC e seus anexos 1, 2 e 3, que são obrigatórios para todos os Membros da organização, assim como o anexo 4 (acordos comerciais plurilaterais), obrigatórios unicamente para os Membros que os ratificaram. O Acordo Geral sobre Tarifas Aduaneiras e Comércio de 1994, conforme especificado no Anexo 1A (GATT 1994), é um acordo legalmente separado do Acordo Geral sobre Tarifas e Comércio de 1947 (GATT 1947), que também deve

commerciaux régionaux. Décision du 14 décembre 2006, WT/L/671, 18 décembre 2006.

4 A competência do OSC para aplicar os dispositivos ligados ao regionalismo foi estabelecida pelo artigo 3 do Memorando do acordo para solução de controvérsias (MASC) e pelo parágrafo 12 do Memorando do acordo sobre o artigo XXIV, que enuncia que os dispositivos de solução de controvérsias são susceptíveis de serem utilizados na contestação de questões ligadas a aplicação das regras da OMC relativas ao tratamento do regionalismo. 
ser considerado como parte deste conjunto de regras chamadas "direito da OMC". O "direito da OMC" deve, contudo, ser distinguidos dos "acordos abrangidos", tendo em vista o fato de que estes restringem o campo de aplicação do Memorando do acordo para solução de controvérsias (MASC).

Da mesma forma, no contexto desta análise, os ACR devem ser entendidos como acordos internacionais celebrados por escrito entre sujeitos de direito internacional e destinados a produzir efeitos jurídicos no direito internacional. Ou seja, os ACR se incluem na categoria de tratados regidos pela Convenção de Viena sobre o Direito dos Tratados de 1969, que prevê no seu art. 2 par. 1 que "tratado" significa um "acordo internacional concluído por escrito entre Estados e regido pelo Direito Internacional, quer conste de um instrumento único, quer de dois ou mais instrumentos conexos, qualquer que seja sua denominação específica.".

No entanto, esses acordos internacionais possuem duas particularidades. Por um lado, são acordos comerciais, sendo concluídos no contexto das trocas comerciais entre os Estados, no domínio de bens, serviços e propriedade intelectual. A essa particularidade material deve ser acrescida sua especificidade especial: esses acordos se diferenciam dos acordos comerciais estabelecidos no âmbito da OMC pelo seu caráter regional, visto que ligam dois (maioria dos ACR) ou apenas alguns Estados.

Esse caráter regional, no sentido estrito do termo, tornou-se insuficiente para definir os ACR. De fato, muitos ACR foram concluídos entre Estados de uma mesma região ou continente, mas a participação de membros que não são vizinhos imediatos aumentou consideravelmente. Os ACR "transatlânticos" e "transpacíficos" estão se tornando cada vez mais frequentes, como por exemplo os acordos de livre comércio entre a Associação Europeia de Livre Comércio (EFTA) - Chile e o acordo Coreia-EUA. ${ }^{8}$

5 Os "acordos abrangidos" estão enumerados no Apêndice 1 do Memorando do acordo para solução de controvérsias.

6 "The rules and procedures of this Understanding shall apply to disputes brought pursuant to the consultation and dispute settlement provisions of the agreements listed in Appendix 1 to this Understanding (referred to in this Understanding as the "covered agreements")."

7 Convention de Vienne sur le droit des traités, faite à Vienne, 23 mai 1969, 1155 R.T.N.U. 331, 8 International Legal Materials 679.

8 "Traditionally, RTA formation occurred between so-called "natural" trading partners, geographically contiguous countries with already well-established trading patterns. [...] Indeed, most countries
Embora a expressão "acordo comercial regional" não seja a mais adequada para o tratamento de diversos acordos que não estão limitados a Estados de uma mesma região, ela continua sendo utilizada no contexto dessa análise, e isso não só porque é a mais empregada pela OMC e pela doutrina, mas também porque, atualmente, não é possível examinar as questões entre bilateralismo e multilateralismo deixando de lado acordos que ultrapassam o quadro regional. De forma mais precisa, a caracterização destes acordos em ACR é justificada pelo fato de que eles mantêm a característica principal dos ACR, ou seja, o aspecto discriminatório em relação aos demais Membros da OMC: esses acordos consistem em exceções ao princípio da nação mais favorecida. Note-se também que esta análise se concentra apenas em acordos preferenciais recíprocos — regionais, bilaterais ou plurilaterais ${ }^{9}$ — uma vez que representam a maioria dos ACR, visto que quase 90 por cento da margem total de preferência correspondem a tarifas preferenciais aplicadas no contexto de acordos recíprocos. ${ }^{10}$

Deve ser ainda definida a noção de "jurisdição" ou de "mecanismo jurisdicional" que no contexto de nossa análise serão entendidos em sentido amplo, abrangendo tribunais permanentes, mas também os tribunais arbitrais ad hoc, previstos na maioria dos ACR. Além disso, esse conceito de jurisdição inclui também as soluções negociadas com a valorização dos aspectos políticos do caso.

sign their first RTA with one or several neighbouring or regional partners. [...] However, once a country has exhausted its strictly regional prospects, it may begin to look further afield for preferential partners." FIORENTINO, R. V.; VERDEJA, L.; TOQUEBOEUF, C. Discussion Paper n. 12: The changing landscape of regional trade agreements 2006 update. p. 12. Disponível em: <http://www.wto.org/english/res_e/ publications_e/disc_paper12_e.htm>. Acesso em: 10 dez. 2014.

9 Em resumo, a diferença entre os acordos bilaterais e plurilaterais está no número de participantes: os bilaterais comportam duas partes e os plurilaterais mais de dois. Entretanto, os acordos bilaterais podem ser constituídos por vários Estados organizados em grupos, como no caso dos ACR compostos por ACR preexistentes. Esta situação parece ser a nova tendência no regionalismo. Alguns exemplos de ACR com tais características concluídos ou em negociação são UE-MERCOSUR, UE-CCG, União Aduaneira da Africa Austral (SACU). GONCALVES, J. B. Livre-comércio ou comércio mais livre? alternativas ao multilateralismo. In: LUZ, M. (Coord). Comércio e negociacões internacionais para jornalistas. Centro Brasileiro de Relações Internacionais, 2009. p. 43-47.

10 Ver OMC. Rapport sur le commerce mondial 2011. L'OMC et les accords commerciaux préférentiels: de la coexistence à la cohérence. p. 72-85. Disponível em: <http://www.wto.org/french/res_f/ publications_f/wtr11_f.htm>. Acesso em: 27 nov. 2014. 
Essa definição flexível do conceito de jurisdição internacional é essencial, visto que, se a natureza jurisdicional do Orgão de Solução de Controvérsias da OMC pode ser questionada, o caráter jurisdicional dos mecanismos dos ACR seria ainda mais questionável. No entanto, mesmo considerando-se que os painéis da OMC seriam uma representação do Conselho Geral, que deve representar os Membros da $\mathrm{OMC}^{11}$ e não um verdadeiro órgão jurisdicional, é preciso considerar que o Órgão de Apelação comporta diversos elementos que o aproxima da noção de jurisdição internacional: composto por membros permanentes, fornece considerações de base jurídica e limitado às questões de direito incluídas no relatório do painel. No entanto, deve ser considerado que os relatórios dos painéis e do Órgão de Apelação não são vinculantes. A aquisição de sua força obrigatória está sujeita à aprovação do relatório pelo Órgão de Solução de Controvérsias. Se esta característica do sistema de solução de controvérsias da OMC pudesse ser um fator decisivo na rejeição da sua qualificação como jurisdição internacional, torna-se indispensável salientar que a aprovação do relatório se dá por consenso negativo. ${ }^{12}$ Logo, na prática, a possibilidade de não se adotar um relatório do Painel e do Órgão de Apelação é quase nula, e por esta razão é possível considerar que a adoção desses relatórios é quase automática. ${ }^{13}$

Estabelecidos tais conceitos operacionais, partiremos para a análise da evolução do regionalismo comercial em paralelo ao sistema multilateral da OMC.

\section{$3 \mathrm{O}$ fortalecimento do regionalismo comercial}

O fenômeno do regionalismo ganhou importância em todo o mundo, não só quantitativamente, mas também qualitativamente. Motivações políticas são subjacentes à formação desses acordos. Desde muito tempo, a redução tarifária ligada aos acordos preferenciais tem sido considerada a principal razão para sua formação. Chegou-se a pensar que, com as reduções oferecidas ao final da Rodada Uruguai, a tendência de participação em ACR seria enfraquecida, o que não

11 "The General Council shall convene as appropriate to discharge the responsibilities of the Dispute Settlement Body provided for in the Dispute Settlement Understanding. [...]" Acordo de Marrakech instituindo a OMC, art. IV: 3.

12 Art. 16 et 17:14 du MASC.

13 No mesmo sentido: ROMANO, C.P.R. The proliferation of international judicial bodies: the pieces of the puzzle. N.Y.U. Journal of International Law and Politics, v. 31, n. 4, p. 709-751, 1999. at. p. 719. ocorreu. Em vez disso, os ACR proliferaram-se de forma ainda mais vigorosa. Podemos, a esse respeito, verificar a complexidade das razões que levam os Estados a optarem por um ou outro sistema, regional ou multilateral. Afinal, devem ser considerados os elementos de ordem política e estratégica, que demonstram que os ACR vão muito além da mera liberalização tarifária. ${ }^{14}$

A formação dos ACR foi a estratégia utilizada pelos Estados Unidos para estabelecer boas relações com o Oriente Médio após os ataques terroristas de 11 de setembro de 2001. Esse país procurou associar, na formação de acordos preferenciais, interesses políticoestratégicos e comerciais, e torná-los uma forma de promover os interesses e parcerias estratégicas em todo o mundo. Quando o acordo entre os Estados Unidos e o Marrocos foi assinado, o representante do comércio norte-americano, Robert Zoellick declarou que: “[s]tep by step, the Administration is working to build bridges of free trade with economic and social reformers in the Middle East. Our plans offer trade and openness as vital tools for leaders striving to build more open, optimistic and tolerant Islamic societies." ${ }^{15}$

A quantidade de ACR aumentou e a taxa do comércio mundial, regido por esses acordos, é cada vez mais importante. No entanto, atualmente, os Estados estão mais interessados na expansão do comércio do que no número de acordos regionais em vigor. Nesse sentido, o que é importante na análise do regionalismo, não é apenas o número de ACR estabelecidos, mas também o volume de comércio que efetivamente acontece no contexto desses acordos.

Em relação ao volume de comércio representado pelos ACR, a OMC não controla esses dados e há uma certa divergência entre os dados fornecidos por diferentes fontes externas a OMC, tais como relatórios e pesquisas de outras organizações internacionais. Pascal Lamy, diretor-geral da OMC, declarou em 2006 que as estatísticas concluíram que tal volume representava um percentual superior a $50 \%$ do comércio mundial. ${ }^{16}$ Essa previsão também foi discutida

14 No mesmo sentido, VAN DEN BOSSCHE, P. The law and policy of the World Trade Organization: text, cases and materials. 2 ed. Cambridge: Cambridge University Press, 2008. p. 697.

15 United States. United States Trade Representative, Press Release, 15 June 2004. United States and Marocco sign historic free trade agreement. Disponível em: <www.ustr.gov> Acesso em: 03 out. 2014.

16 OMC, Nouvelles 2006, M. Lamy salue l'accord de l'OMC sur les accords commerciaux régionaux, ler juillet 2006. 
em estudo de 2003 da Organização para a Cooperação e Desenvolvimento Econômico (OCDE).${ }^{17}$ No entanto, esse percentual equivale ao volume de comércio movimentado pelos ACR em geral, o que não significa que são resultantes das regras preferenciais em relação às taxas estabelecidas na OMC. Além disso, deve ser considerado que muitas tarifas aplicadas em ACR já são consolidadas a zero na OMC. Isso significa que o comércio feito com base nessas taxas não cria preferências para parceiros regionais e, portanto, perde todo o caráter discriminatório em termos de comércio mundial. ${ }^{18} \mathrm{O}$ Banco Mundial também conduziu um estudo que estimou que, em 2004/2005, 30 a 35\% do comércio internacional foi efetivamente praticado no contexto dos ACR. Se for desconsiderado o comércio com base em tarifas consolidadas a zero no sistema da OMC, a percentagem de comércio realmente discriminatório cai para um valor de $21 \%$ do comércio mundial. ${ }^{19}$ Além disso, o relatório da OMC de 2011 confirma esses dados, fornecendo informações que mostram que a participação do comércio intra-ACR no comércio mundial passou de 18\% em 1990 para 35\% em $2008^{20}$. Os dados relacionados ao comércio de serviços intra-ACR também são limitados porque poucos Estados comunicam às organizações internacionais as estatísticas sobre esta categoria de comércio, e não há, no momento, uma base de dados detalhada e padronizada sobre este tema. ${ }^{2}$

17 ORGANISATION for economic co-operation and development. Regionalism and the Multilateral Trading System. Paris: OECD, 2003. p. 12.

18 Esta constatação é confirmada pelo relatório de 2011 da OMC:"si le nombre d'ACPr a augmenté, l'importance du commerce préférentiel n'a pas suivi. Cette évolution résulte d'une forte réduction des droits NPF au cours des deux dernières décennies, soit dans le cadre de négociations commerciales multilatérales soit sur une base unilatérale." OMC, Rapport sur le commerce mondial 2011. L'OMC et les accords commerciaux préférentiels : de la coexistence à la cohérence, p. 72. Disponível em: <http://www.wto.org/french/res_f/ publications_f/wtr11_f.htm>. Acesso em: 27 set. 2014.

19 WORLD Bank, Global economic prospects. Washingon: World Bank, 2005. p. 40-41.

20 OMC. Rapport sur le commerce mondial 2011. L'OMC et les accords commerciaux préférentiels: de la coexistence à la cobérence, p. 64. Disponível em: <http://www.wto.org/french/res_f/publications_f/wtr11_f. htm>. Acesso em: 27 set. 2014.

21 Para maiores informações sobre os dados relativos aos principais exportadores e importadores de serviços (UE e Estados Unidos) ver OMC. Rapport sur le commerce mondial 2011. L'OMC et les accords commerciaux préférentiels : de la coexistence à la cobérence. $\mathrm{p}$. 67-69. Disponível em: <http://www.wto.org/french/res_f/ publications_f/wtr11_f.htm>. Acesso em: 27 set. 2014.
Se nos apoiarmos nos dados da OMC, especialmente na notificação de novos ACR e adesões a ACR existentes, notaremos que até o dia 15 de junho de 2014, 585 ACR (separando as notificações relativas a bens e notificações relativas a serviços) foram notificados ao GATT / OMC. Destes, 391 ACR estão atualmente em vigor, 230 foram notificados nos termos do artigo XXIV do GATT, 37 sob a Cláusula de Habilitação e 124 nos termos do artigo $\mathrm{V}$ do GATS. ${ }^{22}$

Ora, mais de 90\% dos ACR notificados e em vigor consistem em zonas de livre comércio (ZLC) ou acordos de alcance parcial (o termo Inglês 'partial scope'), enquanto menos de $10 \%$ dos ACR notificados são representados por uniões aduaneiras (UA). Quanto aos ACR que ainda não tenham sido notificados ou que estão em fase de negociação ou de proposição, a preferência por ZLC e por acordos parciais é confirmada.

Comparando-se as notificações feitas no âmbito do GAT'T, com as notificações no âmbito da OMC, podese notar um aumento considerável das notificações na OMC em comparação com as realizadas no GATT. ${ }^{23}$ Esse aumento pode ser explicado pela entrada de novos Membros na OMC e pelo reforço da obrigação de notificação no caso do comércio de serviços. No entanto, a metodologia adotada pela OMC tem falhas e nem sempre produz dados que refletem a realidade.

A metodologia utilizada pela OMC não reflete o número real de ACR em vigor, visto que os ACR abrangendo serviços e bens são notificados de forma independente, mesmo que em alguns casos correspondam ao mesmo acordo. Além disso, a adesão de novos membros à ACR existentes é considerada como um novo acordo, prática que pode ser amplamente questionada. Por outro lado, a contabilidade do número "real" de ACR também pode ser questionada, uma vez que não há nenhuma maneira de verificar os dados de ACR que ainda não foram notificados ou que estão em etapas de implementação diferentes. Apesar dessas

22 BASE de données sur les ACR. Disponível em: $<$ http://rtais.wto.org/UI/publicsummarytable.aspx $>$. Acesso em: 02 nov. 2014.

23 A taxa anual de notificação nda OMC é de 20, enquanto no quadro do GATT era de somente 3. Em quase 50 anos de existência do GATT 1947, 124 notificações relativas a ACR foram recebidas, ao passo que, em 20 anos, a OMC já recebeu mais de 300 notificações incluindo comércio de bens e serviços. Ver GHÉRARI, H. Le bilatéralisme conquérant ou le nouveau visage du commerce international. $R G D I P$, n. 2, p. 255-293, 2008. 
limitações, a metodologia adotada pela OMC ainda é considerada a mais adequada para demonstrar um fenômeno sem precedentes: a proliferação de acordos comerciais regionais.

Atualmente, apenas alguns dos 160 membros da OMC não fazem parte de um ACR: Mongólia, Djibouti, Mauritânia, Sudão do Sul, Somália e República Democrática do Congo. Os dados apresentados pelo Comitê de Acordos Regionais (CRTA) em 2000 mostram que, em média, cada um dos Membros do sistema multilateral de comércio está ligado a cinco acordos preferenciais e alguns estão envolvidos em mais de dez acordos. ${ }^{24}$ No caso da União Europeia, a tarifa consolidada na OMC a partir do tratamento da nação mais favorecida se aplica de modo integral a somente seis membros do sistema multilateral. Para os outros parceiros, que ultrapassam uma centena, a União Europeia prevê um tratamento mais favorável do que o previsto pela OMC. ${ }^{25}$

A partir desses dados quantitativos e qualitativos, verifica-se a emergência de uma nova onda de regionalismo que se opõe ao fenômeno constatado pela primeira vez na década de $60 .{ }^{26} \mathrm{O}$ "novo regionalismo" se caracteriza não só pelo forte aumento do número de ACR, mas também por uma nova dimensão espacial, que inclui novos parceiros, incluindo ACR já existentes e novos domínios materiais.

De fato, os novos ACR contêm disposições que abrangem outras áreas. Além do comércio de bens e serviços, esses ACR apresentam disposições relativas a

24 OMC. Comité des accords commerciaux régionaux, Synopsis des "questions systémiques" relatives aux accords commerciaux régionaux, WT/REG/W/37, 2 mars 2000, p. 4. O Chile é um dos membros mais ativos na OMC, participando de mais de 16 ACR ao mesmo tempo. Base de dados sobre os ACR disponível em: $<$ http://rtais.wto.org/UI/PublicMaintainRTAHome.aspx $>$. Os Estados Unidos também utilizam bastante a via bilateral. Para mais detalhes ver o site oficial do United States Trade Representative (USTR): < http://www.ustr.gov/trade-agreements/ free-trade-agreements>. Acesso em: 04 set. 2014.

25 Comentários sobre tais dados são apresentados em: BHAGWATI, J.N. Termites in the trading system: how preferential agreements undermine free trade. Oxford: Oxford University Press, 2008. SAPIR, A. The political economy of EC regionalism. European Economic Review, v. 42, p. 717-732, 1998. WTO, CONSULTATIVE Board to the WTO Director-General, The future of the WTO: advancing institutional challenges in the new Millenium. Geneva: WTO, 2004. p. 21.

26 WHALLEY, J. Recent regional agreements: why so many, why so much variance in form, why coming so fast, and where are they headed? The World Economy, v. 31, n. 4, p. 517-532, 2008. Pour une analyse de l'implication des États-Unis dans le nouveau régionalisme voy. HILAIRE, A; YANG, Y. The United States and the new regionalism/ bilateralism. IMF Working Paper, WP/03/206, 2003. 25 p. investimento, a normas técnicas, a propriedade intelectual, a regras de concorrência, de trabalho e de meio ambiente, algumas vezes visando à inclusão destes na OMC. Mesmo os ACR considerados pouco aprofundados no campo da cooperação, como as zonas de livre comércio, começam a abordar questões como os contratos públicos, investimento, defesa comercial, entre outros. Essa nova tendência de incluir medidas que geralmente não são cobertas pela OMC é chamada de "regionalismo agressivo", sendo o acordo de livre comércio entre a Coreia e os Estados Unidos um bom exemplo. ${ }^{27}$

Além da proliferação quantitativa dos ACR, a observação empírica do regionalismo mostra que os Membros da OMC preferem integrações econômicas menos aprofundadas. Além disso, traços desse novo regionalismo são as novas formas híbridas de integração, os novos domínios incluídos nos ACR, o aumento do número de acordos Norte-Sul e a sobreposição de ACR, além da conclusão de acordos entre dois ACR préexistentes ou entre países geograficamente distantes. Deve ser ressaltado, que, juntamente com a proliferação de novos ACR, em geral, eles possuem seus próprios mecanismos de solução de controvérsia que também apresentam uma proliferação sem precedente.

\section{A proliferação de mecanismos de solução de controvérsias previstos em ACR}

Paralelamente a essa proliferação substancial dos ACR, constata-se que o Órgão de Solução de Controvérsias da OMC está cada vez mais confrontado a proliferação de mecanismos regionais para a solução de controvérsias previstos em ACR. A multiplicação de fóruns internacionais de resolução de controvérsias parte de uma atribuição progressiva de capacidades, contribuindo para o crescimento da complexidade no sistema jurídico internacional e do risco de que tal sistema torne-se cada vez mais fragmentado, incoerente e não sistêmico. ${ }^{28}$ Assim, a proliferação de fóruns regionais, em concorrência ou não com o direito da OMC, chamou a atenção para os perigos da fragmentação do sistema jurídico internacional e para

27 Para uma análise desta nova tendência ver CHOI, W. M. Aggressive regionalism in Korea-US FTA: the present and future of Korea's FTA policy. Journal of international economic law, v. 12, n. 3, p. 595-615, 2009.

28 VARELLA, M. D. A crescente complexidade do sistema jurídico internacional: alguns problemas de coerência sistêmica. Revista de Informação Legislativa, Brasília, v. 42, n. 167, p. 163, jul/set. 2005. 
a necessidade de instrumentos que possam prevenir e tratar possíveis conflitos resultantes da ação paralela destes fóruns internacionais. Os Estados parte nos ACR e Membros da OMC são obrigados a respeitar os dois acordos e a utilização de um fórum regional pode acarretar em violações das regras da OMC e vice-versa.

Decisões conflitantes surgem do fato que vários acordos são aplicados simultaneamente. De fato, não existe uma regra de direito internacional que define uma proibição de recursos paralelos aos dois sistemas, acumulando procedimentos e formando situações de litispendência, na qual um único litígio é submetido a ambas as jurisdições. A análise dos dispositivos da OMC mostra que seus Membros não perceberam o potencial de conflitos passíveis de surgimento entre as jurisdições regionais e o Órgão de Solução de Controvérsias (OSC) da OMC. Como exemplo, o artigo XXIV do GATT, o artigo $\mathrm{V}$ do GATS e a Cláusula de Habilitação não possuem nenhum dispositivo ou limite a incorporação de mecanismos regionais de resolução de litígios nos ACR.

A motivação para a criação de fóruns regionais pode ser explicada pelas lacunas em fóruns universais, no tratamento de questões precisas e específicas do contexto regional. No caso do direito internacional econômico, a criação de fóruns regionais é fundamental porque alguns ACR se concentram em questões que a OMC não trata, o que tem implicações em termos de resolução de disputas. Nesse sentido, os sistemas de resolução de conflitos regionais são necessários, uma vez que são as únicas jurisdições competentes para o tratamento de determinados assuntos.

Alguns mecanismos de resolução de litígios regionais são semelhantes ao OSC da $\mathrm{OMC}^{29}$, como o mecanismo previsto no âmbito do Acordo de Livre Comércio da América do Norte (NAFTA). Entre essas semelhanças, constata-se a pertinência dada a inclusão de cláusulas de eleição de forum no caso de "forum shopping". A prática do fórum shopping ocorre quando mais de uma jurisdição terá a competência para tratar do caso e as partes podem escolher o foro para lidar com o caso. ${ }^{30}$ No entanto, mesmo com essas cláusulas,

29 No mesmo sentido ver GHÉRARI, H. La concurrence des procédures dans le contentieux de l'OMC. In: KERBRAT, Y. Forum Shopping et concurrence des procédures contentieuses internationals. Bruxelles: Bruylant Bruxelles, 2011, p. 77-102. at. p. 82.

30 Existem diversas definicoes para o termo: "Forumshopping: the practice of introducing a proposal or pursuing a dispute in one forum after another until a favourable outcome has been achieved. Sometimes also called forum-shopping." GOODE, W. Dictionary of trade policy terms. 5. ed. WTO : Cambridge, 2007. p. as partes ainda têm a possibilidade de um eventual fórum shopping e um paralelismo de procedimentos que podem resultar em decisões diferentes e até mesmo contrárias geradas por fóruns autônomos. Nessa situação, deve ser verificada a importância dada aos aspectos políticos para a resolução de casos, visto que podem ser decisivos para a escolha da decisão a ser aplicada: processos paralelos e decisões contraditórias podem existir e são admitidas pelo direito internacional.

\section{Os efeitos da proliferação de ACR para o sistema multilateral de comércio da OMC}

A partir desse contexto podemos constatar que a complexidade do sistema internacional se deve a três fatores diferentes: a expansão normativa e a acumulação de normas; o aumento de regimes especiais e a consequente diversificação do direito internacional e da jurisdicionalização desse direito. ${ }^{32}$ Assim, verificase a importância de se analisar a relação entre o sistema multilateral da OMC com o ACR, no sentido de que a criação dos ACR constitui uma violação dos princípios fundamentais da OMC, especialmente o princípio da nação mais favorecida e que a proliferação inesperada desses acordos pode prejudicar a legitimidade da OMC na liderança da liberalização do comércio mundial.

De fato, ACR estão se multiplicando a uma velocidade inesperada, e em alguns casos, eles

179 "Forum-shopping: (terme anglais, sans équivalent en français - Voy. cependant le français québécois «magasinen»: choisir un tribunal comme on choisit d'entrer dans une boutique pour faire ses emplettes): possibilité qu'offre à un demandeur la diversité des règles de compétence internationale de saisir les tribunaux du pays appelé à rendre la décision la plus favorable à ses intérêts.» CORNU, G. Vocabulaire juridique. 8. ed. Paris:PUF, 2004. p. 397. "Forumshopping: the practice of choosing the most favorable jurisdiction or court in which a claim might be heard.” BLACK, H.C. Black's law dictionary: definitions of the terms and phrases of American and English jurisprudence, ancient and modern. St. Paul, Minn.: West Publishing Co., 1990.

31 SANTULLI, C. Droit $d u$ contentieux international. Paris: Montchrestien, 2005. p. 91.

32 GHÉRARI, H. La concurrence des procédures dans le contentieux de l'OMC. In: KERBRAT, Y. Forum Shopping et concurrence des procédures contentieuses internationals. Bruxelles: Bruylant Bruxelles, 2011. p. 77-102. at. p. 78- 79.

33 Um estudo sobre os riscos da interação entre os ACR e o sistema multilateral de comércio da OMC e as possíveis soluções para as relações estabelecidas entre eles foi desenvolvido em TRAN, T.T.P. Les accords régionaux dans le système de l'Organisation mondiale $d u$ commerce. 2007. 534 f. Thése (doctorat) Université Panthéon-Assas. Paris, 2007. 
são considerados uma ameaça ao multilateralismo estabelecido pela OMC. A aproximação entre os Estados Unidos e a União Europeia na construção de uma parceria transatlântica tem sido apontada como um risco potencial para o sistema da OMC. Embora ainda não exista um acordo preferencial entre eles, desde a década de 1990, foram tomadas iniciativas para promover o aumento do comércio e dos investimentos entre as duas entidades. Em 2004, foi adotado um documento chamado 'EU-US Initiative to Enhance Trans-Atlantic Economic Integration and Growth', o qual indica claramente a intenção de liberalizar o comércio entre as duas regiões. ${ }^{34}$

Se um acordo de livre comércio entre eles se materializasse, haveria um impacto significativo sobre o multilateralismo, pois, juntos, respondem por $40 \%$ do volume do comércio mundial e aproximadamente $60 \%$ do PIB mundial. A formação de um acordo de livrecomércio entre os Estados Unidos e a União Europeia comporta, de fato, riscos para o sistema multilateral da OMC, porque se for bem-sucedido, a OMC passaria a ser um brinquedo nas mãos dos Estados Unidos e da União Europeia, servindo somente para dar legitimidade às decisões tomadas no contexto bilateral. No entanto, o sistema multilateral não pode ser substituído por tais acordos e é por isso que um equilíbrio entre os dois polos deve ser procurado. ${ }^{35} \mathrm{Na}$ mensagem do director geral da OMC, Roberto Azevedo, no relatório anual da OMC de 2014, ele deixou bem claro que tais acordos possuem um papel de complementação ao sistema multilateral, mas que não seriam suficientes em si por excluir diversos atores econômicos e diversas "grandes questões", como por exemplo as reduções de subsídios agrícolas, só seriam passíveis de tratamento ao nível mundial. ${ }^{36}$

No entanto, devemos também levar em conta o fato de que, durante a negociação de acordos comerciais regionais, existe a possibilidade de que alguns temas

34 Sobre esse tema ver: SILVA, A. R. Crônicas de Direito Internacional: acordo de livre-comércio transatlântico Estados Unidos-União. Revista de Direito Internacional, v. 10, n.1, 2013.

35 Este foi o título do discurso do Diretor Geral da OMC, Roberto Azevedo no enceramento do Seminário da OMC sobre as questões transversais nos ACR, no dia 25 de setembro de 2014. Disponível em: <http://www.wto.org/french/news_f/spra_f/ spra33_f.htm> Acesso em: 02 nov. 2014.

36 OMC. Rapport annuel 2014. Disponível em: <http://www. wto.org/french/res_f/booksp_f/anrep_f/anrep14_f.pdf $>$. Acesso em: 10 dez. 2014. sejam melhor tratados e esta discussão aprofundada sobre determinados domínios pode ser posteriormente introduzida nas regras multilaterais. Resistências para o aprofundamento do tratamento de determinados assuntos no sistema da OMC podem ser anuladas a nível regional. Além disso, a abertura dos mercados por meio dos ACR se revela menos traumática para os países em desenvolvimento, dada a possibilidade de uma exposição gradual da economia nacional à concorrência externa.

Tópicos tratados superficialmente ou simplesmente ignorados pelo sistema multilateral da OMC estão presentes nos acordos regionais. Isso pode ser explicado pela dificuldade das negociações a nível multilateral, tendo em vista a maior quantidade de Membros e interesse em jogo. A prova disso é que na atual Rodada Doha, as questões que não estão previstas no mandato original da Rodada são eliminadas. Com efeito, a conclusão dessa rodada tornou-se uma prioridade para a Organização e o tratamento destas questões poderia retardar ainda mais o período de negociações para a conclusão da Rodada a partir do estabelecimento de um engajamento único. ${ }^{37}$

Ao estabelecer o mandato da Rodada de Doha, houve uma tentativa de incluir temas como os contratos de investimento e de compras governamentais, mas depois disso eles foram explicitamente excluídos da agenda de negociações. Isso incluiu a questão da facilitação do comércio, que ainda está em negociação. ${ }^{38}$ Outros temas de interesse para as empresas multinacionais, como as regras relativas à governança, corrupção, responsabilidade social e imigração nem sequer são mencionados no sistema multilateral. Isso incentiva os operadores públicos e privados a encontrarem outras instâncias para o tratamento destas questões. Assim, as questões não abrangidas pela OMC estão cada vez mais integradas ao nível regional. Pode-se desta forma considerar a intenção de abordar estas questões no quadro multilateral no futuro.

Em particular, temas sensíveis como as normas de trabalho, de meio ambiente e de propriedade intelectual

37 Diversas sugestões relativas a reformas no processo de negociação da OMC foram apresentadas, entre elas a reavaliação do « engajamento único » ('single undertaking') que pode bloquear as negociações. Para análise das proposições de reforma ver ROLLAND, S.E. Redesigning the negotiation process at the WTO. Journal of International economic Law, v. 13, n. 1, p. 65-110, 2010.

38 OMC. Programme de travail de Doha, Décision adoptée par le Conseil général le 1er août 2004. WT/L/579. 02 août 2004. 
são atualmente tratadas principalmente nos ACR formados pelos principais atores dentro do sistema, dado o maior poder de barganha que eles possuem nesse universo mais restrito. Assim, alguns assuntos estão agora entrando por uma "porta lateral" no sistema da OMC. ${ }^{39}$

Se os ACR podem ser considerados uma ameaça para o sistema da OMC, eles também podem contribuir para o fortalecimento do multilateralismo. Uma verdadeira sinergia entre as duas abordagens pode ocorrer, como no caso do Memorando do GATS sobre compromissos relativos a serviços financeiros, estabelecido com auxílio da experiência adquirida no contexto da abertura dos mercados financeiros no nível regional. No entanto, essa interação nem sempre é fácil, uma vez que a OMC e os acordos comerciais regionais não são elementos estáticos. Considere o fato de que os ACR crescem e evoluem, não apenas na base de regras multilaterais, mas também em função de outros ACR criados. Além disso, as motivações para a criação de compromissos não são as mesmas, a nível regional e no sistema multilateral, visto que no sistema regional o grau de afinidade entre um número menor de parceiros é maior.

Os ACR podem ajudar a liberalização do comércio, afinal os novos compromissos assumidos em sua esfera podem incentivar a abertura de mercados no nível multilateral. A esse argumento soma-se a "teoria da liberalização competitiva", associada à interação positiva entre as duas dinâmicas, regional e multilateral, desencadeada por negociações simultâneas. A liberalização do comércio em ambas as esferas estabelece uma competição entre elas, o que favorece o multilateralismo comercial, na medida em que ele vai tentar expandir no nível multilateral a liberalização realizada a nível regional. Historicamente, a formação de ACR e a liberalização alcançada dentro deles sempre motivou os Estados para iniciar novas rodadas de negociação no âmbito multilateral. ${ }^{40}$

Associada à teoria da liberalização competitiva, a “teoria do dominó” também procura explicar a interação entre as negociações em ambos os níveis. Inicialmente, essa teoria foi usada para explicar como a experiência

39 SUTHERLAND, P. L'avenir de l'OMC: relever les défis institutionnels du nouveau millénaire. Rapport du Conseil consultatif à M. Supachai Panitchpakdi, Directeur Général, OMC. Genève, 2004. p. 23.

40 BERGSTEN, C.F. Fifty years of the GATT/WTO: lessons from the past for strategies for the future. In: WTO Secretariat, From the GATT to the WTO: the multilateral trading system in the new millennium, The Hague, Kluwer/WTO. 2000. regional bem-sucedida incentivou a formação de novos acordos comerciais regionais ou expansão dos ACR existentes. Em uma segunda etapa, essa teoria tem sido utilizada para demonstrar a interação positiva que se desenvolve entre o regionalismo e o sistema da OMC, e foi ainda mais longe ao afirmar que, mesmo que a relação não ocorra de forma muito ordenada e fora do controle da OMC, a formação de ACR contribui para a evolução do sistema multilateral como um todo. ${ }^{41}$

Esse efeito dominó funciona em ambas as direções, a partir do multilateralismo para o regionalismo ou do regionalismo para o multilateralismo. Isso quer dizer que, da mesma forma que as disciplinas negociadas no contexto multilateral influenciam as negociações regionais, as regionais influenciam nas negociações multilaterais. Esse fenômeno foi facilmente percebido no setor de serviços, porque as negociações realizadas por meio de listas positivas de serviços, assim como a definição dos modos de obrigação foram lições aprendidas com o acordo de livre-comércio entre o Canadá e os Estados Unidos (em inglês CanadaUnited States Free Trade Agreement - CUSFTA) e foram refletidas no texto do GATS. Outro exemplo pode ser apreendido com o NAFTA que se inspirou da experiência do GATS e foi além substituindo a lista positiva pela lista negativa, acentuando a liberalização. ${ }^{42}$

Tal teoria deve ser aplicada com cautela e sem generalização sobre a automaticidade dos acontecimentos. Novos estudos empíricos precisam abordar estes quesitos, porque a prática das negociações de serviços da Rodada de Doha tem mostrado o contrário: os países mais aplicados no tratamento desta disciplina a nível regional, como os Estados Unidos, são mais reticentes nas negociações multilaterais, o que parece contradizer a teoria do dominó. ${ }^{43}$ Assim, parece que o jogo de dominós é mais acessível aos principais atores que têm a capacidade de fazer com que a dinâmica regional influencie positivamente o multilateralismo, mas nesse contexto deve ser questionado se estes atores

41 Para análise desta teoria sob o ponto de vista econômico ver BALDWIN, R. Multilateralising regionalism: spaghetti bowls as building blocs on the path to global free trade, Geneva: Institute for International Studies, 2006. p. 15 e ss.

42 Para uma análise mais aprofundada sobre este exemplo ver OSTRY, S. Regional dominoes and the WTO: building blocks or boomerang? Fraser Institute Conference. Toronto: [s.n.], nov. 1999. p. 05.

43 ROY, M.; MARCHETTI, J.; LIM, H. Services liberalization in the new generation of preferential trade agreements (PTAs): how much further than the GATS? WTO Staff Working Paper. Geneva: WTO, 2006. p. 58. 
estão dispostos a pagar o preço para apoiar o sistema da OMC, em detrimento dos ganhos regionais.

Os Estados têm se aproveitado de experiências regionais para o tratamento de vários temas na OMC, mas deve-se ressaltar que o processo não é automático nem linear, afinal existem diversos outros elementos que são essenciais para as negociações a nível multilateral. Basta ter em mente que os Estados podem concordar em participar de ACR que tratem de questões negligenciadas pela $\mathrm{OMC}$ e se recusam a incluir na agenda de negociações multilaterais.

O regionalismo deve ser visto como uma ferramenta e não como um fim em si, devendo ser utilizado para o desenvolvimento do comércio entre os parceiros regionais. ${ }^{44} \mathrm{Um}$ fator positivo é o caráter inclusivo de alguns ACR, que buscam se ampliar através da adesão de novos membros e da inclusão de novos objetos, ao invés de se fechar em si mesmos. ${ }^{45}$ Aliados a esses fatores de proliferação e articulação entre regionalismo e multilateralismo, resta interessante apresentar uma análise prospectiva sobre o papel da OMC e do multilateralismo para a governança mundial aliada a novos arranjos regionais.

\section{O papel da OMC e do multilateralismo para a governança mundial aliada a novos arranjos regionais}

Estudos recentes da OMC demonstram que a tendência de proliferação dos ACR constatada nos últimos anos pode sofrer uma "reversão". Isso não significa que os ACR irão desaparecer e sim que a parte do comércio realizada em tais acordos poderá sofrer uma diminuição. ${ }^{46}$

44 Para a análise desse ponto de vista no contexto do Mercosul ver: KLOR, A.D. O jogo de luzes e sombras do Mercosul. Pontes, v. 5, n. 3, out 2009. Disponível em: < http://ictsd.net/i/news/ pontes/53552/>. Acesso em: 28 out. 2014.

45 Ver por exemplo as boas práticas desenvolvidas no contexto da APEC: MARCEAU, G. The adoption of the 'best practice' for regional and free trade agreements in APEC: a road towards more WTO-consistent regional trade agreements. In: TANIGUCHI, Y.; YANOVICH, A.; BOHANES, J. (Ed.). The WTO in the Twenty-first Century: dispute settlement, negotiations, and regionalism in Asia. Cambridge: Cambridge University Press, 2006. 507 p. at p. 409-422.

46 FONTAGNÉ, Lionel; FOURÉ, Jean; KECK, Alexander. Simulating world trade in the decades ahead: driving forces and policy implications, 2014. Disponível: <http://www.wto.org/english/ res_e/reser_e/ersd201405_e.pdf >.Acesso em: 10 dez. 2014.
Tal estudo deve ser visto com bastante cuidado, sobretudo no aspecto interpretativo de tal "reversão". Isso porque ele traz uma análise prospectiva da economia mundial em 2035, a partir de técnicas e estudos econômicos, demonstrando que a probabilidade será de que os países se reagrupem em blocos amplos, chamados "megaregionais" sugerindo que tais blocos tenham o viés multilateral e não regional.

Ora, se os países estarão reagrupados nesses megablocos, isso pode significar um risco ainda maior para a pertinência da OMC, visto que uma das razões de sua permanência frente a essa proliferação de ACR é justamente a de que ainda não surgiram ACR entre países desenvolvidos, que precisariam do contexto da OMC para concluírem suas negociações.

O estudo ainda indica a necessidade de que a OMC propicie um ambiente econômico dinâmico e aberto à participação de novos atores, propiciando um incremento no comércio entre os países em desenvolvimento e apoiando tais economias para atividades que exigirão maior intensidade de competências.

Isso constitui um dado bastante relevante para a discussão do papel da OMC na governabilidade internacional, visto que essa organização mostrou-se favorável a ações de apoio aos países desenvolvidos, sendo a própria Rodada Doha voltada para a questão do desenvolvimento. Sendo assim, a OMC se mostrará essencial para coordenar as ações de políticas públicas nacionais e internacionais envolvendo países em desenvolvimento, incluindo os novos atores públicos e privados na implementação de ações voltadas para a inserção destes nesse novo cenário.

A probabilidade é de que o progresso tecnológico representará o maior impacto para a conjectura da economia futura, sendo que aspectos relacionados a fatores populacionais também serão fortemente influenciados. Para alguns países, será indispensável que melhorem a competência de seus trabalhadores, enquanto outros suprirão tais falhas com a imigração de mão de obra especializada.

Enfim, a OMC deverá estar preparada para auxiliar seus membros, principalmente os países em desenvolvimento, na aquisição dos meios para competirem nesse mercado internacional. Não só no apoio a blocos os envolvendo, mas também no auxílio direto a suas políticas econômicas e de regulação com o comércio internacional. 


\section{Conclusão}

A partir dessa constatação de uma pluralidade de fontes e de sistemas de solução de controvérsias, devem ser buscados meios capazes de "ordenar o múltiplo" para "garantir a compatibilidade de normas com proveniência diversa". ${ }^{47}$ Para alguns, deve ser reconhecido o pluralismo do direito internacional por meio do uso de "forças imaginativas do direito" não significa necessariamente a "descrição verdadeira e completa da realidade", pois não se limita à aplicação de técnicas jurídicas e princípios comuns existentes no direito internacional. ${ }^{49}$ Isso não impede uma busca pragmática de regras e princípios jurídicos que possam servir de referencial para o processo de integração normativa.

Nessa perspectiva de "pluralismo ordenado" 50 , propõe-se a articulação entre os ACR e o direito da OMC que não se limita apenas à procura de compatibilidade normativa entre eles, mas também à análise das interações desses acordos, do processo de criação de seus dispositivos e dos mecanismos de monitoramento capazes de tornar previsíveis as variáveis resultantes da aplicação da norma. Além disso, essa noção de pluralismo ordenado refere-se a uma ideia de coordenação e não de subordinação, que é compatível com o cenário de interdependência entre esses acordos. ${ }^{51}$

47 CHEVAlLIER, J. Mondialisation du droit ou droit de la mondialisation. In: MORAND, C. A. (Dir.). Le droit saisi par la mondialisation. Bruxelles: Bruylant 2001. p.135.

48 Expressão empregada por Mirelle Delmas-Marty in DELMAS-MARTY, M. Les forces imaginantes du droit (II): Le pluralisme ordonné. Paris: Editions du Seuil, 2006.

49 JOUANNET, E. A quoi sert le droit international ? Le droit international providence du XXIème siècle. In: RUIZ FABRI, H.; JOUANNET, E.; TOMKIEWICZ, V. (Dir). Select proceedings of the european society of international law. Porteland Oregon: Hart Publishing, 2008. p. 4. v. 1.

50 Um estudo aprofundado sobre a ideia do pluralismo ordenado é desenvolvido por Mireille Delmas-Marty. DELMAS-MARTY, M. Les forces imaginantes du droit: Le pluralisme ordonné. Paris: Editions du Seuil, 2006. v. 2.

$51[\ldots]$ le pluralisme n'est que la suite logique de l'histoire du droit international si l'on admet que ce mouvement signifie non seulement admettre les différences, mais aussi les concilier, voire les ordonner, sans les "écraser"” SOREL, J.M. Le rôle du droit international dans le développement du pluralisme (et vice versa): une liaison moins naturelle qu'il n'y parait. In: FONTAINE, Lauréline (Dir). Droit et pluralisme. Bruxelles: Bruylant, 2007. p. 78.
Para isso, a articulação dos ACR com o direito da OMC pode ser realizada por meio da utilização cruzada e recíproca de seus dispositivos em seus respectivos processos de interpretação, bem como o uso de remédios gerais relevantes do direito processual. As disposições previstas na Convenção de Viena de 1969 podem servir de base para o estabelecimento de certos instrumentos propostos para a articulação normativa entre os ACR e o direito da OMC.

No entanto, além das hipóteses de concorrência e de conflito normativo, também devem ser considerados, para a análise da articulação entre os ACR e o direito da OMC, situações de concorrência entre procedimentos contenciosos internacionais que são o produto de estratégias desenvolvidas pelas partes. Algumas delas podem preferir procedimentos conduzidos em paralelo para aumentar suas chances de sucesso e ao mesmo tempo forçar o réu a desistir. Por sua vez, o réu também pode acionar um outro tribunal para tentar obter uma decisão a seu favor. Essa sobreposição de procedimentos pode criar um risco de insegurança jurídica em casos onde decisões contraditórias são oferecidas sobre a mesma medida, com base em regras muito semelhantes.

Os remédios processuais como a incompetência, a coordenação normativa e a consolidação de procedimentos são importantes porque a partir deles, um dos juízes leva em conta a decisão do outro e contribui para a coordenação entre as instâncias. ${ }^{52}$

A "articulação" deve ser entendida a partir de uma perspectiva de harmonização do direito internacional, onde não é mais possível tratar os conjuntos normativos em um aspecto único, e isso porque cada um desses conjuntos tem suas próprias especificidades. Assim, o mais importante está em procurar estabelecer um quadro normativo internacional onde esses diferentes sistemas normativos possam coexistir de forma coerente. Isso porque, no contexto em que o direito internacional contemporâneo se desenvolve, o processo de integração normativa deve ser percebido como o resultado de diversas forças "entre unidade e pluralidade, entre universalismo e cultura, entre mundialização e regionalização, constitucionalização e fragmentação, entre o direito dos Estados e o direito dos indivíduos, entre o direito dos agentes públicos e

52 Nesse sentido ver RÉMY, B. La concurrence des procédures États-investisseurs. In : KERBRAT, Y. Forum Shopping et concurrence des procédures contentieuses internationales, Bruxelles : Bruylant Bruxelles, 2011. p. 15 a 76. spéc. p. 76. 
o direito dos atores privados." ${ }^{53}$ Além disso, devemos reconhecer o direito internacional como uma ordem jurídica que se realiza por meio de "acumulação". ${ }^{54}$

Atualmente os ACR constituem um elemento indispensável na vida comercial dos Estados do mundo inteiro e eles não estão em processo de desaparecimento. Assim, a melhor solução seria a de aceitá-los não como um obstáculo para os objetivos da OMC, mas como uma alternativa dada aos Estados para fortalecer ainda mais a liberalização do comércio e encontrar a melhor

53 Tradução livre. JOUANNET, E. Le même et l'autre. In: FABRI, Hélène Ruiz; SOREL, Jean-Marc; JOUANNET, Emmanuelle (Dir). Regards d'une génération sur le droit international. Paris: Pedone, 2008. p. 223.

54 Nesse sentido ver REUTER, P. Introduction an droit des traités, Paris: PUF, Publications de l'IUHEI, 1985. p. 110. maneira de articular as relações entre eles no contexto internacional.

Vale ressaltar que ao longo de seus vinte anos de existência, a OMC apresentou progressos no tratamento da questão, ao estabelecer meios mais efetivos de supervisão de tais acordos. Todavia, novos desafios surgem nesse cenário cada vez mais globalizado, onde percebe-se o enfraquecimento do Estado como principal sujeito de direito internacional pela participação de outros atores públicos e privados. No cenário de governança apresentado, juntamente com a perspectiva dos megablocos, a OMC deve ser redimensionada no sentido de contornar possíveis falhas que atingirão, sobretudo os países em desenvolvimento. 


\section{Referências}

ACCORD de libre-échange entre les États-Unis et l'Australie, signé le 18 mai 2004, date d'entrée en vigueur le 1er janvier 2005. Disponível em: <http://www.ustr.gov/tradeagreements/free-trade-agreements/australian-fta/ final-text>. Acesso em: 08 fev. 2014.

BALDWIN, R. Multilateralising regionalism: spaghetti bowls as building blocs on the path to global free trade. Geneva: Institute for International Studies, 2006.

BASE de données sur les ACR. Disponível em: < http:// rtais.wto.org/UI/publicsummarytable.aspx $>$. Acesso em: 10 out 2014.

BERGSTEN, C.F. Fifty years of the GATT/WTO: lessons from the past for strategies for the future. In: WTO Secretariat, From the GATT to the WTO: the multilateral trading system in the new millennium, The Hague, Kluwer/WTO. 2000.

BHAGWATI, J.N. Termites in the trading system: how preferential agreements undermine free trade. Oxford: Oxford University Press, 2008.

BLACK, H.C. Black's law dictionary: definitions of the terms and phrases of American and English jurisprudence, ancient and modern. St. Paul, Minn.: West Publishing Co., 1990.

CHEVALLIER, J. Mondialisation du droit ou droit de la mondialisation. In: MORAND, C. A. (Dir.). Le droit saisi par la mondialisation. Bruxelles: Bruylant 2001.

CHOI, W. M. Aggressive regionalism in Korea-US FTA: the present and future of Korea's FTA policy. Journal of international economic law, v. 12, n. 3, 2009.

CONVENTION de Vienne sur le droit des traités, faite à Vienne, 23 mai 1969, 1155 R.T.N.U. 331, 8 International Legal Materials 679.

CORNU, G. Vocabulaire juridique. 8. ed. Paris:PUF, 2004.

DELMAS-MARTY, M. Les forces imaginantes du droit (II): Le pluralisme ordonné. Paris: Editions du Seuil, 2006.

FIORENTINO, R.V; VERDEJA, L.; TOQUEBOEUF,C. Discussion Paper $n .12$ : the changing landscape of regional trade agreements 2006 update. p.12. Disponível em: <http://www.wto.org/english/ res_e/publications_e/disc_paper12_e.htm $>$ Acesso em: 14 abr. 2014.

GATT, Traitement Difference et Plus Favorable Reciprocite et Participation Plus Complete des Pays en Voie de Developpement : Décision du 28 novembre 1979 (Clause d'habilitation), L/4903, 03 décembre 1979.

GHÉRARI, H. La concurrence des procédures dans le contentieux de l'OMC. In: KERBRAT, Y. Forum Shopping et concurrence des procédures contentieuses internationals. Bruxelles: Bruylant Bruxelles, 2011. p. $77-102$.

GHÉRARI, H. Le bilatéralisme conquérant ou le nouveau visage du commerce international. RGDIP, n. 2, p. 255293, 2008.

GONCALVES, J. B. Livre-comércio ou comércio mais livre? alternativas ao multilateralismo. In: LUZ, M. (Coord). Comércio e negociacões internacionais para jornalistas. Centro Brasileiro de Relações Internacionais, 2009.

GOODE, W. Dictionary of trade policy terms. 5. ed. Cambridge: WTO, 2007.

HILAIRE, A; YANG, Y. The United States and the new regionalism/bilateralism. IMF Working Paper, WP/03/206, 2003.

HINDLEY, B. New institutions for Transatlantic Trade? International Affairs, v. 75, n. 1, p. 45-60, 1999.

HUDEC, R. E. The Gatt legal system and world trade diplomacy. Salem: Butterworth Legal Publishers, 1990.

JOUANNET, E. A quoi sert le droit international? Le droit international providence du XXIème siècle. In: RUIZ FABRI, H.; JOUANNET, E.; TOMKIEWICZ, V. (Dir). Select proceedings of the european society of international law. Porteland Oregon: Hart Publishing, 2008. v. I

JOUANNET, E. Le même et l'autre. In: FABRI, Hélène Ruiz; SOREL, Jean-Marc; JOUANNET, Emmanuelle (Dir). Regards d'une génération sur le droit international. Paris: Pedone, 2008. 
KLOR, A. D. O jogo de luzes e sombras do Mercosul. Pontes, v. 5, n. 3, out 2009. Disponível em: <http:// ictsd.net/i/news/pontes/53552/>. Acesso em: 28 out. 2014.

MARCEAU, G. The adoption of the 'best practice' for regional and free trade agreements in APEC: a road towards more WTO-consistent regional trade agreements. In: TANIGUCHI, Y.; YANOVICH, A.; BOHANES, J. (Ed.). The WTO in the Twenty-first Century: dispute settlement, negotiations, and regionalism in asia. Cambridge: Cambridge University Press, 2006. 507 p., at pp. 409-422.

OMC. Comité des accords commerciaux régionaux, Synopsis des "questions systémiques" relatives aux accords commerciaux régionaux, WT/REG/W/37, 2 mars 2000 .

OMC. Mécanisme pour la transparence des accords commerciaux régionaux. Décision du 14 décembre 2006, WT/L/671, 18 décembre 2006.

OMC. Nouvelles 2006, M. Lamy salue l'accord de l'OMC sur les accords commerciaux régionaux, 1er juillet 2006.

OMC. Programme de travail de Doha, Décision adoptée par le Conseil général le 1er août 2004. WT/L/579. 02 août 2004.

OMC. Rapport sur le commerce mondial 2011. L'OMC et les accords commerciaux préférentiels: de la coexistence à la cohérence, p. 72-85. Disponível em: <http://www. wto.org/french/res_f/publications_f/wtr11_f.htm>. Acesso em: 27 out. 2014.

OMC. Rapport sur le commerce mondial 2011. L'OMC et les accords commerciaux préférentiels : de la coexistence à la cohérence. p. 72. Disponível em: <http://www.wto.org/ french/res_f/publications_f/wtr11_f.htm>. Acesso em: 27 out. 2014.

OMC. Rapport sur le commerce mondial 2011. L'OMC et les accords commerciaux préférentiels: de la coexistence à la cohérence. p. 64. Disponível em: <http://www.wto.org/ french/res_f/publications_f/wtr11_f.htm>. Acesso em: 27 out. 2014.

ORGANISATION for economic co-operation and development. Regionalism and the Multilateral Trading System. Paris: OECD, 2003.
OSTRY, S. Regional dominoes and the WTO: building blocks or boomerang? Fraser Institute Conference. Toronto: [s.n.], nov. 1999.

RÉMY, B. La concurrence des procédures États: investisseurs. In: KERBRAT, Y. Forum Shopping et concurrence des procédures contentieuses internationals. Bruxelles: Bruylant, Bruxelles. 2011. p. 15 a 76.

REUTER, P. Introduction au droit des traits. Paris: PUF Publications de l'IUHEI, 1985.

ROLLAND, S. E. Redesigning the negotiation process at the WTO. Journal of International economic Law, v. 13, n. 1, p. 65-110, 2010.

ROMANO, C.P.R. The proliferation of international judicial bodies: the pieces of the puzzle. N.Y.U. Journal of International Law and Politics, v. 31, n. 4, 1999.

ROY, M.; MARCHETTI, J.; LIM, H. Services liberalization in the new generation of preferential trade agreements (PTAs): how much further than the GATS? WTO Staff Working Paper. Geneva: WTO, 2006.

SANTULLI, C. Droit du contentieux international. Paris: Montchrestien, 2005.

SAPIR, A. The political economy of EC regionalism. European Economic Review, v. 42, 1998.

L'UNITED STATES TRADE REPRESENTATIVE (USTR).[Home page]. Disponível em: <http://www.ustr. gov/trade-agreements/free-trade-agreements $>$. Acesso em: 04 fev. 2014.

SOREL, J.M. Le rôle du droit international dans le développement du pluralisme (et vice versa): une liaison moins naturelle qu'il n'y parait. In: FONTAINE, Lauréline (Dir). Droit et pluralisme. Bruxelles: Bruylant, 2007.

SUTHERLAND, P. Lavenir de l'OMC: relever les défis institutionnels du nouveau millénaire. Rapport du Conseil consultatif à M. Supachai Panitchpakdi, Directeur Général, OMC. Genève, 2004.

TRAN, T.T.P. Les accords régionaux dans le système de l'Organisation mondiale du commerce. 2007.534 f. Thése (doctorat) Université Panthéon-Assas. Paris, 2007 
UNITEDSTATES. United States Trade Representative, Press Release, 15 June 2004. United States and Marocco sign historic free trade agreement. Disponível em: <www. ustr.gov>. Acesso em: 03 out. 2014.

VAN DEN BOSSCHE, P. The law and policy of the World Trade Organization: text, cases and materials. 2. ed. Cambridge: Cambridge University Press, 2008.

VARELLA, M.D. A crescente complexidade do sistema jurídico internacional: alguns problemas de coerência sistêmica. Revista de Informação Legislativa, Brasília, v. 42, n. 167, jul/set. 2005.
WHALLEY, J. Recent regional agreements: why so many, why so much variance in form, why coming so fast, and where are they headed? The World Economy, v. 31, n. 4, 2008.

WORLD BANK. Global economic prospects. Washingon: World Bank, 2005.

WTO. CONSULTATIVE Board to the WTO Director-General, The future of the WTO: advancing institutional challenges in the new Millenium. Geneva: WTO, 2004. 


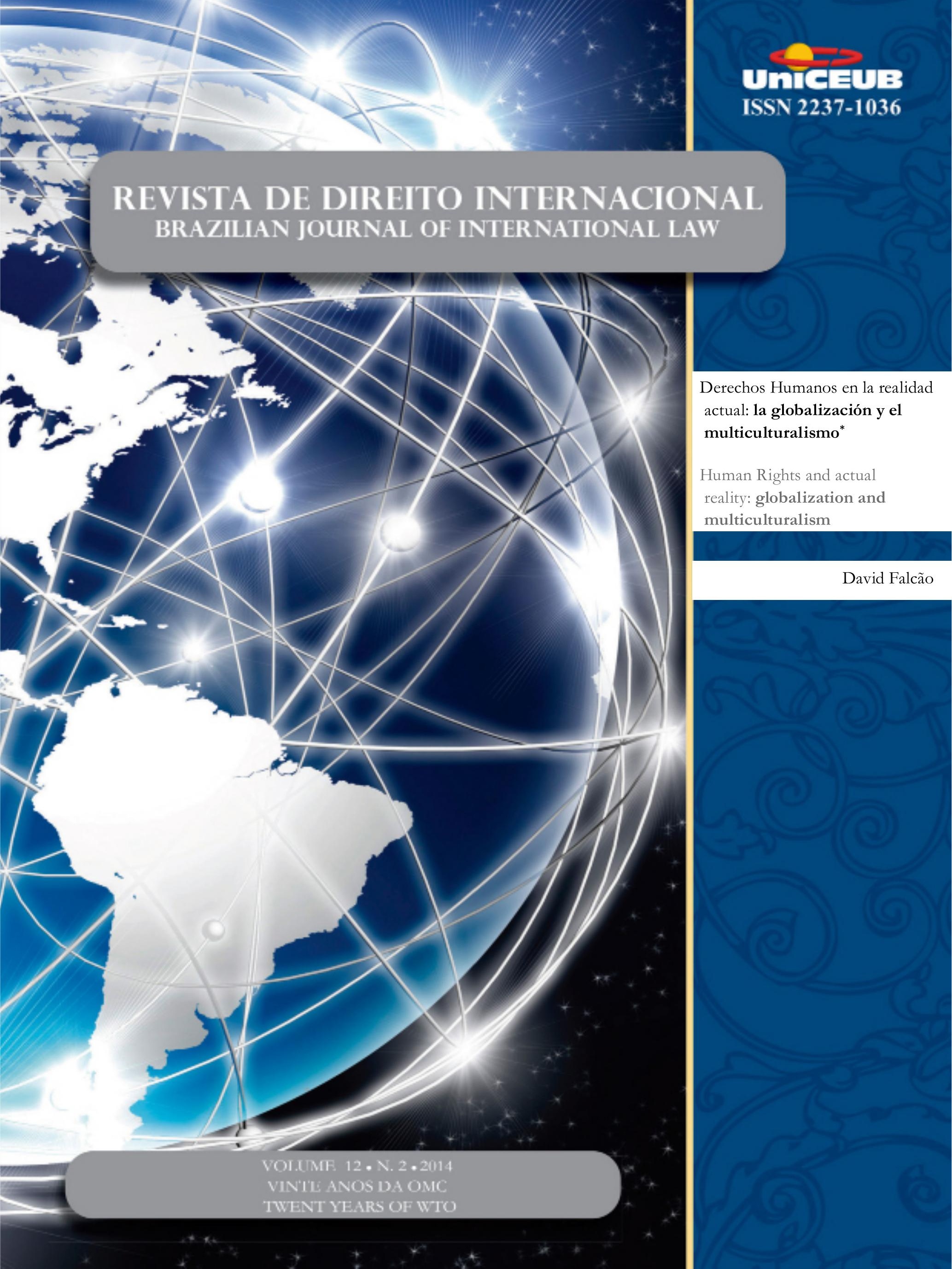




\title{
Derechos Humanos en la realidad actual: la globalización y el multiculturalismo*
}

\section{Human Rights and actual reality: globalization and multiculturalism}

David Falcão**

\section{Resumen}

En el presente artículo se cuida de analizar los elementos que, actualmente, representan una mayor amenaza para los Derechos humanos y a su universalidad: la globalización y las crecientes tesis multiculturalistas. Sin embargo, por otro lado se cuida de abordar las transformaciones positivas en el sentido de la universalización de los Derechos Humanos, como por ejemplo, el creciente reconocimiento del carácter básico y, por lo tanto, universal de los mismos como razón de ser del derecho, de la democracia y del Estado de Derecho, en un número de países cada vez mayor.

Palabras clave: Universalismo. Pluralismo. Relativismo. Globalización. Derechos Humanos.

\begin{abstract}
This article is careful to analyze the elements that currently represent a greater threat to human rights and their universality: globalization and the growing multicultural thesis. However, on the other hand takes care to address the positive changes in the sense of universal human rights, such as the increasing recognition of the basic character and, therefore, the same universal as rationale for the right, democracy and the rule of law in a number of growing countries.
\end{abstract}

Key Words: Universalism. Pluralism. Relativism. Globalization. Human Rights.

\section{Introducción}

Es evidente, en el inicio del siglo XXI, la existencia de nuevos elementos en torno a los derechos humanos: nuevos sujetos de derechos, la creciente mezcla cultural, el proceso de globalización, los imparables avances de la ciencia y tecnología, la manifiesta inestabilidad de las relaciones internacionales (un orden internacional cada vez más unipolar) y, consecuentemente, la toma de conciencia de los riesgos que representan para las pretensiones universalistas de los derechos del hombre.

* Recebido em: 14.07.2014

Aceito em: 01.11.2014

** Profesor Universitario (Universidad de Lisboa y Instituto Politécnico de Castelo Branco) y Doctor en Derechos Humanos. Especialista en Derechos Humanos y Derecho Laboral, david@ ipcb.pt.
Sin embargo, se registran algunas transformaciones positivas en el sentido de la universalización, como por ejemplo, el creciente reconocimiento del carácter básico y, por lo tanto, universal de los derechos humanos como razón de ser del derecho, de la democracia y del Estado de Derecho ${ }^{1}$, en un número de países cada vez mayor.

1 En términos jurídicos, los progresos son considerables: por primera vez en la historia, y cualesquiera que sean los horrores que, en toda parte, manchan de sangre regiones enteras del 
En el campo del diálogo intercultural se verifican esfuerzos importantes de conciliación, concretamente, los encuentros occidental-confuciano ${ }^{2}$ entre pensadores canadienses $y$ chinos $y$, occidental-disidentes musulmanes. Igualmente se han realizado estudios sobre las barreras de implantación de los derechos humanos en la cultura africana ${ }^{3}$.

La universalidad cuenta, igualmente, con algunos (aunque insuficientes) instrumentos importantes, el Tribunal Penal Internacional, de Roma y la afirmación del imperativo de jurisdicción universal.

Otro aspecto positivo, tiene que ver con el entendimiento de la solidaridad como principio jurídico y no apenas como virtud moral, una solidaridad institucionalizada (con la Declaración de Viena) que da, a su vez, lugar a la aparición de deberes positivos de alcance universal. Como ejemplo, el deber de asistencia humanitaria o el de cooperación con los países subdesarrollados.

Sin embargo, cuidaremos de analizar los elementos que, actualmente, representan una mayor amenaza para los derechos humanos y su universalidad: la globalización y las crecientes tesis multiculturalistas.

\section{Globalización: Sus implicaciones en el debate acerca de Derechos Humanos}

Se puede definir globalización de la siguiente forma: the term used to characterize the process of growing interconnection and interdependence in the modern world. It is generated by growing international economic, cultural and political cooperation and links, as well as by the need to respond together to global problems which can be solved only on a planetary scale ${ }^{4}$.

mundo, prácticamente ningún estado se atreve a adoptar leyes contrarias a los derechos humanos. Cfr. AGNÈS COMBESQUE, Marie. Introduction aux Droits de l'Homme. Trad. en portugués de Maria Filomena Duarte Paris: Syros Jeunesse, 1998. Nota: La traducción de portugués a Español a sido de nuestra autoría. p.19.

2 Cfr. BARY, W. T.; Weiming, T. (Ed). Confucianism and Human Rights. Nueva York: Columbia University Press, 1998.

3 Cfr. KABUNDA, M. Badi. Derechos Humanos en Africa. Bilbao: Universidad de Deusto, 2000.

4 Cfr. SYMONIDES, Janusz. New Human Rights. dimensions, obstacles and challenges: introductory remarks. In: SYMONIDES, Janusz (Ed.). Human Rights: new Dimensions and challenges. UNESCO, 1998. p. 28. Traducción a Castellano: "El término
La globalización es ya real en los campos de la economía y de las comunicaciones, y, manifiestamente creciente en el ámbito político, social y cultural. De cierta forma, con este fenómeno sucede como con la revolución industrial, que era imparable y que de poco o nada sirvió la resistencia de socialistas o anarquistas, que en vez de pelear por regular el proceso dentro de esferas humanistas y sociales, lo han rechazado simplemente. Marx ha confundido capitalismo con revolución industrial ${ }^{5}$. Sostenía que la forma de producción industrial sustituiría al modo de producción feudal. Pretendía configurar una forma de producción socialista para terminar con un capitalismo industrial, cuando en realidad se trataba de dar un sentido socialista a todo el proceso. Pero, al final aceptó que era inevitable.

Actualmente en el debate en torno a la globalización, las posiciones a favor o en contra, resultan estériles. La polémica, en ciertos aspectos, es trasladada al debate entre universalistas y relativistas ${ }^{6}$. Los defensores de una lógica universalista radical, herederos de la ilustración, identifican la globalización como una imposición del enfoque neoliberal, de la cual resulta una occidentalización económica y cultural de todo planeta a través de un proceso de homogeneización, que incluso en algunos casos se impone por la fuerza del poder económico y político. Por lo tanto, desde este punto de vista, globalización sería sinónimo de occidentalización de estructuras económicas, políticas y culturales. Todo esto tiene implicaciones en la propia universalización de los derechos humanos, que es, a veces, connotada de paternalista y de carácter liberal

usado para caracterizar el progreso de la creciente interconexión e interdependencia en el mundo moderno. Es generado a través del crecimiento economico internacional, cultural y de la cooperación política, así como como la necesidad de contestar juntos a los problemas globales que solamente pueden ser resueltos a la escala planetária".

5 Este hecho lo demuestra claramente Dahrendorf. Cfr. DAHRENDORF, R. Class and class conflict in industrial society. Londres: Routledge \& Kegan Paul, 1959.

6 The culturally homogenizing effect of globalization, the gradual process of adopting common values and behavioural patterns, reinforces the universality of human rights, establishes ties and linkages between various parts of the world and helps to eliminate certain traditional practices which may be qualified as discriminatory. However, [...] it also undermines existing cultural identities, weakens various ethical norms and social cohesión, as web as the feeling of belonging and, thereby, contributes to the proliferation of various internal conclicts. Cfr. SYMONIDES, Janusz. New Human Rights. dimensions, obstacles and challenges: introductory remarks. In: SYMONIDES, Janusz (Ed.). Human Rights: new Dimensions and challenges. UNESCO, 1998. p. 30. 
y, en consecuencia, como una más de las formas de occidentalización. Una de las soluciones tiene que pasar por el rechazo de fundamentalismos occidentalistas.

A su vez, existe una versión más crítica y consciente de la herencia liberal que defiende una universalización diferenciada en los desarrollos puntuales o políticas concretas de aplicación de los derechos humanos.

Por otro lado, los defensores del relativismo radical, niegan cualquier tipo de legitimidad al proceso de la globalización, en todas sus vertientes, incluyendo los derechos humanos dentro del mismo proceso, rechazando su universalización. En sus versiones más fundamentalistas se oponen, incluso, a la universalización diferenciada o cosmopolita de los derechos humanos. Posiciones que han desembocado en el multiculturalismo comunitarista o relativista y en los nacionalismos radicales que constituyen, en nuestra opinión el cáncer de los derechos humanos.

En realidad, las doctrinas relativistas radicales se han hecho sentir más a lo largo de las ultimas dos décadas, probablemente como reacción a la globalización sobre patrones occidentales.

Sin embargo, en este ámbito existen posturas relativistas moderadas que sostienen un nacionalismo moderado o un multiculturalismo flexible y abierto, a semejanza del universalismo diferenciado.

Nuestra tesis es que, obviamente, las dos vertientes en sus versiones fundamentalistas son totalmente incompatibles, excluyentes e injustificables desde un punto de vista reflexivo. (Nuestra posición, la hemos presentado ya, y, nos parece que la solución pasa por la adopción de una lógica universalista que respete la diferencia cultural).

Lo que resulta lamentable es que el resultado de algunos de los planteamientos hayan implicado una confusión de valores y consecuentemente, han conducido a una errónea inclusión de los derechos humanos, en su versión actual, como una pieza más del neoliberalismo.

Otra de las cuestiones en que la globalización ejerce un efecto directo sobre los derechos humanos es la de las implicaciones que acarrea para los propios Estados. La autonomía y la capacidad de hacer política por parte de los estados están limitadas por la internacionalización económica y cultural. Las constantes liberalizaciones

7 Cfr. INGLIS, C. Multiculturalism: new policy responses to diversity, management of social transformations. Policy Papers, Paris, limitan, determinantemente, el control de los Estados sobre la economía, disminuyendo los envolvimientos de los mismos en los asuntos nacionales. En realidad, esta limitación de los Estados de sus políticas nacionales, principalmente en la intervención en cuestiones económicas, ejerce un efecto perverso sobre los derechos humanos y, en particular en la implementación de los derechos económicos, sociales y culturales. Este efecto perverso no es más que un resultado provocado por la cuestión de los mercados financieros libres y abiertos, que provocan un déficit que obliga a los estados a abdicar de programas sociales, culturales o de servicios de salud, para hacerle frente.

Globalization affects, and sometimes reduces,
the ability of governments to achieve desired
outcomes. While governments continue to provide
the overall framework in which the private sector
must operate, many important decisions are made
by the private sector, especially by companies
operating in an international context ${ }^{8}$.

Por lo tanto, resulta peligrosa la sustitución de los gobiernos por los mercados abiertos y libres para la implementación de los derechos humanos, pues tal implementación es en buena medida responsabilidad de los Estados y, los mercados no pueden sustituir a los Estados en la determinación de las políticas más importantes como las sociales, culturales o económicas.

El fenómeno de la globalización, potencia otro tipo de violaciones de los derechos humanos, por la competencia que desencadena entre las empresas de todo el mundo; la vulnerabilidad de los trabajadores, en particular, de las mujeres y de los grupos indígenas?

The emphasis on competitiveness and economic development has had especially negative effects on such vulnerable groups as migrant workers, women workers and indigenous peoples. Globalization has been cited as a contributing

n.4, 1996, p. 3 y ss.

8 Cita del informe presentado por el Secretario General de la UNESCO en la sesión especial de la Asamblea General n. 51 de junio de 1997. SYMONIDES, Janusz. New Human Rights. dimensions, obstacles and challenges: introductory remarks. In: SYMONIDES, Janusz (Ed.). Human Rights: new Dimensions and challenges. UNESCO, 1998.

9 Para desarrollar este tema: Cfr. LEARY, Virginia A. Globalization and Human Rights. In: SYMONIDES, Janusz (Ed.). Human Rights: new dimensions and challenges. UNESCO, 1998. p. 268 y ss. 
factor in violation of the right to life, the right to protection of health, minority rights $[\ldots]^{10}$.

No obstante, la globalización a pesar de sus efectos negativos, tiene una vertiente positiva, principalmente por su potencial en el combate a la pobreza, en la movilización de la opinión pública para la llamada de atención cuanto a violaciones de derechos humanos.

Some of the benefits of globalization contribute to the enhancement of human rights $[\ldots]$, increased trade often aids developing countries and thus contributes to the alleviation of poverty; increased communication permits countries to learn from each other. In the sphere of human rights, communication via E-mail and the Internet has permitted human rights advocates to call immediate attention to gross violation of human rights in their locality and to communicate with other human rights advocates throughout the world ${ }^{11}$.

\section{Multiculturalismo: El cáncer de los Derechos Humanos versus un pluralismo integrador razonable}

Actualmente, el relativismo cultural encuentra un refuerzo en las tesis multiculturalistas comunitaristas ${ }^{12}$. Su principal argumento pasa por la afirmación de que:

[...] en razón de la complejidad y diversidad de las sociedades actuales, donde convergen múltiples tradiciones culturales distintas entre sí que dan lugar a estructuras o configuraciones sociales netamente plurales y heterogéneas, deviene imposible apelar a la universalidad ${ }^{13}$.

Otra cuestión importante, tiene que ver con el significado de las expresiones multiculturalismo y pluralismo. Existe un mal entendimiento en considerar

10 Cfr LEARY, Virginia A. Globalization and Human Rights. In: SYMONIDES, Janusz (Ed.). Human Rights: new dimensions and challenges. UNESCO, 1998 p. 268.

11 LEARY, Virginia A. Globalization and Human Rights. In: SYMONIDES, Janusz (Ed.). Human Rights: new dimensions and challenges. UNESCO, 1998. p. 268.

12 La universalidad de los derechos humanos ha de hacer frente a otro tipo de impugnaciones o críticas todavía más arduas, $[\ldots]$ bajo la denominación de multiculturalismo. Cfr. SEOANE, José António. La universalidad de los Derechos Humanos y sus desafíos: los derechos especiales de las minorías. Persona y Derecho, n.38, p. 187-226, 1998, p. 206.

13 SEOANE, José António. La universalidad de los Derechos Humanos y sus desafíos: los derechos especiales de las minorías. Persona y Derecho, n.38, p. 187-226, 1998, p. 206. las dos expresiones sinónimas ${ }^{14}$. Pues las visiones multiculturalistas pueden en ciertas versiones separar, al paso que las pluralistas pretenden integrar y promover una convivencia armónica entre culturas.

El pluralismo es una seña de identidad de las sociedades libres ${ }^{15}$. Se refiere a una convivencia armónica de distintos grupos culturales, de distintas formas de pensar actuar y de concebir la vida. Pues todas las formas de vida tienen el derecho a expresarse libremente sin que ninguna se considere en la posesión exclusiva de la verdad, aunque pueda justificarse la elección de unas como mejores que otras. Asimismo, como subraya Sartori "una cultura pluralista implica una visión del mundo basada, en esencia, en la creencia de que la diferencia, y no la semejanza, el disenso, y no la unanimidad, el cambio y no la inmutabilidad, contribuyen a la buena vida" ${ }^{\text {. }}$.

Solamente se puede establecer un paralelo entre las expresiones "multiculturalismo" y "pluralismo" si se entiende multiculturalismo como hecho, como forma de caracterizar y registrar la existencia de múltiples culturas; o sea, haciendo referencia a la convivencia en un mismo país o región de tradiciones culturales distintas, indicando mezcla de culturas y de formas de ver la vida y valores distintos y a veces opuestos, de comparación y contrastación crítica entre culturas. En este caso el multiculturalismo no acarrea problemas a la

14 Hoy la palabra 'pluralismo' está muy de moda; lo que no quiere decir que se entienda bien. Al contrario. La prueba de ello, de eso mal entendimiento, está en creer que el pluralismo encuentra una continuación y su ampliación en el multiculturalismo, es decir, en una política que promueve las diferencias étnicas y culturales. Cfr. SARTORI, Giovanni. Pluralismo, Multiculturalismo e Estranei. Trad. de Ruiz de Azúa, Miguel Ángel. Madrid: Taurus, 2001. p. 7.

15 El pluralismo no hace más que recoger lo que ocurre en una sociedad democrática. Para Rawls cualquiera que sea la concepción de justicia, para tener viabilidad, tiene que tomar en cuenta la diversidad de doctrinas y la pluralidad de concepciones opuestas. Esta diversidad de doctrinas no es una mera circunstancia histórica que pronto vaya a desaparecer; es, creo, un rasgo permanente de la cultura pública de las democracias modernas. En las condiciones políticas y sociales aseguradas por las libertades y derechos fundamentales asociados históricamente con esos regímenes, la diversidad de opiniones persistirá y puede incrementarse. Un acuerdo público y viable sobre una única concepción general y comprehensiva sólo podría ser mantenido mediante el uso opresivo del poder estatal". Cfr. RAWLS, John. La Idea de Consenso por Superposición”. In: BETEGÓN, Jerónimo; PÁRAMO, Juan Ramón de (Coord). Derecho y moral: ensayos analíticos. Trad. de Juan Carlos Bayón. Barcelona: Ariel, 1990. p. 66.

16 Cfr. SARTORI, Giovanni, Los Fundamentos del Pluralismo. Leviatán: Revista de Hechos e Ideas, v. 2, n.61, 1995. p. 115. 
cuestión de la universalidad de los derechos humanos e incluso representa un fenómeno positivo.

El problema surge cuando se considera el multiculturalismo un valor prioritario ${ }^{17}$ y siempre que vaya acompañado de una postura relativista ${ }^{18}$ o sea, el multiculturalismo como doctrina. Pues asimismo, los dos conceptos colisionan. El pluralismo, considera positiva la diversidad, sin suponer que ésta tenga que necesariamente multiplicarse. Es un proceso que se orienta por las bases de la tolerancia racional ${ }^{19} \mathrm{y}$, no por aquella tolerancia ilimitada ${ }^{20}$ que pretende el multiculturalismo con el reto de permitir y valorar las demás practicas culturales, llegando al punto de tolerar a quienes no toleran ${ }^{21}$. Pues la tolerancia debe tener como limites comportamientos que no se concilien con la dignidad. Como afirma Garzón Valdés hay que optar

17 Cfr. SARTORI, Giovanni. Pluralismo, Multiculturalismo $e$ Estranei. Trad. de Ruiz de Azúa, Miguel Ángel. Madrid: Taurus, 2001. p. 61.

18 Está bastante claro que no podemos estar tranquilos ante el desafío del multiculturalismo relativista a la universalidad de los derechos humanos. Independientemente de que la postura envuelva también intereses políticos y sociales disfrazados de luchas por el poder y, en definitiva, postulados ideológicos similares a los que ellos acusan a la tradición occidental, hay que intentar introducirse en el terreno teórico, respondiendo con argumentos racionales a sus argumentos. Cfr. FERNÁNDEZ GARCÍA, Eusebio. dignidad bumana y ciudadanía cosmopolita, en Instituto de Derechos Humanos. Madrid: Dykinson, 2001. (Bartolomé de las Casas, n. 21). p. 69.

19 Rawls, hace una distinción entre "pluralismo razonable y 'pluralismo como tal', optando por la primera acepción, pues sostiene que una sociedad democrática se basa en algunos puntos de vista que tienen que ser universales y que requieren un consenso de todos. Cfr. RAWLS, John. Political liberalism. Nueva York: Columbia University Press. trad. en castellano: El Liberalismo Político. p. 3639. Que en nuestra acepción de esos universales hacen parte los derechos humanos básicos.

20 Se suele defender el multiculturalismo en nombre de la tolerancia. Sin embargo, una tolerancia ilimitada termina por destruirse a sí misma. La tolerancia tiene como fundamento, no el relativismo, sino en el respeto de los que tienen distintas creencias. Pero, una sociedad democrática y liberal no debe tolerar cualquier práctica bajo el pretexto de respeto al pluralismo. En una sociedad liberal el Estado no debe ser totalmente neutral sino que debe promover los fines, los valores y principios que merezcan una valoración superior, y estos constituyen los límites a la tolerancia.

21 Charles Taylor es el representante más emblemático del multiculturalismo. Su trabajo más representativo de esta tesis es 'The Politics of Recognition'. Según este autor, las demás culturas, no solo merecen el mismo respeto, sino igual valor. Esto, es sinónimo de un relativismo absoluto y, incluso, absurdo que destruye la noción de valor y obliga a que se pacte con las barbaries que se practican escudadas de rasgo cultural. Cfr. TAYLOR, Charles. The politics of recognition. In: GUTMANN, A. Multiculturalism: examining the politics of recognition. Princeton: Princeton University Press, 1994. p. 25-73. por "el rechazo de la tolerancia boba y la práctica de una tolerancia activa que no tenga reparos en rechazar lo intolerable" 22 .

Por lo tanto, el multiculturalismo, concebido como un proyecto "creador de diversidades que, precisamente, fabrica la diversidad, porque se dedica a hacer visibles las diferencias y a intensificarlas" ${ }^{23}$, representa una fuerte amenaza a la universalidad de los derechos humanos, una vez que, al supervalorar las diferencias existentes entre culturas, y disminuye y desvaloriza la importancia de compartir valores comunes. Este multiculturalismo segregador, no es más que una nueva expresión doctrinaria que asume el relativismo cultural. Los derechos humanos marcan el límite del reconocimiento entre los pueblos ${ }^{24} \mathrm{y}$, consecuentemente de los contenidos del propio multiculturalismo.

Menos ambiguo, el discurso del pluralismo, valora de forma positiva la diversidad, sin buscar intensificarla artificialmente. El "pluralismo razonable" propuesto por Rawls, se encuadra perfectamente con la defensa de unos derechos humanos básicos válidos para todos. Pues, a pesar de la constatación de la existencia de sociedades diversificadas, se mantiene que algunos puntos de vista tienen que ser universales y, requieren un consenso de todos, principalmente el respeto de los derechos que corresponden a toda persona en virtud de su dignidad.

La respuesta ajustada al fenómeno de la diversidad no pasa por la separación entre los distintos grupos culturales como abogan los multiculturalistas radicales o excluyentes. La solución pasará, como veremos a continuación por una integración respetuosa de las distintas realidades culturales.

\section{La amenaza multiculturalista a la integración respetuosa $^{25}$}

Como hemos antecipado ya cierto multiculturalismo radical es la forma reciente y posmoderna bajo la cual

22 Cfr. GARZÓN VALDÉS, Ernesto. Cinco confusiones acerca de la relevancia moral de la diversidad cultural. Claves de Raz̧ón Práctica. n.74, 1997. p.22.

23 SARTORI, Giovanni. Pluralismo, Multiculturalismo e Estranei. Trad. de Ruiz de Azúa, Miguel Ángel. Madrid: Taurus, 2001. p. 123.

24 RAWLS, John. The law of peoples, en Human Rights. Nueva York: Basic Books, 1993. p. 71.

25 Decidimos usar la expresión 'integración respetuosa' para que no quede duda que la integración respetuosa tiene una finalidad totalmente distinta de la de asimilación. 
se disfraza el relativismo clásico. Se puede establecer un paralelo entre ese multiculturalismo y el escepticismo. El escéptico concibe la duda como una expresión de la verdad, quebrando de esta forma la propia duda, o sea, la ausencia de la verdad es la verdad. A su vez, el multiculturalista radical concibe como verdadera su forma de plantear la convivencia entre culturas, como absoluta, universal y no relativa. Y de la misma forma, estos multiculturalistas

de la constatación de la injusticia y de la opresión,
aunque no siempre indagan correctamente sus
causas ni determinan cabalmente sus responsables,
pasan al elogio de los valores y formas de vida de
los oprimidos ${ }^{26}$.

La mayor parte de las culturas no son puertas cerradas sino ventanas abiertas a la comprensión de otras. El cambio de experiencias entre culturas no limita sino que amplía la visión propia. Como escribió N. Humphrey:

¿Cómo podría usted (producto de la cultura occidental) comparar su comprensión de la psique humana con, por ejemplo, la de un chamán yanomano de la selva amazónica? ¿Quién posee una mayor comprensión del sexo, la guerra, la política familiar, el crimen, etc., y quién ha llegado más lejos recorriendo y atravesando las fronteras que separan a los individuos? Yo no dudaría en contestar que usted. Para ello usted, a diferencia del chamán yanomano, digamos que ha viajado con Defoe, amado con Shakespeare, cantado con Verdi, reído con Runyan, y observado el mundo a través de los ojos de Rembrandt o Van Gogh. Desde su más temprana juventud ha sido partícipe de una cultura que, de hecho, y puede que intencionalmente, ha introducido en cada uno de nosotros la experiencia acumulada de multitud de personas ${ }^{27}$.

El multiculturalismo relativista por ser una doctrina adversa a la integración que respete la diversidad y al diálogo intercultural, promueve "la retórica del separatismo cultural" ${ }^{28}$.

26 Cfr. SÁNCHEZ CÁMARA, Ignacio, Integración o multiculturalismo. Persona y Derecho, n.49, 2003, p. 172.

27 Cfr. HUMPHREY, Nicholas. La mirada interior. Madrid: Alianza, 1995. p. 132.

28 Cfr. HUGHES, Robert. Culture of complaint: the fraying of America. Trad. de Ramón de España. Nueva York: Oxford University Press, 1993. p. 97.
La inmigración no es solamente un asunto de derechos, sino igualmente de deberes. Es necesario recordar y exigir el deber de respetar los valores fundamentales del país de acogida. Sin embargo, no se debe confundir asimilación e integración respetuosa. La asimilación, es un fenómeno que exige la aculturación de los inmigrantes y la consecuente perdida de sus pautas culturales. Pretende una unificación, una uniformidad cultural, a través de la imposición de la cultura de la sociedad de acogida. La asimilación es totalmente opuesta a la dignidad humana. En realidad el valor del diálogo intercultural es muy importante como factor de enriquecimiento, hecho que el asimilacionismo veda.

El respeto a la diversidad cultural, implica también el respeto a los valores y principios del grupo cultural o país de acogida. Los inmigrantes deberán respetar las normas, valores y principios constitucionales del derecho positivo. Todo esto resulta amenazado por la doctrina multiculturalista radical, pues:

entraña la concesión de un derecho ilimitado a los integrantes de toda comunidad cultural que vivan en el seno de una sociedad democrática, a conservar sus creencias y costumbres con independencia de su conformidad con los valores democráticos y liberales [...]. El multiculturalismo produce la segregación entre culturas, convertidas en compartimentos estancos, la marginación y la constitución de guetos ${ }^{29}$.

Por otro lado, la doctrina multiculturalista radical rechaza la integración, incluso si el emigrante la desea, una vez que para sus seguidores integración y asimilación representan lo mismo, pero bajo distintos nombres.

A su vez, sin la regla democrática de respetar a las minorías que aspiran en convertirse en mayoría las propias democracias caminarían hacía la "tiranía de la mayoría" 30 , y, además esta es una afirmación clásica de la tradición liberal.

La protección de los grupos minoritarios es una exigencia liberal que puede alcanzarse mediante el reconocimiento de la autonomía moral de los individuos, de la promoción de la igualdad de los derechos humanos entre individuos de los grupos minoritarios con relación a los de los individuos pertenecientes al

29 SÁNCHEZ CÁMARA, Ignacio, Integración o multiculturalismo. Persona y Derecho, n.49, 2003, p. 175.

30 Cfr. SÁNCHEZ CÁMARA, Ignacio. 'Democracia, mayorías, minorías'. In: Ollero, Andrés (Org.). Valores en una Sociedad Plural. Madrid: FAES, 1999. p. 361-372. 
grupo mayoritario y a través de una tolerancia racional que, por un lado, permita el ejercicio y desarrollo de las especificidades de los grupos minoritarios pero que por otro, imponga un límite a esas especificidades no permitiendo las que no respeten la dignidad humana.

Por otro lado, la democracia liberal solamente puede fundamentarse en valores y principios compartidos. En especial de los derechos básicos de la persona, pero, el pluralismo es uno de los principios de la sociedad liberal, pues admite la diversidad sin suprimir valores y principios compartidos, pero, que quede claro que aunque pluralismo sea vivir juntos en la diferencia no puede olvidarse que existe una contrapartida, entrar en una sociedad pluralista es un adquirir y un conceder; pues, existe una determinada frontera que el pluralismo no puede pasar: Los derechos humanos.

Como explica Sartori, el multiculturalismo, “invierte la dirección de marcha pluralista que sustancia a la civilización liberal" ${ }^{31}$, cambiando integración por política de reconocimiento. "La política de reconocimiento por un lado y la integración por otro se excluyen recíprocamente, entonces querer la primera es no querer la segunda ${ }^{32}$.

El respeto a la ley constituye un límite infranqueable para el multiculturalismo y sus pretensiones de tolerancia desmesurada. A su vez la integración respetuosa, como alternativa al activismo multiculturalista, se puede ver como un derecho, en el que la sociedad de acogida tendrá que promover la igualdad entre extranjeros y nativos en el disfrute de los derechos básicos, pero respetando las diferencias culturales entre los distintos

31 Cfr. SARTORI, Giovanni. Pluralismo, Multiculturalismo e Estranei. Trad. de Ruiz de Azúa, Miguel Ángel. Madrid: Taurus, 2001. p. 129.

32 ARTORI, Giovanni. Pluralismo, Multiculturalismo e Estranei. Trad. de Ruiz de Azúa, Miguel Ángel. Madrid: Taurus, 2001. p. 130. colectivos sociales, siempre que esas diferencias culturales no atenten contra la dignidad y permitan la supervivencia de la sociedad de acogida.

Como advierte Sánchez-Cámara esto constituye un doble dilema, pues, "por un lado, el deber de acogida, exigencia de la civilización liberal (sociedad abierta), puede convertirse en una eventual amenaza para ella. Por otro, el pluralismo y la tolerancia son principios y exigencias de la civilización liberal que, fuera de sus justos límites, pueden amenazarla" ${ }^{33}$.

La realidad es que en el seno de las sociedades abiertas la tendencia es cada vez más la articulación de políticas de convivencia entre distintas realidades culturales. Las reivindicaciones de distintos grupos culturales son cada vez mayores, reivindicaciones esas que tienen como principal argumento, casi siempre las especificidades culturales. Como por ejemplo la escisión del clítoris, la poligamia, la negación de transfusiones de sangre a menores, los tratamientos degradantes a las mujeres.

Si se concede un derecho ilimitado en el sentido de vivir contra los principios y valores esenciales de la sociedad de acogida, no se encuentran razones para prohibir políticas segregacionistas. Por ejemplo, podría parecer legítimo crear instituciones sólo para personas occidentales, pues ¿si es lícito crear un gueto musulmán, porque no un gueto para occidentales?

Los inmigrantes deben gozar de los mismos derechos básicos que los ciudadanos nativos pero no más, incluido el derecho (limitado como todos los derechos) del respeto a la propia cultura en los términos apuntados, no segregadores.

33 SÁNCHEZ CÁMARA, Ignacio, Integración o multiculturalismo. Persona y Derecho, n.49, 2003, p. 181. 


\section{Referencias}

BARY, W. T.; WEIMING, T. (Ed). Confucianism and Human Rights. Nueva York: Columbia University Press, 1998.

COMBESQUE, Marie Agnès. Introduction aux Droits de l'Homme. Paris: Syros Jeunesse, 1998.

DAHRENDORF, R. Class and class conflict in industrial society. Londres: Routledge \& Kegan Paul, 1959.

FERNÁNDEZ GARCÍA, Eusebio. Dignidad bumana y ciudadanía cosmopolita, en Instituto de Derechos Humanos. Madrid: Dykinson, 2001. (Bartolomé de las Casas, n. 21).

GARZÓN VALDÉS, Ernesto. Cinco confusiones acerca de la relevancia moral de la diversidad cultural. Claves de Razón Práctica, n.74, 1997.

HUGHES, Robert. Culture of complaint: the fraying of America. Trad. de Ramón De España. New York: Oxford University Press, 1993.

HUMPHREY, Nicholas. La mirada interior. Madrid: Alianza, 1995.

INGLIS, C., Multiculturalism: new policy responses to diversity, management of social transformations. Policy Papers, Paris, n.4, 1996.

KABUNDA, M. Badi. Derechos Humanos en Africa. Bilbão: Universidad de Deusto, 2000.

LEARY, Virginia A. Globalization and Human Rights. In: SYMONIDES, Janusz (Ed.). Human Rights: new dimensions and challenges. UNESCO, 1998.

RAWLS, John, La idea de consenso por superposición. In: BETEGÓN, Jerónimo; RAMÓN DE PÁRAMO,
Juan (Coord). Derecho y moral: ensayos analíticos. Trad.. de Juan Carlos Bayón. Barcelona: Ariel, 1990.

RAWLS, John. Political liberalism. Nueva York: Columbia University Press, 1996.

RAWLS, John. The Law of Peoples. In: SHUTE, S.; HURLEY, S.(Ed). Human Rights. Nueva York: Basic Books, 1993.

SÁNCHEZ CÁMARA, Ignacio Democracia, mayorías, minorías. In: OLLERO, Andrés (Org.). Valores en una sociedad plural. Madrid: FAES, 1999.

SÁNCHEZ CÁMARA, Ignacio. Integración o multiculturalismo. Persona y Derecho, n. 49, 2003.

SARTORI, Giovanni. Los Fundamentos del Pluralismo. Leviatán: Revista de Hechos e Ideas, v.2, n.61, 1995.

SARTORI, Giovanni. Pluralismo, multiculturalismo e estranei. Trad. de Ruiz de Azúa, Miguel Ángel. Madrid: Taurus, 2001.

SEOANE, José Antonio. La universalidad de los Derechos Humanos y sus desafíos: los derechos especiales de las minorías. Persona y Derecho, n.38, p. 187-226, 1998

SYMONIDES, Janusz. New Human Rights. dimensions, obstacles and challenges: introductory remarks. In: SYMONIDES, Janusz (Ed.). Human Rights: new dimensions and challenges. UNESCO, 1998.

TAYLOR, Charles. The politics of recognition. In: GUTMANN, A. Multiculturalism: examining the politics of recognition. Princeton: Princeton University Press, 1994. 


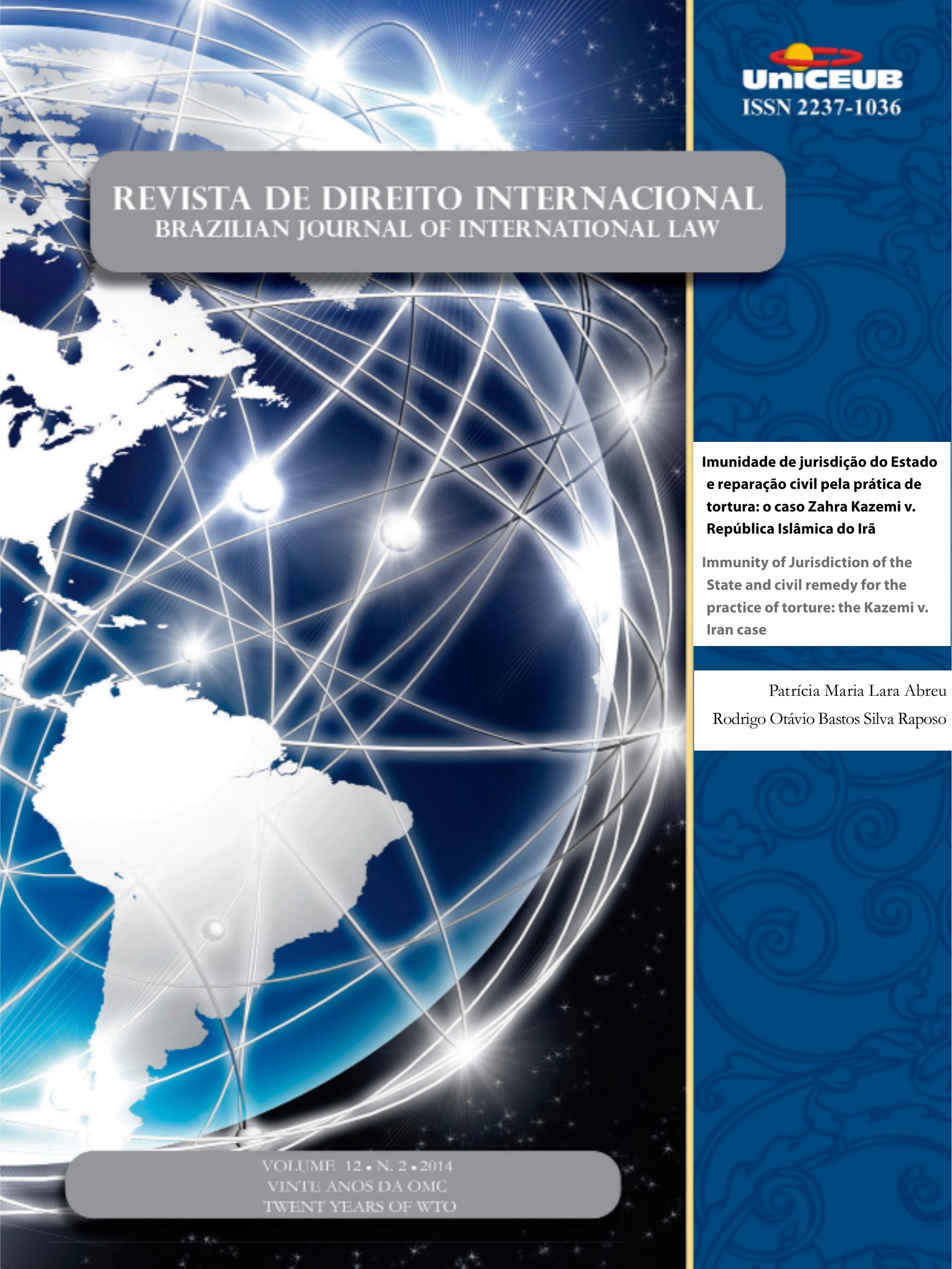




\title{
Imunidade de jurisdição do Estado e reparação civil pela prática de tortura: o caso Zahra Kazemi v. República Islâmica do Irã*
}

\author{
Immunity of Jurisdiction of the State and civil \\ remedy for the practice of torture: the Kazemi v. \\ Iran case
}

\author{
Patrícia Maria Lara Abreu** \\ Rodrigo Otávio Bastos Silva Raposo***
}

\section{Resumo}

A Suprema Corte do Canadá, ao julgar o pedido de reparação civil decorrente da prisão, estupro e morte de Zahra Kazemi, sob custódia da República Islâmica do Irã, em 2003, confirmou o posicionamento de instâncias anteriores da justiça canadense, que decidiram pela manutenção da imunidade de jurisdição do Estado iraniano mesmo diante das alegações de violação de jus cogens e de incidência de uma das exceções à imunidade de jurisdição previstas no Canada State Immunity Act. O julgamento ilustra a tendência atual de manutenção da prerrogativa de imunidade de jurisdição dos Estados em matéria civil, mesmo diante da prática de tortura.

Palavras-chave: Caso Kazemi. Tortura. Imunidade de Jurisdição.

\section{Abstract}

The Supreme Court of Canada have already done its judgment on the plea for civil damages arising out of the prison, rape and death of Zahra Kazemi under custody of the Islamic Republic of Iran in 2003, confirming the results given by earlier instances of the Canadian justice, which have decided to maintain the immunity from jurisdiction of the Iranian State despite alleged jus cogens violations and possible occurrence of an exception to sovereign immunity stated in Canada State Immunity Act. The trial illustrates the current trend of maintaining the prerogative of jurisdictional immunity of States in civil matters, even in face of the practice of torture.

Keywords: Kazemi Case. Torture. State Immunity.

* Recebido em 14.07.2014
Aceito em 02.12 .2014

** Acadêmica do Curso de Direito da Universidade Estadual do Maranhão (UEMA).

*** Professor dos Cursos de Direito da Universidade Estadual do Maranhão (UEMA) e da UNDB (MA). rodrigobastosraposo@hotmail.com.

\section{Introdução}

Normas de direitos humanos com caráter de jus cogens podem justificar o afastamento da imunidade de jurisdição de um Estado soberano? Essa questão, que foi razão de discussão no julgamento do caso Alemanha versus Itália na Corte Internacional de Justiça em 2012 ${ }^{1}$, chegou mais uma vez a uma Corte Suprema, dessa vez a do Canadá, onde aguarda julgamento. Trata-se de um pedido de

1 CORTE INTERNACIONAL DE JUSTIÇA. Jurisdictional Immunities of the State (Germany v. Italy: Greece intervening): Application Instituting Proceedings. 2008. Available at: <http://www.icj-cij.org/ docket/files/143/16883.pdf>. Last access on: 29 maio 2014. 
indenização pela prática de tortura e consequente morte de uma jornalista canadense no Irã. A ação foi apresentada pelo espólio e pelo filho da vítima e envolve a interpretação do Canada State Immunity Act e a possibilidade de alargar as hipóteses de exceção à imunidade de jurisdição em vista da prática de tortura ${ }^{2}$.

Com relação à interpretação da legislação canadense, a questão diz respeito a uma hipótese de competência prevista na legislação desse país pela qual um Estado não fará jus a imunidade se houver causado dano no território do Canadá. No caso, embora a vítima de tortura estivesse no Irã, seu filho, que é autor da ação indenizatória junto com o espólio, estava em território canadense e lá sofreu com a prisão, com os maus tratos e com a morte de sua mãe. Resta às cortes canadenses responderem se esse sofrimento foi causado pelo Irã em território canadense e se esse sofrimento subsumese na hipótese de competência acima mencionada.

Quanto à ampliação das hipóteses de exceção à imunidade de jurisdição em decorrência da prática de tortura, esta remete à discussão sobre o possível conflito entre as normas de jus cogens e as normas relativas à imunidade de jurisdição. O jus cogens é composto pelas normas peremptórias de direito internacional, cuja derrogação só é possível por outra norma da mesma natureza. Essa caracterização do jus cogens, constante do artigo 53 da Convenção de Viena sobre Direito dos Tratados ${ }^{3}$, traduz dois elementos fundamentais dessa categoria normativa: sua obrigatoriedade e sua inderrogabilidade. Ambos os elementos nascem dos mesmos componentes objetivo e subjetivo que formam o costume internacional, mas não se prendem a eles, pois frente a essas normas não há possibilidade de objeção e, uma vez em vigor, a sua derrogação exige uma nova manifestação de vontade da comunidade internacional, dotada da mesma dignidade.

A noção de normas peremptórias é caudatária da ideia de comunidade internacional, que por sua

2 CANADÁ. Supreme Court of Canada. Estate of the Late Zabra (Ziba) Kazemi, et al. v. Islamic Republic of Iran, et al.: 2014 SCC 62. Available at: <http://scc-csc.lexum.com/scc-csc/scc-csc/en/ item/14384/index.do>. Last access on: 26 out. 2014.

3 Convenção de Viena sobre o Direito dos Tratados de 1969, art. 53: É nulo um tratado que, no momento de sua conclusão, conflite com uma norma imperativa de Direito Internacional geral. Para os fins da presente Convenção, uma norma imperativa de Direito Internacional geral é uma norma aceita e reconhecida pela comunidade internacional dos Estados como um todo, como norma da qual nenhuma derrogação é permitida e que só pode ser modificada por norma ulterior de Direito Internacional geral da mesma natureza. vez é uma concepção da sociedade internacional em torno da qual se debate desde o primeiro quartel do século XX. Depois de quase um século de evolução da doutrina jus-internacionalista, sob o impacto de enormes mudanças culturais, políticas e econômicas, e sob o peso de tragédias humanitárias sucessivas, cuja recordação, infelizmente, não chega a esvanecer entre os episódios, a existência de tal categoria de normas já não é contestada. Os debates travam-se agora em torno da definição dos contornos dessa categoria normativa e das obrigações que dela decorrem para os Estados.

Quanto à identificação das normas de jus cogens, há visões mais expansivas e visões mais restritivas. As primeiras elaboram a categoria de modo amplo, buscando dar fundamento legal a diversos pleitos nos campos dos direitos humanos, do direito humanitário, do direito ao desenvolvimento, ao trabalho, à saúde e ao meio ambiente, de forma a superar as reticências dos Estados à obrigatoriedade desses direitos. As últimas tratam a categoria com circunspecção, procurando limitar seu alcance às prescrições jurídicas de conteúdo mais essencial e indiscutível e alertando para o valor jurídico fundamental do conceito de soberania.

Embora relevante, a questão da identificação das normas de jus cogens foge ao objeto deste estudo, que irá focar a questão das obrigações decorrentes dessa categoria normativa e, principalmente, como irá o judiciário canadense resolver o alegado conflito entre as normas internacionais que vedam a prática da tortura e as normas internacionais que preveem a imunidade de jurisdição dos Estados. O julgamento do caso Alemanha $v$. Itália é bem conhecido e sabese que a maioria dos juízes da Corte Internacional de Justiça posicionou-se de modo a distinguir entre o campo de atuação das normas de jus cogens, as quais teriam como foco condutas materiais, e o campo de atuação das normas relativas à imunidade de jurisdição, que afetariam questões procedimentais. É bem sabido também que a própria Corte destacou que o seu papel não é criar normas, mas sim, aplicar as vigentes. No entanto, em seu julgamento, a Corte também ponderou que o direito internacional é um sistema normativo em evolução e que o julgamento não liquida a questão.

De fato, se levar-se em conta que as normas de jus cogens possuem uma natureza fortemente costumeira, chegar-se-á facilmente à conclusão de que a prática dos Estados, isto é, a forma como os Estados as interpretam e aplicam, irá alterar o teor delas. Por 
isso, quando a Itália julgou processos de reparação civil contra a Alemanha pelos crimes cometidos na II Guerra Mundial, a Corte Internacional de Justiça entendeu que tais atos violavam as obrigações da Itália perante a Alemanha. No entanto, se tribunais nacionais passarem a considerar o impacto das normas peremptórias de direito internacional para afastar a imunidade de jurisdição, o entendimento do alcance e da aplicação dessas normas irá se alterar. Por isso, em se tratando da relação entre imunidade de jurisdição e jus cogens, cada julgamento nacional conta para a evolução do direito internacional na matéria.

A análise do Caso Kazemi se mostra, desta forma, interessante na medida em que as argumentações desenvolvidas ao longo do seu desenrolar são frutos não de uma situação isolada, mas da construção de uma jurisprudência no Direito Canadense sobre o assunto, já enfrentado anteriormente por aquele país em casos como Bouzariv. Islamic Republic of Iran ${ }^{4}$, R.v.Hape, [2007 $]^{5}$, entre outros, em consonância com aquilo que debatido e decidido em outros países, em cortes regionais e até mesmo na própria Corte Internacional de Justiça ${ }^{6}$, o que permite que a partir dele se possa traçar o panorama geral acerca da possibilidade ou não de caracterização da prática de tortura como condição suficiente para constituir exceção à imunidade de jurisdição do estado estrangeiro.

Tendo isso em vista, o presente trabalho cuidará da análise dos institutos da imunidade de jurisdição dos estados soberanos e da prática da tortura a partir das decisões prolatadas nas Cortes canadenses quando do julgamento do Caso Kazemi. Neste ínterim, analisarse-ão, além dos conceitos e fundamentos destes institutos, conceitos e fundamentos de institutos correlatos como o das normas de jus cogens, soberania e direitos humanos, bem como os argumentos das partes em litígio e a jurisprudência construída a partir destes.

4 CANADÁ. Court of Appeal for Ontario. Bouzari v. Islamic Republic of Iran (2004), 71 O.R. (3d) 675. Available at: <http:// www.canlii.org/en/on/onca/doc/2004/2004canlii871/2004canl ii871.html>. Last access on: 28 maio 2014.

5 CANADÁ. Supreme Court of Canda. R.v.Hape, [2007] 2S.C.R. 292, 2007 SCC 26. Available at: <http://scc-csclexum.com/scc-csc/scc-csc/ en/item/2364/index.do?r= AAAAAQAjQm91emFyaSB2L iBJc2xhbWljI FJlcHVibGljIG9mIElyYW4AAAAAAQ>. Last access on: 28 maio 2014.

6 CORTE INTERNACIONAL DE JUSTIÇA. Jurisdictional Immunities of the State (Germany v. Italy: Greece intervening): Application Instituting Proceedings (2008). Available at: <http:// www.icj-cij.org/docket/files/ 143/16883.pdf>. Last access on: 29 maio 2014
Apresentar-se-á primeiramente um resumo dos fatos, com apresentação das partes e seus argumentos, das questões procedimentais da jurisdição canadense pertinentes, procedendo-se à individualização das condutas e a uma breve síntese sobre a questão da tortura no plano internacional contemporâneo frente às noções de jus cogens e imunidade de jurisdição do Estado. O capítulo seguinte cuidará do desenvolvimento do Caso Kazemi em primeiro grau, com análise dos fundamentos da acusação e da defesa, em especial no que toca à previsão legal sobre o tratamento dispensado à imunidade de jurisdição no Canadá e à pretensa possibilidade de normas de jus cogens configurarem exceção àquela. Em seguida, abordar-se-á, a partir dos fundamentos da Corte de Apelação, a questão da constitucionalidade das normas que asseguram a imunidade de jurisdição frente à violação de direitos constante da Carta Maior canadense e seus instrumentos, e da definição e extensão das hipóteses de competência, enquanto exceções à garantia da imunidade de jurisdição. Por fim, e tendo por base todos os argumentos sustentados nas instâncias anteriores, analisar-se à questão enfrentada pela Suprema Corte Canadense da adequação do SIA ao ordenamento jurídico-constitucional canadense, notadamente quanto a questões de segurança pessoal e violação a princípios fundamentais de justiça.

\section{0 caso Kazemi e a disputa entre $j u s$ cogens e imunidade de jurisdição}

Antes de se analisar propriamente o posicionamento do Estado canadense em relação à manutenção da imunidade de jurisdição do estado estrangeiro e sua extensão aos servidores que agindo nesta qualidade praticarem atos de tortura, a partir dos fundamentos jurídicos utilizados nas decisões prolatadas ao longo do Caso Kazemi, importa que sejam delineadas as bases fáticas e teóricas tidas por plano de fundo de referida argumentação.

Neste condão, a exposição cronológica dos acontecimentos que deram azo ao caso, bem como aqueles efetivados perante a Justiça canadense, e a delimitação dos institutos teóricos fundamentais para a resolução da temática, notadamente o da própria imunidade de jurisdição e das normas de jus cogens, como a proibição da prática de tortura, se mostram imprescindíveis. 
Portanto, a função deste item é situar o leitor em relação aos fatos e ao andamento do caso na justiça canadense, o que é feito no item 2.1, bem como introduzir a questão teórica de fundo, que é a disputa entre as categorias jus cogens e imunidade de jurisdição, o que é feito no item 2.2. A partir desses elementos, espera-se que o leitor compreenda a importância do caso e o contexto maior no qual sua análise está inserida.

\subsection{O assassinato de Zahra Khazemi e a busca por reparação civil na justiça canadense}

Em 2003, Zahra Kazemi, fotógrafa iraniana e canadense, foi presa no Irã, torturada, abusada sexualmente por autoridades do Estado iraniano, vindo a falecer em consequência dos ferimentos causados por estes atos. O espólio de Zahra Kazemi e seu filho iniciaram, na província de Quebec, uma ação de responsabilidade civil contra o Estado do Irã, seu Chefe de Estado e outras autoridades. Em sua ação, os autores pediram indenização pela dor e sofrimento que os atos do Irã e de seus agentes causaram e pediram ainda, conforme permite o direito canadense, que a condenação fosse substancialmente ampliada de modo a tornar-se punitiva e exemplar. Ao contestar, o Irã e os demais demandados solicitaram o arquivamento da ação, sob o fundamento de que esta era vetada pelo princípio da imunidade de jurisdição do Estado, como definido no artigo 3 do Canada State Immunity Act (doravante SIA). O dispositivo estabelece, como um preceito geral, a proibição do conhecimento de ações contra Estados estrangeiros perante as cortes daquele país, salvo consentimento expresso daqueles neste sentido. ${ }^{7}$ Em sua réplica, os requerentes afirmaram que repelir sua pretensão com base no SI $A$ seria uma afronta à Constituição, pois eles seriam privados do direito de buscar, perante o judiciário canadense, reparação contra os danos sofridos. ${ }^{8}$

Assim, alegaram os requerentes estar fundado seu direito à persecução civil frente o Estado iraniano e suas autoridades pela tortura, abuso e morte da Sra. Kazemi, bem como pelo dano psicológico sofrido por

7 A análise deste dispositivo será feita mais detidamente no item 3.1 deste trabalho.

8 CANADÁ. Supreme Court of Canada. Estate of the Late Zahra (Ziba) Kazemi, et al. v. Islamic Republic of Iran, et al: Summary. Available at: <http://www.scc-csc.gc.ca/case-dossier/info/sumsom-eng.aspx?cas $=35034>$. Last access on: 29 maio 2014 . seu filho em decorrência daqueles acontecimentos, suscitando, ainda, a possível incongruência do SIA com dispositivos da Constituição canadense e de sua Carta de Direitos e Liberdades Individuais e com o entendimento do Direito Internacional de considerar jus cogens a proibição do uso da tortura, de forma que a aplicação da imunidade de jurisdição em casos como o presente consistiria afronta ao ordenamento jurídico internacional.

Buscando referida reparação, ingressaram com a ação na Quebec Superior Court of Justice, corte de primeira instância da província do Quebec, dotada de competência territorial e material para julgar o caso.? Esta, em decisão da lavra do juiz Robert Mongeon, rejeitou a ação no tocante ao espólio da Sra. Kazemi, por entender que, uma vez que as agressões e o evento morte se deram em Teerã, e não em território canadense, como exige o art. 6(a) do $S I A,{ }^{10}$ o evento em que se funda sua pretensão não se amolda à exceção contida naquele artigo.

No tocante ao Sr. Hashemi, entretanto, entendeu o juiz Robert Mongeon estarem preenchidos os requisitos para se afastar a imunidade de jurisdição do Irã, uma vez que as ações praticadas contra a Sra. Kazemi, no Irã, repercutiram na integridade pessoal de seu filho no Canadá, de forma que consentido o prosseguimento da ação relativamente aos pedidos levados a feito com base no direito do Sr. Hashemi.

Os requeridos e os requerentes apelaram à Quebec Court of Appeal, que é competente para julgar os recursos contra as decisões da Quebec Superior Court. ${ }^{11}$

9 Art. 75 The domicile of a person, for the exercise of his civil rights, is at the place of his principal establishment. Art. 83 The parties to a juridical act may, in writing, elect domicile with a view to the execution of the act or the exercise of the rights arising from it. Election of domicile is not presumed. CANADA. Quebec Civil Code. Disponível em: <http://www2. publicationsduquebec.gouv.qc.ca/dynamicSearch/telecharge. php?type=2\&file=/CCQ_1991/CCQ1991_A.htm>. Acesso em: 12 jun. 2014.

Art. 23 The jurisdictions of the Court of Appeal, the Superior Court and the Court of Québec extend throughout Québec; the jurisdiction of a municipal court is limited to a designated territory. Art.31 The Superior Court is the court of original general jurisdiction; it hears in first instance every suit not assigned exclusively to another court by a specific provision of law. CANADA. Quebec Code of Civil Procedure. Available at em: <http://www2. publicationsduquebec.gouv.qc.ca/dynamicSearch/telecharge. php?type $=2 \&$ file $=/$ C_25/C25_A.HTM $>$. Last access on: 12 jun. 2014.

10 A análise deste dispositivo se dará de forma mais detida no item 3.1 deste trabalho.

11 Art. 25 The Court of Appeal is the general appeal tribunal for Québec; it hears appeals from any judgment from which an appeal lies, failing an express 
No julgamento do recurso, o voto do excelentíssimo Yves-Marie Morissette, ${ }^{12}$ seguido unanimemente pelos demais julgadores, foi no sentido de manter decisão de primeiro grau no que toca ao espólio da Sra. Kazemi e modificá-la quanto à pretensão do Sr. Hashemi, que foi rejeitada. Ou seja, a decisão do recurso em segundo grau foi favorável ao Irã e à tese da imunidade de jurisdição do Estado. A pretensão do Sr. Hashemi foi rejeitada com base no juízo de que as evidências por ele apresentadas foram insuficientes para a caracterização de dano pessoal na forma do SIA, tendo feito prova apenas de mero dano moral.

Recorreu então o Sr. Hashemi à última corte final de apelação, a saber, a Suprema Corte, ${ }^{13}$ pugnando pela incompatibilidade do SIA, notadamente seu artigo 3(1), com previsões constitucionais e quase constitucionais, como o artigo 2(e) da Bill of Rights e o artigo 7 da Charter. Ouvidos os interventores e $o$ Attorney General of Canada, a Corte Suprema se posicionou, majoritariamente ${ }^{14} \mathrm{e}$ reafirmando o posicionamento esposado pela Court of Appeal no que toca à completude do SIA, ao caráter político e taxativo das exceções nele previstas, à consequente competência exclusiva do Parlamento para sua alteração, à caracterização dos atos de tortura como atos oficiais, à não configuração da exceção do artigo 6(a) pelo dano psicológico sofrido pelo Sr. Hashemi, dentre outros, no sentido de não configurar a prática da tortura, hipótese geradora de jurisdição cível universal; ausente previsão específica no SIA,

provision to the contrary. Art. 26 Unless otherwise provided, an appeal lies (1) from any final judgment of the Superior Court or the Court of Québec, except in a case where the value of the object of the dispute in appeal is less than \$50,000. CANADA. Quebec Code of Civil Procedure. Available at: $<$ http://www2.publicationsduquebec.gouv.qc.ca/dynamicSearch/ telecharge.php?type $=2 \&$ file $=/$ C_25/C25_A.HTM $>$. Last access on: 12 jun. 2014.

12 A análise das alegações das partes e os fundamentos da decisão da Corte dar-se-á com maior profundidade no item 4 e seus subitens, ao qual se remete o leitor.

13 Art. 101 The Parliament of Canada may, notwithstanding anything in this Act from Time to Time provide for the Constitution, Maintenance, and Organization of a General Court of Appeal for Canada, and for the Establishment of any additional Courts for the better Administration of the Laws of Canada. CANADA. Constitution Act, 1867: An Act for the Union of Canada, Nova Scotia, and New Brunswick, and the Government thereof; and for Purposes connected therewith. Available at: <http://laws-lois.justice.gc.ca/eng/Const/page-5. html\#docCont>. Last access on: 12 jun. 2014.

14 A juíza Abella se posicionou no sentido de considerar que a peremptoriedade da proibição da prática de tortura teria criado uma jurisdição cível universal, a exemplo do que já existe no âmbito penal, de forma que competente o Judiciário canadense para a análise do mérito, como se demonstrará no tópico 4. esta não poderá ser considerada exceção à Imunidade de Jurisdição do Estado estrangeiro para fins de persecução da reparação cível no Canadá, de forma que incompetente o Judiciário canadense para conhecer da ação, confirmando a tendência jurisprudencial internacional sobre a matéria ${ }^{15}$.

\subsection{A disputa entre as categorias jus cogens e imunidade de jurisdição no caso Kazemi}

Casos que envolvem a prática de tortura são sempre complexos e de difícil solução para o Direito Internacional, notavelmente no campo da responsabilização de seus atores, ante o reconhecimento, por um lado, da natureza cogente das normas de proibição da prática de tortura, e de outro da completa ausência de dispositivos que obriguem, ou ao menos, prevejam a possibilidade de reparação civil aos ofendidos. O caso Kazemi não foge à regra.

Ao cuidar do assassinato da Sra. Zahra (Ziba) Kazemi, enquanto sob a custódia do Governo Iraniano, após ter sido presa arbitrariamente e sem direito ao devido processo legal, o judiciário canadense enfrentou necessariamente conceitos como o de tortura, jus cogens, direitos humanos, soberania e imunidade de jurisdição, e suas relações, seja sob o prisma do direito internacional, seja sob o prisma de seu próprio direito interno, em especial quando da análise da aplicação e interpretação do SIA.

Mas o que se entende por tortura? Onde estariam os fundamentos para sua proibição e até que ponto a prática desta poderá ser considerada um ilícito internacional com vistas à plena responsabilização de seus autores?

A tortura é conceituada no art. 1.1 da Convenção das Nações Unidas contra a Tortura e Outros Tratamentos ou Penas Cruéis, Desumanos ou Degradantes (Resolução 39/46 da Assembleia Geral das Nações Unidas), de 10 de dezembro de 1984 como

qualquer ato pelo qual dores ou sofrimentos agudos, físicos ou mentais, são infligidos intencionalmente a uma pessoa a fim de obter, dela ou de uma terceira pessoa, informações ou confissões; de castigá-la por ato cometido; de intimidar ou coagir esta pessoa ou

15 CANADÁ. Supreme Court of Canada. Estate of the Late Zabra (Ziba) Kazemi, et al. v. Islamic Republic of Iran, et al.: 2014 SCC 62. Available at: $\quad<$ http://scc-csc.lexum.com/scc-csc/scc-csc/en/item/14384/ index.do >. Last access on: 26 out. 2014. 
outras pessoas; ou por qualquer motivo baseado em discriminação de qualquer natureza; quando tais dores ou sofrimento são infligidos por um funcionário público ou outra pessoa no exercício de funções públicas, ou por sua instigação, ou com o seu consentimento ou aquiescência. Não se considerará como tortura as dores ou sofrimentos consequência unicamente de sanções legítimas, ou que sejam inerentes a tais sanções ou delas decorram. ${ }^{16}$

Este documento é uma das principais fontes formais da obrigatoriedade da vedação à prática de tortura, a qual não pode ser derrogada por situações excepcionais (art. $2^{\circ}$ da Convenção) e cujo caráter jus cogens está fundado nas condições de existência da comunidade internacional, a qual impõe a todos os Estados a observância de um estado de direito internacional no qual aos Estados é juridicamente reconhecida sua soberania, ao mesmo tempo em que pautado o seu exercício no respeito às regras com as quais os Estados se comprometeram ao longo da história ${ }^{17}$.

A inderrogabilidade e a imperatividade das normas de jus cogens podem ainda ser deduzidas da possibilidade de responsabilização penal dos agentes que praticarem ou autorizarem a prática de tortura, a exemplo do ocorrido nos julgamentos do Tribunal de Nuremberg (Tribunal Militar Internacional) acerca dos crimes de guerra praticados pela Alemanha Nazista durante a segunda guerra mundial, e com a posterior criação em 1998, por meio do Estatuto de Roma, do Tribunal Penal Internacional. No entanto, deve-se destacar que, no direito internacional, o tratamento penal da prática de tortura evoluiu de modo diferente de seu tratamento na esfera civil. Quando observado o aspecto criminal, a prática de tortura tem sido alvo de diversa e crescente produção normativa repressiva e punitiva, o que não ocorreu, até o momento, quanto aos seus reflexos civis. Desta forma, a imunidade dos agentes que praticaram ou autorizaram a prática de tortura

16 BRASIL. Decreto n. 40, de 15 de fevereiro de 1991. Promulga a Convenção Contra a Tortura e Outros Tratamentos ou Penas Crueis, Desumanos ou Degradantes. Disponível em: <http:// www.planalto.gov.br/ccivil_03/decreto/1990-1994/D0040.htm>. Acesso em: 22 maio 2014.

17 “[...] (o) Estado está subordinado ao direito natural, assim como às regras criadas pelo costume internacional. Sua soberania não é soberania absoluta; trata-se de uma competência dada aos Estados pelo direito nacional e o direito positivo dos povos". VERDROSS, Alfred. O Fundamento do Direito Internacional. Revista de Direito Internacional, v. 10, n. 2, p. 1-33, 2013. p. 29. Disponível em: < http:// www. publicacoesacademicas.uniceub.br/index.php/rdi/article/ view/2685>. Acesso em: 23 abr. 2014. não é mais um obstáculo a sua persecução criminal, seja no plano internacional, seja no plano interno dos Estados, desde que haja uma razoável conexão entre o crime praticado e o foro de julgamento. Por outro lado, no que diz respeito às reparações civis, o que há é o funcionamento dos sistemas de monitoramento e julgamento internacionais previamente autorizados pelos Estados, ao passo que, no plano das jurisdições internas, o que há é a previsão, na legislação interna, de exceções à imunidade de jurisdição de certos Estados por atos de terrorismo (caso das legislações americana ${ }^{18}$ e canadens $\mathrm{e}^{19}$ ), ou o julgamento de ações indenizatórias ignorando a imunidade de jurisdição em nome do jus cogens (casos da Grécia e da Itália ${ }^{20}$ ). Em síntese, não há normativa internacional convencional ou costumeira admitindo a possibilidade de reparações civis contra Estados soberanos em foro estrangeiro por violações de jus cogens e, simultaneamente, tais normas ainda não foram admitidas como um fundamento per si para o ajuizamento de tais ações.

Considerando novamente a esfera criminal, o Estatuto do Tribunal Penal Internacional (TPI) prevê, em seu preâmbulo, ${ }^{21}$ hipótese geral de exceção à imunidade de jurisdição penal ao definir como de

18 UNITED STATES OF AMERICA. 28 US Code $\int 1605$ A: Terrorism exception to the jurisdictional immunity of a foreign state. Available at: <http://www.law.cornell. edu/uscode/ text/28/1605A >. Last access on: 27 jun. 2014.

19 CANADA. State Immunity Act: An Act to provide for state immunity in Canadian courts. Available at: <http://laws-lois.justice. gc.ca/PDF/S-18.pdf>. Last acess on: 27 jun. 2014. Para exceção à imunidade de jurisdição na hipótese de terrorismo ver o artigo 6.1 .

20 INTERNATIONAL COURT OF JUSTICE. Jurisdictional Immunities of the State (Germanyv.Italy: Greece intervening). Available at: $<$ http: / / www.icj-cij.org/docket/index.php?p1 =3\&p2=3\&case $=14$ $3 \&$ code $=$ ai\&p3 $=4>$. Last access on: 27 jun. 2014.

21 "Relembrando que é dever de cada Estado exercer a respectiva jurisdição penal sobre os responsáveis por crimes internacionais, [...] Sublinhando que o Tribunal Penal Internacional, criado pelo presente Estatuto, será complementar às jurisdições penais nacionais". BRASIL. Decreto 4.388, de 25 de setembro de 2002. Promulga o Estatuto de Roma do Tribunal Penal Internacional. Disponível em: <http:// www.planalto.gov.br/ccivil_03/_decreto/2002/D4388.htm>. Acesso em: 27 jun. 2014. Nesse mesmo sentido: "Furthermore, at the individual level, that is, that of criminal liability, it would seem that one of the consequences of the jus cogens character bestowed by the international community upon the probibition of torture is that every State is entitled to investigate, prosecute and punish or extradite individuals accused of torture, who are present in a territory under its jurisdiction. [...]". INTERNATIONAL CRIMINAL TRIBUNAL FOR THE FORMER YUGOSLAVIA. Trial Chamber. Prosecutor v. Anto Furundrija. Case n. IT-95-17/1-T . Judges Mumba, Cassese \& May. 10 Dec. 1998. Available at: <http:// www. icty.org/x/cases/furundzija/tjug/en/fur-tj981210e.pdf $>$. Last access on: 27 jun. 2014. Parágrafo 156. 
competência interna de cada Estado a persecução daqueles que praticam esses crimes de maior gravidade, sendo a competência penal internacional apenas subsidiária. Da mesma forma, e especialmente no que toca à prática da tortura, a competência do TPI está assentada no artigo $7^{\circ}$ de seu Estatuto, que dispõe sobre os crimes contra a humanidade que envolvem a prática da tortura. ${ }^{22}$ Nesse sentido, podemos citar o Tribunal Criminal Internacional para a ex-Iugoslávia, Tribunal Internacional ad hoc criado pelas Nações Unidas especialmente para os casos de crimes de guerra ocorridos durante os conflitos nos Balcãs, que, ao tratar sobre as questões e implicações da prática da tortura no caso Prosecutor vs Furundzija, reputou serem elas de caráter jus cogens, mesmo que não configurassem propriamente crimes contra a humanidade. ${ }^{23}$

No tocante à exceção à imunidade de jurisdição propriamente dita, temos o Caso Pinochet, no qual, apesar de se tratar da responsabilização pela prática de atos de império, que costumeiramente atraem a incidência da imunidade de jurisdição, o ex-chefe de Estado do Chile, Augusto Pinochet, foi condenado pela Corte Inglesa, pelos fundamentos aduzidos no voto do Excelentíssimo Lord Millet de que a Convenção contra a Tortura, ao proibir a prática desse ato, não criou novo crime na ordem internacional, uma vez que os

22 Art. 7.1(f) Para os efeitos do presente Estatuto, entende-se por "crime contra a humanidade", qualquer um dos atos seguintes, quando cometido no quadro de um ataque, generalizado ou sistemático, contra qualquer população civil, havendo conhecimento desse ataque: Tortura. Art. 7.2(e) Para efeitos do parágrafo 1: Por "tortura" entende-se o ato por meio do qual uma dor ou sofrimentos agudos, físicos ou mentais, são intencionalmente causados a uma pessoa que esteja sob a custódia ou o controle do acusado; este termo não compreende a dor ou os sofrimentos resultantes unicamente de sanções legais, inerentes a essas sanções ou por elas ocasionadas. BRASIL. Decreto 4.388, de 25 de setembro de 2002: Promulga o Estatuto de Roma do Tribunal Penal Internacional. Disponível em: < http:/ / www.planalto.gov.br/ccivil_03/decreto/2002/D4388.htm>. Acesso em: 27 jun. 2014.

23 "Clearly, the jus cogens nature of the probibition against torture articulates the notion that the probibition has now become one of the most fundamental standards of the international community. Furthermore, this probibition is designed to produce a deterrent effect, in that it signals to all members of the international community and the individuals over whom they wield authority that the probibition of torture is an absolute value from which nobody must deviate"; "Although this case does not deal with crimes against humanity, the Trial Chamber finds that this reasoning can also apply to war crimes and other serious violations of international humanitarian law" INTERNATIONAL CRIMINAL TRIBUNAL FOR THE FORMER YUGOSLAVIA. Trial Chamber. Prosecutor v. Anto Furundzija. Case n. IT-95-17/1-T . Judges Mumba, Cassese \& May. 10 Dec. 1998. Available at: <http:/ / www.icty.org/x/cases/furundzija/tjug/en/fur-tj981210e.pdf $>$. Last access on: 27 jun. 2014. Parágrafos 154 e 289.
Estados já estavam proibidos de utilizá-la, mas apenas instituiu um mecanismo para sua efetivação, atribuindo competência criminal a todo e qualquer estado para a persecução do ofensor. Nesta senda, a imunidade de jurisdição ratione materiae seria completamente incompatível com as disposições sobre a tortura presentes na Convenção, já que a imputabilidade do ato ao Estado, ou seja, a sua caracterização como ato oficial, base da concessão de imunidade de jurisdição, é também elemento integrante do conceito de tortura, de forma que a imunidade não poderia ser oposta àquela, cujo sentido é justamente conferir aos demais Estados a obrigação de agir onde a atuação do Estado-ofensor se mostrar digna de reservas, como no caso da persecução de responsabilização por atos emanados de seu poder soberano. $^{24}$

Não obstante o reconhecimento da imperatividade da proibição à prática da tortura, esta consiste exceção à imunidade de jurisdição somente para permitir a persecução criminal dos agentes, não subsistindo nos casos de persecução civil da responsabilização e reparação do dano. Este é o posicionamento reiterado da Comunidade Internacional, explicitado em casos como Schreiber v. Canada ${ }^{25}$, Bouzari v. Iran (Islamic Republic ${ }^{26}$, decididos pela Suprema Corte do Canadá;

24 UNITED KINGDOM. HOUSE OF LORDS. Regina v. Bartle and the Commissioner of Police for the Metropolis and others EX Parte Pinochet (on appeal from a Divisional Court of the Queen's Bench Division) Regina v. Evans and another and the Commissioner of Police for the Metropolis and others EX Parte Pinochet (on appeal from a Divisional Court of the Queen's Bench Division) 37 I.L.M (1998) 1302 reported as R v. Bow Street Metropolitan Stipendiary Magistrate, ex p. Pinochet Ugarte (No 2) sub nom Pinochet Ugarte, Re (1999) UKHL 1 (1999) 1 All ER 577, (1999) 2 WLR 272, 6 BHRC 1, (2000) 1 AC 119, (1999) NLJR 88. Lords Slynn of Hadley, Lloyd of Berwick, Nicholls of Birkenhead, Steyn, Hoffmann. Available at: <http://www.publications. parliament.uk/pa/ ld199899/ldjudgmt/jd990324/pino7.htm> Last access on: 27 junho 2014. Cabe lembrar, nesse interím que o Caso Pinochet afastou a imunidade de jurisdição individual do ex-chefe de Estado, não refletindo, necessariamente na Imunidade do Estado concebido como soberano.

25 CANADIAN SUPREME COURT. Schreiber v. Canada (Attorney General), [2002] 3 S.C.R. 269, 2002 SCC 62. Case nº28453. Judges LeBel, McLachlin, Gonthier, Iacobucci, Bastarache, Binnie, William, Arbour. 12 set 2002. Available at: <http://scc-csc.lexum. com/scc-csc/scc-csc/en/2003/1/document.do> Last access on: 27 jun. 2014.

26 CANADIAN SUPREME COURT. Bouzari v. Iran, 2004 CanLII 871 (ON CA). Case n ${ }^{\circ}$ 38345. Judges Mac Pherson and Cronk. 30 jun 2004. Available at: <http://www. canlii.org/en/on/ onca/doc/2004/2004canlii871/2004canlii871.html> Last aacess on: 27 jun. 2014. 
Al-Adsani v. United Kingdom ${ }^{27}$, Jones and Others v. the United Kingdom ${ }^{28}$, decididos pela Corte Europeia de Direitos Humanos.

O posicionamento do Judiciário canadense, assim, revela consonância com a jurisprudência dominante da Comunidade Internacional em não reconhecer a tortura como exceção à imunidade de jurisdição civil do Estado estrangeiro, mas explicita ao mesmo tempo a dicotomia no que se refere ao tratamento da prática da tortura que, apesar de punível na ultima ratio do Direito ${ }^{29}$, não o é em termos de mera reparação pecuniária.

30 assassinato da Sra. Kazemi não é justiciável, mas o dano causado a seu filho o é: o caso na Quebec Superior Court

\subsection{A proibição da tortura como jus cogens e o Canada State Immunity Act}

Hashemi, em nome próprio e como representante do espólio da Sra. Kazemi, procura a reparação civil pelos danos causados pela prisão, tortura e morte daquela, cuja responsabilidade foi atribuída ao Estado iraniano, na pessoa do Ayatollah Ali Khamenei, e dos altos funcionários do Governo, o Sr. Saeed Mortazavi, Procurador-Geral do Teerã, de quem teria partido a ordem de prisão da Sra. Ziba Kazemi, e o Sr.

27 EUROPEAN COURT OF HUMAN RIGHTS. Grand Chamber. Al-Adsani v. The United Kingdom (ECHR 2001-XI). Case $\mathrm{n}^{\circ}$ 35763/97. Judges Wildhaber, President,. Palm, Rozakis, Costa, Ferrari Bravo, Jörundsson, Caflisch, Loucaides, Cabral Barreto, Jungwiert, Bratza, Zupančič, Vajić,. Pellonpää, Tsatsa-Nikolovska, Levits, Kovler. Available at: <http://hudoc.echr.coe.int/sites/eng/ pages/search.aspx?i=001-59885\# \{“itemid”:[“001-59885”]\}>. Last access on: 27 jun. 2014.

28 EUROPEAN COURT OF HUMAN RIGHTS. Fourth Section. CASE OF JONES AND OTHERS v. THE UNITED KINGDOM

Case $n^{\circ}$ 34356/06 and 40528/06. Judges Ziemele, President, Hirvelä, Nicolaou, Bianku, Kalaydjieva, De Gaetano, Mahoney. 14 jan 2014. Available at: $\mathrm{y}<\mathrm{http}: / /$ hudoc.echr.coe.int/sites/eng/ pages/search.aspx?i=001-140005\#\{“itemid”:[“001-140005”]\}>. Last access on: 27 jun. 2014.

29 "Dizer que a intervenção do Direito Penal é mínima significa dizer que o Direito Penal deve ser a 'ultima ratio, limitando e orientando o poder incriminador do Estado, preconizando que a criminalização de uma conduta somente se justifica se constituir um meio necessário para a proteção de determinado bem jurídico. O Direito Penal somente deve atuar quando os demais ramos do Direito forem insuficientes para proteger os bens jurídicos em conflito". QUEIROZ, Paulo. Sobre a função do juiz criminal na vigência de um direito penal simbólico. IBCcrim, n. 74, 1999. Disponível em: <http://www.ibccrim.org.br/boletim_artigos/9474---Janeiro---1999>. Acesso em: 30 maio 2014.
Mohammad Bakhshi, então Vice-Comandante do setor de inteligência da prisão de Evin, sob cuja custódia teria permanecido a Sra. Kazemi enquanto presa.

A detenção, a prisão, o interrogatório e as torturas irregulares na Penitenciária de Evin, a transferência ao Hospital de Baghiatollah sem a devida notificação à família e o posterior empecilho à sua visitação e ao atendimento e assistência médica auxiliares; sua controversa morte sob custódia iraniana, sua autópsia e seu enterro no Irã contra a vontade da família, não obstante os esforços da Embaixada canadense de repatriação do corpo da Sra. Zahra Kazemi; a ausência de investigações independentes do Governo, a falta de interesse deste em punir os verdadeiros responsáveis e a suposta ausência de prova para condenar o único formalmente acusado, o Sr. Reza Ahmadi, o prejuízo causado pela Sra.Kazemi e por seu filho, o Sr. Hashemi, constituem o arcabouço fático em que se baseou o presente pleito de reparação civil ${ }^{30}$.

Do ponto de vista jurídico, demonstram a possibilidade de responsabilização civil dos requeridos e a competência da corte canadense pela caracterização dos atos por eles praticados como exceções à imunidade de jurisdição prevista no State Immunity Act, vez que inexistente a possibilidade de se ter um julgamento imparcial no Irã, de forma que o caso não se encontrava sob nenhuma jurisdição estrangeira, e o caráter jus cogens da proibição da prática da tortura, que consiste, além de violação aos termos da Convenção Contra a Tortura e outras punições, violação à Carta Canadense de Direitos e Liberdades Individuais e à Constituição Canadense.

O Irã, seu líder, Ayatollah Ali Khamenei, bem como Saeed Mortazavi e Mohammad Bakhshi, por seu turno, levantaram a exceção de incompetência da Justiça canadense para o caso, com base na própria legislação desse país, vez que, nos termos do State Immunity Act (art.3(1) e 3(2) do $S A I)^{31}$, o Irã e seus funcionários gozavam de imunidade de jurisdição no Canadá, nos termos da doutrina da imunidade de jurisdição dos estados

\section{Ver item 2 e subitens.}

31 3. (1) Except as provided by this Act, a foreign state is immune from the jurisdiction of any court in Canada.

Marginal note:Court to give effect to immunity (2) In any proceedings before a court, the court shall give effect to the immunity conferred on a foreign state by subsection (1) notwithstanding that the state has failed to take any step in the proceedings. CANADA. State Immunity Act. An Act to provide for state immunity in Canadian courts. Available at: <http://laws-lois.justice.gc.ca/PDF/S-18. pdf $>$. Last access on: 27 jun. 2014 
soberanos, em relação a seus atos de império, e de seus oficiais (imunidade funcional ou imunidade de jurisdição individual), as quais têm por apanágio teórico a primazia da soberania absoluta, do condicionamento da eficácia das normas de direito internacional à vontade declarada dos Estados e do não reconhecimento de outra vontade externa ou superior a esta.

Aqui, demandantes e demandados já colocam para a Corte canadense o problema da harmonização do direito interno com o direito internacional, na questão da prevalência ou não da imunidade de jurisdição de estados soberanos, principalmente frente à imperatividade das normas de jus cogens, como aquelas de direitos humanos e da prática de tortura, como é o caso.

O direito internacional enfrenta, desde sua origem, o problema do dualismo com o direito interno e da ausência de hierarquia entre suas normas, corolários diretos da concepção clássica de direito e sociedade internacionais, segundo a qual a vontade dos Estados soberanos é a responsável pela caracterização deste como sujeito de direitos e obrigações no plano internacional, isto é, "o Estado é sujeito de direitos e obrigações no plano internacional por sua vontade e desde que livremente consista em se obrigar, assim a vontade passa a ser tida como única fonte do Direito Internacional." "32 Esta caracterização da vontade do Estado como base exclusiva de suas obrigações compõe a chamada teoria da autolimitação do Estado ${ }^{33}$, a qual, apesar de primar pela proteção da soberania estatal, consiste, ao mesmo tempo, ameaça a essa não subordinação a Poder superior, vez que, serve de impulso para que os Estados, com fundamento no mesmo pressuposto do exercício de sua soberania, deixem de cumprir seus acordos e deveres, na mesma medida e com a mesma discricionariedade com que se obrigaram originariamente, em um verdadeiro cenário de insegurança político-jurídica.

Foi justamente fundado nessa proteção à soberania e com vistas ao atendimento das necessidades internas que Napoleão, por exemplo, conquista e invade o território de diversos países europeus, quebrando

32 BYNKERSHOEK, Corneljus Van apud MENEZES, Wagner. Tribunais internacionais: jurisdição e competência. São Paulo: Saraiva, 2013. cap. 1.

33 JELLYNEK, Georgapud VERDROSS, Alfred. O fundamento do direito internacional. Revista de Direito Internacional, v. 10, n. 2, p. 1-33, 2013. Disponível em: <http://www.publicacoesacademicas. uniceub.br/index.php/rdi/article/view/2685>. Acesso em: 23 abr. 2014. acordos de não agressão e cooperação, levando o cenário internacional a um período de instabilidade e insegurança e demonstrando a facilidade de transgressão das normas de direito internacional quando fundadas exclusivamente na vontade dos Estados. Mostrou-se necessário, desta forma, que a proteção da soberania pelo direito internacional fosse deslocada do fundamento da primazia das vontades para o do respeito à própria soberania, aos direitos e garantias mínimos dos outros Estados e seu povo ${ }^{34}$. Apesar dos esforços, a Primeira Grande guerra mundial foi deflagrada, cujos horrores levaram à retificação da necessidade de criação de um conjunto mínimo de direitos a serem respeitados.

Observou-se, então, a necessidade da "existência de um direito internacional geral, oponível a todos os Estados, independentemente de aceitação ou de participação no processo formador das normas, podendo, inclusive, em alguns casos, impor-se aos Estados que sempre se colocaram em objeção a essas normas, é ideia que ganhou curso e é, por muitos, aceita de modo passivo". ${ }^{35}$ Surge assim a noção de jus cogens para o Direito Internacional. Neste ponto, impende registrar que a noção de normas superiores à vontade do próprio Estado não é nova, podendo ser encontrada em doutrinadores como Francisco Suarez, Francisco de Vitória, Grotius e Vattel. A diferença é que aqui essas normas não se fundamentam mais em uma origem divina ou jusnaturalista do direito, mas surgem dentro da própria noção de vontade dos Estados, não mais tomados individualmente, como nos afirma Triepel, mas conjugados em uma comunidade internacional. ${ }^{36}$

34 É o que se pode observar das Conferências de Haia e do Concerto Europeu promovido pelo Congresso de Viena, que buscaram promover um período de paz e equilíbrio hegemônico entre as potências europeias após a queda de Napoleão. A limitação da soberania pelo respeito à própria soberania se fazia presente nas previsões de não intervenção, traduzidas na noção de guerra justa. Nestes termos: "a segunda Conferência de Haia trouxe alguns avanços na decodificação e sistematização do Direito Internacional, no disciplinamento dos aspectos do direito à decretação da guerra (jus ad bellum) e no direito de conduta dos beligerantes durante o estado de guerra (jus in bellum)". CASTRO, Thales. Teoria das relações internacionais. Brasília: FUNAG, 2012. Available at: <http://funag. gov.br/loja/download/931-Teoria_das_ Relacoes_Internacionais. pdf>. Last access on: 30 jun. 2014.

35 NASSER, Salem Hikmat. Jus Cogens: ainda esse desconhecido. Revista Direito GV, v. 1, n. 2, p. 161-178, jun./dez. 2005. Disponível em: <http://bibliotecadigital.fgv.br/dspace/ bitstream/handle/10438/9658/Salem\%20Hikmat\%20Nasser. pdf? sequence=1>. Acesso em: 18 maio 2014.

36 VERDROSS, Alfred. O Fundamento do Direito Internacional. Revista de Direito Internacional, v. 10, n. 2, p. 1-33, 2013. 
Dentre as normas desta natureza podem ser identificadas aquelas da ordem pública internacional ${ }^{37}$ como a autodeterminação dos povos, a proibição à guerra de agressão, do uso da força, a imperatividade da busca de soluções pacíficas das controvérsias e os direitos do homem, cuja internacionalização foi acelerada com o fim da Segunda Guerra Mundial ${ }^{38}$, com a Declaração Universal dos direitos do Homem e a oposição dos direitos fundados na dignidade da pessoa humana aos Estados, conferindo aos indivíduos, até então atingidos pelo Direito Internacional apenas quando da internalização destas normas pelo Direito de cada país, a condição de sujeitos de direito internacional. ${ }^{39}$ Apesar desta pretensa anterioridade e reconhecimento geral, a noção de jus cogens só ganha positivação na Convenção de Viena onde se estabelece ser o jus cogens "sinônimo de 'norma(s) imperativa(s) de direito internacional geral' e essas normas são por sua vez definidas como aquelas 'aceita(s) e reconhecida(s) pela comunidade internacional dos Estados como um todo, como norma(s) da(s) qual(is) nenhuma derrogação é permitida e que só pode(m) ser modificada(s) por norma ulterior de Direito Internacional geral da mesma natureza'(art. 53)". 40

É o que se observa, por exemplo, com os direitos humanos, cuja natureza erga omnes encontra azo em sua universalidade, a qual, segundo Flávia Piovesan, lhe é atribuída "porque clama pela extensão universal dos direitos humanos, sob a crença de que a condição de pessoa é o requisito único para a titularidade de

Disponível em: <http://www.publicacoesacademicas.uniceub.br/ index.php/rdi/article/view/2685>. Acesso em: 23 abr. 2014.

37 Aqui, entende-se por ordem pública internacional "o núcleo material intangível da constituição internacional”. TOLEDO JÚNIOR, Milton Nunes. Direito Internacional Imperativo: jus cogens. 2006. 120f. Dissertação (Mestrado em Direito Internacional Econômico)-Universidade Católica de Brasília, Brasília, 2006. Disponível em: <http://www.bdtd.ucb.br/tede/tde_busca/ arquivo.php?codArquivo=285> . Acesso em: 22 maio 2014 .

38 PIOVESAN, Flávia. A Proteção Internacional dos Direitos Humanos das Mulheres. Revista EMERJ, Rio de Janeiro, v. 15, n. 57, Ed. Especial. p. 70-89, jan./mar. 2012. Disponível em: <http:// www.emerj.tjrj.jus.br/ revistaemerj_online/edicoes/revista57/ revista57_70.pdf>. Acesso em: 22 maio 2014.

39 LIMA, Renata Matovani de; ALVES, Renata de Sena. A efetividade do ativismo jurídico transnacional no Sistema Interamericano de Direitos Humanos: uma análise a partir de casos contra o Brasil. Revista de Direito Internacional, Brasília, v. 10, n. 2, p. 239-241, 2013.

40 NASSER, Salem Hikmat. Jus Cogens: ainda esse desconhecido. Revista Direito GV, v. 1, n. 2, p. 161-178, jun./dez. 2005. Disponível em: <http://bibliotecadigital.fgv.br/dspace/ bitstream/handle/10438/9658/Salem\%20Hikmat\%20Nasser. pdf?sequence=1>. Acesso em: 18 maio 2014 . direitos, considerando o ser humano como um ser essencialmente moral, dotado de unicidade existencial e dignidade, esta como valor intrínseco à condição humana". ${ }^{41}$

\section{Assim}

Os direitos humanos são uma expressão direta da dignidade da pessoa humana. A obrigação dos Estados para assegurar a sua observância deriva do reconhecimento desta dignidade, consagrados na da Carta das Nações Unidas e na Declaração Universal dos Direitos Humanos. Esta obrigação internacional, tal como expressa pelo Tribunal Internacional de Justiça, é erga omnes, cabe a cada Estado em relação à comunidade internacional como um todo, e cada Estado tem um interesse jurídico na proteção dos direitos humanos. A obrigação adicional implica um dever de solidariedade entre todos os Estados para assegurar o mais rapidamente possível a efetiva proteção dos direitos humanos em todo o mundo. ${ }^{42}$

Dentro desses direitos encontra-se o direito ao tratamento digno e a consequente proibição à prática de tortura e outras penas degradantes, que se encontram positivados na Convenção das Nações Unidas contra a Tortura e Outros Tratamentos ou Penas Cruéis, Desumanos ou Degradantes (Resolução 39/46 da Assembleia Geral das Nações Unidas), de 10 de dezembro de 1984. Esta, por sua vez, encontra fundamento no artigo $5^{\circ}$ da Declaração Universal dos Direitos do Homem, comungando assim, por arrastamento, de seu caráter erga omnes e de jus cogens.

Esse é o entendimento da Corte Interamericana de Direitos Humanos, expressamente declarado no julgamento do Caso Maritza Urrutia vs. Guatemala,

41 PIOVESAN, Flávia. A Proteção Internacional dos Direitos Humanos das Mulheres. Revista EMERJ, Rio de Janeiro, v. 15, n. 57, Ed. Especial. p. 70-89, jan./mar. 2012. Disponível em: <http:// www.emerj.tjri.jus.br/ revistaemerj_online/edicoes/revista57/ revista57_70.pdf>. Acesso em: 22 maio 2014.

42 Tradução livre do artigo Artigo 1 da Resolução aprovada pelo Institut de Droit International (I.D.I.) na Sessão de Santiago de Compostela de 1989, que dispõe: "Les droits de l'homme sont l'expression directe de la dignité de la personne humaine. L'obligation pour les Etats d'en assurer le respect découle de la reconnaissance même de cette dignité que proclament déjà la Charte des Nations Unies et la Déclaration universelle des droits de l'bomme. Cette obligation internationale est, selon une formule utilisée par la Cour internationale de Justice, une obligation erga omnes; elle incombe à tout Etat vis-à-vis de la communauté internationale dans son ensemble, et tout Etat a un intérêt juridique à la protection des droits de l'bomme. Cette obligation implique au surplus un devoir de solidarité entre tous les Etats en vue d'assurer le plus rapidement possible une protection universelle et efficace des droits de l'homme. Resolução Disponível em: <http://www. idi-iil.org/idiF/resolutionsF/ 1989_comp_03_fr.PDF>. Acesso em: 18 maio 2014. 
para a qual "a proibição da prática da tortura é absoluta e não derrogável, mesmo frente às situações mais difíceis, como a guerra, a ameaça de guerra, a luta contra o terrorismo, e qualquer outro crime, martial law ou estado de emergência, comoção ou guerra civil, suspensão das garantias constitucionais, política interna instável, ou qualquer outro desastre ou emergência pública" ${ }^{\text {"3 }}$. Assim, qualquer matéria relacionada aos direitos do homem com vistas à proteção de sua dignidade consistiria núcleo intocável, imperativo e inderrogável do Direito Internacional, oponível a Estados, Organizações e Indivíduos.

São estes conceitos e afirmações que sustentam as pretensões do Sr. Hashemi em ver condenados e punidos o Estado iraniano e seus funcionários, ante a prática de atos de tortura contra a Sra. Kazemi, levados à sua última consequência, e com os quais pretendem opor e descaracterizar a possibilidade de manutenção da proteção da soberania, especialmente por meio da aplicação de legislações regulamentadoras da imunidade de jurisdição do Estado estrangeiro, fio condutor da exceção de incompetência oposta pelos demandados.

Fundamental na argumentação do governo iraniano a noção de soberania, a qual, embora presente desde a antiguidade, encontra em Bodin sua versão mais acurada. Para este jurista francês, a soberania "é o poder absoluto e perpétuo de uma República". ${ }^{44} \mathrm{Ou}$ seja, "só é soberano, por definição, aquele que em nada depende de outrem, nem do Papa, nem do imperador; que tudo resolve por si mesmo; que não está ligado por vínculo algum de sujeição pessoal; cujo poder não é temporário, nem delegado, nem tampouco responsável perante qualquer outro poder sobre a terra". ${ }^{45}$ A vontade do soberano é, nesta senda, ilimitada e suprema.

43 Tradução livre do trecho: The probibition of torture is absolute and non-derogable, even in the most difficult circumstances, such a war, the threat of war, the fight against terrorism, and any other crime, martial law or state of emergency, civil war or commotion, suspension of constitutional guarantees, internal political instability, or any other public disaster or emergency. CORTE INTERAMERICANA DE DIREITOS HUMANOS. Case of Maritza Urrutia v. Guatemala. Judges Cançado Trindade, President,García Ramírez, Salgado Pesantes, Pacheco Gómez, Abreu Burelli, Roux Rengifo, Martínez Gálvez, 27 nov 2003. Disponível em: <http://www.corteidh.or.cr/docs/casos/articulos/ seriec_103_ing.pdf>. Acesso em: 22 maio 2014

44 Tradução livre do trecho «La souveraineté est la puissance absolue et perpétuelle d'une République..». BODIN, Jean. Les six livres de la republique: livro i, capitulo viii, 1576. Disponível em: <http:// gallica.bnf.fr/ark:/12148/bpt6k6546272j.r=monarchie+de+juillet. langPT>. Acesso em: 18 maio 2014.

45 CHEVALIER, Jean-Jacques. As grandes obras politicas de Maquiavel a nossos dias. 8. ed. Rio de Janeiro: AGIR, 1999. Disponível
Esta noção de poder incondicional, por sua vez, serviu de alimento para a construção de um direito internacional de coordenação, ordenado para a proteção da soberania e emanado desta, onde se funda sua legitimidade ${ }^{46}$ como reconhecido no texto intergovernamental da Paz de Westfália (1648-1659), que conferiu a liberdade, o respeito e o tratamento igualitário aos Estados, por serem estes igualmente soberanos, independente das diferenças que de fato os subjugassem, e foi elevado à categoria de princípio pela Carta das Nações Unidas, norteando todas as disposições de direito internacional desde então até a atualidade.

Criou ainda a condição de irresponsabilidade perante qualquer outro poder, fundada no reconhecimento de que, para haver atribuição de responsabilidade, dever-se-ia necessariamente haver uma relação de subordinação, a qual não existe quando se tem por base uma relação de iguais (coordenação). "Essa regra ficou conhecida, em latim, como par in parem non habet judicium, que quer dizer: não se pode ter jurisdição sobre o par; é necessário ir sempre acima. Uma jurisdição sempre dá a ideia de hierarquia. Ora, quem está acima do rei? Ninguém. Portanto, ninguém tem jurisdição sobre o rei". ${ }^{47}$ Assim, ao não reconhecer outra ordem jurídica que aquela emanada de sua própria soberania, o Estado não reconhece a legitimidade de Tribunais que não constituídos a partir da legislação pátria, ${ }^{48} \mathrm{de}$ forma que não subordinado à sua jurisdição.

Essa noção de imunidade de jurisdição pelo não reconhecimento da competência de jurisdições estrangeiras constitui, ao mesmo tempo, garantia de proteção à soberania de um Estado, que se vê protegido da hipótese de subordinação a outro Poder que aquele emanado de sua Soberania, e limitação à soberania de outro, que se encontra impossibilitado ab initio de

em: <http://mpassosbr.files. wordpress.com/2013/03/as-grandesobras-polc3adticas-de-maquiavel-a-nossos-dias-jean-jacqueschevallier-rio-de-janeiro_-agir-1999.pdf $>$. Acesso em: 18 maio 2014.

46 FINKELSTEIN, Cláudio. Hierarquia das normas no direito internacional: jus cogens e metaconstitucionalismo. São Paulo: Saraiva, 2013. p. 154-155.

47 SOUSA, Mônica Tereza C. Imunidade de Jurisdição de Estado Estrangeiro: aspectos doutrinários e a jurisprudência brasileira. Revista Sequência, Florianópolis, v. 21, n. 40, 2000. Disponível em: <https://periodicos.ufsc.br/index.php/sequencia/article/ view/15442>. Acesso em: 23 maio 2014.

48 BODIN, Jean. Les six livres de la republique: livro i, capitulo viii, 1576. Disponível em: <http://gallica.bnf.fr/ark:/12148/ bpt6k6546272j.r $=$ monarchie + de + juillet.langPT $>$. Acesso em: 18 maio 2014. 
exercer jurisdição plena sobre matérias que considera oportunas de serem submetidas a sua jurisdição. Explica-se: uma vez que não há normas de direito internacional acerca da imunidade de jurisdição de estados soberanos, além daquela que reconhece a sua existência ${ }^{49}$ e imperatividade, os limites de seu exercício ficam, ao alvedrio do direito interno de cada País, o qual, na delimitação de sua competência interna, incluirá as questões relativas aos atos de outra Soberania, se assim o entender cabível. ${ }^{50}$

Nesse ponto, indispensável esclarecer que a discricionariedade toca as questões relativas às exceções à teoria da imunidade de jurisdição e não ao reconhecimento da imposição geral desta, matéria afeta à própria questão de soberania que funda o Direito Internacional moderno, de forma que não se pode conceber uma comunidade internacional organizada nos moldes que hoje se observa, sem a salvaguarda desta imunidade, a qual abrange não só o Estado, mas também seus funcionários e servidores ${ }^{51}$.

Apesar da conveniência da tese da autolimitação do Estado e da reiteração do discurso da irresponsabilidade deste frente às instituições jurídicas de outros, o que se observou ao longo dos anos foi uma mudança de paradigma quanto à inderrogabilidade da imunidade de jurisdição do estado soberano, explicitada na opção pela teoria da imunidade de jurisdição relativa em detrimento da teoria da imunidade absoluta, sendo esta traduzida no brocado latino in parem non babet judicium, ou seja, na total e inderrogável imunidade de Estados Soberanos, que não poderiam ser submetidos em qualquer hipótese à jurisdição estrangeira ${ }^{52}$; e aquela, na mitigação da incidência de referida imunidade, pela

49 SOUSA, Mônica Tereza C. Imunidade de Jurisdição de Estado Estrangeiro: aspectos doutrinários e a jurisprudência brasileira. Revista Sequência, Florianópolis, v. 21, n. 40, 2000. Disponível em: $\quad<$ https://periodicos.ufsc.br/index.php/sequencia/article/ view/15442>. Acesso em: 23 maio 2014.

50 SOUSA, Mônica Tereza C. Imunidade de Jurisdição de Estado Estrangeiro: aspectos doutrinários e a jurisprudência brasileira. Revista Sequência, Florianópolis, v. 21, n. 40, 2000. Disponível em: $\quad<$ https://periodicos.ufsc.br/index.php/sequencia/article/ view/15442>. Acesso em: 23 maio 2014.

51 Nesse sentido: Jeff vs Miller; Jones vs. Ministry of Interior Al-Mamlaka Al-Arabiya AS Saudiya; Samantar vs. Youssef; Bouzari et al v. Islamic Republic, Attorney-General of Canada et al, Intervenors; Al-Adsani v. United Kingdom e Jones v. Kingdom of Saudi Arabia.

52 ACCIOLY, Hildebrando; SILVA, G. E. Nascimento e; CASELLA, Paulo Borba. Manual de direito internacional público. 20. ed. São Paulo: Saraiva, 2012. p. 382. distinção entre atos de império e atos de gestão, sendo somente aqueles, ou seja, os atos em que o Estado atua com vistas à consecução de sua função precípua, hipótese idônea de sua aplicação ${ }^{53}$, teoria atualmente aceita pela comunidade internacional, de forma que a imunidade de jurisdição estatal comporta exceções.

Particularmente, no Canadá, a aceitação desta doutrina encontra-se positivada no State Immunity Act (SIA), o qual reconhece a imunidade de jurisdição dos estados estrangeiros, mas estabelece exceções que determinam a competência das Cortes canadenses para a persecução cível de Estados Soberanos. Nesse sentido, determina o SI $A,{ }^{54}$ a partir de seu artigo $3^{\circ}$ (do Título State Immunity), o reconhecimento da imunidade de jurisdição de Estados estrangeiros frente à Justiça canadense, constituindo exceções a esta garantia a submissão voluntária do Estado estrangeiro (art. $4^{\circ}$ e parágrafos), os atos de gestão (art. $5^{\circ}$ e parágrafos - atividade comercial), suporte ao terrorismo (art. 6 (1)), dentre outros, como o relativo à morte e dano à propriedade, ínsito ao art. $6^{\circ}$, e que dispõe, in verbis:

6. A foreign state is not immune from the jurisdiction of a court in any proceedings that relate to

(a) any death or personal or bodily injury, or

$[\ldots]$

that occurs in Canada.

R.S., 1985, c. S-18, s. 6; 2001, c. 4, s. 121.

Assim, a Corte canadense seria competente para julgar Estados que causassem a morte, o dano pessoal, corporal, ao patrimônio ou a perda de propriedade a qualquer pessoa, desde que estes atos fossem praticados dentro do território canadense (exceção com base na competência territorial).

A dualidade entre a configuração ou não de referidas exceções é o argumento central de autores e réus, reconhecendo os primeiros a não implementação direta destas, mas sua aplicação analógica pela prática de ato contrário à norma jus cogens ${ }^{5}$, e estes, não

53 SOARES, Guido E. Silva; MENDES, Gilmar Ferreira; GARCIA, Márcio Pereira Pinto. Imunidade de jurisdição: evolução e tendências. In: IMUNIDADE soberana: o estado estrangeiro diante do juiz nacional. Brasília: CEJ, 2001. (Série Cadernos do CEJ, v. 19). Disponível em: <http://daleth.cjf.jus.br/revista/seriecadernos/ vol19.pdf>. Acesso em: 23 maio 2014.

54 CANADA. State Immunity act. an act to provide for state immunity in Canadian courts. Available at: < http://laws-lois.justice. gc.ca/PDF/S-18.pdf>. Last access on: 27 jun. 2014.

55 Motion to institute proceedings. parágrafo 108: “The prohibition against torture is a principle of costumary international 
implementação destas hipóteses e o consequente afastamento da jurisdição canadense. Da análise dos fatos e alegações das partes sob a luz do State Immunity Act que emanou o posicionamento da Quebec Superior Court no caso Kazemi, a qual, em decisão da lavra do juiz Robert Mogeon, afastou a competência da Corte no tocante ao espólio da Sra. Kazemi, mas definiu sua competência no tocante aos direitos do herdeiro, o Sr. Stephan (Salman) Hashemi, acolhendo parcialmente as alegações das partes autora e da parte ré.

\subsection{Os danos sofridos pelo herdeiro e a hipótese de competência do art. 6(a) do Canada State Immunity Act}

O Excelentíssimo juiz Robert Mongeon, ao proferir a primeira decisão sobre a admissibilidade do caso Kazemi perante a Corte Canadense, reconheceu a veracidade dos fatos e, quanto ao direito, considerando a validade do SIA em confronto com a Constituição canadense, vez que, em remissão a decisões de casos como Schreiber v. Canada; Bouzari et al v. Islamic Republic, Attorney-General of Canada et al, Intervenors; Al-Adsani v. United Kingdom e Jones v. Kingdom of Saudi Arabia, reconheceu que, no âmbito do ordenamento jurídico canadense, o State Immunity Act estabelece "todos os princípios legais aplicáveis à questão da imunidade de jurisdição do Estado estrangeiro... e, a menos que expressamente atestado em contrário, o SIA contém não apenas o princípio geral da imunidade de jurisdição do estado estrangeiro mas também todas as exceções que podem ser invocadas face a este princípio geral". ${ }^{56}$

law so fundamental and widely acknowledged that it has attained the ststus of a peremptory norm. As jus cogens, it is a requirement that takes precedence over all other laws, be they domestic or international, including those which would provide foreign sovereign immunity. Mr Hashemi therefore pleads that Superior Court of Quebec has jurisdiction to hear this action notwithstanding the provisions of the State Immunity Act, R.S.C. 1985, c. S-18”. ESTATE OF LATE ZAHRA KAZEMU ET AL V. THE ISLAMIC REPUBLIC OF IRAN ET AL. Motion to institute proceedings. par. 108. Disponível em: < http://www.zibakazemi.org/archive/documents/suitqc.pdf>.

56 Tradução livre do trecho; "all of the legal principles applicable to the question of foreign state immunity... and, unless expressly stated otherwise, the SIA contains not only the general principle of foreign state immunity but also contains all of the exceptions which may be invoked against such general principle CANADA. Quebec Superior Court of Justice. Kazemi (Estate of) C. Islamic Republic of Iran, 2011 QCCS 196 (Canlii). Case $\mathrm{n}^{\circ}$ 500-17-031760-062. Judge Robert Mongeon. 26 jan. 2011. par 48. Disponível em: <http://canlii.ca/t/2fh0s $>$. Acesso em: 29 maio 2014.
A análise do caso se restringiu, a partir de então, à possibilidade de configuração das hipóteses de exceção do art. 6(a) ou da aplicação irrestrita do art. $3^{\circ}$. Nesse sentido e citando a decisão e fundamentos do caso Schreiber, o magistrado passou a analisar as implicações da expressão personal injury para a configuração ou não da legitimidade do herdeiro, o Sr. Hashemi ${ }^{57}$.

No tocante ao conteúdo material das exceções previstas no artigo 6(a), remete-se o Excelentíssimo Juiz ao caso Schreiber, no qual a Suprema Corte canadense chegou à conclusão de que, para a configuração da personal injury quando da alegação exclusiva de danos psicológicos, como foi o caso do Sr. Hashemi, estes deveriam se manifestar fisicamente, vez que confrontando o SIA em suas duas versões, a outra conclusão não se poderia chegar:

Tendo por base as provisões da C.C.Q, e as leis relevantes para o caso e a doutrina acima exposta, eu acredito que o conceito no direito civil de 'préjudice corporel-bodily injury', apessar de sua flexibilidade, incorporam uma limitação interna ao âmbito potencial do art. 6(a) da Lei, requerendo uma certa forma de interferência sobre a integridade física. Ainda que os termos 'morte' ou 'lesão pessoal', encontrados na versão inglesa, possibilitem a inclusão de uma lesão não corporal entre as hipóteses de exceção do art. 6(a), os conceitos no direito civil de 'dommages corporels' encontrado na versão francesa do art. 6(a) assim não o faz. Como a versão francesa é a mais clara e mais restritiva das duas versões do art. 6(a), ela melhor reflete a intenção comum do legislador encontrada nas duas versões. ${ }^{58}$

57 Tradução livre do trecho: "Based on the provisions of the C.C.Q, and the relevant case law and doctrine set above, I believe that the civil law concepts of 'préjudice corporel - bodily injury', despite their flexibility, incorporate an inner limitation to potential ambits of s. $6($ a) of the Act, requiring some form of interference with physical integrity. Although the term 'death' or 'personal injury' found in the English version allow the possibility of non-physical injury to be captured within the s. 6(a) exception, the civil law concepsts of 'dommages corporels' found in the French version of s. 6(a) does not. As French version is the clearer and more restrictive version of $s .6(a)$ of the two, it best reflects the common intention of the legislator found in both versions CANADA. Quebec Superior Court of Justice. Kazemi (Estate of) C. Islamic Republic of Iran, 2011 QCCS 196 (Canlii). Case no 500-17-031760-062. Judge Robert Mongeon. 26 jan 2011. par. 68. Disponível em: <http://canlii.ca/ t/2fh0s >. Acesso em: 29 maio 2014.

58 Schreiber v. Canada (Attorney General), [2002] 3 SCR 269, 2002 SCC 62 (CanLII), <http://canlii.ca/t/51rl> retrieved on 2014-06-01 apud CANADA. Quebec Superior Court of Justice. Kazemi (Estate of) C. Islamic Republic of Iran, 2011 QCCS 196 (Canlii). Case $n^{\circ}$ 500-17-031760-062. Judge Robert Mongeon. 26 jan 2011. par. 92. Disponível em: <http://canlii.ca/t/2fh0s >. Acesso em: 29 
A admissibilidade da ação no tocante ao Sr. Hashemi teve, então, por fundamento a possibilidade de configuração, ao longo do processo, das consequências físicas do dano psicológico a ele causado pelo evento morte e aqueles que o antecederam, ${ }^{59}$ determinando, por fim, a subsunção da pretensão do herdeiro à exceção contida no artigo 6(a), nos seguintes termos:

O senhor Hashemi sofreu este prejuízo traumático enquanto residindo no Canadá e isto é suficiente para a aplicação da exceção do artigo 6(a) do SIA. Se o demandante puder provar que o 'trauma' alegado interfere em sua integridade física ou constitui o equivalente a um 'choque nervoso', como elaborado pela Corte canadense no caso Schreiber e Andrusiak, então a imunidade dos demandados será inexistente. A existência, os efeitos e extensão do trauma são questões que deverão ser demonstradas em juízo perante o juiz que se ocupará do mérito da causa. Deste modo, o recurso do Sr. Hashemi não pode ser indeferido no presente estágio de julgamento ${ }^{60}$.

A aplicação destas exceções no tocante às pretensões do espólio, por outro lado, não gerou grandes considerações, vez que todos os danos foram sofridos, não no Canadá (competência territorial), mas no Irã. Assim, a exceção dos réus foi aceita no tocante ao espólio da Sra. Kazemi e rejeitada no que toca seu herdeiro, sendo as pretensões deste recebidas e as daquela rejeitadas.

maio 2014.

59 Schreiber v. Canada (Attorney General), [2002] 3 SCR 269, 2002 SCC 62 (CanLII), <http://canlii.ca/t/51rl> retrieved on 2014-06-01 apud CANADA. Quebec Superior Court of Justice. Kazemi (Estate of) C. Islamic Republic of Iran, 2011 QCCS 196 (Canlii). Case $\mathrm{n}^{\circ}$ 500-17-031760-062. Judge Robert Mongeon. 26 jan 2011. par. 83 e 85. Disponível em: <http://canlii.ca/t/2fh0s>. Acesso em: 29 maio 2014.

60 Tradução livre do trecho "Mr. Hashemi endured this traumatic prejudice while he was resinding in Canada and this is sufficient to trigger the exception in section 6(1) SIA. If the Plaintiff can prove that his alleged 'trauma' touches upon physical integrity or constitues the equivalent of a 'nervous shock' as elaborated by Canadian courts in Schreiber and Andrusiak, then the immunity of the Defendants shall be non-existent. The existence, the effects and depth of his trauma are matters that should be demonstrated at trial before the judge seized of the merits of the case. Accordingly, the recourse of Mr. Hashemi cannot be dissmissed at this stage". CANADA. Quebec Superior Court of Justice. Kazemi (Estate of) C. Islamic Republic of Iran, 2011 QCCS 196 (Canlii). Case $n^{\circ}$ 500-17-031760-062. Judge Robert Mongeon. 26 jan 2011. Disponível em: <http://canlii.ca/t/2fh0s $>$. Acesso em: 29 maio 2014 .Par. 92.

\section{0 dano causado ao herdeiro não permite fixar a jurisdição canadense: 0 caso na Quebec Court of Appeal}

\subsection{A Constituição canadense interpretada à luz do jus cogens: razões para indenizar o espólio}

Inconformados com a decisão, autores e réus apelam à Quebec Court of Appeal da decisão supra analisada com base respectivamente na inconstitucionalidade do SIA frente a Canadian Bill of Rights and Freedoms, o Canadian Charter of Rights and Freedoms, e a Convention Against Torture and other Cruel, Inbuman or Degrading Treatment or Punishment; e na não configuração das hipóteses de exceção do art. 6(a), pela simples alegação de dano moral, o que será objeto do próximo tópico.

A pretensa inconstitucionalidade encontra azo no obstáculo imposto pelo SIA a um devido processo legal no caso Kazemi, vez que, em não tendo havido qualquer investigação ou responsabilização por parte das autoridades iranianas no Irã, a admissibilidade da reclamação pela Corte canadense constituiria o único meio para se alcançar referidas reparações e responsabilizações. Nesse ínterim, em não admitindo sua competência, o Estado canadense estaria corroborando com as atrocidades levadas a feito pelo Irã, em clara violação a dispositivos constitucionais.

Desta forma a garantia da imunidade de jurisdição do estado estrangeiro entraria em confronto direto com o art. 2 da Bill of Rights ${ }^{61}$, que prevê o direito ao

61 "BILL OF RIGHTS- Art2. Every law of Canada shall, unless it is expressly declared by an Act of the Parliament of Canada that it shall operate notwithstanding the Canadian Bill of Rights, be so construed and applied as not to abrogate, abridge or infringe or to authorize the abrogation, abridgment or infringement of any of the rights or freedoms herein recognized and declared, and in particular, no law of Canada shall be construed or applied so as to

(a) authorize or effect the arbitrary detention, imprisonment or exile of any person;

(b) impose or authorize the imposition of cruel and unusual treatment or punishment;

(c) deprive a person who has been arrested or detained

(i) of the right to be informed promptly of the reason for his arrest or detention,

(ii) of the right to retain and instruct counsel without delay, or

(iii) of the remedy by way of habeas corpus for the determination of the validity of his detention and for his release if the detention is not lawful;

(d) authorize a court, tribunal, commission, board or other authority to compel a person to give evidence if he is denied counsel, protection against self crimination or other constitutional safeguards;" CANADÁ. Canadian Bill of Rights (S.C. 1960, c. 44). Disponível em: <http://laws-lois.justice.gc.ca/eng/acts/c-12.3/ page-1.html>. Acesso em: 18 maio 2014. 
devido processo legal, o art. 7 da Carta canadense ${ }^{62}$, que prevê a proteção da pessoa humana e a Convenção contra a Tortura ${ }^{63}$ como um todo, por não implementar seus objetivos e fundamentos de vedação à pratica da tortura.

Pretendem, então, os autores que as normas canadenses sejam aplicadas sob a luz dos valores reconhecidos pela soberania canadense, em especial aqueles fundados em normas internacionais cogentes, como a Convenção Contra a Tortura para que se declare a infringência pelo art. $3^{\circ}$ do State Immunity Act aos arts. $2^{\circ}$ da Bill of Rights e $3^{\circ}$ da Carta canadense e sua consequente inconstitucionalidade.

A Quebec Court of Appeal, na análise da constitucionalidade do SIA, reafirma sua completude no tocante às exceções previstas, não constituindo o costume internacional e as normas de jus cogens, instrumentos suficientes para sua ampliação, direito reservado à manifestação soberana do Estado através de seu legislativo. Atesta sua constitucionalidade e compatibilidade com dispositivos da Bill of Rights e da Charter, vez que as determinações fundadas nestas dizem respeito à implementação das garantias já asseguradas por lei. Assim, aqueles dispositivos não criam novos direitos para além daqueles legalmente previstos, mas asseguram o regular cumprimento deste.

Nesta senda, e tendo por base os julgamentos da matéria em casos como Schreiber, v. Canada (Attorney General), Daniel v White, Bouzari v Islamic Republic of Iran, aduzem os juízes da Court of Appeal a completude do SIA em três argumentos principais: a

62 "Charter of rights and freedoms- Art. 7 . Everyone has the right to life, liberty and security of the person and the right not to be deprived thereof except in accordance with the principles of fundamental justice". CANADÁ. Constitution Act, 1982 (80) Part I: Canadian Charter of Rights and Freedoms. Disponível em: <http:/ / laws-lois.justice.gc.ca/eng/Const/page-15.html?texthighlight $=$ canadian charter of rights and freedoms\#inc $>$. Acesso em: 18 maio 2014

63 “Convenção Contra a Tortura - Art. 14 1. Each State Party shall ensure in its legal system that the victim of an act of torture obtains redress and has an enforceable right to fair and adequate compensation, including the means for as full rehabilitation as possible. In the event of the death of the victim as a result of an act of torture, his dependants shall be entitled to compensation. 2 . Nothing in this article shall affect any right of the victim or other persons to compensation which may exist under national law". ONU. Convenção das Nações Unidas contra a Tortura e Outros Tratamentos ou Penas Cruéis, Desumanos ou Degradantes (Resolução 39/46 da Assembleia Geral das Nações Unidas), de 10 de dezembro de 1984. Disponível em: http://bvsms.saude.gov.br/bvs/publicacoes/conv_contra_tortura. pdf. Acesso em: 22 maio 2014. expressão "except as provided by this Act"/ "Sauf execptions prévues dans la présente loi"; a ausência de ambiguidade genuína a permitir uma interpretação das disposições com base nos princípios e valores a ele externos; e a consequente prevalência do direito interno em caso de conflito com o internacional.

\section{Quanto a essa prevalência explica que}

Em casos como o presente, onde um estatuto contém previsão clara e inconsistente com princípios vinculadores do Costume internacional, esta previsão poderá, nas palavras do juiz LeBel no caso Hape 'violar a lei internacional e ofender as cortesias recíprocas entre as nações', mas o Parlamento, no exercício de sua soberania tem o poder de legislar desta forma'. E continua: '... as exceções à imunidade de jurisdição dos Estados no direito positivo canadense são aquelas previstas no SIA, não em algum remanescente de uma hipotética doutrina de commom law que coexistiria com a Lei, ou em alguma regra do direito internacional costumeiro que modularia a interpretação de uma disposição legal que na verdade não precisa de interpretação. Tal norma de direito internacional costumeiro, se existisse, poderia ter sido facilmente integrada ao SIA por meio de uma emenda, mas o Parlamento assim não o fez ${ }^{64}$.

Cita, por fim, a decisão da Corte Internacional de Justiça sobre o caso Germany v. Italy, de 3 de fevereiro de 2012, no qual a República da Alemanha representou contra a República Italiana (Corte di Cassaz̧ione) perante a Corte Internacional pela não aplicação da garantia internacional da Imunidade de Jurisdição ao Estado alemão quando do julgamento de casos de violação de direitos internacionais perpetuados por esta, enquanto

64 Tradução livre do trecho "Where as here a statute contains a provision which is clear and is inconsistent with binding principles of customary international law, this provision may, in words of justice LeBel in Hape, 'violate international law and offend the comity of nations', but Parliament in the exercise of its sovereignty does have the power to enact in that form." E continua: "... the exceptions to state immunity in Canadian positive law are those set out in the SLA, not in some remnant of a bypothetical common law doctrine that would coexist with the Act, or in some rule of customary international law that might modulate the interpretation os a statutory phrase which in fact is in no need of interpretation. Such a rule of customary international law, if it existed, could easily have been integrated in the SLA by a legislative amendment but Parliament did not so." CANADA. Quebec Court of Appeal. Islamic Republic of Iran C. Hashemi, 2012 QCCA 1449. Case no 500-09-021440-110. Judges Yves-Marie Morissette, Richard Wagner, Clément Gascon. 15 ago. 2012. par. 41. Disponível em: <http://www.jugements.qc.ca/php/decision. php?liste $=76814341 \&$ doc $=2 B 1951 \mathrm{E} 730 \mathrm{AB} 4 \mathrm{~F} 1 \mathrm{BFC} 7 \mathrm{DE} 8781 \mathrm{E}$ 40C2D3A534A6207CECDBF438486FE01E90FD30\&page $=1>$. Acesso em: 29 maio 2014. 
nazista, nos territórios da Itália e da Grécia. A CIJ, apesar de reconhecer a atrocidade e ilegalidade dos atos, explicitou a ausência de autonomia entre as normas de jus cogens e a regra da imunidade de jurisdição, vez que atuariam em planos diferentes do Direito: esta é estritamente processual, apenas determina a competência jurisdicional do Estado, sem que seja necessário um juízo de valor sobre as condutas por ela abrangidas para a determinação de sua validade, o que não ocorreria com o direito material de acordo com o argumento de injustiça de Alexy. ${ }^{65}$

Superada a questão da completude, passam a analisar a implementação da hipótese de fixação de competência ínsita ao art. 6(a) em relação ao herdeiro da Sra. Kazemi (a ser analisado no tópico seguinte), e, logo em seguida, ocupam-se da questão da compatibilidade do SIA com a Canadian Bill of Rights, com a Canadian Charter of Rights and Freedoms e sua consequente constitucionalidade.

A constatação da compatibilidade da garantia da imunidade de jurisdição prevista no art. $3^{\circ}$ do State Immunity Act com a previsão de um devido processo legal do art. $2^{\circ}$ da Canadian Bill of Rights teve por fundamento os mesmos argumentos levantados no caso Aristocrat v. National Bank of the Republic of Kazakhstan e no Authorson v Canada (Attorney General), de que não haveria violação ao art. $2^{\circ}$ da Bill of Rights porque este cuida da responsabilidade do Estado canadense no tocante aos atos perpetrados por aqueles que sob seu imperium.

Nesta senda, em não havendo esta subjugação ao Poder Estatal, não haveria que se falar em aplicação do respectivo art. $2^{\circ}$ da Bill of Rights: "A Seção 2(e) da Bil of Rights não impõe ao Parlamento o dever de assegurar a audiência dos interessados antes da promulgação de uma lei. Suas proteções só são operantes na aplicação do direito a circunstâncias individuais no procedimento perante a Corte, Tribunal ou similares". ${ }^{66}$.

65 ALEXY, Conceito e validade do direito. 2. ed. Tradução Gercélia Batista de Oliveira Mendes. São Paulo: WMF Martins Fontes, 2011. p. 48 e ss.

66 Tradução livre do trecho: "Section 2(e) of the Bill of Rights does not impose upon Parliament the duty to provide a bearing before enactment of legislation. Its protections are operative only in the application of law to individual circumstances in a proceeding before a court, tribunal or similar body” CANADA. Quebec Court of Appeal. Islamic Republic of Iran C. Hashemi, 2012 QCCA 1449. Case no 500-09-021440-110. Judges Yves-Marie Morissette, Richard Wagner, Clément Gascon. 15 ago 2012. par. 107. Disponível em: <http://www.jugements.qc.ca/php/ decision. $\quad$ php?liste $=76814341 \&$ doc $=2 B 1951 \mathrm{E} 730 \mathrm{AB} 4 \mathrm{~F} 1 \mathrm{BFC} 7 \mathrm{D}$ E8781E40C2D3A534A6207CECDBF438486FE01E90FD30\&pa ge $=1>$. Acesso em: 29 maio 2014 .
A compatibilidade com o art. $7^{\circ}$ da Charter, no que este dispõe sobre o direito à liberdade de escolha, tomada pelos autores como liberdade de buscar a reparação pelo dano sofrido, encontra azo nos mesmos fundamentos de que ali se asseguram a efetividade de direitos já concedidos e reconhecidos e na medida em que estes se implementaram:

Há inúmeras normas procedimentais no Canadá, e também algumasmatérias, que determinam quem pode ser processado, por quem, quando e onde. Quer de direito ou de fato, essas normas limitam, e por vezes até precluem (como no caso dos litigantes de má-fé), a possibilidade de se trazer a juízo uma ação na forma que se bem entender. A ideia de que essas normas infrigem um 'direito de processar' ínsito ao art. $7^{\circ}$ da Carta me parece altamente problemático. ${ }^{67}$

Assim, não reconhecendo a incompletude do SIA ou sua incompatibilidade com as disposições da Canadian Bill of Rights e da Canadian Charter of Rights and Freedoms, a Corte de Apelação rejeita o primeiro bloco de argumentos dos Plaintiffs, acolhendo, por conseguinte, as pretensões de apelação dos Defendants.

\subsection{Dano moral não configura a hipótese de competência do art. 6(a) do Canada State Immunity Act: a reversão da decisão da Quebec Superior Court}

O acolhimento da competência da Justiça canadense para julgar as pretensões do Sr. Hashemi com base na alegação de que a configuração dos efeitos físicos do dano sofrido deveria ser objeto da análise do mérito, dispensável, portanto, em um juízo sumário de admissibilidade, foi considerada imprópria pela República Islâmica do Irã e demais demandados.

Isso porque, para eles, não houve ab initio, a configuração da hipótese de fixação de competência do art. 6(a) do State Immunity Act, como foi até mesmo

67 Tradução livre do trecho "There are several sets of procedural rules across Canada, and some substantive rules as well, which determine who can be sued, by whom, when and where. Whether de jure or de facto, these rules limit, and sometimes preclude altogether (for example in the case of persistently vexatious litigants), the possibility of bringing an action exactly as one might wish. The idea that such rules may all amout to potencial infrigements of a 'right to sue' subsumed under s. 7 of the Charter strikes me as highly problematic" CANADA. Quebec Court of Appeal. Islamic Republic of Iran C. Hashemi, 2012 QCCA 1449. Case no 500-09-021440-110. Judges Yves-Marie Morissette, Richard Wagner, Clément Gascon. 15 ago 2012. par. 119. Disponível em: <http://www.jugements.qc.ca/php/decision. php?liste $=76814341 \&$ doc $=2 B 1951 \mathrm{E} 730 \mathrm{AB} 4 \mathrm{~F} 1 \mathrm{BFC} 7 \mathrm{DE} 8781 \mathrm{E}$ 40C2D3A534A6207CECDBF438486FE01E90FD30\&page $=1>$. Acesso em: 29 maio 2014. Nota rodapé 107. 
reconhecido pelos autores em sua inicial, vez que intentaram a reparação não pela subsunção de sua situação às hipóteses de exceção previstas no SIA, mas a uma interpretação analógica destas com vistas a ampliar sua aplicação frente os casos de violação a normas de jus cogens. Nesse sentido sustentam ter havido dano apenas indireto e reflexo, de forma que o dano principal em que fundada a ação ficou adstrito ao território iraniano. Por outro lado, o senhor Hashemi em momento algum alegou a consequência física de seus danos psicológicos, constituindo-se em meros danos morais, a exemplo do que ficou decidido no caso Schreiber.

A Corte de Apelação, analisando os conceitos dos termos trazidos pelo art. 6(a) do SIA, e tendo por base os entendimentos esposados em outras decisões similares, decidiu por acolher as pretensões do recurso dos réus para afastar a incidência da Jurisdição canadenses relativamente às pretensões do Sr. Hashemi, por não encontrar em suas alegações base para a configuração de dano físico além dos meramente morais efetivamente demonstrados.

Assim, no que toca à expressão "personal or bodily injury"/ "dommages corporels", a Court of Appeal repete o entendimento do juiz de primeiro grau ${ }^{68}$ no sentido de ser necessária a somatização do dano psicológico, demonstrando claro prejuízo físico ao herdeiro, mas reforma àquela, com base nos casos Greco v. Holy SEE (State of Vatican City), P.(R.) v. Westwood, Ritter v. Donell and Castle v. United State Department of Justice (Attorney general), nos seguintes termos:

... as alegações relevantes do pleito do sr. Hashemi se referem meramente a noções gerais de trauma, prejuízo psicológico e emocional. O juiz de primeiro grau ponderou que esse alegação de trauma poderia, no fim das contas, ter interferido na integridade física do Sr. Hashemi e que em juízo poderia ser evidenciado o dano corporal como resultado. Opinou então que isso era suficiente para permitir que o pleito fosse admitido para julgamento. Eu respeitosamente discordo. Mesmo considerando os fatos como sustentado, as alegações do Sr. Hashemi não conseguem explicitar um prejuízo à integridade física; deste modo, elas falham em demonstrar o cabimento da exceção prevista no art. 6(a). Teria sido fácil para o Sr. Hashemi expor devidamente a

68 Remete-se o leitor à discussão feita no item 3.2 sobre a adequação dos significados das disposições do SIA em inglês e aquelas em francês para que se pudesse chegar à real vontade do legislador. extensão, se houvesse alguma, do prejuízo à integridade física que teria sofrido. Contudo, ele preferiu não fazêlo. Era dele, entretanto, o ônus de provar que a exceção do art. 6(a) se aplicaria ao caso em tela ${ }^{69}$.

Assim, refutando os últimos argumentos dos Plaintiffs, a Quebec Court of Appeal, rejeita o recurso do espólio de Kazemi, dá provimento ao da República Iraniana, Ayatollah Sayd Ali Khamenei, Saeed Mortavazi e Mohammad Bakhshi para rejeitar a ação contra estes intentada pelo herdeiro, o Sr. Hashemi, em consonância com o reiterado posicionamento da jurisprudência canadense de não configuração de exceção à imunidade de jurisdição a infringência às normas que vedam a prática da tortura, ainda que importem na violação de normas de jus cogens.

\section{A limitação à responsabilização patrimonial do estado estrangeiro pela prática de atos de tortura não afronta a sociedade democrática de direito: 0 caso na Supreme Court of Canada}

Inconformados com a negativa geral da Court of Appel, o Sr. Hashemi e o espólio da Sra. Kaz̧emi desafiaram a constitucionalidade do SIA, frente às disposições da Charter e da Bill of Rights canadenses. Em 17 de outubro de 2014, após quase 2 anos de um longo e desgastante processo, e sem um posicionamento unânime, a Suprema Corte do Canadá proferiu a decisão final para o Caso Kazemi, ratificando o posicionamento do Estado canadense acerca da aplicabilidade da imunidade de jurisdição frente à prática de atos de tortura ${ }^{70}$.

69 Tradução livre do trecho: ““'.... the relevant allegations of $M r$. Hashemi's claim merely refer to general notions of trauma, psychological and emotional prejudice. The motion judge noted that this alleged trauma may, in the end, touch upon Mr. Hashemi's physical integrity and that the evidence at trial may indicate the suffere bodily injury as result. He therefore opined that this was suffucuent to allow the claim to go to trial. I respectfully disagree. Even if taken as averred, the allegations of $\mathrm{Mr}$. Hashemi's claim fall short of establishing any breach of physical integrity; accordingly, they fail to bring into play the exception set out in s. 6(a). It would have been easy for Mr. Hashemi to properly articulate the extent, if any, of the breach of physical integrity that he may have suffered. Still, he elected noto to do so. He had, after all, the burden of establishing that the s. 6(a) exception applied here". CANADA. Quebec Court of Appeal. Islamic Republic of Iran C. Hashemi, 2012 QCCA 1449. Case $\mathrm{n}^{\circ} 500-$ 09-021440-110. Judges Yves-Marie Morissette, Richard Wagner, Clément Gascon. 15 ago 2012. par. 84. Disponível em: <http:// www.jugements.qc.ca $/ \mathrm{php} /$ decision.php?liste $=76814341 \& \mathrm{doc}=2 \mathrm{~B}$ 1951E730AB4F1BFC7DE8781E40C2D3A534A6207CECDBF43 8486FE01E90FD30\&page=1>. Acesso em: 29 maio 2014.

70 CANADA. Supreme Court of Canada. Estate of the Late Zabra (Ziba) Kazemi, et al. v. Islamic Republic of Iran. Available at: <http://www.scc-csc.gc.ca/case-dossier/info/sum-som-eng. aspx?cas $=35034>$. Last access on: 29 mai 2014 . 
5.1 Hipóteses de exceção à imunidade de jurisdição e a qualificação da prática de tortura como ato oficial do Estado: impedimentos infraconstitucionais à desconsideração da imunidade de jurisdição.

Antes de adentrar especificamente na questão da constitucionalidade do SIA e como pressuposto para a resolução desta, a Suprema Corte canadense se dignou a analisar todos os argumentos até então trazidos pelas partes e pelas instâncias anteriores.

$\mathrm{O}$ primeiro argumento enfrentado foi o que diz respeito à completude do SIA no que toca à regulamentação da matéria de imunidade de jurisdição, ponto mais afeito ao conflito imunidade de jurisdição versus a violação de norma jus cogens, no qual se perquiriu se a incontestável peremptoriedade da proibição da prática de atos de tortura era condição suficiente para a criação de uma jurisdição cível universal e para a criação de uma exceção cogente e erga omnes à imunidade de jurisdição.

A Corte enfrentou de início o problema da completude do SIA, que, não prevendo a prática de atos de tortura em sentido amplo, estaria, segundo a tese dos autores, defasado frente à evolução do Direito Internacional e do sistema de proteção da pessoa e dos direitos humanos. Para a Corte, conforme voto do relator, ministro LeBell, a questão da imunidade de jurisdição é questão atinente ao direito processual interno, fruto da cortesia, costume internacional e política interna, de forma que apenas o Legislativo, como detentor do Poder de dizer a vontade do Povo, é competente para impor-lhe exceções. Nesse sentido, o Parlamento canadense escolheu o critério da territorialidade para fixar sua jurisdição, inclusive quando um dos elementos da ação for o Estado estrangeiro.

Com isso, a interpretação da suposta "lacuna" do SIA foi no sentido diametralmente oposto àquele sustentado pelos autores, posto que se traduz na proposital não previsão desta exceção. Assim, a completude do SIA emana da própria inexistência de mobilização deste Poder para a inclusão da tortura praticada no estrangeiro como hipótese de exceção à imunidade de jurisdição, bem como da inexistência de uma jurisdição cível universal para casos como o Kazemi ${ }^{71}$. Ainda nesse

71 CANADA. Supreme Court of Canada. Estate of the Late Zabra (Ziba) Kazemi, et al. v. Islamic Republic of Iran, et al. Available at: <http://www.scc-csc.gc.ca/ case-dossier/info/ sum-som-eng. aspx?cas $=35034>$. Last access on: 29 mai 2014 . sentido, é a análise da possibilidade de configuração da hipótese 6(a) em relação ao dano psicológico sofrido pelo Sr. Hashemi, na qual a Corte Suprema reitera o posicionamento da Court of Appeal ${ }^{2}$, retomando e reafirmado a questão da territorialidade da jurisdição canadense e da interpretação do SIA como resultado da manifestação da vontade e opção políticas do Estado. ${ }^{73}$

A Corte seguiu ainda o voto do relator, sendo dissidente a ministra Abella J., no sentido de que, sendo a tortura, na forma em que concebida pelo artigo $1^{\circ}$ da Convenção contra a tortura e outros tratamentos ou penas cruéis desumanos ou degradantes $(1984)^{74}$, um ato tipicamente de Estado, insofismável a incidência da imunidade de jurisdição do estado estrangeiro nos casos em que presentes os atos de tortura, posto que emanados da Soberania estatal. A incidência do instituto se dá, ainda, da forma mais abrangente possível, conglobando os oficiais, que, nesta qualidade, e agindo como longa manus do Estado, levaram a feito os atos cruéis, posto que seus atos são emanação da própria vontade do Estado $^{75}$.

Assim, configuradas a completude do SIA, a caracterização da tortura com ato de império e afastadas as hipóteses de configuração de exceção à imunidade de jurisdição, chegou a Corte à conclusão de que a desconsideração da imunidade de jurisdição do estado estrangeiro ante a prática de atos de tortura não encontra arrimo na legislação infraconstitucional,

72 Remete-se o leitor ao subitem 4.2 do presente trabalho.

73 CANADA. Supreme Court of Canada. Estate of the Late Zabra (Ziba) Kazemi, et al. v. Islamic Republic of Iran. Available at: <http://www.scc-csc.gc.ca/case-dossier/info/sum-som-eng. aspx?cas $=35034>$. Last access on: 29 mai 2014.

74 Convenção contra a tortura e outros tratamentos ou penas degradantes (1984), art. 1: "Para os fins da presente Convenção, o termo "tortura" designa qualquer ato pelo qual dores ou sofrimentos agudos, físicos ou mentais, são infligidos intencionalmente a uma pessoa a fim de obter, dela ou de uma terceira pessoa, informações ou confissões; de castigá-la por ato que ela ou uma terceira pessoa tenha cometido ou seja suspeita de ter cometido; de intimidar ou coagir esta pessoa ou outras pessoas; ou por qualquer motivo baseado em discriminação de qualquer natureza; quando tais dores ou sofrimentos são infligidos por um funcionário público ou outra pessoa no exercício de funções públicas, ou por sua instigação, ou com o seu consentimento ou aquiescência. Não se considerará como tortura as dores ou sofrimentos que sejam conseqüência unicamente de sanções legítimas, ou que sejam inerentes a tais sanções ou delas decorram". Disponível em: <http://bvsms.saude.gov.br/bvs/ publicacoes/conv_contra_tortura.pdf $>$. Acesso em: 22 maio 2014

75 CANADA. Supreme Court of Canada. Estate of the Late Zabra (Ziba) Kazemi, et al. v. Islamic Republic of Iran. Available at: <http://www.scc-csc.gc.ca/case-dossier/info/sum-som-eng. aspx?cas $=35034>$. Last access on: 29 mai 2014. 
de forma que necessário o enfrentamento do desafio constitucional.

\subsection{A limitação ao direito de reparação em casos de tortura é compatível com a sociedade democrática de direito: a constitucionalidade do SIA.}

A argumentação da Corte Suprema no que tange à constitucionalidade do $S A I$ parte do pressuposto de que nenhuma norma canadense poderá ser interpretada ou aplicada de modo a negar ao indivíduo o acesso à justiça. Esse pressuposto, contido na seção 2(e) do Bill of Rights canadense, parece desafiado pelas disposições relativas à imunidade, formando uma barreira procedimental à realização da justiça. Tal linha argumentativa foi combatida pela Advocacia Geral do Canadá, arrazoando que o Bill só protegeria direitos que já existissem quando de sua promulgação em 1960, o que não é o caso do direito de processar um Estado estrangeiro, visto que a imunidade de jurisdição, na época, era absoluta. Além disso, o direito contido na seção 2(e) consiste em um direito procedimental que só pode existir no seio de um processo judicial e, como não é possível instituir um processo judicial no caso Kasemi, o dispositivo não é aplicável. O relator do caso posicionou-se de acordo com a Advocacia Geral, acrescentando que a seção 2(e) não cria um direito autônomo de acesso a justiça quando a lei não autoriza a formação de um processo. ${ }^{76}$

A seguir, foi abordada a questão da compatibilidade do artigo 3(1) o do SIA com o artigo 7 da Canadian Charter of Rights and Freedoms. $\mathrm{O}$ teste em questão envolveu elucidar se a imunidade de jurisdição, na forma como disposta na legislação canadense, implica em uma limitação à segurança de indivíduos e, portanto, tem potencial para ofender a Carta. $\mathrm{O}$ arrazoado partiu da afirmativa dos recorrentes de que o artigo 3(1) amplia o sofrimento dos indivíduos ao impedir que estes busquem reparação após um membro de sua família haver sido torturado e que tal sofrimento vai muito além da ansiedade comum ocasionada pelas vicissitudes da vida. Em seguida, introduziu a posição do Advogado Geral do Canadá, pela qual o artigo 7 não é aplicável à questão, uma vez que o senhor Hashemi limitou-se a alegar que sofreu dano psicológico decorrente da

76 CANADA. Supreme Court of Canada. Estate of the Late Zahra (Ziba) Kazemi, et al. v. Islamic Republic of Iran. Available at: <http://www.scc-csc.gc.ca/case-dossier/info/sum-som-eng. aspx?cas $=35034>$. Last access on: 29 mai 2014. tortura sofrida por sua mãe e da impossibilidade de buscar compensação no Irã, e não dano decorrente da impossibilidade de processar o Irã no Canadá, acrescentando ainda que não há evidência de que a interdição de um processo civil impeça a reabilitação de vítimas de tortura e afirmando, por fim, que o dano sofrido pelo Sr. Hashemi não foi nem profundo nem sério, como exigido pelo artigo $7 \mathrm{da}$ Charter. Por fim, o relator introduziu a perspectiva dos intervenientes, de que o direito internacional provê fundamento aos pedidos do Senhor Hashemi, em particular à alegação de que o artigo 3(1) do SIA causou a ele um trauma psicológico e que há substancial jurisprudência internacional no sentido de que a negativa de acesso à reparação em casos de tortura causa dano psicológico, no caso em questão, o dano seria tão severo que envolveria a violação do artigo 7 da Charter?

Emseguida, orelatorpassou àanálise dos argumentos apresentados, considerando inicialmente que a ação estatal envolve a segurança da pessoa quando possui impacto em sua integridade psicológica individual, sendo que esse impacto deve ser grave, profundo e seus efeitos objetivamente verificáveis. Além disso, tais danos graves, profundos e objetivamente verificáveis devem apresentar uma suficiente conexão causal entre o dano psicológico e as ações do Estado, de modo a permitir afirmar que o dano foi resultante da ação do Estado. O relator admitiu que a impunidade por tortura pode causar significativo dano psicológico à vítima e a seus familiares, posição esta que encontra suporte na jurisprudência internacional, da qual destacou a da Corte Interamericana de Direitos Humanos. Ele ponderou que seria preferível que esse dano tivesse sido verificado pericialmente na fase de instrução, mas que isso não seria razão a obstar a discussão. Observou ainda que não é evidente a equiparação entre ausência de reparação civil devida à imunidade de jurisdição do Estado e impunidade, no entanto, reconheceu que o interesse em obter uma resposta final após um ato de tortura toca aspectos cruciais da dignidade humana ${ }^{78}$.

Com relação ao nexo de causalidade, o relator apontou que sua configuração não exige que o Estado

77 CANADA. Supreme Court of Canada. Estate of the Late Zabra (Ziba) Kazemi, et al. v. Islamic Republic of Iran. Available at: $<$ http://www.scc-csc.gc.ca/case-dossier/info/sum-som-eng. aspx?cas $=35034>$. Last access on: 29 mai 2014.

78 CANADA. Supreme Court of Canada. Estate of the Late Zabra (Ziba) Kazemi, et al. v. Islamic Republic of Iran. Available at: <http://www.scc-csc.gc.ca/case-dossier/info/sum-som-eng. aspx?cas $=35034>$. Last access on: 29 mai 2014. 
seja o único ou mesmo o principal causador do dano sofrido pelas vítimas. Ou seja, embora a razão imediata do dano psicológico causado ao senhor Hashemi tenha sido a tortura da qual sua mãe foi vítima no Irã, isso não elimina necessariamente qualquer papel do Canadá em seu sofrimento. No entanto, embora seja possível, na visão do relator, que a aplicação do artigo 3(1) do SIA possa causar prejuízos psicológicos relevantes, capazes de ameaçar a segurança das pessoas, ele não considerou necessário decidir se o dispositivo está em conflito com a Canadian Charter, pois sua aplicação não viola nenhum princípio fundamental de justiça ${ }^{79}$.

O relator a seguir explicita que, para haver uma violação do artigo 7 da Canadian Charter, é necessário que se demonstre que um princípio fundamental de justiça foi violado devido à aplicação do artigo 3(1) do SIA.

Os apelantes alegam que isso ocorreu, levando em conta as leis do Canadá sobre tortura, a denegação de justiça do Irã e as obrigações internacionais do Canadá em virtude do artigo 14(1) da Convenção Contra a Tortura. Por conta dessas normas, a imunidade concedida pelo SIA, no caso Kazemi, viola princípios fundamentais de justiça. Além disso, deles decorre a obrigação do Canadá prover um remédio para a reparação civil daqueles que forem vítimas de tortura em um Estado estrangeiro e que a ausência de tal remédio é uma violação a princípios fundamentais de justiça, envolvendo, portanto, o artigo 7 da Canadian Charter.

O Advogado Geral do Canadá alegou que a abordagem dos apelantes adotou uma abordagem equivocada do artigo $7 \mathrm{da}$ Charter, falhando em identificar um princípio específico de justiça fundamental que tenha sido violado pelo Estado do Canadá no caso e buscando obter uma nova obrigação substancial do Canadá não prevista na Convenção Contra a Tortura, a saber, prover um mecanismo para reparação civil para vítimas de tortura no Canadá. Na visão do Advogado Geral, um princípio de justiça fundamental envolve significativo consenso na sociedade de que ele é fundamental para o modo pelo qual o sistema de justiça deve funcionar e deve ser identificado com suficiente precisão de modo a prover um padrão operacional pelo qual violações à vida, à liberdade ou à propriedade da pessoa possam ser mensuradas.

79 CANADA. Supreme Court of Canada. Estate of the Late Zabra (Ziba) Kazemi, et al. v. Islamic Republic of Iran. Available at: <http://www.scc-csc.gc.ca/case-dossier/info/sum-som-eng. aspx?cas $=35034>$. Last access on: 29 mai 2014.
No seu voto, o relator afirma não haver consenso de que o artigo 14 da Convenção Contra a Tortura deva ser interpretado da forma sugerida pelos apelantes, ao contrário, a interpretação do artigo 14 por diversos Estados e por tribunais internacionais e domésticos é no sentido de que a reparação prevista refere-se à tortura cometida dentro da jurisdição territorial do Estado-foro. Tem sido a posição adotada pelo Canadá e pelos Estados Unidos da América, acrescentou o relator, que o artigo 14 não exige que os Estados-partes na Convenção Contra a Tortura ofereçam mecanismos de reparação civil para atos de tortura comedidos em países estrangeiros ${ }^{80}$, argumento desenvolvido exaustivamente na decisão, com referências à jurisdição de diversas cortes e exame da redação do dispositivo e de suas possíveis interpretações, cuja análise mais detalhada é necessária e será objeto de próximo estudo.

Assim, a questão da violação ou não de preceitos fundamentais de justiça, bem como a interpretação das obrigações canadenses perante a comunidade internacional, decorrentes da Convenção Contra a Tortura se mostram os pontos-chave para a compreensão da posição canadense no caso, a qual sintetiza o posicionamento da maioria dos países quanto à matéria e expõe o problema crucial colocado no início deste artigo, qual seja, o conflito entre perspectivas substanciais e procedimentais do Direito Internacional Público. Chega-se à conclusão de que, em que pese o reconhecimento da relevância dos direitos violados, a sua proteção demanda uma engenharia processual, inexistente, no momento, que permita aos Estados ou à comunidade internacional oferecer às vítimas de tortura a possibilidade de uma reparação civil, de forma que, enquanto aquela não existir, a responsabilização civil não se mostra cabível.

No fechamento do voto do relator, sua manifestação foi pelo não conhecimento da apelação. Quanto às questões constitucionais, às perguntas se o artigo 3(1) do State Immunity Act é inconsistente com o artigo 2(e) do Canadian Bill of Rights e se ele infringe o artigo 7 da Canadian Charter of Rights and Freedoms, as respostas também foram negativas. ${ }^{81}$

80 CANADA. Supreme Court of Canada. Estate of the Late Zahra (Ziba) Kazemi, et al. v. Islamic Republic of Iran. Available at: $<$ http://www.scc-csc.gc.ca/case-dossier/info/sum-som-eng. aspx?cas $=35034>$. Last access on: 29 mai 2014.

81 CANADA. Supreme Court of Canada. Estate of the Late Zabra (Ziba) Kazemi, et al. v. Islamic Republic of Iran. Available at: <http://www.scc-csc.gc.ca/case-dossier/info/sum-som-eng. aspx?cas $=35034>$. Last access on: 29 mai 2014. 


\section{CONCLUSÃO}

Os Direitos Humanos são atualmente considerados, pela sociedade internacional, normas de jus cogens, cuja coercitividade se impõe independentemente da aceitação expressa dos Estados. O reconhecimento desta indispensabilidade de sua observância deu azo, por outro lado à elaboração de inúmeros tratados sobre a matéria, de forma que, se um Estado não a reconhecer com base no imperativo moral, deverá reconhecê-la no imperativo normativo positivado. A proibição da prática da tortura, por exemplo, regulada pela Convenção Contra a Tortura e Outros Tratamentos ou Penas Cruéis, Desumanos ou Degradantes (1984), como corolário direto da Declaração Universal dos Direitos do Homem, se imporia, nestes termos, no cenário do Direito Internacional como jus cogens, de forma que oponível a qualquer Estado, ainda que não tenha este concordado com os termos daquela Convenção de 1984.

Por outro lado, a doutrina da imunidade de jurisdição dos estados soberanos, baseada na construção do direito internacional a partir da vontade dos Estados, na soberania absoluta dos Estados independentes e no brocado latino par in parem non habet judicium, garante que nenhum Estado será submetido contra sua vontade à jurisdição de outro Estado, de forma que a prática de um ato antijurídico contra particulares, quando não cabível o instituto do endosso, ou a previsão de Corte Internacional com competência para tanto, não poderá gerar responsabilidade àquele sem que haja aceitação expressa quanto a sua subordinação à jurisdição estrangeira, ou que prevista exceção a esta garantia por meio de normas internas de fixação de competência e de jurisdição de cada Estado soberano, com vista1s a se garantir a manutenção da harmonia das relações internacionais.

Desta forma, são institutos de observância obrigatória no plano internacional no que diz respeito à atuação de cada Estado no exercício de sua soberania tanto a não transgressão de normas de jus cogens como a não interferência estrangeira na condução deste exercício. Esta dicotomia coloca para o Direito Internacional o problema da harmonização destes dois institutos, vez que o desrespeito a normas jus cogens, apesar de encontrar no ordenamento jurídico internacional imperativos para sua reparação e consequente responsabilização do Estado transgressor, encontra também naquele, bem como no ordenamento jurídico interno de alguns países, obstáculos a esta responsabilização, sendo o expoente máximo, objetivada na doutrina da imunidade de jurisdição.

Nota-se, nesse ínterim, uma convergência dos pensadores do Direito Internacional para a superação desta dicotomia, no sentido de se proceder a uma mudança no paradigma da soberania absoluta e da consequente imunidade de jurisdição dos Estados soberanos, baseada na teoria da anterioridade do Direito Internacional à própria noção de Estado e na soberania como conceito de Direito Internacional. Até mesmo Bodin "fez distinção entre leis e leis, afirmando que os soberanos estariam acima de leis particulares do país que ele governa, mas, como membro de uma comunidade humana, estaria sujeito à lei divina e natural e às leis das nações, pois, mesmo que se definisse a soberania como isenta de todas as leis, não haveria soberano que teria plenitude dos direitos em razão de que a lei divina e a lei natural abrangeria a todos, inclusive o soberano". ${ }^{82}$ No mesmo sentido, Francisco Rezek leciona ser a soberania atributo essencial do Estado que o faz titular de competências que, "porque precisamente existe uma ordem jurídica internacional, não são ilimitadas, mas nenhuma outra entidade as possui superiores". ${ }^{83}$

Este espírito é claramente observável nas condenações de responsáveis por crimes de tortura e genocídio, ou ainda na existência de projetos de lei nos Parlamento mundo à fora, a exemplo do canadense, que objetiva a emenda às Leis sobre imunidade de jurisdição de Estados soberanos, como o SIA ${ }^{84}$, para incluir a tortura e outras práticas no rol das exceções daquele Ato.

A indispensabilidade, porém, da proteção conferida pela garantia da imunidade de jurisdição à soberania, seja do Estado violador de normas jus cogens, seja daquele que pode dispor livremente sobre a delimitação de competência da sua Jurisdição, impede que aquele instituto seja superado, havendo consenso na jurisprudência internacional da imprescindibilidade de ato emanado do Legislativo de cada país para fins de fixação de exceções. Assim, o posicionamento da Corte canadense, no sentindo de proteger a imunidade do Estado iraniano, reflete este posicionamento ecoado na jurisprudência internacional, de que a questão do limite à imunidade de jurisdição de estados soberanos passa, muito mais pela questão política do posicionamento de cada Estado frente à possibilidade de se ver limitado nos mesmos termos, que propriamente pelo reconhecimento da gravidade das violações perpetradas.

82 MENEZES, Wagner. Tribunais internacionais: jurisdição e competência. São Paulo: Saraiva, 2013. p. 51.

83 REZEK, Francisco. Direito internacional público: curso elementar. 15. ed. São Paulo: Saraiva, 2014. p. 265.

84 CANADA. BILL C-10: an act to enact the justice for victims of terrorism act and to amend the state immunity act, the criminal code, the controlled drugs and substance act, the corrections and conditional release act, the youth criminal justice act, the immigration and refugee protection act and others acts. Available at: <http:// www.parl.gc.ca/About/Parliament/LegislativeSummaries/bills_ ls.asp?ls $=\mathrm{c} 10-02 \& \operatorname{Parl}=41 \&$ Ses $=1>$. Last access on: 25 mai 2014. 


\section{Referências}

ACCIOLY, Hildebrando; SILVA, G. E. Nascimento e; CASELLA, Paulo Borba. Manual de direito internacional público. 20. ed. São Paulo: Saraiva, 2012.

ALEXY, Conceito e validade do direito. 2. ed. Tradução Gercélia Batista de Oliveira Mendes. São Paulo: WMF Martins Fontes, 2011.

BODIN, Jean. Les six livres de la republique: livro i, capitulo viii, 1576. Disponível em: <http://gallica.bnf.fr/ ark:/12148/bpt6k6546272j.r $=$ monarchie + de + juillet. langPT>. Acesso em: 18 maio 2014.

BRASIL. Decreto n. 40, de 15 de fevereiro de 1991. Promulga a Convenção Contra a Tortura e Outros Tratamentos ou Penas Crueis, Desumanos ou Degradantes. Disponível em: <http://www.planalto.gov.br/ccivil_03/decreto/1990-1994/ D0040.htm>. Acesso em: 22 maio 2014.

BRASIL. Decreto n. 4.388, de 25 de setembro de 2002. Promulga o Estatuto de Roma do Tribunal Penal Internacional. Disponível em: <http://www.planalto. gov.br/ccivil_03/decreto/2002/D4388.htm> Acesso em: 22 maio 2014

CANADA. BILL C-10: an act to enact the justice for victims of terrorism act and to amend the state immunity act, the criminal code, the controlled drugs and substance act, the corrections and conditional release act, the youth criminal justice act, the immigration and refugee protection act and others acts. Available at: <http://www.parl.gc.ca/About/ Parliament/LegislativeSummaries/bills_ls.asp?ls=c1002\&Parl $=41 \&$ Ses $=1>$. Last access on: 25 mai 2014.

CANADA. Canadian Bill of Rights: S.C. 1960, c. 44. Available at: <http://laws-lois.justice.gc.ca/eng/ acts/c-12.3/page-1.html>. Last access on: 18 mai 2014.

CANADA. Constitution Act, 1867: an act for the union of Canada, Nova Scotia, and New Brunswick, and the government thereof; and for purposes connected therewith. Available at: <http://laws-lois.justice.gc.ca/eng/Const/ page-5.html\#docCont>. Last access on: 12 jun. 2014.

CANADA. Constitution Act, 1982 (80) Part I: Canadian charter of rights and freedoms. Available at: $<$ http://laws-lois.justice.gc.ca/eng/Const/page-15. html? texthighlight $=$ canadian charter of rights and freedoms\#inc>. Last access on: 18 mai 2014
CANADA. Quebec court of appeal. Islamic Republic of Iran C. Hashemi, 2012 QCCA 1449: case n. 500-09021440-110. Judges Yves-Marie Morissette, Richard Wagner, Clément Gascon. 15 ago 2012. Available at: $<$ http://www.jugements.qc.ca/php/decision.php?liste $=76814341 \& \mathrm{doc}=2 \mathrm{~B} 1951 \mathrm{E} 730 \mathrm{AB} 4 \mathrm{~F} 1 \mathrm{BFC} 7 \mathrm{DE} 8781 \mathrm{E} 4$ 0C2D3A534A6207CECDBF438486FE01E90FD30\& page $=1>$. Last access on: 29 mai 2014 .

CANADA. Quebec Superior Court of Justice. Kazemi (Estate of) C. Islamic Republic of Iran, 2011 QCCS 196 (Canlii): Case n ${ }^{\circ}$ 500-17-031760-062. Judge Robert Mongeon. 26 jan 2011. Available at: <http://canlii.ca/ t/2fh0s>. Last access on: 29 maio 2014.

CANADA. Quebec Civil Code. Available at: $<$ http://www2.publicationsduquebec.gouv.qc.ca/ dynamicSearch/telecharge.php? type $=2 \&$ file $=$ / CCQ_1991/CCQ1991_A.htm>. Last access on: 12 jun. 2014.

CANADA. Quebec Code of Civil Procedure. Available at: $<$ http://www2.publicationsduquebec.gouv.qc.ca/ dynamicSearch/telecharge.php?type $=2 \&$ file $=/ C \_25 /$ C25_A.HTM>. Last access on: 12 jun. 2014.

CANADA. Supreme Court Act: An Act respecting the Supreme Court of Canada. Available at: <http://lawslois.justice.gc.ca/eng/acts/S-26/FullText.html>. Last access on: 12 jun. 2014.

CANADA. Supreme Court of Canada. Estate of the Late Zahra (Ziba) Kazemi, et al. v. Islamic Republic of Iran. Available at: <http://www.scc-csc.gc.ca/case-dossier/ info/sum-som-eng.aspx?cas $=35034>$. Last access on: 29 mai 2014.

CANADA. State Immunity Act: An Act to provide for state immunity in Canadian courts. Available at: $<$ http://laws-lois.justice.gc.ca/PDF/S-18.pdf > $\quad$ Last access on: 27 jun. 2014.

CASTRO, Thales. Teoria das relaçôes internacionais. Brasília: FUNAG, 2012. Available at: < http://funag. gov.br/loja/download/931-Teoria_das__ Relacoes_ Internacionais.pdf $>$. Last access on: 30 jun. 2014

CHEVALIER, Jean-Jacques. As grandes obras politicas de Maquiavel a nossos dias. 8. ed. Rio de Janeiro: AGIR, 1999. Disponível em: <http://mpassosbr.files. wordpress. com/2013/03/as-grandes-obras-polc3adticas-de- 
maquiavel-a-nossos-dias-jean-jacques-chevallier-riode-janeiro_-agir-1999.pdf>. Acesso em: 18 maio 2014.

FINKELSTEIN, Cláudio. Hierarquia das normas no direito internacional: jus cogens e metaconstitucionalismo. São Paulo: Saraiva, 2013.

LIMA, Renata Matovani de; ALVES, Renata de Sena. A efetividade do ativismo jurídico transnacional no Sistema Interamericano de Direitos Humanos: uma análise a partir de casos contra o Brasil. Revista de Direito Internacional, Brasília, v. 10, n. 2, p. 239-241, 2013.

MENEZES, Wagner. Tribunais internacionais: jurisdição e competência. São Paulo: Saraiva, 2013.

NASSER, Salem Hikmat. Jus Cogens: ainda esse desconhecido. RevistaDireitoGV,v.1,n.2,p.161-178,jun./ dez. 2005. Disponível em: <http://bibliotecadigital.fgv. br/dspace/bitstream/handle/10438/9658/Salem\%20 Hikmat $\% 20$ Nasser.pdf?sequence $=1>$. Acesso em: 18 maio 2014.

ONU. Convenção das Nações Unidas contra a tortura $e$ outros tratamentos ou penas cruéis, desumanos ou degradantes: Resolução 39/46 da Assembleia Geral das Nações Unidas, de 10 de dezembro de 1984. Disponível em: $<$ http://bvsms.saude.gov.br/bvs/publicacoes/ conv_ contra_tortura.pdf $>$. Acesso em: 22 maio 2014

ONU. Estatuto de Roma: U.N. Doc. A/CONF.183/9*. Disponível em: <http://legal.un.org/icc/statute/ romefra.htm>. Acesso em 22 maio 2014

PIOVESAN, Flávia. A Proteção Internacional dos Direitos Humanos das Mulheres. Revista EMERJ, Rio de Janeiro, v. 15, n. 57, Ed. Especial. p. 70-89, jan./mar. 2012. Disponível em: <http://www.emerj.tjri.jus.br/ revistaemerj_online/edicoes/revista57/revista57_70. pdf>. Acesso em: 22 maio 2014

REZEK, Francisco. Direito internacional público: curso elementar. 15. ed. São Paulo: Saraiva, 2014.
SOARES, Guido E. Silva; MENDES, Gilmar Ferreira; GARCIA, Márcio Pereira Pinto. Imunidade de jurisdição: evolução e tendências. In: IMUNIDADE soberana: o estado estrangeiro diante do juiz nacional. Brasília: CEJ, 2001. (Série Cadernos do CEJ, v. 19). Disponível em: <http://daleth.cjf.jus.br/revista/ seriecadernos/ vol19.pdf $>$. Acesso em: 23 maio 2014

SOUSA, Mônica Tereza C. Imunidade de Jurisdição de Estado Estrangeiro: aspectos doutrinários e a jurisprudência brasileira. Revista Sequência, Florianópolis, v. 21, n. 40, 2000. Disponível em: <https://periodicos. ufsc.br/index.php/sequencia/article/view/15442>. Acesso em: 23 maio 2014.

TAIAR. Rogério. Direito internacional dos direitos bumanos: uma discussão sobre a relativização da soberania face à efetivação da proteção internacional de direitos humanos. 2009. 321f. Tese (Doutorado em Direitos Humanos)-Faculdade de Direito, Universidade de São Paulo, São Paulo, 2009. Disponível em: <http://www. teses.usp.br/teses/disponiveis/2/2140/tde-24112009133818/pt-br.php>. Acesso em: 18 maio 2014.

TOLEDO JÚNIOR, Milton Nunes. Direito Internacional Imperativo: jus cogens. 2006. 120f. Dissertação (Mestrado em Direito Internacional Econômico)-Universidade Católica de Brasília, Brasília, 2006. Disponível em: $<$ http://www.bdtd.ucb.br/tede/tde_busca/arquivo. php?codArquivo=285>. Acesso em: 22 maio 2014.

UNITED STATES OF AMERICA. 28 US Code $\int 1605 A$ : Terrorism exception to the jurisdictional immunity of a foreign state. Disponível em: <http:// www.law.cornell.edu/uscode/text/28/1605A $>$. Acesso em: 27 jun. 2014.

VERDROSS, Alfred. O Fundamento do Direito Internacional. Revista de Direito Internacional, v. 10, n. 2, p. 1-33, 2013. Disponível em: <http://www. publicacoesacademicas.uniceub.br/index.php/rdi/ article/view/2685>. Acesso em: 23 abr. 2014. 


\title{
Da nacionalidade como direito humano: da necessária ampliação das hipóteses de aplicação do critério do jus sanguinis nos casos de adoção internacional*
}

\author{
Nationality as a human right: the need to expand \\ the application of jus sanguinis hypotheses \\ criterion for cases of intercountry adoption
}

Hitala Mayara Pereira de Vasconcelos

\section{Resumo}

A Convenção da Haia de 1993, ao regular a adoção internacional, manteve um silêncio normativo sobre os seus efeitos no que se refere à nacionalidade da criança adotada. Com isso, a questão tornou-se objeto de interpretação judicial, a demandar considerações sobre qual percepção deve ser adotada no que se refere à noção de nacionalidade, compreendendo-a não como mero fruto do reconhecimento estatal, mas direito humano, elevando o nacional à condição de sujeito de direitos. No Brasil, apesar da previsão do artigo 227, $\$ 6^{\circ}$, da Constituição, que equipara os filhos naturais e adotivos sem quaisquer ressalvas, vem prevalecendo uma interpretação restritiva sobre o tema, que se contrapõe à posição de vanguarda do país no que concerne à redução dos casos de apatridia. Este estudo visa, portanto, examinar os fundamentos da posição restritiva adotada pelo Brasil, contrapondo-a ao entendimento das Cortes regionais de proteção aos Direitos Humanos sobre a matéria. Com isso, poderemos concluir pela necessidade de ampliação das hipóteses de aplicação do critério do jus sanguinis para os casos de adoção internacional, incluindo os filhos adotivos dentre os brasileiros natos nas situações do artigo 12, inciso I, alíneas "b" e "c" da Constituição brasileira.

Palavras-chave: Nacionalidade. Apatridia. Adoção Internacional. Interpretação evolutiva.

\section{Abstract}

The Hague Convention of 1993, to regulate the adoption, kept silence on its legal effects about the adopted children nationality. Because of that, the issue has become the subject of judicial interpretation what demands considerations about which perception should be taken regarding the notion of nationality, no longer understood as a State recognition but as a Human Right, promoting the national to a position of subject of rights. In Brazil, despite article 227, $\$ 6^{\circ}$, of its Constitution, which equalizes natural and adoptive children with no exceptions, a limited position about this theme prevails, what contrasts with the forefront of the country on reduction of statelessness. The aim of this study is to analyse the bases of the limited position adopted by Brazil in contrast to the Regional Courts position for the protection of Human Rights on the matter. Thus, we can conclude by the need to expand the application of jus sanguinis hypotheses criterion for cases of intercountry adoption, including adoptive children among native Brazilians under circunstances of article 12, item I, points "b" and "c" of Brazilian Constitution. Keywords: Nationality. Statelessness. Intercountry Adoption. Evolutionary Interpretation.

* Recebido em: 25.09 .2014

Aceito em: 12.11.2014

** Advogada da União. Graduada em Direito pela Universidade Federal de Pernambuco. Mestranda em Direito das Relações Internacionais pelo Centro Universitário de Brasília - Uniceub. E-mail: hitalampv@ hotmail.com. 


\section{Introdução'}

Em meados de agosto de 2014, o Ministério da Justiça anunciou a conclusão dos trabalhos de elaboração do anteprojeto de lei destinado a revogar o Estatuto do Estrangeiro (Lei no 6.815, de 19 de agosto de 1980), anunciando-o como o 'Anteprojeto de lei de migrações e promoção dos direitos dos migrantes no Brasil'.

Seu texto foi resultado do trabalho de uma comissão de juristas que incluía professores universitários, membros do Ministério Público, cientistas políticos e especialistas em direitos humanos e, segundo expôs o Ministro da Justiça, uma de suas principais características consistiu no abandono do Estatuto do Estrangeiro - fruto do governo ditatorial - em virtude da necessidade de compatibilizar o regime jurídico do migrante com a Constituição brasileira e com os tratados vigentes sobre direitos humanos, inclusive quanto à nomenclatura adotada, substituindose a expressão — tida por pejorativa — 'estrangeiro' por 'migrante'.

Dias antes, o Ministério anunciava também a conclusão de um outro anteprojeto de lei, elaborado em conjunto com o Alto Comissariado das Nações Unidas para Refugiados (ACNUR) no Brasil, voltado à criação de um processo de determinação da condição de apátrida no país, com o estabelecimento de direitos e obrigações para essas pessoas ${ }^{2}$.

Por facilitar a aquisição da nacionalidade brasileira pelo apátrida, o anteprojeto foi elogiado pelo Oficial Regional de Proteção do Alto Comissariado da ONU para Refugiados para o tema da apatridia nas Américas, o qual, além de apontar o Brasil como um exemplo para os demais países da América Latina, ainda destacou a importância da atuação administrativa do país durante o período de vigência da emenda constitucional de

1 Essas informações foram disponibilizadas no sítio eletrônico do Ministério da Justiça, e a notícia foi divulgada no dia 29 de agosto de 2014, data da entrega do anteprojeto de lei à Presidência da República. BRASIL. Ministério da Justiça. Entenda o Anteprojeto de Lei de Migraçoes. Disponível em: <http://www.justica.gov.br/noticias/ proposta-de-nova-lei-de-migracoes-devera-substituir-estatutocriado-durante-a-ditadura/entenda_novo_estatutoestrangeiro2. pdf>. Acesso em: 30 ago. 2014.

2 A notícia foi divulgada no dia 14 de agosto de 2014 e disponibilizada no sítio eletrônico do Ministério da Justiça. BRASIL. Ministério da Justiça. Governo do Brasil anuncia projeto de lei para proteger pessoas sem pátria. Disponível em: <http://www.justica.gov.br/ noticias/governo-do-brasil-anuncia-projeto-de-lei-para-protegerpessoas-sem-patria>. Acesso em: 30 ago. 2014. revisão n ${ }^{\circ}$ 3, de 1994, que, alterando a alínea "c" do inciso I do artigo 12 da Constituição de 1988, reduziu as hipóteses de reconhecimento da nacionalidade brasileira para os filhos de brasileiros nascidos no exterior, demandando outras medidas que resolvessem a situação gerada pelo aumento no número de crianças apátridas $^{34}$.

Essas medidas sinalizam a adoção, pelo Brasil, de uma posição mais atual sobre o tema da nacionalidade, compreendida não mais como mero reflexo da soberania estatal, dependente exclusivamente do reconhecimento do Estado, e sim como um direito humano, posição que demanda também uma atuação proativa no combate à apatridia pelo Estado, por não se poder negar a importância da nacionalidade como pressuposto para a proteção dos demais direitos humanos.

Mas, apesar de relevantes, convém observar se tais medidas normativas refletem uma posição uníssona do Estado brasileiro - quanto à atuação dos seus três Poderes —, tomando-se por parâmetro nesta observação o tema da nacionalidade em matéria de adoção internacional, especificamente nas hipóteses em que a Constituição adota o critério do jus sanguinis para a atribuição da nacionalidade brasileira.

O artigo 12, inciso I, alíneas "b" e "c", da Constituição, apenas atribui a condição de brasileiro nato ao nascido no estrangeiro, de pai brasileiro ou mãe brasileira, desde que qualquer deles esteja a serviço da República Federativa do Brasil, ou desde que a criança seja registrada em repartição brasileira competente ou venha a residir no país e opte a qualquer tempo, após a maioridade, pela nacionalidade brasileira, sendo silente em relação aos casos de adoção no estrangeiro ${ }^{5}$ por

3 A íntegra da notícia pode ser consultada no sítio eletrônico do ACNUR no Brasil. ACNUR. Governo do Brasil anuncia projeto de lei para protegerpessoas sem pátria. Disponível em: < http://www.acnur.org/t3/ portugues/noticias/noticia/governo-do-brasil-anuncia-projeto-delei-para-proteger-pessoas-sem-patria/>. Acesso em: 30 ago. 2014.

4 Vale destacar que a alteração realizada pela emenda constitucional de revisão n ${ }^{\circ}$, de 1994, na alínea "c" do art. 12, inciso I, da Constituição de 1988 não mais opera efeitos, já que foi dada nova redação ao dispositivo com a emenda constitucional $n^{\circ} 54$, de 2007. Apesar disso, sua importância é frequentemente ressaltada por ter sido sua promulgação objeto para diversos problemas envolvendo crianças, filhas de pai(s) brasileiro(s), que, por residirem em locais que adotavam o jus sanguinis, se tornariam apátridas, problemas estes que, à época, foram amenizados através de medida provisória que autorizou a expedição de passaportes provisórios pelo país, somente vindo a ser sanados com a nova redação do artigo constitucional.

5 Vale frisar que o que define uma adoção como internacional não é a nacionalidade dos adotantes ou do adotado, e sim a mudança do local de residência habitual que ela impõe à criança. Esse é o 
pai ou mãe brasileiro nas mesmas hipóteses, apesar da previsão do artigo $227, \S 6^{\circ}$, que prescreve a igualdade de direitos entre os filhos naturais e os havidos por adoção.

Nesse cenário, passível de propiciar a ocorrência da apatria por choque entre critérios de atribuição de nacionalidade, é que se mostra pertinente uma análise sobre quais medidas o direito brasileiro prevê para assegurar o direito humano à nacionalidade à criança adotada no exterior, sendo este tema o objeto do nosso estudo.

Para tanto, iniciaremos observando a evolução do próprio conceito de nacionalidade e sua relação com a soberania do Estado, examinando seus efeitos e a importância de seu reconhecimento. Desse modo, faremos um exame sobre os instrumentos codificados em vigor, analisando sua teleologia e qual interpretação lhes vêm sendo dada pelas Cortes regionais de proteção de direitos humanos.

Mesma lógica será adotada em seguida quanto ao tema da adoção internacional, momento em que examinaremos sua evolução histórica e de que modo as Cortes de direitos humanos vêm compreendendo os efeitos do princípio da proteção ao superior interesse da criança, seu fundamento principal.

Concluído esse exame, poderemos indagar sobre o grau de aplicabilidade do artigo 227, \$6 $6^{\circ}$, da Constituição brasileira, no que se refere especificamente a seus efeitos em relação à nacionalidade, verificando se as mudanças normativas propostas e se as decisões judiciais já proferidas sobre o tema sinalizam ou não a ocorrência de um avanço no direito pátrio sobre a matéria.

Com isso, será possível observar que o Brasil ainda precisa avançar na temática, mas agora não necessariamente na edição de novas normas, e sim na interpretação das já existentes, afastando a concepção restritiva de nacionalidade, bem como o caráter eminentemente patrimonial da adoção, para ampliar a equiparação de direitos entre filhos naturais e adotivos de modo a englobar também o direito de reconhecimento da condição de brasileiro nato aos filhos adotivos, não obstante o silêncio constitucional sobre a questão.

conceito que se infere do artigo 2 da Convenção da Haia relativa à proteção das crianças e à cooperação em matéria de adoção internacional, de 1993. BRASIL. Decreto n. 3.087, de 21 de junho de 1999. Disponível em: <http://www.planalto.gov.br/ccivil_03/ decreto/d3087.htm>. Acesso em: 30 ago. 2014.

\section{Da evolução do conceito de nacionalidade: do mero reflexo da soberania estatal para a noção de direito humano}

Consistindo no "vínculo político entre o Estado soberano e o indivíduo, que faz deste um membro da comunidade constitutiva da dimensão pessoal do Estado", a nacionalidade, embora constitua tema de inegável importância para o direito internacional, ainda é disciplinada eminentemente pelo direito interno de cada Estado, pois a este compete definir aqueles que serão reconhecidos como seus nacionais.

Mas, embora seja algo histórico a necessidade do Estado de estabelecer distinção entre seus nacionais e os estrangeiros, constatou-se que essa distinção não poderia ser algo desarrazoado, tampouco justificar o exercício da violência ou da ameaça com base na soberania ${ }^{7}$. Percebeu-se que a lei internacional não mais podia admitir como absoluta a soberania em matéria de emigração, naturalização, nacionalidade e expulsão ${ }^{8}$.

Essa percepção demandou ao direito internacional estabelecer interpretações e limites à disciplina jurídica do tema, o que ocorreu principalmente após a segunda guerra mundial, em virtude das tragédias por ela ocasionadas, que resultaram em milhares de pessoas refugiadas, órfãs e, principalmente, violentadas pelas consequências que a falta de uma nacionalidade específica lhes gerou ${ }^{9}$ em virtude da utilização da nacionalidade como um critério de exclusão ${ }^{10}$.

6 REZEK, Francisco. Direito internacional público: curso elementar. 14. ed., rev., aumen. e atual. São Paulo: Saraiva, 2013. p. 218.

7 Essa percepção é apresentada pela Comissão Interamericana de Direitos Humanos CORTE INTERAMERICANA DE DERECHOS HUMANOS. 2005. Sentença de 8 de septiembre, Niñas Yean y Bosico v República Dominicana. Disponível em: <http://webcache. googleusercontent.com/search?q=cache:TDCsDySXg2sJ:www. corteidh.or.cr/docs/casos/articulos/seriec_130_esp. $\mathrm{doc}+\& \mathrm{~cd}=2 \& \mathrm{hl}=\mathrm{pt}-\mathrm{BR} \& \mathrm{ct}=\mathrm{clnk} \& \mathrm{gl}=\mathrm{br}>$. Acesso em: 10 set. 2014 .

8 Hannah Arendt vai além, para afirmar que 'somos quase tentados a medir o grau de infecção totalitária de um governo pelo grau em que usa o seu soberano direito de desnacionalização'. ARENDT, Hannah. As origens do totalitarismo. Tradução Roberto Raposo. São Paulo: Companhia das letras, 1989. p. 312.

9 Essa percepção é apresentada também por Hannah Arendt, que destaca que o apátrida, consistindo aparentemente em uma anomalia legal, apenas recebe atenção tardia após a segunda guerra mundial, juntamente com os refugiados, que consistiam em pessoas expulsas de seus países pela revolução social, quando eram desnacionalizados pelos governos vitoriosos. ARENDT, Hannah. As origens do totalitarismo. Tradução Roberto Raposo. São Paulo: Companhia das Letras, 1989. p. 311.

10 LOPES, Cristiane Maria Sbalqueiro. Direito de imigração: o 
A passagem do tempo demonstrou que se estava vivenciando um momento de transformação da soberania, que impunha sua flexibilização tanto no plano interno quanto no externo em virtude da necessidade de integração entre os poderes estatais e de afirmação de uma supremacia dos princípios e dos valores ${ }^{11}$ que determinaram uma reinterpretação dos institutos com a finalidade de adequá-los a essa nova conjuntura marcada pela proteção aos direitos humanos já fortemente violados.

Desse modo, o cenário internacional passou a idealizar princípios que deveriam orientar o exercício da soberania estatal, de forma que, mesmo ainda atribuindo ao Estado liberdade para determinar, por meio de sua legislação interna, quais são os seus nacionais, essa liberdade deveria estar orientada por um mínimo de efetividade, de acordo com "as convenções internacionais, costumes internacionais e princípios de direito geralmente reconhecidos em matéria de nacionalidade ${ }^{12}$ ", sob pena de sua legislação não ser aceita pelos demais Estados ${ }^{13}$.

Nesse aspecto é que se consagrou como princípio geral do direito internacional a regra segundo a qual o Estado não pode arbitrariamente privar o indivíduo de sua nacionalidade, nem do direito de mudar de nacionalidade, previsão expressa do artigo 15 da Declaração Universal dos Direitos do Homem de $1948^{14}$. Desse duplo preceito decorre, ainda, a constatação de que todo indivíduo tem direito a uma nacionalidade ${ }^{15}$.

Estatuto do Estrangeiro em uma perspectiva de Direitos Humanos. Porto Alegre: Núria Fabris, 2009. p. 133.

11 BUSTAMANTE, Thomas da Rosa. Teoria do Precedente judicial: a justificação e a aplicação das regras jurisprudenciais. São Paulo: Noeses, 2012. p. 33.

12 BRASIL. Decreto n. 21.798, de 6 de setembro de 1932. Disponível em: $\quad<$ http://legis.senado.gov.br/legislacao/ListaTextoIntegral. action?id=34326. Acesso em: 4 set. 2014.

13 Rezek destaca que, embora pareça haver uma contradição entre os artigos 1 e 2 da Convenção da Haia sobre conflitos de nacionalidade, essa contradição deve ser sanada pela compreensão de que o artigo 2, ao falar em "legislação do Estado", deve ser compreendido como englobando também todos os compromissos desse Estado no cenário internacional, o que inclui as convenções, costumes e princípios gerais do direito, listados de modo expresso no artigo 1. REZEK, José Francisco. Le Droit International de la Nationalité. Leiden: M. Nijhoff, 1987. (Recueil des Cours de l'Académie de droit international, 198). p. 333-400.

14 ORGANIZAÇÃO DAS NAÇÕES UNIDAS. Declaração Universal dos Direitos do Homem de 1948. Disponível em: <http:// www.ohchr.org/EN/UDHR/Documents/UDHR_Translations/ por.pdf>. Acesso em: 30 ago. 2014.

15 REZEK, Francisco. Direito Internacional Público: curso
Apesar da possível baixa efetividade do preceito ${ }^{16}$, ele já foi reputado suficiente para garantir pronunciamento da Corte Europeia de Direitos Humanos em sua defesa, o que ocorreu no caso Genovese versus Malta, quando a Corte fixou a posição de que, embora caiba ao Estado definir quem são seus nacionais, essa definição não pode se pautar em critérios discriminatórios ou desarrazoados, como ocorre, por exemplo, nos casos em que o Estado não reconhece como nacional o filho havido fora do casamento, ainda que seu genitor seja nacional do Estado de nascimento - situação na qual ao filho concebido na constância do casamento seria atribuída a mesma nacionalidade do pai ${ }^{17}$.

Com o intuito de assegurar efetividade à garantia de nacionalidade a todo e qualquer indivíduo, a Convenção Americana de Direitos Humanos, de 1969, foi além, estipulando o jus soli como critério subsidiário de atribuição de nacionalidade ${ }^{18}$, aplicável sempre que a pessoa não tiver direito a outra nacionalidade, exatamente em virtude da facilidade na sua aplicação, que reduziria substancialmente a incidência dos casos de apatridia ${ }^{19}$.

elementar. 14. ed., rev., aumen. e atual. São Paulo: Saraiva, 2013. p. 220.

Também a Convenção Americana sobre Direitos Humanos, de 1969, é expressa ao prever que 'toda pessoa tem direito a uma nacionalidade' (art. 20). BRASIL. Decreto n. 678, de 6 de novembro de 1992. Disponível em: <http://www.planalto.gov.br/ccivil_03/ decreto/D0678.htm>. Acesso em: 30 ago. 2014.

A Convenção sobre a nacionalidade da mulher, por sua vez, estabelece a impossibilidade de utilização do sexo como fator de discriminação em matéria de nacionalidade (artigo 1). BRASIL. Decreto n. 2.411, de 23 de fevereiro de 1938. Disponível em: <http://www2.camara.leg.br/legin/fed/decret/1930-1939/ decreto-2411-23-fevereiro-1938-345944-publicacaooriginal-1-pe. html>. Acesso em: 30 ago. 2014.

16 Essa é a posição do Professor Marcelo Varella, para quem essas normas possuem baixa efetividade 'porque, na relação entre Estado e indivíduos, prepondera a vontade dos Estados, não havendo como ou a quem recorrer caso um Estado crie uma regra impedindo um indivíduo de ter sua nacionalidade. VARELLA, Marcelo Dias. Direito Internacional Público. 3. ed. São Paulo: Saraiva, 2011. p. 179.

17 EUROPEAN COURT OF HUMAN RIGHTS. Cours Européenne des Dois de L'Homme. 2011. Sentença de 11 de outubro, Genovese v. Malta, Application no. 53124/09. Disponível em: < http://hudoc.echr.coe.int/sites/eng/pages/search.aspx?i=001106785\#\{“itemid”:[“001-106785”]\}>. Acesso em: 30 ago. 2014.

18 BRASIL. Decreto $n^{\circ} 678$, de 6 de novembro de 1992. Disponível em: <http://www.planalto.gov.br/ccivil_03/decreto/D0678.htm>. Acesso em: 30 ago. 2014.

19 A questão é enfatizada por Francisco Rezek, que destaca, ainda, que "esse percuciente princípio não veio à luz, originalmente, em São José da Costa Rica", tendo sido previsto quinze anos antes, pela Comissão do Direito Internacional da ONU em um projeto de convenção "para a supressão da apatria no futuro", que, contudo, 
Previsão semelhante já constava da Convenção para a Redução dos Casos de Apatridia, de 1961, a qual, em seu artigo 1, determinava que 'todo Estado Contratante concederá sua nacionalidade a uma pessoa nascida em seu território e que de outro modo seria apátrida', estipulando, ainda, em outros dispositivos, a possibilidade de atribuição da nacionalidade da mãe (artigo 1.3) ou a do país onde ocorreu o abandono da criança (artigo 2), tudo com vistas a minorar o número de apátridas ${ }^{20}{ }_{-}^{21}$.

Mas, mais do que o vínculo formal, é na existência de laços sociais entre o Estado e o indivíduo que a nacionalidade ganha importância, pois, com isso, abandona-se a ideia do nacional como parte integrante do Estado ${ }^{22}$, reconhecendo-o como 'sujeito de direito de uma relação jurídica como Estado', condição indispensável para garantia de sua dignidade humana ${ }^{23}$.

A nacionalidade, originária de um movimento revolucionário de transformação social,

ganhou dimensão universal relevante na compreensão da sociedade moderna, especialmente por conta de sua correlação com a constituição dos direitos dos cidadãos. ${ }^{24}$

acabou arquivado. REZEK, Francisco. Direito Internacional Público: curso elementar. 14. ed., rev., aumen. e atual. São Paulo: Saraiva, 2013. p. 224.

20 ORGANIZAÇÃO DAS NAÇÕES UNIDAS. Convençãopara a redução dos casos de apatridia. Disponível em: <http://www.acnur.org/ t3/fileadmin/Documentos/portugues/BDL/Convencao_para_a_ Reducao_dos_Casos_de_Apatridia_de_1961.pdf?view=1 >. Acesso em: 30 ago. 2014.

21 A ideia de utilização do vínculo dos pais como mecanismo para ampliar, e não para limitar as hipóteses de atribuição da nacionalidade também foi reconhecida pela Corte Interamericana de Direitos Humanos no caso Las Niñas Yean y Bosico v. República Dominicana CORTE INTERAMERICANA DE DERECHOS HUMANOS. 2005. Sentença de 8 de septiembre, Niñas Yean y Bosico v República Dominicana. Disponível em: <http://webcache.googleusercontent. $\mathrm{com} / \mathrm{search}$ ?q= cache:TDCsDySXg2sJ:www.corteidh.or.cr/ $\mathrm{docs} / \mathrm{casos} / \operatorname{articulos} / \mathrm{seriec} \_130 \_$esp.doc $+\& \mathrm{~cd}=2 \& \mathrm{hl}=\mathrm{pt}-$ $\mathrm{BR} \& \mathrm{ct}=\mathrm{clnk \& gl}=\mathrm{br}>$. Acesso em: 10 set. 2014.

22 E, assim, afasta-se qualquer ideia de que tem o Estado o poder de realizar uma desnacionalização forçada, o que, como destacado por Hannah Arendt, ocasionou o surgimento de diversos apátridas e refugiados no período entre guerras.

23 FONTES, André R. C. Nacionalidade brasileira e adoção internacional. Disponível em: <www.tre-rj.gov.br/eje/gecoi_ arquivos/arq_051202.docx>. Acesso em: 30 ago. 2014.

24 HERANI, Renato Gugliano. Nacionalidade potestativa após a Emenda Constitucional 54/07. Disponível em: <http://www. periodicos.ufgd.edu.br/index.php/videre/article/viewFile/899/ pdf_49. Acesso em: 8 nov. 2012.
Uma vez que o 'povo' se une e se relaciona por esse status comum que os liga entre si e com o Estado.

$\mathrm{E}$ isso ocorre porque não se pode pretender desnacionalizar a proteção aos direitos humanos, observação que justifica a atuação do direito internacional no sentido de impor não só limites, mas a própria adoção de medidas positivas de combate à apatridia pelos Estados $^{25}$.

Essa percepção também foi apontada pela Corte Interamericana de Direitos Humanos no caso Ivcher Bronstein versus Peru, no qual, em remissão ao quanto já decidido no Caso Castillo Petruzzi versus outros, entendeu-se que o direito a uma nacionalidade significa dotar o indivíduo de um mínimo de amparo jurídico, de modo que privá-lo da nacionalidade de forma arbitrária significa privá-lo de seus próprios direitos políticos e dos direitos civis que são sustentados pelo vínculo com o Estado ${ }^{26}$.

No caso Las Niñas Yean y Bosico versus República Dominicana, a Corte Interamericana destacou que a falta de reconhecimento de uma nacionalidade impede o próprio reconhecimento da personalidade jurídica e, com isso, viola flagrantemente a dignidade humana, já que nega ao indivíduo de forma absoluta sua condição de sujeito de direitos ${ }^{27}$.

Tornou-se necessário que, por força de sua natureza de direito humano, a nacionalidade adquirisse o foro de matéria de direito das gentes e, nesse sentido, passível

25 Nesse sentido, veja-se que a Convenção sobre o Estatuto dos Apátridas, aprovada em Nova Iorque em 28 de setembro de 1954, e promulgada pelo Brasil através do Decreto $\mathrm{n}^{\circ} 4.246$, de 22 de maio de 2002, estabelece o dever dos Estados de adotarem as medidas necessárias para facilitar a naturalização dos apátridas que estejam em seu território (artigo 22). BRASIL. Decreto n. 4.246, de 22 de maio de 2002. Disponível em: <http://www.planalto.gov.br/ccivil_03/ decreto/2002/D4246.htm>. Acesso em: 30 ago. 2014.

26 Tradução livre do seguinte trecho: "El derecho a tener una nacionalidad significa dotar al individuo de un mínimo de amparo jurídico en las relaciones internacionales, al estabelecer a través de su nacionalidad su vinculación conun Estado determinado; y El de proteger lo contra la privación de su nacionalidade en forma arbitraria, porque de ese modo se le estaria privando de la totalidad de sus derechos políticos y de aquellos derechos civiles que se sustentan en la nacionalidad del individuo". CORTE INTERAMERICANA DE DERECHOS. 2001. Sentença de 6 de fevereiro, Ivcher Bronstein v. Peru. Disponível em: <http://www.corteidh.or.cr/docs/casos/ articulos/Seriec_74_esp.pdf>. Acesso em: 10 set. 2014.

27 CORTE INTERAMERICANA DE DERECHOS HUMANOS. 2005. Sentença de 8 de septiembre, Niñas Yean $y$ Bosico v República Dominicana. Disponível em: <http://webcache. googleusercontent.com/search?q=cache:TDCsDySXg2sJ:www. corteidh.or.cr/docs/casos/articulos/seriec_130_esp. $\mathrm{doc}+\& \mathrm{~cd}=2 \& \mathrm{hl}=\mathrm{pt}-\mathrm{BR} \& \mathrm{ct}=\mathrm{clnk} \& \mathrm{gl}=\mathrm{br}>$. Acesso em: 10 set. 2014 . 
de ingerência e de decisões por outros entes de direito internacional que não apenas o Estado soberano, tudo isso com o intuito de combater não só a apatridia de jure, a qual considera como apátrida aquele que não é reconhecido, por qualquer Estado, como seu nacional ${ }^{28}$, mas também a apatridia de fato, que acomete aqueles que possuem uma nacionalidade diversa da do Estado onde vivem $^{29}$.

Essa intervenção do direito internacional sobre a matéria passou a ser sentida no plano estatal, e não apenas em relação aos Estados que aderiram aos tratados internacionais voltados à redução dos casos de apatridia, mas por todos, uma vez que os direitos humanos se impõem pela própria lógica do cenário internacional ${ }^{30}$.

No Brasil, essa internacionalização do direito interno foi reconhecida pela Constituição, que, em seu artigo $5^{\circ}, \$ 3^{\circ}$, com a redação dada pela Emenda Constitucional $\mathrm{n}^{\circ} 45$, de 2004, declarou a possibilidade de os tratados e convenções internacionais sobre direitos humanos receberam o status de emenda

28 Esse é o conceito apresentado pela Convenção sobre o Estatuto dos Apátridas em seu artigo 1. Segundo dados do Alto Comissariado das Nações Unidas para Refugiados (ACNUR), estima-se que, atualmente, existam 12 milhões de apátridas no mundo. ACNUR. Governo do Brasil anuncia projeto de lei para proteger pessoas sem pátria. Disponível em: <http://www.acnur.org/t3/ portugues/noticias/noticia/governo-do-brasil-anuncia-projeto-delei-para-proteger-pessoas-sem-patria/> . Acesso em: 30 ago. 2014.

29 Conceito que surgiu a partir do Caso Nottebohn, decidido pela Corte Internacional de Justiça.

30 A respeito, Marcelo Dias Varella destaca que os direitos humanos compõem um conjunto normativo forte, 'que se impõe aos Estados, não necessariamente por tratados, mas pelo avanço de discurso entre diferentes atores subnacionais', o que ocorre através da construção de uma 'lógica de pertencimento ou não a um grupo de países com padrões civilizatórios mais avançados', sendo que a 'desobediência ou não adoção de uma determinada proteção é considerada como um desvio do Estado em relação aos padrões de uma civilização mais avançada'. VARELLA, Marcelo Dias. As transformações do direito internacional e algumas visões sobre um eventual processo de constitucionalização. In LUCCA, Newton de; MEYER-PFLUG, Samantha Ribeiro; NEVES, Mariana Barboza Baeta (Coord.). Direito Constitucional Contemporâneo: Homenagem ao Professor Michel Temer. São Paulo: Quartier Latin do Brasil, 2012. p. 41.

Flávia Piovesan, por sua vez, destaca que a internacionalização dos direitos humanos gerou também a emergência de uma nova feição do Direito Constitucional ocidental, como se o Direito Internacional fosse transformado em parâmetro de validade das próprias Constituições nacionais, concepção inovadora que apresentou duas consequências principais: 1) a revisão da noção tradicional de soberania absoluta do Estado; 2) a cristalização da ideia de que o indivíduo deve ter direitos protegidos na esfera internacional, na condição de sujeito de direitos. PIOVESAN, Flávia. Direitos humanos e justiça internacional. 4. ed. rev., ampl. e atual. São Paulo: Saraiva, 2013. p. 43-44. constitucional caso aprovados segundo o mesmo procedimento delas. Quanto aos tratados ratificados anteriormente à mudança constitucional, o Supremo Tribunal Federal pacificou a matéria, atribuindo-lhes o caráter de supralegalidade e, portanto, incluindo-os na pirâmide normativa apenas abaixo da Constituição ${ }^{31}$.

Desse modo, pode-se concluir que os tratados ratificados pelo Brasil atinentes à redução dos casos de apatridia consistem em normas supralegais, considerado o caráter de direito humano conferido à nacionalidade, sendo de se adotar para nosso estudo, portanto, o viés do nacional como um sujeito de direitos em relação ao Estado, e não mero componente do elemento pessoal deste.

Ademais, a Corte Interamericana de Direitos Humanos, cuja competência o Brasil reconheceu, também já firmou posição de que devem os Estados ser proativos em matéria de nacionalidade, o que significa que eles não devem apenas se abster de produzir normas que tenham efeitos discriminatórios sobre o tema, mas também atuar na adoção de práticas ou legislações cuja aplicação favoreça a redução do número de pessoas apátridas em seu território ${ }^{32}$.

Apesar de todo esse arcabouço jurídico, é preciso observar se tais considerações estão sendo observadas por nosso direito interno nos casos de adoção internacional, sendo necessário, para tanto, primeiro analisar a evolução que também esse instituto sofreu.

\section{0 princípio da proteção ao interesse superior da criança e seus efeitos em matéria de nacionalidade nas hipóteses de adoção internacional}

O contexto pós-guerra, além de ter contribuído para o avanço da temática dos direitos humanos e para a incorporação, por esta, da questão atinente à nacionalidade, também constituiu o momento propício para o crescimento dos números de adoções

31 A decisão representou uma mudança na jurisprudência do STF a respeito da prisão do depositário infiel e foi adotada quando do julgamento dos Recursos Extraordinários RE 349703 e RE 466343 e do Habeas Corpus 87585. Por não ser o objetivo deste estudo, não iremos adentrar na divergência lançada por parte da doutrina em relação à decisão do STF quanto à ideia de supralegalidade dos tratados de direitos humanos e supraconstitucionalidade.

32 CORTE INTERAMERICANA DE DERECHOS HUMANOS. 2005. Sentença de 8 de septiembre, Niñas Yean $y$ Bosico v República Dominicana. Disponível em: <http://webcache. googleusercontent.com/search?q=cache:TDCsDySXg2sJ:www. corteidh.or.cr/docs/casos/articulos/seriec_130_esp. $\mathrm{doc}+\& \mathrm{~cd}=2 \& \mathrm{hl}=\mathrm{pt}-\mathrm{BR} \& \mathrm{ct}=\mathrm{clnk} \& \mathrm{gl}=\mathrm{br}>$. Acesso em: 10 set. 2014 . 
internacionais, pois se tratou de um período marcado pelo sacrifício de milhares de vidas e por um grande número de crianças órfãs.

Originalmente pensada como mecanismo para garantir a continuidade de famílias aristocráticas sem filhos, com a transmissão do nome e de seu patrimônio, a adoção internacional, no cenário das guerras mundiais, transmudou-se em mecanismo para garantir uma família a diversas crianças abandonadas, baseando-se precipuamente na ideia de afetividade.

Apesar desse histórico, apenas em 1993 houve a aprovação do primeiro instrumento a regular especificamente a matéria em caráter internacional ${ }^{33}$ : a Convenção da Haia relativa à Proteção das Crianças e à Cooperação em Matéria de Adoção Internacional, promulgada no Brasil pelo Decreto no 3.087, de 21 de junho de 1999, e que conclui pelo caráter excepcional e subsidiário da adoção internacional, admitindo-a somente depois de esgotadas todas as possibilidades de a criança viver de forma saudável em seu país de origem, no seio de sua família biológica ou mesmo em uma família adotiva nacional.

A excepcionalidade dessa forma de adoção se justificaria em virtude do Princípio da proteção ao interesse superior da criança, que tem por escopo priorizar a permanência do infante em seu país de origem, mantendo-lhe em contato com suas tradições, idioma e cultura, consoante estipulado pelo artigo 4 da Convenção, o qual condiciona o deferimento do pedido de adoção internacional ao esgotamento das possibilidades de colocação da criança em família de seu Estado de origem ${ }^{34}$.

33 Fala-se em "primeiro" por ter sido, realmente, o primeiro tratado a cuidar da matéria de modo universal e a contar com grande adesão, diferentemente de outros tratados sobre a matéria, que ou eram restritos a determinados Estados - como é o caso da Convenção Europeia em Matéria de Adoção, de 1967 - ou contaram com baixa adesão - como a Convenção Interamericana sobre Conflitos de Leis em Matéria de Adoção, de 1984.

34 BRASIL. Decreto n. 3.087, de 21 de junbo de 1999. Disponível em: $<$ http://www.planalto.gov.br/ccivil_03/decreto/d3087.htm>. Acesso em: 30 ago. 2014. Previsão no mesmo sentido é encontrada no Estatuto da Criança e do Adolescente em virtude das alterações promovidas em seu texto pela Lei $n^{\circ} 12.010$, de 2009 , a qual incluiu no art. 50 do ECA o $\$ 10$, segundo o qual A adoção internacional somente será deferida se, após consulta ao cadastro de pessoas ou casais habilitados à adoção, mantido pela Justiça da Infância e da Juventude na comarca, bem como aos cadastros estadual e nacional referidos no $\ 50$ deste artigo, não for encontrado interessado com residência permanente no Brasil. BRASIL. Lei n. 12.010, de 3 de agosto de 2009. Disponível em: <http://www. planalto.gov.br/ccivil 03/ ato2007-2010/2009/lei/112010. htm>. Acesso em: 04 set. 2014.
Uma vez preenchidos todos os requisitos estipulados pela Convenção, a adoção internacional poderá ser autorizada, hipótese em que, certificada sua ocorrência, deverá ser ela "reconhecida de pleno direito pelos demais Estados Contratantes" 35 , segundo redação do artigo 23.

A problemática residiria na ausência de uma definição sobre quais direitos deveriam ser plenamente reconhecidos, pelo Estado de acolhida, ao adotado, questão que ganha reforço no campo na nacionalidade, matéria que por sua própria natureza é autônoma, porquanto intimamente ligada ao regime constitucional nacional ${ }^{36}$.

$\mathrm{E}$ isso porque uma causa bastante frequente de apatridia consiste no choque entre os critérios de atribuição de nacionalidade, o que se reforça no campo da adoção internacional em virtude do rompimento que a criança sofre quanto ao seu vínculo biológico ${ }^{37}$, o qual, em alguns Estados, se estende ao próprio vínculo político, como ocorre, por exemplo, na Grécia e na Coreia, que preveem a adoção como hipótese de perda da nacionalidade ${ }^{38}$.

Embora diversas convenções busquem assegurar o direito à nacionalidade em prol das crianças, evitando que desde o nascimento elas estejam sem a proteção estatal $^{39}$, a única previsão específica sobre a matéria

35 BRASIL. Decreto n. 3.087, de 21 de junho de 1999. Disponível em: <http://www.planalto.gov.br/ccivil_03/decreto/d3087.htm>. Acesso em: 30 ago. 2014.

36 COSTA, Tarcísio José Martins. Adoção transnacional: um estudo sociojurídico e comparativo da legislação atual. Belo Horizonte: Del Rey, 1998. p. 157.

37 Isto porque, embora não contenha cláusula específica sobre o tema, pode-se entender que a Convenção da Haia relativa à Proteção das Crianças e à Cooperação em Matéria de Adoção Internacional preferiu adotar o sistema da confidencialidade em relação à origem da criança, pois, apesar de prever, em seu artigo 30, que serão conservadas as informações sobre sua origem e sobre seus pais biológicos, em outros dispositivos estabelece a total falta de contato entre os pais adotivos e os pais biológicos, impedindo que estes últimos tenham acesso a qualquer informação sobre os primeiros, devendo a adoção operar de pleno direito em relação ao Estado dos adotantes. GRANDINO, João Rodas; MONACO, Gustavo Ferraz de Campos(Org.). Conferência da Haia de Direito Internacional Privado: a participação do Brasil. Brasília: Fundação Alexandre de Gusmão, 2007. p. 316-317.

38 Esses exemplos são apresentados no Guia elaborado pela Conferência da Haia. HCCH. The implementation and operation of the 1993 Hague Intercountry Adoption Convention: Guide to good practice. 2008. Disponível em: <http://www.hcch.net/ index_en.php?act $=$ publications.details\&pid $=4388>$. Acesso em: 08 out. 2014.

39 Como é o caso da Convenção de 1961 para a redução dos 
nas hipóteses de adoção internacional constou da Convenção da Haia sobre Conflitos de Nacionalidade, de 1930, a qual previa em seu artigo 17 que

se a lei de um Estado admitir a perda da nacionalidade em consequência da adoção, esta perda ficará, entretanto, subordinada à aquisição pelo adotado da nacionalidade do adotante, de acordo com a lei do Estado, de que este for nacional, relativa aos efeitos da adoção sobre a nacionalidade ${ }^{40}$

Essa previsão, contudo, não foi reiterada na Convenção da Haia de 1993 relativa à proteção das crianças e à cooperação em matéria de adoção internacional, o que, considerando que a Convenção sobre Conflitos de Nacionalidade data de 1930, gerou um novo hiato em relação à nacionalidade dessas crianças, principalmente no Brasil, que, ao ratificar a Convenção da Haia sobre Conflitos de Nacionalidade, o fez com reserva em relação exatamente ao artigo 17 , considerando-se o regime constitucional da época ${ }^{41}$.

Este, contudo, não pode ser interpretado como um silêncio eloquente, considerando-se a ampla proteção que é conferida às crianças pelo direito das gentes, de modo que a interpretação do dispositivo constante da Convenção da Haia de 1993 deve estar pautada na equiparação plena de direitos entre todos os filhos, sejam eles naturais ou adotivos, uma vez que a adoção visa à completa integração do adotado no seio da nova família, o que não ocorrerá caso não se lhe conceda a nacionalidade do adotante ${ }^{42}$.

Nesse aspecto, vale destacar que o direito à equiparação entre os filhos já foi objeto de estudo pela Corte Europeia de Direitos Humanos no caso Marckx

casos de apatridia, já analisada, e também da Convenção sobre os Direitos da Criança, de 1989, promulgada no Brasil pelo Decreto ${ }^{\circ}$ 99.710, de 21 de novembro de 1990, a qual prevê em seu artigo 7 que a criança terá direito, desde o nascimento, a uma nacionalidade, cabendo aos Estados respeitar e garantir à criança a preservação de sua identidade, inclusive de sua nacionalidade. BRASIL. Decreto n. 99.710, de 21 de novembro de 1990. Disponível em: < http://www. planalto.gov.br/ccivil_03/decreto/1990-1994/D99710.htm>. Acesso em: 08 set. 2014.

40 MAZZUOLI, Valerio de Oliveira. Curso de direito internacional público. 2. ed. rev. atual. e ampl. São Paulo: Revista dos Tribunais, 2007. p. 571.

41 BRASIL. Decreto n. 21.798, de 6 de setembro de 1932. Disponível em: <http://legis.senado.gov.br/legislacao/ ListaTextoIntegral.action?id=34326. Acesso em: 4 set. 2014.

42 COSTA, Tarcísio José Martins. Adoção transnacional: um estudo sociojurídico e comparativo da legislação atual. Belo Horizonte: Del Rey, 1998 p. 157. versus Bélgica, julgado em 1979, e que teve por objeto o exame de uma lei belga que limitava os direitos sucessórios dos filhos de mãe solteira caso eles não fossem adotados pela própria mãe. Embora o caso não tratasse especificamente dos filhos adotivos, a posição adotada pela Corte na ocasião expôs o entendimento de que qualquer previsão legal que limite direitos apenas com base na origem da criança viola o direito de proteção à família, previsto sem quaisquer ressalvas pela Convenção Europeia de Direitos ${ }^{43}$.

Exatamente como decidiu a Corte Europeia, hoje, a adoção internacional é compreendida sob um outro viés, qual seja: o de mecanismo apto a garantir a todas as crianças o exercício de seu direito humano a uma família, a um lar que lhe propicie afeto, educação e uma vida digna, por ser este direito uma decorrência da própria noção de dignidade humana.

A impossibilidade de se discriminar uma criança em razão de sua origem ou em virtude de seus pais ou representantes legais é vedação contida de modo expresso, ainda, na Convenção das Nações Unidas sobre os Direitos da Criança, de 1989, que, em seu artigo 2, estipula que

os Estados Partes comprometem-se a respeitar e a garantir os direitos previstos na presente Convenção a todas as crianças que se encontrem sujeitas à sua jurisdição, sem discriminação alguma, independentemente de [...] sua origem nacional, étnica ou social, fortuna, incapacidade, nascimento ou de qualquer outra situação ${ }^{44}$.

Este tipo de vedação, baseada nos direitos humanos, justificou até mesmo que fosse delineada uma convenção europeia voltada a proteger as crianças nascidas fora do casamento ${ }^{45}$, demonstrando que, ainda que exista um silêncio normativo a respeito dos efeitos da equiparação entre filhos legítimos, ilegítimos e adotivos, este silêncio não pode ser interpretado como uma autorização à discriminação ${ }^{46}$.

43 EUROPEAN COURT OF HUMAN RIGHTS. Cours Européenne des Dois de L'Homme. 1979. Sentença de 13 de Junho. Marckx v. Bélgica. Application n. 6833/74. Disponível em: <http:// hudoc.echr.coe.int/sites/eng/pages/search.aspx?i=001-57534\# \{“it emid”:[“001-57534”]\}>. Acesso em: 7 set. 2014.

44 BRASIL. Decreto n. 99.710, de 21 de novembro de 1990. Disponível em: <http://www.planalto.gov.br/ccivil_03/decreto/1990-1994/ D99710.htm>. Acesso em: 08 set. 2014.

45 Infelizmente, essa Convenção, de 1975, foi objeto de baixa ratificação pelos Estados europeus.

46 Essa conclusão também foi apontada pela $\mathrm{CEDH}$ no caso 
Interpretar a adoção como um direito humano induz, inclusive, ao dever de garantir incentivos a esse meio de construção familiar, o que requer uma flexibilização das matérias consideradas de domínio exclusivo do Estado, como é o caso da nacionalidade ${ }^{47}$, pois, uma vez que o ato de adotar é voluntário - e assim deve continuar sendo - a obrigação por parte das instituições deve ser a de facilitar e fomentar a adoção, garantindo a esses jovens e crianças abandonados o direito a serem integrados em uma família no menor período de tempo possível ${ }^{48}$.

A influência dessa percepção levou a Conferência da Haia a editar a Recomendação no 17 , segundo a qual os Estados de acolhida devem buscar atribuir de modo automático, à criança adotada no contexto da Convenção da Haia, sua nacionalidade ou a nacionalidade de um dos adotantes da Haia. Quando isso não for possível de plano, devem adotar todas as medidas possíveis para facilitar a naturalização da criança, movidos sempre pelo objetivo de evitar que esses menores restem como apátridas ${ }^{49}$.

Marckx v. Bélgica. In EUROPEAN COURT OF HUMAN RIGHTS. Cours Européenne des Dois de L'Homme. 1979. Sentença de 13 de Junho. Marckx v. Bélgica. Application n. 6833/74. Disponível em: $<$ http://hudoc.echr.coe.int/sites/eng/pages/search.aspx?i=00157534\#\{“itemid”:[“001-57534”]\}>. Acesso em: 7 set. 2014.

47 Essa percepção, inclusive, é o que fundamenta a crítica de alguns autores à Convenção da Haia sobre Adoção Internacional de 1993, que não estaria "preocupada em como maximizar o cumprimento do direito humano daqueles privados da relação paisfilhos a serem adotados [...], ao contrário, demonstra desmedida obsessão com violações [...] do domínio monopolista dos Estados sobre suas populações." BARROZO, Paulo D. Por um lar no mundo: fundamentos jusfilosóficos do instituto da adoção como direito humano. Revista de Direito Administrativo, Rio de Janeiro, v. 262, p. 45-93, jan./abr. 2013. p. 53.

48 BARROZO, Paulo D. Por um lar no mundo: fundamentos jusfilosóficos do instituto da adoção como direito humano. Revista de Direito Administrativo, Rio de Janeiro, v. 262, p. 45-93, jan./abr. 2013. p. 83.

49 Tradução livre. O texto original da Recomendação dispõe: "The Special Commission recommends that the child be accorded automatically the nationality of one of the adoptive parents or of the receiving State, without the need to rely on any action of the adoptive parents. Where this is not possible, the receiving States are encouraged to provide the necessary assistance to ensure the child obtains such citizenship. The policy of Contracting States regarding the nationality of the child should be guided by the over riding importance of avoiding a situation in which an adopted child is stateless." HCCH. Conclusions and recommendations of the second meeting of the Special Commission on the practical operation of the Hague Convention of 29 May 1993 on Protection of Children and Co-operation in respect of Intercountry Adoption. Disponível em: <http://www.hcch. net/upload/wop/concl33sc05_e.pdf>. Acesso em: 10 out. 2014.
Em cumprimento a essa orientação, Inglaterra e Estados Unidos $^{50}$ alteraram suas legislações para garantir o reconhecimento automático de sua nacionalidade à criança adotada, bastando, para isso, que o país se torne o seu local de residência habitual. Outros Estados, como Itália ${ }^{51}$ e Suíça ${ }^{52}$, mantiveram a necessidade de um procedimento de homologação da sentença estrangeira de adoção, reconhecendo a atribuição da sua nacionalidade à criança, por sua vez, como um efeito automático não da Convenção da Haia, mas da decisão homologatória posterior.

Nesse cenário interpretativo, portanto, deve-se indagar qual é a posição do direito brasileiro sobre a matéria.

\section{Da postura do Brasil quanto ao reconhecimento da nacionalidade brasileira nos casos de adoção internacional}

No início deste estudo, destacamos a recente iniciativa legislativa do Poder Executivo na elaboração de normas internas voltadas à proteção dos migrantes e à redução do número de apátridas, o que rendeu o reconhecimento, pelo Alto Comissariado das Nações Unidas para Refugiados, de estar o Brasil ocupando papel de destaque na campanha global de redução dos casos de apatridia, situação que se soma ao fato de ser o país signatário da maioria das convenções internacionais que tratam do combate à apatridia, além da própria Convenção Americana de Direitos Humanos.

Contudo, o que se observa é que mesmo as medidas normativas mais recentes adotadas pelo país mantêm

50 Inglaterra, para tanto, editou o United Kingdom's Adoption Act 1999. UNITED KINGDOM. Adoption (Intercountry Aspects) Act 1999. Disponível em: <http://www.legislation.gov.uk/ ukpga/1999/18/contents>. Acesso em: 10 out. 2014. Os Estados Unidos, por sua vez, editaram o Child Citizenship Act 2000. UNITE STATE. Department of State. Acquiring U.S. Citizenship for your Child. Disponivel em: <http://travel.state.gov/content/adoptionsabroad/ en/us-visa-for-your-child/acquiring-us-citizenship-for-your-child. html>. Acesso em: 13 out. 2014.

51 A questão é regulada pela Lei italiana n. 184/83, com as alterações promovidas pela Lei n. 476/68. As informações a respeito são apresentadas em: MONTAGNER, Ângela Christina Boelhouwer. $A$ adoção internacional e a nacionalidade da criança adotada. Disponível em: <http://www.publicacoesacademicas.uniceub.br/ index.php/prisma/article/viewFile/903/849. Acesso em 13 de outubro de 2014>. Acesso em: 13 out. 2014

52 As informações estão disponíveis em: COSTA, Tarcísio José Martins. Adoção transnacional: um estudo sociojurídico e comparativo da legislação atual. Belo Horizonte: Del Rey, 1998. p. 347. 
o silêncio sobre a questão dos efeitos da adoção internacional no que se refere à nacionalidade, silêncio que encontra sua origem na Constituição de 1988, que prevê como brasileiros natos apenas as seguintes pessoas:

\author{
Art. 12. São brasileiros: \\ I- natos: \\ a) os nascidos na República Federativa do Brasil, \\ ainda que de pais estrangeiros, desde que estes não \\ estejam a serviço de seu país;
}

b) os nascidos no estrangeiro, de pai brasileiro ou mãe brasileira, desde que qualquer deles esteja a serviço da República Federativa do Brasil;

c) os nascidos no estrangeiro de pai brasileiro ou de mãe brasileira, desde que sejam registrados em repartição brasileira competente ou venham a residir na República Federativa do Brasil e optem, em qualquer tempo, depois de atingida a maioridade, pela nacionalidade brasileira; (Redação dada pela Emenda Constitucional $n^{\circ} 54$, de 2007)(grifo do autor) ${ }^{53}$

Ao falar especificamente em nascidos - expressão esta que foi mantida mesmo após as alterações realizadas no dispositivo pelas Emendas Constitucionais $\mathrm{n}^{\circ} 3$, de 1994 , e no 54 , de 2007, e que se encontra presente no anteprojeto de lei voltado a revogar o Estatuto do Estrangeiro - , a Constituição parece querer privilegiar o vínculo biológico como única fonte de atribuição de nacionalidade, o que, portanto, impediria que uma criança estrangeira adotada por pai brasileiro ou mãe brasileira, numa das hipóteses das alíneas "b" ou "c" do artigo 12, inciso I, pudesse ser considerada um brasileiro nato.

Contudo, a ideia atual de nacionalidade como direito humano e não mais mero fruto de reconhecimento estatal deve operar como critério para garantir uma atuação proativa do Estado não só na edição de normas, mas na interpretação daquelas já existentes, principalmente no que toca à primordial proteção que deve ser dada às crianças, evitando-se o crescimento do número de menores apátridas.

Este foi, inclusive, o norte interpretativo destacado pela Corte Interamericana de Direitos Humanos no

53 BRASIL. Constituição (1988). Constituição da República Federativa do Brasil. Disponível em: <http://www.planalto.gov.br/ ccivil_03/constituicao/constituicao.htm>. Acesso em: 01 set. 2014.
Parecer Consultivo OC-21/14, de 19 de agosto de 2014, elaborado em resposta à solicitação conjunta do Brasil, Argentina, Uruguai e Paraguai, com o fim de estabelecer quais as obrigações dos Estados com relação às medidas passíveis de serem adotadas a respeito de crianças migrantes.

No início de sua manifestação, a Corte destacou serem os tratados de direitos humanos instrumentos vivos, cuja interpretação deve acompanhar a evolução dos tempos e as condições de vida atuais, principalmente no que se relaciona à temática dos direitos das crianças, considerando que a Convenção sobre os Direitos da Criança constitui-se no tratado internacional com maior vocação de universalidade, não podendo, portanto, tal fato ser desconsiderado do contexto interpretativo ${ }^{54}$.

A essa ideia poderia ser somada, ainda, a previsão expressa da própria Constituição brasileira, que, em seu artigo $227, \$ 6^{\circ}$, estipula que

os filhos, havidos ou não da relação do casamento, ou por adoção, terão os mesmos direitos e qualificações, proibidas quaisquer designações discriminatórias relativas à filiação. ${ }^{55}$

Consistindo em vetor interpretativo expresso no texto constitucional.

Equiparados os filhos naturais e adotivos, e uma vez reconhecida de pleno direito a adoção internacional realizada, nos termos do que estipula a Convenção da Haia de 1993, a única consequência possível seria a ampliação das hipóteses de atribuição da nacionalidade brasileira também para os casos de crianças adotadas, inclusive para possibilitar a completa integração do menor ao país de acolhida, que será seu novo local de residência habitual.

Embora em uma análise superficial a questão pudesse parecer indene de maiores questionamentos, pois pareceria óbvia a necessidade de proteção do interesse da criança adotada, a demandar o reconhecimento da nacionalidade do país do adotante para permitir sua integral inclusão ao novo meio, não é isto que ocorre.

$\mathrm{Na}$ temática, o Brasil parece retroceder em sua postura mais avançada, adotando uma interpretação

54 CORTE INTERAMERICANA DE DERECHOS HUMANOS. Parecer Consultivo OC-21/14, de 19 de agosto de 2014. Disponível em: <http://www.corteidh.or.cr/docs/opiniones/ seriea_21_por.pdf $>$. Acesso em: 15 set. 2014.

55 BRASIL. Constituição (1988). Constituição da República Federativa do Brasil. Disponível em: <http://www.planalto.gov.br/ ccivil_03/constituicao/constituicao.htm>. Acesso em: 01 set. 2014 
restritiva quanto às hipóteses de aplicação do jus sanguinis como critério de atribuição de nacionalidade, no que é apoiado por farta doutrina, como destaca a obra abaixo citada:

[...] o Brasil anda na contramão de seu próprio entendimento, quando se trata de criança estrangeira adotada por brasileiro. [...]

O fundamento para tanto é que a impossibilidade de concessão de nacionalidade decorre do próprio texto constitucional que vincula o Brasil ao critério do jus soli ou, excepcionalmente, ao critério do jus sanguinis, no caso de filhos de brasileiros nascidos no exterior.

Esse entendimento é corroborado por Miguel Jerônymo Ferrante, o qual diz que 'filho adotivo de brasileiros, nascido no estrangeiro, não pode optar pela nacionalidade brasileira. É estrangeiro e, como tal, só poderá adquirir a nacionalidade brasileira por via de naturalização’. [...]

Também Francisco Guimarães afirma que 'a adoção de estrangeiro por brasileiro não produz efeitos sobre a nacionalidade'.

[...] Contudo, novamente entendendo-se que a adoção estabelece vínculo de filiação e que a própria Constituição Federal de 1988 proíbe qualquer designação discriminatória entre filhos, independentemente de sua origem, seja natural ou civil, não há por que dar tratamento diferenciado aos filhos adotados, sob pena de impor uma discriminação vedada pelo próprio texto constitucional no artigo 227, $\$ 6^{\circ}:[\ldots]$ Se os filhos de brasileiros que nascem no exterior são brasileiros natos, os filhos adotados em outro país também deverão ser. ${ }^{56}$

Ocorre que a doutrina que comunga desse posicionamento adota uma posição simplista, baseada na literalidade da norma constitucional, como é o caso, por exemplo, de Valério Mazzuolli, que apoia essa posição unicamente sob o fundamento de o Brasil, no ato de sua ratificação à Convenção da Haia sobre Conflitos de Nacionalidade de 1930, ter feito reservas ao artigo 17 do texto, segundo o qual se

56 MONTAGNER, Ângela Christina Boelhouwer. A adoção internacional e a nacionalidade da criança adotada. Disponível em: $<$ http:// www.publicacoesacademicas.uniceub.br/index.php/prisma/article/ viewFile/903/849. Acesso em 13 de outubro de 2014>. Acesso em: 13 out. 2014 a lei de um Estado admitir a perda da nacionalidade em consequência da adoção, esta perda ficará, entretanto, subordinada à aquisição pelo adotado da nacionalidade do adotante, de acordo com a lei do Estado, de que este for nacional ${ }^{57}$.

Essa reserva, portanto, seria suficiente para garantir o entendimento de que a atuação brasileira deu-se em virtude do não reconhecimento expresso quanto à possibilidade de equiparação entre os filhos naturais e os adotivos.

De fato, embora tenha feito reservas ao mencionado dispositivo, é preciso considerar que o Decreto $\mathrm{n}^{\circ}$ 21.798, que promulgou a referida Convenção da Haia de 1930, foi publicado em 1932, quando ainda em vigor a Constituição de 1981, a qual explicitava concepção totalmente diversa sobre a temática, tendo sido a última Carta a prever, por exemplo, a distinção entre filhos legítimos e ilegítimos ${ }^{58}$.

A diferenciação constitucional, adequada à tradição em vigor no período de vigência da Carta de 1891, repercutia também nas normas infraconstitucionais, como é exemplo o Código Civil vigente à época, que concebia a adoção como um contrato e o parentesco dela decorrente como uma questão meramente de direito privado, incapaz de gerar quaisquer efeitos de direito público, mas apenas patrimoniais ${ }^{59}$.

Desse modo, não é possível que uma conclusão da época se mantenha ao longo dos anos, principalmente quando estamos diante da denominada 'Constituição cidadã de 1988', modelo para outros Estados em virtude dos vários direitos fundamentais reconhecidos em seu texto, e que deve ser, portanto, considerada um instrumento vivo de interpretação, nos termos propostos pela Corte Interamericana de Direitos Humanos.

$\mathrm{Na}$ prática, contudo, o que se constata é que essa postura restritiva e quase exegética quanto

57 MAZZUOLI, Valerio de Oliveira. Curso de direito internacional público. 2. ed. rev. atual. e ampl. São Paulo: Revista dos Tribunais, 2007 p. 571.

58 BRASIL. Constituição (1891). Constituição da República dos Estados Unidos do Brasil. Disponível em: < http://www.planalto.gov. br/ccivil_03/constituicao/constituicao91.htm>. Acesso em: 01 set. 2014. Acesso em: 7 set. 2014.

59 O cenário infraconstitucional da época é utilizado como argumento por Ilmar Penna Marinho para justificar a impossibilidade de a adoção gerar quaisquer efeitos relativos à nacionalidade em favor do adotado. MARINHO, Ilmar Penna. Adoção de nacionalidade no direito brasileiro. Revista Brasileira de Politica Internacional, v.4, n. 16, p. 36-53, dez. 1961. 
à interpretação do dispositivo constitucional é encontrada também no Judiciário brasileiro, para quem a nacionalidade é expressão da soberania do Estado e sujeita a normas rígidas, sendo indiferente a vontade do indivíduo, como demonstra ementa de julgado proferido pelo Tribunal Regional Federal da $2^{\mathrm{a}}$ Região:

OPÇÃO DE NACIONALIDADE BRASILEIRA - NASCIDO NOS ESTADOS UNIDOS, FILHO ADOTIVO DE PAI NATURALIZADO BRASILEIRO E MÃE BRASILEIRA NATAART. 227, \ $6^{\circ}$, DA CRFB/88 - EQUIPARAÇÃO CIVIL - IMPROCEDÊNCIA.

1.A nacionalidade é expressão da soberania do Estado, sujeita a normas rígidas, não preponderando a vontade do indivíduo ou seus interesses.

$2 . \mathrm{O}$ art. 12, I, alínea "c" da CRFB/88 estabelece que são brasileiros natos, os nascidos de pai ou mãe brasileiros, em solo estrangeiro. Comprovou-se não ser o caso da Requerente, que se liga a pais brasileiros pelo vínculo da adoção.

$3 . \mathrm{O}$ art. $227, \int 6^{\circ}$, da $\mathrm{CRFB} / 88$, bem com a legislação infraconstitucional (o Código Civil e o Estatuto da Criança e do Adolescente), garantem tratamento sem discriminação aos filhos adotivos, equiparando-os aos biológicos, para fins civis e sucessórios. In casu, cuida-se de um direito público ligado à soberania do Estado, que a Carta Magna trata de forma particularmente restritiva.

4.A doutrina e a jurisprudência são unânimes ao reconhecer que o vínculo adotivo, no Brasil, não produz efeitos sobre a nacionalidade do adotante. A ser admitido tal posicionamento, estaríamos permitindo a fruição de direitos exclusivos de brasileiros natos, como o de jamais ser extraditado por eventuais crimes cometidos no exterior, ou de ocupar cargos como o de Presidente da República, violando cláusulas constitucionais extremamente rígidas.

5. Não se nega o direito à nacionalidade do Apelante, que lhe será conferida através do processo de naturalização.
6. Recurso desprovido. Sentença mantida ${ }^{60}$.

Embora essa posição não seja uniforme ao Judiciário brasileiro $^{61}$ nem possa ser tida por definitiva em virtude da ausência de uma posição do Supremo Tribunal Federal sobre o tema, ela conta com o respaldo do Ministério Público Federal, órgão responsável por defender os interesses dos incapazes e por velar pela regular aplicação da lei ${ }^{62}$, e se reforça quando observamos que prepondera uma posição patrimonialista sobre os efeitos da adoção ${ }^{63}$, entendendo-se que a previsão

60 BRASIL. Tribunal Regional Federal do Rio de Janeiro (2. Região). Apelação Cível n. 436220. Processo n. 200850010027446/ RJ. Órgão Julgador: Sexta Turma Especializada. Relator: Desembargador Federal Frederico Gueiros. Data da decisão: 20/09/10. Disponível em: <http://jurisprudencia.trf2.jus.br/v1/ search?q=cache:JHceX42kwEwJ:www.trf2.com.br/idx/trf2/ement as $/ \% 3$ Fprocesso $\% 3$ D200850010027446\%26CodDoc $\% 3 D 240160$ + nacionalidade + brasileira + ado $\% \mathrm{C} 3 \% \mathrm{~A} 7 \% \mathrm{C} 3 \% \mathrm{~A} 3 \mathrm{o}+$ internaciona $1+\&$ client $=$ jurisprudencia\&output $=x$ ml_no_dtd\&proxystylesheet $=$ jurisprudencia\&lr $=$ lang_pt\&ie $=U$ UTF-8\&site $=$ ementas\&access $=p \&$ oe $=U$ TTF-8 $>$. Acesso em: 01 set. 2014.

Também no TRF $2^{a}$ Região é possível localizar, no mesmo sentido, o seguinte acórdão: Apelação Cível no 401112. Processo $\mathrm{n}^{\circ}$ 200651020040465/RJ RIO DE JANEIRO. Tribunal Regional Federal (2. Região). Apelação Cível n.401112. Processo n. 2006510200404651. Órgão Julgador: Sexta Turma Especializada. Relator: Desembargador Federal Frederico Gueiros. Data da decisão: 25/02/08. Disponível em: <http://jurisprudencia.trf2. jus.br/v1/search?q=cache:c5FvQ3GMhJoJ:www.trf2.com. $\mathrm{br} / \mathrm{idx} / \mathrm{trf2} / \mathrm{ementas} / \% 3$ Fprocesso\%3D200651020040465 $\% 26$ CodDoc $\% 3 D 178728+200651020040465+\&$ client $=$ ju risprudencia\&output $=\mathrm{xml}$ no $\mathrm{dtd} \&$ proxystylesheet $=\mathrm{juris}$ prudencia\&lr=lang_pt\&ie $=\mathrm{UTF}-8 \&$ site $=$ ementas\&access $=$ p\&oe $=$ UTF-8 $>$. Acesso em: 01 set. 2014.

Posição semelhante é também localizada no TRF $3^{\text {a }}$ Região: SÃO PAULO. Tribunal Regional Federal (3. Região). Apelação Cível n. 759974. Processo n 00152309620004036100. Órgão Julgador: Terceira Turma. Relator: Desembargador Federal Baptista Pereira. DJU: 11/09/2002. Disponível em: < http://web. trf3.jus.br/consultas/Internet/ConsultaProcessual/Processo?Num eroProcesso $=00152309620004036100>$. Acesso em: 28 out. 2014 .

61 Em sentido contrário, é possível localizar o Processo $n$. 48595-64.2011.4.01.3400, ajuizado perante a Justiça Federal no Distrito Federal, cujo pedido foi julgado procedente.

62 Mesmo no precedente favorável encontrado, o Ministério Público Federal proferiu parecer pela improcedência do pedido, arguindo, justamente, a literalidade do art. 12 da Constituição, posição esta que foi defendida e acolhida nos outros três casos citados, julgados pelos TRFs da $2^{\mathrm{a}}$ e $3^{\mathrm{a}}$ Regiões.

63 No julgamento da Ação Rescisória n 1811/PB, o STF definiu que a previsão do art. $227, \$ 6^{\circ}$, da Constituição não autorizaria a não aplicação do artigo 377 do Código Civil de 1916, que previa que a sucessão ocorreria apenas em favor dos filhos naturais, não atingindo os adotivos.

A conclusão do julgamento foi noticiada no informativo $n^{\circ}$ 741, não tendo sido ainda disponibilizado o inteiro teor do acórdão. BRASIL. Supremo Tribunal Federal. Informativo n. 741, Brasília, 31 de março a 4 de abril de 2014. Disponível em: < http://www.stf.jus. 
do artigo 227, $₫ 6^{\circ}$, da Constituição, ao estipular a equiparação de direitos entre os filhos naturais e os adotivos, apenas opera seus efeitos para o futuro e para fins civis e sucessórios, não se aplicando a hipóteses anteriores a 1988, ainda que simplesmente corresponda a um corolário do princípio da igualdade.

Contudo, como destacamos, mesmo no aspecto civil e sucessório, as Cortes Regionais de Direitos Humanos vêm garantindo a plena equiparação entre os filhos, pautando-se, para tanto, no direito humano à proteção da família, que não é estipulado com quaisquer ressalvas, tampouco apenas de modo ex nunc ${ }^{64}$. Assim, embora possa o legislador prever limites à sucessão, tais limitações não podem estar pautadas em questões discriminatórias, como é o caso daquelas existentes entre os filhos naturais e os adotivos unicamente com base no nascimento.

Desse modo, é possível verificar que, tanto no âmbito doutrinário quanto no âmbito judicial, a posição adotada pelo direito brasileiro é uma posição restritiva, que interpreta de modo eloquente o silêncio constitucional para considerá-lo como uma vedação à possibilidade de inclusão dos filhos adotivos dentre os brasileiros natos nas hipóteses em que adotado o critério do jus sanguinis.

Apenas na prática administrativa foi possível verificar a aplicação, pelo Poder Executivo, de entendimento favorável à extensão da condição de brasileiro nato ao filho adotivo por meio da aplicação conjunta dos artigos 12, inciso I, alínea "c" e 227, $\$ 6^{\circ}$, da Constituição, garantindo à criança adotada o reconhecimento da sua condição de brasileiro nato por meio do registro em repartição consular.

Exemplo dessa posição foi manifestada por meio do Parecer no 025/2013/CEP/CONJUR-MJ/CGU/ $\mathrm{AGU}^{65}$, expedido pela Consultoria Jurídica junto ao

$\mathrm{br} / /$ arquivo/informativo/documento/informativo741.htm\#AR: filho adotivo e direito de suceder antes da CF/1988 - 3>. Acesso em: 01 set. de 2014

64 No já citado caso Marckx v. Bélgica, a CEDH enfatizou que a vida familiar, protegida pela Convenção Europeia de Direitos Humanos, deve envolver não apenas questões sociais, culturais ou morais, mas ir além, para garantir a proteção dos meios materiais necessários para o seu desenvolvimento, o que inclui, também, a proteção integral a questões sucessórias, das quais não podem ser excluídos os filhos com base em sua origem. In EUROPEAN COURT OF HUMAN RIGHTS. Cours Européenne des Dois de L'Homme. 1979. Sentença de 13 de Junho. Marckx v. Bélgica. Application n. 6833/74. Disponível em: <http://hudoc.echr. coe.int/sites/eng/pages/search.aspx?i=001-57534\# \{“item id”:[“001-57534”] \} >. Acesso em: 7 set. 2014.

65 Este parecer foi obtido junto ao Ministério da Justiça através
Ministério da Justiça em resposta à consulta formulada pelo Ministério das Relações Exteriores sobre a possibilidade de registro consular de menor estrangeiro adotado por brasileiros no exterior. E, embora o caso não tratasse especificamente de uma adoção internacional - já que adotante e adotado possuíam o mesmo local de residência habitual, mas nacionalidades distintas —, a fundamentação apresentada na análise do pedido demonstra a possibilidade de utilização do mesmo entendimento para os casos regidos pela Convenção da Haia de 1993, já que observa o silêncio constitucional e o interpreta favoravelmente à aplicação do artigo 227, $\$ 6^{\circ}$ da Constituição, concluindo que

[...] o menor estrangeiro adotado por brasileiros no exterior terá direitos iguais aos de um filho biológico, sem quaisquer diferenciações, conforme preceitua a nossa Constituição Federal, o que lhe garante, portanto, o registro consular de nascimento pela autoridade consular, após o término do processo de adoção no país local e a homologação da sentença perante o Superior Tribunal de Justiça, ficando garantida ao mesmo a aplicação do teor da alínea "c" do artigo 12 de nossa Carta constitucional.

Apesar de, na prática, o Poder Executivo estar adotando, em situações individuais, medidas consonantes a uma interpretação sistemática do texto constitucional, não é possível distinguir a posição de cada um dos Poderes do Estado e analisá-las em separado perante o Direito internacional. O Estado, para o direito das gentes, é um só, de modo que, ao se tornar parte de um tratado, este obriga todos os seus órgãos, e a violação por parte de um desses órgãos deve implicar a responsabilidade do Estado como um todo.

Com isso, é possível concluir que, quanto ao Estado brasileiro, prevalece uma posição restritiva a respeito da nacionalidade nas hipóteses de adoção internacional, a qual estaria em desconformidade à posição de vanguarda que o Brasil vem adotando no que se refere ao combate à apatria, e - pode-se dizer — em contrariedade à Opinião Consultiva recentemente proferida pela Corte Interamericana a pedido do país.

de pedido formulado pelo Sistema de Acesso à Informação e consta como Anexo a este artigo. Vale destacar que, embora ele expresse posição da Consultoria Jurídica junto ao Ministério da Justiça, não o faz de modovinculante, pois não se trata de Parecer aprovado pelo Presidente da República. Sua menção neste artigo dá-se com o fim de demonstrar a posição mais avançada do Poder Executivo sobre a matéria. 


\section{Conclusão}

Por força da característica de instrumentos vivos de transformação social, os tratados relativos a direitos humanos devem ser interpretados com base na ideia de efetividade, do que resulta, para os Estados, tanto o dever de suprimir normas e práticas internas que representem violações aos direitos naqueles consagrados, quanto o de atuar de modo proativo na adoção de medidas conducentes à observância das garantias naqueles previstas.

Quanto ao Brasil, foi possível observar ser o país signatário de vários tratados relativos a direitos humanos e direcionados ao combate à apatria, sendo que a própria Constituição Brasileira de 1988 já representava um importante avanço na temática, por consagrar em seu texto uma infinidade de direitos e garantias fundamentais à pessoa humana.

Considerando-se, contudo, a impossibilidade de previsão escrita de todas as possibilidades de choque entre princípios e fundamentos do Estado com suas respectivas soluções, a Constituição de 1988 acabou sendo silente a respeito dos efeitos diretos da adoção internacional no que se refere à nacionalidade da criança adotada.

Esse silêncio não poderia ser interpretado como proposital ou como vedação à ampliação das hipóteses de aplicação do critério do jus sanguinis, principalmente em virtude do quanto disposto no artigo $227, \$ 6^{\circ}$, da Constituição, que prevê a equiparação de direitos entre os filhos naturais e adotivos, sem qualquer ressalva quanto aos direitos que deveriam ser estendidos, se limitados a direitos patrimoniais ou não, justo por ter por fundamento a proteção à família, cuja composição não pode ser objeto de exceções.

Apesardisso, e apesar de todas as medidas legislativas que o país vem adotando na temática do combate à apatria, foi possível perceber que, na interpretação de suas normas, prevalece, em nosso direito interno, uma postura conservadora a respeito da nacionalidade, que a considera fruto do reconhecimento estatal mais do que um direito humano, visão esta, contudo, que não mais encontra respaldo no cenário internacional.

Desse modo, torna-se possível concluir que mais importante do que a edição de novas normas sobre a matéria é a correta interpretação dos dispositivos já vigentes, adotando-se por linha interpretativa o princípio de que a Constituição não possui termos inúteis, devendo ser compreendida a partir de sua teleologia e de seu contexto geral, como instrumento vivo de proteção a direitos humanos, não se podendo retroceder a uma posição exegética e conservadora.

Assim, atribuir a nacionalidade brasileira à criança adotada por pai ou mãe brasileiro nas hipóteses listadas no artigo 12, inciso I, alíneas "b" e "c", da Constituição de 1988, não significa ir além dos limites fixados pelo Constituinte, mas compreender que não há, no caso, um verdadeiro silêncio, mas a necessidade de observação do texto constitucional como um todo harmônico, que nos leva a transportar o dever de equiparação entre os filhos também para as hipóteses de reconhecimento da nacionalidade brasileira, mesmo nas hipóteses de aplicação do critério excepcional do jus sanguinis. 


\section{Referências}

ARENDT, Hannah. As origens do totalitarismo. Tradução Roberto Raposo. São Paulo: Companhia das Letras, 1989.

BARROZO, Paulo D. Por um lar no mundo: fundamentos jusfilosóficos do instituto da adoção como direito humano. Revista de Direito Administrativo, Rio de Janeiro, v. 262, p. 45-93, jan./abr. 2013.

BRASIL. Constituição (1891). Constituição da República dos Estados Unidos do Brasil. Disponível em: <http://www. planalto.gov.br/ccivil_03/constituicao/constituicao91. htm>. Acesso em: 01 set. 2014. Acesso em:7 set. 2014.

BRASIL. Constituição (1988). Constituição da República Federativa do Brasil. Disponível em: <http://www. planalto.gov.br/ccivil_03/constituicao/constituicao. htm>. Acesso em: 01 set. 2014.

BRASIL. Decreto n. 2.411, de 23 de fevereiro de 1938. Disponível em: <http://www2.camara.leg.br/legin/fed/ decret/1930-1939/decreto-2411-23-fevereiro-1938-345944publicacaooriginal-1-pe.html>. Acesso em: 30 ago. 2014.

BRASIL. Decreto n. 21.798, de 6 de setembro de 1932. Disponível em: <http://legis.senado.gov.br/legislacao/ ListaTextoIntegral.action?id=34326. Acesso em: 4 set. 2014 .

BRASIL. Decreto n. 3.087, de 21 de junho de 1999. Disponível em: <http://www.planalto.gov.br/ccivil_03/decreto/ d3087.htm>. Acesso em: 30 ago. 2014.

BRASIL. Decreto n. 4.246, de 22 de maio de 2002. Disponível em: <http://www.planalto.gov.br/ccivil_03/decreto/2002/ D4246.htm>. Acesso em: 30 ago. 2014.

BRASIL. Decreto n. 99.710, de 21 de novembro de 1990. Disponível em: <http://www.planalto.gov.br/ccivil_03/ decreto/1990-1994/D99710.htm>. Acesso em: 08 set. 2014..

BRASIL. Decreto $n^{\circ} 678$, de 6 de novembro de 1992. Disponível em: <http://www.planalto.gov.br/ccivil_03/decreto/ D0678.htm>. Acesso em: 30 ago. 2014.

BRASIL. Lei n. 12.010, de 3 de agosto de 2009. Disponível em: <http://www.planalto.gov.br/ ccivil_03/_ato2007-2010/2009/lei/112010.htm>. Acesso em: 04 set. 2014.
BRASIL. Supremo Tribunal Federal. Ação Rescisória $n^{o}$ 1811/PB. Disponível em: <http://www.stf.jus.br// arquivo/informativo/documento/informativo741. htm\#AR: filho adotivo e direito de suceder antes da CF/1988 - 3>. Acesso em: 01 set. 2014.

BRASIL. Tribunal Regional Federal de São Paulo. (3. Região). Apelação Cível n. 759974. Processo $n$ 00152309620004036100. Órgão Julgador: Terceira Turma. Relator: Desembargador Federal Baptista Pereira. DJU: 11/09/2002. Disponível em: <http://web. trf3.jus.br/consultas/Internet/ConsultaProcessual/Pr ocesso? NumeroProcesso $=00152309620004036100>$. Acesso em: 28 out. 2014.

BRASIL. Tribunal Regional Federal do Rio de Janeiro. (2. Região). Apelação Cível n. 436220. Processon. 200850010027446/RJ. Órgão Julgador: Sexta Turma Especializada. Relator: Desembargador Federal Frederico Gueiros. Data da decisão: 20/09/10. Disponível em: <http://jurisprudencia.trf2.jus.br/v1/ search?q=cache:JHceX42kwEwJ:www.trf2.com.br/ $\mathrm{idx} / \mathrm{trf2} /$ ementas/\%3Fprocesso\%3D20085001002744 $6 \% 26 \mathrm{CodDoc} \% 3 \mathrm{D} 240160+$ nacionalidade+brasileira+ $\mathrm{ado} \% \mathrm{C} 3 \% \mathrm{~A} 7 \% \mathrm{C} 3 \% \mathrm{~A} 3 \mathrm{o}+$ internacional $+\& \mathrm{client}=$ juris prudencia\&output $=x m l \_n o \_d t d \&$ proxystylesheet $=$ jur isprudencia\&lr=lang_pt\&ie $=U T$ TF-8\&site $=$ ementas \&a ccess $=$ p\&oe $=U T F-8>$. Acesso em 01 set. 2014.

BRASIL. Tribunal Regional Federal do Rio de Janeiro. (2. Região). Apelação Cível n.401112. Processo n. 2006510200404651. Órgão Julgador: Sexta Turma Especializada. Relator: Desembargador Federal Frederico Gueiros. Data da decisão: 25/02/08. Disponível em: <http://jurisprudencia.trf2.jus.br/v1/ search?q= cache:c5FvQ3GMhJoJ:www.trf2.com.br/idx/ trf2/ementas/\%3Fprocesso\%3D200651020040465\%26 CodDoc\%3D178728+200651020040465+\&client=juris prudencia\&output=xml_no_dtd\&proxystylesheet $=$ juris prudencia\&lr $=$ lang_pt\&ie $=$ UTF-8\&site $=$ ementas $\&$ acc ess $=$ p\&oe $=U T F-8>$. Acesso em: 01 set. 2014..

BUSTAMANTE, Thomas da Rosa. Teoria do precedente judicial: a justificação e a aplicação das regras jurisprudenciais. São Paulo: Noeses, 2012.

CORTE INTERAMERICANA DE DERECHOS HUMANOS. 2005. Sentença de 8 de septiembre, Niñas Yean y Bosico v República Dominicana. Disponível em: $\quad<$ http://webcache.googleusercontent.com/ search?q=cache:TDCsDySXg2sJ:www.corteidh. 
or.cr/docs/casos/articulos/seriec_130_esp. $\mathrm{doc}+\& \mathrm{~cd}=2 \& \mathrm{hl}=\mathrm{pt}-\mathrm{BR} \& \mathrm{ct}=\mathrm{clnk} \& \mathrm{gl}=\mathrm{br}>$. Acesso em: 10 set. 2014.

CORTE INTERAMERICANA DE DERECHOS HUMANOS. Parecer Consultivo OC-21/14, de 19 de agosto de 2014. Disponível em: <http://www.corteidh.or.cr/ docs/opiniones/seriea_21_por.pdf $>$. Acesso em: 15 set. 2014.

CORTE INTERAMERICANA DE DERECHOS. 2001. Sentença de 6 de fevereiro, Ivcher Bronstein v. Peru. Disponível em: <http://www.corteidh.or.cr/docs/ casos/articulos/Seriec_74_esp.pdf. Acesso em: 10 set. 2014.

COSTA, Tarcísio José Martins. Adoção transnacional: um estudo sociojurídico e comparativo da legislação atual. Belo Horizonte: Del Rey, 1998.

EUROPEAN COURT OF HUMAN RIGHTS. Cours Européenne des Dois de L'Homme. 2011. Sentença de 11 de outubro, Genovese v. Malta, Application no. 53124/09. Disponível em: <http://hudoc.echr.coe. int/sites/eng/pages/search.aspx?i=001-106785\#\{“item id”:[“001-106785”] \}>. Acesso em: 30 ago. 2014.

EUROPEAN COURT OF HUMAN RIGHTS. Cours Européenne des Dois de L'Homme. 1979. Sentença de 13 de Junho. Marckx v. Bélgica. Application n. 6833/74. Disponível em: <http://hudoc.echr.coe. int/sites/eng/pages/search.aspx?i=001-57534\#\{“item id”:[“001-57534”]\}>. Acesso em: 7 set. 2014.

FONTES, André R. C. Nacionalidade brasileira e adoção internacional. Disponível em: <www.tre-ri.gov.br/eje/gecoi_ arquivos/arq_051202.docx>. Acesso em: 30 ago. 2014.

GRANDINO, João Rodas; MONACO, Gustavo Ferraz de Campos(Org.). Conferência da Haia de Direito Internacional Privado: a participação do Brasil. Brasília: Fundação Alexandre de Gusmão, 2007

$\mathrm{HCCH}$. Conclusions and recommendations of the second meeting of the Special Commission on the practical operation of the Hague Conventionof 29 May 1993 on Protection of Children and Cooperation in respect of Intercountry Adoption. Disponível em: <http://www.hcch.net/upload/wop/concl33sc05_e. pdf $>$. Acesso em: 10 out. 2014.
$\mathrm{HCCH}$. The implementation and operation of the 1993 Hague Intercountry Adoption Convention: Guide to good practice. 2008. Disponível em: <http:// www.hcch.net/index_en.php?act=publications. details\&pid $=4388>$. Acesso em: 08 out. 2014.

HERANI, Renato Gugliano. Nacionalidade potestativa após a Emenda Constitucional 54/07. Disponível em: $<$ http://www.periodicos.ufgd.edu.br/index.php/ videre/article/viewFile/899/pdf_49. Acesso em: 8 nov. 2012.

LOPES, Cristiane Maria Sbalqueiro. Direito de imigração: o Estatuto do Estrangeiro em uma perspectiva de Direitos Humanos. Porto Alegre: Núria Fabris, 2009.

MARINHO, Ilmar Penna. Adoção de nacionalidade no direito brasileiro. Revista Brasileira de Política Internacional, v.4, n. 16, p. 36-53, dez. 1961.

MAZZUOLI, Valerio de Oliveira. Curso de direito internacional público. 2. ed. rev. atual. e ampl. São Paulo: Revista dos Tribunais, 2007.

MONTAGNER, Ângela Christina Boelhouwer. Aadoção internacional e a nacionalidade da criança adotada. Disponível em: <http://www.publicacoesacademicas.uniceub.br/ index.php/prisma/article/viewFile/903/849. Acesso em 13 de outubro de 2014>. Acesso em: 13 out. 2014.

ORGANIZAÇÃO DAS NAÇÕES UNIDAS. Convenção para a redução dos casos de apatridia. Disponível em: $<$ http://www.acnur.org/t3/fileadmin/Documentos/ portugues/BDL/Convencao_para_a_Reducao_dos_ Casos_de_Apatridia_de_1961.pdf?view=1>. Acesso em: 30 ago. 2014.

ORGANIZAÇÃO DAS NAÇÕES UNIDAS. Declaração Universal dos Direitos do Homem de 1948. Disponível em: <http://www.ohchr.org/EN/UDHR/ Documents/UDHR_Translations/por.pdf $>$. Acesso em: 30 ago. 2014.

PIOVESAN, Flávia. Direitos humanos ejustiça internacional. 4. ed. rev., ampl. e atual. São Paulo: Saraiva, 2013..

REZEK, Francisco. Direito internacional público: curso elementar. 14. ed., rev., aumen. e atual. São Paulo: Saraiva, 2013. 
REZEK, José Francisco. Le Droit International de la Nationalité. Leiden: M. Nijhoff, 1987. (Recueil des Cours de l'Académie de droit international, 198).

VARELLA, Marcelo Dias. As transformações do direito internacional e algumas visões sobre um eventual processo de constitucionalização. In LUCCA, Newton de; MEYER-PFLUG, Samantha Ribeiro; NEVES, Mariana Barboza Baeta (Coord.). Direito Constitucional Contemporâneo: homenagem ao Professor Michel Temer. São Paulo: Quartier Latin do Brasil, 2012.

VARELLA, Marcelo Dias. Direito internacional público. 3. ed. São Paulo: Saraiva, 2011. 


\title{
Interregional Organizations (IROS) in Europe: new subjects of contemporary international law?*
}

Davorin Lapas**

\begin{abstract}
The topic of this paper is the concept of international legal personality and its applicability to the new-coming participants in legal relations in the international community. Interregional organizations (IROs) gathering in their membership various sub-State entities of different States have appeared in the recent decades as a new form of institutionalized international cooperation but on the sub-State level. The entities like European Groupings of Territorial Cooperation (EGTCs) and Euroregional Co-operation Groupings (ECGs), Association of European Border Regions (AEBR), Assembly of European Regions (AER), or Euroregions that can be found under different names such as "euregios", "euregions", "crossborder" or "transfrontier associations", "communautés d'intérêts", "working communities" etc., equally as so-called hybrid or quasi-IROs (QUAIROs), have undoubtedly achieved some of the elements of international legal personality. Some of them conclude treaties with States and IGOs, the others send and receive representatives in their relations with States and IGOs. Starting from the understanding of legal personality as primarily de facto category, this paper analyzes the place and role of these IGO-like entities in contemporary international community having in mind that the subjects of international law appear, exist and die following the meta-juridical logic of functionality in international relations rather than due to a doctrinal "recognition".
\end{abstract}

Key-words: subjects of international law, international legal personality, interregional organizations, European Groupings of Territorial Cooperation (EGTCs), Euroregional Co-operation Groupings (ECGs) Association of European Border Regions (AEBR), Assembly of European Regions (AER).

\section{Introduction}

More than a half century ago the International Court of Justice (ICJ) in its well-known Advisory opinion in the so-called "Reparation case" expressed the understanding of international legal personality that was going to determine development of that concept in international legal theory and practice in the forthcoming decades: "The subjects of law in any legal system are not necessarily identical in their nature or in the extent of their rights, and their nature depends upon the needs of the community." "1 Thus, in distinction from the international law doctrine at the beginning of the previous century that considered States the only subjects of international law, ${ }^{2}$ the doctrine in the second half of the

* Recebido em: 10/10/2014. Aceito em: 02/12/2014.

** LL.M; Ph.D. Professor of Public International Law, University of Zagreb, Croatia,dlapas@pravo.hr.
1 INTERNATIONAL COURT OF JUSTICE. Reparation for injuries suffered in the service of the United Nations, 11 april 1949. Available at: <http://www.icj-cij.org/docket/index.php?p1= $3 \& \mathrm{p} 2=4 \& \mathrm{k}=41 \&$ case $=4 \&$ code $=$ isun\&p3=4>. Accessed on: 23 sep. 2013. p. 178.

2 Thus, for example, in its Manual of International Law in 1902 Liszt began the Chapter on subjects of International Law with the following wording: "Nur die Staaten sind Subjekte des Völkerrecbts: Träger von välkerrechtlichen Rechten und Pflichten." Liszt, F. von, Das Völkerrecht - systematisch dargestellt, Berlin, Verlag von O. Haering, 1902, p. 34. Similar attitude was expressed by the Permanent Court of International Justice in the Case concerning the S.S. "Lotus" in 1927; see: Judgment No. 9, 1927, 
$20^{\text {th }}$ century turned primarily to the postulations of general theory of law. Such approach has abstracted the notion of international legal personality from any particular entity, defining it by the general elements of legal personality in theory - the legal capacity (capacitas iuridica) and the capacity of an entity to produce legal consequences on its own (capacitas agendi). ${ }^{3}$ This being so, the door of international legal personality were opened for any international entity whose de facto participation in international relations has become intensive enough to result with its legal regulation providing such an entity with the rights and duties, i.e. with the necessary element of legal personality - the legal capacity. Consequently, the international legal personality became a pure factual category independent from any additional recognition by other, already "indisputable" subjects of international law. Thus, the international law doctrine in the 1980s finally identified the subjects of international law with the participants in legally regulated international relations. ${ }^{4}$ Although this topic could seem as a pure theoretical issue, it has recently inspired a number of debates, including on the NGOs-IGOs Relationships. ${ }^{5}$ After all, one should not be surprised with the importance of this topic even in contemporary legal doctrine bearing in mind that the question of legal personality is usually the central

\section{P.C.I.J. Series A, No. 10, p. 18.}

3 Cf. e.g.: EUSTATHIADES, C. Th. Les sujets du droit international et la responsabilité internationale :nouvelles tendances. RCADI, v. 84, n. 3, 1953. p. 414-415; CAPOTORTI, F. Cours général de droit international public, RCADI, v. 248, n. 4, 1994. p. 42; Brownlie, I. Principles of public international law. Oxford: Clarendon Press, 1973. p. 60; JENNINGS, R. ; WATTS, A. (Ed.). Oppenheim's International Law. London: Longman, 1995. v. 1. p. 119-120.

4 Cf. e.g.: HIGGINS, R. Conceptual thinking about the individual in international law. In: FALK, R. (ed.); KRATOCHWIL, F. (ed.); MENDLOWITZ, S. H. (ed.). International law: a contemporary perspective. Boulder; London: Westview Press, 1985. p. 480. Shaw, however, makes difference between legal personality and participation of an entity in international relations. For him, "international personality is participation plus some form of community acceptance." SHAW, M. N. International law. 6. ed. Cambridge: Cambridge University Press, 2008. p. 197.

5 See e.g. ROSSI, I. Legal status of non-governmental organizations in international law. Portland: Intersentia, 2010. (International Law, v. 5). p. 152-169. See also: NIJMAN, J. E. Paul Ricoeur and international law: beyond "the end of the subject": Towards a reconceptualization of international legal personality. In: BIANCHI, A. (ed.). Non-state actors and international law. Surrey; Burlington: Ashgate Publishing Company, 2009. p. 79-118. NOWROT, K. Reconceptualising international legal personality of influential non-state actors: towards a rebuttable presumption of normative responsibilities. In: JOHNS, F. (ed.). International legal personality. Surrey; Burlington: Ashgate Publishing Company, 2010. p. 369- 392. issue in every legal system. Thus, as Mosler correctly remarked:

Tout ordre juridique particulier - droit étatique, canonique, droit international public, ordre d'organismes spéciaux - définit le cercle de ses sujets, d'après son but et ses besoins. Il attache cette qualité en premier lieu aux personnes dans le rapport desquelles il veut réaliser cette idée spécifique du droit à sa base. ${ }^{6}$

However, such development has neither deprived States from their international legal personality, nor has it put in question their place in contemporary international community. Yet, States had to find their place among the other participants in international legal relations. The functional logic of international relations followed by the technological development in the previous century has considerably facilitated the co-operation across the States' borders, as well as its institutionalization. Such a co-operation has resulted not only with establishing of inter-governmental organizations (IGOs), but also with appearing of specific IGO-like entities - the interregional organizations (IROs) composed of local States' organs, sometimes gathering in their membership even the States themselves (quasi-interregional organizations QUAIROs). While the IGOs today are unanimously accepted as subjects of international law, those IGOlike entities still wait for their place in international law doctrine, being from time to time just the topic of research and analyses in the papers like this one.

\section{Interregional organizations (IROs) - new forms of institutionalized sub-state co-operation in Europe}

The development of technology in the previous decades, as we have mentioned above, enabled not only the public but also the private law subjects including individuals from different States to co-operate directly across the States' borders. At the same time, the enlargement of the scope of international issues has meant that central governments have been faced with the internationalized activities that made the centralized decision-making process harder than ever. This situation has necessarily led to the co-operation on the sub-State, i.e. inter-regional level. Gradually, such a cooperation has become more and more institutionalized

6 Vidi: MOSLER, H. Réflexions sur la personnalité juridique en droit international public. In: Mélanges offerts à Henri Rolin : problemes de droit des gens. Paris : Éditions A. Pedone, 1964. p. 239. 
having formed some new international entities - i.e. the organizations substantively different from IGOs. Such a process can be particularly visible in the field of transregional co-operation that led in the previous decades to the appearance of IROs gathering formally in their membership the various sub-State entities of different States. Consequently, these organizations differ from IGOs primarily in respect of their membership. Instead of States or other sovereign subjects of public international law, their membership is consisted of regions, sub-national, even federal units and other local authorities from different States. Therefore, according to the contemporary international law doctrine, the constituent instruments of these organizations are not accepted as treaties in terms of Article 5 of the Vienna Conventions on the Law of Treaties of 1969 and 1986. On the other hand, the main difference between the transgovernmental organizations (TGOs) like INTERPOL or Inter-parliamentary Union (IPU) and IROs lies in the fact that in TGOs the central States' organs formally participate in their membership acting on their own behalf although their activities directly affects the international co-operation of their States. On the contrary, the membership of IROs is formally consisted of the territorially determined subState entities ${ }^{8}$ having legal personality in public law of their States. Therefore, the organs of the sub-State

7 For the text of the Vienna Convention on the Law of Treaties of 1969 see: UNITED UNION. Vienna Convention on the law of treaties between states and international organizations or between international organizations. Available at: <http://legal.un.org/avl/ ha/vcltsio/vcltsio.html>. Accesses on: 3 sep. 2014. For the text of the Vienna Convention on the Law of Treaties between States and International Organizations or between International Organizations see: Official Records of the United Nations Conference on the Law of Treaties between States and International Organizations or between International Organizations, vol. II (United Nations publication, Sales No. E.94.V.5).

8 In this context, several organizations seem to be an exception. Thus, for example, we can mention here the International Union of Local Authorities (IULA), an organization established in 1913 in the Netherlands with the intention to promote democratic local self-government all over the world. Although the IULA gathers in its membership local authorities from different countries and even different continents, its goals and activities are not territorially determined. In its work the IULA is concentrated on the encouraging decentralization, municipal international co-operation and promoting the democratic local government worldwide. Equally, some other, sometimes called "sectoral" IROs, participating in the AER's membership, can be noted here as well, such as the Assembly of European Wine-Producing Regions - AREV, the Assembly of European Fruit and Vegetable Growing and Horticultural Regions AREFLH, the Association of Local Democracy Agencies - ALDA, and the Federation of Local Authority Chief Executives in Europe (UDiTE). See: infra, note 44. entities participating in the membership of such IROs will never act on their own behalf, but in the name of the sub-State entities as the formal members of such organizations. Sometimes these IROs obtain the recognition of their legal personality in the States whose sub-State entities participate in their membership as a result of these States' treaty obligations. However, although quite absurdly, sometimes the very Statutes of these organizations deny their legal personality in spite of their participation in legal relations with States, IGOs or other undisputable subjects of international law. Be that as it may, having in mind the nature of legal personality as de facto category independent of any formal recognition, we are going to analyze these organizations starting from their actual participation in legally regulated international relations.

\subsection{European Groupings of Territorial Cooperation (EGTCs) and Euroregional Co-operation Groupings (ECGs)}

Contrary to almost unlimited States' sovereignty as understood at the beginning of the $20^{\text {th }}$ century, in the last decades some profound changes in the world have taken place, threatening to defy States' borders. Of course, this does not mean that the sovereignty has become an obsolete concept. However, as Pascual and Benner correctly remarked, "sovereignty premised on borders serving as inviolable boundaries simply does not function in a world where money, ideas, capital, labour and even pollution know no bounds." Having in mind the proliferation and diversity of contemporary international relations and their participants some authors came to the conclusion on the appearance of "postnational law". Although one could consider that "the term post-nationalism goes too far", the few would deny a strong transnational character of contemporary international relations characterized not only by the co-operation of individuals and

9 PASCUAL, C.; BENNER, H. Sovereignty's evolution: the role of regions: regional convergence in a transnational world. In: DE LOMBAERDE, Ph.; BAERT F. (Ed.); FELÍCIO, T. (Ed.). The United Nations and the regions: third world report on regional integration. Dordrecht; Heidelberg: Springer, 2012. (United Nations University Series on Regionalism, v. 3).

10 More detailed see in: KRISCH, N. Beyond constitutionalism: the pluralist structure of postnational law. Oxford: Oxford University Press, 2010. p. 5-14.

11 See: SHAFFER, G., A transnational take on krisch's pluralist structure of postnational law, EJIL, v. 23, n. 2, 2012. p. 577-579,582. 
private entities across the States' borders resulting with hundreds of thousands INGOs all over the world, but also by the institutionalized co-operation of regions and other sub-State entities from different, mostly neighbor States related to the questions of their common interest. The institutionalization of such co-operation has resulted with the creation of a new type of "transfrontier organisms" ("organismes transfrontaliers") - IROs. Though the cross-border cooperation can also be found in other continents, ${ }^{12}$ this process had its culmination exactly at the heart of Europe, as Vedovato interestingly remarked: “...[L] à où sont apparues les premières identités nationals." 13 Thus, the European Parliament in 1960 mentioned for the first time the notion of "Europe of regions" starting thereby the process of interregional co-operation in Europe aiming at diminishing of disparities in development among the European regions and making Europe polycentric. ${ }^{14}$ Furthermore, in 1985 the member States of the Council of Europe (CoE) signed the European Charter of Local Self-Government with the aim to enhance "the right and the ability of local authorities, within the limits of the law, to regulate and manage a substantial share of public affairs under their own responsibility and in the interests of the

12 See: CORNAGO, N. On the normalization of sub-state diplomacy. In: CRIEKEMANS D. (Ed.). Regional sub-state diplomacy today. Leiden; Boston: Martinus Nijhoff Publishers, 2010. p. 29.

13 VEDOVATO, G. La cooperation transfrontalière, les eurorégions et le Conseil de l'Europe, Annuaire Européen, v. 43, 1995. p. 1. Such a phenomenon of direct co-operation between the regions or other sub-State entities of different States today is often described by the notion of "paradiplomacy" or "subState diplomacy"; see e.g.: WOLFF, S. Paradiplomacy: scope, opportunities and challenges, Bologna Center Journal of International Affairs, v. 10, 2010. Available at: < http://bcjournal.org/volume-10/ paradiplomacy.html>. Accessed on: 22 may 2013. Although this phenomenon can be found under different names such as "microdiplomacy", "multilayered diplomacy", or "constituent diplomacy", paradiplomacy has usually been defined as "[...] sub-state governments' involvement in international relations, through the establishment of formal and informal contacts, either permanent or ad hoc, with foreign public or private entities, with the aim to promote socio-economic, cultural or political issues, as well as any other foreign dimension of their own constitutional competences." CORNAGO, N. On the normalization of sub-state diplomacy. In: CRIEKEMANS D. (Ed.). Regional sub-state diplomacy today. Leiden; Boston: Martinus Nijhoff Publishers, 2010. note 12, p. 13.

14 For more details on this process, particularly through the INTERREG I, II and III Programs, see: HUET, P. Garcia-Duran. Vers l'Europe des eurorégions? L'objectif de „,cohésion territoriale. Revue du Marché commun et de l'Union européenne, n. 491, p. 499-502, sep. 2005 p. 499-502. Also, for the INTERREG IV Program see: <http://www.interreg-fwvl.eu/fr/page.php?pageId=204>. Accessed on: 4 oct. 2013). local population" (Art. 3(1)). ${ }^{15}$ On the other hand, the Regulation 1082/2006 of the European Parliament and the Council of 5 July 2006 in its Preamble correctly stated that increase in the number of land and maritime borders in the Community following its enlargement made it necessary to facilitate the reinforcement of territorial co-operation in the Community (i.e. within the EU). ${ }^{16}$ One of the most significant forms of such cooperation in Europe today is the European Grouping of Territorial Cooperation (EGTC). Moreover, this Regulation provides the creation of EGTCs as a new type of international entities - i.e. IROs, providing that the tasks and competencies of an EGTC are to be set out in a convention and its statutes, together with its organs and rules for its budget and for the exercise of its financial responsibility. ${ }^{17}$ Besides, the Regulation has envisaged the possibility of participation in an EGTC even for the entities from third countries where the legislation of a third country or agreements between the Community (i.e. the EU) member States and third countries so allow..$^{18}$ At the same time, "the Regulation has allowed subnational units to conclude a cross-border convention with homologous foreign counterparts for a cross-border co-operation body establishment, no matter if such a possibility was previously granted according to the relevant domestic legal order." ${ }^{19}$ However, Article 1 paragraph 3 of the Regulation

15 COUNCIL OF EUROPE. European charter of local selfgovernment, Strasbourg, 15 october 1985. Available at: <http:// conventions.coe.int/Treaty/EN/Treaties/Html/122.htm>. Accessed on: 3 sep. 2013.

16 See: EUROPEAN PARLIAMENT AND COUNCIL. Regulation n. 1082/2006. European grouping of territorial cooperation (EGTC). Official Journal of the European Union, 31 july 2006.

17 EUROPEAN PARLIAMENT AND COUNCIL. Regulation n. 1082/2006. European grouping of territorial cooperation (EGTC). Official Journal of the European Union, 31 july 2006. paras. 10 and 14 .

18 EUROPEAN PARLIAMENT AND COUNCIL. Regulation n. 1082/2006. European grouping of territorial cooperation (EGTC). Official Journal of the European Union, 31 july 2006. para. 16.

19 Strazzari, D., Harmonizing Trends vs. Domestic Regulatory Frameworks: Looking for the European Law on Cross-Border Cooperation, European Journal of Legal Studies, vol. 4, issue 1 (Summer 2011), p. 154. Thus, Strazzari considers the Groupement local de coopération transfrontalière (GLCT), as provided by the Karlsruhe Accord, a legal model that anticipated the following treaties concerning the cross-border co-operation, and even the EGTC Regulation. See: ibid., p. 165. See Art. 11 of the "Accord de Karlsrube sur la coopération transfrontalière entre les collectivités territoriales et organismes publics locaux". The text of the Karlsruhe Accord of 23 January 1996 is available at: <http://www.ge.ch/legislation/rsg/f/s/rsg_A1_11. html>. Accessed on: 23 sep. 2013. 
seems to be the most important in the context of this paper, providing that "an EGTC shall have legal personality." An EGTC acquires legal personality on the day of registration in the EU member State, or publication of its Statutes, whichever day occurs first, ${ }^{20}$ while the EGTC members shall inform thereafter the member States concerned as well as the Committee of the Regions about the registration of an EGTC and publication of its statutes. ${ }^{21}$ Nevertheless, in the context of the EGTCs' legal personality the mentioned provision is not much different from those of Article 47 of the Lisbon Treaty on European Union, ${ }^{22}$ or Article 104 of the UN Charter which provides: "The Organization shall enjoy in the territory of each of its Members such legal capacity as may be necessary for the exercise of its functions and the fulfilment of its purposes." In both cases, the international legal personality of these organizations derives from the international legal obligation of the States to recognize their legal personality primarily in their own domestic legal orders. Thus, according to Article 1 of the Regulation the EU member States accept the international legal obligation to recognize the legal personality of the EGTCs by allowing their regions to participate in their membership. In fact, such a situation is very much alike to the notion of pactum in favorem tertii, i.e. "third-party beneficiary contract" common not only to the Roman law, or civil law in many States, but also to the general legal theory. Hereby, the States accept the legal obligation comprising at the same time the right of the third party - an EGTC to obtain the recognition of legal personality in these States' legal orders according to the provisions of the Regulation. Similarly, even today the legal capacity of an individual

20 Regulation 1082/2006, Art. 5, para. 1. Also, Article 2 of the Regulation provides that "where it is necessary under Community or international private law to establish the choice of law which governs an EGTC's acts, an EGTC shall be treated as an entity of the Member State where it has its registered office."

21 For the List of 39 EGTCs whose establishment has been notified to the Committee of the Regions of the European Union on 2 October 2013 see: https:/ / portal.cor.europa.eu/egtc/Register/ Pages/welcome.aspx (accessed on 29 November 2014). For the map of the EGTCs by November 2013 see: http://cesci-net.eu/ tiny_mce/uploaded/Europa_EGTC_ENG1_9.png (accessed on 30 November 2014).

22 Thus, Article 47 of the Lisbon Treaty on European Union does not mention expressly the EU international legal personality, providing just that: "The Union shall have legal personality." For the text of the Lisbon Treaty on European Union see: EUROPEAN COURT OF JUSTICE. Lisbon treaty on European Union see. Official Journal of the European Union, C83/01, v. 53, 30 march 2010. in international law derives in a certain degree from the States' international legal obligations in respect of human rights, where an individual often appears as "the third party beneficiary". Thus, although primarily directed to the recognition of the EGTCs' legal personality in domestic legal orders of the EU member States, the same provision indirectly contributes to the acquiring of their international legal personality being a derivation of the international treaty obligation of these States, particularly having in mind the provision of Article 288 of the Lisbon Treaty on the Functioning of the European Union. ${ }^{23}$ This being so, the States' international obligation on the recognition of the legal personality of the EGTCs that fulfilled the conditions required by the Regulation appears at the same time as the EGTCs' international right to such recognition, providing these organizations (although as the third party) with the necessary element of international legal personality - the legal capacity deriving from a treaty as a source of international law.

Furthermore, according to Article 3 of the Regulation, the membership of an EGTC may include the EU member States, ${ }^{24}$ regional authorities, local authorities, as well as other bodies governed by public law provided by the Directive 2004/18/EC of the European Parliament and of the Council of 31 March 2004. ${ }^{25}$ In addition, according to the same Article,

23 Thus, Article 288 para. 2 of the Lisbon Treaty on the Functioning of the European Union states as follows: "A regulation shall have general application. It shall be binding in its entirety and directly applicable in all member States." For the text of the Lisbon Treaty on the Functioning of the European Union see: EUROPEAN COURT OF JUSTICE. Lisbon treaty on European Union see. Official Journal of the European Union, C83/01, v. 53, 30 march 2010.

24 Having in mind the possibility of the States' membership in EGTCs as provided by Article 3 of the Regulation, such EGTCs, by analogy with so-called "hybrid or quasi-NGOs" (QUANGOs), could be equally understood as "hybrid or quasi-IROs" (QUAIROs); see: infra, Chapter 3.

25 According to the Directive, it includes the bodies established for the specific purpose of meeting needs in the general interest, not having an industrial or commercial character, having legal personality, and being financed, for the most part, by the State, regional or local authorities, or other bodies governed by public law; or being subject to management supervision by those bodies; or having an administrative, managerial or supervisory board, more than half of whose members are appointed by the State, regional or local authorities, or by other bodies governed by public law. EUROPEAN PARLIAMENT AND COUNCIL. Directive 2004/18/EC of the European Parliament and of the Council of 31 March 2004 on the coordination of procedures for the award of public works contracts, public supply contracts and public service contracts. Official Journal of the European Union, 30 april 2004. Available at: <https:// www.gov.uk/government/uploads/system/uploads/attachment_ 
associations consisting of bodies belonging to one or more of these categories may also become the members of an EGTC. However, according to paragraph 2 of this Article, an EGTC shall be made up of members located on the territory of at least two EU member States.

Besides, an analogy between the EGTCs and IGOs can be found in Article 10, paras. 1 and 2 of the Regulation providing that an EGTC shall have its organs - at least an assembly, which is made up of representatives of its members; and director who represents the EGTC and acts on its behalf, while the statutes may provide for additional organs with clearly defined powers.

However, as an IRO, the EGTC is unique in the sense that it enables public authorities of various EU member States to team up and deliver joint services, without requiring a prior specific international agreement to be signed and ratified by national parliaments. The EU member States must however agree to the participation of potential members in their respective countries.

Finally, Article 10, para. 3 of the Regulation seems also particularly important in this context providing that "an EGTC shall be liable for the acts of its organs as regards third parties, even where such acts do not fall within the tasks of the EGTC." By this provision the EGTCs' liability seems to be regulated more strictly than in the case of the responsibility of IGOs. Pursuant to Article 8 of the Draft articles on the responsibility of international organizations adopted by the ILC in 2011 the conduct of an organ or agent of an international organization shall be considered an act of that organization under international law only provided that such an internationally wrongful act fall "within the overall functions of that organizations [...]." ${ }^{26}$ On the contrary, as we have seen, the Regulation does not contain such limitation. What is more, besides the obligations ex delicto, the Regulation in its Article 12(2) provides the EGTCs' liability ex contractu envisaging that "an EGTC shall be liable for its debts whatever their nature." On the other hand, according

data/file/35922/Classic_Directive_1_13420040430en01140240. pdf $>$. Accessed on: 3 sep. 2013. The non-exhaustive lists of bodies and categories of bodies governed by public law which fulfill these criteria are set out in Annex III to the Directive.

26 UNITED NATIONS. INTERNTIONAL LAW COMISSION. Report of the International Law Commission: sixtythird session, 2011. Available at: <http://legal.un.org/ilc/ reports/2011/2011 report.htm>. Accessed on: 23 sep. 2013. p. 53. to its Article 15, third parties who consider themselves wronged by the act or omissions of an EGTC shall be entitled to pursue their claims against the EGTC, generally before the courts of the EU member State where the EGTC has its registered office, whereby the Regulation, following the above-mentioned logic, has indirectly recognized a kind of international ius standi in iudicio for EGTCs. Moreover, such an extensive wording of the Regulation does not exclude at least a hypothetic possibility of committing an internationally wrongful act by an EGTC violating the international rights of an EU member State.

For all these reasons one can hardly deny the increasing presence of the EGTCs in international legal relations which led the authors as Ramirez and Gabbe to the conclusion that the positive experiences with the EGTCs have emphasized the clear need to create and further develop visible and permanent legal structures for territorial co-operation in Europe. ${ }^{27}$

On the other hand, the EGTCs are not the isolated form of such institutionalized transfrontier co-operation in Europe. Beside the EGTCs, a similar type of IROs appeared more recently at the level of the $\mathrm{CoE}$ in the form of Euroregional Co-operation Groupings (ECGs). In fact, a possibility of acquiring the legal personality for the "transfrontier co-operation groupings" was envisaged much earlier in the Model interstate agreement (bilateral or multilateral) on transfrontier co-operation groupings having legal personality, contained in the Appendix 1.14 to the European Outline Convention on Transfrontier Co-operation between Territorial Communities or Authorities, signed in Madrid on 21 May 1980 (hereinafter the Madrid Convention). ${ }^{28}$ Of course, the Madrid Convention had no intention of using international law in regulation of cross-border co-operation between sub-State entities. Moreover, the Convention in its Article 3 clearly states that the arrangements and agreements concluded between "territorial communities and authorities" have no treaty value. ${ }^{29}$ However, the transfrontier co-operation

27 RAMIREZ, M. G.; GABBE, J.; AEBR and EGTC: a long way to success. Interact, winter 2013. p. 6.

28 For the text of the Madrid Convention see: ETS, No. 106.

29 Thus, the Explanatory report on the Madrid Convention states as follows: "In no event are the central government's powers in general policy-making or the conduct of international relations affected by the Convention. The Convention does not have the effect of conferring an 'international' character on transfrontier relations." (para. 35a). For the text of the Report see: <http:// conventions.coe.int/Treaty/en/Reports/html/106.htm>. Accessed 
as conceived by the Convention turned very soon into a dynamic process followed by evolving international legal regulation. In this regard, Pierre-Marie Dupuy anticipated this development in his article of 1977 on regional transfrontier co-operation, considering that international law should not be an obstacle to the regional transfrontier co-operation. On the contrary, international law is supposed to be at its service. ${ }^{30}$ Thus, the legal personality of "transfrontier co-operation bodies" has expressly been provided in Article 3 of the Additional Protocol to the Madrid Convention, signed in Strasbourg on 9 November 1995. ${ }^{31}$ Later, in 1998 the Protocol No. 2 to the Madrid Convention concerning interterritorial co-operation extended transfrontier co-operation to "interterritorial co-operation" in the meaning of "any concerted action designed to establish relations between territorial communities or authorities of two or more Contracting Parties, other than relations of transfrontier co-operation of neighbouring authorities, including the conclusion of co-operation agreements with territorial communities or authorities of other States." (Art. 1). Although the Protocol No. 2 does not mention either the "interregional co-operation bodies" or the question of legal personality, it is worth pointing out its Article 4 providing that the Contracting Parties to this Protocol, which are also Contracting Parties to the Additional Protocol to the Madrid Convention "shall apply, mutatis mutandis, the aforesaid Protocol to interterritorial co-operation." 32

Finally, some of the CoE member States signed in Utrecht in 2009 the Protocol No. 3 to the Madrid Convention, concerning Euroregional Co-operation Groupings (ECGs). ${ }^{33}$ According to Article 1 of the

on: 26 aug. 2013.

30 Thus, Dupuy said: "Le droit international, loin d'apparaittre un obstacle, serait alors au service de la coopération régionale transfrontalière." DUPUY, P. M. La coopération régionale transfrontalière et le droit international. AFDI, v. 23, 1977. p. 854.

31 For the text of the Additional Protocol see: COUNCIL OF EUROPE. Additional protocol to the european outline convention on transfrontier co-operation between territorial communities or authorities. Strasbourg, 1995. Available at: <http://conventions.coe. int/Treaty/EN/Treaties/Html/159.htm>. Accessed on: 3 sep. 2013.

32 For the text of the Protocol No. 2 see: COUNCIL OF EUROPE. Protocol n. 2 to the European outline convention on transfrontier cooperation between territorial communities or authorities concerning interterritorial co-operation, 1998. Available at: <http://conventions.coe.int/Treaty/ en/Treaties/Html/169.htm>. Accessed on: 3 oct. 2013.

33 For the text see of the Protocol No. 3 see: COUNCIL OF EUROPE. Protocol $n .3$ to the European outline convention on transfrontier co-operation between territorial communities or authorities concerning euroregional co-operation groupings (ECGs): CETS no. 206. Available
Protocol, the territorial communities or authorities of the States Parties to the Protocol may set up a "transfrontier co-operation body" in the form of ECG on the territory of the member States of the CoE, Parties to this Protocol, with the objective to promote, support and develop the transfrontier and interterritorial cooperation between the ECG members. Beside the territorial communities or authorities of a State Party, the membership of the ECG "may also include the respective member State concerned of the Council of Europe" (Art. 3). According to the Protocol, the ECG shall have a legal personality governed by the law of the CoE member State in which it has its headquarters. What is more, the Protocol provides that "the ECG shall have the most extensive legal capacity accorded to legal persons under that State's national law" (Art. 2(2)). Thereby, by analogy with the previously described situation concerning the EGTCs, the Protocol, although regulating the ECGs' legal personality in the domestic legal orders of the States Parties, creates a treaty obligation for these States on recognition of such legal personality turning it, at the same time, into a right established for these organizations as the third party beneficiaries. The ECGs constituent instruments are the agreement between its founding members and the statutes as an integral part of the agreement establishing the ECG. Furthermore, similarly to the case of EGTCs, the Protocol has envisaged the liability of the ECGs, not only with regard to third parties, but also to its members for any breach of the law to which it may be subject (Art. 9). However, some authors point out that while the Protocol and the Regulation seem to be very similar, the Protocol takes into account the fact that due to the broader membership of the $\mathrm{CoE}$ in comparison to that of the EU, an ECG could be, at the same time, an EGTC. Therefore, the range of possibilities opened by the Protocol is broader and more flexible than the solutions offered by the EU Regulation. ${ }^{34}$

at: <http://conventions.coe.int/Treaty/EN/Reports/Html/206. htm >. Accessed on: 3 oct. 2013.

34 See: MĂTUŞESCU, C. European juridical instruments of territorial cooperation: towards a decentralized foreign policy in Europe? AGORA International Journal of Juridical Sciences, n. 2, 2012. p. 92. On the other hand, Strazzari points out that "although the $\mathrm{CoE}$ and the EU legal instruments concerning cross-border cooperation are deeply different in their nature and function (with the $\mathrm{CoE}$ aimed to provide a minimal common regulation, according to international law standards, and the EU aimed to provide substantial legal harmonization of EU Member States legislations), they share nonetheless the common goal of harmonizing European national 


\subsection{Association of European Border Regions (AEBR)}

The Association of European Border Regions (AEBR) is one of the oldest IROs in Europe, founded in September 1971. The representatives of eight European regions from different European States signed in Bonn and Strasbourg the Statutes for the Association of European Border Regions (AEBR). ${ }^{35}$ Today, the AEBR network is composed of approximately 100 members from the EU and beyond. ${ }^{36}$ Thereby, the AEBR differs from the EGTCs whose membership is limited to the EU member States' regions. In paragraph 2 of its Statutes the AEBR is defined as "a registered association" with the headquarters in Gronau (Westphalia, Germany). The same paragraph provides that the headquarters can be moved to another location by decision of the AEBR's General Assembly. This being so, if the AEBR's headquarters moved to another State, the Association would acquire the legal personality according to the law of that State. In this case, the AEBR would continue its legal existence even in the case of withdrawn of its legal personality by the State where its headquarters had been situated. Thus, one can conclude that AEBR's legal personality, although subject to the law of particular State, in some measure goes beyond the mere level of its domestic legal order. After all, the argument in favor to this conclusion can be found in paragraph 14 of the AEBR Statutes providing that the termination of AEBR "can only take place through a specially convened General Assembly for this purpose", i.e. not by the decision of any State. Moreover, according to the Statutes, the

legislation and they highlight common legal developments." STRAZZARI, D. Harmonizing trends vs. domestic regulatory frameworks: looking for the european law on cross-border cooperation, European Journal of Legal Studies, v. 4, n. 1, p. summer 2011. note 19, p. 154-155.

35 There were the following regions: Regione Autonoma Friuli Venezia Giulia, Conseil Régional de Lorraine, Euregio Kommunalgemeinschaft Rhein-Ems, Sønderjyllands Amt, Ems-Dollart-Region, Castilla y León, Extremadura, i Euregio Scheldemond. The AEBR's General Assembly amended the Statutes in 1994 (in Trieste), and in 1997 (in Salamanca). For the text of the Statutes see: <http://www.aebr.eu/files/publications/ Statutes_EN_signed.pdf $>$. Accessed on: 18 mar. 2013.

36 Thus, some members of the AEBR come from Armenia, Belarus, Moldova, Norway, the Russian Federation, Serbia, Switzerland, Turkey and Ukraine; see: RAMIREZ, M. G.; GABBE, J.; AEBR and EGTC: a long way to success. Interact, winter 2013. note 27, p. 7 . decision on termination shall be made by two-thirds majority of the AEBR members present.

Among the aims of AEBR as provided in paragraph 3 of its Statutes are to represent the interests of the European border and cross-border regions to national and international parliaments, organs, authorities and institutions, as well as to initiate, support and coordinate their co-operation throughout Europe. For this purpose, the AEBR's tasks are to implement programs and projects directed to the cross-border co-operation, to apply for funds and to receive and dispose of them; to organize events regarding crossborder problems; to help to solve cross-border problems and to support special activities; to prepare and implement common campaigns; to extend the Centre for European Border and Cross-border regions in close co-operation with the $\mathrm{EU}$ and the $\mathrm{CoE}$; and to inform European political bodies and public about cross-border questions (para. 3(2)).

The European border and cross-border regions in the member States of the EU or CoE can be the full members of the AEBR with the right to vote. Also, according to paragraph 4(1) of the Statutes, the full membership in AEBR is opened to the large-seized amalgamations of border regions within several countries provided not all their members join AEBR individually. ${ }^{37}$

In principle, the rights and duties of the AEBR members do not differ a lot in comparison with those of members of IGOs. Along with the right to vote, to contribute to the work of AEBR and to use its services, programs and facilities, they are required to support the AEBR activities including through the payment of their contributions according to the decisions of the General Assembly and provisions of paragraph 13 of the AEBR Statutes.

Furthermore, even the AEBR's institutional structure does not show much difference comparing to that of IGOs. According to Article 6 of its Statutes the organs of AEBR are General Assembly as the highest and plenary organ in which every full member

37 Besides the full members, the AEBR membership includes the members with observer status and honorary members, as well as the advisory members, all of them without the right to vote. (para. 4(2-3)). Today, the AEBR gathers more than 60 border and crossborder regions in its full membership. For the Member Regions List see: <http://www.aebr.eu/en/members/list_of_members.php >. Accessed on: 19 nov. 2012. 
participates with at least one vote. ${ }^{38}$ Also, similarly to Article 19 of the UN Charter, the Statutes provide the suspension of the right to vote for a member who is in arrears in the payment of its contribution for the previous and current calendar year (para. 7(2)). Besides, among the AEBR's principal organs the Statutes provide the Executive Committee that includes the President, the first Vice-President and at least three further Vice-Presidents, the Treasurer, and at least 20 members as representatives from the border and cross-border regions (para. 8(2)). Finally, the Statutes also provide the Secretary General as the head of the Secretariat General. According to paragraph 10, the AEBR is represented in its international relations by the President, First Vice-President and Secretary General. ${ }^{30}$

Analyzing the establishing and work of AEBR, it seems that this IRO has initiated the process of institutionalization of interregional co-operation in Europe, having anticipated the latter IROs such as the EGTCs and Euroregions with all their variety in names and structure.

On the other hand, among the more recent AEBR's legal activities it should be mentioned that the AEBR has actively participated in the process of reforming of the place and role of EGTCs within the EU system. Thus, in November 2011 the AEBR made the "Statement", as a kind of "soft law" document, on the Proposal for a Regulation of the European Parliament and of the Council amending the aforementioned Regulation 1082/2006 on a European grouping of territorial cooperation as regards the clarification, simplification and improvement of the establishment and implementation of EGTCs. ${ }^{40}$ Similarly, in 2010 the AEBR issued another "soft law" document delivered to the EU Commission: the AEBR Position Paper on the Future EU Strategy 2020 (Post-Lisbon Strategy). ${ }^{41}$

38 According to paragraph 7(2) of the AEBR Statutes the number of votes is regulated by the contribution regulation.

39 Beside these main organs, the Statutes provide the possibility of creating of various committees including the Advisory Committee for Cross-border Co-operation appointed by the Executive Committee (para. 11).

40 AEBR Statement $\operatorname{KOM}(2011) 610$ final; 1 November 2011. For the text of the "Statement" see: <http://www.aebr.eu/files/ publications/111129_statement_proposal_EGTC_regulation_ EN_clean.pdf $>$. Accessed on: 23 sep. 2013.

41 For the text of the AEBR Position Paper see: <http://www. aebr.eu/files/publications/10_01_12_AGEG_Stellungnahme_ Europa_2020_EN_def.pdf $>$. Accessed on: 3 sep. 2013.
Finally, in the context of this paper it is worth noting that on 18 March 2010 the AEBR signed a Co-operation Agreement with one IGO - the CoE represented by its organ - the Congress of Local and Regional Authorities. The Agreement seeks to combine the forces of the both organizations for more effective initiatives in favor of regional authorities and, in particular, in favor of European border regions. ${ }^{42}$

\subsection{Assembly of European Regions (AER)}

The Assembly of European Regions (AER) is a specific IRO established in 1980s with the aim, as defined in its Statutes, "to act as the political voice of the Regions of Europe..." 43 According to the Statutes, the AER is founded as a non-profit association gathering in its membership as full members the regions of the member States of the CoE, as well as other European Regions under the condition that they respect the basic fundamental principles of the CoE. Besides, even the other IROs may become the AER's consultative members (Art. 2).$^{44}$ The organizational structure of the AER is analogous to other similar IROs, but also to many IGOs. The AER's main organs are the General Assembly convened at least once a year and consisted of

42 See: $<$ http://www.aebr.eu/files/publications/100330_20 AEBR_20Newsflash_206_20EN_20final.pdf>. Accessed on: 30 may 2013.

43 For the text of the AER Statutes of 12 October 2012 see: ASSEMBLY OF EUROPEAN REGIONS. Statute. Paris, 17 march 2013. Available at: <http://www.aer.eu/fileadmin/user_upload/ GoverningBodies/GeneralAssembly/Statutes/Statutes-200x/ AER_Statute_17052013-EN.pdf>. Accessed on: 27 apr. 2013.

44 From its beginning in 1980s, the AER functions as so-called "umbrella organization" gathering in its membership the other IROs. Thus, among the IROs participating in the AER membership today we can mention the AEBR, the Alps-Adriatic Working Community, Eurorégion Alpes Méditerranée, the Working Community of the Danube Countries - ARGE Donauländer, the Working Community Pyrenees (Comunidad de Trabajo de los Pirineos - CTP), the Working Community of the Alps - Arge Alp, the Transjurasian Conference CTJ, the Working Community Galice - North Portugal, the Baltic Sea States Subregional Cooperation - BSSSC, Channel Art Manche, the World Mountain People Association (WMPA). Together with the above-mentioned territorially determined IROs, in the AER's membership there are also some of these organizations gathering their member regions on the basis of their specific activities such as the Assembly of European Wine-Producing Regions - AREV, the Assembly of European Fruit and Vegetable Growing and Horticultural Regions - AREFLH, the Association of Local Democracy Agencies - ALDA, and the Federation of Local Authority Chief Executives in Europe (UDiTE). See: <http:// www.aer.eu/members-and-partners/member-organisations.html $>$. Accessed on: 13 jan. 2014. 
the representatives of all the AER members; the Bureau as an executive body that ensure the implementation of the decisions of the General Assembly; and the Secretary General who is in charge of the General Secretariat and responsible for implementing the decision of the other AER bodies presenting a yearly report before the General Assembly. Also, the Statutes provide the President as the highest authority of the AER that represents the organization in all external relations, the Vice-Presidents, the Committees and Standing Committees, ${ }^{45}$ and the Treasurer. Today, the AER participates in interregional relations in Europe as one of the most significant IROs not only having in mind its numerous membership composed of nearly 230 regions from 35 States and 15 IROs, but also its activities in promoting the cross-border co-operation among the CoE member States. The work of the Organization is complementary to the activities of the $\mathrm{CoE}$, as well as of the EU in realization of their common policies, particularly in consideration of its "Positions" adopted by the AER's General Assembly. Thus, for example, it is worth mentioning here the AER Position on the European Neighbourhood Policy Reform, adopted by the AER's General Assembly in November 2011, which initiated the process of redefining of the objectives of future European Neighbourhood Policy (ENP). Moreover, the need for co-operation between the EU and the IROs was recently mentioned by the EU Commissioner Stefan Füle concerning the "need for [...] joint work with the Committee of the Regions" in which context "the interregional organisations should not be ignored." ${ }^{46}$ Consequently, among the objectives of such IGOs-IROs co-operation the AER Position states that the place of interregional and cross-border co-operation in future ENP should be strengthened. Thus, the AER Position calls for multilevel governance and partnership, as well as for paying more attention

45 These Committees are the Executive Committee, Committee 1 for Economy and Regional Development, Committee 2 for Social Policy and Public Health, Committee 3 for Culture, Education, Youth and International Co-operation, as well as the Standing Committees for monitoring and evaluation, for institutional affairs and for equal opportunities.

46 See: the AER Position on the European Neighbourhood Policy Reform adopted at the AER General Assembly, Ponta Delgada (Azores), 24 November 2011. The text available at: <www. aer.eu>. Accessed on: 26 apr. 2013. For the Letter by Commissioner Stefan Füle on the AER ENP position 2011 see: < http://www. aer.eu/en/knowledge-centre/thematic-expertise-thematicissues/neighbourhood-policy-and-aer-in-the-world/europeanneighbourhood-policy.html>. Accessed on: 24 sep. 2013. to territorial diversity in ENP pointing out at the same time the importance of the decentralization processes in Europe. Finally, the similar attitude can be found within the EU as well. The EU Committee of the Regions in its Mission Statement clearly confirmed the need for involvement of regional and local authorities in the European decision-making process encouraging the co-operation between these authorities of different EU member States. ${ }^{47}$

Among the similar "soft law" documents adopted by the AER, one should not forget the Declaration on Regionalism in Europe. Adopted in 1996, the Declaration, among other things, provides in Article 10 that "regions shall have the capability to act at an international level. They may conclude treaties, agreements or protocols which are international in scope, subject to approval by the central government where is required by national legislation." ${ }^{48}$

However, maybe one of the most important steps that the AER has made towards the acquiring of personality in international legal relations is the Memorandum of Understanding signed with Tunisia in May 2011.49 Formally, "the undersigning parties" thereof are the AER and the Ministry for regional development of Tunisia. For this reason, one could conclude that the "Parties" to the Memorandum are actually an IRO and the Ministry as a public law subject of domestic, but not international law, whereby it would stay out of the sphere of interest of public international law. Nevertheless, viewed from within, things could seem different. Starting from the Preamble, the Tunisian Ministry accepts the obligation "to encourage and support the process of decentralization in Tunisia..." Using the teleological interpretation it seems obvious that the Ministry did not act on its own behalf, but as

47 EUROPEAN UNION COMMITTEE OFTHE REGIONS. Mission Statement. Brussels, 21 apr. 2009. Available at: <http:// cor.europa.eu/en/about/Documents/Mission\%20statement/ EN.pdf>. Accessed on: 3 sep. 2013.

48 For the text of the Declaration see: <http://www. aer.eu/fileadmin/user_upload/PressComm/Publications / DeclarationRegionalism/DR_GB.pdf $>$. Accessed on: 24 sep. 2013. Also, in November 2011 the AER General Assembly adopted the Declaration on Culture and Health. The text of the Declaration available at: <http://www.aer.eu/fileadmin/user_ upload/GoverningBodies/GeneralAssembly/Events/AG2011Acores_Adopted/EN-declaration-culture-health.pdf $>$. Accessed on: 24 sep. 2013.

49 The text of the Memorandum available at: <http://www. aer.eu/events/governing-bodies/2011/general-assembly-2011regions-master-globalisation.html>. Accessed on: 24 sep. 2013. 
an organ of Tunisia as a State, particularly having in mind that the above-mentioned obligation does not belong into the sphere of iure gestionis, but in iure imperii activities of States. What is more, Article III of the Memorandum expressly provides that "Tunisia will be granted observer status at the AER" (stress added). Understood this way, it seems that the Memorandum could be considered a treaty, subject to public international law, or more precisely to the customary international law of treaties.

On the other hand, the AER concluded a similar agreement also called Memorandum of Understanding with the United Nations Development Programme (UNDP). In its Part 2 (called "Agreement") the Memorandum provides that its purpose is "to establish a basis for cooperation between the UNDP and the AER.” (para 2.1). According to paragraph 2.2., the Memorandum "represents the initial stage in fostering of a concrete partnership between the UNDP and the AER. Both parties undertake to work together and to decide on concrete methods of cooperation."

In this context it seems appropriate to remind of the provision of Article 2 of the Vienna Convention on the Law of Treaties which clearly states that “'treaty' means an international agreement [...] whatever its particular designation." The similar provision can also be found in the Vienna Convention on the Law of Treaties between States and International Organizations or between International Organizations. Of course, the Conventions leave the international agreements to which one or more States or one or more international organizations and one or more subjects of international law other than States or organizations are parties, outside their scope. However, in their Preambles both Conventions affirm that the rules of customary international law will continue to govern questions not regulated by their provisions. Equally, in their common Article 3 the Conventions provide among other things that the fact that their provisions do not apply to international agreements concluded between States or IGOs and other subjects of international law shall not affect the legal force of such agreements. ${ }^{51}$

50 The text of the Memorandum is available at: <http://www. aer.eu/en/knowledge-centre/thematic-expertise-thematic-issues/ neighbourhood-policy-and-aer-in-the-world/aer-and-undp.html $>$. Accessed on: 23 sep. 2013.

51 For the text of the Vienna Convention on the Law of Treaties see: supra, note 7 . For the text of the Vienna Convention on the Law of Treaties between States and International Organizations or between International Organizations see: supra, note 7.
Therefore, these agreements, such as for example those concluded with the Sovereign Order of Malta, various international territorial administrations (ITAs), insurgents, or liberation movements will be subject to the customary international law of treaties sharing mostly the same legal regulation as contained in the Vienna Conventions that resulted from the codification work of the ILC. This being so, all these treaties fulfill the above condition to be "governed by international law". Consequently, following Aust, a fundamental characteristic of a treaty is its binding character, even if it is called "Memorandum of Understanding" (MOU). ${ }^{52}$ On the other hand, the designation of a treaty as a MOU is not as unusual in international practice as it could seem. One of the well-known examples could be the Memorandum of Understanding between the Governments of Italy, the United Kingdom of Great Britain and Northern Ireland, the United States of America and Yugoslavia regarding the Free Territory of Trieste, signed in London in $1954 .{ }^{53}$ After all, according to Aust, by August 2006 over 880 instruments called "Memorandum of Understanding" had been registered with the UN Treaty Section and "most of them are probably treaties." 54

\subsection{Euroregions}

In his analytic article concerning the transfrontier cooperation in Europe, Vedovato defined "Euroregions" as political territorial organizations that appeared as a symbiosis of the continuing evolution of the historical and cultural, as well as the administrative space in Europe. ${ }^{55}$ According to him, such evolving process

52 See: AUST, A. Modern treaty law and practice. $2^{\text {nd }}$ ed. Cambridge: Cambridge University Press, 2007. p. 27.

53 For the text of the Memorandum of Understanding see: UNTS, v. 235, 1956, p. 100.

54 AUST, A. Modern treaty law and practice. $2^{\text {nd }}$ ed. Cambridge: Cambridge University Press, 2007. p. 344. In its valuable work Aust precisely elaborates terminological distinctions that can be found between treaties and "non legally binding instruments" sometimes called MOUs. However, although the MOUs are usually characterized for example by the terms like "paragraphs" or "participants", the above-mentioned Memorandum of Understanding between the AER and Tunisia has used the terms "articles" and "parties" typical for treaties. Cf. UNITED UNION. Vienna Convention on the law of treaties of 1969. Available at: < https://treaties.un.org/ doc/Publication/UNTS/Volume\%201155/volume-1155-I-18232English.pdf>. Accessed on: 3 sep. 2013, p. 496.

55 See: VEDOVATO, G. La cooperation transfrontalière, les eurorégions et le Conseil de l'Europe, Annuaire Européen, v. 43, 1995. 
of transfrontier co-operation have been determined by social, economical, political, cultural, and other interests, including the protection of environment as the questions of common interest of population in many cross-border regions. ${ }^{56}$

On the first impression, this process could seem rather contradictory opposing the supranational character of the European integration to the so-called "micro-integration" as equally institutionalized process of co-operation, but on the sub-State level. Be that as it may, according to some authors, such process of institutionalized transfrontier co-operation in Europe is not only irreversible, but also it continues to require a more detailed institutional, i.e. primarily legal regulation. ${ }^{57}$ Therefore, one should not be surprised with the increasing number of institutionalized forms of such transfrontier co-operation in Europe that have not always been easily distinguishable one from another. Thus, "euroregions" sometimes seem to be understood as a residual group of IROs, heterogeneous not only in their names and structure, but also in their legal status. Usually gathering in their membership border regions of the neighbor States interested in cross-border co-operation, the euroregions can be found all over Europe and under different names such as "euregios", "euregions", "cross-border or transfrontier associations", "communautés d'intérêts", "working communities" etc. ${ }^{58}$

note 13, p. 1.

56 Cf. VEDOVATO, G. La cooperation transfrontalière, les eurorégions et le Conseil de l'Europe, Annuaire Européen, v. 43, 1995. p. 2.

57 VEDOVATO, G. La cooperation transfrontalière, les eurorégions et le Conseil de l'Europe, Annuaire Européen, v. 43, p. 20-21, 1995.

58 Among the European regions it is important to mention the Baltic Sea Region established by the Baltic Sea Strategy of the EU, comprising around 100 million citizens, i.e. 20 per cent of the EU. It was the beginning of the initiative within the EU for creating socalled "macro-regions" as a new model for regional co-operation that later inspired the creation of similar macro-regions in areas such as the Mediterranean and Danube basin. However, until now these "macro-regions" have not yet achieved a sufficient stage of institutionalization to be considered IROs in the above-mentioned meaning. Therefore, we make difference here between a region as a geographically determined area in which the co-operation of the States or their sub-State entities takes place, and the IROs that are established as a result of institutionalization of such a co-operation. For more details on macro-regions in Europe, see: SCHEWE, Ch. Legal aspects of the baltic sea strategy: international law in a european macro-region. Baltic Yearbook of International Law, v. 10, 2010. p. 189, 191.
Some of the earliest "transfrontier associations" in Europe can be found in the middle of the $20^{\text {th }}$ century, dealing with various cross-border activities such as fishery, tourism, traffic, culture co-operation etc., anticipating the future "Euroregions". Thus, in 1960s the first euroregions were established, such as Communauté d'intérêts Alsace moyenne - Brisgau, and the Working Community Akershus - Hedemark that gathers the regions along the Norwegian Swedish border. Soon, the Danish and Swedish regions established the Øresund Region, ${ }^{59}$ while in same time the Euregio Rhine - Waal was formed alongside the German-Dutch border. ${ }^{60}$ In addition, we can mention here a series of similar euroregions that appeared in the following years, characterized by very developed institutionalized structure, like the Meuse-Rhine Euregion (composed of the Belgian regions Liège and Limbourg, the Dutch region of Limbourg and the German region of Aachen), ${ }^{61}$ Regio Basiliensis, ${ }^{62}$ Conseil parlementaire interrégional (CPI), ${ }^{63}$ Euroregion

59 The main organs of the Region are: Øresund Committee, Øresund Commission, and Øresund Committee's secretariat established in order to handle activities decided on by the Committee and the Commission. For more details see: <http://www.oresund. com/oresund/welcome2.htm>. Accesseed on: 11 apr. 2013.

60 Organizational structure of the Euregio Rhine-Waal is composed of the Euregio Council as a plenary organ consisted of 142 representatives of all member regions, who meet at least twice a year. Three committees have been established to prepare Council's decisions: Committee of Cross-Border Communication, Committee of Commerce, and Committee of Finance and Projects. Besides, the Euroregio has its Chairman and the Board as an executive body. For more details see: <http://euregio.org/seiten/index.cfm>. Accessed on: 11 apr 2013.

61 The main bodies of this Euroregion are the Committe of Directors, Euregional Council, Economic and Social Council, Strategic Groups, and Bureau. For more details see: <http://www. euregio-mr.com/fr/euregiomr/organisation $>$. Accessed on: 11 apr. 2013.

62 The main governing bodies of the Regio Basiliensis are the General meeting, the Board of directors and the Monitoring group. The Board of directors is the supreme executive body; it approves the budget, annual accounts and annual report under the auspices of the General meeting as the plenary organ. The Monitoring group is a consultative body consisting mainly of representatives from cantonal parliaments and administrative departments. For more details see: <http://www.regbas.ch/d_Information_in_English. cfm>. Accessed on: 11 apr. 2013.

63 The basic document of the Conseil parlementaire interrégional is the Convention relating to the creation of the Conseil Parlementaire Interrégional (CPI), signed in 1986 by the representatives of the Grand Duchy of Luxembourg, Landtag de Rhénanie-Palatinat, Landtag de la Sarre, Conseil Régional de Lorraine, and Conseil Provincial du Luxembourg Belge. According to the Convention, the principal organs of the CPI are: Presidency, Permanent Committee, and the Secretariat. In 
"Neisse-Nisa-Nysa" (composed of German, Czech and Polish regions), etc. ${ }^{64}$

It is not rarely that some euroregions can be found under the name of "Working Communities", like the Working Community Galice - North Portugal, Working Community of the Alps (Arge Alp), the "Eurorégion Alpes Méditerranée" (formerly Communauté de travail des Alpes Occidentales - COTRAO), as well as the Alps-Adriatic Working Community. The last one is particularly important for anticipating, although on the interregional level, the integrative process in the Central Europe starting from 1978, i.e. during the Cold War period when the States whose regions have participated in its membership were still divided by the "iron curtain". ${ }^{65}$ Moreover, the Alps-Adriatic Working Community is even more interesting in the context of this paper since today, following the dissolution of exYugoslavia in 1991 two of its former federal units Croatia and Slovenia have continued their membership in the Community now as the independent States, turning this organization into a hybrid or quasi-IRO (QUAIRO). ${ }^{60}$

These euroregions, pursuant to Article 3 of the Additional Protocol to the Madrid Convention "may, or may not have legal personality". ${ }^{67}$ However, the

addition, the organizational structure of the CPI is composed of six Commissions (Commission 1 for economic affairs; Commission 2 for social affairs; Commission 3 for transports and communications; Commission 4 for environment and agriculture; Commission 5 for education, training, research and culture; and Commission 6 for internal security, civil protection and assistance service. For more details see: <http://www.cpi-ipr.com/fr/Conventions/ conv_cre.asp $>$. Accessed on: 11 apr. 2013.

64 Among the euroregions with significantly developed institutionalized structure Vedovato mentions also the euroregions of "Benego", "Creno" (Conférence des régions de l'Europe du Nord-Ouest), "Comregio", Institut régional intercommunal, Association transfrontalière du bassin supérieur de l'Alzette, etc. Equally, in the Rhine basin the same author mentions the series of similar IROs being provided with the legal personality, such as the „Regio” gathering the Swiss region of Jura, the German region of Schwartzwald and the French region of Vosges; as well as the euroregions like the "Groupe de consultation franco-allemand"; "Cimab"; and the "Jura Working Community". See: VEDOVATO, G. La cooperation transfrontalière, les eurorégions et le Conseil de l'Europe, Annuaire Européen, v. 43, 1995. note 13, p. 8-10.

65 In this context Vedovato has mentioned the euroregion "Egrensis" that was gathering in its membership the cross-border regions of the former Czechoslovakia and the Federal Republic of Germany; see: VEDOVATO, G. La cooperation transfrontalière, les eurorégions et le Conseil de l'Europe, Annuaire Européen, v. 43, 1995. p. 10.

66 See: infra, Chapter 3.

67 For the text see: supra, note 31. very Statutes of some of these euroregions sometimes deny their legal personality leading often to the legally absurd situations. Thus, for example, Article 3, para. 2 of the Statutes of the Euroregional co-operation Danube-Drava-Sava ${ }^{68}$ clearly states that the Euroregion does not have the legal capacity, providing at the same time in paragraph 3 of the same Article the legal duty for the Euroregion to respect in its work the provisions contained in international legal documents, as well as in the domestic legal orders of the respective States. Having determined the legal capacity as a quality of an entity to possess legal rights and duties, it seems indisputable that the mentioned Euroregion legally exists not only in respect to the duties provided by the domestic legal orders, but also in regard to the international law obligations. After all, Article 15 of its Statutes speaks in favor of this argument providing, similarly to the majority of IGOs constitutions, a serious of rights and duties between the Euroregion and its member regions. In addition, Articles 10 and 11 of the Statutes precisely define the scope of activities of the Euroregion including the cross-border co-operation, ${ }^{69}$ while Article 15 regulates even the Euroregion's business activities. These provisions not only implicitly recognize the legal capacity of such an IRO, but also its capacity to produce legal consequences by its acting, both in regard to its members, as well as to the third parties, including States. Consequently, Article 5 of the Statutes regulates the representation of the Euroregion in its legal relations with other subjects entrusting

68 The Euroregional co-operation Danube-Drava-Sava gathers in its membership the regions from Croatia, Hungary, and Bosnia and Herzegovina. However, its membership is open also to the regions of other States that gravitate towards the rivers Danube, Drava and Sava. The Euroregion is founded by signing its Statutes in Pecs (Hungary) on 28 November 1998. The official name of the Euroregion in Croatian and Hungarian is „Euroregionalna suradnja Dunav-Drava-Sava“ / „Duna-Dráva- Száva Euroregionális Együttmúködés“. For the revised text of the Statutes see: $<$ http:// www.ddseuro.org/portal/images/pdf/dokumenti/Statut $\% 20 \% 20$ DDS $\% 20-\% 20$ procisceni $\% 20$ tekst $\% 20 \_$hr_.pdf $>$. Accessed on: 4 apr. 2013).

69 Thus, Articles 10 and 11 of the Statutes define the activities of the Euroregion such as organizing common activities to promote common values; preparing, financing and realization of common development programs; organizing and developing of programs in the field of environmental protection, development of the crossborder co-operation in the field of traffic, communication, economy, tourism, science, education, culture, sport, etc. According to Article 11, these activities should be primarily directed to the establishment and promoting of such co-operation between the border regions. See: <http://www.ddseuro.org/portal/images/pdf/dokumenti/ Statut $\% 20 \% 20$ DDS $\% 20-\% 20$ procisceni $\% 20$ tekst $\% 20$ hr_.pdf $>$. Accessed on: 4 apr. 2013). 
this function to its President or vice-presidents, which confirms again the legal personality of this entity. Furthermore, in Article 1 of the Statutes this Euroregion is defined as an "organization". Thereby, it is expressly established as an institutionalized, i.e. not ad hoc form of co-operation among its members. Such institutionalization is particularly visible in the existence of its permanent bodies as provided by Articles 18-36 of the Statutes, such as the Assembly, President, Executive Committee, Auditing Committee and Secretariat. Besides, the analogy with some of the IGOs is present also in the fact that Article 4 of the Statutes defines even the emblem, flag and the official seal of the Euroregion.

Finally, one could also find the additional argument that speaks in favor to the existence of another constitutive element common to IROs and IGOs - a personality of organization distinct from that of its members, particularly having in mind that the will of the organization will not always be necessarily identical to that of each and every of its members. After all, it is visible in the fact that the decisions within this one and many other euroregions, as well as in other IROs, are made by majority voting. However, these decisions will be equally binding for all their members including for those that have not given their affirmative vote.

Anyhow, the Euroregional co-operation DanubeDrava-Sava shows one more particularity in relation to its membership. Its constituent instrument (the Statutes) not only provides the possibility of acquiring the observer status for other regions of the States gravitating to these rivers, ${ }^{70}$ but also in Article 12 it opens the membership of this euroregion for the non-territorial and non-governmental subjects of these States' legal orders, such as industrial, trade or economic chambers and other commercial subjects acting in these States.

Finally, it is worth mentioning here the provision of Article 14 of the mentioned Statutes regulating the succession in the membership of this euroregion as an entity that according to the wording of its own Statutes - i.e. its basic legal document - legally should not have existed!

70 See: Art. 16 of the Statutes. For the text see<http://www. ddseuro.org/portal/images/pdf/dokumenti/Statut $\% 20 \% 20$ DDS $\% 20-\% 20$ procisceni $\% 20$ tekst $\% 20 \_$hr_.pdf $>$. Accessed on: 4 apr. 2013).

\section{Hybrid or quasi-IROs (QUAIROs) - shared membership for states and sub-state entities}

Talking about the EGTCs we have already mentioned the possibility provided in Article 3 of the Regulation 1082/2006 that opened the EGTCs membership not only to the subjects having legal personality in the public law of their States, but also to the EU member States themselves. ${ }^{71}$ In addition, the same possibility can be found in Article 3 of the Protocol No. 3 to the Madrid Convention, ${ }^{72}$ concerning the ECGs. As we have already mentioned, by analogy with the quasi-NGOs (QUANGOs) whose membership includes non-governmental, private organizations together with States or IGOs as subjects of public international law, the organizations having as their members the subjects of public law from different States (like earlier-mentioned various kinds of subState entities) and States or IGOs will be designated here as quasi-IROs (QUAIROs). Understood this way, it could be interesting to apply this criterion to some organizations almost unanimously accepted as IGOs, today with undisputable international legal personality. Thus, for example, the Nordic Council gathers in its membership not only the States (Denmark, Finland, Iceland, Norway and Sweden), but also some of their dependant territories such as Åland, Faroe Islands, and Greenland. By the same logic, some other IGOs like the WMO, WTO, or the Asian Development Bank could also be understood as QUAIROs, having in their membership States including the People's Republic of China, together with Hong Kong as today its "subState entity". Furthermore, beside Hong Kong, five "territories" - British Caribbean Territories, French Polynesia, Macao, Curaçao and Sint Maarten, and New Caledonia - participate in the WMO membership together with the member States. Finally, we could go here a step further understanding even the UN in the same way in the period 1945-1991 when two "sub-State entities" of the former USSR - Belarus and Ukraine were full members of this organization.

71 On the other hand, Strazzari interestingly remarked: “[...] the direct involvement of the State in an EGTC is more difficult to put in place: such a move might be seen as a threat to the regional self-government rights." STRAZZARI, D. Harmonizing trends vs. domestic regulatory frameworks: looking for the european law on cross-border cooperation, European Journal of Legal Studies, v. 4, n. 1, summer 2011. p. 203.

72 See: supra, note 28. 
On the other hand, due to the historical circumstances a similar situation happened with one euroregion - the Alps-Adriatic Working Community in which two former republics of ex-Yugoslavia (Croatia and Slovenia) have continued its membership as the independent States following the dissolution of Yugoslavia in 1991.

As we have earlier mentioned, the Alps-Adriatic Working Community was founded in 1978 in Venice. Its founder members were Bavaria, Friuli-Venezia Giulia, Carinthia, Croatia, Upper Austria, Salzburg, Slovenia, Styria and Veneto, i.e. the regions from four States in that time: Austria, Germany, Italy and Yugoslavia. By signing the "Joint Declaration" the interregional cooperation between the border regions were transformed into an organization with its organs, organizational and procedural rules, and clearly defined tasks and aims. ${ }^{73}$ Today, the Alps-Adriatic Working Community gathers six members: regions Burgenland, Carinthia, Styria, Vas and two States - Croatia and Slovenia. ${ }^{74}$ According to its constitutional instrument the "Organisational and procedural rules of the Alps-Adriatic Working Community" 75 the main organs of the Community are the Plenary Assembly, the Commission of Executive Officers, the Steering Committee and the General Secretariat. The Plenary Assembly and the Commission may found the expert groups in accordance with the goals of the Community. The Plenary Assembly is the highest-ranking organ of the Community. Each member delegates one representative to the Assembly. Among its duties, the Assembly makes decisions on political matters that affect the Community, establishes the income to common funds and controls the financing of the particular projects within the field of activities of the Community (Rule 6.2). The Plenary Assembly meets at least once a year for a formal session, whereas an extraordinary session of the Assembly can be convoked by a minimum of one quarter of its members (Rules 6.4. and 6.7). The Commission of Executive Officers is the executive and coordinating

\footnotetext{
73 Beside its organs, the Community has its Logo, as well as its anthem - the first 41 seconds of the Mendelssohn Bartholdy's $4^{\text {th }}$ Symphony, $1^{\text {st }}$ movement. See: para. 5.4. of the "Organisational and procedural rules of the Alps-Adriatic Working Community" of 2007. For the text see: see: <http://alpeadria.org/english/index. php?page $=595301927 \& f=1 \& \mathrm{i}=595301927>$. Accessed on: $10 \mathrm{apr}$. 2013.

74 For more details see: <http://www.alpeadria.org $>$. Accessed on: 4 apr. 2013.

75 For the text supra, note 73.
}

body of the Assembly composed of one representative by each member of the Community (i.e. the two States and the four sub-State entities) having equal rights and duties. The Commission makes technical preparations for the sessions of the Assembly and authorizes the founding or dissolution of expert groups and their project proposals supporting and monitoring of their realization. Also, the Commission has the duty to supervise and coordinate the work of the General Secretary (Rule 7.4). The Steering Committee's duties include particularly the coordination between the Plenary Assembly and the Commission supporting the executive officers in the implementation of the political mission of the Community, as well as in supporting of the Commission's activities in the work of the Assembly (Rule 8.6). Finally, the General Secretariat is an administrative and technical body of the Community. It is in charge of administrative support and coordination of the activities of the Assembly, Commission, and expert groups; as well as of the coordination of public relations of the Community (Rule 10.1-12).

According to the Preamble of the Organisational and procedural rules, the aims of the Working Community are to contribute to the consolidation of a peaceful, collective, democratic and pluralistic Europe; to promote friendship and wide-ranging collaboration between different peoples; as well as to build up its bridging functions between the regions of the member States of the EU and accession countries. In this context it is worth-noting that the Plenary Assembly of the Heads of Governments of the Alps-Adriatic Working Community passed in 2005 the Resolution "A Way Forward to Europe" in order, among other things, to support Croatia's EU entry that realized in July 2013. ${ }^{76}$

Furthermore, in the context of this Chapter some of the European river commissions, usually accepted as IGOs, according to their membership could also be understood as QUAIROs. Thus, for example, according to the Treaty of Ghent of 2002, the members of the International Scheldt Commission are Belgium, France, the Netherlands, and three Belgian regions: the Walloon Region, the Flemish Region and the Brussels Capital Region. ${ }^{77}$ Similarly, the International Commission

76 The Resolution is available at: <http://www.alpeadria./ org $/$ english $/$ index.php? page $=407896983 \& \mathrm{f}=1 \& \mathrm{i}=733044516$ \&s $=407896983>$. Accessed on: 14 sep. 2013.

77 The Treaty was signed on 3 December 2002 by the representatives of all the above-mentioned subjects and registered 
for the Meuse gathers in its membership five States (Belgium, France, Germany, Luxembourg and the Netherlands) together with the three above-mentioned Belgian regions. ${ }^{78}$ The tasks of the Commissions are similar and include the multilateral coordination regarding matters of common interest concerning the utilization, flood prevention and protection of these rivers. For that purpose both Commissions formulate advices and recommendations to their members, i.e. equally to the States and sub-State entities.

Also, we have already mentioned another specific QUAIRO in the AER's membership - the Working Community of the Danube Countries - ARGE Donauländer. ${ }^{79}$ This being so, even the AER itself could be understood as a QUAIRO. Thus, beside the Danube regions, three States participate in the membership of this Working Community: Moldova, Serbia and Slovakia. ${ }^{80}$ The Working Community was established in 1990 with the objective of promoting co-operation among its members for the development of the Danube area to serve the interests of its inhabitants and to foster peaceful co-operation in Europe. Among its most important achievements and the most significant projects are also some of soft law documents such as the "Study about the development of smaller harbours - Portino", "Cultural Itinerary Danube", the "Study on Traffic Development", the "Cooperation between Danube Cities and Harbours - Donauhanse", as well as the Projects "Portino II" and "Donauhanse II".

In addition, talking about QUAIROs one more organization should be mentioned as well - the Working Community Pyrenees (Comunidad de Trabajo de los Pirineos - CTP). Its Members are three French regions (Aquitaine, Midi-Pyrénées, Languedoc-Roussillon); four Spanish Autonomous Communities (Catalonia, Aragon, Navarre, the Basque Country) all located in the Pyrenees mountain range; and one State - the Principality of Andorra. The organizational structure of the CTP is composed of several main organs also

with the UN Secretariat pursuant to Article 102 of the UN Charter. The text of the Treaty is published in the UNTS, vol. 2351, 2009, pp. 13 et seq.

78 ACCORD international sur la Meuse. Available at: <http:// www.cipm-icbm.be/files/files/FR1.pdf>. Accessed on: 3 oct. 2013.

79 See: supra, note 44.

80 See: <http://www.argedonau.at/neu/arge/mitglieder/ start_f.html >. Accessed on: 21 jan. 2014.

81 See: <http://www.land-oberoesterreich.gv.at/cps/rde/xbcr/ ooe/ARGE_KURZINFO_E.pdf>. Accessed on: 21 jan. 2014. by analogy with IGOs. The General Assembly is the plenary organ being in charge primarily of making political decision for the Community. The Assembly is consisted of the representatives of each member of the Community and it meets in regular sessions every year. In its international relations the CTP is represented by the Presidency headed successively by the presidents of the each Community member with a term of two years.

The Executive Committee is responsible for coordination and realization of the action programs and other decisions adopted by the General Assembly, usually on the basis of the previous proposals by the Presidency. The Committee as an executive organ in its work is supported by the four "thematic Commissions": Commission I for the infrastructure and communication; Commission II for the training and technical development; Commission III for culture, youth and sport; and Commission IV for the sustainable development.

The Community is provided with its administrative organ - the General Secretariat which is responsible for the preparation of meetings of the Executive Committee, as well as for the coordination of its activities with the work of the General Assembly. The Secretariat is headed by a Secretary General appointed by the actual president with the agreement of the other members of the Community. ${ }^{82}$

Similarly to some other IROs, the CTP's participation in international law-making process is mostly visible in the form of "soft-law" documents intending to influence the policy of regional IGOs like the CoE and EU. In this context it is worth mentioning the two "soft law" documents: "Contribution de la CTP an Livre Vert sur la cohésion territoriale" ${ }^{3}$ and "Contribution au Livre Vert de la Commission Européenne sur les réseaux transeuropéens de transports". ${ }^{84}$ All the activities contained

82 For more details on the CTP see: <http://www.ctp.org>. Accessed on: 17 apr. 2013.

83 In the same document the objectives of the CTP are defined as follows: "Les objectifs de la Communauté de Travail des Pyrénés sont: améliorer la qualité de vie de nos concitoyens en élargissant l'offre de transport; renforcer l'intégration transfrontalière; développer les complémentarités en matière économique pour les entreprises et les jeunes en formation; constituer une zone d'échanges au Sud de l'Europe capable de compter face aux pôles économiques du Nord; privilégier l'innovation, la recherche et la coopération inter-universitaire; et mettre en valeur nos territoires riches d'bistoire et notamment notre patrimoine culturel et développer un tourisme durable." For the text see: <http://www. ctp.org/documentacion/contribution_ctp_livre_vert_cohesion_ territorial_fres.pdf $>$. Accessed on: 3 sep. 2013.

84 The activities of the CTP as defined in its "Bilan d'activités 2009-2010 et perspectives" include, among other 
in these documents do not differ much from those which are often subjects to treaties concluded between States or IGOs. Understood this way, it seems that the need for co-operation embodied in the content and purpose of an international document, could prevail over its legal nature or the entities being "parties" thereto.

\section{Concluding remarks}

Today, more than a decade ago that we entered the $21^{\text {st }}$ century, one could maybe rightly question about dealing with a topic such as the legal personality in international law. This doubt seems even more convincing having in mind on the one hand the historical verdict in the ICJ famous "Reparation case" mentioned at the beginning of this paper, ${ }^{85}$ and on the other the attitude that the subjects of international law are basically nothing more than the participants in legally regulated international relations. ${ }^{86}$ Of course, we could go here much further dealing with, for example, the gendered approach to international legal personality, ${ }^{87}$ or even with some of the quite extreme theories concerning the "fragmentation of the self", and the Foucault's "anti-subject approach" that announced the "end of the subject". 88

However, no matter how extensively some of theoreticians determine the concept of legal personality in international law, the consensus in international law doctrine seems to be much more conservative in recognizing of that personality to a new kind of participants in international legal relations, even if some

things: "développement de l'aviation générale et du transport [...]; coopération en matière d'industrie aérodynamique; améliorer la sécurité des communications en zone de montagne transfrontalière ; promouvoir et accompagner la mobilité transfrontalière; proposer des axes de travail commun dans le domaine de la formation professionnelle sur la base de projets existants dans chaque territoire de la CTP; etc. For the text of the documents see: <http://www.ctp. org/documentacion.php?Id=1>. Accessed on: 3 sep. 2013.

85 See: supra, note 1.

86 Cf. Higgins, HIGGINS, R. Conceptual thinking about the individual in international law. In: FALK, R. (ed.); KRATOCHWIL, F. (ed.); MENDLOWITZ, S. H. (ed.). International law: a contemporary perspective. Boulder; London: Westview Press, 1985. note 4, p. 480. 87 See: CHARLESWORTH, H.; CHINKIN Ch.; WRIGHT, Sh. Feminist approaches to international law, $A J I L$, v. 85, n. 4, 1991. p. 621-622.

88 See: For more details on the development of international legal personality in this period see: NIJMAN, J. E. The concept of international legal personality: an inquiry into the history and theory of international law. The Hague: T.M.C. Asser Press, 2004. p. 365-378. of them have obviously achieved international rights and duties, i.e. the legal capacity in international law. On the other hand, such an approach in international law doctrine should not surprise anybody taking into account that the recognition of international legal personality of a new kind of participants in international legal relations has always started with such a recognition given to the particular, "sui generis" entity that had broken the ice for all the future subjects of the same kind.

Analyzing IROs, it seems to us that the same logic of functionality in institutionalization of international co-operation has been the common denominator to the appearance of IGOs, as well as of such IGO-like entities this paper is dealing with. Consequently, any formal recognition of international legal personality for both of these kinds of organizations would have never had but a declaratory meaning. Thus, the ICJ "Reparation case" Advisory opinion has just confirmed the legal presence, i.e. the legal personality of the $\mathrm{UN}$ at that time. However, it has also anticipated the concept of objective, i.e. erga omnes legal personality for all the other organizations of the same kind, including for the future ones. ${ }^{89}$

Unfortunately, although the definition of subject of international law determined by the elements like the legal capacity (capacitas iuridica) and/or the capacity of an entity to produce legal consequences on its own (capacitas agendi) including the treaty-making capacity (ius contrabendi), the right of legation (ius legationis) or even the capacity to sue or be sued for the breach of an international legal obligation (ius standi in iudicio) could seem very clear, their argumentation in relation to every new-coming participant in legal relations within international community has often been faced with the inconsistencies in international law theory.

First, internationallaw doctrine has neverdetermined the "quantity" of rights and/or duties required for acquiring the legal capacity as the basic element of legal

89 Thus, Seyersted considered intergovernmental organizations "general subjects of international law". SEYERSTED, F., Objective international personality of intergovernmental organizations: do their capacities really depend upon their constitutions? Copenhagen: Krohns Bogtrykker, 1963. p. 100. Only few decades later the ICJ clearly stated: "International organizations are subjects of international law and, as such, are bound by any obligations incumbent upon them under general rules of international law, under their constitutions or under international agreement to which they are parties." Interpretation of the Agreement of 25 March 1951 between the WHO and Egypt, Advisory Opinion, I.C.J. Reports 1980, p. 89-90. 
personality in international, or any other legal system. On the other hand, if in domestic legal orders, as well as in general legal theory rights and obligations were sometimes acquirable for the third party, why would international law be an exception here? Moreover, the earlier-mentioned Vienna Conventions on the Law of Treaties expressly provide this possibility. ${ }^{90}$

Anyhow, IROs and particularly TGOs (like INTERPOL or IPU) have achieved much more in acquiring the international rights and duties participating sometimes even directly, as we have seen, in international legal relations with States, IGOs (and other international law subjects) on their own. Moreover, Strazzari interestingly remarked the increasing trend favoring public nature of the cross-border co-operation by means of supranational documents such as the EU Regulation 1082/2006 concerning the EGTCs. ${ }^{91}$

On the other hand, these organizations become not only submitted to (at least customary) international primary norms which outlaw internationally wrongful acts, but also to international secondary norms providing the international responsibility for such acts.

Since the widely accepted understanding of the concept of international legal personality defines an international person as someone who is provided with rights and duties directly by international legal norms, being at the same time capable to breach these duties and responsible for such an internationally wrongful act, the acceptance of international legal personality of these organizations, not only in theory, but in international practice could contribute to disburden tensions in the inter-State relations by activating IROs' own international legal responsibility.

In addition, the argument that the States are still "the masters of the game", 92 as the reason for a priori denying international legal personality of EGTCs or other IROs does not seem to us very convincing. By the same logic, one could deny the international legal

90 Thus, for example, treaties providing for obligations and rights for third States, as well as for third organizations are provided in Articles 35 and 36 of the Vienna Conventions on the Law of Treaties, see: supra, note 7 .

91 STRAZZARI, D. Harmonizing trends vs. domestic regulatory frameworks: looking for the european law on cross-border cooperation, European Journal of Legal Studies, v. 4, n. 1, summer 2011. note 19, p. 156.

92 Cf. MĂTUŞESCU, C. European juridical instruments of territorial cooperation: towards a decentralized foreign policy in Europe? AGORA International Journal of Juridical Sciences, n. 2, 2012. note 34 , p. 92. personality of IGOs and even more that of individual. Similarly, there is no reason for denying the possibility of acquiring the international legal personality for the above-mentioned IGO-like entities using the argument that contemporary international law doctrine (still $)^{93}$ has not accepted the same personality for their members. Such an argument would mislead us to the negation of some other widely accepted international law subjects such as the Sovereign Order of Malta.

Finally, we have seen that IGO-like entities have influenced the law-making process in international community, sometimes indirectly through the "Statements", "Positions", "Position Papers", "Red Lists" and other kinds of "soft-law" instruments, but sometimes even by concluding international agreements no matter of their designation (e.g. Memorandum of Understanding, Co-operation Agreement, Headquarters Agreement etc.). Although the international law doctrine hesitates to accept their treaty character, one cannot neglect the rights and duties that result from some of these instruments not only for these entities but also for IGOs and States acting in their iure imperii capacity. Despite their formal distinction, the content of the mentioned agreements often does not differ much from those concluded between States and/or IGOs. Having in mind the mentioned Vienna Conventions on the Law of Treaties and their explicit recognition of the legal force in international law for the agreements concluded with or between "other subjects of international law" (Art. 3), one could easily conclude that such treaty-making capacity (ius contrahendi) of IGO-like entities offers the undeniable evidence for their international legal personality. However, due to the inconsistency in international law theory, the way to this conclusion is not that simple. Considering the treaty-making capacity as a proof of international legal personality we are faced with the situation similar to

93 It should be noted here that in contemporary international law doctrine there is already a number of valuable books and articles dealing with the international legal personality of subState entities; see e.g.: MICHELMANN, H. J. (ed.); SOLDATOS, P. (ed.). Federalism and international relations: the role of subnational units. Oxford: Clarendon Press, 1990; DUCHACEK, I. D. (ed.); LATOUCHE, D. (ed.); STEVENSON, G. (ed.). Perforated sovereignties and international relations: trans-sovereign contacts of subnational governments. New York: Greenwood Press, 1988; PAQUIN, S. Les actions extérieures des entités subétatiques: quelle signification pour la politique comparée et les relations internationales? Revue international de politique comparée, v. 12, n. 2, 2005; DI MARZO, L. Component units of federal states and international agreements. Alphen aan den Rijn: Sijhoff \& Nordhoff, 1980. 
that of questioning what came first: a hen or an egg, since according to the international law of treaties only "subjects of international law" can be the parties thereto. Then where to cut the vicious circle? Maybe significantly, but Shaw is less restrictive here defining a treaty as "an agreement between parties on the international scene." ${ }^{94}$ Such an approach leads us again to the hypothesis from the beginning of this paper: neither international legal personality, nor international law should be the purpose in themselves. They serve the needs of international community and vary with them. Therefore, the IGO-like entities like TGOs, IROs, QUAIROs or other new-coming participants in international legal relations do not have to wait for some

94 SHAW, M. N. International law. 6 ed. Cambridge: Cambridge University Press, 2008. p. 903.
"New 'Reparation case' Advisory opinion" to obtain the international legal personality. After all, neither the UN had to in 1949. The subjects of international law appear, exist and die following the meta-juridical logic of functionality in international relations, and not due to the legal doctrine.

Reading these lines someone could maybe correctly consider that the thesis on international legal personality of these IGO-like entities (today still) goes too far. Maybe it leaves us with more questions than answers. However, writing on such a dynamic topic like the international legal personality is always dealing with the tendencies rather than with the pure facts. Otherwise, it might happen that our work had become out of date before it was completed. 


\section{Bibliography}

ACCORD de Karlsruhe sur la coopération transfrontalière entre les collectivités territoriales et organismes publics locaux, Karlsruhe, 23 janvier 1996. Available at: <http://www.ge.ch/legislation/rsg/f/s/ rsg_A1_11.html>. Accessed on: 23 September 2013);

ACCORD international sur la Meuse. Available at: <http://www.cipm-icbm.be/files/files/FR1.pdf $>$. Accessed on: 3 oct. 2013.

ASSEMBLY OF EUROPEAN REGIONS. Statute. Paris, 17 march 2013. Available at: <http://www. aer.eu/fileadmin/user_upload/GoverningBodies/ GeneralAssembly/Statutes/Statutes-200x/AER_ Statute_17052013-EN.pdf>. Accessed on: 27 apr. 2013.

ASSOCIATION OF EUROPEAN BORDER REGIONS. AEBR position paper on the future EU strategy 2020, 2010. Available at: <http://www.aebr.eu/ files/publications/10_01_12_AGEG_Stellungnahme_ Europa_2020_EN_def.pdf>. Accessed on: 3 sep. 2013.

\section{ASSOCIATION OF EUROPEAN BORDER}

REGIONS Statement on the proposal for a regulation of the European Parliament and of the Council, 2011. Available at: <http://www.aebr.eu/files/ publications/111129_statement_proposal_EGTC_ regulation_EN_clean.pdf $>$. Accessed on: 23 sep. 2013.

AUST, A. Modern treaty law and practice. 2 ed. Cambridge: Cambridge University Press, 2007.

Brownlie, I. Principles of public international law. Oxford: Clarendon Press, 1973.

CAPOTORTI, F. Cours général de droit international public, RCADI, v. 248, n. 4, 1994.

CHARLESWORTH, H.; CHINKIN Ch.; WRIGHT, Sh. Feminist approaches to international law, AJIL, v. 85, n. 4, 1991.

CORNAGO, N. On the normalization of sub-state diplomacy. In: CRIEKEMANS D. (Ed.). Regional substate diplomacy today. Leiden; Boston: Martinus Nijhoff Publishers, 2010.

COUNCIL OF EUROPE. European charter of local self-government, Strasbourg, 15 october 1985.
Available at: <http://conventions.coe.int/Treaty/EN/

Treaties/Html/122.htm>. Accessed on: 3 sep. 2013.

COUNCIL OF EUROPE. Additional protocol to the european outline convention on transfrontier co-operation between territorial communities or authorities. Strasbourg, 1995. Available at: <http://conventions.coe.int/Treaty/EN/ Treaties/Html/159.htm>. Accessed on: 3 sep. 2013.

COUNCIL OF EUROPE. Protocol n. 2 to the European outline convention on transfrontier co-operation between territorial communities or authorities concerning interterritorial co-operation, 1998. Available at: <http://conventions.coe. int/Treaty/en/Treaties/Html/169.htm>. Accessed on: 3 oct. 2013.

COUNCIL OF EUROPE. Protocol n. 3 to the European outline convention on transfrontier co-operation between territorial communities or authorities concerning euroregional co-operation groupings (ECGs): CETS no. 206. Available at: <http:// conventions.coe.int/Treaty/EN/Reports/Html/206. htm>. Accessed on: 3 oct. 2013.

COUNCIL OF EUROPE. Protocol Relating to the Madrid Agreement Concerning the International Registration of Marks, 2007. Available at: <http:// www.wipo.int/wipolex/en/wipo_treaties/text.jsp?file_ id $=283484>$. Accessed on: 3 oct. 2013.

COUR PERMANENTE DE JUSTICE INTERNATIONALE. Collection of judgments: the case of the S.S. "Lotus", 1927. Available at: <http:// www.icj-cij.org/pcij/serie_A/A_10/30_Lotus_Arret. pdf $>$. Accessed on: 3 sep. 2013.

MARZO, L. Di. Component units of federal states and international agreements. Alphen aan den Rijn: Sijhoff \& Nordhoff, 1980.

DUCHACEK,I.D.; LATOUCHE, D.;STEVENSON, G. (Ed.). Perforated sovereignties and international relations: trans-sovereign contacts of subnational governments. New York: Greenwood Press, 1988.

DUPUY, P. M. La coopération régionale transfrontalière et le droit international, AFDI, v. 23, 1977.

EUROPEAN COURT OF JUSTICE. Lisbon treaty on European Union see. Official Journal of the European Union, C83/01, v. 53, 30 march 2010 
EUROPEAN PARLIAMENT AND COUNCIL. Directive 2004/18/EC of the European Parliament and of the Council of 31 March 2004 on the coordination of procedures for the award of public works contracts, public supply contracts and public service contracts. Official Journal of the European Union, 30 april 2004. Available at: <https://www.gov.uk/government/ uploads/system/uploads/attachment_data/file/35922/ Classic_Directive_1_13420040430en01140240.pdf>. Accessed on: 3 sep. 2013.

EUROPEAN PARLIAMENT AND COUNCIL. Regulation n. 1082/2006. European grouping of territorial cooperation (EGTC). Official Journal of the European Union, 31 july 2006.

EUROPEAN UNION COMMITTEE OF THE REGIONS. Mission Statement. Brussels, 21 apr. 2009. Available at: <http://cor.europa.eu/en/about/ Documents/Mission\%20statement/EN.pdf $>$. Accessed on: 3 sep. 2013.

EUSTATHIADES, C. Th. Les sujets du droit international et la responsabilité internationale: nouvelles tendances. RCADI, v. 84, n. 3, 1953.

HIGGINS, R. Conceptual thinking about the individual in international law. In: FALK, R.; KRATOCHWIL, F.; MENDLOWITZ, S. H. (Ed.). International law: a contemporary perspective. Boulder; London: Westview Press, 1985.

HUET, P. Garcia-Duran. Vers l'Europe des eurorégions? L'objectif de „cohésion territoriale. Revue du Marché commun et de l'Union européenne, n. 491, p. 499502, sep. 2005;

INTERNATIONAL COURT OF JUSTICE. Reparation for injuries suffered in the service of the United Nations, 11 april 1949. Available at: <http:// www.icj-cij.org/docket/index.php?p1 $=3 \& \mathrm{p} 2=4 \& \mathrm{k}=4$ $1 \&$ case $=4 \&$ code $=i$ sun $\& p 3=4>$. Accessed on: 23 sep. 2013.

JENNINGS, R.; WATTS, A. (Ed.). Oppenheim's International Law. London: Longman, 1995. v. 1.

KRISCH, N. Beyond constitutionalism: the pluralist structure of postnational law. Oxford: Oxford University Press, 2010.
LISZT, F. Von. Das völkerrecht: systematisch dargestellt. Berlin: Verlag von O. Haering, 1902.

MĂTUŞESCU, C. European juridical instruments of territorial cooperation: towards a decentralized foreign policy in Europe? AGORA International Journal of Juridical Sciences, n. 2, 2012.

MICHELMANN, H. J.; SOLDATOS, P. (Ed.). Federalism and international relations: the role of subnational units. Oxford: Clarendon Press, 1990.

MOSLER, H. Réflexions sur la personnalité juridique en droit international public. In: Mélanges offerts à Henri Rolin : problemes de droit des gens. Paris : Éditions A. Pedone, 1964.

NIJMAN, J. E. The concept of international legal personality: an inquiry into the history and theory of international law. The Hague: T.M.C. Asser Press, 2004.

NIJMAN, J. E. Paul Ricoeur and international law: beyond "the end of the subject": Towards a reconceptualization of international legal personality. In: BIANCHI, A. (Ed.). Non-state actors and international law. Surrey; Burlington: Ashgate Publishing Company, 2009.

NOWROT, K. Reconceptualising international legal personality of influential non-state actors: towards a rebuttable presumption of normative responsibilities. In: JOHNS, F. (Ed.). International legal personality. Surrey; Burlington: Ashgate Publishing Company, 2010.

ORGANISATIONAL and procedural rules of the Alps-Adriatic working community of 2007. Available at: $\quad<$ http://www.mvep.hr/custompages/static/hrv/ files/111013-Verfahrensregeln_inkl-Anlagen_engl. pdf $>$. Accessed on: 10 apr. 2013.

PAQUIN, S. Les actions extérieures des entités subétatiques: quelle signification pour la politique comparée et les relations internationales? Revue international de politique comparée, v. 12, n. 2, 2005.

PASCUAL, C.; BENNER, H. Sovereignty's evolution: the role of regions: regional convergence in a transnational world. In: DE LOMBAERDE, Ph.; BAERT F.; FELÍCIO, T. (Ed.). The United Nations and the regions: third world report on regional integration. 
Dordrecht; Heidelberg: Springer, 2012. (United Nations University Series on Regionalism, v. 3).

RAMIREZ, M. G.; GABBE, J.; AEBR and EGTC: a long way to success. Interact, winter 2013.

ROSSI, I. Legal status of non-governmental organizations in international law. Portland: Intersentia, 2010. (International Law, v. 5).

SCHEWE, Ch. Legal aspects of the baltic sea strategy: international law in a european macro-region. Baltic Yearbook of International Law, v. 10, 2010.

SEYERSTED, F., Objective international personality of intergovernmental organizations: do their capacities really depend upon their constitutions? Copenhagen: Krohns Bogtrykker, 1963.

SHAFFER, G., A transnational take on krisch's pluralist structure of postnational law, EJIL, v. 23, n. 2, 2012.

SHAW, M. N. International law. 6 ed. Cambridge: Cambridge University Press, 2008.

STRAZZARI, D. Harmonizing trends vs. domestic regulatory frameworks: looking for the european law on cross-border cooperation, European Journal of Legal Studies, v. 4, n. 1, summer 2011.

UNITED NATIONS. INTERNTIONAL LAW COMISSION. Report of the International Law Commission: sixty-third session, 2011. Available at: <http://legal. un.org/ilc/reports/2011/2011report.htm>. Accessed on: 23 sep. 2013.

VEDOVATO, G. La cooperation transfrontalière, les eurorégions et le Conseil de l'Europe, Annuaire Européen, v. 43, 1995.

UNITED UNION. Vienna Convention on the law of treaties between states and international organizations or between international organizations. Available at: <http://legal. un.org/avl/ha/vcltsio/vcltsio.html>. Accesses on: 3 sep. 2014.

UNITED UNION. Vienna Convention on the law of treaties of 1969. Available at: < https://treaties.un.org/doc/ Publication/UNTS/Volume\%201155/volume-1155-I18232-English.pdf $>$. Accessed on: 3 sep. 2013.

WOLFF, S. Paradiplomacy: scope, opportunities and challenges, Bologna Center Journal of International Affairs, v. 10, 2010. Available at: <http://bcjournal.org/volume-10/ paradiplomacy.html>. Accessed on: 22 may 2013. 


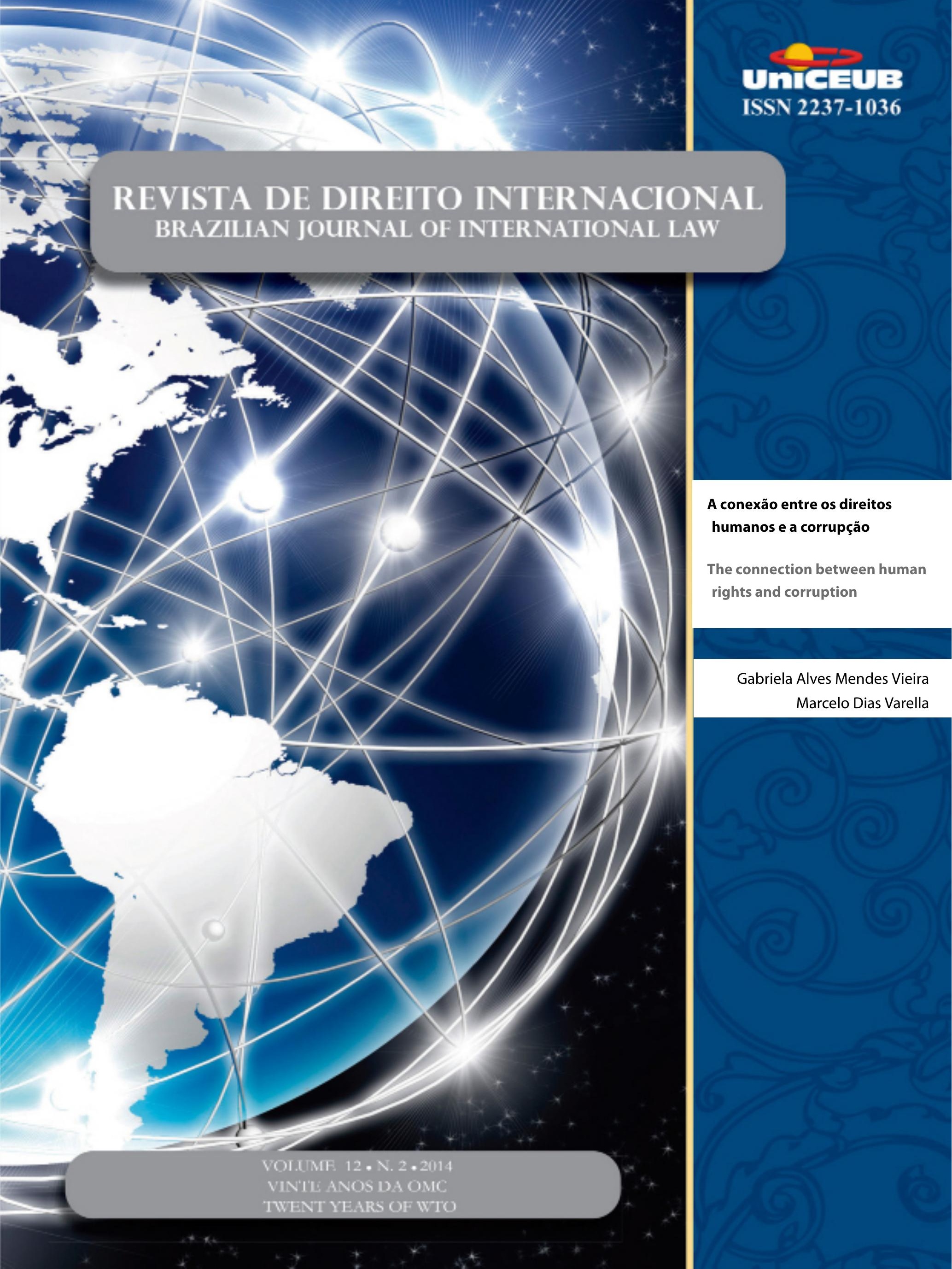




\title{
A conexão entre os direitos humanos e a corrupção*
}

\section{The connection between human rights and corruption}

\author{
Gabriela Alves Mendes Vieira** \\ Marcelo Dias Varella***
}

\section{Resumo}

O combate à corrupção não pode ser considerado só como um fim em si mesmo, mas também como uma maneira de prevenir abusos de direitos humanos, de maneira que os institutos possam ser complementares. A proposta apresentada neste artigo se destina a demonstrar a integração dos direitos humanos nas agendas de combate a corrupção bem como a integração do combate à corrupção nas agendas de direitos humanos como uma chave para o sucesso mútuo. Primeiramente buscase esclarecer a necessidade da conceituação da corrupção, analisando como o tema é tratado nos principais instrumentos de combate à corrupção, bem como as suas causas e consequências multifacetadas que contribuem para o empobrecimento das economias nacionais ameaçando instituições democráticas, enfraquecendo o Estado de Direito e facilitando ameaças de direitos humanos. Como metodologia de análise, além de se analisar as principais agendas de combate à corrupção e as novas agendas que trazem a integração entre os direitos humanos e a corrupção, o trabalho explora como e quando um direito humano é violado e como práticas de atos de corrupção podem influenciar estas violações. Sendo assim, o presente artigo busca demonstrar, de maneira semelhante, a integração das normas e princípios de direitos humanos em programas de combate à corrupção e vice-versa.

Palavras-chave: Corrupção. Direitos Humanos. FCPA. Convenção da OCDE. UNCAC.

\section{Abstract}

The fight against corruption shall not be considered an end by its on means, but it is also a way to prevent human rights violations, in a sense that such themes should be complementaries. This article aims at demonstrating that adding human rights

* Recebido em: 30.10 .2014 Aceito em: 01.12.2014

${ }^{* *}$ Graduanda em Direito pelo Centro Universitário de Brasília - UniCEUB, gabrielaamv03@gmail.com.

*** Doutor em Direito e Livre-Docente. Professor do Programa de Mestrado e Doutorado do Centro Universitário de Brasília. Pesquisador do CNPq. O coautor figura como orientador do trabalho, desenvolvido pela primeira autora, marcelodvarella@gmail.com. concerns on corruption agenda, as well corruption on human rights agenda, are fundamental to mutual success. Initially, it is explained the concept of corruption, analyzing how this topic is approached in several anti-corruption instruments, and the main causes and consequences of this multifaceted phenomenon, which contributes to impoverish national economies, threatening democratic institutions, weakening state of law, and facilitating human rights violation. As a methodology, besides looking at the main anti-corruption agendas, mainly when related to human rights, this text also explores when a human right is violated and how corruption might influence such happening. Therefore, it is demonstrated the connection among norms and principles of human rights with fight against corruption programs.

Keywords: Corruption. Human Rights. FCPA. OEDC Convention. UNCA. 


\section{Introdução}

Apesar de quase intuitiva, a compreensão de que a corrupção afeta setores fundamentais do Estado e da sociedade, a conexão entre esse fenômeno e violações de Direitos Humanos ainda é pouca explorada pela doutrina especializada nos temas, e ainda se mostra incipiente nas principais Organizações Internacionais, apesar de relevante.

É indispensável, diante das interações sociais cada vez mais intensas e sistemas políticos cada vez mais complexos, as legislações e práticas de direitos humanos atribuam uma noção de participação fortalecendo as inciativas de combate à corrupção visando capacitar cidadãos e responsabilizar os governos. Problemas e suas respectivas soluções são construídos mutuamente em diversas áreas do conhecimento e essa não pode ser uma exceção.

Vista a tendência de sistemas corruptos para reproduzir os privilégios abusivos de elites, o empoderamento dos grupos vulneráveis deve ser um componente chave das estratégias de combate à corrupção, e aqui o princípio dos direitos humanos da não discriminação é um instrumento poderoso.

Destarte, cabe aprofundar os estudos nesse sentido, de modo a entender como que o combate à corrupção deve considerar os mecanismos de proteção dos Direitos Humanos; bem como as iniciativas de proteção de Direitos Humanos executarem seus trabalhos tendo em vista a corrupção também.

$\mathrm{Na}$ primeira parte do trabalho, apresentarse-á os tratados internacionais que versam sobre a corrupção, como uma forma de compreender os conceitos de corrupção trazidos por instrumentos internacionais, visualizar seus efeitos, tendo como foco as consequências na proteção de Direitos Humanos.

A segunda parte do trabalho se preocupa em consolidar a conexão entre ambos os institutos. Tanto em nível regional como internacional, a evolução dos mecanismos de responsabilização e de execução propostos pelos direitos humanos podem ser utilizados para fortalecer e aperfeiçoar as estratégias de combate à corrupção. A partir disso e de iniciativas de âmbito global, esse trabalho tem como fim estabelecer e consolidar a conexão entre a corrupção e suas formas de combate, com a violação de Direitos Humanos e suas perspectivas.

Ademais, preconiza-se ser um estudo crítico acerca da corrupção e a proteção de Direitos Humanos, em especial no âmbito internacional, identificando suas principais falhas e carências; coletando, por fim, propostas eminentes que ensejam a visão de concomitância entre esses assuntos.

\section{A difícil conceituação da corrupção e as suas implicações}

O questionamento sobre a definição do termo corrupção não traz respostas fáceis e nem muito claras. Essa dificuldade decorre em razão de ser um fenômeno sistêmico e intercultural; em outras palavras, a corrupção pode existir sobre qualquer forma de governo, em qualquer Estado e em qualquer momento. Perpassa pela doutrina uma dificuldade contínua na definição e conceituação do termo. ${ }^{1} \mathrm{Ou}$ seja, não há o que se falar em um consenso doutrinário sobre isso, inclusive se observada numa abordagem na História, que essa conceituação sempre sofreu variações ao longo do tempo. ${ }^{2}$

São inúmeras as definições do termo corrupção. Contudo, a mais aplicada é o abuso de poder confiado para ganhos privados, abrangendo tanto ganhos financeiros como não financeiros recebidos como resultado de atos de corrupção. Porém, a ampla definição do termo traz diferentes níveis e categorias de manifestação.

\subsection{Os conceitos trazidos pelos principais instrumentos legais de combate à corrupção}

A corrupção exige uma abordagem multidisciplinar, seja na ciência política, na economia ou na sociologia, cada uma delas traz suas definições sobre o fenômeno. A abordagem da ciência política apresenta a corrupção como um abuso do poder estatal resultante da ausência de controle ${ }^{4}$. Enquanto isso, os economistas identificam

FARRALES, M.J. What is corruption? a bistory of corruption studies and the great definitions debate, Carlifórnia, 2005. Disponível em: $<$ http://papers.ssrn.com/sol3/papers.cfm?abstract_id=1739962>. Acesso em: 02 set. 2014.

2 BARBOSA, Carlos Henrique N. A Cooperação internacional à luz da UNCAC: impactos no Brasil. 2014. f. Monografia (Graduação) - Faculdade de Direito - FD da Universidade de Brasília- UnB, Brasília, 2014.

3 BARR, Joshua V.; FINKE, Jorge; PINILLA, Edgar Michael. A legal perspective on the use of models in the fight against Corruption, Carolina do Sul, 2012. Disponível em: <http://scholarcommons. sc.edu/scjilb/vol8/iss2/5>. Acesso em: 02 set. 2014.

4 JOHNSTON, Michael. The political consequences of corruption: a reassement. Ph.D., Nova York, 1986. Disponível em: < http://www. 
a corrupção quando um bem público é vendido para um ganho pessoal ou quando funcionários públicos utilizam o seu monopólio para explorar os rendimentos econômicos. Há ainda uma abordagem sociológica, que vê a corrupção como uma ausência da aceitação social das normas, que ocorre nos países de conflitos históricos e socioeconômicos, resultando em um conflito de valores entre diferentes grupos sociais. ${ }^{5}$ Cada um com seu entendimento particular passou a estudar suas causas, efeitos e métodos pretendidos pelo fenômeno.

Definir o conceito de corrupção não é tão fácil como reconhecer a sua ocorrência, ${ }^{6}$ sendo esse exercício importante para a formação das proibições e controles legais. Segundo a professora Laura Underkuff, as definições de combate à corrupção devem incluir dimensões morais e sociais, além de como o fenômeno é popularmente recebido; uma vez que, quando um governo deixa de responder às emoções populares, essa recusa pode alimentar forças de instabilidade social e política.

Ao procurar por definições adequadas de corrupção, é importante trazer uma diferença gramatical e destacar que o foco aqui recai sob o substantivo corrupção e não sob o adjetivo e advérbio corrupto e corruptamente. Ou seja, não se busca aqui atribuir adjetivos, utilizando o termo corrupto, mas sim, trazer uma abordagem científica com o estudo do termo e fenômeno corrupção. ${ }^{8}$

A corrupção pode se manifestar de várias maneiras. Uma das formas de corrupção que os tratados internacionais de combate à corrupção têm em comum é o suborno de funcionários públicos estrangeiros, uma das heranças do UN International Code of Conduct for Public Offcials ${ }^{9}$, que reforçou a ideia de lealdade dos

jstor.org/stable/421694>. Acesso em: 30 ago. 2014.

5 SPALDING, Andrew Brady. Corruption, corporations, and the New Human Right. Washington, 2012. Disponível em: <http://ssrn. com/abstract $=2232670>$ Acesso em: 31 ago. 2014.

6 GOULD, D. J. Administrative corruption Incidence, causes and Remedial Strategies. In: FARAZMAND, Ali. Hand Book of Comparative Development and Public Administration. Nova York: Taylor \& Francis e-Library, 2005. p. 872-886.

7 UNDERKUFF, Laura S. Defining Corruption. In: ROTBERG, Robert I. Corruption, global security and world order. Washington D.C: Brookings Institution Press, 2009. p. 27-46.

8 SPALDING, Andrew Brady. Corruption, corporations, and the new Human Right. Washington, 2012. Disponível em: <http://ssrn. com/abstract $=2232670>$. Acesso em: 31 de ago. 2014.

9 UNITED NATIONS. A/RES/51/59: 82nd plenary meeting, 12 December 1996 Viena. 1997. Disponível em: <http:/ / www.un.org/documents/ga/res/51/a51r059.htm>. Acesso em: 31 ago. 2014. funcionários públicos. O foco no setor público reflete a definição tradicional de corrupção adotada pelo Banco Mundial como um ganho privado do funcionário público. ${ }^{10}$ Apesar da limitação ao setor público, algumas organizações ampliaram essa definição incluindo o setor privado nas suas abordagens, como é o caso do Banco Asiático de Desenvolvimento e da Transparência Internacional. Entretanto, deve-se prestar atenção nessa definição pautada no abuso do funcionário público para o ganho privado, uma vez que, o foco recai no abuso, e não necessariamente em quem obteve a vantagem indevida. ${ }^{11}$

O Banco Mundial aborda de maneira ampla o termo corrupção, de maneira que o termo engloba mais do que o suborno, abrangendo outras condutas ainda controvertidas e não pensadas geralmente como corrupção. Dessa maneira o conceito dado pelo Banco Mundial pode servir como uma definição ampla no combate à corrupção, mas não deve ser utilizado para uma proposta legal ${ }^{12}$.

A Lei de Práticas Corruptas no Exterior (Foreign Corrupt Practices Act FCPA $)^{13}$ proíbe formas específicas de corrupção como o suborno, de maneira que criminaliza apenas a oferta de suborno, mas não o recebimento. É importante verificar que uma das vítimas trazidas pela FCPA são os acionistas, e isso só é verificado em razão do suborno ter se tornado ilegal. Contudo, o suborno deixa vítimas antes mesmo da promulgação da FCPA. Existem dois tipos de vítimas: os cidadãos que vivem sob um regime corrupto, cujas regulações, segurança

10 Quando se fala em ganho privado é importante diferenciar do ganho pessoal. O ganho privado pode ser interpretado de uma maneira mais ampla do que o ganho pessoal. No ganho privado $\mathrm{o}$ ato corrupto pode beneficiar não só $\mathrm{o}$ funcionário que aceita $\mathrm{o}$ suborno, mas também quando o ganho vai para alguém da família, alguém da família, conhecidos ou ainda para a companhia que o funcionário público que aceitou o suborno trabalha. CLOOTS, Ann Sofie; RYNGAET, Cedric; WOUNTERS, Jan. The fight against corruption in international law. Bélgica, 2012. Disponível em: < https:// ghum.kuleuven.be/ggs/publications/working_papers/new_series/ wp91-100/wp94-jwouters-cryngaert-acloots.pdf> Acesso em: 31 ago. 2014.

11 CLOOTS, Ann Sofie; RYNGAET, Cedric; WOUNTERS, Jan. The Fight Against corruption in international law. Bélgica, 2012. Disponível em: <https://ghum.kuleuven.be/ggs/publications/ working_papers/new_series/wp91-100/wp94-jwouters-cryngaertacloots.pdf> Acesso em: 31 ago. 2014

12 SPALDING, Andrew Brady. Corruption, corporations, and the new human right. Washington, 2012. Disponível em: <http://ssrn. com/abstract $=2232670>$ Acesso em: 31 ago. 2014.

13 UNITED STATE. Department of Justice's. Foreign Corrupt Practices Act (FCPA). Washington, 1977. Disponível em: $<$ http:// www.justice.gov/criminal/fraud/fcpa/>. Acesso em: 31 ago. 2014. 
e prosperidade se encontram comprometidas, e ainda há as empresas em conformidade com as normas antissuborno que perdem negócios para empresas que não aderem a essas normas. ${ }^{14}$

A Convenção sobre o Combate da Corrupção de Funcionários Públicos Estrangeiros em Transações Comerciais Internacionais da $\mathrm{OCDE}^{15}$ foi um dos primeiros instrumentos multilaterais de combate à corrupção, porém com alcance muito limitado a um tipo de corrupção e à realidade europeia. Mais tarde esse instrumento ampliou o seu alcance - inclusive geográfico - tanto em razão das pessoas atingidas quanto em razão dos tipos de corrupção abrangidos. ${ }^{16}$

A mais notável das definições encontrada nessa Convenção da OCDE, é que traz uma preocupação específica, não se restringindo preocupações com um fenômeno geral e suas manifestações. A primeira nota final da convenção traz o "suborno ativo" que é a oferta de suborno a uma autoridade estrangeira por um agente privado. Vale ressaltar que, nessa definição de corrupção, se estende a oferta ou pagamento de suborno por um agente privado.

A Convenção das Nações Unidas de Combate à Corrupção (UNCAC) ${ }^{18}$ o mais elaborado e detalhado dos instrumentos de combate à corrupção aqui trazidos, representou uma notável conquista aludindo responsabilidades globais para um problema global. O tratado enumerou atos específicos de corrupção, como por exemplo, o suborno, tráfico de influências e peculato, entretanto, em nenhum momento trouxe uma definição do termo em sentido amplo. Além de

14 CLOOTS, Ann Sofie; RYNGAET, Cedric; WOUNTERS, Jan. The fight against corruption in international law, Bélgica, 2012. Disponível em: <https://ghum.kuleuven.be/ggs/publications/ working_papers/new_series/wp91-100/wp94-jwouters-cryngaertacloots.pdf> Acesso em: 31 ago. 2014.

15 BRASIL. Decreto lei 3.678, de 30 de novembro de 2000. Promulga a Convenção sobre o combate da corrupção de funcionários públicos estrangeiros em transações comerciais internacionais, concluída em Paris, em 17 de dezembro de 1997. Brasília, 2000. Disponível em: <http://www.planalto.gov.br/ccivil_03/decreto/D3678.htm>. Acesso em: 31 ago. 2014

16 CLOOTS, Ann Sofie; RYNGAET, Cedric; WOUNTERS, Jan. The fight against corruption in international law, Bélgica, 2012. Disponível em: <https://ghum.kuleuven.be/ggs/publications/ working_papers/new_series/wp91-100/wp94-jwouters-cryngaertacloots.pdf> Acesso em: 31 ago. 2014.

17 SPALDING, Andrew Brady. Corruption, corporations, and the new human right. Washington, 2012. Disponível em: <http://ssrn. com/abstract $=2232670>$ Acesso em: 31 ago. 2014.

18 ORGANIZAÇÃO DAS NAÇÕES UNIDAS. Convenção das Nações Unidas Contra a Corrupção (UNCAC). Mérida: 2005. trazer medidas como a cooperação internacional e o retorno dos rendimentos da corrupção, as suas sanções se estendem a qualquer um que tenha concorrido para cometer delitos de corrupção. ${ }^{19}$

A UNCAC abrange não só a corrupção praticada por funcionários públicos estrangeiros, mas também funcionários públicos nacionais e funcionários de organizações internacionais públicas, e ainda, àqueles empregados de órgãos públicos, empresas públicas ou entidades que prestem serviço público. A mera promessa, oferta ou pedido de suborno já é suficiente para se enquadrar nos termos da convenção. ${ }^{20}$

\subsection{Instrumentos legais de combate à corrupção}

A Lei de Práticas Corruptas no Exterior (Foreing Corrupt Practices Act - FCPA) foi promulgada pelo Congresso Norte Americano em 1977 como uma resposta às inúmeras revelações de corrupção, envolvendo funcionários públicos estrangeiros e empresas norte-americanas. ${ }^{21}$ A FCPA acabou figurando como base para outras convenções, pois, além do amplo alcance das suas disposições jurisdicionais, serviu como referência para posteriores esforços internacionais no combate à corrupção de funcionários públicos estrangeiros. $^{22}$ A lei apresenta dois grandes componentes: o compliance e as penalidades civis e criminais, sendo que o compliance estabeleceu normas de manutenção de registros, e o segundo componente tornou certas práticas do comércio internacional ilegais. ${ }^{23}$

19 HECHLER, H. et. al. Can UNCAC address grand corruption? A political economy analysis of the UN Convention against corruption and its implementation in three countries. Berga, 2011. Disponível em: <http://www.u4.no/publications/can-uncac-address-grandcorruption/>. Acesso em: 31 ago. 2014.

20 CLOOTS, Ann Sofie; RYNGAET, Cedric; WOUNTERS, Jan. The fight against corruption in international law, Bélgica, 2012. Disponível em: < https://ghum.kuleuven.be/ggs/publications/ working_papers/new_series/wp91-100/wp94-jwouters-cryngaertacloots.pdf $>$ Acesso em: 31 ago. 2014.

21 UNITED STATE. Department of Justice and Enforcement Division of the U.S. Securities and Exchange Commission. A resource guide to the U.S. Foreing Corrupt Practices Act. Washington. 2012. Disponível em: <http://www.justice.gov/criminal/fraud/fcpa/ guide.pdf> Acesso em: 31 ago. 2014.

22 CLOOTS, Ann Sofie; RYNGAET, Cedric; WOUNTERS, Jan. The fight against corruption in international law, Bélgica, 2012. Disponível em: <https://ghum.kuleuven.be/ggs/publications/ working_papers/new_series/wp91-100/wp94-jwouters-cryngaertacloots.pdf $>$ Acesso em: 31 ago. 2014.

23 SNIDER, Thomas R; KIDANE, Won. Combating corruption 
Essa lei contém tanto medidas de antissuborno como medidas de contabilidade. As medidas antissuborno proíbem nacionais norte-americanos, empresas norteamericanas (questões internas ${ }^{24}$ ) e funcionários públicos estrangeiros de empresas que, listadas na bolsa de valores nos Estados Unidos, ou ainda, àquelas que são obrigadas a apresentar relatórios à Comissão de Valores Mobiliários (Securities and Exchange Commission - SEC), e certas pessoas e empresas que atuam temporariamente em território norte-americano para fazer pagamentos corruptos a funcionários públicos estrangeiros a fim de obter ou conservar negócios. ${ }^{25}$

Alguns autores defendem que há uma variação do princípio da territorialidade, permitindo uma interpretação bastante ampla do princípio da nacionalidade. $O$ que proporciona às agências de execução dos Estados Unidos (Departamento de Justiça e o SEC) processe uma pessoa estrangeira por crime de corrupção, cujos atos de suborno possam ter tido apenas uma tênue ligação com os Estados-Unidos, como por exemplo, quando um pagamento é enviado a contas bancárias nesse país. ${ }^{26}$

O Caso Siemens AG demonstra essa variação do princípio da territorialidade, sendo o caso sobre uma empresa alemã. A empresa foi processada por violações a FCPA, concordando com o pagamento de \$450 milhões pelas acusações criminais investigadas pelo Departamento de Justiça (DOJ) e $\$ 350$ milhões pelas acusações civis investigadas pela Comissão de Valores Mobiliários (SEC). O envolvimento do Departamento de Justiça norte-americano e o SEC decorrem do fato de a Siemens ser uma registrante no SEC, sendo, portanto, uma questão que cabe aos EUA. A empresa tinha ações listadas na bolsa de valores da New York

through international law in Africa: a comparative analysis. cornell intenational law, Seatle, v. 40, n. 691, p. 691-748, 2007.

24 Conforme o $\int 78 \mathrm{dd}-2(\mathrm{~h})(1)$, essas questões internas dizem respeito a qualquer indivíduo que é cidadão, nacional ou residente nos Estados Unidos. Ou ainda, a qualquer empresa, parceria, sociedade anônima, associação, organização sem personalidade jurídica que tenha a sua empresas principal sediada nos Estados Unidos, que seja organizada sob as leis americanas ou seu território, posses ou governo dos Estados Unidos.

25 UNITED STATE. Department of Justice's. Foreign Corrupt Practices Act (FCPA). Washington, 1977. Disponível em:<http:// www.justice.gov/criminal/fraud/fcpa/>. Acesso em: 31 ago. 2014.

26 CLOOTS, Ann Sofie; RYNGAET, Cedric; WOUNTERS, Jan. The fight against corruption in international law, Bélgica, 2012. Disponível em: <https://ghum.kuleuven.be/ggs/publications/ working_papers/new_series/wp91-100/wp94-jwouters-cryngaertacloots.pdf $>$ Acesso em: 31 ago. 2014.
Stock Exchange em março de 2001. Dessa forma o caso Siemens AG representou uma culminação de esforços por parte de autoridades de diversos países. ${ }^{27}$

As disposições que prescrevem as normas de manutenção dos registros se aplicam somente aos emitentes e exige que esta seja dada de forma detalhada, refletindo de maneira precisa e adequada as transações e alienações do emitente. A falha em cumprir com as normas de manutenção dos registros resulta em penalidades civis e criminais. ${ }^{28}$

A responsabilidade da execução da FCPA cabe à Comissão de Valores Mobiliários (SEC) e ao Departamento de Justiça (DOJ). O DOJ é responsável pela execução dos dispositivos criminais da FCPA e pela execução civil das violações antissuborno, desde de que respeitada as questões internas e empresas estrangeiras e nacionais, enquanto o SEC é responsável pela execução civil tanto das disposições antissuborno como das disposições de contabilidade, desde de que respeitado os emitentes de títulos. ${ }^{29}$

A partir dos impactos trazidos, principalmente pelo caso Watergate, a FCPA foi projetada para evitar práticas de corrupção, proteger os investidores e oferecer condições de igualdade para as empresas que estejam de acordo com as suas exigências, sendo um dos primeiros instrumentos jurídicos a abordar o suborno transnacional e restringir atividades empresariais corruptas. $^{30}$

A Convenção sobre o Combate da Corrupção de Funcionários Públicos Estrangeiros em Transações Comerciais Internacionais da OCDE (Convenção da OCDE) foi assinada no dia 17 de dezembro de 1997, tendo 38 países se tornado Estado Parte, inclusive o Brasil. A Convenção veio com o objetivo de assegurar uma equivalência funcional no suborno de funcionários

27 DARroughM, Masako N. The FCPA and the OCDE Convention: some lessons from U.S. experience. Nova York, 2010. Disponível em: <http://www.jstor.org/stable/40605340>. Acesso em: 02 set. 2014.

28 SNIDER, Thomas R; KIDANE, Won. Combating corruption through international law in Africa: a comparative analysis. cornell intenational law, Seatle, v. 40, n. 691, p. 691-748, 2007.

29 DARrougHM, Masako N. The FCPA and the OCDE Convention: some lessons from U.S. experience. Nova York, 2010. Disponível em: <http://www.jstor.org/stable/40605340>. Acesso em 02 set. 2014.

30 BARBOSA, Carlos Henrique N. A Cooperação Internacional à Luz da UNCAC: impactos no Brasil. 2014. Monografia (Graduação) - Faculdade de Direito - FD da Universidade de Brasília- UnB, Brasília, 2014. 
públicos estrangeiros sem exigir uniformidade ou mudanças nos princípios fundamentais no sistema legal de um Estado. ${ }^{31}$

A Convenção apresenta compacta semelhança com a FCPA, tendo seu escopo limitado a corrupção ativa, ou seja, incidindo sobre o doador do suborno. Exibindo rigorosos mecanismos de monitoramento, esse tratado tem seu processo dividido em duas etapas. A primeira etapa traz um sistema de autoavaliação com o objetivo de examinar em que medida o Estado Parte implementou medidas da convenção em sua legislação. A segunda fase avalia a implementação prática através do sistema de avaliação mútua. Esse processo de monitoramento foi implementado em 1991.

$\mathrm{O}$ artigo $8^{\circ}$ da Convenção da OCDE especifica os dispositivos de contabilidade que devem ser adotados pelos países signatários. Penalidades são propostas por omissões ou falsificações que digam respeito aos livros de registros das empresas e contas com a finalidade de subornar funcionários públicos estrangeiros ou esconder subornos. Além disso, o artigo também exige a divulgação de toda facilitação de pagamentos. Por conseguinte, a Convenção traz uma ótica das práticas de suborno, além de outros atos ilícitos praticados com o engajamento da iniciativa privada. ${ }^{33}$

AConvenção das Nações Unidas contra a Corrupção (UNCAC) foi o primeiro tratado global de combate à corrupção, servindo como marco nesse debate. No dia 01 de julho de 2012, 160 Estados, incluindo os Estados Unidos, Índia e China se tornaram parte da UNCAC, refletindo o amplo consenso internacional da convenção. Consenso compartilhado não só entre os Estados, mas também entre o setor privado internacional e a sociedade civil. ${ }^{34}$

31 CLOOTS, Ann Sofie; RYNGAET, Cedric; WOUNTERS, Jan. The fight against corruption in international law, Bélgica, 2012. Disponível em: <https://ghum.kuleuven.be/ggs/publications/ working_papers/new_series/wp91-100/wp94-jwouters-cryngaertacloots.pdf $>$ Acesso em: 31 ago. 2014.

32 CLOOTS, Ann Sofie; RYNGAET, Cedric; WOUNTERS, Jan. The fight against corruption in international law, Bélgica, 2012. Disponível em: <https://ghum.kuleuven.be/ggs/publications/ working_papers/new_series/wp91-100/wp94-jwouters-cryngaertacloots.pdf> Acesso em: 31 ago. 2014.

33 DARrougHM, Masako N. The FCPA and the OCDE Convention: some lessons from U.S. experience. Nova York, 2010. Disponível em: <http://www.jstor.org/stable/40605340>. Acesso em 02 set. 2014

34 CLOOTS, Ann Sofie; RYNGAET, Cedric; WOUNTERS,
Os três maiores focos da UNCAC são a prevenção, a criminalização e o seu cumprimento. ${ }^{35}$ Diferentemente de o que é estabelecido pela OCDE, que meramente recomenda aos Estados Partes que proíbam deduções fiscais de suborno, a UNCAC exige que o Estado Parte pró́ba tal prática. Contudo, as inovações da UNCAC não se restringem à criminalização de atos, mas também traz um enfoco na prevenção, assim como na cooperação internacional e na recuperação de ativos. $^{36}$

O Capítulo II da UNCAC expõe detalhadamente as medidas preventivas para práticas de corrupção tanto no setor público, quanto no setor privado, sendo estas predominantemente não obrigatórias, enfatizando o estabelecimento de políticas, capacitando organismos de controle independente e promovendo a conscientização pública. ${ }^{37}$ Entre outras medidas adotadas, estas incluem contratos transparentes, uma boa gestão financeira, um serviço público baseado no mérito, um efetivo acesso público à informação, auditoria e outras normas para empresas privadas, além de, um judiciário independente, um envolvimento ativo da sociedade civil e organizações não governamentais na prevenção e na luta contra a corrupção e medidas para prevenir a lavagem de dinheiro. ${ }^{38}$

Ademais, a UNCAC propõe que todos os Estados Partes criminalizem o suborno, o peculato de bens públicos e ainda, a obstrução da justiça. 39 A criminalização do suborno inclui tanto a

Jan. The Fight Against Corruption in International Law, Bélgica, 2012. Disponível em: <https://ghum.kuleuven.be/ggs/publications/ working_papers/new_series/wp91-100/wp94-jwouters-cryngaertacloots.pdf> Acesso em: 31 ago. 2014.

35 SNIDER, Thomas R; KIDANE, Won. Combating corruption through international law in Africa: a comparative analysis. cornell intenational law, Seatle, v. 40, n. 691, p. 691-748, 2007.

36 CLOOTS, Ann Sofie; RYNGAET, Cedric; WOUNTERS, Jan. The fight against corruption in international law, Bélgica, 2012. Disponível em: <https://ghum.kuleuven.be/ggs/publications/ working_papers/new_series/wp91-100/wp94-jwouters-cryngaertacloots.pdf $>$ Acesso em: 31 ago. 2014.

37 SNIDER, Thomas R; KIDANE, Won. Combating corruption through international law in Africa: a comparative analysis. Cornell Intenational Law, Seatle, v. 40, n. 691, p. 691-748, 2007.

38 HECHLER, H. et. al. Can UNCAC address grand corruption? A political economy analysis of the UN Convention against Corruption and its implementation in three countries. Berga, 2011. Disponível em: <http://www.u4.no/publications/can-uncac-address-grandcorruption/>. Acesso em: 31 ago. 2014.

39 HECHLER, H. et. al. Can UNCAC address grand corruption? A political economy analysis of the UN Convention against Corruption 
aceitação quanto o oferecimento, além de favores, apropriações indébitas e desvios. ${ }^{40}$ Alguns atos como o enriquecimento ilícito, o peculato de bens no setor privado, tráfico de influências, o abuso de função, a lavagem de dinheiro e a ocultação são atos incentivados a serem criminalizados e não exigidos ao Estado Parte.

As sanções se estendem àqueles que participam em tentativas de cometer crimes de corrupção. Medidas relacionadas ao cumprimento e processamento incluem proteção aos denunciantes, testemunhas, peritos e vítimas nos casos de corrupção, assim como o congelamento de bens e a compensação das vítimas. ${ }^{41}$

O Capítulo IV, da UNCAC traz a cooperação internacional como uma medida obrigatória em matéria criminal, podendo ser considerada em matéria civil ou administrativa, e no que tange a cooperação com instituições privadas, como os bancos, esta é somente encorajada. A exigência de que um Estado Parte coopere em matéria criminal é uma exigência necessária, mas uma condição insuficiente para uma efetiva recuperação de ativos, uma vez que muitas vezes, em casos envolvendo bancos e outras entidades, é necessário desencadear um processo para identificar o potencial das transações corruptas e notificar as autoridades oficias de tais transações. ${ }^{42}$

A recuperação de ativos veio como um "princípio fundamental" da UNCAC, uma das suas principais inovações e também das razões pelas quais muitos países desenvolvidos ratificaram a convenção. As medidas da UNCAC estabelecem uma estrutura para que os países adaptem a sua legislação civil e criminal para facilitar a identificação, localização e embargo preventivo, e o retorno de bens obtidos por meio de práticas corruptas. Essa exigência do Estado em

and its implementation in three countries. Berga, 2011. Disponível em: <http://www.u4.no/publications/can-uncac-address-grandcorruption/>. Acesso em: 31 ago. 2014.

40 SNIDER, Thomas R; KIDANE, Won. Combating corruption through international law in Africa: a comparative analysis. cornell intenational law, Seatle, v. 40, n. 691, p. 691-748, 2007.

41 HECHLER, H. et. al. Can UNCAC address grand corruption? A political economy analysis of the UN Convention against Corruption and its implementation in three countries. Berga, 2011. Disponível em: <http://www.u4.no/publications/can-uncac-address-grandcorruption/>. Acesso em: 31 ago. 2014.

42 CLOOTS, Ann Sofie; RYNGAET, Cedric; WOUNTERS, Jan. The fight against corruption in international law, Bélgica, 2012. Disponível em: < https://ghum.kuleuven.be/ggs/publications/ working_papers/new_series/wp91-100/wp94-jwouters-cryngaertacloots.pdf $>$ Acesso em: 31 ago. 2014. recuperar os bens é possível por meio da sua capacidade de provar a titularidade sobre o bem. ${ }^{43}$

Por fim, alguns dos mecanismos estabelecidos pela UNCAC, que determinam a aplicação da Convenção, é a avaliação por outros Estados Partes, sendo ainda feitas recomendações para melhorar a aplicação da Convenção. ${ }^{44}$ Ademais, é estabelecido a Conferência dos Estados Partes para monitorar a implementação da Convenção. ${ }^{45}$

\subsection{Quadros internacionais e outros instrumentos que relatam a corrupção e os direitos humanos}

O reconhecimento dos danos ocasionados pela corrupção pelos líderes de vários setores da sociedade contribuiu para que a corrupção passasse a ser um tema amplamente discutido na política internacional. $\mathrm{O}$ aumento de uma economia globalizada viveu e vive os danos que a corrupção traz ao desenvolvimento econômico. ${ }^{46}$

Uma análise da Declaração Universal dos Direitos Humanos $^{47}$, promulgada há mais de 60 anos, já lançava luz desse problema havendo uma divisão de opiniões: de uma lado os Estados Unidos e o Leste Europeu que abordavam os direitos humanos em termos políticos, como o direito à liberdade de expressão, e, de outro lado, estava a União Soviética e os países em desenvolvimento que abordavam os direitos humanos como uma capacidade governamental de garantir padrões mínimos de educação e bem-estar. ${ }^{48}$

43 HECHLER, H. et. al. Can UNCAC address grand corruption? A political economy analysis of the UN Convention against corruption and its implementation in three countries. Berga, 2011. Disponível em: <http://www.u4.no/publications/can-uncac-address-grandcorruption/>. Acesso em: 31 ago. 2014.

44 SNIDER, Thomas R; KIDANE, Won. Combating corruption through international law in Africa: a comparative analysis. Cornell Intenational Law, Seatle, v. 40, n. 691, p. 691-748, 2007.

45 CLOOTS, Ann Sofie; RYNGAET, Cedric; WOUNTERS, Jan. The fight against corruption in international law, Bélgica, 2012. Disponível em: < https://ghum.kuleuven.be/ggs/publications/ working_papers/new_series/wp91-100/wp94-jwouters-cryngaertacloots.pdf $>$ Acesso em: 31 ago. 2014.

46 BISHARA, N; HESS, D. Human rights and Corporation's Duty to Combat Corruption, Michigan, 2013. Disponível em: <http://ssrn. com/abstract $=2388395>$. Acesso em: 02 set. 2014.

47 ORGANIZAÇÃO DAS NAÇÕES UNIDAS. Declaração Universal dos Direitos Humanos, 10 dez, 1948.

48 BERENBEIM, Ronald. Linking Human Rights and to antiCorruption: how corruption connects with violations of human rights. Vital Speeches of the day, Nova York, v. 77, n. 2, p. 75-76, fev. 2011. 
O Pacto Global das Nações Unidas ${ }^{49}$ não é um instrumento de regulação, mas sim uma iniciativa voluntária que se baseia no accountability, na transparência e na divulgação de regulações e implementações de políticas corporativas. Essas estratégias estão alinhas aos 10 (dez) princípios universalmente aceitos nas áreas de direitos humanos, meio ambiente, trabalho e combate à corrupção. O Pacto Global das Nações Unidas traz uma mensagem implícita de que a corrupção viola direitos humanos de ambas as categorias ${ }^{50}$.

Entre os benefícios trazidos pela iniciativa voluntária, incluem-se: adotar uma estrutura política estabelecida e reconhecida mundialmente pelo desenvolvimento, implementação e divulgação de políticas e práticas ambientais, sociais e de governança; partilhar boas práticas emergentes para fazer avançar soluções e estratégias práticas para os desafios comuns; desenvolver soluções de sustentabilidade em parceria com uma série de partes interessadas, incluindo as agências da ONU, governos, sociedade civil, trabalho e outros interesses não comerciais; ligar as unidades de negócios e subsidiárias em toda a cadeia de valor com Redes Locais do Pacto Global em todo o mundo - muitas delas no desenvolvimento e mercados emergentes —; acesso a amplo conhecimento das Nações Unidas e experiências com as questões de sustentabilidade e de desenvolvimento; utilização de ferramentas do Pacto Global das Nações Unidas de gestão e recursos, bem como a oportunidade de participar de fluxos de trabalho especializados nos domínios ambientais, sociais e de governança. ${ }^{51}$

Apesar de integrar princípios entre as empresas, trazendo o estímulo a boas práticas, ao diálogo, à parceira com organizações da sociedade civil e promover a autorregulação das empresas, é um instrumento que carece de mecanismos de monitoramento e fiscalização independentes. Além disso, muitas empresas têm considerado o mecanismo vago e de difícil

49 UN GLOBAL COMPACT OFFICE. United Nations Global Compact, Corporate and Sustainability in the World Economy. 2014. Disponível em: <https://www.unglobalcompact.org/docs/ languages/portuguese/GC_Brochure_PT.pdf $>$ Acesso em: 02 set. 2014.

50 ORGANIZAÇÃO DAS NAÇÕES UNIDAS. United Nations Global Compact. 2014.

51 UNITED NATIONS GLOBAL COMPACT \& TRANSPARENCY INTERNATIONAL. Reporting Guidance on the $10^{\text {th }}$ principle against corruption. 2009. Disponivel em: <https://www. unglobalcompact.org/docs/issues_doc/Anti-Corruption/UNGC_ AntiCorruptionReporting.pdf > Acesso em: 02 set. 2014. implementação. Mesmo tendo sido bem-sucedido na conscientização das empresas, a iniciativa voluntária não conseguiu trazer a reconhecimento internacional das empresas em respeitar os direitos humanos. ${ }^{52}$

Em contrapartida, em 2011, foram aprovados, por unanimidade, no Conselho de Direitos Humanos das Nações Unidas, os Princípios Orientadores sobre Empresas e Direitos Humanos, que dão ênfase na responsabilidade internacional de respeitar os Direitos Humanos, invocando aos Estados que apliquem as leis que determinam que as empresas devem lidar com seus impactos sobre os direitos humanos. ${ }^{53}$

Os Princípios Orientadores têm como objetivo trazer uma distinção clara entre os papéis das empresas e dos governos em assegurar que ambos desempenhem suas funções. $O$ governo mantém a exclusiva responsabilidade pela proteção e cumprimento das obrigações de direitos humanos. Essa responsabilidade de respeitar os direitos humanos traz, direta e indiretamente, o dever das empresas de agir com a devida diligência para evitar infringir os direitos fundamentais, além de abordar os impactos nocivos com os quais estejam envolvidos. ${ }^{54}$

Entre as incitações que os Princípios Orientadores fazem para as empresas respeitarem os direitos humanos, as recomendações destacam que as empresas, em as suas atuações, devem evitar causar ou contribuir para impactos negativos nos direitos humanos e enfrentar esses impactos quando ocorrerem. Além disso, as empresas devem procurar mitigar os impactos negativos que estejam diretamente ligados às suas operações, produtos ou serviços por seus relacionamentos comerciais. Sendo assim, os Princípios Orientadores evidenciam que os impactos sobre os direitos humanos das empresas sejam comunicados ao público de forma suficientemente detalhado. ${ }^{55}$

52 SARFATY, Galit A. Human Rights meet securities regulations, Columbia. 2013. Disponível em: <http://ssrn.com/ abstract $=2390192>$. Acesso em: 02 set. 2014.

53 SARFATY, Galit A. Human Rights meet securities regulations, Columbia. 2013. Disponível em: <http://ssrn.com/ abstract $=2390192>$. Acesso em: 02 set. 2014.

54 BLITT, Robert C. Beyong Ruggie's guiding principles on busniss and Human Rights: charting an embracive approach to coporate Human Rights compliance. Texas International Law Journal, Texas, v. 48, n.158, p. 33- 62, mar. 2013.

55 BLITT, Robert C. Beyong Ruggie's guiding principles on busniss and Human Rights: charting an embracive approach to Coporate Human Rights Compliance. Texas International Law Journal, Texas, v. 48, n. 158, p. 33- 62, mar. 2013. 
Ainda que presentes as críticas, continua ganhando impulso a promoção de ações corporativas para combater a corrupção e proteger os direitos humanos. Sendo ainda inevitável falar do Pacto Global sem falar de direitos humanos. Entretanto, mesmo com o diagnóstico de que os impactos nocivos da corrupção afetam diretamente os direitos humanos reconhecidos pelo movimento de combate à corrupção, os institutos ainda caminham de maneira paralela. Demanda-se, pois, que caminhem juntos a fim de alcançar melhorias significativas, o que sugere para empresas um papel mais amplo no combate à corrupção. ${ }^{56}$

\section{A conexão entre a corrupção e os direitos humanos}

\subsection{Determinando quando um direito humano é violado}

Não necessariamente a prática de um ato de corrupção é determinante para a violação de um direito humano. É necessário estabelecer quando um direito humano é violado por práticas de ato de corrupção, determinando o seu nexo de causalidade. Desde que demonstrada que a ação (ou omissão) de um Estado não esteja em conformidade com as normas nacionais e internacionais de direitos humanos, sendo necessário determinar o alcance e o conteúdo da obrigação de direito humano e se deriva de uma norma interna, tratado de direito internacional, costume ou princípios gerais de direito.

Existem três níveis de obrigações de direitos humanos para os Estados: respeitar, proteger e cumprir. A obrigação de proteger traz para o Estado o dever de se abster de qualquer prática que prive a pessoa da fruição dos seus direitos ou capacidade de satisfazer esses direitos. Já o dever de proteção traz para o Estado o dever de evitar que danos irreparáveis ocorram sobre os membros da sociedade, de maneira que devem os Estados evitar violações de direitos humanos por parte de terceiros; evitar e eliminar incentivos para violar direitos de outrem; e fornecer acesso a recursos legais quando as violações ocorrerem. O não cumprimento dessas obrigações pode ser determinante para a

56 BISHARA, N; HESS, D. Human Rights and Corporation's Duty to Combat Corruption, Michigan, 2013. Disponível em: < http://ssrn. com/abstract $=2388395>$. Acesso em: 02 set. 2014.

57 INTERNATIONAL COUNCIL ON HUMAN RIGHTS POLICY. Corruption and Human Rights: making the connection, Suíça, 2009. Disponível em: <http://www.ichrp.org/files/ reports/40/131_web.pdf>. Acesso em: 12 set. 2014. responsabilização do Estado em casos de corrupção. Por exemplo, quando um Estado age de maneira negligente com empregadores que violam as leis trabalhistas ou ainda quando os fiscais do trabalho são sistematicamente subornados para ignorar esse tipo de comportamento. Além disso, a obrigação de cumprir traz para os Estados o dever de tomar medidas para que as pessoas sob a sua jurisdição tenham atendidas as suas necessidades básicas, principalmente quando estes não conseguem garantir tais necessidades por seus próprios esforços. ${ }^{58}$

Existem três relações causais entre a corrupção e as violações de direitos humanos, podendo a corrupção ser uma causa direta, indireta ou remota para as violações de direitos humanos. A corrupção pode ser diretamente ligada a uma violação de direito humano quando esse ato é deliberadamente utilizado para violar um direito, como por exemplo quando uma propina oferecida a um juiz afeta diretamente o seu dever de imparcialidade e independência, violando um julgamento justo. A corrupção pode indiretamente levar a uma violação de direitos humanos quando é uma condição necessária para a violação de um direito, sendo um fator essencial dentro de uma cadeia de atos praticados que, eventualmente, levará a violação de direitos humanos, como por exemplo, quando um funcionário público permite a importação ilegal de resíduos tóxicos em troca de suborno, permitindo que os resíduos fiquem perto de uma área residencial. Se o resíduo tóxico afetar as pessoas que ali vivem, haverá uma violação ao direito à vida ou à integridade. A corrupção poderá ainda violar os direitos humanos de maneira remota, de maneira que a corrupção é um dos elementos que leva a esta violação, como por exemplo, quando durante um processo eleitoral a corrupção desperta preocupações sobre a precisão do resultado formal, levando a agitações sociais e protestos, a repressão a estes protestos sociais poderá levar a graves violações de direitos humanos, não sendo a corrupção o único fator determinante..$^{59}$

58 INTERNATIONAL COUNCIL ON HUMAN RIGHTS POLICY. Corruption and Human Rights: making the connection, Suíça, 2009. Disponível em: <http://www.ichrp.org/files/ reports/40/131_web.pdf>. Acesso em: 12 set. 2014.

59 GEBEYE, Berihun Adugna. Corruption and Human Rights: exploring the relationship. Etiópia, 2012. Disponível em: <http://www. du.edu/korbel/hrhw/workingpapers/2012/70-gebeye-2012.pdf> Acesso em: 14 set. 2014. 


\section{A International Council on Human Rights Policy ${ }^{60}$} afirma que de várias maneiras a corrupção encoraja a discriminação, priva as pessoas vulneráveis de renda, e impede as pessoas de cumprir seus direitos políticos, sociais, civis, culturais e econômicos. Em 2005, no Kosovo, p Sr. Petrit Selimi entrou em um hospital em Pristina em uma condição não especificada. Segundo o Sr. Selimi, o guarda exigiu $€ 10$ a deixá-lo entrar no hospital. Posteriormente, o médico exigiu um suborno de cinco euros para vê-lo. O caso, pelo menos em teoria, envolve cinco infrações jurídicas separadas. A desigualdade ou deficiência preexistente no exercício efetivo dos direitos leva a uma situação em que o Sr. Selimi poderia ser extorquido por um suborno. Sr. Selimi pagou o suborno, o que resultou em seu tratamento médico preferencial. Seu tratamento preferencial implica necessariamente que outras pacientes receberam um nível menor de cuidados de qualidade do que o Sr. Selimi. A falha em detectar o delito de suborno representa, em si, a negligência potencial. Uma vez que a história foi ao ar na televisão, a falta de uma condenação por suborno provavelmente reflete, também, a corrupção (ou negligência) nos sistemas policiais e judiciais. ${ }^{61}$

Situações como essa permitem verificar que a corrupção constitui uma violação dos direitos humanos, enfatizando o impacto maléfico sobre os cidadãos mais vulneráveis ${ }^{62}$. Dessa maneira, o combate à corrupção pode ter grande relevância na promoção dos direitos humanos, garantindo a não discriminação e a participação social; levando, destarte, a capacitação e responsabilidade social. ${ }^{63}$

60 A International Council on Human Rights Policy (ICHRP) é uma organização não-governamental que foi concebida em 1994, composta por um pequeno grupo de defensores dos direitos humanos, estudiosos e gestores de políticas conduzidos por Philip Alston, Thomas Hammarberg e Margo Picken com a finalidade de enfrentar dilemas e desafios nas áreas de direitos humanos. Disponível em: <http://www.ichrp.org/en/history>. Acesso em 14 set. 2014.

61 MICHAEL, Bryane; HAJREDINI, Habit. Topics in anticorruption law: what does Kosovo teach us about using Human Rights Law to prosecute corruption offences? Estocolmo, 2010. Disponível em: < http://works.bepress.com/bryane_michael/52 >. Acesso em: 14 set. 2014.

62 UNDERKUFF, Laura S. Defining corruption. In: ROTBERG, Robert I. Corruption, global security and world order. Washington D.C: Brookings Institution Press, 2009. p. 27-46.

63 GEBEYE, Berihun Adugna. Corruption and Human Rights: exploring the relationship. Etiópia, 2012. Disponível em: < http://www. du.edu/korbel/hrhw/workingpapers/2012/70-gebeye-2012.pdf> Acesso em: 14 set. 2014.

\subsection{O impacto da corrupção sobre os direitos humanos}

O preâmbulo da UNCAC declara a preocupação dos Estados-partes com as ameaças trazidas pela corrupção que promovem instabilidade e insegurança nas sociedades, minando instituições de valores, a democracia e valores éticos, além de comprometer o desenvolvimento sustentável de um Estado de direito. Da mesma forma, o Conselho Europeu destacou fenômeno da corrupção como uma ameaça não só ao Estado de Direito e à democracia, mas também aos direitos humanos, trazendo impactos nocivos a um bom governo, à justiça, distorcendo as competições, dificultando o desenvolvimento da economia e colocando em perigo a estabilidade das instituições democráticas. ${ }^{64}$

Sendo um adversário social, político e econômico, a corrupção resulta direta e indiretamente em violações de direitos e liberdade fundamentais. $O$ fenômeno afeta a própria natureza da igualdade e da dignidade humana. A $11^{a}$ Conferência Internacional sobre Corrupção destacou a incompatibilidade do fenômeno da corrupção com ideais de humanidade trazidos pela Declaração Universal de Direitos Humanos. Além disso, a Convenção da União Africana sobre a Prevenção e o Combate à Corrupção trazem a ligação entre a corrupção e os direitos humanos afirmando expressamente que a corrupção representa uma ameaça aos direitos humanos. ${ }^{65}$

Nos países africanos, a corrupção está diretamente relacionada ao mau desempenho escolar. A população mais pobre depende do sistema de ensino público para educação. Entretanto, o suborno é uma das práticas de corrupção utilizado como uma condição prévia para que alguns estudantes sejam admitidos, prejudicando o sistema de ensino e violando direitos fundamentais como a educação e o direito à igualdade. Há ainda o suborno com a finalidade de obter certificados, professores que subornam funcionários públicos a fim de obter transferências de escolas localizadas em áreas de difícil acesso, regiões que em grande parte são atingidas pela pobreza e demandam professores qualificados. Esse é um dos exemplos que demonstram como uma pequena corrupção pode desencadear elevados custos a uma população, particularmente aos mais pobres. ${ }^{66}$

64 KOECHLIN, Lucy; CARMONA, Magdalena Sepúlveda. In: ROTBERG, Robert I. Corruption, global security and world order. Washington D.C.: Brookings Institution Press, 2009. p. 310-340.

65 GEBEYE, Berihun Adugna. Corruption and Human Rights: exploring the relationship. Etiópia, 2012. Disponível em: <http://www. du.edu/korbel/hrhw/workingpapers/2012/70-gebeye-2012.pdf> Acesso em: 14 set. 2014.

66 GATHII, James Thuo. Defining the relationship between Human 
Não se procura evidenciar os direitos humanos como o único e melhor instrumento de combate a corrupção disponível, mas sim demonstrar que a análise do quadro de direitos humanos produz impactos positivos em certas áreas que são chaves para reformas no combate a corrupção. Esse quadro amplia os sistemas de accountability, transparência e integridade que dão suporte as reformas de combate a corrupção. ${ }^{67}$ Quando países deixam de assegurar direitos como a liberdade de expressão, direito de reunião e associação, participação política em condições de igualdade, e ainda, quando alguns setores da sociedade são excluídos ou marginalizados, encontrase um ambiente propício para a corrupção e a dificuldade de responsabilização dos governos e empresas. ${ }^{68}$

Rights and corruption. Pensilvânia, 2013. Disponível em: <http://ssrn. com/abstract=1342649>. Acesso em 15 set. 2014.

67 KOECHLIN, Lucy; CARMONA, Magdalena Sepúlveda. In: ROTBERG, Robert I. Corruption, global security and world order. Washington D.C.: Brookings Institution Press, 2009. p. 310-340.

68 BRASIL. Ministério da Justiça. Guia para o uso do Sistema Interamericano de Direitos Humanos na proteção dos denunciantes de atos de corrupşão. Brasília, 2014. Disponível em: <http://www.justica.gov.br/ sua-protecao/lavagem-de-dinheiro/institucional-2/publicacoes/ arquivos /guia-para-uso-do-sidh-na-protecao-de-denunciantes-deatos-de-corrupcao.pdf>. Acesso em: 01 out. 2014.
Ainda permanecem tênues os litígios envolvendo violações de direitos humanos que conjuram elementos de combate à corrupção. A tabela abaixo elenca casos que apareceram frente ao Tribunal Europeu dos Direitos Humanos por violações a Convenção Europeia dos Direitos Humanos trazendo casos em que os direitos humanos foram postos a partir de elementos da corrupção. Nesses casos o Tribunal considera alguns elementos relacionados aos direitos humanos. Em primeiro lugar, defende-se o direito de compartilhar informações sobre práticas de corrupção, o que é protegido pelo direito à liberdade de expressão. ${ }^{69} \mathrm{Um}$ dos elementos chaves defendidos, inclusive pela UNCAC com a finalidade de atingir a "cultura política que incentiva, nutre e reforça a exposição e punição" da corrupção. ${ }^{70}$ Em segundo lugar, o Tribunal defende os direitos dos suspeitos envolvidos e condenados por crimes e práticas de corrupção.

69 MICHAEL, Bryane; HAJREDINI, Habit. Topics in anticorruption law: what does Kosovo teach us about using Human Rights Law to prosecute corruption offences? Estocolmo, 2010. Disponível em: < http://works.bepress.com/bryane_michael/52 >. Acesso em: 14 set. 2014 .

70 TERRACINO, Julio Bacio. Hard law connections between corruption and Human Rights. Genebra, 2010. Disponível em: < http://www. ichrp.org/files/papers/130/131_-_Julio_Bacio_Terracino_-_2007. pdf>. Acesso em: 18 set. 2014. 


\begin{tabular}{|c|c|c|}
\hline Casos & Elementos & Implicações da lei de corrupção \\
\hline \multicolumn{3}{|l|}{ Liberdade de expressão } \\
\hline Guja vs. Maldávia (1 4277/04) & & $\begin{array}{l}\text { A Corte considera o vazamento de docu- } \\
\text { mentos confidenciais de interesse público } \\
\text { para combater a corrupção. A liberdade } \\
\text { de expressão tem papel vital no combate à } \\
\text { corrupção. }\end{array}$ \\
\hline $\begin{array}{l}\text { Cumpana e Mazaré vs. Romênia } \\
(33348 / 96)\end{array}$ & $\begin{array}{l}\text { Cartunistas acusaram um político de } \\
\text { corrupção. A Corte reverteu a decisão } \\
\text { do governo. }\end{array}$ & $\begin{array}{l}\text { O papel da liberdade de expressão no } \\
\text { combate à corrupção suspende os direitos } \\
\text { individuais (acusações de calúnia forma } \\
\text { derrubadas). }\end{array}$ \\
\hline Stoll vs. Suíça (69698/01) & $\begin{array}{l}\text { O requerente alegou que a sua condena- } \\
\text { ção por publicar "deliberações oficiais } \\
\text { secretas" tinha sido contrária ao artigo } \\
10 \text { da Convenção. }\end{array}$ & $\begin{array}{l}\text { O direito à liberdade de expressão não é } \\
\text { absoluto. Jornalista deve seguir a ética pro- } \\
\text { fissional na liberação de informações para o } \\
\text { público. }\end{array}$ \\
\hline Sisojeva vs. Letónia $(60654 / 00)$ & $\begin{array}{l}\text { Requerente se recusou a ficar na Letó- } \\
\text { nia alegando retaliação por denunciar } \\
\text { corrupção na Letónia em um programa } \\
\text { de TV na Rússia. CEDH considerou o } \\
\text { apelante como sido deportado. }\end{array}$ & $\begin{array}{l}\text { A Corte — ao ouvir o caso — levou a sério } \\
\text { as alegações de que o governo viola os direi- } \\
\text { tos humanos para encobrir a corrupção. A } \\
\text { Corte certamente é contra as decisões ilegais } \\
\text { tomadas por causa da corrupção. }\end{array}$ \\
\hline \multicolumn{3}{|l|}{ Julgamento Justo } \\
\hline $\begin{array}{l}\text { Ramanauskas vs. Lituânia } \\
(74420 / 01)\end{array}$ & $\begin{array}{l}\text { Recorrente afirma que ele foi vítima } \\
\text { de armadilha para a corrupção e na } \\
\text { oportunidade se negou a examinar uma } \\
\text { testemunha-chave. }\end{array}$ & $\begin{array}{l}\text { As autoridades policiais devem seguir Es- } \\
\text { tado de Direito nos processos de combate } \\
\text { a corrupção. A Corte respeita os direitos } \\
\text { humanos dos suspeitos em casos de corrup- } \\
\text { ção. }\end{array}$ \\
\hline Kart vs. Turquia (8917/05) & $\begin{array}{l}\text { Em um caso raro, um membro do Par- } \\
\text { lamento solicitou imunidade para que } \\
\text { pudesse se defender contra acusações } \\
\text { de corrupção. A Corte concluiu que } \\
\text { o governo se recusou a conceder a } \\
\text { imunidade. }\end{array}$ & $\begin{array}{l}\text { A noções comumente admitidas pelos indi- } \\
\text { víduos dizem que a imunidade parlamentar } \\
\text { impede o trabalho de combate à corrupção. } \\
\text { Caso dará nova perspectiva para os próxi- } \\
\text { mos anos. }\end{array}$ \\
\hline H.L.R. vs. França & $\begin{array}{l}\text { Recorrente pretende derrubar or- } \\
\text { dem de deportação para a Colômbia. } \\
\text { Reivindicações corrupção no sistema } \\
\text { judicial colombiano irão privá-lo de um } \\
\text { julgamento justo. }\end{array}$ & $\begin{array}{l}\text { Os países têm dever de não fornecer assis- } \\
\text { tência às cegas, mas considera a proteção } \\
\text { dos direitos humanos em casos julgados no } \\
\text { exterior. }\end{array}$ \\
\hline $\begin{array}{l}\text { Guerin vs. França } \\
(25201 / 94)\end{array}$ & $\begin{array}{l}\text { Oficial francês foi subornado. O ape- } \\
\text { lante foi privados do direito efetivo de } \\
\text { um recurso. A CEDH julgou a favor do } \\
\text { recorrente. }\end{array}$ & $\begin{array}{l}\text { Teve pouca relevância na teorização da lei } \\
\text { de combate a corrupção. }\end{array}$ \\
\hline Na. vs Reino Unido (25904/07) & $\begin{array}{l}\text { O Sr. Na - um nacional do Sri Lanka- } \\
\text { admitiu ter pago suborno para escapar } \\
\text { autoridades cingalesas. CEDH conside- } \\
\text { ra risco real devolver o nacional ao Sri } \\
\text { Lanka. }\end{array}$ & $\begin{array}{l}\text { No caso notável, a Corte condena implici- } \\
\text { tamente pagamento de propina em um país } \\
\text { altamente disfuncional. A questão da extra- } \\
\text { dição relativamente sem importância. }\end{array}$ \\
\hline $\begin{array}{l}\text { Gorgievski vs. Macedônia } \\
(18002 / 02)\end{array}$ & $\begin{array}{l}\text { O apelante alega ter caído em uma } \\
\text { armadilha para pagar suborno. }\end{array}$ & $\begin{array}{l}\text { A Corte se abstém deliberadamente de fazer } \\
\text { julgamentos sobre os direitos humanos } \\
\text { relacionados a julgamentos doméstico na } \\
\text { Macedônia com base na lei de combate à } \\
\text { corrupção da Macedônia. }\end{array}$ \\
\hline
\end{tabular}




\begin{tabular}{|c|c|c|}
\hline Miliniene vs. Lituânia & $\begin{array}{l}\text { A apelante (juíza) alega que foi presa } \\
\text { pela polícia }\end{array}$ & $\begin{array}{l}\text { CEDH falha (novamente) para manifestar- } \\
\text {-se sobre direitos humanos aspectos } \\
\text { relacionados de quadro legal de combate à } \\
\text { corrupção. }\end{array}$ \\
\hline Abramyan vs. Rússia & $\begin{array}{l}\text { O caso do recorrente foi reclassificado } \\
\text { como corrupção por fraude - causando } \\
\text { um novo julgamento. Ele e o advogado } \\
\text { não apresentaram ao julgamento, sendo } \\
\text { reclassificado (onde ele foi considerado } \\
\text { culpado). A Corte julgou a favor do } \\
\text { recorrente. }\end{array}$ & Caso pouco relevante. \\
\hline $\begin{array}{l}\text { Vilvarajah e outros vs. Reino } \\
\text { Unido }\end{array}$ & $\begin{array}{l}\text { Basicamente o mesmo caso do Sr. Na } \\
\text { vs. Reino Unido (mas cerca de uma dé- } \\
\text { cada antes). A Corte não encontrou ne- } \\
\text { nhum risco de maus-tratos. Recorrentes } \\
\text { também admitiram a pagar suborno. }\end{array}$ & $\begin{array}{l}\text { Tal como acontece com } \mathrm{Na} \text {, tribunal parece } \\
\text { negligenciar elementos de corrupção do } \\
\text { caso. }\end{array}$ \\
\hline \multicolumn{3}{|l|}{ Tratamento Desumano } \\
\hline $\begin{array}{l}\text { Victor Savtchi vs. Maldávia } \\
(81 / 04)\end{array}$ & $\begin{array}{l}\text { Membro da polícia econômica foi su- } \\
\text { bornado. Ele é agredido e afirma que as } \\
\text { provas contra ele são injustas (escutas } \\
\text { telefônicas etc.). CEDH reconhece em } \\
\text { seu favor as agressões, mas não consi- } \\
\text { dera os métodos utilizados pelo como } \\
\text { violadores de direitos humanos. }\end{array}$ & $\begin{array}{l}\text { CEDH - neste caso, como em outros - } \\
\text { concentra-se mais em direitos humanos e } \\
\text { menos sobre a adesão ao Estado de direito. }\end{array}$ \\
\hline Dorokhov vs. Rússia (66802/01) & $\begin{array}{l}\text { O ex-procurador acusado por abusos } \\
\text { poder e levar subornos. Reivindicações } \\
\text { segurando condições horríveis. CEDH } \\
\text { concorda. }\end{array}$ & $\begin{array}{l}\text { Outra "espírito da lei" caso - tribunal tende } \\
\text { a olhar para os resultados, em vez de a ade- } \\
\text { são ao direito interno. }\end{array}$ \\
\hline Direito à propriedade privada & Nenhum caso achado. & $\begin{array}{l}\text { Claramente extorsão de subornos viola o } \\
\text { direito à propriedade privada. }\end{array}$ \\
\hline Direito à educação & $\begin{array}{l}\text { Apenas dois casos, nenhum lidando } \\
\text { diretamente com a corrupção. }\end{array}$ & Corrupção leva à violação de tal princípio. \\
\hline
\end{tabular}

Esses casos, pois, são exemplos de como que os direitos humanos, em âmbito jurisdicional, pode se relacionar com a corrupção; bem como essa temática tem sido tratada. Ademais, o quadro também serve para tornar claro, por meio de exemplos, a conexão entre a corrupção e os direitos humanos, central para compreensão deste artigo.

A corrupção, em qualquer dos seus níveis, trazem altos custos para o desenvolvimento. Abusos em um determinado setor podem desencadear danos colaterais em outras áreas. A corrupção pode se manifestar das formas mais sutis, minando a confiança pública no governo e nos serviços que são prestados por este. ${ }^{71}$

71 TRANPARÊNCIA INTERNACIONAL. The anti-corruption catalyst. realising the MDGs by 2015. Berlim, 2010. Disponível em: $<$ http://issuu.com/transparencyinternational/docs/2010_mdg_ en?e $=2496456 / 2052732>$. Acesso em: 18 set. 2014 .

\subsection{Conectando a corrupção a um direito humano específico}

É importante observar como violações de direitos humanos e atos de corrupção podem estar conectados. Este capítulo apresenta, não de maneira exaustiva, exemplos de como conteúdos de direitos específicos podem ser violados por atos de corrupção já definidos na Convenção. ${ }^{72}$

\section{Educação}

Garantido por vários instrumentos internacionais, incluindo os artigos 13 e 14 do Pacto Internacional sobre os Direitos Econômicos, Sociais e Culturais, que traz ao indivíduo o direito de receber uma

72 INTERNATIONAL COUNCIL ON HUMAN RIGHTS POLICY. Corruption and Human Rights: making the connection, Suíça, 2009. Disponível em: <http://www.ichrp.org/files/ reports/40/131_web.pdf>. Acesso em: 12 set. 2014. 
educação, obrigando o Estado a trazer vários tipos de ensino, sendo, na maioria dos países, um dos maiores componentes do setor público, consumindo de $20 \%$ a $30 \%$ do orçamento total. Isso cria oportunidades e incentivos. $\mathrm{O}$ fato de a educação ter um papel único traz consequências que vão além das perdas de fundos públicos quando violada por direitos humanos.

Uma pesquisa realizada em 50 países revela que há uma clara correlação entre o aumento da corrupção e a redução da qualidade e quantidade de em um país. Além disso uma pesquisa feita pela Transparência Internacional em 42 países demonstra o aumento do pagamento de suborno ligado a baixas taxas de alfabetização entre os 15 e 24 anos de idade. ${ }^{74}$

Outra pesquisa realizada no Quênia pelo Center for Governance and Development revelou que o governo queniano perdeu U\$ 475 bilhões com corrupção, negligências e desperdícios. Só Ministério da Educação desperdiçou U $\$ 33,9$ bilhões. A maior parte dessa perda vem de empréstimos de estudantes não amortizados e bolsas institucionais não cobradas, ou seja, fundos desembolsados mas sem nenhuma conta para mostrar a sua utilização. Dessa forma, o relatório presumiu que muitos dos desvios eram para ganho pessoal.

Sendo assim, crianças expostas a corrupção na escola traz a dificuldade em criar uma cultura de transparência a integridade. Os efeitos da corrupção nesse setor são sofridos a curto e longo prazo, perpassando gerações, deixando marcas especialmente profundas e perniciosas.

\section{Saúde}

O direito à saúde traz para o Estado o dever de garantir, em qualquer circunstancia e independente de recursos disponíveis, o acesso aos cuidados da saúde materna e infantil, incluindo o planejamento familiar,

73 TERRACINO, Julio Bacio. Hard law connections between corruption and Human Rights. Genebra, 2010. Disponível em: <http://www. ichrp.org/files/papers/130/131_-_Julio_Bacio_Terracino_-_2007. pdf $>$. Acesso em: 18 set. 2014.

74 TRANPARENCIA INTERNACIONAL. The anti-corruption catalyst: Realising the MDGs by 2015. Berlim, 2010. Disponível em: $<$ http://issuu.com/transparencyinternational/docs/2010_mdg_ en?e $=2496456 / 2052732>$. Acesso em: 18 set. 2014 .

75 GATHII, James Thuo. Defining the relationship between Human Rights and corruption. Pensilvânia, 2013. Disponível em: <http://ssrn. com/abstract $=1342649>$. Acesso em 15 set. 2014.

76 INTERNATIONAL COUNCIL ON HUMAN RIGHTS POLICY. Corruption and Human Rights: making the connection, Suíça, 2009. Disponível em: <http://www.ichrp.org/files/ reports/40/131_web.pdf $>$. Acesso em: 12 set. 2014. imunização contra as principais doenças infecciosas, o tratamento apropriado de doenças e lesões comuns, medicamentos essenciais, abastecimento adequado de água potável e saneamento básico, e estar livre de graves ameaças à saúde ambiental. Nesse setor a corrupção pode ocorrer em três níveis, incluindo: gestão de recursos financeiros, gestão de suprimentos médicos e ainda o profissional de saúde e o paciente. Desse modo, a corrupção afeta a disponibilidade de financiamento do governo para o setor e também reduz a qualidade dos medicamentos e serviços prestados.

As Auditorias de Execução na Libéria relatam graves irregularidades cometidas por funcionários do Ministério da Saúde e Bem-estar Social, sendo identificada uma diferença de aproximadamente U\$ 4 milhões de fundos não contabilizados. Mesmo que bem planejados os programas de saúde, práticas de suborno e outros atos de corrupção comprometem esses programas nacionais. A má gestão de medicamentos levando a suas alterações e desclassificações resulta de 200.000 a 300.000 mortes anualmente na China. Os resultados, com base em dados de 64 países, sugerem que um aumento na corrupção está associada a um aumento da mortalidade materna, independentemente de quão rico um país é ou o quanto ela investe em saúde. $^{78}$

Desvios de bens, recursos públicos, serviços para o uso provado contribuem significativamente para a deterioração da infraestrutura, que afeta a saúde e segurança do público, em especial de pessoas mais pobres. A corrupção generalizada por desvios de recursos públicos para o uso privado afeta negativamente novos investimentos e o crescimento econômico, implicando na desestimulação de novos investidores em países com problemas de corrupção. ${ }^{79}$

Liberdade de Opinião, Expressão e Informação

$\mathrm{O}$ direito à liberdade de opinião, expressão e informação precisa ser protegido não só das interferências públicas, mas também de interferências

77 TERRACINO, Julio Bacio. Hard law connections between corruption and Human Rights. Genebra, 2010. Disponível em: <http://www. ichrp.org/files/papers/130/131_-_Julio_Bacio_Terracino_-_2007. pdf $>$. Acesso em: 18 set. 2014.

78 TRANPARÊNCIA INTERNACIONAL. The anti-corruption catalyst. realising the MDGs by 2015. Berlim, 2010. Disponível em: $<$ http://issuu.com/transparencyinternational/docs/2010_mdg_ en?e=2496456/2052732> . Acesso em: 18 set. 2014.

79 GATHII, James Thuo. Defining the relationship between Human Rights and corruption. Pensilvânia, 2013. Disponível em: <http://ssrn. com/abstract=1342649>. Acesso em 15 set. 2014. 
privadas. A forte ligação entre esses direitos e a corrupção se deve a sua forte importância no combate à corrupção, particularmente no direito à solicitação de informação. A liberdade de divulgar informações e solicitar informação sobre os casos de corrupção diminui os secretismos da prática e ajuda a identificar as causas e consequências da corrupção, além de permitir a concepção de políticas adequadas para combater a corrupção. Como consequência, aqueles que se beneficiam da corrupção precisam suprir esse direito o máximo que puderem. Isso cria situações em que os de casos de corrupção lidam com a violação do direito a liberdade de opinião, expressão e informação. ${ }^{80}$

O Pacto de Direitos Civis e Políticos, em seu artigo 19 garante o direito à liberdade de expressão incluindo a liberdade de ter opiniões sem interferência e de procurar, receber e transmitir informações e ideias por quaisquer meios. Direito este que deve ser protegido contra ingerências públicas e do setor privado. Certamente este direito sofre algumas limitações ou restrições que devem ser interpretadas de maneira restritiva ${ }^{81}$.

Informações sobre o controle das autoridades públicas e o acesso a elas por parte do público são recursos valiosos promovendo transparência a e o accountability por parte das autoridades públicas. Dessa maneira, o cidadão tem acesso a informações sobre como o governo e o setor privado tomam decisões que lhe dizem respeito. Estratégias efetivas para o combate à corrupção dependem da capacidade de expor a corrupção em primeiro lugar. Liberdade de expressão é um requisito importante para incentivar a "cultura política que incentiva, estimula e reforça a exposição e punição" da corrupção, conduzindo a exposição das causas e consequências da corrupção. ${ }^{82}$

80 TERRACINO, Julio Bacio. Hard law connections between corruption and Human Rights. Genebra, 2010. Disponível em: <http://www. ichrp.org/files/papers/130/131_-_Julio_Bacio_Terracino_-_2007. pdf $>$. Acesso em: 18 set. 2014.

81 INTERNATIONAL COUNCIL ON HUMAN RIGHTS POLICY. Corruption and Human Rights: making the connection, Suíça, 2009. Disponível em: <http://www.ichrp.org/files/ reports/40/131_web.pdf>. Acesso em: 12 set. 2014.

82 GATHII, James Thuo. Defining the relationship between Human

\section{Conclusão}

Apesar de já existente reconhecimento de que a corrupção afeta negativamente os direitos humanos e que os movimentos de promoção destes podem estimular o combate à corrupção, estes institutos ainda têm caminhado de maneira paralela. Melhorias significativas na promoção dos direitos humanos demandam que ambos os institutos percorram juntos de maneira interdependente. Isso enseja um papel mais amplo dos Estados e também empresas em combater a corrupção.

Um importante resultado a ser levado em consideração é conceber a agenda de combate à corrupção como uma forma de fomentar a proteção dos direitos humanos. Deve-se levar em conta que as agendas de combate à corrupção consideram termos econômicos e sociais, de maneira que é possível observar que os atos de corrupção levam um Estado ao não cumprimento das suas obrigações de direitos humanos.

Esse trabalho busca explorar a relação entre os direitos humanos e a corrupção, de maneira que essa relação deva ser uma preocupação real nas medidas de combate à corrupção.

Ainda é necessário um progresso além das análises dos impactos negativos da corrupção nos direitos humanos. Constatou-se que, nas avaliações das leis internacionais de proteção dos direitos humanos, estas carecem de uma identificação de como promover esforços destinados a combater a corrupção. Além disso, foram exploradas neste estudo as medidas éticas empresarias discutidas principalmente pelo Pacto Global das Nações Unidas e pelos Princípios Orientadores sobre Empresas e Direitos Humanos que procuram promover a proteção dos direitos humanos.

Rights and corruption. Pensilvânia, 2013. Disponível em: <http://ssrn. com/abstract $=1342649>$. Acesso em 15 set. 2014. 


\section{Referências}

BARBOSA, Carlos Henrique N. A Cooperação internacional à luz da UNCAC: impactos no Brasil. 2014. Monografia (Graduação) - Faculdade de Direito - FD da Universidade de Brasília- UnB, Brasília, 2014.

BARR, Joshua V.; FINKE, Jorge; PINILLA, Edgar Michael. A legal perspective on the use of models in the fight against corruption. Carolina do Sul, 2012. Disponível em: $<$ http://scholarcommons.sc.edu/scjilb/vol8/iss2/5>. Acesso em: 02 set. 2014.

BERENBEIM, Ronald. Linking Human Rights and to anti-corruption: how corruption connects with violations of Human Rights. Vital Speeches of the day, Nova York, v. 77, n. 2, p. 75-76, fev. 2011.

BISHARA, N; HESS, D. Human Rights and Corporation's Duty to Combat Corruption, Michigan. 2013. Disponível em: <http://ssrn.com/abstract $=2388395>$. Acesso em: 02 set. 2014.

BLITT, Robert C. Beyong Ruggie's guiding principles on busniss and Human Rights: charting an embracive approach to Coporate Human Rights Compliance. Texas International Law Journal, Texas, v. 48, n. 158, p. 33- 62, mar. 2013.

BRASIL. Decreto lei 3.678, de 30 de novembro de 2000. Promulga a convenção sobre o combate da corrupção de funcionários públicos estrangeiros em transações comerciais internacionais, concluída em Paris, em 17 de dezembro de 1997. Brasília, 2000. Disponível em: <http://www.planalto.gov.br/ccivil_03/decreto/ D3678.htm>. Acesso em: 31 ago. 2014.

BRASIL. Ministério da Justiça. Guia para o uso do Sistema Interamericano de Direitos Humanos naproteção dos denunciantes de atos de corrupção. Brasília, 2014. Disponível em: $<$ http://www.justica.gov.br/sua-protecao/lavagem-dedinheiro/institucional-2/publicacoes/arquivos/guiapara-uso-do-sidh-na-protecao-de-denunciantes-deatos-de-corrupcao.pdf $>$. Acesso em: 01 out. 2014.

CLOOTS, Ann Sofie; RYNGAET, Cedric; WOUNTERS, Jan. The Fight Against Corruption in InternationalLaw. Bélgica, 2012.Disponível em: <https:// ghum.kuleuven.be/ggs/publications/working_papers/ new_series/wp91-100/wp94-jwouters-cryngaertacloots.pdf> Acesso em: 31 ago. 2014.
DARROUGHM, Masako N. The FCPA and the OCDE Convention: some lessons from U.S. experience. Nova York, 2010. Disponível em: <http://www.jstor.org/ stable/40605340>. Acesso em 02 set. 2014.

FARRALES, M. J. What is corruption? A bistory of corruption studies and the great definitions debate. Carlifórnia, 2005. Disponível em: <http://papers.ssrn.com/sol3/ papers.cfm?abstract_id=1739962>. Acesso em: 02 set. 2014.

GATHII, James Thuo. Defining the relationship between Human Rights and corruption. Pensilvânia, 2013. Disponível em: <http://ssrn.com/abstract $=1342649>$. Acesso em 15 set. 2014.

GEBEYE, Berihun Adugna. Corruption and Human Rights: exploring the relationship. Etiópia, 2012. Disponível em: <http://www.du.edu/korbel/hrhw/ workingpapers/2012/70-gebeye-2012.pdf $>$ Acesso em: 14 set. 2014.

GOULD, D. J. Administrative corruption Incidence, causes and remedial strategies. In: FARAZMAND, Ali. Hand book of comparative development and public administration. Nova York: Taylor \& Francis e-Library, 2005. p. 872-886.

HECHLER, H. et. al. Can UNCAC address grand corruption? A political economy analysis of the UN Convention against Corruption and its implementation in three countries. Berga, 2011. Disponível em: <http:// www.u4.no/publications/can-uncac-address-grandcorruption/>. Acesso em: 31 ago. 2014.

INTERNATIONAL COUNCIL ON HUMAN RIGHTS POLICY. Corruption and Human Rights: making the connection. Suíça. 2009. Disponível em: <http://www.ichrp.org/files/reports/40/131_web. pdf>. Acesso em: 12 set. 2014.

JOHNSTON, Michael. The political consequences of corruption: a reassement. ph.D. Nova York, 1986. Disponível em: <http://www.jstor.org/stable/421694>. Acesso em: 30 ago. 2014.

KOECHLIN, Lucy; CARMONA, Magdalena Sepúlveda. In: ROTBERG, Robert I. Corruption, global security and world order. Washington D.C.: Brookings Institution Press, 2009. p. 310-340. 
MICHAEL, Bryane; HAJREDINI, Habit. Topics in anti-corruption law: what does Kosovo teach us about using human rights law to prosecute corruption offences? Estocolmo, 2010. Disponível em: <http:// works.bepress.com/bryane_michael/52>. Acesso em: 14 set. 2014.

ORGANIZAÇÃO DAS NAÇÕES UNIDAS. Convenção das Nações Unidas Contra a Corrupção (UNCAC). Mérida: 2005.

ORGANIZAÇÃO DAS NAÇÕES UNIDAS. Declaração Universal dos Direitos Humanos, 10 dez, 1948.

ORGANIZAÇÃO DAS NAÇÕES UNIDAS. United Nations Global Compact. 2014.

UNITED NATIONS. A/RES/51/59: 82nd plenary meeting, 12 December 1996 Viena. 1997. Disponível em: $\quad<$ http://www.un.org/documents/ga/res/51/ a51r059.htm>. Acesso em: 31 ago. 2014.

SARFATY, Galit A. Human Rights meet securities regulations, Columbia. 2013. Disponível em: <http:// ssrn.com/abstract=2390192> Acesso em: 02 set. 2014.

SNIDER, Thomas R; KIDANE, Won. Combating corruption through international law in Africa: a comparative analysis. Cornell Intenational Law, Seatle, v. 40, n. 691, p. 691-748, 2007.

SPALDING, Andrew Brady. Corruption, corporations, and the New Human Right. Washington, 2012. Disponível em: <http://ssrn.com/abstract $=2232670>$ Acesso em: 31 ago. 2014.
TERRACINO, Julio Bacio. Hard law connections between corruption and Human Rights. Genebra, 2010. Disponível em: <http://www.ichrp.org/files/papers/130/131_Julio_Bacio_Terracino_-_2007.pdf>. Acesso em: 18 set. 2014.

TRANPARÊNCIA INTERNACIONAL. The Anti-corruption catalyst: Realising the MDGs by 2015. Berlim, 2010. Disponível em: <http://issuu. com/transparencyinternational/docs/2010_mdg_ en?e $=2496456 / 2052732>$. Acesso em: 18 set. 2014.

UNDERKUFF, Laura S. Defining corruption. In: ROTBERG, Robert I. Corruption, global security and world order. Washington D.C: Brookings Institution Press, 2009. p. 27-46.

UNITED NATIONS GLOBAL COMPACT \& TRANSPARENCY INTERNATIONAL. Reporting Guidance on the $10^{\text {th }}$ principle against corruption. 2009. Disponível em: <https://www.unglobalcompact. org/docs/issues_doc/Anti-Corruption/UNGC_ AntiCorruptionReporting.pdf $>$ Acesso em: 02 set. 2014.

UNITED STATES. Department of Justice and Enforcement Division of the U.S. Securities and Exchange Commission. A resource guide to the U.S. foreing corrupt practices act. Washington. 2012. Disponível em: <http://www.justice.gov/criminal/fraud/fcpa/guide. pdf> Acesso em: 31 ago. 2014.

UNITED STATES. Department of Justice's. Foreign Corrupt Practices Act (FCPA). Washington, 1977. Disponível em: $<$ http://www.justice.gov/criminal/ fraud/fcpa/>. Acesso em: 31 ago. 2014. 


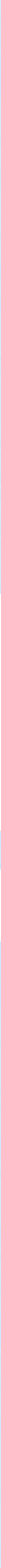




\title{
Grupo de sociedades: instrumento jurídico de organização da empresa plurissocietária
}

\author{
Group of Companies: legal instrument to organize \\ multi-corporate companies
}

Daniel Amin Ferraz*

\section{Resumo}

O grupo de sociedades é, hoje em dia, o instrumento jurídico, por excelência, de inserção da grande empresa transnacional nos mercados globais. Trata-se de técnica jurídica de constituição da empresa plurissocietária, permitindo a concentração de conglomerados que atuam em distintos países e influenciam o desenvolvimento do mercado nestas regiões. Por outro lado, frequentemente é o grupo de sociedades, na doutrina jurídica pátria, confundido com o gênero concentração empresarial, e não caracterizado como mais um instrumento à disposição do mercado para as concentrações desejadas. Importa, assim, distinguir tal instrumento de outros instrumentos de concentração e cooperação empresarial, tais como a Fusão, a Cisão, a Holding e a Joint Venture, promovendo-se a caracterização do grupo como o mais moderno instrumento jurídico plurisocietário de concentração empresarial.

Palavras-chave: Grupo de sociedades. Empresa plurissocietária. Fusão. Cisão. Holding. Joint venture.

\section{Abstract}

The group of companies is, latterly, the only legal instrument in order to insert the great transnacional company into global markets. It is a legal technique that creates the multi coporate company, allowing the concentration of conglomerates that operate in different countries and influence the market development in these regions. On the other hand, often the group of companies, in the national legal doctrine, is mistaken to the business concentration genus, rather be a instrument at hand to the market, to the desirable concentrations. Highlight, thus, the distinguish between this instrument to some other concentrarion and businees cooperation instrument, such as Amalgamation, Spin-off, Holding and Joint Venture, promoting the characterization of the group even with the most recent company concentration multi corporate legal instrument.

Keywords: Corporate groups. Multi corporate company. Amalgamation, Spin-off. Holding. Joint Venture.

* Artigo convidado

Mestre em Direito Empresarial pela Universidade de Coimbra, Portugal; Doutor em Direito Empresarial Internacional pela Universidad de València, Espanha; Professor do Mestrado/Doutorado do UniCeub - Centro Universitário de Brasília; Advogado titular de Amin, Ferraz Coelho Advogados Associados; daniel.amin@afcadvogados.adv.br 


\section{Introdução}

O desenvolvimento do mundo moderno induz, cada vez com maior intensidade, à realização de empreendimentos comuns.

A transnacionalização das empresas, que as faz olhar o mundo como um único mercado, estimula em certa medida a concorrência (com a atuação internacional dos grupos) e exige formas associativas novas para a conquista ou a manutenção de determinadas áreas de domínio.

Tal objetivo implica constante determinação das empresas a favor da diminuição dos custos, com a obtenção de economia de escala. Ademais, o simples crescimento das atividades produtivas, por meio do instrumento de concentração básico (fusão), pode gerar não uma diminuição de tais custos fixos, senão, seu incremento, derivado de um gigantismo da atividade produtiva ${ }^{1}$.

Por outro lado, a necessidade de tecnologia com inovações constantes impõe a necessidade de volumosos investimentos em investigação, com riscos elevados que uma empresa isolada não suportaria. Além disso, o volume de informação que requer a atividade global e tecnológica se entende melhor quando as empresas atuam conjuntamente, em determinado setor da atividade. É importante sublinhar que o melhor controle dos mercados regionais atua como característica fundamental para a busca, pelos empresários, de novas formas associativas ${ }^{2} /{ }^{3}$.

Nesta breve introdução, vale referir que o grupo de sociedades, na doutrina pátria, tanto em sua vertente econômica de análise, mas, precipuamente, em seu viés jurídico é, com frequência, confundido com o gênero concentração empresarial, e não como uma espécie do mesmo.

Assim, se analisada a tipologia dos grupos de sociedades, permitindo contextualizar este instrumento jurídico como uma espécie mais do gênero concentração empresarial (e não como o gênero em si),

1 PEREIRA NETO, Mario. Joint Ventures com a União Européia. São Paulo: Aduaneiras, 1995. p. 33.

2 LAMY FILHO, Alfredo; PEDREIRA, José Luiz Bulhões. $A$ Lei das S.A. Rio de Janeiro: Renovar, 1992. p. 98.

3 No mesmo sentido, todavia agregando a ideia de permitir ao empreendimento comum uma sinergia psicológica entre os entes sociais, facilitando assim a inserção comercial dos mesmos no país acolhedor de investimento, veja: LANGEFELD-WIRTH, Klaus. Les Joint Ventures internationals. Paris: GLN Joly editions, 1992. p. 7. cumpre sublinhar as diferenciações básicas deste com outros instrumentos de concentração e cooperação empresarial.

Importa dizer que não se fará análise exaustiva de todos os instrumentos de concentração empresarial existentes, já que praticamente impossível tal desiderato. Impossível porque, na atualidade, instrumentos de concentração existem tantas quantas operações empresariais existentes no mercado. Assim que, seguidamente, se analisará, comparativamente, o grupo de sociedades com os instrumentos de concentração e cooperação com os quais é confundido de forma mais frequente, quais sejam: 1) fusão; 2); cisão; 3) bolding, e; 4) joint venture.

Observe-se que se realizará estudo mais aprofundado da join venture, já que este instrumento jurídico, em suas duas vertentes (corporated joint venture $e^{4}$ e uncorporated joint venture ${ }^{5}$ ), é com maior frequência confundido com o grupo de sociedades.

Finalmente, ressalta-se que no presente texto, seguindo a moderna teoria do direito empresarial, utiliza-se o vocábulo empresa como sinônimo de empresário, referindo-se aos dois de forma indistinta.

4 Poderia haver confusão com o grupo de sociedades de base societária, vez que ambos os instrumentos tem natureza jurídica de negócio societário, não estando qualificados no campo dos negócios obrigacionais, mas sim societários (plurilaterais ou estatutários).

5 Poderia haver confusão com o grupo de sociedades de base contratual, já que os dois instrumentos possuem natureza jurídica de negócio obrigacional. Neste ponto, importante ressaltar que o grupo de sociedades de base contratual estará classificado como negócio jurídico complexo, no âmbito obrigacional. Por sua vez, a joint venture contratual, no Brasil consórcio de empresas, será também, sempre, negócio obrigacional, podendo ser classificado como bilateral (se não há controle) ou complexo (quando exista controle de uma das co-ventures sobre as demais).

6 Cumpre referir que para o Direito Mercantil clássico há que se falar em distinção entre empresário, empresa e estabelecimento comercial. Assim, por empresário entende-se o individuo, pessoa física ou jurídica, que desenvolve a atividade mercantil em nome próprio. Observe-se que o empresário pode ser registrado na junta comercial (empresário regular) ou não registrado (empresário irregular ou de fato). Por sua vez, o estabelecimento comercial é definido como um bem corpóreo, infungível, composto de bens corpóreos e incorpóreos, fungíveis e infungíveis, sempre móveis. Saliente-se que o imóvel não é elemento do estabelecimento comercial. Finalmente, a empresa, no Direito mercantil clássico, é entendida como a mera atividade empresária, a organização dos fatores de produção: capital, trabalho e informação. Assim, é entendida a empresa como objeto de direito e não sujeito, sendo passível de negociação no mercado, de forma autônoma e independente da figura do empresário e, até mesmo, do estabelecimento mercantil. Por isso mesmo, estaria ela a empresa, em tese, equiparada à mercadoria. Por seu turno, para o moderno Direito Empresarial, não há que se fazer distinção entre empresa e empresário, sendo usados, tais vocábulos, como expressões 
2 Breve tipologia do grupo de sociedades e suas distinções jurídico-doutrinárias: instrumento societário ou obrigacional?

O grupo de sociedades é, hoje em dia, o instrumento, por excelência, de organização da empresa transnacional.

Técnica jurídica apurada pode fundamentarse em três modalidades distintas, a saber: grupo de sociedades de base societária, grupo de sociedades de base contratual, grupo de sociedades de base pessoal ${ }^{7}$.

Por grupo de sociedades de base societária entendese a organização do capital que permitirá coparticipação societária, determinante de um sistema de controle que gere o exercício do poder de gestão de uma sociedade, a sociedade mãe, sobre outros entes societários, as sociedades filhas.

Importa ressaltar que nessa modalidade de grupo (de base societária) o instrumento de participação, constituído entre os membros do grupo, terá natureza jurídica de negócio societário, em sua classificação de negócio jurídico plurilateral (se entre sociedades limitadas) ou estatutário (se entre sociedades anônimas).

Por outro lado, para a constituição de um grupo de sociedades de base contratual, não há que se falar em coparticipação societária, mas, tão somente, na realização de negócios jurídicos de natureza obrigacional.

Assim, em um grupo de sociedades de base contratual, três são os elementos essenciais caracterizadores do grupo, quais sejam:

sinônimas. Por todos, veja-se, no sentido do referido: CARVALHO, Orlando de. Critério e estrutura do estabelecimento comercial: o problema da empresa como objecto de negócios. Coimbra: Coimbra, 1967. A respeito da conceituação do estabelecimento comercial, veja-se: BORGES, João Eunápio. Curso de Direito Comercial Terrestre. Rio de Janeiro: Forense, 1959. p. 283. v. 1. A respeito da definição jurídica de empresa, veja-se: MENDONÇA, José Xavier Carvalho de. Tratado de Direito Comercial Brasileiro. Rio de Janeiro: Freitas Bastos, 1957. p. 482. v. 1. Com relação à definição de empresário, veja-se: FERREIRA, Waldemar Martins. Tratado de Direito Mercantil Brasileiro: o comerciante. Rio de Janeiro: Freitas Bastos, 1939. p. 23. v. 2.

7 As duas primeiras modalidades são as que interessam ao objeto do presente artigo. O grupo de base pessoal é aquele que se dá em virtude da repetição de pessoas físicas nos conselhos de administração das distintas pessoas jurídicas, com capacidade para administrar as mesmas como se se tratasse de uma única personalidade jurídica. Para aprofundamento da tipologia dos grupos de sociedade de base pessoal, veja-se, entre muitos: FERRAZ, Daniel Amin. El Grupo de Sociedades como Mecanismo de Desarrollo de los Países de Periferia. Revista de Direito, Viçosa, MG, v. 1, n.1, p. 205-238, 2004.
A existência de uma relação obrigacional, objeto de contrato (geralmente negócio jurídico complexo), entre as partes;

$O$ poder de direção em controle derivado de tal contrato, em favor de uma das partes e em detrimento dos demais entes societários e;

A dependência econômica também decorrente do desenvolvimento da atividade do grupo.

Claro está, portanto, que para a caracterização do grupo de sociedades de base contratual será fundamental a existência de relações jurídicas contratuais, obrigacionais ${ }^{8}$, entre os membros do grupo, e que tais relações tenham o condão de gerar poder de direção e controle e dependência econômica.

Do até aqui analisado conclui-se que, em sua classificação, o grupo de sociedades possui natureza múltipla, já que caracterizado como negócio jurídico societário (grupo de base societária) ou negócio jurídico obrigacional (grupo de base contratual).

Passa-se, a seguir, a promover-se a distinção entre os grupos de sociedades com estas duas categorias empresariais, quais sejam, os instrumentos de concentração empresarial (negócios societários de fusão, cisão e holding) e os instrumentos de cooperação empresarial (negócio obrigacional de joint venture) ${ }^{9}$.

\section{0 grupo de sociedades de base societária e outros instrumentos de concentração empresarial}

A seguir, aborda-se a distinção do grupo de sociedades de base societária com outros instrumentos de concentração empresarial, quais sejam, a fusão, a cisão e a holding.

Salienta-se que a eleição de tais instrumentos de concentração possui sua lógica jurídico-econômica.

Assim, a fusão foi selecionada por haver sido o instrumento de concentração por excelência, o mais praticado no desenvolvimento econômico e, em virtude do tempo, provavelmente, o mais experimentado.

Por seu turno, a escolha recaiu sobre a cisão para esta análise comparativa com o grupo de sociedades

8 V.g., negócios de distribuição estrito senso, de fornecimento, negócios de franquia, negócios de agência, etc.

9 Para um aprofundamento quanto à tipologia dos grupos de sociedades, entre muitos, veja-se: FERRAZ, Daniel Amin. La concentración empresarial en el comercio internacional - El control de los grupos de sociedades en los EE.UU., la UE y MERCOSUR: un análisis comparado. Valencia: Editorial de la Universidad de Valencia, 2004. 
de base societária por ser qualificada, muitas das vezes, como um instrumento de desconcentração.

Entretanto, ao final, quedará claro que essa "desconcentração" é, em realidade, uma técnica apurada de conversão da empresa plurissocietária em movimento atomístico de concentração empresarial, com dispersão do capital, para dominação de mercado.

Por fim, selecionou-se a figura da holding porque, provavelmente, será este instrumento de concentração que mais se assemelha ao grupo de sociedades de base societária. Ficará demonstrado, contudo, que estes instrumentos não se confundem, sendo mesmo, muitas das vezes, complementários.

A seguir, passa-se a análise de tais elementos diferenciadores, com a ressalva de que o objetivo não é o de esgotar a fundamentação de tais institutos jurídicos, mas, tão somente, promover distinções entre eles e o grupo de sociedades de base societária, para, aí sim, conseguir um melhor enquadramento deste instrumento jurídico de concentração empresarial.

\subsection{Fusão}

No seio da União Européia - UE, a partir da Terceira Diretiva relativa à fusão da S.A. ${ }^{11}$, promoveuse harmonização da matéria. Assim, alguns elementos

10 Veja-se, para aprofundamento do estudo da fusão, entre outros: BEGG, P. F. C. Corporate Acquisitions and Mergers. London: Graham \& Trotman, 1986. p.19 e ss.; WEINBERG, M. A. Take-overs and Mergers. London: Sweet \& Maxwell, 1979; BERCOVITZ, Alberto. La Fusión de Sociedades. In: La Reforma del Derecho Español de Sociedades de Capital. Madrid: Universidad Complutense, 1987, p. 631 e ss.; BERTREL, Jean; JEANTIN, Michel. Fusions et acquisitions de sociétés commerciales. Paris: Litec, 1989, p.47; CHEMINADE, Y. La Nature Juridique des Fusions. In: RTDC p. 15-37, 1970. ; MARTIN, G. La Notion de Fusion. In: RTDC, p. 269-298, 1978. ; SANTAGATA, Carlo. La Fusione fra Società. Napoli: Morano, 1964, p. 153 e ss; TANTINI, Giorgio. Transformazione e Fusione delle Società. In: Tratatto di Diritto Comérciale e di Diritto Pubblico dell'Economia, v. 8., Padova: Cedam, 1985; VENTURA, Raúl. Fusão, Cisão, Transformação de Sociedade. Coimbra: Almedina, 1990, p. 5 e ss.; ANDREU MARTÍ, $\mathrm{M}^{\mathrm{a}}$ del Mar. La nulidad de la fusión de sociedades. Pamplona: Aranzadi Editorial, 2002, p.25 e ss.; VAÑÓ VAÑÓ, Maria José. Fusión heterogénea y cesión global en el sector bancário. Valencia: Tirant lo Blanc, 2001, p. 41 e ss. A respeito da classificação da fusão, vejase, especialmente: BIANCHI, Giorgio. Le Operazioni di Fusione. Torino: Unione Tipografico-Editrice Torinese, 2000, p. 6 e ss.; a respeito da natureza jurídica da fusão, entre outros, veja-se: SACARDULLA, Francesco. La Transformazione e la Fusione delle Società, In: Trattato di Diritto Civile e Comérciale. CICU, Antonio; MESSINEO, Francesco; MENGONI, Luigi. v. 30, t. 2., Milano: Giuffrè editore, 2000, p. 308325.; a respeito do sistema de avaliação de bens das sociedades na fusão, veja-se: PALEA, Vera. Il Rapporto di Cambio nelle Operazioni di Fusione e di Scissione. Torino: Giappichelli Editore, 2000, p. 87-105.

11 Tercera Directiva 78/855/CEE do Conselho, de 09 de outubro de 1978 (Diário Oficial L 295 de 20.10.1978). seriam comuns nas legislações nacionais relativos às fusões.

Os regimes nacionais delimitam a fusão de sociedades mediante elementos comuns: a concepção procedimental; os elementos configuradores ou efeitos parciais, subsequentes à culminação do procedimento traçado para a realização da fusão - a extinção sem liquidação de alguma sociedade, a sucessão universal em todos os direitos e obrigações das sociedades extintas por parte da nova sociedade criada e a entrada dos sócios das sociedades que se extinguem à sociedade nova, mediante a entrega aos mesmos de ações, participações ou cotas - e as modalidades que podem revestir essa instituição única - fusão por absorção ou incorporação e fusão mediante criação de uma nova sociedade $^{12}$.

Conceitualmente, a fusão é um procedimento jurídico através do qual duas ou mais sociedades agrupam seu patrimônio, ativo e passivo, em uma única sociedade, seja nova (fusão criação) ou antiga (fusão absorção). Promoverão, para tal, a prévia dissolução de todas as sociedades que se fusionam (fusão criação), ou de todas menos uma, que mantêm seu patrimônio e sua personalidade jurídica (fusão absorção) ${ }^{13}$.

A fusão de sociedade se diferencia do grupo de sociedades em vários aspectos. Assim, a fusão constitui operação econômica-jurídica de concentração intersocietária que gera, por definição, a extinção da personalidade coletiva das sociedades envolvidas, ao passo que o grupo pressupõe justamente sua manutenção ${ }^{14}$. Esta diferença, unidade ou pluralidade jurídica da empresa emergente, ${ }^{15}$ é absolutamente fundamental para a compreensão do alcance diverso destas duas técnicas jurídicas de concentração empresarial, em termos de eficiência econômica, financeira, organizacional e até jurídica.

12 LARGO GIL, Rita. La fusión de sociedades mercantiles: fase preliminar, proyecto de fusión e informes. 2. ed. Madrid: Civitas, 2000. p.134.

13 Veja-se, por todos para a definição e tipologia da fusão: BROSETA PONT, Manuel. Manual de derecho mercantil.10. ed. Madrid: Editorial tecnos, 2000. p. 342.

$14 \mathrm{Na}$ fusão absorção, a sociedade absorvida transmite a totalidade de seu patrimônio para a sociedade absorvente, desaparecendo como ente jurídico. Por outro lado, na fusão criação, as sociedades fusionadas se extinguem e transferem todo o respectivo patrimônio para uma nova e distinta sociedade.

15 A fusão configura-se como uma empresa unisocietária. Por sua vez, os grupos de sociedades criam uma empresa plurisocietária. 
Por fim, fator determinante na União Europeia para a manutenção das fusões é sua estrutura econômica. Assim, na UE existem 15 milhões de PYMES frente aos 5 milhões existentes nos Estados Unidos. Ainda que, desde o ponto de vista da criação do emprego e das novas tecnologias, tem papel relevante, também é necessário potencializar sua concentração. Tal fato ocorre não somente desde a perspectiva do incremento de sua competitividade, mas também de sua sobrevivência, em um mercado fortemente globalizado, ao supor que a fusão permite vantagens tais como a redução nos custos empresariais de financiamento e da produção $^{16}$.

\subsection{Cisão}

A cisão de uma sociedade é, em contraposição à fusão de sociedades, um procedimento econômico e jurídico de desconcentração empresarial, de especialização e racionalização empresarial, de regionalização da empresa, ou o mecanismo menos oneroso e traumático de separação de acionistas em sociedades muito personalíssimas, com grupos ou sócios bem diferenciados e interesses contrapostos ${ }^{18}$.

À diferença da fusão, a cisão de sociedades constitui técnica de desconcentração ou descentralização societária (demerger), que consiste na operação jurídicoeconômica pela qual uma única sociedade procede à divisão de seu próprio patrimônio, total ou parcialmente, com ou sem extinção da respectiva personalidade jurídica, sendo as partes seccionadas transmitidas para uma nova sociedade ou uma sociedade já existente ${ }^{19}$.

16 SÁNCHEZ MIGUEL, María Candelas. Las fusiones transfronterizas y el derecho de la competência. In: Derecho de Sociedades.. Madrid: McGrawHill, 2002. p. 5088. v. 5.

17 Veja-se, entre outros: MISHKIN, Walter: Techniques in corporate reorganizations. New York: Publisher House, 1972. p. 46; SCHIPPER, K; SMITH, A. The Corporate Spin-Off Phenomenon. In: The Revolution in Corporate Finance. Oxford: Basil Blackwell, 1986. p. 437-444.; SIEGEL, Harold. When Corporations Divide: a financial and legal analysis. In: 79 HarvLR, p. 534-577, 1966.; ROJO, Angel. La Escisión de Sociedades. In: La Reforma del Derecho Español de Sociedades de Capital. Madrid: Universidad Complutense, 1987. p. 663-710; FERREIRA, Durval. Cisão de Sociedades. Coimbra: Almedina, 1985, p. 7.

18 FRAILE BARTALOMÉ, Gregorio; CLEMENTE CLEMENTE, Vicente. Fusiones y Escisiones en las Sociedades Anónimas. Valencia: CISSPRAXIS, 2001. p. 59.

19 Quando se confronta a cisão com a fusão, caracterizando-se a última como uma operação de concentração e a primeira como de desconcentração, toma-se as expressões em um sentido puramente funcional, a fim de sugerir o diferente modus operandi de sua realização.
Assim, a cisão pode constituir um instrumento adequado para a descentralização, desconcentração ou especialização empresariais, motivadas pelas razões de racionalização econômica ou, inclusive, como consequência da execução de políticas antimonopolísticas ${ }^{20}$.

Por meio de uma operação de cisão, uma sociedade pode:

Destacar tão somente uma parte de seu patrimônio para constituir uma nova sociedade (cisão - criação);

Dissolver-se, dividindo todo o seu patrimônio em distintas partes, destinadas à constituição de novas sociedades (cisão - dissolução);

$\mathrm{Ou}$, inclusive, promover a respectiva fusão com sociedades já existentes (cisão - fusão) ${ }^{21}$.

Em suas duas primeiras modalidades, a cisão possui algumas similitudes com o grupo de sociedades.

Assim, tratando-se de uma operação jurídicoeconômica que permite veicular uma lógica de repartição de uma atividade econômica originariamente unitária entre vários entes societários juridicamente autônomos, pode constituir o embrião da formação de um grupo de sociedades.

Tal afirmação é reforçada pelas circunstâncias de que os sócios da sociedade cisionada vêm a dominar as sociedades, novas ou já existentes, destinatárias das parcelas patrimoniais destacadas. Ademais, as operações de cisão-criação ou cisão-dissolução podem constituir métodos alternativos funcionais de constituição de um grupo aos mecanismos de domínio total originário ${ }^{22}$.

É claro que, desde um ponto de vista econômico das empresas, as duas figuras devem considerar-se verdadeiras técnicas jurídicas de suporte de concentração econômica. Uma operará, sobretudo, na fase de expansão pura de uma empresa, a outra em uma fase de respectiva reorganização interna. Veja nesse sentido: CHAMPAUD, Claude. Le Pouvoir de Concentration de la Société par Actions. Paris: Librairies Sirey, 1962. p. 187.

20 RODRÍGUEZ ARTIGAS, Fernando; URIA, Rodrigo; MENÉNDEZ, Aurelio; OLIVENCIA, Manuel. Comentario al régimen legal de las sociedades mercantiles: transformación, fusión y escisión de la sociedad anónima., Madrid: Editorial Civitas, 1993, p. 19-20. v. 3, t. 9. 21 Sobre as varias formas modernas de cisão veja-se: EISENBERG, Melvin. The structure of the corporation: a legal análisis. Boston: Little Brown, 1975. p. 255.

22 A operação de cisão, particularmente cisão-criação, constitui assim um método de constituição de grupos de grupos societários, alternativo ao mecanismo de domínio total originário. As duas figuras são idôneas para realizar a chamada expansão externa da empresa, operando a transformação de uma estrutura originariamente unisocietária em uma estrutura plurisocietária.

Sem embargo, ainda que exista esta identidade funcional, há 
Todavia, deve-se sublinhar que, em si mesma, a cisão constitui uma operação técnico-jurídica neutral. Tratase, tão somente, de um processo de descentralização jurídica, organizativa e patrimonial de uma empresa unitária, sem determinar o respeito das relações futuras dos entes emergentes ${ }^{23}$, e muito menos a subordinação de todos esses a uma direção econômica unitária, exercida pela sociedade cisionada, o que aconteceria no grupo.

\subsection{Holding ${ }^{24}$}

O conceito de holding é utilizado para designar aquelas sociedades que têm como objeto a gestão de uma carteira de títulos.

Neste contexto de sociedades com um objeto financeiro, cabe distinguir dois tipos fundamentais, com a finalidade subjacente da já aludida gestão:

A) Por um lado, existem sociedades que têm por objeto a gestão de uma carteira de participações com uma simples finalidade de rentabilidade dos capitais investidos. São estas as chamadas sociedades financeiras ou sociedades de investimento ${ }^{25}$.

diferenças entre as duas figuras. Desde logo, ao passo que a cisão simples pode ser operada por qualquer tipo societário, a constituição de uma sociedade unipessoal somente poderá ser operada sob a forma de uma sociedade anônima, quanto à sociedade criada, nova. Por outro lado, a diferença está no âmbito dos respectivos orçamentos de criação. Assim, ao passo que na cisão os bens destacados devem ser determinados, os ingressos na sociedade unipessoal podem constituir-se em bens de qualquer espécie.

Finalmente, no âmbito do regime jurídico aplicável. Uma primeira diferença tem que ver com a posição relativa dos sócios e administradores da sociedade cisionada e criadora, resultante da operação em análise. Ao passo que na cisão-criação as partes sociais na nova sociedade são atribuídas aos sócios da sociedade cisionada, mantendo estes um poder de intervenção na condução dos negócios sociais da nova sociedade, na operação de domínio total não passará o mesmo, já que as partes sociais passam a pertencer, exclusivamente, à própria sociedade criadora (o que equivale a um reforço, por via indireta, dos poderes dos órgãos de administração em detrimento do colegiado dos sócios). Veja, neste sentido: ANTUNES, José A. Engrácia. Os direitos dos sócios da sociedade-mãe na formação e direção dos grupos societarios. Porto: UCP, 1996. p. 45.

23 Que costumam evoluir no mercado, ou como entidades independentes, ou como unidades dependentes entre si.

24 Veja: DAEMZ, Herman. The bolding company and corporate control. Boston: Leiden, 1978. p. 51; GALGANO, Francesco. Qual è l’oggetto sociale della holding? CeIm, v. 2, p.327-343, 1986. ; LIBONATI, Berardino. holdings e investment trusts. Milano: Giuffrè, 1977, p.32. ; VENTURA, Raúl. Participações unilaterais de sociedades em sociedades e sociedades gestoras de participacões noutras sociedades. In: XXIX RSI, p. 19-101, 1980.

25 HAMEL, Joseph. Les sociétés dinvestissement. Paris: A.N.S.A. 128, 1960. p.22.; SENN, Georges. Les sociétés de investissement en droit
B) Por outro lado, há sociedades que têm por objeto a gestão de participações sociais com o objetivo de adquirir o controle das sociedades, por meio do exercício dos direitos sociais inerentes ao capital (máximo direito ao voto). Por este segundo tipo de sociedades se costuma reservar, na doutrina especializada, a denominação de sociedade bolding $g^{26}$.

A holding constitui um instrumento valioso de reorganização dos grupos de sociedades. Sem embargo, não se pode confundir com o próprio grupo.

Enquanto este último constitui uma forma organizativa (informal) da atividade econômica da empresa moderna como empresa plurissocietária; a holding representa tão somente uma forma organizativa (formal) do respectivo ápice hierárquico. Nesse sentido, aparece como uma das modalidades jurídicosocietárias possíveis que podem revestir a sociedade matriz de um grupo. Naturalmente, a adoção da forma holding por uma determinada sociedade constitui um forte indício da existência de um grupo de sociedades, já que seu objeto contratual (constituído pela administração de participações sociais como forma indireta do exercício de atividades econômicas) está particularmente destinado a organizar o exercício de uma direção econômica unitária da sociedade sobre seus participantes.

\section{français et droit comparé. Paris: Sirey, 1956.}

26 No quadro das sociedades cujo objeto social consiste na gestão de uma carteira de participações sociais, aquele que diferencia os dois tipos societários referidos é o objetivo ou finalidade para gestão da mesma carteira de participações. No primeiro caso, a gestão das participações sociais constitui um fim em si mesmo, no sentido de que a sociedade participante pretende tão somente maximizar a rentabilização do investimento de capitais feita nas sociedades participadas, seja mediante a percepção de dividendos (lucros), seja pela obtenção de mais valias mediante a rotação da carteira de títulos mobiliários. Importante sublinhar como ponto característico deste tipo de participação o feito de que a sociedade não pretende nenhuma espécie de controle, mas, tão somente, ganhos de capitais.

No segundo caso, pelo contrário, a gestão de participações sociais constitui um meio em relação a um fim, ou seja, constituem um puro instrumento de controle e gestão indireta dos negócios das sociedades participantes. No âmbito das próprias sociedades holdings poderia, ainda, proceder-se ulterior classificação. Assim, estariam classificadas as holdings entre aquelas que tem por objeto tão somente a gestão de uma carteira de participações sociais entre outras sociedades como forma indireta de exercício de atividades econômicas (boldingspuras), e aquelas que, além de ter as participações sociais e gerir a carteira de participações exercem outras atividades, de natureza industrial ou comercial, no âmbito do respectivo objeto social (holdings mistas). 
Não obstante, deve-se apontar que nada pode ser inferido de tal circunstância, nem em geral nem em definitivo, ademais da natureza e intensidade das relações existentes de coligação intersocietárias, dependendo tudo, em última instância, da apreciação das circunstâncias de cada caso em concreto.

Assim, uma sociedade bolding poderá:

a) ser titular de uma vasta estrutura de situações de coligação intersocietária, desde as relações de grupo propriamente ditas (por meio de participações totalitárias que assegurem o domínio total das participantes), até as relações de domínio (máxima, por meio de participações minoritárias);

b) bem como as próprias relações de simples participação (participações oscilantes entre 10\% e 50\%);

c) inclusive gerir participações irrelevantes desde o ponto de vista de aplicação de uma disciplina especial das sociedades coligadas.

Conclui-se, dessa forma, que a sociedade holding não se confunde com o grupo de sociedades, podendo ser, tão somente, uma das formas de organização jurídica da matriz do grupo (ou sociedade mãe).

\section{0 grupo de sociedades a Joint Venture}

O contrato de joint venture é uma das espécies de negócio associativo. Constitui-se mediante a associação de empresas em uma terceira corporação (incorporated joint venture - joint venture societária), ou mediante a constituição de consórcios de empresas (unincorporated joint venture - joint venture contratual).

Poderá se realizar em áreas estritamente tecnológicas (v.g., investigações em biotecnologia); em exploração mineral; entre empresas estrangeiras e nacionais (para vencer barreiras tarifárias); para mobilizar capitais e realizar obras que requeiram tecnologias não dominadas por uma única empresa. É precisamente por esse amplo âmbito de atuação que as joint venture alcançaram, atualmente, um grande desenvolvimento, com forte presença no mercado mundial.

É importante notar que a joint venture, em sua vertente societária, classifica-se como um instrumento de concentração empresarial. Por seu turno, em sua vertente contratual, unincorporated joint venture (consórcio de empresas no Direito brasileiro ${ }^{27}$ ), classifica-se como um instrumento de cooperação empresarial.

27 Lei 6.404, de 15 de dezembro de 1976, publicada no DOU
Cumpre ressaltar que a joint venture muito se aproxima do grupo de sociedades. Assim, também como este, pode ser classificada como negócio jurídico societário (plurissocietário ou estatutário incorporated joint venture/grupo de base societária), ou como negócio jurídico obrigacional (unincorporated joint venture - consórcio /grupo de sociedades de base contratual).

Contudo, por mais que se assemelhe aos grupos de sociedades, em um verdadeiro paralelismo de classificações, com este não se confunde. Passa-se a análise mais aprofundada da joint venture e de suas distinções com o grupo de sociedades.

\subsection{A joint venture e as relações internacionais}

A joint venture aparece como resultado da criação civilista e de interesse prático e consuetudinário do Common Law. É, portanto, uma figura originada da prática dos negócios e da própria jurisprudência americana $28 / 29$.

É uma forma de cooperação entre empresas independentes. Apesar das dificuldades de sua definição jurídica, que poderia gerar sua baixa adoção nas relações mercantis internacionais das empresas transnacionais, alcançou alta internacionalização. Mais ainda, a internacionalização deste contrato foi possível exatamente pela flexibilidade de sua constituição, proporcionando uma perfeita adequação aos negócios internacionais (negócios estes que demandam elevada diversidade de formas jurídicas para sua constituição).

Sua internacionalização se promoveu por meio do desenvolvimento da indústria petrolífera e de minerais.

de 17/12/1976 . Dispõe sobre as Sociedades por Ações. Regula o consórcio de empresas no artigo 278 e seguintes, que é aplicado, supletivamente, para a constituição de outros tipos de consórcio, mesmo quando não envolvam sociedades anônimas. Ademais, o Estatuto da Terra, Lei $\mathrm{n}^{\circ} 4.504$, de 30 de novembro de 1964, publicada no DOU em 31/11/1964, também regula o consórcio, em seu artigo 14, $\ 1^{\circ}$ : “\$1 PPara a implementação dos objetivos referidos neste artigo, os agricultores e trabalhadores rurais poderão constituir entidades societárias por cotas, em forma consorcial ou condominial, com a denominação de "consórcio" ou "condomínio", nos termos dos arts. $3^{\circ}$ e $6^{\circ}$ desta Lei. (Incluído pela Medida Provisória ${ }^{\circ}$ 2.183-56, de 2001)".

28 Veja: BAPTISTA, Olavo; RIOS SIERRALTA, Aníbal. Aspectos jurídicos del comercio internacional. Lima: Fondo Editorial, 1992. p. 185.

29 Veja a respeito do desenvolvimento internacional do contrato de joint venture: SIERRALTA RÍOS, Aníbal. Joint Venture internacional. Buenos Aires: Ediciones Depalma, 1996. p. 30-38. 
As atividades desenvolvidas por estas sociedades no estrangeiro não se qualificavam na estrita operação de importação/exportação, a qual se assemelha a uma conversa entre vizinhos (frente a frente), cada qual em sua casa, em seu território. Ao contrario, as sociedades minerarias e petrolíferas tiveram que ir mais além do habitual, isto é, erigir nesse universo estranho (estrangeiro) as estruturas jurídicas suscetíveis de acolher seus investimentos ${ }^{30}$.

A partir desse entendimento, a doutrina internacional tem definido a joint venture transnacional, concentração mais ampla do que aquela dada pelo direito anglo-saxão (originário).

A internacional joint ventures passa a ser entendida como mecanismo de cooperação entre empresas, o qual tem caráter contratual, sem forma específica. Possui natureza associativa (divisão dos meios e dos riscos), apresentando objetivos e duração limitada ou ilimitada ${ }^{31}$.

Nem sempre a consecução dos benefícios é o elemento essencial da joint venture internacional. É possível a existência de joint ventures em que os benefícios não aparecem como um fim imediato, se não meramente mediato. Esta possibilidade se encontra presente na criação de uma unidade comum de fabricação; centros comuns de investigação; centrais de compra; etc. Os co-ventures ganharão com a economia que poderá resultar de tais associações e com a redução dos custos que se observará ${ }^{32}$.

Outro elemento caracterizado da joint venture originária seria seu caráter ad hoc. Tal ponto nem sempre estará presente na international joint venture, uma vez que perdeu parte de sua relevância na prática comercial internacional. Assim, os contratos associativos para exploração de recursos naturais, que teriam caráter duradouro, conduzindo a uma instalação estável da empresa no mercado onde está localizado o investimento, poderia constituir-se sob a forma de international joint venture ${ }^{33}$.

30 BONVICINI, Daniele. Le joint venture: tecnica giuridica e prassi societaria. Milano: Giuffrè, 1977. p. 8.

31 BASSO, Maristela. Joint venture. Porto Alegre: Livraria do Advogado, 1994. p. 35.

32 BAPTISTA, Luiz Olavo; DURAND-BARTHEZ, Pascal. Les associations dienterprises (joint ventures) dans le comerse international. Paris: FEC, 1991. p. 63.

33 ASTOLFI; Andrea. Contratto internazionale de joint venture. Revista delle Societá, Milano, ano 22, p. 844, 1977.
Pode-se concluir esse ponto afirmando que, em sua internacionalização, a joint venture passou a ser mais flexível que em sua origem no direito anglo-saxão. Por sua vez, tal flexibilização transformou o entendimento do instituto ainda mais difícil, bem como sua definição.

No âmbito internacional se tomou o nome e o conceito global da joint venture corporation, mas não a natureza jurídica da joint venture original, impossível de passar para o campo internacional, ao não poder contrapô-la à partnership. No entanto, após essa fase de internacionalização, ficaram algumas características, as mais importantes: flexibilidade, controle conjunto e dever de fidelidade ${ }^{34}$.

\subsection{Disciplina jurídica da joint venture}

A joint venture, no sentido que é entendida hoje, deriva, em grande medida, de seu desenvolvimento a partir do pós-guerra ${ }^{35}$. Em virtude de sua flexibilidade e facilidade de constituição, a definição da joint venture continua em constante evolução ${ }^{36}$. A figura, no campo internacional, carece de uma disciplina unitária.

Em uma perspectiva europeia, vista sob a ótica do Direito inglês, o sugestivo nome joint venture implica exteriorizar o esforço comercial de duas ou mais partes. O termo seria utilizado para indicar cooperação entre dois ou mais partícipes; cooperação, da qual, o primeiro efeito seria a criação dos meios para facilitar a união de interesses ou mudanças de recursos ${ }^{37}$.

Outra forma de definir as joint ventures será levando-se em consideração o local de constituição do empreendimento comum: se se trata de um país com economia avançada ou se um país em vias de desenvolvimento ${ }^{38}$.

Desta forma, na primeira hipótese, em países de economia avançada, a joint venture constitui, geralmente, um instrumento de concentração dos investidores (os investidores terão a possibilidade de recorrer a um novo instrumento jurídico para concentrar seu capital)

34 MIQUEL RODRÍGUEZ, Jorge. La sociedad conjunta: Joint venture corporation. Madrid: Editorial Civitas SA, 1998. p. 100.

35 HERZFELD, Edgar. Joint ventures. 2. ed. Bristol: Jordans, 1991. p. 3.

36 LE PERA, Sergio. Joint ventures y otras formas de cooperación entre empresas independientes. Buenos Aires: La Ley, 1977. p. 71.

37 KLING, Edward; BURLEY, Stephen. Joint venture in Europe. London: Butterworths, 1991. p. 1.

38 Entre outros: STRENGER, Irineu. Contratos Internacionais do comércio. 2. ed. São Paulo: Revista dos Tribunais, 1992. p. 351. 
Por outro lado, nos PVDs, as joint ventures conformam instrumentos de cooperação industrial essencial para a realização de finalidades econômicas de crescente importância, tais como a ampliação do mercado trabalhista, a atualização tecnológica, a produção em economia de escala, etc. Ademais, seria uma forma de regulamentação dos investimentos estrangeiros, com o fim de favorecer a participação local (do receptor de investimentos) na gestão do empreendimento, garantindo sua presença no âmbito de desenvolvimento nacional.

Finalmente, não somente nos países de economia avançada, mas também nos PVDs , a joint venture é definida como acordos comerciais entre empresas, com vocação para a realização das mais variadas formas de colaboração e inter-relação econômica.

Assim, tais acordos podem possuir natureza puramente contratual (uncorporated joint venture - consórcio de empresas) ou, inversamente, dar origem à criação de um novo ente societário (incorporated joint venture - joint venture societária). Podem ser celebrados entre empresas pertencentes a um mesmo país ou, com maior frequência, entre empresas de nacionalidade distinta. Podem versar sobre múltiplos setores da atividade econômica, da produção e da I\&D até a colaboração tecnológica e administrativa ${ }^{39}$.

Alguns pontos caracterizadores ${ }^{40}$ da joint venture são sua origem e seu caráter contratual; definição do direito dos partícipes, independentes entre si; o sistema de governança e gestão conjunta; sua natureza associativa; a determinação de seu objeto e/ou duração; o caráter não formal do contrato; e facilidade de sua constituição.

Depois de analisadas as definições propostas e já com a certeza de não ser esta definitiva em virtude da flexibilidade e da facilidade de constituição de tal instrumento, entende-se que a international joint venture é um acordo de cooperação (sem forma própria - unincorporated joint venture) ou de associação (corporated joint venture) entre duas ou mais pessoas, físicas ou jurídicas, de direito público ou privado. Os partícipes podem exercer a administração conjunta do empreendimento e têm o dever de buscar um objetivo comum. Ademais, atuam na expectativa de benefícios meramente mediatos. Finalmente, podem constituir-se entre pessoas nacionais ou estrangeiras, sendo a segunda hipótese a mais frequente.

39 ANTUNES, José A. Engracia. Os grupos de sociedades. Coimbra: Almedina, 1993. p. 71-72.

40 Nesse sentido: BAPTISTA, Luiz Olavo. 1981. Les joint venture dans les relations internacionales. Paris II, p. 87-88 (Tesis de doctoramiento - Université de Droit d'économie et des Sciences Sociales de Paris).

\subsection{Tipologia}

Derivada da flexibilidade de constituição da joint venture existiria classificação de seus tipos, a saber:

a) Em relação ao ponto de vista organizativo: incorporated joint venture e unicorporated joint venture ${ }^{41}$;

b) Segundo os setores da atividade: manufatureiras; exploração de recursos naturais; agrupações bancárias; agrupações para construção de obra certa; investigação e produção comum; de investimento; de serviços e; comerciais $^{42}$;

c) Em relação à forma de concentração: horizontal e vertical ${ }^{43}$;

d) Em relação ao grau de participação em dominação: participativa e independente ${ }^{44}$.

\subsection{Joint venture e o grupo de sociedades}

O termo joint venture, como já referido, se formou na prática internacional para designar um vasto setor de acordos comerciais entre empresas, com vocação para realizar as mais variadas gamas de colaborações e interrelações econômicas.

Tais acordos podem possuir natureza puramente contratual (unincorporated joint venture) ou, inversamente, dar origem à criação de um novo ente societário (incorporated joint venture). Podem ser celebradas entre empresas pertencentes ao mesmo país ou, como é mais comum, entre empresas de diferentes nacionalidades. Podem versar sobre múltiplos setores da atividade econômica, de produção ou até da colaboração tecnológica e administrativa ${ }^{45}$.

41 BONVICINI, Daniele. Le joint venture: tecnica giuridica e prassi societaria. Milano: Giuffrè, 1977. p. 181.

42 MORAES NETO, Deraldo Dias de. Joint venture. Revista do Mestrado em direito da UFBA, Salvador, n. 3, p. 248-251, jul./jun. 1993. 43 CHUliá VICENTE, E. ; BELTRÁN ALANDETE, T. Aspectos jurídicos de los contratos atípicos., 4. ed. Barcelona: José Maria Bosch editor, 1999. p. 206. v. 1.

44 LAMY FILHO, Alfredo; PEDREIRA, José Luiz Bulhões. $A$ Lei das S.A. Rio de Janeiro: Renovar, 1992. p. 353.

45 Veja entre outros: BROWN, J. T. International Joint Ventures Contracts in English Law. DPCI, n. 2, p. 193-244, 1979. ; FRIEDMANN, W. G.; BEGUIN, J. P. International Business Joint Ventures in Developing Countries. New York: Columbia University Press, 1971. p. 3.; JAEGER, Walter. Joint Venture: origine, nature, developments. 4 Washburn Law Journal, n. 1, p. 9-44, 1964. ; PROPERSI, Antonio. Le Joint Ventures: gli accordi fra imprese. Roma: Buffetti, 1987. p. 67; PEREIRA, Amorim. O Contrato de Joint 
A figura da joint venture, ainda que não confundida com o grupo de sociedade, se entrelaça com ele e de forma específica com o caso das chamadas filiais comuns (incorparated joint venture) ${ }^{46}$.

Assim, por um lado, a constituição de filiais comuns constitui uma forma privilegiada de implementação dos grupos de sociedades multinacionais. $\mathrm{O}$ mesmo ocorre pelos obstáculos legais impostos aos investimentos estrangeiros pelos sistemas nacionais de licenças nacionais (especialmente se exige uma participação mínima do capital nacional) ${ }^{47}$. Além disso, as condições econômicas próprias das empresas envolvidas, os grupos são obrigados a garantir a sua presença nos mercados locais por meio da criação de empresas comuns com parceiros nacionais ${ }^{48}$. Por outro lado, a filial comum constitui um instrumento de colaboração dos próprios grupos societários entre $\mathrm{si}^{49}$.

Finalmente, em ambos os casos, constituído e controlado por duas ou mais empresas sócias, a filial comum dará sempre origem a problemas de domínio intersocietário (em particular sempre que as participações sejam igualitárias, gerando problemas de domínio múltiplo horizontal).

\section{Conclusão: o grupo de sociedades e as relações de domínio múltiplo}

O direito das sociedades tradicionalmente se baseia no postulado da independência da sociedade mercantil. Constituída a sociedade mercantil individual e autônoma, aparece composta de uma plêiade de sócios individuais e gerenciada por administradores independentes, que procuram maximizar os lucros sociais.

A emergência do fenômeno do controle intersocietário, surgida na sequência do movimento de

Venture. Lisboa: ICEP, 1988.

46 PINHEIRO, Luís de Lima. Joint Venture: contrato de empreendimento comum em direito internacional privado. Lisboa: Edições Cosmos, 1998. p. 186.

47 WALLACE, Cynthia D. Legal Control of the Multinational Enterprise. Boston/London: Martinus Nijhoff, 1982. p. 121.

48 Principalmente pelo fato que, geralmente, a empresa estrangeira possui a capacidade tecnológica ou comercial, mas não tem o conhecimento necessário do mercado local, necessitando da empresa nacional. Veja: ASTOLFI, Andrea. Il Contratto Internazionale de Joint Venture. Revista delle Societá, Milano, ano 22, p. 843, 1977.

49 JEANTIN, Michel. La filiale commune, moyen de colaboration entre sociétés et groupes de sociétés. Paris: Libraries Techniques, 1976. p. 46. concentração econômica dos dias atuais, vem mudar profundamente esta situação.

Efetivamente, verifica-se que o capital social de muitas sociedades não se encontra disperso em pequenos investidores singulares, mas sim nas mãos de outras pessoas coletivas que desenvolvem uma atividade econômica-empresarial. Tais pessoas coletivas, especialmente outras sociedades mercantis, buscam, por meio de seu patrimônio, assegurar o exercício de um domínio e controle sobre a gestão de outras empresas societárias, até então independentes. Neste sentido, a criação de um estatuto de dependência intersocietária pode constituir uma fonte de graves desequilíbrios e contradições para as sociedades controladas.

Estes problemas podem surgir em dois planos:

1) Por um lado, no âmbito da estrutura patrimonial e organizacional da própria sociedade dependente, bem como outros destinatários jurídico-societários que com ela estão em contato (o respectivos sócios, ou credores sociais).

2) Por outro lado, no âmbito da eficiência das normas jurídico-societárias em geral, já que o domínio intersocietário é suscetível de ser usado como uma ferramenta de incumprimento das normas que foram concebidas originariamente para regular a situação dos entes independentes (o direito societário tradicional).

Além disso, em geral, as relações de domínio entre as sociedades revestirão um caráter direto e bilateral. Assim, uma empresa (dominante) exerce direta e imediatamente uma influência dominante sobre outra sociedade (dependente). Trata-se, pois, de relações estabelecidas diretamente de sociedade para sociedade (ligações diretas), envolvendo apenas os dois entes jurídico-societários (relações bilaterais).

Não obstante, a realidade societária é muito mais interessante.

$\mathrm{Na}$ verdade, há casos frequentes em que a relação de domínio assume uma configuração variada. Este fato ocorre por serem distintas as sociedades envolvidas, além do exercício de influência dominante gerar efeitos divergentes daqueles praticados em uma situação normal de domínio individual (empresa individual).

Assim, pode-se afirmar:

a) À medida em que (se a idéia for de proporção, substitua por à medida que) a influência de domínio é exercida indiretamente pela sociedade dominante, por meio da interposição de uma terceira sociedade, tem-se um domínio múltiplo vertical; 
b) Se a influência de domínio múltiplo é exercida conjuntamente pela sociedade dominante e outra sociedade dependente, tem-se uma situação de domínio múltiplo horizontal; $\mathrm{e}$

c) Finalmente, quando a influência de domínio é exercida simultaneamente por distintas sociedades, tem-se uma situação de domínio e dependência plurilaterais.

Passa-se a uma análise breve dessas distintas formas de domínio no seio do grupo de sociedades.

a) Com a designação domínio múltiplo verticat5 pretende-se abarcar todas aquelas relações em que uma sociedade exerce uma influência dominante sobre outra sociedade, a qual, por sua vez, exerce um mesmo tipo de influência sobre uma terceira sociedade (e assim sucessivamente), estabelecendo uma cadeia vertical de domínio ${ }^{51}$.

b) Com a designação domínio múltiplo horiz̧ontal, pretende-se abarcar aqueles casos em que a sociedade se encontra dominada direta e simultaneamente por outras duas sociedades que são, entre si, independentes.

Sob o ponto de vista econômico, a filial comum constitui um instrumento privilegiado de cooperação entre empresas, traduzindo a situação de uma empresa que é constituída ou controlada por duas ou mais empresas diferentes e independentes entre si. Assim, pretendem realizar determinados objetivos comuns, tais como a cooperação em diversas áreas da produção; obtenção do serviço de apoio às respectivas atividades produtivas próprias; ou o simples objetivo de realização dos ganhos conjuntos; etc. ${ }^{52}$.

50 A problemática do domínio múltiplo vertical constitui um único aspecto das relações de coligação intersocietaria de caráter vertical ou piramidal, uma vez que reporta tão somente às relações de domínio entre as sociedades. As relações de coligação vertical entre as sociedades existem, todavia, relativamente a todo tipo de sociedades coligadas, englobando igualitariamente as sociedades em relação de participação simples e recíprocas, as sociedades em relação de grupo, bem como as sociedades que estabeleçam, entre si, diferentes tipos de relação de coligação ou de cooperação.

51 Exemplificando: Se a empresa $A$ detém $60 \%$ do capital social da sociedade $B$ e esta por sua vez, detém $60 \%$ do capital da sociedade $C$, então estaria se diante de um caso de domínio múltiplo vertical, onde $A$ domina diretamente $B$ e indiretamente $C$. Assim, a mesma sociedade (mãe), está simultaneamente em relação de domínio com uma sociedade (filial) e ainda, em virtude do efeito piramidal associado à influência indireta, tem um domínio indireto com outra sociedade dependente de sua filial (que no exemplo será a sociedade C).

52 Cumpre sublinhar que são vários os instrumentos jurídicos que permitem um tal objetivo de cooperação interempresarial, tais como: o contrato de unincorporated joint venture (consórcio de empresas); ou o contrato de grupo paritário; etc.
Sob o ponto de vista jurídico, a filial comum possui relevância não somente para o direito da concorrência ${ }^{53}$, mas também, sempre que as empresas envolvidas revistam a forma societária, para o próprio direito das sociedades.

Em relação ao domínio múltiplo horizontal, podese dizer que a problemática jurídico-societária de fundo, subjacente em tais relações, consiste em saber se será admissível que uma sociedade esteja sujeita, simultaneamente, ao exercício de uma influência dominante por parte de duas sociedades reciprocamente independentes. Em outras palavras, se é admissível a dependência plural ${ }^{4}$. Protótipo desta situação é o caso das filiais 50:50 (fifthy-fifthy subsidiaries), sociedade cujo capital social é controlado total e igualitariamente por duas outras sociedades.

c) Finalmente, cumpre destacar que a pluralidade de sujeitos de uma relação de domínio, já seja de sujeitos ativos (sociedades dominantes), já seja de sujeitos passivos (sociedades dependentes), pode originar a formação de domínio e dependência plurilaterais. Assim, são possíveis situações de domínio-dependência simultâneo. Nestes casos, a sociedade $A$ domina a sociedade $B$ e esta, por sua vez, domina a sociedade $C$. Desta forma, e neste caso, a sociedade $B$ é, simultaneamente, dominante (relativamente à $C$ ) e dependente (em relação à $A$ ). Também cabem situações de dependência plural. Assim, no mesmo exemplo, a sociedade $C$ é, ao mesmo tempo, dependente da sociedade $A$ e dependente da sociedade $B$.

Outra possibilidade é a existência de situações de domínio plural. Por exemplo, a sociedade $A$ detém maioria dos votos nas sociedades $B, C$ e $D$, sendo dominante, por isso mesmo, em relação a todos elas.

53 Veja: CORDEIRO, António Robalo. As Coligações de Empresas e os Direitos Português e Comunitário da Concorrência. XXIX Revista de Direito e Estudos Sociais, Lisboa, p. 82, 1987.; BALEKJIAN, UAE H. Parent and subsidiary companies under european competition law. In: Legal Aspects of International Business Transactions. North-Holland: Elsevier Science, 1984. p. 379.

54 Há que distinguir, todavia, os casos de dependência plural imprópria e dependência plural própria. Os primeiros são consequência de relações de domínio múltiplo vertical, que não suscitam dúvidas, como acima visto (exemplo: $A$ domina $B$ e esta domina $C$. Logo, $C$ é dependente, simultaneamente, de $A$ e $B)$. Os segundos demonstram uma situação distinta, já que as sociedades dominantes são independentes entre si (exemplo: $A$ e $B$ detém, cada uma, $50 \%$ do capital de $C$. Poderia se considerar que neste caso $C$ é dependente de $A$ e $B)$. 
Em conclusão, é significativo mencionar a necessidade de entendimento do grupo de sociedades desde uma perspectiva econômica para uma aproximação à delimitação desta figura jurídica.

A utilização do instrumento do grupo de sociedades está clara como o mecanismo mais utilizado, pelos operadores do mercado, para os investimentos internacionais. $\mathrm{O}$ grupo de sociedades é, neste momento, o instrumento jurídico por excelência que permite com maior fluidez a internacionalização do capital.

Conclui-se, afirmando que o grupo de sociedades se distingue dos instrumentos de concentração e cooperação analisados, apresentando-se como um instrumento de concentração de terceira geração, permitindo a concentração na pluralidade, ou seja, a criação de entes plurissocietários. 


\section{Referências}

ANDREU MARTÍ, Ma del Mar. La nulidad de la fusión de sociedades. Pamplona: Aranzadi Editorial, 2002.

ANTUNES, José A. Engrácia. Os grupos de sociedades. Coimbra: Almedina, 1993.

ANTUNES, José A. Engrácia. Os direitos dos sócios da sociedade-mãe na formação e direção dos grupos societarios. Porto: UCP, 1996.

ASTOLFI; Andrea. Il contratto internazionale de Joint Venture. Revista delle Societá, Milano, ano 22, 1977.

BALEKJIAN, UAE H. Parent and subsidiary companies under european competition law. In: Legal aspects of international business transactions. North-Holland: Elsevier Science, 1984.

BAPTISTA, Luiz Olavo; DURAND-BARTHEZ, Pascal. Les associations d'enterprises (Joint Ventures) dans le comerse international. Paris: FEC, 1991.

BAPTISTA, Luiz Olavo. 1981. Les joint venture dans les relations internacionales. Paris II, p. 87-88 (Tesis de doctoramiento - Université de Droit d économie et des Sciences Sociales de Paris).

BAPTISTA, Luiz Olavo; RIOS SIERRALTA, Aníbal. Aspectos jurídicos del comercio internacional. Lima: Fondo Editorial, 1992.

BASSO, Maristela. Joint venture. Porto Alegre: Livraria do Advogado, 1994.

BEGG, P. F. C. Corporate Acquisitions and Mergers. London: Graham \& Trotman, 1986.

BERCOVITZ, Alberto. La Fusión de Sociedades. In: La Reforma del Derecho Español de Sociedades de Capital. Madrid: Universidad Complutense, 1987.

BERTREL, Jean; JEANTIN, Michel. Fusions et acquisitions de sociétés commerciales. Paris: Litec, 1989.

BIANCHI, Giorgio. Le Operazioni di Fusione. Torino: Unione Tipografico-Editrice Torinese, 2000.

BONVICINI, Daniele. Le joint venture: tecnica giuridica e prassi societaria. Milano: Giuffrè, 1977.
BORGES, João Eunápio. Curso de direito comercial terrestre. Rio de Janeiro: Forense, 1959. v. 1.

BRASIL. Lei $n^{\circ}$ 4.504, de 30 de novembro de 1964. Disponível em:< http://www.planalto.gov.br/ ccivil_03/leis/14504.htm>

BRASIL. Lei 6.404, de 15 de dezembro de 1976. Disponível em:< http://www.planalto.gov.br/ccivil_03/leis/ 16404consol.htm>

BROSETA PONT, Manuel. Manual de derecho mercantil. 10. ed. Madrid: editorial tecnos, 2000.

BROWN, J. T. International Joint Ventures Contracts in English Law. DPCI, n. 2, 1979.

CARVALHO, Orlando de. Critério e estrutura do estabelecimento comercial: o problema da empresa como objecto de negócios. Coimbra: Coimbra Editora, 1967.

CHAMPAUD, Claude. Le pouvoir de concentration de la société par actions. Paris: Librairies Sirey, 1962.

CHEMINADE, Y. La Nature Juridique des Fusion. RTDC, 1970.

CHULIÁ VICENTE, E. ; BELTRÁN ALANDETE, T. Aspectos jurídicos de los contratos atípicos. 4. ed. Barcelona: José Maria Bosch editor, 1999. v. 1.

CORDEIRO, António Robalo. As Coligações de Empresas e os Direitos Português e Comunitário da Concorrência. XXIX Revista de Direito e Estudos Sociais, Lisboa, 1987.

DAEMZ, Herman. The Holding Company and Corporate Control. Boston: Leiden, 1978.

GALGANO, Francesco. Qual è l’Oggetto Sociale della Holding? In: CeIm, v. 2, p.327-343, 1986.

EISENBERG, Melvin. The Structure of the Corporation: a legal análisis. Boston: Little Brown, 1975.

FERRAZ, Daniel Amin. El grupo de sociedades como mecanismo de desarrollo de los países de periferia. Revista de Direito, Viçosa, MG, v. 1, n. 1, p. 205-238, 2004.

FERRAZ, Daniel Amin. La concentración empresarial en el comercio internacional: el control de los grupos de sociedades 
en los EE.UU., la UE y MERCOSUR: un análisis comparado. Valencia: Editorial de la Universidad de Valencia, 2004.

FERREIRA, Durval. Cisão de Sociedades. Coimbra: Almedina, 1985.

FERREIRA, Waldemar Martins. Tratado de Direito Mercantil Brasileiro: o comerciante. Rio de Janeiro: Livraria Freitas Bastos, 1939. v. 2.

FRAILE BARTALOMÉ, Gregorio; CLEMENTE CLEMENTE, Vicente: Fusiones y escisiones en las sociedades anónimas. Valencia: CISSPRAXIS, 2001.

FRIEDMANN, W.G.; BEGUIN, J.P. International business joint ventures in developing countries. New York: Columbia University Press, 1971.

HAMEL, Joseph. Les Sociétés d'Investissement. Paris: A.N.S.A. $128,1960$.

HERZFELD, Edgar. Joint ventures. 2. ed. Bristol: Jordans, 1991.

JAEGER, Walter. Joint Venture: origine, nature, developments. 4 Washburn Law Journal, n. 1, 1964.

JEANTIN, Michel. La filiale commune, moyen de colaboration entre sociétés et groupes de sociétés. Paris: Libraries Techniques, 1976.

KLING, Edward; BURLEY, Stephen. Joint venture in Europe. London: Butterworths, 1991.

LAMY FILHO, Alfredo; PEDREIRA, José Luiz Bulhões. A Lei das S.A. Rio de Janeiro: Renovar, 1992.

LANGEFELD-WIRTH, Klaus. Les Joint Ventures internationals. Paris: GLN Joly editions, 1992.

LARGO GIL, Rita. La fusión de sociedades mercantiles: fase preliminar, proyecto de fusión e informes, 2. ed., Madrid: Civitas, 2000.

LE PERA, Sergio. Joint ventures y otras formas de cooperación entre empresas independientes. Buenos Aires: La Ley, 1977.

LIBONATI, Berardino. Holdings e Investment Trusts. Milano: Giuffrè, 1977.
MARTIN, G. La Notion de Fusion. RTDC, 1978.

MENDONÇA, José Xavier Carvalho de. Tratado de Direito Comercial Brasileiro. Rio de Janeiro: Livraria Freitas Bastos, 1957. v. 1.

MIQUEL RODRÍGUEZ, Jorge. La sociedad conjunta: Joint venture corporation. Madrid: Editorial Civitas SA, 1998.

MISHKIN, Walter. Techniques in corporate reorganizations. New York: Publisher House, 1972.

MORAES NETO, Deraldo Dias de. Joint venture. Revista do Mestrado em direito da UFBA, Salvador, n. 3, jul./jun. 1993.

PALEA, Vera. Il rapporto di cambio nelle operazioni di fusione e di scissione. Torino: Giappichelli Editore, 2000.

PEREIRA NETO, Mario. Joint Ventures com a União Européia. São Paulo: Aduaneiras, 1995.

PEREIRA, Amorim. O Contrato de Joint Venture. Lisboa: ICEP, 1988.

PINHEIRO, Luís de Lima. Joint Venture: contrato de empreendimento comum em direito internacional privado. Lisboa: Edições Cosmos, 1998.

PROPERSI, Antonio. Le Joint Ventures: gli accordi fra imprese. Roma: Buffetti, 1987.

RODRÍGUEZ ARTIGAS, Fernando; URIA, Rodrigo; MENÉNDEZ, Aurelio; OLIVENCIA, Manuel. Comentario al régimen legal de las sociedades mercantiles: transformación, fusión y escisión de la sociedad anónima. Madrid: Editorial Civitas, 1993. v. 3. t. 9.

ROJO, Angel. La escisión de sociedades. La Reforma del Derecho Español de Sociedades de Capital. Madrid: Universidad Complutense, 1987.

SACARDULLA, Francesco. La transformazione e la fusione delle società. In: CICU, Antonio; MESSINEO, Francesco; MENGONI, Luigi. Trattato di diritto civile e comérciale. Milano: Giuffrè editore, 2000. v. 30, t. 2.

SÁNCHEZ MIGUEL, María Candelas. Las fusiones transfronterizas y el derecho de la competência. In: Derecho de Sociedades. Madrid: McGrawHill, 2002. v. 5. 
SANTAGATA, Carlo. La Fusione fra Società. Napoli: Morano, 1964.

SCHIPPER, K.; SMITH, A. The Corporate Spin-Off Phenomenon. In: The Revolution in Corporate Finance. Oxford: Basil Blackwell, 1986.

SENN, Georges. Les sociétés de investissement en droit francais et droit comparé. Paris: Sirey, 1956.

SIEGEL, Harold. When corporations divide: a financial and legal analysis. 79 HarvLR, 1966.

SIERRALTA RÍOS, Aníbal. Joint Venture internacional. Buenos Aires: Ediciones Depalma, 1996.

STRENGER, Irineu. Contratos Internacionais do comércio. 2 ed. São Paulo: Revista dos Tribunais, 1992.

TANTINI, Giorgio. Transformazione e fusione delle società, In: Tratatto di Diritto Comérciale e di Diritto Pubblico dell'Economia. Padova: Cedam, 1985. v. 8.
Tercera Directiva 78/855/CEE do Conselho, de 09 de outubro de 1978 (Diário Oficial L 295 de 20.10.1978).

VAÑÓ VAÑÓ, Maria José. Fusión heterogénea y cesión global en el sector bancario. Valencia: Tirant lo Blanc, 2001.

VENTURA, Raúl. Fusão, cisão, transformação de sociedades. Coimbra: Almedina, 1990.

VENTURA, Raúl. Participações unilaterais de sociedades em sociedades e sociedades gestoras de participações noutras sociedades. XXIX RSI, 1980.

WALLACE, Cynthia D. Legal Control of the Multinational Enterprise. Boston/London: Martinus Nijhoff, 1982.

WEINBERG, M. A. Take-overs and Mergers. London: Sweet \& Maxwell, 1979. 